UNIVERSIDAD DE BURGOS

DPTO. DE CIENCIAS HISTÓRICAS Y GEOGRAFÍA

\title{
ARQUITECTURA DURANTE LA EDAD MODERNA EN LA SIERRA BURGALESA
}

Trabajo de Tesis Doctoral para optar al Título de Doctor realizado por el

Licenciado ÓSCAR MORAL GARACHANA.

Dirigido por el

Prof. Dr. Alberto C. IBÁÑEZ PÉREZ 
Soñé que tú me llevabas por una blanca vereda, en medio del campo verde, hacia el azul de las sierras, hacia los montes azules, una mañana serena.

(Antonio Machado, Campos de Castilla).

De Salas de los Infantes

a Quintanar de la Sierra.

Al pasar por el Arlanza,

Un navajado de frío

Le hirió la flor de la cara.

¡Mi sangre, el amante mío!

¡Se me olvidó mi bufanda!

(Rafael Alberti, La amante).

Al olmo viejo, hendido por el rayo y en su mitad podrido, con las lluvias de abril y el sol de mayo, algunas hojas verdes le han salido. (Antonio Machado, Campos de Castilla). 
ÍNDICE.

I. Introducción..........................................

II. Fuentes.......................................... 17

Fuentes bibliográficas................................. 19

Fuentes documentales................................. $\quad 25$

III. Espacio geográfico.................................... 32

Situación de la comarca............................... 33

Morfología.......................................... $\quad 36$

Variedades litológicas................................ 42

Esquema edafológico................................... 48

Red hidrográfica.................................... 49

Clima........................................ $\quad 56$

Vegetación............................................. 66

IV. Devenir histórico......................................... 69

Prehistoria........................................ 71

Época romana........................................... 78

Época visigoda........................................ 83 
Edad Media..................................... $\quad 85$

Edad Moderna......................................... 102

V. Economía............................................... 131

Agricultura..................................... 138

Ganadería......................................... 152

+ Ganadería trashumante........................ 152

+ Ganadería estante................................ 169

Carretería y explotación forestal.................... 172

Otras actividades................................... 182

VI. Población................................................ 189

Volumen de población............................... 191

Organización social............................... 215

+ Nobles......................................... 216

+ Estamento eclesiástico......................... 223

+ Estado llano..................................... $\quad 232$

VII. Aspectos urbanísticos................................. 237

Núcleos de población............................... 239

Configuración de los pueblos....................... $\quad 246$

• Ámbito religioso................................... $\quad 249$

• Ámbito civil..................................... 260

VIII. Actividad constructiva................................ 269

Tipos de obras emprendidas........................ $\quad 271$

Proceso constructivo.............................. 301

•Comitentes...................................... 318

• Maestros........................................... 335

Materiales y técnicas constructivas................. 359 


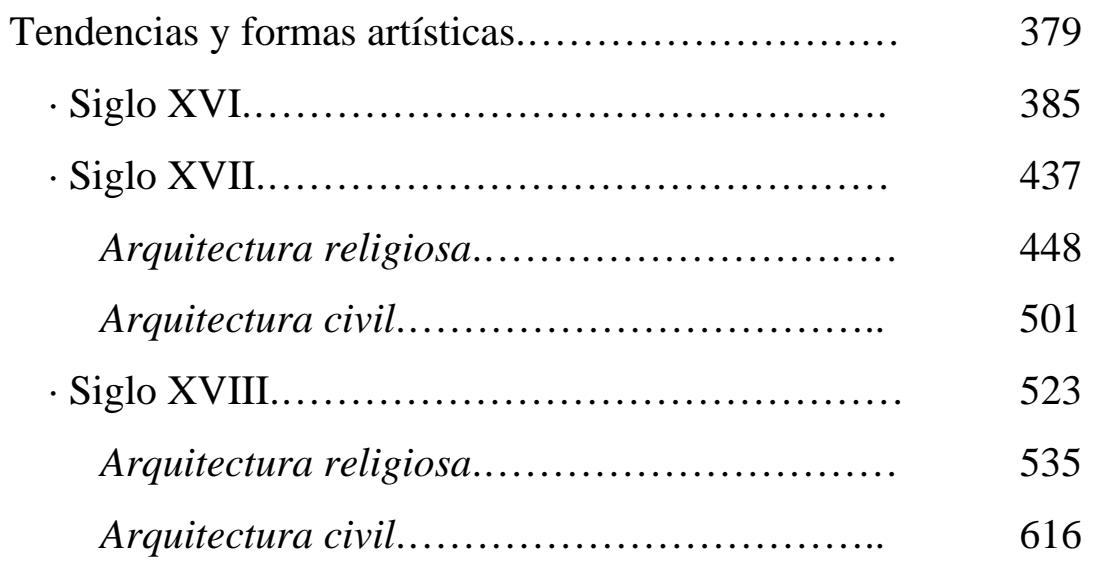

IX. Conclusiones. ........................................ 671

X. Catálogo.............................................. 679

Alveinte........................................... 681

Arroyo de Salas...................................... 689

Barbadillo de Herreros.............................. 703

Barbadillo del Pez.................................. 735

Bezares........................................ 757

Canicosa de la Sierra.............................. $\quad 767$

Castrillo de la Reina............................... $\quad 787$

Castrovido.......................................... $\quad 807$

Hacinas........................................... 819

Hoyuelos de la Sierra............................... 841

Huerta de Abajo.................................... 861

Huerta de Arriba................................... 875

Monasterio de la Sierra............................ 905

Moncalvillo....................................... 921

Monterrubio de la Demanda......................... 935

Neila........................................... 949 
Palacios de la Sierra............................... 977

Quintanar de la Sierra................................. 1009

Quintanilla de Urrilla................................. 1027

Rebollar........................................... 1037

Regumiel de la Sierra............................... 1041

Revenga........................................... 1049

Riocavado de la Sierra............................. 1055

Salas de los Infantes............................... 1071

Terrazas............................................... 1107

Tolbaños de Abajo.................................. 1117

Tolbaños de Arriba................................ 1127

Vallejimeno...................................... 1139

Vega............................................ 1153

Vilviestre del Pinar................................. 1159

XI. Bibliografía.......................................... 1183 


\section{INTRODUCCIÓN.}


8 Arquitectura de la Edad Moderna en la sierra burgalesa. 
“El trazado primitivo era románico y hoy solamente la cabecera y la torre son

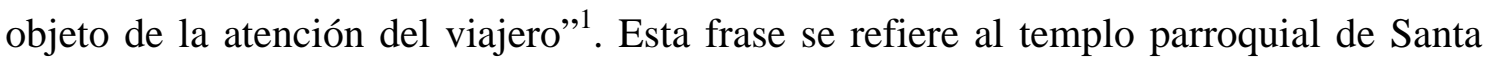
Coloma, en Riocavado de la Sierra, y ha sido extraída de una guía de rutas, encaminada informar al viajero sobre las singularidades de la zona de la sierra burgalesa en materia artística. Lamentablemente se ha convertido en una norma común, dentro de los estudios realizados sobre esta comarca, el hablar de forma pormenorizada de aquellas creaciones procedentes de la época medieval, en detrimento de las obras realizadas en etapas posteriores.

La excepcional calidad de varias de aquellas obras medievales - realizadas dentro de una particular interpretación del estilo románico - ha terminado por relegar a una inmerecida penumbra las creaciones logradas durante la Edad Moderna. Este hecho, además de mostrarse tremendamente injusto, resulta muy poco acorde con la realizada de los núcleos de la zona, cuya imagen característica, la que define su configuración más lograda, es fruto, en la inmensa mayoría de los casos, de las aportaciones llevadas a cabo durante la modernidad.

Aquella iglesia de Santa Coloma de Riocavado de la Sierra posee una interesante nave construida en 1744 en estilo clasicista, mientras que la cabecera y la torre

\footnotetext{
1 B. VALDIVIELSO AUSíN: Rutas del románico en la provincia de Burgos. Valladolid, Castilla Ediciones. 1999. (160 - 161).
} 
románicas se han conseguido mantener en pie gracias a las intensas labores de mantenimiento y remodelación, que se acometieron en torno a estos mismos años del siglo XVIII. Sin embargo, nada de esto último ha merecido el menor interés hasta ahora.

El territorio de la sierra burgalesa, que se extiende entre las formaciones montañosas de las sierras de la Demanda, Neila y Cebollera, constituye una comarca de acusada personalidad dentro de la provincia de Burgos, con un intenso pasado y una comprometida participación en la primitiva configuración de esta demarcación y del propio reino castellano, a pesar de lo recóndito de su situación geográfica y su carácter marcadamente aislado. Primero durante la Edad Media, como lugar de asentamiento de una nutrida población residual, que dio lugar a la tupida red de núcleos, de los que surgen después las poblaciones actuales. Más tarde, en la Edad Moderna, como centro de dos importantes actividades, como eran la ganadería trashumante y la carretería, que contribuyeron a dinamizar de forma clara la economía del reino, y a generar una gran prosperidad. La ganadería lanar trashumante, por ejemplo, fue considerada por la reina Isabel la Católica como la principal sustancia del reino.

En la elección y delimitación del marco de estudio de este trabajo, no obstante, existe un cierto grado de convencionalismo, pues no se ha tratado de ajustar a ninguna de las modernas divisiones administrativas existentes, tanto en el ámbito político, como judicial o eclesiástico. Atenerse a alguna de ellas hubiera supuesto extender notablemente el marco geográfico seleccionado e incluir, por lo tanto, núcleos que por sus características quedan fuera del territorio propiamente serrano. Por otra parte, el inicio de otros trabajos de investigación con objetivos similares a este estudio, centrados en ámbitos cercanos, como es el caso de la cuenca media del Arlanza, ha limitado también la progresión hacia la zona de las tierras más bajas.

De este modo el estudio se ha centrado en el análisis de los siguientes pueblos: Arroyo de Salas, Barbadillo del Pez, Barbadillo de Herreros, Bezares, Canicosa de la Sierra, Castrillo de la Reina, Castrovido, Hacinas, Hoyuelos de la Sierra, Huerta de 
Abajo, Huerta de Arriba, Monasterio de la Sierra, Moncalvillo, Monterrubio de la Demanda, Neila, Palacios de la Sierra, Quintanar de la Sierra, Quintanilla de Urrilla, Regumiel de la Sierra, Riocavado de la Sierra, Salas de los Infantes, Terrazas, Tolbaños de Abajo, Tolbaños de Arriba, Vallejimeno y Vilviestre del Pinar. Son las localidades que configuran el núcleo más representativo y característico de la comarca, recibiendo por ello, tanto sus términos como sus habitantes, la denominación de serranos.

El perfil de la zona delimitada, sin embargo, no ha supuesto en ningún momento un límite imposible de rebasar, siendo sobrepasado siempre que ha sido necesario para ampliar, reforzar o afianzar determinados argumentos.

La elección y delimitación del periodo de estudio presentaba menos dificultades, pues la Edad Moderna, como ya anunciábamos, ha sido una época tradicionalmente obviada, cuando no menospreciada, por la historiografía artística hasta el momento. Un marco temporal que engloba, sin embargo, dos de los momentos más activos en la zona a todos los niveles, como son el vivido entre las décadas finales del siglo XV y principios del siglo XVI, y de modo muy especial el que se extiende a lo largo de la mayor parte del siglo XVIII. En aquellas etapas se creó la base para el desarrollo de una interesante actividad artística, que en el campo arquitectónico permite levantar obras ciertamente destacadas, que superan con mucho la mera funcionalidad, añadiendo otros componentes, que convierten a estos edificios en testimonios de una cultura y elocuentes muestras del ansia de perdurar. No se trataba tanto de satisfacer unas necesidades inmediatas, como habían mostrado hasta el momento, como de lograr creaciones capaces de alcanzar la admiración de sus vecinos y de las generaciones venideras. Estamos hablando de la aplicación de una auténtica estética de lo perdurable, la cual tratará de cambiar la modesta imagen, que todos estos pueblos habían heredado de la etapa medieval, para mostrar en su lugar una configuración arquitectónicourbanística mucho más cuidada, que se convierte en muchos casos, en su elemento más característica. 
En el caso de la arquitectura civil se presta especial atención a aquellos edificios que escapan, a través de este sentido de la perdurabilidad, del amplio campo de la arquitectura popular, pues no sólo son testimonio de unos determinados grupos sociales y de una economía, sino también de una cultura. En las construcciones religiosas, las actuaciones que se realizan entonces suponen, en la mayoría de los casos, la culminación de una larga secuencia constructiva, con la que se alcanza una imagen que ya no sufrirán cambios.

Este patrimonio, sin embargo, presenta un estado de conservación muy desigual, con alteraciones sobre su estructura, acometidas en muchos casos dentro de la propia época de estudio. En las de carácter religioso se produce un brusco contraste entre las creaciones de la religiosidad oficial, es decir, las iglesias parroquiales, y las procedentes de la religiosidad local o popular, como ermitas y humilladeros. Las primeras han sido objeto de continuas obras de mantenimiento y conservación, lo que hace se mantenga con bastante rigor su imagen original. Ermitas y humilladeros, sin embargo, han sufrido un cruento proceso de selección natural, que ha llevado a la desaparición de una buena parte de ellos. De esta depuración sólo se han salvado los santuarios de especial veneración, o aquellos otros cuya proximidad al pueblo facilitaba su atención y cuidado. No obstante, ninguna de estas razones sirvieron para garantizar su supervivencia. Una suerte muy similar ha corrido el patrimonio de carácter civil, en cuyo caso ha sido la desaparición de los factores que propiciaron su creación y desarrollo los que pusieron en marca el proceso desintegrador. Por un lado, los inmuebles desocupados han comenzado a languidecer hasta ser pasto de la ruina. Por otro, los edificios que han permanecido habitados tuvieron que ser adaptados a las necesidades de habitabilidad de la vida moderna, lo que lleva a reformar su organización interna, conservando, en el mejor de los casos, su estructura volumétrica y la configuración de alguna de sus fachadas.

El origen de las transformaciones que han alterado, y en algunos casos eliminado este patrimonio, no se encuentran en hechos puntuales, que actúan de forma súbita, 
como es el caso de las guerras, conflictos sociales, o decisiones de carácter político, generadores de cambios bruscos, que terminan por repercutir en los edificios. En este sentido, por ejemplo, la invasión francesa y posterior Guerra de la Independencia, que propiciaron unas condiciones ciertamente dañinas para el patrimonio religioso (y que tanta devastación propició en otras zonas de la provincia, empezando por la propia capital), apenas tiene repercusión en la comarca de la sierra. Solamente el antiguo convento de Santa María de Alveinte y la localidad de Regumiel de la Sierra parece que sufrieron los efectos de estas calamidades.

La alteración o incluso destrucción de este legado, por el contrario, se produce como consecuencia de situaciones coyunturales de ritmo mucho más largo, algunas de ellas heredadas incluso de la Edad Moderna. Es el caso de la pérdida de valor de la religiosidad local o popular, que propicia el abandono y la consiguiente desaparición de muchas de las ermitas que poblaban estas sierras. Se trata de un fenómeno iniciado en el siglo XVIII, y que tiene sus consecuencias más desastrosas en la centuria del Ochocientos, con la desaparición de la mayor parte de los ejemplos que quedaban. No estamos hablando, por lo tanto, de las consecuencias de un proceso de secularización, pues la desaparición de estas ermitas convive con la ejecución de asombrosas obras de renovación, ampliación y mejora de varios templos parroquiales. Se trata más bien de la ruptura de un equilibrio, que hasta el momento se había mantenido entre la religiosidad popular o local, y la religiosidad oficial, a favor de esta última. Aquella, por su parte, se concentra en la atención de una serie de santuarios muy concretos, que pasan a convertirse en últimos referentes de unas creencias ya casi olvidadas.

En el caso de la arquitectura civil, las alteraciones han venido dadas por los cambios coyunturales de carácter socioeconómico, provocados por la decadencia de las actividades tradicionales, que fueron santo y seña de la comarca. La ganadería trashumante y la carretería de larga distancia sufrieron un duro golpe con la supresión a finales del primer tercio del siglo XIX de la Mesta y la Real Cabaña de Carreteros, después de haber vivido ya sus momentos más gloriosos. No se produce, sin embargo, 
la desaparición de estas actividades, que algunos vaticinaban, pero su desarrollo transcurrirá a partir de ahora inmerso en una humilde existencia, que queda lejos del esplendor pasado. A pesar de ello las tipologías constructivas más características ligadas a estas actividades, como son la casa solariega o blasonada de los grandes propietarios de rebaños merinos, y la casa carretera, en cualquiera de sus variantes, no desaparecen, ni pierden su función, simplemente dejan de construirse. A partir de aquí se produce un gradual vaciado de contenido, ante el progresivo declive de cada uno de estos medios de vida y la desaparición de sus más insignes representantes. Posteriormente, se procede a su compartimentación, alterando con ello su organización interior. Y ya en el siglo XX, con el fenómeno del desarrollismo, asistimos a la mutilación, cuando no la eliminación completa del edificio, realizada en aras de la habitabilidad.

Este fenómeno fue particularmente activo en aquellas localidades que experimentaron un relativo desarrollo durante la segunda mitad de la centuria pasada, como Palacios de la Sierra, Quintanar de la Sierra o Salas de los Infantes, en las cuales se produce una intensa alteración de su fisonomía tradicional, con la expansión de su núcleo antiguo, la cración de un trazado viario nuevo, y la construcción de modernos edificios de bloques de viviendas. Todo ello muy alejado de la imagen tradicional heredada de la Edad Moderna. En las últimas décadas parte de estas consecuencias se han extendido también a los núcleos más pequeños, con el fenómeno de la segunda vivienda. De este modo, muchos vestigios de las últimas casas blasonadas y carreteras están desapareciendo a una gran velocidad.

Pero no hay que pintar un panorama tan desalentador, pues frente al impulso destructor, que generan estos fenómenos, está naciendo un vigoroso interés por rescatar y conservar las tradiciones y el legado del pasado, especialmente el de la Edad Moderna, por ser el que más restos ha dejado, y con el que más se identifica estos pobladores. Se trata de un sentimiento inscrito en una corriente mucho más amplia, centrada en el conocimiento de la cultura y las particularidades de la comarca. 
El presente estudio se encuadra así dentro de esta corriente con una auténtica vocación de servicio, tratando humildemente de contribuir a la valoración del patrimonio legado por los siglos de la Edad Moderna. Para ello, se ha intentado contextualizar en la medida de lo posible este patrimonio arquitectónico, analizando, no solo su proceso de elaboración, las figuras que en ello participan, y las características formales desarrolladas, sino también aquellos otros aspectos de orden histórico, económico y social, que subyacen alrededor.

En lo que se refiere a la actividad artística propiamente dicha, este trabajo se ha apoyado fundamentalmente en el análisis de la propia obra, pues la ausencia de otras fuentes alternativas, tanto bibliográficas como documentales han impedido desarrollar estas otras vías de investigación. En el caso de la bibliografía se produce un secular silencia hacia las obras realizadas en aquellos siglos, ante el mayor atractivo que despierta la producción del periodo románico. En lo que se refiere a las fuentes documentales asistimos a una pérdida prácticamente total de este legado, lo que supone una de las notas más singulares de la comarca. Una pérdida que no deja de suponer un severo inconveniente para el estudio de una época, que tiene en la localización y análisis de este tipo de fuentes uno de sus más sólidos pilares. Para paliar estas carencias ha habido que conceder una gran credibilidad a los escasos documentos conservados, estrapolando parte de su contenido a otros ejemplos próximos, siempre que era posible.

La base fundamental del estudio, por lo tanto, se ha centrado en el análisis meticuloso de la propia obra, para lo que nos hemos servido de todo el material gráfico disponible. Dentro de este material se ha concedido un gran protagonismo a la elaboración de plantas y alzados, especialmente en los edificios religiosos, con los cuales se ha intentado seguir paso a paso la evolución experimentada por varias de estas fábricas. Para el ámbito de la arquitectura civil una valiosa fuente de información han sido las fotografías tomadas con anterioridad a los procesos de remodelación. 
Todo ello se inscribe dentro de un extenso trabajo de campo, en el cual las aportaciones realizadas por los propios habitantes de los pueblos, se ha convertido en fuente de información de primer orden. Agradecemos así a todas aquellas personas que de forma totalmente desinteresada, y con una estricta vocación de ayuda, nos han facilitado datos, proporcionados documentos, fotografías e imágenes, que nos han acercado un poco más a la realidad de cada una de las obras estudiadas. En este amplio y heterogéneo grupo se encuentran desde los alcaldes y sacerdotes de cada una de las localidades, hasta el más humilde de sus vecinos, los cuales han abierto de par en par las puertas de sus casas, en el sentido más literal, con el fin de colaborar en este trabajo. 
II. FUENTES. 


\section{FUENTES BIBLIOGRÁFICAS.}

La comarca de la sierra burgalesa no ha sido, en general, objeto de estudios pormenorizados desde el punto de vista histórico y artístico, lo que hace que sean más bien escasas las referencias bibliográficas que existen sobre el tema. Este silencio se hace especialmente manifiesto en cuanto al periodo de la Edad Moderna. Las escasas noticias que existen, como las del P.Gregorio ARGAIZ ${ }^{2}$, para finales del siglo XVII, o el P. Bernardo PALACIOS ${ }^{3}$, para las primeras décadas del siglo XVIII, se mueven más en el campo de lo legendario y de los tópicos, que en el de la historia propiamente dicha, dando especial protagonismo a figuras como las de los Siete Infantes de Lara, o de Salas, cuyas hazañas, recogidas en el cantar de gesta, se convierten en el primer y más sólido referente histórico de toda la comarca.

A finales del siglo XVIII, sin embargo, otro tipo de literatura, impregnada del espíritu crítico de la Ilustración, como es la obra del P. LOPÉRRAEZ CORVALÁN, para el Obispado de Osma, nos propone otro ángulo de visión sobre la realidad de varios de los pueblos. Un punto de vista centrado, no sólo en los aspectos históricos,

2 Fr. G. ARGAIZ: (OBS): La soledad laureada por San Benito y sus hijos en las Iglesias de España y teatro monástico de la provincia... Madrid, Francisco Nieto: a costa de Gabriel de León. 1669. 
sino también en la realidad de estos pueblos y sus habitantes, donde se hace una valoración, en cierto modo descarnada, de las circunstancias y medios de subsistencia de estos pobladores, de sus manías, hábitos y costumbres ${ }^{4}$. Dentro de esta imagen, como era de esperar, los aspectos artísticos apenas recibieron el menor tratamiento.

Heredera de esta tradición es la bibliografía del siglo XIX, dentro de la cual destaca, de modo especial, el Diccionario de P. MADOZ, compuesto a mediados de este siglo XIX, a partir de las pesquisas realizadas en su momento por el geógrafo T. LÓPEZ, y diferentes actualizaciones de su época ${ }^{5}$. Tampoco aquí, sin embargo, encontramos mayores referencias a los aspectos artísticos en general, y al patrimonio arquitectónico, en particular. Se limita a constatar la existencia de iglesias y ermitas, y de alguna casa notable, dentro de cada uno de estos pueblos, lo cual se realiza sin emitir ningún tipo de juicio de valor hacia este legado. Sólo, en el mejor de los casos, podemos encontrar alguna alusión a la calidad técnica de los edificios, pero nunca a ensalzar sus valores estéticos.

Tenemos que esperar, por lo tanto, hasta el siglo XX para asistir al nacimiento de una atención más decidida, por parte de la bibliografía, hacia esta comarca, donde se inicia un estudio más estrecho y pormenorizado de los pueblos de la zona, desde diferentes perspectivas. Encontramos así algunos trabajos relacionados con el estudio del medio físico, como La sierra de la Demanda y los Montes Obarenses, de W. SCHRIEL, Geologie de la Sierra de la Demanda Burgos-Logroño (Espagne), de M. COLCHEN, o el clima del sector norte de la Cordillera Ibérica: estudio geográfico de la Sierra de la Demanda a la del Moncayo, de Ma T. ORTEGA VILLAZÁN, en los cuales se abordan estos temas con una aplicación meticulosa de un método científico. Al

\footnotetext{
3 Fr. B. PALACIOS (O de M): "Historia de la ciudad de Burgos, de sus familias y de su Iglesia”. En Boletín de la Estadística Municipal de Burgos. Burgos, Ayuntamiento. (pp. 20 - 21).

4 J. LOPÉRRAEZ CORBALÁN: Descripción histórica del Obispado de Osma con el catálogo de sus prelados. Ed. Facsímil. Madrid, Turner. 1978. Tomo I.

5 P. MADOZ: Diccionario geográfico - estadístico - histórico de España y sus posesiones de Ultramar. Valladolid, Ámbito D.L. 1984.
} 
hilo de estas investigaciones tenemos también obras recientes, con un formato más próximo a las guías turísticas, en las que se pretende, de una manera sencilla y pedagógica, ilustrar al visitante sobre las particularidades medioambientales de la zona.

Pero dentro de los diferentes ángulos de visión, destaca de modo muy especial el protagonismo de los estudios de carácter histórico. Entre los trabajos de este tipo merecen siempre una atención prioritaria las etapas de la Edad Antigua y Medieval, con estudios, en este caso, centrados en el proceso formador de Castilla, durante el periodo de la reconquista. Algunos nombres importantes, en este aspecto, son I. ÁLVAREZ BORGE $^{6}$, E. PASTOR DÍAZ DE GARAYO ${ }^{7}$, J. ESCALONA MONGE ${ }^{8}$, o Fr. V. de la $\mathrm{CRUZ}^{9}$. En la misma línea no debemos dejar de mencionar nunca la destacada y extensa aportación de L. SERRANO, con la publicación de los fondos documentales más antiguos de los principales centros religiosos del entorno de esta comarca de la sierra, como Santo Domingo de Silos, Infantado de Covarrubias, San Millán de la Cogolla, San Pedro de Arlanza y San Pedro de Cardeña. Los vínculos e intereses, que estos cenobios tienen en nuestra zona de estudio, hace que encontremos aquí los referentes escritos más antiguos, que existen de todos estos pueblos.

En materia artística la inmensa mayoría de los estudios realizados se han centrado, de forma casi exclusiva, en la producción medieval, y dentro de ella, en la encuadrada dentro del estilo románico. De hecho, los estudios en este campo han sido tan abundantes, que se ha creado la impresión de que fuera de este estilo no vamos a

\footnotetext{
6 I. ÁLVAREZ BORGE: Poder y relaciones sociales en Castilla en la Edad Media. Los territorios entre el Arlanzón y el Duero en los siglos $X-X I V$. Salamanca, Consejería de Educación y Cultura. Junta de Castilla y León. 1996.

7 E. PASTOR DÍAZ DE GARAYO: Castilla en el tránsito de la Antigüedad al Feudalismo. Poblamiento, poder político y estructura social del Arlanza al Duero (siglos VII - IX). Valladolid, Consejería de Educación y Cultura, Junta de Castillo y León. 1996.

8 J. ESCALONA MONGE: "Algunos problemas relativos a la génesis de las estructuras territoriales de Castilla Altomedieval. En II Jornadas burgalesas de Historia. (2 $\left.{ }^{a} 1990\right)$. Burgos en la Alta Edad Media. Burgos, Asociación Provincial de Libreros de Burgos. 1991.
} 
encontrar en la zona ninguna construcción de interés. Dentro de esta labor son muy destacados los trabajos realizados en las últimas décadas por los Drs. F. PALOMERO ARAGÓN y M. ILARDIA GÁLLIGO, con sus estudios sobre la denominada escuela del románico de la sierra ${ }^{10}$. Pero también son interesantes las aportaciones de autores, como S. ANDRÉS ORDAX ${ }^{11}$, G. BILBAO LÓPEZ ${ }^{12}$, J. SÁINZ SÁIZ ${ }^{13}$, y B. VALDIVIELSO AUSÍN ${ }^{14}$.

La actividad artística durante la Edad Moderna, por su parte, sólo ha contado con referencias más o menos extensas en obras de carácter más general. En lo que se refiere al arte mueble, destaca de manera especial la aportación del Dr. R J. PAYO HERNANZ, con su trabajo sobre la actividad retablística burgalesa en los siglos XVII y XVIII, donde hace un detallado estudio de las creaciones de este tipo ${ }^{15}$. En materia arquitectónica, sin embargo, las referencias, no sólo resultan más escasas, sino que además se encuentran bastante más dispersas, centrándose únicamente en obras muy concretas, como por ejemplo, las portadas de las iglesias de Santa María de Salas de los Infantes $^{16}$, y de San Pedro de Hacinas ${ }^{17}$, o determinadas obras llevadas a cabo en otros templos, como el de Castrillo de la Reina ${ }^{18}$.

$9 \quad$ Fr. V. de la CRUZ: Primer milenario de la ciudad de Salas de los Infantes. 974 - 1974. Burgos. Junta Oficial de Milenario. 1974.

10 F. PALOMERO ARAGÓN, M. ILARDIA GÁLLIGO: El arte románico burgalés. Un lenguaje medieval actual. Madrid, Lancia. 1995.

11 S. ANDRÉS ORDAX: La provincia de Burgos. León, Lancia DL. 1991.

12 G. BILBAO LÓPEZ: Iconografía de las pilas bautismales del románico castellano; Burgos y Palencia. Burgos. Editorial la Olmeda. 1996.

13 J. SÁINZ SÁIZ: El románico en Burgos. Madrid, Ediciones Lancia. 2001.

14 B. VALDIVIELSO AUSíN: Rutas del románico en la provincia de Burgos. Valladolid, Castilla Ediciones. 1999.

15 R. J. PAYO HERNANZ: El retablo en Burgos y su comarca durante los siglos XVII y XVIII. Vol. 2. Burgos, Excma. Diputación Provincial de Burgos. 1997.

16 J. CAMÓN AZNAR: La arquitectura y la orfebrería españolas del siglo XVI. En SUMMA ARTIS (dir. J. PIJÁN). Madrid, Espasa Calpe. 1982. Santander. Fundación Obra Pía Juan de Herrera: Universidad de Cantabria. 1993. A. C. IBÁÑEZ PÉREZ: “Arquitectura, escultura, pintura y artes menores del siglo XVI”. En Historia de Burgos. III Edad Moderna 3. Burgos, Caja Burgos. 1999. (pp. 7 $-196)$. 
Dentro de estas obras, un tímido intento por acercarse a la actividad artística, desarrollada de forma concreta en esta comarca de la sierra, se produce con las obras de I. GARCÍA RÁMILA ${ }^{19}$, y J. PÉREZ CARMONA ${ }^{20}$. Sin embargo, sus estudios resultan demasiado superficiales, pues apenas llegan a profundizar en las particularidades de la zona.

Para terminar, un apartado especial merecen las monografías de pueblos, cada vez más abundantes, que están surgiendo en los últimos años. Suelen estar realizadas, en la mayoría de los casos, por eruditos locales o estudiosos vinculados a estos núcleos, los cuales, además de mostrar un amor casi devocional hacia su tierra, suelen contar con un minucioso conocimiento de las fuentes documentales relacionadas con cada uno de estos municipios. Con estas herramientas, logran crear obras ciertamente interesantes, que resultan de una gran utilidad para nuestro trabajo, pues nos ha permitido localizar datos, que por nuestros propios medios hubiera resultado poco menos que imposible.

Estos trabajos, sin embargo, suelen adolecer, en la mayor parte de las ocasiones, de un escaso interés por la vertiente artística, ofreciendo, en el mejor de los casos, pequeñas descripciones de los edificios más representativos, entre las cuales se valora de modo especial la antigüedad de la obra, más que sus calidades estéticas. Esto hace que sean nuevamente los edificios y restos de época románica, los que reciben una mayor dedicación, dejando fuera, o incluso despreciando, las demás épocas.

17 R. J. PAYO HERNANZ: “Aproximación al estudio de la arquitectura clasicista y protobarroca en Burgos y su comarca en el siglo XVII”. En Juan de Herrera y su influencia: actas del Simposio: Camargo 14 / 17 Julio 1992. (pp. 227 - 242).

18 A. C. IBÁÑEZ PÉREZ: “Arquitectura barroca burgalesa”. En Historia de Burgos. III Edad Moderna 3. Burgos, Caja Burgos. 1999. (313 - 359).

19 I. GARCÍA RÁMILA: La zona de Salas de los Infantes en su aspecto histórico, artístico y legendario. Burgos, Aldecoa. 1960.

20 J. PÉREZ CARMONA: "Historia y Arte del partido judicial de Salas de los Infantes (Burgos). En Burgense Collectanea Scientífica, n 3, Burgos (1962). (pp. 349 - 376). 
Pero esta línea de trabajo está empezando a superarse, de forma que muchos de estas obras conceden ya una atención cada vez mayor a las cuestiones relacionadas con la materia artística, dando un mismo tratamiento a unos estilos y que a otros. Así, encontramos algunos edificios representativos de la Edad Moderna, especialmente templos parroquiales y algunas ermitas, perfectamente documentados y analizados, realizando estudios en los que se abordan cuestiones de naturaleza artística, y valoraciones de las formas y técnicas empleadas. Dos buenos ejemplos de ello los tenemos en los libros publicados sobre las localidades de Barbadillo de Herreros ${ }^{21}$ y Hacinas $^{22}$.

El precedente de este tipo de monografías se encuentra en las obras realizadas desde comienzos del siglo XX por T. MEDRAZO LÁZARO sobre Quintanar de la Sierra. Dentro de ellas, existen títulos tan evocadores como A mi desgraciado pueblo (1913); Lo que fue y es Quintanar y para Quintanar de la Sierra (1950); y El patrimonio de Quintanar de la Sierra (1955). A estas primeras iniciativas le siguieron otros trabajos, como el ya citado sobre el partido judicial de Salas de los Infantes de J. PÉREZ CARMONA (1962), si bien, es a partir de la década de 1980 cuando se comienza a producir el gran auge de este tipo de literatura. De esta forma, son ya varios los pueblos que cuentan con algún libro sobre su historia, o con varios, como es el caso de Salas de los Infantes ${ }^{23}$. En esta nómina, además de los ya citados de Barbadillo de Herreros y Hacinas, podemos incluir los de Castrillo de la Reina ${ }^{24}$, Castrovido ${ }^{25}$,

\footnotetext{
21 C. RUBIO VELASCO: Barbadillo de Herreros. Burgos, Imprenta Santos. 2001.

22 R. ALONSO OLALLA: Hacinas. Estella, Gráficas Lizarra. 1995.

23 E. GONZÁLEZ BARRIUSO: Salas de los Infantes en la sierra burgalesa. Burgos, Grupo Editorial 7, 1999; A. MARTÍNEZ IBÁÑEZ: El valle de Salas. Burgos, Edición propia. 2000; A. BENGOECHEA: Historia de Salas I. Paisaje, clima, economía, etnología, apellidos, dinosaurios, primeros pobladores, antigüedad, Edad Media, los 7 infantes de Lara. Burgos, Museo de Salas. 2003.

24 A. ABAD IZQUIERDO, L. M. GONZÁLEZ: Estudio de la iglesia de Castrillo de la Reina y otros documentos históricos. Castrillo de la Reina, Edición propia. 1985.

25 L. A. CONTRERAS ABAD: Castrovido. Nuestros antepasados. Burgos, Asociación Amigos del Castillo de Castrovido. 2002.
} 
Monterrubio de la Demanda ${ }^{26}$, Neila ${ }^{27}$, Palacios de la Sierra ${ }^{28}$, Quintanar de la Sierra ${ }^{29}$ y Vilviestre del Pinar ${ }^{30}$.

A estas monografías debemos sumar también diferentes artículos, publicados en revistas de ámbito provincial, como el Boletín de la Comisión Provincial de Monumentos (BCPM), y su heredero el Boletín de la Institución Fernán González (BIFG), o revistas locales, como Amigos de Hacinas, y la Chinada. En estas publicaciones, además de abordar distintas facetas de interés de la zona, se incluyen también algunos artículos centrados en el estudio pormenorizado de algunos pueblos, en los cuales se abordan, entre otras materias, cuestiones de carácter histórico, artístico, documental o geográfico. Ejemplos de ello los tenemos para las localidades de Hacinas, Hoyuelos, Palacios de la Sierra, Regumiel de la Sierra y Salas de los Infantes.

\section{FUENTES DOCUMENTALES.}

Escasez y modernidad son las dos notas que definen, en general, el panorama documental, que tenemos para esta comarca de la sierra burgalesa, durante la Edad Moderna, pues son muy pocos los documentos que se han conservado de este período. Ello ha afectado de un modo dramático al desarrollo de la investigación, pues son muy pocas las obras que tenemos perfectamente documentadas, con contratos de obras y pliegos de condiciones, en los que se especifiquen las características de la intervención emprendida. Estas pérdidas documentales se han producido por varias causas, que

26 D. ORTEGA GUTIÉRREZ, R. CAMARERO CAMARERO: La villa de Monterrubio de la Demanda. Una del Estado de las Cinco Villa y Valle de Canales. Burgos. 1999.

27 B. VALDIVIELSO AUSíN: Neila, una llamada al turismo. Burgos, Ayuntamiento de Neila. 1980.

28 J. MANRIQUE: Palacios de la Sierra. Burgos.

29 P. GIL ABAD: Quintanar de la Sierra, un pueblo burgalés de la comarca de pinares. Burgos, Excma. Diputación de Burgos. 1986.

30 E. DOMINGO ANGULO: Vilviestre del Pinar, pasado, presente y futuro. Burgos, Ayuntamiento de Vilviestre. 1995. 
26 Arquitectura de la Edad Moderna en la sierra burgalesa.

generalmente no actuaron de forma aislada, sino de un modo conjunto, con lo que sus efectos resultaron aun más letales. Entre ellas, la primera y fundamental, ha sido el propio abandono, provocado por la falta de interés de los responsables de su custodia, lo que ha llevado a un hacinamiento en condiciones inadecuadas, que en algunos casos se convertían en una clara llamada a su destrucción. Esta situación, unida a la fragilidad de este legado, no hacía sino allanar el camino para que los agentes encargados de su destrucción final, como fueron las humedades, el fuego, la podredumbre y degradación de la materia, que servía de soporte, terminaran por convertirse en los auténticos jinetes apocalípticos, que segaron sin miramientos todo documento que encontraban a su paso.

Dentro de la documentación de carácter eclesiástico, que se ha conservado, sin duda la fuente principal la encontramos en los libros parroquiales, y dentro de ellos, en los libros de fábrica, en los que se recoge la contabilidad de los templos y ermitas más importantes. Sin embargo, son ciertamente escasas las parroquias y ermitas, que conservan registros anteriores al siglo XVIII, lo que hace que se puedan considerar como una auténtica rareza aquellas anotaciones anteriores al año 1650. Ante este panorama, sólo dos parroquias, las de San Esteban, en Castrillo de la Reina, y San Pedro, en Hacinas, conservan algunos registros pertenecientes al siglo XVI, que nos han permitido documentar obras emprendidas en aquellos momentos. Para el resto, los libros de fábrica conservados escasamente han servido para ilustrar actuaciones efectuadas a partir de 1700. Algunos casos incluso, como el de las dos parroquias de Salas de los Infantes, la parroquia San Martín, en Castrovido, de San Miguel, en Neila, o la de San Quirico y Santa Julita, en Tolbaños de Abajo, sólo disponen de registros de cuentas para los últimos años del siglo XVIII o principios del XIX, lo que hace que hablen de edificios completamente terminados. Esto mismo sucede con parroquias que cuentan con registros algo más antiguos, pero no lo suficiente como para informar de las obras con las que se remata su estructura. Tal es el caso de Quintanar de la Sierra, cuyos registros de cuentas conservados se inician en 1650, mientras que su templo se finaliza en 1622. En Tolbaños de Arriba la conclusión de las obras de su iglesia se produce en 1724, mientras que los registros de cuentas más antiguos son de 1775 . Y en Huerta de 
Abajo, la construcción de la iglesia se produce en las últimas décadas del siglo XVII, mientras que las anotaciones de sus libros de fábrica que han llegado hasta hoy no se inician hasta 1740. En otros casos, como los de las parroquias de San Adrián, en Regumiel de la Sierra, y Santa Eugenia, en Terrazas, la documentación conservada es prácticamente nula.

Estas fuentes parroquiales, además de escasas, ofrecen grandes dificultades para su consulta, pues, por lo general, están muy fragmentadas, y se hallan agrupadas sin ningún orden ni concierto, lo que hace que queden importantes lagunas sin cubrir. Estos fondos se concentran en el Archivo General Diocesano de Burgos (AGDBU), si bien, en algunos casos, como los de las parroquias de Nuestra Señora de la Visitación de Barbadillo de Herreros, y San Martín de Vilviestre del Pinar, todavía se conservan en el propio pueblo. De igual modo, el archivo de la Casa Parroquial de Salas de los Infantes, lugar donde residen los sacerdotes de varios pueblos, guarda algunos fondos de interés, que todavía no han sido transferidos al AGDBU.

En lo que a los archivos catedralicios se refiere, su aportación ha resultado en ambos casos (el de Burgos y el de Burgos de Osma) más bien escasa, pues las referencias localizadas en ellos se reducen simplemente a disposiciones de carácter general, que afectan a todo el territorio de la diócesis, y no a actuaciones concretas en templos. En cualquier caso, y merced al buen hacer y disponibilidad de sus respectivos directores, las visitas a estos centros siempre han resultado provechosas.

Por último, en lo que se refiere a las fuentes eclesiásticas vinculadas al clero regular, la suerte ha sido muy desigual. De este modo, en la información de carácter histórico, las aportaciones llegadas desde los cartularios y becerros de los monasterios de San Pedro de Arlanza, Santo Domingo de Silos, San Millán de la Cogolla, y en menor medida, San Pedro de Cardeña y el Infantado de Covarrubias, han resultado vitales para conocer los primeros pasos de todos estos pueblos dentro de la historia 
escrita. La mayor parte de este legado, como hemos dicho, fue publicada por L. SERRANO, lo que sin duda facilita y ahorra esfuerzos en su consulta.

Por su parte, la documentación relacionada con el único convento, que se mantuvo en pie durante la Edad Moderna, dentro de nuestro marco geográfico, como es el de Santa María de Alveinte, la suerte es bien diferente. En este caso, todo su legado documental ha desaparecido sin dejar el menor rastro, lo que nos impide conocer datos concretos de su historia, y de la estructura del edificio. Con toda certeza, esta documentación pereció, presa de las llamas, en el incendio declarado en 1810, tras la voladura de parte de sus dependencias por parte de las tropas francesas.

En lo que se refiere a la documentación de carácter civil, el panorama no es mucho más alentador que el caso anterior, pues también aquí el legado conservado, no sólo es muy escaso, sino también bastante moderno. La primera gran fuente que tenemos son los archivos municipales, si bien, su consulta en la mayoría de las ocasiones resulta poco menos que imposible, dada la inexistencia de documentación referente a la Edad Moderna, o las grandes dificultades que hay para localizarla. No obstante, para paliar este inconveniente se ha podido contar con dos apoyos fundamentales. Por un lado, existen las catalogaciones efectuadas por el Servicio de Rescate Documental, de la Excma. Diputación Provincial de Burgos, efectuados en varios pueblos. Se trata de una labor encuadrada dentro del proyecto de recuperación y conservación de archivos municipales, y ya es una realidad en localidades como Castrillo de la Reina, Canicosa de la Sierra, Moncalvillo, Valle de Valdelaguna y Vilviestre del Pinar.

En otros casos, se cuenta con las revisiones previas, realizadas por otros investigadores, la mayoría de las veces locales, los cuales, con mucha dedicación y extraordinario empeño, han conseguido poner un cierto orden, dentro de una maraña documental muy difícil de organizar. Destacamos aquí la interesante labor realizada por C. RUBIO VELASCO, en Barbadillo de Herreros, D. ORTEGA GUTIÉRREZ y R. 
CAMARERO CAMARERO, en Monterrubio de la Demanda, J. MANRIQUE, en Palacios de la Sierra, P. GIL ABAD, en Quintanar de la Sierra, y A. BENGOECHEA, en Salas de los Infantes. Aun con todo, la aportación de estos archivos, en relación con la producción de obras de arte, ha sido siempre muy limitada.

Otra fuente de vital importancia para el seguimiento de la actividad artística durante la Edad Moderna, son los protocolos notariales, dada la necesidad de contratar ante un notario la ejecución de la mayor parte de las construcciones que se realizaban. Pero como en los casos anteriores, los registros conservados aquí tampoco son muy numerosos, ni antiguos. De esta forma, la mayor parte de los escasos notarios, de los que se han conservado registros de sus escrituras, pertenecen ya al siglo XVIII. Tal es el caso de los escribanos de Palacios de la Sierra, Antonio Martínez Sanz (1676-1711), Francisco Antonio Manzio (1769-1784). O el caso de los escribanos de Salas de los Infantes, Felipe Marrón (1701-1742), Ignacio Esteban Marrón (1745-1769), Domingo Esteban Vicente Marrón (1770-1788), Domingo Ortiz Córdoba (1703-1748), Domingo Luís Ortiz Córdoba (1749-1762), y Manuel Gil de la Cuesta (1716-1745), este último perteneciente al Valle de Valdelaguna. La búsqueda casi desesperada de documentación nos ha llevado a probar suerte con los escribanos de otras comarcas vecinas, vinculadas de un modo u otro a los pueblos de nuestra zona de estudio, como es el caso de la comarca de pinares, que se extiende ya en la provincia de Soria. De este modo, en el AHPSO, consultamos también los registros de algunos notarios de San Leonardo, como Pedro de Escalante, Alonso de San Esteban, Juan de Otañe, Antonio Bermejo, Diego Ruiz Mijangos, Bernardo Mijangos Argüero, Sebastián González Valdivielso, o Francisco González Valdivielso.

Otra importante fuente de información, para conocer diferentes aspectos de la realidad de estos pueblos durante la Edad Moderna, son las respuestas dadas al Catastro del Marqués de Ensenada, de mediados del siglo XVIII, cuyos memoriales para la provincia de Burgos se custodian en el Archivo de la Diputación Provincial de Burgos (ADPBU). Ligados a este tipo de información, se encuentran los datos suministrados 
30 Arquitectura de la Edad Moderna en la sierra burgalesa.

por los censos de población, efectuados en distintos momentos de este periodo. Los resultados de algunos de ellos han sido publicados, lo que sin duda facilita su consulta. Este es el caso de los censos de 1591, y el llamado censo de los obispos de 1584-87, publicados ambos por el Padre T. GONZÁLEZ, a comienzos del siglo XIX ${ }^{31}$. Sucede lo mismo con el vecindario del Marqués de Ensenada de $1759^{32}$, y con el censo de Floridablanca de $1787^{33}$, publicados ambos por el Instituto Nacional de Estadística. El resto se encuentran en el Archivo General de Simancas (AGS), donde han sido consultados.

Por último, debemos mencionar también la documentación emanada de los señoríos jurisdiccionales, que se repartían el dominio de varios de estos pueblos. La mayor parte del legado documental de estas familias se custodia actualmente en el Archivo Histórico Nacional (AHN, Sección Nobleza), si bien, la localización de documentos vinculados a la actividad artística no siempre resulta tarea fácil. En primer lugar, porque la promoción de obras artísticas, por parte de este grupo en la comarca de la sierra burgalesa, resulta prácticamente nula, y en segundo, porque la organización de este vasto legado se reduce, en la mayoría de los casos, a un amplio inventariado, que apenas sirve para clasificar vagamente la extensa y heterogénea masa, aglutinada en estos fondos.

31 T. GONZÁLEZ: Censo de población de las provincias y partidos de la Corona de Castilla en el siglo $X V I$. Con varios apéndices para completar la del reto de la península en el mismo siglo, y formar juicio comparativo con la del anterior y siguiente, según resulta de los libros y registros que se custodian en el Real Archivo de Simancas. Ed. Facsímil. Madrid, Imprenta Real. 1829.

32 Censo de Población de la Corona de Castilla "Marqués de Ensenada", 1752: mandado formar por el conde de Valparaiso mediante las Reales Órdenes de 3-7-1756, y 9-7-1759, basándose en los datos recopilados entre 1750 y 1754 para el catastro del Marqués. Madrid, INE. 1993; Vecindario de Ensenada 1759. Vol. I. Madrid, Centro de Gestión Catastral y Cooperación Tributaria: Tabapress. D. L. 1991.

33 INE. Censo de 1787. "Floridablanca”. Madrid. INE. 1989. 


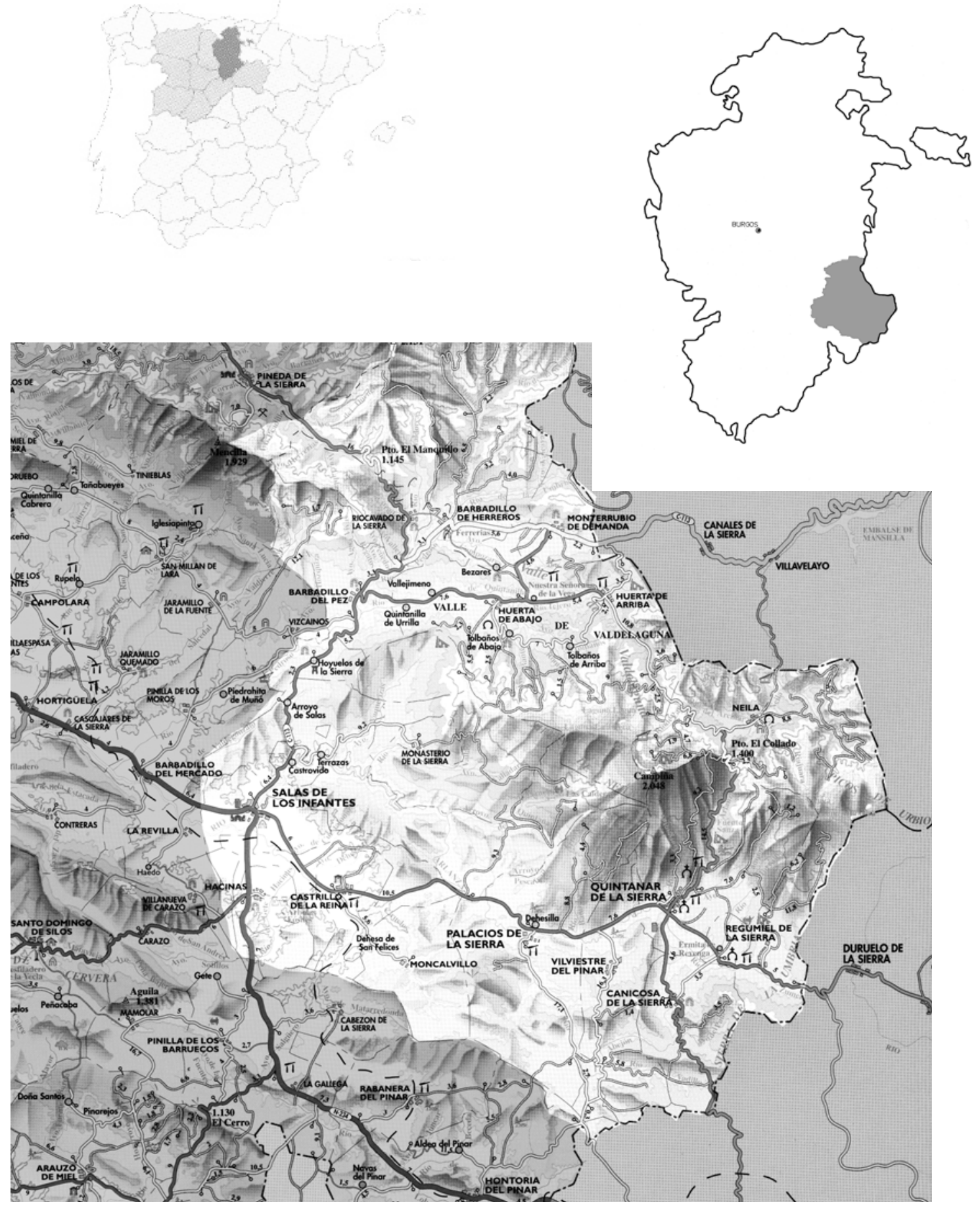


Toda la comarca, que conforma nuestra área de estudio, se halla encuadrada dentro del marco administrativo de la provincia de Burgos, que fue trazado en $1833^{34}$. Este sector se corresponde además con la zona más montañosa de todo el territorio provincial, conociéndose por ello de forma genérica como la comarca de la “sierra” y a sus habitantes como "serranos" 35 . Son las montañas que coinciden con el extremo noroccidental de la Cordillera Ibérica, marcando con su presencia la separación entre dos de las más importantes cuentas hidrográficas de la península, como son la del Duero y la del Ebro. El territorio incluido dentro de nuestro ámbito de estudio se encuentra ubicado en la fachada meridional de este sector montañoso, vertiendo sus aguas, por lo tanto, hacia el Duero, si bien, una pequeña parte de la zona es tributaria del Ebro.

El marco físico de nuestra comarca, por lo tanto, difícilmente puede encuadrarse dentro de la tradicional imagen de la “ancha Castilla”, formada por una amplia extensión de llanuras, salpicadas por suaves y ondulantes colinas. Bien al contrario, esta

34 J. L. MORENO PEÑA: “Burgos. Evolución histórica del espacio administrativo”. En Historia de Burgos, desde sus orígenes hasta nuestros días. Tomo I. Desde los orígenes al año 1000. Burgos, Diario 16 Burgos. 1993. (pp. 27 - 38).

35 J. L. MORENO PEÑA: "Burgos. La configuración física del espacio provincial”. En Historia de Burgos, desde sus orígenes hasta nuestros días. Tomo I. desde los orígenes al año 1000. Burgos, Diario 16 Burgos. 1993. (pp. $5-14$ ). 
comarca serrana presenta una morfología radicalmente alejada de aquella imagen tópica, mostrando una elevada altitud media, un alto grado de accidentación y una cierta heterogeneidad topográfica ${ }^{36}$. Así, por ejemplo, observamos que la mayoría de estos pueblos se encuentran situados por encima de los 1.000 metros sobre el nivel del mar, superando de forma holgada, en muchos casos, esta marca. Lo vemos por ejemplo en localidades como Monterrubio de la Demanda (1.223 m), Regumiel de la Sierra (1.220 m), Huerta de Arriba (1.202 m), Neila (1.175 m), Huerta de Abajo (1.166 m), Riocavado de la Sierra (1.147 m), Vilviestre del Pinar (1.140 m), Canicosa de la Sierra (1.127 m), Barbadillo de Herreros (1.126 m), Quintanar de la Sierra (1.117 m ), o Palacios de la Sierra (1.068 m),

De igual modo, podemos constatar también el hecho de que dentro de los pueblos estudiados, un buen número de ellos presentan pendientes con un desnivel medio igual o superior al 25\% en más del 40 \% de su término municipal. Sucede así en pueblos como Barbadillo de Herreros, Huerta de Arriba o Riocavado de la Sierra. Neila, por su parte, eleva esta proporción de pendientes de más de un 25 \% hasta el 75\% de su territorio, superando, además la mayoría de ellas el 40 \% de desnivel medio. En la zona más meridional, sin embargo, estos valores descienden significativamente, sobre todo en lo que se refiere al valor de las pendientes, que en muchos casos apenas llegan a un 5 \% de desnivel. Esto ocurre en muchas zonas de los términos municipales de Canicosa de la Sierra, Quintanar de la Sierra, Palacios de la Sierra, Vilviestre del Pinar o Regumiel de la Sierra. Por debajo de estos valores se encuentran los territorios de localidades como Castrillo de la Reina, Hacinas, Moncalvillo o Salas de los Infantes, las cuales sirven de tránsito hacía las áreas más planas del Cretácico Inferior y del Terciario.

Otro dato que nos confirma este carácter extraordinariamente accidentado de nuestro territorio, permitiéndonos al mismo tiempo intuir su heterogeneidad topográfica,

\footnotetext{
36 Análisis del medio físico de Burgos. Delimitación de unidades y estructura territorial. Valladolid, Junta de Castilla y León. Consejería de Fomento. 1988.
} 
lo vemos reflejado también en las diferencias que se dan entre las cotas máximas y mínimas de cada término municipal. Así, por ejemplo, dentro del territorio de Barbadillo de Herreros se pasa de los 1.100 metros en su zona más deprimida hasta los $2.132 \mathrm{~m}$. en su punto más alto; Canicosa de la Sierra, de 1.100 metros de mínima a 1.480 metros de máxima; Huerta de Arriba de 940 metros de mínima a 2.006 metros de máxima; Neila de 1.080 metros de mínima a 2.074 de máxima; Quintanar de la Sierra de 1.080 metros a 2.049 metros de máxima; Regumiel de la Sierra de 1.100 metros de mínima a 1.700 de máxima; Riocavado de la Sierra de 1.100 metros de mínima a 1.820 de máxima; Huerta de Abajo de 1.080 metros de mínima a 2.049 de máxima; y Vilviestre del Pinar de 1.080 metros de mínima a 1.380 de máxima. En el territorio que componen las llamadas Ledanías, administrado por los concejos de varios pueblos, igualmente encontramos una importante diferencia, pasando de 980 metros en su cota más baja hasta los 1.890 metros en la más elevada.

Todas estas características, unidas a la posición septentrional de la comarca dentro del mapa peninsular, y a su completo aislamiento del mar (privándola así de sus efectos suavizadores), terminan por influir tanto en el clima como en el medio ecológico. De esta forma, quedan condicionados terriblemente, no sólo las posibilidades de aprovechamiento económico de esta zona, sino también todos los aspectos relacionados con el desarrollo de la vida humana. Así, por ejemplo, las actividades agrícolas, que fueron tradicionalmente las más importantes en el resto de la provincia de Burgos, aquí difícilmente alcanzan un desarrollo suficiente, que permita mantener los niveles mínimos de subsistencia. Por ello, estos trabajos en el campo deben ser alternados, o incluso sustituidos en su totalidad, por otro tipo de actividades, entre las que destaca, por encima de todas, la ganadería lanar, explotada en este caso mediante el desarrollo de un particular sistema de traslado periódico de los ganados de unos pastos a otros, conocido como trashumancia. También destaca igualmente el uso y explotación que se realiza en muchos de estos pueblos de los recursos forestales, creándose con ello una característica forma de vida, que en muchos casos ha marcado el devenir de estas localidades hasta nuestros días. 
Al hilo de esto tenemos que recordar también, que, tanto la elevada altitud media, como la gran accidentalidad existente en este marco físico, termina por condicionar igualmente los asentamientos humanos, marcando tanto las características de su fisonomía, como la ubicación y distribución de cada uno de estos núcleos. Por ello aparece un paisaje salpicado de poblaciones, por lo general de pequeño o mediano tamaño, concentradas en determinados valles especialmente protegidos, con lo que se dejan amplias extensiones sin habitar.

La historia geológica de la zona, por lo tanto, no sólo condiciona las fisonomía de los asentamientos humanos, sino también las características de sus construcciones. Así, las condiciones climáticas y el medio ambiente del que hay que protegerse, unido a los materiales disponibles para la construcción, se convierten en dos de los más importantes factores, que marcan el desarrollo de la arquitectura en esta zona durante el periodo que estudiamos.

MORFOLOGÍA.

Toda nuestra comarca de estudios, como decimos, se halla encuadrada dentro del extremo noroccidental de la Cordillera Ibérica, constituyéndose en una unidad morfoestructural perfectamente definida. Una unidad formada por un poderoso núcleo paleozoico, en el que surgen las principales culminaciones de este relieve, el cual está rodeado, especialmente en su parte meridional, por una amplia orla mesozoica, que da lugar a una morfología de cuestas, con una formación estructural de pliegues con dirección N.O. - S. $E^{37}$.

La parte más destacada de este núcleo principal lo forma la Sierra de la Demanda, constituida, como apuntábamos, por un potente bloque paleozoico, rodeado

37 Análisis del medio físico de Burgos... ob. cit. (pp. 49 - 51). 
de bandas de materiales mesozoicos. Su parte central está constituida fundamentalmente por series de materiales cámbricos, ordovícicos y carboníferos, aflorando hacia la periferia sedimentos triásicos, jurásicos y cretácicos $^{38}$.

La elevada altitud de las cumbres, que alcanzan su techo en el pico San Millán con 2.131 metros (el punto más alto de la provincia de Burgos), hace que toda la región destaque nítidamente sobre el resto del territorio de la provincia, que se extiende mayoritariamente sobre la cuenca sedimentaria terciaria. No obstante, el proceso erosivo, que ha ido sufriendo esta sierra a lo largo del tiempo, ha terminado por dar lugar a unas cumbres redondeadas o aplanadas, aunque de accidentado relieve, merced a las fuertes pendientes, barrancos profundos y escarpes verticales, que hay que salvar para llegar al fondo de los valles ${ }^{39}$.

En la parte suroriental, y separados por el cauce del río Pedroso, estos relieves de la Cordillera Ibérica se prolongan para constituir la otra formación montañosa, que junto con la Demanda, permiten denominar a toda esta zona como la comarca de la “sierra”. Se trata de la Sierra de Neila, la cual sirve para marcar la transición hacia los Picos de Urbión, situados ya en la provincia de Soria. Esta sierra de Neila se encuentra moldeada en materiales calizos y cuarzareniscas del Jurásico, y presenta su máxima cota en el pico de la Campiña de 2.049 metros de altitud sobre el nivel del mar.

Los procesos glaciares de la última gran glaciación conocida, la de Würn, son los responsables de un cierto astillamiento y del modelado más enérgico en los escarpes septentrionales de estos macizos. Los intensos fríos de la glaciación cuaternaria afectaron, tanto a la Sierra de la Demanda, como a la de Neila, siendo objeto con ello de fuertes procesos morfogenéticos glaciares, que terminaron por propiciar relieves más tortuosos en las partes de mayor elevación, junto con algunas acumulaciones sedimentarias en las partes inferiores. Todo ello se refleja en la original presencia de

38 J. L. MORENO PEÑA: “Burgos en su espacio geográfico”. En Historia de Burgos I. Edad Antigua. Burgos. Caja de Ahorros Municipal de Burgos. 1985. (pp. 39 - 82). 
circos glaciares, nichos de nivación y acumulaciones de tipo morrénico, que podemos ver en la cara norte de la Sierra de Neila y en las elevadas paredes del pico San Millán. A esto tenemos que sumar también la presencia de singulares lagunas de origen evidentemente glaciar, que se han conseguido conservar, a pesar de la acción antrópica, en la susodicha Sierra de Neila.

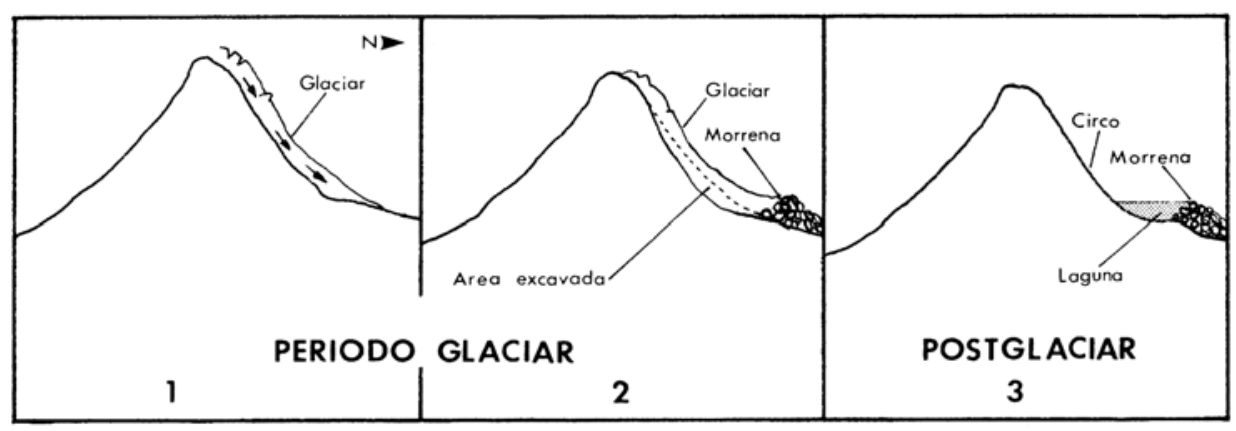

Modelo de formación de lagunas glaciares. (Según Atlas del medio físico de la ciudad de...)

Todo este complejo montañoso se organiza siguiendo una estructura de largos pliegues de dirección N. O. - S. E, a través de los cuales se establece el contacto entre el macizo paleozoico, que forma el núcleo central de la Sierra de la Demanda, y la cuenca sedimentaria del Terciario.

Al Oeste de las sierras, que forman la parte central y más característica de esta comarca, se abren paso los materiales plegados, que constituyen la orla mesozoica antes anunciada. Esta estructura, que podemos considerar como una segunda unidad morfológica, se extiende, en su mayor parte, fuera de nuestra zona de estudio, abarcando desde las tierras de Lara hasta la comarca de Pinares, ubicada en las laderas de la Sierra de Neila. Su estructura está compuesta por largos pliegues, que dan lugar a

39 Ibídem. 
un relieve, en parte conforme, pero también en muchos casos invertido. Se suceden así sinclinales colgados, bóvedas anticlinales y pasillos ortoclinales, que dan lugar a algunas elevaciones, en absoluto comparables a las existentes en el núcleo paleozoico de la Demanda y Neila, pero sí muy significativos por la verticalidad de sus pareces, como pueden ser la llamada Sierra de las Mamblas (1.412 metros), y la Sierra o Mesa de Carazo (1.458 metros) ${ }^{40}$.

Dentro de cada una de estas dos unidades morfológicas principales, que hemos destacado, podemos diferenciar a su vez distintas sub-unidades más pequeñas, las cuales presentan características muy similares en uno y otro caso ${ }^{41}$. Se puede hablar así de:

- Relieves principales: Constituidos por las laderas de fuerte pendiente, que forman la parte central de los principales núcleos montañosos.

- Relieves de tipo cuesta: Aparecen rodeando estas formas montañosas, constituyendo una amplia orla o enmarque en torno a ellas.

- Valles y depresiones: Caracterizados por un fuerte encajamiento en el caso de los valles, y por desarrollar formas estrechas y alargadas, en el caso de las depresiones.

Estas unidades son el resultado de una historia geológica dilatada y compleja, que se viene desarrollando a lo largo de cientos de millones de años hasta constituir las montañas y valles, que actualmente podemos contemplar. El punto de partida se encuentra en el viejo zócalo, que sirve de base para todo el futuro relieve peninsular. Este zócalo se hallaba completamente arrasado por las erosiones del periodo final del Primario, alterándose posteriormente por los consiguientes movimientos orogérnicos, que vienen a rejuvenecerlo ${ }^{42}$.

El primero de estos movimientos es el de la orogenia Herciniana, que se extiende desde el Carbonífero hasta el Premo-Trías, afectando a los materiales más

40 J. L. MORENO PEÑA: “La configuración física del espacio provincial...” ob. cit.

41 Análisis del medio físico de Burgos... ob. cit. (pp. 16). 
antiguos, localizados precisamente en la parte más abrupta de la Sierra de la Demanda. Se trata de una tectónica polifásica, caracterizada por el emplazamiento de estructuras plegadas, planares y lineales, de todos los tamaños y con acompañamiento de recristalizaciones metamórficas de facies epizonal. En total se han detectado tres fases orogénicas diferentes, destacando especialmente la primera, cuyos efectos se observan en los términos de Barbadillo de Herreros, Barbadillo del Pez y Riocavado de la Sierra, a través de sucesiones de pliegues ${ }^{43}$.

Durante la era Secundaria parte de este zócalo, formado por rocas plutónicas y metamórficas (como granito y gneis), y por sedimentarias y metamórficas del Primario (como areniscas, cuarcitas y pizarras), se ve cubierto por aguas de mar a consecuencia de las transgresiones marinas. Esto se manifiesta en una gran abundancia de fósiles marinos, conservados entre los diferentes mantos sedimentarios calizos de algunos puntos de nuestra comarca ${ }^{44}$.

En el Terciario, a causa de la orogenia Alpina, la placa del zócalo se fractura, dando lugar a una cadena de montañas salpicadas de varias líneas de fallas. Esta orogenia tiene su momento culminante en la parte final del periodo Oligoceno, iniciándose a partir de aquí la fase de relleno de las grandes cuencas terciarias, formadas como consecuencia de los hundimientos acaecidos en otras partes. Evidentemente esas zonas más elevadas, como consecuencia del rejuvenecimiento alpino, son las proveedoras de materiales, que terminan colmando estas cuencas sedimentarias ${ }^{45}$.

42 J. L. MORENO PEÑA: “La configuración física del espacio provincial...” ob. cit.

43 IGME. Mapa geológico de España. E. 1:50.000. Salas de los Infantes. Madrid. Servicio de Publicaciones del Ministerio de Industria. 1978. (pp. 21 - 24).

44 J. L. MORENO PEÑA: "La configuración física del espacio provincial..." ob. cit.

45 IGME. Mapa geológico de España. E. 1:50.000. Salas de los Infantes. ob. cit. (pp. 24 - 27). 
La evolución a lo largo del Cuaternario continúa con la conducción de los materiales erosionados en las zonas más elevadas, hacia las cuencas sedimentarias a través, fundamentalmente, de las redes fluviales. Lo más destacado, durante este último periodo, son las oscilaciones climáticas, que ahora se producen, las cuales propician el encajonamiento de la red fluvial, acompañada de una erosión lateral, que tiene su reflejo en la formación de terrazas. Sin embargo, este fenómeno no tiene una especial repercusión en nuestra zona, donde los cauces de los ríos presentan el característico encajonamiento, con valles en forma de $\mathrm{V}$, propio de los cursos altos. Mayor reflejo tiene, sin embargo, el otro gran fenómeno de este periodo, como es el de los retoques

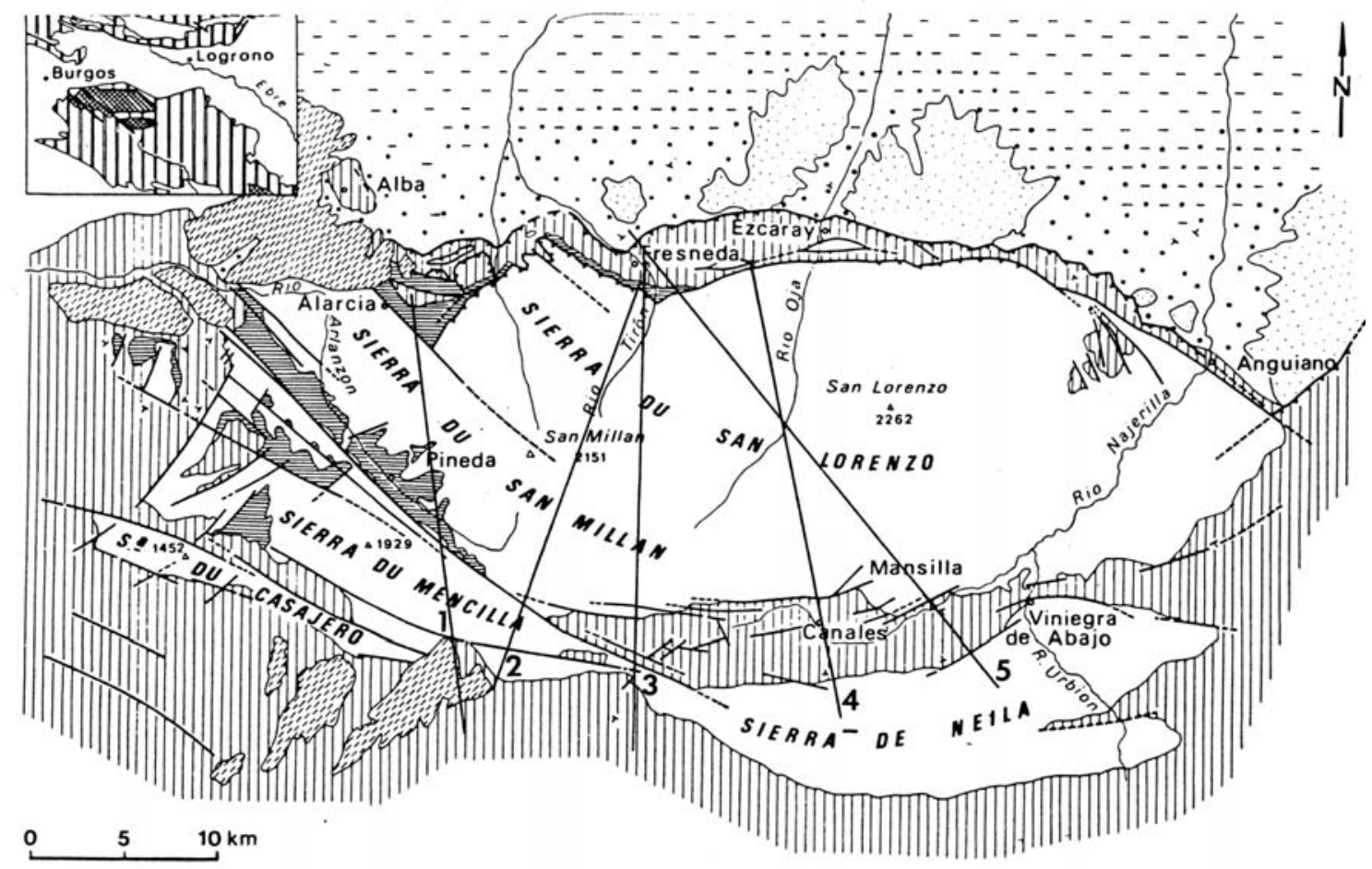

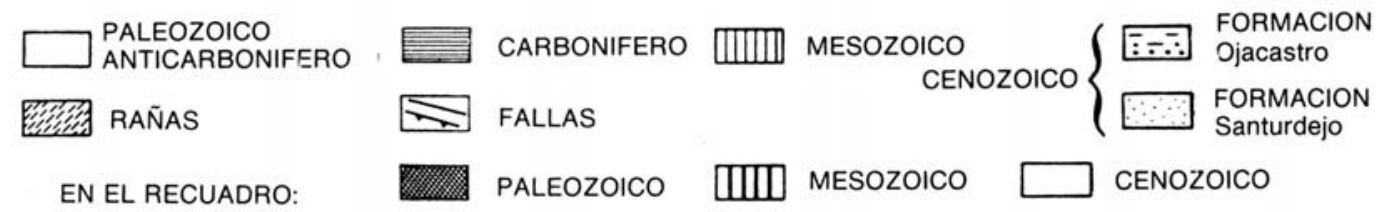

Esquema del Mapa Geológico de la Sierra de la Demanda y sus alrededores, según COLCHEN (1974). 
del modelado glaciar, que se produce, como hemos visto, durante la última gran glaciación. Este retoque se puede apreciar, tanto en el pico de San Millán, como en la cara septentrional de la Campiña, en la Sierra de Neila, dando lugar, en este último caso, al alojamiento de complejos lacustres, apoyados sobre los frentes de morrenas ${ }^{46}$.

\section{VARIEDADES LITOLÓGICAS.}

La variedad litológica que nos ofrece la comarca de la sierra resulta extraordinariamente amplia, encontrando representadas prácticamente todas las épocas geológicas. No obstante, y en virtud de la propia historia geológica, que acabamos de exponer, se reconoce un claro predominio de los materiales procedentes de las eras Paleozoica y Mesozoica, hallándose aquí, por lo tanto, los materiales más antiguos de toda la geografía de la provincia de Burgos.

Los materiales más antiguos que encontramos son los pertenecientes al Cámbrico, con una antigüedad aproximada de entre 500-600 millones de años. Estos materiales son los que forman el núcleo central de la Sierra de la Demanda, dentro de los cuales podemos diferenciar entre los pertenecientes al cámbrico inferior, medio y superior.

Evidentemente los más antiguos son los pertenecientes al Cámbrico Inferior, dentro de los cuales destacan las formaciones detríticas de groseras de Barbadillo del Pez, compuestas por metareniscas conglomeráticas. Los afloramientos más importantes de estos materiales se encuentran en el corte natural que ofrece el valle del río Pedroso en las inmediaciones de este pueblo, y su constitución petrográfica es muy variada,

46 J. L. MORENO PEÑA: “La configuración física del espacio provincial...” ob. cit. 
apareciendo fragmentos de rocas de cuarzo, feldespatos, micas y minerales opacos ${ }^{47}$. También son importantes, dentro de este período, las pizarras de Riocavado de la Sierra, que aparecen en las inmediaciones de este pueblo. Estas pizarras están constituidas por finas alternancias de areniscas y pizarras, con un claro predominio de estas últimas, las cuales muestran unos colores que van del gris azulado oscuro hasta gris verdoso ${ }^{48}$.

El Cámbrico Medio muestra esquistos y areniscas, destacando especialmente los esquistos areniscosos con lentejones calcáreos, seguidos por esquistos verdes, que aparecen en la parte más septentrional del término municipal de Barbadillo de Herreros.

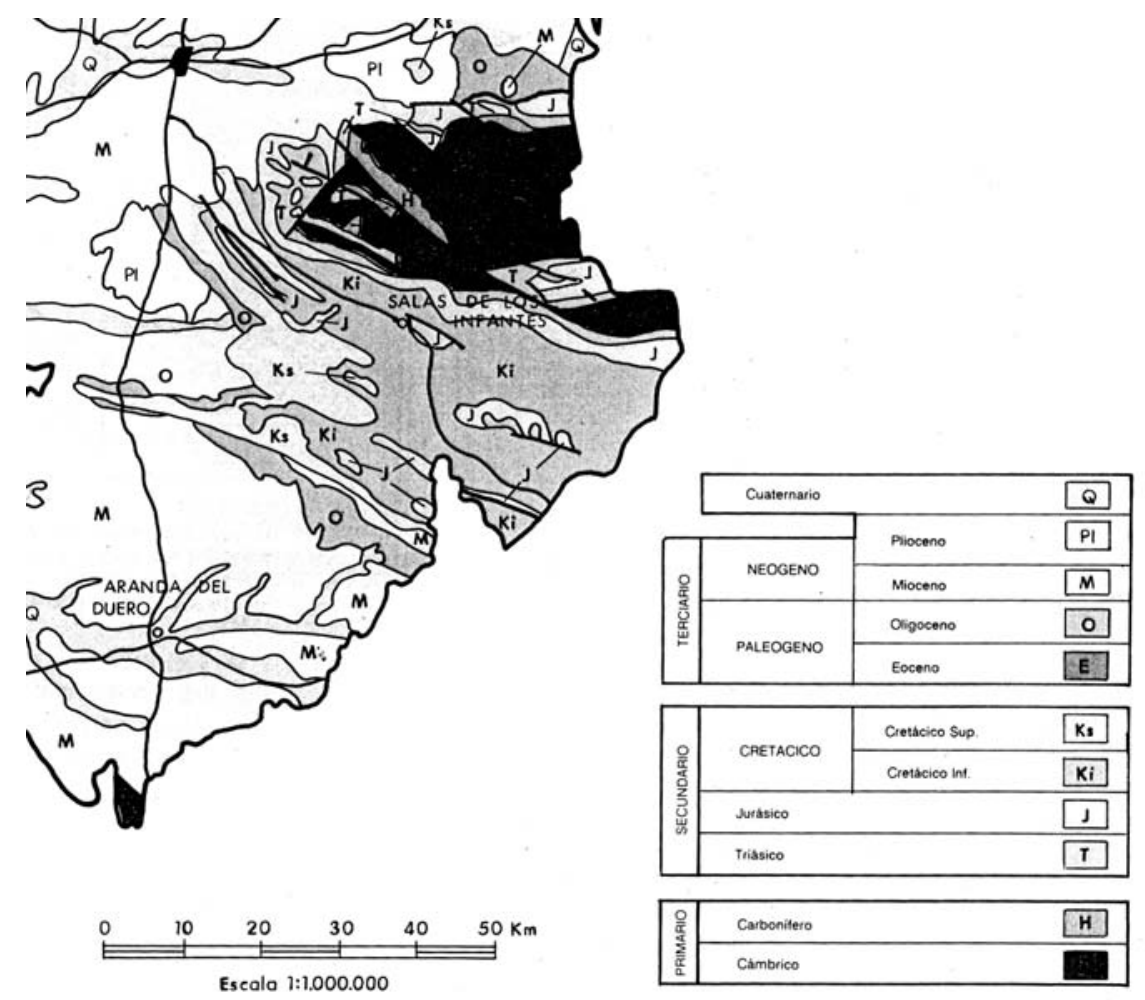

Mapa geológico de la comarca de la Sierra. (Según

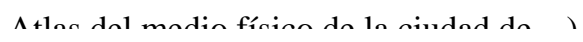

47 IGME. Mapa geológico de España. E. 1:50.000. Salas de los Infantes. ob. cit. (pp. 6 - 7). Atlas del medio físico de la ciudad de Burgos y su marco provincial. Madrid, Instituto Tecnológico Geominero de España. 1988. (pp. 23)

48 IGME. Mapa geológico de España. E. 1:50.000. Salas de los Infantes. ob. cit. (pp. 7 - 8). 
Gran parte de las areniscas pertenecientes a este período se caracterizan por ser extremadamente compactas, adquiriendo un color blanco con tonos rosáceos ${ }^{49}$.

El Cámbrico Superior, por su parte, se halla representado en la parte más occidental de la Sierra de la Demanda, mostrándose a través de esquistos gris azulados y areniscas con nódulos limolíticos ${ }^{50}$.

La época Ordovícica, con una antigüedad situada entre 440-500 millones de años, también cuenta con una pequeña representación dentro de la zona, constituyéndose al mismo tiempo en el único afloramiento de materiales de este periodo, que existe en la provincia de Burgos. Los materiales más representativos encontrados aquí tienen un carácter detrítico, entre los que se encuentran conglomerados cuarcíticos con algunas rocas volcánicas, acompañados por niveles areniscosos y nódulos limolíticos ${ }^{51}$.

El Carbonífero, con el que se cierra esta era Primaria, tiene también una presencia especialmente destacada, si bien su aparición se deja sentir de forma más acusada en la parte Noroeste de la sierra, quedando con ello parcialmente fuera de nuestra zona de estudio. Aun así, en algunos puntos muy concretos de los términos municipales de Barbadillo de Herreros, Monterrubio de la Demanda, o incluso del Valle de Valdelaguna, se pueden encontrar afloramientos de este periodo. Son materiales con una antigüedad de entre 270-350 millones de años, y entre ellos destacan series de conglomerados de clastos, areniscas, gravas, esquistos y diferentes capas de carbón, que han sido objetos de esporádicas explotaciones en distintos periodos ${ }^{52}$. Igualmente, dentro de estos estratos encontramos algunas finas capas de mineral de hierro, cobre y plomo, que también han sido aprovechados con una intensidad variada a lo largo del

\footnotetext{
49 Altas del medio físico de la ciudad de Burgos... ob. cit. (pp. 23 - 24).

50 Ibídem. (pp. 24).

51 Ibídem. J. L. MORENO PEÑA: “La configuración física del espacio provincial...” ob. cit.

52 Altas del medio físico de la ciudad de Burgos... ob. cit. (pp. 24 - 29). J. L. MORENO PEÑA: "La configuración física del espacio provincial...” ob. cit.
} 
tiempo ${ }^{53}$. Su presencia, sin llegar a condicionar la vida y la economía de estos pueblos, ha quedado grabada de forma indeleble en la toponimia de algunos de ellos, como es el caso de Barbadillo de Herreros o el despoblado de Villanueva de los Ferreros, que a través de sus nombres nos indican la existencia, desde antiguo, de determinadas actividades relacionadas con la explotación de estos recursos ${ }^{54}$.

La era Secundaria ofrece también una importante representación de materiales en esta comarca, los cuales se concentran fundamentalmente en la parte meridional, rodeando el núcleo paleozoico, que constituye la Sierra de la Demanda. Estos materiales son los siguientes en antigüedad, abarcando un periodo que va desde los 270 a los 70 millones de años, destacando al mismo tiempo, tanto por la amplia extensión que ocupan en nuestra zona, como por su variedad, ya que ofrecen muestras los diferentes periodos del Triásico, Jurásico y Cretácico ${ }^{55}$.

Dentro del Triásico, con una antigüedad de 270-180 millones de años, los niveles mejor representados son los del Buntsandstein y el Keuper, pues los del Muschelkalk apenas si tienen una pequeña presencia en el término municipal de Riocavado de la Sierra, mediante tenues manchas de calizas dolomíticas azules y blancas difícilmente cartografiables ${ }^{56}$.

El Buntsandstein aflora en forma de conglomerados brechoides con cantos cuarcíticos procedentes a las formaciones del Cámbrico subyacentes, si bien los materiales más característicos de este periodo son las areniscas de color granate, cuyo tono se debe a la oxidación del ión de hierro ${ }^{57}$. La presencia de este tipo de roca es especialmente importante para nuestro estudio, pues no en vano se convierte en uno de

53 M. GONZÁLEZ BUENO: Ferrerías de la Demanda burgalesa. Burgos. Excma. Diputación Provincial de Burgos. 1997.

54 J. PÉREZ CARMONA: “La historia y la geografía burgalesas reflejadas en su toponimia”. En BIFG, Burgos, $n^{\circ} 163$, (1964). pp. $238-271$.

55 J. L. MORENO PEÑA: “La configuración física del espacio provincial...” ob. cit.

56 IGME: Mapa geológico de España. E. 1:50.000. Salas de los Infantes. ob. cit. (pp. 10). 
los materiales de construcción más usados dentro de estos pueblos, tanto para la arquitectura civil como religiosa. Con ello la fisonomía de estos núcleos adquiere ese aspecto sumamente característico, que hace que su imagen prácticamente se funda con el terreno circundante ${ }^{58}$.

El Keuper, por su parte, lo encontraremos representado a través de margas y arcillas abigarradas de color rojizo, areniscas y yesos. Su presencia se aprecia sobre todo en la parte más oriental de la Sierra de la Demanda, si bien sus estratos en ningún caso alcanzan una potencia importante ${ }^{59}$.

El Jurásico, con depósitos de una antigüedad situada entre 180 y 130 millones de años, lo encontraremos en la zona más meridional y del sudoeste de nuestra comarca, en áreas como la Sierra de Neila y en la Sierra o Mesa de Carazo ${ }^{60}$. Dentro de los materiales pertenecientes a este periodo encontraremos una presencia destacada, tanto de las facies marinas, como continentales. Las facies marinas aparecen representadas con materiales del Lías y Dogger, mostrando sucesiones de carniolas, calizas y margas, con algunas series muy fosilíferas ${ }^{61}$, como las que encontramos en el triángulo formado por las localidades de Arroyo de Salas, Castrovido y Terrazas, donde aparece una gran abundancia de Lamelibranquios, Ammonites y Braquiópodos ${ }^{62}$. Todos estos materiales del Lías-Dogger pertenecen a los pisos Hettangiense, Sinemuriense, Pliensbanchiense, Toarciense, Bajociense y Bathoniense ${ }^{63}$.

\footnotetext{
57 Ibídem. (pp. 10). Altas del medio físico de la ciudad de Burgos... ob. cit. (pp. 29).

58 J. L. MORENO PEÑA: “La configuración física del espacio provincial...” ob. cit.

59 IGME: Mapa geológico de España. E. 1:50.000. Salas de los Infantes. ob. cit. (pp. 10). Altas del medio físico de la ciudad de Burgos... ob. cit. (pp. 29).

60 Altas del medio físico de la ciudad de Burgos... ob. cit. (pp. 29 - 30).

61 J. L. MORENO PEÑA: "Burgos en su espacio geográfico”... ob. cit.

62 Altas del medio físico de la ciudad de Burgos... ob. cit. (pp. 29). Museo Arqueológico Paleontológico de Salas de los Infantes.

63 J. L. MORENO PEÑA: “Burgos en su espacio geográfico”... ob. cit. IGME: Mapa geológico de España. E. 1:50.000. Salas de los Infantes. ob. cit. (pp. 11 - 13). IGME: Mapa geológico de España. E. 1:50.000. Quintanar de la Sierra. Madrid. Servicio de Publicaciones del Ministerio de Industria. 1978. (pp. $10-13)$.
} 
Las facies continentales, por su parte, están formadas por materiales detríticos y suelos predominantemente clásticos del Pürbeckiense-Wealdiense. Entre ellos aparecen materiales arenosos, alternados con gravas, conglomerados y algunas series arcillosas calizas y margosas ${ }^{64}$.

Finalmente los materiales del Cretácico, con una antigüedad de entre 130-70 millones de años, cierran esta era, ocupando una amplia extensión dentro del sector meridional de nuestra comarca. En nuestro caso, los materiales más abundantes son los correspondientes al Cretácico Inferior, que se muestra fundamentalmente a través de rocas calizas y algunas series de arenosas y margosas. Aquí, y dado el carácter especialmente resistente que tienen los materiales calizos - los cuales han sido modelados según las directrices de estructuras plegadas -, han llegado a originar, según vimos, formas de relieve invertido, como el que se muestra en la Peña de Carazo ${ }^{65}$.

La presencia de depósitos terciarios resulta extraordinariamente escasa, pues los lugares naturales de estos materiales, dentro de la geografía provincial de Burgos, son, como sabemos, la zona central, meridional y occidental, a las que se añaden las comarcas de la Bureba, Miranda de Ebro y parte del Condado de Treviño ${ }^{66}$. Queda fuera, de este modo, la comarca de la sierra.

La era Cuaternaria, por último, aporta los característicos materiales de gravas, formados por cantos rodados de cuarcita, y en menor medida calizas y matriz arcillosa, todo ello proporcionado por el efecto de la erosión, que efectúan especialmente los

\footnotetext{
64 J. L. MORENO PEÑA: "Burgos en su espacio geográfico”... ob. cit. Altas del medio físico de la ciudad de Burgos... ob. cit. (pp. 30) .IGME: Mapa geológico de España. E. 1:50.000. Salas de los Infantes. ob. cit. (pp. 11 - 19). IGME: Mapa geológico de España. E. 1:50.000. Quintanar de la Sierra. ob. cit. (pp. $14-15)$.

65 J. L. MORENO PEÑA: “Burgos en su espacio geográfico”... ob. cit.

66 Ibídem.
} 
ríos $^{67}$. No obstante, en esta zona, al tratarse de una área de montaña, y discurrir por aquí la parte más alta de los cauces fluviales, estos depósitos apenas son visibles. Lo que encontraremos en los lechos de estos ríos, por lo tanto, es una gran cantidad de gravas, pero formadas por rocas todavía de gran tamaño, las cuales en muchas ocasiones son usadas como material de construcción en aquellas edificaciones más humildes, como pajares y tenadas. La presencia de estas gravas de gran calibre es tan abundante, que llegan a conceder el nombre a algunos ríos, como ocurre con el Pedroso.

ESQUEMA EDAFOLÓGICO.

De alguna forma, y tras hablar de la variedad litológica existente en nuestra zona, debemos dar algunos breves apuntes sobre los tipos de suelos que aquí nos podemos encontrar. En este caso su diferenciación esta marcada por diversos factores, como son, las condiciones climáticas, la influencia del relieve, la acción química y mecánica de la vegetación, y por supuesto la acción antrópica, que se deja sentir especialmente a través de la implantación de la agricultura.

Dentro de las cuatro grandes variedades edáficas, que se dan en el marco de la provincia de Burgos, en nuestra comarca únicamente se encuentran representadas dos, como son los inceptisoles y los alfisoles ${ }^{68}$.

Los inceptisoles son un tipo de suelo medianamente evolucionado, que se extiende a lo largo de la mayor parte de la provincia de Burgos, si bien en nuestra zona de estudio su presencia es más bien discreta. La variedad de este suelo, que aparece en la comarca de la sierra, es la conocida como “ochrepts”, la cual, en función de la

67 J. L. MORENO PEÑA: "La configuración física del espacio provincial...” ob. cit. Altas del medio físico de la ciudad de Burgos... ob. cit. (pp. 32).

68 J. L. MORENO PEÑA: "Burgos. Elementos del complejo ecológico provincial”. En Historia de Burgos, desde sus orígenes hasta nuestros días. Tomo I. desde los orígenes al año 1000. Burgos, Diario 16 Burgos. 1993. (pp. 15 - 26). 
posición topográfica y las condiciones climáticas existentes, resulta extraordinariamente propicia para el uso forestal y el aprovechamiento pastoril ${ }^{69}$.

Los alfisoles, por su parte, son mucho más abundantes dentro de este marco espacial, caracterizándose por ser ligeramente ácidos, al mismo tiempo que resultan fuertemente ricos en minerales. Se trata de suelos formados, tanto a partir de materiales calizos, como silíceos, siendo denominados por ello genéricamente como suelos silíceos. En este caso, su gran permeabilidad y escasa fertilidad, unido al carácter extraordinariamente abrupto de la morfología de la zona, hace de ellos una superficie muy poco apropiada para la agricultura. Sin embargo, estas mismas condiciones hace que sea un espacio perfectamente adaptado para un aprovechamiento forestal, asentándose aquí grandes bosques de robles, hayas y especialmente pinos ${ }^{70}$.

\section{RED HIDROGRÁFICA.}

La compleja y abrupta orografía de esta comarca da lugar a un intrincado sistema hidrológico, compuesto por gran número de ríos de diferentes tamaños, arroyos y torrentes de cauce irregular, que discurren de forma rápida y sinuosa entre valles, por lo general, muy cerrados. Al ser una zona montañosa, perteneciente a uno de los grandes macizos de la península, como es la Cordillera Ibérica, las corrientes que surgen de aquí son tributarias de diferentes cuencas hidrográficas. Estas cuencas son las del Duero y el Ebro, vertiendo respectivamente, por lo tanto, hacia el océano Atlántico y el mar Mediterráneo. Sin embargo, y al contrario de lo que sucede en la mayor parte de esta zona noroccidental del macizo Ibérico, donde la gran mayoría de sus ríos vierten hacia el Ebro, el área que estamos estudiando queda encuadrada de forma mayoritaria

\footnotetext{
69 Ibídem.

70 J. M. G. KLEINPENNING: La región pinariega. Estudio geográfico del Noreste de Soria y Sudeste de Burgos (España). Groningen, Druk V. R. B. Kleine. 1962. (pp. 23 - 27).
} 
dentro de la cuenca del Duero ${ }^{71}$. De hecho observamos que solamente una pequeña zona, situada en el término municipal de Neila, es tributaria del Ebro. Se trata del valle del río Najerilla, que nace dentro del propio casco urbano de Neila, de donde toma el nombre para su tramo inicial el nombre de esta localidad. A este río vierten sus aguas otros dos ríos más pequeños, que nacen igualmente en el término municipal de Neila, como son el río Frío y el Prado del Valle ${ }^{72}$.

El resto de los ríos son tributarios de la cuenca del Duero. Dentro de ellos destacan especialmente dos, el Arlanza y el Pedroso, pues el Arlanzón, aunque nace en el término municipal de Riocavado de la Sierra, tiene un recorrido muy escaso en esta zona. Estos dos ríos nacen en el interior de estas sierras, el Arlanza en Fuentesanza, dentro del término municipal de Quintanar de la Sierra, y el Pedroso en término conocido como Casa la Sierra, en Barbadillo de Herreros, discurriendo por nuestra comarca, la parte más elevada y abrupta de sus respectivos cursos.

A estos dos ríos vierten sus aguas un nutrido número de pequeños ríos, arroyos y torrentes de flujo discontinuo a lo largo del año, incrementando rápidamente su cauce. En el caso del Arlanza los principales afluentes que tiene a lo largo de su recorrido por esta zona de la sierra son:

Río

$\begin{array}{ll}\text { Gargangas } & \text { Quintanar de la Sierra } \\ \text { Bañuelos } & \text { Palacios de la Sierra } \\ \text { Pescafrailes } & \text { Palacios de la Sierra } \\ \text { Palazuelo } & \text { Salas de los Infantes } \\ \text { Valladares } & \text { Huerta de Abajo } \\ \text { Vaquerizas } & \text { Huerta de Abajo } \\ \text { Zumel } & \text { Regumiel de la Sierra }\end{array}$

71 M. T. ORTEGA VILLAZÁN: El clima del sector norte de la Cordillera Ibérica: estudio geográfico de la Sierra de la Demanda a la del Moncayo. Valladolid, Secretariado de Publicaciones, Universidad. 1993. (pp. $19-21$ ). 
Vadillo Canicosa de la Sierra

Ciruelos Moncalvillo

En lo que se refiere a las aportaciones que recibe el río Pedroso destacan sobre todo las de los pequeños cursos de agua, como arroyos y torrentes. Por este motivo su volumen resulta sumamente irregular a lo largo del año, ofreciendo importantes diferencias de nivel de unos meses a otros. Aun así, dentro de sus afluentes tenemos que destacar algunos cursos importantes, como son el río Valdorcas, que nace en Riocavado de la Sierra, el Horquiza, en Barbadillo del Pez, el río de la Umbría, que viene desde Monterrubio de la Demanda, y el Quintanilla, que llega desde Huerta de Abajo. A ellos podemos unir otros cursos menores, entre los que se encuentran:

En Barbadillo de Herreros: el arroyo de la Avellaneda

$$
\begin{array}{ll}
\text { “ } & \text { de Campozares } \\
\text { “ } & \text { de Casa de la Sierra } \\
\text { “ } & \text { de Morales } \\
\text { “ } & \text { de la Secada }
\end{array}
$$

En Riocavado de la Sierra: el arroyo de Vallejo

En Barbadillo del Pez:

$$
\begin{aligned}
& \text { “ de Peñedos } \\
& \text { “ de Regatos } \\
& \text { “ de Aguas Vivas }
\end{aligned}
$$

El trazado de estos dos ríos principales, así como el de sus afluentes, al desarrollarse dentro de una zona montañosa, y constituir la parte inicial de sus cursos, presenta un carácter abrupto y sinuoso, debiendo salvar fuertes desniveles, que en el caso del río Pedroso está próximo a los 1.000 metros en poco más de 30 kilómetros. Esto lleva a que la erosión sea extraordinariamente agresiva, lo que hace que al entrar en contacto con materiales muy resistentes, como son, por ejemplo las pizarras del Cámbrico, surjan los característicos valles en V muy cerrados, llegando incluso a crear

72 Altas del medio físico de la ciudad de Burgos... ob. cit. 
profundos desfiladeros, como se ve en la garganta que se extiende entre los pueblos de Barbadillo de Herreros y Barbadillo del Pez.

En el caso del Arlanza, sin embargo, la ausencia de un desnivel tan pronunciado, unido a la existencia de unos materiales ligeramente menos resistentes a la erosión fluvial, lleva a que los valles resulten mucho más amplios, sin esas gargantas tan profundas, que advertíamos en el caso anterior.

La disposición de estos dos ríos es, al mismo tiempo, otro elemento a tener encuentra dentro de la estructura morfológica de esta comarca, pues juegan un destacado papel en la configuración del relieve. Así, vemos que el Pedroso es el elemento que sirve de frontera o límite entre los dos macizos más destacados de esta zona, como son la Sierra de la Demanda y la Sierra de Neila. El Arlanza, por su lado, sirve para crear un paisaje muy característico, dentro de nuestra zona de estudio, como es el de las colinas de perfiles más suaves y valles de trazado amplio, que se desarrolla sobre los materiales de la orla Mesozoica, que rodean el núcleo principal de estas sierras.

El caudal de estas corrientes se encuentra terriblemente condicionado por el clima y el régimen de precipitaciones. Esto hace que presenten en general una gran irregularidad, con notables oscilaciones a lo largo del año, en función de los periodos de máximas y mínimas lluvias $^{73}$. De este modo, se pasa desde los niveles extraordinariamente bajos en el verano, coincidiendo con la aridez estival, hasta cotas muy altas en los meses de invierno, cuando se producen las máximas pluviométricas y sobre todo el deshielo. Estos fenómenos llegan a provocar con cierta frecuencia súbitas subidas en los cauces de estos ríos, desbordando su curso normal y originando con ello inundaciones en varias localidades. Evidentemente las consecuencias de estos fenómenos resultan más graves en aquellas poblaciones situadas en la parte media y baja de estos cursos, donde los ríos ven incrementar su caudal de forma importante con

73 Ibídem. (pp. 58 y ss.). 
las aportaciones de sus afluentes. Por ello en núcleos como Salas de los Infantes las inundaciones se convierten en un acontecimiento casi habitual, repitiéndose en no menos de dos ocasiones a lo largo del año ${ }^{74}$.

A parte de esta red superficial, dentro de estas cuestiones hidrográficas, no menos importantes son también los aspectos relacionados con la red de aguas subterráneas. Se trata, en este caso, de un campo mucho menos investigado, pero de una gran importancia para nuestro estudio sobre el desarrollo arquitectónico durante la Edad Moderna.

En esta zona los elevados índices medios de precipitaciones (superiores a los del resto de las comarcas de la provincia de Burgos, si exceptuamos las montañas del Norte, pertenecientes a la Cordillera Cantábrica), y la fuerte permeabilidad de gran parte de los suelos, lleva a que sean relativamente abundantes los cursos de aguas subterráneas. Su presencia en el subsuelo de estas localidades trae importantes consecuencias dentro de la actividad constructiva, determinando en definitiva el devenir de muchos edificios.

Este fenómeno se encuentra bastante bien documentado en el caso de la arquitectura religiosa. Así, vemos cómo uno de los principales enemigos que tienen los templos de muchos de estos pueblos es el de las humedades, repercutiendo, tanto en la estabilidad de la estructura arquitectónica del edificio, como en la imposibilidad de realizar enterramientos en su interior, como era costumbre.

El origen de esto se encuentra en el hecho de que muchos de estos edificios se asientan sobre laderas más o menos pronunciadas, lo que obligó a excavar sobre el propio terreno con el fin de conseguir una superficie lo más horizontal posible. Con ello lo que se conseguía frecuentemente era romper mantos freáticos, existentes en el

\footnotetext{
74 Nosotros en el curso de esta investigación hemos podido constatar y sufrir en nuestras propias carnes los efectos de algunos de estos episodios, comprobando las proporciones que pueden llegar a alcanzar.
} 
54 Arquitectura de la Edad Moderna en la sierra burgalesa.

subsuelo, por los que circulaban abundantes cursos de agua, que acababan afectando al templo.

Sin duda, uno de los ejemplos más elocuentes de esto que estamos describiendo lo encontramos en la iglesia parroquial de San Pedro, en Monasterio de la Sierra, donde el manto freático cortado tras allanar la superficie sobre la que se asienta este templo, se convierte en un manantial de abundantes aguas, adosado a su muro septentrional. El curso de estas aguas terminó por cruzar el subsuelo del edificio, provocando con ello una humedad tan fuerte, que impedía de todo punto realizar los enterramientos en su interior. El remedio a esta grave situación parecía difícil, por lo que, después de numerosos intentos de solventar el problema, a finales del siglo XVIII se llegó a tomar la drástica determinación de reconstruir totalmente el templo, no sin antes sanear convenientemente este subsuelo. Para ello, se desvió el agua del manantial a través de diferentes conductos trazados en torno al edificio ${ }^{75}$.

Pero este no es el único caso de este tipo que tenemos, pues ejemplos muy parecidos se producen en varias localidades. En Arroyo de Salas ${ }^{76}$ su iglesia tuvo que

75 AGDBU. LP. Monasterio de la Sierra, parroquia de San Pedro Apóstol. LF. (1776 - 1838), (fols. 35 $\mathrm{v}^{0}-38 \mathrm{v}^{0}$ ). Visita realizada a la parroquia de San Pedro en Monasterio de la Sierra en 1791, por D. Manuel María Izquierdo. Barbadillo del Mercado, 10 - noviembre - 1791. Y por quanto el tiempo que su merced visitó la referida iglesia reconoció que con las muchas humedades que ocasiona el encañado de aguas, que se conduce por debajo de su pabimento desde un pozo o fuente que sube para el surtido del pueblo se causa gravísimo perjuicio tanto en los cimientos y material del edificio quanto a las ropas, ornamentos y vasos sagrados mandaba y mando su merced que con la mayor brevedad disponga dicho cura si fuere posible condenar dicho conducto y dirigir las aguas por otra parte distante de la iglesia construyendo a este fin otro cañal que evita perjuicio de tercero, según hállase por más combeniente el maestro, périto de quien se valga para la obra, procurando ajustarla con la mayor equidad y perfección, de modo que quede con seguridad, y esempta de dichas humedades y peligro de ruina, a cuio fin en caso necesario se le concede lizencia

76 AGDBU. LP. Arroyo de Salas, parroquia de San Julián. LF. (1682 - 1718), (fols. 41 - 44 vº). Visita realizada a la parroquia de San Julián en Arroyo de Salas en 1694, por D. Juan de Caabro. Salas de los Infantes, 9 - septiembre - 1694; Ibídem. LF. (1721 - 1769). Visita realizada a la parroquia de San Julián en Arroyo de Salas en 1726, por D. Andrés Fernández de Tejada. Salas de los Infantes, 16 de septiembre $-1726$. 
ser parcialmente reconstruida en diferentes ocasiones a causa de las humedades. En la parroquial de San Martín en Huerta de Arriba la capilla románica de Nuestra Señora estuvo a punto de ser demolida ${ }^{77}$, mientras que la sacristía tuvo que ser reconstruida por este mismo motivo en $1761^{78}$. En la iglesia de Santa Eulalia de Palacios de la Sierra, las humedades obligaron igualmente a construir una sacristía completamente nueva en $1730^{79}$.

La solución, que se llevó a cabo en muchos casos para evitar este problema, consistió en crear el propio suelo sobre el que levantar estos templos. Para ello se edificaron potentes muros de contención en cuyo interior se depositaba la tierra suficiente para formar la sólida base sobre la que erigir el templo. Los ejemplos son muy numerosos, entre los que destacan las iglesias de Barbadillo de Herreros, Canicosa de la Sierra, Castrillo de la Reina, Hoyuelos de la Sierra, Huerta de Abajo, Monterrubio de la Demanda, Quintanar de la Sierra, Neila (San Miguel), Salas de los Infantes (Santa María y Santa Cecilia), Tolbaños de Abajo o Vilviestre del Pinar.

Otra alternativa a esto la encontraremos en la elección de un substrato rocoso

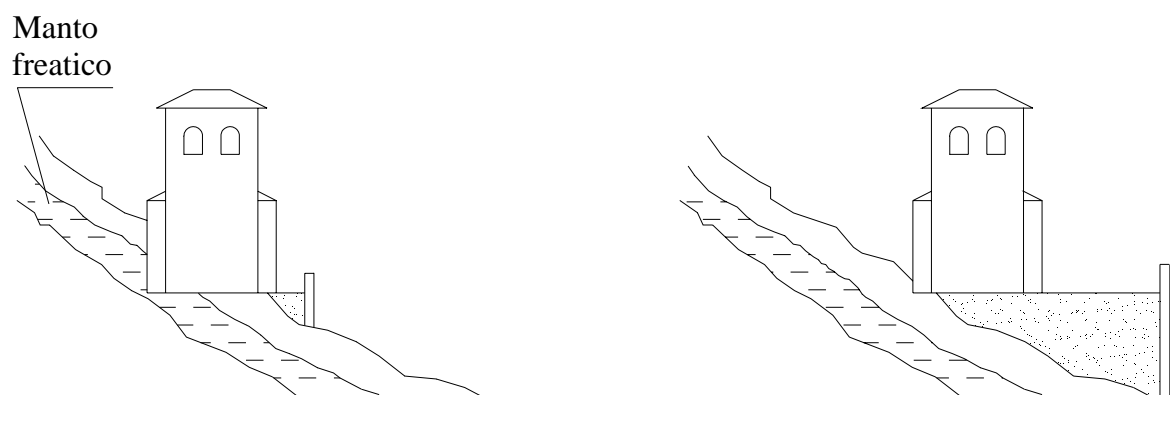

Modelos de asentamiento sobre un terreno inclinado.

77 AGDBU. LP. Huerta de Arriba, parroquia de San Martín. LF. (1723 - 1778). Visita realizada a la parroquia de San Martín en Huerta de Arriba en 1744, por D. Diego de Escalona. Canales20 - mayo 1744.

78 Ibídem. Visita realizada a la parroquia de San Martín en Huerta de Arriba en 1761, por D. Andrés Pérez Bracho. Huerta de Arriba, 27 - mayo - 1761.

79 AGDBU. LP. Palacios de la Sierra, parroquia de Santa Eulalia. LF. (1728 - 1770). Visita realizada a la parroquia de Santa Eulalia en Palacios de la Sierra en 1730, por D. Luis de Alaro. Palacios de la Sierra, 1 - junio - 1730 . 
como superficie sobre la que edificar estos templos, consiguiendo así dar una gran estabilidad al edificio, al mismo tiempo que se lograba evitar las humedades. Los ejemplos más destacados en este caso los hallamos en las iglesias de Hacinas, Moncalvillo y Regumiel de la Sierra, encontrándolo también reflejado en parte del templo parroquial de Castrillo de la Reina, y en la cabecera de las iglesias de Canicosa de la Sierra y Vilviestre del Pinar.

En la arquitectura civil este fenómeno se encuentra peor documentado, si bien, tanto los efectos de las aguas subterráneas, como las soluciones adoptadas, intuimos que fueron las mismas. La única singularidad, que podemos destacar en este caso, es la apertura de pozos en la parte interior de la planta baja de algunas casas. Estos pozos debieron surgir con toda seguridad durante el proceso de cimentación de los edificios, siendo utilizados en un primer momento como foco aglutinador de las humedades del subsuelo sobre el que se estaba levantando la casa, y posteriormente como fuente para abastecer de agua a sus moradores.

CLIMA.

El estudio del clima es otro de los aspectos importantes a tener en cuenta dentro del estudio que estamos llevando acabo, pues no en vano se convierte en un factor fundamental dentro de la actividad constructiva, determinando, no tanto las tipologías desarrolladas, como la forma de edificarlas.

El clima característico, dentro de la mayor parte de nuestra zona, es el típico de montaña, el cual se ve determinado, tanto por el relieve - altitud y desniveles -, como por la situación de la comarca dentro de la península Ibérica. Así, la energía de este relieve, con grandes y bruscos desniveles en pocos kilómetros, y la elevada altitud media de la zona, se manifiestan en el clima principalmente a través de una profunda 
reducción de los valores térmicos, reflejado especialmente en las temperaturas mínimas, y en una gran dificultad para alcanzar temperaturas elevadas en las máximas ${ }^{80}$.

Por su parte, el papel que juega su situación dentro del mapa penínsular no es menos importante, ya que su posición septentrional y su disposición elevada con respecto a las tierras llanas que la rodean, condicionan la llegada de las masas de aire, afianzando así su continentalidad. A ello debemos sumar también su relativo alejamiento del mar, unido a la ubicación de estos pueblos en la cara meridional de esta cadena montañosa, lo cual priva a la zona de la influencia de los efectos atemperantes marinos. De esta forma, las masas de aire que aquí llegan se encuentran fuertemente desvirtuadas, dándose con ello una menor inercia suavizadora entre periodos fríos y cálidos, así como un volumen de precipitaciones más elevado que en las zonas llanas, aunque sensiblemente por debajo de las registradas en la cara septentrional de estas mismas sierras. Aun con todo, esta zona no se libra de padecer una cierta aridez estival más o menos acusada. De esta forma, la fuerte evapotranspiración que se registra durante los meses de verano impide que podamos hablar de un clima húmedo o atlántico, mostrando por ello un carácter más próximo al de las regiones mediterráneas ${ }^{81}$.

Por lo tanto, la acción combinada de estos dos factores (relieve y situación), propicia el desarrollo de un clima propio de montaña, caracterizado por largos y duros inviernos, veranos cortos y frescos, y unas estaciones equinociales poco definidas o prácticamente inexistentes. Junto a esto el rasgo más característico del clima es el frío, que destaca tanto por su intensidad, como por su duración, degenerando en ocasiones en fuertes y prolongadas heladas, que condicionan profundamente el desarrollo de la vida en todo el territorio.

${ }^{80}$ M. T. ORTEGA VILLAZÁN: El clima del sector norte de la Cordillera Ibérica... ob. cit. (pp. 31 35).

81 Ibídem. (pp. 35 - 39). 
En un análisis de este clima por estaciones descubrimos, que el invierno es el periodo más destacado de todos, caracterizándose fundamentalmente por la intensidad de los fríos, y por la excesiva duración de los mismos, ya que abarca más de la mitad de los meses del año. El rigor térmico, como estamos viendo, es el rasgo más destacado de este clima durante todo el año, pero especialmente en invierno, así, son muy frecuentes los registros negativos en las temperaturas medias dentro de las mínimas desde el mes de noviembre hasta abril, mientras que las máximas difícilmente pasarán de los $10^{\circ} \mathrm{C}$. Además con cierta frecuencia se dan casos extremos en los que, ni las mínimas ni las máximas consiguen superar los $0^{\circ} \mathrm{C}$. Sin embargo, lo accidentado del relieve, y los fuertes contrastes existentes entre zonas elevadas y deprimidas, permiten crear espacios, donde el comportamiento térmico se aproxima bastante al de las comarcas llanas.

En general enero es considerado el mes más frío, pues las medias de las mínimas no llegan a superar los $0^{\circ} \mathrm{C}$, alcanzando las mínimas absolutas en algunos casos valores de hasta $-20^{\circ} \mathrm{C}$. Además, estos fríos generales, y hasta cierto punto habituales, se pueden llegar a agravar ocasionalmente por la presencia de determinados fenómenos, como las coladas árticas, procedentes del Polo Norte, o las más frecuentes y temidas olas de frío, que provocan las bajadas térmicas más espectaculares ${ }^{82}$.

El otro rasgo característico de los inviernos es su larga duración, pues durante más de seis meses al año en ningún punto de nuestra comarca las medias superan los $10^{\circ} \mathrm{C}$. En zonas del interior esta situación se puede prolongar incluso otros dos meses más. Un reflejo de este frío continuado se aprecia en el gran número de meses durante el año susceptibles de sufrir heladas, con las consecuencias que esto tiene, especialmente en los ciclos vegetales, perjudicando notablemente el desarrollo de la actividad agrícola $^{83}$.

\footnotetext{
82 Ibídem. (pp. 55 - 70).

83 Ibídem. (pp. 90 y ss.).
} 


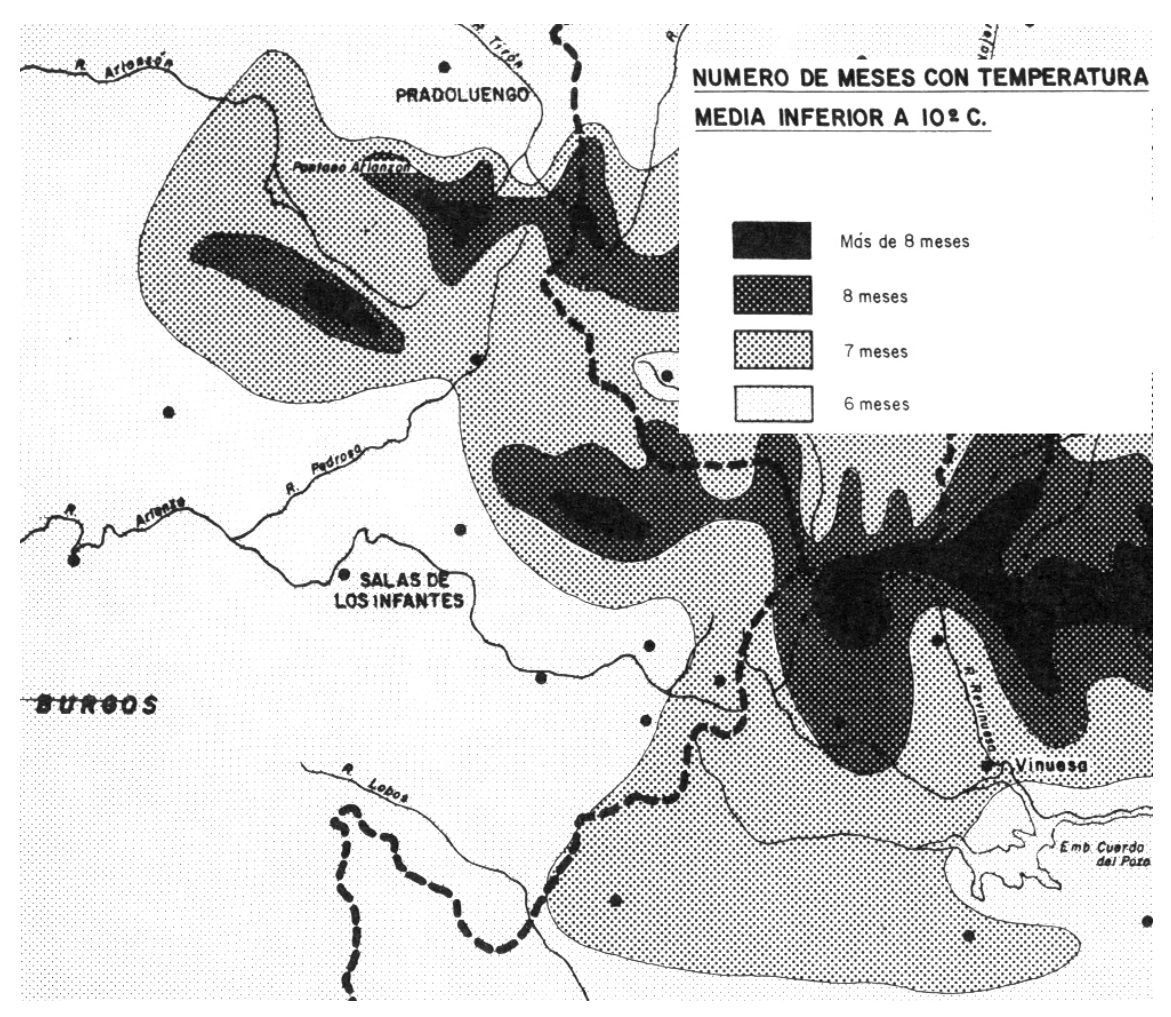

Mapa según Mª T. ORTEGA VILLAZÁN.

La excesiva duración de los fríos invernales hace que las estaciones intermedias se encuentren mal definidas. Así, a su corta duración se suma también una escasa definición, sirviendo simplemente para anticipar o prolongar el invierno. La constante, durante estos períodos, son los cambios frecuentes del tiempo, alternando los días cálidos con los días fríos, y los lluviosos con los secos.

Dentro de estas estaciones la primavera se caracteriza por su brevedad, convirtiéndose en muchos casos en una mera prolongación del invierno. La llegada de esta estación viene marcada por un significativo ascenso térmico, con medias superiores a los $10^{\circ} \mathrm{C}$, lo cual se consigue cuando las máximas empiezan a alcanzar valores más altos, y las mínimas no son tan bajas. Esto suele ocurrir en torno al mes de mayo, sin embargo, la irregularidad, que aquí se da, suele ser la nota dominante, pues en estas fechas aun no ha desaparecido el riesgo de heladas. Por ello, junio es el único mes 
propiamente primaveral, que se conoce dentro de esta zona, pues aquí el riesgo de heladas es ya muy reducido, las temperaturas máximas superan normalmente los $20^{\circ} \mathrm{C}$, y las mínimas difícilmente quedan por debajo de los $0^{\circ} \mathrm{C}$. No obstante, dentro de esta generalización debemos tener en cuenta la elevada altitud de la zona, y sobre todo la propia dinámica atmosférica, que puede llegar a ocasionar súbitos descensos térmicos en estas fechas tan avanzadas ${ }^{84}$.

El otoño se desarrolla aproximadamente entre los meses de septiembre y octubre, si bien, la prolongación de los calores del verano, o el adelanto del invierno, puede propiciar la reducción de este período. En este caso, es el descenso de las temperaturas el que nos indica la llegada del invierno, si bien, dentro de la estación otoñal, el mes de septiembre consigue mantener unas medias relativamente moderadas con unos valores de unos $10^{\circ} \mathrm{C}$. No ocurre lo mismo con el mes de octubre, el cual difícilmente ofrece máximas absolutas por encima de los $20^{\circ} \mathrm{C}$, mientras que el riesgo de las heladas vuelve a aparecer de nuevo. En cualquier caso, este descenso de temperaturas se produce de un modo más gradual, y no de forma tan brusca como el ascenso primaveral, con lo cual esta estación se encuentra algo mejor definida ${ }^{85}$.

Por último, los veranos se caracterizan por ser extremadamente cortos y frescos, extendiéndose a lo largo de los meses de julio y agosto, pues son los únicos en los que las medias de las máximas superan los $20^{\circ} \mathrm{C}$, mientras que las medias de las mínimas no bajan de los $9^{\circ} \mathrm{C}$. El carácter fresco de estos veranos viene dado por el hecho de que en nuestra zona no existe ni un solo punto en el que se consiga superar la isoterma de los $20^{\circ} \mathrm{C}$ de media en ningún momento. Así, por ejemplo, Quintanar de la Sierra, que es el pueblo mejor estudiado en este sentido, presenta unas medias de $17^{\prime} 8^{\circ} \mathrm{C}$ para julio y $17^{\prime} 7^{\circ} \mathrm{C}$ para agosto, según las mediciones efectuadas entre los años $1951-65^{86}$.

\footnotetext{
84 Ibídem. (pp. 117 - 129).

85 Ibídem. (pp. 129 - 140).
} 


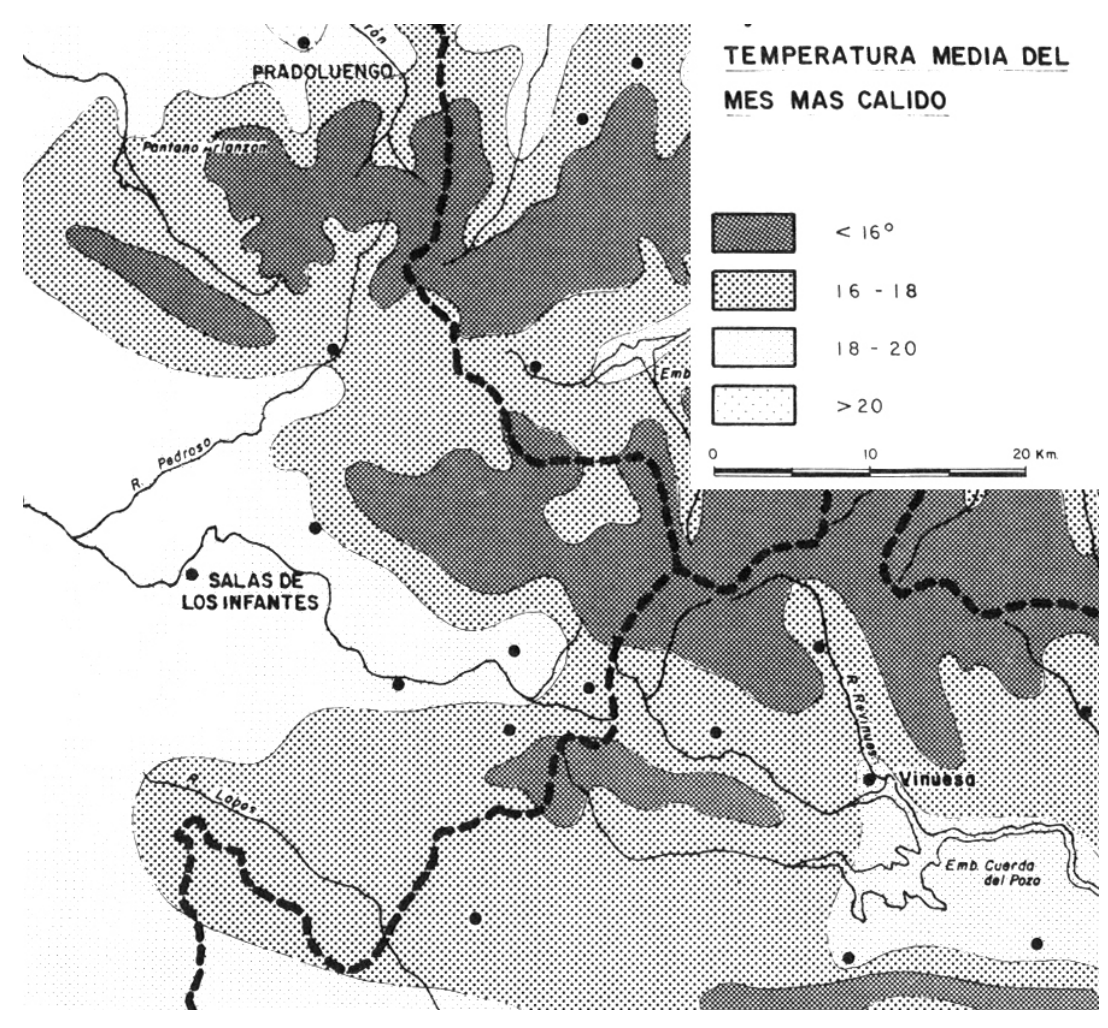

Mapa según $M^{a}$. T. ORTEGA VILLAZÁN.

El relieve, no obstante, se convierte en el condicionante más importante, dentro de esta circunstancia, pues la fuerte altitud media impide una gran elevación de las temperaturas. Junto a ello, la orientación de esta zona juega también un papel no menos destacado, pues como indicábamos anteriormente, la posición de estos pueblos en la parte meridional de la Cordillera Ibérica impide la llegada de los efectos atemperantes de los vientos marinos. Con ello, las oscilaciones diarias son excesivamente amplias, hasta el punto de convertirse en otro de los rasgos característicos de este clima, pues impiden que las medias puedan alcanzar valores medianamente altos. Estas oscilaciones

86 P. GIL ABAD: Quintanar de la Sierra, un pueblo de la comarca de pinares. Burgos, Excma. Diputación Provincial de Burgos. 1986. (pp. 38 y ss.). 
pueden llegar en algunos pueblos, como Quintanar de la Sierra, hasta casi los $18^{\circ} \mathrm{C}$ de diferencia entre las máximas y las mínimas registradas dentro de un mismo día ${ }^{87}$.

Otro aspecto importante a tener en cuenta, dentro del clima, son las precipitaciones, cuyos índices vuelven a estar marcados, al igual que las temperaturas, tanto por la localización de la zona, como por su propia configuración morfológica.

Aquí, la situación interior y su ubicación en la vertiente meridional de este macizo montañoso, llevan a que la humedad sea significativamente menor que la registrada en la fachada septentrional de esta misma cordillera. Esto se ve agravado, además, por la pantalla que forman las montañas de la Cordillera Cantábrica, que impide la llegada directa de los vientos húmedos del Norte, desarrollándose el llamado efecto de "sombra pluviométrica". Por ello, vemos que a pesar de tratarse de una zona elevada, situada en la parte septentrional de la península, difícilmente se consiguen superar los $1.000 \mathrm{~mm}$ de media anual en ninguno de los pueblos que aquí estamos estudiando $^{88}$. No obstante, las medias en casi todos los casos superan los $800 \mathrm{~mm}$ de media anual, siendo muy pocos los pueblos que quedan por debajo de esta línea, como es el caso de Canicosa de la Sierra $\left(786^{\prime} 5 \mathrm{~mm}\right)$ o Salas de los Infantes (646 mm ${ }^{89}$.

La configuración morfológica es el otro gran factor que incide en estos niveles pluviométricos. Así, según los estudios realizados sobre esta zona, debemos suponer que en función del relieve, por cada 100 metros de altitud el incremento aproximado de precipitaciones es de unos $111 \mathrm{~mm}$ aproximadamente ${ }^{90}$. No obstante, son muchas las variables que pueden alterar estas estimaciones medias, actuando también aquí otros factores como por ejemplo, la latitud, las pendientes, la exposición, la orientación, etc ${ }^{91}$.

\footnotetext{
87 Ibídem.

88 M. T. ORTEGA VILLAZÁN: El clima del sector norte de la Cordillera Ibérica... ob. cit. (pp. 183 191).

89 Ibídem.

90 Ibídem. (pp. 193).

91 Ibídem. (pp. 193 - 203).
} 


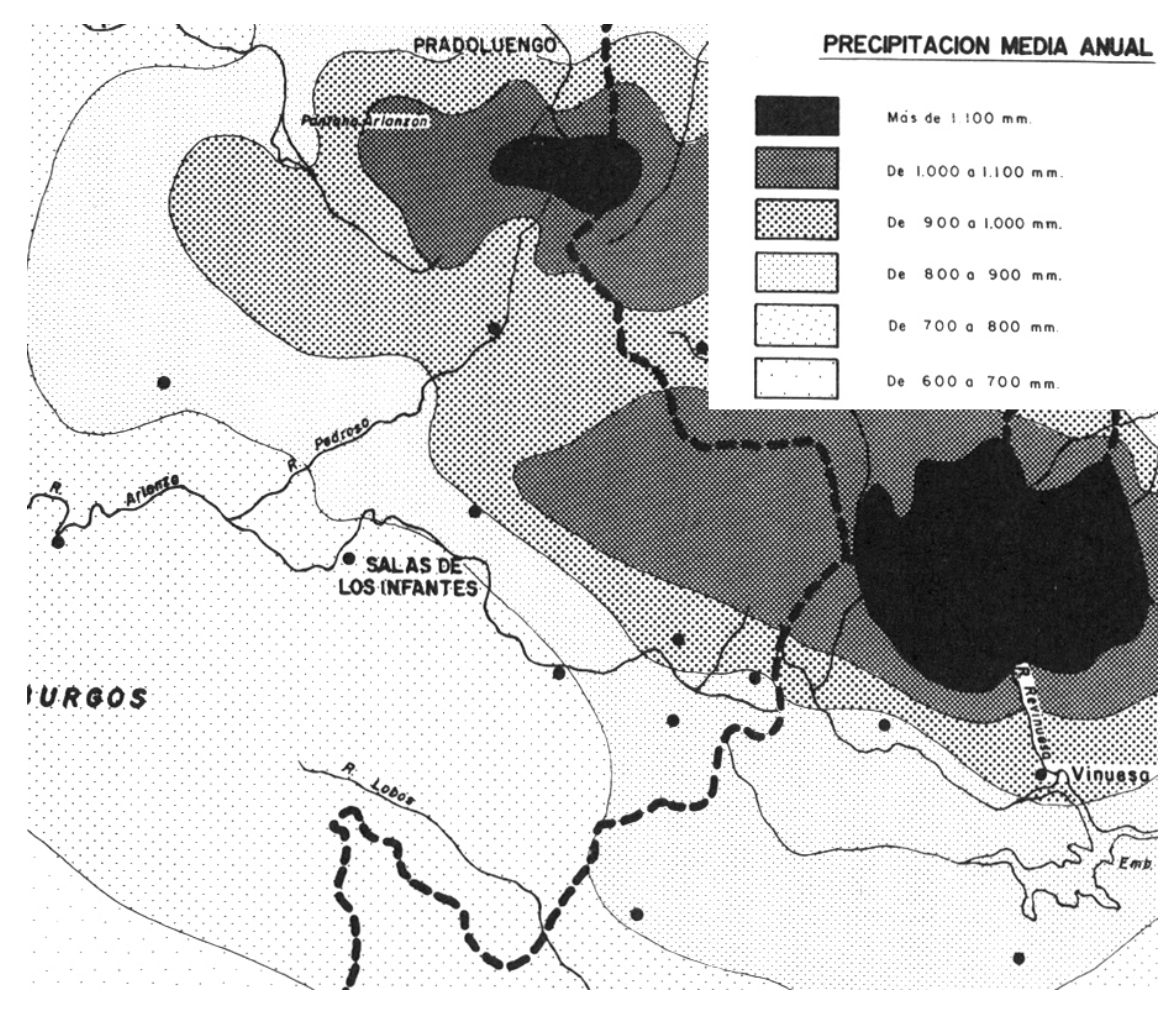

Todos estos factores hacen que el régimen de precipitaciones no alcance los niveles de las tierras del norte de la provincia de Burgos, situadas en la Cordillera Cantábrica, donde participan de un clima típicamente atlántico ${ }^{92}$. Pese a todo, nuestra comarca ha logrado constituirse como una zona de humedad consolidada. Así, en estos pueblos el número medio de días con precipitaciones a lo largo del año resulta relativamente elevado, situándose la mayoría de ellos entre los 110 y 120 días al año, siendo muchos además los que superan estas cifras. Al mismo tiempo, en ningún caso se baja de los 95 días de precipitaciones ${ }^{93}$.

El reparto de estas lluvias a lo largo del año es además relativamente equilibrado, de tal forma que sólo los meses de verano (julio y agosto) se registran, en

\footnotetext{
92 J. L. MORENO PEÑA: "Burgos. Elementos del complejo ecológico provincial”. Ob. cit.

93 M. T. ORTEGA VILLAZÁN: El clima del sector norte de la Cordillera Ibérica... ob. cit. (pp. 201 215).
} 
algunos casos, índices por debajo de los $30 \mathrm{~mm}$, localizándose, por el contrario, los niveles más altos en los meses centrales del invierno. El hecho de que este fuerte descenso pluviométrico coincida además con un periodo de fuerte evapotranspiración lleva a que se produzca una cierta aridez estival, que llega, en algunas zonas, a provocar un pequeño agostamiento de la vegetación ${ }^{94}$.

Este reparto más o menos equilibrado de las precipitaciones a lo largo del año se complementa con una elevada regularidad interanual, pues en ningún caso se producen diferencias superiores al 20\%, mientras que en las zonas mediterráneas y central de la península se llega a superar el 30 ó el 35\% entre unos años y otros ${ }^{95}$.

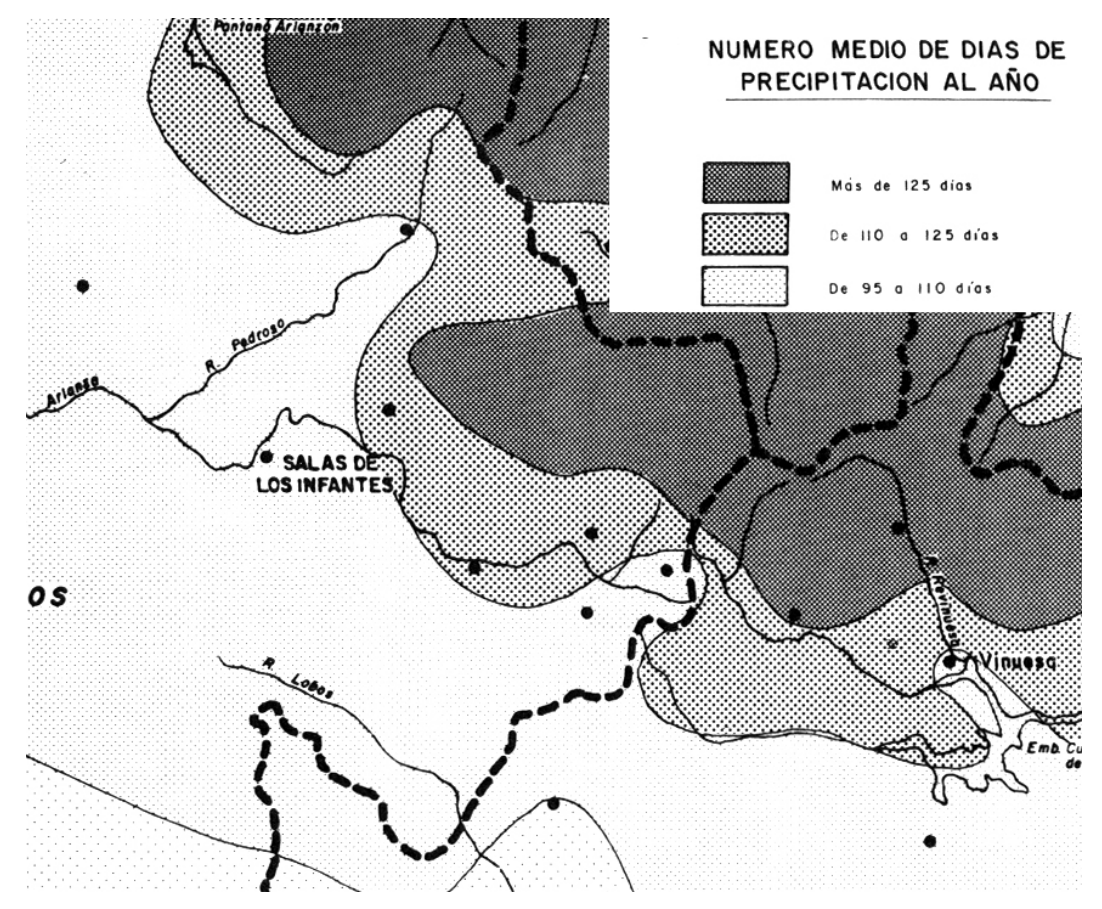

Mapa según $M^{a}$. T. ORTEGA VILLAZÁN.

94 J. L. MORENO PEÑA: “Burgos. Elementos del complejo ecológico provincial”. Ob. cit.

95 Ibídem. M. T. ORTEGA VILLAZÁN: El clima del sector norte de la Cordillera Ibérica... ob. cit. (pp. 203 - 212). 
Dentro de este régimen de precipitaciones, evidentemente tenemos que hacer especial hincapié en las que se producen en forma de nieve, pues, sin duda, constituyen uno de los aspectos distintivos de este clima de montaña. Su aparición, en este caso, no es exclusiva de las zonas más elevadas de la comarca, si bien, su cuantía y duración sí varían significativamente de unas partes a otras, en función de la altitud y el relieve. El periodo de nieves en general es amplio, pues la época susceptible de recibir este tipo de precipitaciones comienza en octubre y no finaliza hasta mayo. Sin embargo, los meses donde se produce el mayor número de nevadas son diciembre, enero y febrero, concentrándose aquí más del $80 \%$ de los días de nieve del año ${ }^{96}$.

Los datos que tenemos para conocer estas cuestiones proceden de las mediciones realizadas a lo largo del siglo XX, con lo cual nos resulta totalmente imposible saber las variaciones que pudieron existir con respecto al clima de la Edad Moderna. No obstante, lo que sí llegamos a sospechar es que las nevadas eran mucho más abundantes y copiosas que en la época actual, condicionando con ello, no sólo la vida diaria de los habitantes de estos pueblos, sino también el desarrollo de la propia actividad constructiva y devenir de los edificios existentes. Un caso significativo, que sirve para hacernos una idea del volumen que alcanzaban estas precipitaciones de nieve, lo tenemos en Huerta de Arriba. Aquí, a principios del siglo XVIII se procede a la eliminación de una de sus dos parroquias, pues, a la pérdida de gran parte de su feligresía, se unía la imposibilidad de los parroquianos de acceder al templo en invierno durante varias semanas. De hecho, este argumento fue uno de los más repetidos en el proceso de supresión de la parroquia ${ }^{97}$.

\footnotetext{
96 Ibídem. (pp. 255 - 270).

97 "el transito en imbierno en que aquella situación y los caminos están llenos de niebe con total imposibilidad, que sucede con frecuencia no poder subir a dicha iglesia, por espacio de quince o veinte días el párroco ni sus feligreses a celebrar y oir misa y frequentar los sacramentos y demás actos y funciones parroquiales". A. Casa Parroquial de Salas de los Infantes. doc. sin clasificar.
} 
VEGETACIÓN.

En un área eminentemente montañosa como ésta el relieve y la climatología imponen importantes restricciones al desarrollo de la agricultura. Por ello, aquí la vegetación natural, y especialmente la masa forestal, han conseguido conservar un peso mucho más significativo, que en el resto de las comarcas de la provincia de Burgos ${ }^{98}$. Esta zona, por lo tanto, se caracteriza por un importante predominio forestal, compuesto especialmente por grandes extensiones de coníferas, que consiguen dar nombre a una amplia zona de nuestra comarca de estudio, conocida genéricamente como la "Tierra de Pinares”. Aquí las especies dominantes son el pino silvestre (Pynus sylvestris) y el pino

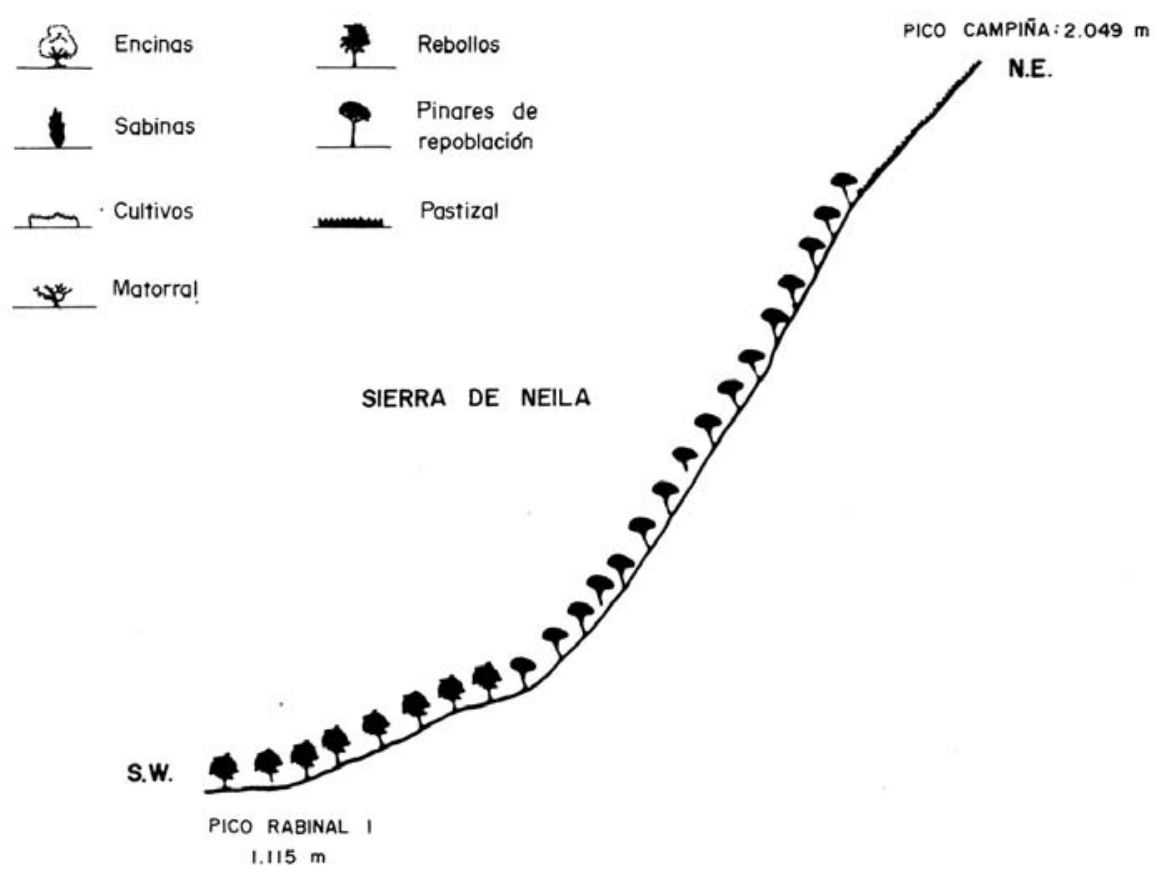

Distribución de la vegetación en la Sierra de Neila según la altitud.

98 J. L. MORENO PEÑA: “Burgos. Elementos del complejo ecológico provincial”. Ob. cit. 
negral (Pinus pinaster), pudiendo encontrar algunos ejemplos, aunque raros, de pino podio (Pinus Laricio).

A estas masas de coníferas se suman amplias masas de robledales (Quercus pyrenaica), masas de quejidos, varios hayedos (Fogus sylvatica), morcajo (Sorbus aria) y serbal (Sorbus aucuparia). Junto a estos bosques se encuentran también grandes extensiones ocupadas por un rico estrato arbustivo y de matorral, donde el número de especies resulta mucho más variado, apareciendo, acebo, rosal silvestre, escaramujo (rosa sp.), esqueo o enebro (juniperus communis), endrino (prunus spinosa), brezo común (calluna vulgaris), biércol (erica vargas), aliagas, helechos (Pteridium aquilinum), retama y estepa, a las que se unen también otras especies, como tomillo, fresas salvajes (fragaria vesca), frambuesas (rubus idaeus), y arándanos (vaccinum myrtillus).

Esta masa vegetal se encuentra determinada también por la altitud. Así, dentro de la zona de la Sierra de Neila, donde el dominio forestal resulta más importante (pues llega a ocupar más del 70 \% del término municipal), vemos que hasta los 1.700 metros de altitud se pueden encontrar tupidas masas de pino albar; a partir de los 1.700 metros y hasta los 1.850 metros estas masas continúan siendo igualmente abundantes, si bien su calidad se ve sensiblemente reducida; y por último de los 1.850 metros en adelante únicamente aparece la característica garriga o simples pastizales, pues el azote de los vientos, impide el desarrollo de cualquier otra forma de vida vegetal ${ }^{99}$.

En la zona del reborde mesozoico, por su parte, se evoluciona hacia una mayor presencia de los robledales y encinas, entre los que aparecen también ejemplos de sabina albar (juniperus thurifera), acompañados de enebro, morcajo, avellano (frangula alnus), majuelo (crataegus), endrinos, y también rosales, escaramujos (rosa sp.), zarzas, aliagas, brezo y estepas.

99 J. M. G. KLEINPENNING: La región pinariega. Estudio geográfico... ob. cit. 
PRESHISTORIA.

En esta zona de la sierra burgalesa aparecen restos, que indican la presencia de grupos humanos, desde alguno de los momentos más antiguos de la evolución del hombre. Por supuesto, para los periodos más primitivos en ningún caso contamos con restos humanos, apareciendo únicamente vestigios materiales, resultantes de su industria lítica. Estos restos arqueológicos proceden, en todos los casos, de meros hallazgos de superficie, producto de esporádicas prospecciones de metodología muy diversa, y nunca de excavaciones intensivas ${ }^{100}$.

Dentro del periodo Paleolítico, los restos hallados son muy escasos, lo que debemos achacar fundamentalmente a la falta de investigaciones concretas sobre esta época. De todos modos, podemos mencionar los vestigios encuadrados dentro del Paleolítico inferior, que se han encontrado dentro de los términos municipales de Palacios de la Sierra y Hacinas, compuestos por sencillos bifaces y otros utensilios

\footnotetext{
100 En este sentido contamos con la amplísima colección de materiales recopilados a lo largo de las últimas décadas por el Colectivo Arqueológico-Paleontológico de Salas, pertenecientes a los distintos periodos de la prehistoria, así como a la época antigua y medieval. Actualmente una buena parte de estos materiales se exponen en el Museo Arqueológico-Paleontológico de Salas de los Infantes, de donde hemos podido recabar gran parte de la información aquí empleada.
} 
líticos, que certifican la presencia humana en este periodo ${ }^{101}$. Mejor estudiado, y por lo tanto con información más precisa, se encuentra el Paleolítico medio, periodo ligado a la presencia del homo de Neanderthal y a la tipología Musteriense. De este periodo existen importantes yacimientos en las inmediaciones de nuestra área de estudio, como son el de la Cueva de la Ermita, y el de la Cueva de San Millán, ambos en las proximidades del monasterio de San Pedro de Arlanza ${ }^{102}$. El primero de ellos fue excavado en 1971 por J. A. Moure y G. Delibes de Castro, encontrando abundante material lítico, formado por cuchillas, buriles, perforadores, raspadores y raederas ${ }^{103}$, mientras que el segundo fue investigado por E. García Soto en 1980, encontrando material muy parecido a los anteriores. Frente a esto, el Paleolítico superior nos depara una drástica disminución del número de restos, lo que podemos relacionar, muy posiblemente, con una menor presencia humana, debido a la especial incidencia que en esta zona tuvo la última glaciación, conocida como Würm ${ }^{104}$.

Tras estos primeros periodos se inicia el proceso de neolitización, el cual se produce en nuestra zona, al igual que en el resto del territorio que conforma la cuenca del Duero, en un momento ciertamente tardío, alcanzando aquí una escasa incidencia. Esto hace que el número de restos pertenecientes a este periodo sea francamente reducido. De igual modo, unido a esta moderada presencia de la revolución Neolítica, nos encontraremos con un escaso desarrollo del fenómeno del megalitismo, pues el ejemplo más próximo se halla en Cubillejo de Lara, es decir, fuera ya de la zona montañosa que conforma la sierra.

\footnotetext{
101 Museo Arqueológico-Paleontológico de Salas de los Infantes.

102 J. A. ABÁSOlO ÁlVAREZ: Carta arqueológica de la provincia de Burgos: Partido Judicial de Salas de los Infantes. Burgos, Excma. Diputación Provincial de Burgos. 1990.

103 J. A. MOURE RAMANILLO: Clasificación de los niveles musterienses de la cueva de la Ermita (Hortigüela, Burgos), BSAA, XXXVII, 1971. pp. 385 - 395. J. A. MOURE RAMANILLO, G. DELIBES DE CASTRO: El yacimiento musteriense de la cueva de la Ermita (Hortigüela, Burgos), NA Hisp. Prehistoria, 1. 1972. pp. 9 - 44.

104 J. A. MOURE RAMANILLO: El Paleolítico y el arte rupestre en Burgos. En Historia de Burgos I. Edad Antigua. Burgos, Caja de Ahorros Municipal de Burgos. 1985. (pp. 93 - 114).
} 
No obstante, dentro de esta época del megalitismo comienza a producirse el desarrollo de los metales, que aquí tiene interesantes manifestaciones a partir de la Edad del Bronce. A ello contribuye, evidentemente, la presencia de depósitos de diferentes minerales en la zona de la Sierra de la Demanda. Aun así, la falta de investigaciones, centradas en el conocimiento de este periodo en concreto, ha hecho que todos los hallazgos que existen, correspondientes a este momento, se hayan producido de forma fortuita, y no como resultado de excavaciones o prospecciones realizadas bajo una metodología científica. Entre estos restos destacan especialmente los conocidos como depósitos de TAM, de Salas de los Infantes, los de Huerta de Arriba y los de Castrillo de la Reina ${ }^{105}$.

Tras esta primera incidencia de la edad de los metales, se llega a la Edad del Hierro, cuyo desarrollo en nuestra comarca, al igual que en el resto de la provincia de Burgos, no se generaliza hasta el 500 a. C., dentro de lo que podemos denominar como segunda Edad del Hierro. Esta fase se divide a su vez en dos periodos, que conocemos como periodo Preceltibérico, que se extiende aproximadamente hasta el 300 a. C., y el Celtibérico, desde este momento hasta el 100 a. C.

Sin duda, el segundo de estos periodos es el más importante, pues a lo largo de él se produce la llegada a esta zona (que permanecía prácticamente despoblada) de los pueblos de origen indoeuropeo, que forman el substrato poblacional de este territorio durante una gran parte de su historia. Estos pueblos son conocidos genéricamente como celtíberos, ya que a su raíz étnica celta incorporan determinados rasgos de la cultura superior de los iberos, con la que entraron en contacto a su llegada a este territorio de la península. Estos pueblos son especialmente conocidos en la historia, pues a los

105 J. A. ABÁSOLO ÁlVAREZ: Carta arqueológica de la provincia de Burgos... ob. cit. J. MARTÍNEZ SANTA OLALLA: Escondrijo de la Edad del Bronce Atlántico en Huerta de Arriba (Burgos). Atlántis, XVII, 1942, (pp. 127 - 164). M. ALMAGRO: Tres nuevos hallazgos del Bronce final en España. Ampurias. V, 1943. pp. 270 - 277. T. LÓPEZ MATA: "Hachas de bronce de Sotoscueva”. En BIFG, $n^{\circ}$ 112, (3º trimestre 1950), (pp. 218 - 219). Museo Arqueológico-Paleontológico de Salas de los Infantes. 
abundantes restos materiales dejados para el mundo de la arqueología, debemos sumar el protagonismo que encontraron dentro de los textos redactados por los cronistas romanos, merced a la atención que despertó su capacidad de lucha y feroz resistencia ante sus invasores.

Estos pueblos se articulan en diferentes grupos o tribus, los cuales se establecen en territorios concretos, aunque sin unos límites o fronteras precisas entre ellos. De este modo, vemos cómo nuestra comarca queda situada en la confluencia de al menos tres de estos pueblos o tribus celtibéricos, como son los Pelendones, Arévacos y Turmogos.

Dentro de ellos, sin duda los primeros constituyen el grupo más importante, pues se extienden por todo el área noroccidental de las montañas del Sistema Ibérico, que forman las sierras de la Demanda, Cebollera, Neila y Urbión. Se trata de un pueblo protoindoeuropeo, de los primeros en llegar desde el centro del continente, estimándose que pudieron ocupar incluso la ciudad de Numancia. Sin embargo, tras la llegada de los arévacos, los pelendones vieron restringido su área de influencia a las zonas más montañosas, lo que no debió ser un problema para ellos, ya que se trataba de un pueblo eminentemente ganadero. Ni Polibio, ni Apiano nos hablan de ellos, de tal modo que son los autores Plinio y Ptolomeo, quienes nos informan sobre su existencia. Según ellos su territorio se extendía a lo largo de las zonas altas de las sierras burgalesa y soriana, limitado al norte con los turmogos, al sur con los arévacos, al este con los berones y al oeste con los vacceos. De igual modo, nos indican, que sus principales ciudades eran Visontium, Augustóbriga y Savia ${ }^{106}$.

No menos importantes fueron los arévacos, uno de los pueblos más destacados y aguerridos de la celtiberia, los cuales llegaron a las inmediaciones de nuestra comarca en torno al siglo III a. C. Forman parte de una de las últimas oleadas de pueblos indoeuropeos, que llegan al ámbito peninsular. Su territorio se extendía a lo largo de la mayor parte de la actual provincia de Soria y parte del sudeste de la provincia de

106 PTOLOMEI, E: Geografía, I - IV. Cap. XXX. 
Burgos, llegando aproximadamente hasta las localidades de Salas de los Infantes y Hacinas. Su presencia, dentro de las fuentes escritas, fue particularmente destacada, en virtud de la abnegada lucha que mantuvieron frente a los invasores romanos, dando lugar a episodios de resistencia realmente épicos, que han quedado grabados para siempre dentro de los anales de la historia bélica. Según la distribución de estos pueblos, elaborado por Ptolomeo, se encontraban situados justo al sur de los pelendones $\mathrm{y}$ al este de sus hermanos los vacceos, contando en su territorio con ciudades tan importantes, dentro del mapa de los pueblos prerromanos de la península Ibérica, como Uxama, Clunia, Segantia o Numancia ${ }^{107}$.

Por último, se encuentran los turmogos, grupo encuadrado también dentro de los pueblos de la celtiberia, que se incorporan a la península Ibérica en torno al siglo IV a. C. Los límites y la ubicación del territorio, que ocuparon, no están del todo claros, sin embargo parece que abarcaba la mayor parte de la zona central de la actual provincia de Burgos, extendiéndose hasta las proximidades de Palencia. Su presencia, dentro de nuestra área de estudio, no parece estar del todo clara, a pesar de las apreciaciones que han querido hacer algunos autores, que atribuyen a este grupo grandes extensiones del territorio pelendón ${ }^{108}$. De este modo, todo parece apuntar a que los asentamientos más próximo a nuestra zona, correspondientes a los turmogos, debían encontrarse en la comarca de Lara y no en la Sierra propiamente dicha.

Uno de los elementos más representativos de todos estos pueblos son sus asentamientos, formados por los característicos castros, los cuales constituyen, por definición, lugares elevados con evidentes cualidades defensivas. Dentro de los dos modelos de asentamientos de este tipo, que encontramos dentro de la provincia de Burgos, el desarrollado en nuestra comarca evidentemente será el característico de las

\footnotetext{
107 Ibídem.

108 A. MONTENEGRO DUQUE: Pueblos y tribus del Burgos prerromano. En Historia de Burgos I.
} Edad Antigua. Burgos, Caja de Ahorros Municipal de Burgos. 1985. (pp. 221 - 284). 
76 Arquitectura de la Edad Moderna en la sierra burgalesa.

zonas serranas ${ }^{109}$, pues dada su orografía abundan los lugares que reúnen las características de altitud y difícil acceso, que requerían. Desde el punto de vista arqueológico, vemos que, aunque son relativamente escasas las excavaciones acometidas sobre este tipo de hábitats en la zona, podemos reconocer dentro de ellos unas características ciertamente arcaicas con respectos a los situados en los llanos, de mayores dimensiones y más espaciados unos de otros. Aquí son de pequeño tamaño y más próximos entre sí, alejándose en todos los casos de las principales vías de comunicación. Se trata, en definitiva, de un tipo de hábitat definido por una cualidad, como es el aislacionismo, y una forma de vida, que es la propiciada por la economía ganadera $^{110}$. De esta forma, vemos cómo a partir de este momento se comienzan ya a manifestar dos de los rasgos que se convierten en una constante en el devenir histórico de esta comarca, como son, un cierto aislacionismo cultural, por un lado, y una economía dominada por la actividad ganadera, por otro, que se complementa, en algunos momentos, con trabajos metalúrgicos.

Los restos materiales, pertenecientes a estos grupos, resultan sumamente abundantes, si bien, como ya apuntábamos, la mayor parte corresponden a hallazgos realizados en superficie, a través de los cuales, en muchos casos se ha conseguido descubrir la presencia de castros. Dentro de estos restos destacan, por encima de todos, los cerámicos, formados por vasijas con decoraciones incisas, de huellas digitales, uñas, en zig - zag y otros motivos geométricos. A estas piezas podemos sumar también las llamadas cajitas celtibéricas, los vasos trípodes, las fichas de juego, fusayolas y canicas decoradas. De todo ello, el castro de Castrovido, ubicado en las proximidades de Salas de los Infantes, aporta alguno de los más brillantes ejemplos ${ }^{111}$. No menos importantes

109 J. D. SACRISTÁN DE LAMA, I. RUÍZ VÉLEZ: La Edad del Hierro. En Historia de Burgos I. Edad Antigua. Burgos, Caja de Ahorros Municipal de Burgos. 1985. (pp. 179 - 220).

110 Estos rasgos, tanto el arcaísmo como el aislacionismo, debemos considerarlos en cierto modo como elementos voluntarios, que se encontrarían ligados a la propia idiosincrasia de estos grupos como a las propias necesidades que su economía ganadera imponía. J. D. SACRISTÁN DE LAMA, I. RUÍZ VÉLEZ: La Edad del Hierro. Ob. cit.

111 Museo Arqueológico-Paleontológico de Salas de los Infantes. J. DE LUIS MONTEVERDE: Hallazgos burgaleses de la Edad del Hierro. En AEArq.,44, 1941. pp. 442. 
son los hallazgos metalúrgicos, compuestos por fíbulas, pulseras o torques, puntas de lanza y puñales, si bien estos resultan mucho menos numerosos. Aun así podemos destacar los restos recogidos en Palacios de la Sierra, Castrillo de la Reina, y una vez más, en Castrovido ${ }^{112}$.

Durante este periodo celtíbero se produce también la llegada de los romanos a la zona, acontecimiento que tiene su hito más importante en la toma de la ciudad arévaca de Numancia en el año 133 a. C. Aun así, la romanización no se deja sentir de forma manifiesta durante este primer periodo, pues a la escasa presencia de romanos en la zona (reducida a algo meramente testimonial, con los pequeños destacamentos militares), debemos unir la pujanza de la cultura celtíbera en este momento, ya que se encontraba en su máximo esplendor. De hecho, para muchos autores estos pueblos constituyen el substrato poblacional y cultural que se mantuvo en nuestra área de estudio hasta la Alta Edad Media y posterior cristianización, sin sufrir durante este tiempo alteraciones importantes. Así, tanto romanos, primero, como visigodos después, no aportaron en ningún caso un volumen importante de población, que permitiera cambiar esta tendencia, de tal modo, que ni unos ni otros llegaron a imponer en esta zona su cultura, como sí ocurrió en otras regiones de la península. Aquí los nativos continuaron hablando su lengua, practicando sus costumbres y adorando a sus divinidades. El latín no vendrá impuesto con la romanización sino con la cristianización $^{113}$. Esta circunstancia se ve confirmada por los hallazgos arqueológicos efectuados en los últimos años, pues se demuestra que en torno al $50 \%$ de los restos cerámicos rescatados en yacimientos pertenecientes al periodo romano, se encuadran dentro de las tipologías características de la cultura celtibérica ${ }^{114}$. A ello tenemos que unir la información epigráfica aportada por las estelas, donde son constantes las

\footnotetext{
112 Museo Arqueológico-Paleontológico de Salas de los Infantes. J. A. ABÁSOLO ÁLVAREZ: Carta arqueológica de la provincia de Burgos... ob. cit.

113 A. MONTENEGRO DUQUE: Pueblos y tribus del Burgos prerromano... ob. cit.

114 J. A. ABÁSOLO ÁLVAREZ: Carta arqueológica de la provincia de Burgos... ob. cit. (pp. 115 148).
} 
alusiones a las divinidades indígenas, incluso en momentos ya muy avanzados de la era cristiana $^{115}$.

\section{ÉPOCA ROMANA.}

La llegada de los romanos a la península ibérica se produjo como consecuencia de la II Guerra Púnica, que enfrentó a romanos y cartaginenses entre los años 218 - 201 a C. La presencia de Cartago en la península evidentemente no se extendió nunca hasta nuestra comarca, ya que existían otras regiones mucho más ricas y atractivas para sus intereses. Sin embargo, tras consumarse la derrota púnica, podremos ver como la llegada y la influencia romana no tarda en manifestarse, incluso en estas zonas del interior.

Así, tras la mencionada fecha de 218 a C. se inicia una maniobra de incursión y ocupación del territorio peninsular, que lleva a que en los primeros años del siglo II a C. la mayor parte de la mitad suroriental del territorio estuviera bajo su control, organizándolo en dos provincias, denominadas Citerior y Ulterior. Sin embargo, la incorporación de nuestra zona a los dominios de este nuevo invasor no se produce hasta las campañas desarrolladas a partir de mediados de este siglo. En este caso hay que decir que nuestra comarca, al igual que la mayor parte de la cuenca del Duero y el resto del noroeste peninsular, en ningún momento constituyeron un objetivo de primer orden, dentro de los planes de ocupación elaborados desde Roma, pues la pobreza de las tierras y la dureza de su clima, así como la manifiesta hostilidad de sus habitantes - los celtíberos - hacía que resultaran muy poco atractivas desde el punto de vista económico y estratégico. No obstante, la necesidad de cortar de raíz las continuas y dañinas incursiones de rapiña, protagonizadas, dentro del territorio ocupado por los romanos, por los desheredados de las tribus celtíberas asentadas en la zona mesteña, propicia la

\footnotetext{
115 Ibídem. L. A. CONTRERAS ABAD: Castrovido. Nuestros antepasados. Burgos, Asociación Amigos del castillo de Castrovido. 2002. (pp. 34).
} 
necesidad de incorporar estas nuevas áreas, dentro de los cuales se encontraba nuestra comarca. Se inician así las llamadas guerras celtíberas, denominadas por Polibio, el cronista romano, que desde primera línea narró los acontecimientos, como guerras de fuego $^{116}$, por la crudeza de los combates y la enconada resistencia de los nativos a ser ocupados. Los arévacos y los pelendones, que ocupaban la zona de la Sierra del sudeste de Burgos, son, sin duda, dos de los grupos que mayor empeño pusieron en esta lucha, de tal modo que con la caída de la ciudad de Numancia en el 133 a C., capital de los pelendones, según unos, y de los arévacos según otros, se pone punto final a esta cruel guerra, incorporándose toda la celtiberia a la provincia romana Citerior.

A finales de siglo I a C., cuando se produce el reajuste de la división administrativa romana, dentro del mapa de la península Ibérica, nuestra zona de estudio queda incluida definitivamente dentro de la provincia imperial Hispánica Citerior, cuyo territorio coincide con el de la antigua provincia Citerior, a la que se habían incorporado los territorios de toda la franja del Cantábrico. A su vez, dentro de la división interna en conventos jurídicos, que presentaba esta provincia, nuestra comarca queda inmersa dentro del convento Cluniacense, con capital en la ciudad de Clunia Sulpicia. Posteriormente, tras la dura crisis vivida dentro del Imperio a lo largo del siglo III d C., y la consiguiente renovación del mapa administrativo romano, esta comarca de la sierra pasa a formar parte de la provincia Cartaghinensis, con capital en Cartagonova, creada como escisión de la antigua Citerior.

La presencia romana esta ligada indefectiblemente al proceso de culturización, conocido como romanización, el cual en nuestra zona se lleva a cabo principalmente a

\footnotetext{
116 POLIBIO XXXV, 1: "La guerra que los romanos hicieron contra los celtíberos, es llamada guerra de fuego. La naturaleza de esta guerra fue extraordinaria al igual que su carácter ininterrumpido. Las guerras de Grecia y del Asia, por lo general, solían concluirse en una sola batalla; rara era la vez que se hacía en dos; e, incluso, las batallas se decidían en el primer encuentro. Pero esta guerra fue diferente, pues la mayor parte de las batallas se terminaban de noche. Los soldados resistían sin acusar fatiga y renunciaban a abandonar el combate. Incluso, ni el invierno suspendía las hostilidades, ni los combates. Si alguien quiere imaginarse una guerra de fuego tiene el mejor ejemplo en ésta”.
} 
través de sus emplazamientos más destacados, como eran Clunia y Lara $^{117}$. Sin embargo, no menos importantes, dentro de este proceso, fueron las vías de comunicación, bien de carácter natural, o bien creadas de forma expresa por los romanos. En el caso de las vías naturales, hay que citar la serie de corredores, a través de los cuales llegaron los primeros representantes de esta nueva cultura, propiciando algunos asentamientos, que en muchos casos, se superponen a los ya existentes. Este es el caso, por ejemplo, de la vía que recorre el cauce del río Arlanza, y del asentamiento romano ubicado sobre el antiguo castro celtíbero de Castrovido-Salas, ligado a una función eminentemente defensiva y de vigilancia. Posteriormente vendrán las auténticas calzadas, que formaban parte del mapa viario romano, creadas por el sistema administrativo, para extender de forma precisa el proceso romanizador, y articular de un modo ordenado y ágil los distintos territorios que componían el Imperio ${ }^{118}$. La importancia de estas comunicaciones fue tal que llega a traspasar incluso el propio marco temporal de la época romana, ya que mayoritariamente se continuaron empleando a lo largo de la Edad Media hasta el siglo X. Varias de esas vías cruzaban nuestra comarca, si bien ninguna de ellas pertenecía a la red principal de calzadas del Imperio. Aun así, algunos testimonios de estos caminos nos han llegado en forma de los restos, como pueden ser las fuentes, que servían de abrevaderos, como las de Lara de los Infantes o Arauzo de la Torre, los puentes construidos para salvar determinados cursos de agua, entre los que tenemos los de Castrovido, Barbadillo del Mercado, Palacios de la Sierra y Cascajares, y algunos fragmentos o tramos de estos caminos, como ocurre en las inmediaciones de Salas de los Infantes.

Al mismo tiempo el Itinerario provinciarium Antonini Augusti nos informa puntualmente del trazado de cada una de ellas, de tal modo que podemos reconocer cuales eran las que servían para comunicar los núcleos existentes en nuestra zona con el exterior, propiciando al mismo tiempo esa labor romanizadora. Dentro de ellas se encuentran:

117 J. A. ABÁSOLO ÁLVAREZ: Carta arqueológica de la provincia de Burgos. (pp. 20 - 23). 
- Vía Clunia-Tritium Magallum. Constituía el eje de comunicación más importante de nuestra zona, pues se trata del camino que se adentraba desde la capital del convento jurídico hasta las tierras altas de las montañas de la Demanda. Restos de la misma son el mencionado puente de Castrovido, así como el antiguo puente de Vallejimeno (sustituido durante la Edad Media por el actual), el miliario hallado en Huerta de Arriba, y muy posiblemente el tramo de calzada de Salas ${ }^{119}$.

- Vía Clunia-Lara. Se trata de la vía que unía la capital del convento con el otro poblamiento más importante de la comarca, como era Lara, prolongándose después hasta la zona de Juarros y Montes de Oca. Aunque su trazado apenas aparece bordeando nuestro ámbito de estudio, resulta obligado mencionarla, pues no en vano unía los dos puntos más importantes, desde los que se propició el proceso romanizador en la zona ${ }^{120}$.

- Vía del curso del río Lobos. Se trata de un camino de existencia dudosa, según el profesor Abásolo Álvarez, pues no se han encontrado muchos restos que corroboren su presencia. Según Taracena, sin embargo, este camino ponía en comunicación la ciudad de Uxama (Osma) con Salas de los Infantes, atravesando en su parte final los actuales términos de Castrillo de la Reina y Moncalvillo ${ }^{121}$.

- Vía Salas-Numancia. Según el profesor Abásolo Álvarez, se trata de una vía más relacionada con el mundo medieval que con el romano, pues según parece fue un camino muy transitado en torno al siglo XII. Aun así, L. Serrano no duda en calificarlo como romano, denominándola vía de los pelendones. Su trazado discurría muy próximo al cauce del río Arlanza, a través de los términos

118 J. A. ABÁSOLO ÁLVAREZ: Comunicaciones de la época romana en la provincia de Burgos. Burgos. 1995.

119 Ibídem. (pp. 203 - 206).

120 Ibídem. (pp. 198 - 206)

121 Ibídem. (pp. 217). 
municipales de Palacios de la Sierra, Vilviestre del Pinar y Quintanar de la Sierra $^{122}$.

En lo que se refiere al poblamiento, que se vive durante el periodo romano, contamos para su conocimiento fundamentalmente con las aportaciones realizadas desde el campo de la arqueología, ya que las fuentes escritas son muy escasas e imprecisas. Aun así, nos encontramos aun bastante lejos de poder conocer con detalles sus características, pues la localización de los asentamientos se ha conseguido a través de hallazgos fortuitos, por desmontes o mediante prospecciones en zonas muy concretas, que han dejado grandes lagunas sin investigar. De igual modo, las excavaciones efectuadas nunca han sido de gran superficie, estableciendo en todos los casos cronologías poco precisas en las que se han manejado marcos temporales muy amplios, que no servían para concretar el periodo de ocupación.

A pesar de todo sabemos que en nuestra zona no existieron núcleos urbanos importantes, situándose las ciudades más próximas en Clunia y Uxama. Los núcleos que aquí existieron corresponden al tipo de poblamiento rural, en el que se encuadran las villas, granjas y otros asentamientos, caracterizados en todos los casos por su escasa importancia y bajo volumen de población, que hacen que apenas podamos encontrar restos de construcciones. Algunos ejemplos tenemos en Palacios de la Sierra, Monasterio de la Sierra y Huerta de Abajo, donde se desarrollaron actividades relacionadas con el aprovechamiento ganadero, en los dos primeros casos, y la minería en el tercero ${ }^{123}$.

Por otra parte, dentro de los asentamientos de época romana encontramos una clara ruptura con la época anterior, pues la mayoría de estos núcleos se crean entre los años centrales del siglo I d. C. y los primeros años de la centuria siguiente. Aun así, se dan algunas excepciones, como es el caso del castro de Castrovido-Salas, que nos

\footnotetext{
122 Ibídem. (pp. 218)

123 A. MONTENEGRO DUQUE: Pueblos y tribus del Burgos prerromano... ob. cit.
} 
ofrece material perteneciente a ambos periodos, sin solución de continuidad. Posteriormente, con la crisis que sufre el Imperio en torno al siglo III, muchos de estos asentamientos comienzan a despoblarse, llegando al siglo V con la mayor parte de ellos deshabitados.

\section{ÉPOCA VISIGODA.}

La incursión de los pueblos llamados bárbaros dentro del territorio del Imperio romano, y la consiguiente desmembración política de éste, marcan el fin de la Edad Antigua y el inicio del periodo medieval. En nuestra comarca esta transición no se produce hasta finales del siglo $\mathrm{V}$ o comienzos del siglo VI, pues las incursiones en la península Ibérica de los suevos, alanos y vándalos no tienen ninguna repercusión, debiendo esperar hasta la llegada de los visigodos, y su posterior expansión dentro de este territorio. Sin embargo, el cambio entre el modo de vida característico de la civilización romana y las nuevas pautas que ahora se viven, ya se había producido aquí entre los siglos III y IV, con la crisis vivida dentro del Imperio, y el proceso ruralizador en el que desembocó el hundimiento de la vida urbana.

Así, en lo que se refiere al periodo visigodo, dentro de nuestra comarca, podemos hablar, en principio, de un claro descenso demográfico, pues así parece demostrarlo el menor número de hallazgos localizados. No obstante, no debemos olvidar las dificultades que encuentra la arqueología para informarnos sobre esta época. De este modo, a la relativa desatención que ha recibido tradicionalmente el campo de la arqueología medieval, debemos unir también la mayor dificultad, que entraña la localización e investigación de los poblamientos visigodos, pues los materiales encontrados son muy escasos, faltando cronologías precisas para su clasificación de forma detallada. 
84 Arquitectura de la Edad Moderna en la sierra burgalesa.

A pesar de ello, no faltan tesis aventuradas, encuadradas dentro de unos postulados claramente continuistas con respecto al periodo romano, que nos hablan de una comarca serrana profundamente romanizada, a partir de lo cual se vive un manifiesto esplendor durante la época visigoda, reaprovechando tanto los asentamientos como sus infraestructuras. Reflejo de todo ello sería la ermita de Santa María de Quintanilla de las Viñas ${ }^{124}$.

Sin embargo, frente a esto, como ya señalábamos, todo parece apuntar a una ruptura total con respecto a la época romana, pues como manifiesta el profesor E. Pastor Díaz de Garayo, muy pocos poblamientos de época romana continúan ocupados durante el período visigodo, mientras que el resto son abandonados ${ }^{125}$. Aun así, existen casos en los que, sobre asentamientos romanos se produce, más tarde, una presencia visigoda, si bien en ninguno de ellos podemos hablar de continuidad, sino más bien de superposición. De este modo, son dos las características que definen la presencia visigoda en la zona: por una parte la clara ruptura con la época anterior, y por otra el carácter inestable y precario de estas poblaciones, marcadas por un innegable descenso demográfico, propiciado por el azote de los jinetes apocalípticos de las guerras, el hambre y las epidemias. Por lo tanto, debemos descartar como un error grave la idea, muchas veces expresada, de que el precedente o embrión de los poblamientos, que más tarde generan nuestros actuales pueblos, se encuentra aquí.

Frente a todo esto, un aspecto sumamente importante, dentro de este periodo visigodo, lo tenemos en la llegada del cristianismo, pues no parece que la cristianización se haya producido con anterioridad a estas fechas. Su desarrollo se encuentra claramente ligado a la consagración de cada una de las sedes episcopales, surgidas entre los siglos V y VI, dentro de las cuales nos interesan de modo especial las de Oca y Osma.

124 J. ANDRIO GONZALO: La Edad Media a través de los estudios arqueológicos. En Historia de Burgos II. Edad Media (2). Burgos, Caja de Ahorros Municipal de Burgos. 1986. (pp. 195 - 216).

125 E. PASTOR DÍAZ DE GARAYO: Castilla en el tránsito de la Antigüedad al Feudalismo. Poblamiento, poder político y estructura social del Arlanza al Duero (siglos VII - IX). Valladolid, Consejería de Educación y Cultura, Junta de Castillo y León. 1996. 
Respecto a ellas, y aunque no tenemos datos precisos que nos sirvan para trazar de forma clara el límite entre los territorios de cada una de ellas, debemos entender que nuestra comarca quedaría repartida entre estas dos, ya que sus ámbitos de influencia vienen a coincidir con los antiguos territorios de los pueblos celtíberos prerromanos ${ }^{126}$. Oca ocuparía, de este modo, el territorio de los Autrigones y Turmogos, mientras que Osma se extendería por el territorio de los Arévacos, cuestionándose la adjudicación del espacio ocupado por los Pelendones, ya que mientras L. Serrano lo sitúa dentro del ámbito de la diócesis de Oca ${ }^{127}$, Fr. Gregorio Argaiz y Lopérraez Corbalán lo encuadran en la diócesis oxomense ${ }^{128}$.

\section{EDAD MEDIA.}

La llegada en el 711 a la península de los musulmanes, y la consiguiente desmembración de la monarquía visigoda, nos lleva al nacimiento de una nueva etapa, que resulta crucial, dentro del devenir histórico de nuestra comarca. Así, en las próximas centurias, veremos surgir los núcleos de población, que generan nuestros pueblos actuales, al mismo tiempo que se determinan las divisiones territoriales de la organización político-administrativa, y religiosa, que se mantiene durante toda la Edad Moderna. Por último, veremos también como a partir de estos momentos comienzan a establecerse las relaciones de poder y dependencia, dentro del propio marco de estos núcleos, que marcarán en gran parte su devenir histórico a lo largo del periodo que comprende esta Edad Media y la época moderna.

\footnotetext{
126 Este aspecto no ha sido plenamente aceptado en la actualidad, si bien de resultar cierto nos permitiría cuestionar seriamente la efectividad del proceso romanizador dentro de nuestra comarca, pues supondría una clara pervivencia de la tradición indígena por encima de varios siglos de ocupación romana.

127 L. SERRANO: El obispado de Burgos y Castilla primitiva. Desde el siglo V al XIII. Vol. I. Madrid. 1935.

128 Fr. G. ARGAIZ (OSB): La soledad laureada por San Benito y sus hijos en las Iglesias de España y teatro monástico de la provincia de Cartaghinensis. Madrid, Francisco Nieto. 1669. J. LOPÉRRAEZ CORBALÁN: Descripción histórica del Obispado de Osma con el catálogo de sus prelados. Ed. Facsímil. Madrid, Turner. 1978. Tomo I.
} 
La invasión musulmana marca, como decimos, el final de una época en la península Ibérica. Sin embargo, dentro del marco, que compone nuestra zona de estudio, observamos que la ruptura con la tradición y la cultura hispanorromana ya había tenido lugar anteriormente ${ }^{129}$. Nuestra comarca, al igual que la mayor parte del territorio de la actual provincia de Burgos, conoce una presencia invasora muy escasa, pues, como ya había ocurrido con romanos y visigodos, aquí no había grandes ciudades o ricos parajes que mereciera la pena ocupar. A esto debemos unir el hecho de que las fuerzas invasoras, que irrumpieron en esta zona de la cuenca del Duero, no eran árabes, como ocurrió en la mitad sur de la península, sino bereberes procedentes del Norte de África, cuya presencia fue extremadamente breve, ya que las revueltas que protagonizaron contra sus compañeros de invasión les llevaron rápidamente de vuelta a su territorio originario en torno al año 739.

Aun así, la tradición popular se encargaría más tarde de engrandecer esta presencia, atribuyendo construcciones o topónimos, que por su origen desconocido, no se dudó en relacionar con estos invasores africanos. Tal es el caso, por ejemplo, del castillo situado sobre la localidad de Castrovido, que el Diccionario de Pascual Madoz no duda en denominar como árabe ${ }^{130}$, o de alguno de los pueblos próximos a nuestra zona de estudio, que incorporaron a sus nombres, apellidos relacionados con estos acontecimientos, como ocurre con Pinilla de los Moros ${ }^{131}$.

\footnotetext{
129 G. MARTínEZ DÍEZ: La época Condal. En Historia de Burgos II. Edad Media (1). Burgos, Caja de Ahorros Municipal de Burgos. 1986. (pp. 41 - 98). E. PASTOR DÍAZ DE GARAYO: Castilla en el tránsito de la Antigüedad al Feudalismo...ob. cit.

130 P. MADOZ: Diccionario geográfico-estadístico-histórico de España y sus posesiones de Ultramar. Valladolid, Ámbito. 1984. (pp. 293).

131 Estos invasores bereberes, procedentes del norte de África recibirán el apelativo genérico de "moros", dado que procedían de la zona de Mauritania, a cuyo pobladores en época romana se los conocía como “mauris”. G. MARTínEZ DÍEZ: “La época condal”. En Historia de Burgos II Edad Media (1). Burgos, Caja de Ahorros Municipal de Burgos. 1986. (pp. 41 - 98).
} 
Tras el enfrentamiento de D. Pelayo a los invasores - el cual deberíamos considerar más una insurrección, que una acción de reconquista ${ }^{132}-$, y la constitución, en esta franja norte de la península, de una nueva entidad política, toda la zona de la cuenca del Duero se convierte en un espacio intermedio, sin un dominador claro. Sin embargo, esto no evita, que dentro de este amplio territorio, se creen zonas claramente diferenciadas entre sí, donde las influencias de una y otra entidad política se ven reflejadas. De este modo, mientras la parte más septentrional se vincula al nuevo reino cristiano del norte, y la meridional se sitúa bajo la influencia de los nuevos dominadores musulmanes, toda la zona central y oriental de la meseta, hasta las estribaciones montañosas, donde se encuadra nuestra comarca de estudio, queda convertida en un gran espacio colchón, situado entre ambos reinos, y sin un dominador claro, ya que hasta el siglo X no podemos hablar de fronteras fijas entre ellos.

Igualmente, y a pesar de las tesis defendidas por las posturas tradiconalistas, que nos hablan de un despoblamiento estratégico en todo este territorio ${ }^{133}$, observamos cómo diferentes autores han conseguido demostrar, que nuestra zona, en ningún momento se vio deshabitada, pues tanto las fuentes documentales como las arqueológicas parecen indicar lo contrario ${ }^{134}$. Estaríamos hablando, por lo tanto, de población residual, que con el tiempo, y merced al propio progreso experimentado en su seno, devienen en los núcleos de población definitivos.

La incorporación de nuestra comarca a los territorios ocupados por los reinos cristianos del norte no se produce hasta el segundo tercio del siglo X, encuadrándose dentro de los avances efectuados desde la línea del Arlanzón (Burgos - Ubierna Castrogeriz), establecida en los años finales de la centuria anterior, hasta la marca del río Duero. Así, una vez superadas las pertinentes réplicas musulmanas, que tienen lugar

\footnotetext{
132 E. PASTOR DÍAZ DE GARAYO: Castilla en el tránsito de la Antigüedad al Feudalismo...ob. cit. 133 Fundadores y defensores de esta posición serán: C. SÁNCHEZ ALBORNOZ, J PÉREZ DE URBEL, G. MARTÍNEZ DÍEZ, S DE MOXÓ, J. GONZÁLEZ, L. KOFMAN, M.I. CARZILIO, R. PASTER, entre otros.

134 E. PASTOR DÍAZ DE GARAYO: Castilla en el tránsito de la Antigüedad al Feudalismo... ob. cit.
} 
durante los años inmediatos al cambio de milenio, podemos considerar que, en torno al año 1010, la zona queda definitivamente estabilizada. Con ello, estas tierras situadas entre los ríos Arlanza y Duero, que habían permanecido vacías para unos y sin dueño para otros, pierden esta condición para convertirse en parte integrante del territorio del reino astur-leonés, gobernado bajo un delegado regio, como era el conde de Castilla.

En lo que se refiere al poblamiento, durante estos momentos, no conocemos muchos datos, que nos ayuden a aclarar las enormes lagunas que existen sobre el tema. Pues, si por un lado se da un bajo número de excavaciones realizadas sobre los yacimientos pertenecientes a este periodo, por otro, existen graves carencias de coordinación y apoyo entre las disciplinas de la arqueología y la historia medieval, ante la insistencia de este último campo por centrar sus esfuerzos en el análisis de las fuentes documentales, consideradas como las únicas capaces de proporcionar información útil sobre el tema ${ }^{135}$. Aun así, y a pesar de todo esto, lo que parece quedar fuera de toda duda, como ya hemos señalado, es que, frente a las tesis tradicionalistas, que preconizan el despoblamiento a ultranza de la zona, todo parece apuntar a un movimiento totalmente contrario, es decir, de ocupación y asentamiento de un gran número de pobladores, que genéricamente han sido considerada como residuales.

De este modo, según el profesor E. Pastor Díaz de Garayo, entre los años 700 y 1000 se produce una auténtica revolución en la estructura de hábitat, pasando de un poblamiento inestable y disperso, durante la época visigoda, a una tupida red de asentamientos estables, formados por pequeñas aldeas dispuestas a escasa distancia unas de otras ${ }^{136}$, que se continúan en muchos casos hasta llegar a nuestros días ${ }^{137}$. Esto se

135 F. REYES TÉLLEZ: Arqueología y cultura material de Burgos en la Alta Edad Media. En II Jornadas burgalesas de historia. (2a Burgos. 1990). Burgos en la Alta Edad Media. Burgos, Asociación Provincial de Libreros de Burgos. 1991. (pp. 77 - 123).

136 E. PASTOR DÍAZ DE GARAYO: Castilla en el tránsito de la Antigüedad al Feudalismo... ob. cit.

137 Un magnífico ejemplo de estos que estamos diciendo lo encontramos en la localidad de Castrillo de la Reina, donde en un radio de poco más de un kilómetro encontramos restos materiales de dos poblados, cuya existencia quedará refrendada por las fuentes documentales. Nos referimos a las localidades de Castriello (actual Castrillo) y San Justo (Santiuste), cuyo yacimiento aparece a las afueras del actual 
produce merced a la llegada de una importante población residual, pero también a partir del propio desarrollo interno vivido en el seno de estos pobladores, el cual se consigue a través de una ocupación del terreno más estable y la consiguiente prosperidad de sus medios de producción ${ }^{138}$. Así, la imagen que presenta nuestra comarca en este momento debía encontrarse muy próxima a la que nos describe el profesor L. Martínez García, para la mayor parte de la provincia de Burgos, cuando dice lo siguiente: ”Destacarían en primer lugar las ya numerosas pequeñas villas o aldeas, lugares fijos, concentrados y homogéneos de asentamiento de los grupos humanos, rodeados de claros que se iban ganando al bosque para el cultivo gracias al esfuerzo de sus pobladores. En los intersticios amplios espacios boscosos, peñedos y eriales, regularmente transitados por cazadores y pastores de las comunidades vecinas. Más raros, aunque bien visibles y estratégicamente situados, despuntarían algunas villas fortificadas con su castillo al frente, dando al conjunto un elevado tono militarista. Y en cada aldea el monasterio o la iglesia propia, convertidos en centro religioso y social donde se fundían el espíritu de solidaridad reinante en el lugar. Ni una sola ciudad había que pudiera romper la imagen de una sociedad campesina, militarizada y cristiana"139.

Reflejo de todo esto es la rica nómina de yacimientos correspondientes a este periodo, que se han conservado en nuestra zona, formados fundamentalmente por necrópolis, lugares de culto y eremitorios. Entre ellos podemos citar a modo de ejemplo

pueblo de Castrillo de la Reina. Su presencia dentro de las fuentes documentales la encontramos en un documento relacionado con la repoblación de Sepúlveda en el siglo XI, donde al hablar de la procedencia de los nuevos pobladores se menciona, entre otras localidades de la zona, estos dos pueblos. M. S. MARTín POSTIGO: San Frutos de Duratón. Historia de un Priorato Benedictino. Segovia, Caja de Ahorros y Monte de Piedad de Segovia. 1970.

138 Los campos se labrarán con una mayor continuidad, lo que obliga a cambiar el asentamiento inestable por uno permanente. E. PASTOR DÍAZ DE GARAYO: Castilla en el tránsito de la Antigüedad al Feudalismo... ob. cit. Estructura del poblamiento en la Castilla Condal. Consideraciones teóricas. En II Jornadas burgalesas de historia. (2 ${ }^{a}$ 1990. Burgos). Burgos en la Alta Edad Media. Burgos. Asociación Provincial de Libreros de Burgos. 1991. (pp. 633 - 651).

139 L. MARTÍNEZ GARCÍA: "Solariegos y señores. La sociedad rural burgalesa en la Plena Edad Media. (ss. XI - XIII). En III Jornadas burgalesas de historia (3ª 1991. Burgos). Burgos en la Plena Edad Media. (pp. 355 - 410). 
los hallazgos de Cuyacabras y Cueva Andrés (Quintanar de la Sierra), Revenga, Regumiel de la Sierra, Palacios de la Sierra, Covacha (Moncalvillo), Santiuste y Viguellas (Castrillo de la Reina), San Andrés (Castrovido), Gozmediano-Bustomediano (Monasterio de la Sierra), y Peña Rota (Salas de los Infantes). Sin embargo, no todos han sido excavados y estudiados con la rigurosidad, que deparan los métodos modernos de investigación, con lo cual las conclusiones y cronología que se han extraído de ellos resultan poco concluyentes.

Junto a esto nos encontramos con que las fuentes documentales no consiguen despejar las dudas dejadas por la arqueología, ya que la información que nos proporcionan para nuestra área de estudio resulta desigual y en la mayoría de los casos excesivamente precaria. Esta ausencia de testimonios documentales se ha querido relacionar tradicionalmente con un vacío poblacional, si bien, bajo nuestro punto de vista habría que achacarlo más a una cuestión de producción, transmisión y conservación documental, que a una imagen real del momento. Por lo tanto, una cosa es el instante en el que estos pueblos nacen y ven su primera luz, desde el punto de vista documental - lo cual ocurrirá fundamentalmente a través del Cartulario de San Pedro de Arlanza -, y otra bien distinta el momento en el que surgen de modo real. Esto provoca graves lapsus temporales, como ocurre en Regumiel de la Sierra, donde la arqueología demuestra una ocupación de su necrópolis desde el siglo $\mathrm{X}^{140}$, mientras que las fuentes documentales no lo citan hasta el año $1213^{141}$. Así, de no ser por la existencia del mencionado Cartulario de Arlanza, la presencia de la gran mayoría de estos pueblos, dentro de las fuentes documentales, no se habría producido antes de los siglos XIII o XIV.

De este modo, la cronología que podemos establecer para la aparición de todos estos pueblos ofrece grandes incógnitas. Aun así, debemos considerar, que las

\footnotetext{
140 A. del CASTILLO: Excavaciones altomedievales en las provincias de Soria, Logroño y Burgos. Madrid, Comisaría General de Excavaciones Arqueológicas. 1972. (pp. 8 - 16).
} 
localidades que aparecen mencionadas en las fuentes documentales a partir de los años finales del siglo XI y durante todo el siglo XII, ya existían con toda seguridad desde principios de la undécima centuria. Para ello, nos basamos en el grado de organización que presentan todos estos núcleos en el momento de su nacimiento documental, lo cual debemos interpretar como el fruto de un esfuerzo colectivo, realizado a lo largo de varias generaciones, y no como un hecho puntual y espontáneo. Un grado de organización que se plasma, por ejemplo, en la edificación de las numerosas iglesias románicas, que se realizaron en esta zona a lo largo del siglo XII, de las cuales en mayor o menor medida nos han llegado vestigios hasta nuestros días ${ }^{142}$. Esto nos habla de poblaciones capaces de acometer empresas colectivas de carácter arquitectónico ciertamente ambiciosas para los recursos con los que contaban, pues de no existir una trayectoria medianamente larga detrás, esto no habría sido posible.

En otro orden de cosa, como ya anunciábamos más arriba, vemos también como durante este periodo medieval se establece una nueva organización sobre el territorio, que forma esta comarca. Así, con la incorporación de esta zona al reino astur-leonés, y la constitución del condado de Castilla, entre la segunda mitad del siglo X y principios del XI, estos pueblos pasan a formar parte de la organización político-administrativa del nuevo reino, que durante estos siglos se estaba creando.

En nuestro caso, y sin ninguna duda, el máximo poder lo detenta, durante estos primeros momentos, el conde, pues la sede de la corte quedaba demasiado lejos para

141 L. SERRANO: Cartulario de San Pedro de Arlanza. antiguo monasterio Benedictino. Madrid. Centro de Estudios Históricos. 1925.

142 J. PÉREZ CARMONA: Arquitectura y escultura románicas en la provincia de Burgos. Madrid. Espasa Calpe. 1974. S. ANDRÉS ORDAX: “Arte románico”. En Historia de Burgos II (2). Burgos. Caja de Ahorros Municipal de Burgos. 1987. J. SÁINZ SÁIZ: El románico rural en Castilla y León. Madrid. Ediciones Lancia. 1991. El románico en Burgos. Madrid, Ediciones Lancia. 2001. G. BILBAO LÓPEZ: Iconografía de las pilas bautismales del románico castellano; Burgos y Palencia. Burgos, Editorial Olmeda. 1996. B. VALDIVIELSO AUSÍN: Rutas del románico en la provincia de Burgos. Valladolid, Castilla Ediciones. 1999. F. PALOMERO ARAGÓN: Rutas para descubrir el arte de la Sierra de la Demanda. Valladolid, Ámbito Ediciones. 2000. 
que la presencia del monarca se dejara sentir. Por debajo de él, durante los siglos IX al XII, el poder se articulaba en alfoces, que son la circunscripción situada entre el condado y la unidad básica, que componían las villas y aldeas. Cada alfoz englobaba a un determinado número de localidades, organizadas en torno a un núcleo central, formado por un castillo o torre defensivos, ubicada junto a uno de estos pueblos, que daría nombre al alfoz, los cuales dependían de este centro para su defensa y regulación de determinadas cuestiones administrativas.

Los orígenes de los alfoces resultan poco claros, pues mientras C. Estepa Díez ${ }^{143}$ los relaciona con cuestiones estrictamente militares, E. González Díez ${ }^{144}$ vincula su aparición al proceso repoblador y defensivo, que presuntamente se estaba llevando a cabo en la zona en este momento. De igual modo, tampoco resulta fácil establecer los límites territoriales de cada uno de ellos, ya que no todas las cabezas de alfoz tenían las mismas atribuciones ${ }^{145}$. Así, nos encontramos con que tampoco podemos hablar de ámbitos o circunscripciones cerradas, pues localidades como Neila, Huerta de Arriba, Barbadillo de Herreros o Riocavado de la Sierra, aparecen vinculados indistintamente a los alfoces de Lara, Barbadillo del Pez o Ibeas de Juarros, en función de las cuestiones a resolver $^{146}$. Aun así, y ante la dificultad que entraña establecer límites territoriales precisos, dentro de esta primitiva organización del espacio efectuada durante el periodo medieval, nos aferraremos a la partición establecida por G. Martínez Díez, en la cual observamos cómo los pueblos, que componen nuestro ámbito de estudio, se encontraban repartidos entre los alfoces de Lara, Barbadillo del Pez y Canales ${ }^{147}$.

\footnotetext{
143 C. ESTEPA DÍEZ: "Estructura de poder en Castilla (siglos XII - XIII). El poder señorial. En III Jornadas burgalesas de historia (3ª 1991. Burgos) Burgos en la Plena Edad Media. (pp. 245 - 294).

144 E. GONZÁLEZ DÍEZ: "Estructura jurídico administrativa”. En Historia de Burgos II Edad Media (1). Burgos, Caja de Ahorros Municipal de Burgos. 1986. (pp. 145 - 246).

145 I. ÁLVAREZ BORGE: Monarquía feudal y organización territorial: alfoces y merindades en Castilla (siglos X - XIV). Madrid, CISC, 1993. (pp. 50 - 89).

146 E. PASTOR DÍAZ DE GARAYO: Castilla en el tránsito de la Antigüedad al Feudalismo... ob. cit.

147 G. MARTÍNEZ DÍEZ: Pueblos y alfoces burgaleses de la repoblación. Valladolid. Junta de Castilla y León. Consejería de Educación y Cultura. 1997.
} 
Posteriormente, entre el siglo XII-XIII, este sistema de alfoces queda desmantelado, pues a la pérdida de contenido, que sufre la figura del conde, durante el reinado de Fernando I con el desarrollo del sistema de tenencias, le sucede la implantación de un nuevo sistema administrativo. En este nuevo sistema la merindad se convierte en la unidad intermedia, situada entre las villas y aldeas, y el monarca, desdoblándose a su vez en Merindades Mayores, que son las circunscripciones más amplias, y Merindades Menores, que funcionan como subdivisiones de aquellas ${ }^{148}$.

Dentro de este nuevo esquema administrativo vemos que la mayor parte de nuestros pueblos quedan incluidos en el territorio de la Merindad Menor de Silos, con la única excepción de Barbadillo del Pez, pues su pertenencia al Infantado de Covarrubias hace que forme parte de la Merindad de Candemuñó. A su vez, todos estos pueblos quedan englobados dentro de la Merindad Mayor de Castilla, como circunscripción superior de estas merindades.

Al mismo tiempo que se establecían estas divisiones en el marco de la organización político-administrativa, vemos que se procede también a fijar el mapa eclesiástico, con la organización diocesana ${ }^{149}$. Su desarrollo, en este caso, resulta de vital importancia, ya que este esquema se va a mantener vigente, con muy escasas variaciones, hasta los años centrales del siglo $\mathrm{XX}$.

Las dos sedes que se reparten los pueblos comprendidos en nuestra zona de estudio son las de Burgos y Osma, a las cuales podemos sumar también la de Calahorra, ya que la localidad de Monterrubio de la Demanda, al estar incluida dentro de la agrupación del valle de Canales y las Cinco Villas, formó parte de aquella diócesis

\footnotetext{
148 I. ÁLVAREZ BORGE: Monarquía feudal y organización territorial...ob. cit. E. GONZÁLEZ DÍEZ: Estructura jurídica administrativa. En Historia de Burgos II. Edad Media (1). Burgos, Caja de Ahorros Municipal de Burgos. 1986. (pp. 145 - 246).

149 I. ÁLVAREZ BORGE: Poder y relaciones sociales en Castilla en la Edad Media. Los territorios entre el Arlanzón y el Duero en los siglos X - XIV. Salamanca, Consejería de Educación y Cultura. Junta de Castilla y León. 1996.
} 
94 Arquitectura de la Edad Moderna en la sierra burgalesa.

durante un tiempo ${ }^{150}$. Por supuesto aquí nos centraremos en estas dos primeras, cuya reorganización se produce durante la segunda mitad del siglo XI. En el caso de Burgos esto tiene lugar en el año 1068, asentándose en un principio en Oca, para pasar poco más tarde definitivamente a Burgos, tras una breve parada en la iglesia de Santa María de Gamonal ${ }^{151}$. La restauración de la sede de Osma, por su parte, debemos relacionarla con la conquista de Toledo y la consiguiente restitución de la provincia eclesiástica de la sede primada, donde quedaba incluido el territorio oxomense ${ }^{152}$.

Los límites entre los territorios de ambas sedes quedaron fijados en un primer momento en el Concilio de Husillos, celebrado en $1088^{153}$. Sin embargo, la desproporción que deparó esta división, a favor de la sede burgalesa, cuyo territorio se extendía incluso hasta las proximidades de la ciudad de Burgo de Osma ${ }^{154}$, llevó a esta última diócesis a iniciar una serie de pleitos, auspiciados desde Toledo, que no se resolverían definitivamente hasta el Concilio celebrado en Burgos en $1136^{155}$. A raíz de este último concilio se establecen los límites definitivos entre ambas sedes, los cuales en nuestra comarca toman como referencia el curso alto del río Arlanza, los montes de Carazo y el río Mataviejas. De este modo, los pueblos situados en la margen derecha del río Arlanza y al norte de los citados montes, quedaban incluidos dentro de la diócesis de Burgos, mientras que los de la margen izquierda y la zona meridional de Carazo, pasaban a formar parte del territorio dependiente de Osma ${ }^{156}$. Esta solución, sin

150 D. MANSILlA REOYO: “Obispado y monasterios”. En Historia de Burgos II. Edad Media (1). Burgos, Caja de Ahorros de Burgos. 1986.

151 L. SERRANO: El Obispado de Burgos y la Castilla primitiva. Siglos V - XIII. Madrid. 1935.

152 Fr. G. ARGAIZ (OBS): La soledad laureada por San Benito y sus hijos en las Iglesias de España y teatro monástico de la provincia de Cartaginensis. Madrid. 1669. J. LOPÉRRAEZ CORVALÁN: Descripción Histórica del Obispado de Osma con el catálogo de sus prelados... ob. cit. I. ÁLVAREZ BORGE: Poder y relaciones sociales en Castilla ... ob. cit.

153 L. SERRANO: El Obispado de Burgos y la Castilla primitiva ... ob. cit. D. MANSILLA REOYO: Obispado y monasterios ... ob. cit.

154 D. MANSILLA REOYO: “Obispado y monasterios ...” ob. cit.

155 L. SERRANO: El Obispado de Burgos y la Castilla primitiva ... ob. cit. D. MANSILLA REOYO: “Obispado y monasterios...” ob. cit.

156 Ibídem. 
embargo, generaba algunas situaciones curiosas, como fue el caso de Salas de los Infantes, donde una de sus parroquias, la de Santa Cecilia, situada en la margen derecha del Arlanza, pertenecía a la diócesis de Burgos, mientras que la de Santa María, por estar situada en la ribera contraria, se encontraba bajo control de la sede oxomense. Esto no se resuelve hasta el siglo XVI, cuando se decide efectuar una serie de trueques entre ambas sedes, de tal modo que la parroquia de Santa María pasaba a formar parte de la diócesis de Burgos, mientras que algunas otras pertenencias de ésta fueron a parar a Osma $^{157}$.

Inmediatamente después de ser restablecidas estas sedes se procede a la reorganización de sus respectivos territorios, estableciendo la característica estructura de la organización eclesiástica, articulada en arcedianatos, arciprestazgos, y parroquias ${ }^{158}$. Dentro de esta organización vemos que todos los pueblos pertenecientes a la diócesis de Burgos quedan incluidos dentro del arciprestazgo de Lara ${ }^{159}$, mientras que los situados bajo la sede oxomense se reparten entre los arciprestazgos de Coruña del Conde y Cabrejas $^{160}$.

Finalmente, como indicábamos en un principio, este periodo medieval resulta también de vital importancia para todos estos pueblos, en lo que se refiere a su propia configuración interna. Así, durante estos siglos, y a lo largo de diferentes etapas, se van estableciendo las relaciones de poder y dependencia, que se mantendrán posteriormente, aunque con ligeros cambios, durante toda la Edad Moderna.

157 E. GONZÁLEZ BARRIUSO: Salas de los Infantes en la Sierra Burgalesa. Burgos, Grupo Editorial 7. 1999. (pp . $69-70$ ).

158 I. ÁLVAREZ BORGE: Poder y relaciones sociales en Castilla ... ob. cit.

159 L. SERRANO: El Obispado de Burgos y la Castilla primitiva ... ob. cit.

160 Las localidades de Hacinas, Canicosa de la Sierra, Palacios de la Sierra, Moncalvillo y Castrillo de la Reina pertenecerían al arciprestazgo de Coruña, mientras que Regumiel de la Sierra y Vilviestre del Pinar se encontrarían dentro del arciprestazgo de Cabrejas. J. LOPÉRRAEZ CORVALÁN: Descripción Histórica del Obispado de Osma ... ob. cit. 
Las llamadas “comunidades de aldea” constituyen el primer punto o paso previo de esta evolución, dentro de las cuales podemos incluir a los pueblos de nuestra comarca en su fase embrionaria de los siglos IX-X. Se trata de grupos reducidos, donde la familia o linaje mantienen derechos individuales sobre sus medios de producción, complementados con derechos colectivos o de aprovechamiento sobre las propiedades comunales (bosques, pastos o ríos), y medios de producción más complejos (molinos), que son conocidos como divisas ${ }^{161}$.

El proceso desarticulador de este sistema es el que permite desarrollar las relaciones de poder y dependencia, que más adelante se viven en estas poblaciones. En los pueblos de nuestro ámbito de estudio esto comienza a producirse en torno al siglo X, consumándose ya en la centuria siguiente. De este modo, vemos como la prosperidad de determinados miembros de estas comunidades les permite incrementar de forma notable el número de heredades, aumentando con ello sus derechos sobre las propiedades comunales, es decir, sus divisas, hasta el punto de poder disponer, en algunos casos, de un gran control sobre estas aldeas.

Estamos hablando, por lo tanto, de un auténtico señorío dominical, donde el poder viene dado por la propiedad directa de la tierra. Los llamados magnates son los que ejercen este poder, los cuales en el siglo XI son ya hombres o familias enteras, que disfrutan de amplias propiedades, repartidas en diferentes localidades, poseyendo al mismo tiempo gran número de divisas, cuyos derechos se ven incrementados, en muchos casos, con un cierto poder político, proporcionado por el control de las tenencias, instauradas a partir del reinado de Fernando I.

161 L. MARTÍNEZ GARCÍA: “Solariegos y señores. La sociedad rural ...” ob. cit. I. ÁLVAREZ BORGE: Poder y relaciones sociales en Castilla ... ob. cit. Estructura social y organización territorial en Castilla la Vieja meridional: los territorios entre el Arlanzón y el Duero, siglos X al XIV. En I Jornadas de Historia (1 $1^{\circ}$ 1989. Burgos). Introducción a la Historia de Burgos en la Edad Media. Burgos. Asociación Provincial de Libreros de Burgos. 1990 (705 - 717). L.V. DÍAZ MARTÍN: “Estructura 
Entre los magnates más destacados de nuestra zona, que las fuentes documentales nos han permitido conocer, se encuentran nombres y apellidos tan ilustres como los Gustios, linaje que culmina en el siglo XI con Gonzalo Gustios, importante divisero de Salas, y padre de los legendarios Siete Infantes de Lara. Se trata en este caso de un linaje que ya en el siglo $\mathrm{X}$ cuenta con destacados personajes, como es el caso de Fernando Gustios, quien junto con Velasco González - otro importante magnate de la zona - poseen el monasterio de San Cristóbal de Vallejimeno, así como otra serie de heredades y divisas repartidas entre esta localidad de Vallejimeno, Huerta de Abajo, Tolbaños de Arriba, Tolbaños de Abajo, Neila, Barbadillo de Herreros, Hoyuelos de la Sierra, y el monasterio de Alveinte ${ }^{162}$.

No menos importante es el linaje de Diego Álvarez, señor de Carazo en el siglo X, al cual pertenecía Pedro Fernández, quien poseía la mayor parte de las divisas de Riocavado de la Sierra, donándolas en 1083 al monasterio de San Pedro de Cardeña ${ }^{163}$. Otro apellido ilustre en la zona es el de los Fortúniz, el cual aparece también ligado a numerosas propiedades dentro de estos pueblos. Uno de sus miembros, doña Juliana, aparece donando en 1082 una divisa, que poseía en Barbadillo de Herreros, al monasterio de San Pedro de Cardeña ${ }^{164}$, lo cual repite posteriormente en 1094 con el monasterio de San Millán de la Cogolla, al que dona importantes posesiones en Salas, Castrovido, Barbadillo de Herreros y Vallejimeno ${ }^{165}$.

social”. En Historia de Burgos II. Edad Media (1). Burgos, Caja de Ahorros Municipal de Burgos. 1986. (pp. 246 - 293).

162 I. ÁLVAREZ BORGE: Poder y relaciones sociales en Castilla ... ob. cit. (pp. 77 - 80). L. SERANO: Cartulario de San Pedro de Arlanza. doc. XII.

163 I. ÁLVAREZ BORGE: Poder y relaciones sociales en Castilla ... ob. cit. (pp. 83 - 87). L. SERRANO: Cartulario Gótico de Cardeña. doc. CCCXXXII.

164 I. ÁLVAREZ BORGE: Poder y relaciones sociales en Castilla ... ob. cit. (pp. 87 - 88). L. SERRANO: Becerro Gótico de Cardeña. doc. CCCXXXIII.

165 I. ÁLVAREZ BORGE: Poder y relaciones sociales en Castilla ... ob. cit. L. SERRANO: Cartulario de San Millán. doc. 282. 
Sin embargo, si hablamos del linaje más importante de estos siglos tenemos que referirnos a los Lara, los cuales, además de poseer en el siglo XI las tenencias de Carazo, Huerta y Lara, también tenían un importante patrimonio repartido a lo largo de toda la comarca de la sierra burgalesa, dentro del cual destacaba, por ejemplo, el monasterio de San Millán de Revenga, que donaron en 1089 a su homónimo de la Cogolla ${ }^{166}$.

Junto con estos magnates, y desempeñando en muchos casos un papel muy parecido, se encuentran también los grandes monasterios asentados en las inmediaciones de la comarca, cuyas propiedades, adquiridas a través de generosas donaciones, los lleva a disfrutar de amplias posesiones dentro de los pueblos de la zona, al mismo tiempo que acaparan numerosas divisas. Entre los centros más destacados se encuentran los monasterios de San Pedro de Arlanza, Santo Domingo de Silos y el Infantado de Covarrubias.

El primero de ellos poseía amplias propiedades diseminadas por toda la zona central del territorio del alfoz de Lara, quedando muy pocos pueblos de nuestro ámbito de estudio que no tuvieran alguna heredad perteneciente a este cenobio ${ }^{167}$. La presencia de Santo Domingo de Silos, sin embargo, resulta más discreta, ya que la gran fama que adquirió este centro tras la muerte del Santo que le da nombre, hace que las donaciones más importantes procedan de zonas relativamente alejadas ${ }^{168}$. Por su parte, el Infantado de Covarrubias, fundado por la infanta Doña Urraca, hija del conde Garcí Fernández, también cuenta con destacadas propiedades en nuestra zona, dentro de las cuales

166 I. ÁLVAREZ BORGE: Poder y relaciones sociales en Castilla ... ob. cit. (pp. 60 - 61). M.L. LEDESMA: Cartulario de San Millán de la Cogolla (1076 - 1200). Zaragoza, 1989, docs. 190 y 254. L. SERRANO: Cartulario de San Millán. doc. 76

167 L. SERRANO: El Obispado de Burgos y la Castilla primitiva ... ob. cit. (pp. 252 - 258). I. ÁLVAREZ BORGE: Poder y relaciones sociales en Castilla ... ob. cit. 168 Ibídem. 
destaca, de modo especial, la villa de Barbadillo del Pez, procedente de una donación regia $^{169}$.

A estos centros tenemos que unir también otros monasterios y centros religiosos más alejados, que poseyeron igualmente importantes intereses en la zona. El más destacado es, sin duda, el monasterio de San Millán de Cogolla, cuya importante influencia en la zona de la Sierra de la Demanda, le lleva a convertirse en un destacado receptor de donaciones, como acabamos de ver con el caso de la familia Fortúniz. A ello debemos unir también la posesión de un tercio de las divisas de Riocavado de la Sierra $^{170}$, que tenía por donación de Sancho de Navarra en 1028, la adquisición de los monasterios de San Millán de Revenga y San Mamés de Huerta de Arriba, igualmente donados a finales de este mismo siglo XI por la familia de los Lara, y una amplia serie de heredades repartidas por Salas, Castrovido y Vallejimeno ${ }^{171}$. Esto le permite, al mismo tiempo, cobrar tributos en la zona, como es el caso del poco conocido Voto de San Millán, el cual efectuaban entre otros pueblos Monterrubio de la Demanda, Barbadillo de Herreros, Villanueva de Ferreros (desaparecido), Riocavado de la Sierra y Arlanzón ${ }^{172}$. Por último tenemos que nombrar también al monasterio de San Pedro de Cardeña, que como hemos visto antes, poseía parte de las divisas de Riocavado de la Sierra, merced a la donación efectuada por Pedro Fernández a finales del siglo XI; y también la del Hospital del Rey, incorporado ya en el siglo XIII a este juego de poder, pero que fue igualmente dotado con destacadas posesiones en la zona, obtenidas por donación regia, o mediante permutas con el monasterio de San Pedro de Arlanza. Entre las posesiones de este Hospital en la zona destaca la localidad de Moncalvillo, la cual mantiene su condición de señorío de abadengo hasta la supresión de este régimen ${ }^{173}$.

\footnotetext{
169 Ibídem.

170 Ibídem. L. SERRANO: Cartulario de San Millán. doc. 96.

171 Ibídem. Cartulario de San Millán. doc. 172, 180, 186, 212, 235, 238, 239, 253, 258, 282, 284.

172 L. SERRANO: El Obispado de Burgos y la Castilla primitiva ... ob. cit. (273 - 281).

173 G. MARTÍNEZ DÍEZ: Libro Becerro de las Behetrías. Estudio y texto crítico. Vol. II. León. Centro de Estudios e Investigación San Isidoro. 1981.
} 
Tras la creación de estos señoríos dominicales, el siguiente paso, dentro de la evolución, que registraron las relaciones de poder en el interior de estos núcleos, es el que nos conduce hacia los señoríos jurisdiccionales. Ahora, el poder sobre los pobladores de estas localidades no deriva de la posesión de la tierra, sino que procede de la adquisición de determinados derechos y privilegios ${ }^{174}$. Esto se plasma, en nuestra comarca, con la llegada de los Velasco en las décadas centrales del siglo XIV. Así, vemos como Pedro Fernández de Velasco, primer conde de Haro, había conseguido hacerse con la casa-palacio de Salas, merced a una interesante e inteligente política de matrimonios, obteniendo con ello la proyección que necesitaba para extender su poder por toda la comarca, cosa que hará de forma inmediata ${ }^{175}$.

Con todo esto, comprobamos cómo entre el siglo XII y mediados del XIV se fija el estatuto señorial de todas y cada una de nuestras villas y lugares, estableciéndose así las distintas condiciones de cada una de ellas, que podían ser de abadengo, solariego, realengo, behetría o condominios de diferentes señores ${ }^{176}$. Para conocer estas cuestiones contamos, en este caso, con la valiosa información recogida en el Becerro de las Behetrías, elaborado a partir de las pesquisas ordenadas por el rey Pedro I en todo el territorio de la Merindad Mayor de Castilla a mediados del siglo XIV.

A través de esta obra sabemos que las localidades de abadengo, no eran muy frecuentes en esta comarca. Todo ello, a pesar del gran número de propiedades, que en todos estos núcleos, poseían los grandes cenobios cercanos. Aun así, entre las poblaciones constituidas en señoríos de abadengo se encontraban núcleos tan destacados

174 L. MARTÍNEZ GARCÍA: El desarrollo institucional burgalés en la Baja Edad Media. En Historia de Burgos. Desde sus orígenes hasta nuestros días. Vol. II. Desde el año 1000 a los Tiempos Modernos. Burgos, Diario 16 Burgos. 1993. (pp. 519 - 530).

175 I. ÁlVAREZ BORGE: Poder y relaciones sociales en Castilla ... ob. cit.(145 - 149). P. LEÓN TELLO: Archivo de los duques de Frías: inventario: Tomo I Casa de Velasco. Madrid. Dirección general de Archivos y bibliotecas y cada de los duques de Frías. 1955.

176 C. ESTEPA DÍEZ: Estructuras de poder en Castilla (siglos XII - XIII). El poder señorial en las merindades burgalesas. En III Jornadas burgalesas de Historia. (3 ${ }^{a} 1991$ Burgos). Burgos en la Plena Edad Media. Burgos, Asociación Provincial de Libreros de Burgos. 1994. (pp. 245 - 294). 
como Canicosa de la Sierra, Quintanar de la Sierra, Regumiel de la Sierra, y el despoblado de Villa Serrazín, que pertenecían al monasterio de San Pedro de Arlanza, Barbadillo del Pez, que pertenecía al Infantado de Covarrubias, y Moncalvillo, que como ya hemos señalado, dependía del Hospital del Rey.

Frente a estos, nos encontramos con los señoríos solariegos, que son los más abundantes dentro de este espacio. Se trata de localidades donde el titular de determinados derechos era un gran señor laico, el cual tenía el privilegio de nombrar oficiales del concejo, impartir justicia y percibir determinadas rentas, pagadas por los vecinos pecheros. Estos privilegios habían sido obtenidos, tanto por la donación regia o el disfrute de tenencias, como por la acaparación de divisas, lo cual se convirtió en una práctica muy común en nuestra zona, donde fue desarrollada principalmente por la familia de los Velasco. El gran señor de esta zona, durante este siglo XIV, fue D. Pedro Fernández de Velasco, I conde de Haro, al cual pertenecen la mayor parte de las localidades declaradas como señoríos solariegos, bien de forma completa o bien de modo compartido con otros señores. Las dos únicas localidades declaradas como solariegas, que no tenían a Pedro Fernández de Velasco como señor son Terrazas y Vilviestre del Pinar, que pertenecían a Iohan Díaz de Roca Fuy e donna Sancha, muger que fue de Diego López de Haro ${ }^{177}$. El resto, donde se encuentran Barbadillo de Herreros, Bezares, Huerta de Abajo, Huerta de Arriba, Palacios de la Sierra, Quintanilla de Urrilla, Riocavado de la Sierra, Tolbaños de Abajo, Tolbaños de Arriba y Vallejimeno, pertenecen al mencionado Pedro Fernández de Velasco.

Los lugares de realengo, por el contrario, son francamente escasos, ya que solamente aparece registrado, dentro de esta condición, el caso de Monterrubio de la Demanda, localidad incluida en el Valle de Canales y las Cinco Villas, todas ellas de realengo.

177 G. MARTÍNEZ DÍEZ: Libro Becerro de las Behetrías... ob. cit. 
Las behetrías, como forma más característica de la estructura feudal castellana durante la Edad Media, también aparecen representadas aquí. Se trata de localidades donde se ha conseguido mantener una comunidad de diviseros, sin predominio a priori de ninguno de ellos, los cuales se encargaban de decidir libremente quién sería su señor. Sin embargo, como podremos ver, en nuestra comarca resulta normal entre los años centrales del siglo XIII y el XIV, que ciertos grandes señores, ajenos a estas localidades, se hicieran con el control de un amplio número de divisas, adquiriendo con ello un elevado poder en el seno de estos núcleos. De este modo, terminan por convertirse en auténticos señoríos solariegos de facto, a pesar de que en la documentación de la época aparezcan recogidos como behetrías. Son, por lo tanto, behetrías heridas de muerte, que estarían a punto de completar su proceso de transición hacia los señoríos solariegos. Este era el caso de Castrillo de la Reina, Hoyuelos de la Sierra, Arroyo de Salas, Monasterio de la Sierra o la propia Salas de los Infantes, donde entre sus más importantes diviseros aparece siempre Pedro Fernández de Velasco o algún familiar suyo. El paso siguiente, para todas estas localidades, fue su incorporación al señorío de la casa de los Velasco, pues un siglo y medio más tarde vemos como todas ellas aparecen formando parte de las Tierras del Condestable de Castilla.

Finalmente tenemos que hablar de los condominios, los cuales, tampoco son muy abundantes, pues solamente Hacinas aparece señalada como tal. Se trata de núcleos que comparten una doble condición, que en este caso es la de solariego y abadengo, ya que esta localidad por una parte pertenece a los fiios de Iohan Martínez de Avellaneda y a donna Iohana muger que fue de Iohan Martínez de Leyva, y por otra al monesterio de Funt Caliente. ${ }^{178}$

EDAD MODERNA.

A finales del siglo XV y principios del XVI, con la unión bajo una sola corona de la mayor parte del territorio de la península, y la definitiva expulsión de los

178 Ibídem. 
musulmanes, que quedaban en el reducto, que constituía el Reino nazarí de Granada, se inicia la Edad Moderna. Este periodo constituye a su vez el marco temporal en el que nos hemos centrado para analizar las manifestaciones artísticas desarrolladas dentro de esta comarca de la sierra burgalesa. Por lo cual, es aquí donde nos detendremos, para realizar un estudio más detallado de la realidad que caracterizó a nuestra zona durante el tiempo en el que se llevaron a cabo estas construcciones.

Durante los primeros momentos de la Edad Moderna nuestra comarca queda situada dentro del área, que se consideraba más pujante de la Corona de Castilla, tanto desde el punto de vista político, como económico y cultural. Esta área era la delimitada por las ciudades de Burgos, Salamanca, Segovia y Toledo, pues no en vano en el interior de este perímetro se hallaban 13 de las 17 ciudades, que en el siglo XVI tenían el privilegio de participar con sus procuradores en las Cortes de Castilla ${ }^{179}$. Posteriormente, sin embargo, con la llegada de la crisis generalizada del siglo XVII, y el sucesivo traslado de los ejes más dinámicos de la vida hispana, desde el centro hacia los territorios de la periferia, que se vivió en la centuria siguiente, terminaron por truncar de forma evidente esta situación ventajosa. No obstante, en lo que se refiere a los efectos que pudo tener en nuestra zona de estudio esta decadencia vivida a partir de la segunda parte de la Edad Moderna, debemos, cuanto menos, ser prudentes a la hora de extrapolar los datos extraídos de una visión demasiado generalizada del ámbito castellano. Así, tal y como tendremos oportunidad de ver, y dentro de las desigualdades que se pudieron dar dentro un territorio tan amplio, no debemos considerar de modo absoluto los siglos XVII-XVIII como un periodo calamitoso para nuestra zona, sino más bien como un momento marcado por continuos avances y retrocesos, característico de las sociedades del Antiguo Régimen.

En este apartado, únicamente nos centraremos en el análisis de la organización territorial del espacio que comprende nuestra comarca, estableciendo siempre la

179 A. DOMÍNGUEZ ORTIZ: El Antiguo Régimen: Los Reyes Católicos y los Austrias. En Historia de España. Tomo 3. Dir. Miguel Artola. Madrid, Alianza Editorial. 1990. 
relación con el marco más amplio de la Corona de Castilla en el que se encuadra. De esta forma, las cuestiones relacionadas con la economía, población y sociedad serán abordadas de forma pormenorizada más adelante.

Analizar el mapa administrativo de nuestra comarca durante la Edad Moderna no resulta una tarea fácil, pues, como ocurre en el resto del extenso territorio, que conformaba la Corona de Castilla, nos enfrentamos aquí ante un auténtico mosaico ininteligible de divisiones, jurisdicciones y administraciones diferentes, difícil de desenmarañar. A ello se suma la total falta de estudios detallados sobre esta cuestión en nuestra zona, lo cual nos obliga a partir de trabajos de ámbito más general, realizados sobre el resto del territorio burgalés, extrapolando sus conclusiones a nuestra zona en la medida de lo posible. Estos resultados, a su vez, deben ser necesariamente contrastados e ilustrados con los datos extraídos de las fuentes documentales, las cuales, aunque no son muy abundantes, resultan sumamente esclarecedoras en la mayoría de los casos. Dentro de estas fuentes, necesariamente tenemos que citar los datos extraídos del censo de 1591, publicados por Tomás González, las Respuestas Generales del Catastro del Marqués de Ensenada, desarrollado a mediados del siglo XVIII, y la obra encargada por Floridablanca en 1785 y publicada tres años después bajo el título de España dividida en provincias e intendencias y subdividia en partidos, corregimientos y alcaldías mayores, gobiernos políticos y militares, así realengos como de órdenes, abadengos y señoríos. Obra formada por las relaciones originales de los respectivos intendentes del reyno, a quienes se pidieron por orden de S. M. por el Excmo. Sr. Conde de Floridablanca y su Ministro de Estado en 22 de marzo de 1785. Con un Nomenclator o Diccionario de todos los pueblos del reyno, que compone la segunda parte ${ }^{180}$.

Al acabar la Edad Media, la comarca de la sierra, al igual que la mayor parte del territorio de la actual provincia de Burgos, se encontraba incluida dentro de la Merindad Mayor de Castilla, la cual se dividía a su vez en 18 circunscripciones o merindades

\footnotetext{
180 Esta última obra citada constituye, a juicio de D. Gonzalo MARTíNEZ DÍEZ, la obra capital para poder conocer el mapa jurisdiccional español del Antiguo Régimen desde el siglo XVI - XVIII.
} 
menores. Dentro de ellas, las de Santo Domingo de Silos y Candemuñó eran las que se repartían los pueblos situados en nuestra comarca, mientras que al sur quedaban las Comunidades de villa y tierra ${ }^{181}$.

Con el inicio del siglo XVI, sin embargo, esta división administrativa se hallaba prácticamente disuelta, ante la proliferación de jurisdicciones exentas, puestas bajo la autoridad de señores laicos o eclesiásticos, que habían acabado por mermar la autoridad de los merinos. Al mismo tiempo, vemos también como el título de Adelantado Mayor de Castilla, máxima autoridad de la Merindad Mayor de Castilla, se había convertido, en cierto modo, en un cargo meramente honorífico y desprovisto de cualquier autoridad efectiva. Su labor era realizada a través de dos Alcaldes Mayores de Adelantamiento, los cuales se repartían el territorio de la Merindad Mayor, correspondiendo a uno la zona de Tierra de Campos y al otro el territorio de Burgos, donde se encuadraba nuestra comarca. La jurisdicción de estos alcaldes, no obstante, sólo alcanzaba a aquellas localidades que habían permanecido como municipios de realengo, o las behetrías que aun se mantenían como tal, y que habían adoptado al monarca como su señor. Esta circunstancia, sin embargo, sólo se cumplía en 21 localidades de las más de 200 que componían la merindad menor de Santo Domingo de Silos, lo cual permite que nos hagamos una idea de la debilidad de estas instituciones ${ }^{182}$.

El Alcalde Mayor de Adelantamiento de Burgos era el encargado de la administración de justicia en la zona de la sierra para los litigios de primera instancia, pero como decimos, esto sólo sucedía en localidades de realengo, como era el caso de Monterrubio de la Demanda, o que habían conservado su condición de behetría, como sucedía con Neila. Aun así, esta división en merindades menores todavía continuó

181 G. MARTÍNEZ DÍEZ: Administración, gobierno y justicia. En Historia de Burgos. III. Edad Moderna (1). Burgos, Caja de Ahorros Municipal de Burgos. 1991. (pp. 327 - 349). Las comunidades de villa y tierra de la Extremadura castellana. Madrid, Editora Nacional. 1983.

182 I. ÁLVAREZ BORGE: Merindades y merinos menores de Silos, Muñó y Castrojerid (1200 - 1350. En Jornadas Burgalesas de Historia ( $3^{\circ}$ 1991. Burgos). Burgos en Plena Edad Media. Burgos, Asociación Provincial de Libreros de Burgos. 1994. 
106 Arquitectura de la Edad Moderna en la sierra burgalesa.

manteniendo una cierta vigencia dentro del campo fiscal, ya que el arrendamiento del cobro de las alcabalas y tercias reales, y más tarde la moneda forera, seguía realizándose, hasta 1523, a través de estas circunscripciones.

Sin embargo, la proliferación de jurisdicciones exentas, y el desarrollo de una nueva organización fiscal, acabaron finalmente con la vigencia de esta organización territorial, para dar paso a un nuevo marco administrativo. A ello debemos sumar también la presencia de la autoridad eclesiástica, con su propia organización territorial, la cual contribuye definitivamente a crear ese complejo mosaico, existente dentro de la estructura administrativa, donde se superponen diferentes autoridades, que nos lleva a analizar nuestro territorio desde una triple perspectiva.

Tenemos que hablar, por lo tanto, y de forma completamente diferenciada, de un espacio eclesiástico, de un espacio fiscal y de un espacio jurisdiccional, con divisiones y compartimentaciones que en ningún caso coinciden entre sí, salvo en muy contadas ocasiones $^{183}$. Al mismo tiempo, y junto a esta convivencia de diferentes organizaciones territoriales en sentido horizontal, debemos tener en cuenta también la articulación, que cada una de las administraciones tiene en sentido vertical, es decir, la estratificación de los diferentes órganos encargados de llevar a cabo estas funciones. Así, mientras en el espacio religioso debemos hablar de los obispados, arciprestazgos y parroquias, en la organización del espacio fiscal y jurisdiccional nos encontramos con los dos ámbitos de poder más destacados de la Edad Moderna, como son los concejos de los municipios y los señoríos ${ }^{184}$. Ante esto, la autoridad del Estado se convierte en una superestructura, que resulta en ocasiones sumamente debilitada y erosionada por el papel desempeñado

183 A. RODRÍGUEZ SÁNCHEZ: Espacio, población y sociedad. Siglos XVI - XVIII. En Historia de Burgos III. Edad Moderna (2). Burgos, Caja de Ahorros Municipal de Burgos. 1992. (pp. 4 - 42). Burgos en el siglo XVI. En Historia de Burgos, desde sus orígenes hasta nuestros días. Tomo 2. Desde el año 1000 hasta los Tiempos Modernos. Burgos, Diario 16 Burgos. 1993. (591 - 602).

184 L. MARTÍNEZ GARCÍA: El desarrollo institucional burgalés en la Baja Edad Media (siglos XIV XV). En Historia de Burgos, desde sus orígenes hasta nuestros días. Tomo 2. Desde el año 1000 a los Tiempos Modernos. Burgos, Diario 16 Burgos. 1993. (pp. 519 - 530). 
por los señoríos ${ }^{185}$. Sin embargo, y frente a ello, esta superestructura estatal cuenta también con sus propios órganos de inspección y control, dependientes de los consejos, que constituyen el característico sistema polisinodal, y en materia jurisdiccional, con una legislación común para todo el territorio de Castilla, así como con la labor de los corregidores y especialmente de los tribunales de apelación, donde se podrían remitir todas las causas ${ }^{186}$.

Comenzamos el análisis con el estudio del espacio eclesiástico, el cual, es sin duda el que experimente un menor número de transformaciones con respecto a la estructura heredada de la Edad Media, y también el que menos cambios vive a lo largo de toda la Edad Moderna. De este modo, vemos cómo nuestra comarca continúa repartida entre las diócesis de Burgos y Osma, manteniendo con muy escasos cambios la repartición territorial y los límites fijados en el Concilio de Burgos del año 1136. No obstante, entre los escasos movimientos que se viven, dentro de estas fronteras, debemos señalar uno que afecta a nuestra comarca de modo especial. Nos referimos a la incorporación, que se produce a mediados del siglo XVI, de la parroquia de Santa María de Salas de los Infantes a la diócesis burgalesa, rompiendo de esta forma una situación ciertamente anómala, que hacía que una misma localidad tuviera sus parroquias repartidas entre dos diócesis distintas ${ }^{187}$. Otro cambio interesante, dentro de los límites de este espacio eclesiástico, aunque en este caso sin ninguna repercusión para nuestra zona de estudio, es el que se vive, a mediados del siglo XVIII, en la diócesis burgalesa con la excisión de sus territorios del norte, que pasan a crear la nueva diócesis de Santander ${ }^{188}$.

\footnotetext{
185 A. DOMÍNGUEZ ORTIZ: Instituciones y sociedad en la España de los Austrias. Barcelona, Editorial Ariel. 1985.

186 A. DOMÍNGEZ ORTIZ: El Antiguo Régimen: los Reyes Católicos... ob cit.

187 E. GONZÁLEZ BARRIUSO: Salas de los Infantes en la Sierra Burgalesa ... ob cit.

188 N. MARTínEZ LÓPEZ: Aspectos de la vida eclesiástica en el Burgos moderno. (siglos XVI XVIII). En Historia de Burgos III. Edad Moderna (1). Burgos, Caja de Ahorros Municipal de Burgos. 1992. (pp. 351 - 420). La iglesia en Burgos durante la Época Moderna. En Historia de Burgos, desde sus orígenes hasta nuestros días. Tomo 2. Desde el año 1000 a los Tiempos Modernos. Burgos, Diario 16 Burgos. 1993. (pp. 675 - 686).
} 
Una última novedad la encontramos en la conversión que sufre la silla burgalesa al ser nombrada Sede Metropolitana, dependiente directamente de Roma. Este hecho se produce en 1574 a instancias del propio rey Felipe II, de forma que, a partir de este momento, tendremos que hablar de la archidiócesis burgalesa ${ }^{189}$.

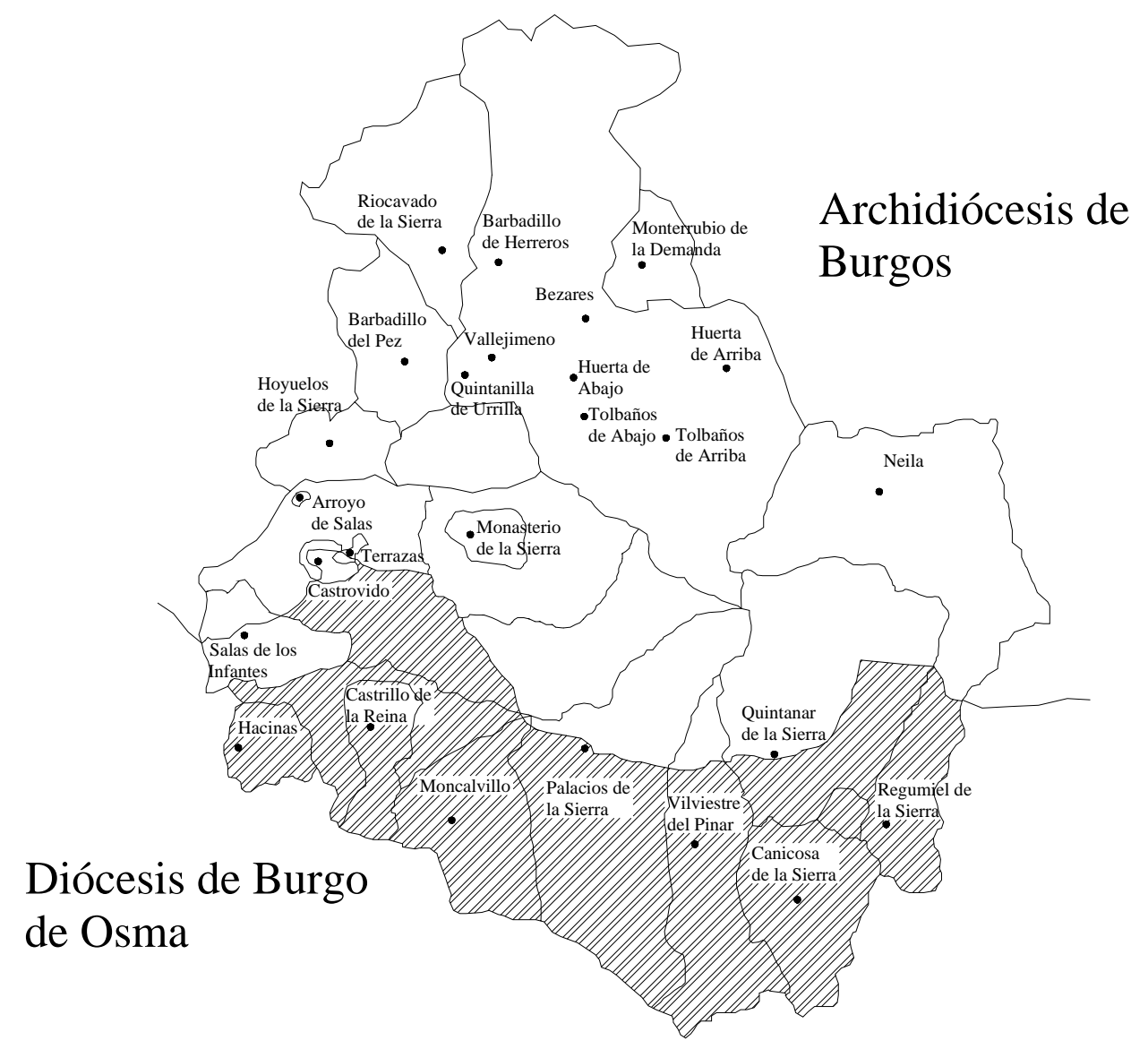

División del espacio eclesiástico

\footnotetext{
189 A. RODRÍGUEZ SÁNCHEZ: Espacio, población y sociedad. Siglos XVI - XVIII ... ob cit. Burgos en el siglo XVI... ob. cit.
} 
Respecto a la organización de este espacio eclesiástico en sentido vertical, vemos que tampoco se aprecian cambios sustanciales desde la Edad Media, en lo que se refiere a la estructura de diócesis, arciprestazgos y parroquias. En el nivel inferior, como vemos, se sitúan las parroquias, donde el único cambio significativo, que se produce es de orden estrictamente cuantitativo y no cualitativo. Así, localidades como Palacios de la Sierra y Huerta de Arriba, que habían contado tradicionalmente con dos parroquias, ven como se reducen a una sola. En el caso de Palacios de la Sierra, este hecho se produce a finales del siglo XVI, durante el mandato del obispo de Osma, Sebastián Pérez, mientras que en Huerta de Arriba la supresión de su parroquia de Santa María no se lleva a efecto hasta el año 1719. Este fenómeno, que se prolonga durante la Edad Contemporánea con las parroquias de Salas de los Infantes y Neila ${ }^{190}$, obedece a causas muy diversas, que en ningún caso debemos reducir a cuestiones de índole estrictamente demográfico. De hecho, en los casos citados de Palacios de la Sierra y Huerta de Arriba, esta fusión de parroquias no trajo aparejada una eliminación física del templo parroquial suprimido, que continuó siendo utilizado. Bien al contrario, en ambas ocasiones el templo convertido en sede de la única parroquia del pueblo es objeto de importantes obras de ampliación ${ }^{191}$.

Por su parte, en el nivel superior de esta estructura organizativa eclesiástica tenemos que mencionar, en este caso, la doble dependencia y obediencia del Estado y el rey, por un lado, y de la Santa Sede y del Papado, por otro. Así, a pesar de la continua reivindicación de la iglesia española de su autonomía gubernativa y judicial durante toda la Edad Moderna, veremos que existe un conjunto de derechos que los reyes de España tendrán sobre sus miembros. Estos derechos son conocidos genéricamente como

190 E. GONZÁleZ BARRIUSO: Salas de los Infantes en la Sierra Burgalesa... ob cit. B. VALDIVIELSO AUSíN: Neila, una llamada al turismo. Burgos, Ayuntamiento de Neila. 1980.

191 No obstante, estos aspectos serán abordados de forma más detallada en los respectivos capítulos dedicados a cada una de estas localidades. 
regalías, de las cuales su principal manifestación la encontraremos en el patronato regio, que otorgaba a los monarcas el derecho de presentación y del pase regio ${ }^{192}$.

Junto a este espacio eclesiástico aparece también el fiscal, el cual, evidentemente no coincide con el anterior. Al contrario de lo que sucedía con aquel, este espacio sí conoce cambios sustanciales con respecto al esquema heredado de la Edad Media, dividido, como hemos visto, en merindades ${ }^{193}$. La disolución de las mismas obliga a crear unas nuevas unidades o circunscripciones territoriales, en torno a las cuales establecer la nueva administración fiscal del Estado. Así, a principios del siglo XVI, aprovechando la distribución del nuevo impuesto denominado servicios reales, ${ }^{194}$ se procede a dividir el territorio de la Corona de Castilla en 18 circunscripciones, denominadas provincias, que se hacen coincidir con cada una de las ciudades que tenían el privilegio, en este momento, de acudir a Cortes ${ }^{195}$. Nace, de esta forma, una nueva circunscripción, como es la provincia, la cual tiene únicamente efectos fiscales.

En este caso, como era de esperar, observamos que la mayor parte de nuestra comarca quedaba incluida en la provincia de Burgos, con la única excepción de Monterrubio de la Demanda, localidad que, al formar parte de la Junta de Canales y las Cinco Villas, se encuadra en la provincia de Soria ${ }^{196}$. Se trataba, en el caso de Burgos,

\footnotetext{
192 A. DOMÍNGEZ ORTIZ: El Antiguo Régimen: los Reyes Católicos... ob cit.

193 J. L. MORENO PEÑA: Burgos: evolución histórica del espacio administrativo. En Historia de Burgos, desde sus orígenes hasta nuestros días. Tomo 1. Desde los orígenes al año 1000. Burgos, Diario 16 Burgos. 1993. (pp. 27 - 38).

194 R. CARANDE: Carlos V y sus banqueros. Tomo II. Barcelona, Editorial Crítica. 1987. (pp. 494 y ss.). A DÍAZ MEDINA: Economía y Hacienda. En Historia de Burgos III. Edad Moderna (2). Burgos, Caja de Ahorros Municipal de Burgos. 1992. (pp. 231 - 266).

195 G. MARTÍNEZ DÍEZ: Génesis histórica de la provincia de Burgos y sus divisiones administrativas. Burgos, Aldecoa. 1983. G. MARTÍNEZ DÍEZ: Administración, gobierno y justicia. ... ob. cit.

196 Ibídem. M. DIAGO HERNANDO: Repoblación e integración política en el Reino de Castilla del ámbito de la Tierra de Soria. En RICUS (Geografía e Historia), XI, 3 (1991 - 1992). (pp. 37 - 58). Expansión señorial en la Tierra de Soria en época Trastámara. En Celtiberia, 74 (1987). (pp. 201 - 238). La Extremadura soriana y su ámbito a finales de la Edad Media. (Universidad Complutense, 1990). J.
} 
de una provincia algo diferente a la actual, tanto en su perfil como en su extensión, pues si por un lado la mayor parte de las tierras al Sur del Duero quedaban fuera de su influencia, por otro, contaba con toda la zona de Cantabria y la mayor parte de la actual Comunidad Autónoma de la Rioja ${ }^{197}$.

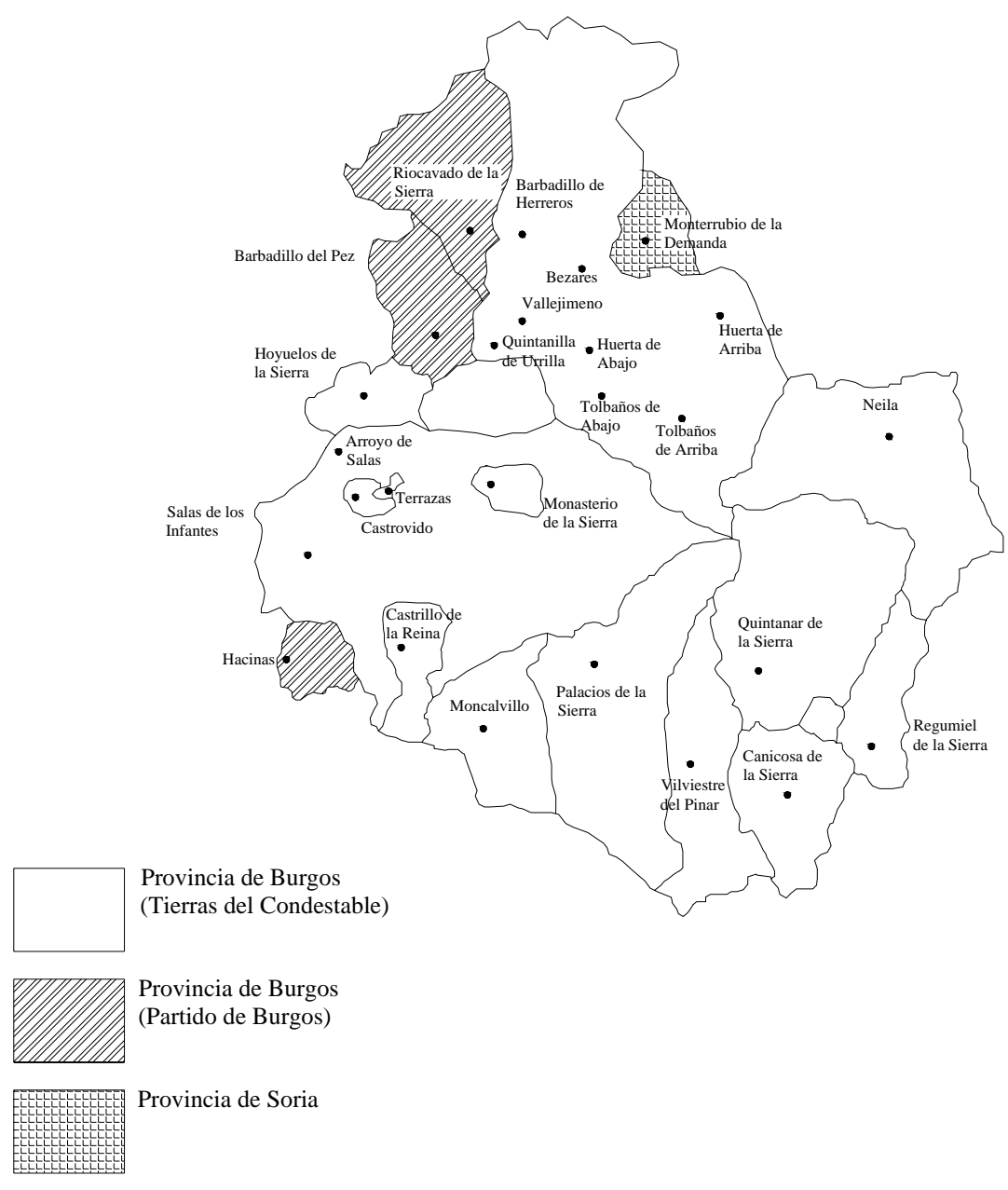

Provincias y partidos. Siglo XVI.

M. ALCALDE JIMÉNEZ: El régimen señorial en la provincia de Soria. Estructura y crisis. Siglos XVIII y XIX. Tesis Doctoral (Universidad de Zaragoza, 1993).

197 Ibídem. J.L. MORENO PEÑA: Burgos: evolución histórica ... ob. cit. 
A su vez, estas provincias se dividen en partidos, los cuales en el caso de Burgos son tres, conocidos como Burgos, Trasmiera y Tierras del Condestable. Dentro de esta división vemos que la mayor parte de nuestros pueblos se incluyen en este último partido, ya que una gran parte del señorío de la casa de los Fernández de Velasco, Duques de Frías y Condestables de Castilla, se extendía, desde la segunda mitad del siglo XIV, por esta comarca. Solamente quedan fuera, a parte de Monterrubio, que pertenecía como hemos dicho a la provincia de Soria, Barbadillo del Pez, Hacinas y Riocavado de la Sierra, que se incluyen dentro del partido de Burgos ${ }^{198}$. En el caso de Barbadillo del Pez esta incorporación al partido de Burgos parece deberse a su dependencia de la jurisdicción de la villa de Covarrubias ${ }^{199}$, mientras que en el de Hacinas y Riocavado de la Sierra la explicación la encontramos en su nula vinculación con la jurisdicción de la casa de los Fernández de Velasco ${ }^{200}$.

La finalidad de estas provincias y partidos es, como hemos indicado, únicamente fiscal, ya que fueron creadas para la recaudación de un tributo muy concreto, como era el de los servicios reales. Sin embargo, con el paso del tiempo irán consiguiendo nuevas atribuciones. Así, a partir del 1523, al establecer la recaudación de la alcabala mediante el sistema de encabezamiento, y no de arrendamiento como se venía haciendo, se acude a estas circunscripciones para establecer el reparto de las cantidades a entregar.

198 T. GONZÁLEZ: Censo de población de las provincias y partidos de la Corona de Castilla en el siglo XVI con varios apéndices para completar la del resto de la península en el mismo siglo, y formar juicio comparativo con la del anterior y siguiente, según resulta de los libros y registros que se custodian en el Real Archivo de Simancas. Ed. Facsímil. Madrid, Imprenta Real. 1829.

199 A esta misma jurisdicción pertenecerían también las localidades de Mencerreyes y Retuerta, situadas fuera de nuestro ámbito de estudio, cuya dependencia de Covarrubias, al igual que en el caso de Barbadillo del Pez, tiene su origen en la época plenomedieval, con la creación del Infantado de Covarrubias.

200 En el caso de Hacinas, esta independencia del señorío de los Duques de Frías es tan manifiesta, que, tal y como manifiestan las propias Respuestas Generales del Catastro del Marqués de Ensenada, constituye uno de los escasos pueblos de la zona en el que, ni las alcabalas ni las tercias reales habían sido usurpadas por la citada familia, percibiéndolos íntegramente el rey. ADPBU. CE. 6. RESPUESTAS GENERALES. Hacinas, 7 - enero - 1753. 
El éxito de esta circunscripción hace que se mantenga vigente, sin experimentar variaciones significativas, hasta principios del siglo XIX, cuando es sustituido por la actual organización territorial. Así, los únicos cambios que se registran a lo largo de este tiempo los encontraremos en sus atribuciones y en las figuras que se sitúan al mando en cada momento. De igual forma, vemos como en el siglo XVII, con el incremento de ciudades con derecho a participar en Cortes, se produce un aumento del número de estas provincias, si bien esto no afecta en modo alguno a nuestra zona.

Por el contrario, y frente a la solidez de estas demarcaciones territoriales, debemos señalar también la presencia de ciertas circunstancias que contribuyeron a minar su autoridad. En este caso, el mayor menoscabo se produce por la acción de grandes señores, propietarios de importantes señoríos jurisdiccionales, ya que muchos de ellos, en su política de ampliar competencias y obtener la mayor rentabilidad económica a sus títulos, no dudan en lanzarse a una campaña de usurpación de privilegios no adscritos a sus jurisdicciones, que les permitían cobrar determinados impuestos - como alcabalas y tercias reales - en detrimento de la fiscalidad de la Corona, encauzada a través de sus circunscripciones provinciales. Así, observamos como en nuestra comarca el Duque de Frías es el principal y casi único beneficiario de lo obtenido por las alcabalas y tercias reales de la mayor parte de los pueblos, percibiéndolas incluso en algunas localidades, que habían dejado de pertenecer a su jurisdicción para convertirse en realengos o en señorío de otro titular, como fue el caso de Quintanar de la Sierra, Palacios de la Sierra, Riocavado de la Sierra o de los ocho pueblos, que constituyen en este momento el Valle de Valdelaguna ${ }^{201}$.

Las usurpaciones de estos tributos se debieron producir, con toda seguridad, durante la primera mitad del siglo XV, aprovechando la debilidad de alguno de los monarcas, que reinaron en estos años, o beneficiándose de determinadas mercedes concedidas por ellos. No obstante, a lo largo de los siglos XVI-XVII no son pocos los

\footnotetext{
201 Esto lo podemos apreciar observando las Respuestas Generales del Catastro del Marqués de Ensenada (ADPBU), y especialmente en las contestaciones dadas a las preguntas $2^{\mathrm{a}}, 15^{\mathrm{a}}$ y $28^{\mathrm{a}}$.
} 
señores que adquieren por distintas vías este derecho, con el consiguiente perjuicio para la hacienda de la Corona. En nuestra zona, y aunque no contamos con datos precisos que avalen esta opción, estimamos que fue la primera modalidad la que permitió a los mencionados Duques de Frías hacerse con este privilegio. Así, en el momento de realizar el Catastro del Marqués de Ensenada, a mediados del siglo XVIII, cuando se pregunta por esta cuestión, no es raro encontrarnos frases como la recogida en las Respuestas Generales de Vallejimeno, donde se dice lo siguiente: se pagan al Duque de Frías alcabalas (...) sin que se pueda dar razón si la goza en excelencia por gracia y merced o por servicio pecuniario ${ }^{202}$.

Por otra parte, y junto a estas cuestiones relacionadas con el espacio fiscal o administrativo de la Corona de Castilla, debemos hablar también de la organización en sentido vertical, donde la unidad básica, y pieza fundamental de todo este engranaje, lo constituye el municipio. Aquí se encuentran, entre otras competencias, las de materia fiscal, pues a través de los concejos, que gobernaban cada una de estas poblaciones (e independientemente de su condición jurisdiccional, de realengo o de señorío), se canalizaban estas obligaciones tributarias, encargándose de la derrama individual entre cada uno de los vecinos. De igual modo, estos concejos son los encargados de confeccionar las listas de padrones, donde se establece la clasificación entre privilegiados y pecheros, documentos, que en muchos casos, y especialmente en las zonas rurales como es la nuestra, se convertían en los únicos mecanismos capaces de establecer la diferencia entre el estamento de los hidalgos y el estado llano ${ }^{203}$.

La unidad superior, en este caso, queda constituida lógicamente por del Consejo de Hacienda, sobre el cual se apoyaba la estructura gubernamental en esta materia.

La tercera perspectiva, desde la que podemos analizar esta compleja organización territorial, es la que hace referencia al espacio jurisdiccional, es decir, a la

\footnotetext{
202 ADPBU. CE. 2179. RESPUESTAS GENERALES. Vallejimeno, 19 - mayo - 1753.

203 A. DOMÍNGUEZ ORTIZ: Instituciones y sociedad en la España de los Austrias ... ob. cit.
} 
titularidad jurídica de cada núcleo. Se trata, sin duda, del campo donde encontraremos una mayor fragmentación espacial, ya que aquí entran en juego factores muy variados, como son la naturaleza de cada una de las localidades analizadas, el origen de esta naturaleza, o la amplitud de poderes de que disfrutaba el titular de la jurisdicción. A todo ello se suma también la extensión de las circunscripciones que surgen de aquí, pues en esta comarca encontramos, desde pequeños señoríos, conformados únicamente por una sola localidad, como es el caso de Riocavado de la Sierra o Quintanar de la Sierra, hasta grandes señoríos, como el de los Duques de Frías, que se extendía no sólo por muchos pueblos de nuestra comarca, sino también por otras zonas de las actuales provincias de Burgos, Santander, la Rioja y Zamora ${ }^{204}$.

En cualquier caso, y aunque se trata de una cuestión perfectamente arraigada en la Edad Moderna (dentro del cual sufre cambios significativos), nos encontramos ante una situación, que desciende, en todos los casos, de la herencia medieval ${ }^{205}$. En nuestro caso, como ya vimos, su primer referente se encuentra en los años finales del siglo XIII y primeros momentos del XIV, cuando comienza a desarrollarse un poder señorial basado, no ya directamente en la propiedad directa de la tierra, sino en la adquisición y disfrute de una serie de derechos jurisdiccionales, que permiten al señor manipular a su antojo los órganos de poder existentes dentro del propio municipio.

La primera clasificación, que podemos hacer dentro de este espacio jurídico, nos lleva a hablar de dos grupos fundamentales, como son los espacios de realengo y los espacios de señorío. Evidentemente, los espacios de realengo son aquellos en los que su titularidad y jurisdicción corresponde al monarca, mientras que en los de señorío esta titularidad puede estar depositada en manos de unas determinadas familias de nobles, denominándose en estos casos señorío laico, o bajo el amparo de una institución

\footnotetext{
204 A. RODRÍGUEZ SÁNCHEZ: Espacio, población y sociedad. Siglos XVI - XVIII ... ob cit.

205 L. MARTÍNEZ GARCÍA: El sector dominante de la sociedad feudal burgalesa (siglos XIV - XV). En Historia de Burgos, desde sus orígenes hasta nuestros días. Tomo 2. Desde el año 1000 a los Tiempos Modernos. Burgos, Diario 16 Burgos. 1993. (pp. 495 - 506).
} 
religiosa, como obispos, cabildos catedralicios o monasterios, tratándose entonces de un señorío eclesiástico ${ }^{206}$.

Las principales diferencias, entre los núcleos de realengo y de señorío, radican en la autonomía o libertad de disponer sobre determinadas cuestiones referentes al gobierno local. Así, en general, las localidades de señorío ven cómo el señor tiene potestad a la hora designar cargos y oficios concejiles, oficios eclesiásticos, y limitar las actuaciones de la población en la toma de determinadas decisiones. Mientras, por el contrario, en aquellas poblaciones de realengo se respiraría a priori un cierto aire más democrático, sujeto siempre, eso sí, al permiso y a la autoridad de las oligarquías locales ${ }^{207}$. De igual modo, el señor, independientemente de si era laico o eclesiástico, se constituye en el auténtico representante del rey dentro del municipio, como si de un corregidor vitalicio se tratara. Por ello, es el encargado de aplicar las leyes dentro de su territorio, pero siempre las propias del rey, ya que no existe una justicia señorial propiamente dicha, resultando más bien una justicia real aplicada por señores. Junto a esto se ocupa igualmente de otras labores como las del reclutamiento de soldados para la guerra, y las de guardián de la paz y el orden. Al mismo tiempo, tal y como hemos señalado anteriormente, este señor tampoco pierde la ocasión de percibir determinados tributos, que habrían sido previamente usurpados a la corona mediante los mecanismos más diversos. Por todo ello, los señoríos no constituyen una cesión de soberanía por parte de los monarcas sobre determinadas partes de su territorio, sino en realidad una simple delegación de poderes, que, en principio, dejaba intacta la autoridad de la corona en todo el Estado.

Para estudiar todas estas cuestiones, y conocer su evolución a lo largo de la Edad Moderna, no contamos con importantes fuentes de información, que nos aclaren el

\footnotetext{
206 A. DOMÍNGUEZ ORTIZ: El Antiguo Régimen: los Reyes Católicos... ob cit.

207 L. MARTÍNEZ GARCÍA: El desarrollo institucional burgalés... ob. cit. A. RODRÍGUEZ SÁNCHEZ: Burgos en el siglo XVI... ob. cit. A. GUTIÉRREZ ALONSO: Gobiernos municipales y haciendas locales durante la Época Moderna. En Historia de Burgos, desde sus orígenes hasta nuestros días. Tomo 2. Desde el año 1000 a los Tiempos Modernos. Burgos, Diario 16 Burgos. 1993
} 
desarrollo de todos estos aspectos, pues las publicaciones concretas sobre el tema resultan prácticamente nulas, mientras que la documentación conservada es realmente escasa. De este modo, nos tenemos que basar únicamente en la información proporcionada por los censos de carácter tributario, realizados en los siglos XVI y XVIII, donde se da cuenta de la condición a la que pertenecía cada municipio. Así, partiendo del censo de 1591, y muy especialmente de los realizados durante la segunda mitad de la centuria de Setecientos, podemos dibujar con bastante precisión el panorama, que existía en la zona.

Vemos, por ejemplo, como aquí se produce un equilibrio total entre poblaciones de realengo y de señorío, ya que de las 26 localidades estudiadas hay 13 de realengo por otras tantas de señorío. Por lo tanto, nos encontramos ante un panorama muy semejante al que existe en el resto de la provincia de Burgos, donde la diferencia entre señoríos y realengos no era importante, con un total de 958 poblaciones de señorío por 904 de realengo ${ }^{208}$. Dentro del grupo de las de señorío, sin embargo, la desproporción resulta brutal, ya que mientras 12 de ellas pertenecen a señoríos laicos sólo una forma parte de un señorío eclesiástico. Los cambios sufrido, por lo tanto, con respecto a la situación heredada de finales del siglo XIV, que con tanta precisión nos presentaba el Becerro de las Behetrías, resultan en algunos casos muy significativos.

Así, dentro de estos cambios, vemos que la mayoría de aquellos lugares que a finales de la Edad Media aun mantenían su condición de behetría experimentan la evolución lógica, que vivieron este tipo de núcleos, acabando en todos los casos como lugares de señorío, formando parte de la jurisdicción de la casa de los Fernández de Velasco $^{209}$. Este fue el camino que recorrieron localidades como Arroyo de Salas, Castrillo de la Reina, Hoyuelos de la Sierra, Monasterio de la Sierra y la propia Salas de

\footnotetext{
208 A. RODRÍGUEZ SÁNCHEZ: Espacio, población y sociedad. Siglos XVI - XVIII...ob. cit.

209 Cuando hablamos de lo reflejado en el contenido de Becerro de las Behetrías, ya señalábamos que en casi todos los pueblos constituidos como behetría figuraba D. Pedro Fernández de Velasco como uno de sus más importantes diviseros, iniciándose así el camino que conduciría hacia la jurisdicción de esta casa.
} 
los Infantes. La única excepción la encontramos, en este caso, en la localidad de Neila, la cual aparece en la Edad Moderna como villa de realengo, hecho que se puede explicar por la extinción biológica de la familia de los Lara, que en el periodo medieval constituye su más importante acaparador de divisas ${ }^{210}$.

Otra circunstancia interesante, que tiene también un importante reflejo en nuestra zona, es la desaparición prácticamente total de los señoríos eclesiásticos, que había desempeñado un papel tan destacado durante la época medieval. Esto se explica por la incidencia de la política de enajenación de bienes eclesiásticos, desarrollada por Carlos V y su hijo Felipe II a lo largo de todo el siglo XVI, con el pleno consentimiento, eso sí, de la Santa Sede. El objetivo era recaudar fondos para la lucha contra el infiel y el mantenimiento del imperio ${ }^{211}$. Las repercusiones, que esto tiene en nuestra comarca, resultan muy visibles. Así, vemos como el monasterio de San Pedro de Arlanza, que había sido hasta el momento el más importante señor eclesiástico de la zona, pierde todos los pueblos que se encontraban hasta el momento bajo su jurisdicción. Las manos de pequeños señores son el destino de alguno de estos municipios, fundando aquí sus señoríos, como fue el caso de Quintanar de la Sierra, adquirido por D. Juan Asenjo de Millán ${ }^{212}$. Otros, por el contrario, entran a formar parte de otros señoríos mayores, como fue el caso de Regumiel de la Sierra, que acaba en manos del Duque de Veraguas ${ }^{213}$, o directamente se convirtieron en realengo, mediante la compra de su propia jurisdicción, como sucede con Canicosa de la Sierra ${ }^{214}$.

\footnotetext{
210 G. MARTÍNEZ DÍEZ: Libro Becerro de las Behetrías... ob. cit.
}

211 A. DOMÍNGUEZ ORTIZ: Instituciones y sociedad en la España de los Austrias ... ob. cit. S. DE MOXÓ: La desamortización eclesiástica del Siglo XVI. En AHDE. No XXX. 1961. R. CARANDE: Carlos $V$ y sus banqueros. Tomo II. Ob. cit. (pp. 412 y ss.). M. MODESTO: La Hacienda Real de Castilla en el reinado de Felipe II. Roma, 1963. N. LÓPEZ MARTÍNEZ: La desamortización de bienes eclesiásticos en 1574. En Hispania, no 86.

212 P. GIL ABAD: Quintanar de la Sierra, un pueblo de la comarca de pinares. Burgos, Excma. Diputación Provincial de Burgos. 1986. (pp. 121 y ss.).

213 ADPBU. CE.1.633. RESPUESTAS GENERALES. Regumiel de la Sierra, 24 - mayo - 1753; Censo de 1787, “Floridablanca”, I.N.E. Madrid. 1989.

214 ADPBU. CE. 396. RESPUESTAS GENERALES. Canicosa de la Sierra, 12 - julio - 1753; Censo de 1787, “Floridablanca”, I.N.E. Madrid. 1989. 
Otro destacado señorío eclesiástico, como era el del Infantado de Covarrubias, también pierde en este momento su única posesión en la zona, como era la localidad de Barbadillo del Pez, la cual, una vez adquirida su propia jurisdicción, acaba constituyéndose en villa de realengo ${ }^{215}$. De esta forma, el único señorío eclesiástico que consigue mantenerse en nuestra comarca hasta el final del Antiguo Régimen es el de Moncalvillo, que continúa formando parte del patrimonio del Hospital del Rey de Burgos, y por ende, del Real Monasterio de las Huelgas de Burgos ${ }^{216}$.

Por otra parte, y junto a esta desaparición de los señoríos eclesiásticos, también tenemos que hablar de otro fenómeno interesante, como es el de la reversión a la corona, es decir, el paso de varios pueblos de la condición de señorío a la de realengo. Esta situación, que como acabamos de ver, se había producido en los casos de Canicosa de la Sierra y Barbadillo del Pez, se repite igualmente en varias localidades pertenecientes a señoríos laicos, como lo eran Palacios de la Sierra o los 8 pueblos que componían el Valle de Valdelaguna (Barbadillo de Herreros, Bezares, Huerta de Abajo, Huerta de Arriba, Quintanilla de Urrilla, Tolbaños de Abajo, Tolbaños de Arriba y Vallejimeno, que pasaría a ser conocido a partir de ahora como Real Villa y Valle de Valdelaguna). Todos estos pueblos, tanto Palacios de la Sierra como los que componían el citado valle, dejan de pertenecer al señorío de los Duques de Frías adquiriendo su jurisdicción propia. Sin embargo, y a pesar de ello, vemos también que dicho señor continúa percibiendo en todos estos núcleos determinados impuestos, como alcabalas y tercias reales, lo que nos lleva a pensar que esta reversión fue en realidad muy relativa.

La tendencia que se produce en esta comarca de la sierra burgalesa, por lo tanto, es, en cierto modo, contraria a la pauta general experimentada en el resto del territorio de la Corona de Castilla durante estos siglos. Así, el periodo de los Austrias se

\footnotetext{
215 ADPBU. CE. 210. RESPUESTAS GENERALES. Barbadillo del Pez, 6 - abril - 1753; Censo de 1787, “Floridablanca”, I.N.E. Madrid. 1989.
} 
caracteriza por la masiva venta de lugares de realengo - que alcanza un ritmo particularmente intenso durante el reinado de Felipe IV - con el consiguiente aumento de los lugares de señorío ${ }^{217}$. En esta zona, por el contrario - y debido fundamentalmente a las especiales circunstancias históricas, económicas y poblacionales que aquí se vivieron -, apreciamos durante este periodo un significativo crecimiento de los lugares de realengo y de los pequeños señoríos, en detrimento claramente de los señoríos eclesiásticos, y en menor grado de los grandes señoríos laicos, como ocurre con el de los Duques de Frías.

Sin embargo, todas estas conclusiones deben ser valoradas con tremenda cautela, encuadrándolas siempre dentro del particular contexto histórico que rodeó los siglos XVI y XVII, y sus repercusiones dentro de nuestro marco territorial de estudio. De este modo, si partimos de las observaciones del profesor A. Domínguez Ortiz, podemos afirmar que la compra de lugares para inaugurar un nuevo señorío no fue nunca un buen negocio. El señorío jurisdiccional únicamente permite percibir las penas de cámara y sangre, calumnias, mostrencos y demás rentas jurisdiccionales, cuyo importe, especialmente en los pueblos de nuestra comarca, sería casi nulo, pues la ausencia de grandes concentraciones de población hacía muy difícil satisfacer siquiera los honorarios que debían percibir los alcaldes propuestos por los señores para desempeñar estas labores. Por lo tanto, la compra de este tipo de señoríos no podemos entenderlo nunca como una actividad lucrativa, sino únicamente como un intento de adquirir, a través de este solar, el título y el prestigio necesario para alcanzar metas más altas, posiblemente en la corte ${ }^{218}$. Por ello, dentro de estas compras no encontraremos nunca a las grandes casas, como en nuestro caso era la de los Fernández de Velasco, Duques de Frías, sino a pequeños y medianos nobles con ansias de títulos y claras intenciones de medrar, como ocurre con los casos de Quintanar de la Sierra, comprado por D. Juan

216 ADPBU. CE. 1.114. RESPUESTAS GENERALES. Moncalvillo, 2 - mayo - 1753; Censo de 1787, "Floridablanca", I.N.E. Madrid. 1989.

217 A. DOMÍNGUEZ ORTIZ: Instituciones y sociedad en la España de los Austrias ... ob. cit. 218 Ibídem. 
Asenjo de Millán ${ }^{219}$, y de Riocavado de la Sierra, adquirido por D. José Hechanz de Velasco, conde de Santa Cruz, Soto y Gargancho y a partir de este momento vizconde de Riocavado ${ }^{220}$.

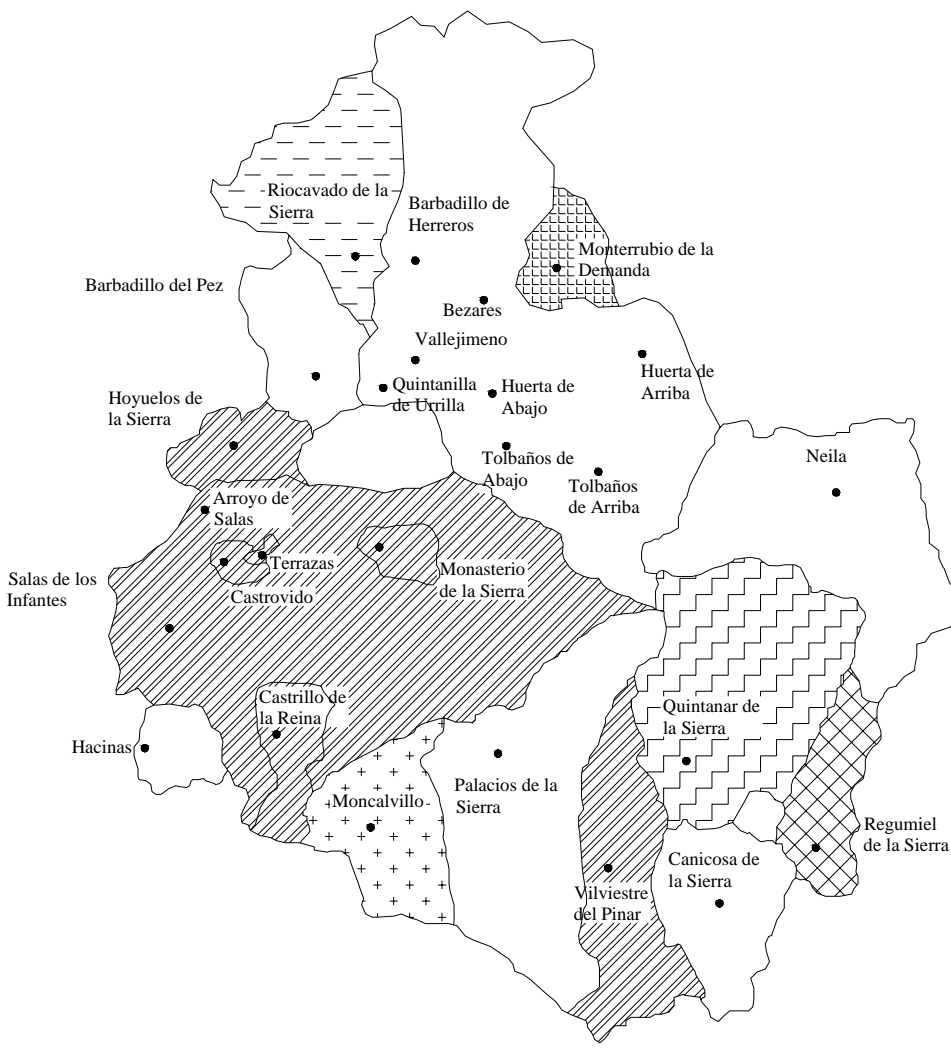

Realengo

Duques de Frías

Conde de Santa Cruz, Soto y Gargancho y Vizconde de Riocavado

${ }^{+}+{ }^{+}+{ }^{+}+{ }^{+}+$Real Monasterio de las Huelgas de Burgos

Conde de Aguilar y Señor de Cameros

Duque de Veraguas

Señorío de Juan Asenjo de Millán

\section{Mapa jurisdiccional durante la Edad Moderna}

219 P. GIL ABAD: Quintanar de la Sierra, un pueblo de ... ob. cit.

220 ADPBU. CE. 1.674. RESPUESTAS GENERALES. Riocavado de la Sierra, 12 - junio - 1753; Censo de 1787, “Floridablanca”, I.N.E. Madrid. 1989. 
La venta de estos señoríos jurisdiccionales, por lo tanto, consiste, como hemos dicho, en la adquisición de una serie de derechos, que bajo el pomposo nombre de “jurisdicción civil y criminal, alta baxa, mero mixto imperio, serñorío y vasallaje, penas de cámara y de sangre, calumnias, mostrencos y demás rentas jurisdiccionales”221, apenas se incluía el derecho de impartir justicia en primera instancia. En definitiva, algo muy poco productivo, pues si nos remitimos a algunos de los ejemplos que podemos conocer dentro de nuestra propia comarca, como es el caso de Moncalvillo, estas rentas jurisdiccionales apenas alcanzaban los 72 reales, que era el equivalente de los 36 conejos, que entregaban al Monasterio de las Huelgas de Burgos por razón de señorío y vasallaje. ${ }^{222}$ Esta misma cantidad era la que pagaban los vecinos de Regumiel de la Sierra al duque de Veraguas por el mismo concepto ${ }^{223}$.

Por consiguiente, la única forma de hacer rentables este tipo de señorío era mediante la usurpación de baldíos o tierras comunales, o a través de la apropiación del derecho de percibir alcabalas y tercias reales. El primero de estos mecanismos apenas tiene repercusión dentro de esta comarca, pues a la escasa productividad de las tierras, de cara a un posible uso agrícola, había que sumar el celo de los concejos y vecinos a la hora de proteger el aprovechamiento de estos terrenos para pastos y leña, lo cual resultaba vital para su economía. La posibilidad de apropiación de determinados tributos, como alcabalas y tercias, sin embargo, era más habitual, lo cual termina por llevar a los Duques de Frías a hacerse con el control de estos impuestos en la práctica totalidad de los pueblos estudiados. De hecho, podemos afirmar con total seguridad, que la política desplegada por esta casa en nuestra zona de estudio estuvo marcada claramente por esta tendencia, permitiéndose sacrificar el dominio jurisdiccional de ciertas villas y lugares a cambio de mantener el control sobre este tipo de impuestos, que eran, a fin de cuentas, la parte más sustanciosa. Esto se comprueba, por ejemplo, en las localidades desgajadas del señorío de los Duques de Frías para convertirse en

\footnotetext{
221 A. DOMÍNGUEZ ORTIZ: Instituciones y sociedad en la España de los Austrias ... ob. cit.

222 ADPBU. CE. 1.114. RESPUESTAS GENERALES. Moncalvillo, 2 - mayo - 1753.
} 
núcleos de realengo, como fue el caso de Palacios de la Sierra o las localidades del Valle de Valdelaguna, donde continuaron percibiendo estos impuestos, al mismo tiempo que se libraban de la pesada carga que suponía disponer alcaldes ordinarios, para los cuales, la mayor parte de las veces, apenas se conseguía cubrir sus honorarios.

En la estructura vertical, de esta organización jurisdiccional, nos volvemos encontrar nuevamente al municipio como unidad básica. Dentro de los municipios, y formando parte de los concejos que regían sus designios, se encuentran los alcaldes ordinarios, los cuales constituyen el eslabón inferior dentro de esta estructura. Estos alcaldes tienen competencias sobre lo civil y lo criminal, aunque limitados siempre a los asuntos de menor cuantía. Sobre ellos, y con atribuciones más amplias están los alcaldes mayores, situados en las localidades de mayor importancia. En ambos casos su nombramiento depende de la jurisdicción a la que pertenezcan, de tal modo que en los núcleos de señorío es el titular de la jurisdicción el que designa a los encargados de cubrir estos puestos, mientras que en los de realengo son elegidos dentro del propio común del pueblo.

Sobre estos alcaldes se hallaba el corregidor, figura creada en época de Alfonso XI, y generalizada a partir de 1480 por los Reyes Católicos, que tiene como función intervenir en nombre del rey en la actividad de los concejos municipales. A ellos se remiten los casos más importantes, que superan las posibilidades de los alcaldes, si bien su jurisdicción se limitaba únicamente a los municipios de realengo, pues en el caso de los de señorío este papel estaría desempeñado por el señor titular de la jurisdicción. No obstante, esta dependencia, que tiene los lugares de realengo del corregidor asentado en el núcleo más cercano, nunca debió ser efectiva, pues si bien en teoría, y a efectos jurisdiccionales, la corona de Castilla se encontraba dividida en corregimientos, éstos nunca llegaron a constituir una demarcación propiamente dicha. En este sentido

223 ADPBU, CE.1.633. RESPUESTAS GENERALES. Regumiel de la Sierra, 24 - mayo - 1753. 
observamos, por ejemplo, como el corregidor de Burgos apenas abarcaba el espacio de la ciudad propiamente dicha y el de sus barrios más inmediatos ${ }^{224}$.

Por encima de todas estas figuras, y realizando las funciones de tribunal de apelación de las sentencias emitidas, tanto por los corregidores, como por los señores en sus respectivos ámbitos, se encuentran las Chancillerías y Audiencias. Desde el reinado de los Reyes Católicos se establecieron dos Chancillerías, que se repartían el territorio de la Corona de Castilla con la marca del río Tajo como límite de sus áreas de influencia. Esto hace que nuestra comarca, al igual que el resto del norte de España, hasta la segregación del noroeste con la creación de la Audiencia de Santiago, tuviera a la Chancillería de Valladolid como su tribunal de apelaciones. Por último, como supremo órgano de justicia, dentro de todo el territorio que componía la Corona de Castilla, se encuentra el Consejo de Castilla, al cual remiten aquellas causas de especial importancia.

Con este apartado, dedicado al análisis del espacio jurisdiccional de nuestra comarca, podemos dar por concluido el recorrido, que hemos hecho a través de la organización territorial, durante el período de la Edad Moderna. Sin embargo, no podemos cerrar por completo este capítulo sin antes hacer una breve alusión a las particularidades, que en esta materia, se viven a lo largo del siglo XVIII y primeras décadas del XIX. Nos estamos refiriendo a las reformas inspiradas por el espíritu de la Ilustración, que comienzan a llegar a la península con el cambio dinástico, que se produjo en España tras la muerte sin descendencia de Carlos II. Esto trae una serie de intentos de reorganizar la estructura del mapa administrativo, existente hasta el momento, por otro modelo nuevo, que se ajuste mejor a los cambios y transformaciones que había experimentado este territorio a lo largo de los dos siglos anteriores.

Así, de la mano de la nueva dinastía borbónica, y de sus ideales centralizadores, se pone en marcha un plan para crear unas circunscripciones territoriales nuevas, en las

224 A. GUTIÉRREZ ALONSO: Gobiernos municipales y haciendas locales ... ob. cit. 
cuales aunar las diferentes competencias administrativas, políticas, jurisdiccionales y por su puesto, fiscales. No obstante, hay que decir también que muchas de las propuestas no pasarán de la fase inicial de mero proyecto, sin llegar nunca a plasmarse en un uso real.

El primero de estos modelos es el desarrollado por el cardenal Alberoni en 1718, el cual sucede a otros anteriores, que simplemente constituyeron meras ideas sobre el pape $^{225}$. Consiste en una división del territorio de España en intendencias, colocando al frente de cada una de ellas a un intendente, que sería un magistrado, inspirado en el modelo territorial francés, con competencias en materia de política, justicia, finanzas y guerra. En el caso del intendente de Burgos, el marco sobre el que este magistrado ejercería sus funciones se correspondía aproximadamente con el de la antigua provincia fiscal de Burgos del siglo XVI, con lo cual la situación para nuestros pueblos no experimentaba variación alguna, pues todos ellos, salvo Monterrubio de la Demanda, que permanecería en la intendencia de Soria, continuaban dentro del territorio burgalés. La vigencia de este modelo, sin embargo, fue sumamente corta, ya que en 1722 estas intendencias quedaron suspendidas.

Los cambios, que se sucedieron a partir de aquí, hasta los primeros años del siglo XIX, apenas aportaron variaciones significativas con respecto a la situación heredada de las centurias anteriores, con lo cual el esquema territorial seguía siendo el mismo que hemos desarrollado anteriormente. Aun así, un momento realmente importante, dentro de esta centuria del Setecientos, es el que se vivió en 1785 con el mandato del conde de Floridablanca, ministro de Carlos III, por el que se procedía a un nuevo intento de reorganizar todo el mapa de España. El más importante reflejo de este proyecto se encuentra en la elaboración de un pormenorizado estudio de la situación real en la que se encontraban los diferentes territorios que componían el reino, teniendo en cuenta las peculiaridades, especialmente en materia jurisdiccional, que cada núcleo poseía. De este modo, se redacta la obra, que citamos anteriormente, bajo el título de

225 G. MARTÍNEZ DÍEZ: Génesis histórica de la provincia de Burgos ... ob. cit. 
España dividida en provincias e intendencias y subdividida en partidos, corregimientos y alcaldías mayores, gobiernos políticos y militares, así realengos como de órdenes, abadengos y señoríos. Obra formada por las relaciones originales de los respectivos intendentes del reyno, a quienes se pidieron por orden de S. M. por el Excmo. Sr. Conde de Floridablanca y su Ministro de Estado en 22 de marzo de 1785. Con un Nomenclator o Diccionario de todos los pueblos del reyno, que compone la segunda parte.

En lo que a nuestra zona respecta, vemos cómo se da cuenta de las 14 circunscripciones menores en la que se dividía el territorio de la provincia de Burgos, las cuales, empleando denominaciones diferentes, sustituyen a los tradicionales partidos de Burgos, Trasmiera y Tierras del Condestable, creados en el siglo XVI. Así, según este mapa, los pueblos de nuestra zona de estudios, salvo, una vez más, Monterrubio de la Demanda, se encuentran repartidos entre los partidos de Aranda y Candemuñó, de la siguiente manera.

Partido de Candemuñó:

- Pueblos solos:

- Barbadillo del Pez (villa de realengo)

· Castrillo de la Reina (villa de señorío)

- Jurisdicción de Salas de los Infantes:

- Arroyo de Salas (lugar de señorío)

- Castrovido (lugar de señorío)

• Hoyuelos de la Sierra (lugar de señorío)

• Monasterio de la Sierra (lugar de señorío)

- Salas de los Infantes (villa de señorío)

• Terrazas (lugar de señorío)

• Viguillas (despoblado de señorío) 
Partido de Aranda:

- Pueblos solos:

- Canicosa de la Sierra (villa de realengo)

• Hacinas (villa de realengo)

- Moncalvillo (lugar de abadengo)

• Neila (villa de realengo)

- Palacios de la Sierra (villa de realengo)

- Quintanar de la Sierra (villa de señorío)

• Regumiel de la Sierra (villa de señorío)

- Riocavado de la Sierra (villa de señorío)

• Vilviestre del Pinar (villa de señorío)

- Jurisdicción del Valle del Valdelaguna:

- Barbadillo de Herreros (villa de realengo)

• Bezares (villa de realengo)

• Huerta de Abajo (villa de realengo)

· Huerta de Arriba (villa de realengo)

- Quintanilla de Urrilla (villa de realengo)

- Tolbaños de Abajo (villa de realengo)

• Tolbaños de Arriba (villa de realengo)

- Vallejimeno (villa de realengo)

Provincia de Soria:

- Villas eximidas:

- Monterrubio de la Demanda (villa de señorío) 
Con el inicio del siglo XIX se produce un momento ciertamente intenso, dentro de nuestra historia, que afecta, no sólo al campo de la política, sino también a las cuestiones relacionadas con las divisiones territoriales. Así, fruto de la situación absolutamente excepcional, que se vive durante la primera década de la nueva centuria, con la ocupación francesa y la implantación de un nuevo monarca, surgen nuevos planes para elaborar una división alternativa del mapa de España. En este caso, nos encontramos con dos proyectos nuevos, de naturaleza bien distinta, pero con objetivos

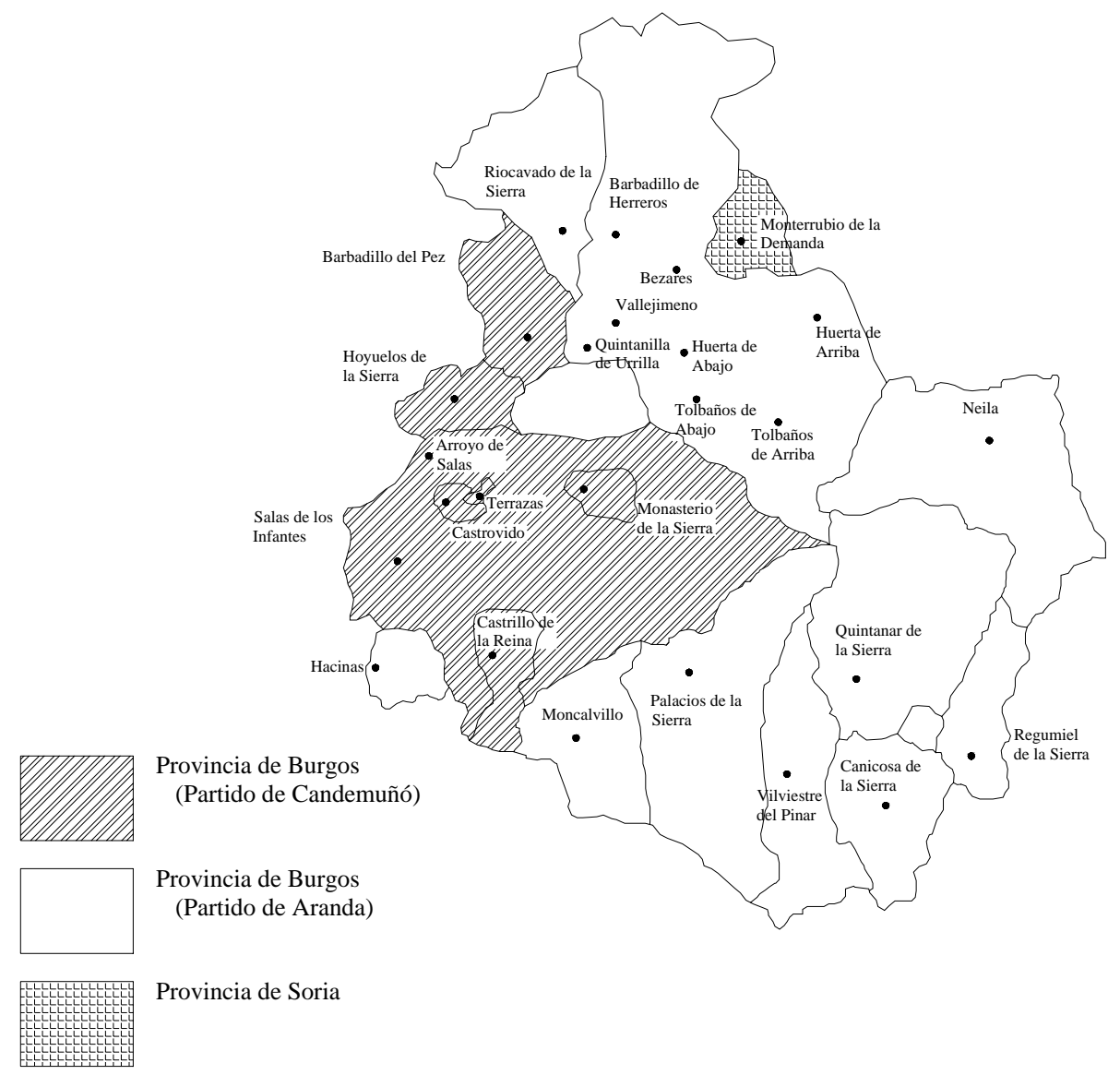


muy parecidos, que proceden del monarca instaurado por las tropas de Napoleón, el uno, y de las Cortes de Cádiz, el otro. En ambos se pretende crear un mapa mucho más ordenado y mejor ajustado a la realidad del país, venciendo incluso las tradicionales limitaciones de carácter histórico.

En la propuesta elaborada desde el gobierno de José I se pretenden crear provincias uniformes y homogéneas, inspiradas en los departamentos franceses, denominadas prefecturas, las cuales servirían de unidad básica para distintos campos, como el eclesiástico, judicial, fiscal, militar, político y de educación o universidades. En este caso, el cambio con respecto a la herencia anterior pretendía ser tan radical, que no sólo se renovaban las fronteras existentes en el mapa de las provincias vigente desde el siglo XVI, sino que además se intentan modificar los nombres de estas circunscripciones, creando denominaciones de un marcado sabor poético.

En virtud de esta propuesta, que apenas fue llevada a la práctica, observamos que los pueblos de nuestra comarca quedaban repartidos entre tres de estas prefecturas, como eran las de Arlanzón (Burgos), Alto Duero (Soria) y Duero y Pisuerga (Valladolid). No obstante, los límites entre cada una de ellas no parecen quedar nada claros, pues si por un lado se había propuesto el curso del río Arlanza como límite para separar la prefectura de Arlanzón, y las de Alto Duero y Duero-Pisuerga, por otro nos encontramos con que algunas localidades, como el caso de Quintanar de la Sierra, aparecen incluidas dentro de la prefectura soriana ${ }^{226}$.

De forma paralela a esta organización territorial napoleónica desde las Cortes de Cádiz se desarrolla una segunda propuesta para dividir el mapa español, que superase la recogida en la obra de Floridablanca. En este plan se mantiene la denominación de provincia para sus circunscripciones, si bien su contenido y atribuciones debían ser bien distintos. Al mismo tiempo, y en clara coincidencia con el modelo de José I, se pretendía elaborar un proyecto que sacrificara las cuestiones de orden histórico, a la que

226 G. MARTÍNEZ DÍEZ: Génesis histórica de la provincia de Burgos ... ob. cit. 
estaban sujetos muchos territorios de la península, en aras de una mayor eficacia y coherencia administrativa.

Este proyecto, que no tuvo ninguna vigencia y que fue inmediatamente derogado tras el regreso al trono de Fernando VII, tiene, a pesar de todo, un gran valor, pues no en vano se encuentra aquí el embrión de lo que más tarde se convertirá en la distribución en provincias, que actualmente conocemos. Así, esta misma idea y este mismo proyecto son retomados posteriormente, durante el breve periodo del Trienio Liberal (1820 1823), dando como fruto una nueva regionalización que ve la luz con el decreto firmado el 27 de enero de 1822. Sin embargo, la vida de este proyecto resulta también sumamente corta, pues antes de que llegara a ser desarrollado plenamente es abolido con la reinstauración del régimen absolutista por Fernando VII y el inicio de la década ominiosa.

De este modo, tenemos que esperar al final de este monarca para poder llevar a la práctica con todas sus consecuencias el proyecto reformador de la organización territorial de España, que venía fraguándose desde unas décadas atrás. Este hecho se produce en 1833, con D. Javier Burgos, como figura destacada. Surge de aquí, no sin polémica, el mapa provincial que actualmente conocemos, donde todas las localidades que componen nuestra área de estudio quedaban englobadas en la provincia de Burgos $^{227}$.

227 Ibídem. J.L. MORENO PEÑA: Burgos: evolución histórica ... ob. cit. 
V. ECONOMÍA. 
Al tratarse de un ámbito de carácter eminentemente rural la economía de esta zona continúa siendo a lo largo de toda la Edad Moderna, esencialmente agraria, siguiendo de esta forma las mismas pautas que se habían dado durante la Baja Edad Media. Así, nos encontraremos ante un dominio prácticamente total de las actividades agropecuarias, las cuales se combinan con otros tipos de trabajos, ligados particularmente a la explotación de los recursos naturales. De este modo, el ritmo de la economía durante este período se ve marcado fundamentalmente por la marcha del campo, es decir, por la alternancia de buenas y malas cosechas, pero al mismo tiempo, también por el desarrollo de otras actividades y trabajos, a las que se unen otros factores, como el crecimiento demográfico, el nivel de rentas y en definitiva la propia subsistencia.

Pero al margen de estas consideraciones de carácter general, que definen a grandes rasgos el panorama dominante en la mayor parte del campo castellano durante el Antiguo Régimen, debemos llamar la atención igualmente sobre una serie de particularidades que, desde el punto de vista económico, se dan aquí. Así, debemos destacar en primer lugar, el escaso peso que tiene la agricultura con respecto a otras comarcas circundantes, pues su desarrollo se ve fuertemente condicionado por las características de un medio físico abiertamente hostil a este tipo de actividad. Sin 
embargo, esta situación queda compensada con el desarrollo de otro tipo de actividades mejor adaptadas a este marco geográfico, como es el caso de la ganadería lanar, por un lado, y el transporte mediante carretas, por otro.

Al mismo tiempo, debemos destacar también la tradicional imagen que se ha venido dando de este territorio, donde se dibujaba un panorama dominado por una extraordinaria limitación de recursos, que depara una situación de pobreza casi endémica a lo largo de toda la Edad Moderna. De ello, tanto las fuentes documentales, como bibliográficas, nos aportan abundantes testimonios. Así, nos encontramos, por ejemplo, con un documento emanado del monasterio de San Pedro de Arlanza de principios del siglo XVII, en el cual se hace un desesperado llamamiento a los superiores de la orden benedictina para obtener la concesión de un censo de 400 ducados, dada la penuria económica en la que este cenobio se encontraba, por la pobreza de los pueblos circundantes ${ }^{228}$ (entre los que se encontraba alguno de nuestra comarca de estudio, donde el citado monasterio tenía posesiones). Otro testimonio de este tipo aparece en la crónica de Juan Lopérraez Corbalán, en la que se describe el Obispado de Osma durante la segunda mitad del siglo XVIII. Aquí nos dice que: “en muchos pueblos de esta parte del Obispado, que son los lugares de Duruelo, Covaleda, Salduero, los Molinos, Palacios, Bilviestre, Regumiel, Cañicosa, Navaleno y Arganza, y otros, nada se siembra; y quitando algunos vecinos que tienen carretas, los demás se mantienen sólo de hacer artesones y gamellas, distrayéndose tanto con este exercicio, que apenas entran en el pueblo en todo el año, viviendo en el campo a las inclemencias”,229.

Por el contrario, frente a esta visión catastrofista, nos encontramos con otro tipo de declaraciones, en las cuales se muestra una visión bien diferente. Esto sucede en un testimonio fechado a finales del siglo XV, que recoge David E. Vassberg, donde al

228 AHPBU. PN. 5951/1, (fols. 1453 - 147). Notario: Francisco de Nanclares. Monasterio de San Pedro de Arlanza, 31 - octubre - 1610. 
referirse a la explotación de los recursos forestales de estos mismos pueblos se afirmaba “que sus vecinos eran enormemente ricos",230.

Al margen de todo ello, los contenidos que desarrollaremos dentro de este apartado consisten simplemente en una visión estática de la vida económica de estos pueblos y de sus principales actividades económicas y recursos. Nos ceñiremos, por lo tanto, a observar los rasgos generales de cada una de estas actividades, contemplando simplemente, de modo general, la evolución y posibles cambios que fueron experimentándose a lo largo de los siglos, que comprende este período. Para ello nos hemos valido de una serie de fuentes de información muy amplias, dentro de las cuales algunas han sido examinadas con mayor detenimiento que otras, en atención principalmente a los objetivos que queríamos cubrir.

En el caso de las fuentes bibliográficas, la falta de trabajos específicos centrados en nuestra comarca nos ha llevado a extraer la información que necesitábamos de otras obras de ámbito más general, extrapolando, en la medida de lo posible, las conclusiones obtenidas a la zona que investigamos. Así, dentro de estas obras debemos citar evidentemente los trabajos, ya clásicos, de Ramón Carande, donde se ofrece una visión global de España durante el siglo $\mathrm{XVI}^{231}$, y los de Ángel García Sanz, centrados, de modo especial, en el ámbito castellanoleonés, y particularmente en la provincia de Segovia $^{232}$. Sin embargo, mucho más ricos en datos, por su proximidad geográfica, y por sus semejanzas en lo que se refiere a las características del medio físico y las actividades económicas desarrolladas, resultan los trabajos de Emilio Pérez Romero

229 J. LOPÉRRAEZ CORBALÁN: Descripción Histórica del Obispado de Osma con el catálogo de sus prelados. Ed. Facsímil. Madrid, Turner. 1978. Tomo II. (pag. 3)

230 D. E. VASSBERG: Tierra y sociedad en Castilla. Señores, poderosos y campesinos en la España del siglo XVI. Barcelona, Editorial Crítica. 1986. (pag. 90). A. REPRESA: "Las comunidades de villa y tierra castellanas: Soria”. En Celtiberia, Centro de Estudios Sorianos. Soria, no 57 (1979). (pp. 7 - 17).

231 R. CARANDE: Carlos Vy sus banqueros. Barcelona, Editorial Crítica. 1987.

232 A. GARCÍA SANZ: Desarrollo y crisis del Antiguo Régimen en Castilla la Vieja. Madrid, Akal. 1986. 
sobre la provincia de Soria $^{233}$, en los cuales hemos basado, de forma casi directa, muchas de las conclusiones expuestas en este apartado. Por supuesto, tampoco podemos olvidar los diferentes trabajos centrados en el ámbito burgalés, realizados por Francis Brumont, José Antonio Bonachía, Adriano Gutiérrez y Concepción Camarero Bullón.

Próximas a estas fuentes se encuentran también las referencias publicadas por autores contemporáneos, como es el caso ya citado de Lopérraez Corbalán, el cual, al margen de lo cuestionable que pueda resultar su obra y las conclusiones que de ella se extraen, no deja de ofrecernos una imagen a tener en cuenta, dentro de la realidad existente en este momento.

Por último, debemos hacer referencia a las fuentes documentales, aspecto en el que contamos con una grandes limitaciones, merced a las importantes pérdidas que se han producido. Aun así, disponemos de la valiosa información suministrada por el Catastro del Marqués de Ensenada, a través del cual conseguimos tener una imagen bastante certera de la situación en la que se encontraban estos pueblos en el tramo final del período del Antiguo Régimen. Esta fuente se complementa con los datos recogidos de la documentación de carácter administrativo, ligada a instituciones religiosas (como parroquias o cofradías), o civiles (como es el caso de los concejos), los cuales nos permiten, llegado el caso, rastrear la evolución que se produjo en el campo económico de esta comarca a lo largo de estos siglos. No obstante, como ya apuntábamos, estos aspectos no forman parte de los objetivos de esta investigación, recurriendo a ellos únicamente en los casos en los que se descubre una incidencia directa en el campo artístico en general, y arquitectónico en particular.

A través de los testimonios aportados por todas estas fuentes, y de modo especial por las de carácter documental, sabemos que son tres las actividades económicas fundamentales, que se desarrollan en este entorno. Por una parte, tenemos una

233 E. PÉREZ ROMERO: Patrimonios comunales, ganadería trashumante y sociedad en la Tierra de Soria. Valladolid, Junta de Castilla y León. Consejería de Educación y Cultura. 1995. 
agricultura de subsistencia de producción muy limitada, que se complementa con pequeños hatos de ganado estante, entre los que encontramos ovejas de raza churra, vacuno y porcino. Por otro lado, destacamos una importante presencia de ganadería trashumante, dedicada a la producción de lana fina de alta calidad, obtenida de ovejas de raza merina, que se destina mayoritariamente a la exportación. En tercer lugar, existe también una interesante y poderosa labor relacionada con el mundo del transporte a largas distancias mediante carretas tiradas por bueyes, denominada de puerto a puerto, la cual ocupaba a la mayor parte de la población en varios de estos pueblos.

En el caso de estas dos últimas actividades hay que decir, que se trata de especialidades a las cuales los habitantes de estos pueblos se ven abocados en muchos casos sin remisión, pues las limitaciones que imponía a la agricultura el medio físico, obligan a desarrollar alternativas con las que subsistir. No obstante, su desarrollo no se extiende de modo generalizado, dentro de todo el territorio que conforma nuestro ámbito de estudio, sino que por el contrario debemos hablar de una auténtica concentración geográfica, existiendo, por una parte, pueblos volcados en el desarrollo de la ganadería lanar trashumante, y por otra, pueblos especializados en el arte de la carretería. Al mismo tiempo, en cada una de estas zonas se produce también una coexistencia o yuxtaposición de las actividades agrícolas, cuyo grado de implantación varía profundamente de unos pueblos a otros, según la disponibilidad de suelo en cada uno de ellos. El interés, que estos aspectos tienen, desde el punto de vista artístico y constructivo, radica en el desarrollo de tipos arquitectónicos perfectamente diferenciados y caracterizados en una y otra zona. Así, y dependiendo de la actividad económica dominante, se producen modelos de arquitectura civil tan característicos, como la casa carretera, o el caserón blasonado de los grandes propietarios de rebaños mesteños.

Al margen de estas actividades dominantes, debemos señalar también la existencia de otro tipo de trabajos de menor relevancia, como son los de carácter artesanal y de transformación de materias primas, que se desarrollaron bajo el impulso 
de la riqueza natural, que aquí podía existir. Se trata, lógicamente, de actividades marginales, concentradas en localidades muy concretas de nuestra comarca, y con un peso específico muy relativo, dentro de la economía de la zona, pero al mismo tiempo con un alto valor significativo, que no debe ser obviado. Dentro de estos trabajos destacan los relacionados con el sector textil, y con la fabricación de determinados paños, que surgió en pueblos como Barbadillo del Pez, desarrollados al abrigo de la importante producción de lana fina y entrefina, que existía en su entorno. Más importantes si cabe, por las resonancias que tuvo en la época, y por la herencia que han dejado posteriormente, son las actividades ligadas al aprovechamiento de los recursos forestales. Se incluyen aquí una amplia y variada nómina de trabajos, que van desde la mera extracción y comercialización de la madera de pino apenas desbastada, hasta la elaboración de determinados útiles con este material, o incluso la obtención de algunos productos, como es el caso del betún, ya a finales de esta Edad Moderna. Por último, y con un desarrollo mucho más limitado, debemos señalar también la explotación de algunos recursos minerales (principalmente pirita), que atesoran las entrañas de algunos de estos pueblos, tema muy poco investigado, cuyo interés no va más allá de lo meramente testimonial.

AGRICULTURA.

Dentro de este panorama, y a pesar del predominante papel que desempeñan las actividades ganaderas y del transporte, debemos reconocer que, salvo determinadas excepciones - como ocurre con algunos de los pueblos carreteros - una gran mayoría de la población de estos núcleos se dedicaba total o parcialmente a la agricultura y la ganadería estante. Una actividad ésta que, en muchos casos, apenas permitía alcanzar los niveles más básicos de subsistencia, con lo cual el trabajo del campo debía ser complementado, en una gran parte de los casos, con algún otro oficio, como el de artesano textil o de la madera, pastor, arriero, herrero, etc. 
La superficie productiva, es decir, el suelo cultivable de la mayoría de estos pueblos era realmente escaso, dada la pobreza general del suelo y la abrupta orografía del terreno. De este modo, aunque carecemos de datos absolutos para este período, podemos estimar que la superficie cultivada, dentro de cada uno de estos municipios, se encontraba entre un 15 y un $20 \%$ en las zonas de llano (Salas de los Infantes, Castrillo de la Reina o Hacinas), y el $8 \%$ aproximadamente para los pueblos del interior de la sierra (Quintanar de la Sierra, Regumiel de la Sierra, Valle de Valdelaguna o Neila).

Lo cierto es que si damos crédito al testimonio de Lopérraez Corbalán, que reproducíamos anteriormente, en muchos de estos pueblos la superficie cultivada sería prácticamente nula. Esta afirmación en cierto modo se ve ratificada por los datos recogidos en las Respuestas Generales del Catastro del Marqués de Ensenada, que dieron pueblos, como Quintanar de la Sierra, Regumiel de la Sierra o Canicosa de la Sierra, donde a la pregunta número $11^{{ }^{\circ} 234}$ se dice que únicamente se producían "hierba, madera, lana, corderos, cabritos, miel y cera”, pero nada de cereal ni otros productos $\operatorname{agrícolas~}^{235}$.

Dejando de lado estos casos extremos, observamos que la distribución del terreno dentro de estos pueblos se realizaba, por lo general, de la forma siguiente:

a) Huertas y tierras de sembradura o de pan llevar:

Son las situadas en el entorno más próximo al núcleo urbano de estos pueblos, constituyendo el suelo más fértil de todo el término municipal, si bien, en la práctica totalidad de los casos se trataba de tierras de secano. Las tierras de regadío existentes dentro de estos pueblos eran realmente excepcionales, hallándose constituidas en todos los casos por huertas de pequeña extensión, situadas en las inmediaciones del caserío y con un curso de agua o manantial cerca, de donde se extraería el agua manualmente.

\footnotetext{
234 ¿Qué especies de frutos se cogen en el término?.

235 ADPBU. CE. 1633. RESPUESTAS GENERALES. Regumiel de la Sierra, 24 - mayo - 1753.
} 
Ejemplos de ello los tenemos en Huerta de $\mathrm{Abajo}^{236}$, Monasterio de la Sierra ${ }^{237}$, Monterrubio de la Demanda ${ }^{238}$ o Quintanilla de Urrilla ${ }^{239}$.

b) Herrenes o prados de guadaña

Constituidos por superficies de suelo relativamente fértil, destinadas de forma exclusiva al cultivo de forraje para el ganado estante y de labor. En la práctica totalidad de estos pueblos, y de modo especial en los más ligados al desarrollo de la actividad ganadera, existían prados comunales, para el disfrute de todos los vecinos, así como prados del concejo, que formaban parte de los propios concejiles, arrendados a ganaderos locales o foráneos, de donde se obtenían importantes recursos para el mantenimiento de la economía municipal. De la importancia que estos terrenos tenían dentro del terrazgo de los pueblos de la zona nos hablan, tanto las respuestas dadas a la pregunta $11^{\circ}$ del Catastro de Ensenada, como las propias listas de ingresos de los Libros de Fábrica de las iglesias parroquiales y ermitas de estos núcleos, donde vemos que los pastos constituyen uno de los principales productos obtenidos en estas tierras.

c) Heras:

Se trata de espacios comunales, usados por los vecinos para el desarrollo de determinadas labores propias del ciclo agrícola, como la trilla o la bielda. Evidentemente no ocupaban un espacio muy amplio dentro del término municipal, el cual, por otra parte, no tenía por qué ser fijo.

d) Dehesas y pastos:

Se trata de amplias extensiones de terreno, normalmente cercado, destinadas por lo general al pastoreo, que se completaba con algún plantío de árboles, y ocasionalmente con algún cultivo. Su nombre habitual era el de “dehesa boyal”, pues en ellas pastaban habitualmente los bueyes de tiro usados en la agricultura, y en nuestro caso también en la carretería, sin embargo, no necesariamente tenían que ser comunales, sino que podían formar parte de los propios del concejo, o incluso ser privadas. Aun así, dentro de esta zona lo habitual era que fueran de uso común para el conjunto de los vecinos de un

\footnotetext{
236 ADPBU. CE. 900. RESPUESTAS GENERALES. Huerta de Abajo, 1 - mayo - 1753.

237 ADPBU. CE. RESPUESTAS GENERALES. Monasterio de la Sierra, 26 - mayo - 1753.

238 ADPBU. CE. 1129. RESPUESTAS GENERALES. Monterrubio de la Demanda, 1 - octubre - 1752.
} 
pueblo, convirtiéndose así en el espacio comunal por excelencia. Su aprovechamiento resulta vital para la economía de todas estas localidades, pues aquí no sólo pastaban los ganados estantes, que cada vecino podía tener, sino también, los bueyes de tiro de la Cabaña Carretera, durante los meses de invierno, cuando realizaban el descanso. Ocasionalmente también podían ser ocupadas por las ovejas merinas trashumantes, que las utilizaban como agostadero. Pero no terminaba aquí su uso, pues al estar pobladas, en muchos casos, de un pequeño bosque de frondosas, proporcionaban una riqueza muy variada, constituida por leña, frutos silvestres, caza, etc. Por supuesto, el desarrollo de cada una de estas actividades se encontraba perfectamente regularizado y controlado por los concejos, que establecían los períodos de tiempo en el que se debían efectuar cada una de estas actividades.

e) Montes.

Constituye la mayor parte del terreno, que se extendía entre los distintos municipios. En teoría se trataba de una zona improductiva, ocupada por una heterogénea masa vegetal de arbustos y otro tipo de árboles, con un aprovechamiento muy diverso, similar al de las dehesas. De esta forma, y a pesar de esta etiqueta de espacio improductivo, que muchas veces se daba a estos terrenos, vemos que habitualmente se convirtieron en la base de la economía local, en función de los aprovechamientos diversificados que hemos señalado. Su cuantificación resulta prácticamente imposible, pues en muchos casos, y según las respuestas del Catastro de Ensenada, bajo la denominación de "pastos”, se escondían superficies de naturaleza arbolada, compuesta en realidad por monte bajo.

En lo que se refiere a la propiedad de la tierra, en este caso, como es característico dentro de estas zonas de montaña, donde el uso agrícola del suelo no es el dominante, los mayores propietarios son los concejos y la propia comunidad de vecinos. Sin embargo, esto no convierte a los concejos en entidades fuertes, desde el punto de vista económico, pues el aprovechamiento de la mayor parte de estas superficies no

239 ADPBU. CE. 1582. RESPUESTAS GENERALES. Quintanilla de Urrilla, 6 - mayo - 1753. 
siempre se daba en arriendo, disfrutándose frecuentemente, de forma gratuita por todos los vecinos inscritos en el censo del pueblo.

Junto a este terreno comunal, formado por dehesas y montes, muy importantes son también los baldíos o tierras administradas y explotadas de forma conjunta por varios pueblos, los cuales son conocidos como comunales. A ellos tendremos que unir también la variante conocida como ledanías, consideradas como entidades jurídicas propias, en cuyo gobierno y administración participan diversos pueblos con un diferente grado de implicación, responsabilidad y aprovechamiento. Su importancia dentro de nuestra comarca radica, no sólo en la peculiar forma de propiedad, que constituyen las ledanías, sino sobre todo en el enorme peso específico, que tiene dentro de la economía de muchos de los pueblos, dada su gran extensión y la variedad de recursos, que de estos terrenos se podían obtener. Son, en definitiva, grandes superficies intersticiales que en muchos casos separan los términos municipales de estos pueblos, hasta dejarlos convertidos en pequeños o medianos islotes dentro de un amplio mar de baldíos ${ }^{240}$.

El origen de estos baldíos, tanto de los comunales como de las ledanías, resulta un tema muy controvertido, pues se ha pretendido ligarlo a diferentes épocas, como la prerromana, romana o visigoda, y muy especialmente al período de la Reconquista, encuadrándose en las concesiones de tierras efectuadas por la Corona a los repobladores de los territorios arrebatados al poder musulmán ${ }^{241}$. Sin embargo, en nuestro caso todo parece apuntar a un origen relacionado con la desaparición de gran parte de los numerosos poblados, que habían surgido entre los siglos IX-X, cuyos términos habían conseguido mantener su cohesión, a pesar de no existir un núcleo poblado que lo centralice. Esta hipótesis está corroborada documentalmente en algunos casos, como sucede en el término conocido como “Trasomo", administrado por los pueblos de Barbadillo del Pez, Hoyuelos de la Sierra, Quintanilla de Urrilla y Vallejimeno. Este territorio constituía el término municipal de un antiguo poblado llamado Santa María

240 Este es el caso de municipios como Arroyo de Salas, Castrovido, Castrillo de la Reina, Hacinas, Monasterio de la Sierra, Hacinas, Salas de los Infantes o Terrazas. 
del Rebollar (o Villanueva de Rebollar), que fue cedido, según un documento fechado el 12 de febrero de 1190, por el rey Alfonso VIII a los concejos de estos pueblos a cambio de una serie de carneros $^{242}$. Otros ejemplos de baldíos repartidos entre varios pueblos son los de Patria, compartido por Huerta de Arriba, Huerta de Abajo, Tolbaños de Arriba y Tolbaños de Abajo; Sierra de Campiña, repartido entre Huerta de Abajo y Tolbaños de Abajo; la Campiña, administrada entre Quintanar de la Sierra y Palacios; o Revenga, compartido por Canicosa de la Sierra, Quintanar de la Sierra y Regumiel de la Sierra. No obstante, dentro de los terrenos en los que se desarrolla esta peculiar forma de propiedad, los más extensos e importantes, desde el punto de vista de su aprovechamiento económico, son las ledanías, que comparten en distinto grado las localidades de Arroyo de Salas, Castrovido, Castrillo de la Reina, Hacinas, Monasterio de la Sierra, Palacios de la Sierra, Salas de los Infantes y Terrazas. En estos casos, la extensión y el gran aprovechamiento que se hace de ellos, desde el punto de vista económico, nos lleva a desechar la tradicional definición de baldíos como tierras pobres e improductivas, asociadas exclusivamente a pastos y agrestes montes. Aquí, por el contrario, se alternan las zonas de pastos con amplias parcelas dedicadas al cultivo.

En lo que se refiere a las tierras de labor propiamente dichas, es decir, los panes, prados y herrenes, y huertas, la titularidad se encuentra más repartida. Así, según los datos arrojados por el Catastro del Marqués de Ensenada, y con la prudencia que nos obliga el hecho de no contar con una fuente de similares características para los siglos XVI y XVII, estimamos que los mayores propietarios fueron los pequeños y medianos

campesinos, los cuales poseían aproximadamente un 60 \% de estas tierras de labor. El resto estaría en manos de los concejos, formando parte de los propios, y de los estamentos privilegiados, es decir, nobles y clérigos.

241 D. E. VASSBERG: Tierra y sociedad en Castilla... ob. cit. (pp. 16 y ss). 
Las propiedades de los concejos aparecen recogidas en las respuestas a la pregunta número $23^{\circ}$ del Catastro del Marqués de Ensenada, donde se da una relación

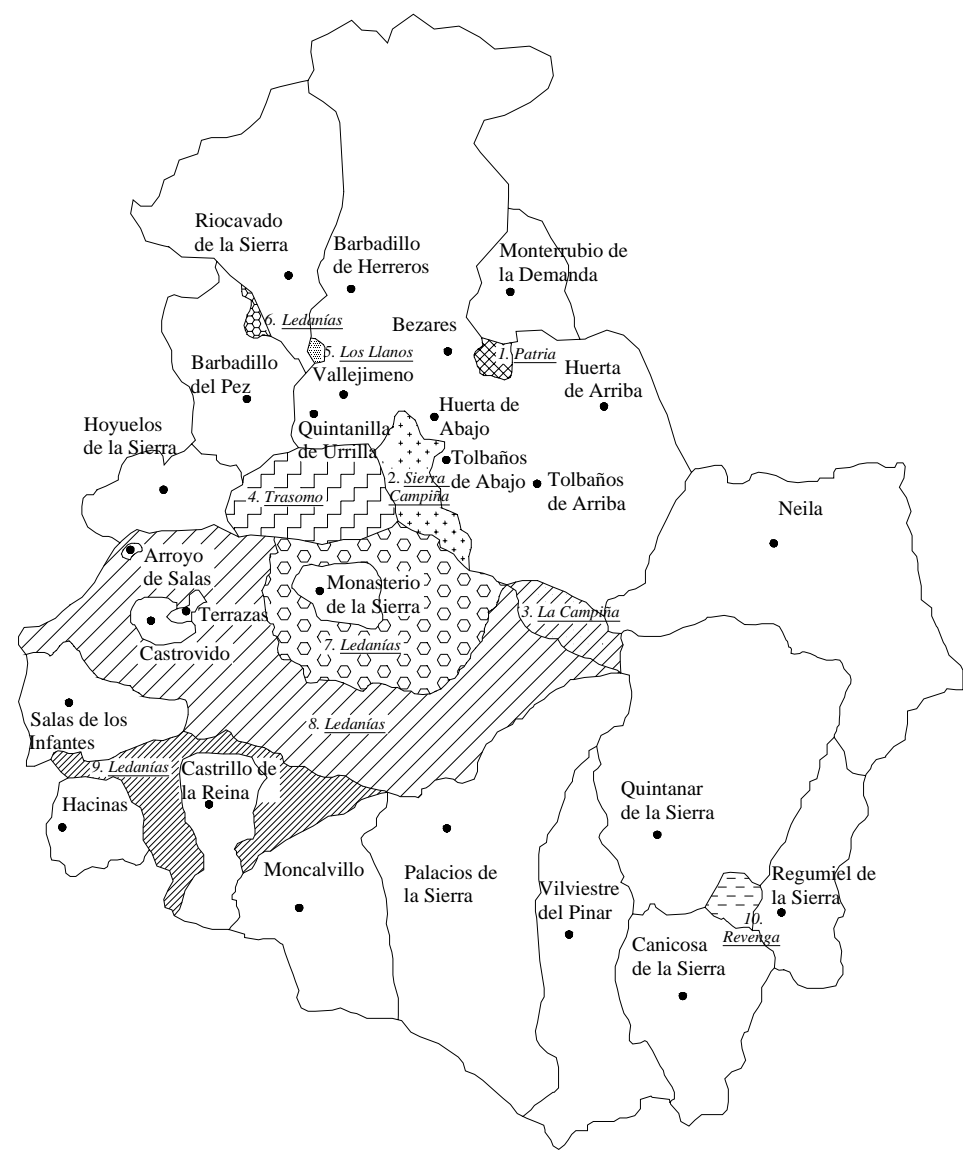

1. Patria (Huerta de Abajo, Huerta de Arriba, Tolbaños de Abajo y Tolbaños de Arriba)

3. La Campiña (Quintanar de la Sierra y Palacios de la Sierra)

5. Los Llanos (Barbadillo de Herreros y Vallejimeno)

7. Ledanías (Salas de los Infantes, Castrillo de la Reina, Hacinas y Monasterio de la Sierra)

9. Ledanías (Salas de los Infantes, Castrillo de la Reina, Hacinas)
2. Sierra Campiña (Huerta de Abajo, Tolbaños de Abajo)

4. Trasomo (Barbadillo del Pez, Hoyuelos de la Sierra, Quintanilla de Urrilla y Vallejimeno)

6. Ledanías (Barbadillo del Pez y Riocavado de la Sierra)

8. Ledanías (Salas de los Infantes, Castrillo de la Reina, Castrovido, Hacinas)

10. Revenga (Canicosa de la Sierra, Quintanar de la Sierra, Regumiel de la Sierra) 
de tierras, compuestas fundamentalmente por prados para el uso de algunos animales comunales (como el caso del toro utilizado como semental), o también destinados para el arriendo, con el fin de obtener los recursos que necesitaban. Estas propiedades se unen a las dehesas, ya señaladas anteriormente, y al resto de propiedades conocidos como propios, entre los cuales entraban generalmente algún molino y diferentes inmuebles destinados a cubrir necesidades colectivas.

Bastante más reducidas, por su parte, son las propiedades de los grupos privilegiados, especialmente en el caso de los nobles, pues la pobreza, que caracteriza a los suelos de esta comarca, hizo que la acumulación de tierras no fuera una buena inversión. A ello cabría añadir, igualmente, el relativo desplazamiento que presentaba esta zona con respecto a los principales circuitos comerciales de grano.

La propiedad eclesiástica queda también marcada por estas circunstancias, de tal modo, que frente a lo que sucede en otras zonas de la provincia, donde sus posesiones se caracterizaban, tanto por su cantidad, como por la calidad de los suelos ocupados, en nuestra comarca éstas son más bien escasas. De este modo, y a pesar de que algunos de los grandes centros religiosos, como los monasterios de San Pedro de Arlanza, Santo Domingo de Silos, las Huelgas Reales de Burgos o el convento de San Agustín de esta misma ciudad, tenían propiedades en la zona, éstas no son comparables a las que poseían en otras comarcas del mapa provincial burgalés. No obstante, la titularidad eclesiástica incluye a otro tipo de propietarios concretos, mucho más modestos que estos grandes cenobios, pero de gran importancia en este medio rural. Estamos hablando de curas beneficados, fábricas parroquiales, cofradías, ermitas, capellanías, obras pías, etc., las cuales sí poseían un número de tierras relativamente significativo dentro de cada uno de estos pueblos, destacando, además, por la calidad de los suelos. Ejemplos de ello los tenemos en algunos santuarios, como los de Nuestra Señora de Costana, de Barbadillo de Herreros, Santa Lucía de Hacinas, o Nuestra Señora del Carrascal, o en 
Canicosa de la Sierra. El origen de estos patrimonios se encuentra, en todos los casos, en las donaciones efectuadas por los fieles.

Sin embargo, la mayor fuente de riqueza, que estos grupos privilegiados encontraron aquí, no se hallaba en la acumulación de tierras, sino en la posesión de censos y apropiación de determinadas rentas. En el primero de los casos destacan sobre todo algunos centros e instituciones eclesiásticas, donde entran, desde los cabildos catedralicios de Burgos y Burgo de Osma, y prestigiosos monasterios, como San Pedro de Arlanza, Silos o las Huelgas Reales de Burgos, hasta las más humildes parroquias, capellanías u obras pías. Cumplida relación de todo ello lo encontramos en los libros mayores de raíz, incluidos en el Catastro del Marqués de Ensenada. El estamento nobiliario, por su parte, se especializará en la apropiación de tributos. Dentro de ello tenemos el llamativo ejemplo de la casa de los Duques de Frías, la cual no sólo controlaba el cobro de las alcabalas en la práctica totalidad de los pueblos de la comarca, - independientemente de la pertenencia a su jurisdicción - sino que además había logrado hacerse con el cobro, dentro de estos mismos pueblos, de las Tercias Reales, constituidas por las dos novenas partes de los diezmos eclesiásticos, que toda la población debía pagar.

La agricultura, que se desarrolla dentro de este marco, consiste en una actividad de mera subsistencia, poco brillante y de escasa productividad, situándose sus niveles de producción muy por debajo de los registrados en otras zonas de la provincia, durante este mismo período. Esta agricultura se encuentra sumamente condicionada por diferentes factores, algunos de los cuales ya han sido señalados anteriormente.

Entre los elementos que limitan este mayor desarrollo se encuentran, en primer lugar, los relacionados con el medio físico, es decir, un clima extremadamente riguroso, una orografía muy abrupta y unos suelos caracterizados, por lo general, por su gran pobreza. En lo que se refiere al clima, apreciamos también que los rigores de una climatología dura, de largos y fríos inviernos y veranos cortos y calurosos, mermaba 
considerablemente la productividad, pues esto conllevaba la obligación de una sementera más temprana y unas mermas en las cosechas, producido por el súbito ascenso de las temperaturas en la primavera, cuando el grano aun está lechoso, provocando el fenómeno del “asustado”243. Respecto a la orografía y pobreza de suelos, sólo cabe decir, que el carácter montañoso y pedregoso, que domina en muchos de estos pueblos, impedía disponer de las amplias y profundas cantidades de tierra, que se hacían aconsejables para la práctica agrícola.

Otra cuestión importante son las reducidas dimensiones medias de las explotaciones. De este modo, según los datos aportados por Francis Brumont para los años finales del siglo XVI, extraídos de las muestras tomadas en varios pueblos de la actual provincia de Burgos, observamos que, mientras en las zonas próximas a nuestra comarca, como son las tomadas en Lara, la media se encontraba entre 15’6 y 18’8 fanegas de sembradura por parcela, y en la comarca de Juarros descendían hasta las 11'5, en la zona eminentemente agraria de la Bureba alcanzaban las 31'9 fanegas, y en Castrojeriz las 37’5 fanegas ${ }^{244}$. Por supuesto, el paso del tiempo no hizo sino afianzar aun más esta situación, con lo cual a mediados del siglo XVIII, y a la luz de los datos aportados por los libros mayores de raíz del Catastro de Ensenada, sabemos que la parcelación dentro de nuestros pueblos había llegado a un grado extremo, lo que hacía que en muchos casos se hiciera difícil incluso el empleo de una yunta de bueyes.

Evidentemente esta masiva parcelación de las tierras de labor lleva a unos índices de producción y una rentabilidad sumamente bajas. Entre las causas que propiciaron este excesivo minifundismo se encuentran, por supuesto, las sucesivas herencias y repartos efectuados generación tras generación. Pero también debemos tener en cuenta la accidentada orografía del territorio, que impedía disponer de amplias superficies llanas, susceptibles de ser unidas en una sola parcela.

243 A. GARCÍA SANZ: Desarrollo y crisis del Antiguo Régimen en Castilla ...ob. cit. 
Junto a esto tenemos que señalar también otra serie de cuestiones, relacionadas con los bajos índices de productividad, los cuales, en este caso, no son exclusivos de nuestra comarca, sino que se trata de un mal endémico, dentro de la agricultura castellana del Antiguo Régimen. Nos estamos refiriendo, entre otras cuestiones, a los sistemas y técnicas de cultivo empleados a lo largo de todo este amplio período, los cuales apenas habían experimentado cambios con el paso del tiempo, mostrándose, por lo general, poco eficaces a la hora de extraer el máximo rendimiento del suelo.

En cuanto al sistema de cultivo empleado, dada la aridez del terreno, el más difundido es el de año y vez, o bienal, consistente en sembrar un año y descansar otro. Este sistema resulta especialmente interesante dentro de nuestra comarca, pues a través del aprovechamiento del terreno en barbecho como zona de pasto, permite el desarrollo complementario de una amplia cabaña de ganado estante, como era el que existía en la mayor parte de estos pueblos ${ }^{245}$. En nuestro caso, además, y dada la especial pobreza de estos suelos, no es del todo raro encontrarnos con períodos de barbecho más extensos, especialmente en los suelos puestos en cultivo dentro de los terrenos comunales de varios pueblos o ledanías.

La única excepción a este pobre aprovechamiento del suelo la encontraremos en las pequeñas huertas, situadas en las proximidades de los caseríos. Aquí, la conjunción de diferentes factores, como son, una mayor dedicación y cuidado, una mejor fertilización mediante el abundante abono animal de los ganados estantes, y la disponibilidad en muchos casos de agua para realizar unas mínimas tareas de regadío,

244 F. BRUMONT: “Economía, actividades industriales y artesanales, agricultura y ganadería”. En Historia de Burgos III. Edad Moderna (2). Burgos, Caja de Ahorros Municipal de Burgos. 1992.(93 146).

245 A. GARCÍA SANZ: Desarrollo y crisis del Antiguo Régimen en Castilla ...ob. cit., F. BRUMONT: “Economía, actividades industriales...” ob. cit. J. P. AMALRIC: “En la España del siglo XVIII ¿una agricultura agarrotada?” En B. BENNASSAR: Orígenes del atraso económico español. Barcelona, 1985. (pp. $33-41)$. 
permitían un cultivo con una intensidad relativamente mayor, alternada con períodos de descanso mucho más breves o casi inexistentes.

Por supuesto, aquí no llega nunca a implantarse el desarrollo del sistema trienal, que sí fue aplicado en otras zonas de la provincia, basado en la alternancia de distintos tipos de cultivos con períodos cortos de barbecho. En general, la pobreza de los suelos, unida a unos sistemas de regeneración de los mismos, basados únicamente en la fertilización animal, llevan a que los índices de productividad fueran francamente bajos. Los rendimientos medios se sitúan aproximadamente, para el caso del trigo, en unas 5 fanegas de producto recogido por una de sembradura, ascendiendo ligeramente hasta algo más de 6 en el caso de otros cereales, como sucede con la cebada, el centeno o la avena. No obstante, el reconocimiento de estas cifras siempre resulta algo arriesgado, pues existen autores que consideran, que en el caso de una comarca montañosa, como es la nuestra, los índices deberían rebajarse hasta las 3’3 ó 4 para el trigo, y ligeramente por debajo de 6 para el resto de los cereales ${ }^{246}$.

Los sistemas de cultivo se completan a su vez con unas técnicas y un utillaje igualmente rudimentarios. Así, por lo que sabemos, muy poco o más bien nada, era lo que se había avanzado con respecto a la época anterior, ya que el arado romano, la azada, la guadaña y el trillo de lascas continuaban siendo los únicos útiles conocidos. De igual modo, la fuerza motora de estos artilugios continuaba siendo el hombre, y en el caso del arado y del trillo, la yunta de bueyes, la cual en nuestra zona apenas se ve sustituida por la mula, como sí ocurre en otras comarcas de la provincia, de mayor tradición agraria, como la zona de la Bureba ${ }^{247}$. Aquí, la excesiva fragmentación del terrazgo, unida al arraigo de la ganadería vacuna, impide este cambio. No obstante, a partir del siglo XVIII la presencia de la mula comienza a ser particularmente importante

\footnotetext{
246 E. PÉREZ ROMERO: Patrimonios comunales, ganadería trashumante...ob. cit.
}

En nuestra zona, y dada las especiales condiciones, ya señaladas, como irregularidad y mala calidad del terreno, gran fragmentación en la estructura de la propiedad de la tierra y demás, debemos dar por supuesto que nunca se superaron estos niveles de productividad.

247 F. BRUMONT: “Economía, actividades industriales...” ob. cit. 
en muchos de nuestros pueblos, si bien esto se produce principalmente por el crecimiento de los arrieros, o pequeños transportistas de ámbito intercomarcal, y no por su aplicación de este animal a las tareas agrícolas como fuerza motora.

En cuanto a los productos más característicos, destacan principalmente los cerealísticos, pues forman parte fundamental de la alimentación, tanto humana como del ganado. Aun así, encontramos algunos pueblos, como era el caso de los volcados en la actividad del transporte, donde el cultivo del cereal resulta prácticamente nulo.

Entre los cereales, por supuesto, el más abundante es el trigo, si bien aquí la variedad dominante no era la candeal, que habitualmente se cosechaba en el resto de la provincia, sino la conocida como "camuña”, o también denominada “morcajo”, que consistía en una mezcla de trigo y centeno, mucho más pobre que la anterior ${ }^{248}$. A su cultivo es al que se dedican un mayor número de tierras de labor. Tras el trigo se encuentran otra serie de cereales, destinados principalmente al consumo animal, dentro de los cuales desataca la cebada, seguida en importancia por el centeno y la avena, si bien ésta última es conocida en la zona por su mala calidad ${ }^{249}$. Dentro de los cereales, y a modo casi testimonial, tendremos que incluir también aquí los yeros, si bien su producción era francamente escasa.

Como complemento a estos productos, destinados en su mayoría al consumo animal, se encuentra también la hierba, procedente de los numerosos y ricos prados que existían en todos estos pueblos, la cual se menciona constantemente dentro de las respuestas dadas en el Catastro del Marqués de Ensenada.

\footnotetext{
248 Según los datos extraídos de las Respuestas Generales del Catastro del Marqués de Ensenada, en su pregunta número $11^{\mathrm{a}}$, los pueblos donde se cultivaba esta variedad serán Hacinas, Huerta de Abajo, Huerta de Arriba, Monasterio de la Sierra, Palacios de la Sierra, Quintanilla de Urrilla, Salas de los Infantes, Tolbaños de Abajo, Tolbaños de Arriba y Vallejimeno.

249 ADPBU. CE. 2179. RESPUESTAS GENERALES. Vallejimeno, 19 - mayo - 1753.
} 
En lo que se refiere al consumo humano, el trigo camuña se complementa con la obtención de algunos productos hortícolas, como legumbres y verduras, donde no faltan berzas, titos y nabos. Menor importancia tiene, sin embargo, la producción frutícola, pues si nos atendemos a las respuestas dadas en el Catastro de Ensenada, sólo algunos pueblos del Valle de Valdelaguna destacan por la recolección habitual de ciertas cantidades de ciruelas, cerezas, guindas, manzanas y peras ${ }^{250}$. Por su puesto, como ya hemos señalado anteriormente, todos estos productos están destinados para el autoconsumo de sus habitantes y nunca para la comercialización.

También debemos llamar la atención sobre el desarrollo de determinados cultivos de carácter no alimenticio, como es el caso de algunas fibras textiles, como el lino, cuya importancia no radica tanto en el volumen del producto obtenido, el cual es ciertamente escaso, como en su significación e implicación dentro de una industria o actividad manufacturera, de elaboración de tejidos.

Finalmente podemos destacar también, como una particularidad de sumo interés para el conocimiento de la agricultura dentro de nuestra comarca, la nula presencia del cultivo de la vid. A ello contribuyen, por igual, la inexistencia de unas condiciones medio ambientales mínimas para su desarrollo, y la proximidad con la zona vinícola de la provincia de Burgos por excelencia, como era la Ribera del Duero. Así, vemos cómo dentro de los intercambios comerciales que se hacen habitualmente desde nuestra comarca de estudio con su entorno más inmediato, en un lugar destacado se encuentra la importación de los caldos de la Ribera, obtenidos a cambio de la venta de productos artesanales, elaborados a partir de las materias primas dominantes.

250 ADPBU. CE. 2.048. RESPUESTAS GENERALES. Tolbaños de Arriba, 22 - agosto - 1753. 


\section{GANADERÍA.}

La ganadería en el campo castellano, durante la Edad Moderna, estaba llamada a ser el necesario complemento de la actividad agraria. Sin embargo, dentro de nuestra zona de estudio se dan una serie de condiciones geográficas e históricas, que llevan a que la ganadería se convierta en la base principal de la economía de varios de estos pueblos. De hecho, y atendiendo a los datos que nos suministran las distintas fuentes consultadas, podemos hablar, en muchos casos, de una auténtica especialización en esta actividad.

Nos estamos refiriendo, en todo momento, fundamentalmente a la ganadería lanar, cuyo desarrollo dentro de nuestra comarca se encuentra confirmado prácticamente desde la época celtibérica ${ }^{251}$ y romana ${ }^{252}$. Esta ganadería frecuenta, dentro de nuestra zona, dos modalidades de explotación, que conocemos como estante y trashumante, cuya diferencia fundamental radica en los recorridos realizados anualmente para buscar los pastos.

\section{Ganadería trashumante.}

La trashumancia es la forma de explotación más característica de este tipo de ganadería lanar, sin embargo, no será la que ocupe a un mayor porcentaje de la población de estos pueblos, pues no es un fenómeno, que se extiende de forma uniforme por todos ellos. Este tipo de explotación consiste en el traslado estacional de los

251 Diferentes vestigios hallados en los yacimientos arqueológicos explorados dentro de esta comarca corroboran esta explotación ganadera, y el uso habitual de sus productos. Museo Arqueológico Paleontológico de Salas de los Infantes.

252 En el entorno de Lara de los Infantes se han hallado varias estelas de época romana en las cuales aparecen representados diversos temas relacionados con este mundo de la ganadería. J. A. ABÁSOLO ÁLVAREZ: Epigrafía romana de la región de Lara de los Infantes. Burgos, Excma. Diputación Provincial de Burgos. 1974.Carta arqueológica de la provincia de Burgos: Partido Judicial de Salas de los Infantes. Burgos, Excma. Diputación Provincial de Burgos. 1990. E. PASTOR DÍAZ DE GARAYO: Castilla en el tránsito de la Antigüedad al Feudalismo: Poblamiento, poder político y estructura social 
ganados, desde las sierras del norte de la península Ibérica, donde pasan los meses de verano, hasta las dehesas meridionales de Extremadura y Andalucía occidental, conocidas genéricamente como extremos, donde pasaban el resto del año. De este modo, el ganado estaba pastando todo el año en pastos frescos, evitando al mismo tiempo las bruscas oscilaciones térmicas, que existen en las sierras de origen ${ }^{253}$.

El fin último de este tipo de ganadería se encuentra en la comercialización de la lana fina de oveja merina, destinada a la industria textil castellana, pero sobre todo del Norte de Europa, teniendo sus principales mercados en la zona de los Países Bajos. Este mercado noreuropeo había empezado a ser dominado por las lanas castellanas fundamentalmente a partir del siglo XV, pues el desarrollo de la Guerra de los Cien Años, unido a la extraordinaria calidad de este producto, había llevado a que los vellones castellanos sustituyeran progresivamente a los ingleses, como materia prima de la industria textil flamenca ${ }^{254}$. Esto lleva a que la lana de los ganados trashumantes y su comercialización, se conviertan en una pieza esencial de la economía castellana durante la Baja Edad Media y toda la Edad Moderna ${ }^{255}$, alcanzando un reconocimiento, que hace que sea denominada por los Reyes Católicos como "la principal sustancia del reino" 256 .

La predilección de Castilla en general, y gran parte de nuestra comarca en particular, por este tipo de ganadería extensiva no fue una elección caprichosa, sino que se ve condicionada por diferentes factores de orden físico e histórico principalmente. En este sentido, los factores climáticos debemos verlos como los principales impulsores de estos traslados, aprovechándose en este caso de los grandes contrastes que se producen

del Arlanza al Duero. (siglos VII - XI). Valladolid, Consejería de Educación y Cultura. Junta de Castilla y León, 1996.

253 A. CABO ALONSO: "Medio natural y trashumancia en la España peninsular". En Mesta, trashumancia y lana en la España Moderna. F. RUÍZ MARTÍN, A. GARCÍA SANZ (eds.). Barcelona, Crítica. Fundación Duques de Soria. 1998. (pp. 11 - 41).

254 R. CARANDE: Carlos $V$ y sus banqueros. Ob. cit.

255 M. BASAS: “Burgos en el comercio lanero del S. XVI”. En Moneda y Crédito, 1961. (pp. 37 - 69).

256 R. CARANDE: Carlos Vy sus banqueros. Ob. cit. 
154 Arquitectura de la Edad Moderna en la sierra burgalesa.

dentro de la península Ibérica entre el sur y el norte. Así, los traslados de ganado permiten aprovechar los ciclos del herbazal de forma complementaria entre el norte y el sur, evitando al mismo tiempo las amplias oscilaciones térmicas ${ }^{257}$.

Su origen también aparece ligado a unas circunstancias históricas muy concretas, como son las relacionadas con el proceso de reconquista y consiguiente repoblación de las tierras, que paulatinamente iban siendo arrebatadas a los reinos musulmanes. Esta coyuntura favorecía más un asentamiento de la ganadería que de la agricultura, pues un bien movible, como el ganado, resultaba más fácil de poner a salvo en caso de verse atacados por razzias musulmanas. Al mismo tiempo esta ganadería resultaba una buena forma de poner en explotación unos territorios extremadamente amplios y poco poblados, que mediante la agricultura hubiera resultado del todo imposible efectuar ${ }^{258}$. De esta forma, a partir del siglo XI, a medida que avanza la reconquista hacia el sur, se van ampliando cada vez más y más lejos los traslados trashumantes. Por ello, en este contexto, la victoria de las Navas de Tolosa en 1212 por el rey Alfonso VIII debe ser entendida como la llave que garantiza la apertura de los extensos pastizales meridionales a los ganados trashumantes serranos ${ }^{259}$.

257 Si tomamos cada uno de los dos extremos unidos por las grandes cañadas que comunicaban las sierras septentrionales con las dehesas del sur, como puede ser el caso de la cañada segoviana, que une las localidades de Neila, Huerta de Arriba y el resto del Valle de Valdelaguna, con los valles de Alcudia y la Serena, observamos que se producen estas circunstancias. Las diferencias existentes en las temperaturas y los ciclos del herbazal a lo largo del año dentro de cada uno de estos puntos quedarían compensados con el traslado de los ganados, de tal modo que al permanecer en las sierras en los meses más suaves y trasladarse a Extremadura y Andalucía en el invierno, se consigue crear para estos ganados unas condiciones ideales, en las que apenas se registran cambios significativos en las temperaturas, mientras que el volumen y calidad de los pastos se mantienen altos todo el año. A. CABO ALONSO: "Medio natural y trashumancia en la España peninsular”. Ob. cit.

258 J. VALDEÓN BARUQUE: "La Mesta y el pastoreo en Castilla en la Baja Edad Media (1273 1474)”. En Mesta, trashumancia y vida pastoril: exposición organizada por la Sociedad V Centenario del Tratado de Tordesillas. Soria, Sede de la Fundación Duques de Soria. 19 de septiembre a 30 de noviembre de 1994. Madrid, I+P Investigación y Progreso.1994.

259 Ibídem. 
Con todo esto, y aunque resulte un tanto aventurado establecer fechas concretas, podemos pensar que entre los siglos XI y XII (coincidiendo con los primeros asentamientos de los poblados definitivos), comienza un desarrollo relativamente importante de la ganadería lanar en nuestra comarca, explotada mediante cortos traslados, efectuados dentro del territorio, que constituía el término municipal de cada núcleo. Así, hacia finales de la undécima centuria, y una vez asimiladas las limitaciones que este territorio serrano ofrece para la práctica agrícola, comienza a practicarse un tipo de ganadería extensiva, basada en el traslado de las reses a pastos de clima más suave en tiempo invernal. En las vecinas localidades de Canalas, Villavelayo y Mansilla, actualmente encuadradas dentro de la Comunidad Autónoma de la Rioja, parecen probados algunos traslados ya en las últimas décadas del siglo XI (1072) ${ }^{260}$. Por nuestra parte, en las primeras décadas del siglo XII ya existen diferentes testimonios documentales que prueban la existencia de una importante cabaña de ganado lanar y cabrío en algunos de nuestros pueblos del entorno de la Sierra de la Demanda, entre los que se incluyen Barbadillo del Pez, Hoyuelos de la Sierra, Quintanilla de Urrilla y Vallejimeno $^{261}$.

A parte de estas circunstancias, se han alegado en algunas ocasiones la existencia de otro tipo de razones, como fuentes impulsoras del desarrollo de la ganadería lanar trashumante. Entre ellas se encuentra la creencia de que el ejercicio del ganado favorecía la buena salud del animal y mejoraba considerablemente la producción de lana. Pero sin duda, una de las más singulares es la que se daba en algunos pueblos de nuestra zona de estudio, como es el caso de Neila, donde se decía

\footnotetext{
260 L. VICENTE ELÍAS: “La Mesta y la cultura pastoril”. En Mesta, trashumancia y vida pastoril: exposición organizada por la Sociedad V Centenario del Tratado de Tordesillas. Soria, Sede de la Fundación Duques de Soria. 19 de septiembre a 30 de noviembre de 1994. Madrid, I+P Investigación y Progreso.1994. (pp. 207 - 237). A. PÉREZ ALONSO: Historia de la Real Abadía de Nuestra Señora de Valvanera en la Rioja. Gijón. 1971. (pag. 179).

261 J. PEÑA PÉREZ: "La ganadería en tierras de Burgos en los siglos centrales de la Edad Media: del corral familiar a la ganadería trashumante”. En Historia de Burgos, desde sus orígenes hasta nuestros días. Tomo II. Desde el año 1000 a los tiempos modernos. Burgos, Diario 16 Burgos. 1993. (pp. 363 374).
} 
que "las mujeres trabajaban la tierra, y los hombres tuvieron que salir del pueblo con los ganados a buscar pastos, obligados por las esposas, que dominaban la vida local”262. Estaríamos, por lo tanto, ante una de las consecuencias de las tesis, que nos hablan de la existencia de una sólida estructura matriarcal, dentro de la sociedad serrana de este período plenomedieval.

Un elemento fundamental dentro de esta actividad trashumante lo constituyen las cañadas o red viaria, a través de las cuales se efectuaban los traslados de estos rebaños. En principio el término cañada aludiría únicamente a los caminos pecuarios, que limitaban con las llamadas cinco cosas prohibidas, es decir, dehesas comunales, panes, viñas, huertos y prados de guadaña, ya que fuera de aquí, en campo abierto, no existiría ningún tipo de limitación, que obligara a los ganados a seguir un trazado fijo. De este modo, según R. Aiken, debía tratarse, más bien, de un terreno de pasto alargado, que de caminos propiamente dichos ${ }^{263}$. Por ello, y dadas las continuas presiones que en diferentes épocas ejercen, tanto agricultores, como ganaderos estantes y los propios concejos de los lugares por donde pasaban, los trazados de estas vías sufrirán multitud de agresiones, así como cambios en su recorrido ${ }^{264}$.

Aun así, sabemos que existían cuatro cañadas principales, conocidas como, Leonesa, Segoviana, Soriana y Manchega o Conquense. Estas cañadas estaban articuladas, a su vez, en varias vías menores, que enlazaban con el camino principal, formando una tupida red viaria de caminos de diferentes amplitud ${ }^{265}$. Cada una de estas vías tenía su denominación, en función a la anchura, lo cual nos permite hablar de:

- Cañadas: 90 varas castellanas.

- Cordeles: 45 varas castellanas.

262 L. VICENTE ELÍAS: "La Mesta y la cultura pastoril”. Ob. cit.

263 R. AITKEN: "Rutas de trashumancia en la meseta castellana”. En Estudios Geográficos. (febrero 1947). (pp. 185 - 199).

264 J. VALDEÓN BARUQUE: “La Mesta y el pastoreo en Castilla en la Baja Edad Media... ob. cit. 
- Veredas: 25 varas castellanas.

- Ramificaciones menores sin medidas fijas, denominadas, según las zonas como coladas o ramales ${ }^{266}$.

Dentro de esta red las más importantes son las cañadas, pues son ellas las que unen directamente las sierras norteñas con los pastos de los extremos, en Extremadura, Andalucía y la Mancha. La vía seguida por los ganaderos de nuestra comarca fue principalmente la Segoviana, pues no en vano nacía precisamente al abrigo de estas montañas. Así, según Javier Teres Landeta, la cabecera de esta cañada principal se situaba entre las sierras de la Demanda y Neila, compuesta por los siguientes pueblos: Barbadillo de Herreros, Pineda, Vallejimeno, Tolbaños de Abajo, Tolbaños de Arriba, Huerta de Abajo, Huerta de Arriba y Neila ${ }^{267}$. La estructura viaria dentro de estos pueblos, sin embargo, resulta poco clara, pues con el paso del tiempo ha ido sufriendo numerosas modificaciones. Así, actualmente tenemos dos rutas de salida totalmente diferentes. Una es la que parte de estos pueblos que acabamos de citar, y continúa a través Moncalvillo hacia Aranda de Duero ${ }^{268}$. La segunda establece como punto de concentración de los rebaños las inmediaciones de la ermita de Nuestra Señora de Vega, en el centro del Valle de Valdelaguna, partiendo desde aquí a través de Vallejimeno, Barbadillo del Pez y Jaramillo de la Fuente, hacia las tierras de Lara y Lerma ${ }^{269}$. El final se situaba en los parajes de la Serena y el valle de Alcudia, en la provincia de Badajoz,

265 J. KEIN: La Mesta. Estudio de la historia económica española. 1273 - 1836. Madrid, Alianza Editorial. 1994. P. GARCÍA MARTÍN (Coord.): Cañadas, cordeles y veredas. Valladolid, Junta de Castilla y León. Consejería de Agricultura y Ganadería. 2000.

266 Según la traducción al sistema métrico decimal recogida en el Art. 9ºl del Reglamento de vías pecuarias de 1944 estas medidas quedarían así: Cañadas, 75 metros y 22 centímetros; Cordeles, 37 metros y 61 centímetros; Veredas, 20 metros y 89 centímetros; y Coladas y ramales, menor de 20 metros y 89 centímetros.

267 J. TERES LANDETA: “La cañada segoviana”. En Cañadas, cordeles y veredas. (P. GARCÍA MARTíN. Coord.). Valladolid, Junta de Castilla y León. Consejería de Agricultura y Ganadería. 2000. (.. 125 - 143).

268 Ibídem. 
158 Arquitectura de la Edad Moderna en la sierra burgalesa.

donde invernaban estos ganados, después de haber recorrido una distancia aproximada de unos 500 kilómetros.

La salvaguarda de estas vías y la protección de los ganados que transitaban por ellas quedaban asegurados por el Horado Concejo de la Mesta, institución creada en 1273 por el rey Alfonso X con el fin de garantizar el normal y buen desarrollo de esta actividad. No obstante, sobre su origen existen notables controversias, pues si para la historiografía tradicional el nacimiento de esta institución se encuentra en la confirmación de los cuatro privilegios otorgados por Alfonso X en $1273^{270}$, para muchos investigadores actuales, esta fecha simplemente marcaría la confirmación de unos privilegios ya existentes con anterioridad, los cuales son ampliados ligeramente. De esta forma, y según los criterios de esta segunda propuesta, con la confirmación de estos privilegios por parte de Alfonso X simplemente se estaba dando carácter institucional a una organización, que de facto, ya venía funcionando desde los años centrales de este siglo XIII ${ }^{271}$.

La Mesta era una reunión de pastores trashumantes en la que se solucionaban diferentes cuestiones relevantes para el desarrollo de su actividad, como por ejemplo, el reparto de las reses extraviadas, conocidas como "mostrencas", la vigilancia del respeto a las cañadas, la protección de los pastores frente a los malhechores, o el control sobre el arrendamiento de los pastos invernales.

Una pieza fundamental, dentro de este organigrama de derechos y privilegios, lo constituyen los alcaldes entregadores, o magistrados ambulantes, dependientes de la

269 L. SAN VALENTÍN BLANCO: De la trashumancia del ganado merino. Desde nuestros puertos de la Sierra de la Demanda hasta las dehesas de Extremadura y Andalucía. Burgos, Excma. Diputación Provincial de Burgos. 1984. (pp. 21 - 28).

270 J. KLEIN: La Mesta. Estudio de la historia económica... ob. cit.

271 J. VALDEÓN BARUQUE: “La Mesta y el pastoreo en Castilla en la Baja Edad Media... ob. cit. 
Corona y no de la Mesta ${ }^{272}$, cuya función consiste en proteger los elementos principales de la actividad trashumante, haciendo guardar los derechos e intereses de los hermanos mesteños frente a las autoridades locales de los lugares de paso. De esta forma, junto a la autoridad jurisdiccional realenga y de señorío, nos encontremos con una jurisdicción nueva, que contribuye a complicar aun más el puzle, que ya existía.

No se conoce el número exacto de alcaldes entregadores que hubo en cada momento, si bien se estima que en un principio existía uno por cañada, pasando posteriormente a ser nombrados por cuadrillas, ajustándose así su jurisdicción a este nuevo marco territorial. Nuestra comarca de estudio, por ejemplo, pasaba así de estar encuadrada dentro de la jurisdicción del alcalde entregador de la cañada segoviana a la jurisdicción del entregador de la cuadrilla soriana. Lo que sí se conoce sobre estos alcaldes es que el excesivo celo, que con frecuencia empleaban para salvaguardar los intereses trashumantes, hizo de ellos una figura temida, e incluso despreciada, por los concejos de los lugares de paso. Así, no dudan, en muchas ocasiones, en extender sus competencias más allá de lo puramente relacionado con la trashumancia, llegando a la protección de baldíos y comunales, que podrían servir de agostaderos a los rebaños ${ }^{273}$.

Todos los ganaderos encuadrados en las Mesta eran conocidos como hermanos mesteños, lo cual en principio solamente correspondería a aquellos que realizaban la trashumancia a larga distancia, partiendo de las sierras del norte hasta llegar a los extremos, en Andalucía y Extremadura. Estos ganaderos eran conocidos genéricamente como serranos, entendiendo por sierra, según Ramón Carande: “a las ciudades, villa y lugares del arzobispado de Burgos, con la abadía de Covarrubias, a los obispados de Osma, Calahorra, Sigüenza, Cuenca, Segovia, Ávila, León y Astorga; a las villas castellanas del obispado de Tarazona, a las del valle de Lozolla y Buitrabo y su tierra,

\footnotetext{
272 J. KEIN: La Mesta. Estudio de la historia económica... ob. cit. A partir de 1568 este cargo será incorporado a la Mesta.

273 Ibídem.
} 
Torrelaguna, Real de Manzanares, marquesado de Cogolludo, señoríos de Hita y Monbeltrán”274.

Posteriormente, a partir de 1556 ingresan también los grandes ganaderos riberiegos, que habían sido hasta el momento trasterminantes ${ }^{275}$, compuestos principalmente por poderosas ganaderías, que poseían rebaños con varios miles de cabezas. Según Ramón Carande, esto supone la pérdida del control de los pequeños ganaderos, y el inicio del fin de la institución de la Mesta ${ }^{276}$.

El conjunto de los ganados pertenecientes a los hermanos mesteños formaba la Cabaña Real, término que no implicaba ningún tipo de titularidad por parte de la corona, sino que simplemente alude al amparo regio, que existía sobre estos ganado. Esta Cabaña estaba articulada en cuatro grandes cuadrillas o distritos, como eran la leonesa, la segoviana, la soriana y la conquense, las cuales comprenden un área geográfica determinada, que no debía coincidir necesariamente con cada una de las cuatro cañadas homónimas. De este modo, los hermanos de nuestra comarca pertenecerían a la cuadrilla soriana y no a la segoviana, pues en la soriana quedaban incluidos los territorios de las diócesis de Burgos, Osma, Calahorra, Sigüenza y parte de Tarazona ${ }^{277}$.

Al frente de cada una de ellas existía un Alcalde de Cuadrilla o de la Mesta, elegido por un período de cuatro años. Estos alcaldes, junto con el Presidente de la Mesta, eran los encargados de presidir las Juntas, que se reunían dos veces al año, para tratar los temas concernientes a la trashumancia. En las Juntas podían participar con voz y voto todos los hermanos que tuvieran un mínimo de 150 cabezas de ganado

\footnotetext{
274 R. CARANDE: Carlos Vy sus banqueros. Ob. cit. (pp.82).

275 Por ganado trasterminante entendemos aquellos rebaños que efectuaban traslados intercomarcales durante los distintos períodos del año, pero sin alcanzar nunca los grandes desplazamientos que realizaban los trashumantes.

276 R. CARANDE: Carlos V y sus banqueros. Ob. cit. (pp.82).

277 J. KLEIN: La Mesta. Estudio de la historia económica... ob. cit.
} 
trashumante, si bien, en la práctica solamente acudían los propietarios de grandes rebaños $^{278}$.

A su vez, cada cuadrilla quedaba dividida en diferentes grupos o circunscripciones menores, denominadas hermandades o cuadrillas menores, las cuales agrupaban a los propietarios de ganados de áreas geográficas muy concretas. Los ganaderos de nuestra zona de estudio formaban la llamada Cuadrilla de San Pedro de la Vega, nombre tomado de la ermita ${ }^{279}$ junto a la que se reunían anualmente estos pastores, durante los meses que duraba el agostadero. En ella se encontraban representados los pastores de todos los pueblos de nuestra comarca, y para su funcionamiento contaba con un alcalde, que era el que presidía las reuniones, un alcalde ordinario y un prior $^{280}$.

El tipo de ganadero, que encontramos aquí, se ajusta a las características del modelo tradicional del ganadero serrano, predominando los pequeños y medianos propietarios con rebaños de 150 a 300 cabezas. De alguna manera, este era el número mínimo de cabezas, que debían poseer para que el rebaño fuera mínimamente rentable, permitiendo al propietario dedicarse de forma exclusiva a esta actividad. Esto era un elemento importante, pues la ganadería trashumante nunca fue entendida en esta zona como una actividad complementaria de la agricultura, sino más bien como una alternativa, ante la imposibilidad de subsistir mediante la labranza. Por ello, nunca existió una complementariedad entre ganadería trashumante y agricultura.

Junto a estos modestos ganaderos también encontramos otros dos grupos no menos significativos. Nos estamos refiriendo, por una parte, a los propietarios de grandes rebaños, y por otra, a los pastores que trabajaban al servicio de ellos.

278 Ibídem.

279 Actualmente esta ermita se encuentra bajo la advocación de Nuestra Señora de Vega. 
En el primero de los casos estamos hablando de los dueños de importantes rebaños, que superan de forma holgada las 1.000 cabezas, llegando alguno de ellos hasta las 4.000. Ejemplos de este grupo aparecen en cada uno de los pueblos, donde la ganadería lanar se convirtió en la actividad económica dominante, como fue el caso de Barbadillo de Herreros, Bezares, Vallejimeno, Monterrubio de la Demanda, Huerta de Abajo, Tolbaños de Abajo o Tolbaños de Arriba. No obstante, los miembros más destacados se encuentran en Huerta de Arriba y Neila. Aquí, podemos citar algunos nombres, como Don Manuel de la Braga, vecino de Huerta de Arriba, con unas 2.400 cabezas de ganado, la mayor parte merino ${ }^{281}$, Don Antonio Pérez Cuesta, vecino de Neila, con 1.100 cabezas $^{282}$, Don Antonio Segura, también vecino de Neila, con 2.700 cabezas $^{283}$, o D. Pedro de Andrés, vecino de este mismo pueblo, con un rebaño de más de 4.300 cabezas $^{284}$. En Vallejimeno, a mediados del siglo XVIII, encontramos también a Juan Blanco de la Torre, con un rebaño próximo a las 3.500 cabezas, de las cuales cerca de 2.500 eran ovejas merinas ${ }^{285}$.

En relación con la actividad arquitectónica, los miembros de este grupo destacan por ser los impulsores de un tipo constructivo muy característico, dentro de la arquitectura civil de la comarca, como son las grandes casonas blasonadas de recia estructura, que pueblan varios de estos municipios. Afortunadamente en muchos de los pueblos, que acabamos de citar, aun se conservan brillantes ejemplos de ellas.

El segundo grupo es el de los pastores, que trabajan al servicio de estos grandes propietarios, los cuales viven del salario que perciben, ajustado según a la categoría a la que pertenecen (mayoral, rabadán, etc.). Muchos de ellos poseen también pequeños

280 AHPBU. PN, Valle de Valdelaguna. Leg. 9802/2, fols. 28 - 29 vº. Manuel Gil de la Cuesta. San Pedro de la Vega, 27 - julio - 1732.

281 ADPBU. CE. 903. LIBROS MAYORES DE LO RAÍZ Y PERSONASLES DE AMBOS ESTADOS. Huerta de Arriba, 27 - julio - 1753.

282 ADPBU. CE. 1.184. LIBRO MAYOR DE LO RAÍZ DE SEGLARES. Neila, 14 - julio - 1753.

283 Ibídem.

284 Ibídem.

285 ADPBU. CE. 2179. RESPUESTAS GENERALES. Vallejimeno, 17 - mayo - 1753. 
hatos de ganado trashumante, que participan dentro de este negocio de la explotación de la lana. Se trata, por lo general, de pequeños rebaños, compuestos por unas 30 ó 40 cabezas, que trashuman junto con las del amo, quedando para dicho amo el derecho de explotación de la lana que producen ${ }^{286}$. Aun así, dentro de este grupo también existen propietarios de rebaños nada despreciables, como es el caso de José de la Cuesta, vecino de Huerta de Arriba, que trabajaba como pastor “al servicio de otros ganaderos”, y que poseía al mismo tiempo unas 240 cabezas de ganado, o el caso de Matías Blanco de la Torre, también de Huerta de Arriba, con 250 cabezas de ganado lanar y cabrío ${ }^{287}$. El número de estos pequeños propietarios-pastores es realmente alto ${ }^{288}$, dándose la circunstancia de que muchos de ellos trabajaban al servicio de ganaderos afincados en otros pueblos de comarcas de la Rioja y Soria.

Respecto al volumen de cabezas de ganado trashumante, que partieron regularmente de estas sierras hacia las tierras del sur, resulta ciertamente difícil establecer unas cifras globales, pues carecemos de fuentes, que nos informen con precisión sobre este aspecto. Además, debemos tener en cuenta, que se trata de una actividad terriblemente sujeta a las fluctuaciones impuestas por el mercado y sus leyes de oferta y demanda, lo que hizo que se experimentasen importantes variaciones de unos momentos a otros. Aun así, durante uno de los períodos de máximo esplendor de esta actividad en la zona, como fue la primera mitad del siglo XVIII, los pueblos

\footnotetext{
286 Ibídem. Este será el caso de Antonio Sanz de Alfaro, el cual "gana anualmente como pastor que es del ganado merino de Don Antonio Segura, vecino de esta villa, 294 reales”, poseyendo al mismo tiempo un rebaño de 55 cabezas de ganado lanar merino y 12 cabezas de ganado cabrío.

287 ADPBU, CE. 903. LIBROS MAYORES DE LO RAÍZ Y PERSONALES DE AMBOS ESTADOS. Huerta de Arriba, 27 - julio - 1753.

288 Ibídem. D. Manuel de la Braga, propietario de ganado lanar merino, que tiene a su servicio a varios pastores de diferentes pueblos de la comarca, como es el caso de Juan Galindo, de Tolbaños de Arriba, Juan de la Vilda, de Quintanilla de Urrilla, Roque Martín, de Vizcainos, Manuel Lucas, de Barbadillo del Pez, Pedro García, vecino de Tolbaños de Arriba, Felipe López del Castillo, de Tolbaños de Abajo, Juan Blanco, de Pinilla de los Moros, etc.
} 
164 Arquitectura de la Edad Moderna en la sierra burgalesa.

integrantes de la cuadrilla de San Pedro de la Vega nos indican que “confesamos tener a lo menos mas de 60.000 cabezas de ganados merinos que trashuman"289.

La composición de los rebaños era por lo general bastante uniforme, dominando la oveja de raza merina, que se caracterizaba por la extraordinaria finura de su lana. El origen de este animal no está del todo claro, por lo que se han dado las más variadas teorías $^{290}$, que van, desde las que contemplan la posibilidad de que se tratara de una raza autóctona, que venía existiendo desde época romana ${ }^{291}$, o aun antes, según parece desprenderse de algunas crónicas de los viajes efectuados por griegos y fenicios, hasta las más peregrinas, que lo relacionan con la influencia de los comerciantes genoveses ${ }^{292}$. Sin embargo, todo parece apuntar a que la presencia de este animal en nuestra geografía debemos relacionarla con la llegada de la tribu de los Beni-Merines del norte de África, que arribaron con sus rebaños a la península a mediados del siglo XII ${ }^{293}$. A partir de este momento, entre los siglos XIII-XIV, se procedió a una cuidada política de importación de ejemplares de estos ganados norteafricanos para ser cruzados de forma meticulosa con las diversas razas autóctonas, hasta perfeccionar una raza de oveja extraordinariamente adaptada para la producción de lana de alta calidad ${ }^{294}$.

Al mismo tiempo, junto a estas grandes manadas de ovejas merinas, también participan en los traslados hacia las tierras del sur, algunos grupos significativos de cabras, las cuales llegan a constituir, según los datos que hemos extraído del Catastro

289 AHPBU. PN. Valle de Valdelaguna. Leg. 9802/2, fols. 28 - 29 vo. Manuel Gil de la Cuesta. San Pedro de la Vega, 27 - julio - 1732.

290 E. LAGUNA SANZ: Historia del merino. Madrid. Ministerio de Agricultura, Pesca y Alimentación. 1986.

291 R. CASTEJÓN Y MARTÍNEZ DE ARIZOLA: El merino andaluz. Tipología artística. Córdoba. 1979. R. DÍAZ MONTILLA: “La raza merina española”. II Congreso Internacional Veterinario de Zootecnia. Madrid. A. SÁNCHEZ BELDA, M. C. SÁNCHEZ TRUJILLANO: Razas ovinas españolas. Madrid, Publicaciones de Extensión Agraria. Ministerio de Agricultura. 1979.

292 R. S. LÓPEZ: The origin of the merino sheep. Barcelona, Estudios de Historia Moderna, 1954.

293 J. KLEIN: La Mesta. Estudio de la historia económica... ob. cit. .

294 C. L. DE LUNA: “Problemas de la producción de lana en los países mediterráneos”. Simposium del Comité Nacional de la FEZ. 1970. 
del Marqués de Ensenada, un porcentaje situado entre el 10 y el 15\% del total de cabezas, que formaban estos rebaños. A estos ganados se unen también una serie de yeguas, mulas y pollinos, que son utilizados para los desplazamientos de algunos pastores, como el mayoral o los rabadanes, y para el transporte de los útiles, que estos pastores podían necesitar a lo largo del viaje, y durante los nueve meses que pasaban fuera de casa.

Los desplazamientos de estos ganados, desde las sierras a los extremos y viceversa, se realizaban en rebaños de unas 1.000 cabezas aproximadamente, los cuales eran conducidos por grupos de unos 5 pastores. Dentro de ellos existía una estricta jerarquía, que establecía diferentes categorías, en virtud de su cualificación, del tipo de trabajo que realizaban, y por consiguiente de su remuneración. Estas categorías eran las siguientes:

\section{- Mayoral:}

Era el mayordomo y hombre de absoluta confianza del propietario del rebaño. Se encargaba de coordinar los movimientos de varios rebaños, pudiendo situarse bajo su control hasta un total de 8 ó 10 rebaños de 1.000 cabezas cada uno. Esto hacía que rara vez estuviera en contacto directo con el ganado, pues iba siempre, o delante, cerrando acuerdos para las zonas de pasto, o detrás, desembolsando el dinero de los diversos tributos que las ovejas tenían que pagar a su paso por determinados puntos. Esta alta responsabilidad que asumían hacía de ellos un bien muy preciado dentro del mundo de la trashumancia, siendo especialmente valorados los de origen soriano, por su honradez y seriedad ${ }^{295}$.

- Rabadán:

Era la segunda categoría en importancia, convirtiéndose en el jefe inmediato de los pastores, que acompañaban al ganado. Su actividad se centraba sobre un solo rebaño, transmitiendo las órdenes del mayoral, si bien, en el caso de los rebaños más pequeños o formados por los hatos de propietarios más modestos - como solía ser frecuente en nuestra comarca - este rabadán vendría a cumplir las

295 L. SAN VALENTÍN BLANCO: De la trashumancia del ganado merino... ob. cit. 
funciones del mayoral. Dentro del grupo de pastores que guiaba un rebaño esta función del rabadán solía recaer en el pastor más veterano o mejor cualificado, siendo siempre un hombre de mente despierta y, por supuesto, perfecto conocedor del mundo de la trashumancia.

El peso que tenía los pastores que desempeñaban este cargo hacía que fueran personas muy respetadas dentro de las relaciones sociales de estos pueblos ${ }^{296}$.

\section{- Compañero:}

Era el ayudante del rabadán, y se encargaba de sustituirlo en caso de ausencia. A parte de esto no tenía ninguna función exclusiva de su puesto.

- Ayudador:

Se trataba, por lo general, de un pastor joven y vigoroso, pero de sobrada experiencia dentro del mundo de la trashumancia. Sus especiales cualidades le llevaban a encargarse de las labores más pesadas dentro del rebaño.

- Zagal:

Era la última categoría, desempeñada por un pastor joven de unos 17 ó 18 años, de escasa experiencia en el mundo de la trashumancia, aprovechando estos primeros viajes para formarse en todos los pormenores, que requería el manejo del ganado. Normalmente era el hijo de alguno de los pastores que componían la cuadrilla, o pariente de pastores que trabajaban en otros rebaños. Sus trabajos solían ser los más duros y desagradables, a lo cual había que unir el hecho de ser una especie de bufón o divertimento del resto de la cuadrilla, pues se convertía en el objeto de todo tipo de bromas por parte de los pastores más experimentados $^{297}$. Aun así, constituía el paso indispensable para iniciar el ascenso, dentro de las distintas categorías que componen la jerarquía pastoril.

\footnotetext{
296 En este sentido tenemos que decir que, dentro del trabajo de campo que hemos podido realizar en muchos de estos pueblos, en los cuales hasta épocas ciertamente recientes continuaban viviendo de la trashumancia, nos ha llamado la atención el respeto y la veneración con que se recordaba a determinados personajes simplemente por el hecho de haber desempeñado en el pasado la función de rabadán.

297 Una de las bromas más frecuentes era la de la caza del "gamusino”. L. SAN VALENTíN BLANCO: De la trashumancia del ganado merino... ob. cit.
} 
Pero la cuadrilla no quedaría completa si no mencionamos a los perros, que acompañaban y vigilaban el ganado, los cuales pertenecían principalmente a la raza mastín. Su papel, dentro de los trabajos de conducción del ganado, era de primer orden, por lo cual, recibían exactamente la misma cantidad de comida que el resto de los pastores.

El ciclo anual de la trashumancia comenzaba con la partida de los ganados desde estos pueblos de la sierra hacia tierras extremeñas, lo cual sucedía en torno a las primeras semanas de octubre, si bien el proceso se había iniciado unos meses antes con la contratación de los diferentes pastores que compondrían la cuadrilla, allá por la fiesta de San Pedro. En el caso de los rebaños de nuestra comarca este traslado se realizaba siguiendo, como hemos dicho, la cañada segoviana, que partía del Valle de Valdelaguna, llegando a los valles de Alcudia y la Serena al cabo de treinta días. Esto suponía un recorrido de unos 500 kilómetros, con una media de algo más de 16 kilómetros por jornada, si bien el trayecto diario no sería en modo alguno regular, pues los 25 ó 30 kilómetros que se podían recorrer en una etapa que transcurriera por cañadas, quedaban reducidos a no más de 10 en las zonas de campo abierto ${ }^{298}$.

Una vez alcanzadas las dehesas meridionales estos rebaños disponían de amplios pastos para su disfrute, los cuales habían sido previamente arrendados mediante el proceso de alenguamiento, que se basaba en el derecho que tenían estos ganaderos, conocido como posesión. ${ }^{299}$ En estas dehesas se producía la paridera, que comenzaba en torno al mes de diciembre, a la que le seguían posteriormente el destete, el raboteo, el mansoneo, etc ${ }^{300}$.

\footnotetext{
298 L. VICENTE ELÍAS: “La Mesta y la cultura pastoril”. Ob. cit.

299 R. CARANDE: Carlos V y sus banqueros. Ob. cit.

300 L. VICENTE ELÍAS: “La Mesta y la cultura pastoril”. Ob. cit.
} 
El regreso a la sierra se iniciaba entre los últimos días de mayo y primeros de junio, llegando a su destino en torno al día de San $\operatorname{Juan}^{301}$, lo que ponía fin al contrato de los pastores. Los lugares de pasto para estos ganados en nuestras sierras estaban constituidos por los montes municipales y dehesas concejiles, pero sobre todo por los amplios espacios comunales y las ledanías, los cuales eran arrendados a estos ganaderos, teniendo así muchos de estos concejos una saneada y segura fuente de ingresos $^{302}$. A estos espacios debemos unir también, en algunos casos, el aprovechamiento que se hacía, como zona de pasto, de las tierras de labor una vez recogida la cosecha. Esta práctica era conocida como derrota de mieses, y resultaba bastante habitual en una zona eminentemente ganadera, como era ésta ${ }^{303}$.

Pero sin duda, el momento culminante lo constituía el esquileo, pues de aquí surgía el producto que servía de motor a esta economía ${ }^{304}$. En nuestra zona, y al contrario de lo que sucedía con los rebaños riberiegos, que solían efectuar esta labor durante el traslado hacia los agostaderos, el esquileo se realizaba una vez retornados al punto de origen. Así lo atestiguan, tanto los datos recogidos en el Catastro del Marqués de Ensenada a la pregunta número 18, como la presencia de lavaderos de lana en varios de estos pueblos, como es el caso de Barbadillo de Herreros, Neila ${ }^{305}$ y Salas de los

301 En el trayecto de regreso, por lo tanto, se solían emplear menos días, pues las ovejas ya habían parido, y los campos se encontraban sembrados, con lo cual el ganado tenía menos oportunidades para detenerse.

302 Los datos extraídos de las Respuestas Generales dadas por varios de estos pueblos al Catastro del Marqués de Ensenada nos aportan una gran luz sobre este tema, pues, por ejemplo, son muchos los pagos y zonas de las ledanías, que eran arrendadas anualmente para el pasto de las merinas trashumantes.

303 D. E. VASSBERG: Tierra y sociedad en Castilla... ob. cit.

304 A. GARCÍA SANZ: "El siglo XVIII: entre la prosperidad de la trashumancia y la crítica antemesteña de Ilustración. (1700 - 1808)”. En Mesta, trashumancia y vida pastoril: exposición organizada por la Sociedad V Centenario del Tratado de Tordesillas. Soria, Sede de la Fundación Duques de Soria. 19 de septiembre a 30 de noviembre de 1994. Madrid, I+P Investigación y Progreso.1994. (137 - 158).

305 C. CAMARERO BULLÓN: "La provincia de Burgos en el Siglo de las Luces". En Historia de Burgos III. Edad Moderna (1). Burgos, Caja de Ahorros Municipal de Burgos. 1991. (153 - 270). 
Infantes $^{306}$. De aquí, una vez lavada, la lana partía en carretas hacia Burgos, desde donde era conducida a los puertos del Cantábrico, y de allí a los Países Bajos.

La contratación de esta lana la realizaban los delegados de los comerciantes burgaleses en la zona, conocidos como hombres de Sierra ${ }^{307}$, los cuales efectuaban los contratos de compra, en algunos casos, antes de que partieran los rebaños hacia Extremadura. Este sistema de contratación, denominado “señalo”, se producía, sobre todo, en el caso de los propietarios más modestos, pues éstos necesitaban el dinero de forma inmediata para así poder arrendar los pastos donde iban a pasar el invierno. Los grandes ganaderos, sin embargo, tenían la posibilidad de especular con el precio de la lana, retrasando su venta hasta el mismo momento del esquileo, lo que permitía alcanzar unas ganancias mucho más altas ${ }^{308}$. No obstante, el precio de la lana también estaba sujeto a otro tipo de variantes, como el nivel de los salarios que había que pagar a los pastores, el precio de los pastos, y sobre todo la demanda de la industria textil ${ }^{309}$.

\section{Ganadería estante.}

Constituye el otro tipo de ganadería que se daba en estos pueblos durante la Edad Moderna, la cual cumplía una importante función de complemento de la actividad agrícola. Así, a través de su explotación, no sólo se obtenía carne para el consumo doméstico, sino también leche, lana, pieles y abono para los campos.

Dentro de esta ganadería destaca especialmente la ovina, compuesta en su mayoría por ovejas de raza churra, de lana mucho más larga y basta que la merina. Aun así, también encontramos aquí un número importante de merinas que no trashumaban, conocidas como “quedadas”.

\footnotetext{
306 E. LAGUNA SANZ: Historia del merino. Ob. cit. (pp. 148).

307 A. GUTIÉRREZ ALONSO: "Burgos en el siglo XVI”. En Historia de Burgos. III Edad Moderna (1). Burgos, Caja de Ahorros Municipal de Burgos. 1991. (pp. 21 - 92).

308 R. CARANDE: Carlos V y sus banqueros. Ob. cit.

309 A. GARCÍA SANZ: “El siglo XVIII: entre la prosperidad de la trashumancia ...” ob. cit.
} 
Este tipo de ganado estante no se desplaza a grandes distancias para buscar su alimento, quedándose, por lo tanto, dentro de los propios términos municipales de estas localidades, o en los parajes comunales, que les correspondían. De igual modo, su desarrollo no está sujeto a una concentración geográfica tan fuerte, como sucedía con la ganadería trashumante, encontrándonos por ello rebaños de ovejas estantes en la práctica totalidad de los pueblos de nuestra comarca de estudio.

El aprovechamiento de este tipo de ganado se centra, tanto en la obtención de lana basta, orientada principalmente al abastecimiento de la demanda de los talleres textiles que existían en algunos pueblos de la zona, como en la producción de alimentos, es decir, carne y leche, destinados para el autoconsumo de sus propietarios.

Su explotación se realizaba en todos los casos en pequeños rebaños, que rara vez superan las 40 cabezas, lo que nos lleva a hablar de un claro minifundismo pecuario, destinado al autoabastacimiento familiar. No obstante, y a pesar de ello, desde 1556 todos estos ganaderos quedaron incluidos también dentro del Honrado Concejo de la Mesta, independientemente del hecho de que ellos no trashumaran en ningún momento. No cabe duda, de que esto desvirtuaba considerablemente la imagen, que podemos tener del panorama que vivía la ganadería en los pueblos de nuestra zona, pues mientras el número de trashumantes era ciertamente limitado, el volumen de hermanos de la Mesta llegó a ser muy elevado.

Un papel no menos importante, en la ganadería estante, lo juega el ganado vacuno, dentro del cual debemos diferenciar entre el destinado a la labranza y el dedicado a la carretería. Aquí nos centraremos únicamente en el primero de los casos, es decir, el de los bueyes que servían de fuerza motora en las diferentes prácticas agrícolas, los cuales constituían un grupo bastante numeroso, pues prácticamente todos los labradores, tanto pequeños como grandes, poseían al menos una yunta. El cuidado y pastoreo de estos bueyes se realizaba, por lo general, de modo comunal, agrupando a todos los de un mismo pueblo en una sola manada o "vacada”, que pastaba en la dehesa 
boyal del concejo. La vigilancia de estos grupos recaía en un pastor - también conocido como boyero o vaquero - contratado para tal fin por los vecinos del pueblo ${ }^{310}$. En algunos casos, sin embargo, esta labor era realizada por los mismos propietarios, que se repartían los diferentes turnos o “adredos”311.

Complementando estos ganados se encuentran las mulas, las cuales en nuestra comarca nunca consiguieron desplazar a los bueyes como animal de tiro en las tareas agrícolas. Aun así, su presencia en algunos pueblos fue realmente importante, pues se constituyeron en la pieza principal del transporte a pequeña escala, que realizaban los arrieros.

Por último, debemos citar, aunque con una relevancia algo menor dentro de la economía local, la presencia de yeguas y cerdos. En el caso de las yeguas se trata de un animal, que rara vez faltaba en las propiedades de los medianos y grandes agricultores. Los cerdos, por su parte, también constituyen un elemento importante, pues, aunque su explotación nunca alcanzó los niveles del resto de los ganados, que acabamos de citar, rara vez faltaban en los hogares serranos, ya que los productos que de él se extraían suponían una interesante fuente de alimentos para los largos meses de invierno. El cuidado de los cerdos se realizaba de modo individual por cada vecino, si bien, en algunos pueblos, como era el caso de Neila, esta labor se efectuaba de forma conjunta, uniendo todos los cerdos del pueblo en una sola manada, que se ponía bajo el cuidado del denominado “pastor de cerdas”,312.

310 Este era el caso, por ejemplo, de Neila. ADPBU. CE. 1.184. RESPUESTAS GENERALES. Neila, 12 - julio - 1753.

311 A. LÓPEZ GÓMEZ: "Valdelaguna: colectivismo agrario en las montañas burgalesas”. En Estudios Geográficos, Madrid, no. 57, (1957). (pp. 551 - 567)

312 ADPBU. CE. 1.184. RESPUESTAS GENERALES. Neila, 12 - julio - 1753. 


\section{CARRETERÍA Y EXPLOTACIÓN FORESTAL.}

Junto con la ganadería lanar trashumante, la carretería era la otra gran actividad desarrollada en la zona, hasta el punto de convertirse en una de las principales señas de identidad de muchos de los pueblos de la comarca. Aquí, al igual que sucedía con los núcleos volcados en la trashumancia, nos encontramos con una auténtica concentración geográfica, pues son también un determinado grupo de pueblos, los que desarrollan esta especialización. Entre ellos aparecen Castrillo de la Reina, Canicosa de la Sierra, Palacios de la Sierra, Quintanar de la Sierra, Regumiel de la Sierra, Vilviestre del Pinar y posiblemente también gran parte de la población de Salas de los Infantes, Moncalvillo y Hacinas.

Su desarrollo está ligado principalmente a las características de un medio físico, dominado por el predominio del monte, el cual favorecía muy poco la práctica de la agricultura. De este modo, y dadas estas condiciones, es el aprovechamiento de estas superficies agrestes y de los recursos en ellas escondidos, el elemento que propicie el desarrollo de un tipo de economía, donde se interrelacionan diferentes actividades, como la ganadería, la explotación forestal, la artesanía de la madera, y por supuesto, la carretería. Todo ello combinado con una ausencia prácticamente total de la agricultura.

El funcionamiento de esta economía se producía de la siguiente manera. Las dehesas y los amplios pastos existentes en muchos de estos pueblos permitían el mantenimiento de una amplia cabaña de ganado vacuno, utilizado especialmente como fuerza motora de las carretas. Se trataba, principalmente, de reses de raza serrana, caracterizada por sus especiales aptitudes para resistir las condiciones climáticas más duras, pero sobre todo por su robustez y fácil manejo ${ }^{313}$. Los montes, por su parte, proporcionaban, no sólo la materia prima para la construcción de resistentes carretas con las que poder emprender largos viajes, sino también madera suficiente para

313 P. GIL ABAD: Junta y Hermandad de la Cabaña Real de Carreteros Burgos - Soria. Burgos, Aldecoa. 1983. 
desarrollar una importante economía exportadora, tanto a comarcas vecinas, como a otras mucho más alejadas. Esta madera su utilizaba principalmente en la construcción. Por último, la proximidad de los lugares en los que se realizaba el esquileo de la lana merina y de los lavaderos de la zona de Valdelaguna y su entorno, donde ésta recibía el primer tratamiento, proporcionaban, junto con la madera y otros productos, un importante volumen de materias para ser transportadas.

De esta forma, vemos cómo se consiguen optimizar unos recursos, en teoría muy limitados, pero que merced a este sistema de explotación se terminan convirtiendo en la base de una economía muy próspera, y en gran medida blindada, frente a los vaivenes que presiden la vida del mundo del Antiguo Régimen.

El desarrollo de la carretería supone, al igual que ocurría con la ganadería trashumante, no tanto una actividad complementaria de la agricultura, como una auténtica alternativa. Así, vemos como en los pueblos donde domina este tipo de economía, la población dedicada a la agricultura prácticamente no existe o es ciertamente escasa. Otro dato revelador es el volumen de suelo destinado al cultivo, que en algunos casos apenas llegaba a un $5 \%{ }^{314}$.

No parece que existan datos concretos, que nos permitan precisar el origen de esta actividad en la zona, sin embargo, todo apunta a que a lo largo del siglo XV ya se efectuaban transportes de determinadas materias, como lana y madera, a diferentes puntos de la provincia y fuera de ella ${ }^{315}$. De esta forma, en estos pueblos la actividad del transporte tenía ya un profundo arraigo, cuando en el año 1497 los Reyes Católicos deciden crear la Cabaña Real de Carreteros, Trajineros Cabañiles y sus derramas, con el fin de proteger y asegurar así la buena salud de los intercambios comerciales. Por ello, con la creación de esta institución, según Pedro Gil Abad, simplemente se estaba

\footnotetext{
314 E. PÉREZ ROMERO: Patrimonios comunales, ganadería trashumante...ob. cit. Información corroborada con los datos extraídos del Catastros del Marqués de Ensenada. Respuestas Generales. 315 P. GIL ABAD: Junta y Hermandad de la Cabaña Real ... ob. cit. (pp. 85).
} 
dando carácter estable y formal a una serie de privilegios concedidos con anterioridad a esta fecha, pero que no siempre eran respetados ${ }^{316}$.

Dentro de esta Cabaña Real de Carreteros se incluía a su vez la llamada Junta y Hermandad de la Cabaña Real de Carreteros Burgos-Soria, cuya existencia, aunque no está probada documentalmente, parece que fue anterior a esta fecha de 1497. En ella se encuadran seis pueblos de la actual provincia de Burgos (Palacios de la Sierra, Vilviestre del Pinar, Quintanar de la Sierra, Canicosa de la Sierra, Regumiel de la Sierra y Hontoria del Pinar con sus aldeas, Navas del Pinar y Aldea del Pinar), y cuatro de la de Soria (Duruelo de la Sierra, Covaleda de la Sierra, Molinos de Salduero y San Leonardo, con sus cuatro aldeas: Arganza, Navaleno, Casarejos y Vadillos.). A estas localidades tenemos que sumar también diferentes derramas, como la que aglutinaba a las localidades de Cabrejas del Pinar, Abejar, Herreros y Villamiel, o la poco conocida Derrama de Abajo, donde se incluía Castrillo de la Reina, y posiblemente también Salas de los Infantes y Hacinas.

La organización jurídico-administrativa de esta Junta y Hermandad quedaba constituida por un concejo, en el que estaban presentes el Alcalde Mayor de Cabaña, los Diputados o Comisarios, que actuaban como delegados de cada uno de estos pueblos, y un escribano. Los asuntos de interés se trataban en una junta, que se reunía una vez al año, bajo convocatoria del propio Alcalde Mayor de Cabaña, trasmitiendo posteriormente cada Diputado las decisiones tomadas a sus respectivos concejos ${ }^{317}$.

En el desarrollo de esta actividad existían diferentes tipos de carretas, que se correspondían con distintas modalidades de transporte. Así, según nos explican las respuestas dadas por algunos de estos pueblos al Catastro del Marqués de Ensenada sabemos que: ...suponían haver dos expecies de carretas conocidas las unas con el nombre de carretas de puerto a puerto por el tráfico que con ellas hacen sus amos, y

\footnotetext{
316 Ibídem. (pp. 41 - 47),

317 Ibídem. (pp. 89 - 114).
} 
otras con el de carretas ordinarias, que se ocupaban de lo común en hacer uno o dos viajes conduciendo madera en el verano a Burgos, Logroño y otras partes ${ }^{318}$. Las carretas ordinarias, por lo tanto, transportaban esencialmente madera desde los bosques de pinos de estos pueblos a ciudades próximas, mientras que las de puerto a puerto tenían un radio mucho más amplio y una mayor variedad de mercancías.

A estos dos tipos de transporte tenemos que unir también el tráfico de los arrieros, los cuales se concentraban principalmente en localidades como Castrillo de la Reina, Canicosa de la Sierra y Quintanar de la Sierra. Entendemos, en este caso, por arrieros a las personas dedicadas al transporte de pequeñas cantidades de mercancías entre distancias relativamente cortas, valiéndose para ello de simples mulas provistas de alforjas. Su radio de acción abarcaba las diferentes comarcas vecinas (principalmente la Ribera del Duero y la vega baja del Arlanza), de donde se traían productos de los que estos pueblos serranos eran deficitarios, como cereales y vino. A cambio se exportaban productos propios de la zona originaria de estos arrieros, como lana basta, carbón

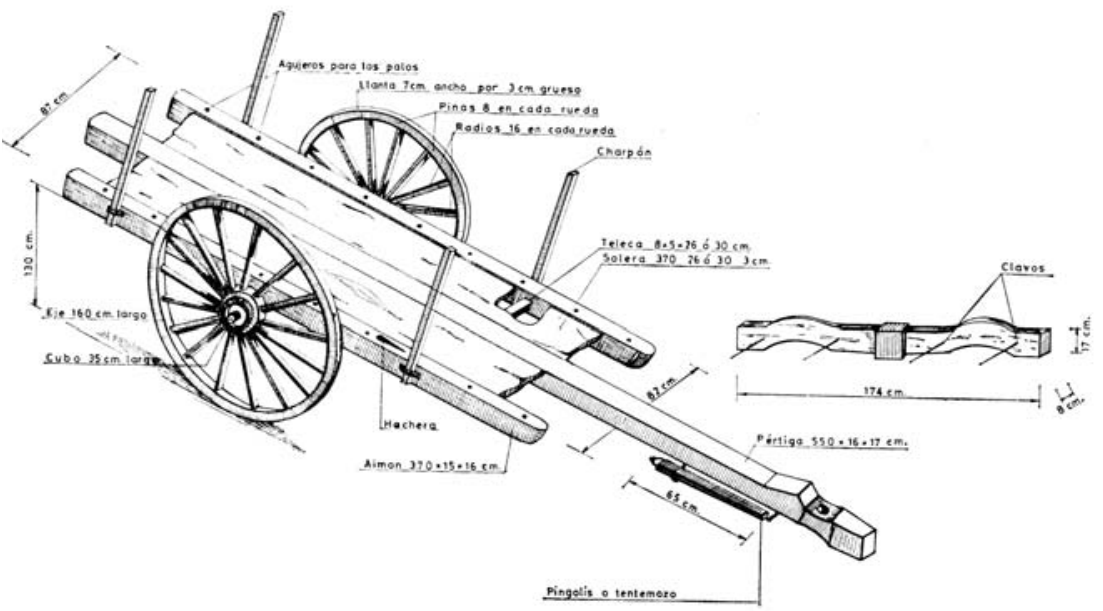

Modelo habitual de carreta empleado en el transporte de puerto a puerto. (Según P. Gil Abad).

318 ADPBU. CE. 1.278. RESPUESTAS GENERALES. Palacios de la Sierra, 21 - mayo - 1753. 
vegetal, y sobre todo objetos de madera elaborados por artesanos locales.

Dentro de estas distintas modalidades de practicar la actividad del transporte, sin duda, la más destacada en nuestra zona, tanto por el volumen de mercancías desplazadas, como por el porcentaje de población que se dedicaba a ello, era la conocida como de puerto a puerto. De hecho, y a falta de un estudio pormenorizado sobre el tema, podemos ver, que en localidades como Canicosa de la Sierra o Palacios de la Sierra más del 75\% de las carretas contabilizadas en los memoriales del Catastro del Marqués de Ensenada se dedicaban a esta carretería.. En el caso de Quintanar, por su parte, todos los carreteros registrados en este catastro declaran participar en la modalidad de puerto a puerto.

El modelo de carreta, que participaba ella, se caracterizaba por su forma alargada y estrecha. Sus elementos principales eran, el bastidor, constituido por una larga y gruesa madera central, llamada pértiga (donde se enganchaba la yunta de bueyes), y dos laterales más cortas, llamadas aimones. Contaba, al mismo tiempo, con un solo eje central, donde se engarzaban dos ruedas despiezadas en cambones, aunque las más habituales fueron las de radios. Este tipo apenas sufre variaciones a lo largo de toda la Edad Moderna, manteniéndose su construcción con estas mismas características durante todo el siglo XIX y gran parte del siglo XX.

El otro elemento fundamental, dentro del mundo de la carretería, lo constituyen los bueyes. En nuestra zona se utiliza exclusivamente el buey de raza serrana, animal que destacaba, tanto por su asombrosa resistencia al clima y al trabajo duro, como por su fuerza y fácil manejo. Dentro de ellos se establecían distintas categorías según su edad, con lo que podemos hablar de:

- Becerros: de 1 a 2 años.

- Añejos: de 2 a 3 años.

- $\quad$ Novillos: de 3 a 5 años.

- $\quad$ Bueyes: de 5 años den adelante. 
Los encargados de tirar de las carretas son los bueyes, que unidos en parejas forman una yunta. A cada yunta, a su vez, le acompaña un novillo (el cual habría sido previamente capado para facilitar su adiestramiento), con la intención de que se fuera amansando y familiarizando con este tipo de trabajo. La vida útil de los bueyes solía oscilar entre los 10 y 15 años, constituyéndose durante ese tiempo en la pieza más cuidada y valorada de la cuadrilla. Cada uno de ellos, además, tenía su nombre, el cual era elegido de acuerdo con determinados rasgos físicos del animal, o particularidades de su carácter.

Su número, como es lógico, llegó a ser elevadísimo, y aunque no disponemos de recuentos anuales, que nos permitan conocer su evolución a lo largo del tiempo, sabemos, por ejemplo, que entre 1664-69 en Vilviestre del Pinar había unos 1.124 bueyes, y en Quintanar en 1667 un total de 1.242. Estos números se consiguieron mantener, en gran medida, durante el siglo XVIII, pues según las respuestas dadas al Catastro de Ensenada, Palacios de la Sierra contaba en 1753 con 1.089 bueyes, Vilviestre del Pinar con 1.176, Quintanar de la Sierra con 1.122, y Canicosa de la Sierra con 1.077 .

El desarrollo de esta actividad se producía entre los meses de abril a noviembre, realizando a partir de aquí el llamado descanso invernal, pues las malas condiciones de los caminos, provocadas por las inclemencias climáticas, y la necesidad de dar descanso a los animales, obligaban a efectuar esta parada. Durante estos meses de invierno los bueyes pastaban libremente por las dehesas boyales, montes municipales y terrenos comunales. De este modo se producía una perfecta coordinación, en cuanto al aprovechamiento de estos pastos, entre los ganados vacunos de la carretería y las ovejas merinas de la trashumancia, pues en ambos casos el espacio de pasto solía ser el mismo. Así, mientras las merinas trashumantes invernaban en Extremadura, los bueyes carreteros aprovechaban, entre los meses de noviembre y abril, los pastos de las sierras. Por el contrario, durante los meses de junio a septiembre, las ovejas merinas ocupaban 
estas sierras, mientras que los bueyes se encontraban recorriendo los caminos tirando de sus carretas. Con ello, además, se conseguía dejar los pastos libres durante dos meses en primavera y otros dos en otoño, con el fin de que pudieran autogenerarse.

No obstante, y a pesar de esta coordinación, la convivencia entre carreteros y trashumantes no siempre fue cordial. Así, dos de las localidades más representativas de una y otra actividad, como eran Neila y Quintanar de la Sierra, protagonizaron diferentes pleitos a lo largo del siglo XVII por los abusos cometidos en el aprovechamiento de estos pastos.

El cuidado de los bueyes durante el período de descanso corría a cargo de boyeros especializados en esta materia, dentro de los cuales existían diferentes categorías, en función de la labor desempeñada.

A partir de abril se ponía en marcha la Cabaña de Carreteros, permaneciendo en ruta durante unos ocho meses, a lo largo de los cuales efectuaban entre 5 y 7 viajes. En cada una de las etapas de estos viajes se solían recorrer entre 30 y 40 kilómetros, si bien esta distancia podía variar, en función de la calidad de los caminos, la orografía del terreno por el que se pasaba, y el tipo de carga transportada.

Durante estos viajes las carretas se organizaban en grupos de unas 25 ó 30 unidades, denominadas cuadrillas, en las cuales participaban diferentes operarios, clasificados en categorías, ordenadas jerárquicamente. Cada una de ellas desempeñaba unas funciones concretas, con un diferente grado de responsabilidad, obteniendo por ello un sueldo determinado, que quedaba fijado en cada pueblo. Estas categorías eran las siguientes:

- Mayoral:

Era la categoría más elevada, ocupada habitualmente por el propietario de las carretas o el administrador que éste hubiera designado. En el caso de cuadrillas formadas por diferentes propietarios, este cargo lo ejercería el propietario del 
mayor número de carretas. Evidentemente el mayoral era el máximo responsable de la cuadrilla, y por ello mismo su sueldo llegaba hasta los 600 reales por temporada, al margen de lo que pudiera percibir por su manutención.

- Aperador:

A parte de conducir carretas se encargaba de revisar su buen estado, reparando las posibles averías. Su labor era extraordinariamente importante dentro de la cuadrilla, y por ello su sueldo se elevaba hasta los 550 reales.

- $\quad$ Ayudante de aperador:

Como su propio nombre indica, era el encargado de auxiliar al aperador en la reparación de las carretas. Su sueldo quedaba ligeramente por debajo del percibido por el aperador, situándose en torno a los 500 reales.

- Pastero:

Era el carretero del cual dependía el cuidado y vigilancia de los bueyes tras el desenganche, al final de cada jornada. Se encargaba, por lo tanto, de poner los bueyes a pastar, echarles pienso, llevarles a abrevadero, etc. Su sueldo alcanzaba los 450 reales.

- $\quad$ Ayudante de pastero:

Al igual que el aperador tenía un ayudante, el pastero también contaba con el suyo, el cual percibía por ello unos 400 reales anuales.

- Gañán:

Era el último puesto, dentro de esta jerarquía, el cual solía ser ocupado por un joven aprendiz de carretero, de edad comprendida entre los 17 y los 20 años. Su trabajo consistía en ayudar a los demás carreteros, realizando aquellas labores especialmente duras o desagradables. Su posición de inferioridad con respecto a ellos ha llevado a que en la actualidad esta palabra haya permanecido en el habla popular de la zona como un término de claras connotaciones peyorativas ${ }^{319}$. Aun así, su sueldo alcanzaba los 400 reales.

319 El término gañán es utilizado, entre otras acepciones, para referirse a un joven vago, torpe o poco habilidoso en el desarrollo de ciertas actividades. 
Como decíamos anteriormente, el número de carretas que componía una cuadrilla solía ser de unas 25 ó 30, sin embargo, rara vez pertenecían a un solo propietario. En la carretería, al igual que en el mundo de la trashumancia, la propiedad se encontraba bastante repartida, existiendo, desde los grandes propietarios, capaces de organizar ellos solos una cuadrilla, hasta los más modestos, que sólo poseían una o dos carretas. En el caso de las carretas de puerto a puerto de Canicosa de la Sierra, por ejemplo, los datos extraídos del Catastro del Marqués de Ensenada arrojan la siguiente distribución ${ }^{320}$ :

Número de propietarios. $\quad$ Número de carretas.

- Pequeños propietarios:

(de 1 a 4 carretas)

- Pequeños y medianos propietarios:

(de 5 a 9 carretas)

- Medianos y grandes propietarios: (de 10 a 20 carretas)

- Grandes propietarios:

(más de 20 carretas)
25 carreteros $^{321}$.

$60 \%$

6 carreteros.

$15 \%$

8 propietarios.

$20 \%$

2 propietarios $^{322}$.

$5 \%$
56 carretas.

$20 \%$

39 carretas.

$14 \%$

97 carretas.

$35 \%$

85 carretas.

$31 \%$

Dentro de esta distribución de la propiedad carreteril, son estos dos últimos grupos los que presentan un mayor interés para nuestro estudio, pues entre ellos encontraremos a los promotores de los más brillantes ejemplos de una de las tipologías

\footnotetext{
320 ADPBU. CE. 396. RESPUESTAS GENERALES. Canicosa de la Sierra, 12 - julio - 1753. En el caso de Quintanar de la Sierra, por ejemplo, los porcentajes son muy similares.

321 Ibídem. Muchos de estos pequeños carreteros trabajan al mismo tiempo como mayorales o aparadores de otros propietarios mayores, incluyendo sus carretas en las cuadrillas de sus amos.

322 Ibídem. Estos propietarios eran Andrés Cuesta con 35 carretas, y Nicolás Mateo con 50 carretas respectivamente.
} 


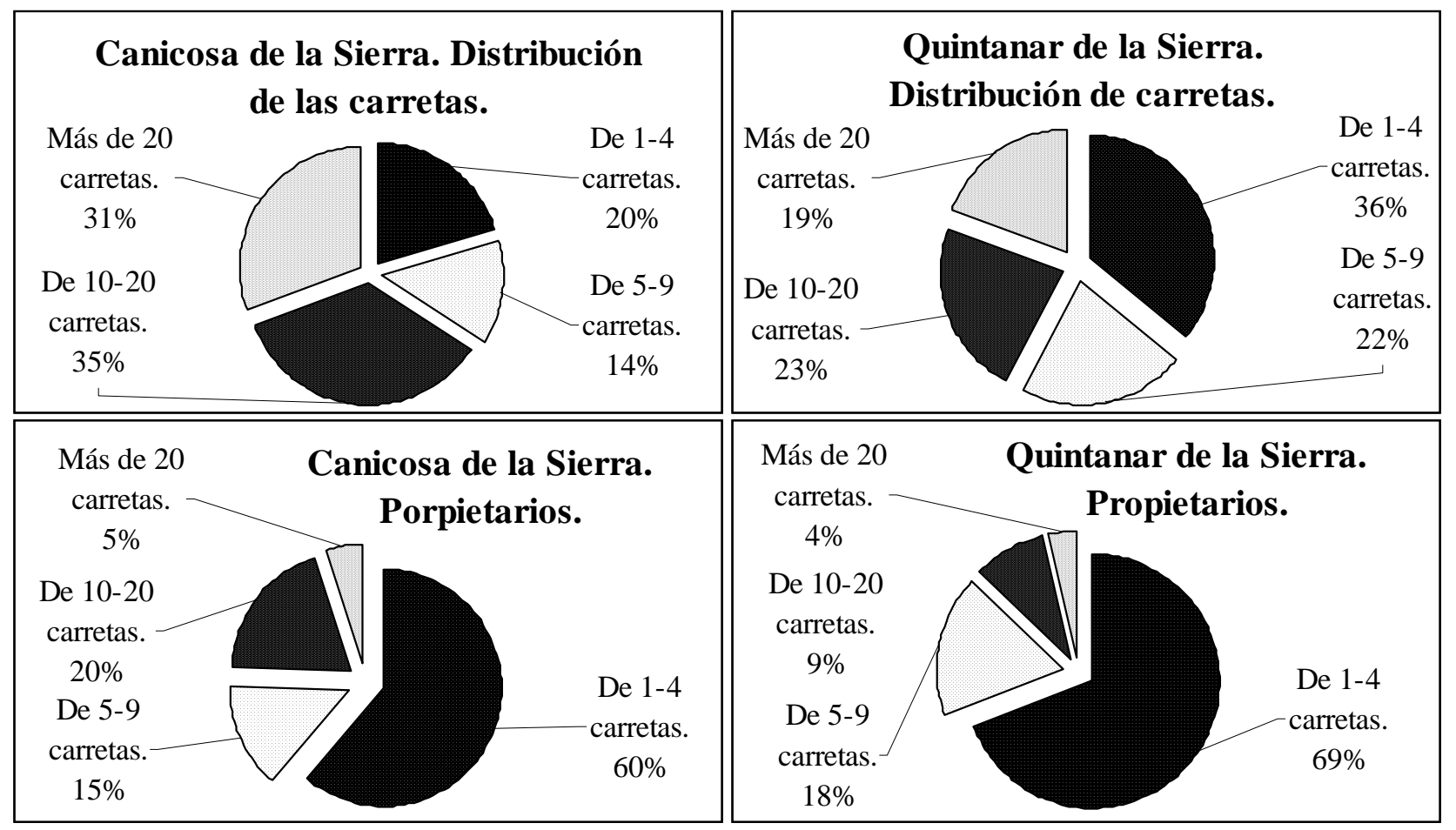

de la arquitectura civil más características de la zona. Nos estamos refiriendo a la casa carretera, en cualquiera de sus variedades.

En lo que se refiere a las mercancías transportadas, las cargas más habituales eran: madera, lana, trigo, sal, carbón vegetal, etc. Dentro de estas mercancías destaca especialmente la madera de pino, obtenida de los abundantes pinares de "pino negral", que existen en la zona, pues la demanda de este producto para uso constructivo, tanto en la provincia de Burgos como fuera de ella, se encuentra perfectamente documentada desde el siglo $\mathrm{XV}^{323}$. En el caso de la carretería ordinaria, este material, como hemos apuntado anteriormente, se convierte prácticamente en el único tipo de mercancía que transportan, sin embargo, en la carretería de puerto a puerto las mercancías resultan mucho más variadas. Aun así, en este segundo caso, la madera serrana también se convierte en una importante mercancía a tener en cuenta, especialmente en las rutas que

323 R. J. PAYO HERNANZ: El retablo en Burgos y su comarca durante los siglos XVII y XVIII. Tomo I. Burgos, Excma. Diputación Provincial de Burgos. 1997. (pp. 191 - 193). 
conducían, en un primer momento, a los puertos del Cantábrico, y posteriormente, en los siglos XVII y XVIII a Madrid.

OTRAS ACTIVIDADES.

Otras ocupaciones de menor peso específico dentro de este mapa económico, pero con una gran significación en todos los casos, son las que tienen que ver con las actividades artesanales y el aprovechamiento de determinados recursos naturales.

En el caso de la artesanía destacan principalmente las desarrolladas en la rama del textil y en la fabricación de determinados útiles de madera, concentrándose, en ambos casos, en puntos muy concretos de nuestra geografía. No obstante, se trata, en todos los casos, de una actividad muy reducida y de carácter claramente autárquico, es decir, destinada a satisfacer una demanda local, o intercomarcal, en el mejor de los $\operatorname{casos}^{324}$.

El desarrollo de la artesanía textil se concentra, de forma casi exclusiva, en la localidad de Barbadillo del Pez, si bien no disponemos de muchos datos, a parte de los aportados por el propio Catastro del Marqués de Ensenada, que nos informen sobre las características que presentaban estos trabajos. A través de esta fuente sabemos que a mediados del siglo XVIII prácticamente la totalidad de la población de este pueblo compaginaba el trabajo en el campo, como labradores y ganaderos, con el oficio de tejedor. Dentro de ellos nos encontramos con un nutrido número de tejedores de lana basta, sin embargo, el grupo más numeroso era el constituido por los fabricantes de sayales, pues representaban más del 75\% de los artesanos dedicados a esta $\operatorname{actividad}^{325}$.

324 J. A. BONACHÍA HERNANDO: "El desarrollo de una artesanía local (siglos XIV - XV)". En Historia de Burgos, desde sus orígenes hasta nuestros días. Tomo 2. Desde el año 1000 a los Tiempos Modernos. Burgos, Diario 16 Burgos. 1993. (pp. 459 - 470).

325 ADPBU. CE. 210. Respuestas Generales. Barbadillo del Pez a 6 de abril de 1753. 
A parte de esto, la presencia de varios batanes, tanto dentro de este pueblo, como en localidades próximas, nos informan sobre el arraigo, que había alcanzado esta artesanía.

Sus productos más característicos fueron el sayal y el manto de gran espesura, que utilizaban los pastores en la trashumancia. En este sentido, hemos encontrado diferentes testimonios en los que se habla de la especial fama que habían adquirido estos mantos, dentro del gremio de los pastores que practicaban la trashumancia, pues a pesar de su tosquedad, constituía una prenda muy práctica y resistente ${ }^{326}$.

Más dudas tenemos en lo que se refiere al origen e implantación de esta actividad en la zona, la cual encontramos documentada ya en la segunda mitad del siglo $\mathrm{XVI}^{327}$. Aun así, el auténtico despegue pensamos que se produce en el siglo XVII, encuadrándose dentro del proceso de ruralización, al que se vio abocada la industria de paños castellana. A esta situación se habría llegado tras la ruina del sector textil en algunos de sus puntos más representativos, como podía ser la zona de Segovia, agobiada por el aumento de los impuestos, que obligaba a elevar considerablemente los precios hasta hacer sus productos poco competitivos. Más fuerte debió ser, sin embargo, el impacto de la competencia de los productos importados desde Europa, los cuales eran mucho más baratos y de una calidad infinitamente mayor ${ }^{328}$. Como consecuencia de todo ello surge una industria especializada en tejidos de peor calidad pero más resistentes, destinada a satisfacer una demanda menos exigente, como era la de la mayor parte de la población de condición humilde. Esta industria se asentaba en localidades ligeramente apartadas de los principales circuitos comerciales, pero próximas a zonas de producción lanera, como era el caso de Barbadillo del Pez con respecto al Valle de

\footnotetext{
326 L. VICENTE ELÍAS: “La Mesta y la cultura pastoril”. Ob. cit.

327 “Documentos de antaño”. (AHPBU. PN. 2784, s/f). BIFG, $n^{\circ}$ 135. (2º trimestre 1956). (pp. 113 114).

328 M. DIAGO HERNANDO: La industria y el comercio de productos textiles en Europa, siglos XI al XV. Madrid, Libros D.C. 1997. (pp. 70). A. GARCÍA SANZ: Desarrollo y crisis del Antiguo Régimen en Castilla ...ob. cit.
} 
Valdelaguna, asegurándose así el abastecimiento de materia prima ${ }^{329}$. A pesar de todo, el desarrollo de esta artesanía en esta localidad resulta algo efímero, pues no sobrevive a los cambios que propicia la llegada del siglo XIX. Aquí, a diferencia de otros núcleos relativamente próximos, en los que se vivió este mismo desarrollo de la artesanía textil, pero donde se consigue mantener, como es el caso de Pradoluengo ${ }^{330}$, no se llega a producir la concentración de capital necesario, que propicia el tránsito hacia la industrialización propiamente dicha de esta actividad.

Para conocer la práctica de la artesanía relacionada con la madera tendremos que trasladarnos a aquellos pueblos eminentemente pinariegos, dentro de los cuales destaca, de modo especial, Canicosa de la Sierra. A través de los datos aportados por el Catastro del Marqués de Ensenada y otras fuentes complementarias, sabemos que en esta localidad existía un alto porcentaje de familias, que pasaba varios meses al año realizando determinadas manufacturas en madera. Entre los objetos que se fabrican aquí, el auténtico producto estrella era la gamella, a la que seguían la composición de sillas y taburetes, así como una variada gama de útiles de cocina y de todo tipo, realizados en este mismo material.

El origen de esta actividad en la zona está relacionado evidentemente con la riqueza de materia prima, procedente de los amplios bosques de pino y roble, que existían en la zona. A ello tenemos que unir la disponibilidad de tiempo libre, que propiciaba el trabajo de la carretería durante los meses de invierno. Más dificultades encontramos, sin embargo, a la hora de intentar precisar el momento concreto en el que esta artesanía pudo ponerse en marcha, si bien, debemos pensar que, de alguna forma, estuvo presente en la vida de estos pobladores desde los primeros momentos de su presencia aquí.

329 R. OJEDA SAN MIGUEL: "Crecimiento y subsistencia de un centro textil rural burgalés (siglos XVI - XVII): Pradoluengo”. En Pasado Histórico de Castilla y León. Volumen II. Edad Moderna. Burgos, Junta de Castilla y León. 1993. (pp. 473 - 492).

330 J. J. MARTÍN GARCÍA: Trabajo rural - trabajo industrial: Belorado y Pradoluengo (1883 1936). Burgos, Aymto. de Belorado - Aymto. de Pradoluengo. 2000. 
Ligado a esta artesanía de la madera se encuentra el aprovechamiento forestal de estos mismos bosques. Como ya hemos indicado al hablar de la carretería y de la artesanía de la madera, la gran riqueza maderera que atesoraban estos bosques llevó a que este material se convirtiera, junto con la lana de las ovejas merinas, en uno de los dos grandes productos, que aportaba esta comarca al mercado castellano. Su utilización, fuera de la comarca como material de construcción se encuentra acreditado documentalmente desde época bajomedieval, extendiéndose su demanda durante la Edad Moderna a puntos tan significativos, como la capital del reino ${ }^{331}$ o los astilleros del Cantábrico. A ello había que unir también la gran calidad que acreditó siempre a este material, lo cual nos lleva a hablar, en cierto modo, de una auténtica denominación de origen, pues son muchos los contratos de obras de todo tipo en los que se especifica textualmente, que la madera empleada en su fabricación debía proceder de Quintanar de la Sierra o de Canicosa de la Sierra ${ }^{332}$.

$\mathrm{Al}$ abrigo de esta riqueza forestal surgen igualmente otro tipo de actividades más variadas, entre las que llama nuestra atención la elaboración de betunes y otros productos, que tuvo su momento álgido a finales del siglo XVIII, cuando Carlos III funda en Quintanar de la Sierra la Real Fábrica de Betunes ${ }^{333}$.

Por último, una actividad menos conocida, pero de una gran significación, es la relacionada con el aprovechamiento de los recursos minerales existentes en parte del

\footnotetext{
331 Dentro de la sección de Protocolos Notariales del AHPBU, pero sobre todo en el AHPSO, hemos encontrado abundantes contratos del siglo XVII, firmados entre maestros de cantería, que trabajaban en Madrid, y carreteros serranos para suministrar madera para sus construcciones. En muchos de estos contratos, además, intervienen como mediadores maestros carpinteros y arquitectos locales, pues sin duda éstos eran capaces de interpretar con mayor exactitud las instrucciones de los compradores, donde se precisaban las características que debían cumplir las maderas solicitadas.

332 R. J. PAYO HERNANZ: El retablo en Burgos y su comarca durante los siglos XVII y XVIII... ob. cit. Tomo I. (pp. 183 y ss.).

333 P. GIL ABAD: Quintanar de la Sierra, un pueblo burgalés de la comarca de Pinares. Burgos, Excma. Diputación Provincial de Burgos. 1986 (pp. 151).
} 
subsuelo serrano, entre los que desataca principalmente el hierro, pero también el cobre, plomo y carbón. Se trata, como decimos, de una actividad muy poco conocida, pues a la ausencia de una investigación pormenorizada del tema, tenemos que unir la falta de referencias en las fuentes clásicas de la economía de la etapa moderna, como puede ser el Catastro del Marqués de Ensenada ${ }^{334}$.

Pese a ello, sin embargo, consideramos que la explotación de estos recursos minerales queda convenientemente acreditada a través de determinados elementos, como puede ser la toponimia, que ha perdurado en algunos pueblos. Así, nos encontramos con pueblos como Barbadillo de Herreros ${ }^{335}$ o la localidad próxima, aunque actualmente desaparecida, de Villanueva de los Herreros ${ }^{336}$, donde su apellido nos habla de esta tradición ${ }^{337}$. Reforzando esta información contamos también con las evidencias aportadas por la arqueología, las cuales nos hablan de un aprovechamiento de estos minerales para épocas tan tempranas, como el período celtíbero, continuándose posteriormente durante la ocupación romana ${ }^{338}$. A estas referencias podemos sumar igualmente la información, que se deduce de algunos documentos medievales, los cuales nos hablan de la existencia de ciertos tributos, que algunos de estos pueblos debían pagar en especie, mediante hierro. Este es el caso del tributo de metal de hierro, conocido como Voto de San Millán, que varios pueblos de nuestra zona, entre los que se encuentra Barbadillo de Herreros, debían pagar al monasterio de San Millán de la Cogolla $^{339}$. Aun así, prácticamente nada es lo que podemos conocer con exactitud de esta actividad para el período que nos ocupa, lo cual, en ningún momento nos debe

334 M. GONZÁLEZ BUENO: Ferrerías de la Demanda burgalesa. Burgos, Excma. Diputación Provincial de Burgos. 1997. (pp. 33 - 37).

335 G. MARTÍNEZ DÍEZ: Pueblos y alfoces burgaleses de la repoblación. Valladolid, Junta de Castilla y León. Consejería de Educación y Cultura. 1997. (pp. 195 - 196.

336 Ibídem.

337 J. PÉREZ CARMONA: “La historia y la geografía burgalesas reflejadas en su toponímia”. En BIFG, Burgos, $n^{\circ} 163$, (1964). pp. $238-271$.

338 Museo Arqueológico-Paleontológico de Salas de los Infantes.

339 L. SERRANO: El obispado de Burgos y Castilla primitiva. Desde el siglo V al XIII. Vol. I. Madrid. 1935. (pp. 273 - 281). 
llevar a pensar que se hubiera dejado de practicar, pues el extraordinario florecimiento que conoció durante la segunda mitad del siglo XIX y principios del XX nos obligan a ser optimistas respecto a ello ${ }^{340}$.

340 M. GONZÁleZ BUENO: Ferrerías de la Demanda burgalesa. Ob. cit. J. L. REOYO: “Explotaciones mineras en la provincia de Burgos durante la centuria 1850 - 1950”. En BIFG, 1969. 


\section{POBLACIÓN.}


VOLUMEN DE POBLACIÓN.

Para conocer el volumen y evolución de la población la época moderna dispone de fuentes más abundantes, y en cierto modo precisas, que los periodos precedentes. Sin embargo, no siempre las fuentes existentes consiguen informarnos con la rigurosidad que deseamos, pues nos encontramos aun en plena época preestadística, y por lo tanto, las consultas que en este momento se realizan no tendrán un interés demográfico, sino que surgen siguiendo otros impulsos, como son los fiscales y de reclutamiento de soldados.

Dentro de estas fuentes una de las más destacadas son los censos, que se efectuaron en distintos momentos de este periodo de la modernidad. Sin embargo, a pesar de la importante novedad que este tipo de registros constituye con respecto al periodo medieval, presentan también serios inconvenientes. Para empezar, hay que señalar que se trata de recuentos muy espaciados en el tiempo, pues entre uno y otro transcurren intervalos demasiado largos como para establecer estudios evolutivos a partir de sus datos. Por otro lado, se trata de recuentos realizados con una finalidad 
eminentemente fiscal o militar, lo cual, sin duda, propicia un elevado volumen de ocultación, difícil de cuantificar en cada caso, pero innegable en todos ellos ${ }^{341}$.

Estos recuentos relacionan además únicamente el número de vecinos y no de habitantes, lo que nos lleva a plantear el espinoso tema de los coeficientes, es decir, los habitantes a los que equivale cada uno de estos vecinos. En este sentido, vemos que a lo largo del tiempo se han establecido muy variadas propuestas, que van desde las más prudentes, que plantean niveles situados entre 3 ó 4 habitantes por cada vecino, hasta las más osadas, que elevan esta cantidad hasta unos niveles de 6 ó 7. La historiografía tradicional ha defendido habitualmente el coeficiente 5 como el más apropiado ${ }^{342}$, si bien últimamente se está generalizando la idea tendente, no sólo a rebajar ligeramente este coeficiente, sino también a flexibilizarlo, pues se ha observado que esta cantidad es susceptible de sufrir variaciones notables en función de la época, el lugar (ambiente rural - ambiente urbano) o de las condiciones políticas, económicas y sociales existentes $^{343}$.

Junto a estos censos, la otra gran fuente para el estudio de la demografía durante la Edad Moderna lo constituyen los Libros Parroquiales, con sus registros de bautismos, matrimonios y defunciones, que se generalizan en todas las parroquias a partir del Concilio de Trento ${ }^{344}$. Sin embargo, dentro de nuestra comarca, al igual que en la mayor parte del resto de la provincia de Burgos, estas fuentes han sido muy poco estudiadas. En el presente trabajo hemos eludido realizar este estudio, pues consideramos que

341 D. S. REHER, A. VALERO LOBO: Fuentes de información demográfica en España. Madrid, Centro de Investigaciones Sociológicas. 1995.

342 T. GONZÁLEZ: Censo de población de las provincias y partidos de la Corona de Castilla en el siglo XVI con varios apéndices para comprender la del resto de la península en el mismo siglo, y formar juicio comparativo con la del anterior y siguiente, según resulta de los libros y registros que se custodian en el Real Archivo de Simancas. Ed. Facsímil. Madrid, Imprenta Real. 1829. R. CARANDE: Carlos V y sus banqueros. Tomo I. Barcelona, Editorial Crítica. 1987.

343 A. GARCIA SANZ: Desarrollo y crisis del Antiguo Régimen en Castilla la Vieja. Madrid. Ed. Akal. 1977. A. DOMÍNGUEZ ORTIZ: Instituciones y sociedad en la España de los Austrias. Barcelona, Ediciones Ariel. 1985. 
excedía de forma notable los propósitos fijados en un principio para nuestra investigación. Aun así, para algunos casos concretos contamos con la información de este tipo, que ha sido extraída por diferentes investigadores, a lo largo de los trabajos realizados sobre determinados pueblos. Esto sucede con las localidades de Quintanar de la Sierra, que ha sido investigada por Pedro Gil Abad, y de Neila, que cuenta con un interesante estudio, realizado por María Begoña Ganzo Pérez y Luis Federico Ibeas Miguel, sobre la fecundidad durante el periodo, que se extiende, desde los años finales del siglo XVII hasta el final del siglo XVIII.

A partir de estas fuentes de información, vemos que los primeros datos fiables sobre el volumen de población de estos pueblos pertenecen ya al siglo XVI. Para el periodo anterior a esta centuria tendremos únicamente hipótesis, elaboradas, por lo general, a partir de la extrapolación de las estimaciones que se han hecho dentro de áreas mucho más amplias. Aun así, la imagen que podemos componer para esta comarca, durante la época medieval, no está exenta de contradicciones. Pues, frente a los postulados tradicionales, que nos hablan de una despoblación estratégica de toda la cuenca del Duero, que en principio abarcaría también a nuestra comarca, existen otras alternativas, que, basándose en la abundancia de restos arqueológicos, nos hablan de una zona, si no densamente poblada, sí al menos con un importante nivel de ocupación. Por todo ello, nos abstenemos de intentar dar cifras concretas, o cuanto menos aproximadas, para cualquiera de los momentos de la época medieval.

La única fuente que poseemos para el periodo inmediato a la Edad Moderna nos lo proporciona el Contador Mayor de los Reyes Católicos, Don Alonso de Quintanilla. No obstante, todas las referencias que hemos encontrado sobre este censo coinciden en afirmar su escasa fiabilidad, dado el alto volumen de población, que propone para todo el reino de Castilla ${ }^{345}$.

344 D. S. REHER, A. VALERO LOBO: Fuentes de información demográfica ... ob. cit. 
El panorama para el siglo XVI, en cuanto al estudio demográfico se refiere, es bien distinto, pues para este periodo contamos ya con la información proporcionada por los primeros censos realizados durante la Edad Moderna. Lógicamente la fiabilidad de cada uno de ellos resulta, en muchos casos, cuestionable, al desconocer, tanto la rigurosidad empleada, como el volumen de ocultación que pudo darse. A ello tenemos que unir el hecho de que no en todos los casos se ha conservado la información completa, concerniente a nuestra zona, con lo cual, existen algunos pueblos para los que no disponemos de datos.

Los censos a los que nos hemos remitido, son los de 1528-36 y el famoso de 1591, a los cuales hemos unido además el conocido como censo de los obispos de 1587-89.

El primero de ellos es el llamado censo de 1528-36, realizado para contar los pecheros o contribuyentes registrados en cada municipio del reino de Castilla, los cuales debían pagar el impuesto llamado “servicios ordinario y extraordinario”, establecido por Carlos $I^{346}$. Quedarían fuera, por lo tanto, los grupos eximidos de pagar este impuesto, como son los nobles y eclesiásticos. Territorialmente este censo pretendía englobar a todos los municipios del reino de Castilla, con lo cual toda nuestra zona quedaría incluida dentro de él. Aun así existen ciertas localidades de nuestro ámbito de estudio que no aparecen en la documentación conservada, como es el caso de Hacinas, Monterrubio de la Demanda y Riocavado de la Sierra. A ello tenemos que añadir también el hecho de que los ocho pueblos que componían en este momento el Valle de Valdelaguna, es decir, Barbadillo de Herreros, Bezares, Huerta de Abajo, Huerta de Arriba, Quintanilla de Urrilla, Tolbaños de Abajo, Tolbaños de Arriba y Vallejimeno, a los que se une Hoyuelos de la Sierra, contestaron de forma conjunta y no

\footnotetext{
345 E. GARCÍA ESPAÑA, A. MOLINIÉ - BERTRAND: Censo de Castilla de 1591. Madrid, Instituto Nacional de Estadística. 1986. (pp. 28).

346 D. S. REHER, A. VALERO LOBO: Fuentes de información demográfica ... ob. cit. E. GARCÍA ESPAÑA, A. MOLINIÉ - BERTRAND: Censo de Castilla de 1591. Ob. cit.
} 
individualmente, lo que nos impide conocer el número concreto de vecinos de cada uno de ellos. De esta forma, los resultados obtenidos tras esta consulta son los siguientes ${ }^{347}$ :

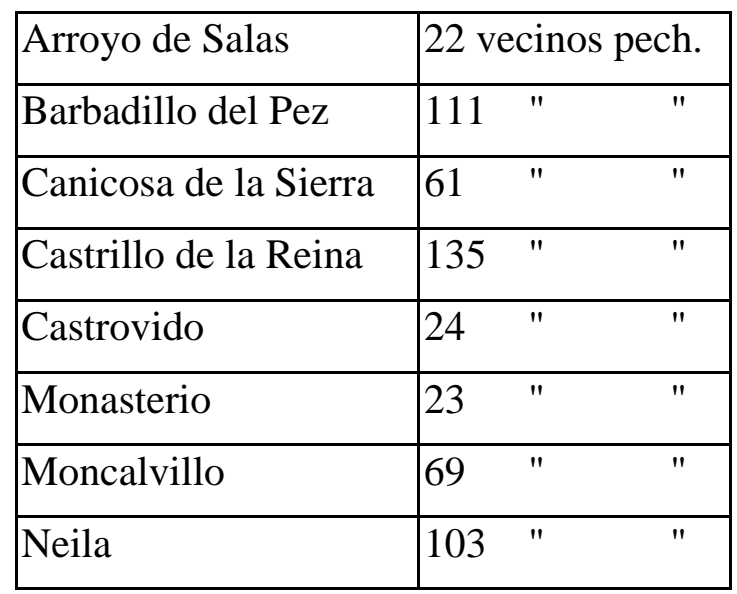

\begin{tabular}{|l|lll|}
\hline Palacios de la Sierra & 138 & " & " \\
\hline Quintanar de la Sierra & 79 & " & " \\
\hline Regumiel de la Sierra & 34 & " & " \\
\hline Salas de los Infantes & 136 & " & " \\
\hline Terrazas & 24 & " & " \\
\hline Valle de Valdelaguna & 251 & " & " \\
\hline Vilviestre del Pinar & 72 & " & \\
\hline
\end{tabular}

El carácter fiscal que tenía este censo nos obliga a pensar que el grado de ocultación, o tendencia natural al disimulo, debió ser alta, sin embargo, no contamos con ningún elemento que nos permita cuantificarlo.

El otro gran censo, realizado dentro de esta centuria, es el de 1591. Su importancia radica, en primer lugar, en la relación o superposición que se puede establecer con respecto al anterior, pues son los únicos del siglo XVI, que nos permiten efectuar un cierto estudio evolutivo de la demografía. Este censo es conocido habitualmente como el censo de Tomás González, pues fue este canónigo de la catedral de Plasencia y archivero de Simancas el primero en estudiarlo de forma detallada, publicando sus resultados en $1829^{348}$.

Al igual que el censo que acabamos de citar, éste también posee un carácter eminentemente fiscal, pues fue realizado con motivo del reparto entre la población del reino de Castilla del nuevo impuesto conocido como "servicio de millones", instaurado por Felipe II para permitir la recuperación de las arcas del Estado tras el desastre sufrido

\footnotetext{
347 AGS. Contaduría General. Legajo 768. (fols. $34-62$ vº).

348 D. S. REHER, A. VALERO LOBO: Fuentes de información demográfica ... ob. cit. (pp. 18).
} 
por la Gran Armada en la campaña de Inglaterra ${ }^{349}$. La particularidad que presenta este censo, con respecto a aquel de 1528-36, es que, mientras el anterior contaba únicamente el número de vecinos pecheros, en éste se incluyen "vecinos de todos los estados”,350, es decir, tanto pecheros como hidalgos y eclesiásticos. Esto nos permite, llegado el momento, conocer de forma mucho más detallada el tipo de organización social, que se daba dentro de cada uno de estos pueblos.

El territorio que se incluye en este censo es nuevamente el de la Corona de Castilla, excluyendo Granada, con lo que los pueblos de nuestra zona de estudio aparecen nuevamente representados. Aun así, también aquí tenemos algunas ausencias, como ocurre nuevamente con las localidades de Riocavado de la Sierra o Monterrubio de la Demanda. En el caso de la exclusión de esta última localidad, o la pérdida de su registro dentro del censo que estamos comentando, es posible que se deba a su pertenencia a la provincia fiscal de Soria, pues la rigurosidad y el detalle con el que estas pesquisas eran efectuadas en cada zona evidentemente no eran las mismas. Para el caso de Riocavado de la Sierra, sin embargo, no contamos con ninguna explicación razonable. Junto a esto, nos encontramos nuevamente con la circunstancia de que los ocho pueblos que componían el Valle de Valdelaguna, más Hoyuelos de la Sierra, son incluidos en un solo registro, lo que nos impide conocer el número de vecinos que existía en cada uno de ellos. Aun con todo, los resultados extraídos son los siguientes ${ }^{351}$ :

Total vecinos Pecheros Hidalgos Clérigos

\begin{tabular}{|l|r|r|r|r|}
\hline Arroyo de Salas & 18 & 17 & 1 \\
\hline Barbadillo del Pez & 99 & 96 & 1 & 2 \\
\hline Canicosa de la Sierra & 147 & 146 & & 1 \\
\hline Castrillo de la Reina & 136 & 133 & & 3 \\
\hline
\end{tabular}

349 E. GARCÍA ESPAÑA, A. MOLINIÉ - BERTRAND: Censo de Castilla de 1591. Ob. cit. (pp. 33 35).

350 T. GONZÁLEZ: Censo de población de las provincias y partidos de la Corona de Castilla en el siglo XVI... ob. cit.

351 Censo de Castilla de 1591. Vecindario. Madrid, Instituto Nacional de Estadística. 1984. 


\begin{tabular}{|l|r|r|r|r|}
\hline Castrovido & 21 & 20 & & 1 \\
\hline Hacinas & 80 & 79 & & 1 \\
\hline Monasterio & 29 & 28 & & 1 \\
\hline Moncalvillo & 74 & 72 & 1 & 1 \\
\hline Neila & 64 & 60 & 1 & 3 \\
\hline Palacios de la Sierra & 179 & 176 & 1 & 2 \\
\hline Quintanar de la Sierra & 159 & 157 & & 1 \\
\hline Regumiel de la Sierra & 58 & 57 & & 1 \\
\hline Salas de los Infantes & 143 & 130 & 10 & 1 \\
\hline Terrazas & 18 & 17 & & 2 \\
\hline Valle de Valdelaguna & 301 & 293 & 1 & \\
\hline Vilviestre del Pinar & 116 & 114 & & \\
\hline
\end{tabular}

Como en el caso anterior, la fiabilidad de este censo ha sido seriamente cuestionado por algunos autores para casos muy concretos. Así, según nos indican García España y Molinié-Bertrand, "se tiene la impresión de que existe una sobreestimación de la población, principalmente en las ciudades importantes, puesto que fue la administración central la que realizó el censo (tanto en 1528 como en 1591). Por el contrario, la indagación de 1591 es bastante más exacta y fiable para los pueblos ${ }^{352}$.

A los datos proporcionados por estos dos grandes censos para el siglo XVI, debemos unir también los resultados ofrecidos por otros recuentos, entre los que destaca por su fiabilidad el llamado Censo de los Obispos, realizado entre los años 1587-89. Se trata de una relación efectuada en aquellos años por los diferentes obispos, arzobispos y prelados en sus respectivas diócesis, contabilizando, en esta caso, la población en "vecinos feligreses”, es decir, cabezas de familia, agrupados en parroquias o pilas

352 E. GARCÍA ESPAÑA, A. MOLINIÉ - BERTRAND: Censo de Castilla de 1591. Ob. cit. (pp. 33 35). 
bautismales, pero sin hacer ningún tipo de distinción entre privilegiados y estado llano $^{353}$.

Este censo fue igualmente investigado y transcrito por Tomás González, el cual nos ofrece una serie completa de todos los pueblos incluidos en nuestra zona de estudio. En este caso, además, al agrupar a los vecinos por parroquias y no por municipios vemos cómo los pueblos que forman el Valle de Valdelaguna no aparecen unidos sino recogidos individualmente. Aun así, también aquí notamos ausencias significativas, como es el caso de Tolbaños de Abajo y Vilviestre del Pinar. El resultado es el siguiente $^{354}$ :

\begin{tabular}{|c|c|c|}
\hline & $\begin{array}{l}\text { Vecinos - } \\
\text { feligreses }\end{array}$ & $\begin{array}{c}\text { Pilas } \\
\text { bautismales. }\end{array}$ \\
\hline Arroyo de Salas & 16 & 1 \\
\hline Barbadillo de Herreros & 60 & 1 \\
\hline Barbadillo del Pez & 24 & 1 \\
\hline Bezares & 14 & 1 \\
\hline Canicosa de la Sierra & 126 & 1 \\
\hline Castrillo de la Reina & 144 & 1 \\
\hline Castrovido & 17 & 1 \\
\hline Hacinas & 77 & 1 \\
\hline Hoyuelos de la Sierra & 16 & 1 \\
\hline Huerta de Abajo & 30 & 1 \\
\hline Huerta de Arriba & 100 & 2 \\
\hline Monasterio & 20 & 1 \\
\hline Moncalvillo & 70 & 1 \\
\hline Monterrubio de la Demanda & 28 & 1 \\
\hline
\end{tabular}

353 D. S. REHER, A. VALERO LOBO: Fuentes de información demográfica ... ob. cit. (pp. 18). E. GARCÍA ESPAÑA, A. MOLINIÉ - BERTRAND: Censo de Castilla de 1591. Ob. cit. (pp. 33).

354 T. GONZÁLEZ: : Censo de población de las provincias y partidos de la Corona de Castilla en el siglo XVI... ob. cit. (pp. 220 - 222). 


\begin{tabular}{|l|c|c|}
\hline Neila & 130 & 2 \\
\hline Palacios de la Sierra & 182 & 1 \\
\hline Quintanar de la Sierra & 170 & 1 \\
\hline Quintanilla de Urrilla & 14 & 1 \\
\hline Regumiel de la Sierra & 52 & 1 \\
\hline Riocavado & 20 & 1 \\
\hline Salas de los Infantes & 140 & 2 \\
\hline Terrazas & 16 & 1 \\
\hline Tolbaños de Abajo & 22 & 1 \\
\hline Tolbaños de Arriba & 40 & \\
\hline Vallejimeno & & \\
\hline Vilviestre del Pinar & & \\
\hline
\end{tabular}

A partir de la comparación de estos datos, la conclusión que podemos extraer es que en general la población de nuestra comarca experimentó un ligero crecimiento, pues la mayor parte de los pueblos arrojan cifran más altas en el censo de 1591 que en el de 1528-36. No obstante, este crecimiento parece quedar lejos del vivido en otras zonas de la propia provincia de Burgos, y por su puesto de la capital, que sin duda encabeza este auge demográfico.

Aun así, debemos tener en cuenta diferentes cuestiones, como es el gran distanciamiento que existe en el tiempo entre estos dos recuentos, el cual nos impide establecer un esquema evolutivo lo suficientemente preciso, como para determinar los diferentes comportamientos vividos a lo largo de cada uno de los periodos que pudieron darse en esta centuria. Estos distintos periodos del siglo XVI, sin embargo, ha sido posible distinguirlos a través de los datos ofrecidos por otras fuentes alternativas, como los Libros Parroquiales. De este modo, se ha comprobado, que el momento en el que se realiza el último de estos censos, el de 1591, se estaba viviendo ya un periodo de 
200 Arquitectura de la Edad Moderna en la sierra burgalesa.

decadencia. El momento de máximo auge, por el contrario se habría producido entre los años 1560-70, iniciándose a partir de aquí un paulatino descenso ${ }^{355}$.

Frente a este generalizado crecimiento, que se experimenta durante el siglo XVI, la centuria del Seiscientos representa en general un periodo de tendencia negativa, continuando así la pauta, que se venía marcando desde el final del siglo anterior. No obstante, y a pesar de este clima dominado por la recesión demográfica, existen ciertos estudios que nos indican un comportamiento contrario en nuestra comarca ${ }^{356}$. Esto es lo que ocurre, por ejemplo, en localidades como $\mathrm{Neila}^{357}$, un núcleo eminentemente ganadero, dedicado a la trashumancia, o en Quintanar de la Sierra ${ }^{358}$, que constituye uno de los principales centro de la carretería. Esto, en algunos casos, podría manifestar una tendencia extensible al resto de los pueblos mesteños y carreteros de la zona de la sierra, si bien, la escasez de fuentes adecuadas nos impiden hacer afirmaciones más rotundas.

Para comprobar de estas apreciaciones únicamente contemos con los estudios, ya señalados, efectuados dentro de este periodo en las localidades de Neila y Quintanar de la Sierra, los cuales vienen a confirmarnos esta impresión de resistencia frente al clima de decadencia, que se aprecia en el resto de la provincia. En cuanto a los censos realizados en este momento, el panorama resulta infinitamente más pobre, que el existente en el periodo anterior, manifestándose así el reflejo del propio declinar, que la capacidad administrativa del aparato del Estado estaba mostrando en este siglo XVII ${ }^{359}$.

355 R. CARANDE: Carlos Vy sus banqueros. Tomo I. ob. cit. A. GUTIÉRREZ ALONSO: "L población burgalesa durante la Edad Moderna” En Historia de Burgos, desde sus orígenes hasta nuestros días. Tomo II. Desde el año 1000 a los Tiempos Modernos. Burgos, Diario 16 Burgos. 1993. (pp. 567 - 578).

356 A. GUTIÉRREZ ALONSO: "La población burgalesa durante la Edad Moderna... ob. cit.

357 M. B. GANZO PÉREZ, L. F. IBEAS MIGUEL: "La fecundidad en un área burgalesa. Neila (1690 1800)”. En El pasado histórico de Castilla y León. Actas del primer Congreso de historia de Castilla y León. Volumen II. Burgos. Junta de Castilla y León. 1983. (pp. 337 - 354).

358 P. GIL ABAD: Quintanar de la Sierra. Un pueblo de la comarca de pinares. Burgos, Excma. Diputación Provincial de Burgos. 1986. (pp. 219 - 241). 
Los únicos censos que nos atrevemos a mencionar aquí son los de 1631 y 1646, los cuales debemos manejar con las mayores reservas, pues su fiabilidad resulta, como poco, muy cuestionable, a juicio de la mayoría de los investigadores que han trabajado sobre el tema ${ }^{360}$.

El primero de ellos es el denominado vecindario de 1631, realizado con motivo del reparto del impuesto de la sal, por lo que es conocido también como el censo de la sal. ${ }^{361}$ Destaca de él, principalmente, su carácter incompleto, pues son numerosas las localidades de nuestra comarca que no aparecen recogidas. A ello debemos unir también el fuerte ocultamiento, que por lo general se le atribuye, pues de lo contrario debemos suponer, que en algunos de estos pueblos los descensos habrían sido catastróficos ${ }^{362}$. Esto es lo que presuntamente había acontecido en Castrillo de la Reina, que de 136 vecinos en 1591 pasaría a sólo 72; en Moncalvillo, que de 72 pasaba a 41; y en Regumiel de la Sierra, que de 57 pasa a sólo 25. Por el contrario, otras localidades muestran un signo completamente distinto, ofreciendo unos niveles similares a los de la centuria anterior, o incluso superiores a los arrojados por el censo de 1591. Este es el caso de Canicosa de la Sierra, localidad que, frente a los datos ofrecidos por el censo de los obispos, con 126 vecinos, y el de 1591, con 146, en este de 1631 se queda en un término medio con 130 vecinos. Un panorama similar es el que se registra en otros núcleos cercanos, tanto geográficamente como por afinidades económico-culturales, como es el caso de Palacios de la Sierra, Hacinas o Salas de los Infantes. En todas ellas observamos un número de vecinos muy similar al que tenían en 1591, pues Palacios de

359 A. DOMÍNGUEZ ORTIZ: La sociedad española en el siglo XVII. Tomo I. Granada, Consejo Superior de Investigaciones Científicas. Universidad de Granada. 1992.

360 D. S. REHER, A. VALERO LOBO: Fuentes de información demográfica ... ob. cit. (pp. 18). M. MARTÍN GALÁN: "Fuente y método para el estudio de la demografía histórica castellana durante la Edad Moderna”. En Hispaniae. Tomo XLI (1981), n 148. (pp. 231 - 325).

361 D. S. REHER, A. VALERO LOBO: Fuentes de información demográfica ... ob. cit. (pp. 18). S. PIQUERO, R. OJEDA, E. FERNÁNDEZ DE PINEDO: “El vecindario de 1631: presentación y primeros resultados”. En Evolución demográfica bajo los Austrias. (Actas del II Congreso de la Asociación Demográfica histórica. Alicante, abril de 1990. Vol. III. Alicante, Instituto de Cultura Juan Gil Albert, Diputación de Alicante, Seminari d’Estudis sobre la Població del Pais Valenciá. 1991. (pp. 77 - 89). 
202 Arquitectura de la Edad Moderna en la sierra burgalesa.

la Sierra presenta un total de 171 vecinos, frente a los 179 de 1591, Hacinas 82, frente a los 80 de 1591, y Salas de los Infantes 167, frente a los 143 de la centuria anterior ${ }^{363}$.

El censo de 1646 se encuadra dentro del conjunto de las averiguaciones realizadas en Castilla con el fin de repartir de forma equitativa un empréstito tomado por la Corona ${ }^{364}$. Nuevamente la información que nos proporciona resulta sumamente desigual, y sus resultados, por supuesto, cuestionables. Aun así, los valores que se presentan - los cuales resultan, por lo general, demasiado bajos -, nos indican la presencia de un cierto clima de crisis, manifestándose también aquí, por lo tanto, el ambiente de decadencia generalizada de la mayor parte del reino de Castilla. Los registros parroquiales, sin embargo, contradicen estos resultados, pues en aquellas poblaciones, donde se han realizado estudios sobre estas fuentes (o se están realizando en estos momentos) ${ }^{365}$, parece que se desprende una imagen bien distinta para esta parte central de la centuria. De todos modos, las generalizaciones en ningún caso son buenas, de esta forma, podemos observar cómo en el único caso que tenemos datos plenamente fiables para este momento del XVII, como es el caso de Monterrubio de la Demanda, la población registrada es de tan solo 14 vecinos $^{366}$, frente a los 28 que había expresado el censo de los obispos de 1587-89.

Frente a esta insuficiencia generalizada de fuentes de información, que se da en este siglo XVII, la centuria siguiente, no sólo nos ofrece una documentación más abundante para el estudio demográfico, sino también datos mucho más fiables. A través de estas fuentes detectamos, en general, un moderado crecimiento de la población en la mayor parte de los pueblos de esta comarca, el cual es más significativo en los núcleos

\footnotetext{
362 M. MARTÍN GALÁN: “Fuentes y método para el estudio de la demografía ...”. Ob. cit.

363 AGS. Dirección General del Tesoro, Inventario n ${ }^{\circ}$ 24. Leg. 1.168 - 2. (fols. $11 \mathrm{v}^{\mathrm{o}}$ - 12).

364 D. S. REHER, A. VALERO LOBO: Fuentes de información demográfica ... ob. cit. (pp. 18).

365 Los estudio que está realizando en este momento para la localidad de Castrillo de la Reina Luis Miguel González, a partir de los Libros Parroquiales, contradicen igualmente la imagen de decadencia generalizada, que proyectan para la zona estos censos de 1631 y 1646.

366 AGS. Cámara de Castilla - Diversos, leg. 23, $\mathrm{n}^{\circ} 4$ (s/f). Vecindario realizado en el lugar de Monterrubio, perteneciente a las Cinco Villas. Monterrubio de la Demanda a 11 de diciembre de 1646.
} 
más pequeños que en los de mayor tamaño. Sin embargo, esta prosperidad se ve frenada de forma periódica por súbitas épocas de crisis y recesión, pues no debemos olvidar que en estos momentos nos encontramos todavía dentro de una sociedad característica del Antiguo Régimen, sumamente frágil y sujeta a diferentes condicionantes, como son la debilidad de la estructura productiva, el equilibrio entre los elevados índices de natalidad y mortalidad, y la posibilidad del desarrollo de hambrunas y brotes epidémicos con cierta frecuencia, que venían a frenar cualquier crecimiento abultado.

Aun así, creemos haber detectado un crecimiento generalizado dentro de estos pueblos a lo largo de esta centuria del Setecientos, el cual se manifiesta especialmente durante la primera mitad del siglo. En los años centrales de la centuria, coincidiendo con el momento en el que se realiza el Catastro del Marqués de Ensenada, observamos que muchas de estas localidades han conseguido igualar o incluso superar los niveles registrados en el censo de 1591.

Las fuentes de que disponemos para este momento son bastante más numerosas, sin embargo, lo que más destaca de ellas es su fiabilidad, pues tanto el Catastro de Ensenada, como especialmente el censo de Floridablanca, se distinguen por su rigor, lo que hace que este último sea considerado como "uno de los mejores llevados a cabo en Europa durante el Antiguo Régimen”367. Por el contrario, hemos decidido no tener en cuenta los datos aportados por el llamado Vecindario de Campoflorido, realizado entre 1712-17, pues las excepcionales circunstancias que rodearon este recuento (relacionado con los tributos solicitados durante la Guerra de Sucesión), hacen que las cifras aportadas sean muy cuestionadas por todo el conjunto de investigadores que lo han manejado $^{368}$.

El primero de estos censos, que hemos tenido en cuenta, por lo tanto, es el ya mencionado del Catastro de Ensenada, encargado por el rey Fernando VI, que fue

\footnotetext{
367 D. S. REHER, A. VALERO LOBO: Fuentes de información demográfica ... ob. cit. (pp. 19 - 21).

368 Ibídem.
} 
realizado entre los años $1749-53^{369}$. Se trata, como sabemos, del primer gran censo de la época ilustrada en España, el cual fue elaborado con el fin de implantar una contribución única, que acabara con el antiguo reparto entre pecheros y privilegiados. La información de carácter demográfico se encuentra recogida principalmente en las Respuestas Generales y en los Memoriales Particulares, si bien dentro de estas pesquisas se encuadran también el llamado Vecindario de Ensenada y el Censo de Ensenada, que recogen información resumida de este tipo, agrupándola por pueblos y provincias.

Nos centramos aquí especialmente en este documento, denominado censo de Ensenada, pues en él la población de cada una de las localidades examinadas aparece perfectamente distribuida según su estado, diferenciando las siguientes categorías:

- Vecinos útiles (nobles).

- Vecinos útiles (estado general).

- Jornaleros (nobles)

- Jornaleros (estado general)

- $\quad$ Pobres de solemnidad (nobles)

- Pobres de solemnidad (estado general)

- Habitantes (nobles)

- Habitantes (estado general)

- Viudas.

- Clérigos

De este modo, el cuadro que obtenemos para nuestra comarca de estudio es el siguiente:

369 En nuestra zona todos los registros pertenecen al año 1753, realizándose los cuestionarios entre los meses de enero y septiembre. La única excepción la presenta la localidad de Monterrubio de la Demanda, 
Óscar Moral Garachana. 205

\begin{tabular}{|c|c|c|c|c|c|c|c|c|c|c|c|}
\hline & \multicolumn{2}{|c|}{ Vecinos útiles } & \multicolumn{2}{|c|}{ Jornaleros } & \multicolumn{2}{|c|}{$\begin{array}{c}\text { Pobres } \\
\text { solemnidad }\end{array}$} & \multicolumn{2}{|c|}{ Habitantes } & \multirow[b]{2}{*}{ Viudas. } & \multirow[b]{2}{*}{ Total. } & \multirow[b]{2}{*}{$\begin{array}{l}\text { Eclesi } \\
\text { ásticos }\end{array}$} \\
\hline & Nobles & $\begin{array}{l}\text { Est. } \\
\text { Gral. }\end{array}$ & Nobles & $\begin{array}{l}\text { Est. } \\
\text { Gral. }\end{array}$ & Nobles & $\begin{array}{l}\text { Est. } \\
\text { Gral. }\end{array}$ & Nobles & $\begin{array}{l}\text { Est. } \\
\text { Gral. }\end{array}$ & & & \\
\hline Arroyo de Salas & & 25,5 & & & & & & & & 25,5 & 1 \\
\hline $\begin{array}{l}\text { Barbadillo de } \\
\text { Herreros }\end{array}$ & 43,5 & 1 & 15 & 3 & 2 & & 12 & & 7 & 83,5 & 3 \\
\hline Barbadillo del Pez & 4,5 & 64,5 & & & & & & 9 & & 78 & 3 \\
\hline Bezares & 6,5 & 1,5 & 11 & 2 & & & 4 & & 4 & 29 & \\
\hline Canicosa & & 95,5 & & & & 5 & & 10 & 1 & 111,5 & 2 \\
\hline $\begin{array}{l}\text { Castrillo de la } \\
\text { Reina }\end{array}$ & & 99,5 & & 1 & & & & 5 & & 105,5 & 1 \\
\hline Castrovido & & 29,5 & & & & & & 2 & & 31,5 & 1 \\
\hline Hacinas & & 80,5 & & & & 5 & & 12 & & 97,5 & 1 \\
\hline $\begin{array}{l}\text { Hoyuelos de la } \\
\text { Sierra }\end{array}$ & & 23 & & 1 & & & & 1 & 4 & 29 & 1 \\
\hline Huerta de Abajo & 26 & & 12 & & & & 9 & 1 & 3 & 51 & 1 \\
\hline Huerta de Arriba & 95,5 & 1 & 53 & 1 & 4 & & 22 & & 7 & 183,5 & 3 \\
\hline $\begin{array}{l}\text { Monasterio de la } \\
\text { Sierra }\end{array}$ & & 39 & & & & & & 4 & & 43 & 1 \\
\hline $\begin{array}{l}\text { Monterrubio de la } \\
\text { Demanda }\end{array}$ & & 82 & & & & & & & & 82 & 1 \\
\hline Neila & 61 & 63,5 & & & & & & & 9 & 133,5 & 3 \\
\hline $\begin{array}{l}\text { Palacios de la } \\
\text { Sierra }\end{array}$ & & 180,5 & & 3 & & 3 & & 27 & 21 & 234,5 & 4 \\
\hline $\begin{array}{l}\text { Quintanar de la } \\
\text { Sierra }\end{array}$ & & 130 & & & & & & 18 & 7 & 155 & 3 \\
\hline $\begin{array}{l}\text { Quintanilla de } \\
\text { Urrilla }\end{array}$ & 15,5 & 1 & 3 & & 1 & 1 & 1 & & & 22,5 & 1 \\
\hline $\begin{array}{l}\text { Regumiel de la } \\
\text { Sierra }\end{array}$ & & 8 & & 3 & & & & 1 & 2 & 14 & \\
\hline $\begin{array}{l}\text { Riocavado de la } \\
\text { Sierra }\end{array}$ & 27,5 & 2 & 30 & 6 & & & 2 & 2 & 12 & 81,5 & 1 \\
\hline $\begin{array}{l}\text { Salas de los } \\
\text { Infantes }\end{array}$ & 3,5 & 108 & & & & & 1 & 31 & & 143,5 & 5 \\
\hline Terrazas & & 16 & & & & & & & & 16 & 1 \\
\hline Tolbaños de Abajo & 13 & & 27 & & 1 & & 3 & & 1 & 45 & 1 \\
\hline $\begin{array}{l}\text { Tolbaños de } \\
\text { Arriba }\end{array}$ & 45,5 & 4 & 11 & 1 & & 1 & 9 & & 1 & 72,5 & 1 \\
\hline Vallejimeno & 39 & 1 & 24 & & & & 6 & & 6 & 76 & 1 \\
\hline $\begin{array}{l}\text { Vilviestre del } \\
\text { Pinar }\end{array}$ & & 120,5 & & & & 13 & & 13 & & 146,5 & 1 \\
\hline
\end{tabular}

que al estar encuadrada dentro de la Intendencia de Soria su consulta se realizó en octubre del año 
La otra gran fuente de información, que hemos tomado como referencia, es el censo de Floridablanca, realizado en 1787. Se trata, como ya hemos indicado, del más fiable de cuantos se hacen durante el Antiguo Régimen, pues su finalidad no es exclusivamente fiscal, sino que tiene ya un carácter primordialmente demográfico. De esta forma, la población de cada municipio no se cuenta por el número de vecinos, sino por habitantes, lo que nos permite conocer el volumen exacto de pobladores. Dentro de este recuento, se realizan además distintas clasificaciones, separando a la población por sexos, por estados y según sus ocupaciones más frecuentes, de tal modo que tenemos una detallada descripción de la organización de la sociedad en cada uno de estos pueblos.

A parte de esto, el censo de Floridablanca nos permite apreciar que la población de estos pueblos apenas había experimentado cambios significativos, en cuanto al número de habitantes, con respecto a los datos ofrecidos por el vecindario de Ensenada. Así, aplicando el coeficiente 3’5 a las cantidades ofrecidas por el censo de Ensenada (pues a raíz de nuestras averiguaciones parece el más adecuado para estos pueblos), vemos que las cifras ofrecidas por uno y otro apenas registran variaciones importantes. Por ello, podemos deducir, que el mayor crecimiento demográfico en estos pueblos se debía haber producido durante la primera mitad de la centuria, coincidiendo con las condiciones especialmente favorables, que parecen haberse dado en estos momentos, tanto para el mundo de la ganadería trashumante, como para el tráfico de carretas ${ }^{370}$.

Todas estas fluctuaciones no hacen sino describirnos la estructura y evolución de unos grupos característicos de la sociedad del Antiguo Régimen. Así, a pesar del relativo blindaje que pudiera presentar esta zona, frente a los desplomes económicos

anterior.

370 A. GARCÍA SANZ: “El siglo XVIII: entre la prosperidad de la trashumancia y la crítica antimesteña de Ilustración. (1700 - 1808)”. En Mesta, trashumancia y vida pastoril: exposición organizada por la Sociedad V Centenario del Tratado de Tordesillas. Soria, Sede de la Fundación Duques de Soria. 19 de septiembre a 30 de noviembre de 1994. Madrid, I+P Investigación y Progreso.1994. (137 - 158). 
producidos por las oscilaciones de las cosechas, de los precios agrícolas y los cambios en la coyuntura, los desplomes demográficos se manifiestan igualmente. Esta evolución se ve marcada, generalmente, por la alternancia de periodos de saldo negativo con otros de signo positivo, lo que deja pequeños crecimientos, truncados periódicamente por repentinos y bruscos descensos.

Las constantes crisis de subsistencia, presente de forma regular durante el Antiguo Régimen, no hacen otra cosa que debilitar aun más a una población, ya de por sí sumamente frágil, con lo que se aumentan de forma importante los riesgos de aparición de nuevos brotes epidémicos. La recuperación frente a estos contratiempos era siempre lenta, pues la estructura familiar no permitía crecimientos rápidos. Para conocer los detalles sobre estas cuestiones en nuestra zona contamos con el estudio, ya mencionado, realizado sobre la villa de Neila para los años 1690 al 1800 . A través de este trabajo sabemos que eran muy raras las familias de más de cuatro miembros (aproximadamente el $15 \%)^{371}$, lo cual debe servirnos, de paso, para precisar lo más posible la cuestión del coeficiente aplicado en los diferentes censos. A ello contribuyen los índices de natalidad, que aunque altos, no consigue sobreponerse a las elevadas tasas de mortalidad infantil (con niveles de 30 - 40 por 1.000 en época normal), siendo poco más del $50 \%$ los niños que alcanzaban la edad de procreación ${ }^{372}$.

Estos niveles de natalidad se ven restringidos por diferentes factores, como es el hecho, en primer lugar, de que no todo el mundo se casaba, pues dentro de esta sociedad del mundo moderno existía un elevado número de religiosos y de viudas mayores ${ }^{373}$,

\footnotetext{
371 A. GUTIÉRREZ ALONSO: "La población burgalesa durante la Edad Moderna”. Ob. cit.

372 M. B. GANZO PÉREZ, L. F. IBEAS MIGUEL: “La fecundidad en un área burgalesa ...” ob. cit. A. DOMÍNGUEZ ORTIZ: La sociedad española en el siglo XVII. Ob. cit. (pp. 63 - 66).

373 El elevado número de este tipo de mujeres de avanzada edad que habían enviudado y no se habían vuelto a casar era tan elevado durante el Antiguo Régimen, que dentro de esta sociedad habían terminado por constituir un auténtico grupo social, perfectamente definido y reconocido estadísticamente. De este modo podemos ver cómo en nuestra zona su número era tan importante, que superaban con creces, por ejemplo, al de los clérigos.
} 
208 Arquitectura de la Edad Moderna en la sierra burgalesa.

para las que, una vez finalizado su ciclo de fertilidad, las posibilidades de contraer matrimonios eran prácticamente nulas.

Respecto a las que se casaban, vemos que la edad habitual de contraer matrimonio se situaba, en nuestra zona, entre los 20 y los 24 años, con una media de 22’30 años aproximadamente ${ }^{374}$, finalizando su etapa de fertilidad entre los 35 y los 40. Un periodo de fertilidad, el de las mujeres serranas de aquella época, que no era excesivamente fecundo, pues los intervalos entre una concepción y otra, lo que se denominan periodos intergestales, se alargaban por lo general hasta los 33 meses de media $^{375}$.

Todo esto hacía que la posibilidad de crecimiento demográfico se encontrara permanentemente amenazada. No obstante, hay que tener en cuenta también, que en las áreas rurales, como este caso, los efectos que tenían las crisis de mortalidad y subsistencia no fueron tan virulentos como en las grandes ciudades ${ }^{376}$. El desarrollo de este proceso se producía siempre de forma cíclica, de este modo, si tomamos, en un esquema ideal, las variables de bautizos, defunciones y matrimonios, observaremos que se produce un equilibrado entrecruzamiento, que permite mantener los niveles de población prácticamente invariables.

No obstante, en las zonas rurales es otro el problema, que se suma a esta serie de inconveniente. Según diferentes autores, entre los que se encuentra Domínguez Ortiz, durante el Antiguo Régimen una parte significativa del mundo rural se vio forzada a abandonar sus pueblos ante la presión ejercida por las crisis de subsistencia, las malas

\footnotetext{
374 M. B. GANZO PÉREZ, L. F. IBEAS MIGUEL: “La fecundidad en un área burgalesa ...” ob. cit.

375 Ibídem. A ello tenemos que unir además la posibilidad de que estos periodos intergestales se alargaban con cierta frecuencia, pues en una sociedad como ésta, sujeta a los ciclos anuales que marcaban las ausencias prolongadas de los maridos, a causa de la trashumancia y de la carretería de larga distancia, no siempre se podía concebir cuando se quería.

376 Si bien esto mismo sucede con los crecimientos.
} 


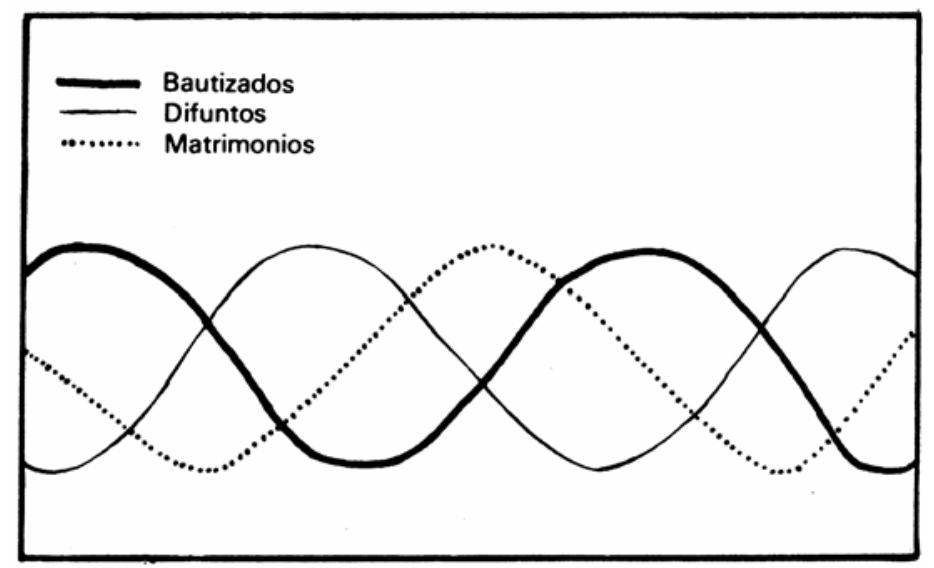

Ciclos de bautismos, difuntos y Matrimonios durante el Antiquo Réqimen. (seqún A. GARCÍA SANZ).

cosechas, el alza de los precios o la pérdida de la propiedad de sus tierras ${ }^{377}$. No obstante, como ya hemos apuntado en diferentes ocasiones, en el caso de nuestra zona de estudio, debemos suponer que la falta de una dependencia exclusiva de la agricultura permitió hacer frente a estos contratiempos con mayor soltura y satisfacción, evitando la emigración de parte de su población. Aquí la gente que emigraba lo hacía de forma periódica, durante los ciclos anuales que forzaban, tanto la ganadería trashumante como la carretería de puerto a puerto, regresando siempre a sus pueblos de origen al final de cada campaña. Aun así, debemos reconocer que cuando no había trigo, no lo había para nadie.

Otro contratiempo demográfico característico de este periodo, del que nuestra zona se vio en cierto modo eximida, es el de las levas militares, las cuales constituyeron también una importante sangría para la corona de Castilla durante la Edad Moderna. En este caso, vemos como los habitantes varones de varios de los pueblos de la sierra se encontraban exentos de esta obligación de incorporarse a filas, por el mero hecho de

377 A. DOMÍNGUEZ ORTIZ: La sociedad española del siglo XVII. Tomo I. ob. cit. (pp. 118 y ss.). 
dedicarse a la ganadería trashumante y a la carretería, y por ello, pertenecer al Honrado Concejo de la Mesta $^{378}$, y a la Cabaña Real de Carreteros $^{379}$, pues la Corona había concedido ciertos privilegios en este sentido. El objetivo no era otro que salvaguardar el normal desarrollo de ambas actividades en tiempos de guerra, pues eran consideradas elementos fundamentales para el sostenimiento de la economía.

Así, con la interrelación de estos diferentes factores, y a partir de la información proporcionada por los censos señalados anteriormente, podemos obtener la siguiente visión general de la población de esta zona para todo el periodo de la Edad Moderna.

Como ya hemos apuntado, apenas contamos con datos que podamos considerar seguros para el periodo de la Baja Edad Media. Aun así, debemos suponer que Castilla en general, y nuestra zona en particular, no se vieron excluidas de la evolución general experimentada en todo el occidente europeo $^{380}$. De este modo, las diferentes estimaciones, que se han realizado sobre el tema, nos indican que la provincia de Burgos habría vivido un momento de cierta regresión demográfica durante el siglo XIV, como efecto de la Peste Negra y demás conflictos existentes ${ }^{381}$. Aun así, existen opiniones tendentes a mitigar estos efectos en la Castilla más septentrional, indicando que esta zona, dentro de la cual se incluía nuestra área de estudio, habría permanecido en cierto modo a salvo de los efectos más devastadores de este brote epidémico ${ }^{382}$.

378 J. KLEIN: La Mesta. Estudio de la historia económica española. 1273 - 1836. Madrid, Alianza Editorial, 1994. (pp. 70).

379 P. GIL ABAD: Junta y Hermandad de la Cabaña Real de Carreteros Burgos - Soria. Burgos, Aldecoa. 1983.

380 V. PÉREZ MOREDA, D. S. REHER (Eds): Demografía histórica en España. Madrid, Ediciones el Arquero. 1988.

381 L. V. DÍAZ MARTÍN: “Estructura social”. En Historia de Burgos II. Edad Media (1). Burgos, Caja de Ahorros Municipal de Burgos. 1986. (pp. 246 - 293).

382 E. GARCÍA ESPAÑA, A. MOLINIÉ - BERTRAND: Censo de Castilla de 1591. Ob. cit. (pp. 27 29). 
A esta tendencia de crecimiento negativo (especialmente acusada durante la segunda mitad de esta centuria del Trescientos), le sigue un siglo XV, marcado, en general, por el signo totalmente contrario. Esto ha llevado a establecer, por parte de la historiografía tradicional, ciertos niveles de triunfalismo para todo el territorio castellano $^{383}$, que algunos autores, como Domínguez Ortiz, no comparten ${ }^{384}$. Este autor considera, que existen determinadas zonas del sur peninsular que no vivieron este presunto crecimiento generalizado. Aun así, en lo referente a nuestra comarca, todos los indicios nos llevan a mostrar un cierto optimismo, pues no en vano, a pesar de encontrarse un tanto aislada con respecto a los ejes más vitales del reino en este momento, sin duda debió verse salpicada por la pujanza económica que se vivía en la capital burgalesa, al abrigo del comercio lanero, del cual muchos de estos pueblos participaban activamente. Un efecto igualmente beneficioso pudieron tener sobre estos pueblos las condiciones privilegiadas en las que se desarrollaban las dos actividades económicas más representativas de la comarca, como eran la trashumancia y la carretería, las cuales fueron especialmente fomentadas durante el reinado de los Reyes Católicos.

Los efectos de la manifiesta prosperidad económica, y de su virtual repercusión en un crecimiento demográfico, se dejarían sentir en el desarrollo de una importante actividad constructiva en la zona, cuyo principal exponente se encuentra en la arquitectura religiosa. Así, vemos que son muchos los templos parroquiales remodelados durante estos años finales del siglo XV y principios del XVI, ampliando en al mayoría de los casos su capacidad, con el fin de dar cabida a un mayor número de feligreses. Ejemplos de ello los tenemos en Barbadillo de Herreros, Castrillo de la Reina, Castrovido, Hacinas, Neila, Palacios de la Sierra, y muy especialmente en las dos iglesias de Salas de los Infantes.

383 L. V. DÍAZ MARTÍN: “Estructura social”. Ob. cit.

384 A. DOMÍNGUEZ ORTIZ: El Antiguo Régimen: Los Reyes Católicos y los Austrias. En Historia de España. Vol. 3. Dir. por M. ARTOLA. Madrid, Alianza Editorial. 1990. (pp. 24 - 26). 
El siglo XVI, como hemos visto, presenta líneas demográficas algo más claras. Del análisis de las fuentes consultadas se desprende un crecimiento generalizado, si bien sabemos que en los medios rurales, como es el nuestro, este auge debió ser menor ${ }^{385}$. Por otra parte, este crecimiento, no es continuo a lo largo de toda la centuria, detectándose momentos especialmente álgidos, como ocurre con el periodo de 1530$70^{386}$, que se compensa con otros en los cuales esta tendencia se trunca, lo que sucede a partir de este año 1570 hasta la crisis de finales de siglo (desarrollada entre 1597$1602)^{387}$. Ante estas apreciaciones de carácter demasiado general, existen algunos autores, como Molinié-Bertrand, que se atreven a dar estimaciones más concretas, cuantificando este crecimiento con unos valores de incremento demográfico para toda la centuria de un 52’8 \% aproximadamente, y un valor acumulativo anual de 0 ’ $7 \%{ }^{388}$.

La tendencia descendente, que se apunta a finales del siglo XVI, se continúa a lo largo de la mayor parte de la centuria siguiente, iniciándose un periodo, que para Castilla, es conocido como de descenso demográfico generalizado (fig. 1). Aun así, y según indican diferentes investigaciones, existen algunas comarcas, entre la que se puede incluir la nuestra, que consiguen librarse de esta tendencia general, mostrando un equilibrio, o incluso un ligero aumento ${ }^{389}$. El gráfico desarrollado por Gil Abad para la localidad de Quintanar de la Sierra, elaborado a partir de los datos suministrados por los Libros Parroquiales, nos muestra un ejemplo de ello (fig. 2$)^{390}$.

La falta de datos precisos para los demás pueblos, sin embargo, nos impide extrapolar estos mismos índices al resto de la comarca con completas garantías. De hecho, si hacemos caso de las escasas fuentes de información con las que contamos para este siglo XVII, debemos sospechar que no todo fue prosperidad, o cuanto menos

\footnotetext{
385 V. PÉREZ MOREDA, D. S. REHER (Eds): Demografía histórica en España. ob. cit.

386 R. CARANDE: Carlos Vy sus banqueros. Ob. cit.

387 V. PÉREZ MOREDA, D. S. REHER (Eds): Demografía histórica en España. ob. cit.

388 E. GARCÍA ESPAÑA, A. MOLINIÉ - BERTRAND: Censo de Castilla de 1591. Ob. cit.

389 A. GUTIÉRREZ ALONSO: “La población burgalesa durante la Edad Moderna”. Ob. cit.

390 P. GIL ABAD: Quintanar de la Sierra. Ob. cit.
} 
continuidad, con respecto a los niveles registrados a finales de la centuria anterior, como parecen indicar estos datos referentes a Quintanar de la Sierra. Un ejemplo de ello lo tenemos en Monterrubio de la Demanda, donde la comparación entre el censo de los obispos de 1587-89 y el conservado en el Archivo de Simancas de 1646, nos arroja una pérdida del 50 \% de su población.

El siglo XVIII, por su parte, conoce un moderado crecimiento, que algunos autores, como G. Anes, cifran en unos niveles del 0’4 \% acumulativo anual para la segunda mitad de la centuria. Si bien, como ya ha quedado aclarado, no se trata de un crecimiento continuado, ni generalizado en todos los núcleos de población ${ }^{391}$. Así, volviendo nuevamente al caso mejor conocido de esta comarca, como es Quintanar de la Sierra, vemos como, mientras la línea de las medias de nacimientos muestran una relativa uniformidad a lo largo de toda la centuria, los índices de mortalidad presentan un perfil significativamente más quebrado (fig. 3). Esto nos indica la presencia de los inevitables periodos de crisis demográficas, que a lo largo de este siglo se continuaron manifestando. Estos ocurrieron principalmente en torno al año 1707, y desde mediados de la década de 1720 hasta los años 1745-50 392 . Coinciden, por lo tanto, con los periodos de recesión registrados durante este siglo en otras comarcas de la provincia de Burgos, como es el caso del partido de Candemuñó, estudiado por Sáenz Casado y Sanz de la Higuera, donde también se aprecia un significativo aumento de la mortalidad dentro de estas mismas franjas de años ${ }^{393}$.

Aun así, y a pesar de estos importantes contratiempos, el momento de bonanza, que parecen vivir durante este periodo las dos actividades económicas más representativas de la zona (ganadería trashumante y carretería de puerto a puerto), nos

\footnotetext{
391 G. ANES: El siglo de las luces. En Historia de España. Vol 4. Dir. M. ARTOLA. Madrid, Alianza Editorial. 1990.

392 P. GIL ABAD: Quintanar de la Sierra. Ob. cit.

393 J. L. SÁINZ CASADO, F. J. SANZ DE LA HIGUERA: “Evolución demográfica del partido de Candemuñó (1700 - 1850)”. En El Pasado Histórico de Castilla y León. Vol. II. Edad Moderna. Burgos, Junta de Castilla y León. 1993. (355 - 379).
} 
empuja a pensar, que se produce un moderado crecimiento demográfico. Este crecimiento sirve para paliar los efectos de los momentos de recesión, y por otra, para recuperar, y aun superar, los índices que teníamos para los años finales del siglo XVI. Así, revisando los registros, que nos ofrece el Censo de Ensenada, vemos como se produce, en la mayor parte de los casos, un crecimiento medio moderadamente alto (fig.4).

Sin embargo, este auge demográfico no es homogéneo en toda nuestra área de estudio, pues resulta mucho más importante en las localidades dedicadas a la ganadería trashumante, que en las eminentemente carreteras. Así, dentro de los pueblos denominados trashumantes vemos en todos los casos, y sin excepción, un crecimiento realmente elevado, que tiene mejor muestra en localidades como Barbadillo de Herreros (pasa de 60 vecinos en 1587, a 85’5 en 1753); Bezares (pasa de 14 en 1587 a 29 en 1753); Huerta de Abajo (pasa de 30 a 51 en las mismas fechas); Huerta de Arriba (de 100 a 183’5); Monterrubio de la Demanda (de 28 a 14 en 1646, y a 82 vecinos en 1752); Neila (de 64 a 133’5); Quintanilla de Urrilla (de 14 a 22’5); Riocavado de la Sierra (de 20 a 81’5); Tolbaños de Abajo (de 22 a 45); o Vallejimeno (de 40 a 76).

Por el contrario los pueblos, denominados carreteros, presentan un comportamiento más desigual. De esta forma, aquí nos encontraremos, por una parte, con pueblos en los que se registran comportamientos muy similares a los que acabamos de ver en el Valle de Valdelaguna y su entorno, como es el caso de Vilviestre del Pinar (que pasa de 116 vecinos en 1591, a 146’5 en 1753); o Palacios de la Sierra (de 179 vecinos en 1591, a 234’5 en 1753). Frente a ellos, sin embargo, aparecen otras localidades donde se registra un signo claramente contrario, que va desde el mero mantenimiento, con cambios muy ligeros, como ocurre en Quintanar de la Sierra, donde se pasa de 159 en 1591 a 155 en 1753, hasta los bruscos descensos, que se registran en localidades como Canicosa de la Sierra (de 147 a 111’5); Castrillo de la Reina (de 136 a 105’5); o el caso más significativo de Regumiel de la Sierra (de 58 a tan solo 14). 
Por su parte, los pueblos donde se registraba una economía mixta, con un predominio de la actividad agrícola, muestran, por lo general, una tendencia alcista. Esto ocurre en Arroyo de Salas (pasa de 18 vecinos en 1591, a 25'5 en 1753); Castrovido (de 21 en 1591, a 31’5 en las mismas fechas); Hacinas (de 80 a 97’5); Hoyuelos de la Sierra (de 16 a 29); Monasterio de la Sierra (de 29 a 43); y Moncalvillo (de 74 a $83 ’ 5$ ).

Las repercusiones, que estos cambios demográficos tienen dentro del campo constructivo, resultan evidentes, sobre todo dentro de la arquitectura religiosa. Así, observamos cómo en la mayor parte de estos pueblos mencionados, donde se produce un crecimiento importante de su población, se edifican durante la primera mitad de este siglo XVIII, e incluso en las décadas iniciales de la segunda mitad, nuevos templos parroquiales, o se remodelan los antiguos. De esta forma, se pretendía dar cabida a un volumen de feligreses, que presuntamente estaba creciendo, produciéndose de nuevo un fenómeno equiparable al registrado durante el periodo que se extiende entre los siglos XV y XVI.

\section{ORGANIZACIÓN SOCIAL.}

Los principios que marcan la organización social en estos pueblos, durante la Edad Moderna, son los mismos que rigieron en el resto de Europa occidental a lo largo de este periodo, es decir, el nacimiento, el estado y la riqueza. Dentro de ellos, los dos primeros tenían un carácter legal, ya que según su aplicación, la población estaría clasificada en nobles y plebeyos, por un lado, y en eclesiásticos y laicos, por otro. La principal repercusión, que tenía el hecho de pertenecer a uno u otro de estos estamentos, radica en el carácter privilegiado que adquieren, tanto los miembros de la nobleza, como los del clero, con respecto al estado llano, simplemente por la circunstancia de pertenecer a estos estamentos. Ello les eximía, por ejemplo, de pagar determinados impuestos de carácter directo, que el resto de la población debía afrontar. 
No obstante, a la hora de la verdad, este esquema estamental de honda tradición medieval, que articulaba la sociedad en tres estamentos perfectamente establecidos (nobles, eclesiásticos y estado llano), queda completamente alterado por el principio dinamizador que constituye la riqueza. Así, según decía Sancho Panza a su señor Don Quijote: “dos linajes solos hay en el mundo, el tener y el no tener”.

De acuerdo con esto, para conocer la verdadera organización de la sociedad de estos pueblos, deberemos prestar más atención al volumen de propiedades acumuladas por cada individuo, que a sus títulos o condición, pues en muchos casos lo uno llevaba implícito lo otro. Sin embargo, y aun con todo, en atención al carácter de las fuentes que hemos manejado para el estudio de estos aspectos, donde se hace especial hincapié en la clasificación por estamentos, pasaremos a desarrollar aquí la organización social de estos pueblos, según esta estructura tradicional.

\section{Nobles.}

Según la imagen tradicional, que desde la Edad Media nos muestra la sociedad del Antiguo Régimen, los nobles son los encargados de guerrear, es decir, de defender con sus armas la seguridad de los otros dos estamentos, adquiriendo por ello una condición privilegiada, que le impedía dedicarse a las labores mundanas, relacionadas con el trabajo y el esfuerzo físico. Durante los primeros momentos de la Edad Moderna resulta un estamento poco importante, dentro de los pueblos de nuestra zona, pese a lo cual irá incrementándose de forma importante, a medida que avanza este periodo, hasta alcanzar unos niveles realmente sorprendentes en varias de estas localidades, cuando lleguemos a la segunda mitad del siglo XVIII.

En general se trataba, en todos los casos, de pequeños hidalgos sin título, cuyo régimen de vida y actividad profesional se diferenciaba bien poco, o prácticamente nada, del desarrollado por el resto de sus convecinos del estado llano. No nos encontraremos aquí, por lo tanto, ni un solo caso de grandes títulos, pues aunque los 
señoríos jurisdiccionales estaban muy extendidos en la zona, sus titulares nunca residían aquí.

Los que predominan son, como decimos, pequeños hidalgos, los cuales se corresponden, por lo general, con los ricos propietarios de tierras y ganados trashumantes, que habían adquirido su condición de hidalgos, bien por compra, o bien mediante la manipulación de los padrones municipales. La finalidad de alcanzar esta condición de hidalgo se explica únicamente por la posibilidad de eludir, mediante su status privilegiado, la incómoda e incluso agobiante presión fiscal de los tributos directos. De estas dos modalidades, sin duda, la segunda era la más habitual, de hecho, tal y como nos indica Domínguez Ortiz, esta práctica debió resultar bastante común en la Edad Moderna, y muy especialmente durante el siglo XVII ${ }^{394}$. La utilidad de estos padrones era doble, por un lado fiscal, para saber quién debía contribuir y quién no, y por otro social, separando estamentos, con el fin de repartir los cargos municipales, en aquellos lugares donde se realizaba esta práctica.

El paso de un estamento a otro, contrariamente a lo que se suele creer, era relativamente frecuente, sobre todo en el caso del paso del estado llano al de hidalgo. Así, citando nuevamente a Domínguez Ortiz, debemos decir, que "en todas partes el plebeyo enriquecido hallaba facilidades para introducirse en la hidalguía, y el hidalgo empobrecido para conservarla”395 . Por supuesto, como decimos, la práctica más habitual para este cambio de condición consiste en esta alteración de padrones, pues las dádivas recibidas muchas veces por los propios concejos hicieron desaparecer todo tipo de impedimento para ello ${ }^{396}$.

\footnotetext{
394 A. DOMÍNGUEZ ORTIZ: La sociedad española en el siglo XVII. Tomo I. ob. cit. (pp. 175 - 178).

395 Ibídem.

396 Ibídem. Este procedimiento se ve afianzado por la escasa relevancia que tienen los testimonios documentales a la hora de probar una hidalguía. Así, el hecho de que los padres de un determinado individuo hubieran figurado toda la vida en el padrón de los pecheros poco importaba si la realidad del momento era otra.
} 
La alteración de los padrones era la responsable última, por lo tanto, de que varios pueblos de nuestra comarca vieran aumentar de forma sospechosa, y en algunos casos incluso escandalosa, el número de hidalgos. De este modo, en el censo de Ensenada de 1753 vemos como algunos pueblos, que tradicionalmente no habían contado con ningún hidalgo dentro de su población, presentan ahora proporciones francamente elevadas (fig. 5). Este es el caso de:

- Barbadillo de Herreros: dentro de una población total de 83.5 vecinos, 72 de ellos se declaran hidalgos.

- Bezares: de 29 vecinos, 21 son hidalgos.

- $\quad$ Huerta de Abajo: de 51, 47.

- $\quad$ Huerta de Arriba: de 183.5, 174.5.

- Neila: de 133.5,.

- Quintanilla de Urrilla: de 22.5, 20.5.

- $\quad$ Riocavado de la Sierra: de 81.5, 59.5.

- Tolbaños de Abajo: de 45, 44.

- Tolbaños de Arriba: de 72.5, 65.5.

- Vallejimeno: de 76, 69.

Salas de los Infantes, por su parte, que había sido tradicionalmente el único pueblo de la comarca, que albergaba en el siglo XVI una comunidad de hidalgos relativamente numerosa, cuenta en este momento únicamente con 4.5 vecinos hidalgos, dentro de una población total de 143.5 vecinos.

Esta proporción de hidalgos desciende de forma notable, durante la segunda mitad de este siglo XVIII. Aun así, según los datos del censo de Floridablanca, existen todavía algunos pueblos donde esta proporción, no sólo no desciende, sino que incluso aumenta todavía más, hasta alcanzar al total de la población. Este es el caso de Riocavado de la Sierra y Tolbaños de Abajo, donde vemos cómo todos sus habitantes declaran ser hidalgos. En el resto, como decimos, esta proporción desciende significativamente, mostrando los siguientes porcentajes, dentro de su población total: 
- Barbadillo de Herreros: pasa del 86’8 \% de hidalgos al 35’3\%.

- $\quad$ Bezares: desciende del 72’4\% al $51 \%$.

- $\quad$ Neila: del 45’6 \% al 27’1\%.

- Quintanilla de Urrilla: del 93’1 \% al 44’7\%.

- Tolbaños de Arriba: del 90’3 \% al 47’8 \%.

- Vallejimeno: del 90’7 \% al 47’2 \%.

Junto a estos niveles de descenso generalizado, Salas de los Infantes pasa del 3’1\% de hidalgos, dentro de su población, a un exiguo 0’7 \%. Al mismo tiempo, la ausencia de registros, en los que se detalla este tipo de información, para localidades como Huerta de Abajo y Huerta de Arriba, nos impiden dar cifras absolutas sobre estas poblaciones, donde existía igualmente una población importante de hidalgos. Si bien, a tenor los datos, que tenemos para el resto de los pueblos de la comarca, podemos estimar, que la reducción aproximada de hidalgos, para esta segunda mitad del siglo XVIII, fue de un $50 \%$.

Comparando, al mismo tiempo, estos datos con los que tenemos para el siglo XVI, donde, como decimos, la presencia de hidalgos en los pueblos de la zona resulta prácticamente nula - pues sólo Salas de los Infantes, Neila y el Valle de Valdelaguna cuentan con algún hidalgo disperso -, debemos suponer que este fenómeno de crecimiento del estamento nobiliar se produjo principalmente a lo largo del siglo XVII. Con la llegada de la dinastía de los Borbones a España, en el inicio del siglo XVIII, se comienzan a imponer importantes trabas a este acceso desde el estado llano a la hidalguía. De esta forma, se prohibe a los pueblos dar el estado hidalgo, mediante inclusión en esta categoría dentro de sus padrones, siempre que no se contara con la conveniente justificación ${ }^{397}$.

El número de hidalgos, por lo tanto, había crecido espectacularmente en nuestra zona a lo largo de esta parte central de la Edad Moderna, no obstante, este crecimiento 
no se produce de forma generalizada y uniforme dentro de todo el territorio que compone nuestra zona de estudio. Así, al igual que sucedía en el resto de la península Ibérica, y dentro del marco de nuestra provincia, donde se daba una especial concentración de los hidalgos en zonas muy concretas, en nuestra comarca ocurre lo mismo. En el ámbito más general vemos que las mayores concentraciones de nobles se producen en el norte del territorio peninsular, correspondiente a Galicia, Asturias, Cantabria, Álava, Vizcaya, Guipúzcoa, norte de León y norte de Burgos. Después sigue la zona de la Meseta del Duero, con una presencia también notable, quedando finalmente el sur, donde su número desciende de forma poderosa ${ }^{398}$.

Igualmente, dentro del ámbito de la provincia de Burgos, se pueden ver estas diferencias en el número de hidalgos entre el sur y el norte. De esta forma, según nos indica Ana Díaz Medina para el siglo XVI, mientras poblaciones norteñas, como Medina de Pomar presentaban hasta un 35 \% de población hidalga, en nuestra zona, Salas de los Infantes, que era casi el único centro, donde este estamento tenía representación, la población de hidalgos apenas llega a un 7 \% ${ }^{399}$.

Al mismo tiempo que se produce esta concentración geográfica, estos nobles tienden a habitar especialmente en ciudades o núcleos importantes, como así sucede en nuestra comarca durante el siglo XVI, pues según los datos arrojados por el censo de 1591, diez de los catorce nobles se hallaban en Salas de los Infantes.

Pero frente a estas consideraciones generales, y a medida que transcurre la Edad Moderna, vemos cómo la comarca de la sierra burgalesa comienza a presentar sus propias particularidades. Para empezar, aquí debemos tener en cuenta las diferentes existentes en este aspecto, entre el siglo XVI y los siglos XVII - XVIII. De este modo, si para la centuria del Quinientos tenemos una escasa presencia de hidalgos - los cuales

\footnotetext{
398 A. DOMÍNGUEZ ORTIZ: Las clases privilegiadas en el Antiguo Régimen. Madrid, Ediciones Istmo.
} 1985. 
se concentran especialmente, como hemos visto, en Salas de los Infantes - para las dos centurias siguientes nos encontramos con un panorama dominado por un importante grupo de hidalgos rurales, concentrados de forma exclusiva en los pueblos en los que la ganadería trashumante era la actividad dominante. Por el contrario, en los pueblos dedicados mayoritariamente a la carretería no aparece ni un solo caso. Si observamos la distribución de estos hidalgos dentro de nuestra zona podemos observar con mayor claridad esta concentración.

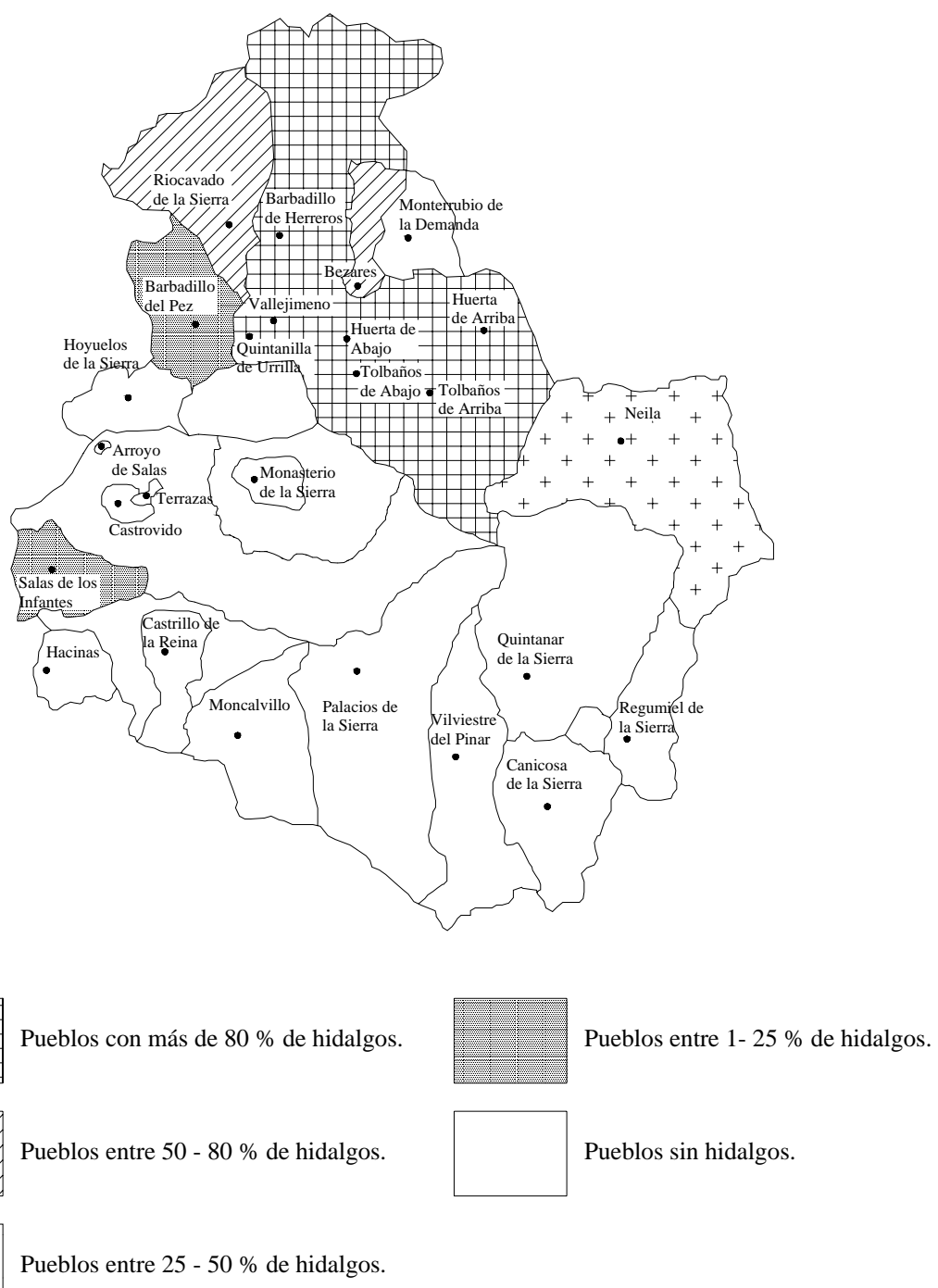

Mapa de distribución de hidalgos, según los datos del Catastro del Marqués de Ensenada (1753).

399 A. DÍAZ MEDINA: "Economía y Hacienda (siglos XVI - XVII). En Historia de Burgos. III Edad Moderna (2). Burgos, Caja de Ahorros Municipal de Burgos. 1992. (pp. 231 - 266). 
La explicación de este fenómeno resulta harto difícil, si bien parece obvio que se encuentra ligada al predominio de determinadas prácticas económicas, como es el caso de la ganadería trashumante y la carretería. Así, podemos pensar que el trabajo de los carreteros debía llevar aparejado algún tipo de connotación negativa, siendo considerado por ello un oficio poco digno, y por lo tanto, incompatible con la condición de hidalguía. Posiblemente esto se ve afianzado, además, por el hecho de que la mayoría de los propietarios de carretas eran gentes que pasaban gran parte de año realizando labores artesanales, fabricando gamellas, taburetes y sillas.

Por el contrario, vemos como en el caso de los ganaderos trashumantes, que poseían la condición de hidalgo, se producen todo tipo de circunstancias y los más variados estratos económicos, dando cabida tanto al grande, como al pequeño y mediano propietario, sin excluir, por supuesto, al jornalero, o incluso al pobre de solemnidad.

Esto nos da pie para hablar brevemente de las características generales que definían a estos hidalgos de la comarca serrana. Para ello podemos tomar prestadas las palabras de Cervantes, recogidas en un fragmento del Quijote, en las cuales, al referirse a los hidalgos dice lo siguiente: "Ellos, en fin, son labradores, gente llana, sin mezcla de alguna raza mal sonante, y, como suele decirse, cristianos viejos ranciosos; pero tan ricos, que su riqueza y magnífico trato les va, poco a poco, adquiriendo nombre de hidalgos y aun de caballeros”. Para trasladar el significado de estas palabras a los pueblos de nuestra zona únicamente tendríamos que unir al término labradores el de ganaderos trashumantes, para encontrar así su reflejo más acertado.

Y es que, como decía otro ilustre literato, en este caso, Lope de Vega, en su obra La prueba de los amigos:

"no dudes que el dinero lo es todo en todo,

Es príncipe, es hidalgo, es caballero, 
Es alta sangre, es descendiente de godo”.

No obstante, como decíamos, la posición económica de estos hidalgos serranos era muy variada. Por ello, aunque la figura del hidalgo pobre, continuamente satirizado por la literatura contemporánea, sí existía en la zona ${ }^{400}$, lo normal es que la hidalguía trajera aparejada la riqueza, o al menos un relativo desahogo económico. Aun así, lo más habitual, como hemos visto, es que sucediera el proceso contrario, es decir, que fuera la riqueza la que allanara el camino hacia la hidalguía. Por lo demás, si observamos el cuadro resultante de la consulta del censo de Ensenada, incluido más arriba, veremos representadas, dentro de este estamento, todas y cada una de las categorías recogidas.

Por lo demás, sólo queda decir que el papel jugado por este grupo, dentro de la promoción de obras arquitectónicas, resultó ciertamente destacado, pues desde el siglo XVII, y especialmente a lo largo de todo el siglo XVIII, se consagraron como importantes impulsores de nuevas construcciones. Esta actividad se plasmo de modo especial en la edificación de un importante número de casas blasonadas, levantadas entre estos años, las cuales vienen a convertirse en una auténtica tipología constructiva, y signo de identidad de este grupo. Evidentemente, las localidades donde se conservan los más importantes conjuntos de este tipo de construcciones se corresponden con aquellas en las que la documentación nos indica un elevado número de hidalgos

\section{Estado eclesiástico.}

Se trata de un estado perfectamente definido por las funciones que desempeñaban, en virtud de las cuales era considerado como un estamento privilegiado. Son los que rezan, atendiendo con ello las necesidades espirituales de la colectividad.

\footnotetext{
400 Ejemplos de ello los encontramos en varios de estos pueblos, así, según el Censo del Marqués de Ensenada de 1753 vemos que en Barbadillo de Herreros existían dos pobres de solemnidad entre sus
} 
Los límites, que lo separan de los otros dos estamentos, viven un tránsito extraordinariamente fluido a lo largo de toda la Edad Moderna, pues no en vano se nutren de estos dos grupos. Por ello, en su interior terminan por reflejarse las mismas diferencias existentes en la sociedad laica. Aun así, la primera gran división, que podemos establecer, dentro del estamento eclesiástico, se produce entre clérigos regulares y clérigos seculares.

Dentro de los seculares se puede establecer, al mismo tiempo, una nueva clasificación, diferenciando los obispos y miembros de los cabildos, de los miembros que componen la amplia masa de clero parroquial y bajo clero en general. Evidentemente nuestro interés se centra, de modo especial, en esta última categoría, cuyos miembros eran los que poblaban nuestros pueblos.

La clasificación, que se puede hacer dentro de ellos, viene ofrecida por las respuestas dadas a la pregunta $38^{\circ}$ de las Respuestas Generales del Catastro del Marqués de Ensenada, donde encontramos los siguientes:

- Clérigos.

- Capellanes.

- Presbíteros.

- Curas párrocos.

- Tenientes de cura.

- Curas vicarios.

- Beneficiados.

- Regentes de cura.

- $\quad$ Órdenes menores.

Las diferencias entre cada una de ellas son prácticamente inapreciables o incluso inexistentes, pues dependen, por lo general, del término elegido a la hora de dar la otro más. 
respuesta a esta pregunta. Por ello, observamos, que existen una serie de términos, como son el de clérigo, presbítero, cura párroco y beneficiario, que son utilizados indistintamente en unos casos y otros para definir una misma realidad, como era la del sacerdote que atendía, por lo general en solitario, los oficios y necesidades espirituales de cada parroquia. Por ello, las únicas categorías, que realmente presentan algún tipo de diferencia entre sí, dentro del clero secular existente en estos pueblos, son las de los sacerdotes o curas párrocos, capellanes y órdenes menores, a las cuales, en algunos momentos podemos unir también la de curas vicarios ${ }^{401}$. Aun así, siendo rigurosos con las respuestas dadas por cada uno de estos pueblos a esta pregunta $38^{\circ}$, de las Respuestas Generales del Catastro del Marqués de Ensenada, nos encontramos con las categorías y números siguientes:

- Clérigos: 14.

- Capellanes: 8.

- Presbíteros: 4.

- Curas párrocos: 7.

- Tenientes de cura: 1.

- Beneficiados: 10.

- Órdenes menores: 2.

Total: 44.

Dejamos fuera, por lo tanto, a los sacristanes laicos, pues a pesar de que en muchos casos suelen ser considerados como una categoría más dentro del estamento eclesiástico, sus funciones generalmente no tenían nada que ver con el campo espiritual y sí con el puramente material, a través de su función de administradores de estas parroquias.

401 Estos curas vicarios se encuentran en localidades como Huerta de Arriba y Palacios de la Sierra, donde la desaparición de una de sus parroquias en diferentes momentos de este periodo de la Edad 
El otro gran grupo, dentro de este estamento eclesiástico, lo constituyen, como hemos indicado, los clérigos regulares. Dentro de ellos, la primera clasificación que se establece es por órdenes, y por sexos, pasando luego a diferenciar las distintas categorías existentes en el seno de cada comunidad o casa religiosa.

Realizar este análisis en nuestra comarca resulta relativamente sencillo, pues únicamente existía un centro religioso conocido, durante la Edad Moderna, como era el convento de Santa María de Alveinte. Se trata de un pequeño convento de religiosos franciscanos, ubicado en las proximidades de la localidad de Monasterio de la Sierra, pero asentado sobre un terreno comunal, que forma parte de las ledanías de Salas de los Infantes, Castrillo de la Reina, Monasterio de la Sierra y Hacinas. Por ello, en las Respuestas Generales del Catastro de Ensenada la información de este convento la encontramos dentro de la documentación correspondiente a Salas de los Infantes ${ }^{402}$.

En el momento de hacerse este catastro se declara que existían en este centro un total de 15 religiosos y 2 legos, sin especificar más detalles sobre la condición de cada uno de ellos. En el caso del censo de Floridablanca, por su parte, y a pesar de los errores que descubrimos en cuanto a su denominación (pues aparece nombrado con su antigua denominación de Nuestra Señora de los Lirios) y su adscripción (encuadrándolo dentro de la orden de los dominicos), encontramos más detalles sobre sus moradores, indicándonos, en consecuencia, que existían:

- Profesos: 8.

- Novicios: 1.

- Legos: 2.

- Criados: 1.

- Niños: 1.

Moderna, llevó a que se crearan estos vicariatos dependientes de la parroquia principal, colocando a su frente a sacerdotes, que pasaban a ocupar esta categoría.

402 ADPBU. CE. 1.740. RESPUESTAS GENERALES. Salas de los Infantes, 10 - febrero - 1753. 
A parte de esto, no es mucho más lo que podamos saber sobre este misterioso convento, al cual, según la tradición popular, iban a parar los frailes más díscolos o de frágil vocación, de la orden franciscana. Según esta misma tradición, en la portería del convento debía existir una inscripción, en la cual se podía leer la siguiente advertencia: “fraile qué hiciste que a Alveinte viniste”. Evidentemente un lugar tan apartado como éste, rodeado de los más bellos paisajes y convenientemente alejado de los grandes núcleos de población, donde residía la tentación, debía ser considerado como el retiro ideal en el que corregir todo tipo de desviaciones.

Dejando de lado a este grupo de los clérigos regulares, y volviendo al de los seculares, podemos observar, a través de los datos arrojados por las fuentes consultadas, que su número apenas registró variaciones significativas, dentro de nuestros pueblos a lo largo de todo el periodo estudiado. Así, tomando las referencias de los censos, en los que aparece especificado el número de clérigos existentes en cada pueblo, obtenemos los siguientes datos:

- Censo de 1591: 35 clérigos seculares.

- Censo de 1753: 44 “ “ “

- Censo de 1787: 39 “ “

Por lo tanto, debemos considerar que la atención espiritual en todos estos pueblos estuvo perfectamente atendida en todo momento durante la Edad Moderna, tanto en los núcleos pertenecientes a la diócesis de Burgos, como los de Osma. En el caso de los dependientes de la sede burgalesa, es necesario dejar perfectamente claro este aspecto, pues según afirma Domínguez Ortiz, parece que este arzobispado tuvo serias dificultades en algunos momentos del siglo XVII, para cubrir con párrocos todas y cada una de sus numerosísimas parroquias ${ }^{403}$. Todo ello a pesar de que la capital de Burgos contaba en estos momentos con 295 sacerdotes y 728 religiosos, para atender a una población de 3.319 vecinos $^{404}$.

\footnotetext{
403 A. DOMÍNGUEZ ORTIZ: La sociedad española en el siglo XVII. Tomo II. ob. cit.(pp. 6 - 7). 
Aun con todo, como decimos, la comarca de la sierra no parece que sufriera en ningún momento este tipo de penurias, pudiendo contar cada pueblo y cada parroquia, al menos, con un sacerdote. Las únicas excepciones las encontramos en Bezares y Regumiel de la Sierra, si bien, esta falta de asistencia en ambos casos parece que fue una simple circunstancia temporal. En Bezares vemos que en el momento de realizarse el Catastro de Ensenada no había cura párroco, pues el beneficiario de dicha parroquia se encontraba residiendo en Neila, mientras que los servicios religiosos eran atendidos por uno de los tres sacerdotes, que existían en la vecina localidad de Barbadillo de Herreros $^{405}$. Pocos años después, sin embargo, en el momento en el que se realiza el censo de Floridablanca, esta situación había sido ya corregida ${ }^{406}$. En el caso de Regumiel de la Sierra, encuadrado dentro de la Diócesis oxomense, se produce una situación parecida, pues en el momento de responder al cuestionario del Catastro de Ensenada se hallaba sin párroco. No obstante, a renglón seguido se indica que existe un curato, el cual se halla a la espera de su inminente designación por parte de la sede diocesana $^{407}$.

Evidentemente los encargados de proveer estos curatos son las respectivas sedes diocesanas, es decir, las de Burgos y Osma, pues en nuestra zona no tenemos constancia de que se produjera la práctica conocida como presentación, que sí era usada con relativa frecuencia en determinadas zonas del norte, en los territorios de diócesis, como la de Calahorra ${ }^{408}$. Las capellanías, sin embargo, eran provistas lógicamente por los propios patronos, según sus criterios.

Al margen de estas cuestiones de orden puramente estadístico, tenemos que hablar también de la calidad y carácter de estos clérigos, pues como bien sabemos, bajo este amplio manto del bajo clero secular se desarrollaba un mundo sumamente

\footnotetext{
405 ADPBU. CE. 297. RESPUESTAS GENERALES. Bezares, 5 - septiembre - 1753.

406 Censo de 1787. "Floridablanca”. Madrid, Instituto Nacional de Estadística. 1989.

407 ADPBU. CE. 1.633. RESPUESTAS GENERALES. Regumiel de la Sierra, 24 - mayo - 1753.
} 
heterogéneo, y en muchos casos complicado de definir, donde actuaban factores de orden espiritual, pero también otros puramente materiales, dependiendo de los recursos de que disponían.

Para analizar estos aspectos lógicamente no contamos con muchas fuentes de información, si bien, en atención a los datos suministrados principalmente por el Catastro de Ensenada, debemos considerar que existía una relativa uniformidad dentro del estamento eclesiástico de la zona. Evidentemente no todas las parroquias tenían el mismo reconocimiento, y por supuesto los mismos recursos, existiendo por ello curatos y beneficios más ricos que otros, sin embargo, las diferencias en ningún caso fueron tan grandes como para ser mencionadas.

Las desigualdades venían dadas, en este plano económico, fundamentalmente por el número de feligreses que diezmaba en cada parroquia, por la parte percibida del diezmo, y por los beneficios existentes dentro de cada curato. A este aspecto, aunque no contamos con datos absolutos para todo el periodo, debemos pensar que, si bien no existían curatos excepcionalmente ricos (como Domínguez Ortiz nos indica para algunos casos de Castilla durante el siglo XVII), absolutamente todos nuestros pueblos, incluidos los más humildes, contaban con los medios suficientes para mantener un curato, con la provisión de un generoso beneficio. Este beneficio estaría formado principalmente por un determinado número de tierras, prados y herrenes, a los que se podían sumar otros derechos y bienes. Las propiedades, que formaban estos beneficios, no tenían que encontrarse necesariamente dentro del propio término municipal del pueblo, sino que, como ocurría con cualquier otro propietario, estas heredades se repartían entre varios municipios vecinos.

Otra parte importante de los beneficios lo constituían los recursos obtenidos a través de los diezmos. El reparto del montante total se realizaba en cada parroquia de modo diferente, estableciendo distintas proporciones y beneficiarios, si bien en la

408 A. DOMÍNGUEZ ORTIZ: La sociedad española en el siglo XVII. Tomo II. ob. cit. (pp. 50 y ss). 
inmensa mayoría de nuestros pueblos, tanto los pertenecientes a la diócesis de Burgos como los de Osma, esa distribución se efectuaba de modo muy similar. Las proporciones eran las siguientes (fig 6):

- $\quad$ 1/3 para el beneficiario o beneficiarios de la parroquia.

- 1/3 para la sede de la diócesis (el arzobispado de Burgos u obispado de Osma, según el caso).

- 2/9 para el mantenimiento de la fábrica parroquial, el cual era conocido como la novena pontifical.

- 1/9 denominado tercias reales, percibido, en teoría, por la Corona, para el mantenimiento de la lucha contra el infiel, si bien en la inmensa mayoría de nuestros pueblos el beneficiario del mismo era el Duque de Frías.

La única excepción, que encontramos sobre este modelo de reparto, se halla en Barbadillo del Pez, donde su dependencia en origen de la colegiata de Covarrubias hace que se produzca una distribución completamente distinta. Aquí el reparto se hacía del siguiente modo (fig. 7):

- $\quad 3 / 9$ para los curas beneficiarios.

- 1.5/9 para la Inquisición de Logroño.

- $\quad$ 1.5/9 para la Colegiata de Covarrubias.

- 2/9 para el abad de esta colegiata de Covarrubias.

- 1/9 para la fábrica de la iglesia, como novena pontifical.

A parte de este caso de Barbadillo del Pez en algunos otros pueblos encontramos también pequeñas variaciones sobre el modelo general, las cuales afectan únicamente al nombre o entidad beneficiaria de cada una de las porciones, pero nunca a las proporciones en las que se distribuía el total recaudado. Dentro estas variaciones, sin duda, la más habitual era la que afectaba al tercio percibido por cada una de las sedes diocesanas, el cual iba a parar en su lugar a los destinatarios más variados. En Hoyuelos de la Sierra, por ejemplo, este tercio de los diezmos lo percibía el Colegio de Santa Cruz de Valladolid, en Monasterio de la Sierra, iba a parar a la Colegiata de San Quirce, en 
Monterrubio de la Demanda, al cabildo de la Colegiata de Valpuesta, en Terrazas al Convento de la Madre de Dios de Burgos, en Tolbaños de Abajo a manos del presbítero capellán de la villa de Canales, en Tolbaños de Arriba a manos de D. Francisco de San Llorente, canónigo magistral de la ciudad de Burgos, y en Vallejimeno era incluido en la parte correspondiente al beneficiario. Menos frecuente era el caso de Barbadillo de Herreros, donde la novena pontifical, destinada para el mantenimiento de la fábrica, era percibido por el Duque de Frías, o el ejemplo de Tolbaños de Abajo, en el cual el tercio correspondiente al beneficiario se repartía, a partes iguales, entre el concejo de la localidad y el propio beneficiario.

Antes de cerrar este apartado de los diezmos, tenemos que hacer una observación para el caso de los pueblos dedicados mayoritariamente a la trashumancia. En todos ellos, las cantidades percibidas por el concepto del diezmo de la lana eran más reducidas de lo que debería ser en realidad, pues una proporción importante del mismo era entregada por los ganaderos en los lugares de invernadero, produciendo el consiguiente menoscabo en la parroquia serrana de origen. Aun así ninguno de estos beneficiarios, ni sus parroquias, vivieron situaciones de apuro económico por esta situación.

Por último, tenemos que hablar también de la presencia y el papel que desempeñaban estos clérigos en la sociedad y la vida diaria de cada uno de estos pueblos. Volvemos a tomar aquí nuevamente las opiniones de Domínguez Ortiz, el cual sostiene, que la relación de estos clérigos con sus feligreses, dentro de un ambiente rural, como era el nuestro, sin duda sería mucho más estrecha y cercana que la que podían desarrollar los curas de parroquias urbanas ${ }^{409}$. Este autor estima que las relaciones con la feligresía debían ser en general cordiales, estando presididas incluso por un cierto tono paternalista, si bien, no existen testimonios ni estudios específicos que lo confirmen.

409 Ibídem. (pp. 59 y ss). 
Al mismo tiempo, junto con esta función pastoral, no debemos olvidar tampoco su destacada labor como impulsores de programas artísticos y obras arquitectónicas, encaminadas a renovar y mejorar sus templos parroquiales. Su implicación en estos proyectos fue, en algunas ocasiones, mucho más allá de la mera propuesta de ejecución, pues llegaron a ofrecer como adelanto importantes cantidades de dinero de su propio patrimonio, para que algunas de estas obras comenzaran a realizarse. Dentro de estos casos, sin duda, el más sobresaliente fue el de Hacinas, donde a lo largo del siglo XVII vemos cómo la iniciativa y el dinero de dos de sus párrocos permitieron iniciar, en momentos distintos, la construcción de la nueva torre del templo, y la ampliación de la zona del cuerpo. Otro caso singular lo encontremos en la pequeña localidad de Monasterio de la Sierra, donde la iniciativa de su sacerdote, D. Felipe Gómez, lleva a que, entre los años finales del siglo XVIII y principios del XIX, se renueve el templo prácticamente en su totalidad. Pero estos no son los únicos casos, pues ejemplos similares los encontraremos en pueblos más.

\section{Estado llano.}

Se trata, lógicamente, del grupo de los no privilegiados. Constituye, por lo tanto, una masa extraordinariamente amplia y heterogénea, donde se pueden establecer diferentes tipos de clasificaciones, si bien las más sencillas son las que podemos hacer en función de los distintos tipos de oficios desarrollados, y de la capacidad económica de cada individuo. Dentro de estas clasificaciones, evidentemente, no debemos olvidar nunca, y de modo especial para la centuria del Setecientos, el hecho de que un gran número de hidalgos llevaban una vida y desarrollaban unos quehaceres, que apenas se diferenciaban de las de sus convecinos, pertenecientes al estado llano.

Esto nos lleva, al mismo tiempo, a hablar de la cuestión de las incompatibilidades, que ciertos oficios parecían presentar con la condición de hidalguía. En el caso de los pueblos de nuestra zona lo vemos claramente reflejado en el mundo de la carretería, donde, cómo ya señalamos anteriormente, se producía una total ausencia de representantes de este estamento nobiliario en aquellas localidades, que vivían 
mayoritariamente de esta actividad del transporte a larga distancia. Por el contrario, no ocurría lo mismo en las localidades donde predominaban, tanto la agricultura como la ganadería, en las cuales la condición de hidalgo no constituyó nunca una barrera para desempeñar estos trabajos. Así, por ejemplo, en la localidad de Riocavado de la Sierra vemos cómo en el censo de Floridablanca de 1787 no existe ningún inconveniente para que sus 225 habitantes se declararan además de labradores, hidalgos ${ }^{410}$. Esta misma circunstancia se produce en el caso de Tolbaños de Abajo, pueblo dedicado mayoritariamente a la ganadería trashumante de ovejas merinas, el cual nos dice, en este mismo censo, que sus 157 habitantes eran todos hidalgos ${ }^{411}$.

Los oficios más corrientes, que podemos encontrar en nuestra comarca, como ya señalamos en el capítulo dedicado a la economía, son los ligados al aprovechamiento de los recursos de la zona, es decir, la agricultura, la ganadería y la carretería. Dentro de cada uno de ellos existía una variada clasificación por categorías, las cuales se encontraban perfectamente ordenadas, en función del trabajo que efectuaban y del salario percibido.

A parte de esto, encontramos también toda una serie de ocupaciones de naturaleza muy diversa, las cuales sirven para acercarnos a la realidad que se vivía en estos núcleos. Las fuentes de información, utilizadas para establecer estos listados de oficios, son las respuestas dadas por cada uno de estos pueblos al Catastro del Marqués de Ensenada, cuya interpretación, sin embargo, no está exenta de ciertas dificultades.

El primer inconveniente lo encontramos en la imposibilidad de conocer en muchos casos la función exacta de cada uno de estos oficios, pues la falta de precisión, tanto en la pregunta, como en las respuestas dadas, hace que una misma labor pueda ser expresada bajo distintas denominaciones. De igual forma, nos podemos encontrar el

\footnotetext{
410 Censo de 1787. “Floridablanca”. Ob. cit.

411 Ibídem.
} 
caso contrario, es decir, que el término empleado para definir un oficio en concreto sea usado en diferentes casos para aludir a actividades no del todo iguales.

Otra dificultad importante viene dada por la compatibilidad de tareas, o pluriempleo, propiciado por el hecho de que algunos oficios, desempeñados por los pobladores de esta comarca, sólo se realizaban ocasionalmente, durante periodos muy concretos del año. El origen de esto se encuentra en la abundante disponibilidad de tiempo libre, que ofrecían algunas ocupaciones, como eran las ligadas al mundo de la agricultura, la carretería o incluso la ganadería. Así, nos encontramos con carreteros que trabajaban también como artesanos de la madera, labradores que se dedicaban igualmente a la artesanía textil, ganaderos, que compaginaban esta actividad con la agricultura, y albañiles, carpinteros, canteros, herreros, etc., que alternaban su oficio con cualquiera de las actividades anteriores. La mayor parte de la población, por lo tanto, alternaba diferentes oficios a lo largo de los distintos periodos del año, con el fin de completar unos ingresos, que garantizaran una subsistencia digna.

Fuera de estas combinaciones, y en atención a las respuestas declaradas en el Catastro del Marqués de Ensenada, vemos que los oficios desarrollados en la zona eran los siguientes:

Administrador

Albañil

Alfarero

Aprendiz de cantero

Arriero

Boticario

Boyero

Campanero

Cantero

Carbonero

Carpintero 
Carretero

Cirujano

Correo

Fabricante de sayal

Guarda

Guarda de campo

Guarda de ganado vacuno

Guarda de ganado bovino

Guarda de ganado cabrío

Guarda de ganado de cerda

Herrador

Herrero

Labrador

Maestro

Maestro de paños

Médico

Notario

Oficial de carpintero

Pobres de solemnidad

Porteadores de vino

Pregonero

Relojero

Sastre

Taburetero

Tejedor

Zapatero 
NÚCLEOS DE POBLACIÓN.

Estos grupos humanos se agrupan en poblaciones de mediano y pequeño tamaño. En esta comarca, como suele ser habitual en las zonas de serranía, no encontramos ni poblaciones de grandes proporciones, ni ciudades, según la definición medieval del término, que considera como tales a las poblaciones que tuvieran “cerca y obispo”.

Tampoco existen aquí importantes centros urbanos, que, escapando de esta estricta definición medieval, aglutinen funciones y oficios propios de ellos, como podían ser los trabajos artesanales y de gobierno, independientemente de su volumen de población. Lo más parecido a esto, en nuestro caso, lo encontramos en la localidad de Salas de los Infantes. Aquí se hallaba uno de los administradores del Duque de Frías, el cual, en función del señorío jurisdiccional que se extendía por gran número de estos pueblos, venía a realizar ciertas funciones propias de gobierno. Igualmente en Salas encontramos asentados distintos oficios claramente diferenciados de las actividades agropecuarias características del medio rural, como es el caso de los médicos, cirujanos, boticarios, escribanos, canteros, sastres, alfareros, etc ${ }^{412}$, que aparecen reflejados dentro de las respuestas del Catastro del Marqués de Ensenada. Sin embargo, estas figuras 
aparecen encuadradas dentro de un medio dominado por una población dedicada mayoritariamente a la agricultura, la ganadería y la carretería, que afianzaba este carácter rural. Circunstancias muy parecidas se producen también en otras localidades de la zona, como es el caso de Palacios de la Sierra y Quintanar de la Sierra.

La presencia de un sector artesanal importante, tampoco constituye un factor atenuante, en este caso, del carácter rural, que nos permita intuir un acercamiento hacia el ambiente urbano. Los artesanos que existen en estos pueblos son, por lo general, hombres de campo, dedicados la mayor parte del tiempo a las actividades propias de la labranza y de la ganadería, si bien esto no impide que puedan efectuar, en algunos casos, determinados trabajos manufactureros. El ejemplo más destacado de ello, como bien sabemos, se encuentra en la villa de Barbadillo del Pez.

En todos los pueblos predomina una población rural poco concentrada, diseminada en poblaciones de pequeño y mediano tamaño, que reproduce el ejemplo de atomización, característico de la mayor parte de la meseta norte de la península durante toda la Edad Moderna. La media de vecinos por pueblo para el periodo de la modernidad, se sitúa en torno a 70, según los datos del censo de 1591, elevándose hasta los 85, en el siglo XVIII, según la información del censo de Ensenada. No obstante, dentro de estas medias nos encontraremos, como hemos visto al hablar de la evolución demográfica, con localidades con un número de vecinos relativamente alto, como es el caso de Canicosa de la Sierra, Castrillo de la Reina, Huerta de Arriba, Palacios de la Sierra, Quintanar de la Sierra, Salas de los Infantes o Vilviestre del Pinar, las cuales consiguen sobrepasar con mayor o menor holgura los 100 vecinos. En el lado contrario encontramos poblaciones extremadamente humildes, con medias que difícilmente superan los 30 vecinos, quedándose por lo general entre los 20 y 25 vecinos. Entre ellas podemos citar las localidades de Arroyo de Salas, Bezares, Castrovido, Hoyuelos de la Sierra, Quintanilla de Urrilla o Terrazas.

412 ADPBU. CE. 1.740. RESPUESTAS GENERALES. Salas de los Infantes, 10 - febrero - 1753. 
Otra cuestión es la relacionada con la fisonomía característica de estos núcleos, la cual se ve condicionada, tanto por las características del medio físico, como por las consecuencias del devenir histórico.

Así, en un medio montañoso como éste, caracterizado por su abrupta orografía, se tiende a buscar zonas especialmente protegidas de los agentes climáticos. Vemos, por lo tanto, que la mayor parte de estos núcleos se encuentran asentados sobre suaves laderas orientadas, por lo general, hacia el mediodía, evitando así las consecuencias demoledoras de los vientos procedentes del norte. De igual forma, se evita ocupar el fondo de los valles, pues aquí se situaba habitualmente la tierra más fértil del término municipal, la cual era necesario emplear para la labranza.

El proceso histórico es el otro gran factor a tener en cuenta, dentro de la creación y configuración de estas poblaciones. La creación de los primeros núcleos de población se produce, como sabemos, en plena época prerromana, con la construcción de los característicos castros celtíberos, formados por pequeños poblados situados en lugares elevados, que se rodeaban de un perímetro amurallado para protegerse de las posibles amenazas exteriores $^{413}$. Sin embargo, no es aquí donde encontramos los antecedentes de las poblaciones, que se desarrollan posteriormente. Para encontrar estos precedentes tenemos que adelantarnos hasta el periodo medieval, y más en concreto hasta los siglos IX y $\mathrm{X}^{414}$. Esto descarta las hipótesis, que sitúan este origen en los periodos romano y visigodo, pues como sabemos durante estas épocas en ninguno de los casos se produjeron asentamientos estables y de tan larga duración, como para permitir, que se constituyeran en el embrión de futuras poblaciones.

413 J. D. SACRISTÁN DE LAMA, I. RUÍZ VÉLEZ: La Edad del Hierro. En Historia de Burgos I. Edad Antigua. Burgos, Caja de Ahorros Municipal de Burgos. 1985. (pp. 179 - 220).

414 F. J. PEÑA PÉREZ: "El triunfo de la aldea en una sociedad en crecimiento: El territorio burgalés en los siglos plenomedievales”. En Historia de Burgos, desde sus orígenes hasta nuestros días. Tomo 2. Desde el año 1000 a los Tiempos Modernos. Burgos, Diario 16 Burgos. 1993. (pp. 339 - 350). 
Este embrión se encuentra, por el contrario, en la tupidísima red de pequeños poblados que surge entre los siglos IX y X, los cuales son mejor conocidos por sus restos arqueológicos, que por los testimonios documentales, que han quedado de ellos. Se trata de un poblamiento efectuado de forma anárquica, el cual viene a constituir una tupida red de pequeños núcleos situados a poca distancia unos de otros. La concentración que se alcanza es tal, que, dentro del marco territorial que actualmente constituyen los 26 pueblos de nuestro estudio, hemos llegado a contabilizar en este periodo un total de 60 núcleos, de los cuales más del 70 \% desaparecen en un corto espacio de tiempo $^{415}$.

Esta excesiva concentración de pequeños núcleos lleva a que, poco después de su formación, comiencen a producirse los primeros despoblados, lo que debemos encuadrar dentro de un proceso lógico de reajuste poblacional. Los centros asentados en las zonas más apropiadas, con unas mejores condiciones medioambientales y con un mayor número de habitantes, comienzan a absorber a los pobladores de los núcleos menos favorecidos. A ello debemos unir el hecho de que muchos de estos primeros asentamientos se habían efectuado en zonas poco propicias para el desarrollo de las actividades agrícolas y pastoriles, llegándose así a un temprano abandono, el cual dejaba tras de sí algunos restos, entre los que se encuentra, muy posiblemente, alguna pequeña ermita.

En nuestra comarca el momento álgido de este reajuste, y la consiguiente despoblación de numerosos núcleos, se produce en torno al siglo XII, lo que descarta las hipótesis que vienen a explicar este proceso como un efecto de los brotes epidémicos, que se sucedieron durante el periodo medieval, entre los que se encuentra la terrible Peste Negra del siglo XIV ${ }^{416}$. De este modo, el Becerro de las Behetrías, de mediados

\footnotetext{
415 G. MARTíNEZ DÍEZ: Pueblos y alfoces burgaleses de la repoblación. Valladolid. Junta de Castilla y León. Consejería de Educación y Cultura. 1997.

416 L. MARTÍNEZ GARCÍA: "La depresión del siglo XIV y la recuperación del siglo XV: la perspectiva demográfica”. En Historia de Burgos, desde sus orígenes hasta nuestros días. Tomo 2. Desde el año 1000 a los Tiempos Modernos. Burgos, Diario 16 Burgos. 1993. (pp. 435 - 446).
} 
del siglo XIV, únicamente viene a dar testimonio del final del proceso de despoblación, pues en él únicamente aparecen recogidas las poblaciones que continúan existiendo hasta nuestros días. La única excepción lo constituye la localidad de Villaserrazín, situada en las inmediaciones de Barbadillo del Pez, que en este momento aparece también como despoblado ${ }^{417}$.

Un efecto de esta concentración lo tenemos en las numerosas iglesias románicas que se construyen durante el siglo XII en la mayoría de estos pueblos, de las cuales, en mayor o menor medida, han quedado restos en casi todos ellos. Evidentemente esto es la respuesta, entre otras cosas, al aumento poblacional que se registra al recibir la población de los núcleos despoblados.

Entre estos núcleos, y durante este mismo periodo, aparecen también en nuestra zona un nutrido grupo de pequeños monasterios, la mayoría de ellos muy poco conocidos. A ello contribuye, evidentemente, el hecho de que ninguno de ellos haya dejado restos materiales importantes, lo que hace que las únicas referencias que confirmen su existencia las encontremos en una serie de escuetas alusiones conservadas en las fuentes documentales. Entre los que hemos conseguido localizar se encuentra el de San Cristóbal, situado entre las actuales localidades de Huerta de Abajo y Vallejimeno, el de San Mamés, que existía en Huerta de Arriba, el de San Millán de Revenga, ubicado en el terreno comunal que actualmente administran Canicosa de la Sierra, Quintanar de la Sierra y Regumiel de la Sierra, y el de San Pelayo en Salas de los Infantes.

Desde el siglo XIII, por lo tanto, tenemos configurado el mapa poblacional definitivo, con el grupo de núcleos que luego se mantienen a lo largo de toda la Edad Moderna. Durante este periodo de la modernidad no se produce ningún nuevo

\footnotetext{
417 G. MARTíNEZ DÍEZ: Libro Becerro de las Behetrías. Estudio y texto crítico. León. Centro de Estudios e Investigación San Isidoro. Caja de Ahorros y Monte de Piedad. Archivo Histórico Diocesano. 1981.
} 
244 Arquitectura de la Edad Moderna en la sierra burgalesa.

despoblamiento, a pesar de los pronunciados descensos demográficos que hemos podido detectar en alguna de estas localidades.

Sin embargo, la despoblación rural durante el periodo que se extiende desde finales del siglo XVI a lo largo de todo el siglo XVII parece que fue una de las principales consecuencias del clima generalizado de crisis que se vivió en Castilla en estos momentos. Las únicas causas de este proceso no debemos buscarlas en las epidemias y hambrunas frecuentes, aunque sin duda constituyeron muchas veces una reiterada cuestión de fondo. Domínguez Ortiz, por su parte, enumera una amplia relación de factores, que llevan a que muchos núcleos castellanos vieran descender su número de habitantes hasta terminar en la despoblación más absoluta. Entre ellos se encuentran algunos de carácter más general, como puede ser el caso de la decadencia de la Monarquía, el exceso de eclesiásticos o el éxodo rural masivo, atraídos por el ejército, las Indias, o los núcleos más populosos y prósperos. Sin embargo, existen otras razones que inciden más directamente en esta cuestión, entre las que se encuentra la agobiante presión fiscal y la venta indiscriminada de tierras baldías ${ }^{418}$.

La cuestión relacionada con la presión fiscal tenemos que relacionarla con el sistema de reparto mediante encabezamientos, pues el descenso del número de vecinos pecheros hacía que aumentara la carga tributaria sobre los que permanecían, hasta hacerla realmente insoportable. La venta de baldíos, a su vez, constituye otro factor igualmente perjudicial, en este caso para los núcleos más pequeños y desprotegidos. Así, la exigüidad del termino municipal de muchas de estas poblaciones hacía que sus habitantes dependieran de forma casi exclusiva para su manutención de lo que podían extraer de las tierras comunales. Dentro de nuestra zona de estudio, esta circunstancia se produce en localidades como Arroyo de Salas, Castrovido o Terrazas, en las cuales la venta de baldíos hubiera llevado a su inevitable desaparición.

418 A. DOMÍNGUEZ ORTIZ: La sociedad española en el siglo XVII. Tomo I. ob. cit. (pp. 118 y ss.). 


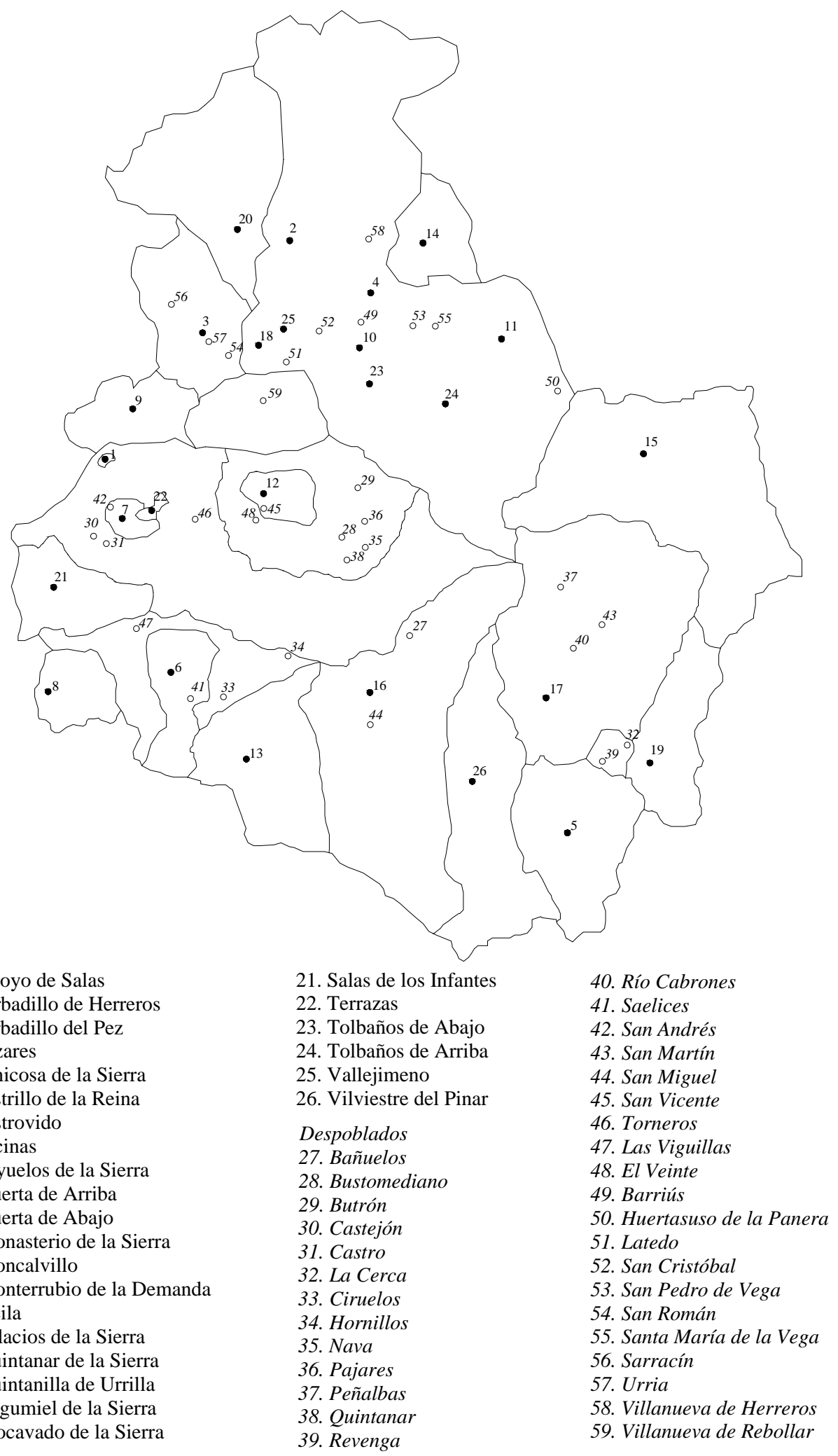

Mapa de despoblados. 
Sin embargo, estas situaciones nunca llegaron a producirse dentro de nuestra comarca, pues como apunta Domínguez Ortiz, en general las poblaciones ubicadas en zonas de serranía consiguieron resistir mejor ante estos factores propiciatorios de despoblación ${ }^{419}$. Así vemos, como su propio aislamiento los deja a salvo de la atracción, que podían ejercer las ciudades sobre sus vecinos, y del tránsito y alojamiento de tropas. Esta misma circunstancia evitaba igualmente los excesos fiscales y amortizaciones de tierras, que tan frecuentes fueron en otras zonas más atractivas, desde el punto de vista tributario. Al mismo tiempo, vemos cómo la posibilidad, que existía en estos pueblos de tener una economía más diversificada, combinando agricultura y ganadería, y no dependiente únicamente de la labranza, hacen que se puedan mantener con mayor seguridad los índices de subsistencia, escapando las más de las veces de las crisis alimentarias, que solían darse en otras zonas. Por todo ello, observamos que en esta comarca no se produce ningún caso de un fenómeno, que por lo que parece, resultó relativamente frecuente en el resto de Castilla.

\section{CONFIGURACIÓN DE LOS PUEBLOS.}

La comarca serrana, comparada con otras zonas de la provincia de Burgos, se caracteriza por su baja densidad poblacional, lo que se debe principalmente a la naturaleza montañosa del medio, ofreciéndonos por ello amplios vacíos poblacionales. Son pueblos, además, de pequeño o mediano tamaño, cuya imagen se llega a confundir, en muchas ocasiones, con el propio medio físico que los rodea, afianzado todo ello por una destacada masa boscosa. Sin embargo, frente a esta tónica general, nos encontramos también con núcleos que superan ampliamente esta media, como ocurre fundamentalmente en la zona de pinares, con pueblos como Canicosa de la Sierra, Palacios, Quintanar o Vilviestre.

419 Ibídem. (pp. 126). 
Los emplazamientos más habituales, elegido por todos estos núcleos, son las suaves laderas, orientadas preferentemente hacia el mediodía, para así evitar los duros efectos del viento norte. De igual modo, se tiende también a evitar la ocupación de los valles y vegas, pues es en estos puntos donde se encuentra la tierra más fértil y productiva, la cual, por ser un bien escaso, había que aprovechar al máximo. Por ello, son muy pocos los pueblos que ocupan las márgenes inmediatas de los ríos, prefiriéndose, por el contrario, respetar en unos cuantos metros estos cursos. Esto ocurre, por ejemplo, en las localidades situadas junto al río Arlanza, como es el caso de Quintanar de la Sierra, Vilviestre del Pinar, Palacios de la Sierra, Terrazas y Salas de los Infantes, donde las primeras viviendas nunca estaban a menos de unos 50 ó 100 metros de estas márgenes ${ }^{420}$. Un caso excepcional lo constituye Barbadillo del Pez, situado en la misma orilla del río Pedroso, en la salida del desfiladero que conduce hacia las localidades de Barbadillo de Herreros y Riocavado de la Sierra, desarrollando así un tipo de emplazamiento que se encuentra perfectamente reconocido dentro de la provincia de Burgos ${ }^{421}$. Sin embargo, incluso en este caso, vemos que las zonas donde están asentados los edificios se corresponden con suelos pedregosos y de escasa productividad agrícola, dejando libre, por el contrario, las parcelas de tierra más fértil.

Casos menos frecuentes son los que desarrollan emplazamientos irregulares, con superficies que combinan diferentes laderas de orientación variada. Este es el caso de Castrillo de la Reina, situada sobre una superficie rocosa de pequeñas y suaves lomas. También bastante infrecuentes son los casos de asentamientos sobre superficies demasiado inclinadas, circunstancia ésta que solamente vemos reflejada en determinados barrios de algunos municipios, pero que en modo alguno es extensible a todo el núcleo. Y por supuesto, los casos que nunca encontraremos aquí son los

420 En los casos de Palacios de la Sierra y Salas de los Infantes, sólo en época muy cercana se ha procedido a ocupar esta zona próxima a las márgenes de los ríos, y ello con unos efectos realmente dramáticos, pues las frecuentes avenidas de este río en época de exceso de lluvias o de deshielo, han creado situaciones francamente comprometidas. 
emplazamientos sobre superficies llanas, fundamentalmente porque éstas apenas existen, y cuando las encontramos quedan reservadas para la actividad agrícola.

En otro orden de cosas, tenemos que decir también, que estos pueblos presentan pocos hitos reconocibles, pues no cuentan en ninguno de los casos con grandes conjuntos monumentales, que consigan atraer la atención del visitante. Así, los únicos elementos que destacan en todos ellos son las torres y espadañas de las iglesias parroquiales, a través de las cuales se pretende señalar la presencia y personalidad de cada población en la distancia.

La falta de una ordenación precisa en el crecimiento de los pueblos a lo largo de la historia ha llevado a que todos ellos presenten un marcado carácter orgánico con profunda inclinación hacia la irregularidad, tanto en la disposición de sus edificios, como en el trazado de sus calles. Se trata además, fundamentalmente, de núcleos compactos, ordenados en torno a grupos de casas, que forman pequeñas manzanas, entre las cuales apenas quedan espacios libres. No obstante, tampoco resultan extraños los núcleos de estructura más esponjosa, en los cuales se produce una mayor dispersión de los edificios. Esto se debe a varias razones, entre ellas a la existencia de distintos barrios, con clara diferenciación entre ellos, lo que lleva a que una misma población pueda estar separada en diversos núcleos más pequeños. Así ocurre en aquellas poblaciones que contaron con más de una parroquia, como es el caso de Neila o Salas de los Infantes, donde existe una separación física evidente ${ }^{422}$. Más frecuente, dentro de estos argumentos propiciadores de estructuras esponjosas, es la inclusión de determinados espacios dedicados a huertas dentro del propio casco urbano. En estos casos, nos encontraremos con amplios grupos de casas, con las cuales se delimitan

421 J. L. GARCÍA GRINDA: Arquitectura popular de Burgos. Crítica y teoría de la arquitectura popular: tipos y caracterización de la arquitectura rural autóctona castellano-leonesa: el caso burgalés. Burgos, Colegio Oficial de Arquitectos de Burgos. 1988. (pp. 111).

422 En el caso de Salas de los Infantes este espacio ha sido cubierto actualmente por el crecimiento de la ciudad en época ya muy reciente, sin embargo, en el caso de Neila esta separación no sólo no ha 
espacios de terreno más o menos amplios, que se dedican al cultivo intensivo. Ejemplos de ello los podemos encontrar en casi todos los núcleos estudiados. Por último, tenemos que señalar también la falta total de cercos amurallados, como elemento favorecedor de esta circunstancia, pues no en vano esto ha permitido un crecimiento mucho más libre y desahogado a lo largo de la historia, tendiendo a diluirse muchas veces la frontera clara entre el campo y el espacio propiamente urbano.

Al margen del tipo de plano desarrollado en cada caso, dentro del caserío que forman todos estos pueblos nos encontramos con la presencia de una serie de edificios, que debemos considerar como elementos relevantes dentro de su estructura, los cuales proceden tanto de la arquitectura religiosa como de la civil.

\section{Ámbito religioso.}

Dentro de la arquitectura religiosa, evidentemente, el elemento principal lo constituye la iglesia parroquial. En este caso, la mayoría de los pueblos de nuestra comarca de estudio presentó, a lo largo de la Edad Moderna, un carácter uniparroquial, con lo cual su iglesia se convierte en el único centro religioso vertebrador del plano. Sin embargo, en los casos donde existía más de una parroquia, como sucedía en Huerta de Arriba, Neila, Palacios de la Sierra o Salas de los Infantes, el comportamiento fue diverso. Neila y Salas, que mantienen sus dos parroquias a lo largo de todo el período estudiado, reflejan esta circunstancia a través de un desdoblamiento de su casco urbano en dos barrios perfectamente diferenciados. De este modo, los barrios de Santa María y San Miguel en Neila, y Santa María y Costana en Salas, presentan un comportamiento similar al de las localidades uniparroquiales, con sus respectivas iglesias como elemento más destacado.

En el caso de Palacios de la Sierra el hecho de ver como desaparece una de sus parroquias en un momento relativamente temprano de la Edad Moderna - hecho que 
quedó consumado en $1591^{423}$ - lleva a que el carácter biparroquial tenga una menor incidencia dentro del propio plano de la villa. No en vano, vemos además que esta fusión de las dos parroquias en una sola no hacía sino reflejar una realidad que ya se había producido dentro de la propia estructura del pueblo, pues a lo largo de la Baja Edad Media y principios de la Edad Moderna esta localidad había experimentado un marcado proceso de compactación de su caserío, aglutinando en un solo conjunto los diferentes barrios, que anteriormente existían. Huerta de Arriba, por su parte, presenta un modelo más original en esta zona, aunque no por ello menos frecuente en otros lugares de la provincia de Burgos. Aquí la desaparición de una de sus dos parroquias, como era la de Santa María, se produce como consecuencia de la paulatina despoblación que sufre el barrio que componía su feligresía, hasta quedar totalmente deshabitado, dejando a su iglesia - convertida ya en ermita - completamente aislada, fuera del caserío del pueblo. Esta desaparición de la parroquia de Santa María se produce en 1718, si bien, durante toda la Edad Moderna se había vivido un gradual traslado de vecinos hacia el barrio encabezado por la iglesia de San Martín, que a la postre queda como sede de la única parroquia del pueblo. Los motivos, en este caso, están sobradamente demostrados, pues las mejores condiciones que ofrecía el emplazamiento del barrio de San Martín, sobre la suave ladera que conduce hacia el valle del río Tejero, terminaron por atraer a todos los vecinos del pueblo.

En los casos de los pueblos con una sola parroquia, que como decimos son los dominantes, su iglesia constituye el más importante hito referencial, el cual se manifiesta, tanto en el propio trazado interior de cada núcleo, como en la imagen que nos ofrecen desde la lejanía. Así, estos templos aparecen presidiendo todos y cada uno de estos pueblos, bien ocupando la parte central del plano ${ }^{424}$, o bien situándose en el punto más alto de las suaves laderas en las que se dispone el resto del caserío ${ }^{425}$.

\footnotetext{
423 A. M. Palacios de la Sierra. Clasific. 040107. Sig. 4849. Palacios de la Sierra, 9 - diciembre - 1591. 424 Es el caso de Barbadillo de Herreros, Barbadillo del Pez, Castrillo de la Reina, Monasterio de la Sierra, Neila (en sus respectivas parroquias), o Quintanar de la Sierra.
} 
Son templos que, como ocurre generalmente en la mayoría de los casos, dentro del mundo católico, exceden de forma notable las propias posibilidades y recursos de la sociedad que se encarga de levantarlos y remodelarlos. Así, dentro de una estructura urbana como es la de los pueblos de la sierra, en la que predominan edificios de escasa altura, elaborados mediante técnicas muy sencillas de sillarejo y mampostería, el templo o templos parroquiales se convierten, en todos los casos, en la construcción más destacada, mostrando una altura muy superior al resto, y una técnica de elaboración mucho más cuidada.

Una superioridad en altura que se afianza por su ubicación en la parte más elevada del pueblo, y sobre todo por la presencia de las torres-campanarios, cuyo papel de voz de llamada a los fieles, rigiendo los distintos momentos de la jornada diaria, se complementa con el carácter de hito referencial dentro del paisaje circundante. Por su parte, en el apartado técnico, estos templos no sólo mantienen durante gran parte de este período la exclusividad del uso de paramentos de sillería, sino que durante toda la Edad Moderna son las únicas construcciones que cubren su espacio interior con bóvedas de piedra. Se trata, en definitiva, de utilizar el valor simbólico que posee la aplicación de estas técnicas, con el fin de dignificar la casa de Dios, diferenciándose así del resto de los edificios circundantes.

Estos templos, en definitiva, no son otra cosa que el fruto del impulso y anhelo colectivo de los habitantes de cada una de estas poblaciones, que tratan de plasmar en ellos sus mejores deseos de superación. Por ello, no importa los sacrificios que había que afrontar para su construcción o remodelación, con tal de poder mostrar a las generaciones venideras y al mundo - especialmente al mundo más próximo, el de sus vecinos más inmediatos -, el poder y la entrega de estos núcleos. No estamos hablando, por lo tanto, de obras funcionales, en el estricto sentido del término, sino de construcciones dominadas por la llamada estética de lo perdurable, que tenía que servir de escaparate ante sus contemporáneos y ante la posteridad. Por ello, estos templos se 
hallan siempre rodeados de conceptos ajenos a su propia finalidad, como edificios dedicados estrictamente a la reunión de fieles para el desarrollo del culto, añadiendo otra serie de componentes, que nos permiten hablar de ellos, como elementos de cultura, como testigos de la historia de cada pueblo, y también como punto de referencia dentro del paisaje, y medio para mostrarse hacia el exterior.

En lo que se refiere al apartado de las advocaciones, vemos que no se producen variaciones significativas con respecto al panorama que podemos ver en el resto del territorio burgalés. No obstante, como principal peculiaridad, debemos destacar aquí la gran variedad de santos que existe. Así, dentro de los 30 templos parroquiales que tenemos, encontramos un total de 15 advocaciones diferentes. Esto hace, que el desequilibrio que existe en la provincia de Burgos, favorable a los templos dedicados a santos, en detrimento de las advocaciones marianas o de las figuras de la Divinidad, sea aquí aun mayor.

De este modo, la Virgen María sólo aparece presidiendo un total de cuatro iglesias parroquiales, de las cuales sólo una, la de Barbadillo de Herreros, presenta una advocación concreta, como es la de Nuestra Señora de la Visitación. Este templo, además presenta una historia curiosa, pues durante buena parte de esta etapa de la Edad Moderna estuvo presidida por la advocación general de Santa María la Mayor, adquiriendo su nueva advocación sólo al final del período ${ }^{426}$. Esto hace que, mientras la portada renacentista se encuentra presidida por la imagen de la Virgen con el Niño, la hornacina central del retablo del altar mayor está ocupada por la escena del encuentro entre María e Isabel. Para complicarlo aun más, debemos decir también que este templo en la actualidad es conocido por los vecinos del pueblo como la iglesia de Santa Isabel.

Otro caso de cambio de advocación durante este período es el que se produce en Palacios de la Sierra, con ocasión de la desaparición de su parroquia de Santa María. En este momento, el trasladar la imagen de la Virgen a la iglesia, que queda como única

426 C. RUBIO VELASCO: Barbadillo de Herreros. Burgos, Imprenta Santos S.L. 2001. (pp. 191). 
parroquia, dedicada hasta el momento a Santa Eulalia, hace que cambie su advocación, dedicándose ahora a Santa María, mientras que la santa emeritense es llevada a la antigua iglesia, ahora ermita, de Santa Eulalia. En el siglo XIX, al producirse la ruina de ésta, la imagen de Santa Eulalia fue llevada nuevamente a su antigua iglesia, que pasa, a partir de entonces, a denominarse parroquia de Santa María y Santa Eulalia (y a nivel popular simplemente como Santa Eulalia), si bien esta santa no consiguió recuperar su puesto honor en la hornacina central del retablo mayor, cuyo puesto sigue ocupando Santa María.

Las figuras de la Divinidad son igualmente escasas, lo que hace que encontremos un solo caso de templo parroquial, dedicado a una de estas Tres Personas. Esto sucede en la parroquial de Barbadillo del Pez, dedicada a Cristo Salvador.

En las iglesias dedicadas a santos, la variedad es tremendamente amplia, lo que hace que sean muy pocos los que repiten parroquia. Aun así, en los casos en los que esto sucede apreciamos una evidente sintonía con lo expresado para el resto de la provincia. Así, San Martín y San Pedro son los santos más repetidos con cinco y tres iglesias respectivamente. Iguala el número de tres iglesias San Esteban, seguido por San Juan Bautista con dos. El resto de las parroquias de estos pueblos nos ofrece un largo listado de once santos diferentes entre los que incluimos también uno dedicado al arcángel San Miguel. Estos santos son los siguientes: San Adrián, Santa Cecilia, Santa Coloma, Santa Cristina, San Cristóbal, Santa Eugenia, Santa Eulalia, San Julián, Santa Lucía, y San Quirico y Santa Julita.

Junto a estas iglesias parroquiales debemos destacar también, dentro de la arquitectura religiosa de la zona, la importante presencia de ermitas, las cuales aparecen situadas, tanto en el interior del propio casco urbano de cada uno de estos pueblos, como en su término municipal. Su presencia, por lo tanto, debemos considerarla como un hito importante, dentro de la configuración y ordenamiento del territorio que 
254 Arquitectura de la Edad Moderna en la sierra burgalesa.

compone nuestra área de estudio, pero al mismo tiempo representan también un fiel reflejo de la espiritualidad popular o local, vivida por estas gentes.

Resulta prácticamente imposible precisar el origen concreto de cada una de ellas, si bien, en nuestro caso parece fácil relacionar la aparición de varios de estos edificios con la presencia de núcleos, que fueron despoblados en época temprana, en torno a los siglos XI-XII, quedando sus edificios religiosos como único testimonio material de su existencia. Esta relación se encuentra perfectamente probada documentalmente en algunos casos como el de Nuestra Señora de Rebollar en el comunal de Trasomo administrado de forma comunal por los pueblos de Barbadillo del Pez, Hoyuelos de la Sierra, Quintanilla de Urrilla y Vallejimeno ${ }^{427}$-, en la ermita de San Quirico y Santa Julita en Barbadillo del Pez, que fue iglesia parroquial de Villaserrazín ${ }^{428}$, en la ermita de San Justo y San Pastor en Bezares ${ }^{429}$, que fue iglesia del antiguo poblado de Villanueva de los Ferreros ${ }^{430}$, y en la ermita de Nuestra Señora de Barriús, en Huerta de Abajo, antigua parroquia del despoblado de Barriús ${ }^{431}$.

El origen de otras ermitas se encuentra relacionado con la presencia de antiguos monasterios o eremitorios, diseminados por la zona desde la Alta Edad Media. Este es

\footnotetext{
427 Este terreno con su ermita fue vendido en 1190 a estos pueblos por el rey Alfonso VIII por un importe de dos mil carneros. El documento, que acredita esta compra-venta, fue hallado de forma casual en el Archivo Municipal de Barbadillo del Pez, entre los escasos restos que se salvaron tras uno de sus incendios. A pesar de que actualmente se encuentra en paradero desconocido, hemos tenido el privilegio de consultarlo a través de una copia facilitada por D. Jesús Moral Quintanilla, antiguo alcalde de Vallejimeno J. GONZÁLEZ: El Reino de Castilla en la época de Alfonso VIII. Madrid, 1960. Tomo II, doc. 540 (pag. 927).

${ }^{428}$ G. MARTíNEZ DÍEZ: Libro Becerro de las Behetrías. Estudio y texto crítico. Vol. II. León. Centro de Estudios e Investigación San Isidoro. Caja de Ahorros y Monte de Piedad. Archivo Histórico Diocesano. 1981.

429 AGDBU. LP. Bezares, parroquia de Santa Lucía. LF. (1685 - 1729). (fols. 54 - 56). Visita realizada a la parroquia de Santa Lucía de Bezares en 1715, por D. Alonso de Cossio Barreda. Barbadillo de Herreros, 5 - junio - 1715.

430 L. SERRANO: Cartulario de San Pedro de Arlanza. Madrid. Centro de Estudios Históricos, 1925. (pp. 276).

431 G. MARTÍNEZ DÍEZ: Pueblos y alfoces burgaleses de la repoblación. Ob. cit. (pp. 198).
} 
el caso de la ermita de San Pelayo en Salas de los Infantes, relacionada con un antiguo priorato, dependiente del monasterio de Santo Domingo de Silos, activo entre los siglos XII y XIV ${ }^{432}$. Un caso similar puede ser el de la ermita de Nuestra Señora de Revenga, vinculado a un antiguo monasterio dedicado a San Millán, si bien, también podríamos relacionar este templo con la presencia de un antiguo despoblado, conocido como Revenga $^{433}$.

El origen del resto de estas ermitas debemos relacionarlo simplemente con la propia devoción de la comunidad de fieles, encauzada, bien a través de cofradías que patrocinan sus propias construcciones, o bien a través del patronato de los concejos de vecinos. Mucho menos frecuentes parecen ser las ermitas que surgieron por el patrocino particular de una sola persona o familia. No obstante, también aquí encontramos algunos ejemplos, como lo demuestra la ermita de la Virgen Blanca de Hoyuelos de la Sierra, patrocinada en 1503 por el clérigo Pedro Fernández Barrio ${ }^{434}$, o la donación de Dña. María de Santiago a principios del siglo XVIII para la construcción de una ermita dedicada a Nuestra Señora de la Soledad en el término de Canicosa de la Sierra, si bien esta última no llegó a construirse nunca ${ }^{435}$.

Todas estas ermitas representan, en cualquier caso, un extraordinario ejemplo de la autoridad de los laicos en materia religiosa, pues como bien podemos entender, la administración de la mayoría de ellas recaía en manos de mayordomos seglares, que dependían de los concejos o cofradías, ejerciendo el papel patronos. Pero al mismo

432 E. GONZÁLEZ BARRIUSO: Salas de los Infantes en la Sierra Burgalesa. Burgos, Grupo Editorial 7. 1999. (pp.109).

433 Ibídem. (pp. 186); I. ÁLVAREZ BORGE: Poder y relaciones sociales en Castilla en la Edad Media. Los territorios entre el Arlanzón y el Duero en los siglos X - XIV. Salamanca, Consejería de Educación y Cultura. Junta de Castilla y León. 1996. (pp. 60 - 61); M.L. LEDESMA: Cartulario de San Millán de la Cogolla (1076 - 1200). Zaragoza, 1989, docs. 190 y 254; L. SERRANO: Cartulario de San Millán. doc. 76.

434 G. MIGUEL OJEDA: “Hoyuelos de la Sierra”. BIFG, nº 149. (1959). (pp. 799 - 805). 
tiempo, debemos verlas también como el reflejo o consecuencia más directa de la forma en que la religión era entendida en el ámbito popular, lo cual algunos autores como William Christian Jr. llaman religiosidad local ${ }^{436}$.

Esta religiosidad se presenta como una auténtica alternativa, frente a la que podemos considerar como la religión oficial, representada por la estructura jerárquica de las Diócesis. Sin embargo, la relación que se establece entre estos dos modos de religiosidad, en ningún momento debemos entenderla como excluyente, sino de clara compenetración. Así, dentro de este marco, estas ermitas y santuarios se constituyen en la alternativa a los lugares de culto oficiales, como eran las iglesias parroquiales. Una alternativa, que termina por convertirse, en muchos casos, en una fuerte competencia para estas fábricas parroquiales, pues gran parte de las limosnas, entregadas de forma voluntaria por los fieles, acaban en las arcas de estos santuarios, con el consiguiente perjuicio para aquellas. Esto lleva, en no pocas ocasiones, a que las fábricas parroquiales tengan que recurrir a la ayuda económica de estas ermitas para poder afrontar los gastos generados por determinados programas constructivos ${ }^{437}$.

Esto, en definitiva, es la consecuencia de la mayor identificación que se produce entre la población y los titulares de estos santuarios, la cual resulta mucho más estrecha que con las advocaciones de carácter más general, que presiden sus iglesias parroquiales. Esta mayor cercanía está propiciada principalmente por la particularización de las advocaciones universales del cristianismo, como son la Virgen o Cristo, en imágenes muy específicas, como es el caso del Santo Cristo de Zalamea (en

435 AGDBU. LP. Canicosa de la Sierra, parroquia de San Esteban, LF, (1677 - 1765), (fols. 112v $117 \mathrm{v}^{0}$ ). Visita realizada a la parroquia de San Esteban de Canicosa de la Sierra en 1704, por D. Blas de Tobalina, canónigo de la catedral de Burgo de Osma. Canicosa de la Sierra, 3 - mayo - 1704.

436 W. CHRISTIAN Jr.: Religiosidad local en la España de Felipe II. Madrid, Nereda. 1991. (pp. 214 y SS).

437 Ejemplos sumamente significativos de esto los encontramos en las localidades de Barbadillo de Herreros, Canicosa de la Sierra o Castrillo de la Reina. De ellos nos ocuparemos más delante, en el capítulo dedicado a los Aspectos constructivos. 
Palacios de la Sierra), Nuestra Señora de Costana (en Barbadillo de Herreros), o Nuestra Señora del Carrascal (en Canicosa de la Sierra), por citar sólo algunos ejemplos.

Dentro de esta tendencia a particularizar imágenes, sin duda, el ejemplo más llamativo lo tenemos, precisamente, en la figura de la Virgen, ya que dentro de las veintitrés ermitas dedicadas a María, que se hallan repartidas por los términos municipales de estos pueblos, encontramos un total de veintidós advocaciones específicas diferentes. La Virgen, por otra parte, es la figura que más ermitas tiene dedicadas en la zona, lo que se repite, tanto en los pueblos de la Diócesis de Burgos, como en los de Osma.

Las figuras de la Divinidad, a su vez, cuentan con una representación menos numerosa y variada, como ya ocurriera en las iglesias parroquiales. Así, solamente la figura de Cristo cuenta con santuarios dedicados a su imagen o a las advocaciones dedicadas a objetos relacionados con su persona, como es el caso de la cruz. Dentro de ellas las más numerosas son las dedicadas a la Vera Cruz, con seis ermitas, a las cuales se añade una más, dedicada a la Santa Cruz. Estas ermitas de la Vera Cruz son el reflejo de la importancia, que las cofradías de este nombre tuvieron dentro de nuestros pueblos, pues como vemos, varias de ellas poseyeron su edificio propio. Son ermitas, además, que suelen ubicarse dentro del propio casco urbano, como ocurría en las localidades de Canicosa de la Sierra, Hacinas, Quintanar de la Sierra o Vilviestre del Pinar, o en las inmediaciones del pueblo, como son los casos de Huerta de Arriba y Tolbaños de Arriba.

Las dedicadas a la propia figura de Cristo se hallan repartidas entre la advocación general del Santo Cristo, con dos ermitas, y las particulares del Santo Cristo de Zalamea, con una, y San Salvador con dos.

En cuanto a las ermitas dedicadas a santos, encontramos una gran variedad, pues dentro de las 87 ermitas dedicadas a este tipo de figuras, hallamos un total de 44 
advocaciones distintas. Dentro de ellos, el grupo mejor representado vuelve a ser, como ya ocurriera en las iglesias parroquiales, el de los mártires, entre los cuales destacan San Cosme y San Damián, los mártires por excelencia, con cuatro ermitas, las mismas que San Justo y San Pastor, y San Sebastián. También repiten ermita San Juan Bautista con tres, y Santa Catalina, San Cristóbal, Santa Eugenia, Santa Lucía, Santa Marina y San Torcuato, con dos cada una. Junto a ellas, los santos mártires con una sola ermita son los siguientes: San Adrián, Santa Águeda, Santa Centola, San Esteban, Santa Inés, San Lorenzo, San Mamés, San Narciso, San Pantaleón, San Pelayo, San Quirico y Santa Julita, y San Vitores.

Otro grupo bien representado es el de los Apóstoles, con un total de veinte ermitas, destacando, de un modo especial, la figura de San Andrés, con ocho ermitas. A él le siguen San Bartolomé con cuatro, Santiago, con tres, San Pedro con dos, y con una solamente, San Matías, San Mateo y San Felipe.

Obispos, abades, fundadores y reformadores de órdenes religiosas también encuentran aquí su sitio. De este modo, la influencia del vecino monasterio de San Millán de la Cogolla tiene su reflejo en la existencia de tres ermitas, dedicadas a este santo. Otras tres ermitas tiene dedicadas San Martín, al cual siguen San Saturnino con dos, y San Benito, San Francisco y San Antonio, con una cada uno. Los santos penitentes tienen su principal representación en la figura de San Roque, con un total de siete ermitas, al que complementa María Magdalena con una. Por último, debemos citar también otros santos y advocaciones más variados, entre los que encontramos figuras como el arcángel San Miguel, con 4 ermitas, Santa Ana con dos y San Jorge, San Cebrián, Santa Elena, San Isidro y las Benditas Ánimas, con una sola.

Destacan, dentro de esta amplia variedad de advocaciones, las relacionadas con la protección de los hombres y animales, actuando como escudo de defensa frente a las posibles pestes y enfermedades que podían llegar a afectarles. Este papel lo cumplían de modo eficaz, según la tradición popular, santos como San Roque, San Sebastián, San 
Martín y los Santos Mártires, San Cosme y San Damián. Junto a ellos destacan también las advocaciones no tan específicas, encargadas de la intercesión por la salvación de las almas o por el cuidado de las actividades diarias. Este papel lo desempeña de un modo especial la figura de la Virgen María, en cualquier de sus advocaciones particulares, hasta el punto de convertirse en referente constante en las plegarias cotidianas de los habitantes de estos pueblos.

Esto lleva, al mismo tiempo, a que las fiestas patronales de muchas de estas localidades no se encuentren dedicadas al santo titular de su iglesia parroquial, sino a la figura que preside alguna de estas ermitas. Así, en Arroyo de Salas la principal fiesta se celebra en honor de San Miguel, y no de San Julián, que preside su parroquia, en Barbadillo de Herreros en honor de Nuestra Señora de Costana, y no de Nuestra Señora de la Visitación, en Canicosa de la Sierra en honor de Nuestra Señora y San Roque, y no de San Esteban, en Huerta de Arriba en honor de San Vitores, y no de San Martín, en Monasterio de la Sierra en honor de San Cosme y San Damián, y no de San Pedro, y en Riocavado de la Sierra en honor de Santa Ana y Santiago, y no de Santa Coloma, por citar algunos ejemplos.

En cuanto a los edificios que albergaban estas imágenes, por lo general vemos que se trata de construcciones sumamente humildes, más próximas a las formas propias de la arquitectura popular, que a las de algún estilo concreto. Por lo tanto, no vamos a encontrar, dentro de esta tipología, obras de gran interés arquitectónico, en el que queden reflejados los rasgos y tendencias estilísticas de cada período. Aun así, también encontramos excepciones dignas de mención, como ocurre en los más importante santuarios de la zona, entre los que se encuentran Nuestra Señora del Arroyal, en Palacios de la Sierra, Nuestra Señora del Carrascal, en Canicosa de la Sierra, Nuestra Señora de Costana, en Barbadillo de Herreros, o Nuestra Señora de la Guía, en Quintanar de la Sierra. También podemos incluir aquí el caso de la ermita de San Quirico y Santa Julita, en Barbadillo del Pez, cuya fábrica se corresponde con la antigua iglesia parroquial de despoblado de Villaserrazín, de bellísimas trazas románicas. 
En lo que se refiere a la localización de estas ermitas, vemos que se hallan repartidas, tanto en el propio casco urbano de estos pueblos, como en su territorio circundante, sin seguir aparentemente, en ningún caso, criterios establecidos. No obstante, y a pesar de ello, se convierten, en todos los casos, en auténticos hitos referenciales dentro de estos espacios, contribuyendo, de modo directo, a su ordenación.

El período de la Edad Moderna afectó de una forma muy desigual a estos edificios. Así, mientras un reducido número de estas ermitas - las correspondientes a las imágenes más veneradas - ven como sus fábricas son remodeladas o incluso totalmente reedificadas, la gran mayoría de ellas termina por desaparecer, víctima del abandono y la ruina al que se ven abocados. Este proceso, como tendremos oportunidad de ver, fue particularmente intenso en el siglo XVIII, momento en el que muchas de estas ermitas se convierten en canteras para las obras emprendidas en las iglesias parroquiales de cada pueblo $^{438}$.

\section{Ámbito civil.}

En lo que se refiere a la arquitectura civil, la actividad desplegada en la zona a lo largo de este período nos depara un tipo de construcciones caracterizadas, ante todo, por la sobriedad, las cuales se encuentran dirigidas principalmente a cubrir unas necesidades originadas por unos tipos de actividades muy concretas, como son la ganadería trashumante, la carretería, y en menor medida la agricultura. No obstante, dentro de este ámbito, podemos hacer una clasificación en dos grandes grupos, que nos lleva a hablar, por un lado, de edificios representativos o relevantes, y por otro, de arquitectura popular o vernácula.

En el primero de estos grupos quedan incluidos, tanto aquellas construcciones destinadas a satisfacer necesidades comunales, y cuya promoción queda en manos de

\footnotetext{
438 Ver capítulo Aspectos constructivos: Materiales y técnicas constructivas; Tendencias y formas: Siglo XVIII.
} 
los respectivos concejos de vecinos, como las edificaciones de carácter privado, pertenecientes a aquellos grupos más destacados de esta sociedad, en las cuales se pretenden plasmar ciertas inquietudes de carácter estético. La arquitectura popular, por su parte, engloba todo el vasto conjunto de construcciones realizadas por el grupo mayoritario de estas poblaciones, como son los pequeños y medianos propietarios de tierras, ganados y carretas, cuyas edificaciones quedan al margen de cualquier mínimo interés por representar los valores estéticos de cada momento. Son edificios, éstos, cuya configuración queda determinada por factores como el tipo de actividad desempeñada por sus propietarios, el nivel económico de los mismos, y las condiciones medioambientales, que caracterizan a la comarca.

Dentro de los edificios relevantes, el primer grupo queda conformado, por lo tanto, por todas aquellas construcciones promovidas por los ayuntamientos, las cuales eran destinadas al bien y utilidad de todos los vecinos. No obstante, durante la Edad Moderna no parece que en estos pueblos existiera una separación o distribución clara en edificios concretos, de las diferentes funciones, que los concejos poseían. De hecho, suele ser el propio edificio del concejo el que concentraba la mayor parte de estas funciones, estableciendo una compartimentación interna, que permitía dar acomodo a las funciones de ayuntamiento, escuela, carnicería, cárcel, hospital, etc.

Solamente conservamos datos más o menos precisos de uno de estos edificios concejiles durante este período, como es el caso de Barbadillo de Herreros, el cual fue remodelado en 1731. Según la información aportada por estos testimonios podemos comprobar, que se trataba de edificios no muy diferentes al del resto del caserío que formaba el núcleo urbano de este pueblo, sin incluir, en ningún caso, signos aparente de su condición ${ }^{439}$. De este modo, y por extensión, si nos atenemos a este modelo, debemos pensar que el panorama no debía ser muy diferente en el resto de los pueblos de la zona, pues las circunstancias que los rodeaban eran las mismas. El único caso singular que

\footnotetext{
439 AHPBU. PN. leg. 9802/1, fols. 61 y ss. Manuel Gil de la Cuesta. Barbadillo de Herreros, 6 - julio 1731.
} 
aquí podemos citar se encuentra en Monasterio de la Sierra, cuyo edificio del concejo se encuentra coronado por un sencillo torreón de forma prismática, levantado sobre base cuadrangular, con muros de mampostería y cubierta a cuatro aguas. En realidad, se trata de una edificación sumamente simple, cuya técnica constructiva apenas se diferencia del resto de casas circundantes, si bien su propia estructura hace que destaque como hito referencial dentro del caserío. Por lo demás, en el resto de los pueblos de la comarca tendremos que esperar hasta los años finales del siglo XIX o incluso el siglo XX, para ver nacer los primeros edificios municipales, en los que se muestran unos ciertos aires de monumentalidad.

Las funciones que cumplían estos edificios, como ya apuntábamos, resultan de lo más diverso, si bien algunas de estas actividades podían realizarse en otras construcciones auxiliares, repartidas por el pueblo. Dentro de estas funciones, tal vez una de las que más nos llama la atención es la de hospital, cuya existencia tenemos documentada en tres pueblos de nuestra comarca, como son Canicosa de la Sierra ${ }^{440}$, Huerta de Arriba $^{441}$ y Quintanar de la Sierra ${ }^{442}$. Se trata, en todos los casos, de pequeñas habitaciones con dos o tres camas, generalmente mal atendidas de sábanas y mantas, cuyo cometido era simplemente el de servir de lugar de descanso a los peregrinos y viajeros sin recursos, que por algún motivo podían atravesar estas sierras. Esto hizo que su existencia fuera constantemente cuestionada por las autoridades diocesanas, las

\footnotetext{
440 AGDBU. LP. Canicosa de la Sierra, parroquia de San Esteban, LF. Visita realizada a la parroquia de San Esteban de Canicosa de la Sierra en 1639, por D. Martín Carrillo Alohese, obispo de Osma. Canicosa de la Sierra, 19 - septiembre - 1639.

441 AGDBU. LP. Huerta de Arriba, parroquia de San Martín, LF. (fols. 27 - 28). Visita realizada a la parroquia de San Martín de Huerta de Arriba en 1608, por D. Antonio de Val de Rábano. Huerta de Arriba, 17 - agosto - 1608.

442 AGDBU. LP. Quintanar de la Sierra, parroquia de San Cristóbal, LF. Visita realizada a la parroquia de San Cristóbal de Quintanar de la Sierra en 1668, por D. Baltasar de la Fuente Sanz. Quintanar de la Sierra, 23 - marzo - 1668.
} 
cuales reprochaban a los concejos su mala atención y el escaso servicio que $\operatorname{prestaban}^{443}$.

El otro tipo de edificios relevantes lo encontramos en las residencias de aquellos grupos más representativos de cada uno de los pueblos, como son los grandes propietarios de ganados y carretas, algunos de los cuales adornaban su apellido con la condición de hidalgos. Nos estamos refiriendo, por supuesto, a los ejemplos de "casona rural”, como tipología plenamente identificable, caracterizada, a grandes rasgos, por su racionalismo compositivo, que se refleja fundamentalmente en la simetría de sus fachadas, en la utilización de unos materiales de calidad, y en la incorporación de determinados elementos decorativos, propios de los lenguajes artísticos dominantes durante este período.

Ninguna de estas construcciones relevantes del ámbito de lo civil, sin embargo, pretendía organizar la disposición del caserío ya existente dentro de la planimetría de cada pueblo, sino que por el contrario se tiende únicamente a buscar espacios más o menos amplios, en los cuales poder asentarse con acomodo. Frente a estas casas, eso sí, se tiende a abrir espacios amplios con los cuales crear microámbitos independientes dentro del trazado viario.

El otro gran grupo, dentro de este ámbito de lo civil, lo constituye la arquitectura popular, la cual no sólo representa el tipo dominante dentro de estos pueblos, sino que se trata del modelo de construcción más ligado al propio medio físico y humano. Esta arquitectura, como ocurre en cualquier zona rural, nos muestra un tipo de construcción sumamente espontáneo, capaz de adaptarse con rapidez a las necesidades de sus propietarios y promotores, pero también susceptible de incorporar elementos procedentes de la arquitectura culta.

443 A. RODRÍGUEZ G. CEBALLOS: Arquitectura barroca en Castillo y León. Siglos XVII y XVIII. Salamanca, Ediciones Colegio de España. 1996. (pp. 52 - 53). 
264 Arquitectura de la Edad Moderna en la sierra burgalesa.

Al mismo tiempo, esta arquitectura constituye el resumen de una herencia cultural, patentizada en el desarrollo de soluciones tradicionales generalizadas, con un lenguaje arquitectónico de pocas variantes. Por ello su estilo se va elaborando de forma lenta, culminando en el momento en el que encuentra su forma más idónea. A partir de entonces, se comienza a repetir, aunque no de forma seriada, sino adaptándose a las necesidades de cada promotor y a las condiciones que la rodean ${ }^{444}$.

Se trata, en definitiva, de una arquitectura que presenta soluciones a problemas inmediatos, los cuales suelen ser de carácter eminentemente funcional, sin albergar una intencionalidad de belleza formal, aunque no por ello carente de sensibilidad. Una arquitectura que es el fruto de una larga experimentación, con la cual se logra encontrar la mejor adecuación de las distintas partes y estructuras para cada uso concreto, combinado con un embellecimiento escueto y nada superfluo. Una característica importante de esta arquitectura es la participación directa del usuario, tanto en el proyecto, como en la propia ejecución del mismo, lo que hace que, a la herencia cultural, se incorporen también las previsiones y necesidades de cada caso, perfeccionando así esta herencia.

Constructivamente, estas edificaciones se basan en los medios existentes en el propio entorno, es decir, los materiales autóctonos, como el resto de la arquitectura de la zona, lo cual, sin embargo, no debemos entenderlo como un condicionante, sino más bien como un factor meramente restrictivo.

Entre las cualidades de esta arquitectura, debemos señalar, que sirve para satisfacer unas necesidades socio-familiares y económicas muy concretas, enfrentándose y superando, al mismo tiempo, esas restricciones del medio físico. Es por ello una arquitectura siempre viva y sumamente versátil, dada esta necesidad de adaptarse a las necesidades de cada caso. Al mismo tiempo, la aportación de nuevas

444 J. F. ESTEBAN LORENTE: “Arquitectura”. En J. F. ESTEBAN LORENTE, G. M. BORRÁS GUALIS, M. I. ALVARO ZAMORA: Introducción general al arte. Arquitectura, escultura, pintura, 
soluciones o técnicas constructivas, también constituyen un factor susceptible de introducir modificaciones en sus fórmulas generales.

Su proceso vital, por lo tanto, lo podemos resumir en tres pasos fundamentales. El primer momento es el de su nacimiento, ligado al estímulo de unas necesidades concretas, que propician su creación. El segundo es el de su desarrollo, adaptándose a las necesidades concretas de cada caso, pero sin abandonar los principios fundamentales, que marcaron su nacimiento. Y un tercer y último paso, es el de su destrucción, la cual se consuma en el momento en el que su utilidad ha desaparecido. Esto es precisamente lo que ha ocurrido en esta comarca de la sierra burgalesa a lo largo de todo el siglo XX, pues el abandono de las actividades tradicionales, practicadas por sus moradores, como eran la ganadería trashumante y la carretería, ha propiciado el agotamiento de este tipo de arquitectura, llegando incluso a producirse la destrucción de los ejemplos existentes ${ }^{445}$. 


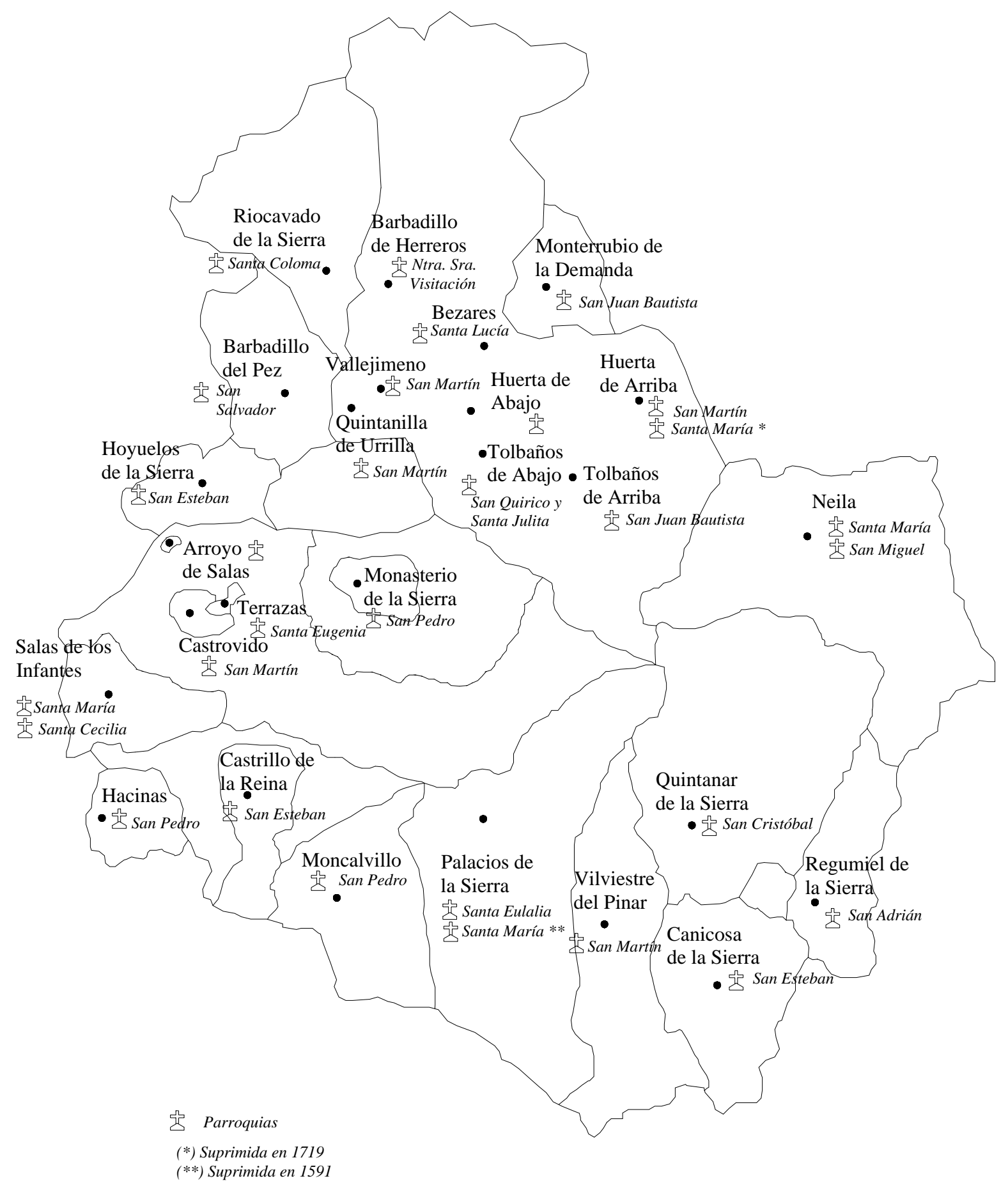

445 Un buen ejemplo de esto lo podemos apreciar en la localidad de Quintanar de la Sierra, que fue uno de los principales núcleos de la Real Cabaña de Carreteros, la cual actualmente no conserva ni un solo caso de casa típica carretera. 


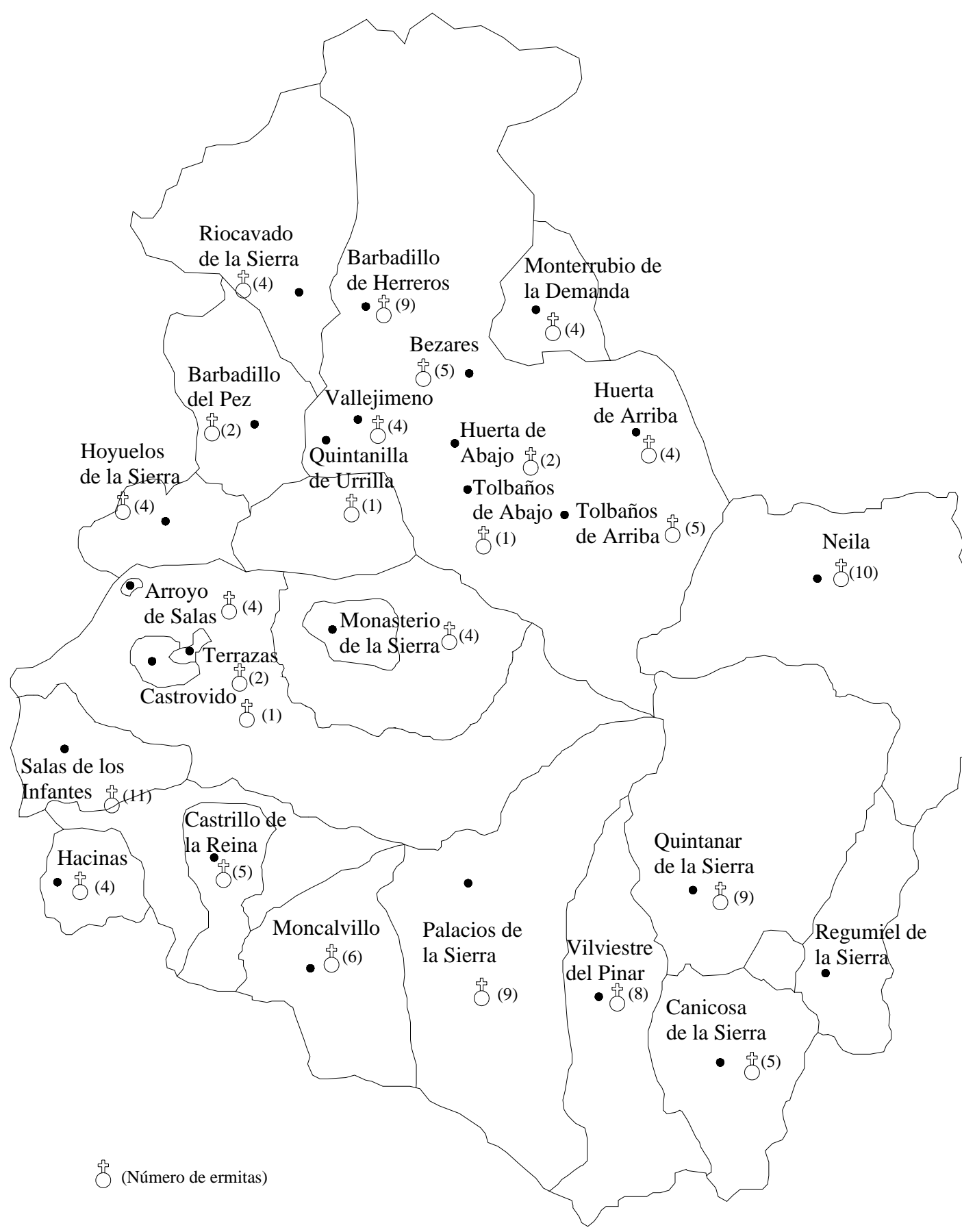


VIII. ACTIVIDAD CONSTRUCTIVA. 
TIPOS DE OBRAS.

El período de la Edad Moderna conoce el desarrollo de una importante actividad constructiva dentro de la comarca de la sierra burgalesa. Ésta afecta, en mayor o menor medida, a los edificios más representativos de cada una de las localidades.

Lógicamente, como ocurre en todos los casos, las actuaciones realizadas durante este período resultan mucho más fáciles de conocer, y determinar su alcance, en las obras de carácter religioso, que en las de la arquitectura civil. Esto se debe, en primer lugar, a la escasez o casi nula presencia de documentación apropiada, que nos informe sobre los acontecimientos vividos por estos edificios, pero también a la mayor facilidad que existe para seguir este proceso constructivo en las construcciones religiosas, merced al mejor reflejo que tienen aquí los distintos cambios estilísticos, que se van sucediendo.

Es dentro de estas construcciones de carácter religioso .donde encontramos una arquitectura propiamente artística, con una plasmación más clara de los gustos y formas predominantes en cada momento. La arquitectura civil, por su parte, queda incluida mayoritariamente dentro de los modelos propios de la llamada arquitectura popular, la 
cual se encuentra sujeta a unos parámetros de sencillez y funcionalidad, que apenas dejan margen para una evolución en el tiempo.

Volviendo a la arquitectura propiamente artística, diremos que las razones que movieron a emprender este tipo de obras, en la inmensa mayoría de los casos, fueron puramente funcionales, pues fue la simple necesidad la que llevó a plantearse la posibilidad de embarcarse en un determinado proyecto constructivo. La naturaleza de estas necesidades, por otra parte, puede ser muy diversa, encontrando causas de todo tipo, como: envejecimiento, ruina (bien por falta de un mantenimiento adecuado, o por causas externas de tipo natural), falta de funcionalidad de la obra antigua, necesidad de adecuarse a los gustos formales de cada época (modernizar el edificio), necesidad de cubrir nuevas funciones, o simplemente la propia devoción.

Evidentemente, tanto el envejecimiento, como la ruina, son los dos motivos más importantes, y que con mayor frecuencia movieron a los responsables de un edificio a emprender su renovación. Así, es muy posible que el envejecimiento de su antigua fábrica fuera la principal causa que impulsó la renovación completa de templos como el de la parroquia de Santa María de Salas de los Infantes. En este caso, el antiguo templo románico fue eliminado en su práctica totalidad, conservando únicamente unos escasos restos en la zona del muro lateral de la nave del evangelio, a la altura de su primer tramo, y en el muro delantero de la nave de la epístola.

Motivos no muy diferentes debieron ser los que animaron muy poco tiempo después a la vecina localidad de Castrillo de la Reina a remodelar igualmente su templo parroquial. Se podría añadir aquí otro tipo de impulsos, complementarios a los ya citados, como puede ser la utilización, como referencia, de lo que se estaba realizando en su entorno más inmediato. No obstante, esto nos llevaría a contemplar ciertas cuestiones de orden muy subjetivo, que lógicamente resultan muy difíciles de probar documentalmente. 
El envejecimiento de los edificios dejaba a los promotores de estas obras un cierto margen de tiempo, durante el cual podrían maniobrar y reflexionar con una tranquilidad suficiente sobre las soluciones más adecuadas que se debían adoptar. No sucedía así cuando el motivo, que propiciaba el inicio de unas nuevas obras, era la quiebra o ruina del edificio anterior, pues en este caso, la necesidad de solucionar con la mayor rapidez posible el problema, obliga a tomar soluciones inmediatas y, en algunos casos, drásticas.

Sin duda, la ruina más previsible era la que venía provocada por una inadecuada labor de mantenimiento, o una total falta de los trabajos de este tipo. En gran medida, esto es lo que venía sucediendo con frecuencia en un buen número de los pueblos de nuestra comarca, donde la relajación, o directamente el abandono, de las más básicas tareas de cuidado de sus templos, terminaba por traer costosas consecuencias. No obstante, hay que decir que esta ruina, provocada por la falta de mantenimiento, rara vez deparó la renovación completa de un edificio, pues lo más habitual era que se saldara con obras de reparación o remodelación de mayor o menor alcance, encaminadas a frenar el avance de la destrucción y poco más.

A este respecto, uno de los casos más significativos lo tenemos en la iglesia de Riocavado de la Sierra durante la década de 1740, pues el grado de deterioro al que había llegado este templo era tal, que fue necesario trasladar el Santísimo Sacramento a la ermita de Santiago, situada dentro del propio pueblo, hasta que la iglesia fuera reparada ${ }^{446}$. Como consecuencia de ello, en estos mismos años se acometieron unas obras de remodelación, que terminaron con la construcción de una nave completamente nueva.

Otros casos de igual interés, aunque indudablemente de magnitud más reducida, fueron los vividos en la ermita de Santa María de la Blanca en Hoyuelos de la Sierra, 
274 Arquitectura de la Edad Moderna en la sierra burgalesa.

reparada en repetidas ocasiones a lo largo del siglo XVIII ${ }^{447}$; también en el templo de la antigua parroquia de Santa María en Palacios de la Sierra, que tuvo que ser prácticamente reconstruido en su totalidad a principios del siglo XVIII ${ }^{448}$; el de la iglesia de Santa Cecilia en Salas de los Infantes, con las intervenciones realizadas en la capilla mayor y del Santo Cristo de la Trinidad en el último cuarto de esta centuria del Setecientos ${ }^{449}$; o el de la iglesia de Santa María en Neila, con la reparación efectuada también a finales de este siglo XVIII sobre la capilla de Santa Ana.

Dentro de estos ejemplos, este último nos llama particularmente la atención, por tratarse de una capilla privada, fundada en el siglo XVI por la familia Márquez de Prada, una de las más prestigiosas de esta villa de Neila ${ }^{450}$. El patrocinio de esta familia, que con tanto entusiasmo había comenzado a principios del Quinientos, parece que comenzó a diluirse a medida que pasaba el tiempo, llegando así a un abandono prácticamente total de sus obligaciones como patronos, durante el siglo XVIII. De esta forma, en los años finales de esta centuria se hace necesario emprender una serie de trabajos de reparación, dentro de los cuales se incluye la construcción de una cubierta, formada por una pequeña bóveda de media naranja, con la que se marca una clara separación de este ámbito con respecto al resto del espacio interior del templo.

446 AGDBU. LP. Riocavado de la Sierra, parroquia de Santa Coloma. LF. (1735 - 1838). (fols. 26 vº 31). Visita realizada a la parroquia de Santa Coloma en 1744, por el visitador del Arzobispado de Burgos D. Diego Escalona, canónigo de la catedral de Burgos. Barbadillo de Herreros, 26 - mayo - 1744.

447 AGDBU. LP. Hoyuelos de la Sierra, parroquia de San Esteban. LF. (1682 - 1728). Visita realizada a la parroquia de San Esteban de Hoyuelos de la Sierra en 1728, por el visitador del Arzobispado de Burgos D. Andrés Madrazo Escalera, canónigo de la catedral de Burgos. Salas de los Infantes, 15 - julio - 1728; Ibídem. LF. (1781 - 1850). Visita realizada a la parroquia de San Esteban de Hoyuelos de la Sierra en 1791, por el visitador del Arzobispado de Burgos D. Manuel María Izquierdo. Barbadillo del Mercado, 4 - noviembre - 1791 .

448 AGDBU. LP. Palacios de la Sierra, Santa Eulalia y Santa María. L F. (1673 - 1726). Visita realizada a la parroquia de Santa Eulalia y Santa María de Palacios de la Sierra en 1710, por el visitador del Obispado de Osma D. Tomás Manuel García de Aguilar. Palacios de la Sierra, 27 - mayo - 1710.

449 A. Parroq. Salas de los Infantes. LP. Salas de los Infantes, parroquia de Santa Cecilia. LF. (1721 1809). Cuentas de 1783. Salas de los Infantes, 2 - octubre - 1783.

450 B. VALDIVIELSO AUSín: Neila, una llamada al turismo. Burgos, Ayuntamiento de Neila. 1980. (pp. $162-163)$. 
El otro tipo de ruina es la impredecible, es decir, la que tiene su origen en causas externas, de carácter natural, como viento, granizo, lluvias torrenciales o copiosas nevadas. De todos estos agentes, sin duda, el que más daños provocó en los edificios de esta comarca fue la humedad procedente del subsuelo. Nos encontramos as, con diferentes ejemplos de templos que tuvieron que ser reconstruidos en su práctica totalidad, o en algunas de sus partes, por la persistencia de este tipo de problema. Esto sucedió en iglesias como las de Monasterio de la Sierra, Arroyo de Salas, Tolbaños de Abajo, Vallejimeno, Santa Eulalia de Palacios de la Sierra, o San Martín de Huerta de Arriba.

En el primero de los casos citados, la reconstrucción del templo, aunque demorada en el tiempo, tuvo finalmente que llevarse a cabo entre los años finales del siglo XVIII y primeros momentos del siguiente. Aquí, los problemas de humedades, que afectaban a todo el subsuelo sobre el que se alzaba el templo, eran tan graves, que no sólo perjudicaban a la propia estructura del edificio, sino que hacía totalmente imposible efectuar los enterramientos en su interior, como era costumbre. El resultado de ello fue la construcción de una fábrica prácticamente nueva en su totalidad, levantada con una gran sencillez de formas, pero con la solidez necesaria para evitar futuros problemas de este tipo.

Similares circunstancias se vivieron en la parroquial de Arroyo de Salas a lo largo de los siglos XVII-XVIII. Aquí, no se llega a levantar un templo complemente nuevo, pero sí tiene que ser remodelada su fábrica en diferentes ocasiones, lo que ocurre en los años 1694, 1726 y 1740. En cada uno de estos momentos se efectuaron actuaciones de diferente alcance en distintas partes del templo y su entorno, con el fin de garantizar la estabilidad de toda la estructura. Aun así, no se consigue evitar el 
derrumbe ocasional de algunas piezas, como ocurrió con la bóveda de la capilla mayor en 1806, momento en el que tuvo que ser reconstruida ${ }^{451}$.

Los casos de Vallejimeno y Tolbaños de Abajo son también parecidos, si bien, aquí no hubo necesidad de remodelar el templo, pues bastó simplemente con despejar el entorno, eliminando para ello el talud de tierra, que descansaba sobre uno de los laterales del edificio. Las instrucciones, que se dan para esta obra, en el caso de la iglesia de Tolbaños de Abajo, no pueden ser más claras: “para quitar las aguas que perjudican dicha yglesia se ha de quitar ocho pies de tierra al rededor de ella anibelando con la esquina de la sachristía que mira al mediodía y por el otro a la yglesia que mira a poniente ${ }^{\mathrm{452}}$.

En los casos de Palacios de la Sierra y Huerta de Arriba estos problemas de humedades fueron responsables únicamente de la construcción de sendas nuevas sacristías, por "ser mui corta y húmeda y que por este motivo tienen peligro los ornamentos de echarse a perder", tal y como se indica en el caso de Palacios de la Sierra, por boca del visitador del Obispado de Osma, D. Luis de Alaro, en su visita realizada en 1730. Así, al envejecimiento, que parecía presentar la estructura de esta sacristía, se unían, en este caso, los problemas de humedades, convirtiéndose con ello en el detonante definitivo, que terminó por provocar su sustitución por una nueva. La renovación de esta pieza, en el caso de la iglesia de San Martín en Huerta de Arriba, presentaba una mayor complicación, pues lo que se trataba de hacer, en este caso, era un auténtico pozo de drenaje, con el cual cortar de una vez por todas las humedades, que estaban afectando al resto de la estructura de la fábrica.

Pero estas no fueron las únicas causas que propiciaron la realización de nuevas obras arquitectónicas, pues existen otros motivos, entre los que aparece, en un lugar

451 AGDBU. LP. Arroyo de Salas, parroquia de San Julián. LF. (1770 - 1852). (pp. 133 - 135). Cuentas del año 1806. Arroyo de Salas, 28 - septiembre - 1807. 
destacado, la pérdida de funcionalidad sufrida por la fábrica antigua. Este fue, en definitiva, el principal fundamento de las continuas ampliaciones a las que se vieron sometidos varios de los templos de nuestra comarca. Vemos así, que muchas las parroquias habían experimentado un notable crecimiento de su feligresía a lo largo de este período, hasta el punto de dejar sus templos prácticamente obsoletos. En estos casos, la solución más frecuencia consistía en ampliar la fábrica existente, hasta alcanzar unas dimensiones que se ajustasen a las nuevas necesidades. Sin embargo, ésta no siempre conseguía ser la solución definitiva, pues los sucesivos incrementos del número de feligreses, podían obligar a nuevas ampliaciones.

En algunos casos, como el de la iglesia de San Pedro en Hacinas, o la parroquia de San Martín en Huerta de Arriba, descubrimos con claridad una única fase de ampliación durante toda la Edad Moderna, si bien, existen otros templos en los que los procesos de ampliación y crecimiento se convirtieron prácticamente en una constante. Este puede ser el caso de iglesias como la de Moncalvillo, Vilviestre del Pinar o la parroquia de Santa Cecilia de Salas de los Infantes, si bien el ejemplo más destacado lo encontramos en la parroquia de Santa Eulalia, en Palacios de la Sierra. Esta iglesia conoció los primeros pasos de su proceso remodelador durante el período central del siglo XVI, lo cual necesariamente nos obliga a relacionar estas obras con el proceso de decadencia en el que se veía sumida la otra parroquia, que existía en esta localidad, dedicada a Santa María. No obstante, fue a partir de las últimas décadas de esta centuria, con la fusión de las dos parroquias en una, y su ubicación en esta iglesia de Santa Eulalia, cuando el proceso de sucesivas ampliaciones y renovaciones se dispara, extendiéndose hasta las primeras décadas del siglo XVIII. Por ello, casi podemos decir, que su proceso de crecimiento estuvo determinado muy directamente por las sucesivas fases de quiebra, que se venían experimentando en el templo de la que fuera segunda parroquia del puelbo.

\footnotetext{
452 AHPBU. PN. Valle de Valdelaguna. Leg. 9802/1, fols. 3 - 4 v . Manuel Gil de la Cuesta. Tolbaños de Abajo, 16 - marzo - 1729.
} 
Otra causa, favorecedora de obras arquitectónicas, fue, como también hemos señalado, la necesidad de adecuarse a los gustos formales de cada época, es decir, el interés por modernizar la fábrica heredada del pasado. Dentro de este impulso queda encuadrada especialmente la edificación de nuevas portadas para templos parroquiales y ermitas, en las cuales se muestra un especial interés por embellecer, pero al mismo tiempo también por dignificar este espacio de tránsito entre el mundo sagrado y el profano. En este grupo de obras la lista es bastante amplia, destacando, como ejemplos más llamativos, los casos de las iglesias de San Esteban de Castrillo de la Reina, Santa María en Salas de los Infantes, San Cristóbal en Quintanar de la Sierra y San Pedro en Hacinas.

En esta misma línea podemos incluir también la construcción de los nuevos campanarios. Aquí los ejemplos son mucho más numerosos, pues casi todos los templos parroquiales de estos pueblos emprendieron la renovación de sus campanarios en uno u momento, dentro de la Edad Moderna.

Igualmente aquí podemos incluir la corriente, desarrollada a partir del siglo XVII, tendente a renovar las sacristías, con la intención, según parece, de dignificar de alguna manera estos espacios en los que se custodiaban todos los objetos sagrados, empleados en el culto. Esta corriente, como veremos, se extiende a lo largo de los siglos XVII-XVIII, desarrollándose en la mayoría de los casos un tipo de sacristía muy concreto, caracterizado por su funcionalidad, y a ausencia de grandes pretensiones artísticas. Aquí la lista abarca a la casi totalidad de los templos parroquiales de la zona, pues se convierte en un tipo de obra muy común.

Por otra parte, la necesidad de cubrir nuevas funciones, como ya apuntábamos, no parece, aparentemente, una buena razón propiciadora de nuevas obras arquitectónicas de primer orden, pues durante la Edad Moderna no se producen los giros necesarios, dentro de la liturgia, que propicien la necesidad de alterar la estructura establecida en estos templos. Aun así, dentro de este período, nos encontramos con un 
cierto tipo de construcciones cuyo fin está encaminado precisamente a satisfacer estas necesidades. Este es el caso de los archivos, que resulta obligado realizar, ante la necesidad de custodiar la creciente masa documental emanada de las propias parroquias (circunstancia que fue acentuada a partir del siglo XVI, ante la obligación de llevar registros de bautizos, difuntos y matrimonios, así como otros tipos de libros). En la inmensa mayoría de los casos estos archivos estaban constituidos simplemente por piezas de madera, a modo de arcones, sin valor artístico de ningún tipo, colocados en las sacristías, en cuyo interior se depositaban los mencionados libros. Sin embargo, en algunas ocasiones se realizan construcciones en piedra, con el fin, no sólo de dar una mayor solidez a este tipo de piezas, sino también de evitar el poder devorador, que tenía el principal enemigo de este legado documental, es decir, el fuego. El único ejemplo que se conserva lo encontramos en la iglesia de Castrillo de la Reina, ubicado en la zona de los pies de la nave del evangelio, si bien, sospechamos que en la parroquia de Santa Eulalia, en Palacios de la Sierra, podría haber existido otro de similares características $^{453}$.

Dentro de este tipo de obras podemos citar también la construcción de los cementerios, en los atrios de los templos, cuya ejecución estaba relacionada con la progresiva tendencia a realizar los enterramientos fuera de los templos, que empieza a finales de este período de la modernidad. Aquí los ejemplos documentados son más numerosos, correspondiendo la mayor parte de ellos, lógicamente, ya al siglo XVIII. Entre ellos están los de Hoyuelos de la Sierra (1714), Tolbaños de Abajo (1728), Santa Eulalia en Palacios de la Sierra (1745), Vallejimeno (1753), o Hacinas (1781).

Sin embargo, la construcción de este tipo de elementos no estaba ligada exclusivamente a las necesidades de sepultar los cuerpos de los difuntos fuera de los

\footnotetext{
453 Esto lo deducimos de los pagos registrados en los Libros de Fábrica, correspondientes a la construcción de dicho archivo, ya que el encargado de su fabricación fue el maestro de cantería Francisco de la Torre, acompañándose dichos gastos de diferentes compras de piedra destinada a esta misma obra. AGDBU. LP. Palacios de la Sierra, parroquia de Santa Eulalia y Santa María. LF. (1673 - 1726). Cuentas del año 1725. Palacios de la Sierra, 1 - abril - 1726.
} 
templos, pues en muchas ocasiones adquieren una función esencialmente estructural, relacionada con la estabilidad de los edificios. Así, al estar situados en el entorno de las iglesias, con sus potentes muros conseguían asegurar la consistencia del suelo sobre el que la fábrica se levanta, evitando, de este modo, el riesgo de los calamitosos movimientos de tierra, que hubieran puesto en peligro la propia consistencia del edificio. Ejemplos ampliamente reveladores de ello los encontramos en las iglesias de Castrillo de la Reina, Quintanar de la Sierra, Arroyo de Salas, Canicosa de la Sierra, y en la parroquia de Santa Cecilia de Salas de los Infantes.

Por último, entre los motivos que llevan a acometer obras dentro de estos templos, se encuentran también los relacionados con aspectos puramente devocionales. No obstante, y a pesar de que se trata de un motivo que favorece fundamentalmente la creación de obras de carácter ornamental, como es el caso de los retablos, también nos encontraremos aquí con obras de cantería. Este es el caso de los camarines y transparentes de templos parroquiales y ermitas, realizados mayoritariamente desde finales del siglo XVII en adelante. Estos transparentes consisten simplemente en la apertura de un vano sobre el testero de la capilla en cuestión, el cual se hace coincidir con el nicho central del retablo, donde se alojaba la imagen titular. Su incorporación, por lo general, se encuentra ligada a la propia obra de renovación o construcción de nueva planta de estas capillas, sin embargo, existen casos en los que este vano se abre con posterioridad, con la expresa intención de crear este efecto de transparente. Así sucede, por ejemplo, en las iglesias de Santa María en Neila (1755), y San Martín en Vilviestre del Pinar (1781), y en la ermita de Nuestra Señora de la Guía, en Quintanar de la Sierra (1689).

Al hilo de estas cuestiones, podemos afirmar, por lo tanto, que un alto porcentaje de las construcciones y actuaciones de carácter arquitectónico, que se realizaron en estos pueblos a lo largo de la Edad Moderna fueron obras tendentes a completar, ampliar, remodelar o reparar edificios ya existentes. Esto nos lleva a hablar, especialmente dentro de la arquitectura religiosa, de edificios de larga y complicada 
génesis, a lo largo de la cual se van manifestando los distintos estilos y formas artísticas predominantes en cada momento. Pero aun así nos encontraremos también con obras en las que ese proceso constructivo resulta muchos menos complicado de seguir, y por supuesto menos extenso. Se trata de edificios realizados de una sola vez, o completados a lo largo de un reducido número de etapas poco distantes entre sí, mostrando por ello un gran sentido de unidad en sus formas.

Esto ocurre preferentemente dentro de la arquitectura civil, y en concreto en las denominadas casas blasonadas, donde se da un mayor predominio de obras de nueva planta. No obstante, a esta circunstancia ayudan diferentes factores, como es la escasa evolución, que estilísticamente experimentan estas construcciones a lo largo de todo este período, o la perfecta adecuación de las obras efectuadas posteriormente con respecto a la estructura originaria.

Más llamativas, por el contrario, resultan estas obras de nueva planta dentro de la arquitectura religiosa, pues, en general, todos estos pueblos llegaron a la Edad Moderna con templos parroquiales perfectamente capacitados para satisfacer las necesidades de culto que podían presentarse. Por otra parte, cuando las necesidades de renovar la fábrica antigua llegaban (fueran del tipo que fueses), siempre se tiende a adecuar lo más posible la naturaleza y grado de estas necesidades a los recursos disponibles. En esta operación el producto resultante rara vez solía ser la construcción de un templo completamente nuevo.

De esta forma, la consideración de templo de nueva planta queda sujeta a distintos tipos de condicionantes, entre los que están, el hecho de asentarse siempre y en todos los casos sobre un solar ocupado por un templo anterior, y la circunstancia de que con el paso del tiempo, en mayor o menor medida, van a ser alterados, con modificaciones en algunas de sus partes, o con la incorporación de diferentes añadidos. 
A pesar de todo, que debemos considerar como construcciones de nueva planta, es relativamente amplio. En esta lista podemos incluir iglesias como la de la parroquia de Santa María de Salas de los Infantes, San Esteban de Castrillo de la Reina, San Cristóbal de Quintanar de la Sierra, Santa Cristina, en Huerta de Abajo, San Juan Bautista, en Tolbaños de Arriba, San Martín, en Huerta de Arriba, San Esteban, en Canicosa, en la Sierra, Santa Lucía, en Bezares o San Pedro, en Monasterio de la Sierra.

Dentro de esta relación, los dos primeros, los de Santa María de Salas de los Infantes y San Esteban de Castrillo de la Reina, son edificios levantados en los albores de la Edad Moderna, realizados, por supuesto, en estilo gótico, y asentados sobre el solar de anteriores construcciones, que sin embargo, apenas condicionaron el desarrollo de la nueva fábrica. En el caso de Salas, lo conservado de la iglesia anterior se reduce al muro lateral del primer tramo de la nave del evangelio y al muro delantero de la nave de la epístola. Restos que, por otro lado, quedan perfectamente integrados dentro de la nueva fábrica. La parroquial de Castrillo de la Reina, por su parte, mantiene todo el muro septentrional de la zona del cuerpo, condicionando con ello ligeramente el trazado de la propia nave del lado del evangelio, y la disposición de los dos pilares torales del centro. No obstante, esta circunstancia no impide desarrollar con perfecta claridad la estructura de templo de planta de salón, que se había planteado.

El templo de San Cristóbal de Quintanar de la Sierra resulta un caso muy parecido a los anteriores, si bien, se trata ya de una obra perteneciente a las primeras décadas del siglo XVII. En este caso, los únicos restos conservados del templo anterior se concentran en su nave de la epístola, a la altura de su segundo tramo. Estos restos nos muestran unos rasgos propios de la arquitectura del gótico final, que se desarrolla en la zona durante todo el siglo XVI. Sin embargo, y a pesar del aparente contraste con el clasicismo dominante en la nueva obra, se hallan perfectamente integrados dentro de este edificio, sin causar con ello un contraste brusco. 
Los casos de Huerta de Abajo y Tolbaños de Arriba, que levantaron sus nuevas fábricas a finales del siglo XVII y principios del siglo XVIII respectivamente, consiguen borrar en su estructura, aparentemente, todo rastro de las edificaciones anteriores. Por ello se convierten, tal vez, en dos de los mejores ejemplos de templo de nueva planta, que aquí podemos encontrar.

Similares circunstancias parecen darse en el templo parroquial de Bezares, si bien aquí, el carácter rústico y popular que impregna toda la construcción hace difícil diferenciar las partes conservadas de la obra antigua, de aquellas que se levantaron a finales del siglo XVII (momento al que corresponde esta renovación efectuada en el edificio $^{454}$ ). Aun así, podemos afirmar con rotundidad, que la obra fue levantada prácticamente de nueva planta en esta intervención.

Un caso sumamente interesante lo constituye el que nos encontramos en la iglesia de la parroquia de San Martín, en Huerta de Arriba. Aquí, aunque los restos conservados del templo anterior son importantes, pues se mantiene en pie, tanto la cabecera como la torre de aquella primitiva fábrica, éstos en modo alguno condicionan el desarrollo de la nueva obra. Para ello se decide alterar la orientación del nuevo templo, de tal modo, que la presencia de la antigua cabecera y de la torre, únicamente sirven para marcar la anchura del edificio ahora levantado.

También podemos considerar como obra de nueva planta la iglesia parroquial de Canicosa de la Sierra, pues, aunque en la fábrica resultante existe una marcada separación volumétrica entre la cabecera y la zona del cuerpo, todo parece apuntar a una construcción acometida en fases muy próximas entre sí, situadas ambas dentro del segundo cuarto del siglo XVIII.

454 AGDBU. LP. Bezares, parroquia de Santa Lucía. LF. (1685 - 1729). (fols. 20 - 21). Cuentas del año 1695. Bezares, 28 - diciembre - 1695. 


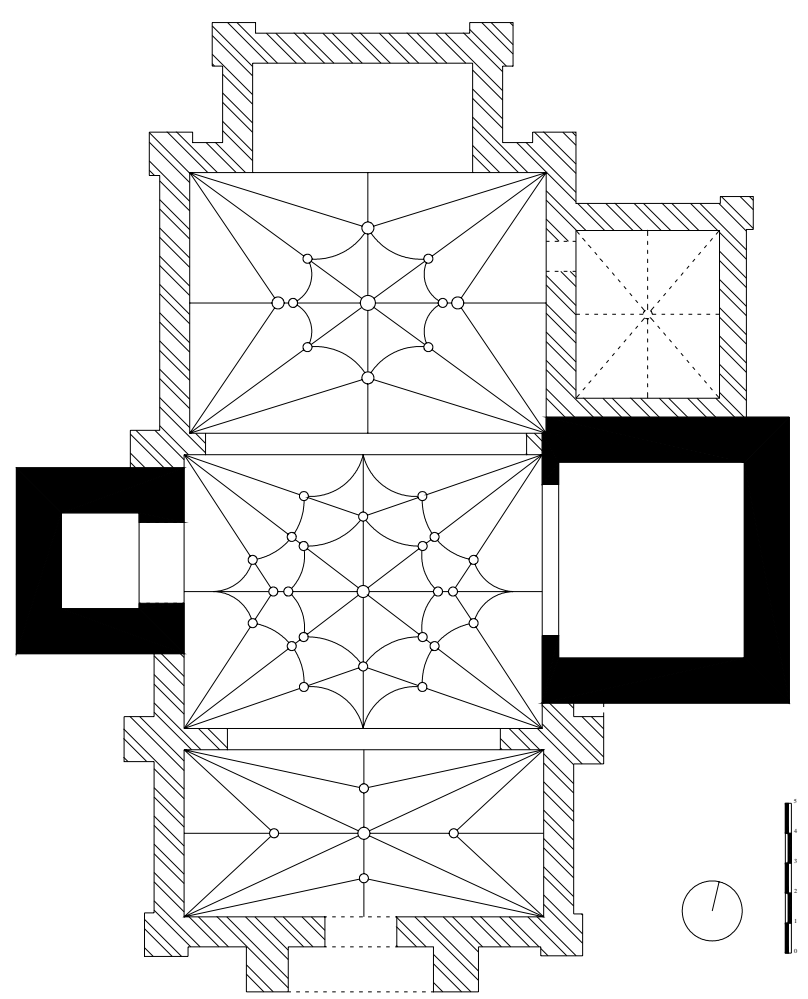

HUERTA DE ARRIBA. Iglesia de San Martín. Fases constructivas.

Este mismo caso se da en la iglesia de Monasterio de la Sierra, donde la renovación de la cabecera y el cuerpo del templo se efectúa en dos fases distintas, pero separadas por un lapsus temporal de apenas siete años ${ }^{455}$. Con ello la unidad conseguida dentro de todo el conjunto es tal, que podemos hablar con total propiedad de un solo proyecto constructivo.

Frente a este tipo de actuaciones, nos encontramos con la otra modalidad de obras, que ya anunciábamos, es decir, las ampliaciones, renovaciones, remodelaciones o reparaciones de edificios ya existentes. Se trata del tipo de intervención más frecuente

\footnotetext{
455 La construcción de la cabecera de este nuevo templo se acomete en 1794, mientras que la remodelación de la parte del cuerpo se efectúa en 1801. AGDBU. LP. Monasterio de la Sierra, parroquia de San Pedro Apóstol. LF. (1776 - 1838), (fols. 43 - 44 vº). Cuentas del año 1794. Monasterio de la Sierra, 5 - septiembre - 1795; Ibídem. (fols. 54 vº 56). Cuentas del año 1801. Monasterio de la Sierra, 15 - septiembre -1802 .
} 
en nuestra zona - especialmente en los edificios religiosos -, pues no en vano son las que mejor se adaptaban al resultado de la ecuación establecida, entre las necesidades existentes y los recursos disponibles para afrontarlas. Ello viene favorecido además por la tradicional forma de pensar, que aquí existía, la cual hacía que la propuesta de renovar o reparar la iglesia antigua siempre fuera vista con mejores ojos, que la que apostaba por construir una fábrica completamente nueva.

La variedad y alcance de esta modalidad de obras, sin embargo, es tan amplia que nos vemos obligados a hacer una pequeña clasificación dentro de ellas, para así obtener una imagen más clara. De este modo, debemos hablar en primer lugar de las obras de ampliación de edificios existentes, pues constituyen las intervenciones de mayor envergadura. Como su propio nombre indica, consisten simplemente en remodelar el espacio interior del templo, para así dar cabida a un mayor número de parroquianos (vivos o muertos ${ }^{456}$ ). Esto se logra, bien sustituyendo partes del templo ya existentes, para levantar en su lugar otras piezas de mayor capacidad, o bien directamente añadiendo nuevos espacios.

De esta forma, comprobamos que lo más habitual es modificar la parte correspondiente a la zona del cuerpo, bien incorporando nuevas naves a las ya existentes, o añadiendo nuevos tramos a estas naves. No obstante, tampoco resultan extrañas las transformaciones que se suceden en la zona de la cabecera, contando aquí con un buen número de ejemplos que lo demuestran.

En el primero de los casos la lista resulta extraordinariamente amplia, pues entran aquí la mayoría de los templos, que sufren algún tipo de actuación, durante la Edad Moderna. Podemos citar, por ejemplo, los casos de las iglesias de Palacios de la

\footnotetext{
456 Decimos esto porque la necesidad de disponer de más espacio en el interior de los templos constituía un notable desahogo, a la hora de inhumar los cuerpos de los finados dentro de cada parroquia. Por otra parte, la venta de estos nuevos sepulcros resultantes (en el caso de hallarse en un lugar preeminente dentro del templo), constituía una buena forma de obtener una sustanciosa ayuda para costear las consiguientes obras de ampliación.
} 
286 Arquitectura de la Edad Moderna en la sierra burgalesa.

Sierra, Santa Cecilia, en Salas de los Infantes, Hacinas, Moncalvillo, Santa María, en Huerta de Arriba, Vilviestre del Pinar, Riocavado de la Sierra, Barbadillo de Herreros, Monterrubio de la Demanda, Castrovido, Terrazas, o San Miguel, en Neila.

En lo que se refiere a las intervenciones efectuadas sobre la zona de la cabecera, su número resulta más reducido, lo cual, sin embargo, no debe restar interés, pues nos encontraremos aquí con ejemplos ciertamente brillantes de lo que fue la actividad constructiva desarrollada en la zona durante la Edad Moderna. Entre estos casos podemos citar los vividos en las iglesias de Palacios de la Sierra, Moncalvillo, Barbadillo del Pez, y especialmente Vilviestre del Pinar, a los que podemos añadir también los de Hoyuelos de la Sierra, Castrovido y Arroyo de Salas.

En el caso de las ampliaciones efectuadas sobre la zona del cuerpo, sin duda alguna, uno de los ejemplos más significativos lo encontramos en la iglesia de Santa Eulalia de Palacios de la Sierra, pues se trata de un templo, cuya estructura se fue formando a lo largo de distintas fases constructivas, desarrolladas durante todo este periodo. Así, partiendo de una estructura, que suponemos, de nave única dividida en diferentes tramos, comienza con una ampliación de la zona del cuerpo mediante la construcción de una nueva nave en el lado de la epístola. Esto se realiza a mediados del siglo XVI. A ella le sigue una segunda ampliación en los años centrales del siglo XVII, en la que se añade una segunda nave lateral, esta vez en la parte septentrional del templo, con lo que se alcanza una estructura de planta de salón con tres naves. Finalmente, ya en el siglo XVIII, se incorpora en la zona de los pies una nueva estancia, como prolongación de la nave de la epístola, que constituye el baptisterio.

Un caso similar a éste es el que nos encontramos en la iglesia de la parroquia de Santa Cecilia en Salas de los Infantes, si bien, con unas proporciones significativamente más modestas. En este caso se parte de una planta próxima a la cruz griega, sobre la cual se añade, en el siglo XVI, un nuevo cuerpo en el lado de la epístola, convirtiendo el brazo meridional del crucero en una nueva nave lateral. Posteriormente, ya en el siglo 


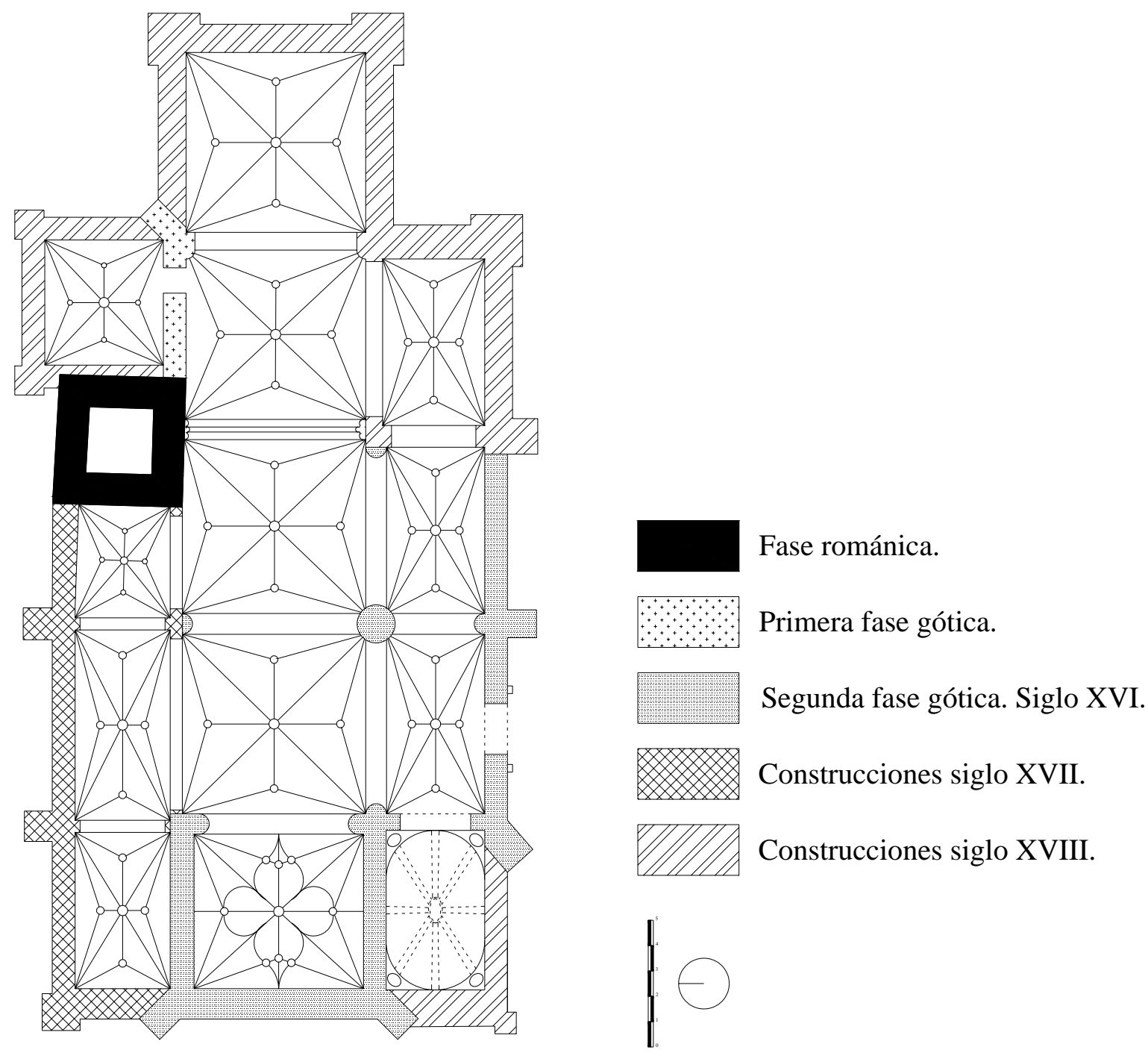

XVIII, se repite la misma operación en el lado contrario, alcanzándose así su estructura definitiva de templo de plata de salón con tres naves, aunque con un escaso desarrollo longitudinal.

Otro ejemplo sumamente interesante de ampliación de esta parte del cuerpo es el que podemos ver en la iglesia de San Pedro de Hacinas. Aquí, sobre la estructura de nave única, dividida en dos tramos, se incorporan, a mediados del siglo XVII, sendas 
naves laterales proporcionadas entre sí, con lo que se lograba prácticamente duplicar el espacio disponible, sin romper con ello la armonía de todo el conjunto.

En el caso de Moncalvillo la ampliación de la zona del cuerpo se logra de un modo muy sencillo, pues la simplicidad de su estructura, con una planta rectangular con techumbre de madera, permitía aumentar el espacio disponible simplemente modificando el trazado de sus muros. Esto es lo que se hace en su parte meridional, en los primeros años del siglo XVIII, para lo cual se aprovechan los arcos de lo que parece ser un antiguo pórtico, que se convierten ahora en el elemento separador entre la nueva nave resultante y el espacio principal del templo.

Una operación muy similar se lleva a cabo en la iglesia de la antigua parroquia de Santa María, en Huerta de Arriba, pues aquí se modifica el trazado del muro septentrional de su nave, para así ganar algo más de espacio en esta parte del templo. A ello debemos sumar las diferentes ampliaciones, que se habían realizado con anterioridad en sentido longitudinal sobre esta misma nave, efectuadas con toda seguridad en un momento anterior al de nuestra época de estudio.

Por último, los casos ya anunciado de las iglesias parroquiales de Riocavado de la Sierra, Barbadillo de Herreros, Monterrubio de la Demanda, Castrovido, Terrazas, o la antigua parroquia de San Miguel de Neila, nos muestran todas ellas ejemplos muy similares. Se trata, en todos los casos, de templos de nave única, donde la ampliación del espacio existente consiste simplemente en la renovación completa de esta nave, levantando en su lugar una nueva, completamente reformada. Al mismo tiempo, dentro de estos ejemplos debemos destacar el caso de Barbadillo de Herreros, pues este templo renueva en dos ocasiones distintas su nave, primero en el siglo XVI, y más tarde en el XVIII, manteniendo en los dos momentos su estructura de nave única, articulada en dos tramos. Posteriormente, ya en los primeros años del siglo XIX, incrementa este espacio longitudinalmente, añadiendo un nuevo tramo en la zona de los pies, más corto que los anteriores. 
En lo que se refiere a las modificaciones efectuadas en la parte delantera de los templos, los ejemplos, aunque menos numerosos, resultan sumamente interesantes. Tenemos que volver a citar aquí el caso de la iglesia de Santa Eulalia, en Palacios de la Sierra, que renueva, en los primeros años del siglo XVIII, toda su parte delantera, construyendo una nueva cabecera, pero no sobre el lugar ocupado por la anterior, sino modificando su posición, de tal modo que se consigue aumentar significativamente la longitud de la fábrica, y por consiguiente su espacio.

Directamente relacionada con esta cabecera, por la afinidad de formas que desarrolla, se encuentra la levantada, unas décadas más tarde, en la iglesia de la vecina localidad de Moncalvillo. Con ello, se consigue dotar de una mayor amplitud a toda esta parte del templo. Es lo mismo que sucede en la iglesia parroquial de Vallejimeno, donde se levanta una nueva cabecera en torno a estos mismos años, con unas formas muy similares a aquellas.

Por el contrario, un menor impacto tuvo la renovación realizada sobre la parte delantera de la iglesia de Barbadillo del Pez, pues en este caso las dimensiones que se siguen en el trazado de la nueva cabecera, en principio, eran las mismas que presentaba la antigua capilla mayor, levantada junto con el resto del templo en el último tercio del siglo XVI. De este modo, su reconstrucción, efectuada a finales del primer cuarto del siglo XVIII, únicamente se deja sentir en algunos detalles de su imagen exterior.

Pero si hablamos de renovación de cabeceras de templos, sin ningún género de dudas, el ejemplo más destacado lo encontramos en la iglesia de San Martín, en Vilviestre del Pinar. Aquí, en la década de 1760, se lleva a cabo uno de los proyectos constructivos de renovación y ampliación de un templo, más ambiciosos de cuantos tienen lugar en nuestra comarca. Así, en este momento, se procede a demoler la antigua cabecera, para levantar en su lugar una espléndida estructura, formada por un amplio crucero, de brazos poco salientes, cubierto en su parte central con una cúpula de media 
naranja, que da paso a una capilla mayor poco profunda con testero poligonal. Con ello, no sólo se lograba aumentar de forma considerable el espacio interior del templo, sino también, y tal vez más importante, se consigue introducir un lenguaje formal completamente nuevo, que choca abiertamente con el aspecto, que mostraba el resto de la fábrica.

Junto a estos casos, otros ejemplos más modestos de este tipo de intervenciones los encontramos en las iglesias de Castrovido y Arroyo de Salas, con cabeceras levantadas durante la transición del siglo XV al XVI, en el primero de ellos, y en el segundo cuarto del siglo XVI el segundo. En la iglesia de Hoyuelos de la Sierra, por su parte, esta renovación de su parte delantera se produce ya en las décadas centrales del siglo XIX.

Al margen de este tipo de intervenciones, relacionadas con la ampliación de los templos existentes, debemos hablar también de otro tipo de obras, que resultan igualmente frecuentes en estas fábricas. Nos referimos a las labores encaminadas a renovar o remodelar partes muy concretas de los templos, así como aquellas destinadas a construir nuevos añadidos. Entre estos añadidos y partes remodeladas se encuentra, la construcción de nuevas portadas, torres-campanario, sacristías, atrios, capillas, coros y sepulcros.

En el caso de las portadas, ya hemos señalado anteriormente algunos de los ejemplos más significativos, al hablar de los impulsos, que llevaban a emprender nuevas construcciones. No obstante, más adelante tendremos que volver a hablar de ellas, pues en estas piezas se encuentra uno de los puntos en los que mejor queda reflejada la evolución, que experimentan las formas artísticas a lo largo de todo este período.

Las torres campanario, por su parte, constituyen también otras piezas en las que se desarrolla una destacada actividad constructiva. Frecuentemente las actuaciones, que se realizan sobre estas torres, consisten en los típicos trabajos de mantenimiento y 
reparación de los posibles daños causados por el paso del tiempo, pues se trata de la parte del templo más expuesta y vulnerable. Los ejemplos, en este caso, son tan numerosos como templos tenemos en nuestra zona, sin embargo, los trabajos que aquí nos interesan son aquellos en los que se trata de remodelar, de forma prácticamente total, la estructura de estas construcciones, así como aquellas en las que, directamente, se toma la determinación de edificar una torre completamente nueva desde sus cimientos.

Esta última posibilidad va a ser menos frecuente, pues casi todas las iglesias de estos pueblos parten de un origen románico, lo que hace que en la mayoría de los casos cuenten con sólidas torres, realizadas en aquel período. Estas torres, en algunos casos se conservan de forma íntegra, como sucede en las iglesias de Santa Coloma, en Riocavado de la Sierra, San Miguel, en Neila, o Santa Eulalia, en Palacios de la Sierra, mientras que en otros se convierten en la sólida base, que sirve de arranque para las estructuras posteriores. Ejemplos de esto último los podemos observar en las iglesias de Barbadillo de Herreros, Tolbaños de Abajo, San Martín, en Huerta de Arriba, o Santa María, en Neila.

Aun así, también existen ejemplos de torres-campanario, que son levantadas de nuevo en su totalidad a lo largo de este período de la Edad Moderna. Esto ocurre, por ejemplo, en la mayor parte de aquellos templos, que consideramos en su momento como construcciones de nueva planta. La edificación de la torre, en estos casos, solía constituir la culminación o remate de toda la obra, con lo cual es habitual que exista un cierto lapsus temporal, más o menos amplio, entre la datación de la parte principal de la fábrica, y la elevación de la torre. Así sucede en los casos de Santa María de Salas de los Infantes y en San Esteban de Castrillo de la Reina. En el primero de ellos nos encontramos con una cierta dificultad para precisar esta diferencia cronológica de la torre con respecto al resto de la fábrica, pues la ausencia de fuentes documentales, que nos informen con detalle de este proceso, supone un serio inconveniente. No obstante, las características de ciertos elementos constructivos empleados en la parte interior, con 
los que se establece la unión con el resto del cuerpo de las naves, delatan una cronología ligeramente posterior, correspondiente ya aun momento ciertamente avanzado del siglo XVI. Más tarde, ya en el siglo XVII, se añade un nuevo cuerpo de campanas.

El proceso constructivo de la torre, que culmina la fábrica de la iglesia de Castrillo de la Reina, se encuentra mejor documentado. Así, sabemos que su construcción se inicia en el año 1572, encargándose de las obras el maestro de cantería de origen trasmerano Juan de la Fragua ${ }^{457}$. Sin embargo, no se había terminado todavía de pagar su ejecución, cuando en 1604 el maestro de cantería, también de origen montañés, Juan Gil, se encargaba de incrementar la altura de esta torre, al construir un nuevo cuerpo de campanas, levantado sobre la estructura de la torre anterior ${ }^{458}$.

Una circunstancia prácticamente idéntica a ésta es la que se vive en la parroquial de Quintanar de la Sierra. En este caso, la construcción de la parte principal de esta torre, levantada en la zona de los pies del edificio, se efectúa al mismo tiempo que el resto de la fábrica, completada en 1622. Un siglo y medio más tarde, sin embargo, se decide añadir un nuevo cuerpo de campanas, con el cual se lograba incrementar de forma considerable la altura de esta pieza, alcanzando su aspecto definitivo ${ }^{459}$.

La iglesia de San Pedro de Hacinas nos muestra otro brillante ejemplo de torre de nueva planta, construida durante la Edad Moderna. Se trata de una obra de escaso desarrollo en altura, pero de una gran solidez constructiva, que fue encargada, durante el segundo cuarto del siglo XVII, al maestro de cantería Pedro Díaz de Palacios ${ }^{460}$. Muy próxima a esta obra, por sus formas constructivas (aunque muy simplificadas), y por su cronología (pese a no tener la confirmación documental definitiva), se encuentra la torre

\footnotetext{
457 AGDBU. LP. Castrillo de la Reina, parroquia de San Estaban. LF. (1572 - 1631). Carta cuenta. Burgo de Osma, 12 - julio - 1609.

458 Ibídem. Cuentas del año 1604. Castrillo de la Reina, 13 - junio - 1606.

459 AGDBU. LP. Quintanar de la Sierra, parroquia de San Cristóbal. LF. Zayos de la Torre, 5 - agosto 1772.

460 AGDBU. LP. Hacinas, parroquia de San Pedro. LF. (1572 - 1702). Hacinas 1628.
} 
levantada en la iglesia de la vecina localidad de Moncalvillo, la cual también se edifica completamente nueva desde sus cimientos.

Por otra parte, junto con estas construcciones de nueva planta, no menos importantes resultan las remodelaciones efectuadas sobre parte de la estructura de estas torres, y de modo especial, sobre el cuerpo de campanas. A los ejemplos de Santa María de Salas de los Infantes, San Esteban, en Castrillo de la Reina, y San Cristóbal, en Quintanar de la Sierra, que acabamos de mencionar, podemos sumar también los episodios vividos en las iglesias de San Martín, en Huerta de Arriba, Santa María, en Neila, y Nuestra Señora de la Visitación, en Barbadillo de Herreros.

Otro tipo de obras de interés, dentro de este apartado, lo constituye la construcción de nuevas sacristías y atrios, situados en el entorno a los templos. En lo que se refiere a la edificación de nuevas sacristías, ya apuntábamos anteriormente, que la lista resulta extraordinariamente amplia. No obstante, hay que decir, que no en todos los casos contamos con la documentación precisa, que nos confirme el momento concreto de su realización. Sin embargo, la estructura y formas desarrolladas en todos ellos resultan tan características, que se convierten en la mejor fuente de información que podemos tener.

Estas piezas solían levantarse sobre uno de los flancos de la cabecera, aprovechando con frecuencia el solar sobre el que se alzaba la antigua. Esto se hacía así incluso en aquellos casos en los que se había sugerido abiertamente, por parte de los visitadores y veedores de obras diocesanos, un posible cambio de ubicación, como ocurrió en el caso de la iglesia de Santa Eulalia de Palacios de la Sierra. Aquí, finalmente, y tras los sucesivos mandatos de los visitadores del Obispado de Osma, en los que se hacía hincapié en la necesidad de realizar esta obra, se procede en 1730 a construir una nueva sacristía ${ }^{461}$. Sin embargo, y a pesar de las órdenes explícitas, en las

\footnotetext{
461 AGDBU. LP. Palacios de la Sierra, parroquia de Santa Eulalia. LF. (1728 - 1770). Cuentas del año 1730. Palacios de la Sierra, 29 - enero - 1731.
} 
que se indicaba la necesidad de buscar un nuevo acomodo para esta estancia ${ }^{462}$, la obra se realiza sobre el solar de la antigua.

Pero también existen excepciones, como es el caso de Castrillo de la Reina, donde la nueva sacristía, levantada por el maestro de cantería Clemente Hermoso a finales de la década de 1650 , fue adosada junto al flanco meridional de la cabecera ${ }^{463}$, mientras que la antigua permanecía en la cara norte. De esta forma, durante casi una década esta iglesia pudo contar con dos sacristías, si bien, sólo una de ellas desempeñaba esta función. Finalmente, en 1668 se solicita la correspondiente licencia para demoler la antigua ${ }^{464}$.

Por lo que respecta a la construcción de los nuevos atrios, simplemente debemos recordar lo ya mencionado anteriormente. Es decir, que no sólo sirven para delimitar este espacio sagrado, dispuesto en torno a los templos, con su consiguiente función funeraria, sino que también, en muchos casos, desempeñan una función de claro contenido estructural, al afianzar la estabilidad del suelo sobre el que se asienta la fábrica. Así, con la construcción de los muros del atrios, y su consiguiente relleno de tierra, se conseguía crear un suelo lo suficientemente llano y estable, como para garantizar la solidez del edificio, levantado en su interior.

Por último, dentro de este tipo de obras de construcción de nuevos elementos añadidos, tenemos que tratar también de la incorporación de nuevas capillas, coros y sepulcros, con los que se completa la fisionomía del edificio. No son un tipo de construcciones tan frecuentes, como las que venimos recogiendo hasta aquí, si bien constituyen también un campo muy representativo de la actividad arquitectónica, realizada en la zona durante este período.

\footnotetext{
462 Ibídem. Visita realizada a la parroquia de Santa Eulalia en Palacios de la Sierra en 1728, por D. Gaspar de Lamas y Montenegro. Palacios de la Sierra, 28 - junio - 1728.

463 AGDBU. LP. Castrillo de la Reina, parroquia de San Esteban. LF. (1632 - 1673). Cuentas del año 1755. Castrillo de la Reina, 1 - noviembre - 1756.

464 Ibídem. Cuentas del año 1668. Castrillo de la Reina, 11 - agosto - 1669.
} 
La construcción de capillas privadas no es un fenómeno muy corriente, fundamentalmente porque, como ya vimos en su momento al hablar de la sociedad de la Edad Moderna en esta comarca, no existe un grupo de comitentes privados lo suficientemente potente, o interesado en este tipo de obras, que faciliten su creación. Por ello, la capilla de Santa Ana, levantada en la iglesia parroquial de Santa María de Neila, bajo el patrocinio de la familia de los Márquez de Prada en la década de 1520, constituye una auténtica excepción ${ }^{465}$.

En esta zona, como veremos más adelante, este tipo de patrocinio se desvía generalmente hacia determinados entes colectivos, como cofradías y hermandades de tipo piadoso. Pero en estos casos, se trata de un mecenazgo más inclinado a la creación de obras de otro tipo, como por ejemplo retablos, que adornan el pequeño espacio asignado dentro del propio templo parroquial, descartando con ello la posibilidad de edificarse su propia capilla. Así, en aquellas ocasiones en las que se emprenden obras de cantería, éstas se dedican especialmente a la construcción de ermitas o pequeños humilladeros, que se situaban en el entorno del núcleo urbano.

De esta forma, son las propias parroquias las que propician la edificación de estas capillas. Uno de los casos más representativos lo encontramos en la iglesia de Palacios de la Sierra, donde se aprovecha la ampliación realizada en 1701 en la parte de la cabecera, para construir una nueva capilla en la zona meridional del templo dedicada a San Juan Bautista. No obstante, este nuevo espacio, más que una capilla en sí, deberíamos considerarlo como una mera prolongación de la nave de la epístola, pues lo único que se hace es añadir un nuevo tramo a esta parte del templo. Así, la pomposa denominación de “capilla”, que se le da en este caso, únicamente viene dado por la incorporación de un pequeño altar, con su correspondiente retablo, sobre el muro frontal.

465 B. VALDIVIELSO AUSín: Neila, una llamada al turismo. Burgos, Ayuntamiento de Neila. 1980. (pp. $161-163$ y 201). 
La incorporación de coros, por su parte, representa una tarea bastante más frecuente dentro de estos templos, si bien, no son muchos los construidos mediante obra de cantería, pues lo más normal era realizarlos en madera. Dentro del reducido grupo de los efectuados en piedra debemos destacar dos: el de la iglesia de la parroquia de Santa María en Salas de los Infantes, y el de San Esteban de Castrillo de la Reina. El primero de ellos fue levantado en el siglo XVI, mostrando en el arco, que sirve de soporte, un buen ejemplo de la arquitectura propia del período plateresco. El segundo se construye ya durante el tercer cuarto del siglo XVII, desarrollando por ello la característica sobriedad que, en general, preside toda la arquitectura realizada durante esta centuria en la zona.

Junto a estos ejemplos, podemos citar otros cuatro casos más, como son, los de las parroquias de Santa Cecilia, en Salas de los Infantes, San Martín, en Huerta de Arriba, San Juan Bautista, en Monterrubio de la Demanda, y el de la iglesia de Barbadillo de Herreros. En todos ellos su construcción está relacionada con las respectivas obras de renovación y ampliación, efectuadas en su momento en cada uno de estos templos.

Tampoco resulta muy frecuente la construcción de sepulcros de tipo monumental, dándose aquí la misma razón que hemos expuesto anteriormente al hablar de las capillas privadas. Lo normal en la zona fue realizar los enterramientos sobre el suelo del templo, cubriéndolos con una simple lápida, en la que rara vez aparecen inscripciones alusivas a la condición destacada del difunto. La uniformidad, por lo tanto, es la tónica dominante dentro del campo funerario, por ello, la especial valoración que se hace de algunos sepulcros en detrimento de otros, vendrá deparada únicamente por su mayor proximidad a la capilla mayor o a algún altar de especial devoción para el finado $^{466}$.

\footnotetext{
466 Un ejemplo de esto lo encontramos en el testamento de María Martínez, viuda de Esteban Santiago, vecinos de la villa de Canicosa de la Sierra, la cual dispondrá que sea sepultada dentro de la yglesia del
} 
Aun así, el intento de perpetuar la memoria de algunos difuntos lleva, en algunos casos, a realizar determinadas inscripciones sobre las losas de estos sepulcros. Esto sucede, por ejemplo, en el sepulcro situado en la parte central del crucero de la iglesia de Hoyuelos de la Sierra, donde presuntamente descansan los restos de D. Pedro Fernández del Barrio, canónigo capellán de D. Pedro Fernández de Velasco, que falleció en 1504. Sobre el borde de esta lápida aparece una inscripción en la que podemos leer el siguiente texto: AQUÍ YACE PERO FERNANDEZ DE BARRIO, CAPILLÁN DEL CONDESTABLE, CANONIGO E CURA BENEFICIADO EN SANTA MARÍA DE OSMA, MURIO A XXVII DE MAYO DE MIL QUINIENTOS Y CUATRO AÑOS. Esto se completa con una serie de relieves en su interior, donde aparecen dos grandes llaves unidas por un cordón, una estrella de seis puntas inscrita en un círculo, y un ancla dispuesta sobre un mar, representado de forma muy esquemática $^{467}$.

Aparte de esto, nos encontramos también con algunos otros ejemplos de sepulcros con un marcado carácter monumental, en los que se desarrolla la característica tipología de arcosolio, adosado al muro. No obstante, en ninguno de ellos poseemos la documentación necesaria, que nos permita conocer los nombres de sus propietarios o la época a la que pertenecieron. Por ello, tenemos que servirnos únicamente del análisis de sus características formales, para establecer una cronología aproximada. Entre ellos se encuentran los situados en los respectivos presbiterios de las iglesias de San Pedro, en Hacinas, y Santa Cecilia, en Salas de los Infantes, conservándose de ellos únicamente los arcos que los cubrían, y un escudo con las armas del propietario, en el primero de los casos.

Sr. San Esteban desta dicha villa en las sepulturas donde obiera más lugar, junto a la capilla e altar de Nuestra Señora del Rosario. AHPSO. PN, caja 3273, vol 5571. (66 - 70). Juan Domingo, San Leonardo. Canicosa de la Sierra, 6 - mayo - 1664.

467 G. MIGUEL OJEDA: “Hoyuelos de la Sierra”. BIFG, Burgos, nº 149 (1959). pp. 799 - 805. 
El ejemplo más destacado lo tenemos en la iglesia de San Estaban, en Castrillo de la Reina. Sobre el muro lateral del primer tramo de la nave del evangelio aparece un magnífico ejemplo de arquitectura funeraria del pleno renacimiento, mostrando la característica estructura de arco de triunfo, acompañada por una equilibrada ornamentación, propia de la plenitud de este estilo.

Finalmente, para cerrar este apartado, debemos señalar brevemente también la presencia de otro tipo de trabajos, que no por su menor brillantez, dejan de tener importancia dentro del panorama arquitectónico. Nos referimos a los relacionados con el mantenimiento y reparación de los edificios existentes, algunos de los cuales alcanzan presupuestos realmente elevados. Obviamente, las actividades de este tipo resultan mucho más fáciles de seguir dentro de la arquitectura religiosa que en la civil, pues en el primero de los casos contamos con la valiosa información que nos proporcionan los libros de fábrica.

Así, mediante estas fuentes, podemos conocer con bastante detalle, qué tipo de trabajos eran los más frecuentes, y cuáles los más costosos para sus responsables. Se trata, en definitiva, de un tipo de trabajo extraordinariamente amplio y heterogéneo, donde quedan incluidos, desde la simple y casi rutinaria labor de retejado, hasta la apertura de un nuevo vano, la construcción de un osario, la fundición de las campanas, o la completa sustitución de toda la estructura de madera, que formaba la techumbre.

Precisamente eran estas reparaciones realizadas sobre las cubiertas, unas de las que mayor cantidad de dinero consumían. De ello nos dan cuenta las obras realizadas sobre el tejado de la iglesia parroquial de Castrillo de la Reina entre los años 16781679 , cuyo coste superó sobradamente los 5.000 reales $^{468}$. Una cantidad muy similar a ésta fue la invertida en 1783 por la parroquia de San Pedro de Hacinas en la misma

\footnotetext{
468 AGDBU. LP. Castrillo de la Reina, parroquia de San Esteban. LF. (1673 - 1708). Cuentas del año 1678. Castrillo de la Reina, 18 - enero - 1679; Ibídem. Cuentas del año 1679. Castrillo de la Reina, 15 enero 1680 .
} 
labor $^{469}$, mientras que la destinada a este fin en la parroquial de Palacios de la Sierra en 1747 se quedó aproximadamente en la $\operatorname{mitad}^{470}$. En la de Santa María de Neila, de 1788, llegó a los 3.230 reales $^{471}$.

Otras obras de este tipo, son las dedicadas al cuidado del suelo, y en concreto a renovar el enlosado y entarimado, que cubría los sepulcros. La importancia de estas labores radica fundamentalmente en el hecho de que, con ellas se acondicionaba el lugar, que debía recibir los enterramientos de la feligresía, pues no debemos olvidar, que los templos parroquiales no sólo eran lugar de reunión de los fieles, sino también, y de modo muy especial, sitio de descanso de los difuntos. Por ello, junto a la frecuencia con la que se hacían estos trabajos, debemos destacar también las importantes cantidades de dinero invertidos en ellos.

Así, por ejemplo, en estos trabajos de enlosado, la iglesia de la parroquia de Santa Cecilia, en Salas de los Infantes, gastó en 1740 un total de 5.103 reales $^{472}$, el pequeño templo de Arroyo de Salas, entre 1753 y 1755 llegó a invertir otros 1.676 reales $^{473}$, y en 1633 la iglesia de San Esteban, en Canicosa de la Sierra, 1.240 reales y medio $^{474}$.

469 AGDBU. LP. Hacinas, parroquia de San Pedro. LF. (1778 - 1866). Cuentas del año 1783. Hacinas, 16 - febrero 1784

470 AGDBU. LP. Palacios de la Sierra, parroquia de Santa Eulalia. LF. (1728 - 1770). Cuentas del año 1747. Palacios de la Sierra, 29 - marzo - 1748.

471 AGDBU. LP. Neila, parroquia de Santa María. LF. (fols. 146 vº). Cuentas del año 1788. Neila, 30 septiembre -1789 .

472 A Parroc. Salas de los Infantes. LP. Salas de los Infantes, parroquia de Santa Cecilia. LF. (1721 1809). Cuentas del año 1740. Salas de los Infantes, 20 - julio - 1741.

473 AGDBU. LP. Arroyo de Salas, parroquia de San Julián. LF. (1721 - 1769). Cuentas del año 1753. Arroyo de Salas, 10 - octubre - 1754; Ibídem. Cuentas del año 1755. Arroyo de Salas, 4 - septiembre 1756.

474 AGDBU. LP. Canicosa de la Sierra, parroquia de San Esteban. LF. Cuentas del año 1633. 
No menos importantes y gravosas fueron las labores de entarimado. Por ejemplo, la parroquial de Barbadillo de Herreros en 1744 destinó 1.890 reales a estos trabajos ${ }^{475}$, la de Huerta de Abajo 1.300 reales en 1757, y otros 750 reales sólo tres años después ${ }^{476}$, Vallejimeno en 1733 dedica 900 reales $^{477}$, y la ermita de Nuestra Señora de Costana, en Barbadillo de Herreros, un total de 5.222 reales, entre los trabajos de entarimado y adoquinado, efectuados en $1803^{478}$.

Todo esto nos permite obtener una visión aproximada de la realidad, que presenta la actividad arquitectónica desplegada en la zona a lo largo de estos tres siglos. No obstante, también debemos conocer de cerca otra serie de aspectos no menos interesantes, entre los que se incluyen, los elementos empleados en el desarrollo de esta actividad, los protagonistas que participaron en su confección, el proceso seguido en su realización, y las cuestiones relacionadas con las formas de las obras resultantes.

\footnotetext{
475 A. Parroc. Barbadillo de Herreros. LP. Barbadillo de Herreros, parroquia de Nuestra Señora de la Visitación. LF. (1718 - 1748). (fols. 121 - 122). Cuentas del año 1744. Barbadillo de Herreros, 10 diciembre -1744 .

476 AGDBU. LP. Huerta de Abajo, parroquia de Santa Cristina. LF. (1741 - 1797). (fols. 45 - 46 v v). Cuentas del año 1757. Huerta de Abajo, 14 - octubre - 1758; Ibídem. (fols. 51 - 53 vo). Cuentas del año 1760. Huerta de Abajo, 28 - septiembre - 1761.

477 AGDBU. LP. Vallejimeno, parroquia de San Martín. LF. (1704 - 1751). Cuentas del año 1733. Vallejimeno, 6 - septiembre - 1734 .
} 
PROCESO CONSTRUCTIVO.

La ausencia de unas fuentes documentales abundantes y ricas en datos nos impide conocer con el rigor que deseamos los aspectos relacionados con los promotores y artífices, así como los entresijos de la realización material de las obras arquitectónicas. Aun así, dentro del análisis, que hemos realizado a distintos niveles, sobre esta comarca a lo largo de la Edad Moderna, no parece que podamos encontrar ningún tipo de particularidad de carácter social, económico, administrativo o cultural, que lleve a sospechar la existencia de diferencias importantes, en lo que se refiere al proceso de construcción, con respecto a los procedimientos, que resultan habituales, dentro del ámbito castellano, durante este mismo periodo.

De este modo, la decisión de realizar una obra partía siempre de la autoridad bajo la cual se encontraba el edificio en cuestión, es decir, que la iniciativa recaía siempre en el propio patrono. En el caso de las obras privadas este patronato reside, lógicamente, en el mismo propietario de la obra, bien se trate de la construcción de una vivienda, o de la edificación de una capilla dentro de un templo, por poner dos ejemplos. Cuando se trata de una obra pública, esta responsabilidad queda en manos de los concejos, por tratarse del nivel inferior, dentro de la jerarquía administrativa, si bien,

\footnotetext{
478 A. Parroc. Barbadillo de Herreros. LP. Barbadillo de Herreros, Ermita de Nuestra Señora de Costana. LF. (1731 - 1840). (fols. 59 - 60 vo). Cuentas de los años 1803 - 06. Barbadillo de Herreros, 6 - marzo 1806.
} 
en los casos de obras de cierta importancia es necesario contar con la aprobación de la autoridad regia.

Algo similar sucede con las obras religiosas. Si se trata de un templo regular, cada orden está facultada para emprender con libertad sus propias obras, para lo cual necesitaban únicamente la autorización de los superiores de la orden religiosa ${ }^{479}$. Si es una parroquia, la advertencia sobre la necesidad de realizar una determinada obra podía partir, bien de la propia parroquia, a través de sus mayordomos, o bien del Visitador del obispado, que sugería su ejecución. Esto nos lleva a hablar del papel desempeñado por estos enviados del Arzobispado de Burgos y Obispado de Osma respectivamente, en las parroquias de nuestra zona. Así, vemos que a lo largo de sus periódicas inspecciones se encargaban, no sólo de hacer cumplir los distintos puntos establecidos en las Constituciones Sinodales, referentes a la propia labor pastoral de los clérigos y a la piedad en general de los feligreses, sino también de vigilar el buen estado de conservación que debían presentar los templos, ermitas, hospitales y demás lugares píos, que se encontraban ubicados en el territorio de cada parroquia. De este modo, en el caso de no hallarse estos edificios con el decoro y buen estado de conservación preciso, o en aquellos otros en los que se consideraba necesario algún tipo de obra de arreglo o ampliación, ellos mismos se encargarían de tomar la iniciativa, haciendo la correspondiente anotación en el acta levantada después de cada visita. Ejemplos de ello se pueden encontrar en obras como la construcción del atrio en la iglesia parroquial de Hoyuelos de la Sierra, la reparación del campanario de la iglesia de Santa María en Neila, la renovación de la sacristía de Santa Eulalia en Palacios de la Sierra, o las ampliaciones de la iglesia de San Pedro, en Vilviestre del Pinar, se iniciaron a partir de este tipo de mandatos de los Visitadores.

No obstante, el control que podían llegar a ejercer estos enviados episcopales no debía ser muy riguroso, pues la extensión de ambos territorios, especialmente en el caso 
de la sede burgalesa, y la poca regularidad que en algunos momentos tuvieron estas visitas pastorales, lleva a que la iniciativa recaiga finalmente, y casi de forma exclusiva, en manos de los propios responsables de cada fábrica. De este modo, la presencia directa de estos representantes diocesanos, como Visitadores, Provisores y Veedores de obras, solamente se producía en aquellos proyectos de mayor envergadura, donde era necesario contar con la correspondiente licencia, pues en el resto de las obras la propia fábrica era autosuficiente.

La realización material de una obra constituía un largo proceso, en el cual quedaban comprendidos una serie de pasos. Entre ellos se incluyen, desde la petición de la correspondiente licencia, que permitía su puesta en marcha, hasta la tasación final, que daba por buena la construcción.

El primer paso consiste en la concesión de la pertinente licencia, en cuya petición se trataba de resaltar la necesidad de la ejecución de la obra, tanto si se trataba de la construcción de un edificio de nueva planta, como de la reparación de una obra ya existente. Esta licencia era concedida siempre por la autoridad correspondiente. Así, si era una obra civil de carácter privado, como puede ser la construcción o remodelación de una vivienda, el organismo encargado de concederla debía ser el concejo del municipio en el que se encontraba. Si la obra era pública, y además presentaba unas ciertas proporciones, la licencia debía ser solicitada ante el Real Consejo de Castilla, por ser este órgano el encargado de las obras públicas, que se realizaban en el territorio de la Corona. El concejo del lugar, por su parte, daría también su aprobación para poder pregonar el anuncio de su adjudicación, en caso de que el sistema elegido fuera la contratación mediante subasta. A partir de este momento el desarrollo de los trabajos quedaría en manos de la propia autoridad civil del lugar, que en nuestro caso debía ser el propio concejo, dada la ausencia de corregidor en estos pueblos (los más próximos se encontraban en Burgos y Aranda de Duero).

479 En nuestro caso, el único ejemplo de templo regular, que encontramos dentro de nuestra zona de estudio, es el de Santa María de Alveinte, perteneciente a la orden franciscana, con lo cual son los 
En las obras emprendidas por las parroquias, esta licencia era concedida por la autoridad diocesana correspondiente, que en nuestro caso son, como sabemos, el Obispado del Burgo de Osma, y el Arzobispado de Burgos. En estos casos, la concesión de licencia era considerada un requisito obligatorio, especialmente a partir del último tercio del siglo XVI, con la aprobación de las respectivas Constituciones Sinodales ${ }^{480}$. En el caso de Burgos se dice, por ejemplo, que “... Y por que no conuiene al seruicio de Dios ni bien de la republica, Synodo aprobante, prohibimos y defendemos, so pena de excomunión y de diez mil marauedís para la fábrica de la yglesia y pobres de tal lugar, que ninguno en este nuestro arçobispado de nueuo edifique yglesia ni monasterio sin la dicha nuestra licencia y autoridad o de nuestros poruisores, precedimiento primero citación para los curas y clérigos y parroquianos de la información si se le da competente dotación, y de aquellas cosas que son necessarias para dar la dicha licencia para que pueda estar reparada para adelante. $Y$ no procediendo lo suso dicho queremos que la dicha licencia sea en si ninguna y de ningún efecto"481. Por su parte, en las de la sede oxomense vemos que el texto no varía mucho, indicando lo siguiente: “...statuimos y ordenamos que de aquí adelante, no se de obra ninguna de oro, plata, ni de ornamentos, ni cantería, ni carpintería, ni otra alguna de las dichas yglesias, hermitas, o hospitales, o lugares píos a hazer, sin que primero se miren las cuentas y se vea el alcance que la yglesia tiene, y si con la renta que tiene se puede acabar, o con la que rentare hasta que se acabe..."482.

\footnotetext{
superiores de esta orden los que tenían la potestad de conceder la autorización para que se llevara a cabo.

480 En el Arzobispado de Burgos estas Constituciones Sinodales fueron redactadas en 1577 por el arzobispo Francisco Pacheco de Toledo, mientras que en el Obispado de Osma esto se produjo en 1584, durante el mandato del obispo Sebastián Pérez.

481 A.C. Burgos. Constituciones Sinodales, del Arçobispado de Burgos, copiladas, hechas y ordenadas agora nuevamente conforme al Santo Concilio de Trento, por el Ilustrísimo y Reverendísimo Señor D. Francisco Pacheco de Toledo. Impresas en Burgos en 1577.

482 A. C. Burgo de Osma. Constituciones Synodales del Obispado de Osma, hechas y ordenadas por el reverendísimo Señor Don Sebastián Pérez, obispo de dicho obispado, del Concejo de Su Majestad:
} 
Evidentemente el sentido de las normas queda claro, especialmente en el caso de estas últimas, de tal modo, que con estas licencias se pretendía no sólo controlar el decoro y buen gusto de las construcciones y reparaciones acometidas dentro de las iglesias, sino sobre todo evitar la quiebra económica de las parroquias ${ }^{483}$, pues muchas de ellas se embarcaban en proyectos tan ambiciosos, que excedían de forma considerable las posibilidades de afrontar su pago. Por todo ello, esta licencia se hace especialmente necesaria en aquellas obras de mayor envergadura, estableciéndose un límite mínimo en el presupuesto de las mismas, a partir del cual se hacía necesario solicitar licencia. Este límite, para las parroquias de la diócesis de Burgos, se fijó en 8.000 maravedís $^{484}$, mientras que para las dependientes de la sede de Osma quedó en $6.000^{485}$. Aun así, nos encontramos con casos excepcionales, en los límites se bajaron de modo considerable, ante el peligro de que alguna parroquia se embarcara en proyectos demasiado costosos, como para ser afrontados con éxito. Este es el caso de la parroquial de Barbadillo del Pez, donde a causa de haber acometido en su momento determinadas obras sin la pertinente petición de licencia, el visitador, que acude aquí en 1747, ordena, que a partir de este momento la licencia se haga necesaria para toda obra que pretenda hacer con un presupuesto superior a los 1.700 maravedís, y no a partir de los 8.000, que estipulaban las Constituciones Sinodales de la Diócesis ${ }^{486}$.

Recibidas y consentidas en la Synodo que celebró en la Catedral, desde tres de julio de mil y quinientos y ochenta y cuatro hasta el quince del dicho mes y año. Impresas en su villa del Burgo. 1586.

483 L. S. IGLESIAS ROUCO, M. J. ZAPARAÍN YÁÑEZ: "En torno a la actividad profesional en la arquitectura religiosa burgalesa, 1600 - 1650”. En Juan de Herrera y su influencia: actas del Simposio: Camargo 14/17 julio 1992. Santander, Fundación Obra Pía Juan de Herrera: Universidad de Cantabria. 1993. (pp. 217 - 225).

484 Constituciones Sinodales del Arçobispado de Burgos, ... impresas en Burgos en 1577. Ob. cit. (pp. $639-340)$.

485 Constituciones Synodales del Obispado de Osma, ... impresas en la Villa del Burgo en 1586. Ob. cit. (pp. 291).

486 AGDBU. LP. Barbadillo del Pez, parroquia de San Salvador. LF. (1685 - 1812). Resulta que por cuenta del cura y de su autoridad se an practicado algunas obras y reparos en ella sin la licencia necesaria del hordinario. Mando merced que desde hoy en adelante por el cura que es o fuere de la referida parroquia no pueda mandar ni mande se practiquen en dicha iglesia obra alguna que exceda de $50 \mathrm{R}$ siendo precisa sin licencia formal de dicho hordinario, y lo cumpla bajo de las referencias. Barbadillo del Pez, 15 - mayo - 1747. 
Con las licencias, por lo tanto, se pretende salvaguardar la buena situación económica de las parroquias, evitando con ello los riesgos de quiebra, que con frecuencia propiciaba la tentadora idea de agrandar o engalanar de forma desmedida sus templos. Pero aun así, se dan situaciones límite, en las que la necesidad imperiosa de emprender una obra, se ve acompañada por una ausencia total de los fondos con que afrontarla. Estos casos son relativamente frecuentes dentro de los pueblos de la sierra, pues aunque los curas beneficiados gozaban de una situación económica ciertamente desahogada, con unos recursos más que suficientes para su mantenimiento (pese a las limitaciones que ofrece la economía de la comarca), las parroquias y sus fábricas se encontraban con demasiada frecuencia viviendo situaciones francamente apuradas, cuando no de auténtica miseria. Los testimonios de ello son constantes a lo largo de toda la época, repitiéndose indistintamente en cada una de las parroquias en diferentes momentos. Uno de los casos más singulares fue el vivido en la iglesia de Quintanilla de Urrilla a mediados del siglo XVIII. Aquí, la situación llegó a tales extremos, que en 1755 el visitador del Arzobispado de Burgos, D. Juan de Tobías y Zuazo, ante la necesidad de realizar diversas obras en la estructura de la fábrica, y dada la extrema pobreza en al que se encontraba la parroquia, llega a plantear, entre otras medidas, el traslado del Santísimo Sacramento a la iglesia de la localidad vecina de Vallejimeno, pues todas las posibles vías alternativas de financiación, a las que se solía acudir en estos casos, ya se habían usado ${ }^{487}$.

Para solventar situaciones tan dramáticas como ésta los Provisores diocesanos disponen de una serie de mecanismos, de carácter auténticamente excepcional, con los cuales se podían paliar estas carencias. Todos ellos, por supuesto, iban acompañados de un estrecho seguimiento, por parte de las autoridades diocesanas, pues de esta forma se aseguraban el correcto empleo de las ayudas. Entre estas medidas, una de las más habituales era la adquisición de censos, con los cuales afrontar los pagos de las obras, si 
bien esto conllevaba el peligro de un casi perpetuo endeudamiento. Un ejemplo concreto de la aprobación de este tipo de ayuda lo tenemos en la construcción de la nueva cabecera, que se levanta en la iglesia de San Pedro en Moncalvillo en 1732. La cantidad tomada en este caso fue de 2.500 reales $^{488}$.

Otra medida similar fue la concesión del permiso necesario para vender determinados objetos pertenecientes al patrimonio de la parroquia, por ejemplo, animales, tierras o incluso objetos litúrgicos, para, así, poder sufragar las obras acometidas. Esto sucede, por ejemplo, en la ermita de Nuestra Señora del Arroyal de Palacios de la Sierra, donde en 1664 el Provisor oficial de la Diócesis de Osma, D. Francisco Beideces y Tamayo, concede permiso al mayordomo de esta Cofradía, D. Pedro Llorente, para que "pueda bender y benda todas las reses que para el tener al presente la dicha hermita a la mayor utilidad que se prediere y con la cantidad que dellos resultare y la del dicho alcance y demás mandas que se ycieron pueda proseguir en hacer que se aga en la dicha hermita la obra del cuerpo de la iglesia della...”489. En la iglesia de Arroyo de Salas, ante la necesidad de reparar el techo que cubría el coro, el propio Arzobispo de Burgos, D. Pedro de la Cuadra Archiaba, en visita realizada el año 1749, indica que: "se ejecuten dichos repara con la brevedad posible de los efectos de dicha fábrica y para ayuda de su coste se desharán de un cáliz y una patena antigua que tiene la iglesia, cuio importe se depositará, vendido que sea, en el archivo de dicha iglesia, llevando en todo la devida quenta y razón dicho cura"490.

\footnotetext{
487 AGDBU. LP. Quintanilla de Urrilla, parroquia de San Martín. LF. (1704 - 1762). (fols. 116vº $119 v^{0}$ ). Visita realizada a la parroquia de San Martín en Quintanilla de Urrilla en 1755, por D. Juan de Tobías y Zuazo, canónigo de la catedral de Burgos. Canales, 31 - julio - 1755.

488 AGDBU. LP. Moncalvillo, parroquia de San Pedro. LF. (1715 - 1759): Cuentas del año 1733. Moncalvillo, 15 - marzo - 1734.

489 AGDBU. LP. Palacios de la Sierra, parroquia de Santa Eulalia y Santa María. Cofradía de Nuestra Señora del Arroyal. Visita a la parroquia de Santa Eulalia en Palacios de la Sierra de 1664 por el Provisor del Obispado de Burgo de Osma, D. Francisco Beideces y Tamayo Burgo de Osma, 10 - octubre - 1664.
} 
308 Arquitectura de la Edad Moderna en la sierra burgalesa.

Junto a esto podemos señalar también la autorización, dada en algunos casos, mediante la cual se permitía la apropiación de determinadas partes de los diezmos, que en teoría no pertenecían a la fábrica, como era el caso del tercio que iba a parar a manos de la sede Diocesana, o los llamados Tercios Reales, que en la práctica totalidad de los pueblos, estaba en manos de los Duques de Frías por usurpación ${ }^{491}$.

Una vez obtenida la licencia, se llegaba al siguiente paso, como era el de la adjudicación de la obra, el cual resultaba fundamental, pues conducía directamente a la ejecución material de la misma. En este proceso participan, por una parte, el patrono del cual había partido la iniciativa del proyecto, y por otra, el artífice, que se encargaría de su realización. Los contratos sólo podían realizarse con artífices, que estuvieran reconocidos como tales, debiendo presentar para ello una fianza y los correspondientes testigos, que actuaban como fiadores. Con ello quedaba garantizada, no sólo la solvencia y seriedad del maestro, sino también la correcta ejecución de la obra.

En general podemos decir que existen dos tipos fundamentales de adjudicación, como son la contratación directa y la contratación indirecta. Esta última, no resulta, a priori, una forma muy común en nuestra comarca, en parte, por estar prohibida por las respectivas Constituciones Sinodales de las Diócesis de Burgos y Osma ${ }^{492}$. Aun así, debemos decir que consiste fundamentalmente en el paso de la respectiva responsabilidad de una obra de manos de un maestro a otro. Para ello, el nuevo artífice

\footnotetext{
490 AGDBU. LP. Arroyo de Salas, parroquia de San Julián. Libros de Fábrica (1721 - 1769). Visita realizada a la parroquia de San Julián de Arroyo de Salas en 1749, por el Arzobispo de Burgos D. Pedro de la Cuadra Archiaga. Salas de los Infantes, 14 - agosto - 1749.

491 Ver capítulo dedicado a la Economía.

492 Constituciones Sinodales del Arçobispado de Burgos, ... impresas en Burgos en 1577. Ob. cit. : “... prohibimos pueda dar ni traspassar la obra que en él fuere remetada a otor, so pena de ser auido por el mesmo hecho inhábil, para que no le sea dada más a hazer obra alguna en este nuestro arçobispado en ningún tiempo, y que la traspassación sea en sí ninguna...”. Constituciones Synodales del Obispado de Osma, ... impresas en la Villa del Burgo en 1586. Ob. cit.: "Otrosi statuymos y mandamos que de aquí adelante, ningún maestro ni official pueda dar ni traspassar la obra que tomare a hazer, ni dar parte della a otro, so pena de dos mil maravedis para la fábrica de la dicha yglesia, y que la traspasación sea en si ninguna y de ningún effecto...”.
} 
firmaba un contrato de obligación similar al signado por el primero, con las mismas obligaciones, pero con sus propios fiadores. Pero como ya decíamos, éste no era un sistema muy habitual, ni en nuestra zona, ni en general dentro del mundo de la arquitectura durante la Edad Moderna, pues se trataba de una práctica más común entre los pintores y escultores que entre los maestros de cantería ${ }^{493}$.

El tipo más común de contratación directa es el conocido como contratación por subasta o remate, empleado muy especialmente en obras de cierta envergadura. Así, se utiliza de forma mayoritaria en obras públicas, tanto civiles (emprendidas por los concejos), como religiosas ( como son las acometidas en las propias parroquias). Igualmente recurren a este tipo, determinados particulares para la ejecución de obras poco corrientes - como podía ser la construcción de una capilla - donde el carácter artístico del proyecto lo justificaba ${ }^{494}$.

En este tipo de contratación se parte de unas trazas y un pliego de condiciones previo, encargados a un maestro, que no necesariamente debía ser el encargado final de su ejecución. En el caso de las obras religiosas de cierta importancia, el encargado de realizar estas trazas y condiciones solía ser el Maestro Mayor de las obras de la catedral, pues a su labor se incorporaban las funciones de Veedor de las obras de la Diócesis, entre las que quedaban recogidas precisamente estas responsabilidades. Este maestro fijaba, dentro de las condiciones, un precio estimado para su ejecución, el cual se convertía en el precio de salida en el momento de hacer la subasta.

Simultáneamente a estos primeros pasos, se procedía a pregonar el anuncio de la obra, lo que se hacía en aquellos lugares más importantes, situados en el entorno de la localidad en la que se iba a realizar el trabajo, donde se sabía de la existencia de maestros en la materia. En el caso de obras religiosas, el primer lugar donde se colocaba

493 B. ALONSO RUIZ: El arte de la cantería. Los maestros trasmeranos de la Junta del Voto. Santander, Universidad de Cantabria. Asamblea Regional de Cantabria. 1991. (pp. 44 - 48). 
este anuncio debía ser, lógicamente, la puerta de la iglesia parroquial a la que pertenecía, pues así lo establecían las propias Constituciones Sinodales. A partir de aquí se ampliaba el radio de acción, en función de la importancia del proyecto. Este pregón quedaba expuesto durante un plazo de tiempo variable, que en los casos de las Diócesis de Burgos y de Osma, no debía bajar de 15 días $^{495}$, si bien lo normal solía ser un mes ${ }^{496}$.

Durante este tiempo los maestros interesados en su ejecución podían analizar las trazas y condiciones, estudiar el lugar de la obra, visitando el emplazamiento, valorar la disponibilidad de materiales, o cualquier otro tipo de elementos que pudieran actuar en el futuro desarrollo de los trabajos. Con ello, se trataba de ajustar lo más posible el presupuesto, que ellos iban a dar, a la realidad de la obra en cuestión, teniendo presente, por supuesto, el margen de beneficio que debía quedar. Este presupuesto, que cada aspirante realiza, se denomina postura.

La subasta o remate de la obra era el momento en el que se ponían en común las diferentes posturas, que cada uno de los maestros aspirantes había calculado. El número de aspirantes, nuevamente, solía variar en función de la importancia que tuviera la obra que se iba a emprender. El lugar elegido para realizar el remate solía ser el propio emplazamiento de la obra, pero también podía ser cualquier otro lugar público y abierto, el cual, obviamente, debía aparecer indicado en el pregón anunciador. Con cierta frecuencia, este lugar solía ser el atrio de la iglesia parroquial del lugar, aunque la obra no fuera religiosa, pues con ello se rememoraba el antiguo papel, que estos espacios

\footnotetext{
494 A. C. IBÁÑEZ PÉREZ: Arquitectura civil del siglo XVI en Burgos. Burgos, Caja de Ahorros Municipal de Burgos. 1977. (pp. 80 - 82).

495 Constituciones Sinodales del Arçobispado de Burgos, ... impresas en Burgos en 1577. Ob. cit.: “...y en la puerta de la yglesia donde se huuiere de hazer la obra, las quales estén a lo menos quinze días fixadas, donde se declare la obra que se ha de hazer, para que los officiales dellas respectiuamente vean si les conuiene tomarlas". En este punto observamos que las Constituciones Sinodales del Burgo de Osma reproducen palabra por palabra lo recogido en la de la Diócesis burgalesa. Constituciones Synodales del Obispado de Osma, ... impresas en la Villa del Burgo en 1586. Ob. cit.

496 B. ALONSO RUIZ: El arte de la cantería... Ob. cit. (pp. 28).
} 
habían tenido en todos estos pueblos, como punto de reunión de los vecinos ${ }^{497}$. El momento del día elegido solía ser el mediodía.

Durante el proceso de remate, cada maestro aspirante exponía su postura, y una vez transcurrido un tiempo, que normalmente venía determinado por la consumición de una vela, se procedía a la adjudicación del proyecto. Esta adjudicación debía recaer en la postura más adecuada a los intereses del comitente, la cual, lógicamente, solía ser la más baja. Sin embargo, también era necesario cuidarse de las llamadas bajas temerarias, es decir, aquellas que ofrecían un precio demasiado bajo, el cual podía poner en peligro la buena ejecución de la obra. Inmediatamente después de la adjudicación, se procedía a firmar el contrato.

Este sistema de contratación, lógicamente, presentaba sus ventajas e inconvenientes. Así, para el comitente suponía tener que hacer una fuerte inversión inicial, ya que debía correr con los gastos ocasionados por el encargo de las trazas y condiciones, y de pregonar la obra. No obstante, el carácter altamente competitivo que el sistema representaba para los aspirantes, llevaba, en muchos casos, a hacer rebajas tan fuertes en las posturas, que rozaban el límite de la rentabilidad para el artífice adjudicatario. Para los maestros, por el contrario, todo parecían desventajas, pues a lo ya indicado, se sumaban otro tipo de cuestiones, como la necesidad de firmar contratos muy restrictivos para sus intereses, obligándose, en ocasiones, a hipotecar sus propios bienes para poder cubrir las fianzas. Además, y por si esto fuera poco, existía también la posibilidad de poder perder la obra, si aparecía una postura más barata ${ }^{498}$.

Además de este sistema de adjudicación, mediante subasta o remate, existen otros tipos de contratación directa, entre los que se encuentra la llamada contratación a jornal. Se trata de una sistema empleado especialmente en obras menores o de poca importancia, como era el caso de la construcción de viviendas, para la mayor parte de la

\footnotetext{
C. R. LAFORA: Por los caminos del románico porticado. Una fórmula arquitectónica para
} albergar el derecho a la libertad. Madrid, Ediciones Encuentro. 1988. 
población que habitaba en estos pueblos, o la realización de determinados trabajos dentro de los templos, para los que no era necesario un seguimiento estrecho por parte de las autoridades diocesanas. Por ello, debemos considerarlo también como un tipo de contrato bastante habitual, dentro del panorama constructivo, que se desarrolla en nuestra comarca. En el caso de las obras privadas esta modalidad recibía el nombre de contratación directa, pues el comitente contrataba directamente con el maestro, sin mediar ningún paso previo. Este comitente, por su parte, habría encargado previamente las trazas a otro maestro, lo cual hace que el artífice trabajase, por lo general, con trazas ajenas, si bien, tampoco resultaba raro que el propio ejecutor fuera al mismo tiempo el encargado de su diseño. Para el modo de pago, el comitente establecía la asignación de un jornal diario ${ }^{499}$.

Otro tipo distinto era la contratación por tasación final, consistente en la adjudicación de una obra a un maestro determinado por un presupuesto global, desglosado en diferentes pagos intermedios. Una vez concluida la obra, se realizaba una tasación final, efectuada por dos maestros, uno representando al comitente, y el otro al artífice. Si el resultado de la misma era superior al precio fijado en un inicio no se abonaría ningún tipo de cantidad complementaria, sin embargo, en el caso de ser inferior, el comitente pagaría únicamente el valor estimado. Evidentemente este sistema entrañaba ciertos riesgos, pues rara vez los tasadores daban un veredicto unánime, constituyéndose, por ello, en una constante fuente de conflictos ${ }^{500}$. Su razón de ser se encontraba en el propósito de salvaguardar los intereses del comitente, especialmente si éste era una humilde parroquia de recursos limitados. De esta forma, en algunas Constituciones Sinodales, como es el caso de las del Burgo de Osma, nos encontramos con diferentes cláusulas en las que se indica que: "los dichos officiales no se puedan llevar a engaño de las obras que así hizieren, aunque las dichas obras se tassen en

\footnotetext{
498 Ibídem. (pp. 40 - 42).

499 Ibídem. (pp. 43).

500 Ibídem. (pp. 44).
} 
mucho más, sino que sean vistos hazer gracia y donación de tales demasías a las yglesias..."501.

Por útlimo, tenemos que citar también la contratación a destajo, sistema empleado en obras demasiado grandes, como para ser acometidas por una sola cuadrilla de canteros. Aquí, cada una de las cuadrillas participantes en el proyecto se hacía cargo de una parte de la obra, fijándose un plazo y un dinero para su ejecución, y cobrando en función de lo trabajado. Si, como era de desear, la coordinación entre los diferentes equipos era buena, los trabajos llegaban a avanzar a un buen ritmo, lo cual era siempre deseable por parte de los comitentes ${ }^{502}$. Sin embargo, se trata de un sistema empleado de forma casi exclusiva en la contratación de grandes proyectos arquitectónicos, lo que hace que no la encontremos aquí.

Después de adjudicar la obra, e independientemente del sistema empleado para ello, el paso siguiente consiste en la firma del contrato, que daba validez legal a este acuerdo. El contrato, como bien sabemos, era una escritura pública, firmada ante notario, de obligación y fianza, en la que se incluían distintos apartados. Era habitual, por ejemplo, incluir una copia detallada de los pliegos de condiciones, donde se hacía especial hincapié en reseñar todos aquellos aspectos relacionados con el desarrollo de la obra, como son, las cuestiones técnicas y estéticas de la misma, los plazos de finalización (que generalmente se hacían coincidir con la celebración de algún santo singular), y por supuesto, el precio definitivo y los modos de pago. Según estas escrituras, por lo tanto, el maestro se comprometía a realizar la obra, de acuerdo con las condiciones y cantidades fijadas, y cumpliendo los plazos establecidos. Para ello se obligaba con sus bienes presentes y futuros, dando fianzas por el valor de la obra, lo cual servía como garantía ante el comitente. Obviamente esto requería el apoyo directo de otros maestros, que actuaban como fiadores, por ello, podemos decir, que la auténtica

\footnotetext{
501 Constituciones Synodales del Obispado de Osma, ... impresas en la Villa del Burgo en 1586. Ob. cit. (pp. 291 - 292).

502 B. ALONSO RUIZ: El arte de la cantería... Ob. cit. (pp.42 - 44).
} 
carta de presentación de un maestro residía precisamente en este apoyo o aval de sus compañeros de profesión, pues sólo se podía contratar si se contaba con fiadores ${ }^{503}$.

Una vez firmado el contrato y determinados los pormenores de la realización de la obra, se procede a su ejecución. La organización del trabajo de construcción comprendía la presencia de un amplio y variado grupo de especialidades, las cuales se clasificaban en función del tipo de trabajo que realizaban, pero también según el grado de cualificación que necesitaban, pues de ello dependía el sueldo percibido. Esta organización, al mismo tiempo, comprendía todo un escalafón de responsabilidades, que iban, desde el maestro de obras, hasta el obrero no cualificado, dibujándose a través de ello todo un orden jerárquico perfectamente establecido. Evidentemente, esta organización era más amplia y compleja en aquellas obras de mayores proporciones, donde participaba un mayor número de operarios, si bien, es aquí también donde encontremos reflejado con mayor detalle su composición. Por su parte, en las obras de proporciones más modestas, como era el caso de la mayor parte de las acometidas en nuestra zona, esta estructura del trabajo tiende a simplificarse de forma acusada, concentrándose determinadas funciones bajo la responsabilidad de un solo grupo de oficiales.

Dentro de esta estructura, la más alta cota de responsabilidad residía en la figura del maestro de obras. Entre sus obligaciones más destacadas se encontraba, obviamente, la de dirigir la obra, pero también debía contratar los oficiales necesarios, determinar la cualificación de los mismos, asignarles tareas, firmar las nóminas, y controlar cuidadosamente el desarrollo de los trabajos. En definitiva, se trata del máximo responsable de todo el proyecto, encargándose de que los trabajos se hicieran con todo rigor, siguiendo fielmente los diseños del tracista.

En el siguiente nivel se encontraba el aparejador, el cual era designado personalmente por el maestro de obras, situándose siempre bajo su directa autoridad.

503 Ibídem. (pp. 48 - 51). 
Recibe, por lo tanto, órdenes directamente de este maestro, convirtiéndose en una especie de intermediario entre la dirección y el resto de los oficiales. Además, en caso de ausencia del maestro de obras, éste se encargaría de cumplir sus funciones, con lo cual, debía acreditar una sobrada cualificación en todos los aspectos técnicos relacionados con el mundo de la construcción. Este alto grado de responsabilidad lleva a que, para muchos maestros de cantería menores, este puesto fuera considerado como una auténtica meta, dentro de su carrera profesional ${ }^{504}$.

Otros cargos directivos, que también podemos considerar dentro de esta organización tradicional de una obra de arquitectura, eran los de Veedor, Tenedor de materiales y Sobrestante. Si bien, por tratarse de figuras ligadas, casi en exclusiva, a obras de gran envergadura, como es el caso de las construcciones reales, resultan totalmente desconocidas, dentro del ambiente constructivo de esta comarca.

Fuera de estos órganos directivos se encontraban los oficiales y peones, los cuales constituyen los verdaderos ejecutores materiales de la obra. Dentro de ellos, como ya señalamos, nos encontramos con un variado grupo de especialidades, entre las que están: canteros, carpinteros, albañiles y yeseros. Evidentemente, dentro de todos ellos, los más destacados eran los canteros, nombre dado, en general, a todo operario que trabajaba la piedra, si bien, también aquí podemos diferenciar una variada gama de especialidades.

El nivel inferior lo ocupaban los sacadores de piedra y desbastadores, labores que en realidad no pueden ser consideradas como tales especialidades, pues su trabajo no requería una maestría o cualificación especiales. Esto hace, que muchas veces estas funciones sean realizadas por los lugareños, que se trasladaban a las canteras, para desde allí proveer del material necesario, conduciéndolo hasta pie de obra. En nuestra comarca, por ejemplo, esto se convirtió prácticamente en una costumbre, dándose, de

504 J. D. HOAG: Rodrigo Gil de Hontañón. Gótico y Renacimiento en la arquitectura española del siglo XVI. Madrid. 1985 (pp. 47). 
modo especial, en las obras religiosas, pues este trabajo era considerado como una forma de limosna por parte de los feligreses.

Inmediatamente después, y por encima de estos, se encontraban los entalladores, los cuales realizaban ya un trabajo más especializado. Así, los encontramos efectuando labores más delicadas, como molduras, capiteles, fustes de columnas y otras piezas por el estilo.

Ligados a estos mismos estaban los labrantes o imagineros, si bien su trabajo era más complejo. Por ello, requerían una mayor especialización, incluyendo en su formación ciertas nociones de dibujo y composición. Ellos se encargaban de esculpir los relieves, escudos y demás decoración, que podía cubrir un edificio, resultando por lo tanto, un trabajo propio de escultores.

El último nivel era el de los asentadores, que eran los encargados de realizar la labor propiamente constructiva, pues son ellos los que colocan las piezas labradas por los anteriores oficiales en su lugar correspondiente. Su labor era sumamente delicada, por lo que, debían ser supervisados directamente por los directores de la obra. Contaban, al mismo tiempo, con la ayuda de diferentes peones y aprendices, que colaboraban con ellos en aquellas labores en las que era necesaria una mayor fuerza física.

Fuera del trabajo propio de la cantería se encontraban otra serie de especialidades, cuya participación resultaba de todo punto obligada. Dentro de la arquitectura desarrollada en nuestra zona los más destacados entre ellos eran los carpinteros, los cuales contaban también con una organización análoga a la de los canteros. Así, en toda construcción existía un maestro carpintero, subordinado al maestro de cantería que dirigía la obra, el cual se encargaba de organizar a los demás oficiales de esta materia. Estos carpinteros se encargaban, lógicamente, de realizar todas aquellas partes del edificio, que tenían en la madera su materia prima, estos es, suelos (entarimado), armaduras de tejados, puertas, ventanas, etc. Al mismo tiempo, 
observamos también como, en gran parte de la arquitectura popular de nuestra zona, donde el trabajo de cantería resultaba menor, alcanzando, por el contrario, la madera un mayor protagonismo, estos carpinteros podían llegar a trabajar incluso como contratistas de obras. Esto ocurría, porque las funciones del carpintero eran en este momento bastante más amplias que las que podemos considerar en la actualidad, ejerciendo en muchas ocasiones labores propias de albañil, como levantar paredes o enlucir muros ${ }^{505}$. Esta capacidad para realizar trabajos tan variados afecta, incluso, a la propia terminología empleada para definirlos, pues conocemos casos de carpinteros que en determinadas obras son denominados como canteros ${ }^{506}$.

Otros oficios importantes, relacionados con la construcción, eran los de albañil y yesero, si bien en muchas ocasiones su trabajo se llegaba a confundir con el de otros artífices, como acabamos de ver que ocurría con el caso de los carpinteros. Esta confusión, evidentemente, era mayor en aquellas obras de menor importancia, como puede ser el caso de las pequeñas reparaciones, que era necesario realizar en los templos parroquiales y ermitas, o la construcción y reparación de edificios civiles, ligados a la arquitectura popular. Sin embargo, en las obras de mayor porte, su labor se concretaba fundamentalmente en levantar muros de ladrillo o adobe, y enlucir los interiores.

Después de todo esto, y una vez verificada la validez de la obra, mediante los respectivos maestros nombrados por el comitente y el artífice, llegamos al colofón de este proceso constructivo, que se produce con el pago del trabajo realizado. Esto podía hacerse en diferentes entregas, a través de cartas de pago, que comenzaban a efectuarse nada más iniciarse la obra, o bien mediante una sola entrega al finalizar el proyecto. Esta segunda opción fue menos frecuente, pues si la obra era de gran envergadura, resultaba poco menos que imposible juntar una cantidad de dinero tan elevada para su entrega en un momento concreto. Aun así, se dan excepciones, como ocurrió en 1732 en

505 A. C. IBÁÑEZ PÉREZ: Arquitectura civil del siglo XVI en Burgos. Ob. cit. (pp. 77 -78). 
la localidad de Moncalvillo, con las obras de construcción de la nueva cabecera realizada para su iglesia, donde los 8.700 reales, más los gastos de materiales, que correspondieron pagar a la fábrica de esta parroquia, fueron entregados de una sola vez en ese mismo año ${ }^{507}$.

El extremo opuesto lo encontramos en la construcción de la torre de la iglesia, que se realiza en la vecina localidad de Castrillo de la Reina a partir de 1572. En este caso, los pagos efectuados al maestro encargado de su ejecución, Juan de la Fragua, llegaron a dilatarse tanto en el tiempo, que tuvieron que ser sus herederos los encargados de recibir las últimas cantidades, pues éstas se abonaron en 1641, es decir, casi 70 años después de iniciarse las obras ${ }^{508}$. Lógicamente, éste es un caso extremo, pues lo normal era no demorar estos pagos más allá de un lustro.

Respecto a las formas de pago empleadas, se solía efectuar tanto en dinero como en especie. En el primero de los casos, las dos monedas más usadas fueron el maravedí y el real de vellón, si bien, a medida que avanza la Edad Moderna, vemos como el real va ganando predomino. En lo que se refiere a los pagos en especie, los productos empleado fueron los propios de la tierra, es decir, cereales, como trigo "camuña”, cebada y centeno, lana, e incluso corderos.

\section{Comitentes.}

Dentro de este proceso creador, que acabamos de recorrer, existen dos figuras de particular interés, que debemos analizar con un mínimo detalle. Se trata, por un lado, de los comitentes o promotores, y por otro de los artífices.

\footnotetext{
506 A. Parroc. Barbadillo de Herreros. LP. Barbadillo de Herreros, parroquia de Nuestra Señora de la Visitación. Cofradía de Nuestra Señora de Costana (1731 - 1840). (fols. 29vº - 31): Cuentas de los años 1750 a 1753. Barbadillo de Herreros, 28 - octubre - 1753.

507 AGDBU. LP. Moncalvillo, parroquia de San Pedro. LF. (1715 - 1759). Cuentas del año 1732. Moncalvillo, 8 - marzo - 1733.
} 
En el caso de los promotores, vemos que no sólo constituyen el punto desde el cual surge la iniciativa, que pone en marca todo el proceso constructivo, sino que también son los encargados de disponer los medios necesarios para hacer frente a los gastos. El análisis de esta figura, por lo tanto, queda plenamente justificado, pues su iniciativa, por un lado, y sus gustos, objetivos y medios económicos, por otro, determinan, en gran medida, una buena parte de los rasgos definidores de la actividad constructiva.

En esta comarca, al igual que en el resto de la provincia de Burgos, los principales impulsores de obras arquitectónicas de carácter artístico son las parroquias, las cuales, a través de su patrocinio, no sólo intentan salvaguardar la integridad de sus templos y adecuarlos a las necesidades de cada momento, sino que también se preocupan del cuidado de su imagen.

La financiación de estas obras se efectúa, en primer lugar, a partir de los propios recursos generados por la fábrica de estas parroquias, si bien, en numerosos casos cuentan también con ayudas de diverso tipo, a través de las cuales, finalmente se lograban satisfacer estos gastos.

Estos recursos eran administrados a través de mayordomos, los cuales controlaban todos los ingresos y gastos, anotándolos con sumo cuidado dentro de los libros de fábrica. Este trabajo administrativo, a su vez, era controlado de forma periódica por los Visitadores diocesanos, los cuales se encargaban, no sólo de controlar el buen estado del templo, la satisfacción con la que se cubrían las necesidades litúrgicas y eran seguidas las preceptivas normas espirituales, marcadas por las Constituciones Sinodales, sino también de vigilar la claridad de las cuentas. Con ello, se pretendían evitar probables desmesuras en los pagos de determinados trabajos, pero

508 AGDBU. LP. Castrillo de la Reina, parroquia de San Esteban. LF. (1632 - 1673). Cuentas del año 1641. Castrillo de la Reina, 11 - junio - 1642. 
también la posible malversación de fondos, que pudiera llevar a la ruina económica de la fábrica. Así, vemos que el primer apartado, que siempre se controlaba en cada visita, era la revisión de las cuentas tomadas durante los últimos ejercicios. La delicadeza y el rigor con el que eran tratados estos aspectos, permite que nos podamos hacer una idea de la importancia que estas cuestiones tenían, no sólo para el desarrollo de la actividad cotidiana de las parroquias, sino también a la hora de afrontar las situaciones de excepcionalidad, que se creaban con la ejecución de algún proyecto constructivo.

En este sentido, debemos retomar alguna de las ideas ya expuestas en su momento, en las cuales aludíamos a la endémica situación de penuria económica en la que vivían la mayor parte de las parroquias de esta comarca. Esto hacía que cualquier mínimo proyecto constructivo, que se pretendiera hacer, por modesto que éste fuera, terminara suponiendo siempre un gran esfuerzo para su economía. No obstante, como vamos a tener oportunidad de ver, rara vez esas fábricas se vieron solas a la hora de sufragar sus obras acometidas en sus edificios.

Aun así, el primer modo que tenían las parroquias de afrontar estos gastos residía fundamentalmente en la utilización de los limitados recursos con los que contaban. Entre ellos estaba el llamado noveno pontifical, o parte del diezmo reservado a la fábrica para su mantenimiento. Pero también se disponía del producto generado por su propio patrimonio, constituido generalmente por tierras de diversa naturaleza, y que se complementaba, en ocasiones, con pequeños hatos de ganado lanar y vacuno, o incluso con el aprovechamiento de algún molino, como ocurría en la parroquia de Santa María, en Neila ${ }^{509}$.

Pero evidentemente con estos recursos, que eran suficientes para costear el mantenimiento periódico del templo, difícilmente se podían afrontar ambiciosos proyectos constructivos de mayor alcance. De todos modos, esto nunca constituyó un

509 AGDBU. LP. Neila, parroquia de Santa María. L F (1682 - 1749). (fols. 196 v ${ }^{0} 197$ voo. Cuentas del año 1735. Neila, 30 - septiembre - 1736. 
problema insalvable, hasta el punto de llegar a condicionar la realización de proyectos constructivos, considerados como necesarios por los responsables de los templos. Por ello resultan relativamente frecuentes las autorizaciones dictadas por las respectivas sedes diocesanas, mediante las cuales se permitía poner en marcha determinados mecanismos, como la venta de enseres, o la toma de censos, con los que poder hacer frente a los gastos ocasionados por las obras.

Sin embargo, mucho más importante fue la ayuda prestada por determinados personajes o grupos, ligados de una u otra forma a las parroquias, pues a través de ellos, no sólo se impedía que estas fábricas tuvieran que afrontar en solitario este gran esfuerzo económico, sino que en algunos casos se llegaba a sufragar de forma prácticamente completa el coste total de la obra. Junto a esto, nos encontramos también con otros casos en los que, si bien estos grupos no son los que aportan el dinero para sufragar directamente la obra, sí permiten la puesta en marcha de la misma, mediante un tipo de financiación, que consistía en adelantar importantes cantidades de dinero, que luego eran convenientemente devueltas por las parroquias en cómodos plazos. Sin duda, esta segunda modalidad, resulta una de las más habituales en esta zona de la sierra.

El análisis de los grupos o personas aisladas, que ayudan de esta forma en la ejecución de las obras realizadas en los templos parroquiales, nos lleva, al mismo tiempo, a hacer una relación del resto de los comitentes más destacados, que nos podemos encontrar.

Un lugar destacado lo constituyen las cofradías y ermitas, las cuales representan, al mismo tiempo, uno de los fenómenos más característicos de la religiosidad popular de estos ámbitos rurales, durante la Edad Moderna. Sin embargo, su origen no se encuentra en este periodo, sino que muchas de ellas habían surgido ya en la época inmediatamente anterior $^{510}$. Su estructura y funcionamiento estaban regidos por una

510 A. MESTRE SANCHÍS: “Religión y cultura en el siglo XVIII”. En Historia de la Iglesia en España. (Tomo IV. La Iglesia en la España de los siglos XVII - XVIII). Madrid, B.A.C. 1979. (pp. 596 - 598). 
serie de normas, debidamente aprobadas por la autoridad diocesana, que debían ser respetadas de modo escrupuloso por todos sus miembros. En lo que a los aspectos económicos se refiere, todos los ingresos y gastos eran anotados en el libro de la cofradía, o de la fábrica, en el caso de las ermitas, el cual, al igual que ocurría con las cuentas parroquiales, era periódicamente revisado por los Visitadores diocesanos.

Los ingresos de estas hermandades procedían fundamentalmente de las cuotas abonadas por los propios miembros, pero sobre todo de las rentas generadas por las propiedades que éstas poseían, dentro de las cuales no faltaban prados de guadaña, tierras de labor, herrenes, y en algunos casos, incluso varias cabezas de ganado $^{511}$. El origen de todas estas posesiones se encontraba, sobre todo, en las donaciones realizadas por los propios hermanos, pero también en las efectuadas por simples devotos, que mostraban así su agradecimiento por los favores concedidos a ellos o a sus ganados y cosechas. De este modo, la gran devoción desarrollada en torno a determinadas imágenes, llevó a que su patrimonio creciera de tal forma, que superaban en algunos casos, incluso, el de las propias parroquias ${ }^{512}$.

En el capítulo de los gastos, se encontraban recogidos, desde los propios relacionados con el culto y desarrollo de determinadas celebraciones, hasta los derechos pagados a las iglesias parroquiales, en las que se encontraban asentadas. No obstante, existían varias de estas cofradías, que contaban con una ermita propia, lo que obligaba a destinar las correspondientes cantidades para su mantenimiento. Pero esto, no evitaba que las cofradías y ermitas se convirtieran, en muchas ocasiones, en un seguro apoyo, al que podían recurrir las fábricas parroquiales, para sufragar los gastos de sus proyectos más ambiciosos. En este caso, los ejemplos resultan tan numerosos y repetidos, que casi

\footnotetext{
511 Esto sucede en ermita de Nuestra Señora del Carrascal, en Canicosa de la Sierra. ADPBU. CE. 396. Libros de Memoriales Eclesiásticos. Ermita de Nuestra Señora del Carrascal.

512 Este puede ser el caso, por ejemplo, de la cofradía de Nuestra Señora de Costana, situada en Barbadillo de Herreros, una de las más poderosas y ricas de nuestra zona, con cuyos recursos se pagaron varias de las obras de ampliación y remodelación efectuadas en la iglesia parroquial de este mismo pueblo entre los años finales del siglo XVIII y principios del XIX.
} 
podemos decir que muchas de las más destacadas obras acometidas en las iglesias de estos pueblos a lo largo de todo el periodo estudiado, jamás hubieran podido ver la luz de no ser por estas ayudas.

No obstante, la actividad de mecenazgo de estas cofradías y ermitas se limitaba, en la mayoría de los casos, a adelantar el dinero necesario, que permitía comenzar la realización de la nueva obra, el cual más tarde era religiosamente reintegrado. Una muestra de ello los encontramos en la iglesia de Castrillo de la Reina, con la construcción de la nueva sacristía, realizada en 1656. Aquí, las ermitas de Santa Ana, San Pelayo y San Roque, situadas en esta localidad, adelantaron diferentes cantidades de dinero, con las cuales fue posible acometer esta obra. La devolución de las sumas, por parte de la fábrica de la iglesia, sin embargo, no se produjo hasta treinta años después ${ }^{513}$.

Un caso parecido lo encontramos en Canicosa de la Sierra, donde la Ermita de Nuestra Señora del Carrascal adelanta varias cantidades de dinero de sus arcas entre los años 1629-1633 para sufragar diversos trabajos de reparación, que era necesario hacer en la iglesia parroquial del pueblo ${ }^{514}$.

Existen muchos casos en los que esta ayuda prestada por parte de las cofradías y ermitas, no era del todo voluntaria, sino que era el resultado de algún mandato realizado por los Visitadores. Uno de los mejores ejemplos de ello lo encontramos en el proceso de construcción de la nueva torre, levantada en la iglesia de Hacinas, durante el primer tercio del siglo XVII. En este caso, fue el propio enviado del Obispado de Osma, el que, en su visita del año 1636, indica que: "Para ayudar a estos pagos se manda a la ermita

513 AGDBU. LP. Castrillo de la Reina, parroquia de San Esteban. LF. (1673 - 1708). Cuentas tomadas entre los años 1689 - 1690. Castrillo de la Reina, 15 - octubre - 1690.

514 AGCBU. LP. Canicosa de la Sierra, parroquia de San Estaban. LF. Visita realizada a la parroquia de San Esteban en Canicosa de la Sierra en 1630 por el Dr. D. Juan Sanz, canónigo magistral en la iglesia catedral de Osma. Canicosa de la Sierra, 29 - octubre - 1630. 
de Santa Lucía que preste 50 ducados, para lo cual se manda arrendar un censo que ella posee ${ }^{, 515}$.

Por el contrario, observamos que el mecenazgo directo de estas cofradías y ermitas, en los casos en los que se produce sobre obras arquitectónicas, se materializa, de forma casi exclusiva, en sus propios santuarios. De este modo, vemos cómo la cofradía de Nuestra Señora del Arroyal de Palacios de la Sierra renueva completamente el cuerpo de su ermita e incorpora una nueva portada en $1665^{516}$. Más tarde, en 1728 , esta misma ermita construye una nueva sacristía-camarín ${ }^{517}$. Otra sacristía de características similares a ésta fue levantada el mismo año por la ermita de Nuestra Señora del Carrascal, en Canicosa de la Sierra ${ }^{518}$. Y la ermita de Nuestra Señora de Costana, en Barbadillo de Herreros, por su parte, construye, entre otras cosas, una nueva fachada para su fábrica durante el tercer cuarto del siglo XVIII ${ }^{519}$.

Las cofradías que no cuentan con edificio propio, y que por lo tanto se asientan dentro del templo de su parroquia, vuelcan sus esfuerzos en el patrocinio de obras de carácter ornamental. Esto se plasma principalmente en la construcción de retablos, altares e imágenes, con las cuales se adornaba el interior de estas fábricas.

En una línea muy similar a ésta, que hemos visto en el caso de cofradías y ermitas, se sitúa la ayuda prestada por los miembros del estamento eclesiástico, dentro de los cuales destacan, de modo muy especial, los propios párrocos de estas iglesias.

\footnotetext{
515 AGDBU. LP. Hacinas, parroquia de San Pedro. LF. (1572 - 1702). Hacinas, 6 - abril - 1634.

516 AGDBU. LP. Palacios de la Sierra, Ermita de Nuestra Señora del Arroyal. Palacios de la Sierra, 31 diciembre - 1664 .

517 AGDBU. LP. Palacios de la Sierra, Ermita de Nuestra Señora del Arroyal. Palacios de la Sierra, 14 junio - 1728.

518 AGDBU. LP. Canicosa de la Sierra, Ermita de Nuestra Señora del Carrascal. LF. (1608 - 1743). (fols. $147 \mathrm{v}^{0}$ - 148). Cuentas de 1728. Canicosa de la Sierra, 5 - marzo - 1729.

519 A. Parroc. Barbadillo de Herreros. LP. Barbadillo de Herreros, parroquia de Nuestra Señora de la Visitación. Cofradía de Nuestra Señora de Costana $\left(1731\right.$ - 1840). (fols. $\left.31 v^{0}-33 v^{0}\right)$. Cuentas de los años 1753 - 1780: Barbadillo de Herreros, 8 - enero - 1780.
} 
Muchos de ellos, aprovechan su posición privilegiada al frente de estas parroquias, y su, más o menos, cómoda situación económica, para participar en la realización de diferentes proyectos constructivos, no sólo como instigadores o impulsores de las obras, sino también financiando parte de sus costas.

Esta promoción, sin embargo, rara vez se materializaba en la construcción de edificios de nueva planta, pues en estos casos estamos hablando ya de un tipo de mecenazgo, que se incluye dentro de la realización de templos y capillas de patrocinio único, ligados a una clara finalidad funeraria. En nuestra zona, tal vez, el ejemplo más próximo a esto es el que encontramos en la figura de D. Pedro Fernández de Barrio entre los años finales del siglo XV y principios de la centuria siguiente. Según parece, este clérigo, que llegó a ser canónigo y capellán de D. Pedro Fernández de Velasco (I Condestable de Castilla), se mandó construir la ermita dedicada a la Virgen Blanca, en las inmediaciones de la localidad de Hoyuelos de la Sierra, donde debían descansar sus restos mortales. Al menos así lo indican las diferentes inscripciones, que se conservan, respectivamente, sobre la clave del arco, que enmarca la puerta de entrada al templo, y en el contorno de la lápida sepulcral, colocada ante el presbiterio. La primera de ellas aparece escoltando un amplio escudo labrado en piedra con campo cubierto mediante los característicos jaqueles y veros de la familia Velasco, y una bordura de castillos y leones, recorriendo todo su contorno. Se trata de un breve texto, escrito en caracteres góticos casi ilegibles, en los cuales, según el profesor Gonzalo Miguel Ojeda se puede llegar a leer el siguiente mensaje: ESTA IGLESIA MANDO HACER PERO FERNÁNDEZ DE BARRIO, CANÓNIGO CAPELLÁN DE DON PERO FERNÁNDEZ DE VELASCO, CONDESTABLE DE CASTILLA, CONDE DE $\mathrm{HARO}^{520}$. Para la segunda inscripción solamente contamos con la transcripción facilitada por este autor, pues el actual estado de ruina, que presenta el edificio, hace que la susodicha lápida sepulcral se halle cubierta por un potente manto de escombros. Así, según este autor, el mensaje aquí recogido sería el siguiente: AQUÍ YACE PERO FERNÁNDEZ DE BARRIO, CAPELLÁN DEL CONDESTABLE, CANÓNIGO E

520 G. MIGUEL OJEDA: "Hoyuelos de la Sierra”. Ob. cit. 
CURA BENEFICIADO EN SANTA MARÍA DE OSMA, MURIO A XXVII DE MAYO DE MIL QUINIENTOS Y CUATRO AÑOS, añadiendo además, EL CUAL HIZO ESTA IGLESIA. EL QUE MÁS HICIERE QUE YO PASE ADELANTE ${ }^{521}$. Todo esto, evidentemente, confirma la existencia de este caso de mecenazgo, si bien, y a pesar de ello, debemos reiterar su carácter ciertamente excepcional dentro de nuestra zona, pues no volveremos a encontrar, a lo largo de todo el periodo, un solo caso semejante.

Frente a esto, la forma más habitual en la que se manifestaba esta promoción de los clérigos la encontraremos en su capacidad para estimular el desarrollo de nuevas construcciones dentro de sus parroquias. Así, comprobamos cómo una gran parte de los programas de renovación y ampliación desarrollados en estos templos a lo largo de la Edad Moderna, partieron de la iniciativa de sus párrocos. No obstante, probar documentalmente esto no resulta una tarea fácil, y más cuando es tan escaso el legado, de este tipo de fuentes, si bien, existen algunos indicios, que nos permiten contemplar esta posibilidad. Así sucede, por ejemplo, en la reconstrucción de la zona de la nave de la iglesia de Monterrubio de la Demanda, realizada finalmente en 1749, tras un duro pleito, mantenido entre esta parroquia y los artífices encargados de su construcción. Aquí, en las claves de una de las bóvedas ahora construidas, se puede ver una inscripción en la que se indica el año de conclusión de la obra, acompañado del mensaje: SIENDO CURA FRANCISCO VELASCO, lo que denota su clara implicación en el proyecto.

Un ejemplo más significativo aun lo encontramos en la pequeña localidad de Monasterio de la Sierra. En este caso, el espíritu inquieto y emprendedor que demostró D. Felipe Gómez, párroco de esta iglesia durante las últimas décadas del siglo XVIII, se convirtió en el auténtico aliento, que impulsó el gran proyecto de renovación de toda la fábrica del templo. En recuerdo de ello, su nombre, junto con el de uno de los

521 Ibídem. 
mayordomos, que tuvo esta iglesia durante esos años, quedó recogido en la leyenda que cubre el dintel de una de las ventanas.

Pero en numerosas ocasiones, la actuación de estos clérigos no se quedaba en una mera labor de impulso y aliento para la ejecución de obras, sino que llegan a involucrarse de una forma más concreta, aportando dinero de su propio patrimonio, para sufragar parte de los gastos, o simplemente adelantándolo, para que estos proyectos pudieran iniciarse. A ello, evidentemente, ayudaba de forma importante, los saneados ingresos, que en muchos casos poseían, pues al tercio de los diezmos que percibían, como beneficiarios de las parroquias, debemos unir también el usufructo de los beneficios asignados por los propios pueblos a su función pastoral. De este modo, su situación económica solía ser, por lo general, mucho más cómoda que la de sus parroquias.

Los ejemplos más destacados, dentro de este tipo de promoción, los encontramos en la iglesia de Hacinas. Aquí, la obra de la torre, realizada a finales del primer tercio del siglo XVII, pudo iniciarse merced a la donación de 1.200 reales, que hizo el párroco del momento, D. Pedro González de Varaona ${ }^{522}$. Dentro de este mismo templo, unas décadas más tarde, se vive una circunstancia similar con la construcción de las dos nuevas naves, con las que se ampliaba el espacio de la iglesia. El cura que anticipa las cantidades necesarias para iniciar el proyecto, en este caso, fue D. Matías Moreno. Estas cantidades adelantadas serían devueltas por la parroquia a sus herederos en diferentes pagos efectuados entre los años finales de esta centuria y principios de la siguiente. El carácter fragmentado de los testimonios documentales conservados, sin embargo, nos impide cuantificar con precisión el valor alcanzado por esta ayuda.

Pero estos casos no son los únicos, pues en algunas otras localidades nos encontramos ejemplos en los que, no sólo colaboran estos párrocos en el patrocino de determinadas obras, sino que en esta labor se terminan implicando también a algunos de

522 AGDBU. LP. Hacinas, parroquia de San Pedro. LF. (1572 - 1702). Hacinas, 6 - abril - 1634. 
sus familiares. Esto es lo que sucede con la construcción del nuevo retablo mayor, que se hace para la iglesia de Santa Cristina, en Huerta de Abajo, en torno a 1768. En el pago del mismo, no sólo colabora el antiguo cura de esta parroquia, D. Fernando Gil de la Cuesta, con 1.750 reales, sino que tres de sus hermanos participan también con la donación de otros de 900 reales $^{523}$.

Los concejos, como representantes y máxima autoridad civil dentro de estos pueblos, también desempeñaron un papel destacado, dentro de la promoción de obras arquitectónicas. Lógicamente su labor más destacada, como impulsor y promotor de obras de este tipo, la encontraremos en las obras públicas de carácter civil, como vías de comunicación, puentes, lavaderos, edificios de aprovechamiento comunal, etc. Sin embargo, se trata, en todos los casos, de obras eminentemente funcionales, cuyas características siguen fielmente las pautas propias de la arquitectura popular, en las cuales resulta difícil descubrir algún tipo de preocupación o intención artística.

El pago de estas obras se realiza, por supuesto, a través de los propios recursos municipales, dentro de los cuales, como ya vimos, destacan especialmente las rentas generadas por el patrimonio del concejo, y en concreto por el arriendo de pastos para el ganado trashumante y la cabaña de las reses carreteras. Pero aun así, no resulta raro encontrar el apoyo de los propios vecinos en la realización de obras de patrocino municipal, el cual se efectuaba fundamentalmente mediante la prestación de su trabajo personal, con la ejecución de determinadas labores, para las cuales no era necesaria una especial cualificación profesional.

En diferentes ocasiones, nos encontraremos también con la participación de estos concejos en la realización de determinadas obras de carácter religioso. Esta participación se refleja principalmente en las obras de reparación y mantenimiento de las diferentes ermitas, que en gran número, aparecen distribuidas a lo largo de los

\footnotetext{
523 AGDBU. LP. Huerta de Abajo, parroquia de Santa Cristina. LF. (1741 - 1797). (fols. 69 - 72). Cuentas del año 1768. Huerta de Abajo, 6 - septiembre - 1769.
} 
diferentes términos municipales. En estos casos, los concejos, como patronos que eran de las mismas (salvo los escasos ejemplos de patronato privado), debían velar, junto con los vecinos, por su cuidado, sufragando con ello todos aquellos trabajos de reparación, que fuera necesario emprender.

A parte de esto, los concejos se ven implicados también, en diferentes ocasiones, en la realización de determinadas obras, acometidas en los templos de las parroquias. El tipo de obras, donde resulta más normal encontrar esta clase de participación, son aquellas en las que, además de la función religiosa, se veía un manifiesto interés civil. Este es el caso de los atrios, situados en el entorno de los templos parroquiales, a los cuales se incorpora una función funeraria. Así, en la construcción de muchos de ellos nos encontramos, con bastante frecuencia, la participación de los concejos, solicitada en la mayoría de los casos por los propios Visitadores diocesanos, como ocurre en Hoyuelos de la Sierra, Arroyo de Salas y Castrillo de la Reina. En este último caso, registramos incluso con una ligera reprimenda, expresada por parte del Visitador de Osma a los miembros del concejo, pues al parecer, la falta de agilidad a la hora de desempeñar la función que le había sido encomendada (que no era otra que el aporte de los materiales necesarios) estaba llevando a paralizar el desarrollo normal de los trabajos, con el inconveniente que ello suponía ${ }^{524}$.

El otro modo de participación de los concejos en las obras de sus parroquias se produce a través de la financiación de ciertos trabajos, mediante el tradicional procedimiento, consistente en adelantar el dinero necesario para su puesta en marcha. Posteriormente, como hemos visto que ocurría en los casos de los párrocos, que realizaban esta misma práctica, estas sumas eran convenientemente devueltas por las parroquias. Uno de los ejemplos más significativo de esta modalidad de ayuda lo volvemos a encontrar en la iglesia de Castrillo de la Reina, durante el proceso de

524 “...y por quanto al presente se estan haciendo el cementerio de dicha iglesia y por razón de no traer la piedra que el maestro tiene sacada no se trabaja en él”. AGDBU. LP. Castrillo de la Reina, parroquia 
construcción de la nueva torre, iniciada en 1572. Aunque los testimonios conservados no resultan muy claros, parece evidente que el concejo de esta localidad adelantó parte del dinero necesario para la puesta en marcha de los trabajos. Así, en las cuentas de la parroquia, correspondientes a las décadas siguientes, podemos ver anotadas distintas cantidades de dinero y diversos bienes, destinados a cubrir este préstamo. Otro ejemplo interesante nos lo proporciona el concejo de Barbadillo de Herreros, con la aportación realizada en 1789 para la ejecución del nuevo cuerpo de campanas, que se construye en su iglesia parroquial ${ }^{525}$.

Sin embargo, existen otros casos en los que el grado de implicación de estos concejos llegó aun más lejos. Esto se puede ver en la renovación que se acomete en la iglesia de la parroquia de San Martín, en Huerta de Arriba, iniciada en 1727. La realización de esta obra jamás hubiera sido posible de no ser por la colaboración de los propios vecinos, pero también del concejo, tal y como se desprende de los datos extraídos de las fuentes documentales conservadas, y que corrobora la inscripción situada en una de las claves de la bóveda, correspondiente al tramo delantero de la nave, en la que se puede leer: A COSTA DE ESTE CONCEXO Y DEBOTOS AÑO 1727.

Un caso similar se produce en su homónima de Vilviestre del Pinar, con la renovación efectuada en su parte delantera, durante el tercer cuarto del siglo XVIII. En esta ocasión, la inscripción, que da fe de esta participación del concejo, se puede ver en el exterior del templo, ocupando parte del friso, que recorre la zona superior del muro, que delimita el brazo meridional del nuevo crucero. En ella podemos leer lo siguiente: ESTA OBRA SE HIZO A COSTA DE ESTA VILLA SIENDO CURA D. PEDRO CAMPOS CUESTA AÑO 1761.

\footnotetext{
de San Esteban. LF. (1632 - 1673). Visita realizada a la parroquia de San Esteban de Castrillo de la Reina en 1672. Castrillo de la Reina, 6 - julio - 1672.

525 A. Parroq. Barbadillo de Herreros. LP. Parroquia de Nuestra Señora de la Visitación. LF. (1718 1748). (s/f). Cuentas del año 1789. Barbadillo de Herreros, 19 - septiembre - 1789.
} 
Dentro de la sociedad estamental, característica de la Edad Moderna, otro grupo con un papel destacado en esta labor de promoción de obras de interés artístico, lo constituye el estado noble. Como ya señalamos, al hablar de la sociedad en nuestra zona, este grupo se encontraba representado aquí por miembros de la pequeña nobleza sin título, los cuales, además, habían adquirido esta condición privilegiada en una época relativamente reciente, y presumiblemente a través de medios no demasiado lícitos. Por ello, y por tratarse de familias con unos recursos económicos desahogados, pero nunca desmesurados, su participación en obras arquitectónicas de carácter religioso fue siempre muy limitada. De este modo, aquí nunca nos encontraremos con los casos, tan frecuentes en la capital y en otras zonas de la provincia, de construcción de grandes y ostentosas capillas funerarias con las cuales perpetuar el recuerdo de su fama ${ }^{526}$. El único ejemplo de ello lo encontramos en la ya mencionada capilla de Santa Ana, situada en la iglesia de Santa María en Neila, que fue levantada bajo el patrocinio de la familia Márquez de Prada.

Otros ejemplos próximos a esta idea, aunque mucho más modestos en su desarrollo, los encontramos en los sepulcros, que vimos en las iglesias de Castrillo de la Reina, Hacinas y en la parroquia de Santa Cecilia en Salas de los Infantes.

Por su parte, la única presencia de nobles pertenecientes a la alta aristocracia viene de la mano de los Duques de Frías, a cuyo señorío pertenecía, como sabemos, la jurisdicción de una buena parte de los pueblos de la zona. Sin embargo, esta posición preponderante rara vez quedó reflejada en una participación directa en la realización de obras arquitectónicas, pues su presencia en la zona siempre fue muy escasa y distante, quedando representada únicamente por la figura de un administrador. Aun así, existen algunos ejemplos de colaboración en el pago de determinados proyectos, como fue el caso de la renovación de la torre de la iglesia de Santa María en Huerta de Arriba,

\footnotetext{
526 C. POLANCO MELERO: Muerte y sociedad en Burgos en el siglo XVI. Burgos, Excma. Diputación
} Provincial de Burgos. 2001. (pp. 267 y ss.). 
efectuada en 1701, donde entregaron la parte que les correspondía de los diezmos de esta parroquia $^{527}$.

Al margen de esto, es en la arquitectura civil donde mejor se manifiesta el papel de esta nobleza local, como promotores de obras arquitectónicas con un cierto carácter artístico. Así lo veremos reflejado especialmente en la construcción de sus viviendas, que dan lugar a las denominadas casonas solariegas o blasonadas, que pueblan gran parte del caserío de algunas de estas localidades. Estas obras no dejan de estar ligadas a los ideales de fírmitas y utilitas, que en gran medida presiden toda la arquitectura de nuestra zona, sin embargo, también encontramos ciertas dosis de ostentación, mostrada, no sólo a través de las propias dimensiones de estos conjuntos, sino también mediante la preocupación por reflejar ciertos aspectos estéticos. El principal reflejo de todo ello lo encontramos en la incorporación de escudos en sus fachadas, con los cuales representan, no sólo su predominio económico, sino también su destacada posición social. Los conjuntos conservados en las localidades de Barbadillo de Herreros, Huerta de Arriba y Neila, sin duda, son los más representativos, pero desde luego no los únicos.

En último lugar, dentro de este recorrido por la figura del comitente, debemos hablar también del papel jugado por el Estado Llano. Su labor fue también destacada, dentro de la arquitectura religiosa, si bien, al igual que sucede en otras partes de la comarca burgalesa, resulta relativamente extraño encontrar a miembros de este estado patrocinando en solitario obras constructivas de cierta importancia. Más normal, por el contrario, resulta su participación en la realización de retablos y otros elementos de adorno, destinados al interior de los templos.

En la iglesia de la parroquia de Santa María, en Salas de los Infantes, por ejemplo, encontramos uno de estos casos en el retablo dedicado a San Benito, situado en el muro anterior de la nave de la epístola, el cual fue mandado construir por D.

\footnotetext{
527 AHN, NOBLEZA, Osuna, Leg. 1354, n. 12. Salas de los Infantes a 30 de marzo de 1703 - Salas de los Infantes a 5 de junio de 1703.
} 
Micael Morcate y Montero, familiar del Santo Oficio, y su mujer ${ }^{528}$. Otro caso lo tenemos en la parroquial de Barbadillo del Pez, cuyo retablo del Santo Cristo fue mandado construir por D. Antón Pérez y su mujer Isabel Peraita ${ }^{529}$.

La participación en obras arquitectónicas, por el contrario, se produce de forma anónima y en grupo (como vecindario o feligresía), recurriendo generalmente a su prestación personal en la realización de determinados trabajos. Esta participación, que ya hemos mencionado en otros casos, consistía, en definitiva, en la sustitución de la entrega de limosnas en forma de dinero, que no siempre se podían prestar, por una prestación personal, mediante su trabajo. Con ello, evidentemente, lo que se conseguía era abaratar de forma considerable el coste final de la obra, facilitando así su ejecución. El reconocimiento, que este tipo de ayuda tuvo en la época, por parte de las diferentes autoridades eclesiásticas, fue siempre el máximo, pues bien sabían que sin esta colaboración de los feligreses muchas de las obras acometidas, especialmente en parroquias modestas, jamás hubieran podido hacerse. Por ello, los Visitadores y Provisores no dejaron nunca de solicitar esta ayuda, utilizando en ocasiones un tono poco menos que angustiado. Esto puede se puede ver en el mandato dado en 1694 por el Visitador del Arzobispado de Burgos, D. Juan de Caabro, para la construcción del atrio de la iglesia de Hoyuelos de la Sierra, en el cual solicita de forma imperiosa la colaboración de los feligreses, a través del propio concejo de la localidad ${ }^{530}$.

528 En el banco de este retablo reza la siguiente inscripción: ESTA OBRA IÇO DON MICAEL DE MORCATE MONTERO FAMILIAR DEL SANTO OFICIO DE LA INQUISICIÓN Y SU MUGER DOÑA MARÍA MARTÍNEZ ZABALA LOS QUALES LO HICIERON A SU QUENTA POR SU DEVOCIÓN. AÑO 1654. R - J. PAYO HERNANZ: El retablo en Burgos y su comarca durante los siglos XVII y XVIII. Burgos, Excma. Diputación Provincial de Burgos. 1997. (Tomo I). (pp. 83).

529 En el banco se puede leer también: A HONRA Y GLORIA DE DIOS HIZO Y DORÓ ESTE RETABLO ANTÓN PÉREZ E ISABLE DE PERAITA. Ibídem.

530 AGDBU. LP. Hoyuelos de la Sierra, parroquia de San Esteban. LF. $(1682$ - 1728). Visita realizada a la parroquia de San Estaban de Hoyuelos de la Sierra en 1694, por el Visitador del Arzobispado de Burgos D. Juan de Caabro. Salas de los Infantes, 7 - septiembre - 1694. 
La otra forma de participación, que encuentra este grupo en las obras religiosas, se produce, como hemos dicho, a través de la entrega de limosnas, efectuadas tanto en metálico como en especie. Esta contribución también se solía hacer de forma anónima, sumándose así los pequeños esfuerzos de cada uno de los feligreses, hasta lograr aportaciones realmente considerables. No obstante, el escaso y poco preciso reflejo que estos actos tenían en las fuentes documentales conservadas no nos permite cuantificar esta ayuda. Aun así, existen algunos casos en los que esto sí es posible valorarlo, como sucede en la parroquia de Santa Cecilia, en Salas de los Infantes, con motivo de las obras de reparación acometidas en torno a 1756 sobre las capillas mayor y del Santo Cristo. Aquí, vemos como, después de hacer una pormenorizada relación de los diferentes gastos ocasionados por la citada obra, se dice que "todo este dinero salió de las limosnas” ${ }^{331}$. Más destacado aun es el ejemplo, que ofrecen los vecinos de Vilviestre del Pinar, en las obras de ampliación de su templo parroquial, llevadas a cabo en 1649. En estas obras, además de su propia aportación personal, en la extracción y acarreo de todos los materiales empleados en el proyecto, lograron acumular con sus limosnas la nada despreciable suma de 200 ducados $^{532}$.

Menos frecuentes fueron los casos en los que se pierde el carácter anónimo de este tipo de donaciones. Esto sucede en la iglesia de Santa María, Neila, con D. Francisco Benito y Doña María Teresa Benito, su esposa, que dejaron la cantidad necesaria para hacer un trasparente en el altar mayor de este templo ${ }^{533}$. También en Castrillo de la Reina, durante la construcción del nuevo osario para su iglesia, nos encontramos a uno de sus feligreses, D. Miguel Alonso, asumiendo personalmente parte

531 AGDBU. LP. Salas de los Infantes, parroquia de Santa Cecilia. LF. (1721 - 1809). Cuentas del año 1756. Salas de los Infantes, 6 - septiembre - 1757.

532 A.P. Vilviestre del Pinar. LP. Vilviestre del Pinar, parroquia de San Martín de Tours. LF. (1635 1673), (fols. $61-66$ v ). Visita realizada a la parroquia de San Pedro de Vilviestre del Pinar en 1748, por D. Mateo Salas. Vilviestre del Pinar, 28 - febrero - 1648.

533 AGDBU. LP. Neila, parroquia de Santa María. LF. (fols. 30vº $-35 v^{0}$ ). Visita realizada a la parroquia de Santa María de Neila en 1755, por D. Juan de Tobía y Zuazo, canónigo de la catedral de Burgos. Canales, 3 - agosto - 1755 . 
del coste de los materiales empleados en la obra ${ }^{534}$. Pero, el caso más significativo de este tipo se produce en Canicosa de la Sierra, con la figura de Doña María Santiago, en cuyo testamento deja una manda con dinero, destinado para la construcción de una ermita dedicada a Nuestra Señora de la Soledad, la cual debía edificarse en el término de esta localidad ${ }^{535}$. Esta ermita, sin embargo, jamás llegó a construirse, ya que después de una larga demora, que duraría algo más de una década, el dinero fue destinado finalmente para la ejecución de un nuevo retablo, dedicado a San Pedro, que se ubicó la iglesia parroquial $^{536}$.

\section{Maestros.}

Junto a los comitentes, que impulsan y pagan las obras, la otra figura fundamental, dentro de esta actividad constructiva, es el artífice encargado de su ejecución material. El acto por el cual se comprometían con los comitentes a su realización era la firma de un contrato o carta de obligación. Son varios, como hemos visto, los profesionales que intervienen en las distintas labores, que componen este proceso, si embargo, los que debemos considerar como auténticos artífices de estas obras son los canteros y maestros de cantería.

A este respecto, no parece que el desarrollo de esta actividad en nuestra zona de estudio, a lo largo de la Edad Moderna, manifieste grandes variaciones con respecto a lo que era el panorama general, vivido en el resto de la comarca burgalesa o castellana durante este mismo periodo. Así, aunque a partir de la influencia de la cultura humanística y los tratados renacentistas, la actividad constructiva comienza a

\footnotetext{
534 AGDBU. LP. Castrillo de la Reina, parroquia de San Esteban. LF. (1673 - 1708). Cuentas del año 1674. Castrillo de la Reina, 29 - diciembre - 1675.

535 AGDBU. LP. Canicosa de la Sierra, parroquia de San Esteban. LF. (1677 - 1765). (fols. 112v $117 \mathrm{v}^{0}$ ). Visita realizada a la parroquia de San Esteban de Canicosa de la Sierra en 1704, por el canónigo de la catedral de Osma, D. Blas de Tobalina. Canales, 3 - mayo - 1704.

536 Ibídem. (fols. $165-167 v^{\circ}$ ). Cuentas del año 1713. Canicosa de la Sierra, 2 - marzo - 1714.
} 
336 Arquitectura de la Edad Moderna en la sierra burgalesa.

experimentar sustanciales cambios en lo que se refiere a la concepción del oficio, estas variaciones apenas se dejan sentir en un ambiente rural, tan sumamente alejado de los grandes centros creadores, como era nuestro caso. Por ello, la imagen que debemos tener de estos artífices mantiene, en gran medida, la herencia de la etapa inmediatamente anterior, con unos profesionales más próximos a la imagen del artesano tradicional, que a la del architecto de origen vitruviano, proyectada, entre otros tratadistas italianos, por León Batista Alberti.

En el ámbito de la cantería, como en el resto de los oficios, se consideraba la clásica división establecida entre aprendices, oficiales y maestros. Si bien, aquí esta división tiene efectos meramente legales, pues va a ser el propio desarrollo de la actividad constructiva la que establezca la auténtica clasificación, que no es otra que la que ya vimos al hablar de organización del trabajo. En ella, las diferencias venían marcadas en virtud de la especialidad practicada y el grado de cualificación que se poseía.

Aun así, tampoco debemos desestimar esta otra división, pues no en vano, reflejaba los diferentes pasos que había que dar para alcanzar la capacitación necesaria. De este modo, los maestros de cantería, como cualquier otro oficio, debían pasar un proceso de formación, que se inicia, como en los demás casos, con la fase de aprendizaje. La particularidad, que el mundo de la cantería ofrece en este punto, es que el taller o maestro a cuyo cargo entraba este aprendiz, solía poseer algún tipo de lazo de parentesco con el mismo, con lo cual no era habitual legalizarlo mediante una escritura pública $^{537}$. En los casos en los que sí se hacía, se firmaba un contrato de carácter bilateral entre aprendiz y maestro, según el cual se establecían una serie de obligaciones por ambas partes, así como una detallada relación de los pormenores, que rodeaban la propia actividad de aprendizaje ${ }^{538}$. Según esto, el aprendiz se comprometía por un periodo de entre 3 y 5 años a cumplir fielmente con los mandatos del maestro, mientras

\footnotetext{
537 B. ALONSO RUIZ: El arte de la cantería... Ob. cit. (pp. 75 - 80).

538 A. C. IBÁÑEZ PÉREZ: Arquitectura civil del siglo XVI en Burgos. Ob. cit. (pp. 73 - 75).
} 
que éste se obligaba a enseñarle correctamente todos los secretos del oficio, sin ocultarle nada, a pesar de existir aquí un potencial competidor ${ }^{539}$. A estas disposiciones principales se unían además toda una gama de cláusulas con pequeños detalles, que variaban de unos contratos a otros. El incumplimiento de los puntos acordados por alguna de las partes, autorizaba a la otra a proceder judicialmente, exigiendo compensación $^{540}$.

La formación impartida mediante este proceso era eminentemente práctica, adiestrándose en cortes de piedra, modelos de cubrición y otros aspectos relacionados con el desarrollo del oficio. No parece que se impartieran, por lo tanto, conocimientos relacionados con el diseño, ni de otro tipo, que tuvieran que ver con los aspectos teóricos, pues estos eran adquiridos posteriormente con el propio desarrollo de la actividad profesional, en la medida en la que el artífice en cuestión pudiera mejorar y medrar en su oficio.

Una vez cumplimentado el periodo de formación, todo apunta a que el aprendiz, como indicaban las ordenanzas gremiales del resto de los oficios, debía superar una prueba, que le acreditara como oficial. Sin embargo, en este punto nos encontramos con otra de las particularidades, que presenta el mundo de la cantería. Así, la falta de exámenes, que confirmen la existencia de esta prueba, obliga a pensar, que sólo el mero reconocimiento del maestro, que había formado a este aspirante, era considerado como prueba suficiente para que el antiguo aprendiz pudiera ser contratado como oficial ${ }^{541}$. Evidentemente, el carácter itinerante que tenía esta profesión contribuía de forma importante a que se dieran estas peculiaridades.

El mismo problema es el que se observa en el paso de oficial a maestro, pues tampoco hay cartas de examen de este tipo. En este sentido, se debe considerar, que la

539 J. J. MARTÍN GONZÁLEZ: El artista en la sociedad española del siglo XVII. Madrid, Ed. Cátedra. 1994. (pp. 32).

540 A. C. IBÁÑEZ PÉREZ: Arquitectura civil del siglo XVI en Burgos. Ob. cit. (pp. 73 - 75). 
verdadera capacidad de un oficial para alcanzar la condición de maestro, y de este modo poder contratar obras por su cuenta, vendría demostrada por su facultad para conseguir los fiadores necesarios, con los cuales poder respaldar una propuesta suya en un proceso de remate a la baja. De no contar con esta garantía, jamás se podría alcanzar tal cosa. Por ello, como ya dijimos en su momento, la auténtica carta de presentación de cada uno de estos maestros de cantería son siempre sus fiadores.

La utilización del término arquitecto, en principio, no tenía que suponer ningún tipo de cualificación superior, pues vamos a ver cómo, a lo largo de todo el periodo estudiado, y especialmente dentro de estos niveles en los que nos movemos, rara vez es aplicado con cierta precisión, existiendo, por el contrario, una gran libertad en su uso. Así, vemos que uno de los grupos de profesionales, que con mayor asiduidad empiezan a usarlo, especialmente durante el siglo XVII, lo encontramos en los ensambladores de retablos. Dentro de ellos, un ejemplo especialmente significativo es Juan de la Piedra, que trabaja, durante los años centrales de esta centuria del Seiscientos, en la fabricación de diferentes retablos en las iglesias de Monasterio de la Sierra ${ }^{542}$, Vilviestre del $\operatorname{Pinar}^{543}$, Hacinas ${ }^{544}$, y en la ermita de Nuestra Señora del Arroyal en Palacios de la Sierra $^{545}$. En todos estos casos vemos que utiliza de forma indiscriminada los títulos de ensamblador, escultor o arquitecto, lo que manifiesta el poco rigor que se ponía en su aplicación.

\footnotetext{
541 B. ALONSO RUIZ: El arte de la cantería... Ob. cit. (pp. 80 - 81.)

542 AGDBU. LP. Monasterio de la Sierra, parroquia de San Pedro. LF. (1614 - 1653): Cuentas del año 1640. Monasterio de la Sierra, 15 - mayo - 1641.

543 A. Parroq. Vilviestre del Pinar, parroquia de San Martín. LF. (1635 - 1673). (fols. 36v $\left.{ }^{\circ}-37\right)$ : Cuentas del año 1640. Vilviestre del Pinar, 13 - junio - 1642; Ibídem. (fols. 55 - 56vº): Cuentas del año 1644. Vilviestre del Pinar, 12 - mayo - 1647.

544 AGDBU. LP. Hacinas, parroquia de San Pedro. LF. (1572 - 1702). Cuentas del año 1642. Hacinas, 22 - enero - 1643.

545 AGDBU. LP. Palacios de la Sierra, Ermita de Nuestra Señora del Arroyal. LF. (1657 - 1781). (fols. 34 - 38). Palacios de la Sierra, 12 - marzo - 1674.
} 
La introducción de este término en España, para definir a los maestros de cantería, se produce a principios del siglo XVI de la mano de Diego de Sagredo, con la publicación de su tratado Medidas del Romano (1526), si bien, su uso no comienza a darse antes de la segunda mitad de siglo. El arquitecto así definido por el renacimiento, debía conocer los aspectos prácticos de la obra, pero ante todo debía dominar las cuestiones teóricas, ya que su trabajo consistía fundamentalmente en pensar y diseñar edificios, que más tarde otros se encargarían de construir ${ }^{546}$. Se trataba, en definitiva, de hacer una defensa del carácter intelectual de la profesión, que la situara por encima de los trabajos meramente manuales, y por lo tanto, artesanales.

Sin embargo, el empleo de este término, dentro del mundo de la arquitectura, queda restringido en principio a aquellos círculos de personas, que estaban relacionados con la construcción en un sentido plenamente humanista ${ }^{547}$, los cuales, además, se encontraban en torno a los ambientes de la corte y las obras de proyección real. Este fue el caso de los maestros Juan Bautista de Toledo o Juan de Herrera. El medio tradicional de la cantería, por su parte, tardaría todavía un tiempo en incorporarlo. Uno de los pocos artífices que así lo hace, dentro de los profesionales que trabajan en la comarca serrana, fue el de Pedro Díaz de Palacios, el cual, según reza la inscripción, que aparece sobre su lápida sepulcral, situada a los pies de la nave central de la iglesia del monasterio de San Pedro de Arlanza, se autotilulaba como maestro de arquitectura ${ }^{548}$. Con ello, no sólo se pretendía hacer un reconocido homenaje a sus muchos años de ejercicio en la profesión como maestro de cantería, sino también a los amplios saberes, tanto teóricos como prácticos, que presuntamente habría acaparado durante todo este tiempo. Todos estos

\footnotetext{
546 L. CABEZAS: “Del arte de la cantería al oficio de la cantería”. En Juan de Herrera y su influencia: actas del Simposio: Camargo 14 / 17 de julio 1992. Santander, Fundación Obra Pía de Juan de Herrera: Universidad de Cantabria. 1993. (pp. 137 - 142).

547 V. TOVAR, J. J. MARTíN GONZÁLEZ: E. Arte barroco I. Arquitectura y escultura. Madrid, Taurus. 1990. (pp. 57).

548 E. CARRETERO SANTAMARÍA, V. GONZÁLEZ DE CASTRO: “Arquitectura clasicista en Burgos: noticias documentales de la obra de Pedro Díaz de Palacios en San Pedro de Arlanza (1629 1659)”. En Anuario del Departamento de Historia y Teoría de Arte. (UAM). Madrid, Universidad Autónoma de Madrid. 1993. (pp. 111 - 119).
} 
saberes, en definitiva, habrían permitido a este maestro, no sólo dirigir numerosas obras a lo largo de su vida, como fue el caso, sino que también le acreditaban como artífice capaz de realizar trazas ${ }^{549}$.

Pero en general, la mayor parte de los artífices, que trabajan en la zona de la sierra, al igual que en el resto de las áreas rurales como ésta, eran maestros muy modestos, que participan, tanto en construcciones del más amplio calado, como renovaciones de templos, construcción de torres, portadas, etc., como en obras menores de mantenimiento y reparación. Estos artífices utilizan la denominación de canteros, maestros de cantería o incluso maestros de obras. Y su formación, en todos los casos, era eminentemente práctica, es decir, de carácter gremial, con conocimientos muy generales, relacionados siempre con los hábitos tradicionales de la construcción ${ }^{550}$. Su capacidad de proyectar era muy limitada, alcanzando sólo para aquellas obras más modestas, ligadas a los usos tradicionales de la arquitectura popular. Sin embargo, para las obras de mayores proporciones, donde se daban además algún tipo de pretensión estética, la responsabilidad del diseño de sus trazas quedaba en manos de un maestro especialmente cualificado para ello. En el caso de las obras emprendidas por las parroquias, esta responsabilidad recaía siempre en el Maestro Mayor de las obras de la catedral, el cual actuaba como Maestro Veedor de la Diócesis, diseñando y vigilando aquellas obras más importantes, que se desarrollaban en este territorio. No obstante, esta vigilancia es siempre muy difícil de calibrar, pues en diócesis tan amplias como la de Osma o la de Burgos, es posible que este control no fuera tan estrecho, quedando reducido sólo a periódicas visitas, para comprobar su marcha y examinar las cuentas ${ }^{551}$. De esta forma, es en estos Maestros Mayores de las respectivas catedrales de Burgos y

\footnotetext{
549 J. J. MARTÍN GONZÁLEZ: El artista en la sociedad española del siglo XVII. Ob. cit. (pp. 55).

550 L. CABEZAS: "Del arte de la cantería al oficio de la cantería”. Ob. cit.

551 L. S. IGLESIAS ROUCO, M. J. ZAPARAÍN YÁÑEZ: "En torno a la actividad profesional en la arquitectura religiosa burgalesa, 1600 - 1650”. En Juan de Herrera y su influencia: actas del Simposio: Camargo 14 / 17 de julio 1992. Santander, Fundación Obra Pía de Juan de Herrera: Universidad de Cantabria. 1993. (pp. 217 - 225).
} 
Burgo de Osma, donde debemos buscar la paternidad última de las creaciones más brillantes.

Los encargados de su ejecución, por su parte, quedan incluidos dentro del grupo de estos maestros de cantería de formación tradicional, basada en la propia experiencia adquirida a lo largo de su trabajo, pero también en la ajena, conseguida fundamentalmente por vía oral ${ }^{552}$.

El relativo anquilosamiento, que caracteriza a estos artífices, se debe, en gran medida, al sistema de cuadrillas en el que se desarrollaba la actividad de la cantería durante la Edad Moderna ${ }^{553}$. Estas cuadrillas eran las auténticas cédulas económicas y de trabajo, en las que se desenvolvía el mundo de la cantería. Cuadrillas que deben ser entendidas, como grupos de oficiales y aprendices, regidos por un maestro, que ejercía de contratistas de las obras, el cual, además de conocer las técnicas de construcción, poseía también unos ciertos rudimentos del arte del diseño arquitectónico. Esto les permitía interpretar con agilidad y corrección los diseños dados por el maestro tracista, pero también, en determinados casos, ser ellos mismos los que diseñaban sus propias trazas.

Evidentemente, uno de los rasgos definidores de estas cuadrillas era su carácter itinerante, el cual hacía que quedaran al margen de cualquier modelo de organización gremial o de otro tipo, pues éstas no podían absorber el nomadismo de los canteros ${ }^{554}$. Aun así, estos contaban siempre con un punto de asentamiento, desde el cual se desplazaban para realizar los trabajos encargados. En el caso de Pedro Díaz de Palacios, uno de los canteros mejor conocidos de cuantos trabajan en nuestra zona, este punto se encontraba en la villa soriana de San Leonardo, donde incluso llegó a ser durante un

552 F. MARÍAS: El largo siglo XVI. Los usos artísticos del renacimiento español. Madrid, Taurus. 1989. (pp. 496 - 498).

553 Ibídem. (pp. 507 - 508).

554 B. ALONSO RUIZ: El arte de la cantería... Ob. cit. (pp 83 y ss.). 
tiempo alcalde mayor ${ }^{555}$. Juan de Maurtúa, maestro natural de la localidad vizcaína de Arrazola, próxima a Durango, muy activo en la zona a lo largo de las décadas centrales del siglo XVIII, fijó su residencia en la localidad de Salas de los Infantes ${ }^{556}$. Por el contrario, cuando se encontraban realizando alguna obra fuera de esta localidad, se veían obligados a alojarse en casas alquiladas, donde dormían y guardaban sus herramientas $^{557}$.

La cuadrilla desempeñaba, en definitiva, el concepto de taller, entendido, en este caso, no como un espacio físico, sino como un medio colectivo, en el cual, se trabajaba, se convivía y se formaba a los futuros canteros ${ }^{558}$.

En general, los soportes de la cuadrilla eran las relaciones familiares, existentes entre los distintos maestros, o las de vecindad o procedencia de un mismo lugar, lo que propicia una auténtica invasión de artífices venidos de fuera, procedentes fundamentalmente de las zonas de Trasmiera y de las provincias vascas. Aun con todo, debemos decir también, que no existen muchos datos sobre la composición interna de estas cuadrillas, pues los canteros que las formaban rara vez superaban el anonimato. El único que solía escapar de esta condición anónima era, lógicamente, el maestro-jefe, si bien, son muchos los casos en los que ni siquiera ellos lo consiguen. De este modo, la información que tenemos sobre la cuadrilla de oficiales, que colaboran con uno de los maestros que trabaja en nuestra zona, durante la primera mitad del siglo XVIII, como es

555 AHPSO. PN. 3281, vol. 5598. (fols. 94vº - 95). Sebastián González Valvivielso. San Leonardo, 29 marzo - 1644 .

556 AHPBU. PN. Valle de Valdelaguna. Leg. 9803/1, fols. 15 - 16. Manuel Gil de la Cuesta. Vallejimeno, 9 - mayo - 1739. ADPBU. CE. 1740. Salas de los Infantes. RESPUESTAS GENERALES. Salas de los Infantes, 10 - febrero - 1753.

557 AGDBU. LP. Quintanar de la Sierra, Cofradía de Nuestra Señora de la Guía. LF. (fols. 68 - 70). Cuentas de los años 1701 - 1702. Quintanar de la Sierra, 21 - abril - 1703.

558 B ALONSO RUIZ: El arte de la cantería... Ob. cit. (pp 83 y ss.). 
el maestro Bernardo de la Torre, constituye un documento auténticamente excepcional $^{559}$.

Al hilo de esto, debemos significar también, que la escasez de datos proporcionados por las fuentes documentales, contribuye a que los nombres de los artífices que nos han llegado, sean muchos menos de los que existen en otras comarcas próximas. Por ello, la relación de artífices que podemos llegar a elaborar resulta sumamente reducida, lo que nos obliga a hacer una simple clasificación y análisis por grupos. En esta ordenación se puede hablar, en definitiva, de tres grandes grupos, bastante bien definidos, cuyo elemento de coexión se encuentra en su lugar de origen o procedencia. Así, podemos hablar de maestros locales, maestros trasmeranos y maestros vascos.

\section{Maestros locales.}

Este grupo está compuesto por una serie de artífices de formación muy limitada, que difícilmente superaban la condición de artesanos. En general aparecen agrupados en pequeños talleres, que no suelen exceder el grupo de la familia nuclear, formado por el padre, como maestro, y el hijo o los hijos, como ayudantes y oficiales.

Su trabajo, lógicamente, no produce obras artísticas de calidad, pero es suficiente para cubrir la demanda local. Una demanda, que en el campo de la arquitectura civil se plasma en la construcción de las viviendas y edificios auxiliares, propios de la arquitectura popular, repitiendo con ello los modelos tradicionales de este tipo de construcciones. De este modo, las únicas variaciones que, en este apartado,

559 La cuadrilla que acompañaba a este maestro en la obra de renovación de la nave de la iglesia de Nuestra Señora de la Visitación de Barbadillo de Herreros, por ejemplo, estaba compuesta por: Simón y Bartolomé Fernández, Francisco Prieto, Francisco Gómez, Domingo Gandarillas, Felipe de la Lomba, y Domingo Gómez de Quintana. Todos procedentes del lugar de Cavárceno y de la Junta de Cudeyo, de donde era natural dicho maestro. AHPBU. PN. Valle de Valdelaguna. Leg. 9802/2, fols. 84 - 84 vº. Manuel Gil de la Cuesta. Huerta de Arriba, 11 - agosto - 1734. 
podemos observar, vendrán determinadas, no tanto, por su mayor o menor capacidad técnica, como por las posibilidades y pretensiones del comitente, que encarga la obra.

En el caso de la arquitectura religiosa, su participación queda limitada a labores muy concretas de reparación y mantenimiento, las cuales debían ser acometidas con cierta inmediatez, y sin necesidad de solicitar la pertinente licencia a los Provisores diocesanos. Se trata, por lo tanto, de trabajos menores, que en muchos casos se acometían sin la firma de un contrato debidamente protocolizado.

En definitiva, son profesionales, cuya labor no exige un alto grado de especialización, y por ello, y por el tipo de obra que acometen - donde era necesario aunar saberes ligados a distintos campos - incorporan a su experiencia conocimientos propios de otras actividades, como puede ser la carpintería, la albañilería o los yeseros. Todo ello complica notablemente incluso su propia denominación, pues en los escasos documentos en los que aparecen citados, reciben títulos tan variados como canteros, carpinteros, albañiles, oficiales, alarifes, etc. Lo cierto es que, por el tipo de trabajo que realizan, tenían un poco de todos ellos.

En sus obras, por supuesto, no encontraremos en ningún caso elementos artísticos destacados, sin embargo, pueden incluirse ciertos rasgos o componentes propios de la arquitectura culta, que son introducidos en estas obras por mera imitación de aquellas.

Respecto a sus nombres, aunque no son muchos los que nos han llegado, se da una circunstancia, que nos llama poderosamente la atención, como es la relativa profusión de maestros con apellidos de origen vasco. Esto se explica, sin duda, por la continuada presencia de artífices de esta procedencia, que poblaron estas sierras a lo largo de gran parte de la Edad Moderna, terminando muchos de ellos por asentarse en estos pueblos. 
Este es el caso del cantero Manuel Achutigui, vecinos de Salas de los Infantes, que trabajó en esta zona a lo largo de las décadas centrales del siglo XVIII. Se trata de un maestro de clara ascendencia vasca, tal y como delata su apellido, el cual, según se declara en las respuestas generales del Catastro del Marqués de Ensenada, trabajaba en este oficio unos 180 días al año, contando para su labor con la colaboración de un oficial $^{560}$. En la villa de Vilviestre del Pinar encontramos otro caso similar en la figura de José Uriarte, cantero, que al parecer trabajaba en solitario ${ }^{561}$. En Barbadillo de Herreros estaba la familia Garachana, los cuales son denominados en el Catastro del Marqués de Ensenada como carpinteros, si bien, y corroborando la polivalencia de estos artífices, observamos cómo en otros documentos, referentes a algunos de sus trabajos, se les da el título de canteros ${ }^{562}$. Dentro de esta familia destaca José Garachana, que trabajó, durante las décadas centrales del siglo XVIII, en toda esta zona del Valle de Valdelaguna, contando para ello con la colaboración de sus dos hijos, Vitores y Matías, que figuraban como oficiales ${ }^{563}$. A esta misma familia pertenece también Juan Garachana Cabezón, el cual trabajó en esta misma zona durante los años finales del siglo XVIII y principios de la centuria siguiente, presentándose bajo el título de maestro de carpintería y cantería ${ }^{564}$.

En la localidad de Huerta de Arriba encontramos afincado, también a mediados del siglo XVIII, al maestro de carpintería de origen vasco Tomás Juariste, el cual, aunque aparece titulado como carpintero, participa, en diferentes ocasiones, en labores propias del arte de la cantería. Esto le permite compatibilizar proyectos como la creación de la estructura del tejado de la iglesia de San Martín, en Huerta de Arriba ${ }^{565}$,

\footnotetext{
560 ADPBU. CE. 1740. RESPUESTAS GENERALES. Salas de los Infantes, 10 - febrero - 1753.

561 ADPBU. CE. 2224. RESPUESTAS GENERALES. Vilviestre del Pinar, 2 - septiembre - 1753.

562 A. Parroq. Barbadillo de Herreros, Ermita de Nuestra Señora de Costana. LF. (1731 - 1840). (fols. 29vo - 31). Cuentas de los años 1750 - 1753. Barbadillo de Herreros, 28 - octubre - 1753.

563 ADPBU. CE. 205. RESPUESTAS GENERALES. Barbadillo de Herreros, 12 - julio - 1753.

564 A. Parroq. Barbadillo de Herreros, Ermita de Nuestra Señora de Costana. LF. (1731 - 1840). (fols. $\left.59-60 v^{\circ}\right)$. Cuentas de los años 1803 - 1806. Barbadillo de Herreros, 6 - marzo - 1806.

565 AHPBU. PN. Valle de Valdelaguna. Leg. 9802/1, fols. 77 - 79 vº. Manuel Gil de la Cuesta. Huerta de Arriba, 31 - mayo - 1728.
} 
efectuada en 1729, con la obra de remodelación y saneamiento, realizada en el entorno de la iglesia de San Quirico y Santa Julita, en Tolbaños de Abajo, contratada en este mismo año ${ }^{566}$.

El ejemplo de este último artífice nos da pie para mencionar algunos otros casos de carpinteros o maestros de carpintería, que trabajaron en labores diferentes a las del tratamiento exclusivo de la madera. Dentro de ellos, sin duda, el caso más destacado lo representa la familia Jarro, asentada en Palacios de la Sierra, la cual trabaja en esta zona de pinares a lo largo de toda la segunda mitad del siglo XVII y primeros años de la centuria siguiente. Se trata de una familia de gran capacidad de trabajo, y sobre todo con unos importantes recursos económicos, lo cual les permitió hacerse con el contrato de obras de elevado presupuesto, para las cuales se hacía necesario presentar grandes cantidades en concepto de fianza ${ }^{567}$. Su poder de trabajo alcanza tales niveles, que prácticamente resulta imposible encontrar una sola obra documentada durante estos años, en los pueblos situados en el entorno de Palacios de la Sierra, en la que no $\operatorname{aparezcan}^{568}$. Los dos miembros de esta familia, que protagonizan este dominio, fueron Pedro y Juan Jarro, padre e hijo, los cuales trabajaron juntos en un primer momento, para luego, una vez fallecido el padre, continuar su hijo el oficio familiar ${ }^{569}$.

\section{Maestros trasmeranos.}

La escasez de fuentes documentales apropiadas nos impiden cuantificar con precisión la presencia de los maestros de origen trasmerano en esta zona de la sierra. Si

\footnotetext{
566 AHPBU. PN. Valle de Valdelaguna. Leg. 9802/1, fols. 3 - 4 vo . Manuel Gil de la Cuesta. Tolbaños de Abajo, 16 - marzo - 1729.

567 AGDBU. LP. Palacios de la Sierra, parroquia de Santa Eulalia y Santa María. LF. (1653 - 1674). Carta cuenta de la obra realizada en las bóvedas y tejado de la iglesia. Palacios de la Sierra, 7 - diciembre $-1670$.

568 Destacadas obras suyas tenemos documentadas también en localidades como Canicosa de la Sierra, Castrillo de la Reina o Vilviestre del Pinar, todo ello sin descartar, por supuesto, el total acaparamiento que hacen de las obras que durante estas décadas tienen lugar en Palacios de la Sierra, que era la villa en la que residían.
} 
bien, debemos suponer, que al igual que ocurrió en el resto de las comarcas burgalesas, ésta tuvo que ser muy abundante, especialmente entre los siglos XVI y XVII. De igual modo, a partir de este momento, y hasta el final de la Edad Moderna, podemos constatar también un progresivo retroceso de éstos, ante el aumento de la presencia de artífices de origen vasco, que terminan por convertirse en mayoría.

La presencia de los maestros trasmeranos en la comarca se comienza a manifestar, al menos, desde la segunda mitad del siglo $\mathrm{XV}$, momento en el que se documenta su participación en algunas obras acometidas en las inmediaciones de la zona, como es el caso de la construcción de la Colegiata de Covarrubias $(1444)^{570}$. Respecto a su procedencia, a pesar de que en muchos casos se utilizan términos, como el de maestros montañeses, (con los que se abarcaría a todo el territorio de la actual Comunidad Autónoma de Cantabria), parece ser, que su lugar de origen se concentra en una zona muy concreta de la parte oriental de esta comunidad, donde se ubican los valles de Cudeyo, las Siete Villas, la Junta del Voto y el valle de Arás. Dentro de estos valles, además, apreciamos un particular predominio de los procedentes del valle de Cudeyo, lo cual confirma, en cierto modo, las teorías, que existen a este respecto, sobre la distribución por zonas concretas, que realizaban estos artífices ${ }^{571}$.

Las causas llevaron a la expansión de estos maestros, desde sus puntos de origen, fueron de naturaleza muy diversa, si bien, se pueden destacar como las más importantes, la existencia de un medio familiar especializado en este oficio, el cual se

569 AGDBU. LP. Palacios de la Sierra, Ermita de Nuestra Señora del Arroyal. LF. (1657 - 1781). (fols. 51 - 53). Palacios de la Sierra, 27 - febrero - 1695.

570 J. M. MUÑOZ JIMÉNEZ: “La aportación de los maestros canteros de Trasmiera a la arquitectura española” Cuadernos de Trasmiera. II. Santander. 1990. (pp. 57 - 100).

571 José Miguel Muñoz Jiménez, en este sentido nos habla de un especial predominio de los maestros procedentes del valle de Arás y la Junta del Voto en la provincia de Guadalajara, J. M. MUÑOZ JIMÉNEZ: La arquitectura del manierismo en Guadalajara. Guadalajara, Instituto Provincial de Cultura “Marqués de Santillana”. 1987. ; mientras que Moya Valgañón detecta en la zona de la Rioja Alta una clara presencia mayoritaria de artífices de origen vizcaíno. J. G. MOYA VALGAÑÓN: Arquitectura 
fue conservando de generación en generación, y por supuesto, la situación socioeconómica vivida en los puntos de origen, donde la falta de recursos suficientes impulsa a sus habitantes a la emigración ${ }^{572}$. Pero como se suele decir, la aportación de esta zona de Trasmiera a la arquitectura de la Edad Moderna en España, no fue de ideas, ni de carácter estilístico, ni tipológico, sino puramente humana, a través de sus artífices ${ }^{573}$.

La importancia de estos maestros en la arquitectura de nuestra zona, no está, tanto en el volumen de obras que llegan a realizar, como en la importancia y calidad de las mismas, pues no en vano, podemos constatar, que para los proyectos más importantes se busca siempre su participación. Otra particularidad que podemos señalar, es que en ningún caso se asentaron en pueblos de la zona, fijando, por el contrario, su residencia en localidades mejor situadas geográficamente o con mayor población. De este modo, estos maestros había que buscarlos en lugares como Burgos, Soria, Burgo de Osma, Aranda de Duero o incluso Silos. Uno de estos maestros, que fija su residencia en nuestro entorno fue, como ya vimos, Pedro Díaz de Palacios, el cual se establece en la villa de San Leonardo.

La relación de nombres de maestros de esta procedencia, que llegaron a trabajar en la zona, no resulta todo lo rica que nos hubiera gustado, pues las fuentes documentales conservadas se muestran sumamente pobres en este aspecto. Aun así, los libros de fábrica de varias de las iglesias y ermitas nos han permitido hacer el siguiente listado:

- Melchor de la Ayuela: Maestro de cantería natural de la localidad de Hermosa, en la Junta de Cudeyo, que trabajó en la zona de la sierra en torno al segundo cuarto del siglo XVIII. Las escasas noticias, que tenemos sobre su trabajo aquí, lo sitúan en el valle de Valdelaguna, actuando, junto con Bernardo de la Torre, como artífice de la renovación del templo de San

religiosa del siglo XVI en la Rioja Alta. Logroño, Instituto de Estudios Riojanos: Servicios de Cultura de la Excma. Diputación Provincial. 1990.

572 J. M. MUÑOZ JIMÉNEZ: “La aportación de los maestros canteros de Trasmiera...” Ob. cit. 
Martín en Huerta de Arriba ${ }^{574}$, y como tracista, con Diego de Barquiero, en la remodelación del entorno de la iglesia de San Quirico y Santa Julita, en Tolbaños de Abajo ${ }^{575}$.

- Juan de Cabarga: Maestro de cantería, cuya única presencia documentada se encuentra relacionada con la tasación de obras de otros maestros, sin embargo, no debemos descartar la posibilidad de que también él participara directamente en algún que otro proyecto.

- Luis Crespo: También denominado en diferentes ocasiones como "maestro montañés”, lo cual despeja toda sombra de duda sobre su procedencia. Sin embargo, al igual que en caso de Juan de la Fragua y otros más, no se precisa en ningún momento la zona concreta de origen. Parte de sus trabajos se encuentran documentados entre los años 1680-1685, en las localidades de Canicosa de la Sierra y Quintanar de la Sierra. En la primera de ellas este maestro trabajó en algunas casas pertenecientes a la parroquia, así como en diversos reparos en los muros del atrio, que circunda la iglesia ${ }^{576}$. Su trabajo en Quintanar de la Sierra se reparte entre la ermita de Nuestra Señora de la Guía y la iglesia parroquial, donde realizó respectivamente, diversas labores de reparación ${ }^{577}$, y el enlosado del templo ${ }^{578}$.

573 Ibídem.

574 AHPBU. PN. Valle de Valdelaguna. Leg. 9802/1, fols. 64 - 70 vo. Manuel Gil de la Cuesta. Huerta de Arriba, 5 - mayo - 1728.

575 AHPBU. PN. Valle de Valdelaguna. Leg. 9802/1, fols. 3 - 4 vº. Manuel Gil de la Cuesta. Tolbaños de Abajo, 16 - marzo - 1729.

576 AGDBU. LP. Canicosa de la Sierra, parroquia de San Esteban. LF. (1609 - 1684). Canicosa de la Sierra, 30 - mayo - 1682.

577 AGDBU. LP. Quintanar de la Sierra, Cofradía de Nuestra Señora de la Guía. LF. (1665 - 1695). (fols. 269 - 271): Cuentas del año 1683. Quintanar de la Sierra, 5 - abril - 1684.

578 Ibídem. Parroquia de San Cristóbal. LF. (1650 - 1711): Cuentas del año 1685. Quintanar de la Sierra, 10 - junio - 1686. 
- Martín Delgado: Maestro de cantería natural de la localidad de Hermosa, en la Junta de Cudeyo. La única obra documentada de este maestro se encuentra en la iglesia de San Martín, en Vallejimeno, donde participó, en 1736, en la remodelación del entorno de dicho templo ${ }^{579}$.

- Pedro Díaz de Palacios: Miembro de una prestigiosa y extensa familia de canteros, originarios de San Miguel de Arás, en la Junta de Voto ${ }^{580}$. Su trabajo en esta parte occidental del territorio de la Diócesis de Osma se encuentra perfectamente documentado a lo largo de la primera mitad del siglo XVII. Durante este tiempo fijó su residencia San Leonardo, donde llegó a ocupar el cargo de Alcalde Mayor ${ }^{581}$. En esta localidad soriana participó en las intensas labores de remodelación acometidas en la iglesia parroquial ${ }^{582}$, si bien sus trabajos más brillantes los deja en el monasterio de San Pedro de Arlanza, donde dirige la construcción de la nueva sacristía, la escalera monumental, el nuevo patio, que se incorpora en la zona oriental del complejo monástico, y la fachada principal, con la que se remata todo este conjunto de obras ${ }^{583}$. La intensa relación que establece con este cenobio hizo que se ganara el derecho de ser enterrado en su iglesia, donde todavía se

579 AHPBU. PN. Valle de Valdelaguna. Leg. 9803/1, fols. 14 - 17 vo. Manuel Gil de la Cuesta. Vallejimeno, 13 - mayo - 1736.

580 Ma C. GONZÁLEZ ECHEGARAY, M. A. ARAMBURU-ZABALA HIGUERA: Artistas cántabros de la Edad Moderna. su aportación al arte hispánico (Diccionario biográfico - artístico). Salamanca, Servicio de Publicaciones de la Universidad de Cantabria. 1991 .(pp. 201).

581 AHPSO. PN. San Leonardo. Leg. 3279, vol. 5594, s/f. Diego Ruiz Mijangos. San Leonardo, 15, octubre -1640 .

582 AHPSO. PN. San Leonardo. Leg. 3278, vol. 5588, s/f. Diego Ruiz Mijangos. San Leonardo, 29 julio - 1636.

583 E. CARRETERO SANTAMARÍA, V. GONZÁLEZ DE CASTRO: “Arquitectura clasicista en Burgos... ob. cit. 
conserva su lápida sepulcral ${ }^{584}$. En la comarca de la sierra su obra más destacada es la torre que levanta para la iglesia de San Pedro en Hacinas ${ }^{585}$.

- Juan de la Fragua: Maestro de cantería, denominado en algunos de los documentos conservados, en los que aparece su nombre, como "maestro montañés”. Su trabajo más destacado se encuentra en la iglesia de Castrillo de la Reina, donde construyó la nueva torre, levantada a partir de 1572.

- Bartolomé González: Maestro de cantería, natural de la localidad de Matienzo, en el valle de Rueloga. Solamente tenemos constancia de su presencia en el remate para la construcción de la ermita de Nuestra Señora de Rebollar, en el comunal de Trasomo, en 1739, el cual ganó en primera instancia, para después perderlo, a causa de una nueva rebaja ${ }^{586}$. Aun así, debemos pensar que pudo trabajar en alguna otra obra de carácter menor.

- Clemente de Hermosa: Maestro trasmerano, activo en esta comarca entre las décadas de 1650-1660. Las obras documentadas, en las cuales participó, son la construcción de la nueva sacristía, que se hizo para la iglesia parroquial de Castrillo de la Reina ${ }^{587}$, y la renovación de toda la zona de la cabecera, acometida durante los mismos años en la ermita de Nuestra Señora del Arroyal, en Palacios de la Sierra ${ }^{588}$.

584 “AQUÍ HACE P. DIEZ DE PALACIOS MAESTRO ARCHITECTO D CANTERÍA BUENECHOR DESTA REAL CASA FUE NATURAL Y VE(CIN)O DEL LUGAR D S. MIGUEL ARAS FALLECIDO ANO DE 1659".

585 AGDBU. LP. Hacinas, parroquia de San Pedro. LF. (1572 - 1702). s/f. Hacinas, 6 - abril - 1634.

586 AHPBU. PN. Valle de Valdelaguna. Leg. 9803/1, fols. $1-4$ v . Manuel Gil de la Cuesta. Barbadillo del Pez, 12 - enero - 1739.

587 AGDBU. LP. Castrillo de la Reina, parroquia de San Esteban. LF. (1632 - 1673). Cuentas del año 1657. Castrillo de la Reina, 18 - mayo - 1686.

588 AGDBU. LP. Palacios de la Sierra, Ermita de Nuestra Señora del Arroyal. LF. (1657 - 1781). (fols. 20 - 24). Cuentas tomadas entre los años 1658 - 1664. Palacios de la Sierra, 28 - septiembre - 1664. 
- Francisco de Hermosa: Maestro de origen trasmerano, como delata su apellido. Su trabajo se puede recorrer a lo largo de diferentes zonas de las provincias de Burgos y Soria, durante el último tercio del siglo XVII ${ }^{589}$. La única obra de este maestro, que tenemos documentada en la sierra, es la bella portada, que levanta en 1685 para la iglesia de Hacinas ${ }^{590}$.

- Juan de Orbe: Maestro trasmerano, aunque asentado en la localidad soriana de San Leonardo. Su trabajo se desarrolló especialmente dentro de los pueblos de la diócesis de Osma, participando en obras tanto civiles como religiosas. Dentro de los pueblos de nuestra zona, participa, a principios del siglo XVII, en la reparación realizada sobre uno de los puentes, que cruzaban el río Arlanza, a su paso por la localidad de Vilviestre del Pinar ${ }^{591}$.

- Domingo de Pontones: Se trata del primer maestro con este apellido, que encontramos, y aunque en la documentación conservada en ningún momento se menciona su procedencia, todo apunta hacia la comarca de Trasmiera, de donde más tarde vienen otros artífices homónimos. Uno de sus trabajos lo encontramos en la iglesia de Vilviestre del Pinar, donde renueva la parte de la entrada y repara la torre ${ }^{592}$.

- Diego de Pontones: Maestro, cuyo apellido delata, indudablemente su origen trasmerano. Su única participación documentada se encuentra en la iglesia de

589 M. J. ZAPARAÍN YÁÑEZ: Desarrollo artístico de la comarca arandina. Siglos XVII y XVIII. Burgos, Excma. Diputación Provincial de Burgos. Ilustre Ayto. de Aranda de Duero. 2001. (pp. 552 553).

590 AGDBU. LP. Hacinas, parroquia de San Pedro. LF. (1572 - 1702): Cuentas de 1685. Hacinas, 18 julio - 1686.

591 AHPSO. PN. 3273, vol. 5571. (fols. 52 - 53vº). Escribano Alonso de San Esteban. San Leonardo, 27 - julio - 1608.

592 A. Parroq. Vilviestre del Pinar, parroquia de San Martín. LF. (1635 - 1673). (fols. 21 - 22vº). Cuentas del año 1638. Vilviestre del Pinar, 14 - septiembre - 1639. 
Santa Eulalia de Palacios de la Sierra, donde participa, con otros canteros, en una serie de reparaciones efectuadas sobre esta fábrica ${ }^{593}$.

- Bartolomé y Francisco de Pontones: Maestros de cantería vecinos de la Junta de Cudeyo, en la merindad de Trasmiera. Con toda seguridad se trata de una pareja formada por padre e hijo, sin embargo, la parquedad de la información de que disponemos no nos permiten confirmarlo. Su único trabajo en la comarca se encuentra en la iglesia de la parroquia de Santa Eulalia, en Palacios de la Sierra, para la que construyeron, durante los primeros años del siglo XVIII, la nueva cabecera. El primero de ellos, además, fue el encargado de dar las trazas y condiciones para dicho proyecto $^{594}$.

- Juan de Solares: Maestro de cantería de origen trasmerano, bastante activo en esta zona durante la década de 1660. En estos años trabajó en el monasterio de Santo Domingo de Silos, participando en la construcción de algunas cámaras, que se estaban edificando en este citado cenobio ${ }^{595}$. Más tarde realiza la estructura arquitectónica de la brillante portada de la iglesia de Barbadillo del Mercado (localidad situada en las inmediaciones de nuestra zona de estudio $)^{596}$. Y termina este periplo en Huerta de Arriba, con la

593 AGDBU. LP. Palacios de la Sierra, parroquia de Santa Eulalia y Santa María. LF. (1653 - 1674). (fols. $20-24 v^{0}$ ). Cuentas del año 1655. Palacios de la Sierra, 10 - enero - 1656.

594 AGDBU. LP. Palacios de la Sierra, parroquia de Santa Eulalia y Santa María. LF. (1673 - 1726). (fols. $184 \mathrm{v}^{0}$ - 188). Pagos realizados en 1703. Palacios de la Sierra, 7 - abril - 1704. AHPBU. PN. 3232/8, fols. 1. Escribano, D. Antonio Martín Sanz. Palacios de la Sierra, 20 - enero - 1705.

595 C. J. PALACIOS PALOMAR: Patrimonio artístico y actividad arquitectónica del monasterio de Santo Domingo de Silos (1512 - 1835). Abadía de Silos, Milenario del Nacimiento de Santo Domingo de Silos (1000 - 2000). 2001. (pp. 31 - 34).

596 AGDBU. LP. Barbadillo del Mercado, parroquia de San Pedro. LF. Cuentas del año 1660. Barbadillo del Mercado, 1 - agosto - 1661. 
354 Arquitectura de la Edad Moderna en la sierra burgalesa.

construcción del coro, que acomoda en el interior de la torre de la iglesia de San Martín ${ }^{597}$.

- Bernardo de la Torre: Maestro de cantería, natural de la localidad de Hermosa, en la Junta de Cudeyo, que trabajó en diversos trabajos, entre las décadas de 1720-30. Sus obras más importantes se encuentran en Huerta de Arriba $^{598}$, donde codirigió la renovación del templo parroquial de San Martín, y en Barbadillo de Herreros, donde se encargó de construir el edificio del concejo ${ }^{599}$, pasando a completar, poco tiempo después la remodelación emprendida en la nave de la iglesia ${ }^{600}$.

- Francisco de la Torre: Maestro de cantería trasmerano, originario de la Junta de Cudeyo, que trabajó entre la última década del siglo XVII y primeros años de la centuria siguiente. Dentro de su obra, destaca especialmente su participación en la construcción del trasparente, realizado en 1689, para la ermita de Nuestra Señora de la Guía, en Quintanar de la Sierra ${ }^{601}$, y su colaboración en el proyecto de la nueva cabecera edificada en la iglesia de la parroquia de Santa Eulalia, en Palacios de la Sierra, en los primeros años del siglo XVIII ${ }^{602}$.

597 AGDBU. LP. Huerta de Arriba, parroquia de San Martín. LF. (1637 - 1675): Cuentas del año 1666. Huerta de Arriba, 7 - diciembre - 1666.

598 AHPBU. PN. Valle de Valdelaguna. Leg. 9802/1, fols. 64 - 70 v . Manuel Gil de la Cuesta. Huerta de Arriba, 5 - mayo - 1728.

599 AHPBU. PN. Valle de Valdelaguna. Leg. 9802/1, fols. 63 y ss. Manuel Gil de la Cuesta. Barbadillo de Herreros, 8 - junio - 1731.

600 AHPBU. PN. Valle de Valdelaguna. Leg. 9802/1, fols. 59 - 61. Manuel Gil de la Cuesta. Barbadillo de Herreros, 18 - octubre - 1733.

601 AGDBU. LP. Quintanar de la Sierra, Cofradía de Nuestra Señora de la Guía. LF. (1665 - 1695). (fols. $216-217 \mathrm{v}^{0}$ ): Cuentas del año 1689. Quintanar de la Sierra, 26 - abril - 1690.

602 AGDBU. LP. Palacios de la Sierra, parroquia de Santa Eulalia y Santa María. LF. (1673 - 1726). Palacios de la Sierra, 10 - abril - 1704 . 
- Manuel de la Torre: Maestro de cantería, natural de la localidad de Hermosa, en la Junta de Cudeyo. Se trata de uno de los maestros más activos en esta zona, cuyo trabajo se extiende a lo largo de las décadas de 1720, 30 y 40. Sus principales trabajos los realizó en localidades de la zona de Pinares, y muy especialmente en Palacios de la Sierra, si bien, también lo encontramos trabajando, en estos mismos años, en los pueblos del valle de Valdelaguna.

- Juan de Villael Riego: Maestro de cantería, vecino de la localidad de Pamenes, en la Junta del Valle de Cudeyo, en Trasmiera. Su única obra documentada se produce en la ermita de Nuestra Señora del Arroyal, en Palacios de la Sierra, donde se encarga de construir la nueva nave ${ }^{603}$.

\section{Maestros vascos.}

Muy próximos a estos se encontraban los maestros procedentes de las actuales provincias de Vizcaya y Guipúzcoa, denominados genéricamente como maestros vizcaínos. No obstante, la llegada de estos artífices a la comarca serrana se produjo con un cierto retraso, con respecto a los trasmeranos, pues tenemos que esperar hasta bien entrado el siglo XVII para encontrarnos una presencia notable y continuada de los mismos. Curiosamente este mayor protagonismo de los canteros vizcaínos coincide en el tiempo con un marcado retroceso del dominio de los grupos y cuadrillas trasmeranas, si bien, esto no debe llevarnos a pensar necesariamente en la existencia de una lucha o pugna entre ellos, pues en la provincia de Burgos no parece que existiera nunca una presión por parte de los trasmeranos para monopolizar el trabajo ${ }^{604}$.

603 AGDBU. LP. Palacios de la Sierra. Ermita de Nuestra Señora del Arroyal. LF. (1657 - 1781). Contrato firmado ante el notario de Palacios de la Sierra, D. Antonio Martín, entre el maestro de cantería Juan de Villael Riego y la ermita de Nuestra Señora del Arroyal para la construcción de la nave del citado templo. Palacios de la Sierra, 31 - diciembre - 1664.

604 C. CÁMARA FERNÁNDEZ: “Arquitectura clasicista en Castilla. En torno a la figura del trasmerano Pedro de la Torre Bueras y su carácter religioso”. En Juan de Herrera y su influencia: actas del Simposio: Camargo 14 / 17 de julio 1992. Santander, Fundación Obra Pía de Juan de Herrera: Universidad de Cantabria. 1993. (pp. 251 - 259). 
La llegada de estos maestros vascos estuvo relacionada, en un principio, con la realización de obras de escasa importancia, como reparaciones y trabajos de mantenimiento. Sin embargo, a medida que fue pasando el tiempo, consiguieron hacerse con encargos de mayor alcance. Con ello, además, vemos como muchos de estos maestros empiezan a asentarse en estos pueblos, cubriendo con su labor gran parte de la demanda local, lo que hace que la barrera entre estos maestros y los artífices locales tienda a desaparecer.

Su actuación en todo tipo de trabajos hace que sus obras no siempre puedan ser perfectamente conocidas, pues la documentación, donde quedaban reflejadas estas actuaciones, se ha perdido, o simplemente jamás existió. A ello debemos sumar también el carácter anónimo de casi todos ellos, pues en la mayor parte de los escasos documentos, en los que se habla de su obra (libros de fábrica de las iglesias, sobre todo) normalmente la fórmula que se utilizaba para su denominación fue la de maestros vizcaínos.

Pese a todo, nos han llegado algunos casos, en los que, junto a sus apellidos de inconfundible sabor vasco, se incorporaba el apelativo de vizcaíno, lo que despeja cualquier duda sobre su procedencia. Entre ellos podemos citar:

- Juan de Arrieta: Maestro de carpintería de origen vasco, afincado, a mediados del siglo XVIII, en la localidad de Riocavado de la Sierra ${ }^{605}$. Su actividad profesional se concentra, fundamentalmente, en los pueblos del Valle de Valdelaguna y demás localidades próximas, contratando obras en iglesias como las de Bezares ${ }^{606}$, Riocavado de la Sierra ${ }^{607}$, y Vallejimeno ${ }^{608}$, a los que se suman las ermitas de Nuestra Señora de Rebollar, en el comunal

\footnotetext{
605 ADPBU. CE. 1674. RESPUESTAS GENERALES. Riocavado de la Sierra, 12 - junio - 1753.

606 AGDBU. LP. Bezares, parroquia de Santa Lucía. LF. (1725 - 1771). (fols. 27vo - 28vo). Cuentas de los años 1748 - 1749. Bezares, 26 - septiembre - 1749.

607 AHPBU. PN. Valle de Valdelaguna. Leg. 9803/2, fols. 61 - 64 vº. Manuel Gil de la Cuesta. Riocavado de la Sierra, 24 - agosto - 1744.
} 
de Trasomo ${ }^{609}$, y la de Nuestra Señora de Costana, en Barbadillo de Herreros $^{610}$. Fue, al mismo tiempo, colaborador habitual del maestro de cantería de origen vasco, Juan de Maurtúa, con el cual participa en diferentes proyectos, encargándose de las labores en madera.

- Juan Berreño: Fue uno de los primeros canteros vizcaínos en llegar a esta zona de la sierra. Se encuentra trabajando aquí ya durante la primera mitad del siglo XVII, participando, entre otras obras, en la construcción del portal de la iglesia de San Esteban de Castrillo de la Reina ${ }^{611}$.

- Martín de Garray y Pedro de Arteche: Son otros dos de los primeros maestros vizcaínos en llegar. Su trabajo, como ocurre con el resto de sus compañeros de procedencia, aunque no muy bien conocido, lo encontramos en la iglesia de Santa Eulalia, en Palacios de la Sierra, donde participan en las importantes labores de reparación y consolidación de las bóvedas, que se llevaron a cabo en torno a los años setenta del siglo XVII ${ }^{612}$.

- Andrés de Goería: Vizcaíno, presentado en las obras que realiza, como maestro de carpintería, si bien sus trabajos se desenvuelven en los distintos campos de la construcción. Su actividad, dentro de los pueblos de la zona, la

608 AHPBU. PN. Valle de Valdelaguna. Leg. 9803/1, fols. 18 - 21. Manuel Gil de la Cuesta. Barbadillo de Herreros, 20 - mayo - 1736.

609 AHPBU. PN. Valle de Valdelaguna. Leg. 9803/1, fols. 15 - 16. Manuel Gil de la Cuesta. Vallejimeno, 9 - mayo - 1739.

610 A. Parroq. Barbadillo de Herreros, Ermita de Nuestra Señora de Costana. LF. (1731 - 1840). (fols. 24

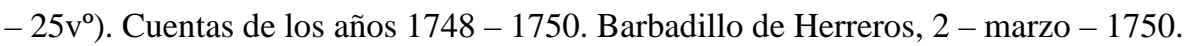

611 AGDBU. LP. Castrillo de la Reina, parroquia de San Esteban. LF. (1572 - 1631). Cuentas del año 1622. Castrillo de la Reina, 3 - mayo - 1624.

612 AGDBU. LP. Palacios de la Sierra, parroquia de Santa Eulalia y Santa María. LF. (1653 - 1674). (fols. $188 v^{0}$ ). Carta cuenta de las obras realizadas en las bóvedas y tejado de la iglesia. Palacios de la Sierra, 7 - diciembre - 1670 . 
tenemos documentada especialmente, en la villa de Canicosa de la Sierra, en la década de $1680^{613}$.

- Juan Gornachea: Maestro vizcaíno, asentado en la localidad de Huerta de Arriba, durante los años centrales del siglo XVIII. Por este motivo, en el momento de realizarse el Catastro del Marqués de Ensenada su nombre aparece recogido, pero no como vecino, sino como habitante ${ }^{614}$. Este caso, por lo tanto, puede ser especialmente representativo de la presencia y asentamiento de los canteros vizcaínos en la zona.

- Pedro de Lasola: Artífice vizcaíno, titulado como carpintero y albañil. Esta condición le permite trabajar en proyectos de diverso tipo, como la reparación del coro de la iglesia de Vilviestre del Pinar, y el aderezo del cuerpo de esta misma fábrica en $1647^{615}$.

- Juan de Maurtúa Maestro de cantería natural de la localidad de Arrazola, en las proximidades de Durango, en Vizcaya. No obstante, desde la década de 1730 vemos que había fijado ya su residencia en Salas de los Infantes ${ }^{616}$, desde donde atendía los numerosos proyectos de los que se hizo cargo. Sin duda, se trata de uno de los maestros más activos de cuantos participaron en la comarca, participando en algunas ocasiones como tracista, tal y como acredita su actuación en la obra de remodelación efectuada en 1744 en la iglesia de Santa Coloma, en Riocavado de la Sierra ${ }^{617}$.

613 AGDBU. LP. Canicosa de la Sierra, parroquia de San Esteban. LF. (1677 - 1765). Canicosa de la Sierra, 30 - mayo - 1682.

614 ADPBU. CE. 902. RESPUESTAS GENERALES. Huerta de Arriba, 26 - julio - 1753.

615 A. Parroq. Vilviestre del Pinar. Parroquia de San Martín. Libro de Fábrica. (1635 - 1673). (fols. 50v ${ }^{\circ}$ - 60). Cuentas del año 1647. Vilviestre del Pinar, 24 - febrero - 1648.

616 ADBUP. CE. 1740. RESPUESTAS GENERALES. Salas de los Infantes, 10 - febrero - 1753.

617 AHPBU. PN. Valle de Valdelaguna. Leg. 9803/2, fols. 73 - 77 vo. Manuel Gil de la Cuesta. Riocavado de la Sierra, 3 - septiembre - 1744. 
MATERIALES Y TÉCNICAS CONSTRUCTIVAS.

\section{Materiales.}

Las características de los materiales empleados de forma mayoritaria en la construcción, dentro de esta comarca de la sierra burgalesa, son los elementos que confieren uniformidad a estos núcleos, por encima de las variaciones deparadas por estilos o épocas concretas. Estos materiales, por lo tanto, determinan algunas de las notas más peculiares de esta arquitectura, como color, calidad de los paramentos, posibilidades constructivas, etc.

En esta zona, como por lo general ocurre en todas las áreas rurales, el elemento que rige la selección de los materiales empleados mayoritariamente en la configuración de sus edificios es el principio universal de la economía. De este modo, la selección de los materiales se encuentra determinada, no sólo por su calidad y adecuación a la actividad constructiva, sino también por su abundancia y su fácil obtención y transporte. No obstante, esto no nos debe llevar a hablar de la existencia de un dictatorial determinismo geográfico, pues junto con el principio de economía, que mencionamos, se encuentra también el principio de conveniencia, ya que solamente se emplean aquellos materiales realmente adecuados a los fines que se pretende conseguir, desechando los que no sirven. 
Aun con todo, si establecemos una visión comparativa entre el mapa de los materiales utilizados mayoritariamente en la construcción y el mapa geológico forestal de la comarca, lo que nos vamos a encontrar es una gran coincidencia. Por ello, al tratarse de una zona de montaña, donde se da un fuerte predominio del suelo rocoso, y la existencia de amplias superficies de masa boscosa, los materiales dominantes en su arquitectura son la piedra y la madera ${ }^{618}$.

\section{Piedra.}

La piedra, por su abundancia y variedad de tipos, es sin duda el principal material constructivo. Dentro de ella, nos encontraremos, desde la piedra menuda, seleccionada sobre el terreno, hasta las piedras perfectamente labradas y escuadradas, que han sido extraídas de las canteras. En el caso de la piedra menuda, los tipos de rocas más corrientes son los característicos cantos de río, procedentes de la erosión fluvial, que son arrastrados por los ríos desde las zonas más elevadas. El calibre de este tipo de rocas es muy variado. Junto a estos podemos mencionar también los materiales pizarrosos, que con una muy ligera labra, se emplean también abundantemente en aquellas localidades, como Barbadillo de Herreros, Barbadillo del Pez o Riocavado de la Sierra, donde existen importantes concentraciones de este material. El uso de todas ellas, sin embargo, está ligado fundamentalmente a la arquitectura popular, tanto para las viviendas, como para los edificios auxiliares. No obstante, podemos encontrar también numerosos ejemplos de la llamada arquitectura culta, donde descubrimos su presencia de forma complementaria, siempre, eso sí, en partes del edificio consideradas secundarias.

En el segundo de los casos, el de las piedras labradas, el tipo de roca usado de forma mayoritaria es la arenisca, la cual, sin embargo, puede aparecer también en forma de piedra tosca, es decir, sin ningún tipo de labra, o con un pequeño desbaste. La larga y

\footnotetext{
618 J. L. GARCÍA GRINDA: Arquitectura popular de Burgos. Crítica y teoría de la arquitectura popular: tipos y caracterización de la arquitectura rural autóctona castellano - leonesa: el caso burgalés. Burgos, Colegio Oficial de Arquitectos de Burgos. 1988. (pp. 83 y ss.)
} 
compleja historia geológica de la comarca, como ya vimos ${ }^{619}$, hace que podamos encontrar una nutrida variedad de tipos de areniscas, que repercuten en la existencia de una rica diversidad cromática y de textura en los paramentos de los edificios. Dentro de estos tipos, los que van a tener un mayor uso como material constructivo son, por una parte, las areniscas de tono gris-verdoso, que adoptan formas cuarzareniscas y conglomeradas, y por otra, las de tonos ocres, que derivan, en ocasiones, hasta los rojizos, llamadas areniscas del Buntsandstein. Las primeras predominan especialmente en las zonas más meridionales de nuestra comarca de estudio, que conforma la llamada zona de pinares, y en la parte occidental, coincidiendo con el borde mesozoico, que rodea el núcleo, que compone la Sierra de la Demanda. Mientras, los afloramientos de areniscas de tonos ocres se encuentran localizados especialmente en la parte septentrional, correspondiente al núcleo paleozoico.

Se trata, en ambos casos, de rocas sedimentarias detríticas, constituidas fundamentalmente por granos de cuarzo de tamaño medio-fino, trabados por medio de una matriz igualmente detrítica, dentro de la cual se incluyen proporciones mínimas de arcillas y sericita. Son tipos de rocas que pueden ser extraídas en bloques de tamaño medio, prestándose bien al trabajo de talla, tanto en sillares regulares, como en relieves, molduras y labras más finas. Sin embargo, ofrecen el inconveniente de su relativa fragilidad frente a la erosión, provocada por los agentes atmosféricos, lo cual no es tanto un problema determinado por el tipo de roca en sí, como por el clima que debe soportar.

Los puntos de extracción de estas rocas se encuentran, por lo general, dentro de los propios términos municipales, contando la mayoría de los núcleos con sus propias canteras, desde las que se autoabastecían del material necesario para sus obras. No obstante, se trata, en todos los casos, de canteras poco importantes, capaces únicamente de satisfacer esta demanda local, y nunca pensadas para la exportación a otros

619 Ver capítulo: Medio Físico. 
lugares $^{620}$. De este modo, resulta siempre extraordinariamente difícil localizarlas, pues rara vez han dejado rastros sobre el terreno, que permitan identificar su ubicación. Aun así, existen algunas excepciones, como es el caso de Castrillo de la Reina, donde a través de los testimonios proporcionados por algunos vecinos, conocedores al milímetro de estos parajes, hemos podido reconocer la presunta localización de uno de estos puntos de extracción de piedra. Este lugar es el conocido como "fuente del Molar", situado a pocos kilómetros del pueblo ${ }^{621}$. Un ejemplo más preciso lo encontramos en la localidad de Hacinas, en la cual, merced a los testimonios ofrecidos por las fuentes documentales, podemos establecer con absoluta precisión uno de estos puntos de extracción de piedra, en el paraje conocido como "Peña Caballera",622. También podemos citar aquí el lugar conocido como “la Zarzaleda”, en el término municipal de Barbadillo del Pez, del que se extrajeron los materiales para diversas obras ${ }^{623}$.

En cualquier caso, y al margen de todas las dificultades, que encontramos a la hora de establecer la localización exacta de las canteras, lo que parece quedar fuera de toda duda es que la piedra utilizada en la inmensa mayoría de las obras, tanto si se trata de edificios destacados, como de aquellos más modestos, es que su procedencia se sitúa siempre en el propio entorno de cada municipio.

Frente a este dominio prácticamente absoluto de la roca arenisca, en algunos casos aislados nos encontramos también con la presencia, casi testimonial, de otro tipo de rocas, las cuales se emplean para construcciones muy concretas, realizadas dentro de

620 La explotación masiva de estos tipos de piedras sólo se ha producido a partir de estas últimas décadas, a través de varias empresas del sector localizadas en la zona. Ello tiene su origen en la especial valoración y reconocimiento, que en actual panorama de la construcción, han encontrado estos materiales, donde se estima, de modo especial, su cálida y brillante tonalidad.

621 A. ABAD IZQUIERDO, L. M. GONZÁLEZ: Estudio de la iglesia de Castrillo de la Reina y otros documentos históricos. Castrillo de la Reina. 1985.

622 De este punto se sacó la piedra necesaria para las reparaciones efectuadas en el cementerio de la iglesia de San Pedro de Hacinas a finales del siglo XVIII. AGDBU. LP. Hacinas, parroquia de San Pedro. LF. (1778 - 1866). Hacinas, 30 - septiembre - 1781. 
edificios ya existentes, y nunca para fábricas completas. Dentro de ellas, la única que podemos destacar mínimamente es la caliza, traída preferentemente de Hontoria de la Cantera. Se trata de una piedra de origen orgánico, con grano fino, que, dada su humedad, resulta muy blanda al ser extraída, pero sin embargo, una vez perdida esta agua se endurece, logrando una gran consistencia. Entre sus cualidades destaca, por lo tanto, la homogeneidad, lo que permite, no sólo su extracción en grandes bloques, sino también unas características mecánicas especiales, que la hacen resistir fuertes empujes, y facilita su labra. No obstante, su elevado precio hacía prohibitivo un uso indiscriminado de la misma, por ello, solamente la encontraremos en obras muy concretas, como puede ser, el coro de la iglesia de Santa María, en Salas de los Infantes, o el sepulcro conservado en la nave del evangelio de la iglesia de Castrillo de la Reina.

Otra caliza, que pudo ser utilizada ocasionalmente, es la procedente de las canteras de Santo Domingo de Silos, cuyo uso resultaba mucho más asequible, tanto por el precio, como por la proximidad. Se trata de una dolomía calcárea, algo pelítica, de grano muy fino y tonos ocre-beige. Su carácter compacto permite trabajar fácilmente con ella, lográndose buenos ejemplos de sillares, columnas, molduras o capiteles. La explotación de estas canteras comenzó a producirse ya en época medieval, como demuestra el magnífico claustro conservado en el propio cenobio silense, continuándose su uso a lo largo de la Edad Moderna ${ }^{624}$.

\section{Madera.}

La madera, dada su gran abundancia en la zona y la alta calidad de la misma, debemos considerarla como el segundo material básico, dentro de los empleados en la arquitectura de la sierra. Esta comarca fue considerada tradicionalmente como una de las más importantes exportadoras de este tipo de material, no sólo dentro del marco provincial, sino también a otros puntos de la Corona de Castilla. Esto se debía a que en

623 AHPBU. PN. Valle de Valdelaguna. Leg. 9803/1, fols. 1 - 4 vº. Manuel Gil de la Cuesta. Barbadillo del Pez, 12 - enero - 1739. 
364 Arquitectura de la Edad Moderna en la sierra burgalesa.

ese momento, igual que ahora, gran parte de este territorio de la sierra burgalesa se encontraba poblado por ricos y frondosos bosques, de los cuales se extraía una madera altamente valorada, tanto por su calidad, como lo asequible de sus precios. Así, ya desde finales de la Edad Media, y a lo largo de toda la Edad Moderna, este material fue ganándose un gran reconocimiento, tanto dentro como fuera de la zona. Por ello, es bastante frecuente encontrar en los pliegos de condiciones de muchas de las obras realizadas en la provincia, el expreso deseo de que la madera utilizada procediera de estos pueblos de la sierra ${ }^{625}$.

A ello debía contribuir, de forma notable, la existencia de la carretería serrana, que recorría de extremo a extremo el territorio de la Corona de Castilla, transportando, entre otros productos, la madera extraída en sus puntos de origen. Así lo vimos, por ejemplo, en los casos de los carreteros, que efectuaban viajes de corto recorrido, denominados en el Catastro del Marqués de Ensenada como carretas ordinarias (para diferenciarlas de las de largo recorrido o de puerto a puerto), los cuales únicamente hacían traslados a ciudades próximas, como Burgos o Logroño, para transportar madera $^{626}$.

Los dos tipos de madera más importantes, que se emplean en la construcción, son el pino, en su variedad de pino albar, y el roble. La distribución de estas dos especies dentro de este territorio, por otra parte, se encuentra perfectamente establecida.

624 AHPSO. PN. San Leonardo. Leg. 3280, vol. 5596. (fols. 32 - 32vº). Sebastián González Valdivielso. San Leonardo. 20 - junio - 1643.

625 En la construcción del retablo mayor de la iglesia de San Esteban de Burgos, por ejemplo, se pide expresamente que la madera utilizada en su ejecución procediera de Canicosa de la Sierra o de Quintanar de la Sierra. I. GARCÍA RÁMILA: "Del Burgos de antaño: Posturas y remate de la obra del retablo mayor de la iglesia parroquial de San Esteban de la ciudad de Burgos. (1666 - 1668)”. BIFG, no 100 (1947). (pp. 623 - 631). Más ejemplos en R. J. PAYO HERNANZ: El retablo en Burgos y su comarca durante los siglos XVII y XVIII. Burgos, Excma. Diputación Provincial de Burgos. 1997. (pp. 191 y ss.). También en el AHPSO hemos encontrado abundantes ejemplos de contratos de compra de madera, firmados entre arquitectos y maestros de cantería de Madrid, y maestros y carreteros de nuestra zona, correspondientes principalmente al siglo XVII.

${ }^{626}$ Ver apartado dedicado a Economía. 
Así, en el primero de los casos nos encontramos con la llamada zona de pinares, la cual se corresponde con la parte sur-oriental de la comarca serrana, obteniendo esta denominación, evidentemente, por la notable abundancia de este tipo de árboles ya desde época antigua ${ }^{627}$. Dentro de ella destacan, de modo especial, pueblos como Canicosa de la Sierra, Palacios de la Sierra o Quintanar de la Sierra, y en menor medida, Vilviestre del Pinar o Regumiel de la Sierra. El tipo de madera, que se produce en la zona, es principalmente la del albar, si bien, también existen algunos ejemplos de pino negral, aunque más escasos. Se trata de un tipo de madera fuerte y muy resistente a las presiones, lo cual hace de ella un material idóneo, no sólo para elaborar estructuras de armaduras de tejados, forjados de suelos, o machones de muros, sino también para la fabricación de andamiajes y cimbras. Al mismo tiempo, al tratarse de árboles muy esbeltos, que superan con facilidad los 30 metros de altura, de tronco recto y sin apenas nudos, permite obtener piezas de gran longitud y potencia. A esto tenemos que añadir, además, su bajo coste, pues su extraordinaria abundancia, unido a las grandes facilidades que existían para su extracción y transporte, hacía que fuera asequible para todo tipo de obras.

Sin embargo, su empleo, aunque mayoritario, no fue único. Así, como ya apuntábamos anteriormente, debemos destacar también la utilización de otros tipos de maderas, entre las que destaca de modo especial el roble. Su presencia en esta parte de la provincia de Burgos es también importante, especialmente en aquellas áreas, incluidas dentro de la Sierra de la Demanda propiamente dicha. En este caso, sin embargo, al tratase de un tipo de bosque bastante corriente, y con una presencia más habitual en otras zonas del mapa provincial burgalés, no se da una explotación tan intensa como en el caso del pino. Muy al contrario, la producción de este material se destina casi de forma plena a satisfacer únicamente la demanda local. Aun así, también nos encontramos aquí con la presencia de algunas localidades, en las que se llegó a

\footnotetext{
627 P. GIL ABAD: Quintanar de la Sierra, un pueblo burgalés de la comarca de pinares. Burgos, Excma. Diputación Provincial de Burgos. 1986. (pp. 101 y ss.).
} 
desarrollar una especial concentración de la producción y comercialización de este material, suministrando desde allí madera al resto de los pueblos circundantes. El mejor ejemplo de ello lo tenemos en Monasterio de la Sierra, localidad donde la explotación de los tupidos bosques de robles, que poblaban su abrupto término municipal, permitía compensar unos ingresos, que era imposible obtener mediante la agricultura ${ }^{628}$.

Entre las cualidades que presenta esta madera de roble se encuentra su carácter compacto y resistente, lo que hace que se muestre especialmente apta para la fabricación de pilares, machones, suelos entarimados, marcos de puertas y ventanas, etc. Sin embargo, al tratarse de un árbol que presenta un limitado desarrollo en altura y un tronco mucho menos esbelto y más rugoso que el pino, su utilización, para la fabricación de vigas y otras piezas de gran longitud, es más reducida. Por ello, en estas zonas de la Sierra de la Demanda, donde no era tan frecuente la presencia del pino albar, el sustituto, para la elaboración de estas piezas de mayor tamaño, era el haya. Este árbol, dadas las especiales condiciones de humedad y luz, que precisa para su desarrollo, fue en el pasado, y continúa siéndolo hoy en día, una especie bastante frecuente en estos parajes, donde aparece poblando las hondonadas más recónditas. La madera, que se extrae de él, presenta también una gran dureza, pero además, permite obtener piezas de unas dimensiones considerables, lo que no era posible en el caso del roble, con lo cual su utilización en la arquitectura de la zona va a tener también un peso notable.

Otras maderas de uso más restringido son las de nogal, olmo y castaño. La primera de ellas, dadas sus especiales características de calidad y precio, se emplea únicamente en elementos ornamentales y muebles, como por ejemplo, cajonerías para las sacristías, por lo que sólo la encontramos presente en edificios religiosos, o en las residencias de las familias más pudientes. Respecto al olmo y al castaño, su empleo en la arquitectura tradicional se produce como sustituto del pino y el roble, en la

\footnotetext{
628 Los ejemplos documentados de venta de madera de roble, por parte de los vecinos de este pueblo, a otras localidades próximas son realmente numerosos a lo largo de todo el periodo estudiado, pero se incrementan de un modo especial, durante las décadas centrales del siglo XVIII.
} 


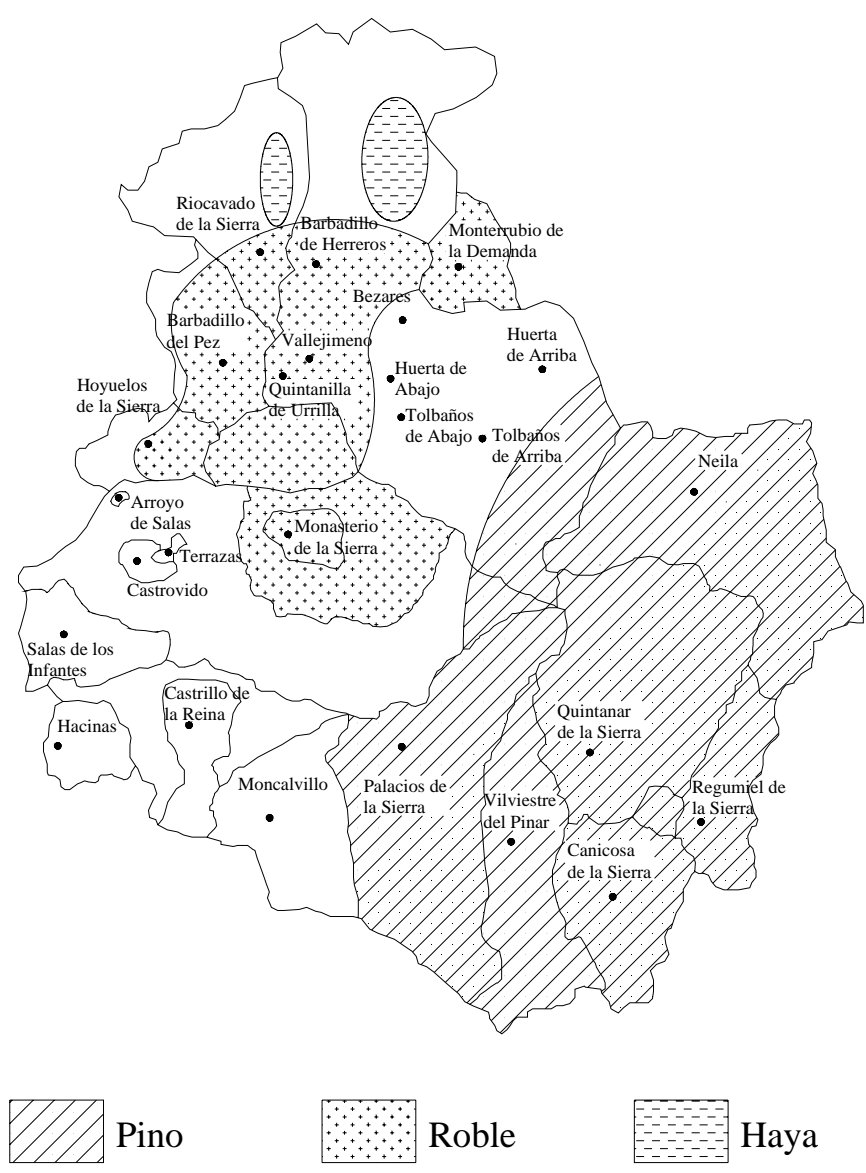

Mapa forestal.

confección de carpintería exterior, como puertas y ventanas, lo que hace que tengan una presencia poco menos que testimonial.

Otra forma de aprovechamiento de la madera es el ramaje. Su uso principal lo vamos a encontrar en la arquitectura más humilde, utilizándose en las cubiertas, como sustituto del entablado, que se colocaba bajo las tejas, o formando encestados, con los que se hace el tabicado interior de algunas construcciones. Con estos ramajes, también 
se fabrica el cerramiento de entramados revestidos, como los que aparecen en las características chimeneas serranas de forma troncocónica ${ }^{629}$.

\section{Otros materiales.}

Un material, que debemos mencionar es la tierra, cuyos diversos usos, que se le han venido dando en la actividad constructiva, hacen de ella un elemento a tener en cuenta. Aun así, su uso, excluyendo su papel como ligante en forma de argamasa, queda restringido casi de forma exclusiva a la arquitectura popular. Su modo de empleo más habitual es en forma de adobe, lo que se consigue a través de la mezcla de tierra arcillosa, bien remojada y batida, con estiércol y paja, con los cuales se logra una mayor unión y consistencia. La utilización de tapiales, por su parte, resulta prácticamente desconocida, tratándose de una técnica más propia de zonas de vega y páramo.

Finalmente, tenemos que hablar también de otros materiales de uso más diverso, como pueden ser el yeso, la cal o algunos metales, como el hierro. En el caso de la cal, se utiliza, principalmente, como elemento ligante, mezclado con la arena. También aparece en la construcción de cementerios, empleándose aquí como elemento purificador y de higiene. La cal, utilizada en esta comarca, procede, en general, de pueblos próximos, donde abundan los suelos calizos, como es el caso de los situados en el llamado borde mesozoico, que rodea, en su parte meridional, el núcleo central de la Sierra de la Demanda, formado por las sierras de las Mamblas y de Carazo. Uno de estos pueblos, donde se compraba habitualmente la cal, era Villanueva de Carazo, tal y como señalan en repetidos casos las fuentes documentales ${ }^{630}$.

El yeso era otro de los materiales de uso diverso. Se utiliza así, tanto para enlucir la parte interior de los muros, como para recubrir las fachadas de los edificios fabricados con materiales más pobres, como entramados de madera, mampuestos o incluso sillarejo. Dentro de la arquitectura culta, y especialmente en la religiosa, lo

629 J. L. GARCIA GRINDA: Arquitectura popular en Burgos...ob. cit. (pp. 225 y ss.) 
encontramos también recubriendo los paramentos de las bóvedas de piedra, o incluso formando cubiertas, compuestas únicamente por este material.

Dentro de los metales, el hierro fue el material más usado, siendo empleado fundamentalmente como elemento de clavazón y herraje. Los encargados de fabricar estos clavos son los herreros y trabajadores de las ferrerías, que existían en algunos de estos pueblos, como Barbadillo de Herreros. Su producción, sin embargo, aunque nunca fue demasiado importante, sí resultó suficiente como para satisfacer la demanda local.

\section{Técnicas constructivas.}

Como ya hemos indicado, la piedra constituye el material dominante dentro de nuestra arquitectura. Este material, sin embargo, puede ofrecernos una amplia variedad de tratamientos, los cuales van, desde la sillería perfectamente labrada, hasta la mampostería con piedra tosca menuda.

Evidentemente, la sillería representa la variante más elevada, mostrando en general piezas de mediano tamaño, perfectamente labradas y ensambladas en hileras regulares, con las que se forman buenos ejemplos de aparejo isódomo. Su elaboración requiere, por lo tanto, la participación de canteros altamente cualificados, los cuales debían ser buscados en aquellos centros arquitectónicos más destacados del entorno. Por todo ello, esta opción resulta la más cara de todas, si bien, con su empleo se conseguía demostrar un poderío y un prestigio, que las otras técnicas no lograban, pues su sola presencia ya era suficiente para dejar patente la condición predominante de sus dueños.

De este modo, la mayor parte de los edificios religiosos presentan en sus muros este tipo de paramento, si bien hay que decir, que son muchos los casos en los que

630 AGDBU. LP. Castrillo de la Reina, parroquia de San Esteban. LF (1632 - 1673). Cuentas del año 1669. Castrillo de la Reina, 3 - julio - 1670. 
resulta imposible desarrollar esta técnica en toda el conjunto de la fábrica. Cuando esto sucede, el trabajo de sillería se reserva para aquellas partes más destacadas del edificio, como son la fachada principal y la cabecera. También es frecuente reservar esta labra más cuidada para la parte exterior del edificio, mientras que los muros interiores, al estar encalados, se rebaja el nivel, mostrando un sillarejo más tosco, o incluso un simple mampuesto. Aun así, en estos casos, los elementos estructurales, como pilastras, columnas, frisos, cornisas, nervaduras de bóvedas, etc., mantienen su elaboración en sillería.

Los edificios civiles, que utilizan este tipo de paramento, corresponden exclusivamente a las residencias de aquellas familias más destacadas de la sociedad del momento en cada pueblo, como son los hidalgos adinerados, y los ricos propietarios de ganados y carretas. Se cumple, de este modo, el sentido de ennoblecimiento, que la utilización de esta técnica concedía a un edificio.

Próximo a la sillería nos encontramos con el sillarejo, el cual supone una técnica algo más tosca, pues se elabora también con piezas de tamaño medio, pero peor trabajadas, y dispuestas de modo menos regular. En los edificios elaborados totalmente con esta técnica se utilizan piezas de mayor tamaño y más regulares en las esquinas, para reforzar la estructura. El desarrollo de este tipo de paramento, por su parte, no requiere unos conocimientos tan profundos del arte de la cantería, ni una selección y elaboración tan meticulosa de los materiales utilizados, con lo cual, su coste resultaba mucho menor. Por ello, también era muy utilizado en la elaboración de edificios religiosos y de viviendas de figuras destacadas, en las cuales, los materiales y las técnicas más nobles se reservan para aquellas zonas más expuestas a la contemplación pública.

La mampostería, por su parte, constituye la forma más económica, que conoce el tratamiento de la piedra. En este tipo de paramentos se usan piedras de formas irregulares y tamaño variado, las cuales van enlazadas con un mortero de barro, cal y 
arena, que actúa como ligante. En los puntos débiles, como esquinas y marcos de vanos, se utilizan, al igual que en el sillarejo, piezas de mayor tamaño y mejor labra, con las que se concede seguridad al edificio. La relativa facilidad de su elaboración y su precio asequible, hacen de esta técnica la más usada dentro del tratamiento de la piedra, empleándose tanto en aquellos edificios más destacados como en los propios de la arquitectura popular.

Todas estas técnicas se desarrollan de forma conjunta, independientemente de las épocas y estilos, lo que hace que puedan convivir perfectamente, incluso, dentro del un mismo edificio. La elección de una u otra va a estar determinada únicamente, por el carácter y significación que cada una de ellas ofrece, pero muy especialmente por la disponibilidad de recursos de los promotores. De este modo, en aquellos edificios de larga y complicada génesis, como es el caso de la mayor parte de los templos parroquiales, nos vamos a encontrar con una rica variedad de paramentos, a través de los cuales, podremos seguir, en muchas ocasiones, la propia historia del edificio.

En relación con esto, debemos apuntar también, que una práctica muy común dentro de esta arquitectura fue la reutilización de materiales resultantes, bien del propio edificio - lo cual sucede en los procesos de renovación de los mismos, donde se emplean los materiales resultantes de la demolición previa -, o bien tomados de otros edificios, que han desaparecido, y cuyos materiales han sido destinados a nuevas construcciones. En ambos casos, es la arquitectura religiosa la que nos ofrece los mejores ejemplos de ello. Así, en el primero de los casos, nos encontramos con numerosas ejemplos de iglesias parroquiales y ermitas, en que en el momento de ser renovadas sus fábricas se aplica la práctica habitual de utilizar los materiales del edificio anterior. Tal vez, uno de los ejemplos más destacados de esto lo encontramos en la iglesia de Barbadillo de Herreros, donde las recientes labores de restauración acometidas sobre la cabecera, construida entre finales del siglo XV y principios del XVI, han sacado a la luz numerosos relieves pertenecientes a la antigua fábrica románica, que allí existía. Otro ejemplo similar lo hallamos en la parroquial de 
372 Arquitectura de la Edad Moderna en la sierra burgalesa.

Hoyuelos de la Sierra, entre cuyos muros aparecen diseminados multitud de sillares, que incluyen relieves, con el característico ajedrezado románico, que confirma su pertenencia al antiguo templo sustituido.

Por lo que se refiere a la utilización de materiales procedentes de otros edificios, vemos que se trata igualmente de una práctica muy habitual. Las “canteras” de donde procedían los materiales, en este caso, solían ser principalmente las pequeñas ermitas, que en gran número poblaban las laderas de estas sierras. Desde finales del siglo XVII, pero muy especialmente a lo largo de todo el siglo XVIII, fueron muchas las que empezaron a conocer sus últimas horas. Cuando esto sucedía, y el peligro de derrumbe se hacía inminente, los Visitadores diocesanos solían indicar, que se procediera a su demolición, colocando una cruz en el lugar que ocupaban, para señalar el carácter sagrado de este suelo, quedando los materiales a disposición de la fábrica parroquial. Ejemplos perfectamente documentados de esta práctica los tenemos en varios pueblos, como es el caso de Hoyuelos de la Sierra, con sus ermitas de San Saturnino, Santa Cruz y Santiago, con cuyos restos fueron reparados en diferentes ocasiones los muros del atrio de la iglesia, o en Bezares, donde la espadaña de la iglesia fue levantada con las piedras sacadas de las ermitas de San Justo y San Pastor, y Santa Marina ${ }^{631}$. En Barbadillo de Herreros encontramos otros dos casos ciertamente significativos de esta práctica. Así, en la ermita de Nuestra Señora de Costana, podemos identificar con claridad los sillares procedentes de la antigua ermita de San Matías (situada en esta misma localidad), que fueron utilizados en una de las reformas de su cabecera. Algunos de estos sillares todavía conservan inscripciones, que delatan su origen ${ }^{632}$. La iglesia parroquial de esta localidad, por su parte, no dudó en utilizar los materiales procedentes

\footnotetext{
631 AGDBU. LP. Bezares. Parroquia de Santa Lucía. LF. (1725 - 1771). (fols. 37 - 39 vº). Visita realizada a la parroquia de Santa Lucía de Bezares en 1755, por D. Juan de Tobías y Zuazo, canónigo de la catedral de Burgos. Canales, 1 - agosto - 1755.

632 A. P. Barbadillo de Herreros. LP. parroquia de Nuestra Señora de la Visitación, LF.(1749 - 1838). Visita realizada a la parroquia de Nuestra Señora de la Visitación en 1803, por el Arzobispo de Burgos D. Manuel Cid Monroy. Barbadillo de Herreros, 4 - septiembre - 180.
} 
de otras dos ermitas, las dedicadas a San Juan y a San Torcuato, para las obras de remodelación de la nave efectuadas entre los años $1733-34^{633}$.

En definitiva, como vemos, las técnicas constructivas, que tienen en el empleo de la piedra su materia básica, son las más destacadas dentro de la arquitectura de nuestra zona. Pero como sabemos, éste no fue el único material utilizado, con lo cual debemos hablar también, aunque brevemente, de las técnicas relacionadas con el uso de estos otros materiales, empleados, bien en solitario, o bien en fábricas mixtas.

Entre ellas se encuentran los paramentos de tierra, realizados principalmente mediante adobe. Se trata de una de las técnicas más antiguas usadas en nuestra arquitectura, pues ya aparecen mencionadas por Plinio, para la zona de la Meseta norte peninsular ${ }^{634}$, circunstancia que corroboran los hallazgos arqueológicos ${ }^{635}$. No obstante, se trata de una técnica ligada especialmente a la arquitectura popular, y por ello, poco presente en la arquitectura culta. Dentro de las variedades, que presenta el tratamiento de este material el tapial resulta prácticamente desconocido. Algo más frecuente, sin embargo, es la presencia del adobe, si bien, prácticamente en ningún caso aparece como constituyente básico de un edificio. Lo más normal es encontrarlo en fábricas mixtas, formando el material de relleno en estructuras de muros realizados mediante entramado de madera. Al mismo tiempo, también podemos encontrarlo formando la tabicación interior de edificios destinados a vivienda, si bien aquí aparece recubierto con el correspondiente enlucido.

La facilidad de su fabricación y la flexibilidad que ofrece su manejo y colocación, son dos de los principales factores, que propician su uso. Sin embargo, y aun con todo, no podemos considerarla como una técnica constructiva especialmente desarrollada en esta comarca, pues su uso queda restringido prácticamente en exclusiva,

633 AHPBU. PN. Valle de Valdelaguna. Leg. 9802/2, fols. 59 - 61. Manuel Gil de la Cuesta. Barbadillo de Herreros, 18 - octubre - 1733.

634 PLINIO: Naturalis Historia. XXXV. (pp. 164). 
como hemos dicho, a la arquitectura popular, y dentro de ella, especialmente a edificios auxiliares, como pajares y tenadas. Por ello, rara vez lo vamos a encontrar en otros edificios que no sean estos. La única excepción aparece en las ampliaciones o añadidos, que en algunos casos, y con pocos medios, se hacen en edificios destinados a vivienda. El resultado de ello son casas con una primera planta construida en piedra (sillarejo o mampostería principalmente) sobre la que se alza un segundo cuerpo con entramado de madera y relleno de adobe. Ejemplos de ello los encontramos en varios de estos pueblos $^{636}$.

Ligada a esta técnica encontramos la de muros constituidos mediante emplentas o aparejos de madera, que se rellenan posteriormente con materiales diversos. Como ocurría con el caso anterior, su uso tampoco se encuentra muy extendido dentro de nuestra zona, quedando reducido de forma exclusiva a las construcciones más humildes de la arquitectura popular. Este tipo de paramentos se elevan sobre un zócalo o basamento de piedra, que en los casos de viviendas alcanza la totalidad del primer piso, el cual sirve para aislar la madera del contacto directo con el suelo, y salvarla así de la humedad.

Los tipos de entramado pueden ser muy variados, pasando desde los más complicados, con intrincado diseño de maderas cruzadas en sentido horizontal, vertical y oblicuo, hasta los más sencillos, con simples listones colocados verticalmente. Este grado depende siempre del tipo de madera usada, de los materiales de relleno que se vayan a emplear, y por supuesto, de las características y dimensiones del edificio. Los rellenos, por su parte, también pueden variar, encontrándonos delgadas piezas de sillería, piezas de cascote de tamaño menudo formando mampuesto ${ }^{637}$, encestado o tablillas cubiertas con mortero, adobe ${ }^{638}$, ladrillo (ya en época relativamente

\footnotetext{
635 Museo Arqueológico - Paleontológico de Salas de los Infantes.

636 Barbadillo de Herreros: Casas situadas en: C. de las Eras 22 (destruida); Riocavado de la Sierra: C. del Centro 3; Huerta de Arriba: C. de las Huertas 15; Huerta de Abajo: Plaza de la Iglesia 15.

637 Barbadillo del Pez: C. San Isidro 128.

638 Barbadillo de Herreros: C. Mayor 180 (Desaparecida).
} 
moderna $)^{639}$, o simple pasta de yeso. No obstante, el tipo de relleno más característico en esta zona de la sierra es el mampuesto, formado por pequeños cantos de río unidos con $\operatorname{argamasa}^{640}$.

Estos paramentos, independientemente de su material de relleno, eran revestidos con una protección de mortero, compuesta por barro, yeso o cal, con la cual se evitaba su rápido deterioro. Para ello, se picaba ligeramente la madera con una azuela, con lo cual se facilitaba y mejoraba el agarre de la masa.

Aparte de todo esto, debemos hablar también de los entramados, que componían los suelos techos y cubiertas, dentro de los cuales, evidentemente, la madera es la auténtica protagonista. Dentro de ellos, los suelos de planta baja son los únicos que no cuentan con un protagonismo exclusivo de este material, pues son muchos los ejemplos que conocemos de embaldosado, especialmente en la arquitectura religiosa, donde el suelo de las fábricas parroquiales era a la vez lugar de enterramiento. No obstante, esto no evita que sean muchos los casos en los que, además de contar con este embaldosado, se disponía encima un entablado, para cubrir y aislar la fría superficie pétrea.

Los techos de las plantas bajas y suelos de las plantas superiores, por su parte, están formados en general por largas y resistentes vigas de madera, entre las que se colocaban las correspondientes tablas (normalmente de roble, aunque también pueden ser de pino, dependiendo de las zonas), que constituían el suelo.

En cuanto a las cubiertas, tanto en los casos en los que existe una estructura abovedada (como en general ocurre en la arquitectura religiosa), como en los que no, nos encontraremos siempre con una armadura de madera rematando todo el conjunto del edificio. Evidentemente se trata de la parte más frágil de toda fábrica, con lo cual, resulta prácticamente imposible encontrar un solo ejemplo en el que se haya conservado

639 Barbadillo de Herreros: C. Mayor 181 (Desaparecida). 
la estructura original, correspondiente a la Edad Moderna. Aun así, la mayor parte de las remodelaciones, que se han hecho a lo largo del tiempo, y muchas de la que se hacen actualmente, siguen respetando, en mayor o menor medida, los modelos primitivos.

De este modo, vemos que los dos tipos de armaduras más utilizados son los conocidos como: parhilera o mojinete, y par y nudillo. El primer de ellos es el más sencillo, consistente simplemente en una estructura de perfil triangular, formada por una serie de parejas de vigas dispuestas en forma oblicua, llamadas pares, que descansan sobre una viga superior horizontal, dispuesta longitudinalmente, llamada hilera, que constituye el vértice superior del tejado. La parte superior del muro, sobre el que descansan los pares, se llama solera, y entre cada una de ellas se colocan una serie de vigas transversales denominadas tirantes, con las cuales se pretende evitar las tensiones hacia el exterior generadas por los pares.

El modelo par y nudillo resulta muy similar al anterior. La única diferencia, en este caso, la encontramos en la incorporación de una viga horizontal, llamada nudillo, colocada como refuerzo entre cada dos pares, dispuesta generalmente a dos tercios aproximadamente de su altura. Con ello se pretende conseguir una mayor seguridad.

Por supuesto, estos dos modelos son muestras ideales, pensados para cerrar superficies regulares, de forma cuadrada o rectangular, mediante cubiertas a dos aguas. Sin embargo, en la práctica deben adaptarse a las más variadas superficies, desarrollando cubiertas a varias aguas.

En el remate de estas cubiertas se emplea, en todos los casos, la teja de cerámica curvada, con la que se forma la clásica disposición de canal y cobija. Estas tejas se asientan, generalmente, sobre un lecho de tabla, utilizando barro para evitar su

640 Barbadillo del Pez es una de las localidades, que hasta hace poco, más y mejores ejemplos ha conservado de este tipo de paramento. 
deslizamiento, no obstante, en algunos casos esta masa de barro puede ser sustituido por otros materiales, como paja, mimbres o pequeñas ramas. 
TENDENCIAS Y FORMAS ARTÍSTICAS.

Como ocurre generalmente en las zonas alejadas de los principales focos rectores del mundo del arte, en la comarca de la sierra burgalesa se produce un evidente estancamiento estilístico, el cual se extiende a lo largo de toda la Edad Moderna. Esta permanencia o arraigo de determinados modelos artísticos fuera de su tiempo natural, unida a una cierta incapacidad de adaptarse a determinadas formas nuevas, representan un fenómeno conocido como ruralización del arte, el cual preside en gran medida la mayor parte de las creaciones, que aquí se acometen.

De este modo, la evolución estilística, que podemos registrar dentro de esta comarca a lo largo de todo el periodo de estudio, queda reducida a dos estilos fundamentales, como son el gótico final, y el barroco clasicista, existiendo junto a ellos ligeras manifestaciones propias de la estética renacentista.

Las obras, donde quedan reflejados los rasgos más característicos de cada uno de estos estilos, son las pertenecientes a la llamada arquitectura culta, es decir, aquellas construcciones, donde se muestra una especial preocupación por desarrollar en su concepción unas ciertas pretensiones estéticas, que permiten diferenciarlas radicalmente de la arquitectura popular. Una arquitectura que no sólo trata de satisfacer una mera necesidad inmediata, sino que nace con la intención de perdurar. 
A través de estas creaciones, por lo tanto, vamos a ver cómo el arraigo del estilo gótico, se extiende a lo largo de la mayor parte del siglo XVI, continuándose en sus creaciones las brillantes formas alcanzadas ya durante los últimos momentos de la centuria anterior. Su fuerte implantación en la zona hace que la presencia del lenguaje propio del renacimiento quede relegada a la realización de obras muy concretas, destinadas a completar la construcción de edificios ya existentes, mostrando por ello un claro carácter epidérmico. Esta circunstancia se produce a pesar de la proximidad de un foco tan activo, durante toda esta centuria del Quinientos, como fue la propia ciudad de Burgos, con figuras de primer orden dentro de este estilo, pues los artistas que trabajan en estos pueblos rara vez participan en aquellas grandes creaciones. De esta forma, el desarrollo del pleno renacimiento aquí sólo se produce en casos muy aislados, con la ejecución de obras ligadas estrechamente a sus focos rectores, como puede ser el caso de la portada de la iglesia de Santa María de Salas de los Infantes - vinculada a los círculos burgaleses de Diego de Siloe ${ }^{641}$ y Juan de Vallejo ${ }^{642}$-, o la portada de la iglesia de Santa Eulalia en Palacios de la Sierra - relacionada con el núcleo plateresco soriano $^{643}-$.

Tras esto, y sin dar opción a que las formas renacentistas terminaran de arraigar, desde principios del siglo XVII comenzó a llegar la nueva estética clasicista, que tenía su punto de partida y referente fundamental en la obra de San Lorenzo de El Escorial y, en general, en la producción de Juan de Herrera y sus sucesores. El calado que este nuevo lenguaje arquitectónico tiene dentro de la comarca de la sierra no sólo se produce de forma súbita, acabando con el dominio prácticamente absoluto que habían mantenido hasta el momento las formas góticas, sino también de un modo bastante más duradero, ya que se extendieron, prácticamente sin solución de continuidad, hasta el final de la

\footnotetext{
641 J. CAMÓN AZNAR: La arquitectura y la orfebrería españolas del siglo XVI. En SUMMA ARTIS. (dir. J. PIJÁN). Madrid, Espasa Calpe. 1982. (pp. 280).

642 A. C. IBÁÑEZ PÉREZ: “Arquitectura, escultura, pintura y artes menores del siglo XVI”. En Historia de Burgos. III. Edad Moderna 3. Burgos, Caja Burgos. 1999. (7 - 196).

${ }^{643}$ Esta portada presenta notables analogías, tanto en la concepción de su estructura como en las formas ornamentales, con la que se conserva en la fachada meridional de la con - catedral de San Pedro en Soria.
} 
Edad Moderna. Entre los factores que contribuyen a ello, propiciando esta rápida implantación, se encuentra principalmente la ejecución de importantes programas constructivos, en lugares próximos a esta comarca, como puede ser la edificación del conjunto urbanístico y monumental de la villa ducal de Lerma, o las remodelaciones, que a lo largo de estos dos siglos, se llevan a cabo en los dos centros monásticos más importantes de nuestro entorno, como son San Pedro de Arlanza y Santo Domingo de Silos $^{644}$. La repercusión que todas estas obras, y de modo muy especial estas dos últimas, van a tener dentro de la arquitectura que aquí se realiza, no sólo afecta en un plano meramente formal, con la consiguiente renovación estilística, sino también en lo que se refiere al desarrollo del puro proceso constructivo. Así, son muchos los maestros que, atraídos por estos grandes proyectos, y después de participar, y en muchos casos formarse, dentro de ellos, terminan después realizando diferentes obras en iglesias de los pueblos de la sierra.

El firme dominio que estos dos estilos constructivos tienen dentro de la arquitectura de la zona, propicia también un curioso fenómeno de encabalgamiento entre lo viejo y lo nuevo, el cual se manifiesta, no mediante una abierta oposición abierta entre ellos, sino a través de una curiosa simbiosis de formas y soluciones constructivas. Así, vemos cómo dentro de un mismo conjunto se llegan a armonizar elementos de diferentes épocas, hasta lograr resultados perfectamente homogéneos. Un ejemplo de ello lo tenemos en la utilización de la bóveda de crucería estrellada con terceletes de origen gótico, la cual es considerada como el tipo de cubierta ideal a lo largo de todo el periodo, manteniéndose su uso incluso en las obras más tardías, lo que obliga a tener que adaptarse a los tipos de arcos y soportes más variados.

Esta combinación o encabalgamiento de elementos de diferentes estilos, en definitiva, lleva a que en el siglo XVIII se desarrolle un tipo de edificio caracterizado por mostrar una recepción y acumulación de elementos relativamente nuevos, sin haber

644 O. MORAL GARACHANA: "La arquitectura de Silos en su entorno durante el periodo barroco". En Silos. Un milenio. Actas del Congreso Internacional sobre la Abadía del Santo Domingo de Silos, octubre 
desechado completamente los antiguos. Unos edificios, en definitiva, que se convierten en síntesis de todo un periodo, y que, para definirlos, algunos autores han terminado por acuñar términos como "barroco - gótico"645.

Por encima de todo esto, una pauta importante, que debemos tener en cuenta dentro de este estudio, pues no en vano preside el desarrollo de todas estas formas, es la tendencia natural a simplificar los modelos habituales de cada uno de los estilos. Así, en todos los edificios levantados o renovados a lo largo de este periodo nos vanos a encontrar siempre con el desarrollo de la vertiente más sobria y sencilla de cada uno de ellos, haciendo más hincapié en los aspectos puramente estructurales, que garanticen la solidez y firmeza de la fábrica, que en aquellos otros en los que se manifiestan verdaderamente los valores estéticos. Las obras donde se muestra el lado más exaltado de cada estilo, por lo tanto, no corresponden a estructuras arquitectónicas en sí, sino a piezas de amueblamiento y elementos ornamentales, destinados a completar el interior de los edificios. Así, dentro de la arquitectura religiosa vemos cómo la severidad, que preside todos y cada uno de estos edificios, no va a continuarse en los retablos que adornan sus altares, sino que en ellos se da rienda suelta a las composiciones más ornamentadas, que ofrecen, tanto el renacimiento, como el barroco. 
De esta forma, si la evolución estilística vivida por la arquitectura de nuestra zona a lo largo de la Edad Moderna se representa en un gráfico, mediante una línea curva, que oscilase entre un extremo, que representara las formas más ornamentadas de cada estilo, y otro, que encarnase las más severas, esta línea apenas mostraría desniveles importantes, discurriendo de forma casi paralela al segundo de los extremos. 


\section{SIGLO XVI: EL RENACIMIENTO POR EL INTERÉS ARTÍSTICO.}

El siglo XVI representa un periodo de especial actividad constructiva dentro de todo el territorio de la actual provincia de Burgos, lo cual termina reflejándose de algún modo en nuestra comarca de estudio. No obstante, esta actividad conoce un desarrollo desigual, dentro de la zona de la sierra, a lo largo de toda esta centuria. Así, cronológicamente vemos cómo la mayor parte de las obras registradas corresponden a la primera mitad del siglo, donde se concentran además las creaciones de mayor interés artístico, mientras que en la segunda mitad se produce una significativa deceleración de este impulso creador.

Los factores propiciadores de esta circunstancia resultan difíciles de determinar, si bien parece, hasta cierto punto, factible poder establecer una relación con el crecimiento económico y poblacional, que se registra en la zona durante este mismo periodo, en cierto modo, al abrigo de la pujante vitalidad, que se vive en la propia ciudad de Burgos ${ }^{646}$. A ello tenemos que añadir también la importante actividad constructiva, que se había iniciado a finales de la centuria anterior, lo que hace que muchos templos parroquiales se financien ya dentro de este siglo XVI, aunque mantengan en su estructura los rasgos y formas del proyecto original.

Otro elemento discordante, dentro de este discurrir, se manifiesta en el campo de las tipologías constructivas desarrolladas. Así, dentro de la llamada arquitectura culta, que por otra parte es la única donde queda reflejada la evolución que experimentan las

646 A. C. IBÁÑEZ PÉREZ: “Arquitectura, escultura, pintura y artes menores en el siglo XVI”. ob. cit. 
formas artísticas, solamente la de carácter religioso es capaz de ofrecernos ejemplos dignos de mención. La arquitectura civil, por su parte, aun tardará un tiempo en salir del campo de las tipologías propiamente populares, en parte, por no existir un grupo lo suficientemente poderoso económica y socialmente, como para iniciar este tipo de obras. A ello tenemos que añadir también la falta de interés de los escasos nobles e hidalgos de la zona por manifestar su posición dominante, a través de elementos tan singulares, como la promoción de residencias distinguidas dentro del conjunto del caserío, que formaba estos pueblos.

Desde el punto de vista formal, el siglo XVI ha sido considerado tradicionalmente como un periodo de conflicto, en el que se produce la convivencia entre el gótico (moderno), que era la forma heredada de la época inmediatamente anterior, y el renacimiento (antiguo), con sus formas importadas desde Italia, a través de las cuales se pretendía rescatar la Antigüedad Clásica ${ }^{647}$. El gótico, por lo tanto, constituía un estilo, que a pesar de su larga vigencia, seguía ofreciendo soluciones válidas a las necesidades constructivas del momento, pues se adecuaba, tanto a los gustos y exigencias de los comitentes, como a la formación de los artífices, que como vimos, continuaba siendo plenamente medieval ${ }^{648}$. Frente a esto, el renacimiento es considerado como el estilo nuevo, importado directamente de Italia, y por lo tanto, no elaborado por los maestros locales a través de un estudio y teorización propios, lo que hacía que no siempre fuera aplicado con unos criterios plenamente clásicos.

Esto nos lleva a un panorama presidido, a priori, por un bilingüismo formal, que permitía contar con una doble alternativa a la hora de acometer un proyecto, resultando, por ello, ambas opciones completamente válidas ${ }^{649}$. Estas alternativas, sin embargo, no

\footnotetext{
647 V. NIETO, A. J. MORALES, F. CHECA: Arquitectura del Renacimiento en España (1488 - 1599). Madrid. Cátedra. 1997.

648 V. NIETO, A. J. MORALES, F. CHECA: Arquitectura del Renacimiento en España...ob. cit. F. MARÍAS: El largo siglo XVI. Los usos artísticos del renacimiento español. Madrid, Taurus. 1989. (pp. $15-16)$.

649 F. MARÍAS: El largo siglo XVI... ob. cit. (pp. 33).
} 
constituían necesariamente una posibilidad de elección entre continuidad (gótico) y cambio (renacimiento), pues ambas ofrecían soluciones igualmente modernas. El gótico, a través de la renovación de una tradición constructiva profundamente arraigada en el panorama arquitectónico local, y el renacimiento mediante la recuperación de la Antigüedad, pero también a través de modelos importados directamente de Italia.

Pero a pesar de todo, esta doble alternativa o posibilidad de elección, este bilingüismo en definitiva, no llegó a manifestarse en ningún momento dentro del panorama arquitectónico de la comarca serrana, pues lo que aquí nos vamos a encontrar es un dominio prácticamente absoluto del estilo gótico, con el cual, por otra parte, suele identificarse fundamentalmente la arquitectura religiosa durante esta época, al menos en la provincia de Burgos ${ }^{650}$.

A ello contribuyó, en esta zona de la sierra especialmente, el relativo aislamiento que se vive, con respecto a los principales centros artísticos del momento, donde podían llegar más directamente las influencias del nuevo estilo importado de Italia. Afianzando esta tendencia nos encontramos también con el papel jugado por unos artífices, formados completamente dentro de unos métodos de tradición medieval, que favorecía el desarrollo de unas soluciones completamente góticas, evitando cualquier mínimo margen a la inventiva, o simplemente a la incorporación de recursos innovadores, como los aportados por la estética renacentista. Además, la composición de un conjunto plenamente renacentista exigía unos conocimientos de órdenes, principios de composición, proporción y modelos tipológicos característicos del nuevo estilo, pero ante todo una idea unitaria de la combinación y articulación de este vocabulario, que estos artífices estaban, en general, muy lejos de poseer.

De esta manera, el definitivo arraigo de las formas tradicionales del estilo gótico resultaba algo prácticamente inevitable. Un estilo gótico además, que lejos de mostrar signos de agotamiento, cansancio o decadencia, nos ofrece sus más altas cotas de

650 A. C. IBÁÑEZ PÉREZ: “Arquitectura, escultura, pintura y artes menores en el siglo XVI”. ob. cit. 
esplendor, evidenciándose, tanto en la cantidad de obras acometidas, como en la calidad alcanzada en las mismas $^{651}$.

Estas formas góticas son las propias del llamado estilo Reyes Católicos, las cuales, por sus criterios, distaban mucho de poder ser consideradas como una mera prolongación del gótico clásico del siglo XIII. Las nuevas tipologías ahora empleadas se caracterizan principalmente por su versatilidad, preocupándose en general por alcanzar unas soluciones estructurales firmes, con las que se propicia una gran solidez y monumentalidad para todo el conjunto exterior del edificio, y una absoluta idea de amplitud y diafanidad en el interior. Todo esto se complementa además, en nuestro caso, con una completa identificación con el lado más austero de esta arquitectura, lo que hace que se restrinja al máximo la presencia de elementos ornamentales, los cuales se concentran en puntos muy concretos del edificio, como capiteles o frisos, donde aparece el característico relieve de bolas, y en casos más excepcionales en la elaboración de portadas monumentales.

No obstante, y a pesar de este predomino del gótico, tampoco debemos ignorar las tenues manifestaciones, que nos ofrecen las formas renacentistas. De esta forma, y aunque de un modo muy limitado, podemos llegar a hablar incluso de una cierta convivencia entre ambos estilos, pues hay varios casos de templos, que iniciaron su construcción en los últimos años del siglo XV o incluso principios del XVI, utilizando el más puro estilo gótico, y terminan este proceso ya en un momento ciertamente avanzado de esta centuria, mostrando con ello los rasgos propios del nuevo lenguaje. Pero aun con todo, la presencia de estos elementos no siempre consiguió ser lo suficientemente significativa como para transformar las estructuras góticas sobre las que se asentaban, ni mucho menos la imagen ofrecida por las fábricas en todo su conjunto.

\footnotetext{
651 Así, por extraño que nos parezca, podemos comprobar cómo dentro de esta zona se produce una ausencia prácticamente total de restos góticos de interés pertenecientes al periodo que se extiende desde el siglo XIII hasta el inicio de la segunda mitad del siglo XV.
} 
Dentro de estas aportaciones renacentistas las más destacadas fueron, sin duda, las que llegaron con la construcción de nuevas portadas, las cuales constituyeron, en muchos casos, la culminación de todo un largo proceso constructivo. Con ellas, no sólo se pretendía engalanar el acceso al interior de los templos, sino también, en cierta medida, modernizar la imagen del edificio, introduciendo, así, en su estructura una bocanada de aire fresco y renovador, con la que se desarrollaba un estilo completamente nuevo, y por su puesto, ajeno al resto de la fábrica. En los ventanales, aunque de forma infinitamente más discreta, también podemos encontrar reflejada esta evolución. Así, se van abandonando de modo progresivo los vanos góticos de arco apuntado con estructura abocinada, divididos en su interior por un mainel central y gabletes en su parte superior, para pasar a una solución en la que se utiliza el arco de medio punto finamente moldurado, sin abocinamiento ni parteluz, y con un fino bocel recorriendo todo su marco exterior. Esto lo observamos, especialmente en los ventanales que debieron abrirse en la parte superior de los muros laterales de los presbiterios, cuando a partir de mediados del siglo XVI comienzan a levantarse en el interior las grandes máquinas retablísticas, con las que se cubre todo el muro del testero de las cabeceras, cegando los vanos que allí existían.

La utilización, sin embargo, de columnas de inspiración renacentista, donde se podría mostrar con mayor claridad la incorporación de los órdenes clásicos, no parece que logró alcanzar especial desarrollo en nuestra zona. Así, los elementos sustentantes empleados continuaron siendo los pilares de tradición gótica, dentro de los cuales, no obstante, encontramos también una interesante evolución a lo largo del siglo.

Con todo esto, podemos afirmar que las novedades aportadas por este nuevo lenguaje a la arquitectura de esta comarca se van a concentrar principalmente en el mero revestimiento ornamental de las estructuras ya construidas o concebidas según las pautas góticas. Por ello, su aplicación en estos edificios tiene un carácter meramente epidérmica y no estructural, pues ni las tipologías desarrolladas, ni las formas de 
concebirlas, experimentan, como tendremos oportunidad de ver, variación alguna a lo largo de toda la centuria.

Al mismo tiempo, respecto a estas formas renacentistas, tenemos que decir también, que su aparición en nuestra arquitectura, como en la del resto de España, no se produce como resultado de la evolución experimentada dentro del estilo anterior, sino a través de la incorporación de unos elementos que ya habían sido elaborados. De este modo, su utilización no siempre se realiza siguiendo unos criterios eminentemente clásicos, pues aunque el léxico empleado sí lo fuera, la forma de utilizarlo raras veces consiguió adaptarse con exactitud a estas normas.

En definitiva, y tras todo esto, debemos decir, que los edificios que ahora se levantan se caracterizan principalmente por su gran pureza constructiva, mostrando en su conjunto limpios volúmenes, que en ningún caso se ven tapados por los elementos ornamentales. Esta decoración se concentra en puntos muy concretos, como por ejemplo las portadas, donde únicamente se pretende realzar el valor simbólico de estas piezas, pero sin enmascarar el edificio.

El tipo de templo más característico, que nos vamos a encontrar, es el tendente al ámbito único, bien en su variedad de iglesia de una sola nave, tipo caja, o en la ampliamente difundida tipología de planta de salón o hallenkirche, con tres naves cubiertas con bóvedas a la misma altura. En cualquiera de los dos casos, se trata de plantas en las que la concepción del espacio responde a un modelo unitario, que busca la mayor amplitud y diafanidad posibles, rompiendo con la tradicional idea del espacio compartido del diseño cruciforme. Aun así, en ninguno de estos dos modelos se llega a perder el sentido longitudinal del espacio camino, tendente hacia la capilla mayor.

Dentro de ellos, el tipo de nave única, presenta una planta dominada, como su propio nombre indica, por una sola nave de trazado rectangular, cubierta generalmente por bóvedas de crucería estrellada con terceletes, que dividen su desarrollo longitudinal 
en diferentes tramos, hasta alcanzar la cabecera. Estas cabeceras se levantan en todos los casos sobre una planta de sencillo trazado cuadrangular con testero plano, reforzado exteriormente por potentes contrafuertes, dispuestos en sus esquinas diagonalmente. Se presentan, por lo tanto, como un espacio perfectamente jerarquizado dentro de todo el conjunto del edificio, mostrando su carácter preponderante desde un punto de vista, no sólo simbólico, sino también estructural, pues el propio suelo se eleva ligeramente sobre el nivel de la nave mediante gradas. De este modo, a pesar de la imagen de unidad dominante, que ofrece el concepto espacial del todo el templo, no se consigue evitar la perspectiva monofocal, que al mismo tiempo adquiere dentro de él la cabecera. A ello contribuye, en ocasiones, el hecho de que la anchura de la cabecera sea la misma que la de la nave, convirtiéndose así en una mera prolongación de la zona del cuerpo, sin aparente separación clara. Exteriormente, estos edificios son concebidos mediante sencillos volúmenes prismáticos, dominados por el correspondiente a la zona de la nave, con el que se consigue su característica imagen de caja, que le da nombre.

Se trata, en definitiva, de un tipo de planta muy sencillo y capaz de ser construido con una gran economía de medios, lo que hace que tenga gran éxito en una zona rural como ésta, donde la modestia de la economía de la mayor parte de las parroquias no permitía embarcarse en grandes proyectos constructivos. A ello debemos unir además su gran versatilidad, pues puede ser ampliada con suma facilidad, bien en sentido longitudinal, incorporando nuevos tramos a los ya existente, o bien de forma transversal, adosando nuevas naves. Por todo ello, la popularidad que alcanza esta tipología es tal, que acaba por rebasar los límites cronológicos de este siglo XVI, continuando su desarrollo en algunos templos levantados durante las dos centurias siguientes.

El otro modelo, que citábamos, es el de las hallenkirche, el cual constituye una tipología importada del centro de Europa (concretamente de las zonas del Bajo Rin y Wesfalia), y desarrollada en Castilla a partir de los últimos años del siglo XV. En este 
caso en concreto, la zona de la sierra burgalesa nos ofrece algunos de los primeros ejemplos.

El término hallenkirche define a la iglesia de 3 ó 5 naves, cuyos tramos se cubren a la misma altura, dando la sensación de un gran espacio único en su interior. Para su denominación se han utilizado también los términos de iglesias columnarias o de planta de salón, sin embargo, ninguna de las dos formas se ajusta completamente a la realidad, que aquí encontramos. Así, el término iglesia columnaria no resulta de todo correcto, pues no todas presentan este tipo de soporte en la separación entre sus naves. De hecho, lo más parecido que encontramos son los pilares cilíndricos, que se emplean en la iglesia de Barbadillo del Pez. Por su parte, la denominación de planta de salón, tampoco se ajusta completamente a la realidad que nos ofrece esta tipología, pues puede llevar a error, dado que se suele utilizar también para designar a las iglesias de nave única.

Lo que esta tipología propone, en definitiva, es un templo de espacio único, alejado de la tradicional compartimentación del espacio gótico clásico, y de la jerarquización, que planteaba una cubierta alzada a distintos niveles. Para ello se abovedan las naves a una misma altura, se suprime el transepto, sin sobresalir, ni en alzado, ni en planta, y se alargan las proporciones del edificio, dando primacía al eje central, que permite mantener, al mismo tiempo, el sentido del espacio camino. Con esta estructura, por lo tanto, no sólo se evitaba la compartimentación del espacio, generada por las naves a diferente altura, sino que también se conseguía simplificar considerablemente la propia estructura arquitectónica. Aquí las naves laterales y la central trasladaban directamente los empujes hacia los estribos laterales, lo cual libera de esta función a los pilares torales, haciendo que fueran innecesarios los arbotantes. De este modo, junto al mayor desahogo espacial, que se alcanzaba en la parte interior del templo, se lograba también un considerable ahorro constructivo. 
Pero no somos nosotros los primeros descubridores de las ventajas, que encierra esta tipología, pues ya Rodrigo Gil de Hontañón se había encargado en su momento de cantarnos sus alabanzas al señalar que: “...yendo así a un alto es edificio más fuerte, porque todo se aiuda uno a otro, lo qual no haçe quando la principal sube más. porque es menester que desde la colateral se le de fuerza a la maior y desde la ornacina a la colateral, lo qual se da con arbontantes. $Y$ haçese así que no se puede subir a un alto o por menoridad de gasto, o por las luçes que si fueren a un alto no se le podrían dar que gozase más de la una nave $\left(f o l .8 v^{\circ}\right)$....El estrivo no tan solamente sustenta a el arco de su capilla, mas también al arco de la colateral y de la maior. Las quales si fueren echas a un alto, ayudale mucho el arco de la una a la otra, como el de la colateral a la maior, el pilar sobre el que carga menester más grueso que quando ba la una al peso de la obra (fol. $\left.21 v^{o}\right)^{, 652}$.

Exteriormente estos edificios siguen mostrando, como la tipología anterior, una imagen dominada por el gran volumen prismático, que define la forma del cuerpo, al cual se adosan la cabecera en uno de sus extremos, y la torre a los pies. Estos elementos pasan a cumplir así, una función de contrarresto de las tensiones generadas por las líneas de los arcos formeros. Dentro de estas piezas, observamos cómo, en todos los ejemplos que encontramos en nuestra zona, la cabecera mantiene siempre las mismas características con su planta cuadrangular y muro del testero plano, reforzado por sendos contrafuertes en las esquinas. Las torres, por su parte, no recibieron una atención especial, desde el punto de vista estético, con la que poder contribuir a transformar la imagen exterior del resto del conjunto. Por ello, continuaron construyéndose las mismas estructuras macizas, en forma de gran prisma, alzado sobre planta cuadrangular, y con un desarrollo vertical de muros completamente lisos en los que no siempre se aprecia una división clara entre los distintos cuerpos.

652 F. MARÍAS: El largo siglo XVI... ob. cit. (pp. 112). 
394 Arquitectura de la Edad Moderna en la sierra burgalesa.

Por lo demás, el desarrollo de cada una de estas tipologías, y demás obras levantadas en nuestra zona a lo largo de toda la centuria, nos ofrece una serie de rasgos comunes en cada uno de sus elementos, que son los que pasamos a señalar.

En todas estas construcciones el muro se convierte en el auténtico protagonista, desde el punto de vista estructural, pues no sólo realiza una labor de cierre, sino también sustentante $^{653}$. Ello propicia que el número y amplitud de los vanos se reduzca de forma significativa. Estos muros, elaborados en la mayor parte de los casos en piedra de sillería, con una cuidada labra, se caracterizan por su gran planitud, si bien en ciertas ocasiones podemos encontrar la presencia de alguna moldura, situada en la parte inferior o media, con las que se introduce un ligero adelgazamiento. En la parte interior de los edificios el desarrollo de los muros se interrumpe frecuentemente por la presencia de los soportes adosados, con los cuales se marca el ritmo compositivo de los diferentes tramos de las naves. El reflejo de estos soportes en la parte exterior se produce a través de los contrafuertes, los cuales compartimentan de forma evidente este normal desarrollo, mediante un fuerte resalte sobre el propio plano del muro. Estos contrafuertes están formados por recias estructuras primásticas de sección rectangular, en cuyo ascenso se suele dibujan, en algunos casos, un ligero perfil escalonado. En los casos en los que aparecen reforzando las esquinas adoptan siempre una disposición en diagonal.

Sobre la parte superior de los muros se abren los ventanales, los cuales, como ya hemos indicado, reducen en este momento, tanto su número, como sus dimensiones. Estos vanos se concentran principalmente en la fachada meridional, y sobre el muro del

653 La confirmación de esta labor estructural que realiza el muro, como elemento sustentante, dentro de estas construcciones, la encontramos en aquellos casos en los que deben ser eliminados en el momento de acometer proyectos de ampliación. Tal vez el ejemplo más ilustrativo de ello lo encontramos en la iglesia de Santa Eulalia de Palacios de la Sierra, donde la ampliación realizada en la parte septentrional del cuerpo a mediados del siglo XVII obligó a eliminar este muro, ocasionando graves consecuencias al resto de la estructura del templo, las cuales fueron especialmente visibles en las bóvedas. AGDBU. LP. Palacios de la Sierra, parroquia de Santa Eulalia. L F. (1653 - 1674) (fols. 188 vo). Palacios de la Sirra, 7 - diciembre - 1670 . 
testero de la capilla mayor, si bien estos últimos, en muchos casos, fueron cegados a mediada que avanzaba el siglo, ante la incorporación en el interior de los grandes retablos.

Dentro del trazado de los ventanales podemos diferenciar al menos dos modelos fundamentales, los cuales se pueden identificar respectivamente con los dos estilos desarrollados en la zona durante esta centuria. Así, por un lado, tenemos el modelo propio del gótico, constituido por una estructura abocinada coronada con arco apuntado con derrame profusamente moldurado, en cuyo interior, sin embargo, han desaparecido ya los maineles, que aun mantienen los ejemplos de finales del siglo XV. Con ello se consigue un mejor aprovechamiento de la luz. La evolución, que desde los primeros años del siglo XVI experimenta este tipo de ventanas, hace que su arco progresivamente vaya perdiendo apuntamiento, hasta convertirse en un arco de medio punto, si bien, dentro de él se continúa manteniendo su profusa molduración, que propicia la creación de la estructura abocinada. Ejemplos de ello los encontramos en la zona de las naves de la iglesia de San Esteban en Castrillo de la Reina, y especialmente en las ampliaciones realizadas durante este siglo XVI en los templos de Santa Eulalia, en Palacios de la Sierra, y en Santa Cecilia, en Salas de los Infantes.

El modelo renacentista, por su parte, se limita simplemente a sustituir el arco apuntado por el de medio punto, eliminando o atenuando, en la medida de lo posible, el perfil abocinado hacia el exterior. Esto se sustituye por una pequeña moldura de tres cuartos de bocel, que recorre todo el contorno del vano. Estas mínimas diferencias con respecto al modelo anterior hacen que en algunos casos se produzcan soluciones híbridas, en las que se incluyen rasgos de los dos modelos. El ejemplo más significativo de ello lo tenemos en la ventana situada en el muro de poniente de la base de la torre de la iglesia de Santa María de Salas de los Infantes. Se trata de un ventanal rematada con arco de medio punto profundamente moldurado, cuyas molduras se extiende, sin solución de continuidad, por el derrame de las jambas, para formar una estructura abocinada. En su interior, su luz queda dividida por un mainel sobre el que se superpone 
un fino baquetón, del que arrancan dos pequeños arcos de medio punto de intradós festoneado. Su apertura, sin duda, debemos relacionarla con la construcción del nuevo retablo, que se levanta en el altar mayor, a mediados de este siglo, pues la luz que penetra por ella a última hora de la tarde, en los días estivales, llega a incidir directamente sobre la imagen titular del templo, logrando un evidente efecto escénico.

Aparte de esto, aunque en menor medida, también nos vamos a encontrar algunos ejemplos de óculos y vanos rectangulares de dintel plano. Los primeros los podemos ver en iglesias como la de San Salvador, en Barbadillo del Pez, San Esteban, en Castrillo de la Reina, y la cabecera de la iglesia del monasterio desaparecido de Santa María del Alveinte. En el primer caso, aparece situada por encima de la portada, en su fachada del mediodía, mientras que en la segunda sólo encontramos sus restos sobre el muro meridional del presbiterio, pues ya en el siglo XVII fue sustituido por el actual ventanal. Respecto a los vanos rectangulares, vemos que se trata de una solución adoptada generalmente en aquellas obras más modestas, en las que existían unas menores pretensiones estéticas, como es el caso de la renovación efectuada sobre el cuerpo de la iglesia de Hoyuelos de la Sierra, o la cabecera de la parroquial de Castrovido.

Ya en la parte interior del edificio, el elemento más destacado lo constituyen las cubiertas, y el sistema de soportes y contrarrestos, que permite su mantenimiento en pie. En las cubiertas se produce un dominio prácticamente total de la bóveda de crucería estrellada con terceletes y cinco claves, resultante de la modernización de la gótica cuatripartita de tradición medieval. Este tipo de bóveda tiene que adaptarse a las dimensiones y trazas, que presentan las diferentes plantas de estos edificios, las cuales, como vimos, no van a ofrecer grandes complicaciones. Esto hace que se recurra siempre a los modelos más básicos, como son el cuadrado y el perlongado, este último en sus diferentes proporciones de cuádrupla, dupla, sexquiáltera, sexquitercia, etc. El diseño y trazado de los nervios de todas ellas, en general, tampoco ofrece grandes variaciones a lo largo de toda la centuria, aunque en la trama básica de nervios diagonales, terceletes 
y de ligadura, podemos llegar a encontrar también algunos ejemplos en los que sí se rompe este diseño. Uno de estos casos lo tenemos nuevamente en la iglesia de Santa María, en Salas de los Infantes, dentro de uno de los tramos de la nave lateral del lado de la epístola. En esta bóveda, a través de la rotación de cuadrados sobre el esquema básico de la bóveda estrellada con terceletes, se logra la formación de un rectángulo central, que hace desaparecer la clave polar ${ }^{654}$. Una variación más habitual, dentro de este diseño, se va a producir con la prolongación de los nervios de ligadura más allá de las claves secundarias de los terceletes, hasta alcanzar la clave de los arcos, que delimitan su espacio en cada uno de sus cuatro lados. Con ello, evidentemente, se pretendía lograr una mejor transmisión de las tensiones generadas por la propia cubierta, hacia los espacios contiguos, aliviando así la presión sobre los restantes nervios.

Pero sin duda, las variantes más interesantes van a venir propiciadas por la incorporación de los nervios combados, los cuales, en principio, deben ser considerados como un mero accesorio decorativo, sin función sustentante de ningún tipo ${ }^{655}$. Su incorporación a la arquitectura de esta zona de la sierra se produce principalmente a partir del segundo cuarto del siglo, si bien, su uso no alcanza un gran protagonismo durante la centuria, pues queda restringido a aquellas partes especialmente señaladas, como son los coros, sotocoros, o el tramo inmediato a la puerta de entrada. Dentro de los diseños, que se pueden conseguir con este tipo de nervios, el más frecuente es el conocido como trebolado, superpuesto a la trama básica de nervios diagonales y terceletes, en cuyos lóbulos, en algunos casos además, se llega a dibujar un ligero apuntamiento, denominado conopio. Otra variante, de la cual encontramos un solo ejemplo en esta zona, consiste en la formación, mediante la incursión de estos nervios curvos, de un círculo central dispuesto en torno al polo de la bóveda y tangente a las claves de los terceletes. Este ejemplo aparece en la iglesia de Castrillo de la Reina,

\footnotetext{
654 Aunque se trata de un diseño extraordinariamente extraño, en absoluto es original de este templo, pues lo encontramos también en uno de los tramos del claustro de la catedral de Palencia, realizado por el maestro Juan Gil de Hontañón, el cual, en este caso, muestra también influencias de Juan Guas. J. GÓMEZ MARTíN: El gótico español de la Edad Moderna...ob. cit. (pp. 84 - 85).

655 Ibídem. (pp. 90 y ss.).
} 
sobre el tramo de la nave de la epístola, situado junto a la puerta de acceso, lo que demuestra la intención de destacar este espacio.

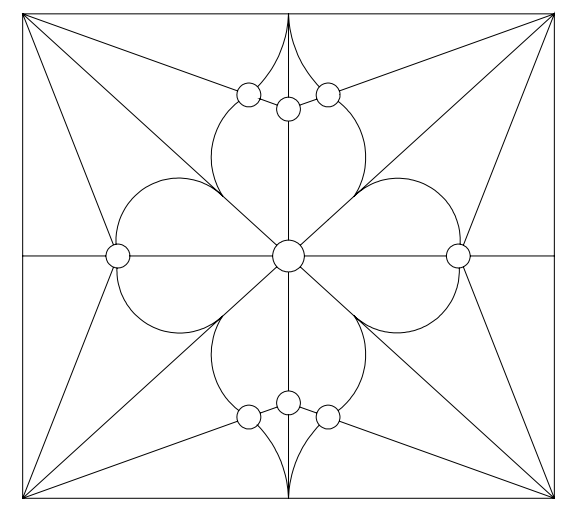

PALACIOS DE LA SIERRA. Iglesia de Santa Eulalia. Bóveda del tramo del coro.

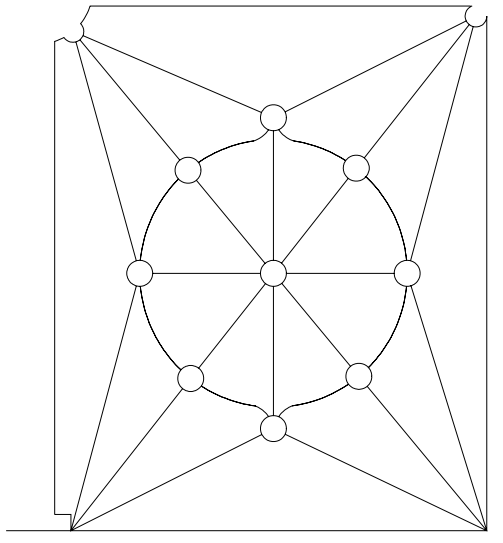

CASTRILLO DE LA REINA. Iglesia de San Esteban. Bóveda del $2^{\circ}$ tramo de la nave de la epístola.

Todos estos nervios, independientemente del tipo de trazado, y de su carácter sustentante o sustentado, se caracterizan por su gran resalte sobre la superficie de la plementería, mostrando además un tipo de molduras muy simplificadas con respecto a las que se podían encontrar en el gótico anterior. Así, en su sección únicamente encontramos, de forma escalonada, una gola o papo de paloma, una fascia y una media caña ${ }^{656}$. Se trata de un tipo de molduras consideradas como romanas, cuyo uso en nuestra zona se extiende a lo largo de los dos siglos siguientes.

Esta misma sencillez se repite igualmente en las claves, las cuales son elaboradas con sillares de pequeño tamaño, mostrando una labra muy cuidada, pero en muchos casos desprovistas por completo de decoración. No obstante, no faltan ejemplos de obras más ornamentadas, donde podemos ver representados diversos motivos - 
Sección nervio.

principalmente signos con un claro simbolismo litúrgico -, acompañados incluso con bordes cairelados, como ocurre en la iglesia de Hacinas, y en algunos ejemplos de las iglesias de Castrillo de la Reina y de Santa Cecilia, en Salas de los Infantes.

Ligadas a estos sistemas de abovedamiento se encuentran, evidentemente, las estructuras que realizan la función sustentante. En nuestro caso, el tipo de arco más utilizado, durante toda esta centuria, es el apuntado de tradición gótica, si bien dentro de él podemos encontrar distintos grados de elevación del punto, abarcando desde los casi alanceados, hasta los próximos al medio punto. Junto a ellos, por supuesto, nos encontraremos también el de medio punto. Todos ellos pueden aparecer de forma conjunta, dentro de un mismo edificio, si bien, la utilización de uno u otro queda regida siempre por criterios estrictamente estructurales, según las necesidades de cada espacio, y no tanto por cuestiones meramente estilísticas. Así, en los casos de iglesias de tres naves con cubiertas a la misma altura, los arcos de medio punto o de punto muy rebajado, son utilizados siempre en los espacios más amplios, como la nave central, pues la forma de transmitir los empujes resulta más oblicua, con lo que necesita estribos exteriores más potentes. Por el contrario, los arcos apuntados de punto más elevado o los de medio punto peraltados, se colocan preferentemente en los fajones de las naves laterales, pues así se gana altura, al mismo tiempo que su perfil hace que las fuerzas se transmitan a través de ellos de un modo más vertical.

656 Ibídem. (pp. 147 y ss.). 


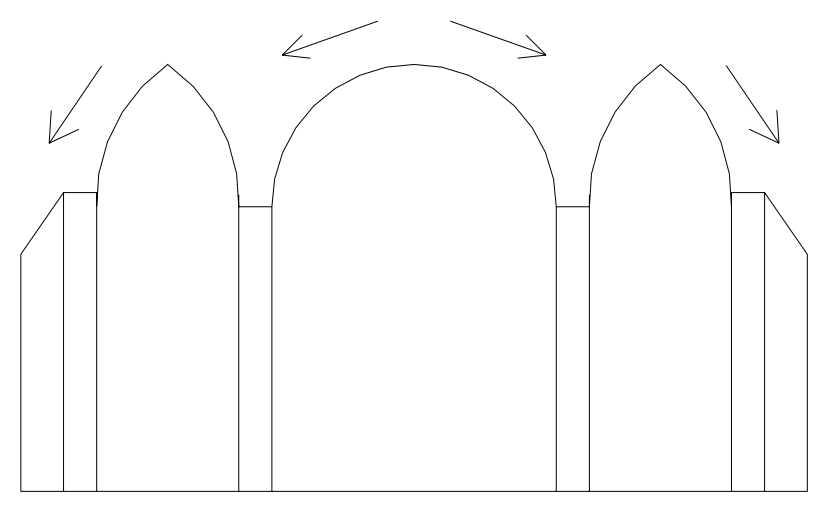

Sección de naves de un templo tipo hallenkirche.

Con todo ello, no sólo se lograba aumentar la altura de las cubiertas en las naves laterales - de menor anchura - hasta alcanzar el mismo nivel de la nave central, sino que esto mismo permitía también aligerar la potencia de los estribos exteriores y especialmente de los pilares centrales, creando soportes más ligeros y estilizados, que interrumpían menos la visión del altar mayor, y hacían ganar sensación de amplitud.

La sección de todos estos arcos, independientemente del tipo de trazado, se caracteriza, a lo largo de la mayor parte de la centuria, por su profusa molduración, ofreciendo un perfil muy característico. Aun así, también aquí encontraremos excepciones, pues existen varios casos en los que se produce un notable esfuerzo simplificador, reduciendo esta moduración a la mínima expresión. A finales de siglo, nos encontramos ya con el arco de sección cuadrada de escasa potencia y un pequeño relieve cajeado, recorriendo su intradós.

Los pilares, sobre los que descansa esta estructura de arcos y bóvedas, por su parte, también nos ofrecen una serie de variantes, las cuales se van sucediendo a lo largo de toda la centuria, permitiéndonos con ello establecer, en muchos casos, la cronología aproximada de varios de los templos. 
El primer modelo que nos encontramos es el formado por un sólido núcleo con columnas de diferente tamaño adosadas sobre sus frentes y ángulos o codillos, desde las cuales arrancan los respectivos arcos y nervios de las bóvedas. Estas columnas generalmente se alzan sobre un potente basamento, y cuentan, en su parte inferior, con una sencilla basa, bien formada con una escocia entre dos finos toros, a partir de la cual arranca un fuste completamente liso, que se remata con una pequeña faja o anillo capitelado, delimitado por finos junquillos. Este modelo se corresponden en los muros con haces de tres columnas entregadas de diferentes tamaños, con un claro predominio de la central, donde se repiten las mismas características de los pilares exentos. En las esquinas, sin embargo, se suele recurrir, en este caso, a una sola columna, o incluso a una simple ménsula con decoración muy simple. El empleo de este modelo de soportes en la arquitectura de la zona se produce, principalmente, durante las dos primeras décadas del siglo, pues constituye el modelo heredado de la centuria anterior. Los mejores ejemplos los vamos a encontrar en las obras de culminación de templos como el de Santa María, en Salas de los Infantes, o San Esteban, en Castrillo de la Reina, los cuales se habían iniciado en las últimas décadas del siglo XV.

A este modelo le sucede el pilar de estructura cilíndrica desprovisto completamente de basa y capitel, y sin ningún tipo de columna o baquetón adosado a su núcleo. Esto hace que los nervios de las bóvedas y los arcos fajones y formeros deban brotar directamente de su parte superior, sin la presencia de ningún tipo de faja o capitel, que sirva de solución de continuidad. En los muros laterales este pilar se corresponde con pilares semicirculares, en los que se repiten estas mismas características, pero con una anchura reducida aproximadamente a la mitad. En las esquinas, en este caso, nos vamos a encontrar con la presencia de ménsulas decoradas con cabezas aladas de ángeles, en los que se introducen tímidamente las formas renacentistas. Su uso comienza a extenderse en la zona aproximadamente a partir del segundo cuarto del siglo, aplicándose, en nuestro caso, siempre a edificios de una altura moderada, si los comparamos con el caso de los pilares anteriores. El primer ejemplo documentado lo encontramos en la capilla de Santa Ana, construida en la década de 
1520 en la iglesia de Santa María, en Neila $^{657}$, si bien, su mejor desarrollo nos lo ofrecen las renovaciones y ampliaciones emprendidas respectivamente en los templos de Santa Eulalia en Palacios, en la Sierra y Santa Cecilia, en Salas de los Infantes.

El último paso, dentro de esta evolución, lo constituyen los pilares cilíndricos rematados por algún tipo de moldura en su parte superior, que en nuestro caso no llega a convertirse en un capitel de resonancias clásicas. Esto sí ocurre en otras zonas de la provincia de Burgos, y de modo especial en las provincias vascas, donde de forma más perfecta se termina desarrollando la tipología de las llamadas iglesias columnarias ${ }^{658}$. El único ejemplo de este tipo de soportes, que podemos ofrecer lo hallamos en la iglesia de San Salvador, en Barbadillo del Pez, donde el remate de los pilares se soluciona mediante una simple moldura o anillo de contorno quebrado en los frentes, en correspondencia con el arranque de los respectivos arcos. Estos pilares, por su parte, se corresponden en la parte de los muros con estilizadas pilastras cajeadas rematadas por pequeñas ménsulas, desde las que parten los respectivos nervios de las bóvedas.

Todos estos elementos, en definitiva, son los que nos encontramos reflejados dentro de los edificios levantados en nuestra zona, a lo largo de esta centuria. Edificios que son el producto del fuerte impulso creador, que se vive ya desde los últimos momentos del siglo XV, pero que en nuestro caso reflejan también un nuevo talante, a la hora de entender la arquitectura. Pues, junto a la firmeza y funcionalidad de estas nuevas fábricas, se incluye también ahora una innegable preocupación por los valores estéticos y monumentales, algo, que en estos lares se había dejado de ejercer prácticamente desde el siglo XII con el estilo románico.

Las primeras obras, donde comenzamos a ver este nuevo talante, constituyen proyectos que han sido iniciados ya en el último tercio del siglo $\mathrm{XV}$, y que, dado lo

657 B. VALDIVIELSO AUSín: Neila, una llamada al turismo. Burgos, Ayuntamiento de Neila. 1980. (pp. 160 - 163). 
dilatado del proceso constructivo de la mayoría de ellos, se concluyen en el siglo XVI. Se trata de proyectos en los que se desarrollan las características tipologías de templos, que ya hemos señalado, manteniéndose la idea original a lo largo de todo el proceso sin grandes cambios desde el punto de vista estructural. Pero no sólo nos encontramos con edificios construidos de nueva planta, sino que dentro del campo de las remodelaciones también podemos señalar un importante número de intervenciones, entre las que se incluyen, tanto las ampliaciones o renovaciones de determinadas partes de templos ya existentes, como la construcción de diferentes añadidos.

\section{Construcciones de nueva planta.}

Dentro de los edificios de nueva planta, los mejores exponentes los tenemos en las iglesias de Hacinas, Santa María de Salas de los Infantes, Castrillo de la Reina y Barbadillo del Pez.

La primera de ellas, dedicada a San Pedro, en Hacinas, nos ofrece un magnífico ejemplo, aunque completamente alterado por las intervenciones posteriores, de iglesia de tipo caja, con una planta de nave única, prolongada en su extremo oriental con un tramo adicional, que constituye la cabecera. La separación entre tramos se realiza mediante potentes arcos apuntados profusamente moldurados, y se cubren con bóvedas de crucería estrellada con terceletes, dentro de las cuales destacan las claves de los dos tramos correspondientes a la nave, pues en ellas se representa una abultada decoración, compuesta por una serie de festones cairelados, formando su marco. Los soportes, por su parte, están formados por haces de tres columnas, con la central más gruesa, en las que se repiten las características señaladas en su momento, con basas bien formadas, y anillos capitelados entre junquillos en su parte superior. En este caso incorpora, además, en los capiteles los característicos relieves de bolas, propios del llamado estilo Reyes Católicos, lo cual nos ayuda a fijar su cronología. Los soportes, sobre los que descansa el arco, que da paso al presbiterio, sin embargo, están

658 Ma A. ARRÁzOLA ECHEVARRÍA: El renacimiento en Guipúzcoa. San Sebastián, Diputación de Guipúzcoa. 1967. (T. I. pp. 107 - 167, 197 - 241). 
compuestos por una única columna de grueso fuste, en cuya parte superior incorporan sendos capiteles románicos, reutilizados, con toda seguridad, de la fábrica anterior.

Se trata, por lo tanto, de una obra característica del llamado estilo Reyes Católicos, iniciada a finales del siglo XV, cuya construcción, sin embargo, bien pudo completarse ya en los primeros años del siglo XVI, pues como sabemos, el desarrollo pleno de estas formas un una zona rural, como ésta, siempre se produjo con un cierto retraso. Dentro de ella, y a pesar de la importante alteración sufrida posteriormente destaca la gran pureza constructiva con la que son concebidos todos los elementos de su estructura, encontrando una mínima, aunque manifiesta, presencia ornamental, la cual se localiza en punto muy concretos, remarcando siempre las líneas arquitectónicas, y en ningún caso ocultándolas. No obstante, como decimos, se trata de una obra profundamente alterada por las intervenciones posteriores, pues como tendremos oportunidad de ver, a lo largo del siglo XVII se levanta una nueva nave a cada lado, con las que se consigue crear un concepto espacial completamente nuevo, que nada tiene que ver con el que presentaba su diseño original.

HACINAS. Iglesia de San

Pedro. Planta siglo XVI.
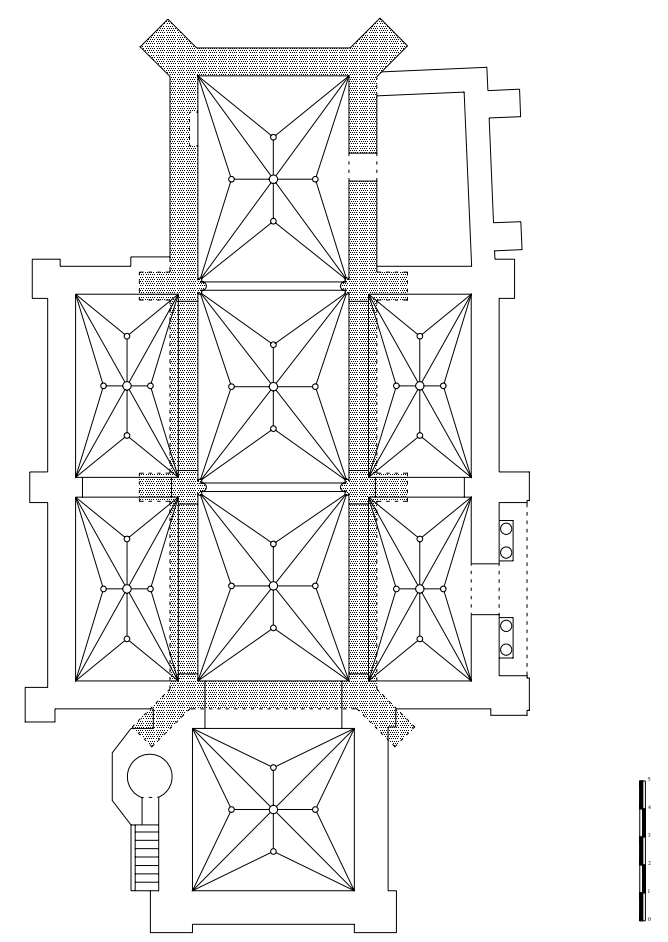
La iglesia de la parroquia de Santa María, en Salas de los Infantes nos introduce en la segunda de las tipologías características de este periodo. En ella se desarrolla una estructura hallenkirche de tres naves con tres tramos cada una, dentro de las cuales se aprecia un marcado predominio de la central sobre las laterales por su mayor anchura. Esta nave central, a su vez, se prolonga con sendos tramos en los dos extremos para formar la cabecera y la torre, respectivamente. La cabecera queda así conformada por un espacio cuadrangular amplio y desahogado, con testero plano, reforzado en el exterior con potentes contrafuertes dispuestos diagonalmente. La base de la torre, por su parte, incorpora su espacio al resto del ámbito del templo, formando una especie de contraábside, donde posteriormente se levantará el coro.

El sistema de cubiertas, con el que se cierran todos estos espacios, está formado por bóvedas de crucería estrelladas, alzadas a una misma altura, con lo que se consigue la sensación de ámbito único, que persigue este modelo de templo. Aun así, dentro de estas bóvedas encontramos diversas variantes, propiciadas por pequeñas modificaciones en el diseño de su trama, los cuales se introducen siempre en función de las necesidades exigidas por cada uno de los tramos. Así, por ejemplo, en los perlongados, que forman las naves laterales y el último de la nave central, los terceletes únicamente aparecen en sus lados más cortos, mientras que en los lados largos el nervio de ligadura se extiende hasta alcanzar la clave de los arcos, que la secundan. Estas libertades, que no son tanto, si tenemos en cuenta que su trazado queda determinado en la mayor parte de las ocasiones por criterios estrictamente estructurales, son un rasgo característico de las fábricas que comienzan a construirse a partir de los años finales del siglo XV, pues en ello se mostraba la pericia de los maestros ${ }^{659}$. No obstante, debemos señalar también, que salvo el sotocoro, construido ya en un momento avanzado de la centuria del Quinientos, y la sacristía y el baptisterio, añadidos en el siglo XVII, en ningún caso nos vamos a encontrar la utilización de nervios combados, lo cual resulta también significativo.

659 J. GÓMEZ MARTíN: El gótico español de la Edad Moderna...ob. cit. 
Las fechas exactas en las que se construye esta fábrica vuelven a ser un auténtico misterio, pues aquí la falta de fuentes documentales precisas se complementa con un extenso proceso constructivo. Aun así, y a pesar de la aparente unidad que respira todo el conjunto, se pueden llegar a apreciar las pequeñas diferencias existentes entre los elementos constructivos empleados en uno u otro momento, de tal forma que, a través de ellas se llegan a manifestar las distintas etapas constructivas que aquí se vivieron.

Como suele ser frecuente dentro de estas obras de grandes proporciones, la construcción de la fábrica comenzó a realizarse por la zona de la cabecera, en cuya estructura se desarrollan las soluciones propias del siglo XV, con la planta cuadrangular y testero plano, que hemos visto. Sobre este muro del testero se abren dos esbeltos ventanales de arco muy apuntado y estructura abocinada, en cuyo interior nos encontramos el característico mainel y las tracerías flamígeras de este momento. A partir de aquí, ya desde los últimos años de este siglo $\mathrm{XV}$, se fueron levantando en etapas sucesivas los diferentes tramos que componen las naves, manteniendo en todas ellas las mismas formas sin apenas variaciones. De este modo, en los soportes se emplearon la solución de pilares compuestos, rodeados de columnas en sus frentes y ángulos o codillos de los que parten los diferentes arcos y nervios de las bóvedas, mientras que en las cubiertas se repite la bóveda de crucería estrellada con terceletes (con las variaciones ya señaladas). Las únicas novedades las aporta el campo ornamental, y así vemos como en el último tramo de las naves aparecen tímidamente algunos relieves de bolas, colocados en los anillos capitelados de los soportes, evidenciando claramente la llegada del estilo Reyes Católicos.

La culminación de todo el conjunto estuvo marcada por la construcción de la torre, levantada probablemente a partir de la década de 1520, tal y como nos indican las formas de los pilares, que marcan la entrada al espacio abierto en su interior. En este caso se emplea el pilar cilíndrico desprovisto de basa y capitel, característico del gótico más avanzado. 


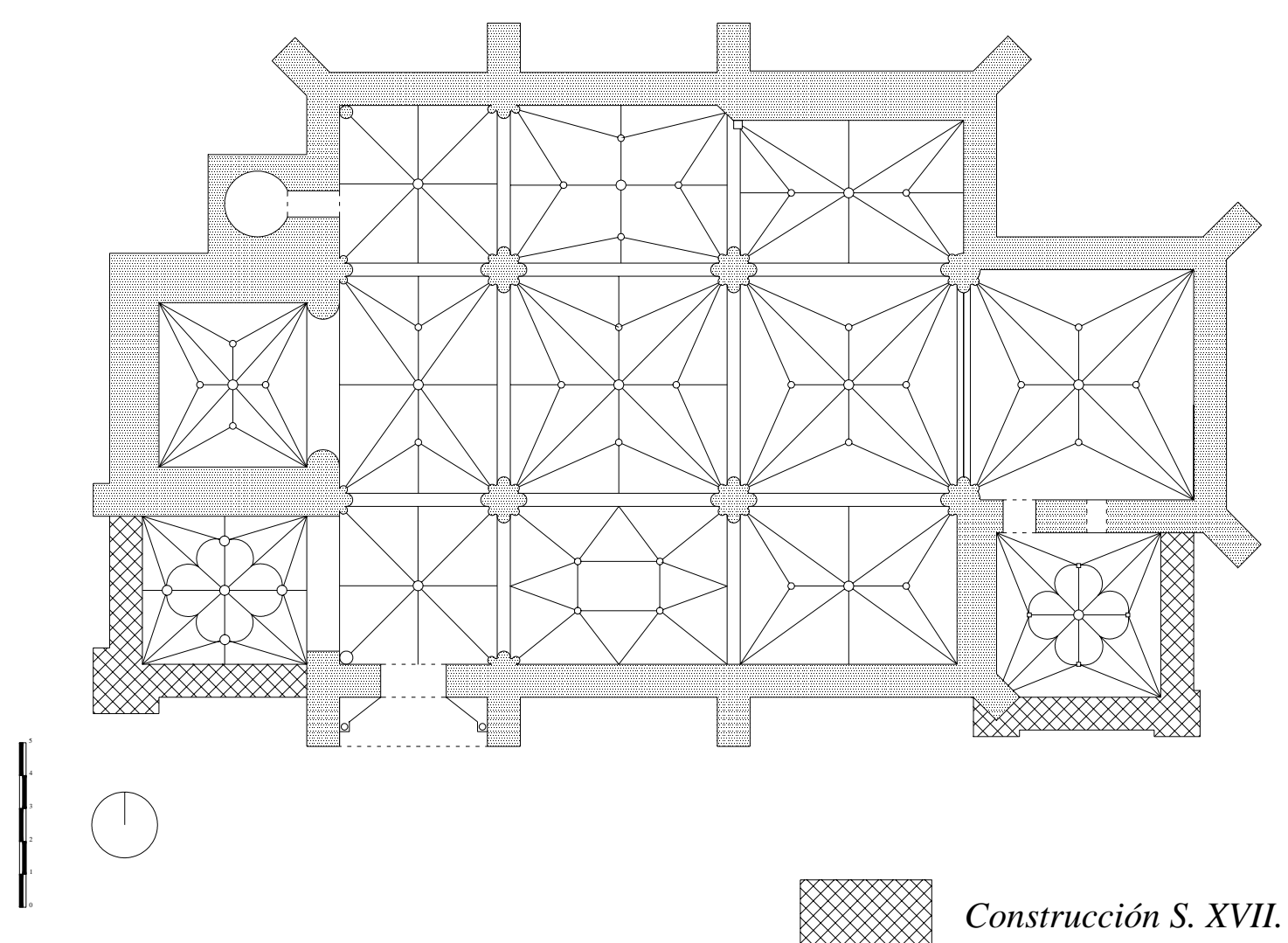

SALAS DE LOS INFANTES.

Iglesia de Santa María. Planta.

El resultado final, a pesar de esta larga sucesión de etapas constructivas, nos muestra un conjunto sumamente homogéneo, en el cual a lo largo de sus diferentes fases se ha sabido respetar el plan original, tanto en su trazado, como en sus formas. Esto hace que las únicas notas discordantes vengan de la mano de los añadidos, que comienzan a realizarse a partir de los años centrales del siglo, entre los que destacan la construcción del coro, y de modo especial, la nueva portada, de los cuales nos ocuparemos más adelante. El interés de estas nuevas obras, más allá de su mayor o menor calidad artística, radica esencialmente en su capacidad de introducir un lenguaje 
formal radicalmente distinto al gótico imperante en el resto de la fábrica, pues como veremos, estos dos añadidos se inscriben ya dentro de la estética renacentista.

Otro de los ejemplos de esta tipología de templo hallenkirche en esta zona lo encontramos en la vecina localidad de Castrillo de la Reina. Su iglesia, dedicada a San Esteban Protomártir, presenta notables afinidades con la anterior, tanto en su estructura y formas como en su cronología, si bien, constituye una versión ligeramente simplificada con respecto a aquella. De este modo, aquí nos volvemos a encontrar con el empleo de la característica planta de salón hallenkirche con tres naves cubiertas a una misma altura, pero con un desarrollo longitudinal algo menor, ya que cada una de ellas sólo cuenta con dos tramos. Por lo demás, al igual que en Salas, la nave central continúa mostrando un claro predominio en anchura sobre las laterales, prolongándose en los extremos para dar lugar respectivamente, al tramo que conforma la cabecera en el extremo oriental, y la base de la torre en la zona de los pies. La cabecera, por lo tanto, se levanta sobre una planta de trazado cuadrangular y testero plano, reforzado en las esquinas por potentes contrafuertes dispuestos diagonalmente. Este mismo trazado se repite en la base de la torre, eliminándose, en este caso, todo tipo de contrafuertes, pues esta función la realizan directamente los potentes muros, que aquí se emplean.

Las cubiertas de todos los espacios se alzan a un mismo nivel, empleando en todos ellos el modelo de bóveda de crucería estrellada con terceletes y cinco claves. Las únicas novedades sobre este trazado básico, como en casos anteriores, vienen propiciadas por las características y dimensiones de cada uno de los tramos, lo que hace que en algunos casos desaparezcan los terceletes de uno de los lados. No obstante, tenemos que recordar también la inclusión de nervios combados en uno de los tramos de la nave de la epístola, con los que se forma un amplio círculo central tangente a las claves de los terceletes, diseño que constituye una auténtica novedad dentro de la comarca. 


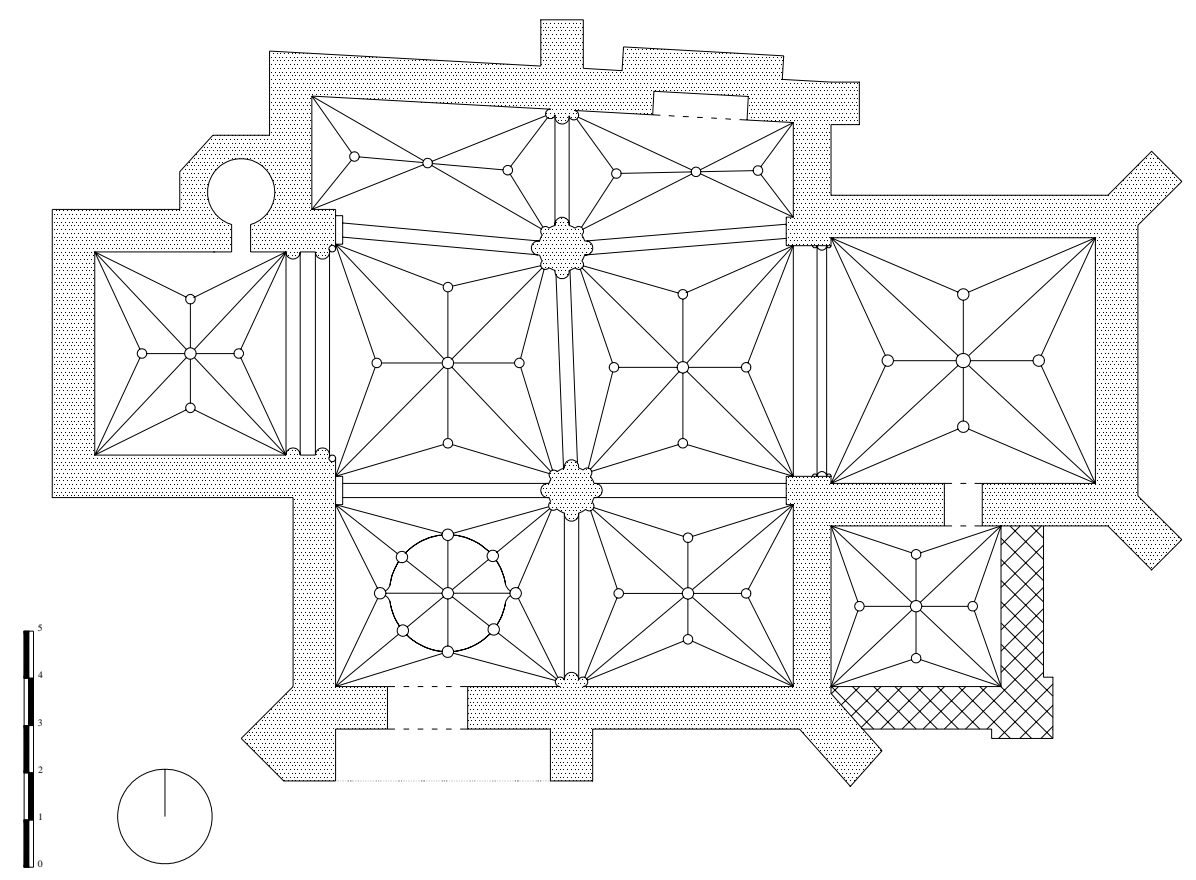

Construcción S. XVII.

CASTRILLO DE LA REINA. Iglesia de San Esteban. Planta.

Respecto a los arcos que separan cada uno de estos tramos, vemos cómo se combinan los de medio punto, utilizados en la nave central, con los apuntados, de las laterales. Al mismo tiempo, dentro de los primeros también existen claras diferencias, pues, mientras los arcos fajones, que separan cada uno de los tramos de esta nave, presentan una rosca profusamente moldurada, los de la línea de formeros, que separan esta nave central de las naves laterales, muestran una sobria sección cuadrangular de intradós completamente plano, que da una sensación de gran pesadez. La explicación a esta convivencia solamente puede venir dada por la época en la que se construye esta parte central del templo, y por el bilingüismo formal que en este momento se empieza a 
vivir, pues nos encontramos ya en los primeros años del siglo XVI, periodo en el que el gótico admite este tipo de modificaciones sobre sus formas más características.

Los pilares, por su parte, mantienen la misma estructura de sólido núcleo de sección circular rodeado por columnas adosadas en sus frentes y codillos, en cuyos capiteles no encontramos ya la decoración de bolas, que hemos podido ver en algunos ejemplos de Salas y Hacinas. Ésta se sustituye, en algunos casos, por pequeños roleos de talla muy plana y formas simples, que nos anuncian ya la llegada de las formas ornamentales propias del renacimiento. Aun así, esto no evita que en algunos casos aparezcan los característicos relieves de bolas del estilo de este periodo de entre siglos, como vemos en la moldura que trasdosa uno de los arcos fajones de la nave de la epístola.

Al margen de esto, el elemento más destacado de todo el conjunto de la iglesia lo constituye su portada, ubicada en la fachada meridional, a la altura del segundo tramo de la nave. Se trata de una obra característica del periodo final del siglo XV y principios del XVI, ligada al denominado estilo Reyes Católicos, cuya estructura y formas ornamentales nos permiten relacionarla con algunos de los ejemplos más representativos de esta tipología en la provincia de Burgos, como es el caso de la conservada en la iglesia de Santa María en Aranda de Duero. En gran medida podemos decir que se trata de una versión reducida y simplificada de aquella. Presenta, en su parte central, un amplio vano de arco de medio punto con la rosca recorrida por una serie de pequeños arquillos y bandas con decoración de ojarasca, dispuestas a modo de arquivoltas, que se continúan a lo largo de las jambas, consiguiéndose una estructura ligeramente abocinada. Sobre esta puerta se disponen un arco conopial, decorado en su extradós por las características macollas, heredadas del estilo de los Colonia. A partir de aquí, en sentido vertical, se extiende una superficie rectangular, limitada a los lados por estilizados pináculos, que sirven de marco a todo el conjunto. La superficie de la mitad inferior de este marco se encuentra recubierta completamente por un manto de escamas, característico de este estilo, mientras que la zona superior muestra un sencillo relieve de 
CASTRILLO DE LA REINA.

Iglesia de San Esteban. Portada.

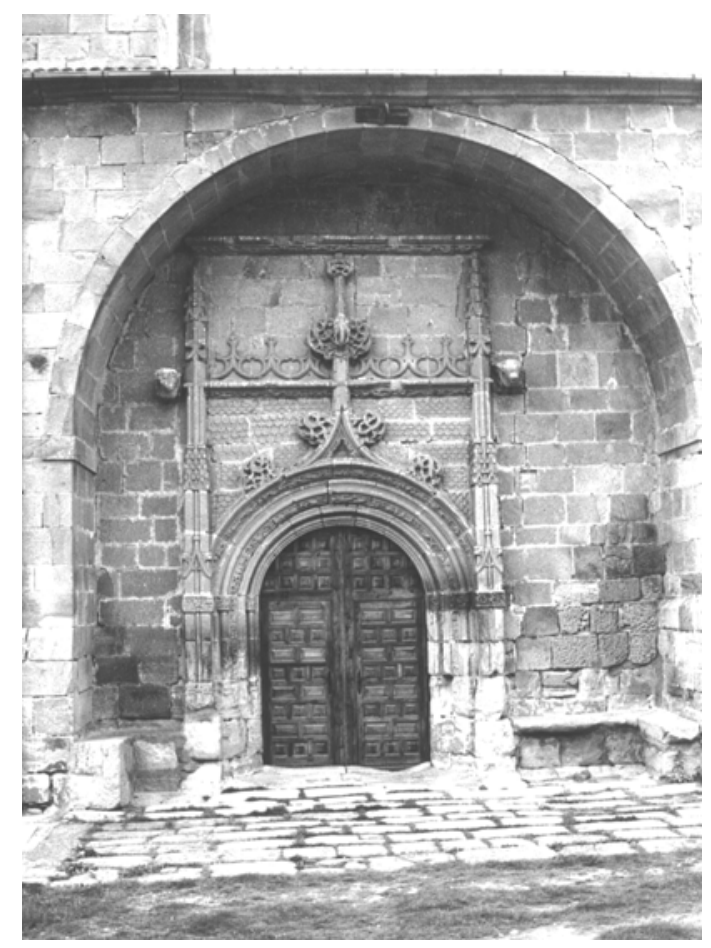

caireles adosados al paramento del muro. La única presencia de elementos figurados en la obra queda reducida a dos leones, de talla sumamente esquematizada, que aparecen en los extremos de la parte superior del conjunto, fuera incluso del propio marco de esta estructura. Se trata de figuras con las que se pretende evitar la llegada de cualquier tipo de mal al interior de este templo, representando, por ello, el simbolismo profiláctico, que estos animales poseían dentro del arte gótico. Un ejemplo muy similar a éste lo podemos encontrar en el retablo mayor de la Cartuja de Miraflores de Burgos, realizado a finales del siglo XV por el maestro Gil Silóe.

La presencia de todos estos elementos, como son el relieve de escamas, los caireles o el arco conopial con macollas, nos permite situar su autoría en el círculo próximo a Simón de Colonia, si bien la sencillez de toda la estructura, unida a unas meras cuestiones cronológicas, nos obligan a descartar por completo cualquier presencia de este genial artista en su realización. 
Por lo que respecta al conjunto del templo, debemos decir, que constituye una obra muy próxima a la iglesia de Santa María de Salas, aunque claramente posterior en el tiempo, pues a pesar de las similitudes estructurales, el hecho de contar con una mayor carga ornamental y mostrar algunos motivos nuevos, nos lleva a establecer una cronología más avanzada. Esta cronología puede situarse, para la parte central de esta fábrica, en torno a los años iniciales del siglo XVI, pues debemos tener en cuenta el retraso con el que llegan las distintas innovaciones formales a zonas tan apartadas como ésta. Junto a esto tenemos que señalar también la existencia de una secuencia constructiva notablemente más extensa, pues aunque el proceso de edificación fue muy similar en ambos casos, comenzando las obras por la cabecera y rematándose con la torre, el tiempo que se extiende entre una y otra edificación es mucho más amplio. Así, mientras la cabecera de esta iglesia de Castrillo de la Reina resulta contemporánea de la de Salas, tal y como demuestran las características que muestra el ventanal conservado sobre el muro del testero ${ }^{660}$, donde se repiten las mismas trazas del gótico flamígero, la torre, que culmina la obra, no se empezó a construir hasta el año 1572.

El tercer y último ejemplo de iglesia de este tipo nos lo ofrece el templo parroquial del San Salvador en Barbadillo del Pez, si bien, en este caso nos encontramos ya ante una variante ciertamente avanzada de esta tipología. Su construcción tiene lugar en la segunda mitad de siglo, momento en el cual la esta zona de la sierra, al igual que en el resto del territorio de la actual provincia de Burgos, el volumen de construcciones había descendido notablemente. En este caso, aunque no existen datos precisos sobre su proceso de construcción, todo apunta a que el diseño de la misma - y en gran medida la dirección de parte de los trabajos - pudo recaer en la figura de Juan de la Puente “maestro de geometría y arquitectura”, que durante este periodo se encontraba cubriendo el puesto de Veedor de las obras del Arzobispado de Burgos, al cual pertenecía esta parroquia. Esta posibilidad queda confirmada, en parte, 
por el concierto firmado en 1575 entre este maestro y el canónigo de la catedral de Burgos, D. Andrés de Salazar, por el cual se compromete a realizar la obra de la cabecera del templo de Barbadillo del Pez, antes de partir hacia El Escorial ${ }^{661}$. De este modo, y a pesar de no contar con la documentación completa, que acredite su participación en las obras del resto del templo, las características formales desarrolladas en él nos obligan a contemplar con cierto optimismo esta posibilidad. Esto quedaría avalado además por el cargo que ocupaba, como Veedor de las obras del Arzobispado de Burgos, pues ello le obligaba a tener una estrecha relación con las nuevas construcciones, que se realizaban en el territorio de la Diócesis. De este modo, esta iglesia pasaría a formar parte de la serie de obras trazadas por este autor en la Diócesis burgalesa, entre las que se encuentran templos como el de Villasandino o Melgar de Fernamental, en los cuales se reproduce el diseño característico de las iglesias de planta de salón de tipo hallenkirche, pero con una notable depuración de sus elementos.

Así, esta iglesia de Barbadillo del Pez, como el resto de sus compañeras de época, sigue empleando el tipo de bóveda de crucería estrellada con terceletes, pero en su forma más elemental, sin introducir variaciones significativas en el diseño de la trama, ni elementos ornamentales de ningún tipo en sus claves. El único aspecto que nos llama la atención de ellas, por lo tanto, es su rampante prácticamente plana, lo que contribuye a afianzar aun más la sensación de espacialidad. Esto se completa con la sustitución de los pesados arcos apuntados de tradición gótica por arcos de medio punto mucho más ligeros, de sección cuadrada e intradós ligeramente cajeado, los cuales introducen en su trazado un perfil sutilmente peraltado, que incrementa de modo significativo el nivel de las cubiertas y con ello la sensación de amplitud. Finalmente los soportes, sobre los que descansan arcos y cubiertas, están formados por pilares cilíndricos, más esbeltos que los utilizados durante la primera mitad de la centuria, que se rematan en su parte superior con una fina pieza horizontal de sección quebrada en sus

660 De esta ventana, como en el caso de la iglesia de Santa María de Salas de los Infantes, actualmente sólo se conserva su trazado exterior, pues como en aquella, en este caso tuvo que ser cegada a mediados de este siglo XVI, cuando se construye el primer gran retablo para esta capilla mayor. 


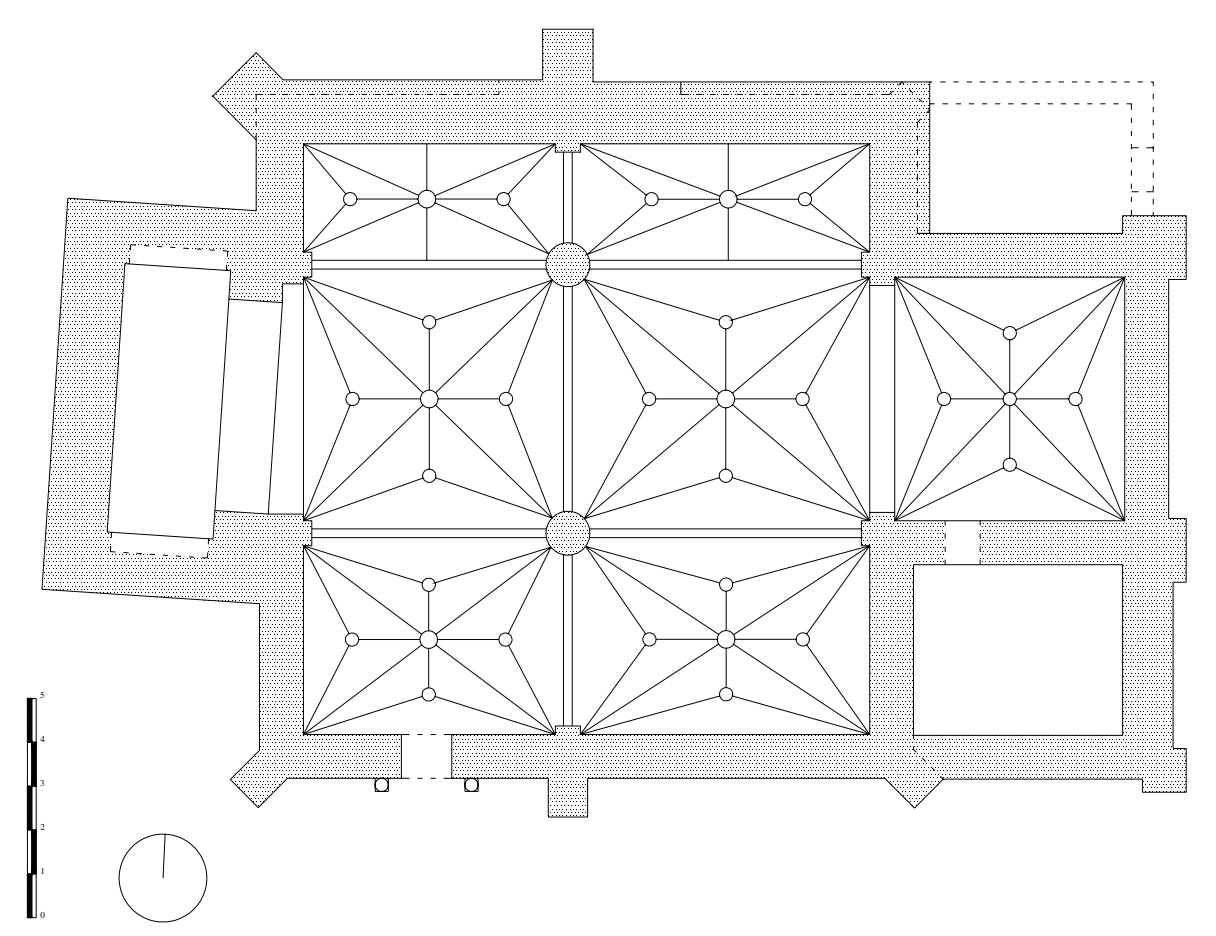

BARBADILLO DEL PEZ. Iglesia de San Salvador. Planta.

frentes, que sirve para marcar el arranque de los arcos y nervios de las respectivas bóvedas.

El resultado de todo ello es una iglesia de planta de salón articulada en tres naves de dos tramos cada una, con una mayor anchura de la central, y cubiertas, como hemos visito, por bóvedas estrelladas con terceletes, elevadas a una misma altura. En el eje de esta nave central se disponen, al mismo tiempo, la cabecera en la parte delantera, y la torre a los pies. Esta cabecera, aunque fue posteriormente remodelada a comienzos del siglo XVIII, consideramos que mantiene en general los rasgos de la estructura original, pues se levanta sobre una planta cuadrangular, con el suelo ligeramente elevado sobre el nivel de las naves, con testero plano y sólidos contrafuertes en las esquinas. La torre, sin

661 A. C. IBÁÑEZ PÉREZ: “Arquitectura, escultura, pintura y artes menores en el siglo XVI”. ob. cit. 
embargo, corresponde a un periodo anterior, pues se trata del único resto conservado del templo, que fue destruido para edificar la nueva fábrica. Esto se aprecia incluso en su propia disposición, pues dentro de ella se observa una evidente desviación con respecto al eje longitudinal, que marca la nave central y sigue el resto del templo.

El elemento que remata toda esta estructura es la portada, ubicada en su fachada meridional, a la altura de su segundo tramo, en la cual se muestran de modo muy sencillo las pautas propias del nuevo estilo renacentista. Está formada por un amplio vano rematado por un doble arco de medio punto de aristas redondeadas con molduras de cuarto de bocel, que se continúan por las jambas sin ningún tipo de interrupción. A los lados, sobre un elevado plinto, y colocadas delante de retropilastras cajeadas, se alzan sendas columnas de fuste liso, interrumpido en su tercio inferior con un pequeño anillo, y rematadas con un capitel de orden próximo al compuesto de talla muy esquematizada. Sobre estos soportes discurre un entablamento quebrado, con el friso decorado con puntas de diamante, y airosa cornisa, que da paso al remate, formado por un frontón triangular decorado con un pequeño jarrón en su vértice superior. Se trata, por lo tanto, de una obra propia de la estética renacentista, aunque de gran sobriedad compositiva, tanto en su estructura, como en su ornamentación. Las formas de este estilo, que aquí se muestran, aparecen desarrolladas en su variante más sencilla, no obstante, consiguen mostrar, a pesar de todo, una pureza que evidencia la superación de la fase plateresca.

Este mismo avance se observa igualmente en la configuración del resto de la fábrica, pues aunque la estructura de la planta, que define a esta tipología de templo, no ha cambiado de modo significativo con respecto a sus predecesoras de principios de siglo, su alzado practica un nuevo lenguaje, que se aleja de modo manifiesto de la tradición gótica. Sin embargo, en la inclusión de todos estos nuevos elementos - como son los arcos de medio punto peraltados y los pilares cilíndricos más estilizados - no sólo debemos ver una intención manifiesta de incorporarse definitivamente a la estética de inspiración clasicista, sino también un intento de afianzar la sensación de ámbito 
único y diafanidad espacial. Un concepto de espacio, en definitiva, que tanto las versiones más avanzadas del gótico, como la propia concepción renacentistas, pretendían alcanzar.

Renovaciones y ampliaciones de edificios.

Sin duda estos trabajos de nueva planta, que acabamos de señalar, fueron los más significativos de cuantos se acometen en este momento. Sin embargo, como sabemos, no fueron los únicos, pues junto a ellos también encontramos una amplia serie de proyectos de variado alcance, encaminados a renovar, sólo en parte, la estructura de los templos existentes.

Dentro de estas intervenciones tenemos que mencionar, en primer lugar, las encaminadas a renovar la parte delantera de los templos con la construcción de una nueva cabecera. Esto sucedió en las iglesias de Barbadillo de Herreros, la parroquia de Santa María, en Neila, Castrovido y Arroyo de Salas. Todas ellas desarrollan las características formas del gótico de transición entre los siglos XV-XVI, que ya vimos en los templos, que acabamos de reconocer. De esta forma, nos ofrecen estructuras sencillas, levantadas sobre planta cuadrangular con testero plano, reforzado en las esquinas por potentes contrafuertes dispuestos diagonalmente, y cubiertas con la característica bóveda de crucería estrellada con terceletes y cinco claves. Su espacio, amplio y desahogado, se comunica con el resto del templo, en todos los casos, a través de un arco apuntado de punto bajo, el cual descansa sobre columnas de fuste liso y sencillo capitel, formado por un simple anillo delimitado por finos junquillos. Las únicas variaciones, que encontramos dentro de ellas, por lo tanto, proceden de la propia evolución experimentada por cada uno de estos elementos a lo largo de la centuria. Esto nos sirve, al mismo tiempo, para poder establecer una cronología aproximada para su construcción, y descubrir así, que la mayor parte de las mismas fueron levantadas en los primeros momentos de este siglo XVI o incluso en los últimos años de la centuria anterior (situándose en el periodo de máxima actividad constructiva de la zona). En un 
momento algo más avanzado podemos situar la renovación de la cabecera de la iglesia de San Julián, en Arroyo de Salas, pues en ella se utiliza ya el soporte formado por el pilar cilíndrico desprovisto de capitel y basa, que se emplea aproximadamente a partir de la década de 1520, incorporando además el arco de medio punto de rosca profusamente moldurada.

Dos ejemplos más los encontramos en las ermitas de Nuestra Señora de Costana, en Barbadillo de Herreros, y en la de Nuestra Señora del Carrascal, en Canicosa de la Sierra. En ambas se repite el modelo establecido de planta cuadrangular con testero plano reforzado en el exterior por potentes contrafuertes dispuestos en diagonal, y cubierta con bóveda de crucería con terceletes. El arco de acceso desde la zona del cuerpo, en el primero de los casos, muestra ya un trazado de medio punto, aunque su sección sigue siendo trapezoidal, sin ningún tipo de moldura, continuándose hasta alcanzar el suelo, a través de un sencillo capitel de sección poligonal, delimitado por finos junquillos. En el caso de Nuestra Señora del Carrascal, este arco muestra todavía el trazado apuntado, característico del gótico, si bien su sección es idéntica a la anterior. Aquí, por otra parte, no aparece capitel de separación de ningún tipo entre el arco y el soporte, si bien este último incorpora un fino baquetón en su parte central. Todos estos rasgos, sin lugar a dudas, nos permiten situar estas dos obras dentro de los primeros años de la centuria.

Junto a estas renovaciones, efectuadas en la zona de la cabecera, podemos hablar también de la construcción de nuevas capillas, que se añaden a las fábricas ya existentes, si bien, como sabemos, en ningún momento fue éste un fenómeno generalizado en la comarca. De hecho, el único caso que conocemos, dentro de este siglo XVI, lo constituye la capilla dedicada a Santa Ana, que mandó construir la familia Márquez de Prada hacia 1520, en la iglesia de Santa María, en Neila ${ }^{662}$. Esta capilla está formada por un simple espacio de planta cuadrangular adosada junto al lado meridional de la cabecera, lo que hace que se convierta, en cierto modo, en la culminación visual de

662 B. VALDIVIELSO AUSÍN: Neila, una llamada al turismo. ob. cit. 
la nave de la epístola. Su espacio, cubierto actualmente con una cúpula de media naranja sobre pechinas, contaba originalmente con una bóveda de crucería estrellada con terceletes, comunicándose con los tramos contiguos, del presbiterio y de la nave de la epístola, respectivamente, a través de sencillos arcos ligeramente apuntados, dispuestos sobre un grueso pilar de estructura cilíndrica, desprovisto de capitel. Su interior se ilumina a través de un ventanal practicado sobre su muro meridional, rematado por arco de medio punto cuya rosca recorre una moldura de bocel, que se extiende por las jambas para formar el marco. No obstante, y a pesar de este aire renovador, este vano mantiene aun la estructura abocinada hacia el exterior, y un grueso mainel en el interior, sobre el cual descansan dos pequeños arcos de medio punto.

Unas formas muy similares a éstas son las que se desarrollan en las ampliaciones más destacadas, que tienen lugar en varios de los templos de la zona a lo largo de este siglo. Dentro de ellas, tal vez una de las más interesantes es la que se lleva a cabo en la iglesia de la parroquia de Santa Eulalia, en Palacios de la Sierra, en torno a la década de 1530. En esta fábrica, que originalmente debía presentar una sencilla estructura de nave única, se decide renovar toda la parte correspondiente al cuerpo, con el fin de incrementar de forma considerable el espacio disponible en su interior. De esta forma, se levanta un nuevo cuerpo, de estructura irregular, compuesto por dos naves, de diferente tamaño, con la septentrional, que se convierte en la principal, organizada en tres tramos, mientras que la meridional cuenta con sólo dos, de menor anchura y cubierta algo más baja. Esto hace que la situada en el lado meridional quede relegada, por sus menores dimensiones, y por su evidente desplazamiento del eje vertebrador del templo, a un papel claramente secundario.

Las formas desarrolladas en esta ampliación son las propias del gótico más avanzado, dentro de las cuales, sin embargo, no resulta del todo extraño encontrar una relativa permeabilidad hacia ciertos nuevos elementos característicos del estilo renacentista. De este modo, las cubiertas siguen empleado la bóveda de crucería estrellada con terceletes, dentro de las cuales, en algunos casos, como ocurre con el 
tramo que cubre el espacio del coro, en los pies de la nave principal, se añaden una serie de nervios combados en su parte central con los que se forma una estructura trebolada con los lóbulos situados sobre el eje longitudinal ligeramente apuntados, creando una conopia. Este rasgo resulta propio de las formas más avanzadas, en el diseño de bóvedas, que se emplean a partir de estas décadas de 1520-30.

En relación con esto vemos cómo, en los arcos que separan cada uno de los tramos de bóveda, se utiliza el arco apuntado ligeramente rebajado, con su rosca moldurada, lo que confiere cierta sensación de ligereza. A su vez, los soportes sobre los que descansan presentan el modelo de estructura cilíndrica, desprovisto de capitel y basa, que ya hemos visto en otras obras, y que confirman la cronología estimada para

PALACIOS DE LA SIERRA.

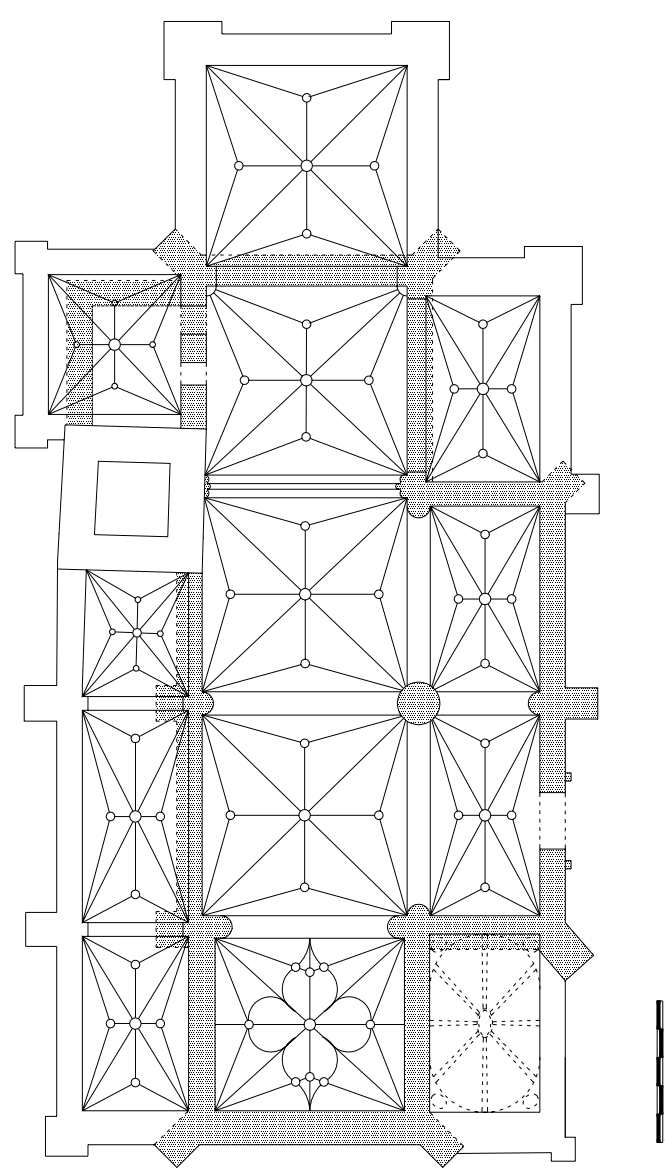
Iglesia de Santa Eulalia. Templo siglo XVI. 
este conjunto. Estos pilares se combinan con pequeñas ménsulas en las esquinas, de las cuales se conserva todavía una, en lo que fuera el ángulo, que formaba, en su parte delantera, la nave meridional. En ella se representa una cabeza de un angelito, toscamente labrada, de inspiración renacentista, con grandes mofletes y cabellos rizados, rodeada por dos pares de alas, correspondiente, por lo tanto, al grupo de los Querubines.

Los ventanales con los que se ilumina el espacio interior, orientados hacia el mediodía y poniente, muestran esta misma sintonía, y así desarrollan la característica estructura abocinada, pero coronada con arco de medio punto, desapareciendo al mismo tiempo cualquier tipo de división en su interior, mediante maineles o parteluces. Por último, toda esta obra se culmina con la incorporación de una portada en la fachada meridional, la cual nos muestra las formas propias del renacimiento, dentro de su fase más ornamentada. De ella, sin embargo, trataremos algo más adelante.

El resultado de esta importante intervención es difícil de apreciar y valorar en la actualidad, pues este templo sufrió posteriormente importantes modificaciones, que acabaron por desdibujar casi por completo la estructura ahora conseguida. Aun así, a través de la recreación, que hemos conseguido hacer de su planta observamos que se trata de un espacio todavía bastante compartimentado y jerarquizado, existiendo una clara separación entre cada uno de los ámbitos, que definen las respectivas naves. A ello contribuye de forma clara, la escasa altura, que alcanzan las cubiertas, con una ligera pero evidente diferencia a favor de la nave principal, y la gran potencia del único soporte exento, que aparece en el centro de estas dos naves. Aun con todo, la apuesta hacia un espacio de ámbito único también aquí parece quedar clara.

Un ejemplo similar a éste, aunque con un grado de complejidad, si cabe, mayor, lo tenemos en la iglesia de la parroquia de Santa Cecilia, en Salas de los Infantes. Aquí, en un espacio de tiempo, que transcurre desde las últimas décadas del siglo XV hasta aproximadamente la década de 1530 , se consigue levantar un templo 
prácticamente nuevo, dentro de cuyos elementos, sin embargo, se aprecian notables variaciones estilísticas.

Este proyecto, como viene siendo habitual, comenzó con la construcción de la cabecera, la cual debió realizarse al mismo tiempo que la ejecutada para la iglesia de la otra iglesia de esta localidad. De esta forma, las características aquí desarrolladas son prácticamente las mismas, aunque con unas proporciones notablemente más modestas. Ésta se levanta sobre una estructura de planta cuadrangular con testero plano, reforzado en las esquinas por potentes contrafuertes dispuestos en diagonal, en cuyo centro se abre un ventanal abocinado coronado con arco de medio punto, mainel central y finas tracerías en su interior. Su espacio, que se cubre con una bóveda de crucería octopartita de gruesos y pesados nervios, se comunica con el espacio de las naves, a través de un amplio arco apuntado de rosca escasamente moldurada, que descansa sobre pequeñas columnas entregadas con capiteles prácticamente sin labrar.

A esta obra le siguió, en el tránsito hacia el siglo XVI, la construcción de la zona del cuerpo, donde se levanta una estructura de nave única, dividida en dos tramos, a cuyos lados se añaden dos amplios espacios cuadrangulares, con los que se conforma un espacioso transepto, que viene a deparar una original planta de cruz griega. Las formas empleadas en esta parte muestran un significativo avance con respecto a la zona de la cabecera, pues las bóvedas con las que se cubre la nave central presentan ya un diseño estrellado con terceletes y claves decoradas con diferentes motivos ornamentales. No obstante, en los brazos del crucero se mantiene el trazado octopartito de la cabecera, lo que no evita que sus respectivas claves, muestren un afiligranado borde festoneado con pequeños caireles, como los que hemos visto en otros ejemplos de la zona. Los arcos apuntados, que separan cada uno de estos tramos de bóveda, muestran igualmente, una serie de molduras en su rosca, que les confiere cierta sensación de ligereza. Y por último, los soportes están concebidos mediante haces de tres columnas, con la central de mayor anchura, alzadas sobre un potente plinto, con las mismas características que hemos señalado en diferentes ocasiones para obras de este periodo. 
El tipo de planta, que de esta forma se ha conseguido, no parecía adecuarse perfectamente a las necesidades de culto, pues la excesiva compartimentación, que introducen los amplios brazos del transepto, limitaba notablemente la contemplación del altar mayor. Por ello, a principios del segundo cuarto de este siglo XVI se hace necesario añadir un pequeño espacio en la zona meridional, convirtiendo este brazo del crucero en una nave lateral, al mismo tiempo que se alargaba ligeramente la zona posterior del cuerpo, para colocar un coro alto a los pies. Las formas desarrolladas en esta ampliación resultaron muy semejantes a las anteriores, continuándose así con las bóvedas de crucería estrelladas con terceletes, y con los arcos apuntados de rosca finamente moldurada. Sin embargo, en los soportes se emplea ya el pilar cilíndrico sin capitel ni basa, que evidencia una cronología ciertamente más avanzada.

Esta nueva ampliación se complementa con una portada. Sin embargo, en ella no se recurre a una estructura de estilo renacentista, como sí se hizo en otros ejemplos de la zona, con el fin de dar un toque de modernidad e innovación a todo el edificio. Está formada por una puerta, coronada con arco carpanel de aristas redondeadas con una moldura de tres cuartos de bocel, sobre el cual se superponen tres niveles de arquivoltas, formadas por arcos apuntados, que apean sobre finos baquetones, dispuestos en el derrame de las jambas. Formas, por lo tanto, muy depuradas y de gran sobriedad, pero estrictamente góticas, al fin y al cabo, lo cual contrasta radicalmente, como decimos, con lo que en este mismo momento se estaba realizando en otros templos de la zona, en los cuales, el broche final se solía poner con una portada renacentista.

Otras intervenciones de este tipo, relacionadas con la renovación de parte de la estructura del cuerpo, se realizan también en las iglesias de Hoyuelos de la Sierra, Quintanar de la Sierra y Vilviestre del Pinar. En la primera de ellas, se procede en estos primeros años del siglo XVI a renovar toda la estructura de la cubierta del antiguo templo románico, que debía ser de madera, levantando en su lugar una estructura abovedada, con bóvedas de crucería estrellada con terceletes. Los dos únicos tramos que 
se conservan actualmente se encuentran separados por un estilizado arco fajón de medio punto, finamente moldurado, que engarza en los muros a través de pequeñas ménsulas, sin dar lugar a ningún tipo de pilar adosado. En la imagen exterior se aprecia cómo esta intervención obligó a un incremento notable de la altura de los muros, los cuales, además, debieron ser reforzados mediante la incorporación de sólidos contrafuertes laterales. El modo en el que esta intervención pudo afectar al resto de la estructura del templo resulta actualmente imposible de precisar, pues la posterior remodelación de toda la parte delantera, emprendida a mediados del siglo XIX, eliminó cualquier posibilidad de conocerlo.

Esta misma circunstancia es la que se vive en el templo parroquial de San Cristóbal, en Quintanar de la Sierra, donde la construcción de la nueva iglesia, en las primeras décadas del siglo XVII, consiguió acabar de forma casi completa con todo vestigio del templo o templos anteriores. Aun así, en la zona de la actual nave de la Epístola se conservan ciertos elementos, que nos indican la existencia de una fase constructiva desarrollada durante las décadas centrales del siglo XVI. Estos restos se concentran, en concreto, en el segundo tramo de esta nave de la Epístola, y entre ellos podemos destacar: una bóveda de crucería estrellada con terceletes, dentro de la cual se añaden una serie de nervios combados, con los que se forma una estructura trebolada en torno a la clave central; dos arcos de medio punto de rosca finamente moldurada, que delimitan este tramo con los contiguos, situados en el flanco norte y oeste, respectivamente; diferentes soportes, formados por columnas entregadas, levantadas sobre elevado podio, con basas bien formadas, con escocia entre dos toros, pero desprovistas de capitel; una ménsula sobre el muro, decorada con una cabeza de angelito entre dos pares de alas, muy similar a la que mencionamos al hablar del templo de Santa Eulalia, en Palacios de la Sierra; y un ventanal, dentro de este mismo tramo, de estructura abocinada hacia el exterior, y coronado con arco de medio punto.

Finalmente, en la iglesia de San Pedro, en Vilviestre del Pinar se procede también, durante esta centuria, a renovar toda la parte correspondiente a la zona del 
cuerpo. En concreto, lo que se hace es levantar una sencilla estructura de tres naves separadas por dos galerías de potentes arcos formeros de medio punto, de gran luz, y sección finamente moldurada, que descansan sobre simples pilares cilíndricos de escaso grosor, desprovistos de basa y capitel. Todo este espacio debería quedar cubierto con una sencilla techumbre de madera, ya que no se conserva ningún tipo de indicio, que nos lleve a sospechar la presencia de una cubierta abovedada. Al exterior, el único elemento de interés se encuentra en la portada, orientada hacia el mediodía. En ella se repite un esquema similar al que hemos visto en la iglesia de Santa Cecilia, en Salas de los Infantes, con un vano central con arco carpanel, enmarcado por tres arquivoltas, formadas por arcos apuntados de aristas redondeadas, cuya rosca se extiende sin interrupción a lo largo de las jambas, formando finos baquetones, que dan lugar a una estructura abocinada. De esta forma, dada la presencia de estos elementos, y ante la falta de otras fuentes, que nos informen sobre su proceso constructivo, debemos considerarla como una obra contemporánea de aquella.

Todo esto, por lo tanto, nos lleva a relacionar esta obra con el gótico más avanzado, que empezó a desarrollarse en la zona aproximadamente a partir del segundo cuarto del siglo XVI, del cual contamos con diferentes ejemplos, entre los que destaca, por su proximidad, el ya mencionado de Santa Eulalia, en Palacios de la Sierra. Sin embargo, estos restos, que sí parecen suficientes para establecer una cronología aproximada, se muestran escasos a la hora de poder averiguar algún rasgo concreto sobre la estructura del templo al que pertenecieron, así como sobre las características de la intervención que se realizó en este momento

Otro tipo de obras de gran interés es la construcción de diversos añadidos, con los que se pretende completar la estructura de fábricas ya existentes, o levantadas en este mismo momento. Su interés, en este caso, no se centra tanto en aspectos puramente cuantitativos, como en valoraciones de tipo cualitativo, pues si observamos detenidamente el fenómeno de estas construcciones, vemos que se convierten en la 
principal puerta de acceso para la penetración de las formas propias del arte renacentista.

Entre estos añadidos se encuentran, en primer lugar, las torres, las cuales sin embargo, no reciben un tratamiento especial dentro del conjunto de las fábricas a las que se incorporaron, ni muestran tampoco una evolución clara a lo largo de la centuria. En ellas, simplemente se desarrolla una estructura maciza de limpias formas prismáticas, con muros completamente lisos, que ascienden verticalmente sin incluir ningún tipo de moldura, que marque la separación entre cuerpos. Los dos ejemplos más representativos los encontramos en las iglesias de Santa María, en Salas de los Infantes y San Esteban, en Castrillo de la Reina, donde su incorporación supone el punto final del proceso constructivo de ambos templos. Los dos casos fueron modificados posteriormente en los primeros años de la centuria siguiente, con la incorporación de nuevos cuerpos de campanas, si bien, esto no alteró de forma importante su estructura original. Así, en el caso de Castrillo de la Reina, donde esta alteración sufrida fue menor, es posible observar con total claridad la forma prismática de su estructura primitiva, dentro de la cual únicamente se pueden destacar las troneras abiertas en la parte superior para alojar las campanas, formadas por dos vanos en cada uno de sus paños, rematados por arcos de medio punto rebajados, y ligero perfil abocinado. El encargado de su construcción fue el maestro de origen trasmerano Juan de la Fragua, el cual comenzó las obras en 1572, según nos indica la carta cuenta redactada por los Provisores del Obispado de Osma años más tarde ${ }^{663}$.

Junto a la construcción de estas dos torres, podemos incluir también la incorporación del nuevo cuerpo de campanas, que se añade en la iglesia parroquial de Vilviestre del Pinar. Este nuevo cuerpo se levanta sobre el gran prisma de sección cuadrangular, que forma la sólida estructura de la torre anterior, y está constituido por un prisma de anchura algo menor, separado por una pequeña moldura. En su cara

\footnotetext{
663 AGDBU. LP. Castrillo de la Reina, parroquia de San Esteban. LF. (1572 - 1631). Burgo de Osma, 12 - julio -1609 .
} 
meridional se abren dos vanos con arco de medio punto y uno solo en cada uno de los tres restantes. A ellos se une una cornisa, formada por moldura de codillo, interrumpida por tres gárgolas con forma de cañón. Este tipo de gárgola constituye un elemento relacionado ya con el mundo renacentista, lo cual nos permite estimar una fecha de construcción, situada en torno a los años centrales de este siglo XVI. Este elemento aparece también en la fachada meridional de la iglesia de Santa María, en Salas de los Infantes, y fue incorporado en torno a 1549, con motivo de la construcción de la nueva portada.

Otra pieza que se suele incorporar en estos momentos es el coro, desarrollando en todos los casos el característico modelo de coro alto situado en la zona de los pies, y alojado preferentemente en el espacio incorporado bajo la base de la torre. Esto es lo que sucede en el caso de la iglesia de Santa María, en Salas de los Infantes. Aunque no contamos con la documentación, que nos informe sobre el proceso de construcción, debemos suponer que esta obra se levanta ya en un momento ciertamente avanzado del siglo XVI, pues en ella se muestran ya con claridad los rasgos formales propios de la arquitectura plateresca. Su estructura está formada por un gran arco escarzano con la rosca recorrida por una fina decoración, en la que no faltan las clásicas ovas y puntas de flecha, sobre el cual se dispone una airosa cornisa en la que se vuelve a repetir la misma ornamentación. Esta parte frontal se remata con una balaustrada también de piedra, pero de formas más sobrias, lo que contribuye a incluir un cierto rasgo de austeridad. El sotocoro, por su parte, se cubre con una bóveda de crucería estrellada con terceletes, dentro de cuyo trazado se añaden una serie de nervios combados, con los que se forma una especie de círculo central, con perfiles conopiales en sus extremos longitudinales y transversales. Esta bóveda, como ocurre con todas aquellas cubiertas abovedadas, donde existe un suelo pisado encima, presenta una rampante muy plana, que en este caso resulta prácticamente llana.

Sin salir de esta localidad, en el templo de su otra parroquia (Santa Cecilia), nos encontramos con un coro de fabricación mucho más sencilla, con estructura mixta, en la 
que se utiliza piedra y madera. Este coro, también de tipo alto, ocupa todo el pequeño espacio del último tramo de las naves, y presenta una estructura formada por dos arcos escarzanos con aristas finalmente molduradas, sobre los cuales descansa la correspondiente viguería y entramado de madera, que forma el piso.

Otro tipo de añadidos, también escaso, aunque de gran significación estilística, en cuanto a la incorporación de un nuevo lenguaje artístico, lo constituyen los sepulcros. Dentro de ellos, el único ejemplo realmente interesante lo encontramos en la iglesia de San Esteban, en Castrillo de la Reina, ubicado en el primer tramo de su nave del evangelio. Se trata de un sepulcro adosado, en el que se desarrolla el modelo de arco de triunfo, característico del mundo renacentista. Su estructura está formada por un gran nicho coronado con arco de medio punto de rosca finamente moldurada y dos pequeños medallones en las enjutas. Dos retropilastras cajeadas, elevadas sobre potente plinto y rematadas con capitel compuesto, escoltan este nicho a los lados, sobre las cuales se disponen finas columnas del mismo orden, con capiteles igualmente esquematizados, y fuste estriado, con estrías vivas en sus dos tercios superiores, y macizas o a contracanal

CASTRILLO DE LA REINA. Iglesia de San Esteban. Sepulcro de la nave de la Epístola.

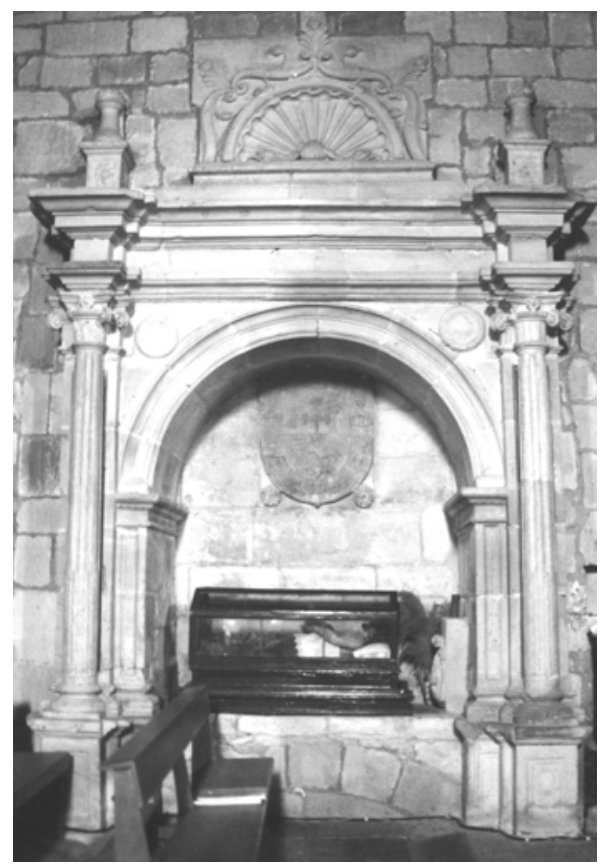


en el tercio inferior. Sobre estos soportes se extiende un entablamento quebrado de gran clasicismo, con friso completamente liso y airosa cornisa, a través del cual se da paso al remate. Éste se encuentra formado por una venera en el centro, enmarcada por un bocel y una serie de roleos finamente entrelazados en el exterior, y dos jarrones a los lados, en correspondencia con los soportes inferiores, dispuestos sobre un sencillo neto con decoración floral en sus frentes.

Se presenta aquí, por lo tanto, una obra sobria en sus formas, pero bien proporcionada en su composición, mostrándose en ella, con total perfección, los rasgos característicos del lenguaje renacentista más avanzado. Así, dentro de todo el conjunto, los elementos estructurales son los auténticos y únicos protagonistas, pues la decoración, además de escasa, se encuentra en todos los casos remarcando las propias líneas arquitectónicas, y no tapándolas. Todo esto hace que debamos considerarla una pieza auténticamente aislada, dentro del panorama constructivo de la comarca, pues ni su tipología, ni, por supuesto, sus formas llegaron a triunfar plenamente aquí. Por ello, debemos sospechar que su construcción tuvo que deberse al patrocinio de algún personaje o familia con estrechos vínculos con esta localidad, pero indefectiblemente asentada en algún lugar próximo a los principales centros artísticos del momento, pues su concepción no parece el fruto de un mecenas de la zona, ya que se aleja mucho de los gustos y preferencias dominantes en ella.

Respecto a su cronología, indudablemente se trata de una obra correspondiente ya a un momento avanzado del siglo XVI, pues la tupida trama ornamental, característica de la fase plateresca, que cubre por completo las estructuras arquitectónicas durante los primeros momentos, ha desaparecido en su totalidad para dar paso a una estructura limpia y bien ordenada, donde la correspondencia y proporción entre cada uno de los elementos se convierte en su principal rasgo definidor.

Al hilo de estas incorporaciones, sin duda, las piezas donde se reflejan con especial vigor y elocuencia los elementos artísticos de este momento, son las portadas, 
las cuales se levantan, en muchos casos, con el fin de completar edificios levantados o renovados a lo largo del siglo. Se constituyen, de este modo, en el elemento más interesante, desde el punto de vista artístico, con el que cuentan la mayor parte de estas fábricas, pues, no sólo representan el lugar en el que se concentra la mayor parte de la ornamentación del edificio, sino que además son el elemento en el que mejor se muestran los cambios y la evolución estilística experimentada en el panorama constructivo de la comarca.

Una evolución, que dentro de este siglo XVI, abarca, desde las formas propias del llamado estilo Reyes Católicos, como hemos visto en el caso de la iglesia de Castrillo de la Reina, hasta el renacimiento más sobrio, que pudimos reconocer en las sencillas formas empleadas en el templo de Barbadillo del Pez. El espacio, que se extiende entre ambos ejemplos, se puebla de una variada gama de casos, que, si bien, no son muy numerosos, sí resultan suficientes para mostrar el reflejo que los diferentes cambios experimentados en arte burgalés durante este siglo, tienen en este ámbito de la comarca de la sierra.

Por otro lado, junto al manifiesto carácter ornamental, que tienen estas piezas en todos los casos, otro rasgo que debemos tener en cuenta es su clara autonomía con respecto al resto del conjunto de la fábrica. Pues no sólo son piezas añadidas, en muchos casos, con bastante posterioridad a la ejecución del resto de la estructura del edificio, sino que además dentro de ellas se permiten unas libertades compositivas y ornamentales, que difícilmente podremos encontrar en ninguna de las otras partes del templo. Esto termina convirtiendo a estas piezas en el lugar predilecto para el desarrollo de las formas renacentistas, pues, tal y como hemos tenido oportunidad de ver, ni en la concepción, ni en la propia edificación de los templos levantados a lo largo de esta centuria, encontraron una especial cabida las formas propias de este nuevo lenguaje. En definitiva, estas portadas debemos entenderlas como auténticos elementos con personalidad propia, dentro de los conjuntos a los que adosan, pues rara vez existe una relación estilística directa entre ellos. 
Esto nos lleva a plantearnos el sentido que tenía su incorporación, dentro de unos edificios de estructura complemente gótica. La respuesta, sin ninguna duda, se halla en el interés, por parte de los responsables de estas fábricas, de renovar, y en definitiva modernizar, los edificios, pues sólo así podemos entender casos como los de las iglesias de Santa María, en Salas de los Infantes, o el de Santa Eulalia, en Palacios de la Sierra, donde la culminación de unas obras elaboradas dentro del más puro estilo gótico se realiza levantando sendas portadas típicamente renacentistas. A ello debemos unir también el interés por sorprender y singularizarse, pues la incorporación de una obra de estas características en una zona como ésta, donde las formas renacentistas tuvieron un éxito tan limitado, no sólo suponía un intento de incorporarse a las corrientes más renovadoras, desde el punto de vista estilístico, sino que al mismo tiempo terminaba convirtiéndose en un auténtico hecho diferencial.

Esta circunstancia sirve para explicarnos, en parte, la construcción, a mediados del siglo, de la magnífica portada en la iglesia de Santa María, en Salas de los Infantes, templo que, por determinadas circunstancias históricas - en su interior se custodiaban las cabezas de los Siete Infantes de Lara, auténticos héroes legendarios de la comarca - y monumentales, se había convertido en el punto de referencia de la espiritualidad entre los núcleos de su entorno. La construcción de esta innovadora portada serviría, en definitiva, para afianzar aun más este papel preponderante y de referencia.

Esta portada constituye, al mismo tiempo, uno de los ejemplos más representativos del arte y las formas renacentistas en esta comarca de la sierra burgalesa, y en gran medida del resto del marco provincial.

Se encuentra situada en la fachada meridional, cobijada bajo un amplio arco de medio punto con casetones floreados en su intradós y dragones rampantes y cestas de frutas en las enjutas. La portada en sí muestra una sencilla estructura abocinada, 


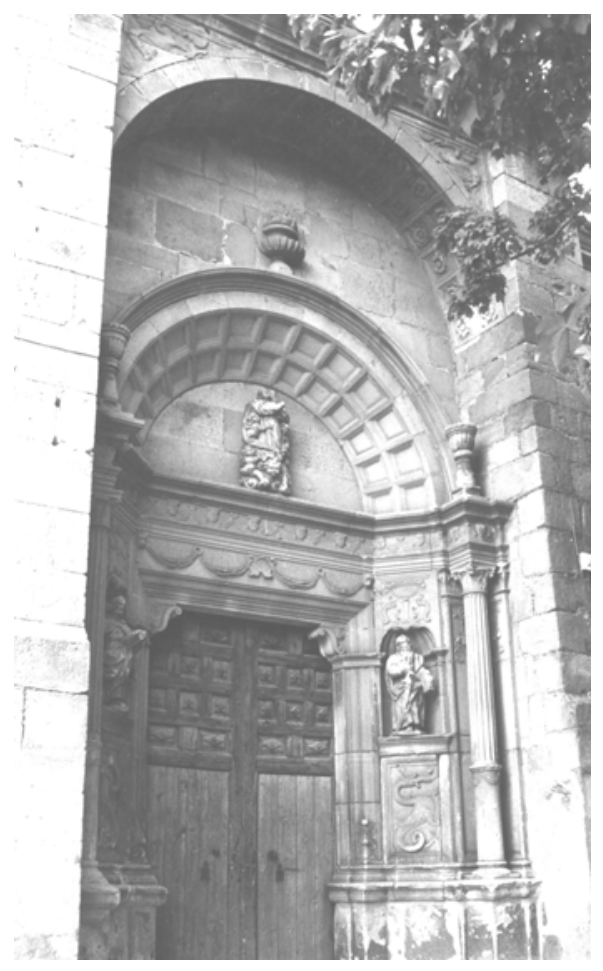

SALAS DE LOS INFANTES.

Iglesia de Santa María. Portada.

coronada con arco de medio punto con profundos casetones decorando su rosca, a modo de arquivoltas. Bajo él se abre un amplio vano adintelado, escoltado en sus jambas por sendos nichos avenerados, donde se sitúan las imágenes en piedra de San Pedro y San Pablo. Estos nichos se ven acompañados nuevamente por sencillas representaciones de dragones rampantes y copas decoradas con frutos y roleos, todo ello elaborado mediante la técnica de relieve plano o schiacciato. En los extremos de estas jambas se disponen dos columnas de orden compuesto, con fuste liso en su tercio inferior y estriado en sus dos superiores, sobre las cuales discurre un quebrado entablamento con decoración de cabezas de ángeles recorriendo el friso.

Sobre el dintel de la puerta se conserva una pequeña cartela, donde se puede leer la fecha en la que finaliza la obra, la cual corresponde a 1549. Se trata, por lo tanto, de una obra plenamente renacentista, desarrollada por maestros que conocían y dominaban perfectamente el estilo. En ella se ha producido ya una profunda simplificación de los 
elementos ornamentales, resaltando así las líneas arquitectónicas, que sirven de base a las imágenes.

Respecto a su autoría, aunque no se ha conservado la documentación que nos permita fijar con rotundidad un nombre concreto, todo apunta al círculo próximo al maestro Diego Guillén - personaje ligado por su estilo al ambiente cercano a Diego de Siloe, en su etapa burgalesa -, al cual se le atribuye también la ejecución del magnífico retablo, que preside el altar mayor de esta misma iglesia de Santa María de Salas de los Infantes. Antecedentes de la misma los encontramos en la portada del Colegio de San Nicolás de Burgos, realizado por el propio Diego Gillén, si bien también podemos encontrar otro tipo de influencias, como son las de Juan de Vallejo, en las columnas que aparecen en los extremos de las jambas.

Todo ello la convierte en la obra más destacada y de mayor calidad artística del renacimiento en esta comarca. Pero, al mismo tiempo, se trata de una obra auténticamente aislada, dentro de un mar gótico, pues a pesar de este indudable valor y calidad, mostrado en sus formas, y del gran peso que este templo tiene, no llegará a tener una gran repercusión dentro del panorama artístico local (al menos de forma inmediata), motivando la aparición de portadas en las que se intentara emular sus formas y modelos. De esta forma, vemos cómo el resto de las portadas renacentistas, que se levantan en su entorno a lo largo de la centuria, van a seguir modelos muy diferentes.

Pero si la influencia, que esta obra muestra dentro de la arquitectura religiosa contemporánea, podemos calificarla de prácticamente nula, no debemos decir lo mismo de la acogida que tiene posteriormente en la arquitectura civil. Así, uno de los rasgos más singulares de su estructura, como es el arco decorado con casetones en su rosca, lo vamos a encontrar reflejado en varias de las numerosas casas blasonadas, que se levantaron en la zona en el siglo XVIII, salpicando su influencia, incluso a la 
arquitectura popular, como muestran algunas casas carreteras, conservadas en Canicosa de la Sierra y Vilviestre del Pinar.

El otro ejemplo de interés, dentro de este tipo de obras, lo encontramos en la portada construida para la iglesia de Santa Eulalia, en Palacios de la Sierra. Se trata de una obra concebida como culminación de las importantes obras de renovación, que se habían emprendido durante el segundo cuarto de siglo. Desde el punto de vista estilístico, esta obra resulta algo anterior a la de Salas, pues en ella se muestran todavía las formas planas y sumamente ornamentadas del plateresco. No obstante, dado el retraso con el que habitualmente se desarrolla toda innovación estilística en la comarca, tampoco deberíamos descartar la posibilidad de que pudiera tratarse de obras contemporáneas.

Su estructura está compuesta por un amplio vano cubierto con arco de medio punto, con decoración de flores recorriendo toda su rosca, la cual se extiende a lo largo de las pilastras cajeadas, que forman las jambas. Esto se completa con sendos jarrones en las enjutas, los cuales aparecen rodeados por delicados roleos, que se entrecruzan suavemente, adaptándose a las dimensiones y formas de este espacio. A cada uno de los lados, sobre elevado plinto, se alza una esbelta pilastra cajeada de orden compuesto, en la que aparece nuevamente la decoración floreada cubriendo su fuste. Entre ellas se dispone un sencillo entablamento de formas clásicas, con el friso completamente liso y airosa cornisa, con el que se da paso al remate. Éste aparece formado por una venera central rodeada por un fino bocel y roleos entrelazados en el exterior, exactamente igual a lo que vimos en el sepulcro conservado en la iglesia de Castrillo de la Reina, y dos pequeños balaustres en los extremos, en correspondencia con las pilastras inferiores. Todo el conjunto destaca por su gran planitud, con un escaso resalte sobre el muro, a lo cual se une la fina decoración elaborada mediante elementos vegetales, que llega a cubrir prácticamente por completo toda la estructura. Se trata, en definitiva, de una obra sumamente representativa, a pesar de su sencillez, de la tendencia plateresca, que dominó en gran medida el panorama artístico de estas Díocesis de Burgos y Osma a lo 
PALACIOS DE LA SIERRA. Iglesia de Santa Eulalia. Portada.

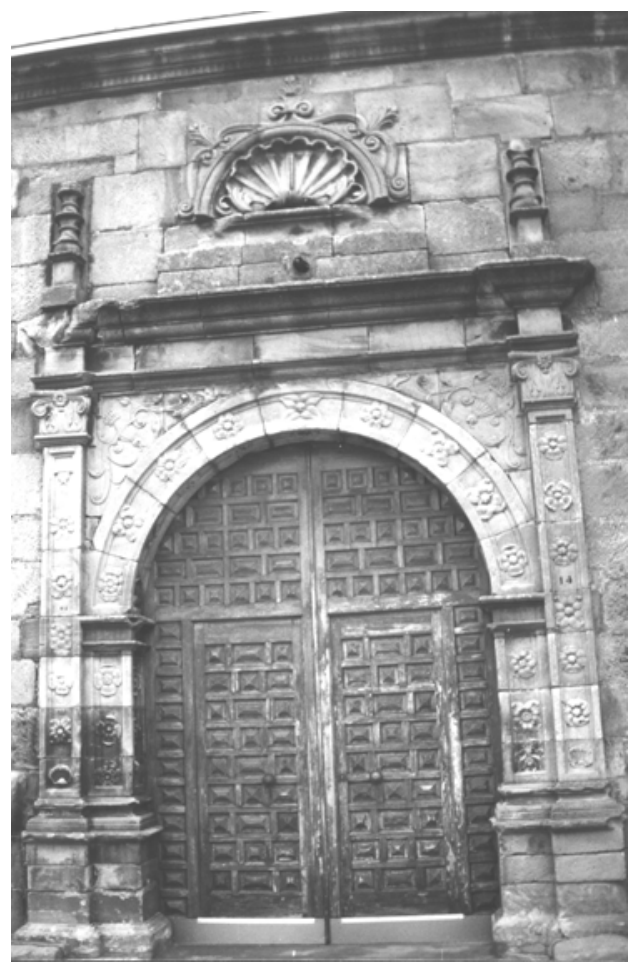

largo de toda la primera mitad del siglo XVI, pero que tan poco éxito tuvo en la zona. Sobre su autoría, nuevamente volvemos a desconocer los nombres de los posibles artífices que participaron en su diseño y elaboración, sin embargo, y a pesar de todo, resulta relativamente fácil relacionarla con algunas otras obras realizadas dentro del marco de la Diócesis de Osma, a la que pertenecía esta parroquia, entre las que destaca, de modo especial, la levantada en la concatedral de San Pedro de la ciudad de Soria.

Un último ejemplo de este tipo de construcciones lo encontramos en la iglesia parroquial de Barbadillo de Herreros. En este caso, la portada, que se conserva sobre el muro meridional de su nave, constituye el único resto perteneciente a este periodo, exceptuando la cabecera, que como ya señalamos en su momento, fue remodelada por completo entre los últimos años del siglo XV y principios del XVI. Sobre el resto de las obras entonces emprendidas más bien nada es lo que podemos conocer con certeza. Aun con todo, y a partir del tipo de contrafuertes, que, en parte, todavía se conservan sobre 
BARBADILLO DE HERREROS. Iglesia de Nuestra Señora de la Visitación . Portada.

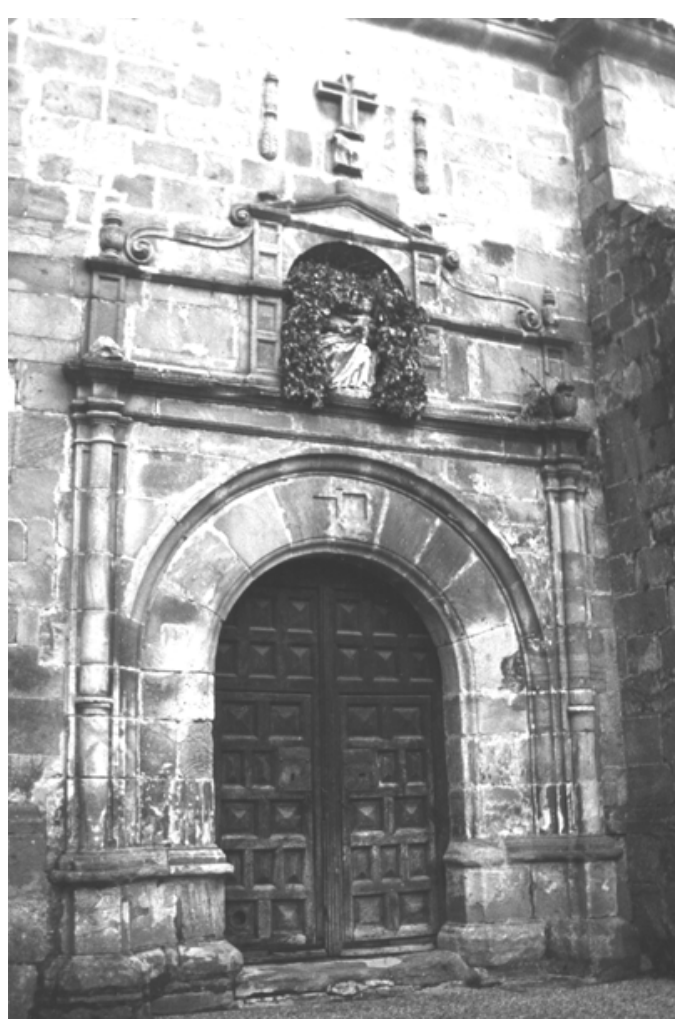

este muro meridional del templo, resulta fácil pensar que éste, como otros que ya hemos visto, pudo haber vivido un periodo de intensa actividad constructiva a lo largo de la centuria, desarrollando unas formas estrictamente góticas. Así, la incorporación de esta portada renacentista, se entiende, al igual que en los casos anteriores, como la culminación de una gran obra, a la cual era necesario dar un toque de modernidad.

En esta portada nos volvemos a encontrar las formas sobrias y depuradas del renacimiento más avanzado, del que ha desaparecido ya el manto ornamental del plateresco. Su estructura, sin embargo, sigue mostrando una singular planitud en su composición, con un ligerísimo resalte sobre el muro, que apenas introduce contrastes lumínicos, convirtiéndose en definitiva en uno de los rasgos definidores dentro de estas obras más modestas, realizadas en el mundo rural. Su estructura presenta un gran arco central, de arista redondeada, trasdosado con una gruesa moldura mixta de tipo gola, 
con la que se delimita una potente rosca completamente lisa, que se continúa sin interrupción por las jambas. Escoltando este vano, a los lados, y sobre un elevado plinto, se dispone un conjunto de retropilastra cajeada de orden toscano, y estilizada columna superpuesta de fuste fino, dividido en su tercio inferior por un anillo, y capitel en el que se repite el mismo orden toscano que en la pilastra. Sobre ellos se dispone un friso completamente liso, y una cornisa de escaso resalte, de perfil ligeramente quebrado en los extremos, con el que se da paso al remate. Este cuerpo se encuentra formado por una pequeña hornacina central con arco de medio punto, donde se coloca la imagen de la Virgen con el Niño, escoltada por pilastras tableteadas en los lados y un pequeño frontón triangular en su parte superior, con los extremos ligeramente quebrados. Desde los vértices laterales de este frontón, a su vez, surgen pequeños roleos, finamente trabajados, que unen esta parte central con dos pequeños netos dispuestos en los extremos, formando una especie de aletones.

Representa, en consecuencia, una obra modesta y sumamente sobria en su composición, pero al mismo tiempo original, en cuanto al lenguaje empleado, pues como venimos señalando, la singularidad de estas obras no radicaba tanto en su perfección técnica, ni en su valoración estética, como en su capacidad para innovar. Este hecho en ningún caso debe ser despreciado o minusvalorado dentro de un área como ésta, donde el estilo gótico era aceptado comúnmente como la solución más válida. 


\section{S. XVII: LA LLEGADA DEL CLASICISMO.}

El panorama arquitectónico, que se vive en esta comarca de la Sierra burgalesa, durante esta centuria, se ve presidido por una moderada actividad constructiva. Así, por una parte, aunque se encuentre lejos de alcanzar el brillante impulso creador, que se había vivido entre los años finales del siglo XV y primeras décadas del XVI, por otra, consigue recuperarse del virtual estancamiento en el que se había visto sumida durante la mayor parte de la segunda mitad del Quinientos.

A este escaso incremento de la actividad constructiva contribuyeron diferentes factores, entre los que no debemos olvidar los de orden estrictamente económico, relacionado con el clima de decadencia generalizada que se vivió en este campo, limitando el desarrollo de nuevos impulsos creadores. No obstante, la razón fundamental para que no podamos hablar de un auténtico despegue en el ámbito de la arquitectura, la encontramos en la gran actividad constructiva que se había vivido durante las primeras décadas del siglo XVI, haciendo que la demanda de nuevos edificios, o de renovación y ampliación de los ya existentes, apenas existiera.

Aun con todo, siempre que las necesidades impusieron una remodelación, que propiciara la ampliación de un templo, o incluso su completa renovación, no se dudó un instante en acometer el proyecto. Por ello, en esta zona de la sierra parece acertado descartar los factores estrictamente económicos como uno de los principales condicionantes de la mengua de la actividad constructiva, obligándonos a dejarlos a un segundo plano. Esta afirmación se confirma con los datos expuestos en los capítulos 
dedicados al análisis de la economía y la población, de los que se desprende, que esta comarca consiguió hacer frente, de forma aparentemente satisfactoria, a los envites más duros de la crisis económica y el descenso demográfico, que en general se vivieron en el resto de las comarcas burgalesas ${ }^{664}$, pues aquí no existía una dependencia tan directa de la estabilidad agraria ${ }^{665}$.

El desarrollo de la actividad constructiva, por lo tanto, transcurre de un modo aparentemente uniforme a lo largo de toda la centuria, sin que podamos destacar momentos en los que se vive una especial fiebre por edificar, frente a otros en los que se produce un claro estancamiento. Esto podría ser un síntoma de la aparente calma, que se vive durante este siglo (a pesar del clima generalizado de crisis), sin embargo, frente a ello tenemos que hacer notar también la imposibilidad que encontramos en muchos casos para fechar con precisión y rotundidad diversas obras, que por las formas desarrolladas en ellas, no tenemos ninguna duda que fueron levantadas entonces.

Otro rasgo característico del siglo XVII en esta comarca es que, al igual que ocurría durante el siglo XVI, nos volvemos a encontrar con un marcado predominio de la arquitectura de carácter religioso sobre la civil. Así, mientras esta última continúa sumida, en general, dentro de los rasgos y morfología propios de la arquitectura popular, la de ámbito religioso es la única que manifiesta en su concepción una preocupación clara por reflejar ciertos valores estéticos, así como por desarrollar los rasgos característicos de los estilos artísticos dominantes.

No obstante, y a pesar de la menor representación de las preocupaciones artísticas en la arquitectura civil, ésta comienza a experimentar un importante salto cualitativo a lo largo de la centuria. De este modo, ya desde los primeros momentos del siglo, nos encontramos con algunos ejemplos de residencias en las que se empiezan a

664 A. GUTIÉRREZ ALONSO: "La economía y la sociedad burgalesa durante la época Moderna”. En Historia de Burgos, desde sus orígenes hasta nuestros días. Tomo 2. Desde el año 1000 a los Tiempos Modernos. Burgos, Diario 16 Burgos. 1993. (pp. 627 - 638). 
mostrar unos sutiles, pero evidentes, rasgos compositivos y ornamentales claramente diferenciados del resto de la gran masa de la arquitectura popular, evidenciando unas claras inquietudes, en sus propietarios y promotores, por cuidar también los aspectos estéticos. Estas construcciones no sólo van aumentando en número a medida que avanza el siglo, sino que además constituyen la base de las tipologías más representativas de los edificios, que más tarde se van a desarrollar, alcanzando su momento culminante en el siglo siguiente.

Mientras tanto, como decimos, la arquitectura religiosa continúa siendo el principal escenario en el que se plasman los diferentes gustos artísticos del momento. De tal modo que, tanto los templos parroquiales como las ermitas donde se custodian las imágenes más veneradas, siguen siendo el lugar elegido por las comunidades de estos pueblos para mostrar su pujanza e inquietudes expresivas.

Por el contrario, y frente a toda la serie de aparentes coincidencias con respecto al período final del siglo XVI, esta nueva centuria aporta, como novedad más destacada dentro del panorama constructivo, la adopción de un lenguaje artístico completamente nuevo, el cual consigue acabar con el dominio, que hasta el momento había mantenido el estilo gótico.

Pero este cambio estilístico no se produjo de un modo tan radical como podemos imaginar, pues son muchos los aspectos y elementos característicos del estilo anterior, que se mantienen, sin experimentar grandes cambios. De esta forma, la estructura de los templos, tanto en el diseño de sus plantas, como en el alzado y composición volumétrica, apenas muestran cambios realmente significativos, que nos deban llamar la atención. De igual modo, dentro de los sistemas de cubiertas la bóveda de crucería estrellada con terceletes continúa siendo la solución más empleada.

665 Ver capítulos de Economía y Población. 
Esto nos muestra, nuevamente, el fenómeno de encabalgamiento estilístico, que, en gran medida, caracteriza el desarrollo de la arquitectura de la zona a lo largo de toda la Edad Moderna.

Esta nueva estética, que es la propia del clasicismo, concepto para cuya denominación se han utilizado diferentes términos, como escurialense, herreriano o posherreriano, trentino, protobarroco, barroco clasicista, o estilo desornamentado, entre otros. Algunos de ellos, como es el caso del término herreriano, fue duramente criticado en diferentes momentos, al cuestionarse la paternidad del propio Juan de Herrera en la obra que sirve de referente, como es el Monasterio de El Escorial ${ }^{666}$. Camón Aznar, por su parte, se inclina por el término trentino, para denominar a este estilo $^{667}$, el cual es aceptado igualmente por Juan José Martín González, empleándolo indistintamente, junto con la denominación escurialense. Agustín Bustamante García, sin embargo, en sus estudios sobre la arquitectura de este período en la zona de la Meseta Norte castellana se decanta por el término clasicismo, como denominación más adecuada, pues se trata, en definitiva, de un estilo complejo, constituido por las aportaciones de diversos artistas de amplia y variada formación teórica, cuyo denominador común se encuentra en la imitación de lo antiguo, de lo romano ${ }^{668}$.

Esta arquitectura se caracteriza por mostrarnos edificios concebidos con un claro sentido unitario, respetando, dentro del conjunto, la personalidad y significado de cada elemento. Esta concepción se mantiene igualmente incluso en aquellas construcciones, que se incorporan a edificios ya existentes, pues en ellas se representan las proporciones e incluso algunos elementos del estilo anterior, en favor de una perfecta adecuación. Dentro de los edificios levantados durante este período encontramos, en la mayoría de los casos, unas composiciones equilibradas, de cuidadas proporciones y perfectamente

\footnotetext{
666 A. PORTABALES PICHEL: Los verdaderos artífices de El Escorial y el estilo indebidamente llamado herreriano. Madrid. 1945.

667 J. CAMÓN AZNAR: El estilo herreriano. En RIE nº 12 Madrid (1945). pp. 429 y ss.

668 A. BUSTAMENTE GARCÍA: La arquitectura clasicista en el foco vallisoletano: 1561 - 1640. Valladolid, Instituto Simancas. 1983. (pp. 529 y ss.).
} 
ordenadas, las cuales se apoyan en el empleo del trazado cuadriculado y en la máxima severidad ornamental. Esto se complementa con un dominio total de la línea recta, tanto en planta como en alzado, unas superficies completamente lisas en los muros, en los que no se dan bruscos contrastes lumínicos, y una especial valoración de las masas y los volúmenes, concebidos como prismas perfectos, que se convierten en los grandes protagonistas de su imagen exterior.

Este rigor estructural se complementa con una auténtica depuración en los aspectos ornamentales, los cuales quedan reducidos a sencillos elementos heredados de la arquitectura de finales del Quinientos, como placas de trazado rectilíneo y escaso resalte, pirámides, pináculos de bola y cadenetas (estas últimas prácticamente inexistentes en la comarca de la sierra). Queda excluida, por lo tanto, la verbosidad y acumulación de ornamentos propios del pleno barroquismo, lo cual se refleja únicamente en obras muy concretas, desarrolladas ya en un momento ciertamente avanzado de la centuria.

Por lo tanto, los valores defendidos en El Escorial, con el toque propio de simplificación, que se imprime en las áreas rurales, pasan a convertirse a partir de este momento, y prácticamente hasta el final de la Edad Moderna, en norma incontestable, dentro de la arquitectura serrana. Se trata, en definitiva, de un estilo sobrio, severo, sencillo de desarrollar, aparentemente económico (pues no ofrece grandes complicaciones técnicas, ni estéticas), y con ciertas gotas de rusticidad, que en nuestro caso, aparecen convenientemente acentuadas.

Todo esto hace que su adaptación a los gustos y posibilidades de una zona, como es la de la sierra burgalesa, no sólo se produzca de forma inmediata, sino también de un modo sumamente duradero. Por ello, no sólo se consigue desbancar el domino que el estilo gótico tenía dentro de esta arquitectura (manteniéndose, eso si, aquellos elementos especialmente válidos para los gustos de los comitentes y las capacidades de los artífices), sino que con su actitud conservadora, consigue perpetuarse, hasta exceder de 
forma holgada los límites cronológicos, que presenta en otras zonas. Sólo así podemos explicar la realización, a finales del siglo XVIII, de obras como el nuevo campanario, que se construye en la iglesia parroquial de Barbadillo de Herreros, en el cual las formas escurialenses se desarrollan con tal perfección, que parecen una copia casi literal de las dos torres, que Francisco de Mora realiza, en los últimos años del siglo XVI, para la iglesia de San Bernabé en El Escorial de Abajo.

El arraigo tan fuerte, que se produce de estas formas, llega a evitar incluso que podamos establecer una diferenciación clara entre los distintos períodos, que se viven dentro del siglo XVII, o entre la arquitectura que se produce en esta centuria y la siguiente. Solamente en algunos casos muy concretos, desarrollados ya a finales de esta centuria o en pleno siglo XVIII, podemos llegar a encontrar un desarrollo perfecto de los conceptos y formas propios de la estética del pleno barroco.

Este apego a la severidad clasicista, por otra parte, no evita, sin embargo, que en el interior de los templos se levanten espectaculares y complicados conjuntos retablísticos de movidas estructuras y ostentosa decoración barroca. Con lo cual, la barroquización de los espacios, aunque en muchos casos no hubieran sido modificados en su estructura arquitectónica (manteniéndose la fábrica gótica o incluso románica), sí llego a producirse, en cierta manera, de la mano del arte mueble.

En definitiva, podemos decir que el estilo clasicista, al cual se suman determinados elementos, que perduran de la etapa anterior gótica, llega a convertirse en el lenguaje más representativo de la arquitectura de la comarca de la sierra burgalesa, encauzando de modo perfecto los deseos y necesidades expresivos de sus habitantes, y contribuyendo a constituir, en muchos casos, su imagen definitiva y más característica. A esto último contribuye, no sólo el gran número de edificios de nueva planta, que se levantan durante esta fase final de la Edad Moderna (especialmente en el siglo XVIII), sino también el hecho de constituir la última fase constructiva en la mayoría de las iglesias parroquiales, cuyas fábricas son el resultado de una larga génesis, en la que se 
han ido acumulando elementos y rasgos de cada uno de los períodos vividos anteriormente.

La llegada de las nuevas formas a la arquitectura de la zona se produce fundamentalmente a través de la influencia emanada de los principales focos, en los que se desarrollaba este estilo. No obstante, tampoco debemos menospreciar otras vías, no menos importantes, como pudiera ser el caso de los maestros, que trabajan primero en estos focos para luego, más tarde, terminar participando en obras de esta comarca, o de forma más directa, a través del papel desempeñado por los Maestros Mayores de las respectivas Diócesis, que se reparten este territorio.

Dentro de los centros rectores de este estilo, Valladolid se había convertido en el principal foco creador y difusor de la arquitectura clasicista desde finales del siglo XVI en toda el área de la Meseta Norte castellana. A ello contribuyeron una serie de circunstancias, como la reconstrucción de la ciudad tras el incendio de 1561, el inicio de las obras de construcción de la catedral, diseñada por Juan de Herrera, el traslado de la Corte durante los primeros años de este siglo XVII, o el asentamiento de una larga lista de maestros, que no sólo difunden estas formas, sino que las llevan hasta sus más altas $\operatorname{cotas}^{669}$.

El otro gran foco rector del clasicismo se encuentra representado por la propia Corte, el cual tiene su reflejo en la provincia de Burgos, a través de una de sus más destacadas creaciones, como es el conjunto palacial y monástico de la villa de Lerma, mandado construir por el valido de Felipe III, D. Francisco Gómez Sandoval y Rojas, duque de Lerma. Dentro de este conjunto, aparte del propio palacio ducal y la estructura urbanística desarrollada en su entorno, destacan igualmente la serie de conventos que lo acompañan, entre los que podemos citar el de la Asunción y el de San Blas. En todas

669 A. BUSTAMANTE GARCÍA: La arquitectura clasicista en el foco vallisoletano... ob. cit.; A. RODRÍGUEZ G. DE CEBALLOS: Arquitectura barroca en Castilla y León. Siglos XVII y XVIII. 
estas construcciones se desarrollan estructuras de gran clasicismo, presididas por una extraordinaria simplicidad de formas, que no queda exenta de una gran elegancia. No obstante, el aspecto más destacado lo encontramos en la participación en su diseño de los más afamados e insignes artistas del momento, ligados a este foco cortesano, entre los que se encuentran, Francisco de Mora, Juan Gómez de Mora o Fr. Alberto de la Madre de Dios.

Aun así, y a pesar de todo, no parece que este conjunto de Lerma tuviera una repercusión demasiado importante, dentro de la arquitectura del ámbito burgalés en general $^{670}$. Así, en la comarca de la sierra en concreto, no creemos descubrir un reflejo explícito de estas formas desarrolladas en Lerma, quizás, sobre todo, por no ajustarse a los gustos y necesidades que aquí existen. La única excepción, que mínimamente se acerca a estas formas, la encontramos en la remodelación de la zona del cuerpo, que se lleva a cabo en la iglesia de la parroquia de San Miguel, en Neila, dentro de la cual destaca, de modo especial, su nueva fachada principal.

Por ello, debemos pensar que la auténtica repercusión que este foco tiene dentro del panorama arquitectónico burgalés, y en concreto en nuestra comarca de estudio, no debemos buscarlo en la imitación de los modelos aquí desarrollados, sino en la utilización de determinados elementos y piezas, introducidas en estas obras, y muy especialmente en la implantación de unas nuevas técnicas de trabajo, que rápidamente son asimiladas por los canteros locales.

Más próximos a nuestro entorno se encuentran dos focos, que sin duda alguna, tienen una repercusión mucho más directa en la llegada de la nueva estética. Nos

\footnotetext{
Salamanca, Ediciones Colegio de España. 1996. (pp. 20 y ss.); F. CHUECA GOITIA: Historia de la arquitectura occidental. Tomo VII. Barroco en España. Madrid, Editorial Dossar. 1985. (pp. 58 - 61).

670 R. J. PAYO HERNANZ: "Aproximación al estudio de la arquitectura clasicista protobarroca en Burgos y su comarca en el siglo XVII”. En Juan de Herrera y su influencia: actas del Simposio: Camargo 14 / 17 Julio 1992. Santander, Fundación Obra Pía Juan de Herrera: Universidad de Cantabria. 1993. (pp. 251 - 259).
} 
estamos refiriendo a los monasterios de San Pedro de Arlanza y Santo Domingo de Silos. Se trata de dos cenobios, situados en las inmediaciones de la sierra, que habían vivido su primera etapa de esplendor entre los siglos XI-XII ${ }^{671}$, debilitándose posteriormente, para experimentar una extraordinaria revitalización a partir del siglo XVI, lo cual se manifiesta con la puesta en marcha de un intenso plan constructivo, que se desarrolla entre los siglos XVII-XVIII, modificando prácticamente por completo la fisonomía de ambos centros.

Esto se traduce, en el caso de San Pedro de Arlanza, en la construcción de una nueva sacristía, la renovación del llamado Claustro Procesional (eliminando para ello el primitivo de estilo románico), una escalera monumental sobre el espacio de la antigua sala capitular, y la creación de una amplia serie de nuevas estancias en la parte oriental del monasterio, donde se incluye la fachada principal, portería, y un pequeño patio con el que articular gran parte de estos espacios recién levantados. Todo ello fue construido en un breve espacio de tiempo de apenas treinta años, que es el tiempo que transcurre entre la renovación del Claustro Procesional (1617), y la culminación de la fachada principal $(1647)^{672}$.

El monasterio de Santo Domingo de Silos, por su parte, se muestra algo más tardío en la realización de sus empresas más importantes, concentrándose éstas entre las décadas finales del siglo XVII y el primer tercio del XVIII. Destacan entre ellas, la llamada escalera de los leones, el patio de San José, la cámara del Santo y de modo especial la capilla del Santo, culminando todo este proceso, ya en el último cuarto de

671 J. VALLEJO BOZAL, M. D. TEIJERIA PABLOS: "Fuentes para el estudio de la iglesia del Monasterio de San Pedro de Arlanza. En los inicios del románico pleno en España”. En BMAA, $n^{\circ} 1-2$. Madrid. (1995). (pp. 55 - 70).

672 E. CARRETERO SANTAMARÍA, V. GONZÁLEZ DE CASTRO: “Arquitectura clasicista en Burgos: noticias documentales de la obra de Pedro Díaz de Palacios en San Pedro de Arlanza (1629 1659). En Anuario del Departamento de Historia y Teoría del Arte. (UAM). nº 5, (1993). (pp. 111 - 119). 
esta centuria del Setecientos, con la renovación de la iglesia monástica, que supone la eliminación del primitivo templo románico ${ }^{673}$.

La repercusión que estos dos conjuntos, y de modo especial el de San Pedro de Arlanza, por ser el más temprano en su remodelación, pudieron llegar a tener en el panorama arquitectónico de la sierra no sólo resulta algo incuestionable, sino que además alcanzó un gran calado. Sólo así podemos llegar a entender la rápida llegada y asimilación de la estética clasicista, dentro de una zona tan sumamente apartada de los grandes centros artísticos del momento, como es esta comarca, más aun, cuando al final de la centuria anterior apenas se habían dejado ver estas nuevas formas.

A todo ello contribuyó de manera especial, evidentemente, la llegada de maestros formados dentro de este nuevo lenguaje, los cuales, atraídos por los proyectos que se estaban llevando a cabo en estos cenobios, acuden a trabajar aquí, para terminar más tarde participando en las diferentes obras realizadas dentro de estos pueblos. La lista de artistas, que, siguieron este proceso, es tan amplia, que resulta, de por sí, sobradamente esclarecedora ${ }^{674}$.

Esto nos lleva a hablar de la segunda vía de penetración de estas formas clasicistas, representada por la serie de maestros que trabajan en diferentes obras de cada uno de estos focos, bajo las órdenes de los más destacados representantes del estilo, para luego, más tarde, participar en diversos proyectos, realizados en esta comarca. Lógicamente, por su proximidad, tanto Lerma como los monasterios de Arlanza y Silos, se convierten en los principales lugares, que sirven de auténtica escuela para la mayor parte de los maestros, que más tarde trabajan en estos pueblos,

673 C. J. PALACIOS PALOMAR: Patrimonio artístico y actividad arquitectónica del monasterio de Santo Domingo de Silos (1512 - 1835). Santo Domingo de Silos, Milenario de Santo Domingo de Silos (1000 - 2000). Abadía de Silos. 2001.

674 O. MORAL GARACHANA: "La arquitectura de Silos en su entorno durante el periodo barroco". En Silos. Un milenio. Actas del Congreso Internacional sobre la Abadía del Santo Domingo de Silos, octubre de 2001. Burgos, Universidad de Burgos - Abadía de Silos. 2003. (pp. 615 - 621). 
independientemente de sus capacidades técnicas y reconocimiento profesional. La mayoría de estos maestros, como ya señalamos en su momento, son de origen trasmerano, contando con una sólida formación técnica, adquirida en el seno de sus cuadrillas.

Por último, junto a estos artífices, tampoco debemos pasar por alto el papel desempeñado por los diferentes Maestros Mayores de las respectivas Diócesis, en la penetración y consolidación de las formas clasicistas. Su responsabilidad, en este caso, radica en su participación en el diseño de muchas de las construcciones, que se realizan en el territorio de sus Diócesis, bajo los auspicios de las autoridades eclesiásticas, dando trazas y condiciones, especialmente para aquellos proyectos más importantes, donde sus dimensiones, o lo delicado de la intervención, hacían precisa la participación de estos maestros en calidad de Veedores.

Su labor venía avalada por las respectivas Constituciones Sinodales de las Diócesis de Burgos y Osma, las cuales, como vimos en su momento, habían sido aprobadas a finales de la centuria anterior, llevándose a la práctica sus postulados en su integridad a partir de este momento. De la mano de estos maestros, por lo tanto, comienzan a llegar a las zonas apartadas los rasgos propios de este nuevo lenguaje, trasladándose por esta vía la influencia que las propias sedes diocesanas tienen en sus respectivos territorios en materia artística. De esta forma, y enlazando con la primera vía de penetración de las formas clasicistas, que hemos señalados, tenemos que incluir también aquí la contribución realizada por cada uno de estos centros diocesanos. Todo ello, a pesar de la relativa importancia, que tanto Burgos como el Burgo de Osma y Soria, tienen como centros artísticos destacados, durante los siglos XVII y XVIII.

La falta de documentación no siempre nos permite confirmar esta relación, si bien, la coincidencia de fechas, en la ejecución de algunos proyectos, con la presencia, al frente de estos cargos, de determinados maestros, cuyas formas quedan reflejadas en estas obras, terminan por evidenciar los lazos de los que hablamos. Así, por ejemplo, 
podemos situar a Juan de Naveda detrás de obras como la renovación de la iglesia de San Cristóbal, en Quintanar de la Sierra, o la construcción del campanario de la iglesia de Santa María, en Salas de los Infantes. A Fr. Pedro Martínez, igualmente, podemos relacionarlo con la remodelación acometida en la iglesia de la parroquia de San Martín, en Huerta de Arriba, y con la construcción de la iglesia parroquial de Tolbaños de Arriba. Y ya con un respaldo documental, podemos igualmente confirmar la participación de Domingo de Ondátigui, en calidad de Maestro Mayor del Obispado de Osma, en la construcción del nuevo crucero, que se realiza en la iglesia de Vilviestre del Pinar, en la segunda mitad del siglo XVIII ${ }^{675}$.

\section{Arquitectura religiosa. Siglo XVII.}

Las principales construcciones, que se realizan en esta zona de la sierra a lo largo de este siglo XVII, se producen dentro del ámbito religioso. Por ello, dentro del recorrido, que a continuación pasamos a realizar, es lógico que comencemos con ellas.

Dentro de estas construcciones destacan de manera especial, como es lógico, las realizadas dentro de los templos parroquiales. Sin embargo, en este campo tampoco debemos desdeñar las acometidas en algunas ermitas, que por sus dimensiones y posibilidades, bien podrían equipararse con aquellas. Las construcciones realizadas en todos estos edificios, empero, conocieron un desarrollo moderado durante esta centuria, pues a las limitaciones económicas, que tradicionalmente vivieron muchas de estas parroquias se sumaba el hecho de que la mayoría de los pueblos contaban ya con unas fábricas parroquiales recién remodelada y capaces de satisfacer las necesidades de culto de sus feligreses. En cualquier caso, debe quedar claro que las estrecheces económicas nunca constituyeron un impedimento insalvable, aunque si un duro condicionante.

\footnotetext{
675 A. Parr. Vilviestre del Pinar, LP, Vilviestre del Pinar, parroquia de San Martín, LF. (1755 y ss.). (fols. 23 - 26vº ). Cuentas del año 1756. Vilviestre del Pinar 8 - febrero - 1757.
} 
Aun así, existen diversas excepciones, las cuales vienen a confirmar la menor repercusión, que en esta comarca tuvo la crisis generalizado, que se vivío en el resto de la provincia, la cual alcanzó uno de sus momentos culminantes en el primer tercio del siglo. Se pueden citar, de este modo, ejemplos como las ampliaciones efectuadas en los templos de Hacinas, Palacios de la Sierra, Vilviestre del Pinar o San Miguel, en Neila, donde se incrementa de modo considerable el espacio disponible. Igualmente, aparecen numerosos ejemplos de construcciones de diversas piezas, como portadas, torres, sacristías, coros, atrios, etc., que se incorporan a edificios ya existentes. Y por supuesto, encontramos fábricas de nueva planta, o remodelaciones íntegras de templos anteriores, como sucede en las parroquiales de Quintanar de la Sierra, Huerta de Abajo y Bezares.

Obras, todas ellas, encaminadas a renovar, pero sobre todo a engrandecer sus edificios religiosos, a través de las cuales los habitantes de estas localidades encontraban su principal vía de expresión, para manifestar al mundo su vigor y sus posibilidades de acometer grandes proyectos. Por ello, un papel importante, dentro de todas estas empresas, lo tienen los propios responsables de cada una de las parroquias y santuarios, como impulsores de las obras, pero también, y no menos destacada es la participación de vecinos, feligreses, concejos y demás instituciones, que vuelcan en estas iniciativas todos sus esfuerzos y gran parte de sus recursos.

Los edificios ahora realizados siguen en general un esquema prácticamente similar al desarrollado en el siglo anterior, pues el Concilio de Trento, cuyos postulados habían sido difundidos por las respectivas Constituciones Sinodales y estaban llevándose a la práctica, no había tomado ningún tipo de disposición concreta sobre la arquitectura religiosa, que hiciera referencia a la organización u ordenación de los templos ${ }^{676}$. Las únicas alusiones, en cuestiones de este tipo, son las que hacen referencia al decoro, que deben guardar estos edificios, donde se indica, que todas las iglesias debían presentar un aspecto exterior e interior digno, procediendo a su reparación

676 A. CÁMARA MUÑOZ: Arquitectura y sociedad en el Siglo de Oro. Madrid, Ediciones el Arquero. 1990. (pp. 134 y ss.). 
siempre que fuera necesario ${ }^{677}$. Esto, sin embargo, traerá una importante repercusión dentro de nuestra comarca, pues un volumen importante de las obras, que se acometen durante esta centuria y la siguiente, estarán relacionadas con la reparación de edificios y su acondicionamiento, para dejarlos con la mayor decencia.

Con todo esto, vemos que en general no se muestra ningún tipo de tendencia hacia la experimentación, dentro de la concepción de los templos ahora levantados o remodelados, ofreciendo, por el contrario, un claro continuismo de los modelos tradicionales de planta de salón tipo “caja”, de una o tres naves, con un claro predominio de la central, como sucede en el caso de Quintanar de la Sierra. Estas plantas, de estricto trazado rectilíneo, se completan en su extremo oriental con una cabecera de planta cuadrangular muy poco profunda y con testero plano, la cual se corresponde, en los dos casos que tenemos de fábricas de nueva planta, con la torre a los pies. Esta torre, sin embargo, no incorpora su espacio al interior del templo, pues su parte interna aparece ocupada por la escalera de acceso a la parte superior, prescindiendo del tradicional husillo.

Se trata, por lo tanto, de edificios con una estructura de claro sentido longitudinal, lo que no impide, sin embargo, desarrollar una cierta idea o concepto de ámbito único. Su precedente se encuentra en los templos elaborados desde finales del siglo $\mathrm{XV}$, que se mantienen con un gran éxito a lo largo de todo este nuevo período que ahora se abre, pues no hay que olvidar su gran funcionalidad, que permite un fácil seguimiento de los oficios celebrados en el altar mayor. Lo que no nos vamos a encontrar, ni ahora, ni posteriormente en el siglo XVIII, es el desarrollo de planta estrictamente centralizadas u ovales, en las que se requiere un diseño notablemente más movido.

En los alzados, el muro continúa siendo el auténtico protagonista del edificio, manteniendo además las mismas técnicas constructivas, que se habían empleado

677 A. S. TESSARI: “Antonio Possevino e l’architettura”. En AHSI, año LII, fas. 104. (1983). 
anteriormente. De este modo, nos encontraremos con cuidadas estructuras de sillería, de piezas perfectamente escuadradas y ensambladas, con las que se forman buenos ejemplos de aparejo isódomo. Solamente en aquellas obras más humildes, y en algunos casos en la parte interior, aparecen paramentos de mampuesto y sillarejo, que luego eran convenientemente enlucidos. Aun así, en estos casos, los elementos activos del edificio, como pilastras, arcos, impostas y nervios de las bóvedas, continúan ofreciendo una cuidada sillería.

En la parte interior el tratamiento del muro es siempre muy simple, pues no aparece ningún tipo de trama rítmica, que articule su desarrollo de una forma preestablecida. Con lo cual, dentro de su absoluta planitud, sólo resaltan el entablamento, que marca el final de muro, generalmente formado por una simple línea de imposta plana de gran grosor y escaso resalte, y las pilastras adosadas, que dividen estos paramentos, reflejando los distintos tramos, que componen las naves.

Al exterior vemos como se suprimen los poderosos estribos, que sobresalían de forma pronunciada sobre la planitud del muro, para dar paso a otros de trazado cuadrangular y menor resalte. Al mismo tiempo, en las esquinas ya no adoptan una

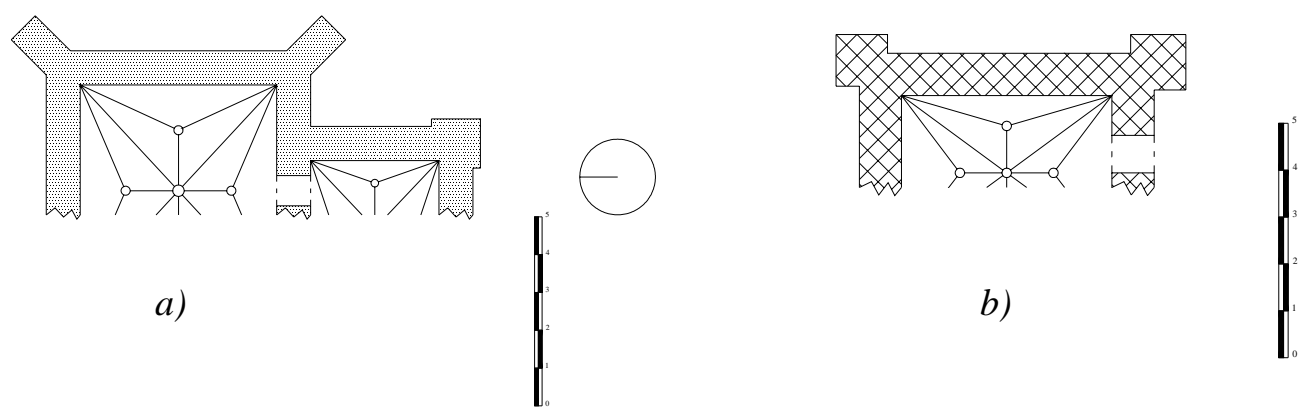

Disposición de los contrafuertes en las esquinas: a) Cabecera de la iglesia de San Esteban, en Castrillo de la Reina (S. XVI); b) Cabecera iglesia de Santa Cristina, Huerta de Abajo (S. XVII) 
disposición diagonal, sino que se colocan de forma perpendicular al muro y dispuestos en ángulo recto.

Los vanos, que se abren sobre los muros, están presididos por esta misma idea de sencillez. Así, las ventanas presentan un simple trazado rectangular adintelado, mostrando en algunos casos un ligero abocinado con derrame hacia ambos lados. En otros, este abocinado se sustituye por un grueso marco, formado por una moldura de escaso resalte con orejones. Las puertas, que marcan el acceso al interior del templo, por su parte, constituyen el único punto en el que se rompe esta tendencia a la desornamentación, dando lugar, como veremos, a una ligeras concesiones en este campo.

Con todo ello, la imagen, que estos templos proyectan hacia el exterior, consigue destacar únicamente por su limpia volumetría, donde se ofrecen severos conjuntos de recias masas prismáticas perfectamente perfiladas, mediante trazos y ángulos rectos, que se complementan a través de interesantes juegos de proporciones, establecidos entre los diferentes módulos.

La imagen interior, por su parte, continúa presidida por una evidente tendencia hacia el ámbito único, dentro del cual se singulariza claramente la zona correspondiente a la cabecera, que mantiene su independencia como el espacio más destacado dentro de todo el conjunto. Esta preponderancia se ve afianzada además por las propias Constituciones Sinodales, que tratan de llevar a la práctica los decretos y disciplinas trentinos, según las cuales se establece que el altar mayor fuese, a partir de ahora, el único sitio del templo en el que se venerase el Santísimo Sacramento ${ }^{678}$. Esto potencia el papel del altar mayor como eje vertebrador del espacio del templo, al mismo tiempo que afianza el sentido longitudinal del espacio camino. 
Dentro del espacio del cuerpo, un elemento que suele aparecer es el coro, el cual se encuentra situado, en todos los casos, en la zona de los pies y en alto, siguiendo así el esquema que gozaba de larga tradición, desde los últimos momentos del gótico ${ }^{679}$. En esta zona, y a lo largo de todo el siglo XVII, los coros se realizan generalmente en madera, con una gran viga transversal sobre la que descansa todo el entramado. No obstante, también existen casos en los que se desarrollan estructuras mixtas, con arco de piedra y superficie de madera, o incluso otras totalmente de cantería, con arco y bóveda sumamente rebajados.

En las cubiertas, con las que se cierran todos estos espacios, encontramos un claro dominio de la bóveda de crucería estrellada con terceletes de tradición gótica. La trama utilizada, en este caso, es la más básica, resultando difícil, aunque no imposible, encontrar la incorporación de nervios combados con los que se dibujan figuras en su interior, como ocurría en el siglo XVI. Las claves, por su parte, acogen pequeñas representaciones ornamentales de formas sencillas, en las que se dibujan, desde simples flores, adaptadas a esta superficie circular, hasta símbolos más complejos, alusivos a temas litúrgicos o a los santos titulares de los templos.

El dominio prácticamente absoluto de este tipo de cubierta ha sido interpretado tradicionalmente como un signo arcaizante y de apego a las viejas estructuras góticas,

678 A. RODRÍGUEZ G. CEBALLOS: "Liturgia y configuración del espacio en la arquitectura española y portuguesa a raíz del Concilio de Trento”. En Anuario del Departamento de Historia y Teoría del Arte. (UAM), nº 3, (1991). (pp. 43 - 52).

679 Se trata, por lo tanto, de un tipo de coro sumamente tradicional, que además venía avalado por las Sagradas Escrituras, pues según defendía Lázaro de Velasco, maestro mayor de la catedral de Granada, el coro debe estar inter vestibulum et altare. Esto, sin embargo, no deja de ser una pedantería, pues utiliza para ello una cita del libro del profeta Joel (Jl. 2, 17) completamente sacada de contexto, pues en realidad no hace alusión a la colocación del coro dentro del templo cristiano. M. GÓMEZ MORENO: “Juan de Herrera y Francisco de Mora en Santa María de la Alhambra”. En AEA, t. XIV (1940 - 41). (pp. 5). A. CÁMARA MUÑOZ: Arquitectura y sociedad ... ob. cit. (pp. 134 y ss.). A. RODRÍGUEZ G. DE CEBALLOS: “La arquitectura religiosa de Juan de Herrera y la Contrarreforma”. En Juan de Herrera y su influencia: actas del Simposio: Camargo 14 / 17 julio 1992. Santander, Fundación Obra Pía Juan de Herrera: Universidad de Cantabria. 1993. (197 - 203). 
propio de la arquitectura desarrollada en las zonas rurales y secularmente apartadas de los grandes focos artísticos del momento ${ }^{680}$. No obstante, en su defensa, no debemos menospreciar la propia capacidad de evolución y modernización, que encierra este tipo de cubierta ${ }^{681}$, a lo cual debemos sumar también la fiabilidad que inspiraba, dentro de los promotores y artífices de la zona, avalada por la solidez de las fábricas góticas conservadas hasta el momento. Por otra parte, tampoco debemos olvidar, especialmente en aquellas obras de renovación y ampliación de edificios ya existentes, el deseo de guardar la armonía con la estructura anterior, donde ya existía este tipo de cubierta. El absoluto predominio de estos abovedamientos hace que durante todo este siglo XVII apenas podamos encontrar otros modelos de cubiertas.

La única alternativa digna de mención, por lo tanto, la encontramos en las cubiertas de madera, formadas por armaduras de tipo par y nudillo, las cuales se usan en las construcciones más humildes, empleándose generalmente para cubrir la zona de la nave, pues para el presbiterio se utiliza una bóveda de piedra. Sin embargo, no debemos olvidar tampoco los ejemplos de artesonados de madera, en forma de artesa invertida, que podemos encontrar en algunos de estos templos, decorando su interior con complicados entrelazados, con los que se logra formar interesantes y bellas figuras geométricas. Dentro de este tipo de cubiertas, sin duda, la más destacada, por lo complicado de su diseño y sus amplias dimensiones, fue la construida para la nave central de la iglesia de Vilviestre del Pinar, tras su remodelación de 1649. A pesar de que el deterioro sufrido por el paso del tiempo obligó a sustituirla por una réplica en la década de 1990, la reproducción ha conseguido imitar fielmente el modelo original. Junto a ella podemos citar también los ejemplos de la iglesia de Santa Eugenia, en Terrazas, y el de la ermita de la Vera Cruz, en Canicosa de la Sierra, en los cuales este tipo de cubierta se utiliza para cerrar el espacio de la cabecera. La estructura desarrollada, sin embargo, sigue siendo la misma de artesa invertida. Sin duda, se trata

\footnotetext{
680 R. J. PAYO HERNANZ: “Aproximación al estudio de la arquitectura clasicista protobarroca en Burgos...” ob. cit.
} 
de uno de los elementos más singulares de la arquitectura de la comarca de la sierra durante esta centuria, continuándose aquí la mejor tradición de los alarifes mudéjares.

En cuanto a los elementos sustentantes, el tipo de arco comúnmente usado durante todo el siglo es el de medio punto, de gran potencia, con sección rectangular e intradós plano, que en muchos casos aparece recorrido por un sencillo cajeado. Esto no evita que en aquellos casos en los que es necesario incrementar la altura de la cubierta se varíe ligeramente este trazado, dando lugar a arcos peraltados o incluso apuntados. Aun así, dentro de todos ellos se mantiene el mismo tipo de sección, que ya hemos indicado. Estas variaciones se producen especialmente en aquellas obras de ampliación o incorporación de nuevas piezas a un edificio anterior, en los que las cubiertas del nuevo espacio deben alcanzar un determinado nivel. Por lo tanto, en ningún caso

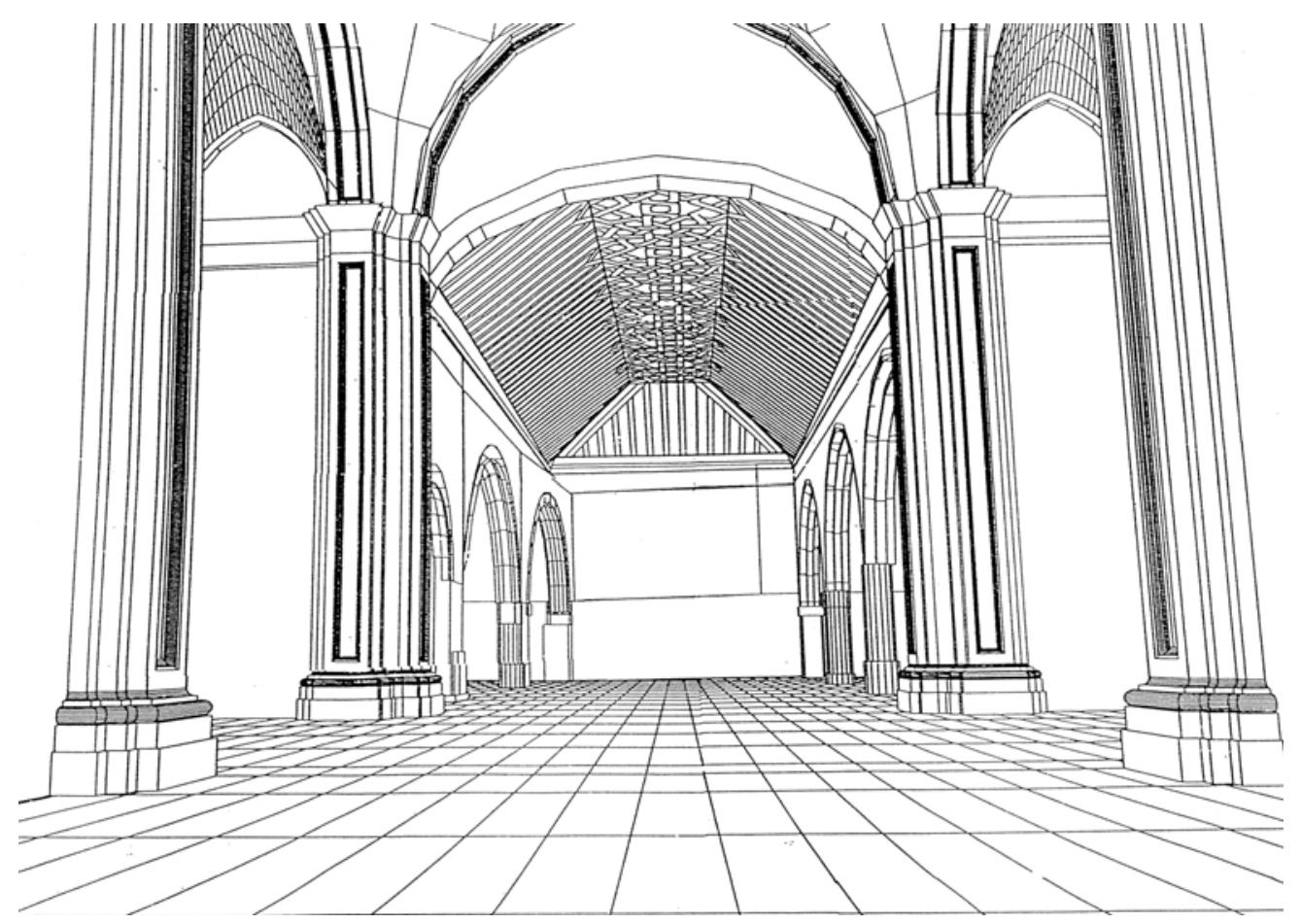

VILVIESTRE DEL PINAR. Iglesia de San Martín. Proyecto de restauración de la cubierta de la nave central.

681 J. GÓMEZ MARTíN: El gótico español de la Edad Moderna. Bóveda de crucería. Valladolid, Secretariado de Publicaciones e intercambio científico. Universidad de Valladolid. 1998. 
debemos considerarlo como un arcaísmo, ya que se trata de una solución constructiva, que ya había sido empleada con anterioridad para resolver determinadas situaciones de tipo similar. Este tipo de soluciones se mantiene igualmente a lo largo del siglo XVIII en algunos de los templos de la zona, recurriendo a ellas siempre que era necesario.

En lo que se refiere a los soportes, el tipo más común, en aquellas fábricas de varias naves, es el pilar exento de núcleo cuadrangular, frenteado por pilastras cajeadas de orden seudo-dórico o toscano, o rematadas simplemente con una sencilla línea de imposta de escaso resalte, que cumple la función de capitel. En los muros se repite igualmente este tipo de pilastras, incorporando en estos casos pequeñas ménsula, prácticamente sin decoración de ningún tipo, a ambos lados de su parte superior, para recibir los nervios de las bóvedas. Brillan por su ausencia, por lo tanto, las columnas salomónicas y los estípites, considerados como los soportes más típicamente barrocos. Estos únicamente aparecen en los retablos con los que se ornamenta el espacio interior. De igual forma, tampoco aparecen las columnas de órdenes clásicos, las cuales únicamente las encontramos en casos muy concretos, como las incorporadas en la estructura de ciertas portadas.

Con todo esto, se logra un espacio interior caracterizado, en líneas generales, por su extremada austeridad, la cual, sin embargo, se irá superando a medida que avanza este siglo y nos internamos en la centuria siguiente, con la incorporación de los grandes conjuntos retablísticos. En estas piezas, como ya hemos señalado en diferentes ocasiones, sí se produce el desarrollo de los rasgos movidos y ornamentados del barroquismo más exaltado, de tal modo, que a través de su presencia la característica teatralidad y efectismo barrocos, consiguen finalmente, introducir su impronta dentro de estos recintos.

Respecto al simbolismo interior de estos templos, Bermúdez de Pedraza fue uno de los autores de mediados de este siglo, que más se esforzó en explicar su carácter. En sus escritos viene a decir, que el respeto que se debe tener en el interior de un templo 
debe ser comparado, como mínimo, al que tenemos que sentir frente a un monarca, pues la iglesia es la casa-palacio del Rey de reyes ${ }^{682}$.

A parte de los rasgos generales, que nos pueden ofrecer los templos, levantados de nueva planta, o que son remodelados en su mayor parte, debemos centrarnos también en las características mostradas por aquellas piezas añadidas a edificios ya existentes. Nos referimos muy especialmente a la construcción de portadas, torres, sacristías y coros. Entre estos añadidos, las portadas son el elemento más variado y dinámico dentro de la estructura de estos edificios, pues son la única parte exterior del templo que mereció ser tratada con un cierto esmero, y por añadidura, también el único lugar en el que podemos encontrar desarrollados los conceptos propios del estilo barroco. Este dinamismo hace, al mismo tiempo, que sea el único elemento del templo en el que llegan a reflejarse con claridad los cambios estilísticos registrados a lo largo del siglo, pudiendo establecer, a partir de su análisis, una cierta evolución en las formas. Son fachadas, que, además de marcar el acceso al interior del templo, estableciendo el límite entre el espacio profano y el sagrado, son concebidas, en muchos casos, como un elemento de relación entre el edificio y su entorno, integrándose dentro del esquema urbano, donde juegan un papel de marco referencial ${ }^{683}$.

Dentro de la sobriedad que preside el desarrollo de toda la arquitectura de este periodo, las portadas incorporadas a estos edificios nos ofrecen, sin embargo, una relativa variedad de tipologías, mediante las cuales podemos ir comprobando los distintos cambios sufridos a lo largo del siglo. Aun con todo, incluso en aquellos ejemplos más atrevidos, nos vamos a encontrar siempre con unas construcciones, que se

682 "La iglesia es Palacio del Rey Eterno, es la Corte de los Ángeles; su cielo, y su domicilio, abreviado en el pequeño espacio de un templo (...). Qualquier Iglesia donde se aposenta el Rey Eterno Sacramentado, es su casa, y es su Palacio Real; porque en ella da sus audiencias este Gran Rey”. F. BERBÚDEZ DE PEDRAZA: "Historia Eucharística y Reformada de Abusos". Granada, 1643. (fols. 46 $\mathrm{v}^{0}, 47 \mathrm{v}^{0}, 82,21-23 \mathrm{v}^{0}$ ). A. CÁMARA MUÑOZ: Arquitectura y sociedad ... ob. cit. (pp. 146).

683 V. TOVAR. J. J. MARTÍN GONZÁLEZ: El arte del Barroco I. Arquitectura y escultura. Madrid, Ed. Taurus, 1990. (pp. 166 y ss.). A. CÁMARA MUÑOZ: Arquitectura y sociedad ... ob. cit. (pp. 139 145). 
encuentran muy lejos de las estructuras y formas movidas y ricamente ornamentadas, desarrolladas en el campo de la retablística. En todas ellas predomina, por el contrario, un marcado apego a los modelos clasicistas.

Así, en general, salvo el ejemplo que nos ofrece la portada levantada para la iglesia de San Pedro, en Hacinas, el resto (y esto puede hacerse extensible también al siglo XVIII) se caracteriza por su gran planitud y sencillez compositiva. Sus elementos, en los que el trazado curvilíneo brilla por su ausencia, se disponen siempre dentro de un esquema presidido por el orden y el equilibrio, mostrándose asimismo como composiciones absolutamente desornamentadas, que se adhieren al muro, sin mostrar prácticamente contrastes lumínicos, que den cierta vitalidad al conjunto.

Su estructura compositiva en general, a pesar de las variantes que pueda introducir cada caso concreto, es bastante sobria. Cuenta con un solo cuerpo, compuesto por un vano central, generalmente coronado con arco de medio punto, y escoltado por pilastras cajeadas de orden toscano o dórico, alzadas sobre elevado podio. Este cuerpo se remata con un sencillo frontón recto partido, que suele dejar sitio, en la parte central del tímpano, para la colocación de una pequeña hornacina, en la que se coloca la imagen titular del templo. Como vemos, una composición sencilla y profundamente desornamentada, en la que las únicas concesiones a la decoración vienen dadas en forma de pináculos de bola o piramidales colocados en el remate.

Este siglo, además de portadas, nos ofrece una amplia colección de torres y campanarios, en muchos casos construidos de nueva planta, y en otros simplemente incorporados sobre estructuras anteriores. Son construcciones, que continúan, con bastante exactitud, el modelo desarrollado en la centuria anterior, con una estructura prismática de sección cuadrada y sólidos muros de piedra, que ascienden verticalmente sin interrupción de ningún tipo. No obstante, podemos ver cómo se introducen una serie de variaciones, ciertamente significativas, sobre este esquema, las cuales se reflejan en la incorporación de pináculos de bola o piramidales sobre el tejado, actuando como 
remate, en la colocación también de líneas de imposta, en forma de molduras planas de escaso resalte, marcando la separación entre los diferentes cuerpos, y en la apertura, en algunos casos, de óculos sobre las troneras. Los huecos para las campanas, por su parte, mantienen su estilizado trazado rectangular, con antepecho a los pies y arco de medio punto de sección cuadrangular, que arranca de una sencilla imposta plana de escaso resalte.

Igualmente, dentro de esta centuria, se construyen un buen número de sacristías, si bien, ninguna de ellas destaca por mostrar un especial valor artístico. Se levantan en todos los casos sobre uno de los lados de la capilla mayor, con una planta cuadrangular y sólidos muros de piedra sillar, reforzados en las esquinas con contrafuertes. Su interior se cubre con bóveda de crucería estrellada con terceletes, con la que se sigue la tendencia mostrada en el resto del templo. Son obras, como vemos, realizadas sin grandes pretensiones artísticas, donde prima el valor funcional antes que cualquier otra consideración de orden estético.

Pasamos a abordar, a continuación, las obras más interesantes, llevadas a cabo a lo largo de esta centuria. Dentro de ellas, sin lugar a dudas, las más importantes, por su envergadura, son las que propician la construcción de templos de nueva planta, a las que siguen aquellas otras correspondientes a modificaciones y ampliaciones efectuadas sobre edificios ya existentes. No en vano, en estas obras es donde mejor se reflejan los rasgos propios de este lenguaje arquitectónico, que a partir de este momento comienza a presidir el desarrollo de las construcciones efectuadas en la comarca.

En el apartado de las construcciones de nueva planta nos encontramos con tres ejemplos de iglesias parroquiales, que fueron completamente renovadas durante esta centuria. A ellas debemos sumar también los casos de algunas ermitas de especial importancia. No obstante, estas construcciones constituyen, en todos los casos, remodelaciones prácticamente completas de fábricas anteriores, lo que en rigor no nos permite considerarlas como obras de nueva planta, en el estricto sentido del término. 
Aun así, la escasa o prácticamente nula presencia de restos o elementos pertenecientes al antiguo edificio, así como el hecho de no verse condicionada la nueva fábrica por estos vestigios (en aquellos casos en los que sí se han conservado algunos), nos permite aplicar con total autoridad esta consideración.

La obra más interesante, tanto por sus dimensiones como por el interés, que ofrece su estructura y formas, es la iglesia que se levanta a comienzos de siglo para la parroquia de San Cristóbal, en Quintanar de la Sierra. El edificio se alza sobre una ladera de acusada pendiente, para lo cual se construye un potente muro de contención con el que se consigue formar una superficie llana, al mismo tiempo que se delimita el espacio del atrio. La fábrica en sí presenta una planta formada por un gran rectángulo del que sobresalen la cabecera en el extremo oriental, sobre cuyo costado se adosa la sacristía, y la torre a los pies. Este rectángulo, que forma el cuerpo, se divide en tres naves de igual altura, pero con un evidente predomino en anchura de la central. Estas naves se articulan, al mismo tiempo, en cuatro tramos cada una, de diferente longitud, que aumenta progresivamente a medida que nos alejamos de la cabecera. Se trata de un templo, por lo tanto, que rescata la tipología de las iglesias de planta de salón de tipo hallenkirche, que vimos a principios del siglo XVI, si bien, introduce importantes modificaciones sobre el diseño original.

Así, en este caso, toda la estructura de planta y alzado se encuentra reducida a una concepción rigurosamente geométrica, que impone un cuidado tratamiento de todos y cada uno de sus elementos constructivos, dotando a todo el conjunto de una extrema rigidez. Junto a esto, en su imagen interna, vemos cómo la escasa altura que alcanzan las cubiertas, unido a la excesiva fortaleza de los pilares sobre los que descansan, imprimen a este espacio un excesivo predominio de los respectivos ejes direccionales trazados a lo largo de cada nave, impidiendo con ello modelar el concepto de espacio único, amplio y diáfano, que caracterizaba las plantas de este tipo en la centuria anterior. 


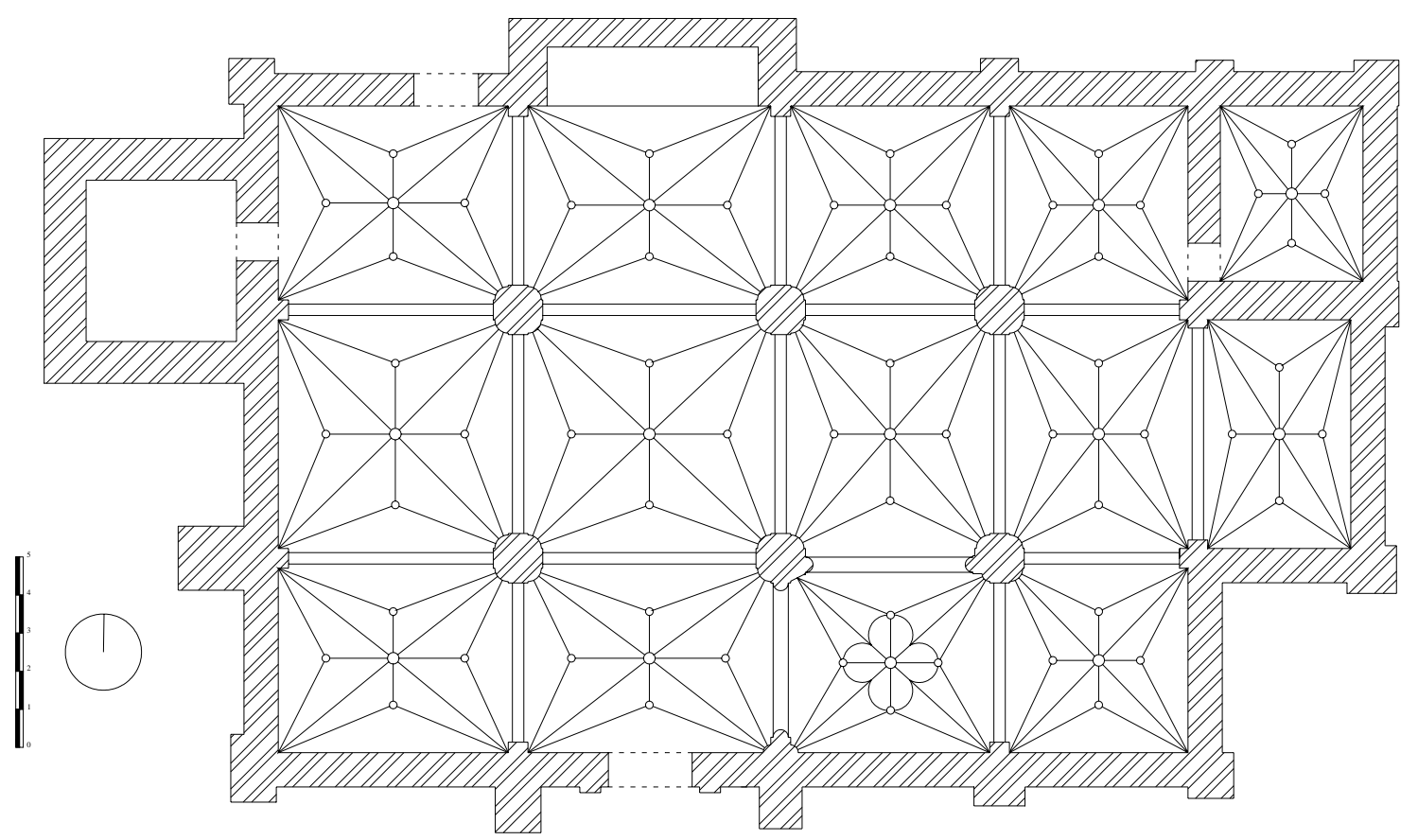

QUINTANAR DE LA SIERRA.

Iglesia de San Cristóbal. Planta.

Toda la fábrica se encuentra levantada en piedra de sillería de excelente calidad, tanto en labra como en ensamblaje, formando un magnífico ejemplo de aparejo isódomo, que se mantiene uniforme a lo largo de toda la estructura del templo. Esto nos sirve para probar la presencia en su construcción de maestros altamente cualificados en el manejo de este material, al mismo tiempo, que certifica la existencia de unos recursos ciertamente saneados.

La imagen exterior aparece dominada por el gran prisma, que constituye la zona del cuerpo, al cual se añaden los diferentes módulos, que forman la cabecera y sacristía, en la parte delantera, la torre a los pies, y una pequeña capilla dedicada a la Inmaculada Concepción, incorporada en la parte septentrional, a la altura del tercer tramo de la nave del Evangelio. Una imagen presidida por un estricto sentido de horizontalidad, cuyo 
contrapunto se encuentra en la torre, con la cual se introduce un marcado carácter ascendente, en la zona de los pies.

Esta torre, sin embargo, sabemos que originalmente presentaba un desarrollo en altura notablemente más reducido, pues sobre las caras de su actual tramo medio es posible distinguir con bastante claridad los contornos de los vanos, que anteriormente servían para alojar las campanas. Actualmente, y tras añadir un nuevo cuerpo de campanas durante la década de 1770, este conjunto logra alcanzar un aspecto realmente estilizado. Está formado por un recio prisma de base cuadrangular y muros completamente planos, articulado en tres cuerpos de desiguales proporciones, separados por líneas de imposta. Dentro de ellos destaca el inferior, que sirve de base, con un gran desarrollo en altura, hasta superar ligeramente el nivel de cubiertas de la nave, y el superior, que constituye el cuerpo de campanas. El central, por su parte, es el más reducido, y conserva en sus caras, como decíamos, la impronta de las antiguas troneras.

La planitud de los muros de la torre se continúa en el resto de la estructura exterior del templo, la cual queda articulada por la presencia intercalada de los estribos, que sirven de refuerzo, reflejando hacia el exterior la estructura de naves y tramos del interior. Se trata de estribos de sección cuadrada y escaso resalte sobre el plano del muro, o al menos no tan pronunciado como ocurría en la centuria anterior. Además, en las esquinas abandonan la disposición en diagonal para colocarse con sus lados en paralelo a los del muro.

El fuerte predominio del muro sobre el vano hace que presenten un reducido número de ventanas, las cuales se encuentran orientadas preferentemente hacia el mediodía, al igual que la puerta principal. Estas ventanas presentan un sencillo trazado rectangular adintelado ligeramente abocinado con derrame hacia el exterior. Sobre la portada, por su parte, trataremos más adelante. 
En el interior la falta de un concepto espacial de ámbito único se ve sustituida por el predominio de los respectivos ejes direccionales de cada una de las naves, dentro de las cuales existe una evidente primacía de la central sobre las laterales. Ésta culmina en una pequeña cabecera de planta rectangular y testero plano de escasa profundidad, lo que hace que apenas exista una clara separación entre ambos espacios, acercando el altar mayor deliberadamente hacia los fieles. Las naves laterales culminan, a su vez, en sus respectivos altares, dedicados a la Virgen del Rosario, el de la Epístola, y a San Pedro Regalado, el del lado del Evangelio. Esta última nave cuenta también, a la altura de su tercer tramo, como ya hemos indicado, con una pequeña capilla, dedicada a la Inmaculada Concepción, levantada sobre una pequeña planta rectangular de escasa profundidad y cubierta con bóveda de medio cañón, dispuesta transversalmente al eje de las naves. Estas pequeñas dimensiones hacen que adquiera el aspecto de una gran hornacina. Por último, a los pies, y ocupando todo el último tramo de las naves central y del Evangelio, se dispone el coro, construido en madera, donde se desarrolla el característico tipo de coro alto.

Todo este espacio interior, incluyendo la cabecera, aparece cubierto con bóvedas de crucería estrelladas con terceletes de trazado sencillo y limpia y cuidada cantería, tanto en los nervios como en la plementería. Las claves aparecen decoradas con diferentes motivos florales, entre los que se intercalan algunos símbolos de carácter mariano y de la Pasión de Cristo ${ }^{684}$. Su rampante, por otra parte, presenta todavía un perfil demasiado curvo, lo que no facilita tampoco la sensación de ámbito único.

Cada uno de estos tramos de bóveda aparece delimitado por arcos de medio punto ligeramente peraltados de sección cuadrangular, trasdosados con una pequeña moldura de cuarto de bocel, e intradós plano con un pequeño relieve cajeado en su interior. Los soportes, sobre los que descansan, están formados por sólidos pilares de sección cuadrada frenteados por pilastras de fuste plano y con un cuarto de columna

\footnotetext{
684 Entre otros objetos se reproducen una cruz, los clavos, el martillo, la escalera o el látigo de la Flagelación.
} 
entregada en los codillos. Todo ello aparece rematado por una gruesa imposta plana de escaso resalte, que hace las funciones de capitel. Estos pilares se corresponden en los muros con pilastras cajeadas, rematadas igualmente por una gruesa imposta plana, que se extiende a lo largo del muro, marcando la separación con el nivel de cubiertas.

Todo este conjunto constituye, en definitiva, un magnífico ejemplo de esa arquitectura tremendamente sobria y austera, heredera de la mejor tradición herreriana, tanto por su concepción volumétrica, como por la cuidada técnica canteril, que fue introducida en el ámbito burgalés a través de las obras de Lerma, donde se formaron tanto maestros locales.

Más difícil resulta determinar su autoría, pues lamentablemente los registros más antiguos, que se conservan, dentro de los Libros de Fábrica de esta parroquia, datan ya del año 1650, momento en el cual el proceso constructivo había finalizado. Aun así, merced a la inscripción conservada sobre el dintel de una de las ventanas, sabemos que la obra fue terminada el año 1622. Esto, unido a los rasgos estilísticos desarrollados en ella, hace factible que podamos atribuir el diseño de sus trazas al maestro de cantería de origen trasmerano Juan de Naveda, ya que desde el año 1615 se encontraba ocupando el puesto de Veedor de las obras del Arzobispado de Burgos ${ }^{685}$. De esta forma, en virtud de las obligaciones, que entrañaba este cargo con respecto a los grandes proyectos acometidos dentro del territorio diocesano, y en orden a la formación estética adquirida tras su participación en parte de las obras del complejo de la villa ducal de Lerma ${ }^{686}$, debemos considerar como segura esta participación.

685 A. C. IBÁÑEZ PÉREZ: “Arquitectura barroca burgalesa”. En Historia de Burgos. III. Edad Moderna (3). Burgos, Caja Burgos. 1999. (pp. 313 - 359).

686 L. S. IGLESIAS ROUCO, M. J. ZAPARAÍN YÁÑEZ: "En torno a la actividad profesional en la arquitectura religiosa burgalesa, 1600 - 1650)”. En Juan de Herrera y su influencia: actas del Simposio: Camargo 14 / 17 Julio 1992. Santander, Fundación Obra Pía Juan de Herrera: Universidad de Cantabria. 1993. (pp. 217 - 226). 
Avalando esta hipótesis se encuentran los propios rasgos, que muestra el resultado final de la obra, la cual nos ofrece un sólido conjunto de extraordinaria unidad estilística, donde se manifiesta la rectitud de líneas y el perfecto perfilado de las diferentes masas y volúmenes, que lo componen. Todo lo cual tuvo oportunidad de aprenderlo como alumno aventajado en su participación en las obras de Lerma. En contra de esta posibilidad se encuentra, como siempre, la falta de las oportunas fuentes documentales, que terminen de confirmarnos esta autoría.

La parroquia de Santa Cristina, en Huerta de Abajo ofrece otro interesante ejemplo de templo de nueva planta, construido a lo largo de esta centuria. Si bien, en este caso contamos con la dificultad de no disponer de ningún tipo de fuente documental o epigráfica, que nos permita establecer con exactitud la fecha concreta de su construcción. Esta iglesia se encuentra situada en la parte central del pueblo, ocupando un solar de acusada inclinación, que obliga a reforzar la parte de la cabecera, que se levanta sobre la zona más deprimida. El edificio presenta una sencilla estructura de tipo caja, heredera del modelo desarrollado a finales del siglo XV, con una amplia nave de trazado rectangular, articulada en dos tramos, que se completa con una cabecera cuadrangular y testero plano en el extremo oriental, de anchura decreciente, y la torre a los pies, también de planta cuadrangular, cuya anchura prácticamente iguala a la de la nave.

Toda la estructura se encuentra levantada en piedra, predominando el aparejo isódomo, elaborada con sillares de perfecta labra, si bien, no es raro encontrar en algunas de sus partes paramentos de mampuesto. Esta mampostería domina, sin embargo, en el interior, donde los muros originalmente estaban cubiertos con una capa de enlucido, quedando arcos, pilastras y nervios de las bóvedas sin enlucir, mostrando la piedra sillar en la que están realizados, resaltando, de este modo, los componentes activos de la estructura. 


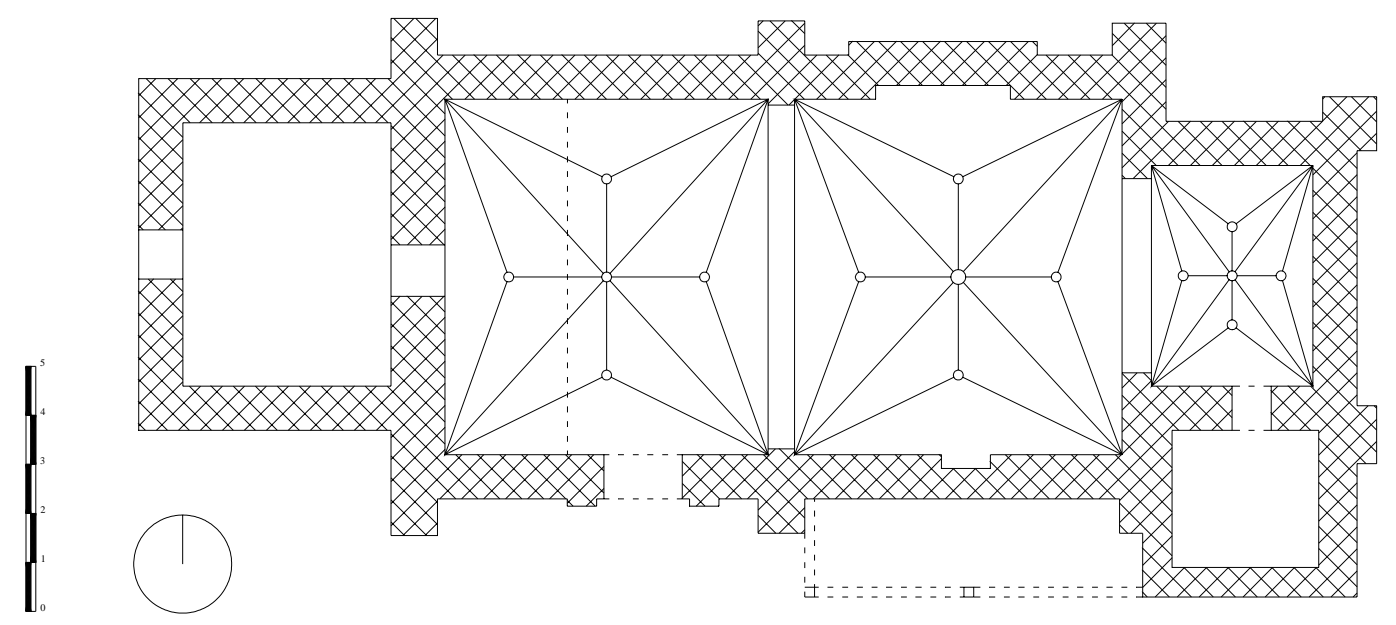

HUERTA DE ABAJO. Iglesia de Santa Cristina. Planta.

Los muros, en su parte exterior, aparecen articulados por la presencia de los sólidos contrafuertes, que reflejan la división de los tramos del interior. En la parte superior se abren los diferentes ventanales, orientados, como en el caso anterior, hacia el mediodía, repitiendo el mismo tipo de trazado rectangular con ligero abocinado hacia el exterior. Sobre esta misma fachada, a la altura del segundo tramo de la nave, se abre la puerta de acceso, la cual participa igualmente de esta idea de sobriedad y mesura, que domina en el resto de la estructura que estamos recorriendo. Está formada por un arco central de medio punto flanqueado por pilastras cajeadas que sustentan un entablamento de amplio friso, ligeramente quebrado en los extremos, en correspondencia con las pilastras, con el que se da paso al remate. Éste se encuentra formado por un frontón recto partido, que deja lugar en el centro para una pequeña cruz en relieve, a la cual acompañan dos pináculos de bola en los vértices laterales, colocados sobre los ejes de las pilastras. Una pieza extraordinariamente sobria, por lo tanto, que une a la sencillez 
de sus formas, la planitud de toda su estructura, haciendo que apenas resalte sobre el muro. Se muestran aquí, de esta forma, los rasgos más característicos, que la interpretación del lenguaje clasicista ofrece en nuestra zona de estudio, a lo largo de este siglo XVII, y en gran medida, durante toda la centuria siguiente. Una interpretación, que se basa en la simplificación máxima de los modelos establecidos.

Con todo esto, se consigue una imagen exterior extraordinariamente sobria, dominada por el sentido de horizontalidad, que imprimen el contorno de la zona del cuerpo y la capilla mayor, cuyas cubiertas se elevan a una misma altura. Dentro de ella, como en el caso de Quintanar, la torre, situada a los pies, actúa como contrapunto vertical. Una torre formada por un gran prisma de base cuadrangular y muros completamente planos, que se articula en dos cuerpos de desigual altura, separados por una línea de imposta. El cuerpo inferior, que forma la base, cuenta con una gran altura, que sobrepasa el nivel de la cubierta de la nave, mientras que el superior, más reducido, constituye el cuerpo de campanas, mostrando en cada uno de sus caras un vano coronado con arco de medio punto levantado sobre una sencilla línea de imposta. Rematando esta estructura, aparecen pináculos de bola en las esquinas del tejado.

En el interior del edificio, destaca el amplio espacio de ámbito único, constituido por la nave, dentro del cual se manifiesta un marcado predominio del eje direccional, que conduce hacia la capilla mayor. Ésta se presenta como un espacio claramente diferenciado, a cuyo interior se accede a través de un potente arco de medio punto de sección cuadrada e intradós cajeado, que descansa sobre pilastras seudodóricas con fuste cajeado decorado con placas cuadrangulares, formando un tableteado. En la zona de los pies de la nave se eleva el coro, concebido mediante una sencilla estructura de madera. Todo este espacio interior se cubre con bóvedas de crucería estrellada con terceletes de trama extremadamente simple, con claves decoradas con sencillos motivos alusivos a la Santa titular y otros santos, y rampante prácticamente plana, lo que incrementa la sensación de amplitud. Un amplio arco de medio punto ligeramente rebajado, apeado 
sobre pilastras de orden seudodórico y fuste tableteado, igual que el arco toral, separa los dos tramos de la nave.

Nos encontramos, por lo tanto, con un templo en el que se continúa el desarrollo de las formas propias del lenguaje clasicista, tamizadas por el filtro de la arquitectura popular, que se imprime dentro de toda la comarca. Dentro de este conjunto, sin embargo, también podemos destacar la presencia de determinados rasgos indicativos de que nos encontramos ante una obra correspondiente a un periodo más avanzado, dentro del siglo XVII. Nos referimos, en concreto, a la decoración de placas, que aparece sobre los fustes de las pilastras. Su cronología exacta, sin embargo, resulta imposible de determinar.

El último ejemplo de iglesia parroquial levantada de nueva planta durante esta centuria, lo encontramos en la localidad, hoy despoblada, de Bezares. Se trata de un templo actualmente abandonado, el cual, milagrosamente permanece en pie, mientras contempla cómo el resto del caserío, que se levanta en sus inmediaciones, desaparece presa de la ruina, bajo desgarradores montones de escombros. Su fábrica, extremadamente modesta, se levanta sobre una planta de trazado rectangular, dentro de cuyo perímetro se incluyen su única nave, la cabecera, que aparece ligeramente desplazada sobre el eje central, y la sacristía, acomodada sobre el flanco septentrional del presbiterio.

De esta forma, su imagen exterior queda definida por un sencillo prisma de escasa altura, formado por muros de mampostería, reforzados en las esquinas por sillares de mejor labra. La espadaña, levantada sobre el muro de los pies, a comienzos de la centuria siguiente, se convierte, por lo tanto, en el único elemento que rompe esta monótona estampa.

En su interior, y participando de estos mismos rasgos, se desarrolla un espacio dominado por el amplio ámbito de la nave, cubierta con sencilla estructura de madera, 
con armadura de tipo par y nudillo, a cuyos pies se levanta un pequeño coro, también realizado en madera, que apenas se eleva unos cincuenta centímetros sobre el nivel general del suelo (lo que hace que no exista sotocoro). La cabecera, en el extremo oriental, se muestra como un espacio totalmente separado, a cuyo interior se accede a través de un arco escarzano de sección cuadrangular e intradós cajeado, que como en otros casos, descansa sobre pilastras igualmente cajeadas, rematadas por una airosa cornisa. Su interior se cubre con un pequeño tramo de bóveda de medio cañón muy rebajada, con lunetos.

Se trata, por lo tanto, de una obra de marcado carácter popular, cuyas formas apenas permiten identificar rasgos concretos del estilo clasicista. La documentación conservada no nos permite conocer los nombres de los artífices, que participaron en su construcción, si bien, debemos pensar que se trataba de maestros locales poco cualificados. Aun así, merced a la información conservada en los Libros de Fábrica, sabemos que estos trabajos se estaban realizando en torno al año 1695, dándose por finalizados muy poco tiempo después ${ }^{687}$.

Aparte de estos templos parroquiales, dentro de las construcciones de nueva planta, tenemos que mencionar también la completa remodelación, que sufrieron las fábricas de algunas ermitas de estos pueblos. Entre ellas, sin duda, la que mayor interés despierta, tanto por el alcance de la obra, como por la importancia que en sí tiene este santuario, es la acometida en la ermita de Nuestra Señora del Arroyal, en Palacios de la Sierra. Esta remodelación se acomete a lo largo de dos fases sucesivas, las cuales afectan, en primer lugar, a la zona de la cabecera, para centrarse en un segundo momento en la parte del cuerpo.

La primera de ellas tiene lugar entre los años 1651-1663, que es el periodo que duró la mayordomía de Francisco Gil, bajo cuya iniciativa se puso en marcha el

687 AGDBU. LP. Bezares, parroquia de Santa Lucía, LF. (1685 - 1729). (fols. 20 - 21). Cuentas del año 1695. Bezares, 28 - diciembre - 1695. 
proyecto. El encargado de dirigir los trabajos, por su parte, fue el maestro de cantería trasmerano Clemente de Hermosa, por cuya participación percibió del citado mayordomo un total de 170.000 maravedís $^{688}$. El resultado final es una modesta cabecera de planta cuadrangular y testero plano, reforzada en las esquinas por potentes contrafuertes, dispuestos del modo habitual en este momento. En el interior, el espacio resultante se cubre con una sencilla bóveda de crucería estrellada con terceletes, accediendo a él a través de un amplio arco de medio punto de sección cuadrangular e intradós cajeado, que descansa sobre pilastras seudotoscanas de fuste igualmente cajeado.

Toda esta obra se encuentra elaborada en magnífica piedra sillar, con al que se forman unas sólidos muros, interrumpidos por una moldura, con la que se introduce un ligero decrecimiento en su grosor. En la parte superior, una moldura de papo de paloma conduce al tejado. Una obra, por lo tanto, sencilla y sobria, característica del lenguaje clasicista, que seguía imperando en unas fechas tan avanzadas como el inicio de la segunda mitad del siglo XVII.

La segunda fase de este proyecto afectó a la zona del cuerpo, tratándose, en este caso, de una obra más ambiciosa en proporciones, aunque modesta en sus pretensiones artísticas. El promotor del proyecto fue el mayordomo Pedro Llorente, también vecino de la localidad de Palacios de la Sierra, el cual impuso un acelerado ritmo a estos trabajos, concluyéndose entre los años 1665-66.

El encargado de dirigir la obra de cantería fue, en este caso, el maestro Juan de Vellael Riego, natural de Pameses, en la Junta de Cudeyo, por el que percibió de esta fábrica los 330 ducados acordados, más otros 200 reales, concedidos por mejora ${ }^{689}$. Por su parte, los maestros de carpintería locales, Juan y Pedro Jarro, fueron los adjudicatarios del trabajo en madera, incluyendo también en el contrato firmado con la

688 AGDBU. LP. Palacios de la Sierra, Cofradía de Nuestra Señora del Arroyal, LF. (fols. 20 - 24). Palacios de la Sierra, 28 - septiembre - 1664 . 
ermita, la composición de la armadura, que cubría la parte correspondiente a la cabecera $^{690}$.

El resultado final de las obras nos depara una nave de amplias dimensiones, levantada sobre una planta rectangular de trazado muy alargado, cuyo alzado lo componen muros de sillarejo, reforzados en su parte inferior y en las esquinas por sillares mejor labrados. En el interior desarrolla un espacio amplio y desahogado, con coro alto de madera, en la zona de los pies, cubriéndose todo con techumbre a dos aguas sobre armadura de tipo par y nudillo. No obstante, el elemento más destacado de esta obra lo constituye la portada orientada hacia el mediodía, con la que se remata todo el conjunto. Consta de un amplio vano adintelado en el centro, con pilastras cajeadas sobre elevado podio a los lados, sobre las cuales se dispone un entablamento, ligeramente quebrado en los extremos, de gran clasicismo. De aquí se pasa al remate, formado por un esbelto frontón recto partido, decorado con una cruz sobre su vértice superior y sendos pináculos de forma piramidal en los extremos, en correspondencia con los ejes de las pilastras inferiores. Dentro del tímpano de este frontón se abre una pequeña hornacina avenerada, escoltada por pilastras planas rematadas con pináculos de bola, en cuyo interior se aloja una pequeña imagen en piedra de la Virgen con el Niño. Se trata de una rígida imagen de estructura troncocónica, imitando el tipo de Virgen de vestir, ricamente ornamentada, tanto en el manto como en la corona, con decoración finamente labrada, que se repite igualmente en la figura del Niño, que sostiene con su mano izquierda. Una portada, en definitiva, de formas sumamente sencillas y de gran planitud, que se inscribe dentro de la corriente del más sobrio clasicismo, inaugurando, junto con otros ejemplos, una tipología, que alcanzará un gran desarrollo a lo largo de toda la centuria siguiente.

Respecto al resultado final de todo el conjunto de esta ermita, una vez acabadas las dos fases constructivas, nos ofrece un edificio de aspecto recio y austero, dominado

\footnotetext{
689 Ibídem. Palacios de la Sierra, 31 - diciembre - 1664.

690 Ibídem. Palacios de la Sierra, 26 - septiembre - 1666.
} 
por un claro sentido de horizonatalidad, en el que no aparece ningún elemento que rompa esta imagen aplanada. En el interior, sin embargo, podemos apreciar con total claridad la perfecta separación entre los dos espacios que lo componen, creándose, a través de la nave, un marcado eje longitudinal, que conduce hasta la capilla mayor.

Otro ejemplo de ermita, cuya fábrica se renueva durante esta centuria, lo tenemos en el edificio de la Cofradía de la Vera Cruz, en Canicosa de la Sierra. Esta ermita, que se encuentra emplazada en la parte central del pueblo, asentada entre la plaza mayor y la iglesia parroquial, renovó igualmente su estructura, adquiriendo entonces su aspecto definitivo. Como la mayoría de los edificios de este tipo en la comarca de la sierra, presenta una estructura extremadamente sencilla, compuesta por una sola nave de trazado rectangular, sobre cuyo extremo oriental se adosa la cabecera, formada por una estructura igualmente cuadrangular con testero plano, de anchura inferior a la nave. Todo el edificio se halla construido en piedra de sillería, perfectamente labrada y ensamblada, formando unos muros de perfecto aparejo isódomo, rematados por una cornisa de papo de paloma. Por lo demás, en su imagen exterior, apenas encontramos ningún otro signo que nos permita identificar esta ermita como un edificio religioso, llegando a confundirse con el resto del caserío que la rodea.

En su interior, hoy muy alterado, pues parte del espacio de la nave se encuentra compartimentado y separado del resto del templo, destinándose a otros usos, se muestra la misma sencillez externa. Así, el concepto espacial desarrollado no ofrece complicaciones de ningún tipo, presentando el gran ámbito de la nave única, como espacio principal, dentro del cual se establece un marcado eje direccional, que conduce hacia la cabecera. Ésta, merced a su menor anchura, se muestra como un ámbito separado y claramente diferenciado del resto, que marca su carácter preponderante a través de una cubierta de madera en forma de artesa invertida, en la que se desarrolla una labor de artesonado. Actualmente, sin embargo, se encuentra bastante deteriorada, lo que nos impide valorar la belleza, que originalmente debía presentar. La zona 
correspondiente a la nave, por su parte, se cierra con una simple techumbre de madera, dispuesta a dos aguas, sobre armadura de par y nudillo.

Respecto a la construcción de esta ermita, como ocurre en la mayor parte de los casos, no es mucho lo que podemos saber, pues no se han conservado ningún documento referente al proceso en sí. Aun así, sabemos que existieron dos fases. La primera tuvo lugar en 1606, como atestigua la inscripción conservada sobre el dintel de su puerta de entrada, abierta sobre el muro meridional de la nave, si bien la falta de datos concretos, procedentes de los libros de esta cofradía, que complemente esta noticia, nos impide precisar el alcance de dichas obras. Aun con todo, sí aparecen registrados algunos pagos entregados a un grupo de canteros en torno a esos años ${ }^{691}$.

La segunda fase parece que tuvo lugar en torno al año 1640, tal y como acreditan los registros anotados en los libros de la cofradía. En este caso, a juzgar por las notas conservadas, todo apunta a que las obras acometidas debieron tener un cariz mucho más importante, pues junto al registro de las cantidades gastadas, se incluye el siguiente texto: “por hacer la hermita de la Vera Cruz”. Estas cantidades, entregadas a los canteros y carpinteros, sumaron un total de 2.622 reales, ${ }^{692}$ a los cuales deberíamos añadir también diversas cantidades menores, procedentes de las personas que habían contraído diferentes deudas con esta ermita. Estas cantidades habían sido previamente solicitadas a los deudores por el propio Obispo de Osma, en visita realizada unos años antes $\mathrm{a}^{693}$.

Un ejemplo más de ermita de nueva creación lo hallamos en Monasterio de la Sierra, en su santuario dedicado a los Santos Mártires, San Cosme y San Damián, cuya

\footnotetext{
691 AGDBU. LP. Canicosa de la Sierra, Cofradía de la Vera Cruz. (1595 - 1663). Cuentas del año 1606. Canicosa de la Sierra, 5 - febrero - 1607.

692 Ibídem. Cuentas tomadas a la cofradía de la Vera Cruz de Canicosa de la Sierra por el visitador del Obispado de Osma del año 1642, D. Mateo de Salas: Canicosa de la Sierra, 14 - junio - 1642.

693 AGDBU. LP. Canicosa de la Sierra, parroquia de San Esteban, LF. Visita de 1638 realizada por el obispo de Osma D. Martín Carrillo de Aloeche. Canicosa de la Sierra, 19 - septiembre - 1639.
} 
fábrica fue demolida y reedificada desde sus cimientos, en torno a la década de 1670. El encargado de informarnos de este proceso fue el Visitador del Arzobispado de Burgos, D. Hilario de Noriega, en el informe dejado en 1680, tras su visita a esta parroquia. En él se da cuenta de que el concejo de esta localidad, como patrono de la misma, ayudado por los vecinos del pueblo, había llevado a cabo esta obra, dado que la antigua ermita estaba vieja y maltratada y de calidad que no se podía celebrar misa en ella. Para solucionar esta situación se había optado por levantar una fábrica completamente nueva, a la cual se había decidido darla algún jénero de ensanche más del que antes tenía por ser pequeña ${ }^{694}$. La falta de los registros correspondientes a estos años, dentro del Archivo Municipal del pueblo, nos impide conocer los detalles de la obra, con lo que el único testimonio que nos queda es el propio edificio.

Éste se halla situado a las afueras del pueblo, próximo a las primeras edificaciones, que conforman su caserío. Presenta, como los modelos anteriores, una sencilla estructura de tipo caja, compuesto por una amplia nave de trazado rectangular, la cual se completa en su extremo oriental con una cabecera, de planta cuadrangular, algo más estrecha que la nave. Así, como viene siendo habitual en los templos de este periodo, nos encontramos en su interior con dos espacios perfectamente definidos, como son la cabecera y la nave, a través de los cuales se establece una clara estructura de carácter longitudinal. La parte correspondiente a la nave cuenta con un pequeño coro alto a los pies, levantado sobre una gruesa viga, que cruza de lado a lado, mientras que la cubierta se resuelve con sencilla techumbre de madera, dispuesta a dos aguas, sobre armadura de tipo par y nudillo. La cabecera, por su parte, cuenta con una acceso marcado a través de un potente arco de medio punto de sección rectangular, que descansa sobre pilastras sin orden preciso y fuste liso. Su interior, más recogido que el de la nave, se cubre con bóveda estrellada de crucería con terceletes.

694 AGDBU. LP. Monasterio de la Sierra, parroquia de San Pedro, LF. (1654 - 1701), (fols. 56v $\left.{ }^{\circ}-60\right)$. Visita realizada a la parroquia de San Pedro de Monasterio de la Sierra en 1680, por D. Hilario de Noriega, canónigo de la catedral. Salas de los Infantes, 3 - septiembre - 1680. 
Al exterior, la sencillez se convierte en su elemento más característico, mostrando limpios volúmenes prismáticos, con cubiertas elevadas a la misma altura, y muros de trazado recto, levantados en mampuesto, que se refuerza en las esquinas con sillares de mejor labra y mayor tamaño. Los escasos vanos abiertos están formados por pequeñas ventanas de dintel plano, orientadas hacia el mediodía y poniente. La puerta de acceso, queda orientada igualmente hacia el mediodía, mostrando un sencillo arco de medio punto, alzado sobre impostas planas de escaso resalte, desprovisto por completo de elemento ornamentales. La sacristía, que se adosa junto al muro meridional del presbiterio, es el único elemento que rompe mínimamente esta monotonía, destacando, ante todo, por la buena labra que muestran sus muros, con un cuidado aparejo isódomo, compuesto por sillares bien labrados y ensamblados. Este aspecto nos confirma, que se trata de una pieza añadida con posterioridad, si bien, la falta de documentación nos impide precisar el momento en el que se produce esta incorporación.

Por lo demás, este templo nos muestra una obra caracterizada, como suele ser normal en ese tipo de edificios, por su sencillez y carácter popular. Al mismo tiempo, se advierte, especialmente en el interior, determinados rasgos propios de esta tendencia clasicista, que impregna la arquitectura desarrollada aquí a lo largo de toda la centuria.

Terminamos esta relación de ermitas, renovadas o construidas de nuevo durante esta centuria, con el santuario de Nuestra Señora de la Guía, en Quintanar de la Sierra. Se trata de un templo complejo, en el que se adivinan sin dificultad la presencia de diferentes fases constructivas, todas ellas, desarrolladas, sin embargo, dentro de este siglo XVII. Consta de una sola nave de planta rectangular, rematada en la parte delantera por una especie de crucero de trazado cuadrangular, únicamente marcado en altura, al que sigue la cabecera, también de planta cuadrangular, pero de anchura considerablemente menor. Al exterior, estos cuerpos se manifiestan como tres grandes masas prismáticas dispuestas en torno a un mismo eje, dentro de los cuales destaca el cuerpo central, formado por una gran masa cúbica de limpios perfiles. Al mismo tiempo, dentro de su imagen exterior, destaca la espadaña, alzada sobre el muro de los 
pies, articulada en dos cuerpos decrecientes, unidos mediante sencillos aletones de forma triangular, rematados en los extremos con pináculos de bola. El primer cuerpo conforma en realidad el basamento sobre el que se alza la espadaña propiamente dicha, la cual presenta un único vano coronado con arco de medio punto, sobre el que se dispone un frontón triangular. En el interior, se desarrolla un concepto de espacio claramente longitudinal, articulándose los distintos ámbitos en torno al eje central, que recorre todo el edificio. Así, a los pies nos encontramos con la nave con coro alto en la parte posterior, y cubierta con techumbre de madera dispuesta sobre armadura de par y nudillo. A continuación, a través de un amplio arco de medio punto de sección cuadrada e intradós plano, dispuesto sobre pilastras de orden toscano, se pasa al espacio, que hemos identificado como el crucero. Este espacio de esquinas achaflanadas, está cubierto actualmente con una techumbre de madera dispuesta a cuatro aguas, si bien, los arcos formaletes, que se dibujan sobre sus muros laterales y frontal, nos indican con total claridad la presencia, en su estructura original, de una cubierta abovedada. Estos rasgos nos llevan a establecer su construcción dentro de este siglo XVII, lo mismo que sucede en la cabecera, con la que se remata esta sucesión de espacios. A su interior se accede a través de un arco toral de medio punto de sección cuadrada e intradós cajeado, que descansa sobre pilastras de orden seudotoscano y fuste liso. En ella se desarrolla un pequeño espacio muy recogido y tenuemente iluminado, que se cubre con bóveda de crucería estrellada con terceletes.

Todos los elementos y piezas, que componen esta estructura, por lo tanto, nos muestran en su composición los rasgos propios del clasicismo, desarrollado en esta comarca a lo largo de toda esta centuria del Seiscientos. Además, y reafirmando esta cronología, nos encontramos con que los Libros de Fábrica de la ermita, cuyos registros se conservan a partir del año 1665, nos describen la imagen de un edificio cuya estructura se encuentra ya completamente terminada. No obstante, todavía en los últimos años de este siglo se acometen algunas obras, como es el caso del transparente, abierto en la capilla mayor en 1689. Se trata de una pieza extremadamente sencilla, pues se compone de su simple vano de dintel plano, abierto sobre el muro del testero de esta 
capilla, el cual se hace coincidir con la hornacina central del retablo. De este modo, la la luz que penetra por el ventanal hace que se cree un efecto de ingravidez sobre la imagen aquí situada, ofreciéndose, ante los fieles, con un halo luminoso rodeando su figura. No es, por lo tanto, una obra especialmente compleja en cuanto a su estructura y configuración, si bien, nos llama poderosamente la atención, primero por tratarse de un interesante intento de introducir, dentro de estos espacios, el efectismo propio de la escenografía característica del mundo barroco. Y segundo, por tratarse del primer ejemplo de una tipología, que sin llegar a ser muy frecuente, sí nos ofrece varios casos más, durante la centuria siguiente. El autor de esta obra fue el maestro de cantería Francisco de la Torre, el cual percibió de esta cofradía la cantidad de 140 reales $^{695}$.

Otro tipo de obras, que también alcanzan un papel destacado, dentro de este siglo, son las ampliaciones y remodelaciones de edificios ya existentes. Se trata, en definitiva, de obras encaminadas a engrandecer los templos, dotándoles de un mayor espacio disponible para acoger a sus feligreses. Los mecanismos, que para ello se emplean, fueron muy sencillos, consistiendo simplemente en incorporar nuevas naves a las ya existentes, o bien, en alargar el edificio, con nuevos tramos.

Dentro del primer caso, la iglesia parroquial de San Pedro, en Hacinas, nos ofrece, sin duda, uno de los ejemplos más interesantes. En este caso, se partía de la estructura, heredada del siglo anterior, con una iglesia de tipo caja de nave única articulada en dos tramos, que se prolonga con un tramo más en el extremo oriental, para formar la cabecera. Sobre esta estructura, a mediados de este siglo XVII, y sin que podamos conocer con seguridad los motivos, que movieron a ello, se decidió incorporar dos nuevas naves, dispuestas a cada uno de los lados de la anterior, de tal forma, que el templo de nave única, duplicaba su espacio, quedando convertida en una planta de salón de tres naves, articuladas en dos tramos cada una. La obra se hizo con un gran respeto hacia la estructura del templo anterior, así, salvo la eliminación de los muros laterales,

\footnotetext{
695 AGDBU. LP. Quintanar de la Sierra, Cofradía de Nuestra Señora de la Guía. (1665 - 1695). (fols. $216-217 v^{0}$ ). Cuentas del año 1689. Quintanar de la Sierra, 26 - abril - 1690.
} 
el resto de los elementos de la primitiva nave se conservaron. Por otra parte, las cubiertas de los espacios recién incorporados, no sólo se elevan a la misma altura que la central, sino que se realizan manteniendo el mismo tipo de abovedamiento, con bóvedas de crucería estrellada con terceletes, adaptadas, eso sí, a la estructura perlongada de sus tramos, pues estas naves presentan una anchura menor que la central. No ocurre lo mismo con los arcos y soportes, que sustentan esta estructura. Los arcos ahora levantados pierden por completo la profusa molduración anterior, para mostrarnos la habitual sección rectangular con intradós plano, que estamos viendo en el resto de las obras contemporáneas. Por lo demás, estos arcos siguen mostrando un perfil de medio punto en las líneas de los arcos formeros, que separan las naves, mientras que los fajones de cada tramo, presentan un perfil apuntado, que permite alcanzar la altura deseada en las cubiertas.

Los soportes, por su parte, forman pilares exentos de sección cuadrada, sobre cuyos frentes se adosan pilastras de orden toscano, exceptuando su cara interna, donde se mantienen los haces de columnas de la obra gótica. Estos pilares se corresponden en los muros con pilastras adosadas, en las que se repiten las mismas características que en las anteriores.

Con todo ello se consigue, como vemos, una renovada imagen interna con un concepto de espacio amplio y desahogado, próximo al propio de la tipología hallenkirche, dentro del cual encontramos un predominio claro del sentido longitudinal, que imprime el eje, que recorre la nave central. Al exterior, la incorporación de las nuevas naves, supuso una importante modificación en el aspecto del templo, con respecto al edificio anterior. De este modo, la imagen que se consigue, queda dominada por el gran prisma, que dibuja esta zona del cuerpo, al cual se incorporan los elementos que forman la cabecera, en el extremo oriental, y la torre en la parte de los pies, construida también durante el siglo XVII. Un sólido prisma, en definitiva, constituido por firmes muros de sillería, rematados por una cornisa de codillo, y articulados por la 
presencia de los potentes contrafuertes de escaso resalte, que reflejan al exterior la división interna.

Sobre la ejecución de la obra, desconocemos, tanto los nombres de los artífices encargados de su diseño y construcción, como el momento exacto en el que se culminaron los trabajos, pues las importantes lagunas existentes en la documentación, que se ha conservado, referente a esta iglesia, hacen imposible conocer estos datos. No obstante, a partir de los testimonios indirectos, que sí nos han llegado, hemos podido averiguar, que una de las figuras claves, en la puesta en marcha de este proyecto, fue el cura párroco de esta iglesia, D. Matías Moreno, el cual estuvo al frente de esta parroquia en torno a las décadas centrales de la centuria. Esto nos permite, en cierto modo, establecer una cronología aproximada para su realización.

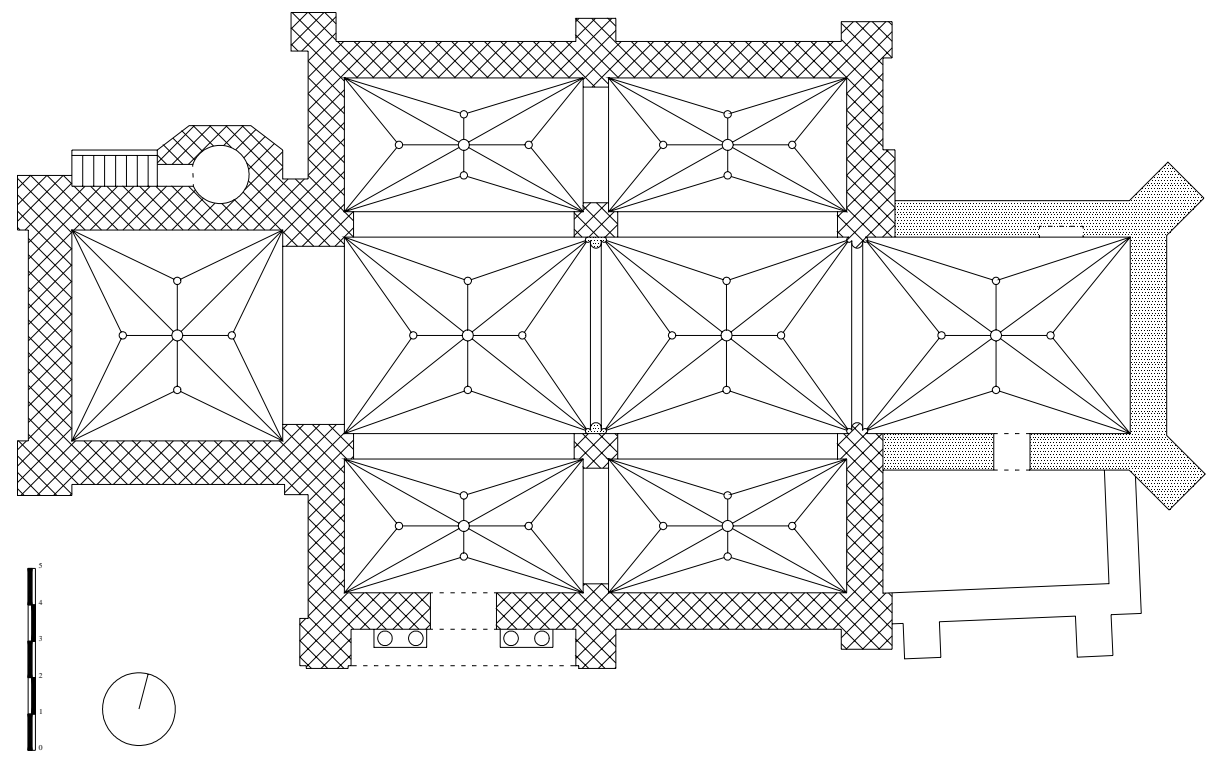

Fase gótica.

Construcción S. XVII.

HACINAS. Iglesia de San Pedro

Fases constructivas. 
Otra obra importante, de este tipo, la encontramos en la ampliación, llevada acabo en torno a estas mismas fechas, en la iglesia de la parroquia de Santa Eulalia, en Palacios de la Sierra. En este caso, se decide incrementar su espacio, formado, como sabemos, por una estructura de dos naves, añadiendo una tercera en la parte septentrional del templo. Con ello se conseguía dibujar una estructura aparentemente similar a la iglesia de Hacinas, con tres naves de dos tramos cada una, prolongándose la central con un tramo más en los pies, donde se alojaba el coro. Sin embargo, este caso de Palacios de la Sierra presenta algunas irregularidades, pues la presencia de la torre románica, que se había conservado precisamente en esta parte septentrional, impedía un desarrollo normal de la nueva nave, viendo interrumpido su tramo delantero, que apenas alcanzaba a cubrir la mitad del espacio, que mostraba su compañera del lado de la Epístola. Por otro lado, en la parte de los pies, esta nueva nave se prolonga con un tramo más, alcanzando el mismo desarrollo que la central, lo que da lugar a la formación de una capilla, que más tarde se puso bajo la advocación de Nuestra Señora del Rosario.

Al exterior, el añadido hace que la estructura de este templo comience a caminar hacia su aspecto definitivo de prisma achaparrado de amplia base rectangular, que se termina consiguiendo, con las posteriores incorporaciones, efectuadas durante el siglo XVIII. Llama la atención en este caso, no obstante, la gran potencia de los estribos colocados sobre el nuevo muro, pues presentan un fuerte resalte, lo que no resulta muy habitual dentro del siglo XVII, si bien podría explicarse por la necesidad de reforzar esta parte del templo, ante el desnivel, que se abre a pocos metros.

En el interior, los diferentes tramos de esta nave y la capilla incorporada a los pies, se cubren con bóvedas de crucería estrellada con terceletes, las cuales se elevan a la misma altura que las que cubren la nave meridional, situándose, por lo tanto, ligeramente por debajo de las que cierran la nave central. 
Los arcos que separan cada uno de estos tramos presentan la habitual sección cuadrangular e intradós plano con relieve cajeado, si bien, su trazado debe adecuarse a las necesidades constructivas. Así, mientras el segundo tramo de la línea de formeros muestra un trazado de medio punto, en el resto, incluyendo el formero del tramo delantero, se utiliza un trazado apuntado, que permite elevar las cubiertas a la misma altura que las de la nave de la Epístola. Los soportes sobre los que éstos descansan quedan constituidos por pilastras cajeadas, que se constituyen, en gran medida, como simples prolongaciones del intradós de cada arco.

Dentro del concepto general del espacio de este templo, sin embargo, la nueva nave se convierte en un ámbito auténticamente aislado, pues a la imposibilidad de progresar en su parte delantera, por la presencia de la torre, se une un ambiente de penumbra, propiciado por la escasa presencia de vanos, ya que sólo cuenta con una pequeña ventana en la parte de los pies, sobre el muro posterior de la capilla, creada allí.

En lo que se refiere a su proceso constructivo, no es mucho lo que podemos conocer, pues las fuentes documentales conservadas no terminan de aportarnos una información lo suficientemente precisa sobre el tema. Aun así, debemos suponer que la obra debió realizarse en torno a los años finales de la década de 1660, participando en su ejecución los maestros de cantería Martín Garray y Pedro de Arteche ${ }^{696}$. De igual modo, hemos podido saber, a partir de los datos extraídos de los maltratados Libros de Fábrica de esta parroquia, que el desarrollo de estos trabajos de ampliación no estuvo exento de problemas para el resto de la estructura del templo. Así, a raíz de la eliminación del muro septentrional, gran parte del edificio se vio afectado, lo que hizo necesaria una inmediata reparación. Entre las partes dañadas, sin duda, la más acusada

696 AGDBU. LP. Palacios de la Sierra, parroquia de Santa Eulalia, LF. (1653 - 1674). Cuentas de los años 1668 - 69. Palacios de la Sierra, 7 - agosto - 1669. Ibídem. (fols. 188 vº). Cuentas del año 1670. Palacios de la Sierra, 7 - diciembre - 1670. 
fue la estructura de bóvedas, que tuvo que ser reparada concienzudamente en su totalidad, de forma inmediata ${ }^{697}$.

Un ejemplo de ampliación algo diferente a los anteriores es el de la iglesia de Vilviestre del Pinar. Aquí se parte de una estructura de tres naves, articulada en dos tramos cada una, lo que lleva a que el incremento de espacio se realice en sentido longitudinal, derribando el muro de los pies y añadiendo un nuevo tramo a cada una de ellas. Para ello se incorpora un nuevo arco en cada una de las líneas de formeros, que ya existían, repitiendo el mismo trazado de amplio arco de medio punto de gran luz, pero con una sección completamente diferente, ya que en este caso se abandona la profusa molduración anterior, para dar paso a una sencilla sección cuadrada con intradós cajeado, como los vistos en el ejemplo anterior.

Junto con esta intervención, y aunque no tengamos datos definitivos, que lo confirmen, es posible que se pueda incluir también la construcción de la magnífica cubierta de madera con la que se cierra el espacio de las naves. Se trata, como ya apuntábamos en su momento, de un extraordinario ejemplo de artesonado de inspiración mudéjar, en forma de artesa invertida, adaptado a la forma trapezoidal de la nave central, en cuyo interior se desarrollaban diferentes figuras geométricas mediante el entrecruzado de sus listones.

Toda esta obra de ampliación, aunque no contamos con los datos concretos, que nos informen sobre su proceso constructivo, se completa en 1649, según nos indica la inscripción, que se conserva en el muro meridional, bajo la cornisa que da paso al tejado. Se trata de un proyecto realizado a instancias del Visitador del Obispado de Osma, D. Mateo de Salas, el cual, dos años antes, había ordenado expresamente, que se alargara el templo, “por no ser capaz para la jente que ay”. En dicho mandato se indica también la necesidad de contar con el apoyo de los feligreses y ermitas de la localidad, con “materiales y demás que ubiere menester”, para poder afrontar los gastos de la obra,

697 Ibídem. 
pues la fábrica no parecía contar con los recursos suficientes para hacerse cargo de ella $^{698}$. La respuesta de los vecinos no pudo ser más positiva, pues aparte de su colaboración en la extracción y transporte de los materiales empleados, sus limosnas sumaron una cantidad superior a los 200 ducados $^{699}$.

Un último ejemplo de renovación parcial de la estructura de un templo parroquial lo encontramos en la fábrica de la antigua parroquia de San Miguel, en Neila. Se trata, sin duda, del caso que más dudas nos ofrece, desde el punto de vista de la cronología, pues la falta de documentación nos obliga a depender únicamente del análisis formal. Éste nos revela unos rasgos, que pese a su tosquedad y sencillez, muestran un neto sabor clasicista, el cual podemos relacionar vagamente con algunas de las obras del foco lermeño.

Esta obra consiste en la renovación completa de toda la zona del cuerpo, levantando en su lugar una estructura de una sola nave con planta rectangular, articulada en dos tramos, separados por potente arco fajón de medio punto ligeramente rebajado, de sección cuadrangular e intradós plano, que descansa sobre sencillas pilastras seudodóricas, elaboradas en perfecta sillería, al igual que el arco, mientras que el paramento de los muros muestra un tosco sillarejo, que originalmente estaba enlucido. Estos dos tramos se cubren con sencillas bóvedas de crucería cuatripartitas de finos nervios y rampante prácticamente llana. Con todo esto, se dibuja un amplio espacio de ámbito único, dentro del cual predomina un claro sentido longitudinal, tendente hacia el altar mayor, situado en la cabecera románica de profundo presbiterio, que se presenta como un ámbito perfectamente diferenciado.

Al exterior, esta construcción se muestra como un sólido volumen prismático, con muros de sillería, perfectamente labrados y ensamblados, rematados por una cornisa

\footnotetext{
698 A. Parr. Vilviestre del Pinar. LP. Vilviestre del Pinar, parroquia de San Martín, LF. (1635 - 1673). (fols. $61-66 v^{\circ}$ ). Visita realizada a la parroquia de San Martín en Vilviestre del Pinar en 1648, por D. Mateo de Salas. Vilviestre del Pinar, 28 - febrero, 1648.
} 


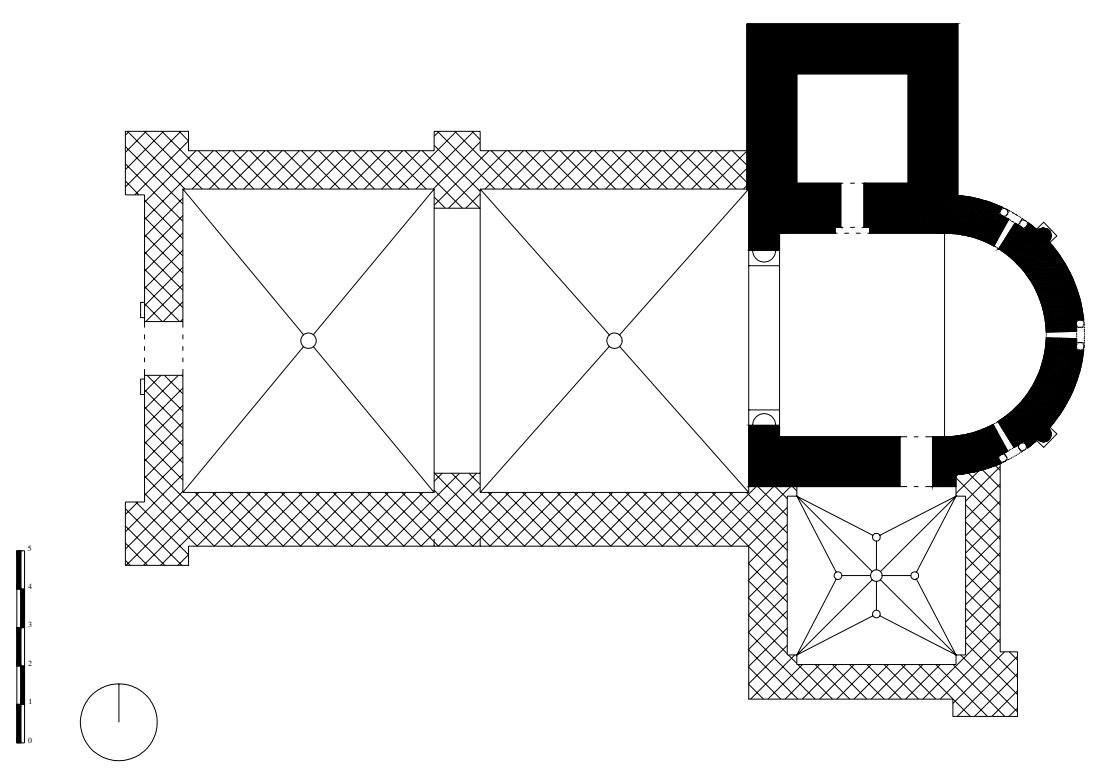

Parte románica. S. XII.

Construcción S. XVII.

NEILA. Iglesia de San Miguel.

Fases constructivas.

de codillo, y articulados longitudinalmente mediante los potentes contrafuertes, que reflejan los tramos de la nave. Una estructura, en definitiva, que consigue adaptarse de modo perfecto a la concepción volumétrica del resto del conjunto del templo, formado por la torre y cabecera románicas, sin crear, a pesar de la diferencia cronológica y estilística, la sensación de un contraste brusco. El elemento más destacado, dentro de esta nueva obra, lo encontramos en su fachada principal, levantada sobre el muro de los pies, donde se realiza una construcción de formas sencillas y de gran planitud, que nos conduce, de forma inmediata hacia la influencia del foco lermeño. 
Esta fachada ocupa todo el muro de los pies, formando un amplio rectángulo delimitado por los contrafuertes en las esquinas, que actúan a modo de grandes pilastras, entre las que se extiende una airosa cornisa que da paso un frontón triangular con el que se remata todo el conjunto. Este frontón se acompaña de pináculos piramidales sobre sus vértices, representándose en la parte central del tímpano un óculo simplemente contorneado. Sobre el eje central de la fachada se disponen el resto de los elementos, entre los que se encuentra la puerta de acceso y un ventanal rectangular con arco de medio punto, todo ello enmarcado por una moldura plana de escaso resalte. La puerta de acceso, por su parte, presenta un amplio vano coronado con arco de medio punto, escoltado por pilastras, sobre las que se dispone un entablamento quebrado en sus extremos, de friso completamente liso y airosa cornisa, sobre cuyos extremos, y siguiendo el eje marcado por las pilastras inferiores, se disponen sencillos pináculos piramidales.

Representa, por lo tanto, una obra inspirada, aunque lejanamente, en los modelos de fachada de tipo carmelita, de los cuales, como sabemos, la villa ducal de Lerma nos provee de abundantes ejemplos en la provincia de Burgos. En ella, como en los modelos que la inspiran, van a predominar, tanto las medidas y cuidadas proporciones, establecidas en base a un esquema cuadricular, como la absoluta planitud de todo el conjunto, sin que encontremos elementos que sobresalgan sobre el plano marcado por el propio muro. Dentro de ella se combina el ritmo ascendente, marcado por el propio eje central, sobre el que se disponen la puerta de acceso y el ventanal situado sobre ella, con el concepto de horizontalidad, que imprime el propio trazado del rectángulo en el que se inscribe, delimitado por los potentes y pesados contrafuertes laterales. Toda la composición muestra, al mismo tiempo, un claro desprecio por los valores y elementos ornamentales, lo que nos permite inscribirla dentro del más puro y recio estilo herreriano. Así, en virtud de estos rasgos, debemos situar la ejecución de esta obra, sin ningún género de dudas, dentro de esta centuria del Seiscientos. 
Aparte de estas construcciones de nueva planta y de las renovaciones y ampliaciones, que acabamos de ver, también tenemos que hablar de la incorporación de determinadas piezas a edificios ya existentes.

Dentro de estas intervenciones, sin duda, las que despiertan un mayor interés, desde el punto de vista artístico, son las portadas, dado que en ellas, no sólo se concentra la mayor parte de la ornamentación exterior de los templos, sino porque al actuar, en la mayoría de los casos, como elementos autónomos, dentro de la estructura del edificio, sus posibilidades de evolución, rompiendo el estricto encorsetamiento de la estética clasicista, son mayores, manifestando algunos rasgos propios del barroco. De este modo, al igual que ocurrió en el siglo XVI, su función no sólo se centra en intentar modernizar y dar un aire nuevo a la estructura del edificio, sino que también en trata de mostrar el propio templo hacia el exterior, integrándolo dentro del marco urbanístico.

En este apartado, además de las portadas que ya hemos visto en los templos de Huerta de Arriba, San Miguel de Neila y la ermita de Nuestra Señora del Arroyal, en Palacios de la Sierra, esta centuria también nos deja algunos otros ejemplos interesantes, como son los incorporados a las iglesias de San Cristóbal, en Quintanar de la Sierra, y San Pedro, en Hacinas. En ambos casos se trata de templos, cuyas fábricas habían experimentado una profunda remodelación a lo largo de este siglo, merced al desarrollo de amplios y ambiciosos programas constructivos. De este modo, la incorporación de estas portadas debemos entenderlas, en ambos casos, como la culminación de estos programas.

La portada de la iglesia de Quintanar de la Sierra se realiza en 1630, tal y como se advierte en la inscripción conservada sobre el arco que sirve de marco ${ }^{700}$. Esto hace que resulte difícil separar su ejecución del resto de la obra del templo, pues la renovación del edificio se había concluido en 1622. Esta portada se sitúa sobre la

\footnotetext{
700 "ESTA PORTADA SE ACABÓ DE HACER AÑO 1630, SIENDO CURA EL LICENCIADO BLANCO MARCOS”.
} 


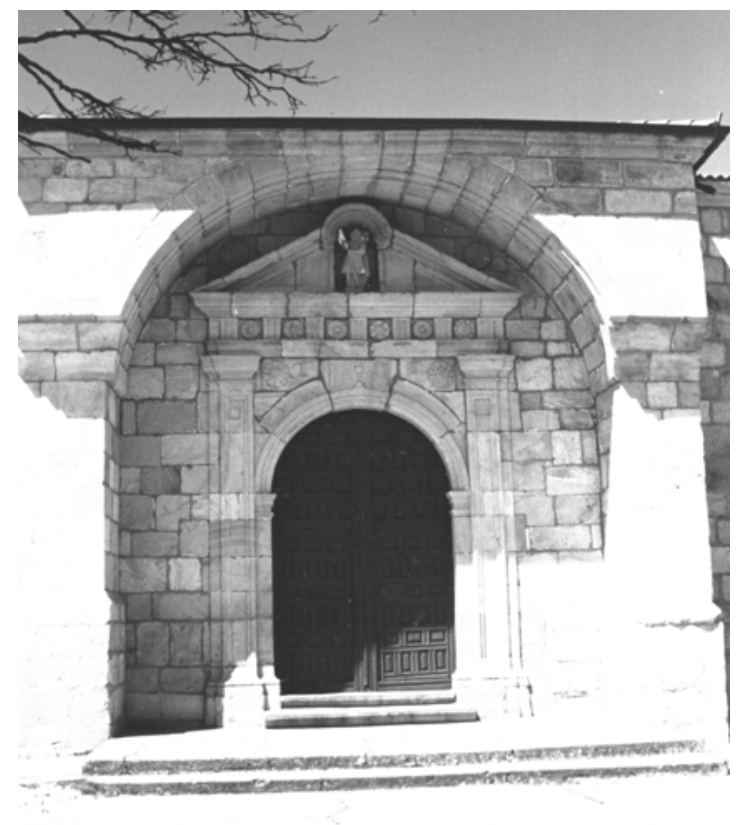

QUINTANAR DE LA SIERRA.

Iglesia de San Cristóbal. Portada.

fachada meridional del templo, a la altura del tercer tramo, cobijándose bajo un amplio arco de medio punto, dispuesto entre contrafuertes. Se encuentra formada por un amplio vano coronado con arco de medio punto, de rosca recorrida por pequeñas molduras, y escoltado a cada lado por pilastras y retropilastras cajeadas de orden dórico, que se alzan sobre elevado podio. Estas pilastras sustentan un entablamento de gran clasicismo, con el friso articulado en triglifos y metopas, decoradas, estas últimas, con grandes rosetas, y una airosa cornisa que da paso al remate. Éste se encuentra formado por un frontón recto, con el vértice superior ligeramente curvado, dando cabida, en el tímpano, a una pequeña hornacina avenerada, donde se coloca la imagen en piedra de San Cristóbal, santo titular del templo.

Constituye, por lo tanto, una obra en la que se desarrolla un vocabulario plenamente clasicista, el cual, sin embargo, comienza a romper ligeramente la severidad propia de esta estética. Así, la planitud, que mantiene este estilo, comienza a ser superada de un modo sutil, a través de ligeras molduraciones y un mayor vuelo de las 
cornisas y pilastras, elementos estos que resaltan ligeramente sobre el muro, creando pequeños contrastes lumínicos. De igual modo, toda la composición muestra un manifiesto ritmo ascendente, expresado a través de las esbeltas proporciones de cada uno de sus elementos, dentro de los cuales, al mismo tiempo, comienzan a incluirse algunos elementos ornamentales, en forma de rosetas, que acaban definitivamente con la severidad anterior. Todo ello, nos anuncia ya la llegada de ciertas libertades propias del mundo barroco, que sin embargo, apenas tendrán acogida en esta comarca.

No obstante, siempre hay excepciones, y en este sentido, sin duda, la más clara la tenemos en la portada, que se levanta en la década de 1680 para la iglesia de San Pedro, en Hacinas. A diferencia del ejemplo anterior, en este caso sí conocemos el nombre del encargado de su ejecución, responsabilidad que recayó en el maestro de cantería trasmerano Francisco de Hermosa ${ }^{701}$, uno de los más destacado artífices de cuantos trabajan durante el siglo XVII en la comarca serrana.

Esta portada aparece dispuesta sobre el muro meridional, a la altura del segundo tramo del cuerpo, y se cobija bajo un amplio arco de medio punto, dispuesto, al igual que en el caso anterior, sobre los contrafuertes, que delimitan este espacio. Cuenta con una estructura articulada en dos cuerpos decrecientes, unidos mediante un frontón partido, situado sobre el cuerpo inferior, que sustituyen a las clásicas aletas. Esto nos recuerda ciertas soluciones propias de la arquitectura palladiana, empleadas y ampliamente difundidas en el área de la Meseta Norte castellana por diversos maestros ligados al foco vallisoletano de principios de la centuria del Seiscientos ${ }^{702}$.

El cuerpo inferior presenta un amplio vano, coronado con arco de medio punto, a cuyos lados se disponen dos parejas de columnas de orden toscano, con fuste estriado y acentuado éntasis. Sobre el quebrado entablamento, dispuesto sobre estas columnas, se

\footnotetext{
701 AGDBU. LP. Hacinas, parroquia de San Pedro, LF (1572 - 1702). Cuentas del año 1685. Hacinas, $18-$ julio -1686 .
} 
HACINAS. Iglesia de San Pedro. Portada.

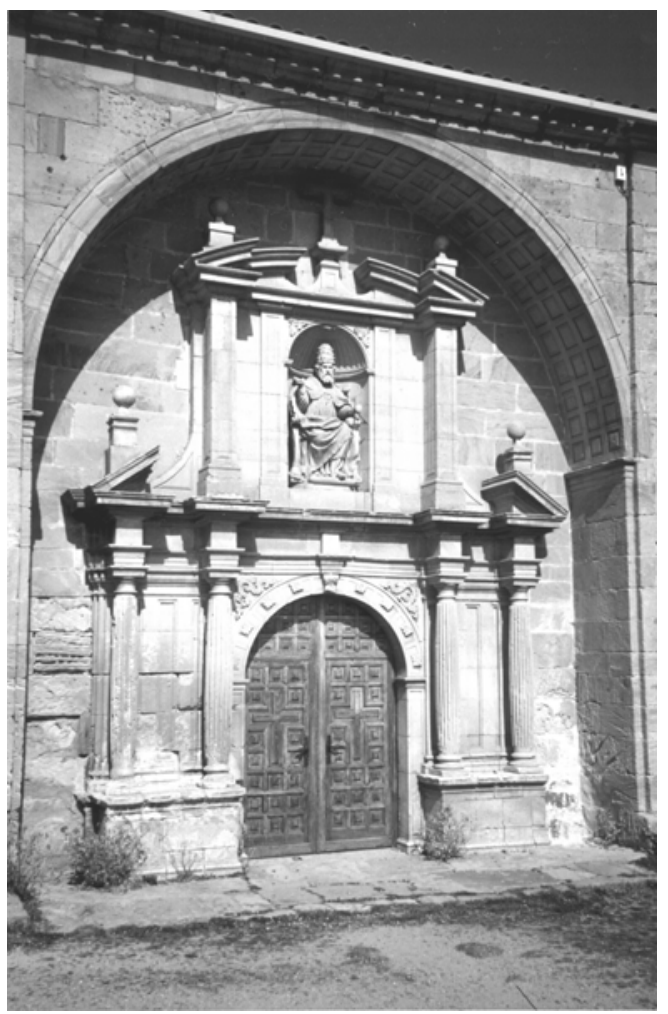

alza el segundo cuerpo, formado por una amplia hornacina avenerada en el centro, escoltada por pilastras cajeadas, colocadas en distinto plano, y rematada por un frontón semicircular partido de perfil retranqueado. En su interior se cobija una magnífica talla en piedra del santo titular del templo, San Pedro, el cual aparece dispuesto de modo sedente y caracterizado con los atributos propios del tipo iconográfico de este santo como papa, es decir, capa pluvial, cruz de triple travesaño, tiara papal y las llaves sobre su mano ${ }^{703}$.

Se trata, en definitiva, de una obra propia del periodo avanzado del barroco, en la cual se juega con los elementos estructurales, a los cuales se da un carácter ornamental, al mismo tiempo que se rompe con la planitud propia del lenguaje

702 A. BUSTAMANTE GARCÍA: "En torno al clasicismo: Paladio en Valladolid" En AEA, no 205, (1979). pp. $34-54$. 
clasicista. Con ello se consigue una obra mucho más movida, en la cual se alternan distintos planos, con constantes entrantes y salientes, a través de los que se logran interesantes juegos de luces y sombras. Una obra, por lo tanto, sumamente original y bien trazada, que prácticamente no tendrá ningún tipo de continuidad dentro de esta comarca, ni en lo que resta de esta centuria, ni en la siguiente.

No menos interesante, que la incorporación de las portadas, fue la construcción de nuevas torres-campanario, como las que se levantaron en varias de estas iglesias a lo largo del siglo. Se trata de torres que parten del modelo de prisma cerrado, desarrollado durante el siglo XVI, sobre el cual se incorporan las diferentes líneas de imposta, que marcan la separación entre los cuerpos, así como los pináculos de bola o piramidales en el remate. De igual modo, resulta habitual encontrar un grueso friso recorriendo el remate del cuerpo de campanas, con el cual se da paso a la cornisa del tejado.

Dentro de los ejemplos de este tipo de obras, sin duda uno de los más interesantes lo encontramos en la iglesia de San Pedro en Hacinas. En esta iglesia, en torno a la década de 1630, con la iniciativa y el apoyo económico del párroco del pueblo, D. Pedro González Varaona ${ }^{704}$, se decide construir una nueva torre a los pies de la nave, levantada a comienzos del siglo anterior. El encargado de su realización (y es posible que incluso de su diseño), fue el maestro de cantería Pedro Díaz de Palacios, el cual, con esta obra, inauguraba la amplia serie de actuaciones, que, a partir de este momento, iba a dejar por toda esta comarca, las cuales alcanzaron su culminación en el monasterio de San Pedro de Arlanza ${ }^{705}$. Esta participación sirve para garantizar la cuidada calidad técnica de la obra, así como su adscripción a la estética clasicista, de la

\footnotetext{
703 J. FERRANDO ROIG: Iconografía de los Santos. Barcelona, Ediciones Omega. 1996. (pp. 218).

704 AGDBU. LP. Hacinas, parroquia de San Pedro, LF. (1572 - 1702). Hacinas, 1628.

705 E. CARRETERO SANTAMARÍA, V. GONZÁLEZ DE CASTRO: "Arquitectura clasicista en Burgos: noticias documentales de la obra de Pedro Díaz de Palacios...” ob. cit., C. J. PALACIOS PALOMAR: Patrimonio artístico y actividad arquitectónica del monasterio de Santo Domingo de Silos...ob. cit. (pp. 35).
} 
cual este artífice fue uno de sus más firmes y aventajados representantes, dentro del territorio de la Diócesis de Osma y parte de la de Burgos

La obra en sí, presenta una estructura articulada en dos cuerpos, separados por una moldura, que forman un sólido prisma de escaso desarrollo en altura, reforzado en las esquinas por potentes contrafuertes de lados perpendiculares a los muros y ángulo recto. Dentro de estos dos cuerpos destaca de modo particular el superior, pues el inferior, que forma la base, únicamente presenta una ventana en su parte occidental, de trazado rectangular y dintel plano, enmarcada por una moldura plana con orejones.

En la segunda altura, que forma el cuerpo de campanas, cada una de las caras del prisma se articulan con pilastras colocadas en el centro y en las esquinas, superponiéndose estas últimas a los estribos de refuerzo. Entre ellas se abren dos vanos para las campanas, coronados con arco de medio punto, que arrancan sobre unas impostas planas, y con un antepecho en la parte inferior. Estos muros aparecen rematados por un friso quebrado, delimitado por un fino junquillo, con el que se da paso a una cornisa de codillo, que conduce al tejado. Aquí, coronando los ejes de las pilastras inferiores, se disponen los correspondientes pináculos piramidales, que rematan todo el conjunto.

Se trata, en definitiva, de una estructura en la que se rompe de modo manifiesto la absoluta planitud de los modelos anteriores, introduciendo ligeros contrastes entre planos, con los que se generan juegos de claroscuro. Por lo demás, no es una obra que destaque especialmente por su altura, si bien, dada la ubicación del templo en la parte más elevada de la abrupta orografía, sobre la que se asiente esta localidad, termina convirtiéndose en un auténtico hito referencial, dentro del propio casco urbano del pueblo, y de su entorno más inmediato.

Una obra similar a ésta, aunque notablemente simplificada en su composición, es la que se levanta en la vecina localidad de Moncalvillo. Desconocemos por completo 
los datos referentes a su autoría, así, como el momento exacto de su construcción, si bien, debemos pensar que se trata a una obra contemporánea de la anterior. En cierto modo, confirmando esto, observamos cómo los Libros de Fábrica de esta iglesia, cuyos registros de cuentas conservados, arrancan en 1644, nos presentan esta pieza como una obra ya completada.

En su composición presenta la misma estructura de gran prisma de planta cuadrangular, articulado en dos cuerpos, separados por una línea de imposta, que hemos visto en Hacinas. No obstante, en este caso, desaparecen los estribos de refuerzo en las esquinas, de igual modo que no encontramos tampoco las pilastras, que articulan el desarrollo del cuerpo de campanas. Por ello, sus muros, en ambos cuerpos, se muestran como paños completamente planos, realizados en piedra de sillería, perfectamente labrada y ensamblada. De este modo, el cuerpo inferior apenas nos muestra elementos de interés, que podamos destacar. El superior, por su parte, cuenta con un solo vano en cada una de sus caras, que cierra con sencillo arco de medio punto, al que se añade un pequeño antepecho en su parte inferior. Un amplio friso completamente plano, delimitado por un junquillo, remata este cuerpo en su parte superior, sobre el cual se coloca una cornisa de codillo, que conduce al tejado. sobre cuyas esquinas se alzan los correspondientes pináculos de bola de tradición herreriana.

Se trata, por lo tanto, de una torre mucho más sencilla que la de Hacinas, la cual podemos poner en relación con las levantadas para los templos de Quintanar de la Sierra y Huerta de Abajo, que ya vimos en su momento. Por otra parte, al igual que sucedía en el caso anterior, no es una obra que destaque especialmente por su elevada altura, sin embargo, como ya ocurriera en Hacinas, la posición dominante de esta iglesia, dentro del entramado del pueblo, hace que se convierte en un auténtico hito referencial.

En relación directa con esta torre de Moncalvillo podemos mencionar otros ejemplos, para los que no tenemos la confirmación documental necesaria, pero cuyas formas delatan, sin duda alguna, su pertenencia a esta centuria. Es el caso de las torres 
de las iglesias de San Julián, en Arroyo de Salas, San Juan Bautista, en Tolbaños de Arriba, Santa Eugenia, en Terrazas y la parroquia de San Martín en Huerta de Arriba. Las tres primeras nos ofrecen una estructura prácticamente idéntica entre sí, con un gran prisma de sección cuadrangular, articulado en dos cuerpos, separados por una línea de imposta plana de escaso resalte. Dentro de ellos destaca el superior, que constituye el cuerpo de campanas, en el cual se abre los vanos coronados con arco de medio punto. Finalmente, su cubierta, dispuesta a cuatro aguas, se encuentra rematada con pináculos de bola dispuestos sobre cada una de sus esquinas. La iglesia de San Martín en Huerta de Arriba, por su parte, a pesar de la importante renovación que sufre su fábrica, durante las primeras décadas de la centuria siguiente, consigue mantener en pie su torre, la cual también nos ofrece signos evidentes, que pueden confirmar su pertenencia a al siglo XVII. Esta torre se alza sobre un elevado zócalo, que se corresponde con los restos de una primitiva torre románica. Sobre él se dispone una sencilla estructura prismática de sección cuadrangular, articulada en tres pequeños cuerpos, separados por impostas planas de escaso resalte. De ellos, el tramo superior corresponde al cuerpo de campanas, sobre el cual se abría, en cada uno de sus lados, un sencillo vano coronado con arco de medio punto, que actualmente, y tras la construcción del nuevo cuerpo de campanas añadido a mediados del siglo XVIII, se encuentran cegadas.

Por último, debemos citar también los casos de Castrillo de la Reina y de la parroquia de Santa María en Salas de los Infantes, en los cuales simplemente se remodela la estructura de sus respectivas torres, elaboradas durante el siglo XVI, añadiendo un nuevo cuerpo de campanas, con el que consiguen incrementar de modo notable su altura.

El caso de Castrillo de la Reina, se realiza en los primeros momentos del siglo, cuando aun no se había terminado de pagar la construcción de la torre anterior, que ahora servía de base para la nueva obra. El encargado de su ejecución fue el maestro 
Juan Gil, de origen trasmerano ${ }^{706}$, concluyendo las obras en torno al año $1604^{707}$. La obra se concibe como una clara continuación de la anterior, formando un pequeño prisma en forma de cubo, aunque con un ligero decrecimiento de su planta, marcado a través de dos líneas de imposta superpuestas. Se halla elaborada en piedra de sillería de buena calidad, formando un cubo en cada una de cuyas caras se abren dos vanos coronados con arco de medio punto, que arranca sobre impostas, y con un pequeño antepecho en la parte inferior. Sobre estos vanos, igual que en los casos anteriores, se extiende un friso culminando el desarrollo de los muros, el cual da paso a una cornisa con la que se accede al tejado, donde se colocan también los pináculos de bola sobre sus esquinas.

No se trata, por lo tanto, de una pieza de grandes proporciones, sin embargo, constituye el complemento ideal para convertir esta torre en el contrapunto ascensional, que rompe con la excesiva sensación de horizontalidad, que domina en la imagen exterior del templo. En este caso, la reconstrucción, que hemos podido hacer, a través de los programas informáticos de tratamientos de imágenes, nos han permitido conseguir unos resultados ciertamente reveladores de esto que estamos diciendo.

El otro ejemplo lo tenemos en la iglesia de la parroquia de Santa María, en Salas de los Infantes. En este caso, la total ausencia de testimonios documentales precisos nos impide conocer el nombre de sus autores, así como el momento exacto de su ejecución. No obstante, en virtud de sus formas de tradición herreriana, debemos suponer que se llevó a cabo en torno a las primeras décadas de esta centuria del Seiscientos.

En este caso, la total ausencia de restos conservados del cuerpo de campanas anterior nos hace pensar que esta nueva pieza se realizó suplantando completamente a la

\footnotetext{
706 M. C. GONZÁLEZ ECHEGARÁY, M. A. ARAMBURU-ZABALA HIGUERAl: Artistas cántabros de la Edad Moderna. Su aportación al arte hispánico. (Diccionario biográfico - artístico). Salamanca, Servicio de Publicaciones de la Universidad de Cantabria. 1991. (pp. 243).

707 AGDBU. LP. Castrillo de la Reina, parroquia de San Esteban, LF. (1572 - 1631). Cuentas del año 1604. Castrillo de la Reina, 13 - junio - 1606.
} 


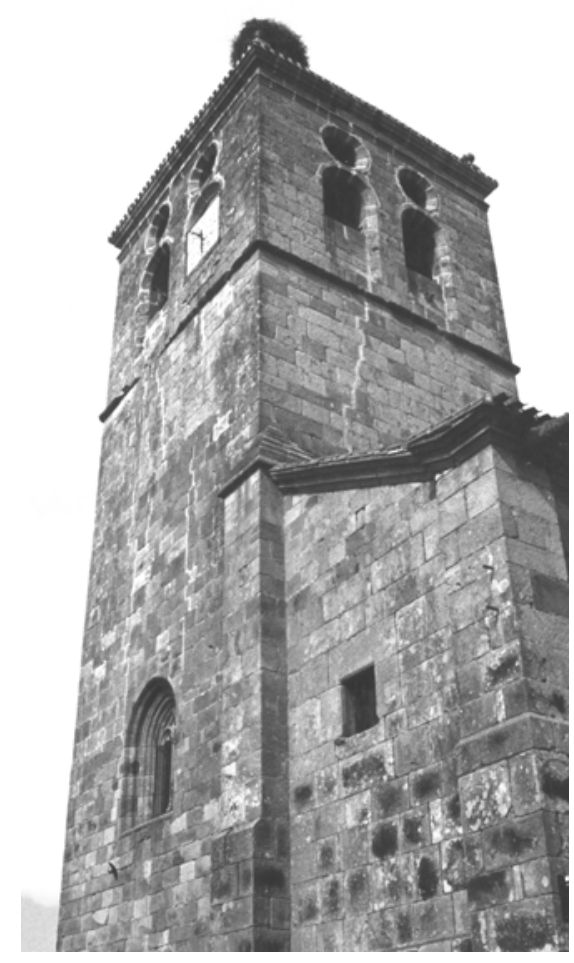

SALAS DE LOS INFANTES. Torre de la iglesia de Santa María.

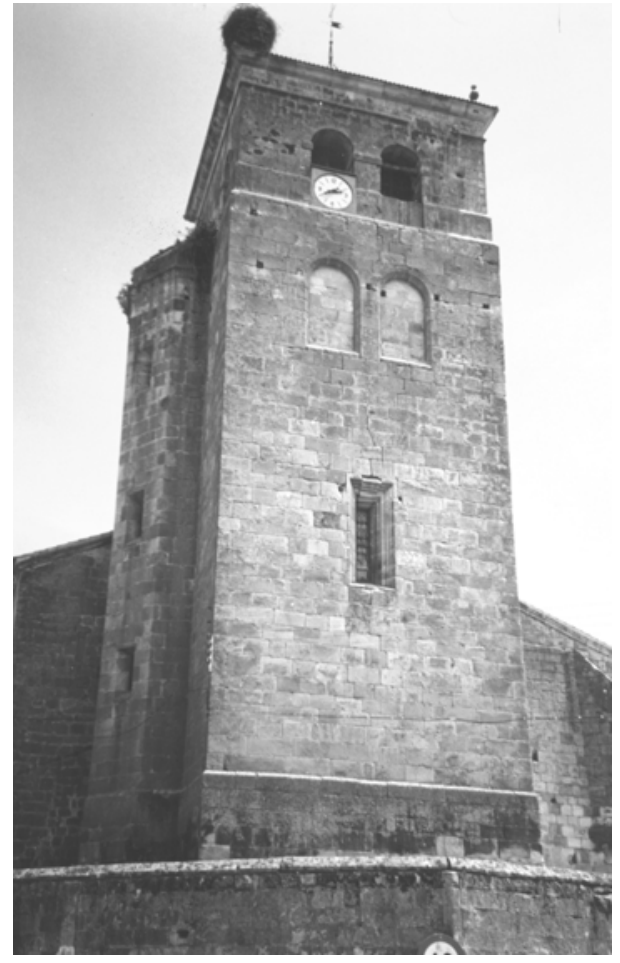

CASTRILLO DE LA REINA. Torre de la iglesia de San Esteban.

anterior, y no superponiéndose a aquella, como había ocurrido en Castrillo de la Reina. Aquí, este nuevo cuerpo se presenta como una clara continuación de la estructura anterior, formando un volumen cúbico perfecto de muros completamente planos, que se separan del cuerpo inferior mediante una sencilla imposta. En cada una de sus caras se abren dos vanos coronados con arco de medio punto y pequeño antepecho, sobre los cuales se disponen grandes óculos, que se convierte en el elemento más representativo de la obra. Estos muros, a su vez, y como ocurría en los ejemplos anteriores, se culminan con un friso y una cornisa de doble moldura de codillo y papo de paloma, que conduce al tejado, donde se alzan pináculos de bola en las esquinas. 
La obra se incluye, por lo tanto, dentro de la corriente más pura del clasicismo, heredado de la tradición de Juan de Herrera, en la cual se desarrollan muchos de los rasgos definidos por este autor en sus creaciones más destacadas. Estas formas, al mismo tiempo, nos llevan a relacionarla inevitablemente con el cuerpo de campanas, que a finales del siglo anterior, había construido Juan de la Torre Bueras para la iglesia del Hospital del Rey en las afueras de Burgos. El caso de Salas representa una versión simplificada con respecto a aquella, pues en este caso desaparecen las pilastras, que articulan el desarrollo del muro.

Por lo demás, al igual que sucedía en el caso de Castrillo, su incorporación supone la creación del contrapunto ascensional a la imagen de un templo, dominado por la sensación de horizontalidad. Al mismo tiempo, esta obra supone crear un extraordinario hito referencial, hasta el punto que se convierte en el elemento más destacado de la estampa, que ofrece la localidad desde la lejanía.

Junto a la construcción de nuevas torres y campanarios, debemos mencionar también la renovación de sus sacristías, que realizaron varias de las iglesias de la zona. Bajo estas obras se esconde, en este caso, una clara intención de dignificar este espacio, concediendo un marco más digno y adecuado para el lugar donde se custodiaban las ropas y demás utensilios litúrgicos, usados durante los oficios. Como ya vimos en su momento, el resultado de estas intervenciones nos depara piezas de estilo no bien definido, y sin un especial valor artístico, pero claramente funcionales, pues saben adaptarse a las necesidades de las parroquias.

Aparecen en todos los casos adosadas junto a uno de los flancos de la cabecera, mostrando una planta cuadrangular con muros planos, con los que se dibuja una estructura prismática. En su interior, el espacio resultante, se cubre con bóveda de crucería estrellada con terceletes de gran planitud, continuando, de este modo, el tipo de cubierta, que con más frecuencia se empleaba en el interior de los templos, durante la centuria. Entre los ejemplos más destacados podemos citar las sacristías construidas en 


\section{SALAS DE LOS INFANTES.}

Iglesia de Santa María.

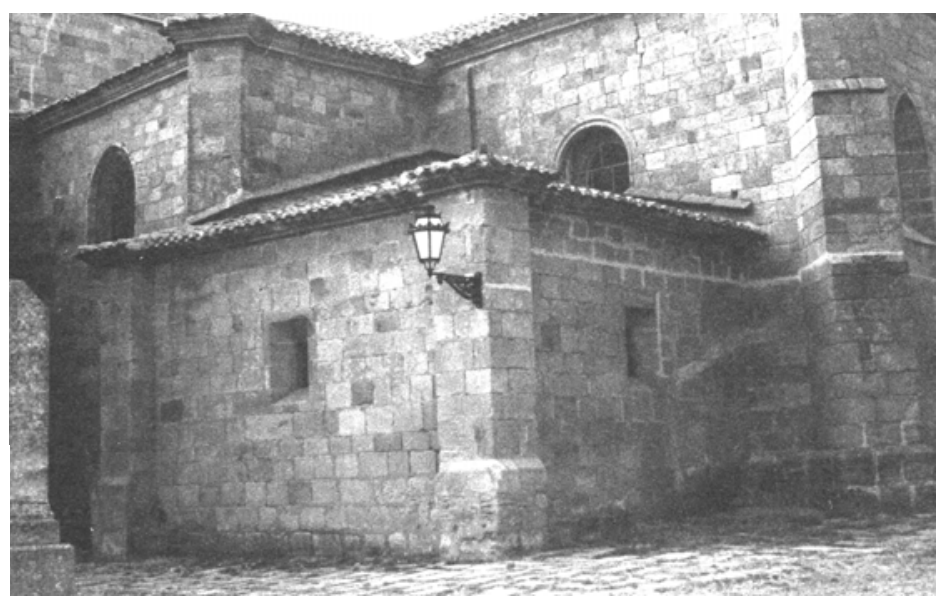

la iglesia de Castrillo de la Reina, en la parroquia de Santa María, en Salas de los Infantes, en la iglesia de Santa Coloma, en Riocavado de la Sierra ${ }^{708}$, y en las dos parroquias de Neila, la de Santa María y la de San Miguel.

Dentro de ellas, la única que nos ofrece algún tipo de variante, dentro de este modelo, la encontramos en la parroquial de Santa María, en Salas de los Infantes, donde se introducen en su cubierta una serie de nervios combados, con los que se dibuja una estructura trebolada en la parte central, incluyendo además una serie de claves con forma de cueros recortados, dentro de una de las cuales aparece la inscripción del año 1659, que indudablemente indica el año de su finalización.

Otro tipo de construcciones menos frecuentes son los baptisterios, dentro de los cuales el más destacado es el realizado hacia 1660 para la iglesia de Santa María, en Salas de los Infantes. Se trata de una estancia de trazado rectangular, incorporada en la parte de los pies del templo, como una prolongación de la nave de la Epístola,

\footnotetext{
708 Esta sacristía actualmente no existe, pues ha sido destruida recientemente con el fin de no entorpecer la contemplación de la magnífica cabecera románica que este templo posee. Sin embargo, a través de distintas fotografía tomadas antes de su destrucción hemos podido comprobar cómo por su aspecto y rasgos se ajustaba plenamente al modelo que hemos visto en estos otros templos.
} 
adosándose, al mismo tiempo, al flanco meridional de la torre. Exteriormente, por lo tanto, queda integrado perfectamente en el bloque, que forma la estructura del cuerpo, pues su tejado guarda el mismo nivel que el de las naves Toda su estructura, además, se halla levantada en piedra de sillería, con lo que se mantiene la técnica, que desarrolla el resto de esta fábrica. La única novedad la aporta el estribo que refuerza su esquina, el cual ya no presenta la disposición diagonal del edificio gótico.

En el interior, esta pieza se articula en dos pisos, de los cuales el inferior constituye el baptisterio propiamente dicho. A su interior se accede, desde la nave de la Epístola, a través de un potente arco escarzano de grueso intradós casetonado, con el que se da paso a un sencillo espacio rectangular, cubierto con una bóveda de crucería estrellada con nervios terceletes, dentro de cuya trama se incluyen una serie de nervios combados, con los que se dibuja una figura trebolada, similar a la que aparece en la sacristía. Esta bóveda destaca, al mismo tiempo, por su extraordinaria planitud, pues presenta una rampante completamente llana, como suele ocurrir en aquellas cubiertas, que llevan una superficie pisada encima. El cuerpo superior está compuesto por una sencilla estancia a la que se accede a través del coro, mediante una pequeña puerta situada en la parte lateral. Su función, con toda seguridad, debió ser la de almacén, pues en su estructura no presenta ningún tipo de tratamiento especial.

La falta de documentación precisa nos impide, no sólo conocer los nombres de los artífices encargados de su ejecución, sino también establecer una cronología precisa. No obstante, las notables afinidades, que muestra con respecto a la obra de la sacristía, especialmente en el tipo de cubierta, nos lleva a considerarlas como obras contemporáneas.

Otra obra interesante, es la construcción del nuevo coro, que se realiza en la iglesia de Castrillo de la Reina, entre los años 1669-70, dentro del espacio abierto en el interior de la base de la torre. Se trata de una construcción poco frecuente en la zona, pues aunque desarrolla el característico tipo de coro alto situado en la parte de los pies, 
que se utiliza desde finales del gótico, éste se encuentra realizado totalmente en piedra, algo que no solemos ver en estas iglesias. El encargado de su ejecución fue el maestro de cantería Diego de Olano, el cual recibió por su trabajo la cantidad de 3.286 reales $^{709}$, a los que debemos sumar el coste de los materiales.

El resultado es una obra sumamente sencilla, donde se refleja la severidad arquitectónica del momento. Se encuentra formado por un amplio arco escarzano de rosca finamente moldurada (algo no muy corriente en este siglo), sobre el que discurre una cornisa de codillo, que da paso a una sencilla balaustrada, realizada también en piedra. El espacio del sotocor se cubre con bóveda de crucería estrellada con terceletes de rampante completamente llana.

En cierto modo, próximo a este tipo de coro, podemos mencionar también el construido, en torno a estas mismas fechas, en la iglesia de San Martín, en Huerta de Arriba. Se trata, en este caso, de una construcción mixta, donde se alterna piedra y madera, ubicada igualmente en el espacio abierto en el interior de la base de la torre. El encargado de la obra fue el maestro de cantería Juan de Solares, el cual simplemente tuvo que trazar dos grandes vanos superpuestos, sobre el muro de los pies del templo, coronados con arco de medio punto, destinados a comunicar respectivamente, el ámbito del coro y sotocoro, con el espacio de la nave. La cubierta de este sotocoro, estaría compuesta por una simple viguería de madera, sobre la que se disponía el entablado, que formaba el suelo del piso superior ${ }^{710}$.

Otra obra singular es la arquería que existe en la iglesia de Moncalvillo, comenzada a construir, según reza la inscripción conservada en uno de los arcos, en el año 1601. Está formada por dos amplios arcos de medio punto de sección trapezoidal e intradós plano con relieve cajeado, que actualmente cumplen la función de arcos formeros de separación entre la nave principal y la pequeña nave, dispuesta al mediodía.

709 Ibídem. LF. (1632 - 1673). Cuentas del año 1669. Castrillo de la Reina, 3 - julio - 1670. 
Por sus características, bien podríamos relacionar esta obra con las líneas de arcos formeros, que componen las naves de la iglesia de Vilviestre del Pinar. No obstante, dada la estructura de este templo, no parece que ésta fuera su primitiva función, pues la nave lateral, a la que dan paso, fue levantada exactamente un siglo más tarde, según nos confirman los Libros de Fábrica de la parroquia. De esta forma, nuestra hipótesis apunta a que pudiera tratarse, más bien, de una especie de pórtico, heredero de la tipología desarrollada en la zona, especialmente durante el período románico, el cual encuentra en estas construcciones sus más firmes referentes. Esta idea se puede confirmar, si tenemos en cuenta que la mayoría de las iglesias de la zona continuaron mostrando, durante esta época, algún tipo de pórtico o portal, previo a la puerta de acceso, en el que se puede ver reflejada la antigua tradición de los pórticos románicos. No obstante, debemos suponer, que se trataba, en todos los casos, de obras de extremada sencillez, y sin ningún tipo de valor artístico, ya que estarían compuestos por simples estructura de madera, con las que se formaba un pequeño tejadillo ante la entrada. Al menos esto es lo que se desprende de los materiales empleados en los constantes trabajos de reparación, que su mantenimiento requería. El único ejemplo de este tipo de estructuras, que ha llegado hasta nosotros, se encuentra en la iglesia de la parroquia de Santa María, en Neila, el cual, a pesar de pertenecer al siglo XVI, resulta válido para poder hacernos una ligera idea de sus características.

Terminamos este recorrido con las obras de construcción y remodelación del atrio y cementerio, que se llevan a cabo, respectivamente, en las iglesias de Castrillo de la Reina y Quintanar de la Sierra.

El primero se efectúa en la década de 1670, y está formado por un amplio muro de sillería, dispuesto en torno al templo, cuya construcción se aprovecha para reforzar la seguridad de la fábrica, en aquellas zonas más deprimidas. Para ello se indica textualmente que se debe "allanar el cementerio y pasar la tierra por detrás de la

\footnotetext{
710 AGDBU. LP. Huerta de Arriba, parroquia de San Martín, LF. (1637 - 1675). Cuentas del año 1666. Huerta de Arriba, 7 - diciembre - 1666 .
} 
iglesia y terraplenar»" ${ }^{, 11}$. Los trabajos alcanzaron, por lo tanto, una gran magnitud, lo cual queda reflejado, de modo especial, en las elevadas cantidades desembolsadas por esta parroquia, a lo largo de las distintas fases en que se acometió el proyecto. Así, a pesar de las ayudas prestadas por los vecinos, con sus limosnas y trabajo personal, la fábrica tuvo que desembolsar algo más de 240.000 maravedís $^{712}$.

En Quintanar de la Sierra estos trabajos se efectúan una década más tarde, y se centran fundamentalmente en asegurar la estabilidad del suelo sobre el que se alza el templo, pues al tratarse de una superficie creada de modo artificial, los reparos sobre sus muros eran una cuestión de auténtica supervivencia para el edificio ${ }^{713}$.

\section{Arquitectura civil. Siglo XVII.}

En el ámbito de la arquitectura civil continúan predominando, durante todo el siglo XVII, los modelos propios de la arquitectura popular. Esto sucede así, porque las estructuras y formas propias de estos edificios conseguían adecuarse de un modo perfecto, tanto a las necesidades constructivas de sus propietarios, como a las condiciones medioambientales, sociales y económicas del entorno. Sin embargo, dentro de este campo, esta centuria es testigo de un importante salto cualitativo. Así, por primera vez durante toda la Edad Moderna, vamos a ver cómo los grupos más relevantes de la sociedad, que pueblan estas localidades, empiezan a sentir la necesidad de manifestar su carácter preponderante, no sólo a través de una vivienda más grande y

711 AGDBU. LP. Castrillo de la Reina, parroquia de San Esteban, LF. (1673 - 1708). Cuentas de 1686 1687. Castrillo de la Reina, 7 - diciembre - 1687.

712 Ibídem. LF (1632 - 1673). Cuentas del año 1672. Castrillo de la Reina, 22 - abril - 1673. Ibídem. LF (1673 - 1708). Cuentas del año 1673. Castrillo de la Reina, 21 - septiembre - 1673. Ibídem. Cuentas del año 1674. Castrillo de la Reina, 29 - diciembre - 1675.

713 AGDBU. LP. Quintanar de la Sierra, parroquia de San Cristóbal, LF. Visita realizada a la parroquia de San Cristóbal de Quintanar de la Sierra en 1668, por el visitador del Arzobispado de Burgos, D. Baltasar de Fuente Sanz. Quintanar de la Sierra, 23 - marzo - 1668. 
sólida, sino también mediante la inclusión en ella de ciertos rasgos, con los que se manifiestan unas determinadas inquietudes por los valores estéticos. Son elementos, que no han surgido dentro del propio ambiente popular de la zona, ni siquiera han sido importados de la arquitectura de otras comarcas próximas, sino que se han traido directamente desde la arquitectura culta, en la que se manifestaban los gustos y formas artísticos preponderantes de cada momento. Se trata, en definitiva, de utilizar la casa como un símbolo parlante, indicador del status social de sus propietarios.

De este modo, se inicia, dentro de este ámbito de la arquitectura civil, lo que podemos llamar, el desarrollo de una arquitectura culta, entendida como el fiel reflejo del dinamismo, que esta sociedad de la sierra burgalesa, estaba empezando a manifestar. Dinamismo y pujanza, que alcanzan su momento culminante durante el siglo XVIII, como bien se encargan de mostrarnos las construcciones emprendidas durante aquel periodo.

A todo ello contribuyeron diferentes factores, entre los que no debemos olvidar los de índole estrictamente económica, mostrándose así el relativo blindaje de una sociedad como la serrana, cuya dependencia no exclusiva de la agricultura, sino más bien de otras actividades (como la ganadería trashumante y la carretería), permitía una cierta inmunidad frente a la inestabilidad de las cosechas. Junto a esto, no menos importantes, debieron ser los factores de orden social, pues, como ya tuvimos oportunidad de ver al hablar de la sociedad de la zona durante la Edad Moderna, este siglo marca el inicio de un proceso de ennoblecimiento, que culmina en la centuria siguiente con la población de varios de estos pueblos incluida, de forma mayoritaria, dentro de la lista de los vecinos privilegiados, merced a la adquisición de la condición de hidalgos ${ }^{714}$.

El estudio de esta arquitectura civil, sin embargo, se enfrenta ante dos serios inconvenientes. Uno de ellos se encuentra en la total ausencia de documentación, que

\footnotetext{
714 Ver capítulo: Sociedad.
} 
nos facilite información sobre el proceso de construcción de estos edificios, aportándonos datos concretos sobre sus promotores, artífices y cronología. De este modo, prácticamente todas nuestras conclusiones quedan en manos del análisis que podamos hacer de sus estructuras y formas, complementados en diferentes ocasiones con la información aportada por las inscripciones que se conservan sobre sus fachadas y los elementos heráldicos, que les acompañan. Por otro lado, y junto a esto, nos topamos también con la grave alteración de los edificios que nos han llegado hasta nosotros, propiciadas, en unos casos, por las modificaciones introducidas a lo largo de los siglos, y en otros, por el liso y llano abandono, que termina por convertir sus restos en una pura ruina $^{715}$.

El tipo básico, dentro de esta arquitectura civil, es la vivienda familiar, la cual, salvando las distancias, comienza a convertirse, en cierto modo, en una auténtica mansión, merced a la incorporación de determinados componentes sociológicos, que adquieren la función de símbolo y testimonio de sus habitantes. Nos referimos, en definitiva, a la casa solariega o blasonada, la cual es, sin lugar a dudas, la tipología más representativa, dentro de este ámbito. De este modo, la casa deja de ser una simple construcción con una única función de guarecerse y servir de centro de la economía familiar (bien agraria, ganadera o carreteril), en la que los valores fundamentales son la fírmitas y la utilitas, para convertirse en un hecho artístico, en el que se incluye la vanitas, como nuevo valor. Esto queda reflejado a través de una serie de elementos, que exceden lo meramente constructivo, para alcanzar el campo de lo ornamental, entre los que destacan, de modo especial, la presencia de los escudos con los que se ennoblece su

\footnotetext{
715 En este apartado referente a las modificaciones, tenemos que apuntar el grave deterioro, cuando no, destrucción total, que ha sufrido el aspecto y fisonomía de varios de estos edificios con las reparaciones y remodelaciones, que se continúan haciendo actualmente. Así, la insensibilidad de los ayuntamientos de varios de estos municipios ha llevado a que algunos de los edificios de interés para nuestra investigación, únicamente los podamos conocer a través de fotografías tomadas no muchos años atrás. De igual modo, en el colmo de esta circunstancia, se ha llegado a producir el hecho de comprobar cómo en el momento de verificar algunos datos correspondientes a determinados edificios, obtenidos tras las primeras visitas efectuadas dentro del trabajo de campo, hemos observado con gran decepción, que el edificio objeto de nuestro estudio había desaparecido.
} 
imagen $^{716}$. De esta forma, la casa termina convirtiéndose en un símbolo de poder, en el que se plasman las ideas clásicas expuestas por Vitrubio y recogidas por los tratadistas del renacimiento, como Alberti o Serlio. Precisamente en el prólogo de la traducción del tratado de este último, realizado por Francisco de Villalpando, se incluyen la siguiente idea, que ilustra el fenómeno del que estamos hablando: "aunque ovo muchos que perpetuaron su memoria con palabras admirables escriptas, los architectos con superbissimos edificios: porque si leyendo una historia o coronica (sic) de un príncipe parece que en ella se oyen sus hechos, en la architectura se veen..."717.

También contribuyen al engrandecimiento de estos edificios ciertas pautas, que generalmente se repiten en todos los casos, entre las que se encuentran un innegable interés por acrecentar sus dimensiones, con respecto a las humildes medidas de la arquitectura doméstica de esta zona; equilibrio de proporciones, con elementos sujetos a un cierto orden; y una evidente riqueza de los materiales y técnicas empleados.

En el apartado de los promotores de este tipo de construcciones no encontraremos, en ningún caso, la presencia de miembros pertenecientes a la alta nobleza. Fundamentalmente porque, a pesar de que muchos de los pueblos pertenecen a los señoríos jurisdiccionales de miembros de este selecto grupo, éstos nunca tuvieron una presencia directa en esta parte de sus dominios. Lo más parecido a un signo de este tipo, tal vez lo podamos encontrar en el viejo torreón de los Velasco, que se conserva, aunque muy alterado, en la localidad de Hoyuelos de la Sierra. Se trata de una recia construcción, profundamente modificada por las numerosas reparaciones que ha sufrido, constituida por un sólido prisma de base cuadrangular, con muros de sillarejo y mampuesto de gran calibre, reforzado en las esquinas con gruesos sillares. Estos muros se encuentran salpicados por una serie de ventanales, enmarcados con dinteles festoneados, imitando una especie de oleaje, y con alféizar volado decorado con los

\footnotetext{
716 A. C. IBÁÑEZ PÉREZ: Arquitectura civil del siglo XVI en Burgos. Burgos, Caja de Ahorros Municipal de Burgos, 1977. (pp. 103 y ss.).
} 
característicos relieves de bola. Cronológicamente, por lo tanto, y con todas las reservas a que nos obliga la falta de fuentes documentales, podemos situar su construcción en torno a las décadas finales del siglo XV, vinculando su presencia, con toda seguridad, al dominio señorial que sobre la zona ejercía en este momento la familia Velasco.

Menor representación encuentra la clientela eclesiástica, pues ni monasterios, ni órdenes religiosas, ni prelados, participaron en este tipo de patrocinio. Las únicas excepciones, que podemos citar, aunque de forma muy vaga, se encuentran, respectivamente, en las localidades de Tolbaños de Arriba y Huerta de Arriba. En la primera, dentro de un edificio hoy desaparecido, se conservaba una inscripción apenas legible, que indicaba la promoción de un religioso, cuyo nombre resultaba imposible de descifrar, si bien el sobrenombre de FRAI, queda perfectamente claro ${ }^{718}$. El caso de Huerta de Arriba corresponde ya al siglo XVIII, y el patrocinador de la misma, D. Francisco de Santa Coloma, se presenta como comisario del Santo Oficio ${ }^{719}$. Los clérigos locales, por su parte, aunque en unos casos intuimos, y comprobamos en otros, que poseían casas realmente dignas, todas ellas quedan lejos de mostrar el porte y la prestancia de las casas solariegas o blasonadas, de las que estamos tratando. Así, aunque su situación económica era, en la mayoría de los casos, ciertamente cómoda, su condición de clérigos quedaba reñida en estos lares, con la ostentación a través de una residencia de carácter señorial. Sin embargo, una clara excepción, la encontramos en la casa construida por D. Juan de la Barga y Sedano en 1733 en Riocavado de la Sierra ${ }^{720}$. Hay que decir, como atenuante, que en la figura de este clérigo se unían, además de su condición de miembro del estado eclesiástico y cura beneficiado de la parroquia de esta localidad, su pertenencia a una de las familias de más rancio abolengo de estas tierras,

717 F. MARÍAS: El largo siglo XVI. Los usos artísticos del renacimiento español. Madrid, Ed. Taurus. 1989. (pp. 525 - 526).

718 Tolbaños de Arriba: C. del Norte, s/n. (actualmente desaparecida, pues ha sido derribada en la primavera de 2003).

719 Huerta de Arriba: C. de las Huertas $n^{\circ} 25$ bis.

720 Riocavado de la Sierra: C. de la Olma $n^{\circ} 17$. 
como eran los Barga y Sedano, con distintas casas construidas por los miembros pertenecientes a este linaje en Barbadillo de Herreros.

El principal grupo de promotores de residencias de cierto porte en la zona, por lo tanto, lo encontramos en los grandes propietarios, principalmente de rebaños trashumantes, pero también de tierras, ganados, y de carretas. Muchos de ellos, además (especialmente en el caso de los ganaderos), fueron adquiriendo la condición de hidalgos a lo largo de esta centuria, lo que indudablemente debió acrecentar su interés por manifestar su nueva condición, a través de su vivienda. De esta forma, tal vez resulte posible establecer, como ya apuntábamos, una relación entre estas dos circunstancias, que alcanzan su momento álgido, en la centuria siguiente.

Ligado también a la economía ganadera de la trashumancia, debemos incluir igualmente, como grupo representativo de esta actividad, a aquellos pastores, que desempeñaban labores de alta responsabilidad en la conducción de los ganados. Nos estamos refiriendo, en concreto, a los mayorales y rabadanes, cuya posición de prestigio y respeto entre sus convecinos, queda reflejada, en muchas ocasiones, en la construcción de casas destacadas, que trataban de emular a las de sus patronos ${ }^{721}$.

Al mismo tiempo, dentro de este grupo de los grandes propietarios tampoco debemos olvidar, como ya decíamos, a los poseedores de gran número de carretas, algunos de los cuales podían llegar a formar cuadrillas enteras por sí solos. Estos representantes del esforzado mundo de la carretería, si bien en raras ocasiones adquirieron la condición de hidalgos, no dejaron de sentir la necesidad de plasmar su próspera posición económica, en forma de una vivienda destacada.

En lo que se refiere a la localización geográfica de los ejemplos más representativos de este tipo de arquitectura que las conclusiones, que podamos sacar, 
tanto para el siglo XVII como para el XVIII, quedarán siempre condicionadas por el grado de destrucción, que han ido sufriendo estos edificios en cada lugar. Aun así, en lo que respecta al siglo XVII, observamos una especial concentración en la zona del valle de Valdelaguna, punto en el que comienza con un mayor vigor el desarrollo de las características casas blasonadas. Ligadas a esta zona, y como extensión dentro del ámbito de la economía de base eminentemente ganadera, podemos incluir también algunos pueblos como Monterrubio de la Demanda, Neila o Barbadillo de Herreros. Dentro de los núcleos de economía fundamentalmente carreteril destaca, con un protagonismo especial, Vilviestre del Pinar, la cual todavía nos ofrece un destacado número de ejemplos, seguida de Canicosa de la Sierra y Palacios de la Sierra. Por último, debemos señalar también el caso de Salas de los Infantes, localidad que, dada su condición de centro de la comarca, había aglutinado, desde el siglo XVI, la presencia de las familias nobles en la zona, deparando, por consiguiente, un interesante grupo de casas de este tipo. No obstante, la mayor parte de las que nos han llegado, pertenecen ya al siglo XVIII. Por otro lado, dentro de esta distribución no vemos que tenga ninguna repercusión la condición jurisdiccional de cada núcleo, es decir, si son núcleos de realengo o de señorío.

Por lo que respecta a la ubicación de estos edificios, dentro del entramado urbano de cada uno de los pueblos, en general, observamos que existe una marcada tendencia hacia la ocupación de aquellas parcelas más próximas a los principales centro de cada pueblo, como es el caso de la plaza mayor o las inmediaciones de la iglesia o iglesias parroquiales ${ }^{722}$. Sin embargo, existe otro tipo de condicionantes, que obligan a que esta preferencia quede, en diferentes ocasiones, en un segundo plano. Nos referimos, fundamentalmente, a la orografía especialmente abrupta sobre la que se asientan estos pueblos, y a la disponibilidad de una parcela los suficientemente amplia,

\footnotetext{
721 Reforzando esta idea encontramos cómo en algunos pueblos de Valle de Valdelaguna, de cultura eminentemente trashumante, se conservan casas, que la tradición popular aun hoy las sigue denominando como "la casa de mayoral".

722 En este sentido, localidades como Barbadillo de Herreros, Neila o Vilviestre del Pinar, nos ofrecen elocuentes ejemplos de ello.
} 
que permita levantar edificios de envergadura, lo cual no siempre resulta factible, dentro de un caserío tan sumamente apretado como el que aquí nos encontramos. De este modo, hallamos ejemplos, como los de Monterrubio de la Demanda, en los que se prefiere un cierto alejamiento de la iglesia y plaza mayor, para colocarse en una zona más llana y despejada.

Dentro del análisis de los edificios conservados, y a pesar de contar con los condicionantes ya señalados, podemos extraer una serie de características comunes, que pueden ser aplicadas en la mayoría de los casos. Estas casas, por lo general, no presentan grandes complicaciones, ni estructurales, ni decorativas, predominando, por el contrario, la forma de bloque compacto de estructura cerrada, con una concepción de muros limpia y sin apenas ornamentación, que vaya más allá de los elementos heráldicos. No se trata, en definitiva, de realizar grandes construcciones, sino simplemente de mostrar la prosapia de sus dueños, a través de obras no exentas de un profundo aire de rusticidad, en todo su conjunto.

Así, este tipo nos muestra una casa caracterizada por su gran solidez, con planta cuadrangular, y desarrollo en altura articulado en dos plantas, el cual no suele mostrar, al menos durante esta centuria del Seiscientos, separación de ningún tipo. Toda su estructura se encuentra elaborada en piedra, utilizando preferentemente el sillarejo y el mampuesto de gran calibre, y reservando los sillares para reforzar las esquinas y hacer los enmarques de los vanos. De igual modo, la sillería más cuidada se suele emplear también en la ejecución de la fachada principal, la cual constituye, evidentemente, el elemento más cuidado de todo el edificio.

Las fachadas, al igual que el resto del conjunto, muestran un esquema rigurosamente geométrico con un muro completamente plano, articulado en dos cuerpos, dinamizados a través de los diferentes vanos. Dentro de ellos, destaca la puerta de entrada, situada en la parte central de la planta baja, la cual se enmarca, generalmente, con un potente arco de medio punto de amplio dovelaje. Sobre ella se 
dispone un balcón o una pequeña ventana, acompañada por dos ventanas más a los lados, que se corresponden con las situadas en el piso inferior. Este esquema se reproduce, de forma simplificada, en algunos edificios más modestos, en los cuales aparece, en la planta baja, la puerta de entrada desplazada del eje central hacia uno de los laterales de la fachada, acompañándola en el otro extremo una ventana. Estos vanos se corresponden, a su vez, con otras dos ventanas en el piso superior, dispuestas sobre sus mismos ejes, para dibujar un esquema reticular. El marco de la puerta de entrada, como decimos, suele hacerse con arco de amplio dovelaje, que continúa la tradición del siglo XVI, si bien, en los últimos momentos de este siglo XVII, empezaremos a ver algunos ejemplos de roscas casetonadas, que más tarde se convierten en uno de sus elementos más característicos. Menos frecuente en estas casas, por ser un elemento más propio de la arquitectura popular, es la puerta adintelada con doble dintel, entre los cuales se deja una pequeña ranura, que sirve de elemento de descarga. Las ventanas, por su parte, desarrollan la característica estructura adintelada, enmarcada con una gruesa moldura plana con orejones. Tanto su número como su tamaño son aquí reducidos, lo cual queda justificado por la propia dureza del clima.

Pero sin duda, el elemento más destacado de las fachadas, y de este tipo de casas en general, lo constituye el escudo de armas. Estos suelen aparecer colocados, tanto en la parte central, entre los vanos del piso superior, como sobre el dintel de alguna de las ventanas, o incluso sobre la dovela central de la propia puerta de entrada. Su presencia constituye, sin ninguna duda, la máxima expresión del interés de sus propietarios por mostrarse hacia el exterior, reafirmando su propio status.

Estas fachadas se rematan con la cornisa, que da paso al tejado, formada por una moldura de piedra en forma de papo de paloma, si bien, más frecuentes son los aleros de gran vuelo, formados por las cabezas de las propias vigas del tejado, las cuales forman canes, que en algunas ocasiones aparecen primorosamente tallados. El tejado, por su parte, se dispone generalmente a cuatro aguas, utilizando, como en el resto de la arquitectura local, la teja curva de origen árabe. 
En lo que se refiere a la división interna, nos resulta sumamente difícil teorizar, pues todos los ejemplos, que hemos conseguido encuadrar cronológicamente dentro de esta centuria, se hallan profundamente alterados por las divisiones posteriores. Aun así, existen algunas piezas que sí podemos aventurar su estructura y función. Este es el caso del zaguán, que se sitúa de forma inmediata a la puerta de entrada, el cual aparece conformado por una estancia rectangular, que a falta de patio interior, cumple la función de elemento articulador de las diferentes estancias dispuestas sobre la planta baja. Desde este zaguán parte, igualmente, la escalera, que conduce a la planta superior.

La separación entre plantas, como ocurre en toda la arquitectura civil de la zona, se realiza mediante una viguería de madera apoyada sobre postes del mismo material, entre las cuales se coloca el entarimado, que forma la superficie del suelo. Para estas vigas generalmente se utiliza madera de pino, dada su gran longitud, mientras que para los postes se recurre a la de roble, dada su mayor resistencia a las presiones. Esto se hacía así incluso en aquellos pueblos eminentemente pinariegos. Por su parte, en ningún caso hemos encontrado la más mínima prueba de la existencia de un techo abovedado.

Esta tipología, con muy ligeros cambios, consigue mantenerse vigente prácticamente hasta finales del siglo XVIII, desarrollando precisamente en esta centuria sus ejemplos más brillantes. A ello contribuyeron diferentes factores, entre los que no debemos olvidar su extraordinaria adaptación a los gustos y necesidades, que imponía la economía de la zona. Así, estas casas se convierten en el mejor reflejo de la sociedad en la que nacen, con unas formas condicionadas, tanto por los gustos individuales de sus propietarios, como por los elementos pertenecientes al estilo del lugar y de la zona. Junto a esto, es obligado tener en cuenta también el hecho de que es una arquitectura que no surge de forma espontánea, sino como fruto de una larga experiencia, después de la cual se logra encontrar la mejor adecuación de cada una de sus partes al uso determinado. Por ello, una vez logrado este tipo de casa, su desarrollo se continúa en el 
tiempo, sin otras modificaciones, que no sean las impuestas por las posibilidades de cada propietario.

Los ejemplos que pasamos a citar, por desgracia, se encuentran en la mayor parte de los casos sumamente deteriorados, si bien, resulta relativamente fácil distinguir dentro de ellos gran parte de los rasgos, que acabamos de señalar. De igual modo, estos ejemplos en ningún caso resultan suficientes como para poder establecer unas mínimas pautas evolutivas, dentro del desarrollo, que esta tipología vive a lo largo de la centuria. Por todo ello, la relación que pasamos a hacer, de ninguna forma podemos establecerla en función de unos criterios cronológicos o evolutivos, que resultan imposibles de fijar, limitándonos únicamente a hacer un recorrido por las diferentes localidades, señalando los ejemplos, que encontramos en cada una de ellas.

La villa de Monterrubio de la Demanda, es lugar en el que hallamos alguno de los casos datados más antiguos. En concreto nos referimos a la casa situada en la plaza Mayor $n^{\circ}$, en la cual se conservan restos de lo que debió ser uno de los primeros ejemplos de este tipo de casas blasonadas. De ella únicamente se conserva la parte correspondiente a uno de los extremos de lo que fuera su fachada principal, y el resto de alguno de los muros laterales. De este fragmento de su fachada destaca la cuidada piedra de sillería con que se encuentra realizada, contrastando vivamente con el mampuesto más tosco, que existe en los muros laterales. Sobre este fragmento de la fachada principal se conserva todavía una ventana adintelada con el característico enmarque y orejones, y rematada con dos pequeños pináculos piramidales, dispuestos en los extremos del dintel. Precisamente a lo largo de todo este dintel se conserva una pequeña inscripción en al que se puede leer: ESTA OBRA IÇO PEDRO BELASCO, y sobre los pináculos el año 1600, que indudablemente alude al año de su construcción. Bajo esta ventana se abre una pequeña puerta adintelada, sobre cuyo dintel se conserva parte de una cruz resarcelada, toscamente labrada, que se acompaña de una inscripción, en la que únicamente alcanzamos a leer la confirmación de la fecha representada en la ventana superior, y un texto con el trigrama IHS, de Cristo, y los nombres de MARÍA Y 
JOSÉ. Se trata de una leyenda, muy repetida dentro de este tipo de arquitectura, extendiéndose su uso también a la arquitectura popular, donde mantiene el mismo simbolismo profiláctico, que vemos aquí. En la parte superior de la fachada, por último, se conserva un pequeño escudo con su campo ocupado por una cruz lanceolada, próxima al tipo de cruz de Jerusalén. Son restos, todos ellos, sumamente toscos, pero suficientes para apreciar el momento tan temprano en el que comienzan a desarrollarse este tipo de edificios.

Otro ejemplo, dentro de esta localidad, se halla en la plaza de San Roque $n^{\circ} 10$, en la parte baja del pueblo. Aquí se levanta una casa de limpia fachada cuadrangular, elaborada en magnífica piedra de sillería, articulada en dos pisos sin separación de ningún tipo entre ellos. Dentro de ella destaca la puerta, desplazada con respecto al eje central, que aparece coronada con arco apainelado de grandes dovelas, y las dos ventanas del piso superior, decoradas con molduras salientes de papo de paloma, que recorren el alféizar y la parte superior del dintel. Precisamente es en el dintel de estas ventanas el lugar en el que aparece la siguiente inscripción: JUAN BARRIO - AÑO DE 1643. Se trata, por lo tanto, de una obra que presenta notables variaciones con respecto al modelo general de este tipo de casa, que hemos descrito anteriormente, lo cual se

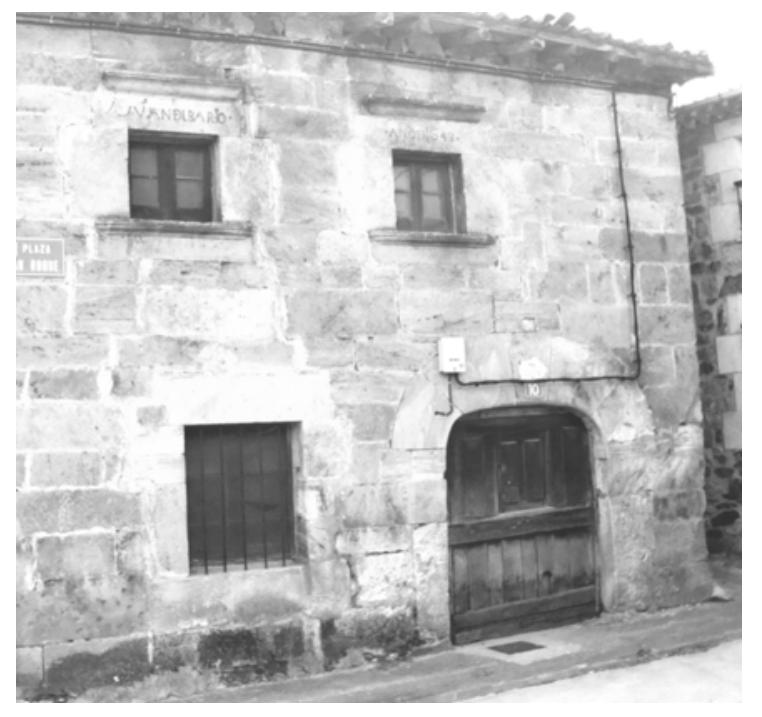

MONTERRUBIO DE LA DEMANDA. Plaza de San Roque $n^{\circ} 10$. 
manifiesta especialmente en los vanos, tanto por su enmarque como por su distribución. De igual modo, tampoco aparece ningún tipo de elemento heráldico, aunque no podemos excluirlo de este tipo de construcciones.

Justo enfrente de este inmueble, se encuentra otra muestra de estas casas solariegas, construida, según reza la inscripción, que aparece sobre una de las ventanas de la fachada lateral, en 1663, acompañada con la siguiente leyenda: HIÇO ESTA CASA ELIECE(R) PEDRO BELASCO. De ella, lo que suponemos fue su fachada principal, orientada hacia poniente, aparece en la actualidad totalmente alterada por las reparticiones, realizadas a lo largo del tiempo. Sin embargo, en el resto de su estructura aun conserva varios ejemplos de ventanas de dintel plano con orejones. De igual modo, podemos apreciar también la estructura volumétrica que poseía este conjunto, con una amplia planta rectangular con alzado articulado en dos pisos y cubierta dispuesta a cuatro aguas. Constituye, por lo tanto, uno de los primeros ejemplos en los que podemos apreciar las proporciones y estructura de este tipo de construcciones, en su forma exenta, y no incluido dentro de una manzana con más edificios.

Sin salir de esta localidad encontramos dos ejemplos más que, a pesar de no contar con inscripciones, que nos aclaren el momento exacto de su construcción, muestran rasgos inequívocos de su pertenencia a esta centuria.

El primero de ellos se encuentra en la calle Santiago $n^{\circ}$ 9, la cual únicamente conserva de su primitiva fachada principal el arco de medio punto, que sirve de marco para la puerta de acceso, y un pequeño escudo situado sobre ella. Es un escudo partido $1^{\mathrm{o}}$ tronchado con una banda y con una venera en la parte superior, y $2^{\circ}$ con una barra en el jefe y un brazo con un estandarte en el resto.

El segundo se halla en la calle de la Iglesia $n^{\circ} 2$, el cual se conservan una serie de restos ordenados verticalmente, dentro de una estrecha fachada elaborada en sillarejo. Aquí aparece una pequeña puerta adintelada, sobre la que se dispone un 
escudo, y una ventana también adintelada enmarcada con moldura plana con orejones. El escudo presenta el campo cuartelado en cruz con el $1^{\circ}$ cuartel ocupado por un águila de alas desplegadas, $2^{\circ}$ surcado por cuatro barras, $3^{\circ}$ ocupado por un castillo donjonado de tres torres, $\mathrm{y}^{\circ}$ con cinco amilletos colocados en dos palos de 3 y 2 respectivamente.

Otra localidad, que ofrece ejemplos interesantes es Huerta de Arriba, en la cual, durante esta centuria, se comienzan a poner las bases del brillante conjunto urbanístico, que se logra completar tras las aportaciones realizadas en el siglo XVIII. Dentro de esta centuria del Seiscientos el ejemplo más interesante se localiza en la calle Sebastianas, entre los números 24 al 28, los cuales formaban originalmente un solo edificio de amplias proporciones, articulado en dos plantas, con muros de mampostería reforzados en las esquinas con sillares de mayor tamaño. Su fachada principal, orientada hacia naciente, aunque muy alterada por el paso del tiempo, conserva todavía el amplio arco de medio punto de su entrada, y dos ventanas con el clásico marco con orejones, dispuestas sin orden definido. En su fachada lateral, orientada hacia el mediodía, se conservan otras dos ventanas, que constituyen, sin duda, los elementos más interesantes, en virtud de las inscripciones y escudos, que aparecen sobre su respectivo dintel. En la primera de ellas se puede leer lo siguiente: QVESTA ME FECIT. Y entre ella un escudo partido con el $1^{\circ}$ cuartel ocupado por un castillo donjonado de tres torres, la central con un estandarte, y el $2^{\circ}$ con una panela con dos aspas sobre ella y tres barras en la parte inferior. La otra ventana incluye dos inscripciones, la primera con los nombres de IHS, MARÍA Y JOSÉ, de claro sentido protector, y la segunda indicando: QVESTA ME FECIT ANDADO EL AÑO 1686, lo que nos aclara el año de su construcción. Intercalada entre esta segunda inscripción se representa un segundo escudo con el mismo contorno que el anterior, de estructura cuadrilonga, y campo partido, con el $1^{\circ}$ cuartel ocupado por una cruz de la orden de Calatrava y sobre ella una flor de lis, y el $2^{\circ}$ repitiendo el mismo que el siniestro del escudo anterior, es decir, una panela con dos aspas sobre ella, y tres barras en la parte inferior. 
HUERTA DE ARRIBA.

Calle Sebastianas $n^{\circ} 28$.

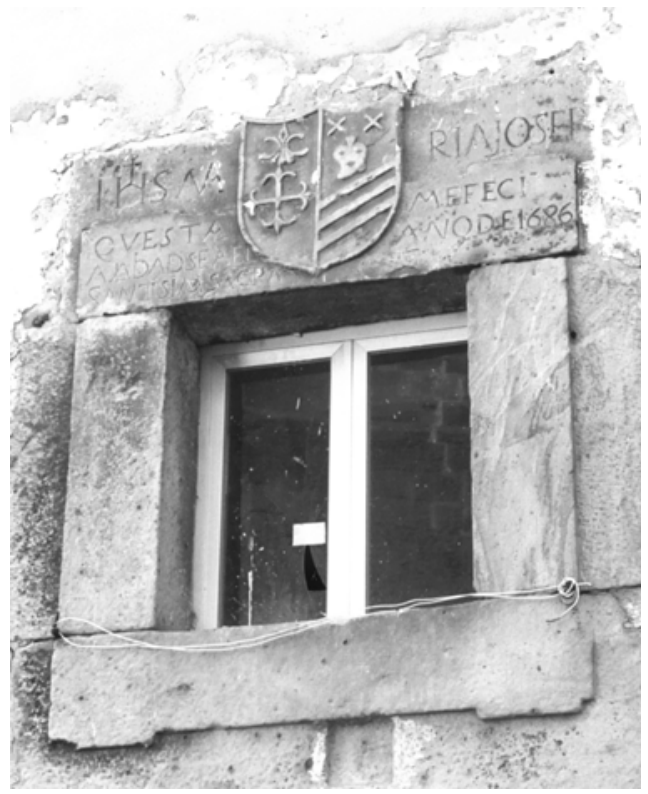

Próxima a esta casa se encuentra otro ejemplo en la calle Sebastianas $n^{\circ} 32$, en la cual, a falta de inscripción y escudos aclaratorios sobre su cronología, el amplio arco de medio punto con grandes dovelas completamente planas, se convierte en elemento suficiente para confirmar su pertenencia a esta centuria.

En esta misma calle se hallan otros dos ejemplos más, en los números 38 y 50. En el primero de ellos se conserva una soberbia fachada de sillería con un magnífico escudo sobre el dintel de su ventana superior, junto a cual se incluye una pequeña leyenda, que nos proporciona el nombre de su propietario: JUAN MARTÍNEZ TEMIÑO. Este escudo presenta el mismo contorno cuadrilongo, que hemos visto en los casos anteriores, y campo cuartelado en cruz, con el $1^{\circ}$ cuartel ocupado por castillo donjonado con tres torres, $2^{\circ}$ con un león rampante, $3^{\circ}$ las letras $\mathrm{M} \mathrm{T}$, correspondientes a las iniciales de los apellidos de su propietario, y el $4^{\circ}$ surcado por tres barras.

La segunda de estas casas conserva todavía, aunque muy alterada, parte de su fachada principal, orientada, como el caso anterior, hacia naciente, en la cual todavía 
podemos ver la puerta de acceso, con el característico arco de medio punto de amplio dovelaje, y varias ventanas, también con el común marco con orejones. Entre dos de las ventanas del piso superior, aunque con toda seguridad desplazado de su ubicación original, se conserva también un escudo, sumamente erosionado, con las iniciales de JESÚS Y MARÍA, representadas sobre su parte superior, y campo cuartelado en cruz, con el $1^{\circ}$ cuartel ocupado por una estrella de seis puntas, el $2^{\circ}$ imposible de descifrar, $3^{\circ}$ una cruz decussata, y $4^{\circ}$ una simple cruz griega acompañada por una pequeña estrella.

Próxima a estas dos casas, aunque ya en la calle Mayor $n^{\circ} 5$, se encuentra otro inmueble, en el que también se muestran elementos, que nos permiten situar su construcción dentro de este periodo. Para ello, debemos desechar la fecha inscrita en su parte superior, donde se indica el año 1871, que alude, con toda seguridad, a alguna modificación o reforma posterior, pues ésta no se corresponde con las características del arco de la puerta de entrada, ni con la ventana, que aparece sobre ella, enmarcada con

HUERTA DE ARRIBA.

Calle Sebastianas $n^{\circ} 38$

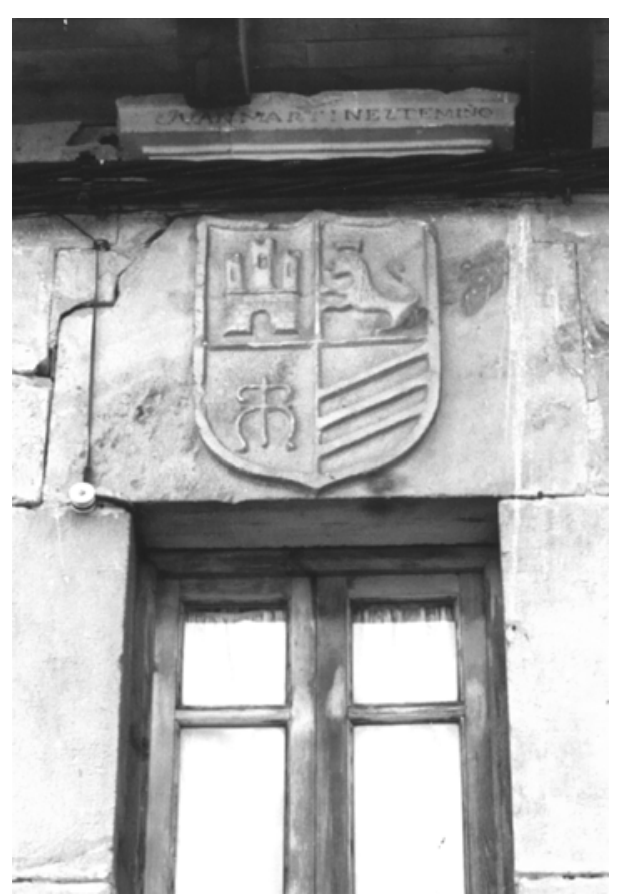


moldura plana con orejones, ni por supuesto, con el escudo situado entre ambos elementos. Este escudo se ajusta a las mismas características, que los vistos hasta el momento, con un contorno cuadrilongo, sin decoración exterior de ningún tipo, y campo cuartelado en cruz, con el $1^{\circ}$ campo ocupado por una flor de lis, el $2^{\circ}$ una oveja con una estrella de seis puntas, $3^{\circ}$ una cruz decussata, y $4^{\circ}$ una cruz griega.

Finalmente, otros ejemplos de edificios con fachadas de estructura muy similar a esta última los encontramos en la calle Real, en los números 1, 33 y 39; en la calle San Juan $n^{\circ} 17$; y en la calle de las Huertas $n^{\circ} 5$. En todos ellos el elemento más destacado, que se ha conservado, es el arco de su puerta de entrada, compuesto por grandes dovelas y rosca absolutamente plana, que se continúa a lo largo de las jambas sin interrupción de ningún tipo, y las ventanas enmarcadas con gruesa moldura plana con orejones. No obstante, en todas ellas echamos de menos la presencia de los escudos o inscripciones, que certifiquen definitivamente su pertenencia a este periodo.

Otras localidades, situadas dentro de esta zona de economía eminentemente ganadera, en las que también aparcen ejemplos interesantes de este tipo de arquitectura, realizados durante esta centuria del Seiscientos, son Neila y Huerta de Abajo.

NEILA. Calle Real $n^{\circ} 66$

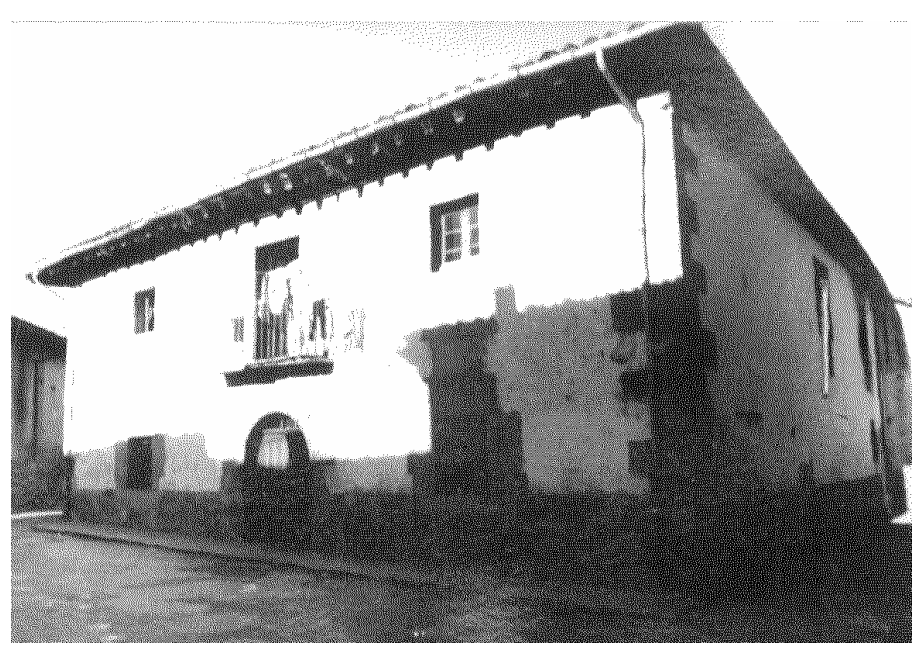


Neila, al igual que la localidad de Huerta de Arriba, comienza a levantar durante este siglo los primeros edificios, que más tarde constituyen la imagen característica de sus respectivos cascos urbanos. Aquí, los ejemplos más interesantes se encuentran en el barrio de Santa María, concentrados en la calle Real, ocupando los números 30, 66 y 72. Estos edificios presentan, como elemento más significativo, el arco de medio punto de amplio dovelaje, que enmarca su puerta de entrada. Al mismo tiempo, la situada en el número 30 cuenta con un pequeño escudo sobre la dovela central de su arco, de pequeño tamaño y muy maltratado por los efectos de la erosión, con campo ocupado por una sencilla cruz latina. Los otros dos ejemplos conservan, con bastante fidelidad, la estructura general de sus respectivas fachadas, mostrando su trazado rectangular, dominado por un marcado sentido de horizontalidad, que se cierra en su parte superior con airosos aleros volados.

En el barrio de San Miguel de esta misma localidad podemos descubrir también algunos ejemplos interesantes de este tipo de casas, situadas todas en ellas en el entorno de la iglesia de la parroquia, que daba nombre al barrio. Todas ellas, además del gran arco, que enmarca su puerta de entrada, y las ventanas con orejones, destacan por la perfecta sillería que muestran sus muros principales, compuestos por grandes sillares magníficamente labrados y ensamblados. Algunos de los ejemplos son ya una auténtica ruina, sin embargo otros, como el caso de la casa situada en la entrada del pueblo, todavía muestra su flamante escudo sobre la dovela central de su puerta de entrada, con una organización un tanto heterodoxa.

La localidad de Huerta de Abajo también guarda algunos sencillos ejemplos de esta tipología, como son los que se encuentran en su calle Real, en los números 16, 27 y 37. Todos estos edificios conservan, en su fachada principal, el característico arco de medio punto en su entrada, que estamos viendo en los ejemplos anteriores, si bien, han desaparecido los escudos, que pudieron adornarlos. Al mismo tiempo, la situada en el número 16 conserva todavía un bello ejemplo de alero volado con las cabezas de las 
vigas muy salientes y primorosamente labradas, formando sencillos dibujos de motivos geométricos. La ubicada en el $n^{0} 37$, a su vez, muestra sobre el dintel de su ventana central la inscripción con la fecha 1695, correspondiente al momento de su construcción.

Dentro de esta relación de pueblos, situados en la zona de economía ganadera, se pede incluir también a Tolbaños de Arriba, localidad en la que comenzaron a edificarse entonces los primeros ejemplos de este tipo de casas, que más tarde se continuarán levantando, durante la centuria siguiente. Entre los ejemplos correspondientes a este siglo XVII el más destacado se halla en la calle Mayor $n^{\circ} 49$, de cuya fachada principal, orientada hacia poniente, se conserva el arco de su puerta de entrada, y algunas de sus ventanas, con el característico marco con orejones. Precisamente sobre el dintel de la ventana central del segundo piso, situada sobre la puerta de entrada, podemos leer la siguiente inscripción: LORENZO MARTYNEZ TEMIÑO ME FEZY DEL AÑO DE 1691 AÑOS. Evidentemente debía tratarse de un personaje relacinado de algún modo, con la familia, que durante estos mismos años manda levantar una de las casas mencionadas en Huerta de Arriba.

Los otros dos ejemplos localizados en este mismo pueblo, se encuentran en el $n^{o}$ 39 de esta misma calle Mayor, y en la calle de los Pajares $n^{\circ} 21$. La primera de ellas actualmente ha desaparecido, si bien conocemos el aspecto que tuvo hasta la década de 1970, a través de una serie de fotografías, tomadas en este momento. Gracias a ellas descubrimos la presencia del amplio arco de medio punto en su parte central, como elemento más representativo. Sucede lo mismo con el ejemplo de la calle de los Pajares 21. Igual suerte, que el caso anterior, sufrieron, por último, los restos conservados en la calle del Norte $s / n$, cuya destrucción se ha producido en el transcurso de esta investigación. Estos restos estaban formados por una ventana adintelada, enmarcada por una moldura quebrada marcando orejones en las esquinas, y levantada sobre un alféizar, decorado por una doble moldura de medio bocel. Sobre ella se disponía un escudo invertido, con su campo ocupado por las llaves de San Pedro colocadas en forma de aspa. Todo esto se completaba con una inscripción sobre el dintel, en la que, con 
grandes dificultades, se podía leer lo siguiente: HIZO ESTA OBRA EL LIZDO. FRAI GRASVC(...) AÑO 168(...). Se trata, en definitiva, de una obra que nos llama poderosamente la atención, pues a lo movido de sus formas, algo prácticamente insólito en esta comarca, se une lo prematuro de su ejecución.

Por último, dentro de la zona de economía ganadera, debemos citar también los casos conservados en Barbadillo de Herreros (C. Mayor $n^{\circ}$ 33), Hoyuelos de la Sierra (C. lo Perales $n^{o} 4$ ), y Vallejimeno (C. Corralejos $n^{\circ}$ 98). En todos ellos se puede apreciar el gran arco de medio punto, como elemento más destacado, así como algunos otras rasgos, entre los que no faltan las ventanas enmarcadas con moldura plana y orejones, algunos sencillos escudos, o las inscripciones, que revelan su fecha exacta de construcción, como sucede en el caso de Barbadillo de Herreros, donde se indica el año 1695.

Cambiando de área, en la zona de pinares, cuyos habitantes aparecen ligados al mundo de la carretería, los ejemplos conservados son notablemente más escasos. Esto, no obstante, resulta más achacable a la suerte que la mayoría de los edificios han sufrido con el paso del tiempo que a la falta de iniciativa constructiva por parte de sus vecinos más pudientes. A través de los pocos testimonios correspondientes al siglo XVII, que existen en estos pueblos se advierte que la tipología desarrollada se ajusta más a las características de la casa carretera, que a los rasgos propios de las casas blasonadas, que hasta ahora hemos visto. Dentro de ellas, uno de los ejemplos más representativos era el que se encontraba en la localidad de Canicosa de la Sierra, en la plaza de San Esteban $n^{\circ} 11$, frente a la iglesia parroquial, si bien, las reformas sufridas hacen que actualmente sólo podamos conocer su aspecto original gracias a fotografías antiguas. Se trataba de una casa de estructura típicamente carretera, levantada sobre amplia planta cuadrangular, con fachada principal articulada en dos pisos, el inferior de piedra, y el superior de entramado de madera, y con la parte central abierta, formando un amplio portalón, en el que se cobijaban las carretas. 
En la localidad e Vilviestre del Pinar se conserva un interesante ejemplo de casa solariega, que se aparta de forma clara, de las características de estas casas carreteras. Se encuentra situada en el barrio de San Martín $n^{\circ} 13$, y en sus rasgos anuncian ya los cambios más destacados, que experimenta esta tipología, con respecto a los modelos entonces desarrollados, para mostrarnos la variante más común de casa solariega, que se consagra durante la siguiente centuria. Fue construida en 1691, como atestigua una de las inscripciones conservadas sobre su fachada meridional, y se levanta sobre una planta rectangular con muros de magnífica piedra de sillería en todos sus lados, articulados en dos plantas, separadas por una gruesa moldura plana de escaso resalte, y rematadas por un airoso alero volado. Sus fachadas, por lo tanto, aunque han sido profundamente alteradas por las divisiones posteriores, lo que ha afectado especialmente a la distribución de los vanos, todavía mantienen elementos sumamente interesantes. Así, en la orientada hacia poniente, se abría la puerta principal, la cual conserva todavía su magnífico arco de medio punto de rosca casetonada, anunciando así uno de los rasgos, que serán más característicos durante el siglo XVIII. Sobre la dovela central de este arco, al mismo tiempo, se representa un corazón flanqueado con tallos entrelazados finalmente labrados, en cuyo interior se recoge la inscripción del trigrama IHS, de

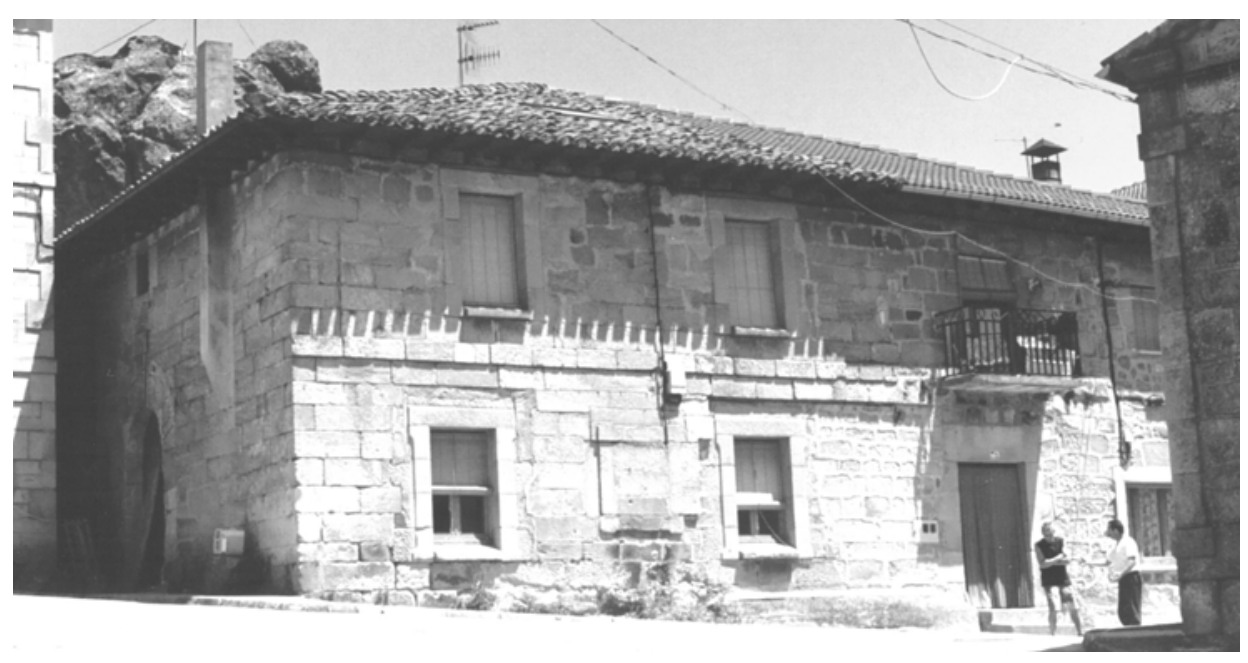

VILVIESTRE DEL PINAR. Barrio de San Martín, $n^{\circ} 13$ 
Jesucristo. Ésta se completa con las inscripciones de los nombres de MARÍA y JOSÉ, dispuestos en las dovelas contiguas, lo que completa la trinidad protectora.

En la fachada meridional de este mismo edificio, sobre el dintel de una de las antiguas ventanas del piso principal, se ha conservado parte de una nueva inscripción, con el mismo trigrama IHS y el nombre de MARÍA, acompañado del AÑO 1691, que alude al momento de su construcción. Intercalado dentro de este texto se sitúa un escudo de contorno cuadrilongo, y campo partido, con el $1^{\circ}$ cuartel ocupado por unas llaves de San Pedro, dispuestas en aspa, y el $2^{\circ}$ con una cruz del calvario con tres pequeños clavos dispuestos sobre cada uno de sus travesaños. Se trata, en definitiva, como ya apuntábamos, de una obra característica de este final del siglo, en la cual se manifiestan ya con total claridad algunos de los rasgos más representativos de las construcciones, que dentro de esta misma tipología, se realizarán ya durante la centuria siguiente. 


\section{SIGLO XVIII: EL DESPEGUE DE LA ACTIVIDAD CONSTRUCTIVA.}

Las consecuencias, que la llegada del siglo XVIII, tiene para nuestra comarca de estudio, dentro del campo arquitectónico, se dejan sentir, más en aspectos de orden cuantitativo, que en los de carácter estrictamente cualitativo y estilístico. De este modo, si por un lado detectamos una profunda aceleración de la actividad constructiva desplegada, tanto en el ámbito de lo religioso como de lo civil, por otro, comprobamos cómo las formas empleadas en la ejecución de estas empresas tienen bien poco de innovador, con respecto a las desarrolladas durante la centuria anterior.

Así, si algo define a la actividad constructiva, llevada a cabo en la sierra burgalesa a lo largo de este siglo es, junto a su importante crecimiento, el profundo conservadurismo, que se aprecia en cuanto a sus formas. Vemos con ello, como se da un profundo apego a unas soluciones estructurales y compositivas, que si en el siglo XVII habían demostrado adaptarse perfectamente a las necesidades y disponibilidad de medios de estos pobladores, en el XVIII continuaban hallándose en perfecta sintonía con los gustos de esta sociedad.

Entre las causas que propiciaron el crecimiento de la actividad constructiva se encuentra, fundamentalmente, el propio dinamismo, que durante esta centuria, experimentan la sociedad y economía de la zona. En el aspecto demográfico, tal y como ya observamos en su momento, se aprecia un continuo crecimiento a lo largo de toda la centuria, el cual, a pesar de las recesiones provocadas por las crisis de subsistencia, propias del Antiguo Régimen, consigue hacer que aumente de modo constante el 
número de habitantes. Esto repercute en la arquitectura religiosa, donde se hace necesario aumentar la capacidad de varios templos, al mostrarse insuficientes para acoger el creciente número de fieles.

Del mismo modo, entre los años finales del siglo XVII y primeras décadas de la centuria siguiente, se concentra también el momento álgido del fenómeno de ennoblecimiento, que experimenta la sociedad de varios de estos pueblos a lo largo de la Edad Moderna. Mediante este proceso, gran parte de los habitantes de algunos núcleos alcanzaron la condición de hidalgos, como acreditan los censos de la segunda mitad del siglo. Esto tiene sus consecuencias en el campo de la arquitectura civil, con la construcción de un importante número de casas solariegas, con las cuales se trataba de exteriorizar su nueva condición ${ }^{723}$.

Otro factor importante, que incide en el incremento de la actividad constructiva, lo encontramos en el campo de la economía, pues, mientras para el resto de las comarcas de la provincia de Burgos este siglo supone un período de recuperación, frente a la crisis sufrida durante la centuria anterior, en esta zona se vive un momento de aceleración, que lleva a que las actividades más representativas, como eran la ganadería trashumante y la carretería, experimentaran uno de sus momentos culminantes ${ }^{724}$. De este modo, parece cómo si nunca antes hubiera habido tantas cabezas de ovejas merinas y cabras emigrando desde la sierra burgalesa hacia las tierras del sur, ni tantas carretas cruzando de norte a sur y de este a oeste los caminos del reino. Y todo ello, a pesar de los momentos de crisis que, de forma periódica, llegaron a visitar estos pueblos ${ }^{725}$.

\footnotetext{
723 Ver capítulo: Sociedad.

724 Ver capítulo: Economía.

725 En la localidad de Huerta de Arriba, por ejemplo, en el momento de hacer el Catastro de Ensenada, se indica a la hora de dar el número de cabezas de ganado trashumante que existían en dicho pueblo que su número "no asciendo ni con mucho al de los años pasados por la gran mortandaz que se va experimentando este año a causa de la escasez de las hierbas por la carestía de aguas”. ADPBU. CE 920. Huerta de Arriba, 26 - julio - 1753.
} 
La pujanza económica se deja sentir de modo especial, una vez más, en el ámbito de la arquitectura civil, con la construcción de los más importantes e impresionantes ejemplos de casas blasonadas y casas carreteras, pertenecientes a los grandes propietarios de ambos sectores económicos. No obstante, esta próspera situación también tiene su reflejo en el campo de las construcciones religiosas, donde asistimos a la renovación de varios templos parroquiales y ermitas, impulsadas, no por una mera cuestión de necesidad de espacio, sino por el interés de conseguir edificios más llamativos y espectaculares.

El otro aspecto que como venimos diciendo, caracteriza el desarrollo de la actividad constructiva en este siglo, es el apego a las formas propias del clasicismo, utilizadas durante la centuria anterior. Lo mismo en la arquitectura civil que en la religiosa, no vamos a encontrar aquí una inclinación hacia la experimentación y el desarrollo de nuevas tendencias constructivas, sino que más bien se produce un claro continuismo de los modelos anteriores, tanto en plantas como alzados. Esto se debe, en gran medida, al conservadurismo local, que en definitiva viene a ser una de las características comunes a todas las zonas rurales, y en cierto modo apartadas, como es nuestro caso. Sin embargo, tampoco debemos obviar otros motivos, como la influencia de determinados maestros catedralicios, que participaron de la corriente revitalizadora de la tendencia clasicista, como pude ser el caso del religioso Fr. Pedro Martín, y la presencia de maestros de segunda fila, poco destacados y profundamente apegados a unas formas no evolucionadas. Junto a ello, por otra parte, también es importante tener en cuenta el afán integrador con respecto a la obra anterior, algo que podemos ver especialmente en aquellas construcciones adosadas a edificios ya existentes.

En definitiva, lo que se hace es aplicar unas soluciones que hasta el momento habían resultado ser válidas y sumamente sólidas, cubriendo con ello las expectativas de los comitentes, no sólo desde un punto de vista funcional, sino también estético. 
Otra de las particularidades, que podemos señalar para este siglo, es el equilibrio al que se tiende, entre la arquitectura de ámbito religioso y la civil. Así, frente al absoluto predominio que había mantenido hasta el momento la arquitectura religiosa, cuyas obras deben ser vistas como el reflejo de una sociedad rural, que dirige sus esfuerzos e inquietudes hacia estas empresas de carácter colectivo, la arquitectura civil alcanza ahora sus más altas cotas de calidad. Esto tiene su reflejo en el pleno desarrollo de sus tipologías más representativas en esta comarca, como son la casa solariega y la casa carretera, las cuales consiguen elevarse por encima del umbral de la arquitectura popular. Esto, en definitiva, no es otra cosa que el fiel reflejo del dinamismo mostrado por una sociedad, que se encuentra viviendo su momento culminante.

Con estas construcciones, muchos de los pueblos consiguen elaborar ahora su imagen más característica, constituida por grandes casonas solariegas y carreteras, de formas prismáticas, elaboradas mayoritariamente en piedra, y dispuestas en torno a un trazado viario irregular, que permite abrir pequeños espacios frente a sus fachadas principales, para lograr una mayor proyección de su imagen externa. Una imagen, que en la mayoría de los casos, se ha perdido o se ha visto notablemente alterada por las remodelaciones emprendidas a partir de las últimas décadas del siglo XX, si bien, existen ejemplos como Neila, Barbadillo de Herreros, Huerta de Arriba, o Vilviestre del Pinar, en los que todavía resulta fácil percibir la atmósfera de aquel momento.

En la arquitectura religiosa, por su parte, las abundantes intervenciones, que ahora se acometen sobre los respectivos templos parroquiales y ermitas, contribuyen, en la mayoría de los casos, a configurar la imagen definitiva de la inmensa mayoría de estos templos. Se realizan en este momento, por lo tanto, las obras que ponen fin a un largo proceso constructivo, que, en la práctica totalidad de los casos, se había iniciado en el período románico. Por supuesto, la preocupación prioritaria en todas estas intervenciones, llevadas a cabo sobre iglesias parroquiales y ermitas, - tanto ahora que en los siglos pasados - es la ampliación y adecuación del espacio existente al número de fieles, tal y como lo demanda el crecimiento demográfico. Sin embargo, tampoco 


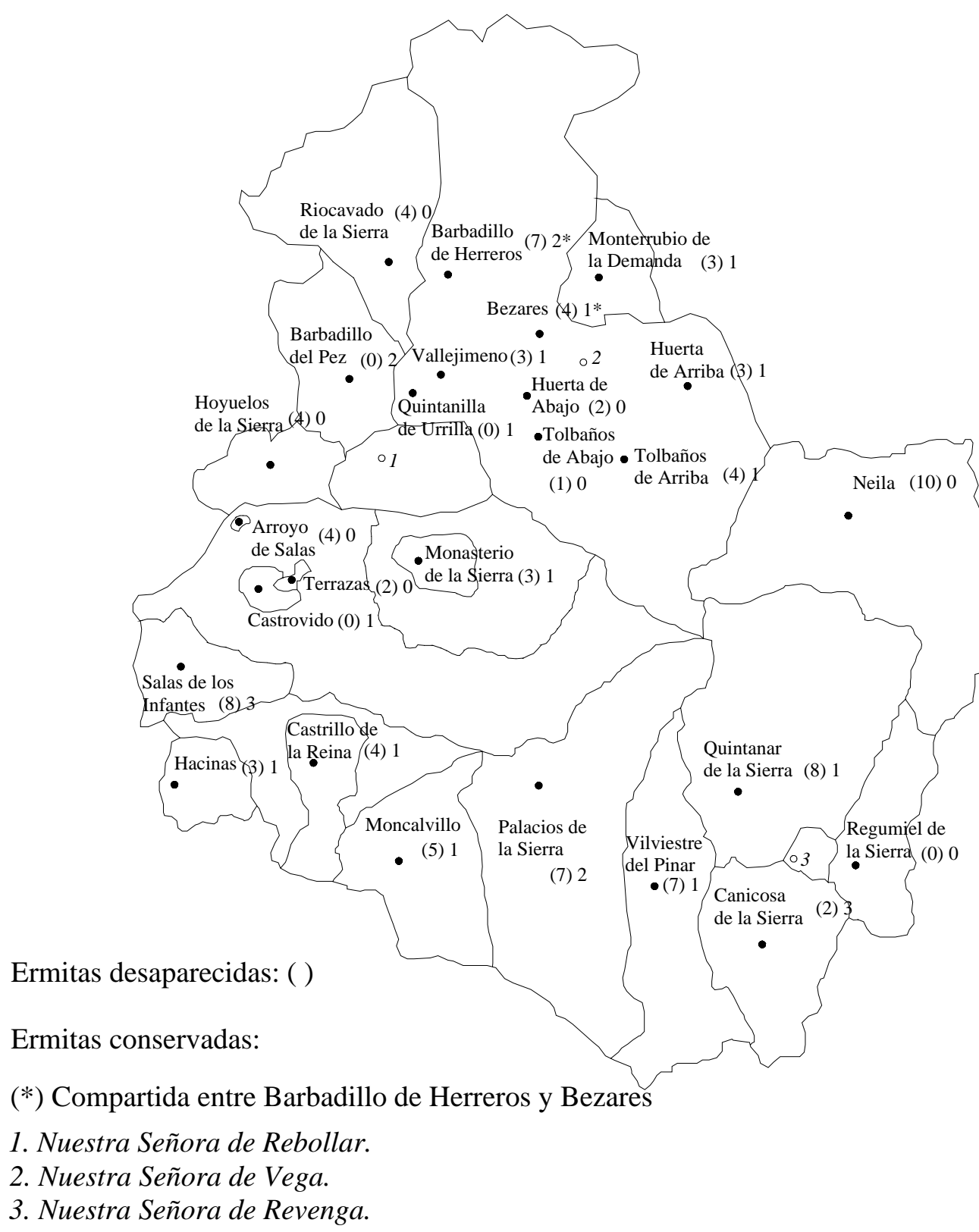

Mapa de ermitas conservadas y desaparecidas.

debemos obviar otro tipo de implicaciones, relacionadas con los valores estéticos y cuestiones de orden litúrgico, los cuales también son tenidos en cuenta a la hora de emprender muchas de las empresas. Estamos pensando, por ejemplo, en la construcción 
de los camarines y transparentes, que se realizaron en algunos de los edificios, con los cuales se introducen determinados valores relacionados con la escenografía y teatralidad, propia del mundo barroco.

Pero al mismo tiempo, y sin salir del ámbito de la arquitectura religiosa, el siglo XVIII es también un período de destrucción, pues son muchas las ermitas y oratorios, repartidos por el territorio de los respectivos términos municipales de estos pueblos, que viven ahora los últimos momentos de su existencia. Se trata de un fenómeno que comienza a manifestarse en las primeras décadas de este siglo, acelerándose a medida que avanza la centuria, para encontrar su momento culminante entre los años finales del Setecientos y comienzos del siguiente. Las víctimas, en todos los casos, son pequeñas ermitas, dependientes de los propios concejos de cada localidad, las cuales acaban por sufrir las consecuencias del abandono y falta de cuidados de sus vecinos. Esta falta de atención se ve favorecida, en muchos casos, por su ubicación lejos del propio centro urbano, ya que muchas de ellas se hallan situadas en parajes ciertamente recónditos, incrustadas entre las escarpadas laderas de estas sierras, lo que hacía difícil atender con regularidad sus necesidades y cuidados.

Ejemplos sangrantes de este fenómeno los encontramos en la práctica totalidad de estos pueblos, si bien es cierto, que en algunos casos el mayor número de pérdidas se produjo ya en un momento avanzado del siglo XIX. Aun así, podemos citar ejemplos como el de Neila, que a mediados del siglo XIX, ya había perdido 8 de sus 10 ermitas, Salas de los infantes, que sólo conservaba 3 de 11, Quintanar de la Sierra 1 de 9, o Barbadillo de Herreros, con sólo 2 en pie, de las 9 que llegó a tener ${ }^{726}$.

En general las que lograron salvarse de este azote destructor son siempre santuarios dependientes de importantes cofradías, las cuales garantizan su conservación, sin importar la lejanía del pueblo o lo recóndito de su ubicación. Estas ermitas, no sólo 
no vieron destruidas sus fábricas, sino que además, en la mayoría de los casos, registraron una importante actividad constructiva a lo largo de la centuria. Nos referimos a ermitas como la de Nuestra Señora de Vega, (en el valle de Valdelaguna), Nuestra Señora del Arroyal (Palacios de la Sierra), Nuestra Señora del Carrascal (Canicosa de la Sierra), Nuestra Señora de Costana (Barbadillo de Herreros), o Nuestra Señora del Torrejón (Vilviestre del Pinar). Como vemos se trata, en todos los casos, de santuarios dedicados a la Virgen, lo que constituye otro elemento común a todas ellas $^{727}$.

En lo referente al capítulo estilístico, durante el siglo se produce, como ya apuntábamos, un claro continuismo con respecto a las formas desarrolladas a lo largo de la centuria anterior. Esto hace que, dentro de las obras de cantería, ni siquiera lleguen a manifestarse las pautas propias del barroquismo más exaltado, que propician la incorporación de un auténtico manto ornamental, con el que se cubren los elementos estructurales. Nos encontramos, por lo tanto, con un tipo de construcciones profundamente ancladas en las formas clasicistas anteriores, en las que el carácter dieciochesco únicamente está marcado por la inclusión de leves notas decorativas, que no siempre aparecen. Entre ellos podemos mencionar la presencia de gruesas molduras quebradas, utilizados en el recercado de vanos, algunos ejemplos de decoración de placas y elementos vegetales aplicados sobre fustes de pilastras o marcos de puertas y ventanas.

Por lo demás, los edificios presentan composiciones extraordinariamente sencillas, con un predominio absoluto de la línea recta (tanto en planta como en alzado), ritmos ordenados, y una especial valoración de las superficies planas, como ya ocurriera

\footnotetext{
726 En este caso de Barbadillo de Herreros debemos puntualizar, que una de estas ermitas, la de los Santos Mártires, San Cosme y San Damián, se trata de una titularidad compartida entre los concejos de la propia localidad de Barbadillo de Herreros y Bezares.

727 Debemos anotar aquí, sin embargo, una excepción, pues el santuario de Nuestra Señora de Vega, durante todo el periodo de la Edad Moderna estuvo bajo la advocación de San Pedro.
} 
anteriormente. De igual modo, en su concepción volumétrica destaca el predominio de las masas limpias, de formas prismáticas y fuerte componente del sentido horizontal.

Las plantas, en el caso de los edificios religiosos, continúan con su habitual estructura rectangular, dominando de forma plena el modelo de nave única, con cabecera poco profunda, que puede ir precedida por un amplio presbiterio, que sirve de transición entre el espacio de la nave y el ámbito de la capilla mayor. Domina, de este modo, dentro de todas las construcciones, el modelo de planta longitudinal de tradición gótica, pero presidido por un claro sentido de espacialidad, que hace que se tienda, de forma manifiesta, hacia el ámbito único.

En el apartado de las cubiertas, se mantiene el dominio de la bóveda de crucería estrellada con terceletes y cinco claves. No obstante, esta tipología experimenta un intenso proceso de modernización, que se manifiesta en el desarrollo de una rampante prácticamente llana y en la incorporación de nervios combados dispuestos a modo de ondas, en torno a la clave polar. Esto no evita, sin embargo, que en diferentes ocasiones aparezcan casos en los que se desarrolla la trama más sencilla de nervios diagonales, ligadura y terceletes, o incluso la crucería más simple, con los nervios diagonales únicamente. Por lo demás, en cualquiera de sus variantes, este tipo de cubierta es, sin ninguna duda, el más común de cuantos podemos encontrar, especialmente en la arquitectura religiosa, pues en la civil se mantiene el tradicional entramado de madera como única solución.

Pero estos tipos de cubierta no son los únicos, se puede hablar también de las cúpulas de media naranja, que comienzan a emplearse ahora por primera vez en esta comarca durante la Edad Moderna. Estas cúpulas se presentan siempre sin tambor, levantadas sobre un anillo muy moldurado y pechinas. Su superficie interior suele estar articulada mediante costillas o fajas, que convergen en una clave central, donde no existe linterna, pues se trata de cúpulas ciegas. Los gajos delimitados por estas fajas, al igual que las pechinas, suelen estar decoradas con figuras geométricas con perfil 
mixtilíneo, adaptadas a las dimensiones de los espacios, si bien, tampoco es raro que permanezcan completamente lisas, sin acoger decoración de ningún tipo. Un buen ejemplo de ello lo tenemos en la cúpula, que se levanta para la capilla de Santa Ana, en la iglesia de la parroquia de Santa María, en Neila, tras la renovación realizada en torno a 1791, a instancias del Visitador del Arzobispado de Burgos ${ }^{728}$.

La manifestación de las cúpulas hacia el exterior no suele mostrar ningún interés, pues generalmente no aparecen trasdosadas. La única excepción a esta norma la encontramos en la pequeña cúpula, que remata el nuevo cuerpo de campanas añadido a la torre de la iglesia de San Cristóbal, en Quintanar de la Sierra, la cual llega a trasdosarse, si bien resulta muy difícil de apreciar, al quedar oculta tras la balaustrada que recorre todo el remate de esta construcción. Así, en el mejor de los casos, las cúpulas se muestran como un simple cubo superpuesto sobre la línea de cubiertas del edificio, aunque lo más normal es que queden integradas bajo la estructura general de la techumbre de todo el conjunto. En cualquier caso, estas cubiertas, aunque escasas en número, suponen una auténtica novedad con respecto a la época inmediatamente anterior, convirtiéndose en elementos generadores de espacio, aunque no en factores de iluminación.

Menos frecuentes aun, son las bóvedas de cañón con lunetos, las cuales constituyen, sin embargo, una de las soluciones más típicas de este período barroco en la provincia de Burgos ${ }^{729}$. De hecho, su elección, en la mayoría de los escasos ejemplos que existen en esta comarca, se encuentra determinada, más bien por las condiciones económicas de las parroquias promotoras (la escasez de medios impedía levantar una bóveda de crucería), que por criterios estrictamente estéticos. Esto tiene su excepción, no obstante, en el conjunto del crucero y cabecera levantados en la iglesia de San

\footnotetext{
728 AGDBU. LP. Neila, parroquia de Santa María, LF. (fols. 151 - 161). Visita realizada a la parroquia de Santa María de Neila en 1791, por D. Manuel María, arcediano de Palenzuela y canónigo de la catedral de Burgos. Huerta de Arriba, 11 - septiembre - 1791.

${ }^{729}$ A. C. IBÁÑEZ PÉREZ: “Arquitectura barroca burgalesa”. Ob. cit.
} 
Martín, en Vilviestre del Pinar, donde se producen interesantes ejemplos de este tipo de cubierta, decorados con movidos elementos geométricos de trazo mixtilíneo.

De los arcos, utilizados durante este siglo, como ya ocurriera durante la centuria anterior, el más común suele ser el de medio punto de gruesa sección cuadrangular e intradós plano, decorado con un sencillo cajeado. Este arco, sin embargo, queda sujeto a los cambios impuestos por las propias necesidades constructivas que presenta cada edificio, lo que lleva, en algunos casos, a que, sin variar su sección ni el cajeado de su intradós, pueda adoptar un perfil rebajado, peraltado o incluso apuntado. Una novedad sumamente interesante de estos arcos, durante el siglo XVIII, lo constituye la decoración de casetones, que aparece sobre su rosca. Esto lo vamos a encontrar representado especialmente en los arcos que presiden la entrada principal de las grandes casas solariegas, en la arquitectura civil, donde se llega a extender incluso a algunos ejemplos de casas carreteras. Nos encontramos, por lo tanto, ante uno de los elementos más representativos de la arquitectura civil de esta comarca de la sierra burgalesa durante este siglo XVIII. Su referente, sin embargo, se encuentra mucho más atrás en el tiempo, pues tenemos que buscarlo en algunas obras renacentistas, desarrolladas durante el siglo XVI, y más concretamente en la portada levantada para la iglesia de Santa María, en Salas de los Infantes ${ }^{730}$. La incorporación de este elemento a la arquitectura civil comienza a producirse, como ya vimos, en algunos ejemplos de los últimos años del siglo XVII ${ }^{731}$.

En lo que se refiere a los soportes, la pilastra cajeada de orden toscano o dórico, continúa siendo el elemento más utilizado. La única particularidad, que ofrece es el fuerte resalte, que muestran en algunas ocasiones, sobre el plano del muro, el cual se incrementa a medida que aumenta la altura y anchura de la nave, pues en estos casos es necesario contrarrestar una mayor presión.

\footnotetext{
730 A. C. IBÁÑEZ PÉREZ: “Arquitectura, escultura, pintura y artes menores del siglo XVI”. ob. cit.

731 Vilviestre del Pinar: Barrio de San Martín, $n^{\circ} 13$.
} 
Todos los elementos que conforman los nervios de las bóvedas, arcos y pilastras, aparecen, también ahora, labrados en piedra de sillería, lo que hace que destaquen de modo especial sobre los muros, realizados, en el mejor de los casos, en sillarejo, cuando no en simple mampostería. Con ello se reafirma su carácter preponderante, como elementos activos, dentro de la estructura del edificio, al mismo tiempo que contribuye a establecer una especie de ritmo compositivo, con el que se dinamiza la composición interna del muro.

Al exterior, los edificios continúan destacando por su limpia concepción volumétrica, constituida por sencillas estructuras prismáticas de muros completamente planos, apenas interrumpidos por la presencia de contrafuertes, los cuales reducen de forma importante su resalte, hasta terminar por desaparecer dentro del propio muro. Existen otros casos, sin embargo, en los que este resalte no sólo no se reduce, sino que se acentúa de forma importante, introduciendo en su parte superior un perfil aletonado de extremos avolutados. Esto es lo que sucede en el estribo construido en la iglesia de

SALAS DE LOS INFANTES. Iglesia de Santa Cecilia. Contrafuerte.

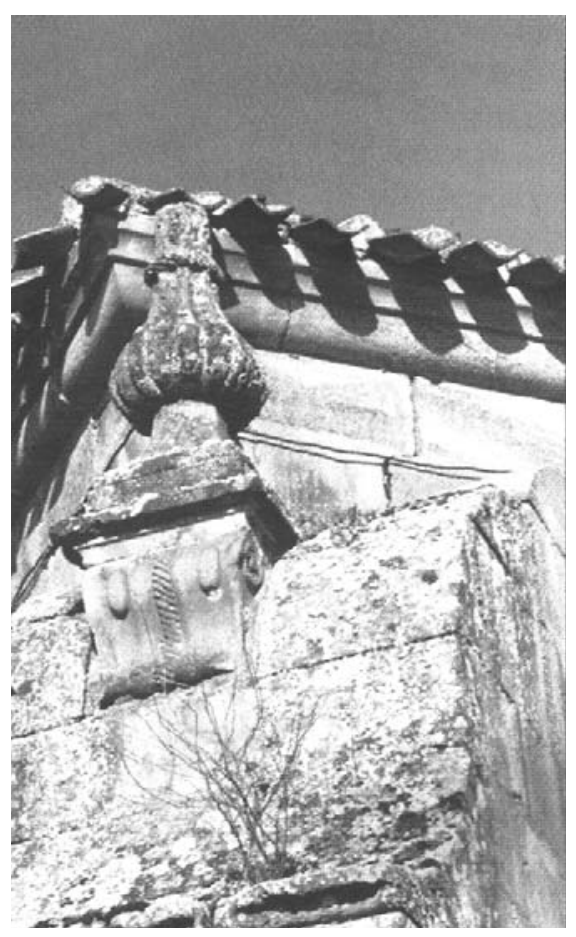


534 Arquitectura de la Edad Moderna en la sierra burgalesa.

Santa Cecilia, en Salas de los Infantes, tras la reforma emprendida en 1783 en la capilla del Santo Cristo $^{732}$, si bien, en este caso se parte de la obra anterior, realizada en el siglo XVI.

En la concepción de los muros continúa predominando la piedra, con un mayor uso de la sillería, con la que se forma el característico aparejo isódomo. No obstante, también es frecuente, especialmente en la arquitectura civil, el empleo de sillarejo y mampuesto para aquellas partes menos destacadas. Esto mismo lo encontramos en la cara interna de los muros en los edificios religiosos. Hacia el exterior, los muros quedan rematados por molduras de codillo o de papo de paloma, las cuales están precedidas, en algunos casos, por un friso delimitado por finos junquillos, que recorren todo el perímetro del edificio.

Las ventanas continúan siendo escasas y de pequeño tamaño, orientándose preferentemente hacia el mediodía y poniente. Todas ellas presentan, por lo general, dintel plano, si bien, los edificios religiosos se decantan por un trazado más alargado de estructura abocinada con derrame hacia el exterior, la arquitectura civil mantiene un trazado más ancho, recercado mediante moldura plana de escaso resalte con orejones.

Para la portada, tanto en la arquitectura religiosa como en la civil, se suele recurrir al vano coronado con arco de medio punto, el cual, en el segundo caso, presenta una característica decoración de casetones sobre la rosca. Por su parte, en los edificios religiosos bien poco cambia con respecto a la etapa inmediatamente anterior, manteniendo los mismo modelos de estructura clasicista, con arco de medio punto dispuesto entre pilastras cajeadas, y coronado con frontón triangular partido. Aun así, estas portadas continúan siendo el lugar en el que se concentra la mayor parte de los elementos ornamentales, que aparecen en la parte exterior del edificio, manteniendo con

\footnotetext{
732 A. P. Salas de los Infantes. LP, Salas de los Infantes, parroquia de Santa Cecilia. LF. (1721 - 1809). Cuentas del año 1782. Salas de los Infantes, 2 - octubre - 1783.
} 
ello su carácter simbólico de elemento de tránsito entre el mundo profano y el sagrado, a la cual une su función de referente visual dentro del entramado urbano.

En definitiva, nos encontramos ante una arquitectura en la que se continúan, practicando, sin solución de continuidad, las mismas formas ya desarrolladas desde principios de la centuria anterior. Sin embargo, y a pesar de que esta circunstancia, en algunos casos, constituye un claro signo de arcaísmo, en otros representa una manifiesta inclinación por la llamada alternativa clasicista. Una tendencia que se define en el siglo XVIII como una firme alternativa frente al barroquismo más exaltado, la cual encontró en este territorio del Arzobispado de Burgos una de las áreas de mayor arraigo ${ }^{733}$. La adhesión a esta tendencia queda confirmada desde el mismo momento en el que consideramos probada la presencia en la comarca de figuras determinantes en la elaboración de esta línea, como es el caso de Fr. Pedro Martín o Domingo de Ondátegui $^{734}$.

Arquitectura religiosa.

A pesar del gran desarrollo experimentado por la arquitectura civil durante este siglo, en general las construcciones más destacadas, es decir, aquellas en las que de forma más clara se manifiestan los rasgos propios del lenguaje artístico dominante en este período, continúan siendo las de carácter religioso. El número de obras que se emprende es realmente elevado, llegando a afectar, de un modo u otro, a la gran mayoría de edificios religiosos.

Sin embargo, al margen de las cuestiones de orden estrictamente estadístico, el verdadero interés de la importante actividad, desplegada dentro del ámbito religioso, se

733 J. GÓMEZ MARTÍN: El gótico español en la Edad Moderna... Ob. cit. (pp. 228 - 235). 
encuentra en el hecho de que constituye, en la mayoría de los casos, la última gran fase constructiva, que conocen estos edificios. De este modo, con estas obras se pone fin a una secuencia, que en la práctica totalidad de los templos parroquiales de la comarca, había arrancado en el período románico, contribuyendo con ello a alcanzar su imagen definitiva.

Como ya hemos apuntado en diferentes momentos, la preocupación fundamental en todos los casos, era ampliar el espacio disponible, para así acoger a un mayor número de fieles. No obstante, al igual que había ocurrido en las dos centurias anteriores, vemos como también otras piezas reciben una atención destacada. Esto propicia que se renueven o construyan de nuevo elementos como sacristías, torres y muy especialmente portadas.

Las obras más destacadas, de cuantas ahora se emprenden, son las relacionadas con la renovación y ampliación de edificios existentes, algunas de las cuales alcanzan tal intensidad, que acaban por eliminar la mayor parte de la fábrica anterior, ofreciéndonos auténticas estructuras de nueva planta. Es el caso de iglesias como la de la parroquia de San Martín, en Huerta de Arriba, San Juan Bautista, en Tolbaños de Arriba, San Martín, en Vallejimeno, San Esteban, en Canicosa de la Sierra, o San Pedro, en Monasterio de la Sierra. Y también el de algunas ermitas, como la de Nuestra Señora de Vega, en el Valle de Valdelaguna, la de Nuestra Señora de Rebollar, en el comunal de Trasomo, la de San Antonio, en Vilviestre del Pinar, la de San Miguel, en Arroyo de Salas, y la de Santa Marina, en Moncalvillo. Junto a estos ejemplos, podemos citar otros, no menos importantes, en los que la remodelación sólo afecta a zonas muy concretas del edificio, bien ampliando o renovando parte de su estructura. En este caso la lista, evidentemente, resulta mucho más amplia.

734 M. J. ZAPARAÍN YÁÑEZ: “La aportación de los maestros vascos a la arquitectura barroca castellana. Nuevos datos sobre la obra de Domingo de Ondátegui”. En Ondare. Cuadernos de artes plásticas y monumentales. $\mathrm{n}^{\circ} 19$ (2000). pp. 425 - 433. 
Dentro de los ejemplos de remodelación completa de un edificio, sin duda, uno de los más destacados, y no sólo por la envergadura de las obras acometidas, sino también por el modo en el que éstas afectaron a su estructura, es el de San Martín, en Huerta de Arriba. La de San Martín constituía una de las dos parroquias con las que tradicionalmente contó esta localidad. Sin embargo, el continuo desplazamiento de la población, desde la zona más elevada, donde se encontraba la parroquia de Santa María, hacia la parte más baja, en la que se situaba esta iglesia de San Martín, llevó a que las autoridades diocesanas tomaran la decisión definitiva de prescindir de la primera de ellas. La plena consumación de este hecho se produjo finalmente en 1719, quedando convertida la iglesia de San Martín en la única parroquia del pueblo, mientras que la de Santa María pasaba a ser una simple ermita ${ }^{735}$.

Para entonces, la parroquia de San Martín llevaba ya varias décadas viendo como su feligresía no dejaba de crecer, merced al goteo constante de nuevos vecinos, que se instalaban, procedentes de la parte alta del pueblo. Este goteo terminó por convertirse, tras la fusión de las dos parroquias, en un auténtico torrente, lo que hizo, que la necesidad de ampliar el templo - que hasta el momento se contemplaba como una posibilidad lejana, que algún día debían acometer, - se convirtiera, de forma súbita, en una cuestión de primer orden, que era obligado resolver con la mayor premura.

La iglesia, que la parroquia de San Martín había heredado de la época anterior, era un pequeño templo de origen románico, formado por una estructura de nave única, cubierta con techumbre de madera dispuesta a dos aguas, sobre la que se agregaba en su extremo oriental, una amplia cabecera de planta rectangular y testero plano, cubierta con bóveda de medio cañón ligeramente apuntada. Este conjunto se completaba, en la zona de los pies, con una torre, alzada sobre un poderoso basamento de origen románico, al que se añadían tres cuerpos más, incorporados durante el siglo XVII. En definitiva, se trataba de un templo muy sencillo en cuanto a su estructura, y sumamente modesto en

735 Ver apartado dedicado a Huerta de Arriba. 
sus proporciones, lo cual hacía que resultara insuficiente para acoger a la creciente feligresía.

Ante este panorama, la solución que debía adoptarse parece obvia, es decir, derribar el antiguo templo, y levantar en su lugar una nueva fábrica más amplia y capaz, en la que poder acoger a todo el vecindario del pueblo. Y en gran medida fue esto lo que se hizo, si bien, durante este proceso se decidió reinterpretar la primera de las premisas. De esta forma, se procedió a conservar la primitiva cabecera y su torre, eliminando, por el contrario, los muros laterales de la antigua nave, lo que permitía prolongar, de modo casi ilimitado, las dimensiones del nuevo templo en sentido transversal. Al mismo tiempo que se hacía esto, sobre el extremo septentrional del espacio de la nueva nave resultante, se incorporó una nueva cabecera, formada por una pieza de planta cuadrangular y testero plano, muy poco profunda y enmarcada por un gran arco toral. En el tramo de los pies, finalmente, se levanta un amplio coro, constituido por un potente arco escarzano, asentado sobre las pilastras que delimitan este espacio.

Esto hacía que la disposición del templo cambiara de forma radical, pues, lo que en un principio parecía una importante obra de remodelación y ampliación de un edificio antiguo, terminó por convertirse en una fábrica completamente nueva, que bien poco tenía que ver con la anterior, pues ha cambiado incluso su orientación. El cambio hace que la antigua cabecera quede convertida ahora en una simple capilla lateral, adosada sobre uno de los muros laterales del templo, situándose con ello en correspondencia con la torre, que permanece apoyada sobre el flanco contrario. Para culminar todo el proceso renovador, sobre el muro de los pies, situado ahora en la parte meridional, se levanta una monumental portada, desde la cual se marca el inicio del eje longitudinal, que recorre y dirige el espacio del nuevo templo.

En su interior, el nuevo espacio resultante destaca especialmente por su gran amplitud, mostrando, dentro de la estructura longitudinal, un claro concepto de ámbito único, afianzado en este caso, por la escasa profundidad de la nueva cabecera, y por la 
importante anchura y altura de la nave. Los únicos espacio que escapan a este ideal de ámbito único, por lo tanto, son los situados en aquellas partes conservadas de la fábrica anterior, es decir, la primitiva capilla mayor - dedicada ahora a Santa María - y los antiguos coro y sotocoro, ubicados en el interior de la base de la torre.

Dentro de esta nueva imagen interior destacan especialmente las cubiertas que cierran cada uno de los tres tramos en los que quedaba articulada la nave. Estos tramos se cubren con bóvedas de crucería estrelladas con terceletes, dentro de las cuales, las dos primeras incorporan una serie de nervios combados, dispuestos a modo de ondas, que se expanden desde la clave central, dando lugar a una complicada trama, que alcanza su mayor dificultad en el tramo central. Son bóvedas de rampante totalmente llana, con nervios realizados en sillería y plementería de mampuesto, convenientemente enlucida mediante una capa de yeso.

Los diferentes tramos aparecen separados por amplios arcos fajones de medio punto rebajados, de sección cuadrada e intradós cajeado, que descansan sobre potentes pilastras seudodóricas de fuste cajeado. Como es habitual, mientras los muros presentan en su cara interna un tosco mampuesto, los arcos, pilastras y nervios de las bóvedas se encuentran realizados en piedra de sillería, destacando así su papel, como elementos activos.

Respecto a la nueva cabecera, su pequeño espacio se cubre con un tramo de bóveda de cañón, realizada también en piedra de sillería, mientras que los muros sobre los que descansa están fabricados en mampostería. A su interior se accede a través de un amplio arco toral de medio punto de intradós cajeado, que apoya sobre ménsulas avolutadas.

$\mathrm{Al}$ exterior la fábrica resultante se muestra como un edificio de recia estructura prismática, articulada por una gran masa central, sobre la cual se añaden distintos 


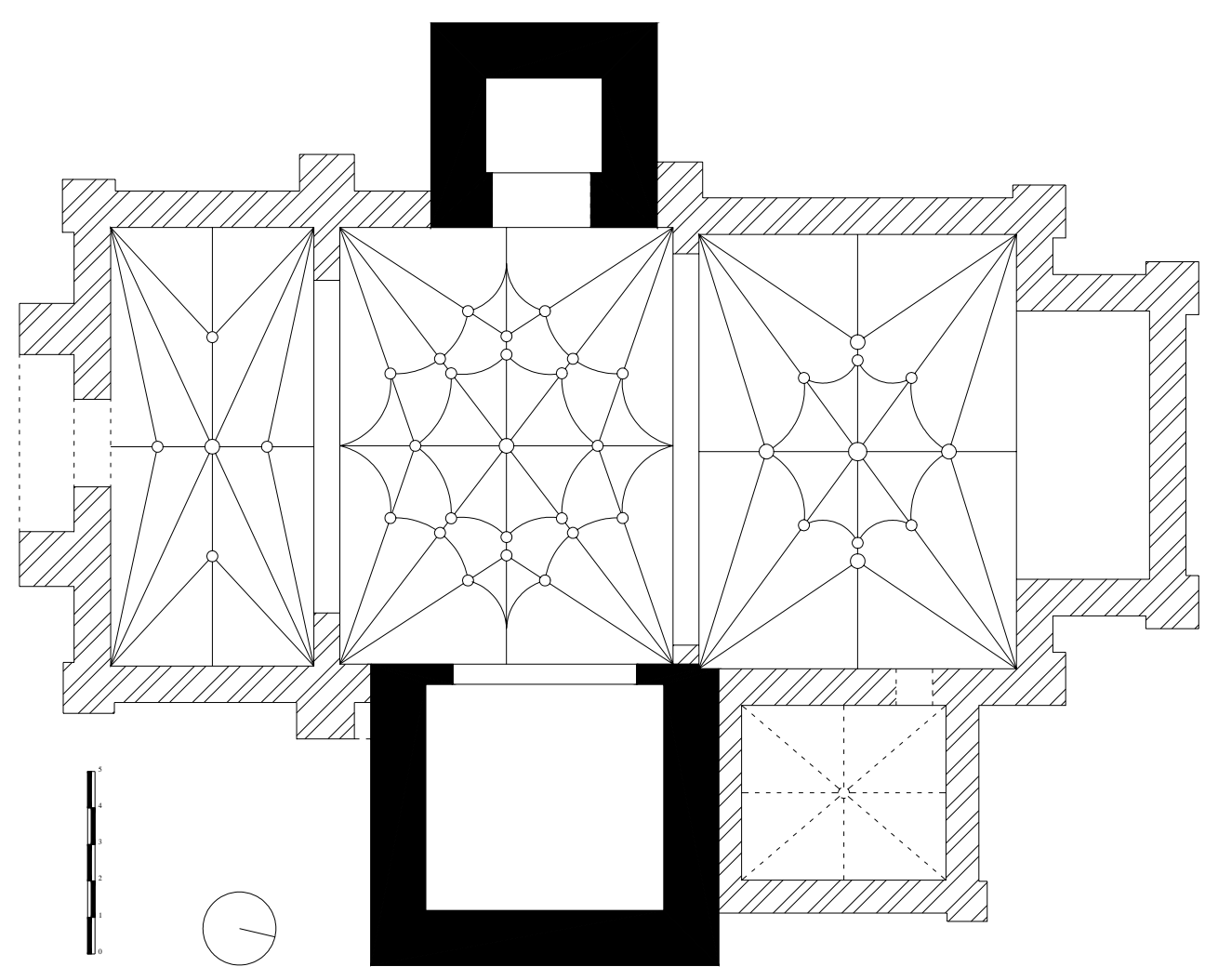

Restos románicos.

Renovación siglo XVIII.

HUERTA DE ARRIBA. Iglesia de San Martín. Planta.

cuerpos, heredados de la fábrica anterior, como la antigua capilla mayor y la torre, o nuevos, como la nueva cabecera o la sacristía.

Destacan en este conjunto sus recios muros, elaborados en sillería, mostrando una total planitud, que apenas se ve interrumpida por la presencia de los contrafuertes, que articulan su desarrollo. Los muros están rematados por una cornisa de doble 
moldura de papo de paloma y codillo, precedida de un grueso friso, delimitado por un fino listel, que recorre todo el contorno del templo. Los escasos ventanales con los que cuenta están repartidos por los diferentes muros, exceptuando la cara norte, empleando en todos los casos estilizados vanos de trazado rectangular ligeramente abocinado hacia el exterior, y rematados con doble dintel, que sirve de elemento de descarga. La portada, abierta sobre el muro de los pies, constituye el único punto en el que se rompe la absoluta severidad, que preside la imagen exterior de todo el conjunto, si bien, de ella hablaremos más adelante.

Un conjunto, en definitiva, sobrio y austero, que comparte su sencillez estructural con un gran sentido de monumentalidad, mostrado a través de sus grandes proporciones, de formas recias y limpios perfiles, propios de la estética clasicista. Vemos en este edificio, por lo tanto, la fiel continuación de la estética desarrollada en la arquitectura de la zona desde los inicios de la centuria anterior, en la cual, sin embargo, se incluyen ciertas novedades en la concepción espacial, donde se da un deliberado intento por alcanzar un sentido de ámbito único, aplicado a una estructura de tipo claramente longitudinal.

La ejecución de este ambicioso proyecto de renovación se realizó en dos fases sucesivas, completadas entre los años 1727 y 1729 respectivamente. En ellas intervinieron los maestros de cantería trasmeranos Bernardo de la Torre y Melchor de la Ayuela, y el maestro de carpintería Tomás Juariste. En la primera de estas fases se procedió a construir únicamente la nueva cabecera, con su bóveda de cañón, y el tramo delantero de la nueva nave. Esto permitía conservar de forma íntegra la antigua fábrica, sin tener que demoler, de momento, ninguna de sus partes. Los encargados de realizar estos trabajos fueron los maestros ya citados, Bernardo de la Torre y Melchor de la Ayuela, si bien, desconocemos el importe, que alcanza la obra.

Una vez concluida la primera fase, se procedió a completar todo el proyecto remodelador con la eliminación de los muros laterales de la antigua iglesia, la 
incorporación de la nueva cabecera, y la construcción de los dos tramos que faltaban de la nave, a los cuales se añadía la portada, levantada sobre el muro de los pies. La ejecución de esta segunda fase, con la que se culminaba todo el proyecto, fue adjudicada al maestro de cantería Juan de la Vega, el cual presentó una postura de 29.500 reales para los trabajos de cantería. Sin embargo, la imposibilidad de dirigir personalmente la obra, dados los compromisos que tenía con otros proyectos, obligó a ceder el contrato a los maestros Bernardo de la Torre y Melchor de la Ayuela, que habían realizado la primera fase, respetando en todo las condiciones fijadas, tanto en el precio, como en los plazos. Esta circunstancia, lejos de constituir un inconveniente, fue vista con buenos ojos por los miembros del concejo de la localidad, pues como ellos mismos dicen, en alusión a la primera parte de esta obra ... an correspondido como hombres de bien y por tales son muy conocidos ${ }^{736}$. La parte correspondiente a la carpintería de la segunda fase fue adjudicada al maestro Tomás Juariste, el cual presentó una postura de 5.800 reales, por la ejecución de todo el entramado de la cubierta, las puertas y el coro $^{737}$.

En lo que respecta a la autoría de las trazas y condiciones, sin embargo, carecemos de datos fiables. Aun así, en virtud de las formas severas, aunque no exentas de cierta monumentalidad, que muestra todo el conjunto del edificio, y de las fechas en las que nos movemos, resulta más que probable pensar que detrás de la concepción del proyecto pudiera estar la figura del maestro de cantería Fr. Pedro Martín. No en vano, sabemos que en este momento se encontraba ocupando el puesto de Maestro Mayor de la catedral de Burgos, y por consiguiente Veedor de las obras del Arzobispado. Este maestro se convirtió en uno de los más importantes representantes de la alternativa clasicista, desarrollada dentro del Arzobispado de Burgos desde los inicios de este siglo, con lo cual, y en virtud de las obligaciones que implicaba su presencia al frente del cargo de Veedor de obras de la Diócesis, resulta más que probable pensar, que su mano

\footnotetext{
736 AHPBU. PN. Valle de Valdelaguna. Leg. 9802/1, fols. $64-70 v^{\circ}$. Manuel Gil de la Cuesta. Huerta de Arriba, 5 - mayo - 1728.

737 AHPBU. PN. Valle de Valdelaguna. Leg. 9802/1, fols. 77 - 79 v . Manuel Gil de la Cuesta. Huerta de Arriba, 31 - mayo - 1728.
} 
pudo estar detrás de este proyecto, cuanto menos en la elaboración de sus líneas generales.

Muy próxima a Huerta de Arriba se encuentra la localidad de Tolbaños de Arriba, la cual también renueva en este momento su templo parroquial, dedicado a San Juan Bautista. La obra se concluye, según nos indica una inscripción conservada sobre la clave de una de sus bóvedas, en 1724, lo que hace que sea prácticamente contemporánea a la anterior. Nuestras únicas fuentes de información prácticamente comienzan y terminan con esta inscripción, lo que hace que resulte ciertamente difícil intentar teorizar sobre las cuestiones relacionadas con su construcción, desde las circunstancias que pudieron propiciar la obra, hasta la autoría de la misma. De todos modos, se trata de un proyecto infinitamente más modesto que el que acabamos de ver, ofreciendo un menor interés desde el punto de vista artístico.

El edificio se encuentra situado en la parte más elevada del pueblo, ocupando una superficie de notable pendiente. Presenta una estructura de tipo caja con una gran nave única de trazado rectangular, articulada en tres tramos, de los cuales el delantero

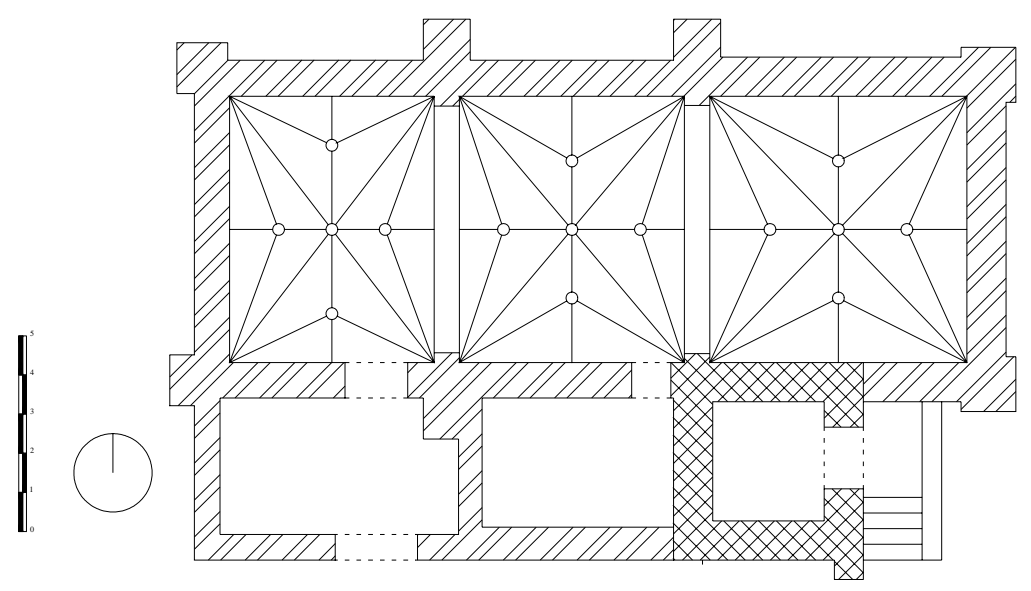

TOLBAÑOS DE ARRIBA. Iglesia de San Juan Bautista. Planta. 
544 Arquitectura de la Edad Moderna en la sierra burgalesa.

constituye la cabecera. No existe, por lo tanto, ningún tipo de separación que marque de forma clara el tránsito entre el presbiterio y el resto de la nave, dibujándose, con ello, un típico espacio de ámbito único, dentro del cual existe un marcado carácter longitudinal. Todos y cada uno de sus tramos están cubiertos con bóveda de crucería estrellada con terceletes, de trama simple y rampante llana, con claves decoradas con cruces, estrellas y elementos florales de talla sencilla y muy plana. Los arcos y soportes sobre los que éstos descansan, se ajustan a los modelos utilizados mayoritariamente en la zona durante este período. Son arcos, por lo tanto, de medio punto de sección cuadrada e intradós levemente cajeado, que descansan sobre pilastras de orden toscano y fuste igualmente cajeado. Estos elementos, al igual que los nervios de las bóvedas, se encuentran realizados en piedra de sillería, lo que hace que destaquen sobre el paramento de los muros, elaborados en mampostería.

$\mathrm{Al}$ exterior, la imagen que proyecta el edificio se encuentra dominada por el gran prisma, que forma el núcleo central del templo, sobre cuyo flanco meridional se incorporan, de forma perfectamente ordenada, la torre, la sacristía y un pequeño pórtico cerrado. Todos estos elementos forman un bloque compacto, que respeta perfectamente la proporcionalidad del núcleo principal del templo, con lo cual su incorporación se produce sin ningún tipo de brusquedad. Solamente la torre, situada a la altura del presbiterio, logra romper esta uniformidad, constituyéndose así en el auténtico contrapunto ascensional, dentro de una estructura de marcado sentido horizontal.

Un templo que nos ofrece, por lo tanto, una versión sumamente simplificada del tipo de arquitectura de inspiración clasicista, que en este momento se desarrolla en la comarca. En él se aprecia la sobriedad y sencillez estructural característica de este lenguaje, con un dominio absoluto de las líneas rectas y una total ausencia de elemento ornamentales. Al mismo tiempo, debemos valorar también el hecho de que nos encontramos ante una obra concebida prácticamente de nueva planta en la que se desarrolla - sin condicionantes aparentes de los elementos conservados de la fábrica anterior - una estructura de tipo caja muy similar a las que ya vimos en las últimas 
décadas del siglo XV y principios del siglo XVI. No obstante, esta circunstancia no nos permite hablar, tanto de la recuperación de una tipología constructiva, como de su conservación a lo largo del tiempo, pues prácticamente, desde el período de los Reyes Católicos no había dejado de emplearse.

Sin salir del Valle de Valdelaguna, hallamos un tercer ejemplo de templo parroquial renovado en su práctica totalidad, en la iglesia de San Martín, en Vallejimeno. Se trata de un templo remodelado a lo largo de varias fases, comprendidas todas ellas, dentro de este siglo. No obstante, para conocer la secuencia constructiva, apenas contamos con fuentes documentales que nos informen sobre el proceso.

Así, contrastando los diferentes datos de que disponemos, podemos saber que esta actividad renovadora se divide en dos momentos especialmente intensos, de los cuales, el primero se sitúa en torno a la década de 1720, afectando a la parte de la cabecera, mientras que la remodelación de la zona de la nave tiene lugar aproximadamente una década más tarde.

Sobre la primera de las fases, desconocemos tanto el momento exacto de su realización, como los nombres de los artífices, que participaron en ella. No obstante, si nos centramos en el tipo de elementos que aquí se emplean, y fijamos nuestra atención, de modo, especial en la bóveda que cubre el espacio de la cabecera, que ahora se levanta, parece quedar totalmente clara la cronología apuntada.

En lo que se refiere a la zona de la nave, contamos con una mayor información. Así, sabemos que el proyecto se lleva a cabo en 1736, participando en los trabajos de cantería los maestros trasmeranos Martín Delgado y Manuel de la Torre, ambos de la localidad de Hermosa, en la Junta de Cudeyo, en los cuales se remató la obra por un 


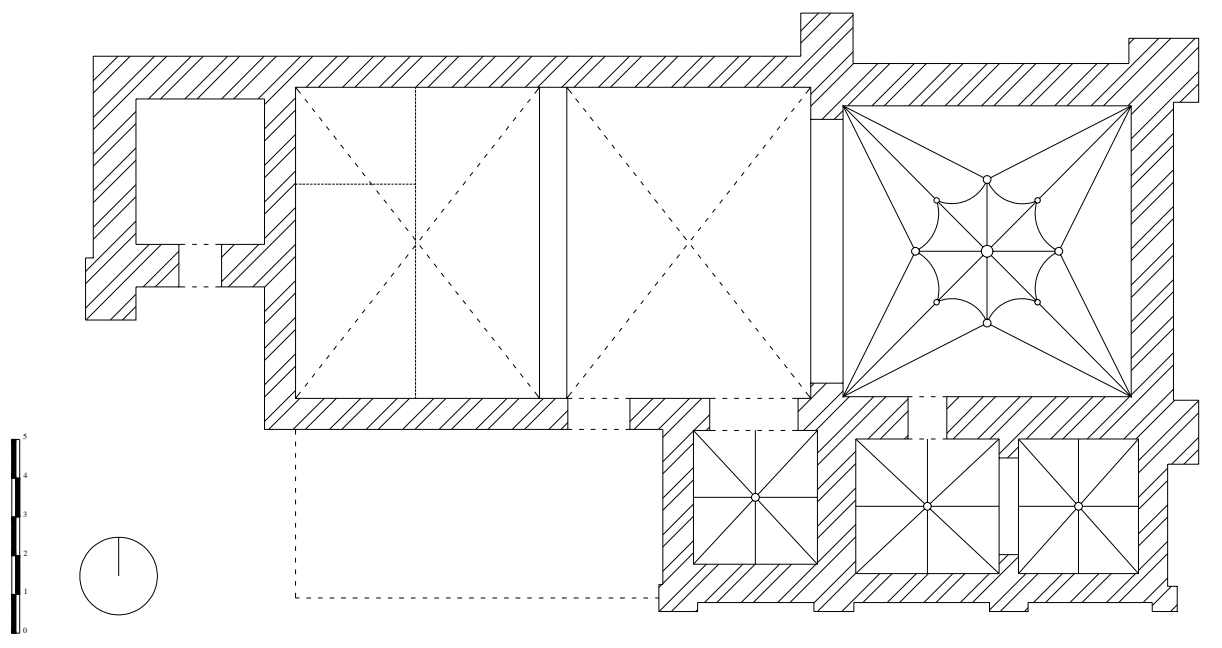

VALLEJIMENO. Iglesia de San Martín. Planta.

total de 3.715 reales $^{738}$. La parte correspondiente a la carpintería, por su parte, se adjudica al maestro Juan de Arrieta, por un importe de 2.800 reales $^{739}$.

Como resultado de todo ello surge un templo de tipo caja, muy parecido al que acabamos de ver en Tolbaños de Arriba, aunque de dimensiones algo mayores. Muestra así, una estructura de nave única articulada en tres tramos, de los cuales el delantero constituye la cabecera. De este modo, en su interior, como es habitual en este período, se forma un gran espacio de ámbito único, dominado por un claro carácter longitudinal. No obstante, en este caso, la separación entre el tramo que constituye la cabecera y el resto del templo, queda mejor marcada, pues además de utilizar un tipo de cubierta diferente, se levanta entre ambos un potente arco toral de medio punto, alzado sobre

738 AHPBU. PN. Valle de Valdelaguna. Leg. 9803/1, fols. 14 - 17 vo. Manuel Gil de la Cuesta. Vallejimeno, 13 - mayo - 1736.

739 AHPBU. PN. Valle de Valdelaguna. Leg. 9803/1, fols. 18 - 21. Manuel Gil de la Cuesta. Barbadillo de Herreros, 20 - mayo - 1736. 
pilastras de orden seudotoscano y fuste cajeado, propio de este período. El espacio de la cabecera se cierra con una bóveda de crucería estrellada con terceletes en cuya trama se incluyen una serie de nervios combados, dispuestos a modo de ondas, como sucedía en la nave de la iglesia de Huerta de Arriba. Mientras, los tramos de la nave se cubren con sencillas bóvedas de aristas, separadas por amplio arco fajón de medio punto, que descansa sobre una línea de imposta plana de escaso resalte, con la cual se marca el límite superior de los muros. Estas cubiertas, sin embargo, se añaden más tarde, en una tercera fase llevada a cabo en 1794, con un conste para la fábrica de 6.572 reales $^{740}$.

Al exterior, el templo presenta la característica imagen de las iglesias de tipo caja, definida por un amplio prisma de forma alargada, en el que predomina un claro sentido de horizontalidad, solamente roto por el contrapunto vertical, que introduce la torre, situada a los pies. Esta imagen se completa con la incorporación de un pequeño cuerpo, adosado sobre la fachada meridional, en el cual quedan incluidos la sacristía y una diminuta capilla dedicada al Santo Cristo, cuya cubierta se prolonga a lo largo de todo este flanco, para formar un pequeño porche, que actúa como pórtico. Los muros de todo el conjunto se encuentran realizados en tosco aparejo de mampostería, reforzado en las esquinas por sillares de mayor tamaño y mejor labra, que en el caso del testero de la cabecera, se convierten en sólidos contrafuertes de estructura prismática, dispuestos con sus lados en paralelo a los del muro.

Una iglesia, en definitiva, sumamente tosca, en cuanto a su técnica constructiva, y de gran sencillez estructural, en la cual, sin embargo, se manifiesta uno de los rasgos más característicos de este período, como es el concepto de espacio único, que hasta el momento hemos visto repetido en todos y cada uno de los ejemplos citados.

Si pasamos a la zona de esta comarca, incluida en la Diócesis de Osma, nos encontramos con otro nuevo ejemplo de construcción de nueva planta en la iglesia de

740 AGDBU. LP. Vallejimeno, parroquia de San Martín. LF. (1751 - 1851). Cuentas del año 1794. Vallejimeno, 4 - octubre - 1795. 
San Esteban, en Canicosa de la Sierra. Se trata de una iglesia igual de enigmática que las anteriores, en lo que a su proceso constructivo se refiere, pues volvemos a encontrarnos totalmente desasitidos, desde el punto de vista documental, sin datos que nos certifiquen la fecha concreta de su ejecución, ni los nombres de los artífices que participaron en ella. El único dato concreto con el que contamos es la fecha inscrita en la portada abierta sobre la parte septentrional del templo, donde se indica el año 1739. Evidentemente esta fecha alude únicamente a la construcción de la portada, sin embargo, podemos utilizarla como referencia para el resto del edificio, pues su construcción debió suponer la culminación de todo el proceso renovador.

Un proceso constructivo, que a pesar de no contar con los datos oportunos, se nos antoja, cuanto menos, complicado, si analizamos la propia estructura del edificio resultante. En ella vemos una clara diferenciación entre la cabecera y la zona correspondiente al cuerpo, la cual afecta incluso a su propia disposición, pues la línea que recorre todo el eje longitudinal no sigue un trazado recto, sino que muestra un brusco quiebro en el momento de alcanzar el presbiterio.

Por lo demás, y a pesar de estas irregularidades, el templo se puede incluir también dentro de los llamados tipo caja, pues muestra una estructura sencilla de una sola nave, que se completa en su extremo oriental con la cabecera. La nave presenta una planta irregular, con un trazado trapezoidal, en el que no encontramos, ni lados paralelos, ni ángulos rectos. La cabecera, por su parte, cuenta con una capilla mayor de testero poligonal, precedida por un amplio presbiterio de planta cuadrangular, al cual se accede a través de un potente arco de medio punto con intradós cajeado, dispuesto sobre una sencilla línea de imposta plana de escaso resalte, que se extiende a lo largo del muro, marcando la separación con la cubierta. Esta cubierta, en el caso de presbiterio, se encuentra formada por una amplia bóveda de crucería estrellada con terceletes y nervios combados, con los que se dibuja una gran cruz, que nos recuerda algunos ejemplos del gótico del siglo XVI. Constituye, sin duda, el elemento más destacado de la imagen interior del templo. La nave, por su parte, se cierra con una simple estructura de madera 


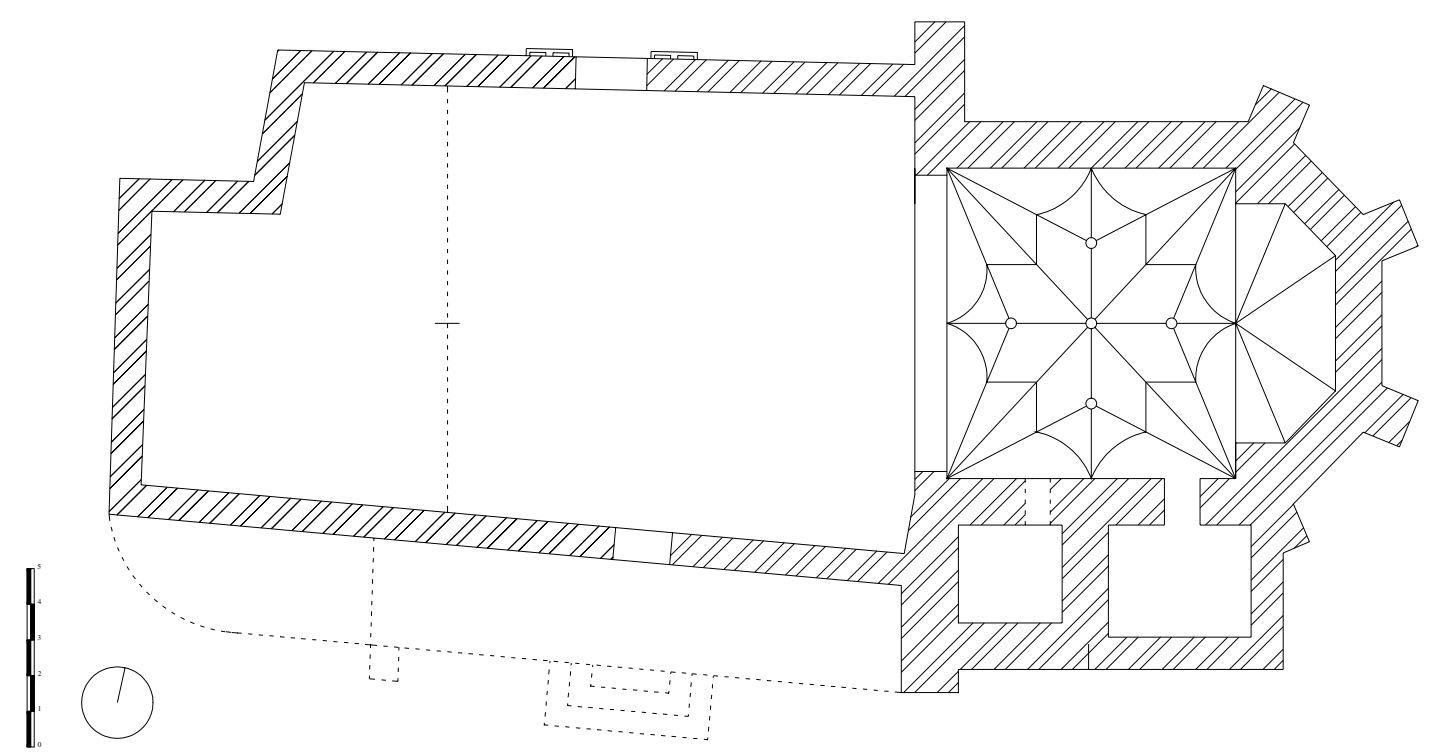

CANICOSA DE LA SIERRA.

Iglesia de San Esteban. Planta.

dispuesta a dos aguas, y soportada actualmente por una moderna armadura de hierro, que en origen debió ser también de madera. En cualquier caso, lo que parece quedar fuera de toda duda es que jamás existió aquí una cubierta abovedada de piedra como la del presbiterio.

Con todos estos elementos, se dibuja una concepción espacial típica de este momento, con una marcada inclinación hacia el ámbito único, dentro del cual, sin embargo, no se pierde el sentido longitudinal. No obstante, dentro de esta lectura espacial, en la que apenas existen divisiones reales, resulta fácil distinguir la personalidad y el carácter diferenciado de la cabecera y la nave.

Esta diferencia se muestra con mayor claridad hacia el exterior, donde la cubierta abovedada de la cabecera, se manifiesta a través de importante diferencia de 
altura sobre el tejado de la nave, dando la sensación de hallarnos ante un templo de estructura macrocéfala. Por lo demás, todo el conjunto presenta una composición sencilla dominada por sólidos prismas de limpios perfiles en los que se aprecia el trazado irregular de su planta. Dentro de la severidad que domina por completo la imagen exterior del templo, el perfecto trabajo de cantería manifestado en sus muros vuelve a ser uno de sus aspectos más destacados. En esta cuestión, la uniformidad resulta absoluta en todo el conjunto.

Los únicos elementos conservados del edificio anterior se concentran en el flanco meridional, sobre cuyo muro podemos apreciar las huellas dejadas por las etapas constructivas más importantes que conoció el templo a lo largo de su historia, convirtiéndose, por ello, en un valioso documento en el que podemos seguir el recorrido de este proceso. Esto mismo sucede con la torre, situada en este mismo lado, junto al presbiterio. En ella se pueden distinguir hasta tres niveles distintos de vanos, en los que, de modo sucesivo, se fueron alojando las campanas, hasta culminar con la última ampliación, que tiene lugar en el momento que se realiza la renovación del templo. Con este último incremento de su altura lo que se pretendía era superar el nivel de la cubierta del nuevo presbiterio, para que la voz de sus campanas se extendiera por todo el vecindario del pueblo.

Una obra en definitiva, en la que se suman la tradición gótica, por un lado, y la clasicista, por otro, para ofrecernos con ello un conjunto sumamente sencillo en sus formas y estructura, pero de gran monumentalidad, debido a las dimensiones y técnica empleada. Los elementos más destacados, no obstante, los encontramos, como ya decíamos, en la parte de la cabecera, donde se desarrolla un tipo de estructura absolutamente nuevo en la comarca, el cual, sin embargo, apenas encuentra continuación en las construcciones posteriores.

Un último ejemplo de templo parroquial, que renueva de forma completa su fábrica, lo encontramos en la iglesia de San Pedro, en Monasterio de la Sierra. Se 
trata de una obra tardía - pues parte de ella se completa ya en los primeros años del siglo XIX - la cual se acomete a lo largo de dos fases sucesivas, que afectan, respectivamente, a la cabecera y a la zona del cuerpo. El principal promotor de esta empresa fue el inquieto párroco, durante los años finales del siglo XVIII, D. Felipe Gómez, el cual, con la ayuda del mayordomo Juan Esteban, decidió poner los medios necesarios para remodelar por completo la estructura de este templo. El objetivo de todo ello no era levantar una gran fábrica, que superara en capacidad y belleza al edificio anterior, sino subsanar los continuos problemas de humedades, que esta iglesia venía padeciendo desde sus inicios, tal y como nos recuerdan los continuos informes dejados por los visitadores, que acudieron a inspeccionarla ${ }^{741}$. Por ello, el resultado final no nos ofrece un templo preocupado por cuidar los valores estéticos, sino que nos muestra una obra sencilla y funcional, perfectamente adaptada a las necesidades y recursos de la parroquia y de sus feligreses.

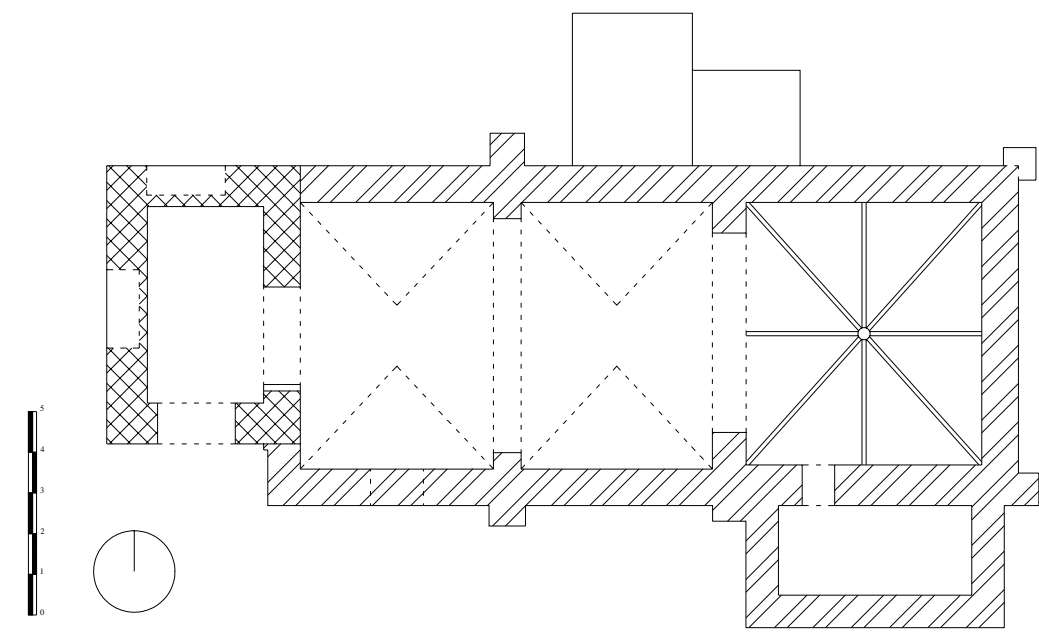

Construcción Siglo XVII.

MONASTERIO DE LA SIERRA.

Iglesia de San Pedro. Planta.

741 AGDBU. LP. Monasterio de la Sierra, parroquia de San Pedro, LF. (1776 - 1838), (fols. 35v $\mathrm{v}^{\mathrm{O}}-38 \mathrm{v}^{\mathrm{o}}$ ). Visita realizada a la parroquia de San Pedro en Monasterio de la Sierra en 1791, por D. Manuel María Izquierdo. Barbadillo del Mercado, 10 - noviembre - 1791. 
La primera parte del proyecto afecta a la zona de la cabecera, cuyos trabajos se llevan a cabo, según los datos aportados por los libros de fábrica, entre los años 179394, con un desembolso para esta parroquia de 10.000 reales, a los que podemos sumar las limosnas y ayudas de los feligreses ${ }^{742}$.

La segunda fase se realiza entre los años 1801-02, y en ella se acomete la remodelación de toda la parte correspondiente a la nave. La cantidad, que en esta ocasión tuvo que entregar la parroquia, rondó los 4.500 reales, a los cuales debemos sumar otros 200 reales más, gastados en el remate de pequeños detalles que quedaron por terminar $^{743}$.

Como resultado de ello surge un templo de tipo caja, muy similar a los casos anteriores, pero de estructura infinitamente más modesta, tanto en su composición como en sus dimensiones. Así, cuenta con una estructura de planta rectangular, articulada en tres tramos, de los cuales el primero de ellos forma la cabecera. Este tramo se comunica con el espacio del cuerpo a través de un potente arco toral de medio punto de sección cuadrada e intradós plano. Su espacio interior se cubre con una bóveda de crucería octopartita de gruesos y pesados nervios, muy diferente del resto del templo, que se cierra con una bóveda de cañón con lunetos, reforzada en su parte media con un amplio arco fajón de medio punto, dispuesto sobre pilastras adosadas al muro. Dentro de este templo, por lo tanto, se repite el mismo concepto de espacio, que hemos visto en los casos anteriores, en los que se tendía hacia el ámbito único, dentro de una disposición de claro sentido longitudinal.

742 Ibídem. (fols. $43-44 v^{\circ}$ ). Cuentas del año 1793. Monasterio de la Sierra, 5 - septiembre - 1795. AGDBU. LP. Monasterio de la Sierra, parroquia de San Pedro, Libros de Mayordomos. (1731 - 1841). Cuentas del año 1793. Monasterio de la Sierra, 24 - julio - 1795.

743 AGDBU. LP. Monasterio de la Sierra, parroquia de San Pedro, LF. (1776 - 1838), (fols. 54v $\mathrm{v}^{\mathrm{O}}$ 56). Cuentas del año 1801. Monasterio de la Sierra, 15 - septiembre - 1802. (fols. 56 - 57). Cuentas del año 1802. Monasterio de la Sierra, 4 - septiembre - 1803. 
$\mathrm{Al}$ exterior nos ofrece una imagen de extrema austeridad, dominada por un gran prisma de aspecto achaparrado, en el que no se refleja la división interna, entre cabecera y nave. Los muros, que conforman este cuerpo, se encuentran elaborados en piedra, con paramento de sillarejo en la cabecera y mampuesto en el resto, reforzando sus esquinas con sólidos sillares de mayor tamaño, que en el caso de la cabecera se convierten en pequeños estribos, que se elevan sólo hasta la mitad del muro. El contrapunto vertical, dentro de la imagen exterior del templo, lo pone la torre, situada a los pies, la cual está formada por una sencilla estructura de planta cuadrangular, articulada en tres cuerpos separados por impostas planas, de los cuales, solamente el superior, que forma el cuerpo de campanas, supera el nivel de la cubierta de la nave.

Una obra dominada, en su conjunto, por un claro sentido popular, que se completa, en este caso, con una evidente tosquedad en cuanto a la técnica constructiva empleada en su realización. No obstante, y a pesar de todo, resulta fácil apreciar la presencia de ciertos rasgos claramente representativos de este periodo, entre los que destaca, de manera especial, el desarrollo de un concepto espacial de ámbito único, tendiendo a fundir los ámbitos de la nave y de la cabecera en un solo espacio.

Junto a estas obras, y como complemento al apartado de construcciones de nueva planta, tenemos que recoger aquí también los casos de algunas ermitas, que acometieron, durante el siglo, importantes obras de remodelación en sus fábricas, hasta el punto de poder hablar de obras de nueva creación.

Uno de estos casos es el de la ermita de Nuestra Señora de Vega, situada en el Valle de Valdelaguna, cuya fiesta celebran de forma conjunta las localidades de Huerta de Abajo, Huerta de Arriba, Tolbaños de Abajo y Tolbaños de Arriba. Su actual fábrica fue construida, según reza la inscripción conservada sobre el arco toral de la cabecera, en $1772^{744}$, si bien, nos tememos que esta fecha solamente sea válida para la propia cabecera, mientras que el resto, donde se incluye la nave y la sacristía-camarín, 


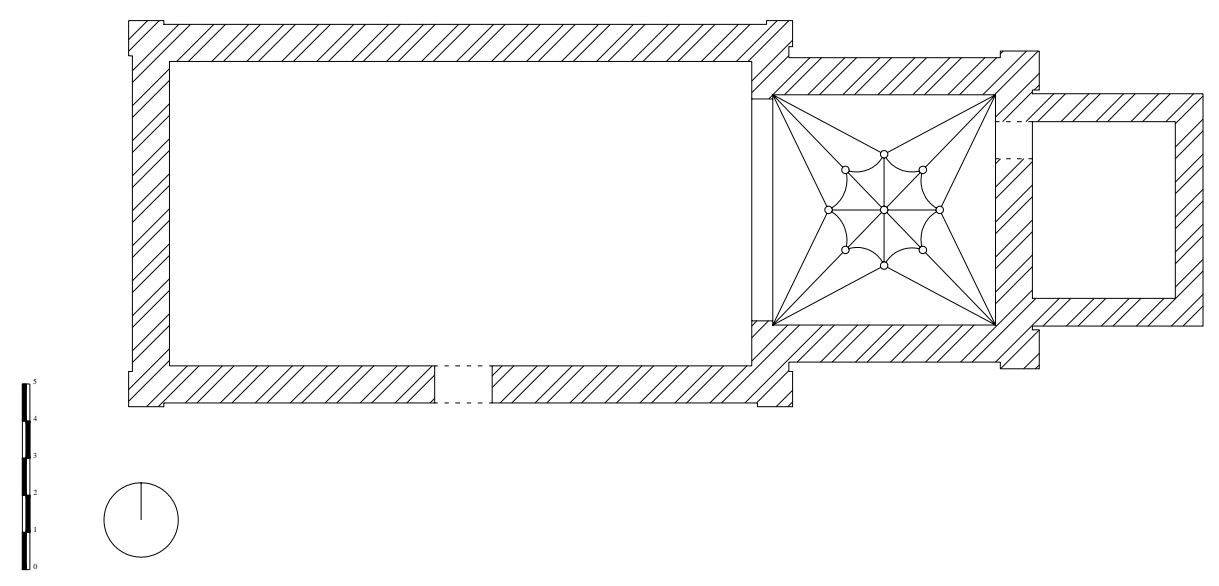

VALLE DE VALDELAGUNA. Ermita de Nuestra Señora de Vega. Planta.

corresponden a fases constructivas distintas. A pesar de todo, el templo logra ofrecer una imagen de absoluta de unidad, presidida por un marcado aire clasicista.

Consta de una estructura de nave única, de trazado rectangular, acompañada, en su parte delantera, por una cabecera de menor anchura y planta cuadrada con testero plano, a la cual sigue una pieza separada del resto, también de planta cuadrangular, que cumple las funciones de sacristía y camarín. Con estos elementos, se configura un espacio interior de marcado carácter longitudinal, en el que los ámbitos de la nave y la cabecera quedan claramente diferenciados mediante un amplio arco toral, de medio punto con intradós cajeado, dispuesto sobre pilastras de orden toscano y fuste igualmente cajeado. En el interior de la cabecera se desarrolla un espacio cubierto con bóveda de crucería estrellada con terceletes y nervios combados, dispuestos a modo de ondas en torno a su clave central, como viene ocurriendo desde las primeras décadas de la centuria en varios ejemplos de su entorno. La nave, por su parte, se cubre con una sencilla techumbre a dos aguas, dispuesta, actualmente, sobre una armadura metálica, que originalmente debió ser de madera. 
Al exterior cada uno de estos espacios se manifiesta en forma de prismas, dispuestos de modo encadenado, en los que se respeta un mismo nivel de cubiertas. Esto hace que predomine un marcado aire de horizontalidad en todo el conjunto. Sus muros, levantados sobre un pequeño zócalo de mayor anchura, presentan un paramento de piedra de sillería en la zona de la cabecera, que se convierte en mampuesto en el caso de la nave, reservando aquí la sillería para el refuerzo de las esquinas y recercado de los vanos. Estos muros se rematan por una cornisa, que en el caso de la nave es de papo de paloma, mientras que en la cabecera combina una moldura de codillo con el papo de paloma. Se evidencia, así la presencia de fases constructivas diferentes.

El remate de todo el conjunto lo forma la portada, que adorna el acceso al interior, abierta sobre el muro meridional de la nave. Ésta se encuentra formada por una sencilla estructura de recio sabor clasicista, en la que aparece un vano central, coronado con arco de medio punto, escoltado a los lados por pilastras de orden toscano y fuste cajeado, entre las que se dispone un entablamento ligeramente quebrado, de grueso friso y volada cornisa, coronada con una cruz sobre neto en el centro, y pináculos piramidales en los extremos, en correspondencia con el eje de las pilastras. Una composición sobria de hondo sabor clasicista, muy mesurada en sus líneas, y con un claro carácter ascensional. Sobre su cronología, sin embargo, resulta más difícil pronunciarse, pues, como veremos más adelante, al hablar de este tipo de piezas, se trata de un modelo que viene repitiéndose, sin grandes cambios durante todo el período barroco.

Otro importante proyecto de renovación se lleva a cabo en la ermita de Nuestra Señora de Rebollar, situada en la junta de Trasomo. Término comunal que administraban de modo conjunto, a través de un cabildo, las localidades de Barbadillo del Pez, Hoyuelos de la Sierra, Quintanilla de Urrilla y Vallejimeno. La obra fue ajustada en enero de 1739 con el maestro de cantería Bartolomé González, el cual se comprometía a realizar las trazas y condiciones del nuevo proyecto, así como la ejecución del mismo, por un precio de 5.000 reales, dando por concluida la obra en 
noviembre de este mismo año ${ }^{745}$. Unos meses después, sin embargo, se produce una rebaja sobre esta postura, efectuada por el maestro de carpintería Juan de Arrieta, y el maestro de cantería Juan de Maurtúa, los cuales se comprometían a realizar este proyecto según los plazos y condiciones previstos por un precio de 4.166 reales y 24 maravedís, es decir una sexta parte más barato ${ }^{746}$.

La falta de noticias a partir de este momento debe hacernos entender que la obra se ejecutó a entera satisfacción de los patronos, respetando todas y cada una de las condiciones, que se especificaban en el pliego de condiciones, sobre las características formales del nuevo edificio.

De este modo, nos encontramos ante una estructura de tipo caja, con una única nave de planta rectangular, que se complementa con una cabecera, en su extremo oriental, de planta cuadrangular, pero de menor anchura que la nave. Esta nave se cubre con techumbre de madera sobre armadura de tipo par y nudillo, mientras que la cabecera reafirma su carácter preponderante a través de una cubierta abovedada, con bóveda de crucería estrellada con terceletes. La comunicación entre ambos espacios se realiza a través de un potente arco toral de medio punto, de sección cuadrangular e intradós cajeado, que descansa sobre pilastras de orden toscano y fuste igualmente cajeado. En la parte de los pies de la nave, como es habitual, se alza un sencillo coro de madera.

$\mathrm{Al}$ exterior los dos espacios se manifiestan como sólidos prismas perfectamente enlazados, formados por muros de mampostería, completamente planos, reforzados en sus esquinas por sillares de mayor tamaño. Este refuerzo se lleva a cabo, en el caso de la cabecera, mediante sólidos contrafuertes de estructura prismática, realizados, igualmente, en piedra de sillería. La puerta de acceso queda situada en la fachada

745 AHPBU. PN. Valle de Valdelaguna. Leg. 9803/1. fols. $1-4 v^{\circ}$. Manuel Gil de la Cuesta. Barbadillo de Herreros, 12, enero, 1739. 


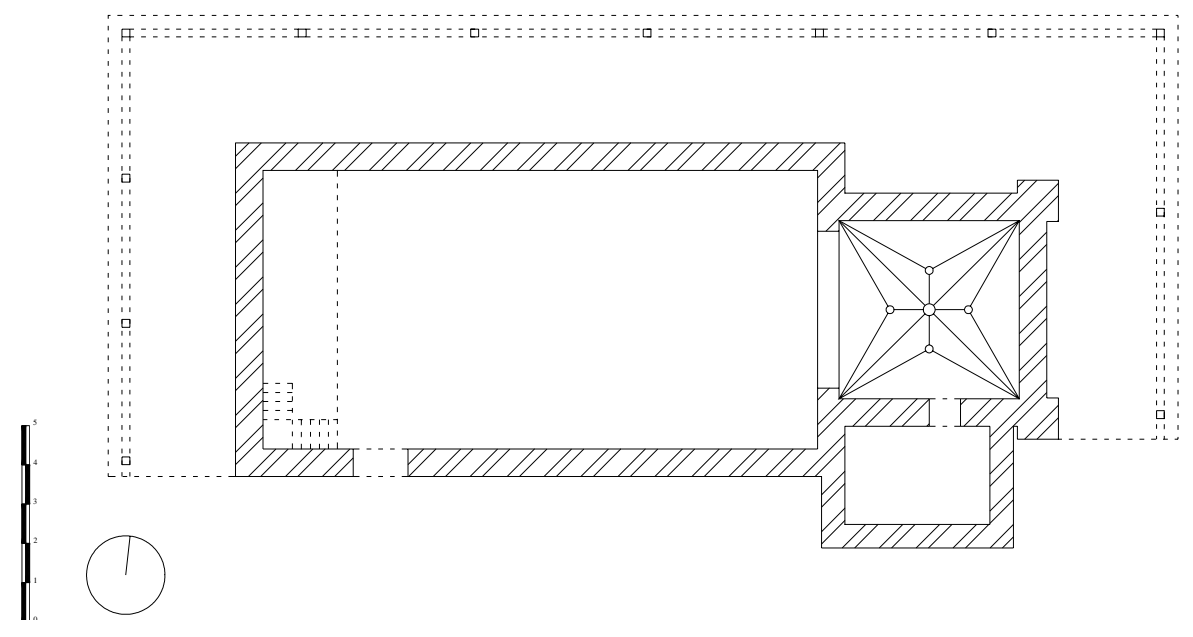

TRASOMO. Ermita de Nuestra Señora de Rebollar. Planta.

meridional del templo, aproximadamente en la parte central de la nave, y está formada por un sencillo arco de medio punto, dispuesto sobre impostas planas de escaso resalte, en el que no aparece ningún tipo de elemento ornamental. La misma orientación y sobriedad se repite en las dos ventanas que iluminan el interior, las cuales muestran un sencillo trazado rectangular de dintel plano. Una tercera ventana, con este mismo tipo de trazado, se abre sobre el muro de poniente, a fin de contemplar y venerar la imagen situada en el altar mayor desde el exterior del templo, según indica el pliego de condiciones $^{747}$.

Sin embargo, el elemento más interesante que nos ofrece este exterior, lo encontramos en el gran porche corrido, que se extiende a lo largo de tres de sus

\footnotetext{
746 AHPBU. PN. Valle de Valdelaguna. Leg. 9803/1, fols. 15 - 16. Manuel Gil de la Cuesta. Vallejimeno, 9 - mayo - 1739.

747 AHPBU. PN. Valle de Valdelaguna. Leg. 9803/1. fols. 1 - 4v $v^{\circ}$. Manuel Gil de la Cuesta. Barbadillo de Herreros, 12 - enero - 1739.
} 
fachadas, excluyendo la meridional, y que está concebido como una mera prolongación del alero del tejado. Esta cubierta descansa sobre una serie de pies derechos, dispuestos sobre piedras poyales y rematados con zapata. Se trata, sin ninguna duda, de un elemento añadido con posterioridad, pues en ningún apartado del pliego de condiciones se incluye su construcción. Su finalidad no era otra que la de servir de protección a los miembros del cabildo de Trasomo, que poseían el patronato de esta ermita, y feligreses en general, que se congregaban en torno al edificio el día de su fiesta. Una tradición que se ha venido guardando desde el siglo XII, momento en el que el término de Trasomo fue vendido a estos pueblos por el rey Alfonso VIII.

En esta misma década se acomete la renovación de la ermita de San Antonio y Santa Catalina, en Vilviestre del Pinar. Sin embargo, en este caso, se trata de una renovación obligada, ya que estuvo marcada por el traslado del templo, efectuado a petición del Visitador del Obispado de Osma, D. Ventura Gaitero, tras su visita de $1732^{748}$. Según este Visitador, su ubicación al otro lado del río Arlanza hacía que no fuera convenientemente atendida, lo que no ocurriría en caso de encontrarse situada junto al pueblo. El traslado se efectuó entre los años 1736-37, ubicando la ermita en su emplazamiento actual, a escasos quinientos metros del pueblo en dirección norte ${ }^{749}$.

El resultado que surge de ello nos ofrece una fábrica de una sola nave de planta rectangular, completada con una cabecera de menor anchura de trazado cuadrangular, adosada sobre su extremo oriental. Se presenta aquí, por lo tanto, la típica estructura que encontramos en la inmensa mayoría de las ermitas de la zona, con los dos ámbitos dispuestos en torno al eje central, y separados, en este caso, por un amplio arco toral de medio punto ligeramente rebajado, de intradós casetonado, dispuesto sobre pilastras de orden toscano. El espacio de la nave se cubre, como es normal, con una cubierta de

\footnotetext{
748 A. P. Vilviestre del Pinar, LP, parroquia de San Martín, LF. (1716 - 1737). (fols. 136 - 136vº). Visita realizada a la parroquia de San Martín de Vilviestre del Pinar en 1732, por D. Ventura Gaitero. Vilviestre del Pinar, 20 - octubre - 1732.

749 E. DOMINGO ANGULO: Vilviestre del Pinar, pasado, presente y futuro. Burgos, Ayuntamiento de Vilviestre del Pinar. 1995. (pp. 42 - 43).
} 


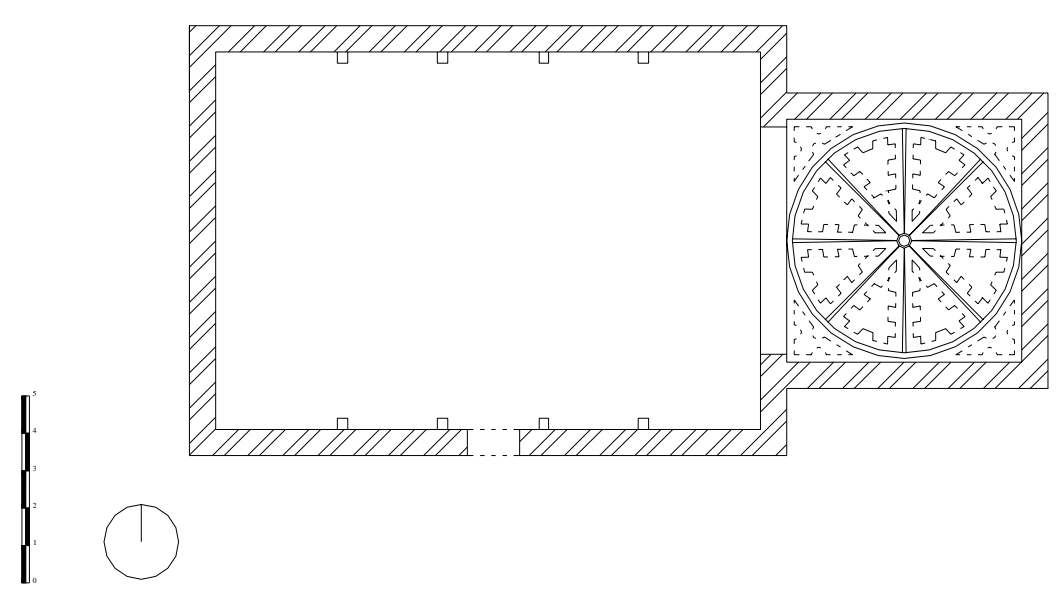

VILVIESTRE DEL PINAR. Ermita de San Antonio y Santa Catalina. Planta.

madera sobre armadura de tipo par y nudillo a dos aguas. Mientras, la capilla mayor marca su carácter preponderante a través de un magnífico ejemplo de cúpula de media naranja, alzada sobre pechinas y anillo moldurado, con su superficie interior dividida en diferentes paños mediante fajas que confluyen en un florón central. Estos paños se cubren con la habitual decoración de escayola, representando figuras geométricas de perfil mixtilíneo. Sin duda, se trata del elemento más destacado de todo el conjunto.

Al exterior su imagen destaca por su extraordinaria sencillez, la cual se encuentra dominada por el juego de volúmenes establecido entre los dos prismas de limpios perfiles, que configuran los respectivos espacios de la nave y la cabecera.

Una ermita que vivió, en cierto modo, una historia parecida a ésta fue la de San Miguel, en Arroyo de Salas. Esta ermita se encontraba situada en la parte superior del pueblo, a unos trescientos metros de las primeras casas, en un paraje poco adecuado, según el visitador que llegó hasta aquí en 1726, D. Andrés Fernández de Tejada. Según se expresa en su informe, el lugar "es húmedo y se halla rodeado de heredades 
labrantías y labrándolas la perjudican"750 . Sin embargo, ni este aviso, ni los efectuados anteriormente por sus predecesores, fueron tenidos en cuenta por el concejo del pueblo, que a la sazón ejercía el patronato de la ermita. De esta forma, en 1740, el Visitador D. Francisco López de Angulo no tuvo más remedio que declarar la ermita en ruina, pues ni siquiera se habían efectuado los mínimos trabajos de mantenimiento, que todo edificio necesita ${ }^{751}$.

Ante esto, los miembros del concejo y vecinos del pueblo decidieron poner remedio al asunto, y así, cuatro años más tarde, en un informe dejado por el mismo visitador se indica que la ermita había sido finalmente reconstruida, aunque respetando su emplazamiento original ${ }^{752}$, el cual se decidió ampliar mediante la compra de algunos terrenos situados en su entorno ${ }^{753}$. El resultado de la reconstrucción, sin embargo, resulta actualmente imposible de apreciar, pues aunque la ermita salió victoriosa de este primer envite, no consiguió sobrevivir más tarde al abandono producido durante el período decimonónico. Aun así, gran parte de sus restos aun se conservan, formando parte del cementerio.

Un último ejemplo de este tipo de obras lo tenemos en la ermita de Santa Marina en Moncalvillo. En este caso aun se mantiene en pie, si bien, las sucesivas obras de reparación y restauración han dejado muy alterado su aspecto interior original. Se encuentra ubicada en la parte central del pueblo, perdida entre su apretado caserío, lo cual sin duda ha facilitado su conservación. Su construcción es relativamente tardía, pues no se completa hasta el año 1788, tal y como indican los libros de fábrica de la iglesia parroquial del pueblo y confirma la inscripción conservada sobre su fachada.

750 AGDBU. LP. Arroyo de Salas, parroquia de San Julián, Libros de la ermita de San Miguel (1710 1849). Vista realizada a la ermita de San Miguel en Arroyo de Salas en 1726, por D. Andrés Fernández de Tejada. Salas de los Infantes, 16 - septiembre - 1726.

751 Ibídem. Visita realizada a la ermita de San Miguel en Arroyo de Salas en 1740, por D. Francisco López Angulo. Salas de los Infantes, 28 - noviembre - 1740.

752 Ibídem. Visita realizada a la ermita de San Miguel en Arroyo de Salas en 1744, por D. Francisco López Angulo. Salas de los Infantes, 2 - mayo - 1744.

753 Ibídem. Cuentas del año 1745. Arroyo de Salas, 20 - febrero - 1746. 
Según estas mismas fuentes, la fábrica de la iglesia participó en la obra con un total de 9.769 reales, de los cuales, una buena parte se destinó a pagar los honorarios del maestro Baltasar de la Torre ${ }^{754}$. Los vecinos del pueblo, por su parte, participaron, como suele ser habitual, con "la saca de piedra (...)conducción de materiales y otras cosas ${ }^{\prime 755}$.

El resultado nos muestra un edificio sobrio de estructura tipo caja, formada por una única nave de planta rectangular, con techumbre a dos aguas, dentro de la cual quedaba inscrita la cabecera. Al exterior su imagen nos muestra una fábrica de gran solidez, aunque de reducidas proporciones, dibujando una sencilla estructura prismática, elaborada en piedra de sillería, que bien poco se diferencia del resto de las construcciones circundantes. El único elemento que exteriormente denota su condición de edificio religioso lo constituye su fachada principal, orientada hacia poniente. Aquí se abre una puerta con arco de medio punto dispuesto sobre impostas planas con escaso resalte, escoltada, a su vez, por pilastras cajeadas, entre las que se dispone una pequeña cornisa quebrada, que sirve de soporte para una cruz situada en el centro, entre dos pináculos piramidales, colocados sobre los ejes de las pilastras. Esta fachada se remata con una pequeña espadaña, situada sobre el vértice del hastial, compuesta por un solo vano de arco de medio punto, sobre el que se alza una diminuta cruz acompañada por dos pináculos piramidales.

Una obra tardía y de formas sencilla, en la que, dentro de su marcado aire popular, se aprecian ciertos rasgos propios del lenguaje culto, ligados a la arquitectura clasicista. Por lo demás, el elemento más destacable de ella lo constituye es el magnífico trabajo de cantería que podemos apreciar en sus muros.

A parte de estas obras, que podemos considerar de nueva planta, es necesario hablar también de la importante serie de proyectos encaminados a ampliar y renovar

754 AGDBU. LP. Moncalvillo, parroquia de San Pedro, LF. (1760 - 1892). Cuentas del año 1788. Moncalvillo, 16 - enero - 1789. 
parcialmente edificios ya existentes. El objetivo de todos estos proyectos no es otro que intentar engrandecer los templos, para así satisfacer la demanda de mayor espacio. No obstante, también se deben tener en cuenta otras cuestiones tan dispares, como el mero interés por mejorar y modernizar la propia imagen del edificio, o la necesidad de efectuar unas reformas, que se hacían absolutamente necesarias, ante una eventual amenaza de ruina.

Como había sucedido en los siglos anteriores, las empresas de ampliación y remodelación se centraron, tanto en la construcción de nuevas cabeceras, como en la renovación de la zona del cuerpo, con lo cual, podemos hacer una clasificación en función de esta circunstancia. Evidentemente, la mayoría de las obras de este tipo se centraron en la remodelación de la zona de las naves, pues era la forma más fácil y rápida de ampliar el espacio disponible. Sin embargo, también son varios los ejemplos que podemos citar de reestructuración de la zona delantera, propiciando la creación de nuevas cabeceras.

En el segundo caso, las nuevas cabeceras presentan, por lo general, una estructura sencilla, variando bien poco en su diseño con respecto al modelo elaborado durante el siglo XVI. Son espacios amplios de planta cuadrangular y testero plano, cubiertos con sencillas bóvedas de crucería estrellada con terceletes, en las que no suelen faltar algunos nervios combados. Hacia el exterior se muestran como un sencillo volumen de forma cúbica, reforzado en las esquinas con sólidos contrafuertes prismáticos de lados paralelos a los del muro.

El ejemplo más temprano, en el que se representa este tipo de estructura, se encuentra en la iglesia de Santa Eulalia, en Palacios de la Sierra, si bien aquí se trata de un proyecto más ambicioso, ya que se aprovecha el desarrollo de las obras para incrementar el espacio de la iglesia, añadiendo un nuevo tramo a la nave. Los trabajos de construcción se realizan entre los años 1703-04, según trazas del maestro trasmerano

755 Ibídem. 
Baltasar de Pontones ${ }^{756}$, encargándose de su ejecución los maestros de cantería Francisco de la Torre y Francisco de Pontones ${ }^{757}$. La cantidad desembolsada por esta fábrica ascendió a 112.786 reales, o al menos esta es la cifra que suman las distintas partidas entregadas por los responsables de la parroquia. No obstante, suponemos que el precio final debió ser algo superior, pues varios años después esta parroquia todavía continuaba buscando formas alternativas con las que conseguir recaudar fondos para terminar de pagar la obra ${ }^{758}$.

El resultado del proyecto nos depara una cabecera completamente nueva, levantada, sin embargo, por detrás de la anterior, de tal modo, que el ámbito de la antigua capilla mayor se transforma ahora en el espacio previo al altar mayor, alargando así la nave central con un nuevo tramo. Este mismo incremento se repite en la nave de la Epístola, incorporando un nuevo tramo, en el que se levanta la capilla dedicada a San Juan Bautista. Esto, sin embargo, no puede realizarse en el lado contrario, pues, como ya vimos al hablar de las ampliaciones realizadas dentro de este templo en el siglo XVII, la presencia de la torre románica, impedía toda progresión en este sentido.

Toda esta obra se realiza respetando las características tipológicas y proporcionales de la obra ya existente, con lo cual el sentido de horizontalidad, que ya existía en este templo, se ve incrementado de forma importante a partir de ahora. La nueva cabecera, por lo demás, se ajusta perfectamente a las características del modelo descrito anteriormente. Es decir, presenta una estructura de planta cuadrangular con testero plano reforzado hacia el exterior por potentes contrafuertes de estructura

\footnotetext{
756 AGDBU. LP. Palacios de la Sierra, parroquia de Santa Eulalia, LF. (1673 - 1726), (fols. 184v 188). Cuentas del año 1703. Palacios de la Sierra, 7 - abril - 1704.

757 AHPBU. PN. Palacios de la Sierra, leg. 3232/8, fols. 1. Antonio Martín Sanz. Palacios de la Sierra, 20 - enero - 1705.

758 AGDBU. LP. Palacios de la Sierra, parroquia de Santa Eulalia, LF. (1673 - 1726). (fols. 201 - 205). Visita realizada a la parroquia de Santa Eulalia de Palacios de la Sierra en 1706, por D. Blas de Tobalina, canónigo de la catedral de Osma. Palacios de la Sierra, 12 - abril - 1706. Ibídem. Visita realizada a la parroquia de Santa Eulalia de Palacios de la Sierra en 1710, por D. Tomás Manuel García de Aguilar. Palacios de la Sierra, 27 - mayo - 1710.
} 


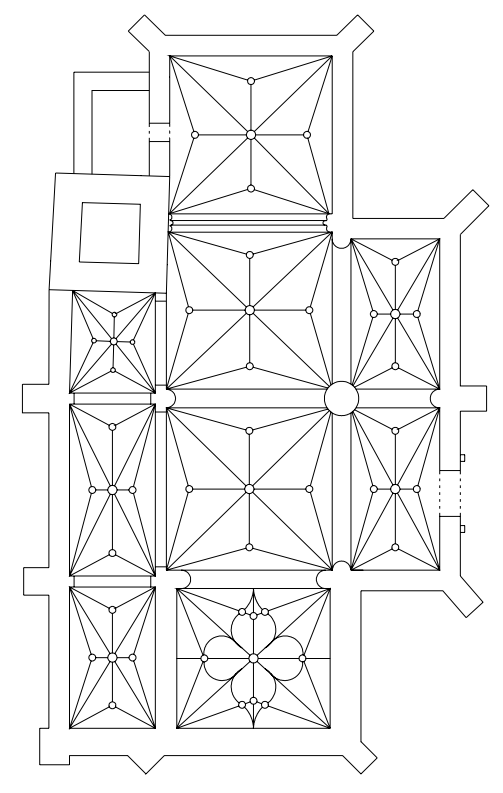

a)

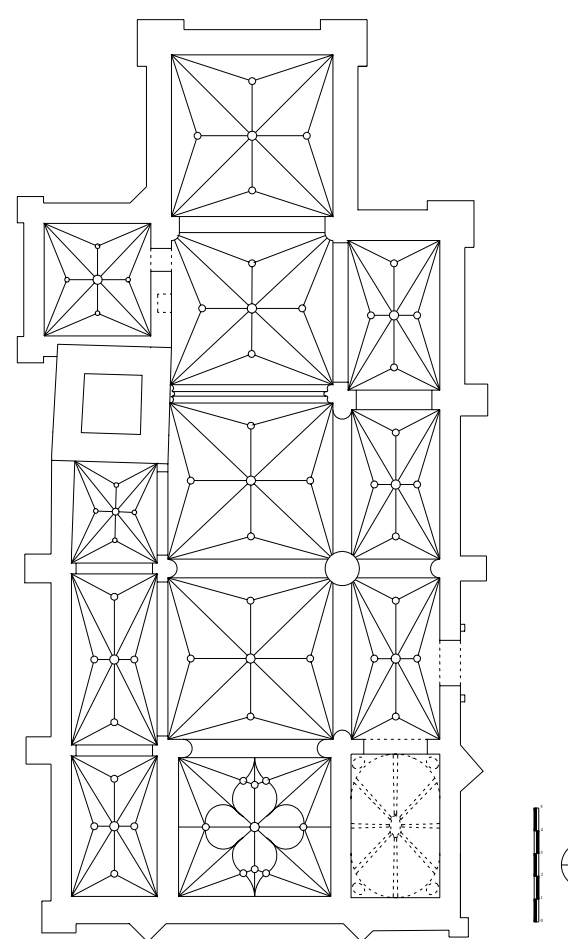

b)

PALACIOS DE LA SIERRA. Iglesia de Santa Eulalia: a) templo siglo XVII; b) templo siglo XVIII.

prismática, dispuestos con sus lados en paralelo con respecto a los lados del muro. Con esta estructura, por lo demás, se dibuja una imagen exterior concebida mediante cuerpos cúbicos, dispuestos como una mera continuación del edificio anterior.

En el interior, los nuevos espacios creados se cubren con sencillas bóvedas de crucería estrelladas con terceletes, que manifiesta, igualmente, un auténtico afán integrador con respecto a la estructura anterior. Esta misma intención se manifiesta en los arcos, los cuales se adecuan a las necesidades constructivas del edificio, tal y como ocurría en las tipologías de templos de tres naves del siglo XVI. Así, se emplean arcos de medio punto para los espacios más anchos, como el toral de la capilla mayor y el lateral de la nave de la Epístola, y apuntados, para ganar altura, en los espacios más 


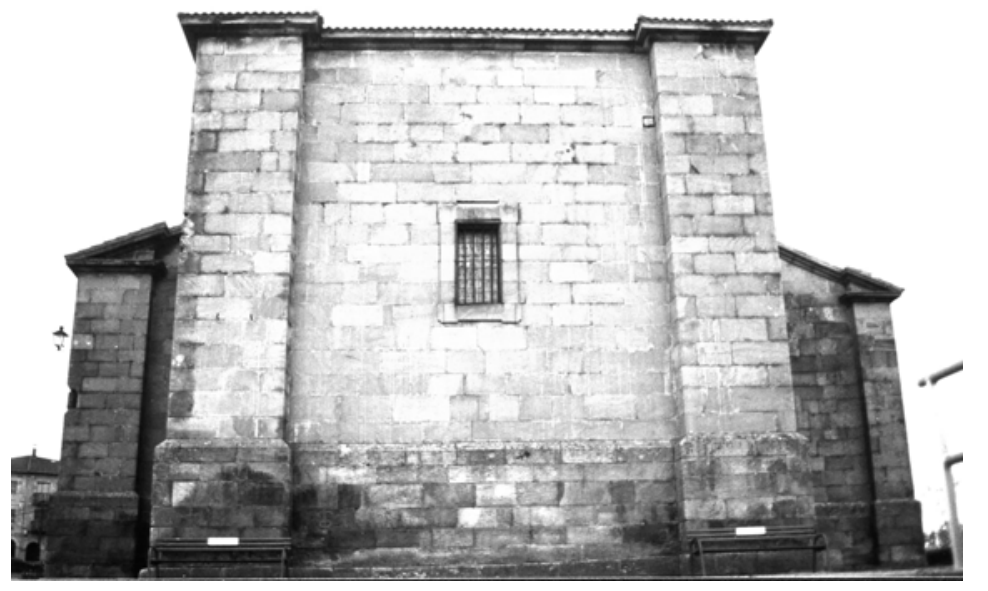

PALACIOS DE LA SIERRA. Cabecera de lnirlonin dn Conto Eulnlin

estrechos, como es el caso del fajón del nuevo tramo de la nave de la Epístola. Todos ellos presentan sección cuadrada con intradós plano decorado con un leve cajeado. Los soportes sobre los que descansan están formados por pilastras de orden toscano y fuste cajeado, que en el caso de la nave lateral, se adosan a los frentes del nuevo pilar exento, que surge en este punto.

Al exterior la integración también es completa, de tal modo, que la incorporación de la cabecera y los nuevos tramos ahora añadidos, se manifiesta como una mera prolongación hacia delante de la estructura anterior, respetando sus proporciones y su misma técnica constructiva. Las únicas novedades aparecen en los estribos, que refuerzan cada una de las esquinas, y en los vanos abiertos sobre el muro meridional y del testero de la capilla mayor. Los estribos están formados por una sólida estructura prismática de lados paralelos a los muros, y no en diagonal, como en el período gótico. Los ventanales, por su parte, son adintelados, mostrando el característico marco de moldura planta de escaso resalte con orejones. Dentro de ellos, 
destaca especialmente el situado sobre el muro del testero de la capilla mayor, pues se hace coincidir con el nicho central del retablo de este altar, para crear, con ello, un curioso efecto de transparente, como el que ya vimos en el siglo XVII en la ermita de Nuestra Señora de la Guía, en Quintanar de la Sierra. No obstante, el elemento que más nos llama la atención, dentro de la imagen exterior, que proyecta esta nueva construcción, lo encontramos en el remate del muro frontal de la nave lateral. Aquí se incorpora lo que parece ser el vértice lateral de un frontón recto partido, el cual se corresponde con el situado en el lado contrario, sobre el muro frontal de la sacristía, que se construye años más tarde. Con ello se consigue, que la estructura cúbica, que forma la cabecera, aparezca enmarcada mediante este gran frontón partido, desarrollando con ello una sencilla, pero original, solución ${ }^{759}$, que debemos relacionar directamente con la influencia que la arquitectura palladiana deja en el área castellana, a través del foco clasicista vallisoletano ${ }^{760}$. Sin embargo, para que esta imagen terminara de formarse, debieron pasar 30 años, pues, como veremos más adelante, hasta 1734 no se construye la sacristía.

Sin ningún género de dudas, esta obra de Santa Eulalia de Palacios de la Sierra fue el modelo que sirvió de inspiración para la construcción de la cabecera, que en 1732, se realiza en la vecina localidad de Moncalvillo. La iglesia de San Pedro, de esta localidad, había iniciado a comienzos de este siglo XVIII, un plan renovador, que se puso en marcha con la ampliación del espacio de la nave, absorbiendo el ámbito de su antiguo pórtico, construido en la centuria anterior, para crear en su lugar una pequeña nave lateral. Sin embargo, la empresa más importante, que acomete esta parroquia durante el siglo, y con la cual se consigue fijar la imagen definitiva del templo, es la renovación de su cabecera. La obra se completa, como decimos, en 1732, según reza la inscripción conservada sobre el muro del testero, y confirman sus libros de fábrica.

\footnotetext{
759 Esta imagen podemos relacionarla, por ejemplo, con la proyectada por la fachada principal del templo de San Ambrosio de Valladolid, en la cual, sobre los cuerpos de las naves laterales se extiende un amplio frontón recto, interrumpido en su parte central, para dar cabida al cuerpo superior de la portada 760 A. BUSTAMENTE GARCÍA: “En torno al clasicismo: Paladio en Valladolid”. En AEA n ${ }^{\circ}$ LII (205), 1979. (pp. $34-54)$.
} 
MONCALVILLO. Cabecera de la iglesia de San Pedro.

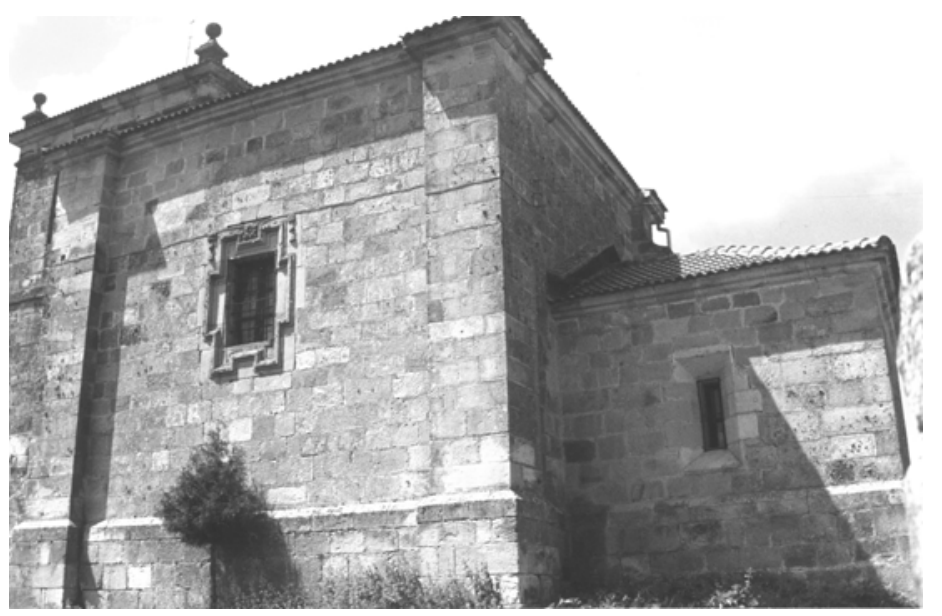

Desconocemos, en este caso, los nombres de los artífices, que participaron en su construcción, sin embargo, sabemos que la parroquia tuvo que desembolsar una cantidad próxima a los 10.000 reales; 8.700 reales para el maestro y el resto en materiales $^{761}$. Para poder afrontar el duro esfuerzo económico, la parroquia tuvo que valerse de la ayuda de un censo ${ }^{762}$.

El resultado, como decimos, es una obra muy parecida a la anterior de Palacios, si bien, en este caso, no parece que exista un condicionante tan fuerte, por parte de la estructura de la nave, a la que debe acoplarse. Presenta, por lo demás, el mismo aspecto de bloque cúbico de muros de piedra de sillería, reforzados en las esquinas por potentes contrafuertes de forma prismática. Cuenta con dos ventanales, situados en el muro del testero y el lado del mediodía. De ellos llama especialmente la atención el primero, ya que cuenta con un recercado, formado por una doble moldura quebrada, en cuyos lados cuelgan unas pequeñas ramas de frutas. Se trata de una ligera concesión al campo de la ornamentación, propia del mundo barroco, muy poco frecuente dentro de la arquitectura

\footnotetext{
761 AGDBU. LP. Moncalvillo, parroquia de San Pedro, LF. (1715 - 1759). Cuentas del año 1732. Moncalvillo, 8 - marzo - 1733.

762 Ibídem. Cuentas del año 1733. Moncalvillo, 15 - marzo - 1734; Ibídem. Cuentas del año 1734. Moncalvillo, 15 - abril - 1735.
} 
de esta comarca. Un rasgo mínimo pero, en definitiva, de gran valor significativo desde el punto de vista formal. Con este ventanal, además se consigue crear el mismo efecto de transparente sobre el nicho central del retablo del altar mayor, que vimos en el caso anterior.

En el interior, la única variante con respecto al ejemplo de Palacios, la encontramos en la cubierta, cuya bóveda de crucería estrellada con terceletes incorpora una serie de nervios combados, con los que se forma el círculo en forma de ondas dispuestas en torno a la clave central, que son tan habituales en la comarca a lo largo del siglo XVIII. Por lo demás, el concepto espacial resultante no sufre ningún tipo de variación.

Otro templo, que renueva su cabecera en este momento, lo tenemos en la parroquial de Barbadillo del Pez, si bien, apenas contamos con fuentes que nos informen sobre las circunstancias que rodearon la obra, y los detalles concretos de su realización. Aun así, sabemos que su construcción se completó en 1724, pues así lo indica la inscripción conservada sobre una de las claves de su bóveda.

La obra resultante, sin embargo, apenas debía mostrar diferencias importantes en su aspecto y volumetría, con respecto a la cabecera anterior, construida en el siglo XVI por Juan de la Puente. De este modo, vemos que se mantiene el mismo arco toral, que antes existía, con lo que su altura sigue siendo la de antes. Suponemos que esto mismo sucede con la planta sobre la que se alza, y con el concepto de espacio desarrollado en su interior, conservando el espacio cuadrangular con testero plano y cubierta formada por bóveda estrellada de crucería con terceletes y cinco claves, similar a las que existen en las naves. Al exterior, la única diferencia se encuentra en sus estribos, en los cuales se sustituye la disposición en diagonal, característica del siglo XVI, por la propia de este nuevo momento, con forma prismática y los lados en paralelo a los del muro. 
Todo ello nos lleva a pensar, que las causas que pudieron motivar su renovación no deben encontrarse en un interés por remodelar este espacio, sino en la necesidad propiciada por el mal estado de la anterior. Esto explicaría el hecho de que se mantenga la misma estructura, sin introducir modificación alguna, ni en su disposición, ni en sus proporciones.

Una mención especial, dentro de este apartado, dedicado a la renovación de cabeceras de templos, se merece la obra realizada en la iglesia de San Martín en Vilviestre del Pinar, pues es, sin duda, la más interesante y espectacular de cuantas aquí se acometen. En esta iglesia, a mediados del siglo XVIII, y posiblemente a partir de la iniciativa del propio cura de la misma, D. Pedro Campo Cuesta, se decide renovar por completo toda la parte delantera del templo, levantando en su lugar una estructura, que bien poco tiene que ver con la obra anterior, o con el resto del templo junto al que va adosada. Una estructura, que, por lo demás, resulta absolutamente novedosa dentro del panorama arquitectónico de la comarca, pues no existe aquí ningún otro ejemplo parecido. El proyecto se termina en 1761, según reza la inscripción, que recorre la parte exterior del brazo meridional del crucero, en la cual se recoge también el nombre del párroco, como impulsor del proyecto. No obstante, los preparativos de la obra habían comenzado ya unos años antes. Así, en 1756, el visitador del Obispado de Osma, D. Juan Fernández Arcos, ordena al cura y mayordomos, que de forma inmediata procedieran a recuperar todas aquellas deudas contraidas con la parroquia, para que “con la maior brevedad se execute la capilla mayor y crucero...,"763.

Este mismo año se produce la visita a la iglesia del maestro de cantería, Domingo de Ondátigui, el cual vino “a ver y tratar de la obra de la capilla de la iglesia, llamado por ella"764. Esto, evidentemente, no quiere decir que este maestro fuera el

\footnotetext{
763 A. P. Vilviestre del Pinar, LP, parroquia de San Martín, LF. (1755 y ss.), (fols. 10 v $^{0}-20$ vo). Visita realizada a la parroquia de San Martín en Vilviestre del Pinar en 1756, por D. Juan Fernández Arcos. Vilviestre del Pinar, 20 - agosto - 1756.

764 Ibídem. (fols. $23-26$ v ). Cuentas del año 1756. Vilviestre del Pinar, 8 - febrero - 1757.
} 
encargado final de llevar a cabo el proyecto, si bien es más que probable, que al menos las trazas, puedan ser atribuidas a él, sin ningún genero de dudas.

El resultado final nos ofrece una estructura formada por un amplio crucero de brazos poco salientes en planta pero de gran anchura, el cual antecede a una capilla mayor, de estructura poco profunda, con testero poligonal, precedida por un pequeño presbiterio de tramo rectangular. Todo esto se completa con una pequeña sacristía, ubicada sobre el ángulo formado por el presbiterio y el brazo meridional del crucero, la cual está articulada en dos tramos, separados por un arco fajón.

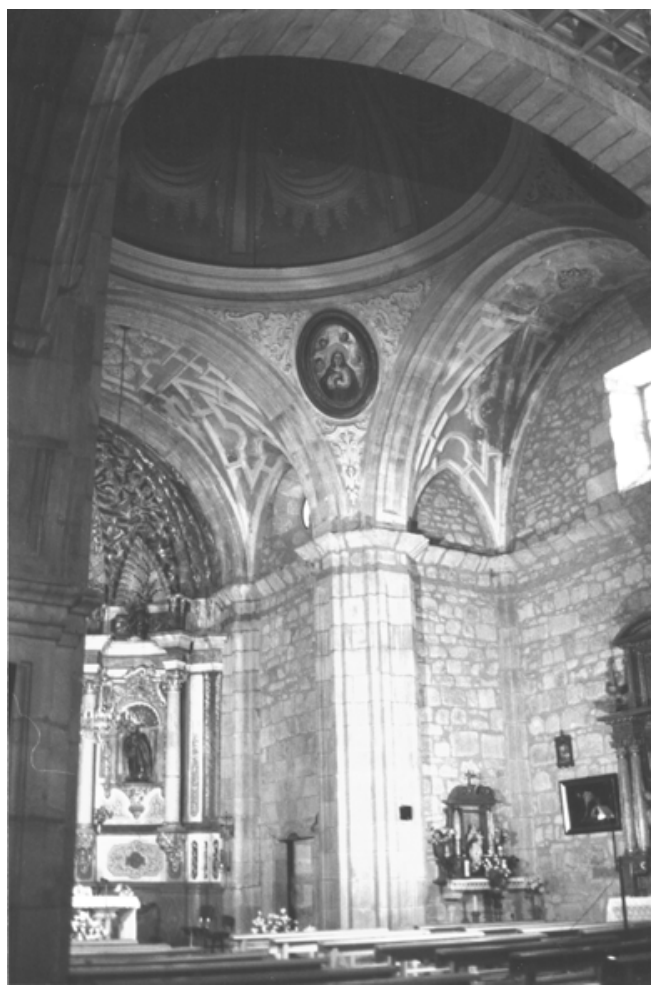

VILVIESTRE DEL PINAR. Iglesia

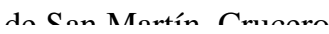

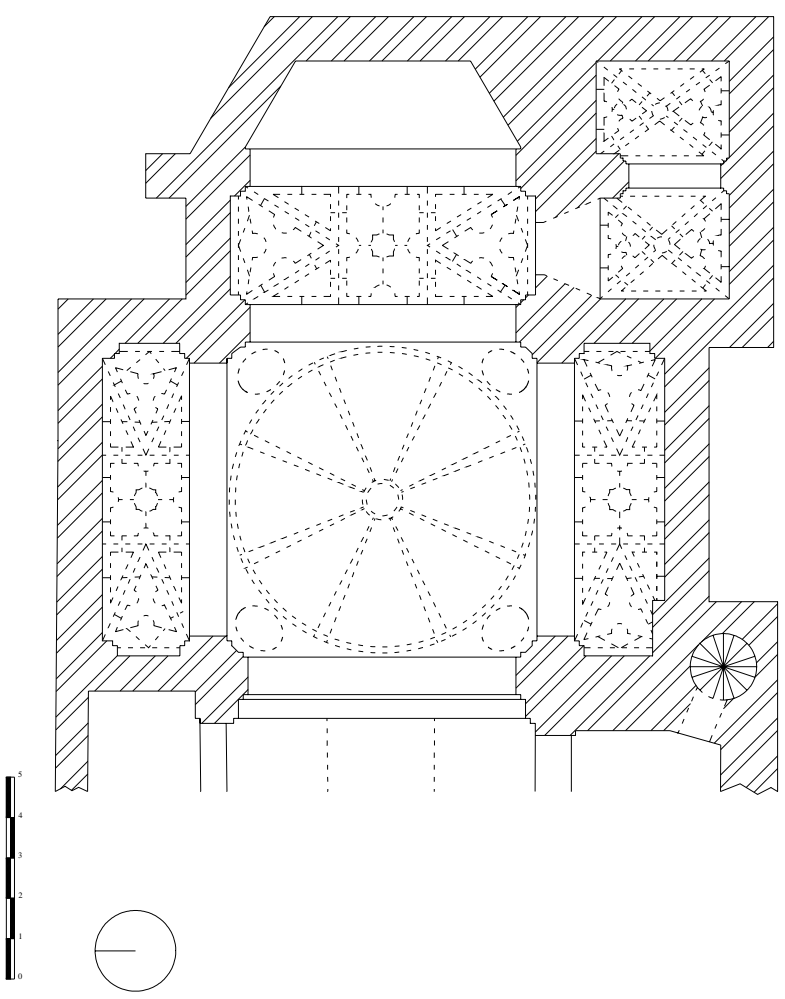

VILVIESTRE DEL PÌNAR. Iglesia de Con MAnutín Dlontn dal nmonomo 
Sin duda, el elemento más desatacado de toda la obra lo constituye la gran cúpula, con la que se cubre el espacio central del crucero. Se trata de una cúpula de media naranja alzada sobre pechinas y anillo muy moldurado, que cuenta con una superficie interna dividida en ocho paños, separados por fajas cajeadas, que confluyen en un gran florón central. Cada uno de estos paños se cubre con abundante decoración de carácter naturalista no muy abultada, que se extiende a las pechinas, donde se incorporan cuatro grandes tondos. Los brazos del crucero y el presbiterio, por su parte, se cubren con pequeños tramos de bóveda de cañón con lunetos, cuya superficie se decora con placas geométricas de perfil mixtilíneo, realizadas en escayola. El tránsito entre cada uno de estos espacios y el crucero se realiza mediante amplios arcos doblados de medio punto e intradós cajeado, los cuales descansan sobre las esquinas de perfil achaflanado del crucero, a través de pilastras y retropilastras de fuste cajeado y voladas cornisas, que se extienden a lo largo del muro, marcando la separación con el espacio de las cubiertas.

Con todo esto se dibuja un concepto espacial de claro ámbito único, dominado por el amplio espacio central, cuya cúpula introduce un evidente sentido ascensional, que se convierte en el contrapunto ideal a la excesiva horizontalidad, que manifiesta la zona del cuerpo. Los brazos del crucero especialmente cortos, por una parte, y la escasa profundidad de la capilla mayor, por otra, contribuyen de modo definitivo a que este concepto de espacio único se desarrolle con total claridad.

Al exterior la nueva obra se muestra como una suma de volúmenes bien perfilados, dispuestos de forma escalonada, que van descendiendo desde la pieza que conforma el centro del crucero, hasta el cuerpo correspondiente a la sacristía. Dentro de la desnudez y planitud de los muros, sin embargo, destaca el recercado de algunos vanos, orientados en todos los casos hacia el mediodía, entre los cuales nos llama particularmente la atención el situado sobre el extremo del brazo meridional del crucero, y los dos de la sacristía. Estos dos últimos presentan un marco formado por una gruesa moldura de medio bocel de perfil quebrado y marcados orejones en los ángulos. La 


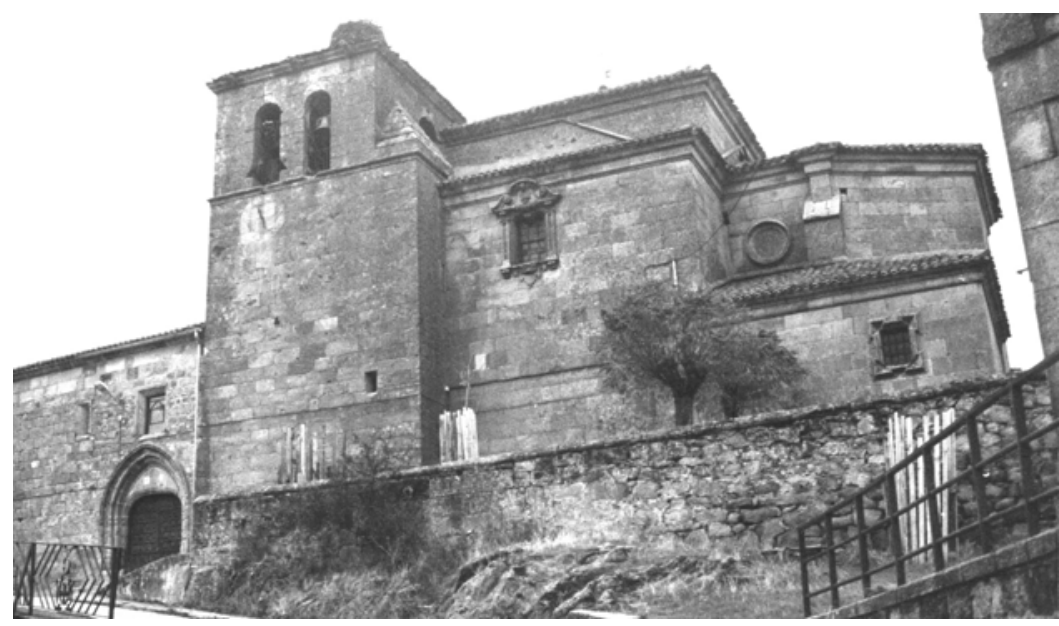

VILVIESTRE DEL PINAR.

Iglesia de San Martín. Cabecera.

ventana del crucero, por su parte, nos ofrece un vano adintelado, escoltado por pilastras cajeadas y rematado por un frontón semicircular partido de perfil avolutado, el cual descansa sobre ménsulas igualmente avolutadas, dispuestas a cada lado, en correspondencia con los ejes de las pilastras. Dentro del tímpano del frontón aparece representada la cabeza de un pequeño ángel, dispuesta sobre una decoración de placas, la cual se repite igualmente en la parte del alfeizar.

Toda la obra se encuentra realizada en piedra, con muros de sillería, en los que se manifiesta un perfecto trabajo de cantería. No obstante, hacia el interior el paramento de estos muros presenta una sencilla labor de sillarejo y mampostería, que originalmente se hallaba convenientemente enlucida. Se mantiene la sillería, sin embargo, para aquellas piezas consideradas como elementos activos del edificio, como es el caso de las pilastras y los arcos torales.

Una obra, en definitiva, de neto sabor barroco, en la cual, junto al desarrollo de un tipo de estructura poco corriente en la zona, se une el protagonismo de unos elementos ornamentales, que rara vez hemos visto representados dentro del clasicismo 
dominante en esta arquitectura, desde principios del siglo XVII. Aún con todo, también aquí se manifiesta uno de los rasgos comunes a todas estas construcciones emprendidas en la zona durante la centuria, como es el caso del concepto espacial de ámbito único, desarrollado en torno a la zona del crucero.

Y sin salir de esta localidad, cerramos la relación de nuevas cabeceras, con el ejemplo que encontramos en la ermita de Nuestra Señora del Torrejón. Este análisis no contamos con ningún testimonio documental, que nos informe sobre su construcción, con lo cual, como nos ocurre en tantos otros casos, es el propio análisis formal el que nos da la confirmación definitiva. Así, vemos cómo se repite, de forma casi mimética, el tipo de estructura, que acabamos de ver en los casos de Palacios de la Sierra y Moncalvillo. Su estructura está formada por un sólido cubo, alzado sobre planta cuadrangular, con muros de sillería, elaborados mediante una cuidada labor de cantería, reforzados en las esquinas por estribos de forma prismática, y rematados por un friso corrido, al que sigue una doble moldura de codillo y cuarto de bocel. En el interior, presenta un robusto arco de medio punto, de sección cuadrada e intradós cajeado, que descansa sobre pilastras de orden toscano y fuste igualmente cajeado. Tras este arco se accede a un espacio cubierto con bóveda de crucería estrellada con terceletes y nervios combados, con los que se forma un círculo en torno a la clave polar, que nos recuerda algunos modelos del Quinientos.

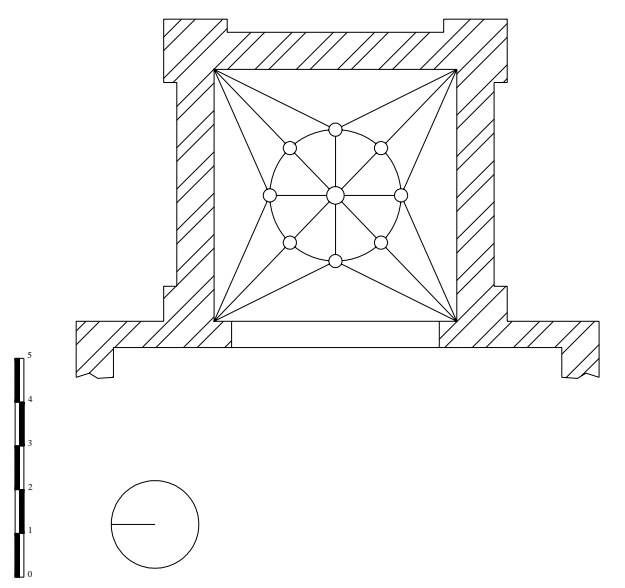

VILVIESTRE DEL PINAR. Cabecera de la ermita de Nuestra Señora del Torrejón. Planta. 
Con estos rasgos, y a falta de otras fuentes, que nos proporcionen información complementaria, debemos suponer que su construcción se sitúa en torno al segundo cuarto de este siglo XVIII, pues el tipo de estructura empleada, y los elementos que en ella se incluyen, así parecen indicarlo. No obstante, este arco temporal puede ser mucho más amplio, pues como sabemos, el proceso de ruralización, que aquí sufren las formas artísticas de los distintos estilos, hace que los modelos empleados tiendan a perpetuarse en el tiempo, desarrollándose fuera de su espacio cronológico habitual.

Mucho más frecuentes que las actuaciones sobre la zona de la cabecera, son las llevadas a cabo sobre el cuerpo, pues como ya ocurriera en los siglos anteriores, éste era el método más rápido y económico de conseguir agrandar un templo, sin causar graves perjuicios al resto de la fábrica. Estas actuaciones consistían principalmente en alargar o ensanchar el espacio disponible, amoldándose en la medida de lo posible a las características y proporciones que poseía el edificio anterior. No obstante, en este momento, son más los casos en los que se decide renovar por completo toda la zona de la nave, antes que emprender la reparación de la estructura antigua.

Un primer caso, aunque muy sencillo, de ampliación de la zona del cuerpo, lo mencionábamos al hablar de la iglesia de San Pedro, en Moncalvillo. En este templo, como ya hemos dicho, se decide ampliar el espacio existente, mediante la creación de una segunda nave, para lo que se aprovechan los arcos de un antiguo pórtico, que adquieren ahora la función de arcos formeros. Junto con esta obra, se construye también una pequeña portada sobre el muro meridional de la nave recién creada, con la cual se enmarca el único acceso al interior. Consta de un vano central, coronado con arco de medio punto de rosca cajeada, el cual descansa sobre pilastras, igualmente cajeadas, alzadas sobre un pequeño plinto y coronadas con una sencilla imposta plana. Dos pilastras, también cajeadas, de orden toscano escoltan esta puerta, sobre las cuales se extiende un sencillo entablamento con el que se remata todo el conjunto. Una obra, como decimos, sencilla, dentro de la cual, y a pesar de su extrema simplificación, 
consiguen mostrarse algunos rasgos propios de la estética clasicista, heredada de la centuria anterior.

Toda la obra se realizó en torno al año 1704, con un coste para la fábrica de 1.200 reales $^{765}$. Respecto a los artífices, en ninguna parte de la documentación conservada se mencionan sus nombres, si bien debemos suponer que se trataba de maestros locales, ya que la obra no plantea ningún problema importante, desde el punto de vista técnico.

Otro ejemplo interesante se produce en la iglesia de Santa Cecilia, en Salas de los Infantes. Como tuvimos oportunidad de ver en su momento, la fábrica, que esta iglesia había heredado del siglo XVI, era una estructura irregular, con planta de dos naves, originada a partir de una cruz griega, que dejaba el tramo, que componía el brazo septentrional del crucero, como un espacio aislado. Por eso, durante el siglo XVIII, aunque en un momento difícil de precisar, se procede a completar el rectángulo en el que se inscribe toda la zona del cuerpo, añadiendo dos nuevos tramos en la parte septentrional, para formar aquí una nave, similar a la que ya existía en el flanco meridional, con el baptisterio a los pies.

Al exterior, esta incorporación propicia la consecución del aspecto definitivo del templo, conformando un gran prisma de trazado prácticamente cuadrangular y escaso desarrollo en altura, al cual se incorpora en la parte delantera el cubo de menor anchura, que forma la cabecera.

En el interior, la incorporación de la nueva nave supone la unificación de todo el espacio del cuerpo, con lo que rompe definitivamente la compartimentación, que anteriormente existía. Todo esto se realiza además con un gran respeto por las formas y proporciones empleadas en la fábrica anterior. Así, la cubierta del nuevo espacio sigue

\footnotetext{
765 AGDBU. LP. Moncalvillo, parroquia de San Pedro, LF.(1644 - 1714). Cuentas del año 1704. Moncalvillo, 4 - marzo - 1705.
} 
siendo la bóveda de crucería estrellada con terceletes y cinco claves, que se usa en la fase gótica. No ocurre lo mismo, sin embargo, con los elementos sustentantes, donde se recurre a arcos de medio punto de sección cuadrada e intradós cajeado, apeados sobre pilastras de orden toscano y fuste igualmente cajeado. Los arcos fajones adquieren además un perfil ligeramente peraltado, con el fin de incrementar la altura de la nave, hasta igualarla con la del lado meridional.

Se trata, en definitiva, de una obra funcional de escasas complicaciones técnicas y compositivas, en la cual, a falta de fuentes documentales precisas, que nos informen sobre su proceso constructivo y su cronología, debe ser el propio análisis formal el que nos proporcione esta información. Así, en virtud de esto, y dadas las analogías que muestra con otras obras pertenecientes a este mismo siglo XVIII, podemos situar su realización en torno a las primeras décadas de la centuria.

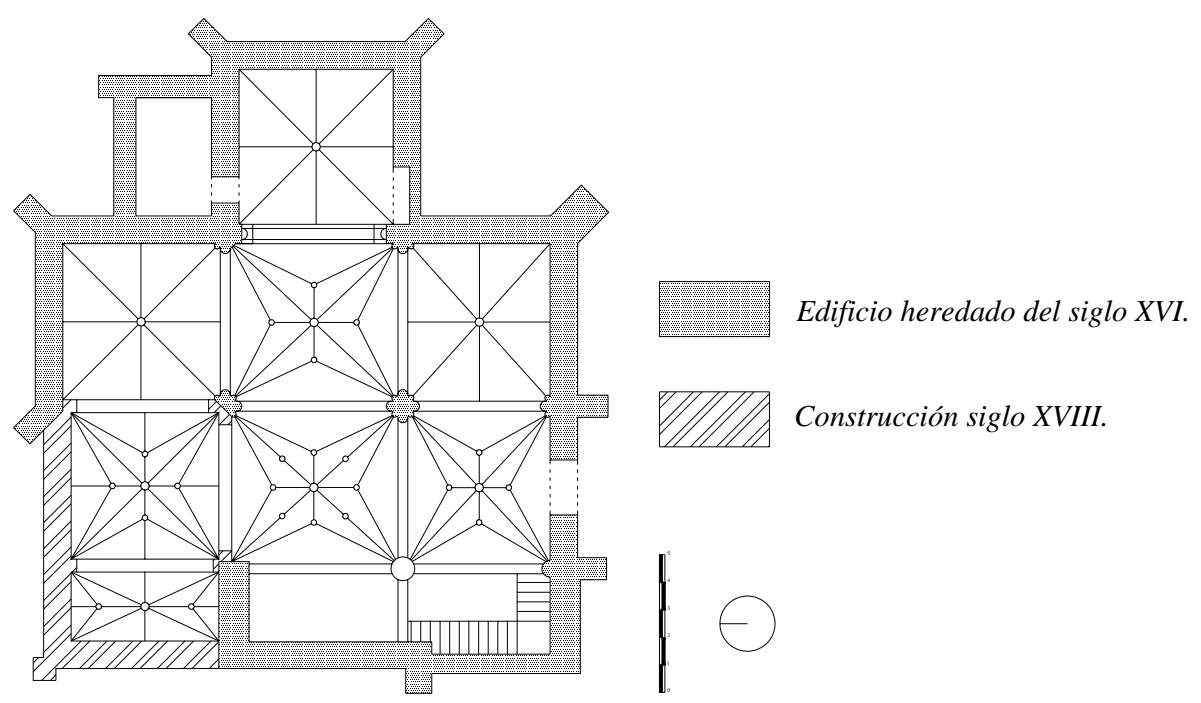

SALAS DE LOS INFANTES. Iglesia de Santa Cecilia. 
Al margen de estas actuaciones, el tipo de obra más común, dentro de estos proyectos, encaminados a remodelar o ampliar el espacio del cuerpo, era el consistente en renovar por completo la zona, construyendo en su lugar un cuerpo completamente nuevo. En este caso, lo más habitual fue levantar amplias estructuras de una sola nave de planta rectangular, articulada en diferentes tramos (por lo general dos o tres), que se cubren con bóvedas de crucería estrellada con terceletes. Al exterior esto se traduce en una recia estructura de tipo caja, formada por un gran prisma de marcado sentido horizontal, de muros completamente planos, reforzados en las esquinas y lados mayores con estribos de escaso resalte. En el interior, por su parte, esta estructura permite crear amplios y desahogados espacios de ámbito único, dentro de los cuales se dibuja una estructura longitudinal, desarrollada en torno al eje central, que conduce al altar mayor.

Un primer ejemplo de este tipo de estructura lo tenemos en la iglesia de Nuestra Señora de la Visitación en Barbadillo de Herreros. Desconocemos los motivos concretos, que pudieron llevar a emprender una obra de este tipo, si bien, sospechamos que pudo ser debido al mal estado de conservación en el que se hallaba la fábrica, causado por las constantes humedades a las que se veía sometida. Lo que no parece probable, sin embargo, es que se trate de cuestiones relacionadas con la falta de capacidad del templo, pues los muros laterales, levantados durante el siglo XVI, son respetados en su mayor parte, con lo que apenas se produce un aumento significativo de las dimensiones de la planta.

Este primer proceso de renovación se desarrolla a lo largo de dos fases distintas, que tienen lugar entre los años 1728-1734. El largo período de obras hace que el templo quede durante un tiempo impracticable para el culto, lo que obliga al Visitador del Arzobispado de Burgos a ordenar el traslado del Santísimo Sacramento a la ermita de Nuestra Señora de Costana, donde se continúa el desarrollo normal de los oficios ${ }^{766}$.

766 C. RUBIO VELASCO: Barbadillo de Herreros. Burgos, Imprenta Santos S.L, 2001. (pp. 194 - 196). 
Los trabajos se ponen en marcha, como decimos, en 1728, si bien, desde dos años antes se venía embargando el producto de las Tercias Reales, correspondientes a los diezmos, que en este pueblo, como en la mayoría de los de la zona, percibían los Duques de Frías. Con ello se pretendía obtener el dinero suficiente para sufragar las obras. El encargado de realizar la primera parte del proyecto fue el maestro de cantería Sebastián de Foncea, el cual, poco tiempo antes, había trabajado en las reparaciones, que se habían hecho en la capilla mayor de esta misma iglesia ${ }^{767}$. Su trabajo, sin embargo, apenas modificó la estructura del templo, pues simplemente se encargó de remodelar los muros correspondientes a la zona de la nave, cubriendo este espacio con una sencilla techumbre de madera.

Esta primera fase renovadora se culmina poco tiempo después, entre los años 1733-34 con la construcción de las cubiertas abovedadas. El encargado de realizar estos trabajos fue el maestro de cantería trasmerano Bernardo de la Torre Barquero, el cual se hizo con el remate del proyecto con una postura de 10.980 reales $^{768}$. Las trazas para la obra correspondieron al maestro Diego Barquirero.

Como resultado de esta intervención surge una estructura en la que se reproducen fielmente los rasgos descritos en el modelo general. Presenta una planta de nave única articulada en dos tramos, los cuales se cubren con bóveda de crucería estrellada con terceletes y nervios combados, con los que se forma la habitual estructura de ondas en torno a la clave polar. Se trata, al mismo tiempo, de bóvedas de rampante prácticamente llana. Estos tramos se encuentran separados por un amplio arco fajón de medio punto de sección cuadrada e intradós cajeado, que descansa sobre pilastras adosadas al muro, de orden dórico y fuste igualmente cajeado, elaborado todo ello en sillería, mientras que los muros presentan un simple paramento de sillarejo y mampostería. De esta forma, el concepto de espacio, que aquí vemos, es el propio de

\footnotetext{
767 AHPBU. PN. Valle de Valdelaguna. Leg. 9802/1, fols. 114 - 114 v $^{0}$. Manuel Gil de la Cuesta. Bezares, 15 - julio - 1728 .
} 


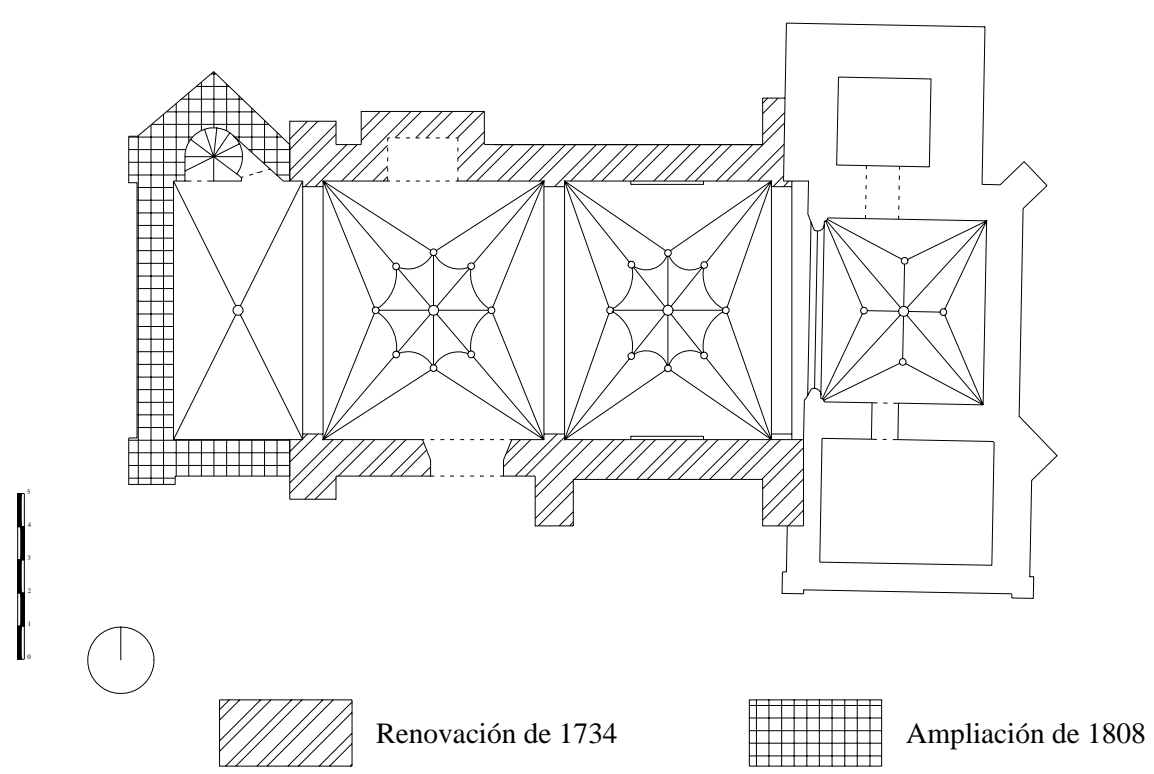

BARBADILLO DE HERREROS. Iglesia de Nuestra Señora de la Visitación. Fases de ampliación.

este tipo de construcciones, con una marcada tendencia hacia el ámbito único, dentro de la cual se define con claridad un sentido longitudinal.

$\mathrm{Al}$ exterior presenta la característica estructura de tipo caja, con muros de sillería completamente planos, articulados mediante estribos, que refuerzan sus esquinas y lados mayores. La adaptación de la nueva estructura al módulo, que constituye la antigua cabecera, se produce sin ningún tipo de brusquedad, lo que hace que la imagen exterior de este templo aparezca como un bloque compacto y homogéneo, presidido por un claro sentido de horizontalidad. Los materiales empleados en la construcción, por su parte, fueron aprovechados, en su mayoría, de la propia fábrica de la iglesia, a los que se

768 AHPBU. PN. Valle de Valdelaguna. Leg. 9802/2, fols. 59 - 61. Manuel Gil de la Cuesta. Barbadillo de Herreros, 18 - octubre - 1733. 
suman también los procedentes de las ermitas de San Juan y San Torcuato, existentes en esta localidad, y que fueron demolidas para tal fin, dado el avanzado estado de ruina que presentaban.

Pero ésta no fue la última intervención de este tipo, que sufre el edificio. Así, años más tarde, en los primeros momentos del siglo XIX, se realiza una nueva ampliación en esta zona de la iglesia, consistente en la incorporación de un nuevo tramo en la parte de los pies. Se trata de un tramo algo más corto que los dos anteriores, si bien dentro de él se siguen las mismas características y proporciones que desarrolla en la obra anterior. La única variante la encontramos en la cubierta, pues en este caso se recurre a una simple bóveda de crucería cuatripartita, sin terceletes, ni nervios combados.

Las obras de esta segunda ampliación se iniciaron en 1806, concluyéndose dos años más tarde, según reza la inscripción colocada sobre la bóveda, que cubre el nuevo espacio, y certifican las fuentes documentales. Según estas mismas fuentes sabemos, que el encargado de realizar los trabajos fue el maestro de cantería Simón de la Gándara, el cual percibió de esta fábrica un total de 21.000 reales $^{769}$. Unos años más tarde, en 1814, este mismo maestro se encarga de construir el coro, ubicado dentro de este último tramo, el cual se levanta sobre un potente arco escarzano, dispuesto entre las pilastras, que delimitan el tramo final, sobre el cual se asienta el entramado de madera que forma el suelo. Se trata, por lo tanto, de una sencilla estructura mixta, de piedra y madera, en la que se repite el modelo tradicional, que nos venimos encontrando desde el siglo XVI. La cantidad que percibe, en esta ocasión, llega hasta los 7.500 reales, a lo que hay que sumar los gastos de los materiales empleados ${ }^{770}$.

Otro ejemplo de este tipo de renovación lo tenemos en la iglesia de Santa Coloma, en Riocavado de la Sierra. En este caso, las causas que llevaron a tomar esta

\footnotetext{
769 A. P. Barbadillo de Herreros, LP, Barbadillo de Herreros, parroquia de Nuestra Señora de la
} Visitación, LF. (1749 - 1838). Cuentas del año 1809. Barbadillo de Herreros, 20 - octubre - 1809. 
decisión parecen bastante claras, pues según venían informando diferentes visitadores del Arzobispado de Burgos desde las primeras décadas del siglo, el templo, y en concreto su nave, se hallaba en un estado deplorable, lo que imposibilitaba el desarrollo del culto $^{771}$. Para llegar a esta situación habían contribuido fundamentalmente dos factores. Primero, la falta de mantenimiento, justificado, por los responsables de la parroquia por lo limitado de sus recursos. Y en segundo lugar, la costumbre de inhumar los cuerpos de los difuntos en el interior del templo, lo que resultaba particularmente difícil en este caso, por la escasa profundidad del suelo, quedando enterrados, la mayor parte de las veces, de forma inadecuada.

Pero las obras de renovación no se pusieron en marcha hasta el momento en el que el templo fue declarado literalmente en ruina, lo cual ocurrió en 1744, tras la visita de D. Diego Escalona, canónigo de la catedral de Burgos. Este visitador obligó, al mismo tiempo, a trasladar el Santísimo Sacramento a la ermita de Santiago, situada dentro del propio pueblo, pues resultaba totalmente imposible continuar el culto en el interior del templo parroquial.

Las obras de renovación comenzaron entonces de forma inmediata, fijando como fecha de conclusión el primer día del mes de septiembre del año siguiente de 1745. Las trazas y condiciones para la obra fueron encargadas al maestro de cantería Juan de Maurtúa, el cual finalmente consiguió hacerse con el contrato para su ejecución, con una postura de 9.500 reales $^{772}$. A través del pliego de condiciones, podemos comprobar también cómo se aprovecharon las obras para acometer una completa reparación del resto del templo, actuando sobre la torre, la cabecera y la sacristía ${ }^{773}$.

770 Ibídem. Cuentas del año 1814. Barbadillo de Herreros, 14 - octubre - 1815.

771 AGDBU. LP. Riocavado de la Sierra, parroquia de Santa Coloma, LF. (1705 - 1734). Visita realizada a la parroquia de Santa Coloma en Riocavado de la Sierra en 1726, por D. Andrés Fernández de Tejada. Barbadillo de Herreros, 12 - septiembre - 1726.

772 AHPBU. PN. Valle de Valdelaguna. Leg. 9803/2, fols. 73 - 77 vº Manuel Gil de la Cuesta. Riocavado de la Sierra, 3 - septiembre - 1744. 
Los trabajos de carpintería, por su parte, fueron encargados al maestro Juan de Arrieta, el cual, además de ejecutar toda la parte correspondiente a su arte, dentro de la nueva nave, llevó a cabo también una completa remodelación de las partes de madera situadas en el resto del templo. Esto hizo que el presupuesto de su intervención en este proyecto se elevara hasta los 6.660 reales $^{774}$.

Como resultado de ello surge un cuerpo completamente nuevo, el cual se ajusta a las características descritas en el caso anterior. Consta así, de una sencilla estructura de una sola nave de trazado rectangular, articulada en dos tramos, que se cubren con bóveda de crucería estrellada con terceletes de rampante llana. Estos tramos aparecen separados por un arco fajón de medio punto de intradós cajeado, dispuesto sobre pilastras de orden toscano y fuste también cajeado. Estos elementos, como en el caso anterior, se encuentran realizados en piedra de sillería, mientras que los muros y plementería de las bóvedas presentan un sencillo sillarejo y mampuesto. Se configura aquí, por lo tanto, el mismo tipo de espacio desahogado, de ámbito único, que permanece claramente diferenciado del espacio que constituye la cabecera, perteneciente al período románico.

Hacia el exterior, el nuevo cuerpo presenta la clásica estructura prismática de muros completamente planos, articulados en diferentes tramos, mediante los contrafuertes. Estos muros se encuentran realizados en sillería, mostrando un magnífico trabajo de cantería, si bien, gran parte de estos sillares habían sido reaprovechados de la fábrica anterior. Por otra parte, la integración de esta nueva nave con la estructura de la cabecera, perteneciente al período románico, no resulta tan afortunada como en el caso anterior, mostrándose como dos módulos completamente diferenciados, entre los cuales no existe ningún tipo de relación de proporcionalidad.

\footnotetext{
773 Ibídem.

774 AHPBU. PN. Valle de Valdelaguna. Leg. 9803/2, fols. 61 - 64 vo. Manuel Gil de la Cuesta. Riocavado de la Sierra, 24 - agosto - 1744.
} 


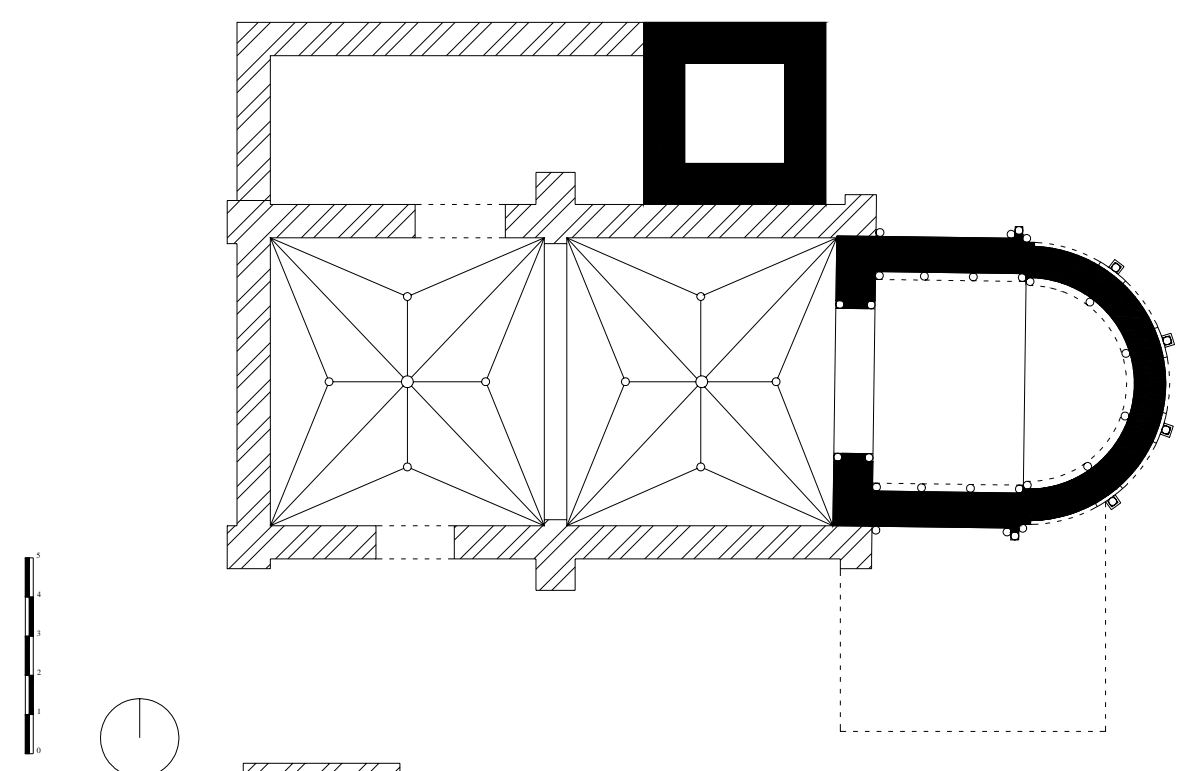

Renovación. S. XVIII.

RIOCAVADO DE LA SIERRA. Iglesia de Santa Coloma. Fases de renovación.

Dentro de esta remodelación, se aprovecha también para levantar un pequeño cuerpo, adosado sobre flanco meridional de la nave, en cuyo interior se ubica el baptisterio y las trojes, donde almacenar el grano. Para entrar a estas últimas se abre una pequeña puerta sobre el muro de poniente, mientras que el acceso al baptisterio se realiza, desde el interior de la nave, a través de un sencillo arco de medio punto dispuesto sobre impostas planas, que anteriormente había pertenecido a una capilla dedicada al Santo Cristo, existente en la fábrica antigua.

Todo el proyecto culmina con la incorporación de una nueva portada, dispuesta sobre el segundo tramo de la fachada meridional de este cuerpo, la cual, desde el punto de vista artístico, se convierte en el elemento más interesante de cuantos entonces se construyen. Su diseño, por lo que sabemos, fue incorporado por el propio maestro Juan 
de Maurtúa a este proyecto, a través de unas trazas que le habían llegado desde el Burgo de Osma ${ }^{775}$. Se trata de una obra sencilla, constituida por un arco de medio punto con la rosca recorrida con una doble moldura, que se continúa a lo largo de las jambas a través de una sencilla imposta. Dos pilastras arquitrabadas de fuste cajeado se alzan a los lados, dando paso, a través de una volada cornisa, al remate, formado por un frontón triangular partido, decorado con una pequeña cruz dispuesta sobre el tímpano, y dos pináculos de bola colocados en los extremos, en correspondencia con el eje de las pilastras. Una estructura, por lo tanto, de recio sabor clasicista, y fuerte impulso vertical, marcada por una total contención ornamental, en la que el componente arquitectónico se erige en el único protagonista. En lo que se refiere al resto del proyecto, solo cabe decir, que nos hallamos ante un ejemplo más de pervivencia de la estructura de tipo caja, en el que la severidad de sus formas y la simplicidad compositiva, son llevadas a su extremo más austero.

Muy parecido, en su resultado final, a estos dos casos, es la renovación emprendida en la parroquial de Monterrubio de la Demanda. Como en el ejemplo que acabamos de ver, aquí se conserva también la cabecera, perteneciente al período románico, mientras que todo lo demás es construido de nuevo. No es mucho lo que las fuentes documentales nos permiten saber del proceso constructivo de esta obra, con lo cual, desconocemos tanto los nombres de sus promotores y artífices, como los detalles que rodearon su ejecución. Aun así, tenemos sobrados indicios para pensar que detrás de esta empresa se encuentran motivos no muy diferentes a los vistos en el caso anterior de la iglesia de Riocavado de la Sierra. Así, en esta ocasión, los testimonios de los Visitadores del Arzobispado, que nos anuncian el peligro de ruina, comienzan a hacerse constantes desde los primeros momentos de la centuria. Esto hace que en 1737 se decida poner en marcha un ambicioso programa renovador, del cual únicamente se salva la

\footnotetext{
775 AHPBU. PN. Valle de Valdelaguna. Leg. 9803/2, fols. 73 - 77 vo. Manuel Gil de la Cuesta. Riocavado de la Sierra, 3 - septiembre - 1744.
} 
cabecera $^{776}$. El desarrollo de los trabajos, sin embargo, estuvo sujeto a todo tipo de contratiempos, lo que llevó a que no se concluyeran hasta el año $1749^{777}$.

El resultado nos depara un templo de estructura completamente renovada, con un cuerpo levantado de nueva planta, y una cabecera sustancialmente modificada. En la zona del cuerpo se levanta una estructura prácticamente igual a las que hemos visto en los dos casos anteriores, con una planta de nave única de trazado rectangular, articulada en dos tramos, cubiertos con bóveda de crucería estrellada con terceletes y nervios combados dispuestos en forma de onda en torno a la clave polar. Este mimetismo se repite también en la estructura de arcos y soportes. Con todo ello, se consigue representar el mismo concepto espacial de ámbito único, que estamos viendo en los casos anteriores, manteniendo, eso sí, el claro sentido longitudinal.

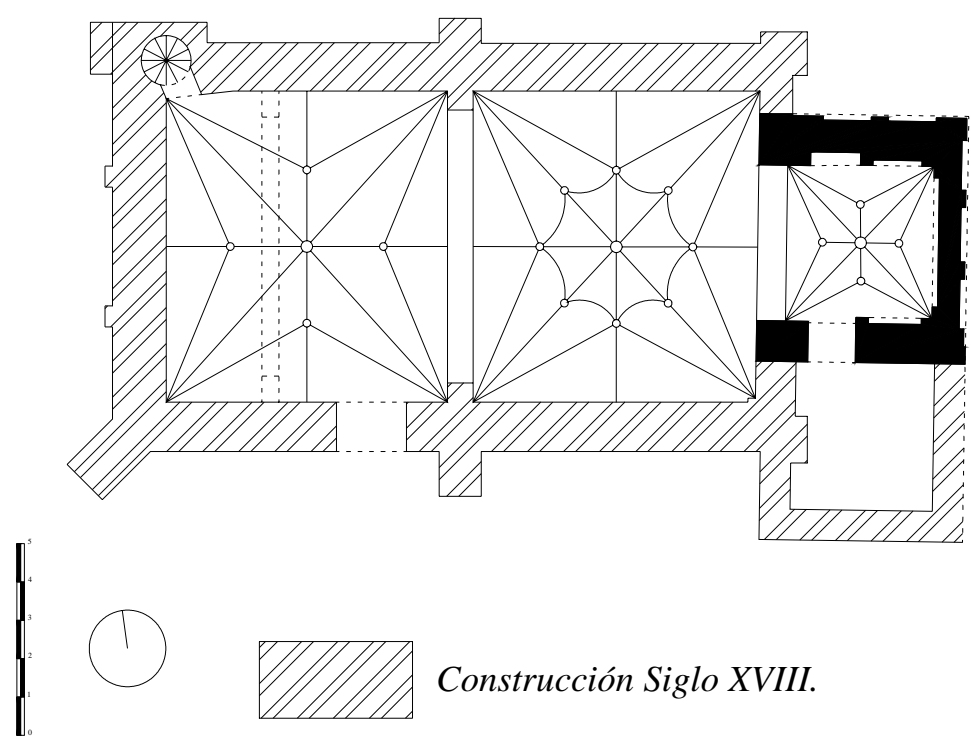

MONTERRUBIO DE LA DEMANDA.

Iglesia de San Juan Bautista. Planta.

\footnotetext{
776 AGDBU. LP. Monterrubio de la Demanda, parroquia de San Juan Bautista, LF. (1715 - 1781). Visita realizada a la parroquia de San Juan Bautista en Monterrubio de la Demanda en 1740, por D. Francisco López Angulo. Barbadillo de Herreros, 15 - noviembre - 1740.

777 Esta fecha, nuevamente, la encontramos recogida dentro de una de las claves de la bóveda que cubre el primer tramo de la nueva nave.
} 
Esta remodelación afecta también, como decimos, a la cabecera, en la cual, aunque se mantiene la estructura original de planta cuadrangular y testero plano del período románico, la cubierta se renueva por completo. Para ello se elimina la anterior bóveda de medio cañón, levantando, en su lugar, una bóveda de crucería estrellada con terceletes, elevada prácticamente a la misma altura que las de la nave. Su acceso, de igual forma, queda ahora enmarcado por un amplio arco toral de medio punto de sección cuadrangular e intradós cajeado, dispuesto sobre pilastras de orden toscano y fuste también cajeado. Todo ello encuadrado, por lo tanto, dentro de las formas propias del clasicismo desarrollado en la zona durante el siglo XVIII.

Al exterior, esta intervención se traduce en la constitución de un conjunto de formas compactas, en el que destaca la perfecta integración de los distintos elementos que lo componen, dominados, eso sí, por el gran prisma, que conforma la zona del cuerpo. Dentro de esta imagen exterior, el elemento más destacado lo vuelve a constituir la portada, abierta en este caso sobre el muro de los pies, si bien, tras las obras de renovación realizadas a principios del siglo XX, fue cegada, perdiendo parte de sus elementos. Aun así, podemos advertir que se trataba de una estructura de fuerte resalte sobre el plano del muro, formada por un arco central de medio punto, con pilastras dóricas de fuste cajeado a los lados, unidas con una imposta plana de escaso resalte, sobre las que se alzan sencillos pináculos de bola en los extremos. Una obra, por lo tanto, sumamente sencilla, que debemos incluir, como el resto del conjunto, que surge a partir de esta renovación, dentro de la sobria tradición clasicista, que caracteriza a todas las obras que estamos repasando.

Infinitamente más modesta, que estos ejemplos, es la renovación que se efectúa sobre el cuerpo de la iglesia de Santa Eugenia, en Terrazas, realizada, según nos indica la inscripción conservada sobre el dintel de una de sus ventanas, en 1764. La nueva obra resultante nos ofrece una sencilla planta rectangular con cubierta de madera dispuesta a dos aguas sobre armadura de tipo par y nudillo. Al exterior se presenta como un simple 
prisma, superado en altura, tanto por cabecera, dispuesta en el extremo oriental, como por la torre, colocada a los pies. Sus muros, realizados en tosca mampostería, presentan un perfil absolutamente plano, sin contrafuertes que interrumpan su desarrollo. El único elemento que rompe esta sobriedad lo constituye la portada, orientada hacia el mediodía, en la cual se conserva la mayor parte de su estructura románica original.

Se trata, en definitiva, de una obra de marcado sabor popular, totalmente desprovista de cualquier elemento ornamental, que demuestre una mínima inclinación por representar valores estéticos. La falta de fuentes documentales, que nos informen sobre su creación, por otra parte, nos impide conocer las circunstancias que pudieron motivar la renovación. Sin embargo, dadas las características de la obra resultante, y su disposición entre dos piezas, como son la torre y la cabecera, pertenecientes ambas a épocas anteriores, debemos pensar que se trataba simplemente de solucionar un problema de envejecimiento. De esta forma, surge una pieza en la que las únicas pretensiones que se persiguen son la solidez y la firmeza constructiva.

Un último ejemplo de este tipo de obras, realizado dentro de un templo parroquial, lo encontramos en la iglesia de San Julián en Arroyo de Salas. En este caso, como en varios de los ejemplos anteriores, fue el mal estado de conservación del edificio lo que obligó a realizar la intervención. Aquí, por lo tanto, vuelven a ser también los Visitadores del Arzobispado de Burgos los encargados de dar la voz de alarma sobre esta situación, propiciando con ello la puesta en marcha de las obras ${ }^{778}$. Esto sucede a finales de la década de 1730, para lo cual, esta humilde parroquia cuenta con la colaboración del Arzobispado de Burgos y el Duque de Frías, que ceden sus respectivas partes de los diezmos de esta iglesia. A esta ayuda se une la colaboración del

\footnotetext{
778 AGDBU. LP. Arroyo de Salas, parroquia de San Julián, LF. (1721 - 1769). Visita realizada a la parroquia de San Julián en Arroyo de Salas en 1726, por D. Andrés Fernández de Tejada. Salas de los Infantes, 16 - septiembre - 1726.
} 
concejo y la participación de los propios feligreses, que cooperan con sus limosnas y la prestación de su trabajo personal $^{779}$.

El resultado, sin embargo, no parece que sea fácil de evaluar, pues aparentemente la obra consistió en una simple reconstrucción del edificio ya existente, sin introducir cambios sustanciales dentro de la estructura heredada. Aun así, podemos descubrir la impronta dejada en las pilastras adosadas a los muros, las cuales rematan con gruesas impostas planas de escaso resalte. Al exterior, sin embargo, la continuidad, con respecto a la imagen original, parece total, manteniendo así su estructura de tipo caja, formada por muros de sillería fuertemente reforzados por gruesos estribos adosados a sus esquinas y lados mayores. Una obra, en definitiva, que difícilmente podemos separar de las típicas labores de mantenimiento y reparación, que de forma periódica, se venían efectuaban en todos estos edificios, en las que se mostraba un gran respeto por la estructura heredada.

Fuera de las iglesias parroquiales también encontramos otros ejemplos de templos que deciden renovar en este momento la parte correspondiente a la zona del cuerpo. Este es el caso de las ermitas de Nuestra Señora del Carrascal, en Canicosa de la Sierra, y Nuestra Señora de Costana, en Barbadillo de Herreros.

El primero de estos santuarios acomete su proyecto de renovación en torno al año 1717, según nos informan sus libros de fábrica. Las obras fueron efectuadas bajo la dirección del maestro de cantería Francisco de Maeda, por un salario de 3.335 reales $^{780}$, colaborando el maestro de carpintería Diego de la Torre, que percibió 2.810 reales $^{781}$, y del maestro albañil Antonio Mazal, encargado del lucimiento de los muros interiores,

779 Ibídem. Visita realizada a la parroquia de San Julián en Arroyo de Salas en 1728, por D. Andrés Madrazo Escalera. Salas de los Infantes, 15 - julio - 1728.

780 AGDBU. LP. Canicosa de la Sierra, Ermita de Nuestra Señora del Carrascal, LF. (1608 - 1743). (fols. 123 - 128). Cuentas del año 1717. Canicosa de la Sierra, 1 - abril - 1718.

781 Ibídem. (fols. 120 v ${ }^{\circ}$ 123). Cuentas del año 1716. Canicosa de la Sierra, 22 - enero - 1717. 
cobrando 580 reales $^{782}$. Como resultado surge una obra sencilla de carácter absolutamente funcional, en la que se observa una escasa o prácticamente nula preocupación por la representación de valores estéticos. El nuevo cuerpo está constituido por una sola nave de planta rectangular muy alargada, con la que se dibuja un espacio de marcado carácter longitudinal, amplio y desahogado, que se completa con un sencillo coro de madera, alzado en la parte de los pies. Toda esta estructura queda cubierta con simple techumbre de madera dispuesta a dos aguas, apoyada sobre armadura de tipo par y nudillo. Al exterior se manifiesta como un sobrio prisma de marcada horizontalidad, el cual consigue integrarse de modo perfecto con la cabecera gótica, realizada en el siglo XVI. sólo destaca el perfecto trabajo de cantería, que se aprecia en sus muros, elaborados en piedra de sillería.

La ermita de Nuestra Señora de Costana, en Barbadillo de Herreros, también conoce una importante actividad constructiva, la cual se plasma en la renovación de gran parte de su fábrica. Este programa de obras se inicia, como ocurría en otros casos, a partir de las denuncias efectuadas por los Visitadores del Arzobispado de Burgos, en las cuales se indica el mal estado de conservación en el que se encontraba la fábrica, merced a la falta de atención en las labores de mantenimiento. Algo, en principio, sorprendente dentro de un santuario muy próspero, en el campo económico, y sumamente venerado, en lo espiritual.

El encargado de realizar el aviso fue el licenciado Francisco López de Angulo, tras su visita de 1740, lo que motivó que las obras se pusieran en marcha de forma inmediata $^{783}$. En ella participaron el maestro de cantería Juan de Maurtúa, y el maestro de carpintería José de Verano, si bien, el resultado de su trabajo no parece que alterara,

\footnotetext{
782 Ibídem. Canicosa de la Sierra, 1 - abril - 1718.

783 A. P. Barbadillo de Herreros. LP. Barbadillo de Herreros, ermita de Nuestra Señora de Costana, LF. (1731 - 1840), (fols. $11 \mathrm{v}^{\mathrm{o}}-13 \mathrm{v}^{\mathrm{o}}$ ). Visita realizada a la ermita de Nuestra Señora de Costana de Barbadillo de Herreros en 1740, por D. Francisco López Angulo. Barbadillo de Herreros, 25 - noviembre -1740 .
} 
BARBADILLO DE HERREROS. Nuestra

Señora de Costana. Fachada principal.

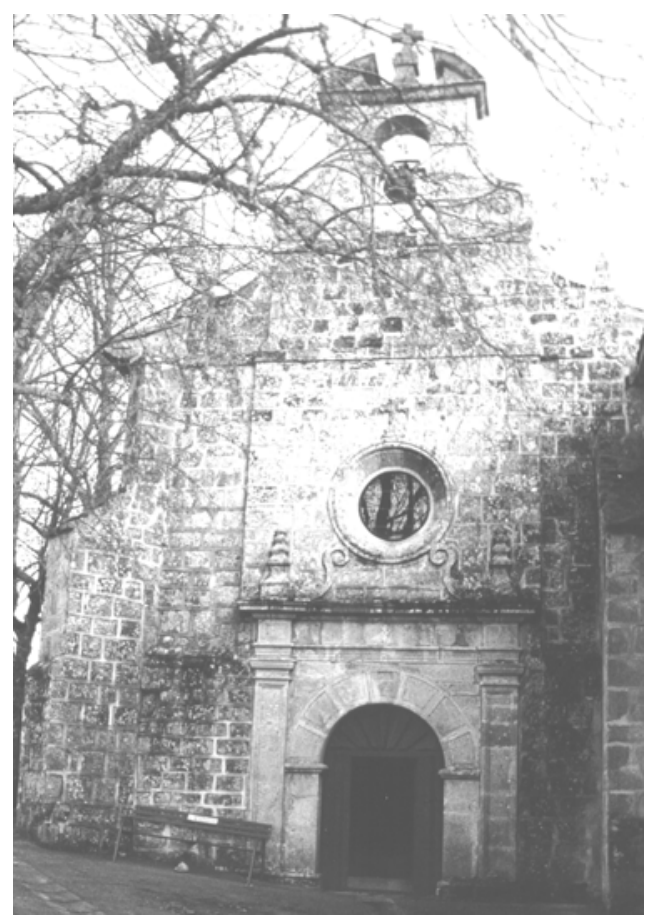

de modo sustancial, la estructura original del templo ${ }^{784}$. De este modo, se mantiene la nave de planta rectangular, articulada en tres tramos, cubiertos con bóveda de crucería estrellada con terceletes, de los cuales, el delantero forma la cabecera. Por ello, más que de una nueva construcción, debemos hablar, en este caso, de una mera reconstrucción, sin más, en la cual se mantienen todos los rasgos que caracterizaban a la fábrica anterior.

El auténtico cambio de imagen llega con la construcción de la nueva fachada principal, que se levanta entre los años 1753-80 sobre el muro de los pies. Se trata de una estructura en la que apreciamos un marcado carácter ascensional, ordenándose verticalmente en tres niveles, en los que se disponen la portada propiamente dicha, un gran óculo central, y la espadaña, que remata todo el conjunto. La portada, dispuesta en

784 Ibídem. (fols. 29 vo - 31). Cuentas de los años 1750 - 53. Barbadillo de Herreros, 28 - octubre 1753. 
la parte central del nivel inferior, presenta un vano coronado con arco de medio punto de rosca casetonada, que acompañan a los lados pilastras de orden toscano y fuste cajeado, sobre las que se dispone un entablamento de gran clasicismo ligeramente retranqueado. Sobre él, y en correspondencia con los ejes de las pilastras, se incluyen sendos pináculos de bolas superpuestas, dejando sitio, en la parte central, para que surjan dos roleos avolutados, que enlazan esta portada con el segundo nivel de la fachada, en el que se abre el amplio óculo.

El óculo presenta una estructura ligeramente abocinada, con derrame hacia el exterior, recorriendo su contorno una moldura de tres cuartos de bocel. Sobre ella, se alza una pequeña cruz latina de brazos serpentiformes, representada en un relieve de escaso resalte. Finalmente, a través de una línea de imposta planta de escaso resalte, se pasa a la espadaña, con la que se remata todo este conjunto. Ésta se levanta sobre un sencillo zócalo, unido al muro a través de aletones de forma triangular, rematados en los extremos por pináculos piramidales. En ella se abre un único vano coronado con arco de medio punto, dispuesto sobre una imposta plana, que se extiende hacia los lados. La unión con el zócalo inferior queda marcada mediante aletas avolutadas con decoración de placas en espiral, mientras que el remate lo forma un frontón curvo partido, en cuyo centro se alza una pequeña cruz de piedra, dispuesta sobre un neto. Un conjunto, en definitiva de marcado carácter ascensinal, en el cual, dentro de la severidad propia de la herencia clasicista, que impregna toda la actividad arquitectónica de la zona durante el siglo XVIII, se manifiestan ciertos rasgos propios del barroco de decoración de placas. Nada sabemos, sin embargo, en lo referente a la autoría de la obra, pues la documentación conservada mantiene un absoluto silencio en este aspecto. Aun así, sabemos que su realización supuso un desembolso para la ermita superior a los 4.000 reales $^{785}$.

\footnotetext{
785 Ibídem. (fols. $31 v^{0}-33$ v ). Cuentas de los años 1753 - 1780. Barbadillo de Herreros, 8 de enero de 1780.
} 
Como ya indicamos, dentro de los edificios religiosos de la comarca, no sólo se realizaron obras de ampliación y renovación. Así, junto a este tipo de intervenciones, debemos destacar también la atención que recibieron otras piezas, no menos importantes para la configuración de los templos. Nos referimos, especialmente a la construcción de ciertos elementos como torres, espadañas, sacristías y portadas, con las que se completa la imagen definitiva de varios de estos edificios.

Evidentemente, dentro de estos elementos, los más destacados, desde el punto de vista artístico, son las portadas, pues en ellas se manifiestan de un modo más claro los rasgos propios del lenguaje y formas artísticas dominantes. En general, en estas piezas se aprecia la misma continuidad de formas, que ya hemos constatado para el resto de la estructura del templo, a lo largo de toda la centuria. Así, tal y como ya hemos visto en los casos de Moncalvillo, Riocavado, Monterrubio y las ermitas de Nuestra Señora de Vega y de Costana, los modelos que predominan son los propios del lenguaje clasicista, con estructuras sencillas, de escaso resalte sobre el plano del muro y gran sobriedad compositiva, en la cual se aprecia un marcado dominio del componente estructural por encima de lo meramente decorativo, que se reduce, en el mejor de los casos, a una sencilla ornamentación de placas, combinada con pináculos de bola o piramidales en los remates.

Tres ejemplos podemos citar, que completan los casos ya señalados. El primero se encuentra en la iglesia de San Martín, en Huerta de Arriba, cuya construcción forma parte del proyecto de renovación, que vimos en su momento ${ }^{786}$. Esta pieza, por lo tanto, participa de la misma estética propia del más severo clasicismo, que queda reflejado en el resto del conjunto, con lo cual debemos pensar nuevamente en la mano de Fr. Pedro Martín, como autor de las trazas que guiaron su construcción.

\footnotetext{
786 AHPBU. PN. Valle de Valdelaguna. Leg. 9802/1, fols. 64 - 70 v . Manuel Gil de la Cuesta. Huerta de Arriba, 5 - mayo - 1728.
} 
La portada en cuestión se levanta en la zona de los pies del templo, lo que hace que en este caso quede orientada hacia el mediodía, ubicándose bajo un amplio arco de medio punto de rosca casetonada, dispuesto entre los contrafuertes, que delimitan este espacio. Consta de una estructura articulada en dos cuerpos de proporciones decrecientes, unidos por sencillos aletones avolutados decorados con elemento vegetales. El cuerpo inferior presenta un amplio vano en su parte central, coronado con arco de medio punto finamente moldurado, al que se superpone una gran arquivolta de tres cuartos de bocel, que se continúa a lo largo de las jambas, a través de una sencilla imposta, formando sendos baquetones. Una pareja de pilastras de orden seudo-toscano escoltan este vano, mostrando, sobre su fuste cajeado, una decoración de frutas colgantes, ocupando su tercio superior. Sobre estas pilastras se dispone un ancho entablamento de gran clasicismo, fuertemente retranqueado en los extremos, coincidiendo con las propias pilastras, dando paso con ello al segundo cuerpo.

Este segundo cuerpo se organiza en torno a una hornacina central, coronada con arco de medio punto de rosca casetonada, la cual se encuentra escoltada por pilastras de orden seudo-toscano y fuste cajeado, como las del cuerpo inferior, pero desprovistas de decoración vegetal. Sobre estas pilastras se dispone un entablamento igualmente quebrado, con el que se da paso al remate, formado por un frontón curvo partido de perfil avolutado, en cuyo tímpano se acomoda una pequeña cruz latina. La unión entre los dos cuerpos se realiza, como ya hemos dicho, mediante aletas avolutadas, las cuales se rematan en los extremos con copas con decoración vegetal, dispuestos en correspondencia con el eje de las pilastras del cuerpo inferior.

Se trata, en definitiva, de una obra bien proporcionada y de ajustado equilibrio entre cada una de sus partes, en la que se guarda una cuidada relación entre los elementos estructurales y la presencia de la masa ornamental. Además del atrevido resalte sobre el plano del muro, con el que se consiguen alcanzar interesantes contrastes luminosos, en ella destaca también la inclusión de ritmos curvos dentro de una estructura de evidente inspiración clasicista. Todo esto, en definitiva, atribuye a su 


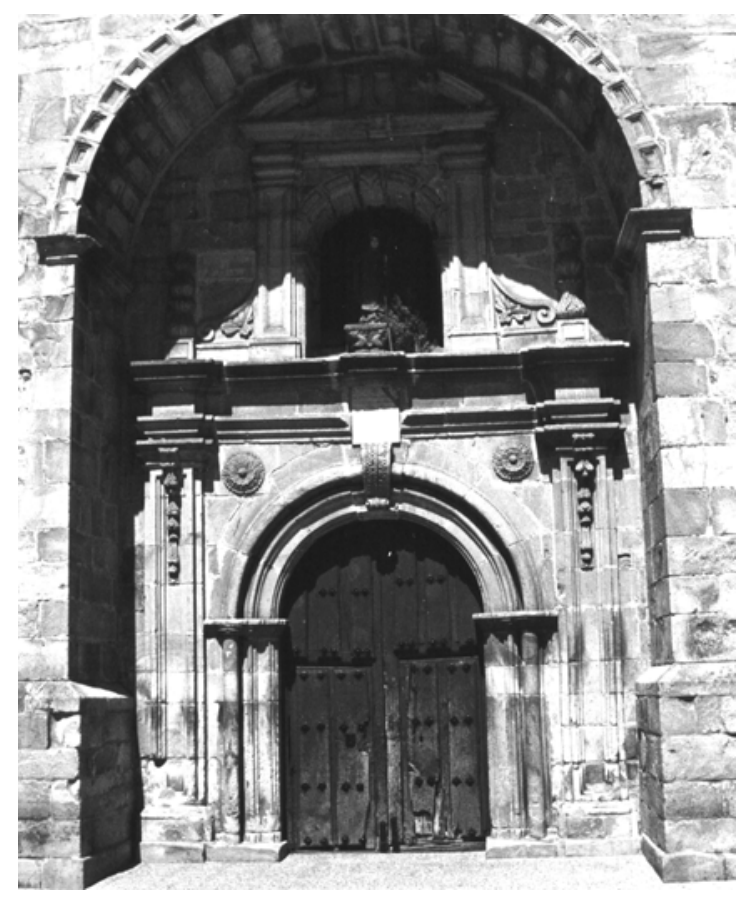

HUERTA DE ARRIBA. Iglesia de San Martín. Portada.

creador un perfecto conocimiento del lenguaje clasicista, al mismo tiempo que denota una acusada familiaridad con la plástica propia del mundo típicamente barroco, evidenciada en la ruptura de líneas, la multiplicación de planos, la utilización de elementos estructurales con un sentido ornamental, y en la sabia y moderada incorporación de elementos decorativos, que en ningún caso consiguen tapar la estructura arquitectónica. Nos estamos refiriendo, con todo ello, a un artista plenamente incluido dentro de la llamada alternativa clasicista, en la cual se halla inscrito el mencionado maestro Fr. Pedro Martín, como uno de sus más destacados representantes.

El segundo ejemplo de nueva portada lo hallamos en la iglesia de San Esteban, en Canicosa de la Sierra, cuya construcción se encuentra relacionada, como en el caso anterior, con las obras de remodelación llevadas a cabo sobre la fábrica. De igual modo, en este caso nos encontramos totalmente desprovistos de información referente a su proceso constructivo, de tal forma, que lo único que sabemos con seguridad es que fue 
terminada el año al año 1739, tal y como señala la inscripción recogida en el interior de la cartela dispuesta sobre el dintel.

Esta portada se abre, sorprendentemente, sobre el muro septentrional del templo, hecho que debemos entender como un intento, por parte de esta iglesia, de relacionarse con el propio caserío del pueblo, el cual se extendía en torno a esta vertiente. Presenta, por lo demás, una estructura sencilla, articulada en dos cuerpos no muy bien proporcionados, dentro de los cuales destaca el inferior, por sus mayores dimensiones, lo que convierte al superior en un sencillo ático. El inferior está formado por un amplio vano central adintelado, al cual escoltan dos parejas de pilastras de orden toscano y fuste completamente liso, alzadas sobre un pequeño plinto común. Sobre ellas se dispone, a su vez, un entablamento interrumpido en su parte central para dar cabida a la amplia cartela, enmarcada entre cueros recortados, plumas y una corona de conde, que ocupa toda la parte correspondiente al dintel de la puerta ${ }^{787}$. Este primer cuerpo se culmina con un amplio frontón recto partido, con elevados pináculos de bola dispuestos en correspondencia con las pilastras inferiores, sobre cuya parte central se acomoda el segundo cuerpo. Se trata de un elemento, por lo tanto, de clara inspiración palladiana.

El segundo cuerpo presenta una hornacina avenerada con arco escarzano sobre impostas planas, que se extienden hacia los lados, hasta alcanzar las pilastras, que escoltan este nicho. Sobre estas pilastras, por último, se dispone un pequeño frontón recto partido, desde cuyo tímpano arrancan tres cruces, con las que se forma un calvario, la central de tipo cruz latina y las laterales de tipo tao. En el interior de la hornacina de este cuerpo superior aparece una imagen en piedra de San Esteban, representado, como es habitual, con su dalmática diaconal sobre túnica talar, acompañado de la palma del martirio y el libro de los Evangelios con dos piedras sobre sus tapas.

\footnotetext{
787 En esta cartela se puede leer la siguiente inscripción: "O QVAM METVENDVS EST LOCVS ISTE VERENON HICALIVD NISI DOMVS DEI AETOR TACOLIA 1739”.
} 


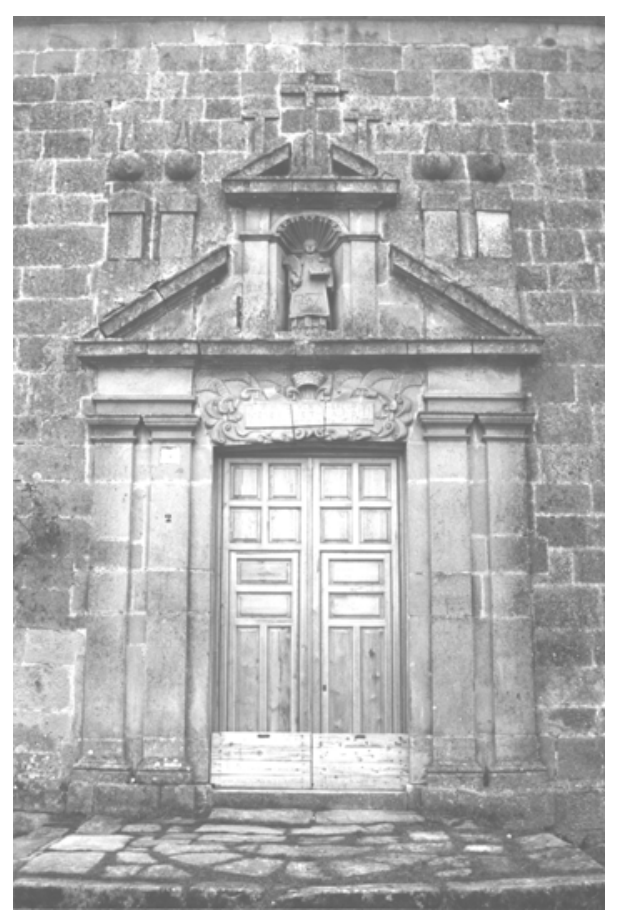

CANICOSA DE LA SIERRA.

Iglesia de San Esteban. Portada.

El conjunto de esta portada, en definitiva, constituye una obra sobria, de gran planitud, que apenas introduce contrastes lumínicos, y de marcado carácter ascensional, realzado, en este caso, por el fuerte impulso, que imprimen las pilastras laterales, y su continuación en los pináculos del remate. Una pieza, que, merced a su severidad y la marcada desproporción de sus cuerpos, debemos relacinar más con la estética manierista, de ruptura de los cánones clasicistas del final de la arquitectura Quinientista, que con los modelos propios del clasicismo herreriano, prolongados en esta zona hasta muy avanzado el siglo XVIII. A ello se unen también, como señalamos, ciertos rasgos de influencia palladiana, comunes a otras composiciones realizadas en la comarca. Por todo ello, esta obra destaca por su originalidad, ya que se trata de un modelo que apenas tiene continuidad en la zona, y que tampoco posee referentes concretos dentro del resto de la provincia de Burgos.

El último ejemplo, dentro de este tipo de portadas, lo encontramos en la iglesia de San Adrián, en Regumiel de la Sierra. Se encuentra situada en la fachada meridional 


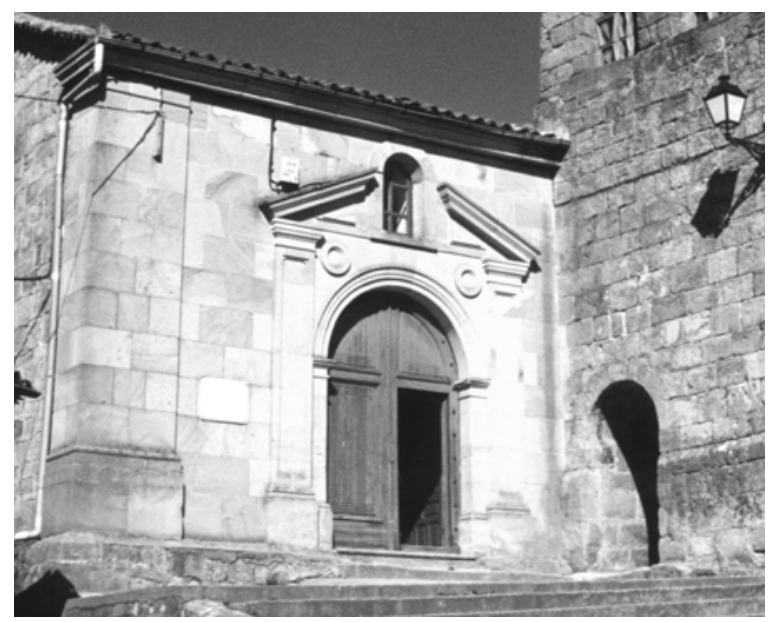

REGUMIEL DE LA SIERRA.

Iglesia de San Adrián. Portada.

del templo, protegida por el ángulo que forma este muro con el lateral de la torre. Consta de un gran arco de medio punto de rosca finamente moldurada, decorado con pequeños tondos en las enjutas, escoltado a ambos lados por gruesas pilastras toscanas de fuste cajeado. Sobre estas pilastras, y sin presencia de entablamento de ningún tipo, se dispone un sencillo frontón recto partido con decoración de placas en los ángulos laterales del tímpano, y una pequeña hornacina en la parte central, hoy convertida en ventana.

Una obra, por lo tanto, sumamente sencilla, que podemos encuadrar dentro de la mejor tradición clasicista, desarrollada en la zona durante todo este siglo XVIII. En ella destaca, junto a la planitud con la que son concebidos todos sus elementos, el cuidado equilibrio con el que aparecen dispuestos, deparando una obra bien proporcionada. Todo ello, dentro de una composición desprovista por completo de elementos decorativos, en la que la estructura arquitectónica se convierte en el único protagonista, buscando así un cierto sentido ornamental en sus elementos estructurales. Destaca, igualmente, el magnífico trabajo de cantería con el que fue elaborada, lo que nos habla, evidentemente, de la participación de maestros altamente cualificados en la materia. 
Las torres y espadañas son otro tipo de piezas, que reciben un cuidado tratamiento durante la centuria. En este caso, sin embargo, más que construir piezas totalmente nuevas desde sus cimientos, lo que vamos a ver fundamentalmente son remodelaciones de estructuras ya existentes, reparando y reforzando el elemento anterior, pero sobre todo añadiendo nuevos cuerpos de campanas, con los cuales se conseguía incrementar de modo considerable su altura. Con ello, se afianzaba también su papel de hitos referenciales dentro del espacio circundante. Dentro de estas obras observamos un claro continuismo con respecto a las construidas durante el siglo anterior, lo que hace que sigan predominando las estructuras prismáticas con cuerpos separados mediante sencillas líneas de imposta. Lo mismo sucede con los vanos de las campanas, rematados con arco de medio punto alzados sobre impostas planas de escaso resalte. Los muros, al igual que en la centuria anterior, se rematan con un grueso friso y una cornisa de papo de paloma o codillo, con la que se da paso al tejado, en el que tampoco suelen faltar los pináculos de bola o piramidales.

La variedad, en este caso, aparece en las circunstancias que motivaron su construcción. Así, en el caso de la iglesia de Quintanar de la Sierra, simplemente se pretendía incrementar la altura de la torre, construida como el resto del edificio en 1622, para así ganar mayor esbeltez. Para ello, en 1772 el maestro Bernardo de Ordoricos, construye un nuevo cuerpo de campanas, dispuesto simplemente como continuación del anterior, sin introducir con ello mayores cambios ${ }^{788}$. La separación con la parte antigua se realiza mediante una simple línea de imposta plana de escaso resalte, mostrando en sus muros, como principal elemento diferenciador, una sillería de mayor tamaño y mejor labra que la de los cuerpos inferiores.

Este cuerpo presenta una estructura cúbica de muros completamente planos, con un único vano en cada una de sus caras, con antepecho de piedra y arco de medio punto sobre impostas planas. Lo más destacado de la nueva construcción, sin embargo, se

\footnotetext{
788 AGDBU. LP. Quintanar de la Sierra, parroquia de San Cristóbal, LF. Zayos de la Torre, 5 - agosto 1772.
} 


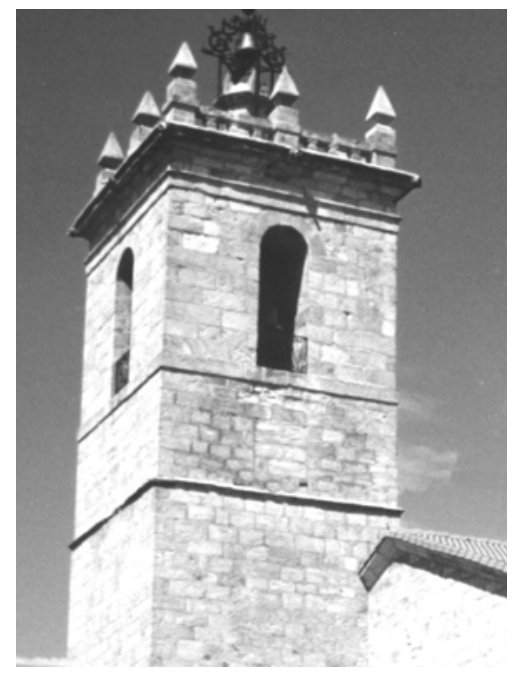

QUINTANAR DE LA SIERRA.

Iglesia de San Cristóbal. Torre.

halla en el remate, al cual se llega a través de una volada cornisa, donde nos encontramos con tres pináculos piramidales en cada lado, alzados sobre elevados netos, entre los cuales discurre una balaustrada. La cubierta, por su parte, se resuelve con una original cúpula de media naranja trasdosada, la cual, sin embargo, resulta difícil de apreciar, al quedar oculta por los elementos anteriores.

Se trata, por lo tanto, de una obra sencilla, en la que nos se pretende realizar ningún tipo de experimento, ni formal, ni estructural. Aun así, con su construcción se consiguió alcanzar el objetivo deseado, que no era otro que realzar la imagen general del templo, imprimiendo un cierto carácter ascensional, que compensara la excesiva horizontalidad mostrada por todo el conjunto. Al mismo tiempo se creaba un auténtico hito referencial dentro de la imagen del pueblo.

Razones, en cierto modo, similares fueron las que acompañaron la ejecución de los nuevos cuerpos de campanas, que se incorporan respectivamente a las torres de las iglesias de San Martín, en Huerta de Arriba, y San Esteban, en Canicosa de la Sierra. Ambos templos habían sido objeto, como hemos visto, de importantes obras de renovación durante la primera mitad del siglo, y en los dos casos se había decidido 
conservar la primitiva torre, perteneciente al templo anterior. El único tributo que debían pagar para salvarse, y poderse así incorporar a sus respectivas fábricas recién renovadas, consistía en aumentar su altura. Para ello se construyen, en ambos casos, nuevos cuerpos de campanas añadidos a la estructura anterior, los cuales, como el caso que acabamos de ver, mantienen las mismas características de la estructura que sirve de base.

Esta operación, en el caso de San Martín de Huerta de Arriba, se realiza en 1752, invirtiendo la fábrica un total de 6.776 reales y 15 maravedís ${ }^{789}$. Desconocemos, sin embargo, el nombre o nombres de los artífices encargados de llevarla a cabo.

En el caso de Canicosa de la Sierra desconocemos incluso el año de su ejecución, si bien, nos inclinamos a pensar en una mayor proximidad con respecto a las obras de remodelación emprendidas en el resto del templo, pues la afinidad del tipo de piedra empleada y su técnica de trabajo así parecen indicarlo.

Un tercer motivo, que propicia la renovación de parte de una torre, lo encontramos en la iglesia de la parroquia de Santa María, en Neila. Aquí, las constantes amenazas de ruina, que venía ofreciendo la antigua torre románica, llevaron a los feligreses y responsables de la parroquia a considerar la posibilidad de derribarla, y construir en su lugar una estructura completamente nueva. Esta posibilidad, por otra parte, ya había sido expuesta por el Visitador del Arzobispado de Burgos, D. Íñigo López de Angulo, en 1701, el cual además de advertir las limitaciones que presentaba la torre actual, expresa la idea de construir una nueva, aprovechando para ello una generosa donación de 600 ducados, que la parroquia había recibido unos años antes ${ }^{790}$.

\footnotetext{
789 AGDBU. LP. Huerta de Arriba, parroquia de San Martín, LF. (1723 - 1778). Cuentas del año 1750. Huerta de Arriba, 12 - octubre - 1751; Ibídem. Cuentas del año 1752. Huerta de Arriba, 18 - octubre 1753.

790 AGDBU. LP. Neila, parroquia de Santa María, LF. (fols. $71-78$ v ${ }^{\circ}$ ). Visita realizada a la parroquia de Santa María de Neila en 1701, por D. Íñigo López de Angulo, canónigo de la catedral de Burgos. Neila, 5 - octubre - 1701 .
} 
Sin embargo, este mandato, lejos de ser atendido con la inmediatez que requería, quedó aparentemente aparcado en el olvido de los justos, mientras que la quiebra de la torre empezaba a dar los primeros signos de alarma, fruto del paso inexorable del tiempo y de falta de cuidados dispensados. Decimos, sin embargo, que sólo quedó aparentemente olvidado, pues todo apunta a que los pasos necesarios para su renovación se estaban realizando, aunque con una angustiosa lentitud. Así, en 1728, diferentes maestros acudieron a examinar dicha torre ${ }^{791}$. Ocho años más tarde, se comienzan a comprar los materiales necesarios para su reconstrucción ${ }^{792}$ y un año después se manda venir a un maestro para que diera las trazas de la nueva obra ${ }^{793}$.

Aún con todo, parece que al final se llegó con retraso, pues un año más tarde, en 1739, los Provisores y Veedores del Arzobispado de Burgos deben transladarse hasta allí para declarar la ruina de dicha torre ${ }^{794}$. Esto queda corroborado por el Visitador D. Francisco López Angulo, en 1740, el cual comienza a poner las bases para su remodelación ${ }^{795}$. Sin embargo, esto, que parecía el final de un largo proceso, no fue sino el inicio de un tormentoso enfrentamiento de pareceres entre los Provisores y Veedores del Arzobispado, por una parte, que proponían la reparación de la torre existente, subsanando los daños que afectaban a su cuerpo de campanas, y los feligreses y responsables de la parroquia, por otra, que abogaban por la construcción de una torre completamente nueva

Sin embargo, la segunda propuesta jamás pudo realizarse, pues, como dicen los diferentes Visitadores, que acudieron aquí en los años sucesivos, esto solamente sería posible si los propios feligreses se comprometían a sufragarlo, pues de lo contrario

\footnotetext{
791 Ibídem. (fols. 190 - 192). Cuentas del año 1728. Neila, 4 - septiembre - 1729.

792 Ibídem. (fols. $200 \mathrm{v}^{\mathrm{o}}-201 \mathrm{v}^{\mathrm{o}}$ ). Cuentas del año 1736. Neila, 19 - septiembre - 1737.

793 Ibídem. (fols. $202 \mathrm{v}^{0}$ ). Cuentas del año 1737. Neila, 10 - septiembre - 1738.

794 Ibídem. (fols. 202 v - 205). Cuentas del año 1739. Neila, 7 - octubre - 1740.

795 Ibídem. (fols. 206 v ${ }^{\circ}$ - 217). Visita realizada a la parroquia de Santa María de Neila en 1740, por D. Francisco López Angulo. Canales, 6 - noviembre - 1740.
} 
acarrearía la ruina económica de la parroquia. Así, tras una dura contienda la obra finalmente pudo llevarse a cabo, pero no cumpliendo los anhelos de los feligreses, sino pisando con los pies en el duro suelo del pragmatismo de los Provisores diocesanos.

La obra realizada consistió, simplemente, en la renovación del cuerpo de campanas, lo que hizo que se conservara de forma íntegra el resto de la estructura de la torre románica. El nuevo cuerpo de campanas se proyecta, por lo tanto, como una mera prolongación del cuerpo inferior, del cual aparece separado a través de una sencilla cenefa decorada con el característico ajedrezado románico, reaprovechada de la construcción anterior. Presenta así una sencilla forma prismática de muros completamente planos, rematados en su parte superior por una cornisa de papo de paloma con la que se da paso al tejado, sobre cuyas esquinas se alzan pequeños pináculos de bola. Un único vano se abre en cada frente, coronado con arco de medio punto, sobre una imposta plana, que se extiende hacia los lados, para terminar recorriendo todo el contorno de este cuerpo. La extrema sencillez de esta obra hace que apenas se aprecien diferencias sustanciales con respecto a la base románica, consiguiendo con ello una total integración entre ambas partes. De esta forma, se logra crear un conjunto homogéneo de perfil extraordinariamente espigado, que se convierte en el idóneo contrapunto ascensional ideal dentro de un edifico presidido por una extrema sensación de horizontalidad.

Una obra muy similar a ésta se lleva a cabo en la iglesia de Nuestra Señora de la Visitación, en Barbadillo de Herreros, si bien, en este caso no contamos con tantos datos, que nos informen sobre las circunstancias que rodearon su construcción. Aun así, sabemos que la obra se acomete en 1789, con un costo para la fábrica de 12.469 reales, los cuales fueron abonados en una sola partida, contando para ello con la ayuda de la 
ermita de Nuestra Señora de Costana, que aportó 3.000 reales $^{796}$, y del concejo de la localidad, que contribuyó con otros $2.469^{797}$.

El nuevo cuerpo de campanas se levanta sobre el gran prisma de sección cuadrada y columnas entregadas en las esquinas, que se conserva de la primitiva fábrica románica. Este cuerpo se articula en dos piezas superpuestas, de anchura decreciente, en las que se mantiene la misma sección cuadrangular. De ellos, el inferior, de escaso desarrollo en altura, está formado por una pequeña pieza maciza, que actúa como zócalo del cuerpo de campanas propiamente dicho. El nivel superior presenta, en cada una de sus caras, un solo vano coronado con arco de medio punto y antepecho de piedra a los pies, escoltado en los extremos por sencillas pilastras sin orden determinado y fuste liso, con las que se crea un sencillo, pero interesante, ritmo compositivo. Sobre estas

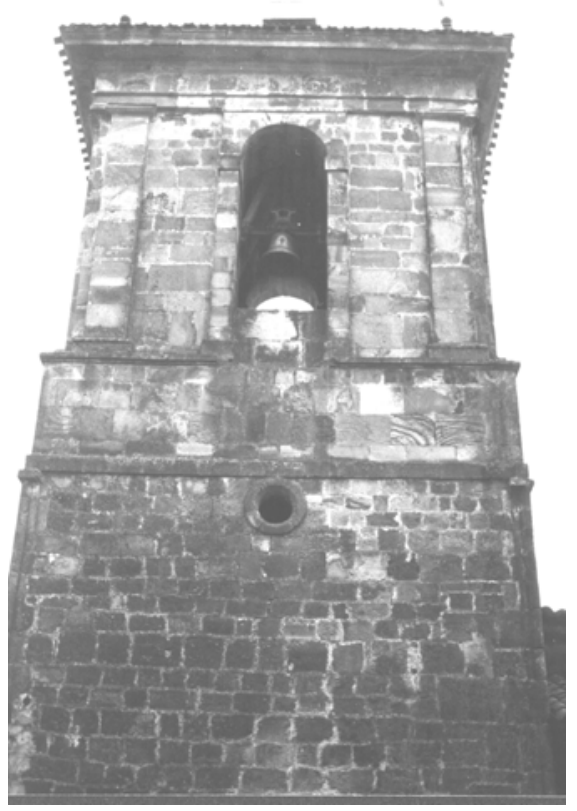

BARBADILLO DE HERREROS. Iglesia de Nuestra Señora de la Visitación. Torre.

\footnotetext{
796 A. P. Barbadillo de Herreros. LP. Barbadillo de Herreros, ermita de Nuestra Señora de Costana, LF. (1731 - 1840), (fols. 35 v - 36). Cuentas de los años 1783 - 1788. Barbadillo de Herreros, 8 - octubre 1788.

797 A. P. Barbadillo de Herreros. LP. Barbadillo de Herreros, parroquia de Nuestra Señora de la Visitación, LF. (1749 - 1838). Cuentas del año 1789. Barbadillo de Herreros, 19 - septiembre - 1789.
} 
pilastras se extiende un ancho friso, que recorre todo el contorno de la torre, dando paso a una volada cornisa de codillo. En el tejado, por último, cuatro pequeños pináculos de bola aparecen dispuestos sobre las esquinas, mientras que sobre el vértice central se eleva un airoso chapitel, compuesto por dos esbeltas pirámides superpuestas, producto de un añadido reciente ${ }^{798}$.

Se trata, en definitiva, de una obra de neto sabor clasicista incluida dentro de la mejor tradición herreriana, hasta el punto de mostrar, como ya hemos apuntado en alguna ocasión, cierta similitud con obras procedentes del círculo más íntimo de continuadores de Herrera, como pueden ser las torres, que realiza Francisco de Mora para la iglesia de San Bernabé, en El Escorial de Abajo. Sin duda, constituye uno de los mejores ejemplos de cómo las formas propias del clasicismo, desarrolladas a principios del siglo XVII, se prolongan en el tiempo dentro de la tradición constructiva de la zona, hasta enlazar con los postulados academicistas de la segunda mitad del XVIII. Un viaje dentro de este amplio espacio de tiempo, que tal y como estamos viendo, en lo que se refiere a la evolución de las formas arquitectónicas, apenas tiene repercusión dentro de esta comarca de la sierra.

Junto a las torres, podemos incluir también aquí la construcción de algunas espadañas, si bien, se trata de una tipología menos frecuente dentro de la arquitectura religiosa de la sierra. La más destacada de ellas, aparte de la levantada en la ermita de Nuestra Señora de Costana, en Barbadillo de Herreros, se encuentra en la iglesia de la parroquia de Santa Lucía, en Bezares. Fue construida en 1756, cumpliendo el mandato, que un año antes había dado el Visitador del Arzobispado de Burgos, D. Juan de Tobías y Zuazo, el cual, aparte de advertir sobre el mal estado, que en general presentaba todo el templo, señala la necesidad de una espadaña para colocar las campanas. Dada la extraordinaria pobreza en la que vivía la parroquia, este mismo Visitador pide la colaboración de los feligreses en el desarrollo de los trabajos, con el fin de abaratar los costes, al mismo tiempo que solicita el apoyo económico de los llevadores de diezmos

798 C. RUBIO VELASCO: Barbadillo de Herreros... ob. cit. (pp. 192 - 194). 
del Arzobispado de Burgos y del Duque de Frías, para que cediesen su parte de beneficios en los diezmos de la parroquia. En lo que se refiere a los materiales empleados, los vecinos del pueblo fueron los encargados de proporcionar la madera necesaria para el andamiaje, la cual extrajeron de los bosques próximos. La piedra, por su parte, se tomó de las ermitas de San Justo y San Pastor, y de Santa Marina, situadas dentro del propio término municipal de Bezares, las cuales se hallaban en este momento en un estado de avanzada ruina. De este modo, con su extinción se conseguía dar vida al nuevo proyecto de su iglesia parroquial, al mismo tiempo que se lograba abaratar considerablemente el proceso constructivo ${ }^{799}$. Con todas estas aportaciones y ayudas, la obra pudo ejecutarse de forma inmediata, con un desembolso para esta fábrica de sólo 864 reales y 19 maravedís $^{800}$.

Como resultado de ello surge una modesta construcción, levantada sobre el muro de los pies del templo, articulada en dos cuerpos decrecientes, delimitados por líneas de imposta planas de escaso resalte, y unidos por aletas triangulares, rematadas con pináculos de bola en los extremos. Dos vanos se abren en el primer cuerpo y uno solo en el segundo, repitiendo en ambos la misma estructura con arco de medio punto sobre impostas planas. El segundo cuerpo se remata con un pequeño frontón triangular partido, sobre cuyo tímpano se eleva un neto, en el que se asentaba una cruz.

Es una obra sencilla, sin grandes complicaciones compositivas ni técnicas, y de un estricto sabor clasicista, en el que no falta el marcado carácter de rusticidad, con el que se interpreta este estilo en las obras más modestas de la comarca. Aun así, vemos cómo esta pieza llega a jugar un papel ciertamente destacado, dentro de la configuración de la imagen exterior del templo, pues con su incorporación no sólo se introduce un evidente contrapunto vertical dentro de una fábrica ampliamente dominada por el

\footnotetext{
799 AGDBU. LP. Bezares, parroquia de Santa Lucía, LF. (1725 - 1771). (fols. 37 - 39 vº). Visita realizada a la parroquia de Santa Lucía de Bezares en 1755, por D. Juan de Tobías y Zuazao, canónigo de la catedral de Burgos. Canales, 1 - agosto - 1755.

800 Ibídem. (fols. 41 - 42 v ). Cuentas del año 1755. Bezares, 30 - septiembre - 1756.
} 
606 Arquitectura de la Edad Moderna en la sierra burgalesa.

aspecto aplanado de su estructura, sino que además se introducen ciertos valores estéticos en un conjunto de acusado sabor popular.

Las sacristías, durante esta centuria, también fueron objeto de importantes obras de renovación. En general, en estas construcciones no vamos a encontrar modificaciones sustanciales con respecto a las realizadas durante la centuria anterior, si bien, debemos reconocer que se trata de un tipo de obra que, dada su sencillez y eminente carácter funcional, ofrece escasas posibilidades de aportar novedades importantes. Su renovación, en varias ocasiones, quedó incluida dentro del programa de remodelación de la cabecera del templo, como ocurrió en los casos de Moncalvillo y Vilviestre del Pinar, sin embargo, lo más frecuente es que se tratara de obras concebidas de forma totalmente independiente.

Su intención, en todos los casos, era ofrecer un espacio más amplio y digno, en el cual poder custodiar los objetos y ropas litúrgicos. En cuanto a su estructura, vemos que no se producen grandes variaciones con respecto al modelo elaborado durante la centuria anterior, manteniendo su forma prismática de muros completamente planos, sobre planta cuadrangular, que en ocasiones deriva en rectangular, articulada en dos tramos separados por arco fajón. En las cubiertas, sin embargo, sí se aprecian ciertas novedades. Así, aunque se mantiene la tradicional bóveda de crucería de la etapa anterior, ésta se combina con otro tipo de soluciones, como son la bóveda de aristas de superficie compartimentada por sencillas fajas de escayola, la bóveda de cañón, o el simple cielo raso, empleado en las construcciones más modestas.

Entre los ejemplos que podemos citar, el más temprano fue el de la iglesia de San Martín, en Huerta de Arriba, levantada en 1729, el cual se incluye dentro de los trabajos de remodelación del templo emprendidos en aquel momento. Esta pieza, sin embargo, tuvo que ser reparada, e incluso parcialmente reconstruida, en diferentes ocasiones, pues su proximidad a la antigua capilla mayor y las humedades del subsuelo, sobre el que se asentaba, fueron una continua fuente de problemas. Como consecuencia 
de todo ello en 1761 fue necesario acometer una importante intervención dentro de toda la parte oriental del templo, en el transcurso de la cual se incluye la renovación de la sacristía. De la importancia que alcanzaron estos trabajos nos habla el elevado presupuesto que la parroquia tuvo que destinar, el cual rondó los 6.000 reales ${ }^{801}$. Como resultado de ello surge una sacristía de planta rectangular y muros completamente planos, realizados en piedra de sillería, en cuyo interior se configura un espacio amplio y desahogado, cubierto con bóveda de aristas de superficie compartimentada en ocho paños, mediante fajas de escayola.

Prácticamente contemporánea a la primera construcción de esta obra es la sacristía realizada para la iglesia de Santa Eulalia, en Palacios de la Sierra. Su renovación, en este caso, estuvo precedida de varios mandatos emitidos por los Visitadores del Obispado de Osma, en los cuales, además de señalar la necesidad que la parroquia tenía de contar con una sacristía más amplia y capaz, se abogaba por un cambio de emplazamiento "por ser en el que está úmedo"802. Este mandato fue repetido en los mismos términos en la visita de $1730^{803}$, hasta que finalmente en 1734 se ajustó la ejecución de la nueva sacristía con el maestro de cantería Manuel de la Torre, por un total de 5.895 reales y 22 maravedís $^{804}$. Sin embargo, no parece que las exigencias de los Visitadores fueran acatadas de modo estricto, pues todos los indicios apuntan a que la nueva sacristía se levantó en el mismo emplazamiento que ocupaba la antigua.

La obra resultante, por lo demás, se ajusta con todo rigor a las características del modelo desarrollado desde principios de la centuria anterior, mostrando así una sencilla

\footnotetext{
801 AGDBU. LP. Huerta de Arriba, parroquia de San Martín, LF. (1723 - 1778). Cuentas del año 1761. Huerta de Arriba, 2 - octubre - 1762. Ibídem. Cuentas del año 1763. Huerta de Arriba, 15 - septiembre 1764.

802 AGDBU. LP. Palacios de la Sierra, parroquia de Santa Eulalia, LF. (1728 - 1770). Visita realizada a la parroquia de Santa Eulalia de Palacios de la Sierra en 1728, por D. Gaspar de Lamas y Montenegro. Palacios de la Sierra, 18 - junio - 1728.

803 Ibídem. Visita realizada a la parroquia de Santa Eulalia de Palacios de la Sierra en 1730, por D. Luis de Alaro. Palacios de la Sierra, 1 - junio - 1730.

804 Ibídem. Cuentas del año 1734. Palacios de la Sierra, 11 - enero - 1735.
} 
estructura prismática de planta cuadrangular, con muros completamente planos elaborados en piedra de sillería y espacio interior cubierto con bóveda de crucería estrellada con terceletes. La única particularidad, que aquí podemos señalar, la encontramos en su imagen exterior, sobre la parte superior de su muro oriental, donde aparece lo que constituye el vértice lateral de un frontón recto partido, el cual se corresponde con el que ya existía desde principios de siglo, en el lado contrario del edificio, correspondiente a la capilla de San Juan Bautista. De este modo, aunque con treinta años de diferencia, se consigue completar el efecto de enmarque que se pretendía para el muro del testero de la capilla mayor. Un efecto, que como ya señalamos en su momento, ineludiblemente debemos relacionar con la influencia de la arquitectura palladiana, desarrollada principalmente a partir del trabajo de determinados artífices como Francisco de Praves en el foco clasicista vallisoletano de principios del siglo $\mathrm{XVII}^{805}$.

También, en torno a estos años, se sitúa la construcción de la sacristía de la iglesia de Moncalvillo, obra, que como ya apuntábamos, queda incluida dentro de la renovación de toda la parte delantera de este templo. El resultado es una pieza similar al caso anterior, de estructura prismática, sobre planta cuadrangular, con muros de sillería completamente planos, y espacio interior cubierto con bóveda de crucería cuatripartita. Una versión, por lo tanto, muy simplificada de esta tipología.

Similar a ésta última es la levantada en la década de 1740 para la iglesia parroquial de Barbadillo de Herreros. El impulsor de la obra fue el Visitador del Arzobispado de Burgos que acudió a esta parroquia en 1740, D. Francisco López de Angulo, el cual ordenó que "por quenta de esta renta de dicha fábrica se aga nueva una sacristía al lado de la epístola y sitio que ocupa el osario, abriendo la puerta en el arco

805 A. BUSTAMENTE GARCÍA: “En torno al clasicismo: Paladio en Valladolid” ob. cit. 
correpondiente inmediata al estribo de la capilla mayor, mudando el referido osario a paraje cómodo" 806 .

La obra se hizo tal y como se había indicado, apoyándose sobre el flanco meridional de la cabecera, desarrollando en ella una sencilla estructura prismática de planta rectangular, con muros de mampostería reforzados en las esquinas con sillares de mayor tamaño y espacio interior cubierto con una simple techumbre de cielo raso.

Otro ejemplo de sacristía de nueva creación lo tenemos en la iglesia de Vallejimeno, si bien, en este caso lo que se hace, realmente, es ampliar la estructura de la anterior. La obra se realiza, según nos indican los libros de fábrica, en 1774, y con su construcción no sólo se pretendía agrandar este espacio, sino sobre todo reforzar la estructura de la cabecera del templo, junto a la que se adosa, pues según nos indican las mismas fuentes, venía amenazando ruina desde varios años atrás ${ }^{807}$. La ejecución del proyecto alcanzó un presupuesto superior a los 4.000 reales, y el resultado final nos

VALLEJIMENO. Iglesia de San Martín. Corte transversal de la cabecera.

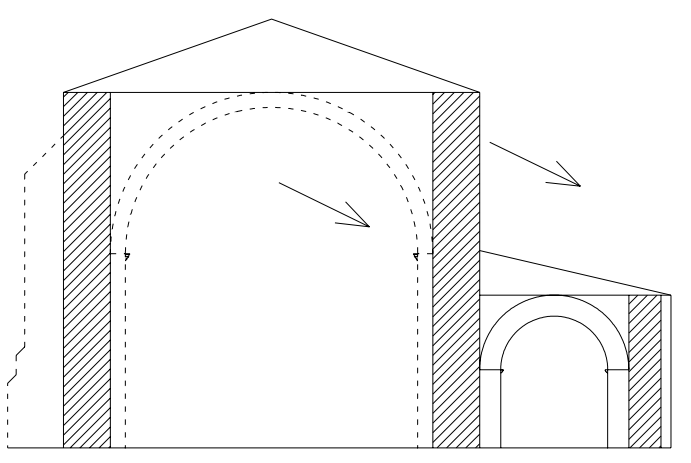

806 A. P. Barbadillo de Herreros. LP. Barbadillo de Herreros, parroquia de Nuestra Señora de la Visitación, LF. (1718 - 1748). (fols. $93 v^{0}-103 v^{0}$ ). Visita realizada a la parroquia de Nuestra Señora de la Visitación de Barbadillo de Herreros en 1740, por D. Francisco López de Angulo. Barbadillo de Herreros, 15 - noviembre - 1740 .

807 AGDBU. LP. Vallejimeno, parroquia de San Martín, LF. (1751 - 1851). Cuentas del año 1774. Vallejimeno, 23 - septiembre - 1775. 
ofrece una estructura de planta rectangular, articulada en dos tramos, separados por arco de medio punto de intradós cajeado, apoyado sobre pilastras de fuste igualmente cajeado, y cubiertos con bóvedas de crucería octopartitas. Es precisamente este arco, que divide los tramos de la sacristía, el elemento que realiza la función de descarga de las presiones generadas por el muro de la cabecera, actuando, de este modo, como un auténtico arbotante. Por lo demás, y al margen de estas consideraciones de carácter estructural, desde el punto de vista estético, esta sacristía, al igual que el resto de los ejemplos citados, no ofrece ningún otro detalle de interés.

Una estructura similar a ésta, con planta rectangular articulada en dos tramos, se encuentra en la sacristía levantada en la iglesia de San Martín, en Vilviestre del Pinar, cuya construcción se incluye dentro de la renovación de toda la parte delantera del templo. En este caso, como ya vimos en su momento, se observa una mayor atención hacia los valores estéticos, lo cual podemos apreciar en la parte exterior, en el recercado de marco quebrado, que muestran sus ventanas, o en el interior, con sus bóvedas de arista con decoración geométrica de perfil mixtilíeno. Dentro de ella, un elemento singular lo constituye la puerta de entrada, abierta sobre el muro del presbiterio, donde aparece un vano recercado por una doble moldura de perfil quebrado y agitada traza, en el que se combinan trazos recto y curvos. Una obra, por lo tanto, en la que se aprecia, como en el resto del conjunto en el que se incluye, un evidente alejamiento de las formas severas del clasicismo dominante, para dar paso a los ritmos más movidos y de marcados contrastes, próximos al barroco más exaltado.

Una puerta, en cierto modo, similar a ésta de la sacristía de Vilviestre, aunque algo más sencilla, la encontramos en la sacristía construida para la iglesia de la parroquia de Santa Cecilia, en Salas de los Infantes. En este caso, la falta de fuentes documentales nos impide precisar el momento exacto de su construcción, si bien, las formas desarrolladas nos llevan a pensar en una fecha cercana a la anterior, situada en torno a las décadas centrales de este siglo XVIII. 
Ligado a la construcción de nuevas sacristías debemos hablar también de la incorporación de las llamadas capillas-camarín, pues en definitiva, todos los casos encontrados en la zona terminan desempeñando esta misma función. La composición de estas piezas constituye un fenómeno característico del mundo barroco y de su interés por el desarrollo de determinados efectos escénicos. En nuestro caso, se plasma principalmente en aquellos santuarios de especial veneración, quedando excluidos los templos parroquiales. En cualquier caso, los ejemplos de este tipo de obras en ningún caso destacan por su especial espectacularidad, sino que se trata, en todos los casos, de obras muy modestas, en las que se repiten, de forma mimética, unas mismas pautas.

Todas estas capillas quedan reducidas a una estancia de pequeñas dimensiones, adosadas sobre el muro del testero, como si fueran una prolongación de la capilla mayor, con la cual se comunican a través de un vano, que se hace coincidir con la hornacina central del retablo, donde se aloja la imagen titular del templo. Esta capilla, a su vez, cuenta con un gran ventanal, abierto sobre su muro frontal, lo que suministra una generosa iluminación, que permite crear el efecto de transparente sobre la hornacina del altar mayor. De este modo, a través de la luz que recibe desde su parte posterior, la imagen titular adquiere un efecto nimbado, dando una sensación de ingravidez, que la hace aparecer ante los fieles, como si estuviera flotando en el aire.

Obras, en cualquier caso, en las que la sencillez compositiva se convierte en su nota más destacada, la cual, sin embargo, no debe hacernos olvidar la importancia que este tipo de construcciones tiene dentro de la arquitectura de la comarca, pues suponen un destacado intento de incorporar los efectos propios de la estética barroca dentro de una arquitectura, que seguía apegada con fuerza a las severas formas del clasicismo.

Los tres ejemplos de esta tipología, que podemos citar, presentan importantes afinidades entre sí, pues no sólo reproducen un esquema muy similar, sino que se levantan en importantes santuarios marianos, como son los de Nuestra Señora del Arroyal (Palacios de la Sierra), Nuestra Señora del Carrascal (Canicosa de la Sierra), y 


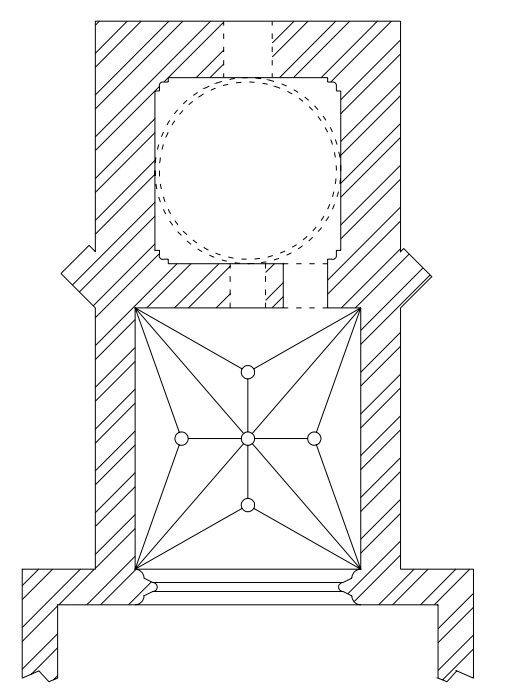

CANICOSA DE LA SIERRA. Ermita de Nuestra Señora del Carrascal. Cabecera.

Nuestra Señora de Vega (Valle de Valdelaguna). Las dos primeras, además, se construyen en el mismo año.

El camarín de la ermita de Nuestra Señora del Arroyal fue construido en 1728, por el maestro de cantería Manuel de la Torre, con un coste de 1.270 reales, a los cuales debemos sumar los 1.200 reales, que costó la ejecución del pequeño retablo que decora su espacio interior ${ }^{808}$. El resultado de ello nos ofrece una obra en la que se reproducen fielmente las características ya mencionadas. Así, vemos una pieza de planta cuadrangular, concebida como una prolongación de la cabecera, en cuyo interior se desarrolla un pequeño espacio cubierto con sencilla bóveda de crucería cuatripartita. Un amplio ventanal, abierto sobre su muro frontal, hace que toda la estancia se inunde de luz, para crear así el efecto de transparente sobre la hornacina central del retablo mayor, con la cual se comunica a través de una pequeña abertura.

\footnotetext{
808 AGDBU. LP. Palacios de la Sierra, ermita de Nuestra Señora del Arroyal, LF. (1657 - 1781). Cuentas del año 1728. Palacios de la Sierra, 14 - junio - 1728.
} 
El camarín de la ermita de Nuestra Señora del Carrascal se construye en este mismo año, y aunque desconocemos el nombre de su artífice, sabemos que su construcción supuso para esta ermita un desembolso de 2.786 reales $^{809}$. Presenta una estructura idéntica al anterior, aunque sin estribos de refuerzo en las esquinas, lo que hace que presente una imagen exterior en forma de cubo perfecto. En el interior, dibuja un espacio cuadrangular de ángulos achaflanados, cubierto, en este caso, mediante una sencilla cúpula de media naranja, alzada sobre pechinas y anillo ligeramente moldurado, de superficie interior completamente lisa. Dentro de esta estructura, vuelve a destacar el gran ventanal abierto sobre el muro del testero, a través del cual penetra la luz necesaria, para crear el efecto de transparente en la hornacina central del retablo de la capilla mayor.

El último ejemplo, el de Nuestra Señora de Vega, es obra más tardía, pues aunque no contamos con los datos, que nos sitúen con precisión el momento exacto de su ejecución, la lectura de paramentos nos indica que se trata de una construcción posterior a la cabecera, la cual había sido realizada en 1772. Sin embargo, no propicia variaciones importantes en su estructura, con respecto a los dos ejemplos ya citados. De este modo, presenta la característica imagen de bloque cúbico, adosado sobre el testero de la capilla mayor, de planta cuadrangular y muros de mampostería, reforzados en las esquinas con sillares de mejor labra, y rematados con gruesa cornisa de papo de paloma. En el interior, una sencilla techumbre de cielo raso cubre un espacio bien iluminado por el ventanal abierto sobre el muro del testero. Se ha perdido, sin embargo, el efecto de transparente, que existía en los ejemplos anteriores, ya que el vano que comunicaba con la capilla mayor ha sido cegado.

La construcción de estos camarines nos da pie para hablar también de la ejecución de transparentes. Éstos repiten el modelo introducido en la zona a finales de la

809 AGDBU. LP. Canicosa de la Sierra, ermita de Nuestra Señora del Carrascal, LF. (1608 - 1743), (fols. 147 v $^{\circ}$ - 148). Cuentas del año 1728. Canicosa de la Sierra, 5 - marzo - 1729. 
centuria anterior, con el construido en la capilla mayor de la ermita de Nuestra Señora de la Guía, en Quintanar de la Sierra. Consistía simplemente en la apertura un vano sobre el muro del testero, haciéndolo coincidir con la hornacina central del retablo, en la que se hallaba situada la imagen titular del templo. Así, con la luz filtrada desde su parte posterior, se conseguía crear el efecto nimbado, que ya hemos descrito.

Esta sencilla operación se realizó, en algunos casos, aprovechando la construcción de nueva planta de toda la estructura de la cabecera, como sucede en los templos de Santa Eulalia, Palacios de la Sierra, San Pedro, en Moncalvillo, o la ermita de Nuestra Señora del Torrejón, en Vilviestre del Pinar. De este modo, ya desde la propia concepción de la capilla se plantea la posibilidad de incorporar este efecto. En otros casos, como sucede en la iglesia de la parroquia de Santa María, en Neila, o en la de San Martín, en Vilviestre del Pinar, se trata de una obra realizada con posterioridad, sobre una estructura ya existente.

En el caso de Santa María de Neila, su construcción se debe a una donación particular, efectuada por el matrimonio de D. Francisco Benito y su esposa Dña. María Teresa Benito, los cuales, según nos indica el Visitador del Arzobispado de Burgos, D. Juan de Tobías y Zuazo, en 1755, habían dejado en su testamento la cantidad necesaria para su construcción ${ }^{810}$. La obra consiste en un simple vano abierto sobre la parte central del muro del testero de la capilla mayor, el cual se hace coincidir con la hornacina central del retablo, en la que se encuentra la imagen de Nuestra Señora con el Niño. De este modo, y aprovechando la oscuridad del interior del templo, se consigue crear el efecto escénico deseado, según el cual la imagen de la Virgen aparece suspendida sobre un haz de luz, adquiriendo con ello una sorprendente sensación de ingravidez.

810 AGDBU. LP. Neila, parroquia de Santa María, LP. (fols. $30 \mathrm{v}^{0}-35 \mathrm{v}^{0}$ ). Visita realizada a la parroquia de Santa María de Neila en 1755, por D. Juan de Tobías y Zuazo, canónigo de la catedral de Burgos. Canales, 3 - agosto - 1755. 
El de la iglesia de Vilviestre del Pinar se realiza unos años más tarde, en 1781, es decir, apenas veinte años después de concluirse la renovación de toda la parte de la cabecera y el crucero. La iniciativa de esta obra parece que parte de la propia parroquia, la cual invierte en su realización un total de 130 reales $^{811}$. Con este presupuesto se abre, como en el caso anterior, un sencillo vano adintelado sobre el muro del testero de la capilla mayor, el cual se hacía coincidir, en este caso, con el nicho ovalado del remate del retablo del altar mayor, creándose así el efecto de transparente. Actualmente, sin embargo, este vano se encuentra cegado, quedando como único recuerdo la impronta que su marco deja en la parte exterior del muro.

Una última construcción, encuadrada dentro de este grupo de piezas añadidas, es el baptisterio de la iglesia de Santa Eulalia, en Palacios de la Sierra. Aunque no tenemos datos concretos sobre su ejecución, debido a lo confuso de las anotaciones realizadas en los libros de fábrica de esta parroquia, todo apunta a que la obra se realizó entre los años 1715-16, participando en ella el maestro de cantería Francisco de Maeda. De igual forma, a través de estas mismas fuentes, y sumando los diferentes pagos anotados en estos libros, vemos que las cantidades entregadas a este maestro rondaron los 3.200 reales, si bien es muy posible que el presupuesto final superara holgadamente esta suma, pues nos consta que son varios los folios de estos documentos que han desaparecido.

La obra resultante está formada por una pequeña pieza de planta rectangular, que se incorpora en la parte de los pies del templo, sobre el ángulo formado por el último tramo de la nave central, en la que se alza el coro, y el último tramo de la nave de la Epístola. De este modo, con su incorporación se cierra esta parte del cuerpo del templo, adquiriendo así una forma de prisma perfecto. Hacia el exterior esta pieza consigue guardar una perfecta relación de proporcionalidad con el resto de la fábrica, la cual se mantiene también en su técnica constructiva, con muros completamente planos, realizados en piedra de sillería, reforzados en su esquina con un estribo de forma

\footnotetext{
811 A. P. Vilviestre del Pinar. LP. Vilviestre del Pinar, parroquia de San Martín, LF. (1755 y ss.) (fols. 148 - 150). Cuentas del año 1781. Vilviestre del Pinar, 12 - abril - 1782.
} 
prismática de lados paralelos a los del muro. La tonalidad algo más clara de esta piedra, sin embargo, delata su cronología diferente con respecto al resto de la fábrica. En su lado meridional se abren dos vanos de dintel plano, dispuestos sobre el mismo eje vertical, que forman la puerta de acceso - actualmente cegada - recercada por una doble moldura ligeramente quebrada en las esquinas y la ventana que ilumina su espacio interior.

En el interior su elemento más destacado lo constituye la cubierta, formada por una cúpula ovalada, levantada sobre anillo moldurado y pechinas en las esquinas. Su superficie interior queda compartimentada por pequeñas fajas, que confluyen en un florón central, con los campos decorados con las características yeserías con formas geométricas de perfil mixtilíneo.

Una obra, en definitiva, en la que se combina, el afán de integración dentro de la estructura anterior, con el interés por incorporar los rasgos propios de la estética barroca, mediante una decoración más movida. No obstante, al margen de estos aspectos formales, lo que más nos llama la atención es la propia concepción en sí de esta pieza, pues no es muy frecuente, dentro de la arquitectura de la comarca, la separación de estas estancias del resto del espacio interior del templo. El único precedente con el que contábamos, se encuentra en la iglesia de Santa María, en Salas de los Infantes, levantado a mediados del siglo XVII.

\section{Arquitectura civil. Siglo XVIII.}

A lo largo de este siglo XVIII, dentro de este ámbito se produce un importante incremento de la actividad constructiva, lo cual debemos considerar como una consecuencia directa del propio dinamismo económico vivido en estos pueblos a lo largo de la centuria, y del reflejo que esto tiene en el progreso de los grupos sociales 
más destacados. De esta forma, las tipologías constructivas desarrolladas a lo largo del siglo anterior, alcanzan ahora su momento de máximo apogeo, tanto en el número de creaciones, como en la calidad y brillantez con las que son concebidas. Un avance en el aspecto cuantitativo, por lo tanto, que no se ve acompañado de una evolución en las formas, pues tanto las tipologías desarrolladas, como su concepción, apenas experimentan cambios significativos con respecto al panorama descrito para la centuria pasada.

De igual modo, durante el siglo XVIII los factores económicos y sociales continúan siendo los dos elementos más destacados, que propician el desarrollo arquitectónico. En lo económico, porque, como ya señalamos al inicio de este apartado, durante la centuria se alcanza el momento de mayor esplendor de las actividades más representativas de la zona. En lo social, porque es ahora cuando culmina el proceso de ennoblecimiento, que estaba viviendo la sociedad serrana en la etapa final de la Edad Moderna, haciendo que muchos pueblos muestren porcentajes de hidalgos escandalosamente elevados, dentro de sus respectivos censos ${ }^{812}$. Estos nuevos nobles, aunque la mayoría fueran de condición muy humilde, no dejaron pasar la ocasión de mostrar, siempre que pudieron, su nuevo estado, a través de una vivienda amplia y confortable, que destacara sobre las de sus convecinos.

Los promotores de estas construcciones, por lo tanto, tenemos que buscarlos, nuevamente dentro del grupo de los ricos propietarios de rebaños de ganados y carretas, muchos de los cuales, además, habían conseguido revestir sus riquezas con la adquisición del título de hidalguía. Así, ni miembros de la alta nobleza, ni destacados representantes del estamento eclesiástico figuraron en la promoción de empresas de carácter civil, dentro de esta última centuria de la Edad Moderna.

\footnotetext{
812 Ejemplos de ello los hemos visto, dentro del capítulo dedicado a la Sociedad, en pueblos como Barbadillo de Herreros, Huerta de Abajo, Huerta de Arriba, Riocavado de la Sierra, Tolbaños de Abajo, Tolbaños de Arriba o Vallejimeno.
} 
Al hilo de todo esto, debemos decir, igualmente, que la casa solariega o blasonada continúa siendo la tipología más desarrollada, la cual, por otra parte, apenas experimenta cambios sustanciales con respecto a las características ya descritas. Así, se repite la sencilla estructura de bloque prismático, con muros completamente planos, en los que se abren pequeños y escasos vanos, acompañados de una limitada presencia ornamental, que se reduce, en la mayoría de los casos, a la inclusión de blasones, como su elemento más característico. Dentro de estos edificios la parte más cuidada sigue siendo la fachada principal, la cual se abre hacia vías o plazas importantes del trazado urbano, donde se convierten en destacados puntos de referencia. En las fachadas, además de la esmerada sillería empleada en su paramento, destaca su cuidada estructura geométrica, articulada en dos cuerpos separados por imposta plana, y rematada por aleros volados, formados por vigas ricamente talladas. Los vanos, igualmente, se reparten sobre esta superficie siguiendo una disposición perfectamente ordenada de base reticular.

El arco que enmarca la puerta de entrada, y el escudo con el que se ennoblece su imagen, siguen siendo sus elementos más singulares. No obstante, no están exentos de sufrir ciertos cambios. Así, los arcos de las puertas, como ya anunciábamos en su momento, muestran ahora una rosca casetonada, que se convierte en su elemento más representativo. Los escudos, por su parte, aunque mantienen su anterior contorno cuadrilongo, decoran ahora su parte exterior con diferentes motivos ornamentales, que van desde un sencillo sogueado, hasta la inclusión de penachos de plumas, lambrequines, y ostentosos yelmos.

Cambios escasos y de carácter ciertamente epidérmico, pero muy significativos a fin de cuentas, pues merced a ellos, en muchas ocasiones, podremos catalogar construcciones para las que no tenemos otra fuente de información que el mero análisis formal. 
La estructura interna, por su parte, tampoco registra variaciones destacadas con respecto al modelo ya descrito durante la centuria anterior. De hecho, es aquí donde menor número de variaciones vamos a encontrar, pues ni las necesidades de sus propietarios ni los propios requisitos generados por las ocupaciones de éstos, obligan a introducir cambios en la distribución y características de las estancias.

Respecto a su ubicación, la tendencia general es la de aparecer ligeramente separadas del resto del caserío, sin lindar con otros edificios, que no fueran los pertenecientes al mismo propietario, los cuales eran utilizados como estancias auxiliares de las actividades económicas. Aun así, tampoco resulta extraño encontrarnos agrupaciones de edificios, que forman manzanas enteras, o delimitan espacios más amplios, dentro de cuyas fachadas se intenta seguir un esquema uniforme, respetando unas mismas características estilísticas y proporciones. Con ello se pretende crear una imagen urbana de cierto orden, que contrasta con el caos y la espontaneidad habitual, generada dentro de la arquitectura popular. De este modo, las casas solariegas consiguen afianzar su propio carácter diferencial, al mismo tiempo que realzan su imagen, al poder contemplarlas en un marco amplio y despejado. Ejemplos sumamente representativos de ello los encontramos en Barbadillo de Herreros, en el grupo que forman los inmuebles de los números 1, 3, 5 y 7 de su calle Mayor, en Huerta de Arriba, entre los números 25, 25 bis y 29 de la calle Moralas, y en Salas de los Infantes, en el grupo de casas que rodean la plaza de Santa María, abierta frente a la iglesia del mismo nombre.

Los ejemplos que podemos citar de esta tipología, correspondientes a al siglo XVIII, se concentran en general en las mismas localidades que ya señalamos durante la centuria anterior, es decir, núcleos ligados fundamentalmente a la ganadería trashumante, como los del Valle de Valdelaguna, Barbadillo de Herreros, Riocavado de la Sierra, Neila y Monterrubio de la Demanda. A ellos podemos unir también otros casos, como los conservados en Salas de los Infantes y Vilviestre del Pinar. En varios de estos pueblos se logran desarrollar interesantes conjuntos de casas blasonadas, con las que se configura su imagen más representativa. En otros, sin embargo, las renovaciones 
experimentadas en sus caseríos a partir de las últimas décadas del siglo $\mathrm{XX}$, han terminado por distorsionar, cuando no destruir por completo, la mayor parte de estas construcciones.

La localidad de Barbadillo de Herreros constituye, sin duda alguna, uno de los núcleos que mayor número de casas de este tipo, y de mejor calidad, ha logrado conservar. Varias de ellas, además, se encuentran agrupadas en grandes manzanas o dispuestas en torno a plazas, con las que se delimitan espacios, que sirven de marco ideal para sus fachadas principales, al mismo tiempo que desarrollan tímidos intentos de organización urbanística. El mejor ejemplo de ello, como ya indicábamos, lo encontramos en la parte oriental del pueblo, en el conjunto formado por las casas situadas en los números 1, 3, 5 y 7 de su calle Mayor. De ellas, las tres primeras están agrupadas en una manzana, formando sus fachadas un solo frente de estructura uniforme, en el que predomina un marcado carácter horizontal, y fuerte predominio del muro sobre el vano, que se remata con un volado alero. El número 7, por su parte, se dispone formando un ángulo recto con respecto a aquellas, delimitando uno de los lados de la pequeña plaza, que surge como una ampliación de la calle mayor.

Las cuatro casas presentan unos rasgos similares, con fachada principal completamente plana, realizada en sillarejo, con esquinas y marcos de los vanos reforzados con sillares de mejor labra, articulada en dos cuerpos y rematada por un volado alero, formado por las cabezas salientes de las vigas del tejado. Sobre el eje central del tramo correspondiente a cada una de ellas se dispone la puerta de entrada, formada por un amplio arco de medio punto, alzado sobre impostas planas de escaso resalte, y con rosca casetonada. Sobre esta puerta, en la planta principal, se abre un balcón, al que se accede a través de una puerta de dintel plano, enmarcado, en el número 1, con moldura rehundida de perfil quebrado, dibujando orejones, y coronada en su parte central, por una pequeña cruz. Sobre el dintel de esta puerta del balcón, en los números 1 y 3, se incluyen además sendas inscripciones, en las cuales se indican los nombres de sus promotores y las fechas de su realización. En la primer la inscripción 


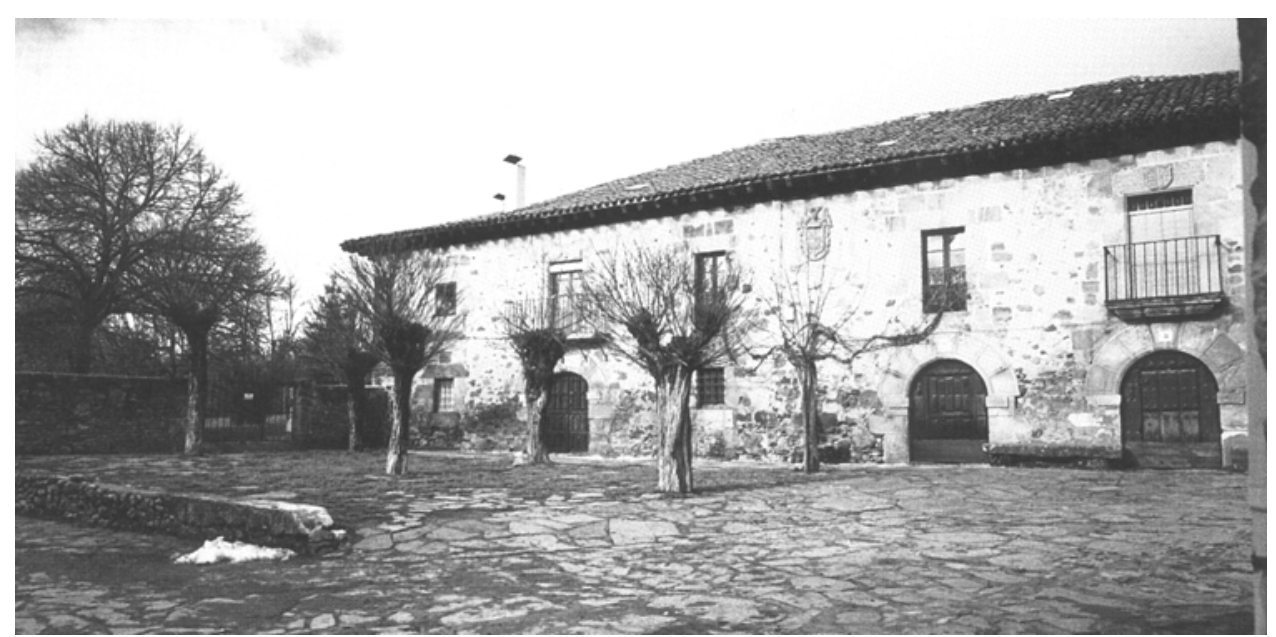

BARBADILLO DE HERREROS.

Calle Mayor $n^{\circ} 1-3-5$.

dice únicamente: AÑO DE 1739. En la segunda se amplía, indicando lo siguiente: IHS MARÍA Y JOSEPH / REDIFICARON ESTA CASA / D. MANVEL GIL DE LA CVESTA / Y D. ANA MARIA DE SEDANO / SV MVGER AÑO DE 1737. Esto nos confirma que todo el conjunto fue realizado siguiendo una idea preconcebida, a partir de la cual se intentaba crear, de forma deliberada, un espacio disgregado de la calle mayor, delimitado en sus frentes por fachadas en las que se respeta un orden esquema regular.

La segunda inscripción está acompañada por un escudo, enmarcado por un sencillo cordón, de campo partido, $1^{\circ}$ con cuatro fajas cargadas cada una de ellas con tres cruces en aspa, y $2^{\circ}$ con una cotiza cargada con tres cruces en aspa, acompañada por dos torres donjonadas, una en el cantón siniestro del jefe y otra en el cantón diestro de la punta.

Otro escudo aparece coronando la fachada del número 3, dispuesta sobre uno de los lados del balcón del piso principal. En este caso se trata una pieza algo más compleja, pues aparece recercado por una serie de ornamentos, compuestos por cintas 
dispuestas en forma de ces y eses, las cuales culminan en un yelmo con penacho de plumas, que timbra el escudo. Su campo aparece partido y cortado de dos, $1^{\circ}$ con una travesa acompañada de dos veneras, una en el cantón diestro del jefe y otra en el cantón siniestro de la punta, $2^{\circ}$ con león rampante, $3^{\circ}$ castillo donjonado con tres torres, $4^{\circ}$ una flor de lis, y $5^{\circ}$ y $6^{\circ}$ con una caldera cada uno.

Lo más destacado de este grupo de casas, obviamente, queda representado por la propia unidad que forma todo el conjunto, dentro de la cual se mantiene una misma proporción y disposiciones, creando así un espacio homogéneo y bien ordenado, en el que todavía podemos apreciar el concepto urbanístico, que aquí se pretendía desarrollar.

Próxima a este conjunto, se halla la casa situada en la calle Mayor $n^{\circ} 4$. Se trata de un gran edificio aislado, alzado sobre una amplia planta rectangular, con la que se consigue una estructura prismática perfecta, de muros de sillarejo y mampuesto, reforzados en las esquinas y en los marcos de los vanos con grandes sillares de buena labra. Cuenta con dos fachadas principales, orientadas respectivamente hacia levante y mediodía, en las cuales se repite el mismo esquema compositivo, es decir, estructura geométrica, articulada en dos pisos rematados con alero volado, sobre cuya superficie se disponen los vanos cuidadosamente ordenados siguiendo un esquema de base reticular. Sobre el eje central de cada una de ella se abre una puerta de acceso, coronada con arco de medio punto ligeramente rebajado, alzado sobre impostas planas. En este mismo eje, en su plata principal, se dispone un balcón con puerta adintelada, como ocurriera en los casos anteriores.

La misma estructura, con muy ligeros cambios, se repite en las casas situadas en la calle San Esteban $n^{\circ} 26$ y calle Francisco Granmontagne $n^{\circ}$ 57, construidas con sólo dos años de diferencia. En ambas aparece una gran masa prismática de planta cuadrangular y muros de sillarejo, articulados en dos cuerpos, rematados por un pronunciado alero, y cubierta dispuesta a cuatro aguas. La fachada principal de cada una de ellas nos presenta un amplio lienzo de estructura rectangular y composición 


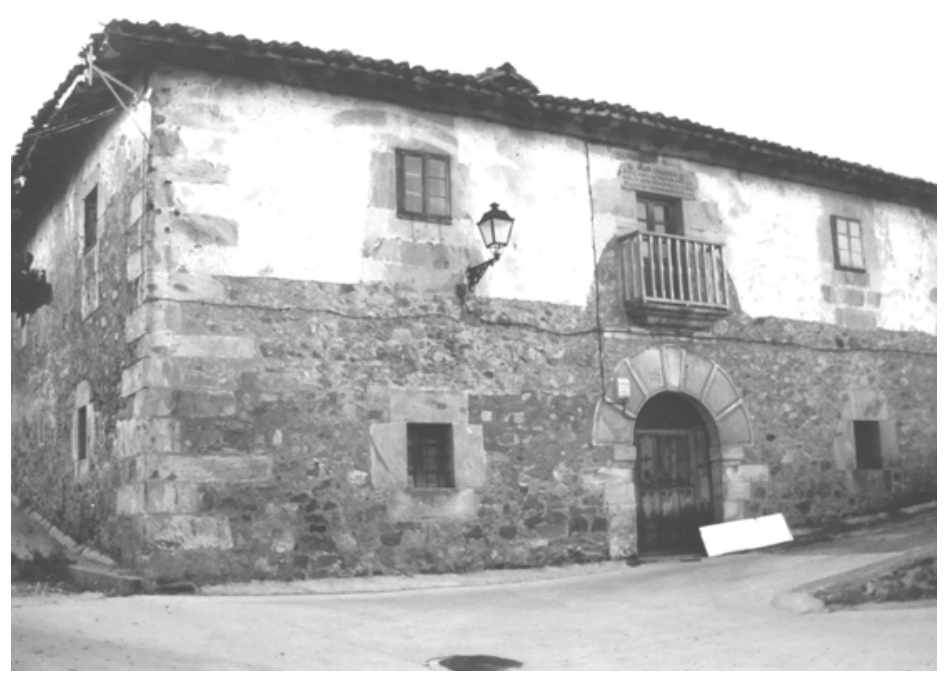

BARBADILLO DE HERREROS.

Calle de San Esteban $n^{\circ} 26$

simétrica, con tres vanos en cada planta, articulados en ejes verticales, con la puerta de acceso situada en el centro de la planta baja, cubierto con arco de medio punto de rosca casetonada y pequeño balcón abierto sobre ella, dispuesto sobre una pequeña plataforma de perfil moldurado. Es precisamente sobre el dintel de la puerta, que conduce a este balcón, donde se incluye la inscripción aclaratoria, sobre la fecha y nombres de los promotores de cada una de las construcciones. La primera de ellas, la de San Esteban $\mathrm{n}^{\circ}$ 26, con fachada orientada hacia el mediodía, incluye la siguiente leyenda: IHS MARÍA I JOSEPH / FABRICARON ESTA CASA MANVEL / GARCÍA DE SEGVRA I SV MVGER TERESA / DE LA BARGA Y SEDANO AÑO DE 1730.

La situada en Francisco Granmontagne $n^{0} 57$, por su parte, presenta su fachada principal mirando hacia poniente, abriéndose frente a ella una pequeña plazoleta, delimitada en uno de sus frentes por el ábside y la torre de la iglesia, y en el otro por el muro, que sirve de talud, al hallarnos en superficie inclinada. Sobre el dintel de la puerta de su balcón podemos leer el siguiente texto: IHS MARÍA Y JOSEPH / FABRICARON ESTA CASA JOSEPH GARCÍA SEGURA Y MARÍA DE LA BARGA SV MVGER 
AÑO DE 1732. Esta evidente relación de parentesco que existe entre los promotores, unido la proximidad cronológica entre ambos proyectos y a la afinidad de sus formas, nos lleva a pensar necesariamente en la participación de los mismos artífices.

Sin salir de esta localidad, y dentro de la variante más característica de la tipología de casas blasonadas dispuestas de forma aislada, uno de los ejemplos más brillantes, tanto por sus dimensiones, como por su cuidada composición, se encuentra en el edificio formado por los números 46, 48, 50 de la calle Mayor. Evidentemente, esto nos indica que nos encontramos ante una casa actualmente fragmentada en diferentes viviendas, lo que ha hecho que toda su compartimentación interna haya desaparecido. No mucha mejor suerte ha corrido su imagen exterior, si bien, aquí todavía podemos apreciar su volumetría, formada por un gran prisma levantado sobre planta cuadrangular, cubierta con tejado dispuesto a cuatro aguas, con muros completamente planos de mampuesto y sillarejo, reforzados en las esquinas con sillares de mayor tamaño, articulados en dos cuerpos, rematados con un grueso friso y un una cornisa de papo de paloma, al que sigue el alero, formado por las cabezas de las vigas del tejado.

La parte más destacada vuelve a ser la fachada principal, la cual queda orientada hacia naciente, buscando con ello la mejor disposición en relación con los puntos más destacados del pueblo, como son la Plaza Mayor y la iglesia parroquial. Esta fachada, sin embargo, ha sido brutalmente mutilada por las propias reparticiones, y por las obras de remodelación, destacando en este aspecto las efectuadas durante la última década del siglo XX. Para reconstruir la imagen de su estructura original, por lo tanto, debemos valernos del material fotográfico, tomado con anterioridad a estas bárbaras obras. Así podemos saber que esta fachada presentaba el tradicional diseño geométrico de estructura rectangular articulada en dos plantas, separadas por una línea de imposta plana. En la planta baja se abría un único vano, situado en su parte central, que formaba la puerta de acceso, coronada con el tradicional arco de medio punto de rosca casetonada. Sobre este mismo eje, en la planta principal, se situaba un balcón de escaso vuelo, proyectado sobre una pequeña plataforma de piedra ligeramente moldurada, al 


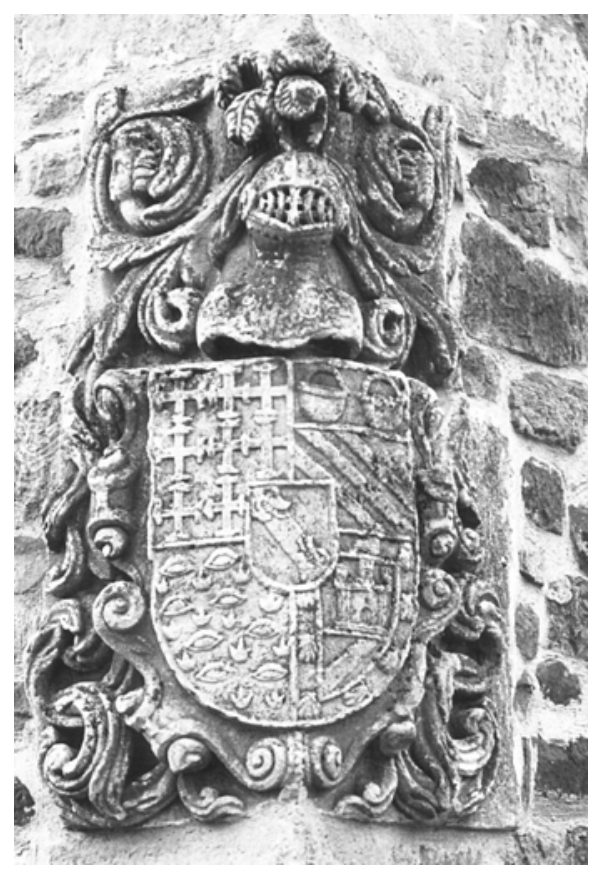

BARBADILLO DE HERREROS.

Calle Mayor no 46. Escudo.

que se accedía a través una puerta de dintel plano recercado con moldura plana de escaso resalte con orejones. Este mismo tipo de marco se repetía en las otras dos ventanas abiertas en la planta principal, dispuestas a cada uno de los lados del balcón ${ }^{813}$.

Un escudo, dispuesto sobre la puerta de este balcón, en correspondencia con el eje central de la fachada, culmina toda su estructura. Presenta el característico contorno en forma cuadrilonga, dispuesto sobre ornamentación de cueros recortados. De campo partido y cortado de dos, $1^{\circ}$ y $4^{\circ}$ con castillo donjonado con tres torres, $2^{\circ}$ con león contornado, $3^{\circ}$ con león rampante, y $5^{\circ}$ y $6^{\circ}$ con calderas. Sin embargo, este no es el único elemento heráldico con el que cuenta el edificio. Así, en la esquina nororiental de la planta principal, mirando hacia la calle y plaza mayor, aparece un imponente escudo de estructura cuadrilonga y contorno rodeado por agitados cueros recortados $\mathrm{y}$ lambrequines, que culminan en un desafiante yelmo tocado con vistoso penacho de

813 De todo ello actualmente sólo se conserva el marco de una de las ventanas del piso superior, pues el resto ha desaparecido sin dejar el más mínimo rastro. De este modo, resulta totalmente imposible apreciar hoy la estructura original de esta fachada. 
plumas. Su campo aparece cuartelado en cruz, $1^{\circ}$ con ocho cruces potenzadas dispuestas en tres palos de tres, tres y dos, $2^{\circ}$ con dos calderas dispuestas en faja sobre el jefe y tres bandas en el resto, $3^{\circ}$ cubierto con ocho ojos y doce llamas, dispuestos de manera desordenada, $4^{\circ}$ cortado, $4-1$ castillo donjonado con tres torres, $4-2$ una barra, bordura con ocho veneras. Y sobre el todo escusón con una banda.

Nos hallamos, con todo ello, ante uno de los ejemplos más interesantes de esta tipología de casas blasonadas, dentro de la comarca de la sierra burgalesa. Así, vemos que se trata de un edificio sobrio y bien proporcionado, organizado sobre a un gran módulo cerrado de limpias superficies, con una estructura dominada por un estricto sentido del orden y del equilibrio compositivo.

Muy próxima a esta casa, en la calle Mayor $n^{\circ} 48$, y por lo tanto, también en las inmediaciones de la plaza mayor y junto a la iglesia parroquial, se levanta otro de los ejemplos más interesantes de casa solariega de estructura aislada. Se trata de un edificio conocido popularmente como la casa de los Sedanos, pues fue levantada por un miembro de esta familia durante el siglo $\mathrm{XIX}^{814}$. Se trata, por lo tanto, de un ejemplo ciertamente tardío, en el que se mantienen, sin embargo, todas las características propias de este tipo de construcciones. Presenta la misma estructura que los ejemplos anteriores, si bien cuenta en su alzado con una planta más, lo que hace que adquiera la imagen de un gran cubo con cubierta dispuesta a cuatro aguas. Todos sus muros están realizados en mampostería, reforzados con grandes sillares en las esquinas. Su parte superior, al mismo tiempo, aparece recorrida por un friso, que da paso a un alero volado, formado por las cabezas de las vigas del tejado. Su fachada principal queda orientada sorprendentemente hacia el norte, si bien se halla protegida por los edificios situados frente a ella. Su lienzo, de forma cuadrangular, está articulado en tres alturas, con tres vanos en cada una de ellas, que se corresponden entre sí, formando ejes verticales, con los que se introduce un marcado carácter ascensional. Dentro de ellos, solamente los situados sobre el eje central de la planta baja y piso principal reciben un tratamiento

814 C. RUBIO VELASCO: Barbadillo de Herreros. Burgos, Imprenta Santos, 2001. (pp. 256 - 259). 
destacado, mientras que el resto muestran el característico marco con moldura plana de escaso resalte con orejones. Los dos vanos centrales, que forman respectivamente la puerta de acceso y un pequeño balcón, muestran, por su parte, una estructura adintelada con marco almohadillado. La estructura del balcón, como en los casos anteriores, queda formada a través de una pequeña plataforma moldurada de escaso resalte, que en este caso se extiende ligeramente hacia los lados, colocando sobre sus extremos pináculos piramidales. Dos pequeñas aletas avolutadas realizan la unión entre esta plataforma y la puerta del balcón.

La fachada se completa con la incorporación de dos escudos, situados en la planta principal, a ambos lados del balcón. Ambos presentan el tradicional contorno cuadrilongo, dispuesto sobre placas recortadas, con abundante decoración de lambrequines a su alrededor y timbrados con yelmo tocado con penacho de plumas. El situado en la parte derecha de la fachada presenta campo cuartelado en cruz con el $1^{\circ}$ cuartel ocupado por un castillo donjonado con tres torres, $2^{\circ}$ con tres bandas y siete veneras intercaladas entre ellas, $3^{\circ}$ con dos calderas dispuestas en faja, y $4^{\circ}$ con león rampante. El segundo de estos escudos, situado al lado contrario, repite la misma división cuartelada en cruz, con $1^{\circ}$ cuartel con tres palos, $2^{\circ}$ una barra, $3^{\circ}$ cuatro cruces potenzadas dispuestas en dos palos dos y dos, $\mathrm{y} 4^{\circ}$ con seis ojos entre lenguas de fuego dispuestos de forma no ordenada.

En definitiva, este edificio, aunque tardío, ofrece un ejemplo sumamente interesante de este tipo de casas, en el que se intentan plasmar determinados elementos propios del lenguaje arquitectónico culto, siguiendo en su aplicación unos criterios de marcado carácter clasicista. Nos referimos muy especialmente al almohadillado que enmarca los vanos centrales de esta fachada principal, el cual ya había sido utilizado con anterioridad en otras construcciones realizadas en este pueblo dentro del siglo XVIII. 
Es el caso de los inmuebles situados en la calle Francisco Granmontagne $n^{\circ} 54$ y en la calle Mayor $n^{\circ} 27$. El primero de ellos repite el tradicional esquema, que estamos viendo en los ejemplos de edificios aislados, con estructura prismática alzada sobre planta cuadrangular, de muros de mampuesto articulados en dos cuerpos, reforzados en las esquinas con sillares de mayor tamaño, y rematados con un alero volado, formado por las cabezas de las vigas del tejado. De igual forma, su fachada principal, orientada hacia el mediodía, muestra un lienzo rectangular, de dos cuerpos, con tres vanos en cada uno de ellos, dispuestos en perfecta correlación, dentro de los cuales, solamente los del eje central reciben un tratamiento especial. El de la planta baja, que forma la puerta de acceso, está coronado con arco de medio punto de rosca casetonada dispuesto sobre impostas planas, mientas que el de la planta principal, que conduce hacia el balcón, presenta dintel plano con un marco almohadillado, similar al que luego se repite en el caso que acabamos de ver. Sobre este dintel se incorpora una breve inscripción en la que se indica el momento de construcción: AÑO 1771.

El caso de la calle Mayor $n^{\circ} 27$, constituye un ejemplo más modesto. Presenta una planta trapezpoidal, sobre la que se alza una estructura prismática de muros de mampuesto, articulados en dos plantas, reforzados en las esquinas por sillares de mejor labra, y rematados por un volado alero, en el que destaca la cuidada talla de varias cabezas de sus vigas, convirtiéndose esto en su elemento más singular. La fachada principal, dispuesta sobre su lado más corto, y orientada hacia el mediodía, presenta un pequeño lienzo cuadrangular, dentro del cual se distribuyen vanos de dintel plano sin orden aparente. Dentro de ellos, el único que recibe un tratamiento especial es el situado sobre la puerta de acceso, que da paso a un pequeño balcón de escaso vuelo, en el cual se repite el marco almohadillado, que veíamos anteriormente.

A pocos kilómetros de esta localidad se encuentra Riocavado de la Sierra, la cual ofrece también un conjunto ciertamente interesante de este tipo de construcciones. Estos ejemplos, sin embargo, se encuentran diseminados dentro del propio casco urbano, sin llegar a crear conjuntos de casas dispuestas según un plan preconcebido, como los 
vistos en algunos ejemplos de Barbadillo de Herreros. Las características que presentan todas ellas, no obstante, se continúan ajustando a las normas propias de la interpretación que la tipología de las casas solariegas tiene en la zona de la sierra.

Así, son varios los ejemplos que muestran la estructura prismática, levantada sobre planta cuadrangular, articulada en dos cuerpos, con muros de mampuesto reforzados en las esquinas con sillares de mejor labra y remate con alero volado. Los ejemplos más destacados se encuentran en la calle de las Eras $n^{\circ} 1$, calle de la Olma $n^{o}$ 17, calle San Juan $n^{\circ} 11$, calle San Joaquín $n^{\circ} 21-23$, y calle Real $n^{o} 17$. En todas ellas, evidentemente, la parte más destacada lo constituye su fachada principal, orientada hacia naciente en los dos primeros casos y al mediodía en los tres restantes. Son fachadas que presentan la característica estructura geométrica con lienzo rectangular, articulada en dos pisos con tres vanos en cada uno, dispuestos en perfecta correlación entre ellos, siguiendo los ejes verticales. De ellos, solamente los dispuestos sobre el eje central reciben un tratamiento muy cuidado, mostrando el resto una sencilla estructura adintelada sin ningún tipo de adorno en su marco. El central de la planta baja, que conforma la puerta de acceso, está coronado, en todos los casos, con arco de medio punto de rosca casetonada, como suele ser frecuente durante la centuria. Justo encima de la puerta, en la planta principal, se abre un balcón, dispuesto sobre plataforma moldurada con ligero saliente. La puerta de acceso a este balcón muestra, igualmente, un simple vano adintelado, sobre cuyo dintel es frecuente encontrar algún tipo de inscripción alusiva al año de su construcción junto con los nombres de sus promotores.

En el caso de la calle Real $n^{\circ} 17$ esta leyenda se sitúa, sin embargo, en la clave del arco de entrada, indicando únicamente el año 1744 de su construcción. La inscripción está acompañada por un pequeño escudo de contorno cuadrilongo, con campo ocupado por unas llaves en aspa, escoltadas por dos flores. 


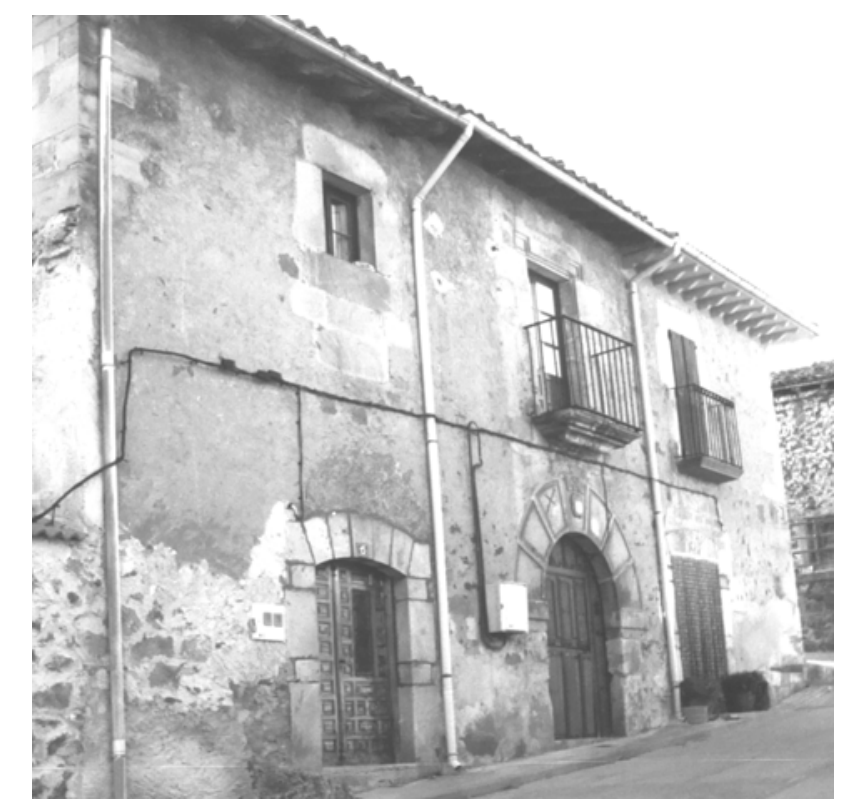

RIOCAVADO DE LA SIERRA.

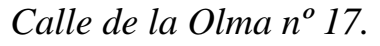

La casa de la calle de las Eras $n^{\circ} 1$ ha eliminado el balcón sobre la planta principal, para sustituirlo por una pequeña ventana. No obstante, su dintel recoge igualmente una leyenda, en la que se lee lo siguiente: AÑO DE 1788 / FABRICARON ESTA CASA PEDRO CRESPO I SU MVGER ACEDA GARZIAR / JESÚS MARÍA Y JOSEPH. La situada en la calle San Juan $n^{\circ} 11$ muestra la siguiente inscripción: AÑO DE IHS 1742 / FABRICARON ESTA CASA MANUEL GARCÍA / SAINZ Y MARÍA APARICIO SV MVGER. La casa de la calle de la Olma $n^{\circ} 17$, además de un marco recercado con una doble moldura quebrada con orejones, sobre este dintel podemos leer el siguiente texto: FABRICARON ESTA CASA DON JVAN / DE LA BARGA Y SEDANO / CURA BENEFICIADO DE ESTA / VILLA AÑO 1733. Bajo este baldón, y sobre la clave del arco de la puerta de entrada, podemos ver también una pequeña cartela con unas llaves cruzadas, escoltada por la inscripción IHS-MARÍA. Se trata de uno de los escasos ejemplos, en los que aparece un miembro del estado eclesiástico como promotor de una obra de este tipo.

Por último, la casa situada la calle San Joaquín $n^{\circ}$ 21-23, tras las remodelaciones emprendidas durante la última década del siglo XX, ha perdido toda la 
estructura del balcón de su segundo piso, y con ella la inscripción que existía sobre el dintel, junto a la cual aparecía también un pequeño escudo. La existencia de estos elementos hemos podido conocerla a través de fotografías tomadas con anterioridad a las obras de remodelación, sin embargo, la mala calidad de las mismas nos impiden descifrar el contenido de los mismos.

Huerta de Arriba es otra de las localidades de la comarca, que nos ofrece una destacada relación de casas solariegas, levantadas durante la centuria del Setecientos. Con estas construcciones, en definitiva, lo que se hace es continuar el importante impulso constructor de este tipo de edificaciones, que ya se había vivido aquí durante el siglo anterior, dando ahora sus mejores frutos. En general, podemos decir que todos los inmuebles conservados en este núcleo se ajustan en mayor o menor medida a los rasgos generales, que venimos observando en el resto de ejemplos de esta tipología. Las únicas variantes, por lo tanto, vendrán marcadas por las posibilidades y recursos de sus promotores.

El ejemplo más temprano de casa de este tipo lo encontramos en la calle de las Huertas $n^{\circ} 55$. Se trata de una construcción muy sencilla y de marcado aire popular, en la cual todavía se aprecian, de forma evidente, los rasgos propios de la centuria anterior. Así, muestra una sencilla estructura cúbica, levantada sobre planta cuadrangular de reducidas dimensiones, y alzado articulado en dos cuerpos, con muros de mampostería, reforzados en las esquinas con sillares de mejor labra, y rematados con alero volado. Su fachada principal queda orientada hacia el mediodía, destacando en ella únicamente la puerta de acceso, con arco de medio punto de rosca sin decorar, y la ventana del cuerpo superior, con dintel plano y marco con moldura plana con orejones. Sobre este dintel se inscribe la fecha de construcción con la siguiente leyenda: AÑO 1701 IHS. Se confirma su pertenencia a esta centuria, aunque formalmente se halle ligada todavía al siglo XVII.

Las novedades propias de la nueva centuria se muestran ya con todo su vigor en el edificio formado por los números 20, 22, y 24 de la calle Mayor, construido, según 
nos indica la inscripción conservada sobre el dintel de uno de sus vanos, en 1716. Se trata de un edificio muy alterado por las particiones efectuadas sobre su estructura, lo cual ha propiciado que desaparezcan alguno de sus elementos más destacados, como es el caso de su portada principal, recientemente eliminada ${ }^{815}$. Aun así conserva la estructura volumétrica original, en la que se manifiesta un edificio de forma prismática, dispuesto sobre amplia planta cuadrangular, con alzado articulado en dos cuerpos, separados, en la fachada principal, por una imposta plana, con muros de sillarejo y mampuesto, reforzados en las esquinas con sillares de mejor labra, que se repiten en el recercado de los vanos.

La fachada principal, dispuesta sobre la calle Mayor, y orientada hacia naciente, es, sin duda, una de las partes que más daños ha sufrido, de tal modo, que para poder hacernos una idea de su aspecto original tenemos que valernos de las fotografías tomadas con anterioridad a estas últimas reformas. Presenta, en cualquier caso, el característico lienzo rectangular, articulado en dos pisos, separados, como hemos dicho, por una línea de imposta plana. No conocemos la distribución original de los vanos, si bien, a través de los restos conservados, y las imágenes que hemos visto de su estado durante la década de 1970, parece que no existía un orden preciso. Dentro de ellos destacaba, no obstante, la puerta principal, dispuesta sobre el eje central de esta fachada, en la cual aparecía un amplio arco de medio punto de rosca casetonada, escoltado a los lados por pilastras cajeadas, rematadas con sencillos pináculos piramidales. Una obra, por lo tanto, ciertamente interesante, en la que, de forma tímida, se muestran rasgos propios del lenguaje culto, que hasta el momento sólo estabamos acostumbrados a ver en obras de carácter religioso. Una segunda puerta, coronada también con arco de medio punto sobre impostas planas, se abre en uno de los extremos de esta fachada principal, la cual conduciría, seguramente, al interior de algún tipo de dependencia auxiliar.

\footnotetext{
815 Ha desaparecido dentro de la renovación que se efectuó en 1997 en la parte correspondiente al número 22 de esta calle.
} 


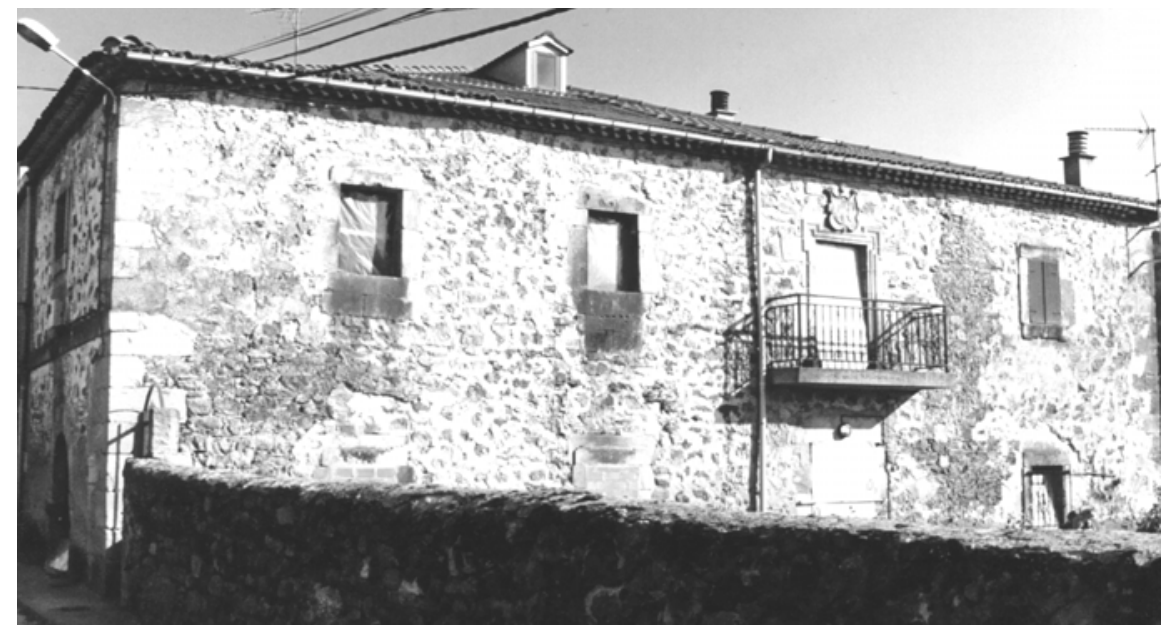

HUERTA DE ARRIBA. Calle

Mayor $n^{\circ}$ 20, fachada de poniente.

Mejor suerte ha corrido la fachada lateral de poniente, la cual conserva todavía la disposición original de sus vanos, con cuatro ventanas de dintel plano enmarcadas con moldura plana con orejones, en cada planta, dispuesta en perfecta correlación entre uno y otro piso. Dentro de estos vanos, el situado en tercer lugar, de la planta principal, comenzando por la izquierda, constituye el acceso a un pequeño balcón, recibiendo por ello un tratamiento especial. Presenta así un marco formado por una doble moldura quebrada, marcando los orejones, sobre cuyo dintel se incluye un escudo en el centro, de forma cuadrilonga, enmarcado por una decoración de cueros recortados y rocallas, que culmina en un yelmo con penacho de plumas en su parte superior. Su campo aparece cortado y partido de dos, $1^{\circ}$ tajado con dos barras y con una estrella de seis puntas en el cantón diestro del jefe y una panela en el cantón siniestro de la punta, $2^{\circ}$ con seis árboles dispuestos en dos fajas de tres y tres, $3^{\circ}$ partido 3-1 castillo donjonado con tres torres, 3-2 con una pluma y una caldera dispuestos en palo, $4^{\circ}$ león contornado, $5^{\circ}$ castillo donjonado con tres torres, y $6^{\circ}$ león rampante. A los lados de este escudo se extiende una inscripción, en la cual solamente se conserva la parte final, que indica el año 1716, correspondiente a la fecha de construcción del edificio, mientras que el tramo 
634 Arquitectura de la Edad Moderna en la sierra burgalesa.

inicial, donde aparecerían, con toda seguridad, los nombres de sus promotores, ha sido convenientemente borrado.

De 1724 es la casa situada en la calle Sebastianas $n^{\circ} 14$. Dentro de este conjunto destaca, una vez más, su fachada principal, orientada hacia el noreste, de estructura rectangular, articulada en dos cuerpos separados por línea de imposta plana. La disposición de sus vanos ha sido alterada, con lo cual no resulta fácil reconstruir su composición original, sin embargo, todavía se conserva su majestuosa puerta de entrada, abierta sobre la parte central del cuerpo inferior, y coronada con arco de medio punto de rosca casetonada. En el piso principal, en correlación con el eje trazado por la puerta, se abre una pequeña ventana de dintel plano, acompañada de una inscripción en la parte inferior y un escudo sobre el sillar que forma el dintel. La inscripción recoge el siguiente texto: IHS MARÍA - FABRICARON / ESTA CASA ANDRÉS FERNANDEZ DE LA C / VESTA I SEGURA I SU MVGER ANA PEREZ / GIL DE LA CVIESTA AÑO DE 1724. El escudo, por su parte, presenta el habitual contorno cuadrilongo, recercado, en este caso, por un sencillo cordón, similar al que ya hemos visto en otros ejemplos de edificios construidos durante esta centuria. Su campo, cuartelado en cruz, está ocupado en el $1^{\circ}$ cuartel por una afiligranada cruz de Calatrava, $2^{\circ}$ con un castillo donjonado con tres torres, $3^{\circ}$ con dos aspas en el cantón diestro del jefe y una panela en el cantón siniestro de la punta, y $4^{\circ}$ tajado por dos barras con una estrella de seis puntas sobre el cantón diestro del jefe.

Construido en la misma década, y con un esquema muy similar, aunque de estructura simplificada con respecto al ejemplo anterior, tenemos la casa situada en la calle de las Huertas $n^{\circ}$ 127. Se trata de una fábrica muy alterada por las obras posteriores, con estructura prismática de muros de sillarejo reforzados en las esquinas con sillares de mejor labra, y fachada principal orientada hacia naciente. Dentro de ella, el único elemento destacable es la portada, coronada con el tradicional arco de medio punto de rosca casetonada. Una inscripción, situada sobre el dintel de una de las ventanas abiertas en la planta principal, nos informa, al mismo tiempo, del nombre de 
sus propietarios y del año de construcción. En ella podemos leer lo siguiente: IHS MARÍA I JOSEPH FABRICARON / ESTA OBRA JO(SE) LOPEZ I SV / MVJER ISABEL ARNAIZ / OCHOA AÑO DE 1729. No existe, sin embargo, ningún escudo que ennoblezca su imagen.

Próxima a esta casa, en la antigua calle de las Huertas $n^{\circ} 29$, actual calle Moralas, se alza otro interesantes ejemplo de este tipo de construcciones. Se trata, en este caso, de un sencillo edificio en el que se desarrolla la tradicional estructura prismática, levantada sobre planta cuadrangular con alzado articulado en dos cuerpos, de muros de mampostería con refuerzo de sillares de mejor labra en las esquinas y coronados con un volado alero. Su fachada principal, orientada hacia poniente, nos presenta la habitual disposición de vanos, con la puerta de entrada en la parte central de la planta baja, coronada con arco de medio punto, acompañada de dos pequeñas ventanas de dintel plano a los lados, que se corresponden en el piso superior con ventanas similares, dispuestas sobre sus mismos ejes. De estas ventanas, solamente la situada en el centro del piso principal, sobre el eje de la puerta, recibe un tratamiento más cuidado, con un marco formado por moldura plana con orejones, sobre cuyo dintel aparece un sencillo escudo acompañado por la siguiente leyenda: OCHOA AÑO DE 177( ). El escudo muestra el habitual contorno cuadrilongo, desprovisto, en este caso, de decoración exterior. Su campo cuartelado en cruz está ocupado $1^{\circ}$ por una cruz de Jerusalén, $2^{\circ}$ con punta de lanza, $3^{\circ}$ con estrella de seis puntas y panela colocados en palo, y $4^{\circ}$ con tres barras. Un conjunto, por lo tanto, que dada su sencillez, nos recuerda más a los modelos desarrollados durante la centuria anterior, que a los propios de siglo XVIII.

Justo frente de a ella, en el número 25 bis nos encontramos otro edificio sumamente interesante, el cual cuenta con una pequeña construcción adosada sobre uno de sus laterales, dispuesta en ángulo recto, con lo que se delimita el espacio abierto frente a ella para formar una pequeña plaza. La fachada de este edificio presenta un lienzo rectangular de mayores dimensiones que el anterior, articulada en dos cuerpos 
con vanos distribuidos de forma perfectamente ordenada, según ejes verticales, que relacionan ambas plantas. Varios son los elementos que debemos destacar aquí. En primer lugar la puerta de acceso, compuesta por un sencillo arco de medio punto de rosca plana, que nos recuerda, como el caso anterior, las formas más sobrias del siglo XVII. Sobre ella, dentro de este eje central, se abre una ventana abalconada de dintel plano, enmarcado, como el resto de las ventanas, con moldura plana de escaso resalte con orejones. Una amplia inscripción recorre el dintel de este vano, y en ella podemos leer el siguiente texto: IHS MARÍA Y JOSEPH SEAN CONMIGO D. FRANZISCO GARZÍA DE SANTA COLOMA COMISARIO DEL SANTO / OFICIO. Intercalado dentro de esta inscripción se alza un escudo de contorno cuadrilongo, deprovisto, como en el caso precedente, de decoración exterior. Su campo aparece ocupado por una amplia cruz flordesilada acompañada de cuatro estrellas en el centro, con una espada en el cantón diestro del jefe, en el lado contrario una pluma y una pequeña cruz latina, y dos panelas en la punta, dispuestas en faja. Una pieza, por lo tanto, que confirma la pertenencia de este promotor al Santo Oficio, pues en su escudo de armas se incluyen varias de las figuras pertenecientes al escudo de la Inquisición.

El último elemento de interés lo constituye en el alero, que sobresale del tejado, en el cual las cabezas de las vigas muestran una cuidada decoración, en la que se representan diferentes elementos y formas geométricas finamente tallados. Respecto a la cronología del edificio, aunque su fecha de construcción no aparece representada en ninguna parte de su fachada, como viene siendo costumbre, todo apunta a que debe tratarse de una obra contemporánea de la citada anteriormente. Estas dos construcciones, como decíamos, consiguen delimitar un pequeño espacio frente a ellas, creando una plazuela, en la que se manifiesta el evidente interés de sus promotores, por ordenar este espacio urbano.

Otra localidad, incluida dentro de esta zona de economía relacionada con el mundo de la trashumancia y la Mesta, es Neila, en la cual también encontramos algunos destacados ejemplos de casas solariegas, construidas durante esta centuria. Los ejemplos 


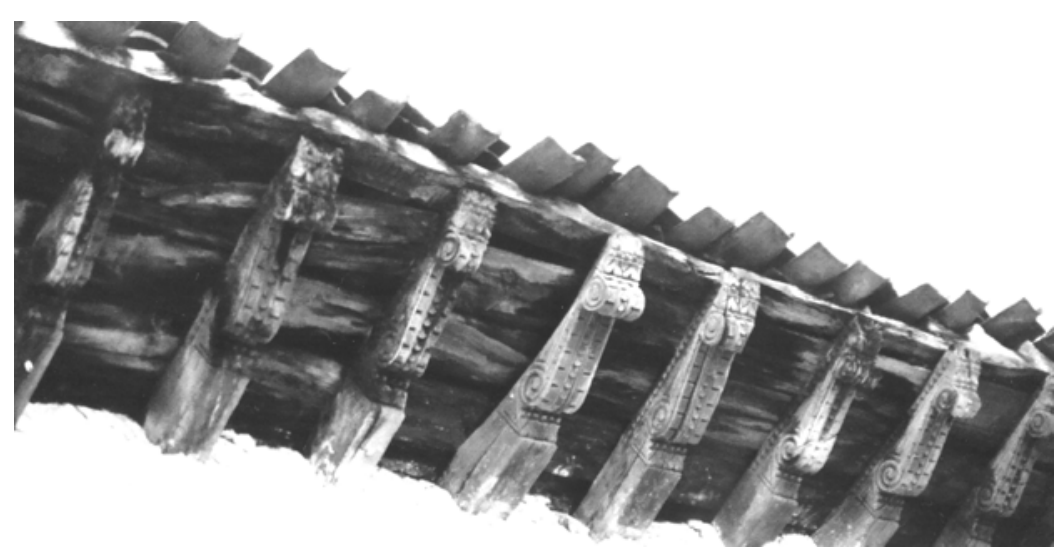

HUERTA DE ARRIBA. Calle

Moralas $n^{\circ} 25$ bis. Alero.

más significativos se encuentran en la calle Real $n^{\circ}$ 34-38 C, calle del Cristo $n^{\circ} 4-6$, y calle de San Roque $n^{\circ} 57$. Como ya ocurriera en el caso anterior son edificios que continúan la brillante actividad constructiva, que se había iniciado en la villa, durante la centuria anterior, dentro de este ámbito de la arquitectura civil.

El primero de los edificios citados fue la casa solar de la prestigiosa familia de los Márquez de Prado ${ }^{816}$. Su estructura, sin embargo, se encuentra notablemente alterada por las divisiones introducidas dentro del edificio y por el derrumbe de algunas de sus partes. Aun así, su fachada principal todavía conserva orgullosa su escudo de armas, alojado en la parte central de su primera planta. Presenta el habitual contorno cuadrilongo, enmarcado por abultada decoración de lambrequines, guirnaldas y festones, y timbrado en su parte superior por un yelmo con gran penacho de plumas. Su campo partido y semicortado presenta, $1^{\circ}$ cuartel con gran cruz de Calatrava acompañada de calderas, colocadas en el cantón diestro del jefe y siniestro de la punta, $2^{\circ}$ castillo donjonado con tres torres, y $3^{\circ}$ con león rampante

816 B. VALDIVIELSO AUSín: Neila, una llamada al turismo. Burgos, Ayuntamiento de Neila. 1980. 
Sin abandonar este barrio de Santa María observamos el segundo de los ejemplos citados, situado en la calle del Cristo $n^{o} 4-6$. Se trata de la casa solar de los Márquez, otra de las familias distinguidas de la villa, y popularmente conocida, desde la guerra de la Independencia, como la casa del cura Merino, pues según parece éste fue uno de los lugares utilizados como refugio por este conocido guerrillero ${ }^{817}$. Se halla situada en la parte central del barrio, con una de sus fachadas laterales orientada hacia la calle Real (la vía más importante del pueblo), y la principal hacia naciente, mirando con ello hacia el lugar en el que se encuentra la iglesia parroquial. Como los casos anteriores, su estructura interna y parte de la imagen exterior, se encuentran notablemente alteradas por las divisiones efectuadas sobre el edificio. Sin embargo, y a pesar de ello, todavía es fácil reconocer su forma volumétrica y algunos de los elementos más característicos de su estructura exterior. Dentro de ellos destaca de modo especial su fachada principal, por ser el elemento más interesante del edificio y el que mejor nos permite reconstruir la imagen que presentaba su estructura original.

Toda ella está realizada en piedra de sillería de magnífica labra, lo cual marca la diferencia con el resto de edificio, construido en sillarejo y mampuesto. Desarrolla la característica estructura plana de forma rectangular, articulada en dos cuerpos separados por línea de imposta plana de escaso resalte, y rematada con una cornisa de codillo dispuesta entre dos molduras de cuarto de bocel. Tres vanos se abren en cada una de estas plantas, dispuestos en perfecta correlación entre ellos, dentro de los cuales los dos laterales presentan un sencillo perfil adintelado con marco de moldura plana de escaso resalte con orejones, mientras que los dos centrales reciben un tratamiento más cuidado. El de la planta baja, que forma la puerta de entrada, está coronado con arco de medio punto, de rosca rebajada con un leve cajeado, que se continúa, sin interrupción, a lo largo de las jambas. Sobre esta puerta, en la planta principal, se abre un pequeño balcón, de escaso vuelo, apoyado sobre una plataforma moldurada, al cual se accede a través de una puerta de dintel plano, recercada por un marco de doble moldura de perfil quebrado.

817 Ibídem. 
Esta fachada se completa con la incorporación de dos escudos, situados a ambos lados de este balcón, engalanados, como viene siendo habitual durante este siglo XVIII, por un marco ornamentado con abultada y movida decoración de cueros recortados, lambrequines y tenantes, que se completa con suntuoso yelmo con penacho de plumas. Su campo, por lo demás, presenta el característico contorno cuadrilongo. Dentro de ellos, el situado en la parte derecha de la fachada, presenta una estructura sencilla, con campo cuartelado en cruz, $1^{\circ}$ y $4^{\circ}$ con cruz de Alcántara, y $2^{\circ}$ y $3^{\circ}$ con tres bandas. El situado al lado izquierdo, sin embargo, resulta algo más complejo. Presenta también campo cuartelado en cruz, $1^{\circ}$ con castillo donjonado con tres torres, $2^{\circ}$ con seis estrellas de ocho puntas, dispuestas en dos palos de tres y tres, $3^{\circ}$ con un árbol con una flecha clavada sobre su tronco, y $4^{\circ}$ con león rampante. En este segundo caso, la ornamentación exterior también se complica de forma acusada con la incorporación de

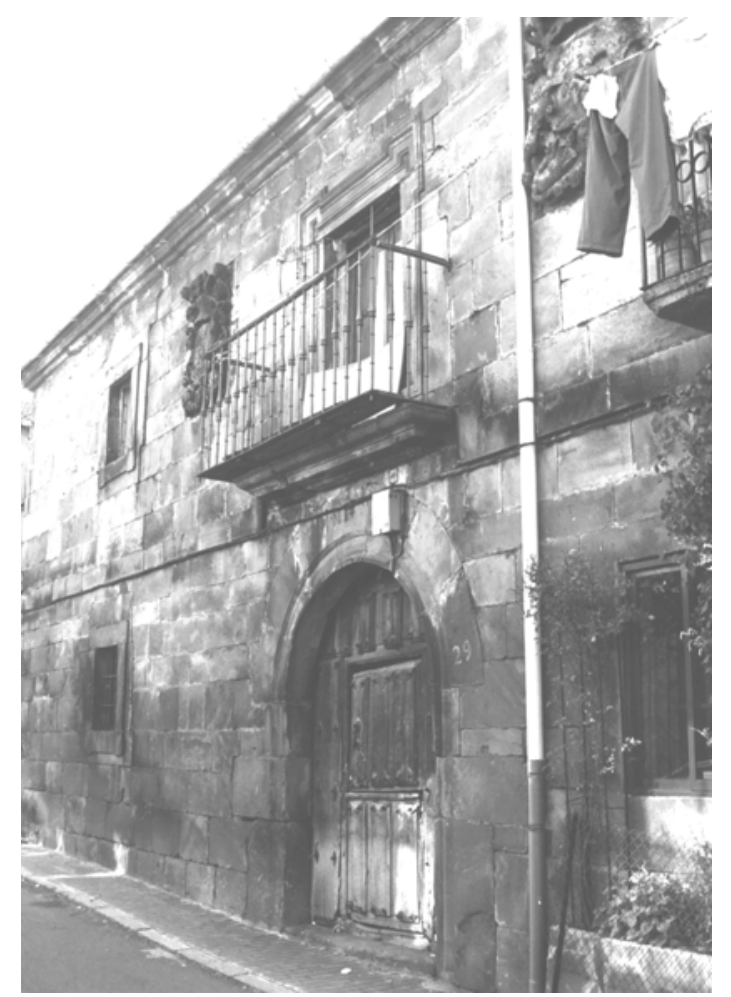


dos leones enfrentados a los lados, que actúan como tenantes, junto a los cuales aparecen, en la parte inferior, dos sirenas y dos cañones, mientras que el yelmo de la parte superior es portado por dos niños desnudos.

En definitiva, podemos afirmar que nos encontramos ante uno de los conjuntos de la arquitectura civil del siglo XVIII, en el que se plasman de forma más clara los postulados propios de la estética clasicista. Dentro del cual, al mismo tiempo, también aparecen ciertos rasgos con los que se rompe la quietud y severidad propios de este estilo, lo cual se manifiesta de modo especial en la incorporación de la moldura quebrada, que recorre la puerta del balcón central, o la abultada ornamentación exterior, que rodea a cada uno de los escudos. Todo ello nos permite situar su construcción, a falta de fuentes documentales o epigráficas, que lo confirmen definitivamente, en torno a las décadas centrales de esta centuria del Setecientos.

El tercer y último ejemplo de casa solariega, citado en esta localidad de Neila se halla en el barrio de San Miguel, en la calle San Roque número 57. Es la casa de los Fernández de la Cuesta, otra destacada familia de esta villa, propietaria de un inmenso rebaño de ovejas merinas trashumantes.

Dentro de ella destaca, en primer lugar, su poderosa volumetría, en la cual se dibuja un amplio prisma de base rectangular de más de cuarenta metros de largo, con alzado articulado en dos plantas, formado por muros de mampostería reforzados en las esquinas por sillares, y cubierta a cuatro aguas, de la cual sobresale un pronunciado alero. En sus muros advertimos una escasa presencia de vanos, los cuales se distribuyen de forma ordenada en cada planta, sin establecer correspondencia entre ambas. De igual modo, los del piso superior presentan el característico recercado con moldura plana de escaso resalte con orejones, mientras que los de la planta baja carecen de cualquier tipo de marco. 
En cualquier caso, la pieza más importante de todo el conjunto se encuentra en su fachada principal, que queda orientada hacia naciente, en la que se levanta una soberbia portada de marcada inspiración clasicista, situada sobre su parte central, la cual podemos comparar con los mejores ejemplos, de este tipo de construcciones, realizados para las iglesias parroquiales de los pueblos de la zona. Consta de un amplio vano central, coronado con arco de medio punto de rosca casetonada, acompañado de tondos floreados en las enjutas. Dos pilastras cajeadas escoltan la puerta, sobre las cuales se dispone un ancho friso ligeramente quebrado en los extremos, y una volada cornisa, que conduce al remate. Éste se encuentra formado por un esbelto frontón recto partido, con pináculos de bola sobre elevados netos, dispuestos a los lados, en correspondencia con el eje de las pilastras inferiores. Sobre el tímpano se despliega un gran escudo, acompañado de dos tondos floreados, similares a los de las enjutas, aunque de mayor tamaño. Este escudo presenta la característica forma cuadrilonga, con adornos exteriores

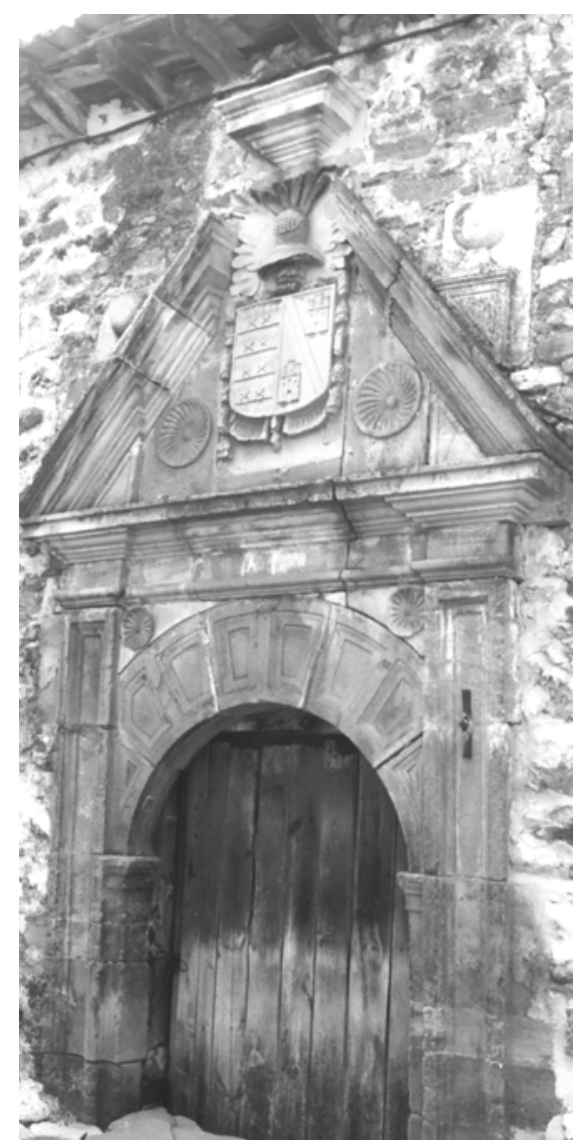


en forma de guirnaldas colgantes y rocallas. Su campo partido, cuenta con el apellido QVESTA inscrito sobre el jefe, con el $1^{\circ}$ cuartel ocupado por cuatro fajas cargadas con dos cruces en aspa cada una de ellas, y $2^{\circ}$ con dos castillos donjonados con tres torres, dispuestos respectivamente sobre el cantón siniestro del jefe, y el diestro de la punta.

Una obra de marcado sabor clasicista, dentro de la cual se introduce un acusado carácter ascensional, acompañado de otros rasgos propios de la arquitectura desarrollada dentro de la zona a lo largo de esta centuria, como puede ser la presencia del habitual casetonado sobre la rosca del arco. Su resalte sobre el plano del muro, acompañado del retranqueado de algunas de sus piezas, hace, además, que se aprecie un ritmo compositivo más vivo, al mismo tiempo que se introducen ricos contrastes lumínicos. Un conjunto, en definitiva, caracterizado por el abrumador predominio de los elementos estructurales, que viene acompañado de una evidente contención ornamental, que se extiende incluso al propio escudo que corona todo el conjunto, donde reduce y esquematiza al máximo la decoración exterior.

Respecto a su cronología, como en el caso anterior, carecemos de fuentes que nos informen sobre la fecha concreta en la que fue construido este edificio, si bien, en virtud de la evidente similitud que muestra con el ejemplo (desaparecido), localizada en Huerta de Arriba (en la calle Mayor no 20 - 22 - 24), fechado en 1716, bien podemos situar esta obra en torno a las décadas iniciales del siglo XVIII.

Con Neila cerramos el grupo de localidades en las que se concentran los conjuntos más representativos y mejor conservados de esta tipología. Sin embargo, fuera de aquí también podemos encontrar otros ejemplos ciertamente interesantes, en los que se repiten las características propias de las casas solariegas.

Es el caso de Monterrubio de la Demanda, localidad que ya nos ofreció para el siglo XVII un interesante grupo de construcciones de este tipo. En esta ocasión, las casas más destacadas se concentran en la parte alta del pueblo, en torno a su plaza 
mayor. La primera de ellas ocupa, precisamente, el número 10 de esta plaza, orientando su fachada hacia el mediodía. La fachada principal constituye su elemento más destacado, la cual nos ofrece una composición sencilla, realizada en piedra de sillería, de estructura rectangular completamente plana, articulada en dos cuerpos separados por una línea de imposta plana de escaso resalte y rematada por un volado alero, precedido de un grueso friso y cornisa de papo de paloma. Los vanos se distribuyen de forma perfectamente ordenada, con la puerta de entrada y una ventana abalconada sobre el eje central y ventanas a los lados de sencillo dintel plano y sin ningún tipo de marco.

Los vanos centrales, sin embargo, sí reciben un tratamiento más cuidado, así, la puerta de acceso queda enmarcada por un arco de medio punto de rosca lisa, mientras que la puerta del balcón presenta un dintel plano recercado con una moldura plana de escaso resalte con orejones. Sobre este dintel se incluye una inscripción en la que se indica el año 1726, correspondiente, sin duda, a la fecha de su construcción. El actual balcón, de estructura muy volada, que recorre todo el frente de esta fachada, constituye con toda seguridad un añadido posterior, pues sobre el arco de la puerta de entrada todavía podemos apreciar los restos de la pequeña plataforma de perfil moldurado, que servía de soporte para el balcón original. De este modo, se respeta el modelo habitual de balcón, que venimos observando en el resto de construcciones de la época. Por lo demás, nos encontramos con un edificio sumamente sencillo, de gran severidad, tanto en su composición, como en sus formas, en el que a falta de blasones, su aire distinguido queda representado a través del cuidado trabajo de cantería de su fachada.

En el otro lado de la plaza se halla un segundo ejemplo de este tipo de edificio, si bien, su fachada principal queda orientada hacia la calle Santiago $n^{\circ} 2$. Aquí se muestra una estructura prismática sobre planta cuadrangular, de muros de mampostería de gran calibre, articulados en dos cuerpos, reforzados en las esquinas con sillares de mejor labra, y rematados por un friso corrido con cornisa de codillo y papo de paloma, que dan paso al tejado. 
Su fachada principal mantiene el característico lienzo plano de estructura rectangular, articulado en dos cuerpos, con tres vanos de dintel plano abiertos en cada cuerpo, dispuestos de forma ordenada, en perfecta correlación entre los de un piso y otro. La puerta de entrada aparece en el centro de la planta baja, y está formada por un simple vano de dintel plano, sin ningún tipo de adorno. En este sentido, sólo las ventanas del cuerpo principal reciben un tratamiento especial, con un marco formado por un fino listel, rematado en los ángulos con gruesos tacos cúbicos. Constituye un tipo de marco absolutamente novedoso dentro de esta comarca, del cual no encontramos referentes en otros lugares.

Esta fachada se remata con un gran escudo, colocado sobre la ventana central del cuerpo principal. Se trata de un escudo de estructura cuadrilonga, dispuesto sobre superficie de cueros recortados, adornado con cintas avolutadas en los ángulos, y timbrado con yelmo con penacho de plumas. Presenta campo partido y cortado de dos, $1^{\circ}$ con figura de hombre armado con una espada en la mano derecha y lanza con estandarte en la izquierda, $2^{\circ}$ con flor de lis, $3^{\circ}$ con castillo donjonado con tres torres, $4^{\circ}$

MONTERRUBIO DE LA DEMANDA.

Calle Santiago $n^{\circ} 2$

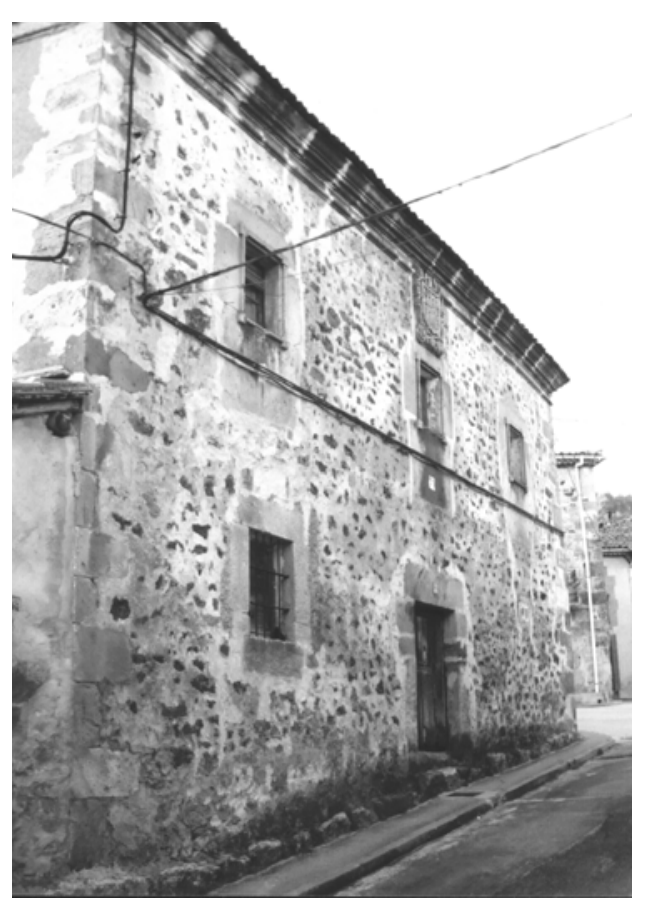


con roble arrancado, $5^{\circ}$ con dos bandas y $6^{\circ}$ con una caldera. Todo con bordura cargada de veintiocho cruces en aspa.

A falta de fuentes documentales, que nos aporten una información precisa sobre su cronología, la presencia del escudo, unido a la utilización de ciertos elementos, como el singular recercado de los vanos del piso superior, y el remate de sus muros, debemos considerarlos indicios suficientes para situar su construcción en este siglo XVIII. Un segundo escudo aparece sobre el dintel de una de las ventanas abierta en la fachada lateral, orientada hacia la plaza mayor. Se trata de una pieza más sencilla, la cual se ajusta más a los modelos, que hemos visto durante el siglo XVII. Debemos pensar, por lo tanto, que pudiera constituir una pieza reaprovechada de una construcción anterior. Presenta un sencillo contorno cuadrilongo, sin ningún tipo de adorno exterior, con campo partido en dos, $1^{\circ}$ con dos bandas y una $\mathrm{M}$ colocada en la punta, y $2^{\circ}$ con un brazo sujetando un estandarte y una cruz puntiaguda en la parte central de la punta.

Un último ejemplo de casa levantada durante esta centuria, en esta localidad de Monterrubio de la Demanda, aparece en la calle Mayor $n^{o}$ 28, si bien, las modificaciones introducidas durante estos últimos años hacen que apenas pueda adivinarse su aspecto original. De hecho, el único elemento que se ha conservado es el escudo, que ennoblecía su fachada, situado en la primera planta, dispuesto entre dos de sus vanos. Presenta un contorno ciertamente extraño en nuestra comarca, con forma de cueros recortados, que nos recuerda los diseños propios del mundo italiano. Su campo aparece terciado en palo, $1^{\circ}$ con campo de veros, $2^{\circ}$ con león rampante enmarcado con un billetado y tres barras en la punta, y $3^{\circ}$ cuartelado en cruz, $3-1$ y $3-4$ con una mano extendida, y 3 - 2 y $3-3$ con estrella de ocho puntas sobre un mar. Sobre el todo bordura con cruces en aspa, y timbrado con yelmo con tocado de plumas, sujetado por dragones. Este escudo aparece acompañado por una pequeña inscripción dispuesta sobre su base, en la que podemos leer lo siguiente: VELASCO GARCÍA M(...) LLH. Dentro de estos restos, en ninguna parte se indica la fecha de su construcción, si bien, la propia forma del escudo así como los elementos que adornan su contorno, resultan suficientes para indicar su pertenencia a esta centuria de Setecientos. 
Más ejemplos de este tipo de construcciones aparecen en diferentes localidades ligadas a este mundo de la trashumancia, como son Huerta de Abajo, Tolbaños de Arriba y Vallejimeno. La primera de ellas todavía conserva algunos ejemplos interesantes de esta tipología en la calle de San Antonio $n^{\circ} 35$ y en la plaza de la Iglesia $n^{o}$ 2. El primero de estos inmuebles muestra la forma prismática de su estructura original, levantada sobre planta cuadrangular, con muros de sillarejo, articulados en dos cuerpos, reforzados en las esquinas con sillares de mejor labra, y rematados con volado alero de cabezas talladas con formas sencillas. Dentro de ella se conserva también parte de lo que fuera su fachada original, orientada hacia el mediodía, en la que se incluye la puerta de acceso, formada por arco de medio punto con la rosca casetonada. Esto nos sirve para situar cronológicamente su construcción dentro de este siglo. Estos mismos rasgos se repiten en el otro ejemplo citado, donde el arco de medio punto con rosca casetonada vuelve a convertirse en su elemento más destacado.

En Tolbaños de Arriba los ejemplos conservados, pertenecientes al siglo XVIII, se localizan en la calle de los Pajares $n^{\circ} 19$, calle del Norte $n^{\circ} 15$, calle del Pinar $n^{\circ} 9 \mathrm{y}$ calle Mayor $s / n$. La primera de ellas nos muestra una fábrica extremadamente austera, impregnada de recio sabor popular, en la que el único elemento destacado lo constituye el escudo, que preside su fachada principal. El edificio en sí muestra la característica forma de prisma cerrado, articulado en dos cuerpos, de sólidos muros de sillarejo y mampuesto, que se refuerzan en las esquinas y marcos de los vanos con sillares de mejor labra. La mayor parte de estos vanos, especialmente en su fachada principal, han sido alterados, con lo cual desconocemos su disposición original, si bien el escudo que coronaba este lienzo ha sido respetado. Muestra el acostumbrado contorno cuadrilongo, recercado, en esta ocasión, con un tallo con hojas, que culminan en su parte superior con un yelmo tocado con un sencillo penacho de plumas. Su campo aparece cuartelado en cruz, $1^{\circ}$ con tres fajas, $2^{\circ}$ cortado $2-1$ leyenda donde se puede leer SERANOS, 2-2 dos calderas en faja, $3^{\circ}$ con una banda y flor de lis en el cantón siniestro del jefe, y $4^{\circ}$ brazo izquierdo con estandarte. 
Muy similares entre sí son los ejemplos de la calle del Norte $n^{o} 15$ y calle del Pinar $n^{\circ}$ 9, si bien, en ambos casos se han producido importantes modificaciones, que han acabado por alterar de modo sustancial la estructura de sus fachadas. Ambas desarrollan una variante simplificada con estructura prismática, levantada sobre planta rectangular, con alzado articulado en dos cuerpos, con muros de mampuesto reforzados en las esquinas con sillares de mejor labra. Su fachada principal, levantada sobre uno de los lados cortos, dibuja un lienzo plano próximo al cuadrado, con dos ventanas adinteladas en la primera planta y una en la baja, acompañando a la puerta de acceso, que aparece dispuesta así sobre uno de los lados. Esta puerta se encuentra coronada con arco de medio punto dispuesto sobre impostas planas.

Una estructura muy similar a estas dos casas presenta el último de los ejemplos citados dentro de este pueblo, el cual recupera el relieve casetonado para la rosca del arco de su puerta de entrada, al mismo tiempo que nos ofrece en su ventana del piso principal, enmarcada con moldura planta de escaso resalte con orejones, una inscripción en la que se indica el año 1729, como su fecha de construcción. Obras todas ellas, en definitiva, muy sencillas, en las que no aparecen grandes complicaciones compositivas ni técnicas, lo que hace que destaque, de modo más acusado, su fuerte componente popular.

Esto mismo sucede, con los ejemplos hallados en Vallejimeno, para este mismo siglo XVIII. Son las casas situadas en la calle Mayor $n^{\circ} 6-8, n^{\circ} 9, n^{\circ} 24-26$, Paraje de las Eras $n^{\circ} 6$, calle de San Cristóbal $n^{\circ} 16$, calle Principal $n^{\circ} 28$ y $n^{\circ} 30$. Todas ellas desarrollan limpias estructuras prismáticas, alzadas sobre planta rectangular, con muros de mampuesto o sillarejo, articulados en dos alturas, con las esquinas reforzadas por sillares de mejor labra y alero volado en el remate. De igual modo, su fachada principal suele mostrar un lienzo rectangular, con vanos perfectamente ordenados siguiendo los ejes verticales y horizontales, destacando, dentro de ellos, el que compone la puerta de entrada, coronada con arco de medio punto dispuesto sobre impostas planas. Las 
648 Arquitectura de la Edad Moderna en la sierra burgalesa.

ventanas, por su parte, son de dintel plano, en todos los casos, presentando, sólo en algunas de ellas, el característico marco con moldura planta de escaso resalte con orejones.

Entre las particularidades que ofrecemos de cada uno de estos edificios, vemos cómo los situados en la calle de San Cristóbal $n^{\circ} 16$ y calle Mayor $n^{\circ}$ 6-8, han conservado inscripciones alusivas a sus promotores y fechas de construcción, sobre el dintel de una de sus ventanas. En la primera de ellas se puede leer el siguiente texto: AÑO DE 1772 / SE IZO ESTA OBRA A COSTA DE D. JOSEPH Y DÑA. / JOSEPHA SV MVGER AMBOS GOMEZ DE LA FUENTE. En la segunda simplemente se indica la fecha de su construcción: AÑO 1794.

Esta última casa destaca también por sus dimensiones, pues se levanta sobre una amplia planta rectangular de más de 30 metros de longitud, en su lado más largo. Esto mismo sucede en los inmuebles del Paraje de las Eras $n^{\circ} 6$ y en los situados en la calle Principal $n^{\circ} 28$ y $n^{o} 30$. Estas dos casas de la calle Principal, además, aparecen adosadas, formando con sus fachadas un solo lienzo corrido de estructura uniforme, articulada en dos cuerpos, rematados por un alero volado. Sobre esta fachada se abren distintos vanos, dispuestos según el habitual esquema reticular. Dentro de estos vanos destaca la puerta de entrada de cada una de las casas, la cual está coronada con arco de medio punto sobre impostas planas. El $\mathrm{n}^{0} 30$ incorpora sobre la clave de este arco un pequeño escudo, de contorno cuadrilongo, con campo ocupado por una gran flor de lis. No aparece, sin embargo, ninguna inscripción que nos certifique la fecha concreta de su construcción, si bien las afinidades, que muestran con respecto a otras obras levantadas dentro de esta centuria no dejan ninguna duda sobre su cronología.

En esta misma línea podemos citar algunos ejemplos de casas, que de forma aislada, se han conservado en otros pueblos, cuyos habitantes se dedicaron también, de forma mayoritaria, a la actividad trashumante. Este es el caso de los edificios situados 
en la localidad despoblada de Bezares, en su calle Mayor $n^{\circ} 28$; en Hoyuelos de la Sierra, en calle de San Esteban $n^{\circ} 55$; y Tolbaños de Abajo, en la calle de Abajo $n^{\circ} 10$.

Todos ellos son ejemplos sencillos de esta tipología, en los que la disposición más o menos regular de los vanos, dentro de su fachada principal, con el arco de medio punto sobre impostas planas y rosca casetonada en la puerta de entrada y el trazado adintelado de sus ventanas con marco de moldura plana con orejones, vuelven a ser sus rasgos más representativos. El ejemplo de Hoyuelos de la Sierra, a pesar de su avanzado estado de ruina, conserva todavía gran parte de estos elementos, entre los que se incluye un sillar con la siguiente inscripción: IHS MARIA Y JOSEPH / JVAN GARZÍA GONZÁLEZ / BARIO ME FEZISTES ANO / DE 1717. El caso de Tolbaños de Abajo, por su parte, incorpora dos escudos situados sobre su fachada principal, que queda orientada hacia levante. Son escudos muy sencillos, de contorno cuadrilongo, en los que no encontramos ningún tipo de decoración exterior. El situado en la parte derecha de la fachada presenta campo cortado, $1^{\circ}$ con una cruz de Santiago acompañada de una estrella de seis puntas en el cantón diestro del jefe, y una pequeña flor de lis en el lado contrario del jefe, mientras que la punta aparece recorrida por una inscripción con el siguiente texto: IHS MARÍA, $2^{\circ}$ con la leyenda HOGORAS. El escudo del lado izquierdo presenta su campo ocupado por un gran VICTOR en la parte central, acompañado por tres estrellas de seis puntas, dispuestas en el centro del jefe y en los flancos.

Aunque parezca lo contrario, el desarrollo de esta tipología de casas solariegas, no fue exclusivo de los pueblos de economía eminentemente ganadera, ligada a la trashumancia, sino que fuera de esta zona también podemos encontrar algunos ejemplos. De este modo, nos encontramos con algunos casos en localidades como Salas de los Infantes y Vilviestre del Pinar. En la primera de ellas la explicación parece clara, pues desde finales de la Edad Media se había convertido en el lugar desde el que los Duques de Frías administraban los dominios pertenecientes a su señorío, repartidos por esta comarca de la sierra. De igual modo, la presencia de hidalgos en la villa, aunque 
escasa, había sido detectada ya desde los primeros censos realizados durante el siglo XVI, algo que, salvo en el caso de Neila, no ocurría en el resto de las localidades citadas anteriormente. El caso de Vilviestre, sin embargo, resulta algo más difícil de explicar, pues en ninguno de sus censos, ni siquiera en los realizados ya a finales del siglo XVIII, encontramos la presencia de hidalgos dentro de su población. Por lo cual, debemos pensar que estas casas fueron mandadas construir por residentes, que no vivían habitualmente en esta localidad, o quizá por ricos carreteros, que trataron de emular con sus viviendas la ostentación y el alarde de los nobles, propietarios de los grandes rebaños trashumantes del valle de Valdelaguna.

Los ejemplos de Salas de los Infantes se concentran en la plaza de Santa María, situada a los pies de la iglesia parroquial del mismo nombre, y en la plaza de los Condestables de Castilla, esquina con avenida Cardenal Benlloch. En el primero de los casos nos encontramos con un conjunto de edificios de estructura uniforme, dispuestos a lo largo de los lados occidental y septentrional de la plaza, con fachadas corridas, articuladas en dos plantas, con vanos dispuestos en perfecto orden, siguiendo una correlación de ejes entre los situados en uno y otro piso. Dentro de ellos, los que forman las puertas de acceso, situadas en la parte central del cuerpo inferior, reciben un tratamiento especial, con arco de medio punto alzado sobre impostas planas. Las ventanas, por su parte, muestran una sencilla estructura adintelada, sin tratamiento especial en el marco.

El carácter integrador y la evidente tendencia hacia la uniformidad se convierte en el aspecto más destacado de este grupo de casas, con las cuales se dibuja, dentro del apretado trazado de calles de este barrio de Salas, un espacio amplio y desahogado, que resulta sumamente representativo del concepto urbanístico, que se pretendía desarrollar en aquel momento. Dentro de este grupo destaca, de un modo especial, la situada en el $n^{o} 15$, la cual, además de contar con una fachada principal construida toda ella en perfecta piedra de sillería, ennoblece su imagen con la presencia de un magnífico escudo, dispuesto sobre la clave del arco de la puerta de entrada. Se trata de un escudo 


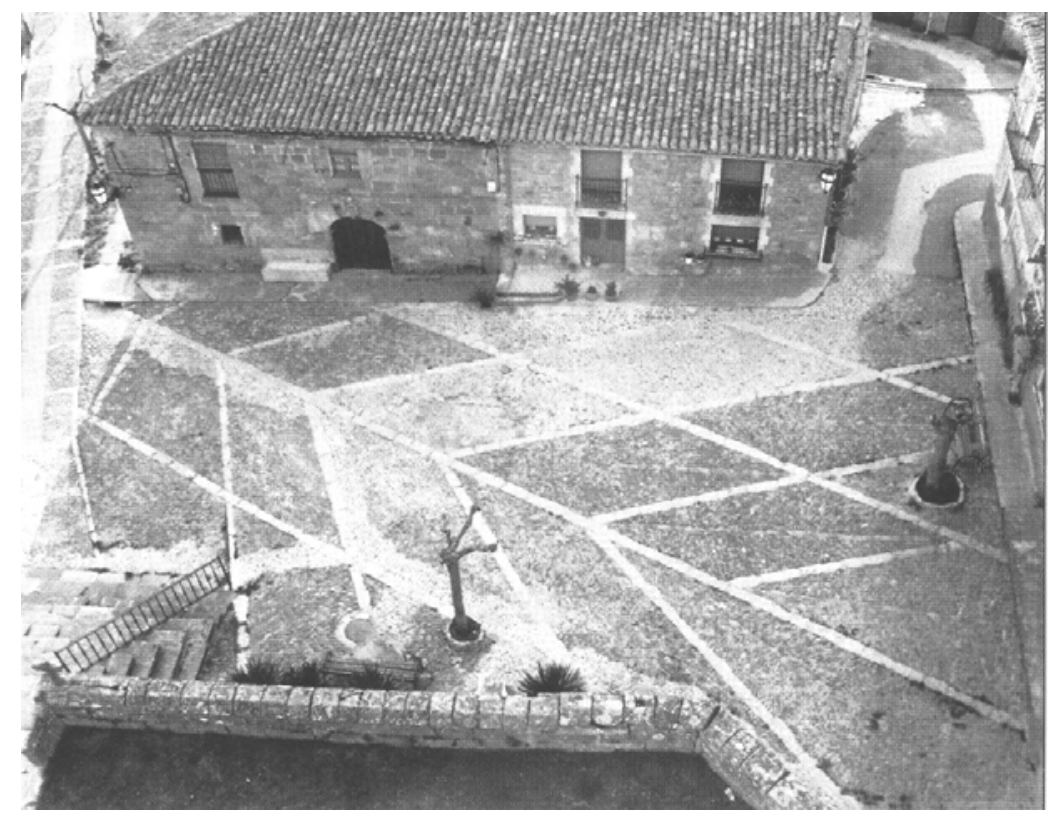

SALAS DE LOS INFANTES.

Plaza de Santa María.

de estructura cuadrilonga, dispuesto sobre un marco de cueros recortados y timbrado por un yelmo. Su campo está cuartelado en cruz, $1^{\circ}$ y $4^{\circ}$ con castillo donjonado con tres torres, y $2^{\circ}$ y $3^{\circ}$ con cruz de Calatrava. Sobre el todo una bordura recorrida por una leyenda interrumpida por cruces en aspa, en la que se puede leer: DON FRANCISCO DE SANTA ANA GANAELLO.

Otros ejemplos de casas blasonadas los encontramos, también, en algunas de las calles, que desembocan en esta plaza de Santa María. Este es el caso del inmueble situado en la Travesía de Santa María $n^{\circ}$ 6, sobre cuya fachada aparecen dos pequeños escudos, el primero con campo ocupado por dos llaves unidas por una cadena dispuestas en aspa, acompañado por cuatro estrellas de seis puntas, y el segundo con campo ocupado por una gran flor de lis. La estructura original de esta fachada, sin embargo, se halla totalmente alterada. 
El otro ejemplo de esta tipología, situado en la plaza de los Condestables, esquina con avenida Cardenal Benlloch, conserva todavía dos de sus fachadas, a través de las cuales podemos intuir su estructura original, de forma prismática, alzada sobre planta cuadrangular, y muros de sillarejo, reforzados en las esquinas por sillares de mejor labra, que rematan con un volado alero. Su fachada principal, sin embargo, se encuentra realizada totalmente en piedra de sillería, con la que se dibuja un lienzo rectangular en el que desatacan la puerta de acceso y el balcón dispuestos sobre el eje central. La puerta cuenta con un arco de medio punto ligeramente rebajado, dispuesto sobre impostas con moldura de medio bocel, mientras que el acceso al balcón se realiza a través de un sencillo vano adintelado. Sobre este mismo eje, y culminando la fachada, aparece el escudo, que ennoblece su imagen. Un escudo de campo cuartelado en cruz y semipartido en la punta, $1^{\circ}$ con un águila, $2^{\circ}$ con león rampante, $3^{\circ}$ con dos lobos dispuestos en palo, $4^{\circ}$ con un brazo derecho con una espada, y $5^{\circ}$ con tres barras. Todo su contorno se encuentra decorado, como suele ocurrir en esta centuria, con una ornamentación de cueros recortados, y coronado con una torre, acompañada a los lados por dos cruces en aspa.

Vilviestre del Pinar, a pesar de ser un núcleo de economía eminentemente carretera, cuenta también con un importante conjunto de edificios, que podemos incluir dentro de esta tipología de casas solariegas. Todas ellas se concentran en el barrio de San Martín, asentadas sobre las faldas del cerro que corona su iglesia parroquial. La más destacada de ellas se encuentra en el $n^{\circ} 85$ del barrio, la cual es conocida popularmente como la casa de los Calatravas, merced a los motivos que adornan el escudo de su fachada principal. Nos encontramos aquí con un edificio de sólida estructura prismática, asentada sobre una planta cuadrangular de más de 20 metros de lado, con muros elaborados en magnífica piedra de sillería, articulados en dos cuerpos, rematados, como es habitual, con un volado alero. A la propia nobleza aportada por la técnica empleada en la realización de sus muros, este edificio incorpora una solemne fachada principal, orientada hacia levante, con la puerta de entrada en el centro, con arco de medio punto 


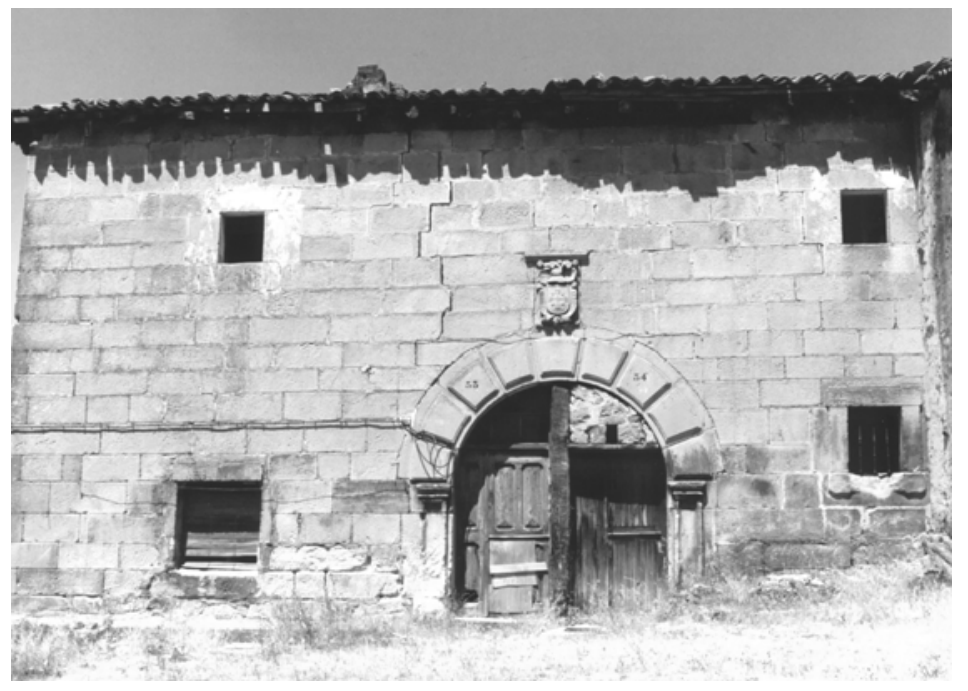

VILVIESTRE DEL PINAR.

Barrio de San Martín $n^{\circ} 85$

de rosca casetonada sobre pilastras cajeadas de orden toscano, acompañada por dos pequeñas ventanas adinteladas a los lados, que se corresponden con otras dos abiertas en el piso principal. Esto se completa con un escudo, dispuesto sobre la puerta de entrada, de contorno cuadrilongo y rodeado por un marco de cueros recortados y rocallas, que culminan en un pequeño yelmo con penacho de plumas. Su campo está ocupado por una gran cruz de Calatrava en el centro, acompañada de cuatro estrellas de ocho puntas.

Dentro de este edificio, la fachada lateral orientada hacia el mediodía también recibe un tratamiento especial. En cada una de sus dos plantas se abren tres vanos de dintel plano recercados con moldura plana de escaso resalte con orejones, dispuestos en perfecta correspondencia, siguiendo unos mismos ejes. Dentro de ellos, el vano central del piso principal conduce a un balcón, apoyado sobre una volada plataforma, dentro de cuyo dintel podemos ver la inscripción donde dice: AÑO 1762, correspondiente al momento de su construcción. Constituye por todo ello, uno de los ejemplos más brillantes de este tipo de casas, pues a la nobleza de su porte y equilibrada estructura, 
654 Arquitectura de la Edad Moderna en la sierra burgalesa.

une la calidad de la técnica empleada en su construcción, dando lugar con ello a una composición severa y equilibrada.

Justo frente a este inmueble nos encontramos con otro interesante ejemplo de la tipología de casas solariegas, si bien se trata de una obra muy deteriorada por el paso del tiempo, lo que ha hecho que parte de ella esté totalmente destruida, mientras que el resto se halla repartida entre varias viviendas. Aun así, todavía podemos adivinar la forma exterior de su estructura original, con una gran planta de trazado irregular, próximo al cuadrado, un alzado articulado en dos cuerpos, muros de sillería en la mayor parte de ella, y sillarejo en el resto. Su fachada principal quedaba orientada hacia poniente, dibujándose aquí un ligero retranqueo del muro en uno de sus laterales, que tal vez podamos relacionar con algún tipo de contaminación o influencia de la variante de casa carretera, conocida como casa portalón, de la que más adelante nos ocuparemos. Sobre este rebajado de la fachada principal se abre la puerta de entrada, la cual está coronada por un arco de medio punto de rosca casetonada, dispuesto sobre toscas pilastras de orden toscano. El resto de esta fachada, sin embargo, se encuentra terriblemente deteriorada, lo que hace que sea imposible reconstruir la distribución original de sus vanos. Los que se han conservado presentan la habitual estructura adintelada, enmarcada con moldura plana de escaso resalte con orejones. Algo mejor suerte ha corrido la fachada meridional del edificio, la cual aun conserva una buena parte de sus vanos, en los que se repite este mismo tipo de estructura, si bien, su distribución se realiza de forma anárquica, sin respetar ningún tipo de eje de correspondencia entre los de una planta y otra.

Otro ejemplo aparece en el $n^{\circ} 161$ de este mismo barrio de San Martín, si bien, al igual que el caso anterior, se encuentra bastante alterado por las divisiones introducidas dentro de su estructura. Conserva, no obstante, interesantes restos de su fachada principal, la cual estaba formada por un lienzo completamente plano de estructura rectangular, articulado en dos cuerpos, y realizado todo en ello piedra de sillería de magnífica labra. Sobre uno de sus extremos se abre la que fuera puerta principal, 
coronada con un amplio arco de medio punto de rosca casetonada, dispuesto sobre pilastras seudo toscanas de fuste cajeado. En las dovelas centrales de este arco aparecen representados una cruz del calvario, acompañada por dos espléndidas cruces de Calatrava. Al mismo tiempo, dentro de esta la fachada, podemos ver una pequeña puerta de dintel plano, recercada con moldura plana de escaso resalte con orejones, sobre cuyo marco aparece la siguiente inscripción: ME HIZO FRANCISCO AMANZIO Y SV / MVGER FRANCISCA MARTÍNEZ / AÑO DE 1737. Esto nos indica la pertenencia del edificio a este siglo, si bien, la mayor parte de su estructura original, tanto interna, como externa, han desaparecido o se han visto notablemente alteradas. Aun así, vemos cómo las características de los elementos conservadas se ajustan perfectamente a la cronología indicada en la inscripción.

Dentro de esta misma línea se incluye la casa situada en el $n^{\circ} 176$ de este barrio. En ella, nuevamente, y a pesar de las divisiones introducidas en su estructura, todavía podemos ver con claridad el volumen prismático, que dibuja su imagen exterior. Éste se alza sobre una amplia planta cuadrangular con muros planos, realizados en sillería en su fachada principal y sillarejo en el resto, articulados todos ellos en dos cuerpos, que se rematan con un alero volado. Su fachada principal, orientada hacia poniente, aunque muy alterada, nos permite adivinar todavía su limpia composición de base reticular. Así, en el centro de su planta baja se abría la puerta de entrada, coronada con amplio arco de medio punto de rosca casetonada, al cual acompañaban dos ventanas adinteladas más pequeñas a los extremos, recercadas por moldura plana con orejones de escaso resalte. Otros tres vanos de similares características se abrían en el piso principal, situados en correspondencia con los ejes verticales trazados por ellos. Un esquema, por lo tanto, sumamente sencillo y equilibrado, el cual, a falta de otras fuentes, que nos permitan fijar con precisión su cronología, resultan suficientes, para que la situemos, junto con los casos anteriores, dentro del siglo XVIII.

Este tipo de construcciones no son las únicas que alcanzan su momento culminante durante esta centuria. De este modo, debemos tratar también de la otra 
tipología característica de la arquitectura civil serrana, como es la casa carretera, la cual experimenta una interesante evolución a lo largo del siglo XVIII. Este tipo de casa comienza, desde los primeros momentos de la centuria, a incorporar ciertos elementos, que hasta el momento habían sido propios del mundo de la arquitectura culta, para terminar emancipándose de la arquitectura popular, ofreciéndonos ejemplos ciertamente interesantes, equiparables a las más destacadas representaciones de casas solariegas. Con estos elementos, sus promotores no pretendían otra cosa que añadir un cierto aire de distinción a sus residencias, hasta el punto de convertirlas en auténtico símbolo de su prosperidad ante sus convecinos.

El punto de partida, en cualquier caso, se encuentra en la casa carretera tradicional, que venía desarrollándose en toda esta zona de pinares, durante los siglos XVI y XVII. Estas casas se alzaban sobre planta cuadrangular, y constaban de una sola altura, cubierta con techumbre dispuesta a dos aguas, sobre estructura de madera, lo que permitía crear una entrecubierta, utilizada habitualmente como almacén. No obstante, el elemento más característico lo constituía el gran porche corrido, que se abría ante su fachada principal, el cual estaba protegido por el vuelo de la cubierta, soportado mediante pies derechos. Este espacio era utilizado por sus propietarios para guardar y reparar las carretas, durante los meses en los que no se circulaba. En el interior, por su parte, la pieza más destacada lo forma el gran zaguán, que se abre nada más atravesar la

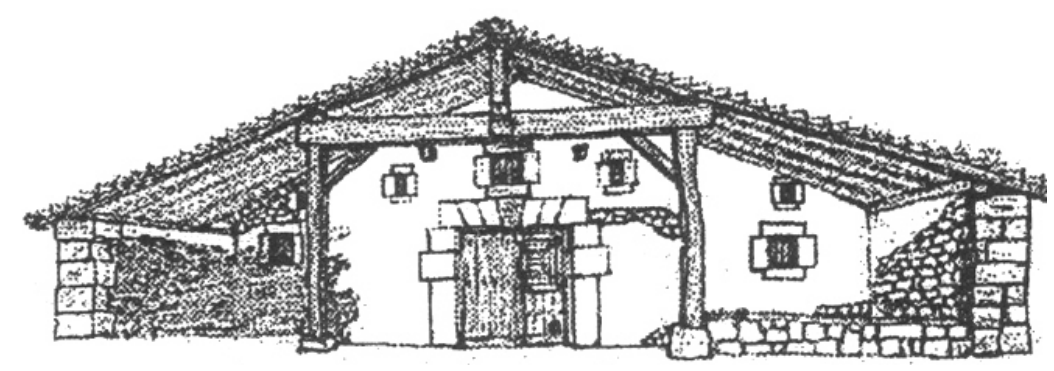

Modelo casa carretera tradicional. Siglos XVII - XVIII. 
puerta de entrada, el cual sirve de elemento articulador de las distintas estancias que aquí aparecen. Entre ellas destacan las habitaciones, la cocina, con su tradicional chimenea serrana, el almacén y la despensa, que se abren a los lados, quedando el fondo reservado siempre para las cuadras.

Este es el modelo tradicional de casa carretera, que se vino desarrollando en los pueblos de la zona, ligados a la actividad del transporte, a lo largo de los siglos XVI y XVII, si bien aquí no se ha conservado ningún ejemplo de ellos. Los únicos ejemplos conocidos se localizan en núcleos próximos, como Pinilla de los Barruecos o Aldea del Pinar, así como otras localidades, pertenecientes ya a la provincia de Soria ${ }^{818}$.

Las modificaciones, que se introducen, durante el siglo XVIII, sobre este tipo de casa, se concentran principalmente en la estructura externa, pues su distribución interior apenas sí va a experimentar cambios. De hecho las únicas variaciones que podemos detectar en este apartado, son las propiciadas por el incremento de altura, lo cual hace que parte del piso superior pueda ser utilizado como vivienda.

En el exterior se mantiene la misma estructura de amplia planta cuadrangular con cubierta dispuesta a dos aguas. Sin embargo, vemos cómo el gran porche, abierto frente a la fachada principal, comienza a reducir sus dimensiones, quedando limitado, en algunos casos, a un pequeño espacio o portalón, dispuesto en la parte central de la fachada, mientras que en otros desaparece por completo. Esto, evidentemente, da un nuevo aire a sus fachadas, las cuales, además de doblar en algunos casos su altura, introduciendo una segunda planta, presentan paramentos elaborados en cuidada piedra de sillería, circunstancia que debe ser interpretada en clave simbólica, como reflejo del poder económico alcanzado por sus propietarios.

818 J. L. GARCÍA GRINCA: Arquitectura popular de Burgos. Crítica y teoría de la arquitectura popular: tipos y características de la arquitectura rural autóctona castellano - leonesa: el caso burgalés. Burgos, Colegio Oficial de Arquitectos de Burgos. 1988. (pp. 234 - 240). 
Los vanos abiertos empiezan a recibir, también, un tratamiento más cuidado. Así, las ventanas, aunque escasas en número y de pequeño tamaño, presentan el característico recercado, que ya vimos en las casas solariegas, mediante moldura plana de escaso resalte con orejones. En las puertas, por su parte, no se duda en utilizar potentes arcos de medio punto de amplio dovelaje, que en algunos casos incluyen la característica decoración de casetones en su rosca, como observamos en la tipología anterior.

Todo esto se complementa con la incorporación de algunos elementos ornamentales, muy escasos, pero ciertamente interesantes por su presencia. Entre ellos, el más singular lo constituye el relieve sogeado, utilizados en el recercado de algunos vanos, así como en la decoración de vigas, tanto del interior, como del exterior, en la zona del porche. A ello se suman otros elementos de sentido claramente protector, como son las cruces y otros símbolos, que aparecen con frecuencia sobre los dinteles de puertas y ventanas.

Tres son las variantes más destacadas de casa carretera, que podemos diferenciar dentro de estos pueblos para el siglo XVIII. Esta clasificación se realiza en virtud de las distintas alteraciones que sufre el porche dispuesto frente a su fachada principal, el cual, en unos casos tiende a reducirse, mientras que en otros desaparece de forma completa. Estas variaciones, sin embargo, no están sujetas a un ritmo cronológico, es decir, no constituyen los distintos pasos vividos dentro de una evolución, ya que un modelo no conduce a otro, sino que todos ellos se desarrollan de forma conjunta, desde los primeros momentos de la centuria. No obstante, esto no evita que con el paso del tiempo unas variantes tengan más éxito que otras. Respecto a su denominación, hemos decidido finalmente utilizar los términos acuñados por las investigaciones, que existen sobre este tema, ${ }^{819}$. No obstante, mantenemos serias reservas con algunas de ellas, pues consideramos, no sólo, que no se ajustan con precisión al modelo que tratan de definir,

\footnotetext{
819 V. M. ARMENDÁRIZ, J. BARINAGARRAMENTERÍA, Ma. C. GONZÁLEZ: Las casonas de los carreteros. Burgos, Escuela Universitaria de Arquitectura Técnica. UBU. 1998.
} 
sino que en algunos casos pueden llevar a confusión, al coincidir con el término empleado para denominar a otras tipologías, que hemos tratado anteriormente.

El primero de estos modelos o variantes es la conocida como casa de portalón. Se denomina así por la reducción que sufre el espacio del porche, al ser ocupados sus lados laterales por estancias vivideras. El porche resultante, llamado ahora portalón, queda formado por un amplio ámbito de planta cuadrangular, delimitado en tres de sus lados por sólidos muros de piedra, que lindan con estancias de la casa, mientras que su cubierta está formada por una prolongación del tejado, soportado por estructura de madera dispuesta entre los dos nuevos módulos laterales. De este modo, la fachada principal pierde su planitud original, para mostrar un fuerte retranqueado en su parte central, que se manifiesta en la cubierta, con un hastial achaflanado. Algunas de estas casas doblan también su altura, introduciendo una segunda planta, que permite incrementar de forma notable la superficie aprovechable en el interior.

Los paramentos de la fachada principal se encuentran elaborados totalmente en piedra de sillería, mostrando magnífico trabajo de cantería. Junto a ella, por otra parte, aparece también una destacada labor de carpintería, que se hace patente en la robusta viguería de la cubierta del portalón. Los vanos continúan siendo muy escasos, si bien en este modelo aumentan ligeramente su tamaño, incluyendo el característico recercado, mediante moldura planta de escaso resalte con orejones.

Solamente nos han llegado dos ejemplos de este modelo de casa, en los cuales es posible reconocer con claridad los rasgos, que acabamos de describir. El primero de ellos lo tenemos en Palacios de la Sierra en la calle de la Peña número $n^{\circ} 17$. Se trata de un edificio ciertamente antiguo, cuya construcción bien podríamos situar incluso en las últimas décadas del siglo XVII. Presenta una estructura de una sola planta y entrecubierta, en cuya fachada principal, construida totalmente en piedra de sillería, el elemento más destacado lo constituye, evidentemente, el amplio portalón abierto en su parte central. Éste presenta la característica estructura cuadrangular, delimitado por los 
módulos laterales proyectados hacia delante, mientras que la cubierta se resuelve con una magnífica estructura de madera, dispuesta sobre una pesada viga, colocada entre estos módulos. En el muro frontal se abre la puerta, que conduce al zaguán interior, la cual está coronada con amplio arco de medio punto, del que todavía se conserva la rosca, con un magnífico despiece de sus dovelas.

Respecto a los módulos laterales de la fachada principal, solamente el situado en el lado izquierdo conserva su aspecto original, pues el del lado contrario se ha visto alterado al añadir una segunda altura. En el conservado en el lado izquierdo se abre una única ventana de dintel plano enmarcada con moldura plana de escaso resalte con orejones, sobre la cual se dispone un diminuto ojo de buey, recercado mediante un relieve sogueado. La parte superior de este muro está rematada por un alero inclinado, lo que manifiesta la presencia de una techumbre dispuesta a dos aguas, achaflanada en su parte central, para formar la cubierta del portalón. Un ejemplo, en definitiva, ciertamente interesante de este modelo de casa carretera, en la cual se funden, la austeridad y funcionalidad de este tipo de construcciones, con un claro sentido de ostentación, manifestado fundamentalmente a través de la cuidada cantería empleada en su fachada principal. Sin embargo, se trata de un edificio que corre un serio riesgo de desaparecer, pues junto al evidente deterioro que muestra su estructura, se produce una ausencia total de medidas encaminadas a garantizar su conservación.

El otro ejemplo de esta variante se encuentra en Vilviestre del Pinar, en el $n^{\circ} 82$ $B$ del Barrio de San Martín. Se trata de una obra de dimensiones mayores que la anterior, tanto en planta como en altura, pues incorpora un segundo piso. Esto hace que el volumen del portalón resulte también mucho mayor, ya que abarca la altura de las dos plantas. En el interior del mismo, el elemento más destacado lo constituye el muro central, donde se abre la puerta de dintel plano, que conduce al zaguán. Sobre ella aparecen diferentes relieves, en los que se representa un jarrón de azucenas, acompañado de una inscripción con el nombre de MARÍA, y sobre él una amplia cruz acompañada por dos roleos avolutados de tosca talla a los lados. A ambos lados de estas 


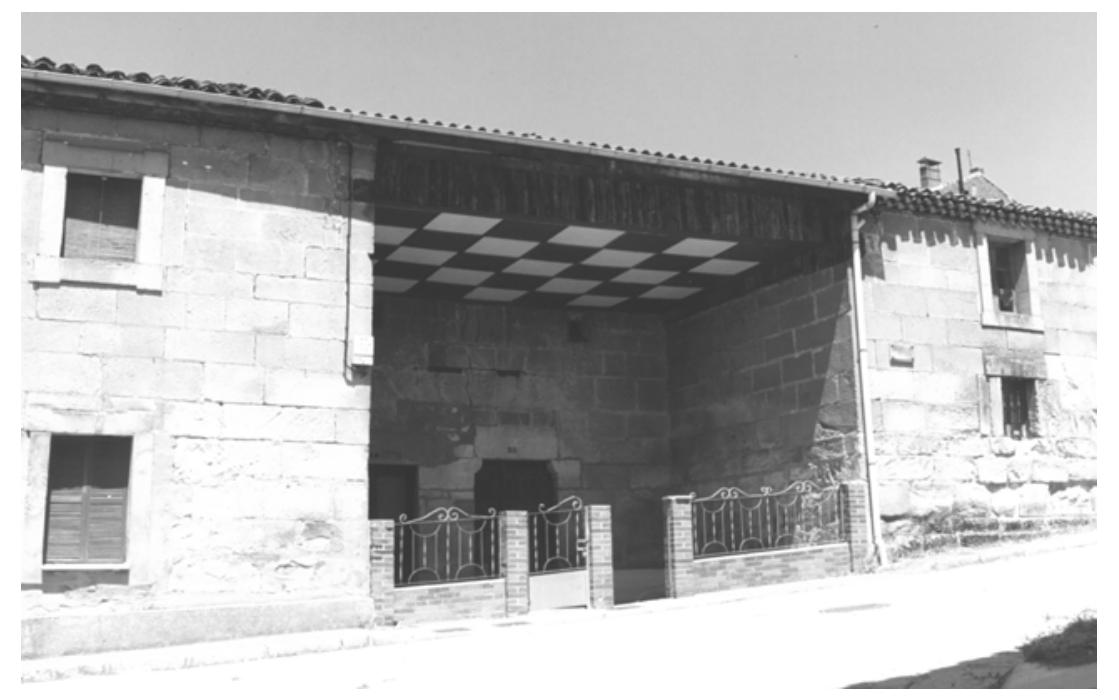

VILVIESTRE DEL PINAR.

Barrio de San Martín No 82 B.

representaciones se abren dos pequeños vanos adintelados de estructura abocinada, que debemos identificar como respiraderos del almacén o pajar, que se situaba en esta parte del piso principal. Sobre los lienzos de los módulos laterales, por su parte, únicamente se abren dos ventanas adinteladas, dispuestas sobre el mismo eje y recercadas con moldura plana de escaso resalte con orejones.

Por lo demás, toda la estructura de la fachada principal se encuentra realizada en piedra de sillería de perfecta labra, formando un magnífico ejemplo de aparejo isódomo. Con todo ello se consigue un conjunto de aspecto ciertamente recio y bien proporcionado, cuya nobleza viene dada fundamentalmente por la utilización de este tipo de aparejo.

Junto a estos dos ejemplos, en la localidad de Castrillo de la Reina se encuentran restos de lo que pudo ser una casa de este tipo, en el $n^{\circ} 98$ de la calle Corralejo. Se trata de una construcción mucho más austera que las anteriores, realizada en sillarejo y 
mampuesto, en la cual, hasta hace poco, todavía era posible apreciar parte de la estructura del portalón, así como el arco de medio punto de la puerta que conducía al zaguán. Estos restos hemos podido conocerlos a través de fotografías tomadas en torno a la década de 1970, cuando ya se hallaba en avanzado estado de ruina. Desde entonces su estado no ha hecho sino empeorar.

La segunda variante de la casa carretera es la conocida como casa solariega, denominada así por las afinidades que presenta con respecto a la tipología, que hemos identificado anteriormente como un tipo de construcción vinculado de modo especial a los núcleos de economía relacionada con la trashumancia. No obstante, en ningún momento deben ser confundidas, pues se trata de modelos muy diferentes entre sí, y con características bien definidas. Así, la principal particularidad que nos ofrece esta variante de la casa carretera es la importante reducción, que sufre el portalón o porche de su fachada, el cual pasa a ocupar únicamente la parte central de la planta baja. A su interior se accede ahora a través de un amplio arco escarzano, que en la mayoría de los casos suele presentar en su rosca el característico casetonado, que aparece en numerosos edificios de la zona durante el siglo XVIII.

Con ello, la fachada principal del edificio recupera, en cierto modo, su planitud original, constituida con un amplio lienzo, elaborado en piedra de sillería, en el que se muestra el característico perfil de tejado, dispuesto a dos aguas. Su interior, por lo demás, mantiene la habitual compartimentación de este tipo de construcciones, con el gran zaguán situado en el centro, en torno al cual se disponen el resto de las estancias. Lo normal es que esta variante de casa cuente con una sola planta y entrecubierta, si bien, tampoco es extraño encontrarnos ejemplos de mayor porte, en las que aparecen dos plantas y entrecubierta. 
Los ejemplos más destacados se encuentran en Canicosa de la Sierra, de los cuales, una buena parte se concentran en el barrio de Santa María. Dentro de ellos, tal vez los más representativos, por el rigor con el que se ajustan a las características generales, que hemos descrito, y por el buen estado de conservación que presentan, son los situados en la calle de Nuestra Señora del Carrascal, $n^{\circ} 33$ y $n^{\circ} 54$. El segundo de ellos, además, conserva una inscripción sobre el vértice superior del hastial de su fachada principal, donde se puede leer: AÑO 1742 / FABRICARON ESTA / OBRA JVAN GIL Y SV / MVGER JOSEFA HANERO, lo que nos sirve para fijar el momento de su construcción.

Por lo demás, sus fachadas son prácticamente idénticas, mostrando un amplio lienzo plano, elaborado en piedra de sillería, articulado en dos cuerpos (planta baja y entrecubierta), separados por una línea de imposta plana de escaso resalte. Dentro de ella destaca la planta baja, sobre cuya parte central se abre el amplio arco escarzano de rosca decorada con profundo casetonado, que conduce al porche, el cual está acompañado a los lados por dos ventanas de dintel plano de pequeño tamaño, recercadas por una moldura plana con orejones. En el segundo cuerpo, sobre el eje del arco que conduce al porche, se abre un pequeño balcón, con puerta también adintelada, pero

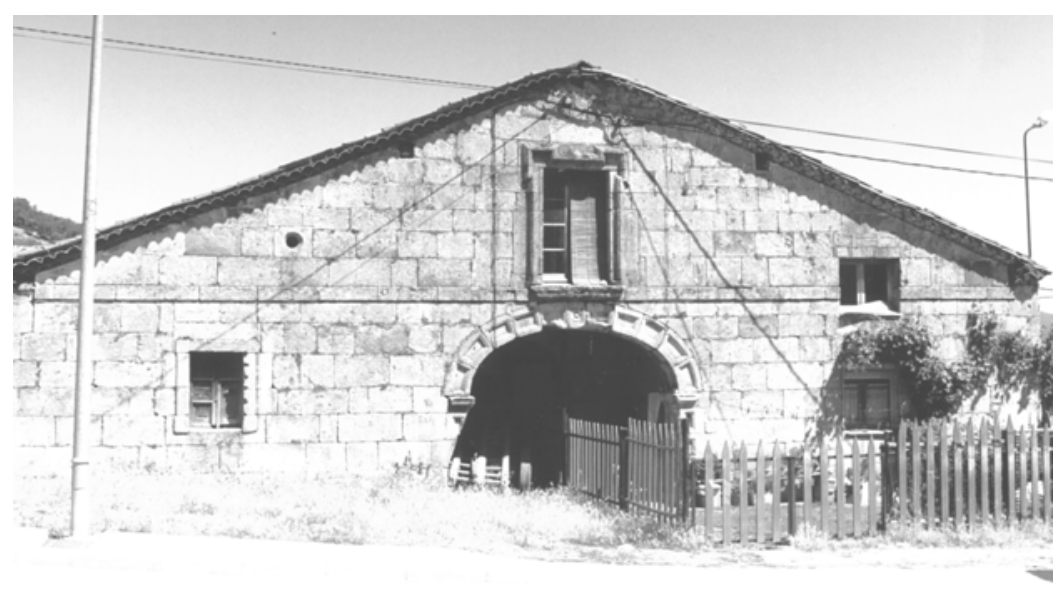

CANICOSA DE LA SIERRA. Calle Nuestra Señora del Carrascal n ${ }^{\circ} 54$ 
664 Arquitectura de la Edad Moderna en la sierra burgalesa.

recercada con una abultada moldura quebrada con orejones.

En el interior del porche, un segundo arco de medio punto y rosca decorada también con casetones, conducía al interior de la casa. De estos dos ejemplos, sin embargo, solamente la segunda casa lo mantiene en pie. En ella, igualmente nos encontramos varios ejemplos de sogueado, con el que se decoran las aristas de las vigas, dispuestas, tanto en la zona del porche, como en las habitaciones del interior.

Son casas, por lo tanto, de clara inspiración popular, ya que parten del modelo general de casa carretera, en el cual, sin embargo, no se duda en incluir determinados elementos, como el casetonado de los arcos o el recercado de sus ventanas, en los cuales se manifiesta una clara influencia de la arquitectura culta. De igual modo, la cuidada cantería, empleada en sus fachadas, constituye otro signo más del interés de sus promotores por mostrar su elevada posición económica. Todos estos rasgos, en definitiva, hacen que se adopte de forma generalizada el término casa solariega para denominar a esta variante.

Otro ejemplo de esta variante de casa, en la que se adivina una estructura prácticamente idéntica a las dos anteriores, la encontramos en el $n^{o} 36$ de esta misma calle de Nuestra Señora del Carrascal. No obstante, su imagen original se halla profundamente alterada, al incorporar un nuevo piso, que ha terminado por absorber el hastial de su cubierta a dos aguas. Aun así, conserva la estructura de su planta baja, con el gran arco escarzano de rosca casetonada en el centro, que conduce al porche, y las dos ventanas laterales, que en este caso parecen haber sido ampliadas. De igual modo, sobre el paramento del muro de la planta superior, todavía es posible apreciar el contorno de las dos vertientes del hastial, junto con la imposta plana, que separaba la planta baja de la entrecubierta. Por supuesto, toda esta fachada se encuentra realizada, como los casos anteriores, en piedra de sillería, introduciendo también con ello un claro componente de distinción. Una pequeña inscripción nos anuncia que este edificio fue 
construido en el año 1741, lo que nos hace sospechar la participación de la misma cuadrilla de canteros, que realizaron los dos ejemplos anteriores.

Dos ejemplos más de esta variante los encontramos en la calle del Obispo $n^{\circ} 12$ y en la calle Gregorio López $n^{o}$ 1, de la misma localidad de Canicosa de la Sierra. La primera de ellas conserva el gran arco de rosca casetonada, que conduce al interior del porche, si bien, el resto de la fachada ha desaparecido por completo, sin dejar rastro alguno de lo que debió ser su estructura original. La segunda casa, por su parte, representa una interpretación mucho más modesta y simplificada del modelo general de esta variante. Así, nos encontramos con una gran fachada levantada en parte en piedra de sillería, y en parte en sillarejo, con un lienzo completamente plano, articulado en dos cuerpos, rematados con un tejado dispuesto a doble vertiente. El portalón, como en los casos anteriores, sólo abarca la parte central de la planta baja, si bien, en este caso, no aparece el típico arco de rosca casetonada, que es sustituido por una amplia puerta de dintel plano, rematada por una gruesa viga de madera.

La tercera y última variante de esta tipología de la casa carretera, es la denominada gran casona carretera. Constituye, sin duda alguna, la variante más sencilla de las tres, pues nos ofrece una fachada completamente plana, de rasgos muy similares, en cuanto a su estructura, composición y perfiles, al modelo que acabamos de ver, si bien, en este caso desaparece el porche o portalón abierto en el centro. Representa así la versión más cercana al modelo original de casa carretera, del cual parten todas estas variantes, procediendo únicamente a eliminar el porche, que en aquella, abarcaba todo el frente de su fachada principal.

Tal vez por ello, y por constituir un modelo muy fácil de construir y de ampliar, esta variante se convierte en la más popular de todas, y también en la que mayor número de ejemplos nos ha dejado, perpetuándose en la arquitectura popular de la zona a lo largo de toda la centuria siguiente, hasta alcanzar las primeras décadas del siglo XX. Esto hace que resulte muy difícil establecer una cronología precisa para muchos de los 
ejemplos, pues sus características prácticamente no sufren cambios significativos a lo largo de todo este tiempo.

Ejemplos de este modelo de casa los encontramos en todos los pueblos, que de forma más o menos intensa, participaron en esta actividad de la carretería. No obstante, los más interesantes y representativos se localizan en los pueblos incluidos dentro de la llamada comarca de pinares, como es el caso de Canicosa de la Sierra, Palacios de la Sierra, Vilviestre del Pinar y Quintanar de la Sierra. Junto a ellos, también podemos ver muestras de este tipo de construcciones en Castrillo de la Reina, Hacinas e incluso en Salas de los Infantes.

Canicosa de la Sierra conserva un magnífico ejemplo de esta variedad de casa carretera en la calle Pinachón $n^{\circ} 18-16$, si bien este edificio ha sufrido una importante remodelación durante los últimos años de la década de 1990, que ha terminado por desdibujar su aspecto original. A pesar de ello se ha logrado conservar el dintel de lo que debió ser su antigua puerta de entrada, en el cual aparece una inscripción, en la que se indica el año 1742, correspondiente a fecha de su construcción, acompañado del texto: JESVS MARÍA / SANCTE ANTONIO RAPRO. Sobre ella se representa una elevada cruz latina acompañada de un pequeño tondo con una flor en su interior y un triángulo inscrito dentro de un cuadrado.

Para apreciar su estructura, sin embargo, tenemos que acudir a las fotografías previas a su reforma. En ellas podemos ver la característica fachada levantada en piedra de sillería, articulada en dos cuerpos y entrecubierta, que queda rematada con techumbre dispuesta a dos aguas. Una obra característica de este momento, en la que se desarrolla un modelo de casa propio de la arquitectura popular, ennoblecido, en este caso, por el delicado trabajo de cantería que se ha desarrollado en sus muros, con un especial cuidad en los de su fachada principal. 


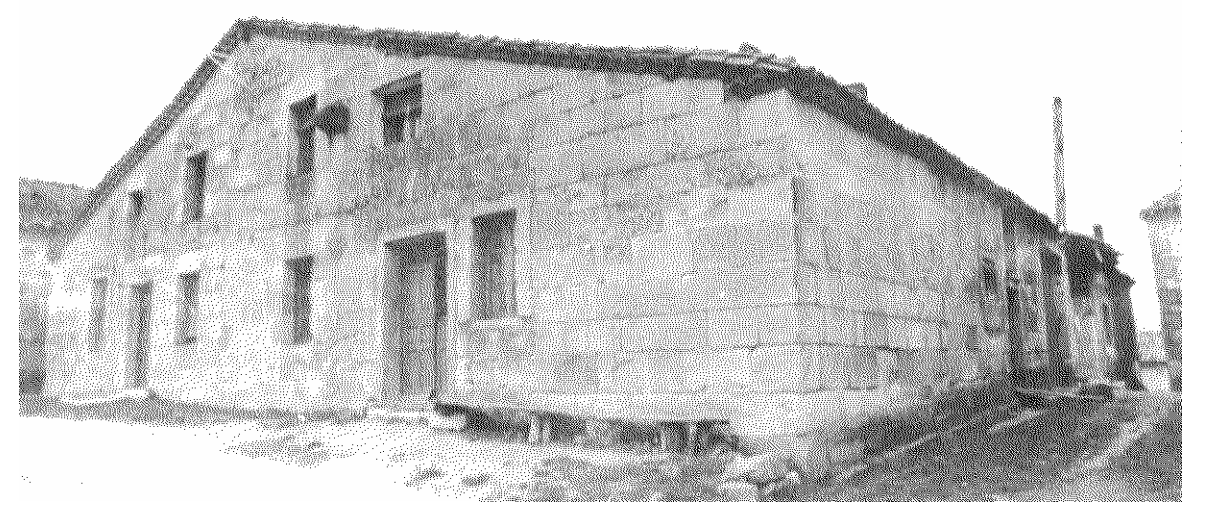

CANICOSA DE LA SIERRA. Calle Pinachón $n^{\circ} 18$ - 16 (Imagen tomada en la década de 1970)

Más ejemplos de este modelo encontramos en la localidad de Palacios de la Sierra. El más destacado se halla en la Travesía del Rosario $n^{\circ} 4$, la cual nos ofrece un edificio de amplias proporciones, levantado sobre extensa planta cuadrangular, con muros de sillería en todos sus lados, articulados en dos cuerpos. Su fachada principal queda orientada hacia el mediodía, y en ella se desarrolla la característica estructura de muro completamente plano, articulado en dos cuerpos, rematados mediante cubierta a dos aguas de hastial achaflanado. No tenemos la certeza de que todos los vanos con los que cuenta actualmente pertenezcan a su estructura original, si bien, a pesar de todo, dentro de ellos creemos descubrir una cuidada ordenación de base reticular, repitiendo siempre el mismo tipo de vano adintelado. La puerta de acceso queda situada en la parte central de la planta baja, acompañada por dos vanos más a los lados, que se corresponden con otros similares en el piso superior. El único de todos ellos que recibe un tratamiento especial es el situado en la parte central de la planta principal, el cual conduce al balcón dispuesto sobre la puerta de entrada, que se apoya sobre plataforma moldurada. Esta puerta se encuentra enmarcada por una doble moldura quebrada con orejones, muy similar a las que vimos en Canicosa de la Sierra en alguno de los 
modelos de casa solariega, lo que nos hace sospechar una cronología similar, situada en torno a las décadas centrales de este siglo XVIII.

Justo frente a esta casa, ocupando los $n^{\circ} 7$ y 9 de la Travesía del Rosario, encontramos otro ejemplo de esta variante, si bien, se trata de una interpretación sumamente simplificada del modelo general. Aun así, y a pesar de las alteraciones sufridas a lo largo del tiempo, su fachada principal conserva todavía su estructura de muro completamente plano, articulado en dos cuerpos, rematado con cubierta a dos aguas de hastial achaflanado.

Mucho más interesantes resultan los restos conservados de la casa situada en la calle Mayor $n^{\circ}$ 87, dentro de los cuales el elemento más llamativo lo constituye, sin duda alguna, el espectacular arco, que sirve de marco para su entrada principal. Se trata de un arco de medio punto, de rosca casetonada, como suele ocurrir durante este siglo XVIII, el cual incorpora, sobre estos casetones, una serie de motivos ornamentales, compuestos por veneras y elementos vegetales, con los que se introduce un componente poco habitual dentro de estos edificios. El resto de la estructura del inmueble, sin embargo, se encuentra totalmente alterado por las modificaciones introducidas a lo largo del tiempo, lo que nos impide reconocer su aspecto original.

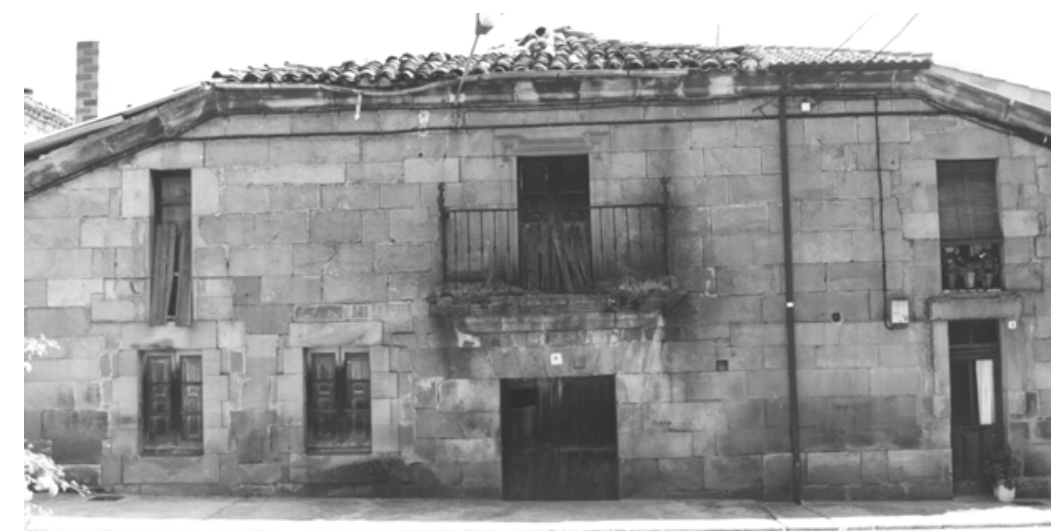

PALACIOS DE LA SIERRA.

Travesía del Rosario $n^{\circ} 4$ 
Esto mismo sucede en la casa situada en la calle San Vicente $n^{\circ} 30$, donde también se ha perdido la estructura original del edificio. Lo único que encontramos, en este caso, es una serie de vanos de estructura adintelada, recercados mediante moldura plana de escaso resalte con orejones. Precisamente sobre el dintel de uno de ellos podemos ver una inscripción, donde dice: JESVUS MARÍA Y JOSEPH AÑO DE 1711 AÑOS, la cual, de forma reiterada nos indica su fecha de construcción. Por último, dentro de esta misma localidad de Palacios de la Sierra, encontramos también otro ejemplo interesante de esta variedad en la calle de la Peña $n^{o} 32$. En ella se puede ver la habitual estructura de fachada planta, articulada en dos plantas y rematada por cubierta dispuesta a dos aguas, en la que se abren vanos de dintel plano recercados con moldura plana de escaso resalte con orejones. No obstante, la técnica constructiva empleada, en este caso nos indica que pudiera tratarse de una construcción algo más tardía, situada ya en pleno siglo XIX.

Vilviestre del Pinar nos ofrece algunos tímidos ejemplos de este modelo en el Barrio de San Martín $n^{\circ}$ 256, y en el Barrio de San Roque $n^{\circ} 137,144$ y 179. No obstante, se trata, en todos los casos, de obras sumamente toscas, en las que resulta muy difícil apreciar la incorporación de elementos, que podamos considerar propios de la arquitectura culta.

Esto mismo sucede con los ejemplos, que podemos citar, para este caso, en Quintanar de la Sierra, los cuales, además se hallan notablemente alterados por las modificaciones introducidas durante las últimas décadas del siglo XX. De este modo, hoy no podamos destacar ni un solo ejemplo de casa típicamente carretera dentro de esta localidad, lo que no deja de ser paradójico, pues se trata de unos de los principales núcleos ligados a la actividad del transporte.

En Castrillo de la Reina, Hacinas y Salas de los Infantes, lo más que encontramos son casas en las que repite el tradicional tipo de fachada de amplio lienzo 
completamente plano, rematado con tejado a dos aguas, de hastial, en algunos casos, achaflanado. En Castrillo de la Reina, existen ejemplos en la calle Mayor $n^{\circ} 66$, y $n^{\circ} 75$, en la calle Corralejo $n^{o} 10$. En Hacinas, aparecen ejemplos similares en la calle Laín Calvo $n^{\circ} 59$, y en la calle San Juan $n^{o} 31$. Mientras que en Salas los ejemplos mejor conservados se concentran en el barrio de Santa María, en la calle de la Luna $n^{\circ} 29$ y en la calle del Prado $n^{\circ} 9$. 
IX. CONCLUSIONES. 
La comarca de la sierra burgalesa durante la Edad Moderna es un centro artístico de carácter secundario, claramente dependiente de las formas y artífices venidos de fuera. Ello no impide que su arquitectura culta desarrolle unas líneas generales coincidentes en gran medida con las mantenidas en el resto del ámbito provincial y regional. No obstante, estos lenguajes predominantes son acogidos con una evidente lentitud, que no queda exenta en algunos casos de cierta indecisión.

Esta actividad constructiva vive durante el período de la modernidad dos momentos particularmente destacados, como son, por un lado, los albores de ésta época, entre los años finales del siglo XV y primeras décadas del XVI, y por otro, el siglo XVIII. Ambos coinciden con sendos momentos de aceleración económica y especial pujanza social y cultural, lo que se canaliza a través de esta necesidad de plasmar sus inquietudes expresivas por medio de construcciones representativas.

Durante todo el periodo estudiado se observa la convivencia de diferentes estilos, desarrollados siempre en su vertiente menos dinámica. Esta comarca, por lo tanto, se limita a asimilar los modelos, soluciones y experiencias ya desarrolladas en los principales focos rectores de la actividad constructiva, interpretándolos bajo un prisma popular, que hace desaparecer los aspectos más artificiosos y atrevidos de cada lenguaje. Quedan reducidos así a fórmulas y repertorios muy sencillos, fáciles de 
ejecutar, y por ello mismo susceptibles de ser imitados hasta la saciedad sin ningún tipo de cambio.

En esta dinámica son varios los factores que intervienen. Hay que tener en cuenta la pugna que existe entre tradición y modernidad, conceptos que implican conservadurismo y defensa de lo nativo, el primero de ellos, y aceptación de lo nuevo y desconocido, el segundo. En este caso, el predominio aparente de la primera de las posturas no parece que consiga evitar la llegada de nuevas formas, pero sí logra imprimir una fuerte impronta de severidad. Un panorama que se veía afianzado por el carácter aislado de la comarca, situada muy lejos de los principales focos rectores de la actividad artística, no sólo geográficamente, sino también desde el punto de vista cultural.

Otro factor de peso dentro en este conservadurismo es el papel jugado por los clientes y promotores de obras, por un lado, y los artífices, por otro. En el primer caso, la falta de contacto con un ambiente cultura más avanzado y refinado, y el férreo apego a unas soluciones constructivas de solidez y durabilidad sobradamente demostradas, hacía poco menos que imposible la incorporación de un lenguaje más atrevido, especialmente en los aspectos estructurales. Las formas más avanzadas quedaban reducidas a aquellos elementos epidérmicos. El conservadurismo de los clientes se explica, en cierto modo, por el predominio de la estética de lo perdurable, dentro de su escala de valores. Debían entender, por lo tanto, que la calidad de una obra se medía, no tanto por su capacidad de impresionar mediante el desarrollo de determinados elementos efectistas, como por su durabilidad, convirtiendo sus creaciones en referente para las generaciones venideras.

Por su parte, en el ámbito de la arquitectura civil la ausencia de nobles de la alta aristocracia es determinante para que no existan edificios concebidos con una mínima calidad artística durante una buena parte de la Edad Moderna. Sólo a partir de un momento avanzado del siglo XVII, cuando se produce un singular proceso de 
ennoblecimiento de parte de la sociedad serrana, es cuando asistimos al nacimiento de una arquitectura civil que se despega mínimamente de los modelos tradicionales de las construcciones populares. Son edificios, en cualquier caso, muy sencillos, que introducen como novedades más valientes, junto a una contundente definición volumétrica, la presencia de ciertos elementos como arcos, molduras y escudos en sus fachadas principales.

En lo que se refiere a los artífices, el carácter aislado de la comarca hace que no se conozcan figuras de primera línea. Esto lleva, por parte de aquellos maestros, a una férrea protección de lo asimilado, que resulta totalmente contraria a aceptar con facilidad las novedades que se producen en el campo constructivo. Son maestros que proceden en la inmensa mayoría de los casos de fuera, con una formación mediocre, apegada a formas y modelos tradicionales (conservadores), que se convierten en frente de resistencia ante cualquier incorporación de formas nuevas. Esto no supone cortar de raíz toda posibilidad de aceptar novedades en su repertorio, pero sí la ralentización en la llegada de nuevas soluciones, desarrollándose ya fuera de su tiempo natural.

Por último, el desarrollo económico también juega un papel importante en el conservadurismo artístico. Así, los periodos de expansión, que se corresponden con un auge en la actividad constructiva, eliminan la necesidad de nuevas obras en las etapas inmediatas. Es lo que sucede con el espectacular progreso que se vive durante la segunda mitad del siglo XV, plasmado en la creación de importantes fábricas religiosas entre la etapa final de la centuria y las décadas iniciales de la siguiente. Con ello lo que se consigue es que las necesidades de calidad y cantidad queden cubiertas para el resto del siglo XVI, periodo en el que se produce la expansión de las formas renacentistas, de modo que este estilo apenas encuentra espacios en los cuales desarrollase.

Cabe preguntarse, que papel juega esta comarca de la sierra burgalesa dentro del panorama artístico de la provincia. Observamos que constituye un destacado exponente de las creaciones tardogóticas emprendidas ya en pleno siglo XVI, como bien se 
encargan de demostrar las iglesias de Santa María de Salas de los Infantes, Castrillo de la Reina, Barbadillo del Pez, y la parroquia de Santa Eulalia en Palacios de la Sierra (en su fase gótica). En la estética renacentista sus aportaciones son más bien escasas, aunque en los pocos ejemplos existentes se aprecia su alta calidad, como demuestra de modo especial la portada de la iglesia de Santa María de Salas de los Infantes.

A partir de aquí cualquier atisbo de modernidad e innovación se pierde ante el fuerte arraigo que alcanza la estética clasicista, impuesta desde principios del Seiscientos. Esto termina por cerrar cualquier mínimo resquicio para el desarrollo de las formas propiamente barrocas, tanto en los elementos estructurales, como en el campo ornamental. De los pocas excepciones que conoce esta situación son buena cuenta la portada de la iglesia de San Pedro, en Hacinas, y la magnífica cabecera levantada para la iglesia de San Martín, en Vilviestre del Pinar.

En definitiva, el carácter asimilardor de formas ya elaboradas y receptor de artífices foráneos, hace que las aportaciones efectuadas al ámbito provincial circundante sean más bien escasas. Existen, sin embargo, una serie de particularidades, que resulta obligado recordar, valorándolas en su justa medida.

Son interesantes, así, algunas de las tipologías desarrolladas, especialmente en el ámbito de la arquitectura civil, como las casas blasonadas de los propietarios de rebaños trashumantes, y las casas carreteras, en cualquier de sus variantes. Se trata de unos tipos de edificios que destacan, no sólo por la cuidada configuración de su estructura y su poderosa imagen exterior, sino también por su papel de trasmisores de una cultura ya perdida y en cierto modo olvidada. Son construcciones, que sin perder su evidente carácter funcional, saben introducir una serie de elementos ajenos a este papel básico que desempeñan, para convertirse en referente dentro de sus respectivos núcleos y testigos de la historia. 
Un rasgo muy representativo de estas construcciones, que debemos hacer extensible en gran medida al resto de los edificios representativos de la zona, es su magnífica estereotomía, con una técnica extraordinariamente cuidada, que hace de la solidez de sus muros y la pureza de sus volúmenes, una de sus señas de identidad más logradas. En el campo de la arquitectura civil esta técnica únicamente se aplica en aquellas construcciones más destacadas, pertenecientes a los miembros más poderosos de cada núcleo, con lo que adquiere un evidente sentido simbólico de poder y prestigio. En lo que se refiere a la de carácter religioso, sin embargo, se extiende en la mayoría de los casos incluso a las construcciones más modestas, como ermitas y humilladeros.

Unas ermitas que se extendieron en gran número por todo el territorio de estas sierras, hasta el punto de convertirse en uno de los fenómenos más singulares de la comarca, pues no existe parangón en el resto de la provincia. El origen de cada una de ellas es muy diverso, si bien, todas se fundamentan en un mismo sentimiento, como es el de la religiosidad popular o local. Una forma alternativa de vivir la piedad cristiana, que no se consideró nunca enfrentada a la religión oficial de la jerarquía eclesiástica.

La actividad constructiva en la zona de la sierra durante la Edad Moderna, en definitiva, presenta unas particularidades que son comunes a todo el mundo rural, las cuales se ven afianzadas además por su condición de zona aislada. Esto, sin embargo, no evita que por una parte sus líneas generales coincidan con las desarrolladas en un marco mucho más amplio, como es el medio provincial, y por otro lado, que presente al mismo tiempo sus propias singularidades. Entre estas últimas destaca especialmente la contribución que esta arquitectura hace a la formación de la imagen más representativa de unos núcleos, que vivieron en estos momentos su periodo de mayor esplendor. Un esplendor que queda ya muy lejos, y una imagen que está terminando de borrarse. 
ALVEINTE. (Convento de Santa María de Alveinte)

“Fraile que hiciste que Alveinte viniste”. Con esta frase lapidara colocada, según unos, en la portería del convento, y según otros, en alguno de los arcos del templo, se recibía a los frailes que llegaban hasta aquí, pues este centro tuvo fama de ser lugar de acogida para aquellos miembros díscolos de la orden franciscana. Lo apartado del paraje y la belleza de la naturaleza que lo rodea, se convertían de este modo, en los principales medios con los que se pretendía corregir la relajación y la moral distraída de algunos hermanos de la orden.

Este pequeño cenobio se encontraba situado en las inmediaciones de la localidad de Monasterio de la Sierra, dentro ya, de los terrenos de ledanías, administrados por Salas de los Infantes, Castrillo de la Reina, Hacinas y Monasterio de la Sierra. Se halla, por lo tanto, en medio de un paraje agreste, de bucólica belleza, dispuesto sobre las laderas de un encajado un valle, que forma en este tramo el río Arlanza.

Las primeras referencias escritas, que tenemos sobre este cenobio proceden de un documento fechado el 1-I- 1044, en el que se da cuenta de la donación, que el patrono del convento hasta el momento, D. Laín González, hace al monasterio de San Pedro de Arlanza ${ }^{820}$. El lugar en el que se asentaba, no obstante, según nos indica el P. Bernardo PALACIOS, era en este momento propiedad del mismo monasterio de San

820 L. SERRANO: Cartulario de San Pedro de Arlanza. Madrid, Centro de Estudios Históricos. 1925. (pp. 86). 
Pedro de Arlanza ${ }^{821}$. El origen del convento, por lo tanto, se encuentra incluido dentro del proceso de creación de pequeños centros religiosos, que se produce de modo paralelo a la aparición de los núcleos de población estable, surgidos en estas sierras entre los siglos X y XI. Esto dio lugar a pequeños monasterios como el de San Cristóbal, en Vallejimeno, San Mamés, en Huerta de Arriba, San Millán, en Revenga, y San Pelayo, en Salas de los Infantes. De todos ellos, el de Alveinte fue el único que sobrevivió hasta la Edad Moderna.

Su despegue definitivo, no obstante, no se produce hasta mediados del siglo XV, momento en el cual se efectúa su refundación, y se incorpora a la orden franciscana. El encargado de dirigir este proceso fue el venerado Fr. Lope de Salinas, el cual, en 1441, tras el incendio de la casa, que los franciscanos tenían en la villa de Belorado, decide trasladarse aquí con sus frailes, mientras se acometen las labores de reconstrucción de su convento. Esta refundación se acomete por iniciativa de D. Pedro Fernández de Velasco, I Conde de Haro y señor de Salas, el cual se había hecho con el patronato del cenobio, al mismo tiempo que incorporaba a su señorío jurisdiccional gran parte de los pueblos de la zona. Su patronato sobre el convento no sufrirá cambios a lo largo de todo el periodo de la Edad Moderna, lo cual queda reflejado en el edificio, entre cuyas ruinas descubrimos varios restos de elementos ornamentales, en los que se incluyen los característicos veros de las armas de los Velasco.

Según nos indica el texto de la refundación, los frailes franciscanos que acompañaban a Fr. Lope de Salinas, se asentaron en un primer momento en una pequeña ermita que existía en las inmediacione, dedicada a San Luís, la cual fue adquirida por D. Pedro Fernández de Velasco al monasterio de San Pedro de Arlanza. Junto a ella existía otra ermita, dedicada a Nuestra Señora de los Lirios, cuya imagen

821 Fr. B. PALACIOS (O de M): "Historia de la ciudad de Burgos, de sus familias y de su Iglesia”. En Boletín de la Estadística Municipal de Burgos. Burgos, Ayuntamiento. (pp. 20 - 21). 
pasó finalmente a presidir el altar mayor de la iglesia conventual ${ }^{822}$. Esto hizo que en algunos momentos este convento franciscano fuera designado con los nombres de San Luís y de Nuestra Señora de los Lirios. Sin embargo, la denominación más común fue la de Santa María de Alveinte, tomado del el Veinte, un pequeño despoblado, que existió en sus inmediaciones, deshabitado en torno al siglo XII.

Sabemos, en cualquier caso, que fue siempre una comunidad pequeña, compuesta, según indica la tradición que apuntábamos, por frailes poco rigurosos en la observancia de la regla, o directamente de moral distraída, los cuales debían ser correguidos, o mantenidos lejos de la tentación mundana. Los dos únicos recuentos con los que contamos, en los cuales se hace una relación detallada del número de religiosos, que aquí existían en momentos concretos, pertenecen ya a la segunda mitad del siglo XVIII, y son los del Catastro del Marqués de Ensenada y el censo de Floridablanca. En el primero, realizado en 1753, simplemente se da cuenta de una comunidad compuesta por 15 religiosos y 2 legos ${ }^{823}$. En el de Floridablanca de 1787, se hace una relación más detallada, indicándonos que existían 8 profesos, 1 novicio, 2 legos, 1 criado y 1 niño ${ }^{824}$.

Este escaso crecimiento hizo que sus dependencias apenas experimentaran cambios notables a lo largo de la Edad Moderna, manteniendo, en gran medida, la estructura que se levanta en la segunda mitad del siglo XV. No obstante, la degradación, o directamente la destrucción de la mayor parte de la estructura del convento, hace imposible reconstruir su fisonomía.

Su historia, por otra parte, tampoco estuvo salpicada de hechos notables, pues su situación aislada, y el carácter de recogimiento que se esperaba de esta comunidad, no dejaban lugar a su participación en sucesos importantes dentro de la historia de la orden

822 A. BENGOECHEA: Historia de Salas I. Paisaje, clima, economía, etnología, apellidos, dinosaurios, primeros pobladores, antigüedad, Edad Media, los 7 infantes de Lara. Burgos, Museo de Salas. 2003. (pp. 116 - 118).

823 ADPBU. CE - 1740. RESPUESTAS GENERALES. Salas de los Infantes, 10 - febrero - 1753.

824 INE. Censo de 1787. “Floridablanca”. Madrid. INE. 1989. 
franciscana en Castilla. Solamente en la última etapa de su historia, previa a la exclaustración definitiva, encontramos algunos episodios revestidos de cierta gloria. De esta forma, vemos cómo su condición de lugar apartado y de difícil acceso hizo que este convento se convirtiera en refugio ideal para los gerrilleros y opositores en general, que lucharon contra las tropas francesas, durante la Guerra de la Independencia de principios del siglo XIX. Tanto es así, que en el año 1810, durante un breve espacio de tiempo, se convirtió en sede de la Junta Provincial de Defensa de Burgos, la cual llegó a instalar en sus dependencias una pequeña imprenta clandestina, desde la que difundía panfletos con soflamas contra los invasores. Esta circunstancia, sin embargo, marcó el final de este convento, pues una vez descubierta la presencia de la Junta de Defensa en este lugar, las tropas francesas no dudaron en dinamitar parte de sus dependencias, lo que originó un brutal incendio, que devoró parte de su legado artístico y documental.

Tras este episodio, su reconstrucción fue ciertamente difícil, lo que hizo que la desamortización de Mendizábal simplemente afectara a la venta de los bienes del convento, pues su exclaustración se había producido ya ${ }^{825}$. D. Atanasio Oyuelos y Barguillas, cura de la iglesia de Santa María de Salas de los Infantes, fue el que se hizo con los terrenos sobre los que se asentaba el convento por un precio de 901 escudos, mientras que la iglesia fue cedida más tarde por los Duques de Frías a la villa de Salas de los Infantes ${ }^{826}$. Los objetos muebles e imágenes del convento se repartieron entre los pueblos de la comarca. Dentro de estas piezas, sin duda, la más preciada es la imagen de Nuestra Señora de los Lirios, que presidía el altar mayor del convento, la cual fue a parar a la iglesia parroquial de Monasterio de la Sierra. Es una talla de madera policromada, de la Virgen con el Niño, perteneciente al gótico final, en la que se adivinan algunos rasgos renacentistas.

De la primitiva estructura del convento, la parte que mejor se ha conservado es la iglesia, pues el resto fue destruido por los soldados franceses, convirtiéndose a partir

825 A. PACHO POLVORINOS: “Exclaustrados en Burgos (1835 - 1837)”. En Burgense, $n^{\circ}$ 37/1 (1996), pp. $329-358$. 
de este momento en una suculenta cantera. La mayoría de sus restos fueron empleados en la construcción de una presa hidroeléctrica, levantada en las inmediaciones, durante la primera mitad del siglo XX. Esto hace que toda la parte correspondiente a las celdas y demás dependencias conventuales, haya desaparecido en su totalidad.

Algo mejor suerte ha corrido la iglesia, la cual, al menos, ha conseguido mantener en pie una buena parte de sus muros y un tramo de su cubierta. Para su estudio, sin embargo, únicamente contamos con el material que nos ofrece el análisis formal, pues la documentación donde se recoge su historia ha desaparecido.

Es un templo sencillo de tipo caja de una única nave de trazado rectangular, precedida de un pequeño nartex a los pies, y rematada, en su extremo orienta, por una cabecera de planta cuadrangular y testero plano, reforzado en las esquinas con estribos dispuestos en diagonal. Este conjunto se completa con una capilla latera, adosada sobre la parte delantera del lado del evangelio, de trazado rectangular, dedicada al Santo Crucifijo, cuya construcción, a juzgar por las formas empleadas, se produce en un periodo más tardío, que podemos situar hacia la primera mitad del siglo XVIII. El resto de la iglesia pertenece a los años finales del siglo XV o principios del siglo XVI, y nos muestra un estilo gótico muy austero de formas desonamentadas y líneas puras.

Estas pautas se manifiestan especialmente en la zona de la cabecera, pues no sólo es la parte más cuidada, sino también la zona que mejor se ha conservado. Es una capilla característica de aquel periodo, con planta de trazado cuadrangular y testero plano con estribos en las esquinas, dispuestos en diagonal, y cubierta con bóveda de crucería estrellada con terceletes. A su interior se accedía a través de un estilizado arco toral apuntado, dispuesto sobre soportes constituidos como una mera prolongación de su rosca, que rematan con una sencilla imposta. Iluminaban este lugar dos ventanales, abiertos sobre el muro del testero, de arco apuntado y fuerte derrame hacia ambas partes, con parteluz y tracerías góticas en su parte interior. Dos vanos más se abren en

826 A. BENGOECHEA: Historia de Salas... ob. cit. 
los muros laterales, el del lado septentrional, formado por una pequeña ventana con arco de medio punto y fuerte derrame hacia el interior, mientras que el del lado meridional está formado por un óculo. A estas ventanas se une más tarde el amplio vano coronado con arco de medio punto, abierto sobre la parte central del muro del testero, el cual, sin duda, estaba destinado a crear un efecto de transparente sobre la imagen titular del altar. La construcción de este último vano, por lo tanto, debemos situarla hacia finales del siglo XVII, o principios del XVIII, que es cuando se acometen este tipo de estructuras en la arquitectura religiosa de la zona. Los demás vanos, incluido el óculo, se corresponden cronológicamente con el resto de la estructura de esta cabecera.

La zona de la nave, por su parte, resulta más difícil de clasificar y datar, pues no sólo ha perdido gran parte de su estructura, sino que apenas conserva elementos destacados, que nos aporten pistas sobre su proceso constructivo. Aun así, observamos que se trata de una construcción mucho más modesta que la zona de la cabecera, pues en sus muros se alterna, sin aparente solución de continuidad, el sillarejo y el mampuesto, mientras que en la parte delantera existía únicamente sillería. De igual modo, en esta parte de la nave, a pesar de haber desaparecido toda su cubierta, no hay ningún elemento que nos permita sospechar la existencia de una estructura abovedada, como la que vemos en la cabecera, lo que hace que nos inclinemos por una solución más modesta de armadura de madera, con disposición a dos vertientes. Estos mismos rasgos se pueden extender al pequeño nartex, dispuesto a los pies, al cual se accedía a través de una pequeña escalinata.

Nos queda, por último, la capilla lateral dedicada al Santo Crucifijo, situada sobre el lado del evangelio. Se trata de una construcción más tardía, que debió sustituir a otra anterior, dedicada a esta misma advocación, en la que se custodiaban las reliquias de los monjes benedictinos San Freburario y San Camilo, que murieron martirizados durante la invasión musulmana ${ }^{827}$. A su interior se accedía a través de un amplio arco de medio punto de intradós ligeramente cajeado, apeado sobre gruesas pilastras de orden

827 Fr. B. PALACIOS (O de M): "Historia de la ciudad de Burgos...” ob. cit. 
toscano, cuyo fuste repite el mismo tipo de cajeado del intradós del arco. En ella se dibujaba un amplio espacio de planta cuadrangular, que se cubría con bóveda de crucería estrellada con terceletes, tal y como indica la impronta dejada en los muros por los arcos formaletes, y los abundantes restos de nervios y claves, hallados en su interior. Su cronología resulta difícil de precisar, si bien, las contundentes analogías, que muestra este arco de entrada con otras obras realizadas en la zona, como es el caso de la cabecera añadida a la iglesia de Santa Eulalia, en Palacios de la Sierra, nos lleva a situar su construcción en torno a las décadas iniciales del siglo XVIII.

SANTA MARÍA DE ALVEINTE.

Ruinas de su iglesia.

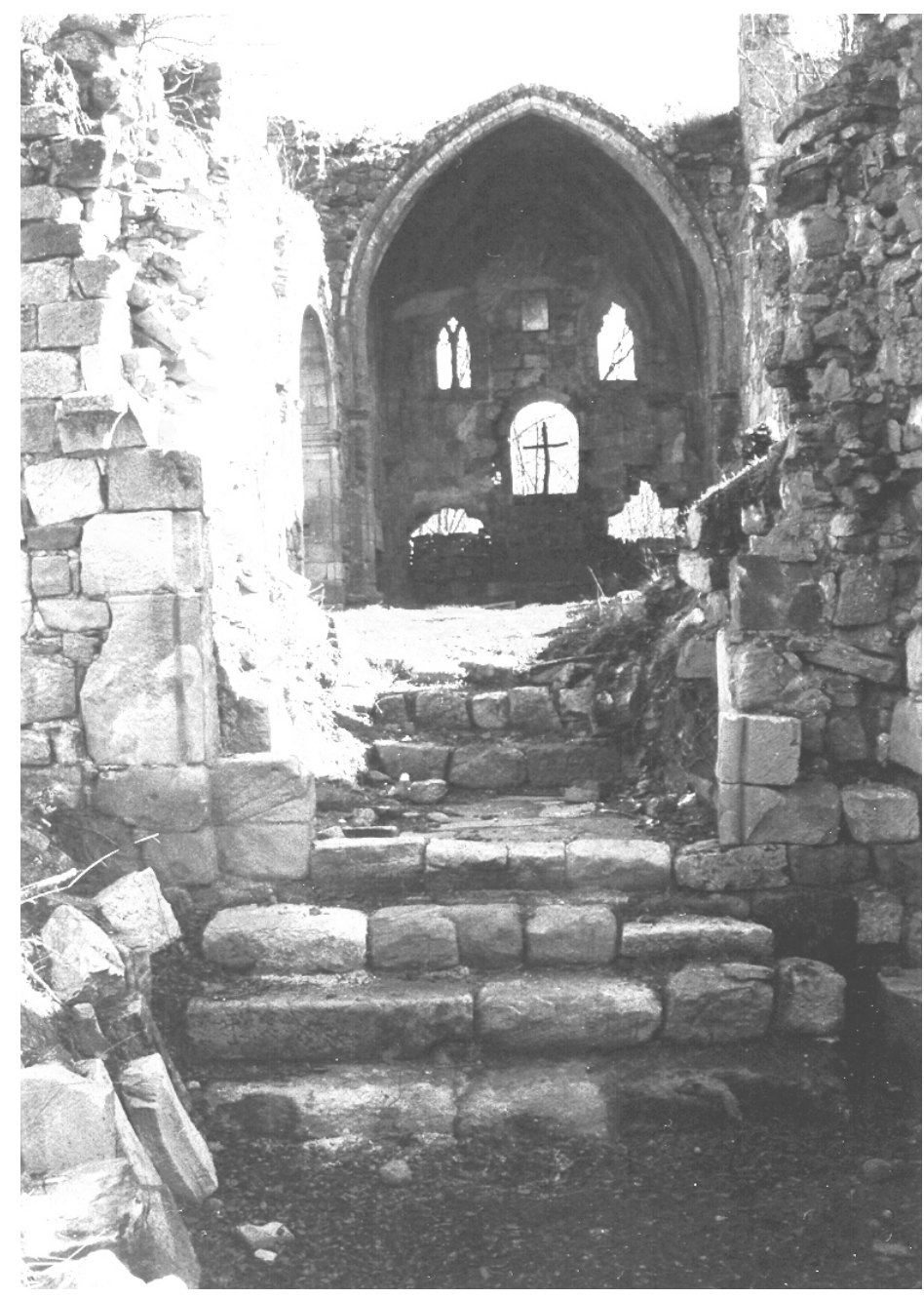


En lo que se refiere a las restantes partes del convento, como ya hemos indicado, apenas quedan unos escasos restos en pie, que en modo alguno resultan suficientes para poder adivinar la estructura y organización de las estancias. No obstante, en virtud de la técnica constructiva, que apreciamos en sus muros, debemos suponer que participaban de la misma modestia y sobriedad, que el conjunto del templo. 
ARROYO DE SALAS.

La pequeña localidad de Arroyo de Salas se encuentra situada en las agrestes estribaciones de la Sierra de la Demanda, ocupando el centro de un diminuto término municipal, rodeado en todos sus lados por terrenos pertenecientes a las ledanías. La economía de sus habitantes, por lo tanto, estuvo siempre marcada por su dependencia del aprovechamiento de estas tierras comunales, tanto para el uso agrario como ganadero. Esta última actividad suponía, de hecho, el principal sustento de estos vecinos, predominando los ganados estantes, aunque también existían algunos rebaños trashumantes $^{828}$.

El término Arroyo tiene una derivación obvia, que debemos relacionar con los topónimos extraídos de este elemento hidrográfico ${ }^{829}$. Su apellido, sin embargo, debemos relacionarlo con su vinculación hacia la vecina villa de Salas de los Infantes, a cuya jurisdicción pertenecía.

El origen de esta localidad, sin duda, se encuentra relacionado con los numerosos poblamientos, que se crearon en la zona, entre los años finales del siglo IX y el siglo X, si bien, tenemos que esperar hasta los primeros momentos del siglo XII para encontrar las primeras referencias escritas de su nombre ${ }^{830}$.

\footnotetext{
828 ADPBU. CE. 149. Respuestas Generales. Arroyo de Salas, 8 - febrero - 1753.

829 J. PÉREZ CARMONA: "La historia y la geografía burgalesas reflejadas en su toponimia”. BIRG, $n^{o}$ 163, (1964), pp. $238-271$.
} 
Hasta el siglo XII se halla encuadrada en el alfoz de Lara ${ }^{831}$, quedando incluida, desde finales de esta centuria y a lo largo de los dos siglos siguientes, en la Merindad Menor de Santo Domingo de Silos ${ }^{832}$.

En el plano fiscal, durante Edad Moderna, Arroyo forma parte de la provincia de Burgos, y como el resto de las localidades dependientes del señorío de los Duques de Frías, en la circunscripción menor, que formaba el partido de las Tierras del Condestable $^{833}$. Jurisdiccionalmente, como vemos, pertenecía al señorío de los citados Duques de Frías, si bien, esto no siempre había sido así, pues según nos indica el Becerro de las Behetrías, esta localidad era una de las que todavía mantenía, a mediados del siglo XIV, la condición de behetría ${ }^{834}$. En el ámbito eclesiástico, la parroquia de Arroyo formó parte siempre de la Diócesis de Burgos, desde la restitución de este obispado.

Durante el siglo XVIII, con el reajuste introducido por la dinastía borbónica en las estructuras administrativas del Estado, Arroyo, como el resto de los pueblos de la jurisdicción de Salas, queda encuadrada dentro del partido de Can de Muñó ${ }^{835}$.

Su población siempre fue escasa, manteniéndose en niveles bastante regulares a lo largo de todo el periodo estudiado. Así, en el censo de 1541 declara tener 22 vecinos

\footnotetext{
830 L. SERRANO: Cartulario de San Pedro de Arlanza. Madrid. 1925. (pag. 182).

831 G. MARTÍNEZ DÍEZ: Pueblos y alfoces burgaleses de la repoblación. Valladolid. Junta de Castillo y León. Consejería de Educación y Cultura. 1997. (pp. 172).

832 C. ESTEPA DÍEZ: "Estructura de poder en Castilla (siglos XII - XIII). El poder señorial en las merindades burgalesas. En III Jornadas burgalesas de Historia (3 1991). Burgos en la Plena Edad Media. Burgos, Asociación Provincial de Libreros de Burgos. 1994. (pp. 245 - 294).G. MARTÍNEZ DÍEZ: Libro Becerro de las Behetrías. Estudio y texto crítico. León, Centro de Estudios e Investigación San Isidoro. Caja de Ahorros y Monte de Piedad. Archivo Histórico Diocesano. 1981. (pp. 611 - 612).

${ }^{833}$ G. MARTÍNEZ DÍEZ: Génesis histórica de la provincia de Burgos y sus divisiones administrativas. Burgos, Aldecoa. 1983.

834 Ibídem.

835 G. MARTÍNEZ DÍEZ: Génesis histórica de la provincia de Burgos... ob. cit.; INE. Censo de 1787. “Floridablanca”. Madrid. INE. 1989.
} 
pecheros $^{836}$, los cuales quedan reducidos a 16 , en el registro de $1584-87^{837}$, y a 17 más un clérigo en el censo de $1591^{838}$. Esta cifra baja hasta los 15 vecinos en el censo fechado en $1646^{839}$, experimentando una recuperación en el siglo XVIII, con 25’5 vecinos a mediados de esta centuria, según el Catastro del Marqués de Ensenada ${ }^{840}, \mathrm{y}$ 59 habitantes, según el censo de Floridablanca de $1787^{841}$.

Esta localidad presenta un tipo de poblamiento característico de la zona, con un caserío muy apretado, dispuesto sobre una suave ladera, orientada hacia el mediodía. El único edificio mínimamente destacable, dentro de todo el conjunto, lo constituye la iglesia parroquial, situada en el extremo nor-oriental del pueblo.

\section{Iglesia de San Julián.}

La iglesia parroquial se encuentra dedicada, como vemos, a San Julián, advocación poco frecuente dentro de esta zona, ya que se trata del único templo dedicado a este santo, que nos vamos a encontrar. Presenta una sencilla estructura de tipo caja, sobre planta rectangular de una sola nave, articulada en tres tramos, de los cuales el delantero conforma la cabecera, y un tramo más e los pies, sobre el que se alza la torre.

Todo el edificio está realizado en piedra, alternando en sus muros la sillería, el sillarejo y el mampuesto, mostrando así las huellas dejadas por cada una de las fases constructivas, que se fueron sucediendo a lo largo de su historia. Al exterior, esta fábrica se muestra como una sencilla estructura prismática de carácter achaparrado, fuertemente reforzada por estribos laterales, que se completa con la torre, dispuesta a los

\footnotetext{
836 AGS. Contaduría General. Leg. 768. (fols. 61 vº).

${ }^{837}$ T. GONZÁLEZ: Censo de población de las provincias y partidos de la Corona de Castilla en el siglo XVI... Ed. Facsímil. Madrid, Imprenta Real. 1829.

838 Censo de Castilla de 1591. Vecindario. Madrid, Instituto Nacional de Estadística. 1984.

839 AGS. Cámara de Castilla - Diversos. Leg. 23, nº 24 (s/f).

840 Vecindario de Ensenada 1759. Vol. I. Madrid, Centro de Gestión Catastral y Cooperación Tributaria: Tabapress. D. L. 1991.

841 INE. Censo de 1787. "Floridablanca”. Ob. cit.
} 
pies, convirtiéndose en su único contrapunto vertical. Se trata de una torre de estructura igualmente prismática, sobre amplia base rectangular, articulada en dos cuerpos separados por imposta plana de escaso resalte. En su cuerpo superior se abren las troneras, formadas por arcos de medio punto, orientadas a los cuatro puntos cardinales.

La puerta de acceso queda orientada al mediodía, sobre el segundo tramo de la nave, y está formada por un simple arco ligeramente apuntado, de amplio dovelaje y aristas vivas, desprovisto por completo de decoración. Acompañando a esta puerta, sobre este mismo lado, se abren tres ventanas, distribuidas entre el tramo de la cabecera y los dos de la nave, a las cuales acompaña una más, dispuesta sobre el muro de los pies, en el cuerpo inferior de la torre, con la que se ilumina la zona del coro. Todas ellas presentan un sencillo trazado rectangular con dintel plano y ligero derrame a ambas partes, salvo la del presbiterio, que corona con arco ligeramente apuntado.

En el interior aparece un sencillo espacio de ámbito único, presidido por un claro carácter longitudinal, dentro del cual no se llega a establecer una separación clara entre la zona del presbiterio y el cuerpo. En el tramo de los pies, dentro de la base de la torre, se alza un sencillo coro alto, elaborado en madera. Los tres tramos que conforman la cabecera y la nave, están cubiertos con bóveda de crucería, estrellada con terceletes para el tramo de la capilla mayor (actualmente destruida), y cuatripartita para los dos restantes. El espacio del coro, por su parte, queda cubierto con un sencillo cielo raso.

Cada uno de estos tramos se halla separado por arcos, con diferentes tipos de trazados. Así, el tramo de la cabecera presenta un arco de medio punto de rosca moldurada, sobre pilares cilíndricos adosados al muro, sin capitel ni basa, mientras que en los tramos restantes se utilizan sencillos arcos ligeramente apuntados, de sección cuadrada, dispuestos sobre pilastras de fuste liso rematadas con imposta plana.

Se trata, en definitiva, de un edificio de reducidas dimensiones y formas extremadamente sencillas, en el que, por otra parte, resultan perfectamente visibles las 


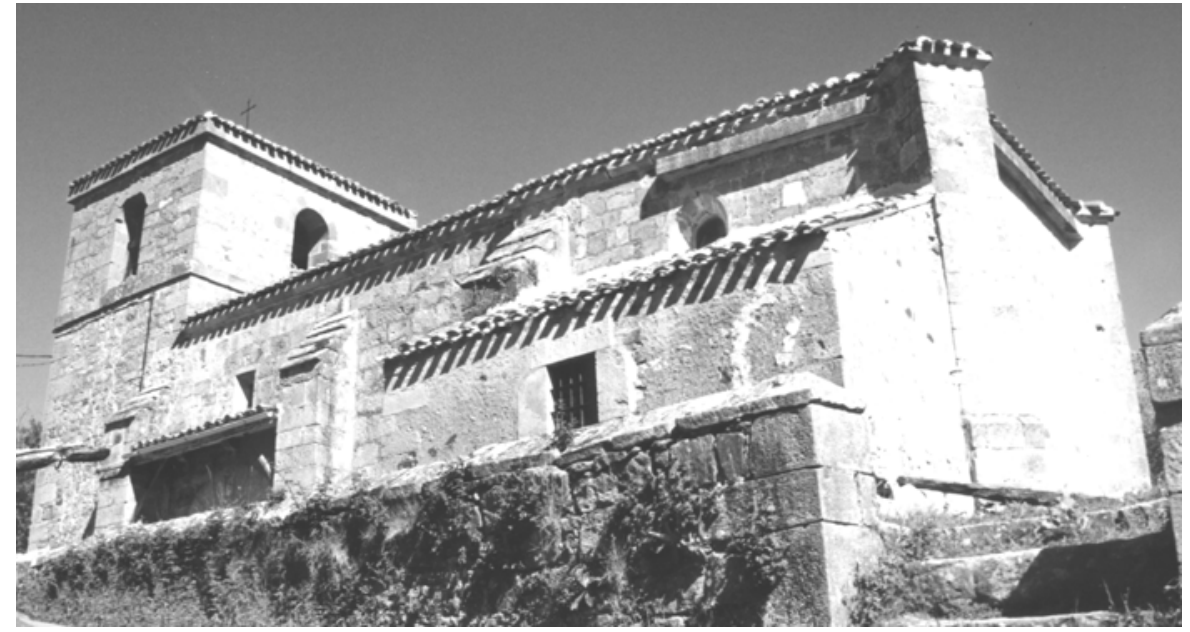

ARROYO DE SALAS.

Iglesia de San Julián.

huellas dejadas por las distintas fases constructivas, que en el transcurso de su historia, se han venido dando. Sin embargo, dentro de las aportaciones realizadas por cada una de estas etapas, así como en la imagen general ofrecida por todo el conjunto del edificio, no encontraremos elementos que muestren la más mínima calidad artística. Bien al contrario, resulta un edificio tosco y funcional, en el que únicamente cabe resaltar su extraordinaria firmeza constructiva, que hace de él una fábrica recia y de gran consistencia, preparada para afrontar las distintas embestidas, que le propicia el paso de tiempo.

Esta fábrica, por lo tanto, constituye, como decimos, el resultado final de una larga historia constructiva, en la que se han ido sucediendo diferentes fases. Sin embargo, cada una de ellas, más que añadir piezas nuevas, se han dedicado a renovar elementos ya existentes, lo que hace que resulte difícil encontrar restos de sus períodos primitivos. 
Así, la parte más antigua, que actualmente se conserva, corresponde a la zona del presbiterio, donde se muestran, a pesar de las reparaciones sufridas, los rasgos propios del gótico final, desarrollado en la arquitectura de la zona durante el siglo XVI. El tipo de soporte empleado en el interior, así como la cubierta (intuida a través del arranque de las jarjas), y la disposición de los contrafuertes exteriores, sobre los lados del muro del testero, nos permiten situar su construcción en torno al segundo cuarto de esta centuria del Quinientos.

El siglo XVII nos aporta la edificación de la torre, la cual presenta los rasgos típicos de sobriedad y firmeza, que muestran los otros ejemplos de este tipo de construcciones, levantados en la zona a lo largo de esta centuria. No obstante, como ya ocurriera con el caso anterior, la falta de fuentes documentales apropiadas nos impiden precisar el momento exacto de su construcción.

El siglo XVIII, por su parte, únicamente nos ofrece la serie de renovaciones, que fue necesario acometer, para garantizar la supervivencia del edificio. El origen de los problemas, que hicieron necesarias esta serie de reparaciones, se encuentra siempre en la inestabilidad del suelo sobre el que se asienta el templo, generada por las continuas humedades, que recorren el subsuelo. Esta humedad se manifiesta, de modo especial, en el manantial, que brota junto a la iglesia, a pocos metros de la torre.

El primer testimonio realmente serio de esta circunstancia, y los problemas por ella generados, lo tenemos en 1694, por voz del visitador del Visitador del Arzobispado de Burgos, D. Juan de Caabro, el cual, indica en su informe textualmente lo siguiente:

"Y porque su merzed a sido informado que la dicha iglesia está sin zimenterio y con algo de yndezencia y a peligro de venir alguna ruina a ella porque socabando la tierra con un arroyo de agua que pasa por el lado de ande está el coro y sitio más alto que iglesia y se presume que por resumirse las aguas hacia la dicha iglesia un poco de bizio que ha hecho eroxionado de la dicha agua y para obiar estos inconbenientes y poner el 
remedio que más convenga mando su merced al concexo y vecinos del lugar alcaldes y rexidores en birtud de santa obediencia pena de excomunión mayor la que sentencie dentro de un mes agan quitar y quiten la dicha agua por donde al presente va y guien por el otro lado apartándolo lo más que fuere posible para que no perjudique ni aga daño a dicha iglesia... (...). Su merced da lizencia en bastante firma de dicho a los mayordomos de la fábrica de la dicha iglesia para sin yncurrir en pena ni calumnia alguna puedan dar y den hazer el dicho zementerio a la persona o personas que con más comodidad lo hizieren rematándolo en el menor porte ${ }^{\text {842. }}$.

Sin embargo, este problema no parece que fuera afrontado de forma seria hasta los años finales de la década de 1720, cuando el deterioro del templo parece conducirlo, de manera inexorable, hacia la ruina total. Esta ruina, además, venía acompañada de una crítica situación económica para esta parroquia, lo cual obliga a los Visitadores del Arzobispado, al mismo tiempo que concede la licencia de la obra, a disponer posibles medios alternativos para poder obtener los recursos necesarios. El mandato, en este caso, es el siguiente:

"si quisieren nombren personas peritas en el arte que tasen y valuen lo que puede de costar ponerla (la mencionada iglesia de San Julián de Arroyo) perfectamente o hacerla nueva como se considera nezesario, y disponerse de prinzipio a la obra y no lo ejecutando pasados dos meses de dicho abiso sequestrará y embargará todos los años y hasta la concurrente cantidad de diezmos que les corresponden dispositándolos en los sitios y tiempos enos postrernos haciendo quenta formal de todo para que con claridad se sepa su producto y la pueda dar siempre que le sea pedida"843.

\footnotetext{
842 AGDBU. LP. Arroyo de Salas, parroquia de San Julián. LF. (1682 - 1718). (fols. 41 - 44vº . Visita realizada a la parroquia de San Julián de Arroyo de Salas en 1694, por D. Juan de Caabro. Salas de los Infantes, 9 - septiembre - 1694.

843 Ibídem. LF. (1721 - 1769). Visita realizada a la parroquia de San Julián de Arroyo de Salas en 1726, por D. Andrés Fernández de Tejada. Salas de los Infantes, 16 - septiembre - 1726.
} 
696 Arquitectura de la Edad Moderna en la sierra burgalesa.

La licencia para fijar los edictos y contratar la obra, sin embargo, tarda todavía dos años en concederse ${ }^{844}$.

Los trabajos emprendidos consistieron, simplemente, en una remodelación de los dos tramos correspondientes a la nave, lo cual se realizó respetando las proporciones de la fábrica anterior, y sin mostrar ningún tipo de pretensión de carácter artístico. El elemento más destacado de esta obra lo encontramos en los gruesos contrafuertes, que ahora se incorporan, los cuales resultan, a todas luces, excesivos, para una construcción de tan escaso desarrollo en altura, como era ésta.

La falta de cuidados en el desarrollo de esta obra, sin embargo, hizo que el resto de la estructura del templo se resintiera. Así, en 1740 el visitador del Arzobispado de Burgos, D. Francisco López de Angulo, denuncia la amenaza de ruina, que presenta la zona de la cabecera, la cual estaba provocada, no por las humedades, sino por las obras realizadas anteriormente en la nave ${ }^{845}$. Para la ejecución de estas obras, nuevamente se hacía necesaria la ayuda de los llevadores de diezmos, pues como el propio visitador indica“... y no alcanzando las rentas de dicha fábrica por lo que faltare pasará noticia a los llevadores de diezmos para que cada uno contribuia a proporción, y en caso de excusarse procederá a secuestrar los dichos decimales hasta la concurrente cantidad" ${ }^{846}$.

Con el desarrollo de estas obras, por lo tanto, podemos dar por concluido el proceso de construcción de este templo, ya que a partir de aquí las únicas intervenciones realizadas, estarán relacionadas con el mero mantenimiento del edificio. Dentro de ellas, no obstante, merece la pena destacar, por el elevado presupuesto invertido, y el esfuerzo

844 Ibídem. Visita realizada a la parroquia de San Julián de Arroyo de Salas en 1728, por D. Andrés Madrazo de Escalera, canónigo de la catedral. Salas de los Infantes, 15 - julio - 1728.

845 "Al mismo tiempo de la visita de dicha iglesia se reconoció apeada la capilla maior por la ruina que amenaza y procede de la que an hecho los estribos de dicha iglesia...” AGDBU. LP. Arroyo de Salas, parroquia de San Julián. (1721 - 1769). Visita realizada a la parroquia de San Julián de Arroyo de Salas en 1740, por D. Francisco López de Angulo. Salas de los Infantes, 28 - noviembre - 1740. 
que para esta parroquia suponía, la renovación del enlosado, que cubría el suelo del templo, la cual se llevó a cabo en diferentes etapas, entre los años 1753-64, con un presupuesto aproximado de 1.950 reales $^{847}$. Otra intervención interesante de este tipo, es realizada sobre las cubiertas, las cuales debieron ser reparadas, para la parte correspondiente a la nave, en 1793, con un coste para la parroquia de 670 reales $^{848}$, y para la de la zona de la cabecera en 1806 , con un desembolso de 1.100 reales $^{849}$.

Ermitas.

Cuatro fueron las ermitas, que existieron en este pequeño término municipal de Arroyo de Salas, las cuales dependían del propio concejo y vecinos del pueblo. Estas ermitas se encontraban dedicadas a San Miguel, San Andrés, Santa María Magdalena y San Martín. Lamentablemente tenemos que hablar de todas ellas en pasado, pues ninguna ha llegado hasta nuestros días.

La única que todavía nos muestra algún tímido resto de su estructura es la de San Miguel, la cual, además, era la más importante de ellas, hasta el punto de celebrarse en su honor la festividad mayor del pueblo. Se encontraba situada en las inmediaciones del pueblo, a escasos metros de las primeras casas, en dirección sudoeste. Sobre esta ermita, en época ya reciente, se construyó el cementerio, heredando de ella, no sólo parte de sus muros, sino el carácter sagrado de dicho solar (algo que resultó muy habitual desde los primeros momentos del siglo XIX).

Por lo demás, no es mucho lo que podemos conocer sobre su historia, pues como ocurre en la inmensa mayoría de los ejemplos de este tipo de construcciones, que encontramos en esta comarca, su origen se encuentra perdido en la noche de los tiempos. Contó, eso sí, con libros de fábrica propios, cuyos registros se han conservado

\footnotetext{
846 Ibídem.

847 Ibídem. Cuentas de 1753. Arroyo de Salas, 10 - octubre - 1754; Cuentas de 1755. Arroyo de Salas, 4 - septiembre - 1756; Cuentas de 1764. Arroyo de Salas, 11 - septiembre - 1765.

848 Ibídem. (1770 - 1852). (pp. 92 - 94). Cuentas de 1793. Arroyo de Salas, 15 - septiembre - 1794.

849 Ibídem. Cuentas de 1806. (pp. 133 - 135). Arroyo de Salas, 28 - septiembre - 1807.
} 
a partir del año 1710, lo que nos permite conocer su devenir a lo largo de todo el siglo XVIII. A través de estas fuentes sabemos que el edificio no presentaba un buen estado de conservación a comienzos de esta centuria, lo cual aparece denunciado constantemente por los visitadores diocesanos ${ }^{850}$.

Esta circunstancia culmina en 1726, con la visita de D. Andrés Fernández de Tejada, el cual plantea la posibilidad de construir una nueva ermita, sugiriendo, al mismo tiempo, la posibilidad de trasladarla a otro lugar, "porque el que tiene es muy húmedo y se halla rodeado de heredades labrantías y labrándolas la perjudican”851.

Sin embargo, parece que esto no llegó nunca a realizarse, pues a pesar de las prórrogas dadas sobre el calendario previsto para la reedificación ${ }^{852}$, en la visita de 1740, realizada por D. Francisco López de Angulo, se anuncia que el santuario se hallaba completamente en ruinas ${ }^{853}$. Esta circunstancia hace que sus rentas pasen ahora a la ermita de San Andrés.

Sin embargo, cuatro años más tarde, y como si de un auténtico ave fénix se tratara, somos testigos de la reconstrucción de la ermita, lo cual pudo hacerse gracias al esfuerzo y generosidad de los propios vecinos del pueblo ${ }^{854}$. Para ello, incluso se

850 Ibídem. LP, Arroyo de Salas, parroquia de San Julián, ermita de San Miguel. LF (1710 - 1849). Visita realizada a la ermita de San Miguel de Arroyo de Salas en 1721, por Fr. Ángel Benito, visitador del Arzobispado de Burgos. Salas de los Infantes, 13 - junio - 1721.

851 Ibídem. Visita realizada a la ermita de San Miguel de Arroyo de Salas en 1726, por D. Andrés Fernández de Tejada visitador del Arzobispado de Burgos. Salas de los Infantes, 16 - septiembre - 1726.

852 Ibídem. Visita realizada a la ermita de San Miguel de Arroyo de Salas en 1728, por D. Andrés Madrazo Escalera, canónigo de la catedral y visitador del Arzobispado de Burgos. Salas de los Infantes, 18 - julio - 1728 .

853 Ibídem. Visita realizada a la ermita de San Miguel de Arroyo de Salas en 1740, por D. Francisco López de Angulo, visitador del Arzobispado de Burgos. Salas de los Infantes, 18 - noviembre - 1740.

854 Ibídem. Visita realizada a la ermita de San Miguel de Arroyo de Salas en 1744, por D. Diego Escalona, visitador del Arzobispado de Burgos. Salas de los Infantes, 2 - mayo - 1744. 
compra un pequeño terreno próximo a ella, “que se añadió a la propia hermita de San Miguel”,855.

Esta obra se completa con la incorporación de un nuevo retablo y una imagen del santo titular, mandados realizar en 1750 por el visitador del Arzobispado, D. José $\mathrm{Cacho}^{856}$, para el adorno de su altar mayor. Si bien, estos encargos, como todo en esta ermita, tardaron en ser atendidos, de tal modo que la compra del cuadro con la imagen de San Miguel no se realiza hasta $1759^{857}$, mientras que las primeras referencias expresas de la compra del retablo no llegan antes del año $1793^{858}$.

Por último, la desaparición de esta ermita se produce en torno a los años centrales del siglo XIX, registrándose las últimas anotaciones en sus libros de fábrica en 1849. En el Diccionario de P. MADOZ (cuya información, para esta zona, fue recopilada en 1852), ya no aparece mencionada ${ }^{859}$.

La otra ermita más destacada de esta localidad es la de San Andrés, de la cual no conservamos ningún vestigio material de su existencia, lo que hace que tengamos que valernos únicamente de las fuentes documentales. A partir de los testimonios arrojados por los visitadores diocesanos, sabemos, por ejemplo, que la década de 1720 no fue un buen momento para ella, pues no dejan de repetirnos los importantes desperfectos que presentaba su fábrica. Por el contrario, los primeros años de la década de 1740 fueron especialmente dulces, ya que, como hemos visto, pudo disfrutar durante algún tiempo de los efectos beneficiosos de las rentas de la ermita de San Miguel. Sin embargo, como todo lo bueno, esto se acabó pronto, y así, a partir de 1756 ya no volveremos a tener más noticias sobre ella, hasta que en 1791, el visitador D. Manuel María Izquierdo, nos

\footnotetext{
855 Ibídem. Cuentas del año 1745. Arroyo de Salas, 20 - febrero - 1746.

856 Ibídem. Visita realizada a la ermita de San Miguel de Arroyo de Salas en 1750, por D. José Cacho, canónigo de la catedral y visitador del Arzobispado de Burgos. Salas de los Infantes, 25 - octubre - 1750.

857 Ibídem. Cuentas de 1758. Cuentas de 1759. Arroyo de Salas, 18 - julio - 1760.

858 Ibídem. Cuentas de 1793. Arroyo de Salas, 10 - mayo - 1764.
} 
dice que: "la hermita de San Andrés, que se cita en visitas antecedentes, ya no existe, y sólo hay la de San Miguel”860.

Mucha menos información es la que tenemos sobre las otras dos ermitas restantes, pues su temprana desaparición ha hecho que se pierda incluso el recuerdo de su existencia entre los habitantes del pueblo. Así, las referencias que tenemos sobre ellas apenas alcanzan para dar cumplida cuenta de su desaparición, la cual debió producirse entre los últimos años del siglo XVII y primeros momentos del XVIII. De este modo, el propio Arzobispo de Burgos, D. Manuel Francisco Navarrete Ladrón de Guevara es el que ordena, en su visita a esta parroquia en 1711, que “las (ermitas) de la Magdalena y San Martín se tapien las puertas por estar muy yndezentes y no se celebre en ellas, pena de excomunión y apercibimiento”,861.

\section{Arquitectura civil.}

El caserío de este pueblo, como decimos, no nos ofrece ningún ejemplo de interés, dentro del ámbito de las construcciones civiles, pues todo el conjunto queda incluido dentro de los rasgos propios de la llamada arquitectura popular. Aun así, hasta hace bien poco, este pueblo todavía nos ofrecía, en algunas de sus casas, buenos ejemplos de chimeneas serranas, con su característica estructura cónica sobre el tejado, formada por pequeños fragmentos de tejas, dispuestas de forma de escamas. De igual modo, dentro de los edificios auxiliares, como pajares, cuadras y tenadas, todavía podemos encontrarnos algunas piezas de interés, que nos ilustran sobre la economía

\footnotetext{
859 P. MADOZ: Diccionario geográfico - estadístico - histórico de España y sus posesiones de Ultramar. Valladolid, Ámbito D.L. 1984. (pp. 63).

860 AGDBU, LP, Arroyo de Salas, parroquia de San Julián, Libros de Fábrica. (1770 - 1852). (hojas 79 84). Visita realizada a la parroquia de San Julián de Arroyo de Salas en 1791, por D. Manuel María Izquierdo, canónigo de la catedral y visitador del Arzobispado de Burgos. Barbadillo del Mercado, 3 noviembre -1791 .

861 Ibídem. LF. (1682 - 1718), (fols. 93 v ${ }^{0} 94$ vo), Visita realizada a la parroquia de San Julián de Arroyo de Salas en 1711, por el Ilmo. Arzobispo de Burgos, D. Manuel Francisco Navarrete Ladrón de Guevara. Salas de los Infantes, 25 - junio - 1711.
} 
tradicional de este pueblo. Este es el caso del potro para herrar los animales de labor, que se conserva en la calle San Julián $n^{\circ} 23$.

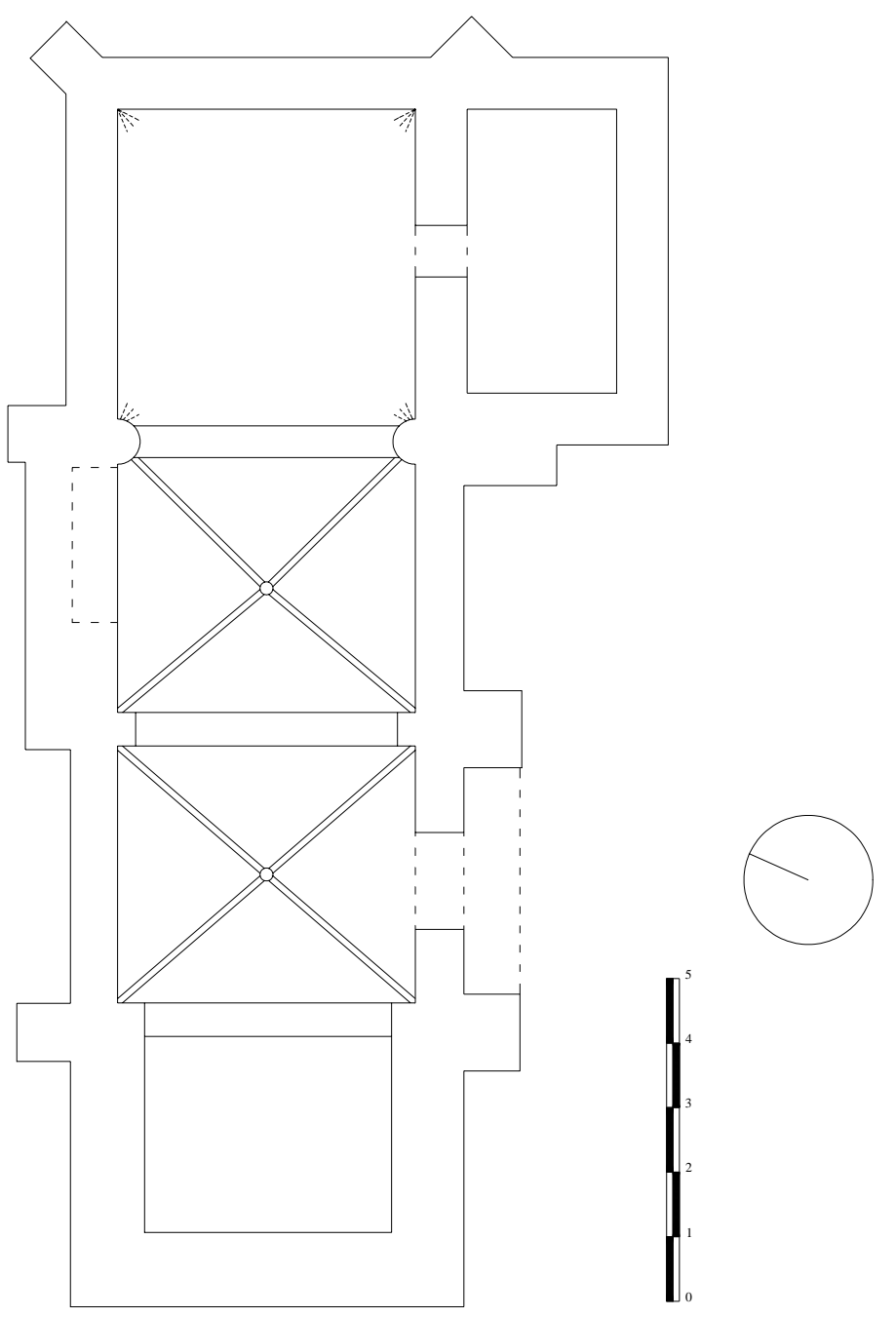

ARROYO DE SALAS. Iglesia de San Julián. Planta. 
BARBADILLO DE HERREROS.

Barbadillo de Herreros es el pueblo que se encuentra más próximo al llamado corazón de la Sierra de la Demanda, situado en la zona más septentrional de nuestra comarca de estudio, junto al agreste cauce alto del río Pedroso.

Sobre el origen de su topónimo se han apuntado las más variadas hipótesis, si bien, ninguna de ellas parece dejar completamente cerrado el tema ${ }^{862}$. Más fácil resulta aclarar este aspecto para el caso de su apellido, el cual estaría relacionado con la industria del metal y actividades mineras, desarrolladas aquí desde épocas muy tempranas $^{863}$. En su forma original, Ferreros, lo encontramos escrito por primera vez en un documento emanado del Monasterio de San Pedro de Arlanza en $1062^{864}$, pasando posteriormente a ser nombrado con su forma actual. Por su parte, las referencias documentales más antiguas, que encontramos sobre el nombre este pueblo, datan del año 978, donde aparece recogido con la forma de Barbatiello ${ }^{865}$, a la cual une, en algunos casos posteriores, el determinante de Ferreros ${ }^{866}$.

862 C. RUBIO VELASCO: Barbadillo de Herreros. Burgos, Imprenta Santos. 2001. (pp. 24 - 34).

863 J. PÉREZ CARMONA: “La historia y la geografía burgalesas reflejadas en su toponimia”. BIRG, $n^{\circ}$ 163, (1694). (pp. 238 - 271).

864 L. SERRANO: Cartulario de San Pedro de Arlanza. Madrid, Centro de Estudios Históricos. 1925. (pp. 131).

865 Ibídem. (pp. 18, 67, 126, 141; Ibídem. Fuentes para la historia de Castilla, I, colección diplomática de San Salvador de El Moral. Madrid, 1906. (pp. 8). Ibídem. Cartulario de Covarrubias. Madrid, Centro de Estudios Históricos. 1906. (pp. 16). C. RUBIO VELASCO: Barbadillo de Herreros ob. cit. (pp. 24 27). 
Los hallazgos de restos metalúrgicos de distintas épocas deben hacernos entender, que existieron poblaciones muy anteriores, sin duda desde época celtíbera, atraídos por esta riqueza mineral ${ }^{867}$. Pero aun con todo, la gran fuente de riqueza de esta localidad, desde la Baja Edad Media, se encuentra en la explotación de la ganadería lanar trashumante, localizándose aquí algunos de los más importantes propietarios de rebaños de ovejas merinas de la comarca de la Sierra burgalesa. Estos ganaderos se encuadraban en la cuadrilla de San Pedro de Vega ${ }^{868}$, como el resto de los ganaderos del Valle de Valdelaguna y alrededores, los cuales, a su vez, formaban parte del Horado Consejo de la Mesta. A mediados del siglo XVIII, cuando se realiza el Catastro del Marqués de Ensenada, esta localidad declara tener más de 3.000 cabezas de ganados trashumantes, de los cuales la mayor parte eran ovejas merinas de lana fina ${ }^{869}$, al mismo tiempo que poseía su propio lavadero de lana. ${ }^{870}$

A lo largo de la historia, esta localidad estuvo encuadrada, hasta el siglo XII, en el pequeño alfoz de Barbadillo del Pez, como el resto del Valle de Valdelaguna ${ }^{871}$, pasando luego, en los siglos siguientes, a forma parte de la Merindad Menor de Santo Domingo de Silos ${ }^{872}$.

866 Ibídem. (pp. 17, 41); Cartulario de San Millán. Madrid, 1930. (pp. 284); Cartulario de San Pedro de Arlanza ob. cit. (pp. 131). C. RUBIO VELASCO: Barbadillo de Herreros ob. cit. (pp. 24 - 27).

867 Museo Arqueológico - Paleontológico de Salas de los Infantes.

868 AHPBU. PN. Valle de Valdelaguna. Leg. 9802/2, fols. 28 - 29 vº. Manuel Gil de la Cuesta. Ermita de San Pedro de la Vega, Valle de Valdelaguna, 27 - julio - 1732.

869 ADPBU. CE 205. Respuestas Generales. Barbadillo de Herreros, 12 - julio - 1753.

870 C. CAMARERO BULLÓN: "La provincia de Burgos en el Siglo de las Luces". En Historia de Burgos III. Edad Moderna (1). Burgos, Caja de Ahorros Municipal de Burgos. 1991. (153 - 270).

871 G. MARTÍNEZ DÍEZ: Pueblos y alfoces burgaleses de la repoblación. Valladolid. Junta de Castillo y León. Consejería de Educación y Cultura. 1997. (pp. 196 - 197).

872 G. MARTínEZ DíEZ: Libro Becerro de las Behetrías. Estudio y texto crítico. León, Centro de Estudios e Investigación San Isidoro. Caja de Ahorros y Monte de Piedad. Archivo Histórico Diocesano. 1981. (pp. 617). C. ESTEPA DÍEZ: "Estructura de poder en Castilla (siglos XII - XIII). El poder señorial en las merindades burgalesas. En III Jornadas burgalesas de Historia (3 1991). Burgos en la Plena Edad Media. Burgos, Asociación Provincial de Libreros de Burgos. 1994. (pp. 245 - 294). 
Desde este período bajomedieval, y a lo largo de toda la Edad Moderna, su destino estuvo vinculado siempre al de las ocho localidades, que entonces constituían el Real Valle y Villa de Valdelaguna, dependiendo su jurisdicción directamente del rey ${ }^{873}$. Sin embargo, esto no siempre fue así, pues en el Becerro de las Behetrías, en el cual aparece nombrado como Baruadiel de Ferreros, se la menciona como señorío solariego, dependiente de Pedro Fernández de Velasco, María, su hermana, muger de Diego Pérez Sarmiento, Iohan Sánchez de Velasco, de fiios de Gómez Carriello, e fiios de Iohan Martínez de Leyva ${ }^{874}$.

En el plano fiscal, desde el siglo XVI queda incluida dentro del Partido de Burgos, perteneciente a la provincia fiscal del mismo nombre ${ }^{875}$. Esto sólo cambia a finales del siglo XVIII con la reforma borbónica, momento en el que Barbadillo de Herreros, como el resto de los pueblos de la jurisdicción del Valle de Valdelaguna, aparecen formando parte del Partido de Aranda ${ }^{876}$.

En el ámbito eclesiástico, la parroquia de Barbadillo de Herreros perteneció siempre a la Diócesis de Burgos, desde su restitución. Y dentro de ella, primero al arciprestazgo de Mansilla, pasando luego, más tarde, al de Lara.

Esta localidad mostró siempre unos niveles demográficos moderadamente elevados, situándose ligeramente por encima de la media general del resto de los pueblos de la comarca. Sin embargo, apenas disponemos de datos, que nos permitan estudiar de forma detallada la evolución demográfica a lo largo de la Edad Moderna, pues al formar parte del Valle de Valdelaguna, lo normal es que el recuento de su población quedara incluido siempre dentro del conjunto de los pueblos, que componían este valle. Aun así, merced al llamado censo de los obispos, sabemos que entre los años

\footnotetext{
873 ADPBU. CE 205. RESPUESTAS GENERALES. Barbadillo de Herreros, 12 - julio - 1753.

${ }^{874}$ G. MARTÍNEZ DÍEZ: Libro Becerro de las Behetrías... ob. cit.

${ }^{875}$ G. MARTÍNEZ DÍEZ: Génesis histórica de la provincia de Burgos y sus divisiones administrativas. Burgos, Aldecoa. 1983.

${ }^{876}$ ADPBU. CE 205. RESPUESTAS GENERALES. Barbadillo de Herreros, 12 - julio - 1753.
} 
1584-87 contaba con 60 vecinos y un párroco ${ }^{877}$. Este valor se ve ampliamente superado a mediados del siglo XVIII, en el Catastro del Marqués de Ensenada, donde declara tener 83 ’5 vecinos y 3 clérigos ${ }^{878}$. Finalmente, en el censo de Floridablanca, de finales de esta centuria, declara tener 352 habitantes ${ }^{879}$.

En el año 1841 Barbadillo de Herreros consigue su emancipación definitiva del Valle de Valdelaguna, constituyéndose a partir de este momento como ayuntamiento totalmente independiente ${ }^{880}$.

Su núcleo urbano se asiente en la zona más baja y de orografía menos agreste, de su extenso término municipal, ocupando la falda de una suave ladera orientada hacia el mediodía, que deja a sus pies una fértil porción de tierra, con huertas y prados, que permitan complementar su economía ganadera. Su casco urbano, por otra parte, nos ofrece uno de los más bellos, y mejor conservados, ejemplos de la arquitectura desarrollada en esta zona a lo largo de la Edad Moderna, formado por su espléndida iglesia parroquial, en la parte central, y una interesante relación de casas solariegas, cuya presencia debemos relacionar con los grupos de grandes propietarios de rebaños trashumantes.

Iglesia parroquial de Nuestra Señora de la Visitación.

La iglesia se encuentra situada, como decimos, en la parte central del pueblo, junto a la plaza mayor, y rodeada por algunas de las casas blasonadas más importantes, que pueblan esta localidad. Se asiente, por lo tanto, sobre una superficie inclinada, ante lo cual, debe crear un suelo llano, que se continúa en su flanco meridional con la formación de un amplio atrio.

877 T. GONZÁLEZ: Censo de población de las provincias y partidos de la Corona de Castilla en el siglo XVI... Ed. Facsímil. Madrid, Imprenta Real. 1829.

878 Vecindario de Ensenada 1759. Vol. I. Madrid, Centro de Gestión Catastral y Cooperación Tributaria: Tabapress. D. L. 1991

879 INE. Censo de 1787. “Floridablanca”. Ob. cit. 
El primer problema que plantea este edificio es el de su advocación, pues aunque actualmente está dedicada a Nuestra Señora de la Visitación, esto no siempre fue así. De este modo, durante todo el siglo XVI y gran parte del XVII esta iglesia estuvo bajo la advocación genérica de Santa María. Tenemos que esperar hasta el año 1656 para encontrar las primeras referencias a esta nueva advocación de Nuestra Señora de la Visitación, iniciándose a partir de aquí un amplio período de convivencia, sin aparente predominio de una sobre otra. Finalmente, a partir de 1773 esta segunda advocación queda como su única titular.

El templo en sí presenta una sencilla estructura basilical de tipo caja, con una sola nave, articulada en tres tramos de desigual longitud, y una cabecera en la zona oriental, de planta cuadrangular y testero plano, de menor anchura que la nave, a cuyos lados se incorporan, respectivamente, la torre y la sacristía. Todo el edificio se encuentra realizado en piedra arenisca local, predominando los muros de sillería, en los que apenas encontramos diferencias significativas entre unas zonas y otras. Su cara interna, sin embargo, sí ofrece mayor variedad, con tramos de sillería (en la cabecera), sillarejo (en los dos primeros tramos de la nave), y mampuesto (en el tramo de los pies). Esto no hace sino reflejar las diferentes fases constructivas, que fue conociendo a lo largo de su historia.

Exteriormente muestra la imagen característica de este tipo de templos, con un gran prisma de forma alargada, reforzado con potentes contrafuertes, sobre cuya parte delantera se incorporan la cabecera, la sacristía y la torre. Esta torre, dispuesta sobre el flanco septentrional de la cabecera, está compuesta por dos cuerpos perfectamente diferenciados. El inferior, de origen románico, muestra un sólido prisma de amplia base cuadrangular con las esquinas redondeadas mediante columnas entregadas. El superior, o cuerpo de campanas, se eleva sobre un pequeño zócalo, para formar una estructura

880 P. MADOZ: Diccionario geográfico - estadístico - histórico de España y sus posesiones de Ultramar. Valladolid, Ámbito D.L. 1984. (pp.67). 
simétrica de cuatro lados iguales, con un solo vano en el centro de cada uno de ellos, coronado con arco de medio punto y escoltado por sencillas pilastras lisas a los lados. Queda rematado, este cuerpo, con un friso corrido y una airosa cornisa, que conducen al tejado, donde se alza un curioso chapitel, formado por dos esbeltas pirámides superpuestas, al que acompañan pináculos de bola en las esquinas.

En la fachada meridional de este templo, a la altura del tramo central de la nave, se abre la puerta de entrada. Desarrolla las formas propias del renacimiento ya avanzado, y cuenta con un potente arco de medio punto de amplio dovelaje, con el extradós delimitado por una gruesa moldura de papo de paloma, que se continúa a lo largo de las jambas sin interrupción. A los lados, sobre elevados pedestales, se alzan sendas columnas de orden seudo-dórico, con fuste liso, anillado en su tercio inferior, las cuales se disponen sobre retropilastras del mismo orden y fuste cajeado. Un estrecho entablamento, quebrado en los extremos, se extiende sobre ellas, dando paso al remate, formado por una hornacina central, con arco de medio punto, escoltada por pilastras tableadas y frontón recto, a la que acompañan en los extremos, en correspondencia con las columnas inferiores, estilizados netos, coronados con jarrones, unidos a la pieza central mediante roleos avolutados, dibujando una especie de aletones.

Las escasas ventanas, con las que cuenta este edificio, se hallan repartidas entre las fachadas meridional y de poniente, y presentan un sencillo trazado rectangular con dintel plano y ligero derrame hacia ambas partes.

En el interior, se dibuja un espacio tendente al ámbito único, con un claro sentido longitudinal, que culmina en el altar mayor. La cabecera, sin embargo, se muestra como un espacio perfectamente diferenciado, de menor anchura que la nave, y con el suelo más elevado, formando gradas. A su interior se accede a través de un amplio arco ligeramente apuntado, de rosca muy moldurada, que descansa sobre un haz de tres columnas, rematadas por capiteles de sección poligonal, delimitados por finos junquillos. Otro espacio, que se incorpora a este ámbito general del templo, es el 
baptisterio, formado por un pequeño nicho de planta cuadrangular, abierto sobre el muro septentrional, justo enfrente de la puerta de entrada. Su cubierta queda formada por la bóveda de medio cañón, que proyecta el arco que enmarca su entrada. Finalmente, en la zona de los pies, se eleva el coro, formado por un amplio arco escarzano, dispuesto entre las pilastras que delimitan este tramo posterior, al cual se accede a través de una escalera de caracol, practicada en el interior de uno de los muros laterales.

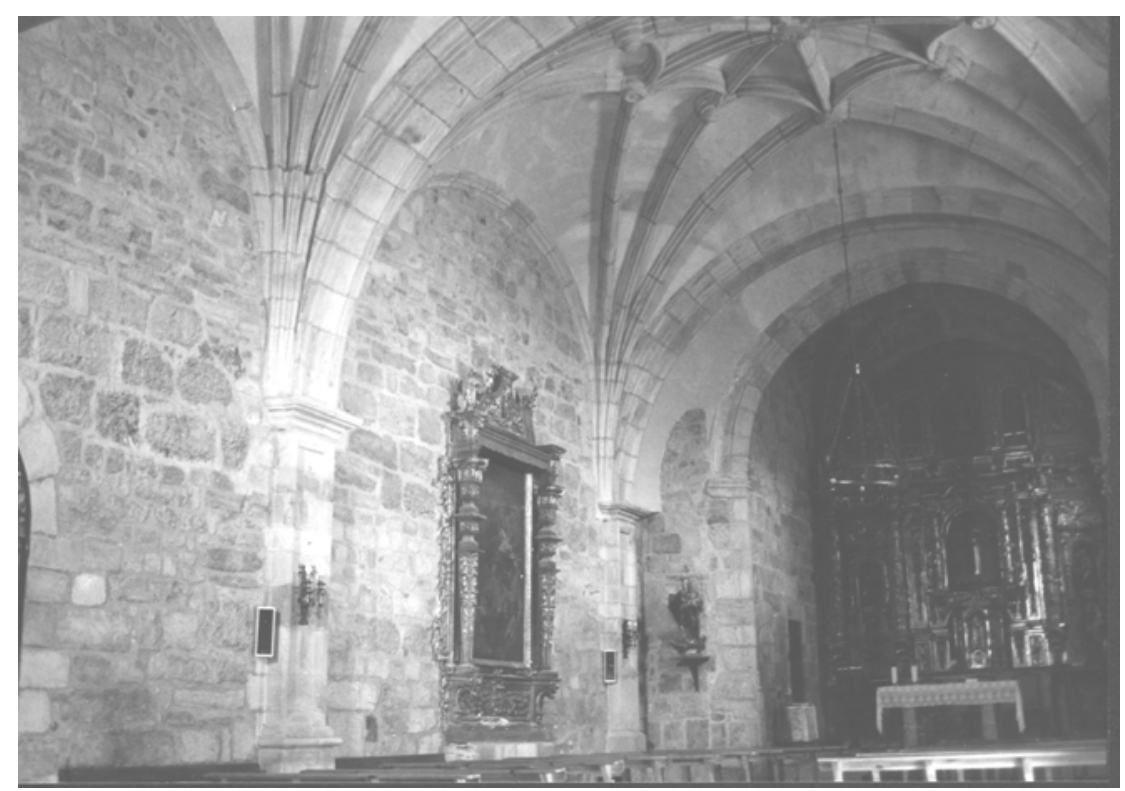

BARBADILLO DE HERREROS. Iglesia de Nuestra Señora de la Visitación.

Cada uno de los tramos, que forman la zona de la nave, se cubre con bóveda de crucería estrellada con terceletes, de rampante casi llana, más complicados en los dos primeros, con la inclusión de terceletes, ligaduras y combados en forma de onda, en torno a la clave central, y más sencilla en el tramo final, donde sólo aparecen los nervios diagonales. La capilla mayor, por su parte, se cubre con bóveda estrellada con terceletes y cinco clave, de rampante más curva. 
Un templo, en definitiva, compacto y de gran homogeneidad, en el que su imagen queda presidida por un claro sentido de horizontalidad, afianzado, tanto por su escasa altura, como por la uniformidad, que mantiene en todo el conjunto el nivel de sus cubiertas. Dentro de esta imagen, la torre, como ya dijimos, representa el único contrapunto vertical. En el interior su aspecto se completa con la incorporación de los distintos retablos, que decoran cada uno de sus altares. El del altar mayor es obra rococó, realizado entre las décadas de 1760-70. Consta de banco, un solo cuerpo articulado en tres calles, y remate. El nicho central del cuerpo está ocupado por la escena de la Visitación, a la cual acompañan las tallas de San Pedro y San Pablo, en las calles laterales. En el remate, por su parte, aparecen el arcángel San Miguel, en el centro, y Santiago y San Juan Bautista a los lados. Este retablo del altar mayor está acompañado por otros dos retablos colaterales, dispuestos a ambos lados del primer tramo de la nave. Son retablos gemelos de tipo marco, de estilo churrigueresco, en los que se aprecia la transición hacia el rococó. El del lado de la epístola está presidido por un Santo Cristo, mientras que el del lado del evangelio se dedica a las Benditas Ánimas del Purgatorio ${ }^{881}$.

Como ocurre en la mayoría de los templos de la comarca, esta imagen es el resultado de una larga y compleja historia constructiva, dentro de la cual podemos diferenciar algunas fases especialmente activas. Esta historia arranca en el período románico, si bien, su imagen definitiva se debe, fundamentalmente, al resultado de las intervenciones acometidas a lo largo de la Edad Moderna. Esto ha hecho que los elementos pertenecientes al edificio primitivo hayan desaparecido, o se encuentren, en su mayor parte, camuflados dentro de la fábrica moderna.

La etapa más antigua, que conocemos, pertenece, como decimos, al período románico, del cual únicamente se ha conservado la parte inferior de la torre. Junto a ella podemos incluir también la serie de capiteles labrados, que han aparecido durante las

881 R. J. PAYO HERNANZ: El retablo en Burgos y su comarca durante los siglos XVII y XVIII. Burgos, Excma. Diputación Provincial de Burgos. 1997. (T. II, pp. 450 - 451). 
recientes obras de restauración, realizadas en la cabecera ${ }^{882}$ correspondientes, con toda seguridad, a su primitiva portada, y la magnífica pila bautismal, ornamentada con una cuidada cenefa de tallos de vil, cuidadosamente entrelazados ${ }^{883}$. El análisis de estos elementos nos permiten situar su construcción en torno al periodo final del siglo XII, encuadrado dentro de la fase avanzada de la llamada escuela del románico de la sierra.

La primera gran fase renovadora de este primitivo templo se produce en la intersección de los siglos XV y XVI. Fruto de ella surge un edificio de estructura muy parecida a la actual, con una sola nave y cabecera cuadrangular con testero plano, aunque de proporciones más reducidas, tanto en longitud como en altura. Por lo tanto, con estas obras se establecen las bases de lo que será el edificio definitivo.

Aun así, la única parte de este templo, que se ha logrado conservar de forma más o menos íntegra es la cabecera, la cual muestra los rasgos propios, que desarrollan este tipo de piezas durante el período en el que nos encontramos. Es decir, volumen prismático sobre planta cuadrangular, con testero plano y sólidos contrafuertes en las esquinas, dispuesto en diagonal. Respecto a su cronología, aunque no disponemos de fuentes documentales, que nos precisen el momento concreto de su construcción, debemos situarla en torno a los años finales del siglo XV y primeros momentos del XVI, pues el marcado arcaísmo del arco de entrada de la capilla mayor, unido al tipo de soportes empleados, nos impiden pensar en una fecha más avanzada.

Igualmente, dentro de esta fase podemos encuadrar también la construcción de la portada, la cual debió suponer el broche final a toda esta renovación, aunque su

\footnotetext{
882 Se trata de una serie de capiteles, destinados, con toda seguridad, a las jambas de una portada, pues mantienen dos de sus caras completamente lisas, mientras que las otras dos recogen las imágenes talladas. Estos sillares fueron incorporados dentro de los muros de la cabecera, con la superficie lisa hacia el exterior, mientras que la parte labrada quedaba oculta. Esto ha permitido, al mismo tiempo, una buena conservación de los mismos.

883 J. PÉREZ CARMONA: Arquitectura y escultura románica en la provincia de Burgos. Burgos, 1959.

G. BILBAO LÓPEZ: Iconografía de las pilas bautismales del románico castellano; Burgos y Palencia. Burgos, Editorial la Olmeda. 1996.
} 
ejecución debió realizarse ya en un momento ciertamente avanzado de esta centuria. Su incorporación resulta ciertamente importante, pues logra introducir un nuevo lenguaje artístico, dentro de este edificio, como es el del renacimiento. Supone, por lo tanto, un auténtico contrapunto de modernidad.

El siglo XVII está marcado fundamentalmente por las diferentes labores de reparación y mantenimiento, que se vinieron realizando en todo el edificio, dentro de las cuales destacan, de modo especial, las realizadas sobre la zona de la cabecera. Un primer testimonio de ello lo tenemos en la reconstrucción del tejado de esta estancia, realizada en 1678, pues el anterior se había hundido ${ }^{884}$. Unos años antes fue necesario reparar uno de los estribos de dicha capilla, invirtiendo un total de 440 reales $^{885}$. Y no fue la única vez que esto sucede. Así, en 1694 el visitador del Arzobispado de Burgos, D. Juan de Caabro declara el estado de ruina de toda la cabecera del templo, ordenando “... a los mayordomos eclesiástico y seglar de la fábrica de la dicha yglesia dentro de quatro meses agan se ponga el reparo de que necesita buscando maestro perito en el arte que vea y reconozca lo que se debe hacer, atendiendo todo al bien y utilidad de la dicha fábrica...”886.

La única construcción nueva, realizada durante este siglo, la encontramos en el atrio, que bordea el lado meridional de este edificio. Esta obra fue realizada por el maestro Domingo de Valdevilla, y aunque los pagos por la misma no se registran hasta los años $1646-47^{887}$, todo apunta a que los trabajos habían concluido en torno a $1643^{888}$.

\footnotetext{
884 A. Parroq. Barbadillo de Herreros. LP. Parroquia de Nuestra Señora de la Visitación. LF. (1665 1717). (fols. $49 \mathrm{v}^{0}-51$ vo). Cuentas del año 1678. Barbadillo de Herreros, 30 - septiembre - 1679.

885 Ibídem. LF. (1635 - 1664). (fols. 71 - 72). Cuentas del año 1656. Barbadillo de Herreros, 11 noviembre -1656.

886 Ibídem. LF. (1665 - 1717). (fols. 109 - 112). Visita realizada a la parroquia de Nuestra Señora de la Visitación de Barbadillo de Herreros en 1694, por D. Juan de Caabra. Barbadillo de Herreros, 16 - agosto $-1694$.

887 Ibídem. LF. (1635 - 1664). (fols. 46 - 48).Cuentas del año 1646. Barbadillo de Herreros, 19 octubre - 1647; Ibídem. (fols. 48 - 50). Cuentas del año 1647. Barbadillo de Herreros, 15 - diciembre 1648.
} 
La importancia de esta obra estriba, no sólo en que dota a la parroquia de un nuevo espacio en el que sepultar a sus difuntos, sino que con su construcción se contribuía a reforzar la estabilidad del suelo sobre el que se asienta la fábrica.

Más interesante resulta esta centuria en los aspectos ornamentales, relacionados con el adorno el interior del templo. Aquí podemos incluir la realización de un nuevo relicario para el altar mayor ${ }^{889}$, al que siguen, en torno a estos mismos años, los trabajos de dorado del dicho altar mayor ${ }^{890}$, y la construcción de un nuevo retablo colateral entre 1640-41, dedicado al Santo Cristo ${ }^{891}$. Años más tarde, en 1686, este mismo retablo es sustituido por uno nuevo ${ }^{892}$, al mismo tiempo que se levanta otro colateral, dedicado a Nuestra Señora del Rosario ${ }^{893}$.

Tras este período, el siglo XVIII marca el inicio de una importante actividad constructiva, la cual no finalizará hasta los primeros años de la centuria siguiente. De ella surge la imagen definitiva de este templo. En este caso, las principales actuaciones se centraron en la parte de la nave, incrementando sus dimensiones en longitud y altura, si bien, se mantiene el mismo concepto de espacio.

La primera de estas intervenciones tiene lugar entre los años 1728 y 1734, realizándose los trabajos en dos fases consecutivas. Se inicia así, este proyecto con la remodelación de los muros de la nave, la cual fue encargada al maestro Sebastián de

\footnotetext{
888 Ibídem. (fols. 39 - 40 v ). Cuentas del año 1643. Barbadillo de Herreros, 28 - noviembre - 1664.

889 Ibídem. LF. (1635 - 1664). (fols. 17 - 18). Cuentas del año 1638. Barbadillo de Herreros, 1639; Ibídem. (fols. 25 - 26vº). Cuentas del año 1639. Barbadillo de Herreros, 15 - noviembre - 1640; Ibídem. (fols. $27 \mathrm{v}^{\circ}$ - 28). Cuentas del año 1640. Barbadillo de Herreros, 4 - octubre - 1641.

890 Ibídem. Barbadillo, 15 - noviembre - 1640.

891 Ibídem. Barbadillo, 4 - octubre - 1641; Ibídem. (fols. 30vº - 32). Cuentas del año 1641. Barbadillo de Herreros, 9 - noviembre - 1642 .

892 Ibídem. LF. (1665 - 1717). (fols. 77vº - 80). Cuentas del año 1686. Barbadillo de Herreros, 5 noviembre - 1686.

893 Ibídem.
} 
714 Arquitectura de la Edad Moderna en la sierra burgalesa.

Foncea $^{894}$, quien en este mismo momento se encontraba realizando una serie de trabajos de reparación en la zona de la cabecera. Estos trabajos habían sido ordenados por el visitador del Arzobispado de Burgos en 1726, pues: “Alló su merced que la capilla mayor está amenazando ruina de la que seguirá mui grande acudiendose muy breve con el reparo necesario...” ${ }^{895}$. Unos años después, en 1733, el maestro trasmerano Bernardo de la Torre Barquero, se encargó de rematar esta remodelación de la nave, con la construcción de las bóvedas, siguiendo para ello las trazas dadas por el maestro Diego Barquiero. La obra fue presupuestada en 10.980 reales $^{896}$ y se concluyó al año siguiente, tal y como anuncia la inscripción conservada sobre la fachada principal del templo.

La segunda gran intervención no se produce hasta los primeros años del siglo XIX, desarrollándose mientras, otra serie de actuaciones no menos importantes, en diferentes partes del edificio. Así, durante los primeros años de la segunda mitad de este siglo se acomete una nueva renovación de la imagen interior del templo, que tiene su principal manifestación en la renovación del retablo del altar mayor. Esta obra fue encargada al maestro Andrés Vallado, el cual había realizado también las trazas, con un coste para esta fábrica de 6.475 reales $^{897}$. Unos años más tarde, en la década de 1780 , se procede a completar esta obra, con el proceso de dorado del mismo, donde se invirtieron 6.000 reales $^{898}$, y la compra de las imágenes de San Pedro y San Pablo, con un precio de 300 reales $^{899}$.

894 AHPBU. PN. Valle de Valdelaguna. Leg. 9802/1, fols. 114 - 114 vº. Manuel Gil de la Cuesta. Bezares, 15 - julio - 1728.

895 A. Parroq. Barbadillo de Herreros. parroquia de Nuestra Señora de la Visitación. LF. (1718 - 1748). (fols. $44 v^{0}-53 v^{0}$ ). Visita realizada a la parroquia de Nuestra Señora de la Visitación de Barbadillo de Herreros en 1726, por D. Andrés Fernández de Tejada. Barbadillo de Herreros, 9 - septiembre - 1726.

896 AHPBU. PN. Valle de Valdelaguna. Leg. 9802/2, fols. 59 - 61. Manuel Gil de la Cuesta. Barbadillo de Herreros, 18 - octubre - 1733.

897 A. Parroq. Barbadillo de Herreros. LP. Parroquia de Nuestra Señora de la Visitación. LF. (1749 1838). (fols. $38-40 v^{0}$ ). Cuentas del año 1760. Barbadillo de Herreros, 7 - octubre - 1760; Ibídem. (fols. $\left.34 v^{\circ}-36\right)$. Cuentas del año 1758. Barbadillo de Herreros, 10 - octubre - 1758.

898 Ibídem. (s/f).Cuentas del año 1780. Barbadillo de Herreros, 14 - septiembre - 1781.

899 Ibídem. (s/f). Cuentas del año 1782. Barbadillo de Herreros, 13 - septiembre - 1782. 
En lo que se refiere a las obras de cantería, este siglo se cierra con dos importantes actuaciones, como son la construcción de la nueva sacristía, y la renovación de la parte superior de la torre.

La primera de ellas fue ordenada por el visitador del Arzobispado de Burgos en 1740, D. Francisco López de Angulo, el cual manda que "por quenta de esta renta de dicha fábrica se aga nueva una sacristía al lado de la epístola y sitio que ocupa el osario, abriendo en el arco correspondiente inmediata al estribo de la capilla maior, mudando el referido osario a paraje cómodo" ${ }^{\text {900 }}$. La obra resultante, como sabemos, queda formada por una sencilla estancia de trazado rectangular, adosada al muro meridional de la capilla mayor, cubierta con sencillo cielo raso.

Más importante, por el resultado final, fue la obra de renovación de la torre, consistente en la construcción de un nuevo cuerpo de campanas. Con ella, en definitiva, se pretendía frenar de forma definitiva, la serie de problemas, que venían presentando esta construcción, desde hacía ya bastante tiempo. Estos trabajos se efectuaron en torno al año 1789, y aunque desconocemos los nombres de los artífices, que participaron en su diseño y ejecución, si sabemos que la fábrica de esta iglesia tuvo que desembolsar un total de 12.469 reales $^{901}$. Para hacer frente a este gasto, no obstante, contó con la colaboración del concejo del pueblo, que aportó 2.469 reales ${ }^{902}$, y de la ermita de Nuestra Señora de Costana, que donó otros 3.000 reales $^{903}$. Esta misma colaboración se repitió una década más tarde, con motivo de la fundición de las campanas, para lo que este concejo pagó 4.304 reales de los 9.608 reales, que costaba toda la operación ${ }^{904}$.

\footnotetext{
900 Ibídem. LP. (1718 - 1748). (fols. 93v $-103 v^{\circ}$ ). Visita realizada a la parroquia de Nuestra Señora de la Visitación de Barbadillo de Herreros en 1740, por D. Francisco López de Angulo. Barbadillo de Herreros, 15 - noviembre - 1740 .

901 Ibídem. (s/f). Cuentas del año 1789. Barbadillo de Herreros, 19 - septiembre - 1789.

902 Ibídem.

903 A. Parroq. Barbadillo de Herreros. LP. Ermita de Nuestra Señora de Costana. LF.(1731 - 1840). (fols. 35 v $^{0}$ - 36). Cuentas de los años 1783 - 88. Barbadillo de Herreros, 8 - octubre - 1788.

904 Ibídem. LP. Barbadillo de Herreros. Parroquia de Nuestra Señora de la Visitación. Libros de Fábrica. (1749 - 1838). Cuentas del año 1798. Barbadillo de Herreros, 15 - septiembre - 1799.
} 
El epílogo final, dentro de la historia constructiva de esta fábrica, se escribe, como venimos diciendo, en los años iniciales del siglo XIX, con la ampliación de la nave, que incorpora un nuevo tramo en la zona de los pies. Este añadido se realiza respetando totalmente las proporciones y formas marcadas por la obra precedente, de tal modo, que el impacto de su incorporación apenas se deja notar. La licencia para su ejecución fue concedida en 1806, dándose los trabajos por finalizados dos años más tarde, como nos indica la inscripción conservada en la bóveda. El encargado de dirigir estos trabajos fue el maestro de cantería Simón de Gándara, el cual percibió por ello un total de 21.000 reales, a los que debemos sumar otros 1.655 reales por los materiales ${ }^{905}$. La ermita de Nuestra Señora de Costana, en este caso, volvió a colaborar en este proyecto, con la aportación de 8.000 reales $^{906}$.

Unos años más tarde, en 1814, este mismo maestro se encarga de completar el proyecto de ampliación, con la construcción del coro, que se ubica, como vimos, en este tramo de los pies. La obra fue presupuestada en 7.500 reales, a los que debemos sumar los 1.580 reales del coste de los materiales ${ }^{907}$.

\footnotetext{
905 Ibídem. Cuentas del año 1809. Barbadillo de Herreros, 20 - octubre - 1809.

906 C. RUBIO VELASCO: Barbadillo de Herreros. ob. cit.
} 


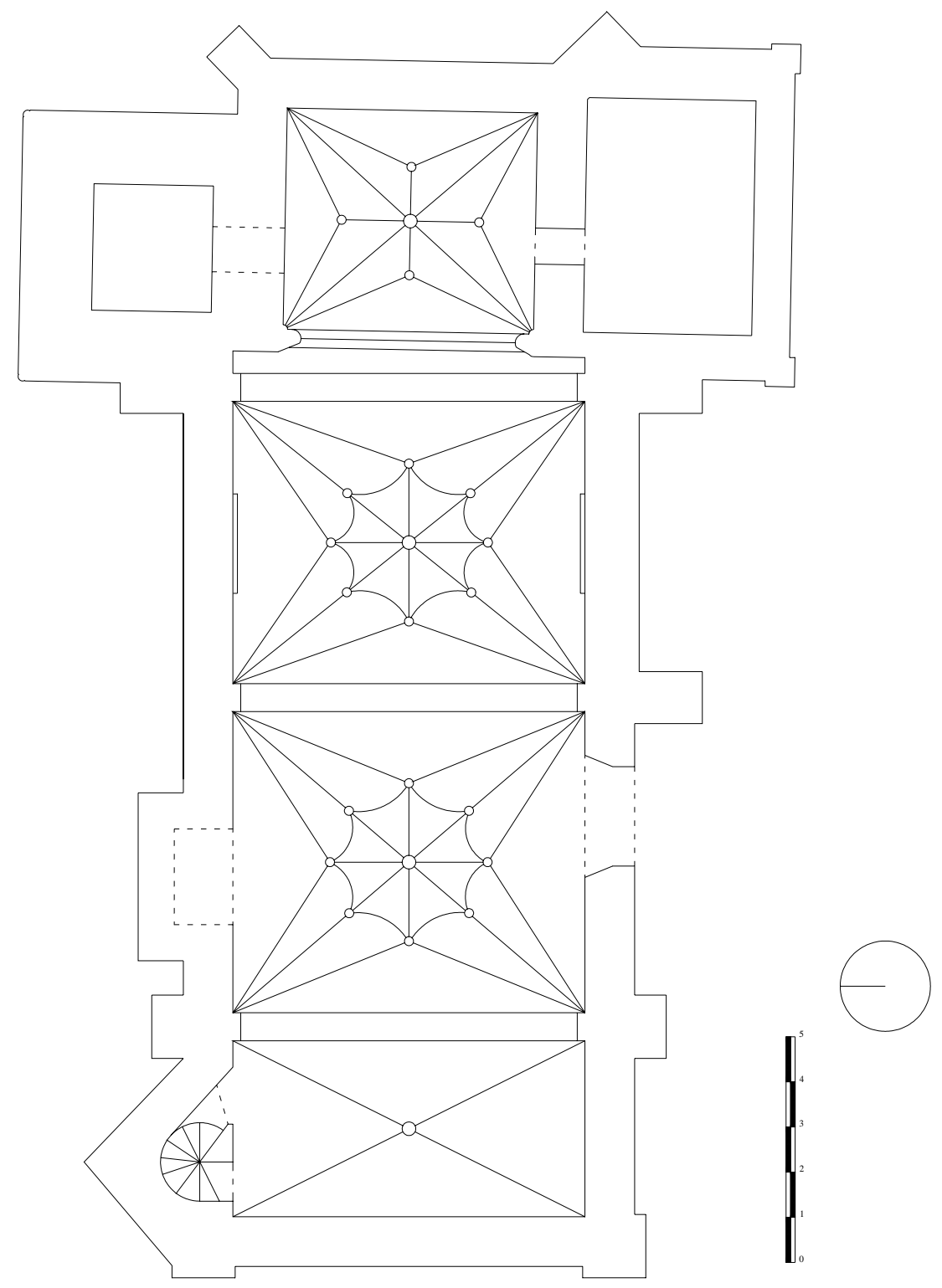

BARBADILLO DE HERREROS. Iglesia de Nuestra. Señora de la Visitación. Planta.

907 A. Parroq. Barbadillo de Herreros. LP. Parroquia de Nuestra Señora de la Visitación. LF. (1749 - 
Ermitas.

Un aspecto importante, que debemos tener en cuenta, dentro de la arquitectura religiosa de Barbadillo de Herreros, son sus ermitas, las cuales se repartían por buena parte de su término municipal. La mayor parte de ellas han desaparecido, sin embargo, a través de las fuentes documentales hemos conseguido certificar la existencia de al menos nueve de ellas. Son las dedicadas a Nuestra Señora de Costana, Santos Mártires (San Cosme y San Damián), San Juan, San Torcuato, San Saturnino, San Matías, Nuestra Señora del Rosario, San Justo y San Pastor, y San Sebastián. A esta lista el investigador local C. Rubio Velasco ha sumado otras ocho ermitas más, extraídas del estudio de la toponimia del pueblo ${ }^{908}$. Nosotros únicamente nos centraremos en el estudio de las nueve documentadas, dentro de las cuales solamente se han conservado en pie dos.

\section{Nuestra Señora de Costana.}

Es, sin duda, la ermita más importante del pueblo, y al mismo tiempo, uno de los santuarios más destacados de la zona, con devotos y cofrades repartidos por todos los pueblos del entorno ${ }^{909}$. Esto hizo que disfrutara siempre de una economía saneada, la cual era administrada, de forma conjunta, por el concejo de la localidad y la parroquia $^{910}$.

Esta ermita se encuentra situada a unos 2 kilómetros del pueblo, en dirección sudeste, a los pies del cerro de Motote, en medio de una extensa y fértil pradera, que constituía, al mismo tiempo, una de las posesiones más preciosas de su patrimonio. Su edificio está compuesto por la ermita propiamente dicha, y la llamada casa del ermitaño, cada uno de los cuales da lugar a un gran bloque prismático de planta rectangular, adosados uno junto al otro. La parte correspondiente a la ermita, presenta un templo de

\footnotetext{
1838). (s/f). Cuentas del año 1814. Barbadillo de Herreros, 14 - octubre - 1815.

908 C. RUBIO VELASCO: Barbadillo de Herreros. ob. cit. (pp. 232 - 237).

909 Ibídem. (pp. 307 - 308).

910 Esto aparece reflejado en los libros de fábrica propios, que esta ermita poseía, de los cuales se han conservado registros de cuentas desde el año 1602 en adelante.
} 


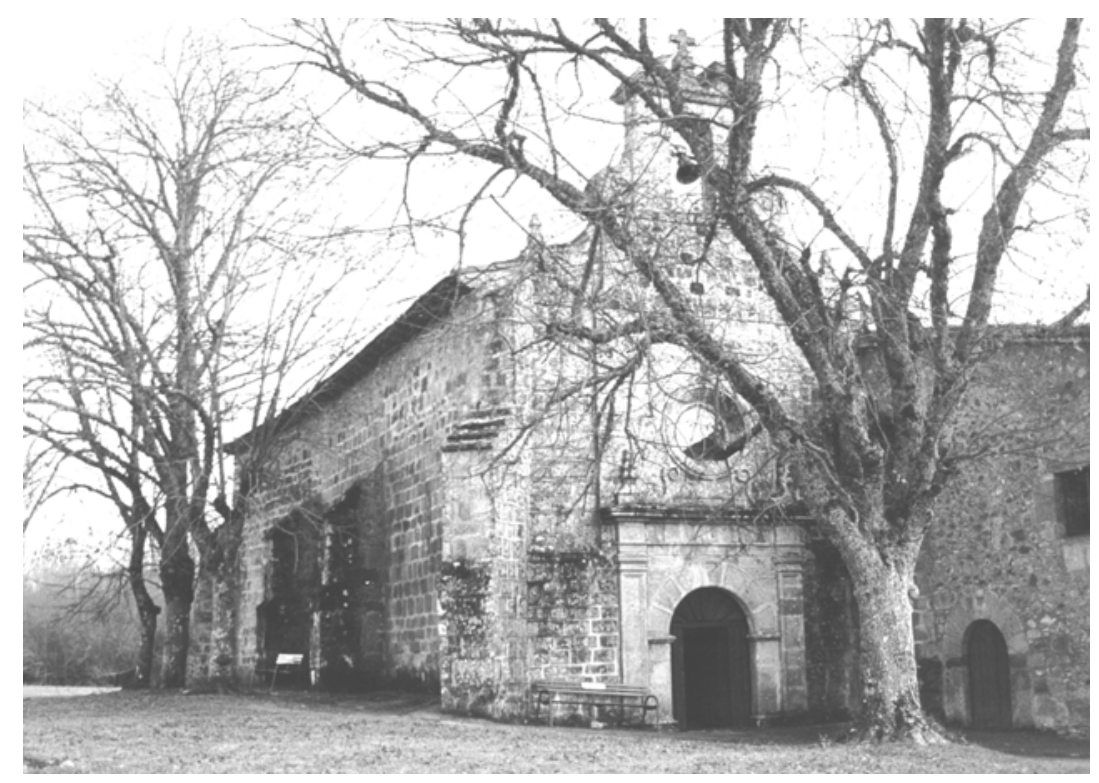

BARBADILLO DE HERREROS. Ermita de Nuestra Señora de Costana.

raíz románica, sumamente renovado en épocas posteriores, en el que se dibuja una estructura de tipo caja, sobre planta rectangular, articulada en tres tramos, dentro de los cuales el delantero forma la cabecera, con un simple testero plano.

Todo el edificio se halla realizado en piedra, con recios muros de sillería, reforzados con contrafuertes, que en las esquinas adoptan una disposición en diagonal. La casa del ermitaño, sin embargo, aunque muestra una estructura volumétrica parecida, presenta en sus muros un tosco aparejo de mampostería, reforzado en las esquinas y marcos de los vanos con sillares de mejor labra.

La imagen exterior de este conjunto, por lo tanto, queda formada por dos grandes estructuras prismáticas de parecidas proporciones, adosadas una junto a la otra, pero no a la misma altura, sino que la casa del ermitaño arranca a partir del segundo tramo de la ermita, prolongándose en la zona de los pies. Esto permite crear un pequeño compás, frente al extremo occidental de la ermita, donde se levanta su fachada principal. 
Esta fachada se encuentra articulada en tres niveles, ocupados por la portada, propiamente dicha, en la parte baja, un gran óculo en el centro, y la espadaña en el nivel superior. La puerta nos muestra una sencilla estructura de marcado sabor clasicista, formada por un amplio arco central de medio punto de rosca casetonada, escoltado por pilastras de orden dórico con fuste cajeado, entre las que se dispone un entablamento característico del mismo orden, con los triglifos y metopas simplemente marcados pero no labrados. Dos pináculos piramidales, situados en los extremos, en correspondencia con el eje de las pilastras, rematan esta parte, dejado sitio en el centro para que surjan dos finos roleos de perfil avolutado, que unen con el óculo central. Este óculo muestra una estructura abocinada con derrame hacia el exterior, enmarcado por moldura de tres cuartos de bocel. El remate, como decimos, lo constituye una sencilla espadaña, en la que se muestra una estructura mucho más movida, donde se combinan trazos rectos y curvos, mostrando una mayor proximidad con las formas propias del mundo barroco. Esta espadaña está compuesta por un único vano con arco de medio punto, escoltado por grandes aletas avolutadas, mediante las cuales se une al nivel inferior, y rematado por frontón curvo partido, con cruz griega sobre neto, en el centro.

Dentro de este mismo compás se abre la puerta de entrada a la casa del ermitaño, compuesta por un sencillo arco de medio punto de amplio dovelaje.

El resto de los vanos, en el caso de la ermita, lo forman pequeñas ventanas de trazado rectangular y dintel plano, entre las que se incluyen también algunas de tipo aspillera con amplio abocinamiento y remate semicircular, de origen románico. La casa del ermitaño, por su parte, presenta vanos más amplios, de estructura adintelada, enmarcados, en ocasiones, por una ancha moldura plana con orejones.

En el interior, esta ermita nos ofrece una típica estructura de ámbito único, con un marcado concepto espacio longitudinal. Los tres tramos, en los que se articula, se encuentran separados por arcos de medio punto de sección trapezoidal, dispuestos, en el 
tramo delantero, sobre pilastras rematadas por capitel poligonal delimitado por finos junquillos, mientras que en el segundo caso el arco continúa sin interrupción hasta el suelo. En las cubiertas se emplean bóvedas de crucería, de trazado algo más simple en la cabecera, con una estructura octopartita, y estrellada con terceletes y cinco claves en los tramos de la nave. Estos tramos, por otra parte, se encuentran a una altura ligeramente mayor que el de la capilla mayor.

Entre los elementos, que podemos destacar de esta imagen interior, se encuentran el coro, dispuesto en la zona de los pies, y el púlpito, adosado sobre el muro del evangelio del primer tramo de la nave. En el primero de ellos se desarrolla el característico tipo de coro alto, elaborado en madera, mientras que en el segundo nos encontramos con una curiosa construcción en piedra, que nos recuerdo, en cierto modo, aquellos púlpitos de los monasterios cistercienses, cuyas escaleras de acceso se

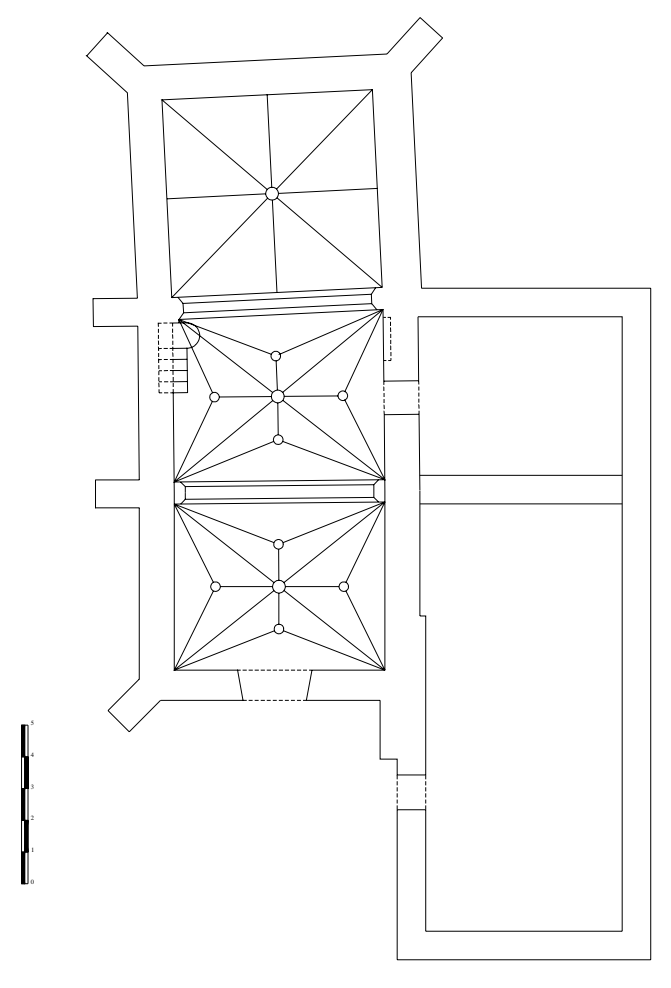

BARBADILLO DE HERREROS. Ermita de Nuestra Señora de Costana. Planta. 
encontraban incrustadas en el interior del muro.

En lo que respecta a la casa del ermitaño, su compartimentación interior ha sido totalmente alterada por las remodelaciones posteriores, con lo cual nos resulta imposible precisar su aspecto original. No obstante, debemos pensar que ésta no debía diferir mucho de la que podía ofrecernos cualquier otra casa del pueblo.

Todo este conjunto, y de modo particular la ermita, es el resultado de un largo proceso constructivo, el cual, sin duda, debió arrancar durante el período románico, tal y como nos indican las ventanas conservadas en la zona delantera. Aun así, todo apunta a que los períodos de mayor intensidad constructiva, y con una repercusión más clara en imagen definitiva del templo, se encuentran, como en el caso de la iglesia parroquial, en el tránsito del siglo XV al XVI, y en el siglo XVIII.

En la primera de estas fases parece perfilarse la estructura definitiva del templo, con su cabecera de testero plano, reforzada con contrafuertes diagonales en las esquinas, y nave articulada en dos tramos, como prolongación de esta cabecera. El ligero giro que presenta el eje longitudinal del templo, sin embargo, nos indica que esta obra no fue realizada de una sola vez, sino en diferentes fases.

El siglo XVIII comienza con la necesidad de emprender numerosas reparaciones en el edificio heredado, ante la poca atención, que durante la centuria precedente, se había prestado a estas labores de mantenimiento. Este abandono culmina en 1740 con la inspección del visitador del Arzobispado de Burgos, D. Francisco López de Angulo, en cuyo informe indica que: "Y aviendo visitado personalmente la dicha ermita reconoció su merced la ruina que amenaza por no se haber fenecer perfectamente la obra de cantería y carpintería ejecutada de orden de Francisco Pablo de Irrea y D. Francisco 
de Sedano Mayor, patronos de dicha hermita, como cura y alcalde que a la sazón eran por el defecto de afianzado en los maestros que la ejecutaron"911.

Tras este aviso, los responsables de la ermita se ponen en marcha, y entre 174850 acometen las reparaciones más urgentes, valoradas en 1.122 reales, aderezando los elementos más dañados ${ }^{912}$. Durante el trienio siguiente se procede a renovar gran parte de la zona correspondiente a la nave, para lo cual se destinan 2.500 reales, encargándose de su ejecución el maestro de cantería Juan de Maurtúa, y el maestro de carpintería Juan de Arrieta $^{913}$. Este último había participado también en la reparación anterior. Esta renovación se culmina, en los años siguientes, con la construcción de la fachada principal de la ermita y otras obras de acabado en el interior, sumando todo ello 6.876 reales $^{914}$. Lamentablemente desconocemos, en este caso, los nombres de los artífices, así como el año concreto de finalización de los trabajos.

El broche final a este amplio programa constructivo lo ponen las labores de ornamentación del interior del edificio, con la reparación y dorado del retablo del altar mayor, efectuado entre los años 1780-83. En este proceso se incluye también la compra de una serie de imágenes, con las que acompañar a la titular del templo. El coste de todo ello alcanzó los 6.270 reales $^{915}$.

\section{Ermita de los Santo Mártires ( San Cosme y San Damián).}

Es la segunda de las ermitas conservadas actualmente en Barbadillo de Herreros. Se encuentra ubicada al este del pueblo, a mitad de camino con la vecina localidad de Monterrubio de la Demanda, en medio de uno de los más bellos parajes que ofrecen estos montes, rodeada de un extenso y centenario robledal.

\footnotetext{
911 A.P. Barbadillo de Herreros. LP. Cofradía de Nuestra Señora de Costana. Libros de Fábrica. (1731 1840). (fols. $11 v^{o}-13 v^{0}$ ). Visita realizada a la ermita de Nuestra Señora de Costana de Barbadillo de Herreros en 1740, por D. Francisco López de Angulo. Barbadillo de Herreros, 25 - noviembre - 1740.

912 Ibídem. (fols. 24v 0 - 25). Cuentas del trienio 1748 - 50. Barbadillo de Herreros, 2 - marzo - 1750.

913 Ibídem. (fols. $31 v^{0}-33 v^{\circ}$ ). Cuentas de 1753 - 80. Barbadillo de Herreros, 8 - enero - 1780 .

914 Ibídem. (fols. 34 - 35). Cuentas del trienio 1780 - 83. Barbadillo de Herreros, 8 - julio - 1786
} 

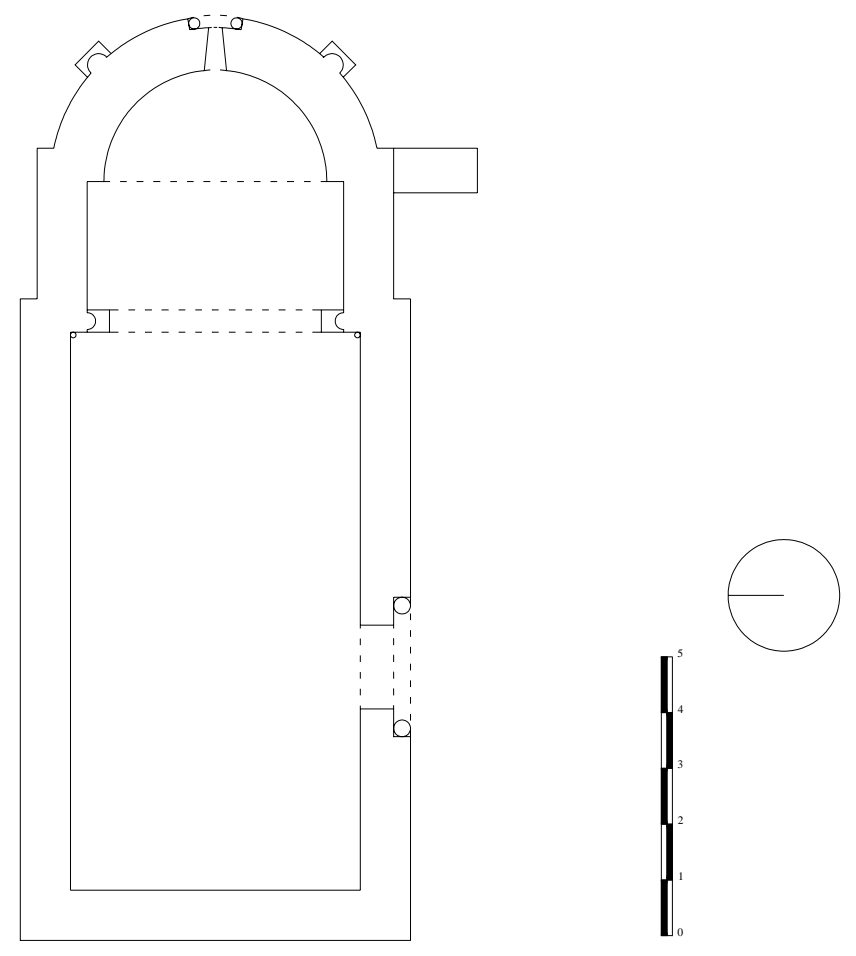

BARADILLO DE HERREROS. Ermita de los Santos Mártires. Planta.

El documento más antiguo, que nos habla de su existencia, data del año 1174, y en él se hace referencia a la vinculación de esta ermita con la desaparecida localidad de Villanueva de los Ferreros ${ }^{916}$. Siglos más tarde, en 1517, un documento emanado del monasterio de San Pedro de Arlanza da cuenta de la concesión que se hace de esta ermita a las localidades de Barbadillo de Herreros y Bezares, cuya titularidad

915 Ibídem. (fols. 34 - 35). Cuentas del trienio 1780 - 83. Barbadillo de Herreros, 8 - julio - 1786.

916 C. RUBIO VELASCO: Barbadillo de Herreros. ob. cit. (pp. 224 - 229). 
compartirán a partir de este momento, repartiéndose las obligaciones de su mantenimiento ${ }^{917}$.

El edificio nos muestra uno de los más bellos ejemplos del románico primitivo, que se desarrollo en esta comarca, durante los primeros momentos del siglo XII. Consta de una planta de una sola nave de trazado rectangular, que se completa en su parte oriental con una cabecera de testero semicircular, precedida de un corto presbiterio. Toda la fábrica se encuentra elaborada en piedra, con sillares bien labrados y ensamblados, dentro de cuyos muros apenas llegamos a advertir las huellas dejadas por las diferentes reedificaciones de que fue objeto.

Con ello, su estructura exterior nos ofrece una imagen sencilla de limpios volúmenes y cuidadas proporciones. Dentro de ella destaca, de modo especial, la cabecera, donde aparece un perfecto ejemplo de este tipo de ábsides de época románica, con el muro semicircular del testero, dividido en tres paños, mediante columnas entregadas, que se rematan con bellos capiteles de sencilla labra. Estos capiteles se unen, a su vez, a la serie de canecillos, que recorren toda la cornisa, en los que se muestran diferentes motivos propios de este período. Una bella ventana de tipo aspillera, se abre sobre el tramo central de este testero, la cual aparece enmarcada por un potente arco de medio punto de aristas aboceladas y arquivoltas con relieve de punta de diamante, que descansa sobre gruesa imposta, también finamente labrada, que se extiende hacia los laterales. Bajo ella, aparecen dos sólidas columnas con capiteles decorados con motivos vegetales y de animales fantásticos.

Esta ventana se corresponde con otra similar, situada en la parte superior del muro de los pies, la cual, sin embargo, presenta un desarrollo más sencillo. La puerta de acceso se abre en el muro meridional de la nave, y consta de un doble arco de medio punto de aristas redondeadas, que se corresponden con pequeñas columnas en el derrame de las jambas.

917 Ibídem. 
En el interior, su lúgubre ambiente, nos muestra un característico espacio camino, dentro del cual podemos diferenciar claramente los ámbitos de la nave y la cabecera. La primera, con una simple estructura cuadrangular cubierta con techumbre de madera, dispuesta a dos aguas sobre armadura de tipo parhilera, y la segunda, articulada, a su vez, en el presbiterio, cubierto con bóveda de medio cañón, y la capilla mayor, que cierra con bóveda de horno o cuarto de esfera. El tránsito entre un ámbito y otro se realiza a través de un potente arco de medio punto.

Los elementos escultóricos, que decoran este templo, nos permiten vincularlo al primer grupo de maestros de la escuela del románico de la sierra, que trabajaron en torno a la primera mitad del siglo XII. No obstante, el profesor S. ANDRÉS ORDAX apunta la posibilidad de poder incluirla dentro de una corriente primitiva del estilo románico, caracterizada por incorporar o mantener en su fisonomía determinados elementos de clara influencia musulmana ${ }^{918}$.

En cualquier caso, y aunque no disponemos de pruebas precisas sobre sus orígenes, las fuentes documentales sí nos dan alguna información sobre las numerosas reedificaciones, de que fue objeto a lo largo de su dilatada historia. En este sentido, tal vez una de las más importantes se produce entre los años 1745-46, cuando localidad de Barbadillo de Herreros tuvo que invertir un total de 2.682 reales y 3 maravedís en "hacer la bóveda y el arco toral de la capilla, excepto la media izaranga que abraza al altar hasta cerca de la imposta, y levantar las paredes por fuera y dentro, especialmente los estribos del mediodía y cubrirlos ambos con chapa de sillería bien sobrepuesta para que no calen las aguas”919. Una situación igualmente difícil es la que se vivió en 1903, cuando un incendio acabó con gran parte de su estructura, reduciendo a cenizas los retablos, que adornaban su interior. La reconstrucción del edificio sí pudo

918 S. ANDRÉS ORDAX: “Arte románico”. Historia de Burgos. volumen 2. Tomo II. Burgos, Caja de Ahorros Municipal de Burgos. 1987. (27 - 82).

919 C. RUBIO VELASCO: Barbadillo de Herreros. Ob. cit. 
llevarse a cabo con total satisfacción, pero no la recuperación de sus elementos ornamentales, quedando su interior, a partir de este momento, completamente desnudo.

Ermitas desaparecidas.

San Matías.

La historia de esta ermita resulta muy parecida a la del templo que acabamos de ver, pues también pertenecía al antiguo despoblado de Villanueva de los Ferreros, pasando después a ser administrada de forma conjunta por los concejos de Barbadillo de Herreros y Bezares. Se encontraba situada a medio camino de ambas localidades, en las cercanías del paraje conocido como Campozares, si bien, actualmente no quedan de ella más que unos pocos sillares esparcidos por el suelo. Esta estratégica situación la convirtió en punto de encuentro de los representantes de los concejos de ambas localidades, los cuales aprovechaban las reuniones para solucionar temas, no sólo concernientes a la administración de la ermita, sino también de carácter administrativo y económico, que afectaban a ambos pueblos.

Su desaparición se produjo en los primeros años del siglo XIX, dándonos cumplida cuenta de ello los informes emitidos por los visitadores del Arzobispado de Burgos. Así, en 1791 D. Manuel María Izquierdo dice lo siguiente:

“En el término de dicho pueblo existen las ermitas de (...), otras dos con el título de los Santos Mártires y de San Matías, que son igualmente comunes de la feligresía de Bezares, y la última se halló indecente, ruinosa y de mal aspecto, por lo cual se manda a las personas a cuio cargo corren procuren su reforma, reparándola de todo lo necesario y poniéndola decente y ornamentada..."920.

Poco después, en 1803, durante la visita del propio Arzobispo, al referirse a las ermitas de esta localidad nos encontramos en siguiente aviso: “... y otra de los Santos 
Mártires, que se halló decente para poder celebrar en ella el Santísimo Sacrificio de la Misa y es común de la feligresía de Bezares, como lo era así mismo la de San Mathías, que ya no existe por haberse demolido mediante hallarse indecente y mal reparada, según se declaró en la última visita"921. Los libros parroquiales de Bezares se hacen eco de esta misma pérdida ${ }^{922}$.

Tras su desaparición, la mayor parte de sus materiales fueron reaprovechados en la reparación de otros edificios, según era costumbre. De este modo, y sin ningún rubor, el muro del testero de la ermita de Nuestra Señora de Costana, de esta misma localidad, nos muestra un sillar en el que los efectos de la erosión todavía nos dejan leer una inscripción con la leyenda: SAN MATÍAS 1712.

\section{San Juan.}

Se encontraba situada en la parte sudoeste del pueblo, a medio camino de la ermita de Nuestra Señora de Costana, ocupando un pequeño solar, dispuesto frente al actual cementerio. No es mucho lo que podemos saber sobre su estructura, pues no existen restos materiales de ella, y la documentación conservada tampoco nos da muchas pistas al respecto. No obstante, a través de algunos documentos sabemos que contaba con una pequeña torre junto a ella, cuyo origen y características desconocemos. De igual modo, también sabemos que los últimos años de su vida acabó convirtiéndose en cantera para otras edificaciones del pueblo.

\footnotetext{
920 Ibídem. (1749 - 1838). Visita realizada a la parroquia de Nuestra Señora de la Visitación de Barbadillo de Herreros del año 1797, por D. Manuel María Izquierdo. Barbadillo de Herreros, 4 septiembre -1791 .

921 Ibídem. Visita realizada a la parroquia de Nuestra Señora de la Visitación de Barbadillo de Herreros en 1803, por el Arzobispo de Burgos, D. Manuel Cid Monroy. Barbadillo de Herreros, 4 - septiembre 1803.

922 AGDBU. LP. Bezares, parroquia de Santa Lucía. LF. . (1772 - 1832). (pp. 133 - 142). Visita realizada a la parroquia de Santa Lucía de Bezares en 1803, por D. Manuel Cid Monroy, arzobispo de Burgos. Canales, 16 - septiembre - 1803.
} 
De este forma, en 1656, durante las obras de reparación realizadas en la iglesia parroquial del pueblo, es el propio visitador del Arzobispado, D. Lucas Ruiz Sarmiento, quien propone la utilización de los materiales procedentes de esta ermita para su utilización en estos trabajos ${ }^{923}$.

El siglo XVIII, por su parte, fue el momento de su desaparición definitiva, la cual comenzó a anunciarse desde los primeros años, con la visita realizada en 1707, en la que se ordena reconstruir una de sus paredes, que se había venido abajo ${ }^{924}$. Pero el deterioro siguió avanzando, y en 1728, el visitador del Arzobispado D. Andrés Madrazo Escalera, se manifiesta con esta contundencia:

"la ermita de San Juan que está indecente y amenazando ruina toda ella por lo cual mandó su merced a las personas a cuyo cargo está su mantenimiento que dentro de cuatro meses se reedifique y repare de todo lo necesario poniéndola decente de suerte que se pueda celebrar en ella el Santo Sacrificio de la misa y no lo executando en dicho término la demuela a fundamento y apliquen sus materiales de valor de ellos a la fábrica de la parroquia de este lugar poniendo en el sitio donde está fundada una cruz

923 A. Parroq. Barbadillo de Herreros, parroquia de Nuestra Señora de la Visitación. LF. (1635 - 1664). (fols. $67 \mathrm{v}^{0}-70 \mathrm{v}^{0}$ ). Visita realizada a la parroquia de Nuestra Señora de la Visitación de Barbadillo de Herreros en 1656, por Lucas Ruiz Sarmiento: "Que una torre que está pegante a la ermita de San Juan, que no es de ningún provecho antes de grande daño, porque cada día se están cayendo piedras del sobre el tejado de la dicha ermita y por esto causa a la dicha ermita grande gasto. Y para abiarle y con la piedra de dicha torre se aderece el estribo de dicha iglesia por la presente su tener su merced da licencia en bastante forma a los mayordomos clérigo y legos desta iglesia y al concexo y vecinos desto dicho lugar para que sin que incurran en pensa ni en alguna puedan demoler y demuelan dicha pedazo de torre y con la piedra que resultare se aderece dicha torre con que se ponga todo cuidado cuando se demuela, que no se aga daño ninguno a la dicha ermita de San Juan, que para ello se les da licencia cuan bastante dicho es necesario". Barbadillo de Herreros, 30 - abril - 1656.

924 Ibídem. LF. (1665 - 1717). (fols. 162 vo - 190). Visita realizada a la parroquia de Nuestra Señora de la Visitación de Barbadillo de Herreros en 1707, por D. Manuel Francisco Navarrete Ladrón de Guevara, arzobispo de Burgos. Barbadillo de Herreros, 27 - marzo - 1707. 
decente para que quede memoria de que fue lugar dedicado a culto divino"925.

Finalmente se decidió adoptar esta segunda opción, lo que hizo que se convirtiera en una de las canteras, que suministraron piedra para la renovación de la nave de la iglesia parroquial, realizada en $1733^{926}$

\section{San Justo y San Pastor.}

Muy pocos datos son los que tenemos sobre esta ermita, pues después del año 1707 no volveremos a encontrar más referencias de ella. Tampoco han quedado restos materiales, que nos permitan establecer con exactitud su ubicación. No obstante, C. RUBIO VELASCO, a través del análisis de la toponimia, ha finado su ubicación en el paraje conocido como Santiuste, situado en las inmediaciones del pueblo, junto al camino que conduce hacia el lugar denominado Casa de la Sierra ${ }^{927}$.

\section{Nuestra Señora del Rosario.}

Presenta un caso muy similar al anterior, pues tampoco tenemos noticias de ella, posteriores al año 1707. Su origen, sin embargo, parece estar relacionado, como el resto de los altares y cofradías dedicadas a esta advocación en la zona, con la labor divulgadora de la misma, que hicieron los frailes dominicos del convento de San Pablo de Burgos, a través de su priorato de Barbadillo del Mercado. No obstante, tampoco tenemos prueba documental de ello.

Su temprana desaparición, por otra parte, ha hecho que desaparezca todo tipo de vestigio material, y con ellos incluso el recuerdo de su ubicación.

\footnotetext{
925 Ibídem. (1718 - 1748). (59 - 62). Visita realizada a la parroquia de Nuestra Señora de la Visitación de Barbadillo de Herreros en 1728, por D. Andrés Madrazo Escalera. Barbadillo de Herreros, 12 - julio 1728.

926 AHBPU. PN. Valle de Valdelaguna. Leg. 9802/2, fols. 59 - 61. Manuel Gil de la Cuesta. Barbadillo de Herreros, 18 - octubre - 1733.

927 C. RUBIO VELASCO: Barbadillo de Herreros. ob. cit.
} 
San Sebastián.

Fue una de las que más tarde perdió su condición de lugar sagrado, y una de las últimas en desaparecer físicamente. Sin embargo, esto no ha permitido que podamos conocer mejor sus características formales. Se encontraba situada a las afueras del pueblo, junto a las casonas solariegas, que escoltan la salida del camino hacia Salas de los Infantes.

La etapa final de la vida de esta ermita se produce ya en un momento avanzado del siglo XIX, como atestigua el informe del visitador del Arzobispado de Burgos de 1831, donde dice:

"existía otra (ermita) en el casco del pueblo con el título de San Sebastián que se halló actualmente sirviendo para recogimiento de cosas contrarias a su destino, por lo que manda su merced que inmediatamente se limpie y despeje de quanto existe en su interior de semejantes ni otros especies ni utensilios secuelas; no permitiendo en lo sucesivo que sirva para recolectar género ni cosa profana vajo del mayor apercibimiento al cura y patronos que lo toleran, y de no haber fondos, limosnas ni diposiciones para asearla ni repararla se cierre con correspondientes cerradura y llave para que no pueda ser profanada" ${ }^{928}$.

Una vez confirmada esta situación de abandono, vemos que no aparece recogida en el Diccionario de P. Madoz. Sin embargo, en este momento, tanto el edificio, como su recuerdo, permanecía aun vivos en la memoria de esta localidad. De esta forma, el visitador del Arzobispado de 1853, D. Manuel del Río Ballesteros, señala que esta

\footnotetext{
928 A. Parroq. Barbadillo de Herreros, parroquia de Nuestra Señora de la Visitación. LF. (1749 - 1838). (s/f). Visita realizada a la parroquia de Nuestra Señora de la Visitación de Barbadillo de Herreros en 1831, por D. José López. Barbadillo de Herreros, 25 - octubre - 1831.
} 
ermita había sido convertida en lugar de enterramiento de párbulos e inubilicenda por falta de adorno para celebrar en ella el Santo Sacrificio de la misa ${ }^{929}$.

Su desaparición definitiva se produce en 1911, con la construcción del frontón municipal, para lo cual el Arzobispado de Burgos cede al Ayuntamiento del pueblo este solar, en el que se hallaban los restos de la ermita ${ }^{930}$. De esta forma, Barbadillo de Herreros, perdía una de sus últimas ermitas, ganando a cambio el conocido popularmente como juego de pelota.

\section{San Torcuato.}

Es la última de las ermitas desaparecidas, la cual se encontraba ubicada en el paraje conocido como San Torcaz, situado fuera del pueblo, en dirección este. Se trata, evidentemente, de un topónimo derivado del nombre del santo titular de este templo.

Los testimonios, que se conservan sobre ella, son también escasos, si bien, resultan suficientemente explícitos como para establecer con precisión el momento exacto de su desaparición. Así, vemos que el mandato expresado por el visitador del Arzobispado de Burgos en 1726, con relación a la ermita de San Saturnino, se hace extensible igualmente a ésta. Sin embargo, en esta ocasión se decide acabar con ella, en vez de acometer su reparación. De este modo, sólo dos años después, vemos cómo sus materiales son utilizados en las obras de remodelación de la nave de la iglesia parroquial, tal y como había ocurrido con la ermita de San Juan.

\section{Arquitectura civil.}

Como decimos, Barbadillo de Herreros nos ofrece algunos de los ejemplos más representativos y mejor conservados, que la arquitectura civil, y en concreto la tipología de las casas solariegas, nos puede mostrar en esta comarca. En su gran mayoría fueron

\footnotetext{
929 Ibídem. LP. (1852 - 1886). (fols. 2v $v^{0}$ - 7). Visita realizada a la parroquia de Nuestra Señora de la Visitación de Barbadillo de Herreros en 1853, por D. Manuel del Río Ballestero. Barbadillo de Herreros, 10 - noviembre - 1853.
} 
construidas durante el siglo XVIII, coincidiendo con el período de mayor esplendor de la actividad trashumante, y por ello fueron estudiadas con detalle en su capítulo correspondiente de la arquitectura civil. Aun así, nos permitimos citar de nuevo la localización de los ejemplos más destacados, entre los que sobresalen, de modo muy especial, el conjunto formado por los edificios situados en los números $1-3-5-7$ de la calle Mayor. Se trata de un grupo de casas que forman una agrupación homogénea, de fachadas uniformes, ciertamente interesantes para poder conocer determinados rasgos propios del urbanismo de este momento.

Dentro de esta misma calle, podemos encontrar otros ejemplos aislados en los números 4, 27, 42, y los números 46 - 48 - 50, que en su momento constituían una sola vivienda. A ellos tenemos que añadir también los situados en la calle Francisco Granmontagne 54 y 57, y en la calle San Esteban 26, por citar sólo los casos más sobresalientes.

Por último, debemos mencionar también aquí el caso de la antigua casa del concejo, que fue remodelada en el año 1734, conservándose la documentación correspondiente a esta obra ${ }^{931}$. Esta circunstancia hace que, a pesar de haber desaparecido el edificio, nos encontremos con un buen medio para poder conocer las características que presentaban este tipo de inmuebles en esta zona. De este modo, podemos observar que estos edificios apenas lograban diferenciarse del resto de construcciones, de carácter popular, destinadas a vivienda. Esto se aprecia, tanto en la que debía ser su imagen exterior, en la que no existen signos que identifiquen este edificio, como en la compartimentación interior, en la que muestra la distribución habitual de salas dispuestas en torno al zaguán, en la planta baja, y abiertas al final de la escalera, en la superior. 
931 AHPBU. PN. Valle de Valdelaguna. Leg. 9802/1. (fols.61 - y ss). Manuel Gil de la Cuesta. Barbadillo de Herreros, 8 - junio - 1731. 
BARBADILLO DEL PEZ.

Barbadillo del Pez se encuentra ubicado en el fondo de una hondonada, abierta al final del abrupto desfiladero, labrado por el río Pedroso sobre los materiales pizarrosos de esta zona de la Sierra de la Demanda, en un lugar, como decía P. Madoz, bien protegido de los vientos, y por lo tanto, de clima sano ${ }^{932}$. Es difícil establecer el origen de este topónimo, si bien han aparecido algunas teorías que lo vinculan a los términos sabaenos Barbad y Mirbaz, que quiere decir dehesa para animales ${ }^{933}$. Su primera referencia documental está fechada el 24-XI-978, donde aparece nombrado como Barbatiello de Alvaro Telliz o Barbatiello de Penia Forella ${ }^{934}$, pasando más tarde (19 - IV - 1148) a ser denominado ya como Barbadello de Pece ${ }^{935}$. No obstante, la forma con la que popularmente es conocido este pueblo en la zona es Valdepez ${ }^{936}$.

Su origen, sin embargo, tenemos que buscarlo mucho más atrás en el tiempo. Así, debemos pensar que su aparición se encuentra ligada al proceso de creación de asentamientos definitivos, que se vive en esta zona a lo largo de los siglos IX-X. Su

932 P. MADOZ: Diccionario geográfico - estadístico - histórico de España y sus posesiones de Ultramar. Valladolid, Ámbito D.L. 1984. (pp.67 - 68).

933 El sabaeno es el idioma que hablan los habitantes del sur de Yemen desde antes de la llegada del islam. La existencia de estos términos entre los topónimos españoles se explica por la importante presencia de naturales de estas tierras de Arabia entre los musulmanes, que participaron en la invasión islámica de la península Ibérica desde los primeros momentos. M. AGUIRRE: "Benidrom, noria... vienen de Yemen”. En “Crónica” del Diario el Mundo, n 435 (Domingo 15 de febrero de 2004). pp. 12 13.

934 L. SERRANO: Cartulario de Covarrubias. Madrid. Centro de Estudios Históricos. 1906. (pp. 16, 26).

935 Ibídem. (pp. 55). 
736 Arquitectura de la Edad Moderna en la sierra burgalesa.

consolidación, e inmediato crecimiento, vendría ligado al progresivo despoblamiento y desaparición de diferentes núcleos cercanos, como San Román, Urrilla o Villaserracín, situados en las inmediaciones, cuya población debió trasladarse a esta localidad de Barbadillo del Pez, atraídos por las mejores condiciones que presentaba este núcleo ${ }^{937}$.

Su temprano origen, y crecimiento relativamente rápido, convierten a esta localidad, según algunos investigadores, en la cabeza de un hipotético alfoz de efímera existencia, que englobaría a las ocho localidades del Valle de Valdelaguna, además de Neila y Riocavado de la Sierra ${ }^{938}$. No obstante, este alfoz apenas sí llegó a tener un contenido realmente importante, pues la vecindad de los poderosos alfoces de Lara y Juarros, terminaron por absorber sus competencias. Así, finalmente Barbadillo del Pez, como el resto de sus pueblos dependientes, quedaron incluidos dentro del alfoz de Lara.

Tras la desmembración del sistema de alfoces, y la creación de la nueva estructura administrativa de Merindades, nos encontramos a Barbadillo del Pez encuadrado dentro de la Merindad Menor de Can de Muñó, lo que la convierte en la única localidad de nuestra zona de estudio que no pertenece a la Merindad de Santo Domingo de Silos ${ }^{939}$. Tal vez la explicación a esto debamos buscarla en la dependencia jurisdiccional de esta localidad del abad de Covarrubias, circunstancia que tampoco comparte con ninguna otra localidad vecina.

\footnotetext{
936 Una buena forma de reconocer en esta zona a los forasteros se consigue observando el nombre utilizado para denominar a este pueblo, pues solamente alguien que no esté familiarizado con la comarca utiliza el término Barbadillo del Pez.

937 Todas estas poblaciones se encontraban ubicadas en lugares altos y muy expuestos a la incidencia de vientos y demás agentes climáticos, mientras que Barbadillo del Pez, como hemos visto, ocupaba un emplazamiento más protegido.

938 G. MARTÍNEZ DÍEZ: Pueblos y alfoces burgaleses de la repoblación. Valladolid, Junta de Castilla y León. Consejería de Educación y Cultura. 1997. (pp. 195 - 200).

939 E. GONZÁLEZ DÍEZ: "Estructura jurídico administrativa”. En Historia de Burgos II. Edad Media (1). Burgos, Caja de Ahorros Municipal de Burgos. 1986. (pp. 145 - 246). C. ESTEPA DÍEZ: "Estructura de poder en Castilla (siglos XII - XIII). El poder señorial en las merindades burgalesas. En III Jornadas burgalesas de Historia (3 1991). Burgos en la Plena Edad Media. Burgos, Asociación Provincial de Libreros de Burgos. 1994. (pp. 245 - 294).
} 
Así, en este sentido, Barbadillo del Pez aparece formando parte de la relación de pueblos con los que fue dotado en el año 978 el Infantado de Covarrubias, fundado por el conde García Fernández para su hija Doña Urraca ${ }^{940}$. De este modo, su jurisdicción pasó a depender del señorío abadengo de Covarrubias, lo cual continuó siendo así durante el resto de la Edad Media ${ }^{941}$.

Ya en la Edad Moderna, esta dependencia del señorío de Covarrubias se mantuvo durante algún tiempo, si bien, en un momento todavía sin determinar, Barbadillo del Pez adquiere su condición de realengo, la cual no perderá en ningún momento. Este cambio debió producirse, posiblemente, en algún momento del siglo XVI, encuadrándose así, dentro de la política de enajenación de bienes eclesiásticos, que desarrollaron, tanto Carlos I, como su hijo Felipe II, y que llevó a que muchas localidades, encuadradas hasta la fecha en señoríos eclesiásticos, compraran su propia jurisdicción, pasando a ser localidades de realengo ${ }^{942}$.

En el plano fiscal, tras la creación de las provincias y partidos en que se divide el mapa de Castilla, en las primeras décadas del siglo XVI, Barbadillo del Pez queda incluido en el partido de la capital burgalesa, que a su vez formaba parte de la provincia del mismo nombre ${ }^{943}$. A finales del siglo XVIII, sin embargo, esta localidad aparece formando parte del partido de Can de Muñó, junto al resto de los pueblos encuadrados

940 L. SERRANO: El obispado de Burgos y Castilla primitiva. Desde el siglo V al XIII. Madrid. 1935. Tomo II (pp. 237 - 240).

941 G. MARTÍNEZ DÍEZ: Libro Becerro de las Behetrías. Estudio y texto crítico. León, Centro de Estudios e Investigación San Isidoro. Caja de Ahorros y Monte de Piedad. Archivo Histórico Diocesano. 1981. (pp.316).

942 Ver capítulo: Devenir histórico. A. DOMÍNGUEZ ORTIZ: Instituciones y sociedad en la España de los Austrias ... ob. cit. S. DE MOXÓ: La desamortización eclesiástica del Siglo XVI. En AHDE. No XXX. 1961. R. CARANDE: Carlos V y sus banqueros. Tomo II. Ob. cit. (pp. 412 y ss.). M. MODESTO: La Hacienda Real de Castilla en el reinado de Felipe II. Roma, 1963. N. LÓPEZ MARTÍNEZ: La desamortización de bienes eclesiásticos en 1574. En Hispania, $n^{\circ} 86$.

943 G. MARTÍNEZ DÍEZ: Génesis histórica de la provincia de Burgos y sus divisiones administrativas. Burgos, Aldecoa. 1983. 
en la jurisdicción de Salas, y no en la de Aranda, como sucedió con la mayoría de los núcleos de realengo de la zona ${ }^{944}$.

Por último, en el plano de la administración eclesiástica, Barbadillo del Pez forma parte de la diócesis de Burgos, si bien su iglesia parroquial dependía directamente del abad de Covarrubias. Esto hace que, en el reparto de los beneficios de los diezmos de esta parroquia, un 16’6 \% (es decir 1’5/9), fuera a parar ala propia colegiata de Covarrubias, un22’2 \% (esto es, los 2/9), quedaran para el propio abad de esta colegiata, mientras que, el Arzobispado y la catedral de Burgos no percibían nada ${ }^{945}$.

En lo que se refiere a su población, los datos arrojados por los distintos censos realizados a lo largo de la Edad Moderna, nos indican que el momento de máximo esplendor demográfico, que vivió esta villa, se produce en la primera mitad del siglo XVI, con 111 vecinos pecheros, declarados en el censo de $1541^{946}$. A partir de aquí, sin embargo, se inicia un descenso continuado, que tiene su primer reflejo en el censo de 1591, en el que declara tener 96 vecinos pecheros y 3 no pecheros ${ }^{947}$. Esta tendencia se agudiza de forma notable en el siglo XVII, llegando a un valor mínimo conocido en 1646, con sólo 36 vecinos $^{948}$. De aquí en adelante, comienza una lenta recuperación, que se confirma a mediados del siglo XVIII con un censo de 78 vecinos y 3 clérigos, según el Catastro del Marqués de Ensenada ${ }^{949}$. Estos valores se mantienen sin grandes cambios hasta el final de la centuria, de tal modo, que el censo de Floridablanca, de 1787, ofrece un total de 226 habitantes ${ }^{950}$.

\footnotetext{
944 Ibídem. ADPBU. CE. 210. RESPUESTAS GENERALES. Barbadillo del Pez, 6 - abril - 1753.

945 Ver capítulo Población. (fig. 7).

946 AGS. Contaduría General. Leg. 768. (fols. 34).

947 Censo de Castilla de 1591. Vecindario. Madrid, Instituto Nacional de Estadística. 1984.

948 AGS. Cámara de Castilla - Diversos. Leg. 23, nº 24 (s/f).

949 Vecindario de Ensenada 1759. Vol. I. Madrid, Centro de Gestión Catastral y Cooperación Tributaria: Tabapress. D. L. 1991.

950 INE. Censo de 1787. "Floridablanca”. Madrid. INE. 1989.
} 
Esta población vivía fundamentalmente de la agricultura, y no tanto de la ganadería lanar, como ocurre con la mayoría de los pueblos de su entorno. No obstante, el Catastro del Marqués de Ensenada nos confirma la existencia de unas 1.000 cabezas de ganado merino, que trashumaban a Extremadura ${ }^{951}$. Esta circunstancia, sin embargo, no evita que Barbadillo del Pez quedara fuera de la Cuadrilla de San Pedro de Vega, que agrupaba al resto de pueblos de la zona, pertenecientes al Honrado Concejo de la Mesta. Al menos, esto es lo que se desprende de la documentación conservada.

Una repercusión mucho mayor parece que tuvo la artesanía, relacionada con el sector textil, en el cual, según datos del propio Catastro del Marqués de Ensenada, participaba, de un modo u otro, la gran mayoría de los habitantes del pueblo ${ }^{952}$. Nos encontramos, por lo tanto, ante el principal motor de la economía de este pueblo, durante la mayor parte de la Edad Moderna.

Su desarrollo, evidentemente, se encuentra ligado a la disponibilidad de lana abundante, procedente de los rebaños trashumantes, que realizaban el esquileo en estas sierras en los meses de verano, y a la existencia de fuertes y regulares cursos de agua, que permitían impulsar los batanes. Más difícil resulta, sin embargo, precisar el origen de esta actividad, ya que carecemos de datos que puedan confirmarlo. No obstante, y en virtud de la comparación que podemos establecer con otros estudios paralelos, realizados sobre localidades que vivieron un fenómeno semejante, podemos situar este origen en torno a las primeras décadas del siglo XVII, encuadrándolo dentro del fenómeno de ruralización, que sufre la industria textil castellana, con la decadencia de los principales centros productores del reino ${ }^{953}$. La decadencia de esta actividad en

\footnotetext{
951 ADPBU. CE 210. Respuestas Generales. Barbadillo del Pez, 6 - abril - 1753.

952 Ibídem. Respuesta a la pregunta ${ }^{\circ} 33$.

953 Ver capítulo de Economía. M. DIAGO HERNANDO: La industria y el comercio de productos textiles en Europa, siglos XI al XV. Madrid, Libros D.C. 1997. (pp. 70). A. GARCÍA SANZ: Desarrollo y crisis del Antiguo Régimen en Castilla la Vieja. Madrid, Akal. 1977. R. OJEDA SAN MIGUEL: “Crecimiento y subsistencia de un centro textil rural burgalés (siglos XVI - XVII): Pradoluengo”. En Pasado Histórico de Castilla y León. Volumen II. Edad Moderna. Burgos, Junta de Castilla y León. 1993. (pp. 473 - 492).
} 
Barbadillo del Pez, por otra parte, estuvo relacionada con el fenómeno de la industrialización y la incapacidad, que se vive en este pueblo, para realizar la necesaria concentración de capital, que sí se pudo hacer en otras localidades burgalesas como Pradoluengo $^{954}$. Aun así, a mediados del siglo XIX todavía quedaban restos de esta actividad, según nos indica P. Madoz en su Diccionario ${ }^{955}$. Los principales productos que, durante la Edad Moderna, salían de esta localidad fueron sayales y mantos, estos últimos, muy apreciados por los pastores trashumantes ${ }^{956}$.

El núcleo urbano, que compone esta localidad, como decíamos, se encuentra ubicado en el fondo de una suave hondonada, con su caserío repartido a ambos lados del río Pedroso, cuyas márgenes sirven para crear una pequeña, pero fértil franja de huertas. La estructura de este casco urbano, por lo tanto, es la típica de estos pueblos de la Sierra de la Demanda, con un claro carácter compacto, en el que se aprecia una ligera forma alargada, impuesta por el propio cauce del río, y por la vía de comunicación, que cruza el desfiladero, a cuya salida se halla esta localidad. El edificio más interesante, y tal vez el único que muestra una cierta relevancia, es su iglesia parroquial, ya que el resto del caserío participa plenamente de los rasgos propios de la arquitectura popular.

\section{Iglesia de San Salvador.}

Esta iglesia está dedicada a San Salvador, advocación poco frecuente, en general, dentro de la Diócesis de Burgos, y menos aun en nuestra zona de estudio, donde es el único templo parroquial dedicada a una de las figuras de la Trinidad. Se encuentra situada en la parte central del pueblo, junto al cauce del río Pedroso, ocupando uno de los puntos más bajos de la orografía de esta localidad, lo cual no deja

\footnotetext{
954 J. J. MARTÍN GARCÍA: Trabajo rural - trabajo industrial: Belorado y Pradoluengo (1883 - 1936). Burgos, Aymto. de Belorado - Aymto. de Pradoluengo. 2000.

955 P. MADOZ: Diccionario... ob. cit.

956 L. VICENTE ELÍAS: “La Mesta y la cultura pastoril”. En Mesta, trashumancia y vida pastoril.: exposición organizada por la Sociedad V Centenario del Tratado de Tordesillas. Soria, Sede de la Fundación Duques de Soria. 19 de septiembre a 30 de noviembre 1994. Madrid, I P Investigación y Progreso. 1994. (pp. 207 - 237).
} 
de llamarnos la atención, pues lo habitual es encontrarnos a estos templos emplazados en puntos dominantes sobre el resto del caserío.

Presenta este edificio una estructura de planta de salón de tipo hallenkirche, con su cuerpo articulado en tres naves de dos tramos cada una, con un claro predominio de la central en anchura, y desigual desarrollo de las laterales, pues la del lado de la epístola resulta mucho más ancha que la del evangelio. Todas ellas, sin embargo, aparecen cubiertas a una misma altura. La nave central, al mismo tiempo, se prolonga en el extremo oriental con un nuevo tramo, para formar la capilla mayor, la cual presenta una estructura cuadrangular de testero plano, sobre cuyo flanco meridional se añade la sacristía. Por último, a los pies, y en correspondencia con la capilla mayor, aunque mostrando un ligero quiebro con respecto al eje longitudinal trazado en torno a la nave central, se alza la torre.

Una planta, por lo tanto, de esquema homogéneo, pero no exenta de ciertas irregularidades, las cuales debemos achacar, a partes iguales, a la orografía del suelo sobre el que se asienta (en especial a la proximidad de río), y a la propia historia constructiva del templo.

Todo el edificio está realizado en piedra, predominando el aparejo de mampostería, con piedras de tamaño medio, mínimamente labradas, o simples guijarros de río de gran calibre, unidos con argamasa. No obstante, también encontramos la presencia de sillares de mejor labra en determinados puntos, como sucede en la estructura de la torre, el pequeño zócalo sobre el que se alza el resto del edificio, la cornisa superior que remata estos muros, los marcos de los vanos, o los contrafuertes exteriores, y pilares, pilastras y arcos del interior, que forman los elementos activos del templo.

Con todo esto, nos encontramos con una imagen exterior sólida y de carácter compacto, en la que domina el gran prisma, que forma el núcleo central del cuerpo, 
sobre el cual se añaden el módulo, correspondiente a la cabecera, en la que se mantienen sus mismas proporciones. Este núcleo central aparece reforzado con sólidos estribos, que en el caso de las esquinas adoptan una posición en diagonal. En la cabecera, sin embargo, quedan dispuestos en ángulo recto, con los lados en paralelo a los ejes del muro.

La torre, levantada a los pies, se convierte, por su parte, en el único contrapunto vertical, dentro de esta estructura. Esta torre está compuesta por tres cuerpos desiguales, cada uno de los cuales introduce un significativo decrecimiento en anchura sobre la planta rectangular, que todos ellos comparten. En el último de ellos se abren los vanos, para alojar las campanas, coronados con arco de medio punto, y distribuidos de forma desigual, con dos en el lado del poniente, y uno en los lados septentrional y meridional.

La imagen exterior se completa con la portada, abierta sobre el flanco meridional, a la altura del segundo tramo de la nave. Consta de un amplio arco de medio punto, de aristas redondeadas con moldura de cuarto de bocel, que se repite en el extradós, continuándose, sin interrupción a lo largo de las jambas. A los lados, sobre elevado pedestal, se alzan dos columnas de orden próximo al orden compuesta, aunque de talla muy esquematizada, con fuste liso, delimitado en su tercio inferior con un anillo, y dispuestos sobre retropilastras del mismo orden con fuste cajeado. Un estrecho entablamento quebrado en los extremos, se dispone entre ellas con el friso decorado con puntas de diamante, dando paso al remate, formado por frontón recto, de escaso resalte, coronado, en su vértice superior, por un pequeño jarrón, que da paso a un gran óculo. Una obra, en definitiva, como ya señalamos al hablar de la arquitectura religiosa durante el siglo XVI, propia de la estética renacentista, desarrollada en esta zona, desde mediados del Quinientos, de extraordinaria sobriedad compositiva y mesura ornamental. Responde, en definitiva, a los modos en los que se interpreta este estilo en el ambiente arquitectónico de la zona. 


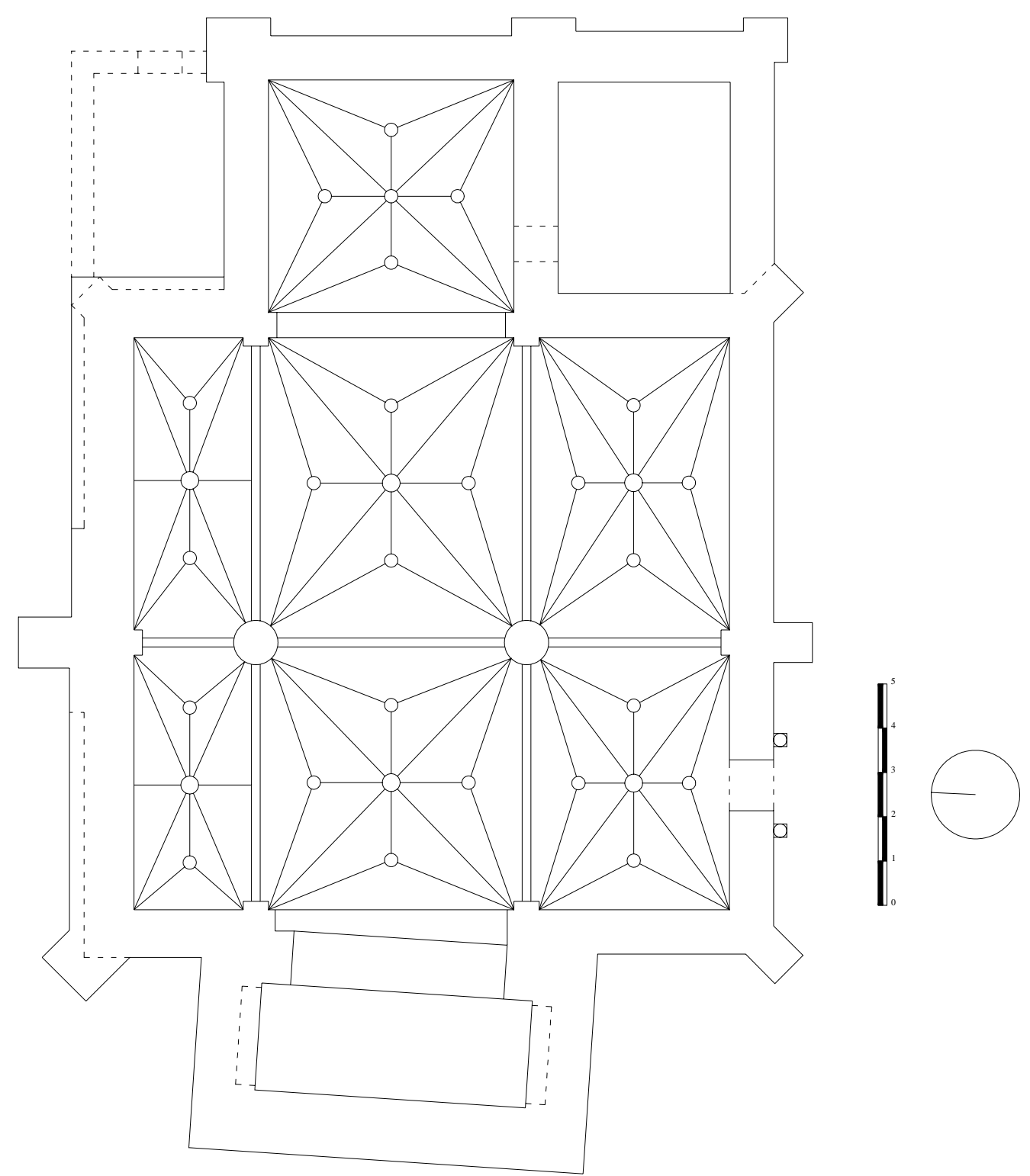

BARBADILLO DEL PEZ.

Iglesia de San Salvador. Planta. 
El resto de los vanos, que forman las ventanas, quedan repartidos entre los diferentes muros del templo, exceptuando el del testero de la capilla mayor. Dentro de ellas, dominan las de trazado rectangular con dintel plano, abocinadas en ambas partes, destacando, a su vez, las orientadas al mediodía, por su mayor tamaño. Sin embargo, podemos destacar también algunas variantes, como es el caso del óculo, mencionado en el tramo de la portada, las dos ventanas de tipo aspillera coronadas con arco de medio punto, que encontramos en el tramo delantero de la nave del evangelio, y en el muro de los pies de la torre, entre el primer y segundo cuerpo. Esta última, muestra además un marco con arco de medio punto, dispuesto sobre pequeñas columnas, coronadas con capiteles de talla muy simple.

En el interior, nos encontramos con el desarrollo de un concepto espacial de ámbito único, característico de este tipo de templos, en el que destaca de modo especial su marcada amplitud y diafanidad, conseguidas por la elevación de todas las cubiertas a un mismo nivel, y por el adelgazamiento de los soportes, evitando con ello que interrumpan en exceso la visión del altar mayor. En las cubiertas se emplea, en todos los casos, la bóveda de crucería estrellada con terceletes y cinco claves, cuyas únicas variantes aparecen en la nave del evangelio, al tratarse de tramos perlongados de proporción próxima a la dupla. Ello obliga a eliminar aquí los terceletes de los lados mayores, prolongando, a su vez, el nervio de ligadura transversal, hasta alcanzar la clave de los arcos formaletes.

La separación entre cada uno de estos tramos se consigue mediante arcos de medio punto peraltados, con lo que se logra incrementar aun más la altura de las cubiertas, y afianzar, por lo tanto, la sensación de espacialidad. Estos arcos presentan una sencilla sección cuadrada con un intradós cajeado, que en algunos casos incluye una serie de casetones. Los soportes, sobre los que estos arcos descansan, están formados por dos sólidos pilares cilíndricos, situados en el centro del cuerpo, que se corresponden en los muros con pilastras cajeadas. Estos pilares muestran una mayor anchura en su tercio inferior, el cual aparece separado por una moldura de medio bocel, mientras que 


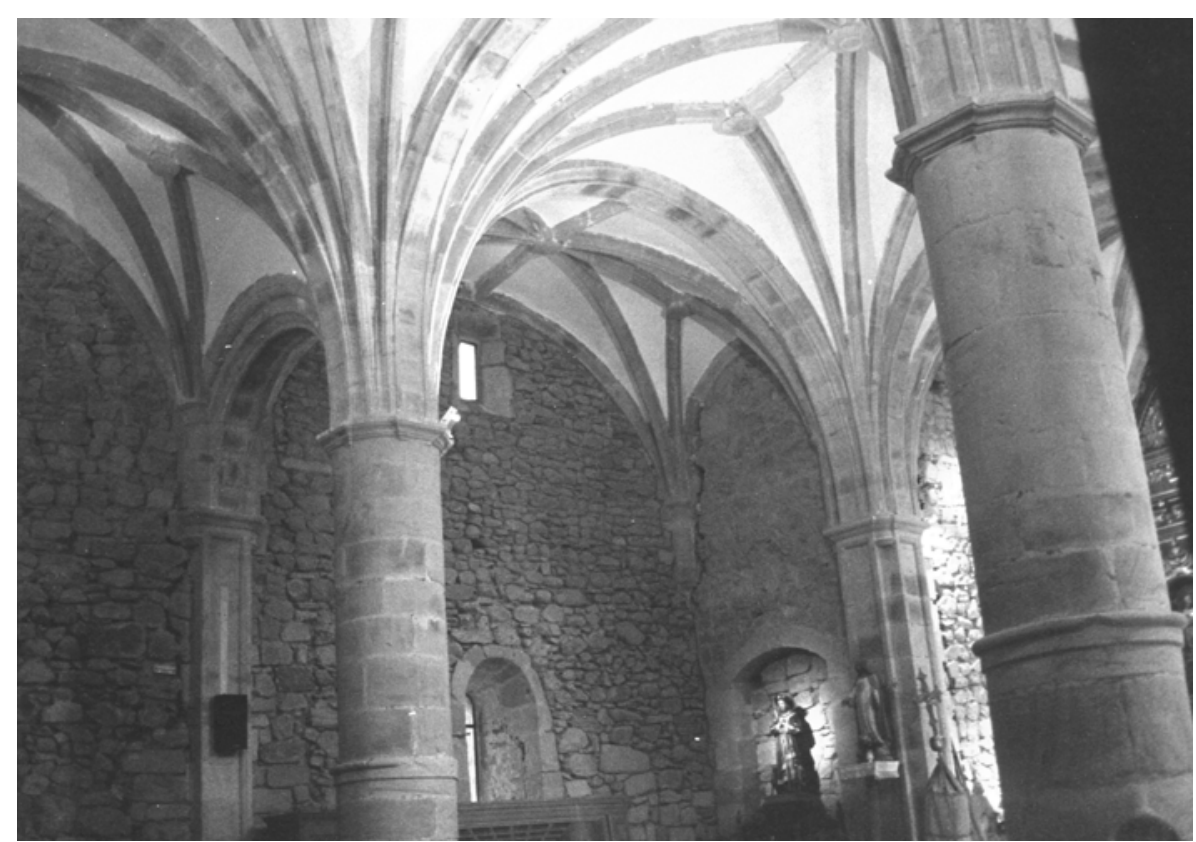

BARBADILLO DEL PEZ. Iglesia de San Salvador. Interior.

el remate queda formado por una pieza horizontal de sección quebrada en sus frentes, con la que se marca el arranque de los arcos fajones y formeros.

La imagen interior se completa con el coro, situado a los pies, en el espacio interior de la base de la torre, al cual se accede a través de un potente arco apuntado de intradós plano. Se trata del típico coro alto, elaborado en madera, cuya parte inferior sirve para ubicar el baptisterio. A este coro debemos añadir los dos retablos, que actualmente se conservan. En la capilla mayor, el retablo que preside su altar es obra rococó, realizado en 1773. Consta de banco, un solo cuerpo, articulado en tres calles, y remate $^{957}$. El nicho principal está presidido por una talla del San Salvador de principios del siglo XVI, al cual acompañan, en las calles laterales San José y San Bartolomé, y en 
el remate una imagen moderna de la Virgen del Carmen. El segundo retablo, que se conserva, es el de la Inmaculada Concepción, situado en la parte delantera de la nave de la epístola. Es obra barroca, realizado hacia 1720, y cuenta con una estructura de un solo cuerpo, articulado en tres calles, y remate. En la hornacina central encontramos una imagen moderna de la Inmaculada, a la cual acompañan una talla de San Antonio Abad, y otro santo sin identificar, a los lados, y un San Roque en el remate.

Un templo, por lo tanto, en el que destaca, por encima de todo, su gran unidad estilística, lo que nos permite adivinar la existencia de una fase constructiva dominante, dentro de su larga historia. Esta fase se produce en la segunda mitad del siglo XVI. No obstante, dentro de esta imagen, podemos descubrir también la presencia de determinados elementos, que nos hablan de la existencia de otros períodos constructivos anteriores y posteriores a esta fase.

Entre estos vestigios se encuentran los ventanales, que señalamos en la base de la torre y en el segundo tramo de la nave del evangelio, que nos hablan de un origen románico para este templo. Esta posibilidad queda reforzada por la presencia de otros elementos, como la magnífica pila bautismal ${ }^{958}$, o los restos de una portada, situada en el muro de los pies de la nave del evangelio. Estos vestigios, sin embargo, resultan insuficientes para poder establecer una hipotética reconstrucción de este templo.

También encontramos restos pertenecientes al período gótico, los cuales se localizan en la zona de la torre, correspondiente a los dos cuerpos inferiores. Observamos aquí, además del potente arco apuntado de la entrada al espacio del coro, otros dos arcos más, similares a éste, en la parte interior de este espacio. Estos elementos, sin embargo, tampoco nos permiten conocer mucho más sobre el alcance de esta fase constructiva.

957 R. J. PAYO HERNANZ: El retablo en Burgos y su comarca durante los siglos XVII y XVIII. Burgos, Excma. Diputación Provincial de Burgos. 1997. (T. II, pp. 452). 
De esta forma, llegamos a la segunda mitad del siglo XVI, momento en el que se acomete la renovación definitiva de este templo. Una obra que nos sorprende fundamentalmente por dos motivos. Primero, por la propia renovación en si, la cual coincide con un momento de recesión a todos los niveles, lo que hace que sea la única obra de estas características, que encontramos en la zona durante este período. Y segundo, por las formas desarrolladas en su estructura, convirtiéndose en el único edificio de la comarca, concebido según estos gustos.

En lo que se refiere a su ejecución, todo apunta a la participación del maestro de cantería Juan de la Puente, pues su presencia se encuentra documentada en la construcción de la cabecera. Si a ello sumamos, el hecho de que en este momento se encontraba ocupando el puesto de Maestro Veedor de obras del Arzobispado de Burgos, tenemos sobrados motivos para pensar, que pudo participar en la realización del resto de la fábrica, bien como artífice material, o bien en la elaboración de las trazas.

El resultado final nos ofrece, como hemos visto, un templo encuadrado dentro del tipo hallenkirche, de escaso desarrollo longitudinal, en el que se emplea un tipo de soporte, que nos permite situarla en la antesala de las llamadas iglesias columnarias propiamente dichas. Sin embargo, la falta de un empleo apropiado de los órdenes clásicos, nos impide situarla ya dentro de esta nueva variante.

A partir de aquí, muy pocas son las variaciones que registra este templo, las cuales, además, apenas llegan a alterar la estructura heredada. Dentro de estas actuaciones, tal vez la más destacada es la que se produce a finales del primer cuarto del siglo XVIII, en la cual se remodela toda la parte correspondiente a la cabecera. Sus resultados, sin embargo, apenas son apreciables, pues la perfecta adaptación a la obra anterior, y el respeto por continuar las mismas formas y proporciones, llevan a que

958 G. BILBAO LÓPEZ: Iconografía de las pilas bautismales del románico castellano; Burgos y Palencia. Burgos, Editorial la Olmeda. 1996. 
resulte difícil valorar el alcance de estos proyectos. Solamente en el exterior podemos identificar la impronta de esta remodelación, en los nuevos estribos, que ahora se incluyen para reforzar el muro del testero. Una inscripción, incluida en una de las claves de la bóveda de la cabecera, nos informa de que la obra se concluyó en 1724.

Por lo demás, el resto del período, que se extiende desde la segunda mitad del siglo XVI, hasta el final de la Edad Moderna, transcurre sin mayores incidencias para la fábrica de esta iglesia. Las únicas obras que conoce, por lo tanto, serán las propias de mantenimiento y conservación.

\section{Ermitas.}

Las fuentes documentales conservadas sobre este pueblo en ningún momento nos informan sobre la existencia de ermitas dentro de su término municipal. De este modo, para obtener estas referencias tendremos que irnos a fuentes de información mucho más recientes, como es el Diccionario de P. Madoz, de mediados del siglo XIX. En esta obra se habla de la existencia de un total de cuatro ermitas, dentro del término municipal de Barbadillo del Pez, las cuales estaban dedicadas a San Sebastián, San Jorge, Nuestra Señora de las Nieves y Nuestra Señora de Serracín ${ }^{959}$. Sobre las dos últimas se dice también, que en su momento fueron parroquias de sendos despoblados, existentes en las inmediaciones. Al contrastar esta información con los datos procedentes de otras fuentes, hemos podido relacionar estas ermitas con los despoblados de Urrilla y Vaillaserracín (o simplemente Serracín), ambos ubicados dentro del actual término municipal de Barbadillo del Pez.

Nuestra Señora de las Nieves.

Esta ermita se encuentra situada en lo alto de una colina próxima al pueblo, situada en dirección sudeste, desde donde se domina un amplio valle, surcado por los ríos Pedroso y Quintanilla, cuyos cauces confluyen a sus pies. Esto convierte a este

959 P. MADOZ: Diccionario... ob. cit. 


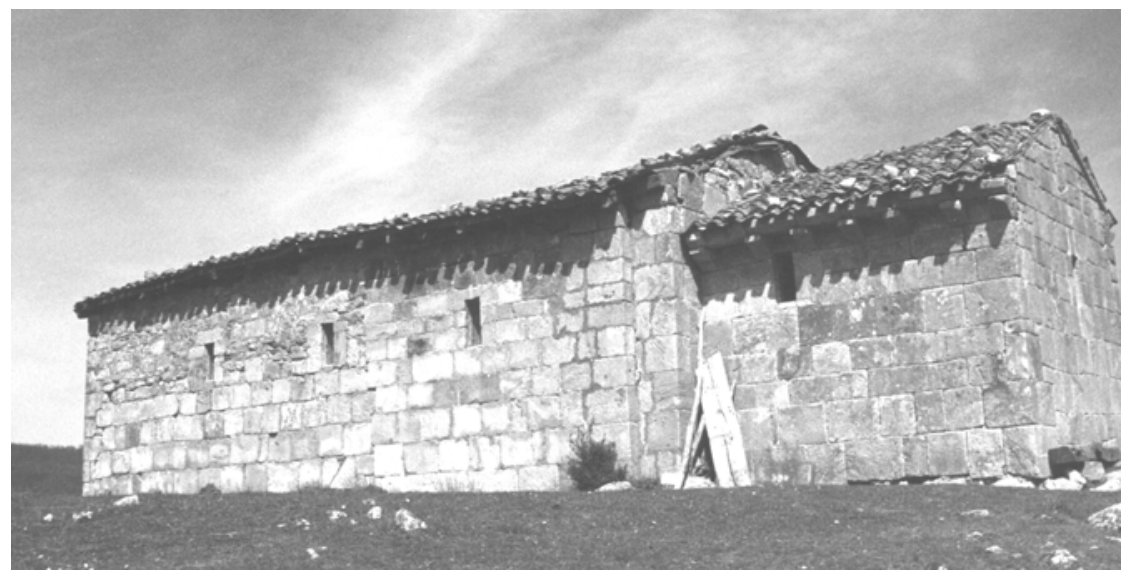

BARBADILLO DEL PEZ. Ermita de Nuestra Señora de las Nieves.

cerro en un lugar de alto valor estratégico, y por lo tanto, ideal para acoger diferentes asentamientos.

El origen de esta ermita, por lo tanto, se encuentra relacionado con el despoblado de Urrilla, núcleo cuya existencia únicamente se encuentra registrada documentalmente a partir del año $1250^{960}$. No obstante, las tumbas labradas en roca, halladas en las inmediaciones de esta ermita nos hablan de una antigüedad mucho mayor.

El edificio actual conserva todavía el neto sabor prerrománico de su fábrica original, en gran parte de su estructura, completando el resto con elementos del período románico. Consta de una sencilla planta de nave única de trazado rectangular muy alargado, que se completa en su extremo oriental con una cabecera de trazado igualmente rectangular y testero plano. Todo el edificio se encuentra realizado en piedra, mostrando una perfecta labor de cantería en la mayor parte de su estructura, con

960 E. PASTOR DÍAZ DE GARAYO: Castilla en el tránsito de la Antigüedad al Feudalismo. Poblamiento, poder político y estructura social del Arlanza al Duero. (siglos VII - IX). Valladolid, Junta de Castilla y León. Consejería de Educación y Cultura. 1996. (pp. 52). 
muros de sillería perfectamente labrados y ensamblados, entre los que encontramos algunos breves tramos de sillarejo y mampuesto, producto de diferentes reparaciones.

Al exterior este edificio nos muestra una estructura compuesta por sendos bloques prismáticos de limpios perfiles y volumen decreciente, dispuestos sobre un mismo eje, con los cuales queda reflejada la estructura de su planta. Dentro de esta imagen destaca especialmente la portada, abierta sobre el muro de los pies, y protegida por un ligero tejadillo, dispuesto sobre estructura de madera. Esta portada queda encuadrada dentro de estilo románico, y muestra una sencilla estructura abocinada, compuesta por dos niveles de arquivoltas, con arco de medio punto, separados por una faja ajedrezada, y enmarcadas exteriormente por una moldura de cuarto de bocel, a modo de guardapolvo. Estos arcos descansan sobre dos gruesas impostas. Una estructura, por lo tanto, sumamente sobria, dentro de la cual nos llama poderosamente la atención los relieves de círculos concéntricos y espirales, que decoran toda la rosca del arco, que forma el nivel inferior de las arquivoltas. La representación de este tipo de motivos no resulta del todo extraña dentro del arte románico de esta comarca, ya que nos encontramos representaciones similares en otras obras próximas a este lugar, como puede ser el caso del relieve que decora la parte exterior la copa de la pila bautismal de la iglesia de San Martín de Huerta de Arriba, o el de algunos sillares encontrados entre los muros de la otra ermita, de esta localidad e Barbadillo del Pez, la de San Quirico y Santa Julita. En cualquier caso, lo que parece más difícil es interpretar su significado. Tal vez se trate de algún tipo de símbolos de carácter cósmico, vinculados al paso del tiempo o al desarrollo de los ciclos vitales. O tal vez debamos relacionarlo con determinados signos profilácticos, ligados a prácticas mágicas de origen ancestral, con los cuales se pretendían alejar los malos espíritus del edificio, evitando su entrada.

En el interior del templo, nos encontramos con el desarrollo del característico concepto de espacio camino, articulado en torno a los dos ámbitos, que conforman su imagen interior, como son la nave y la cabecera. La primera aparece cubierta con una sencilla techumbre de madera dispuesta a dos aguas, sobre armadura de tipo parhilera, 
mientras que la cabecera muestra una sólida bóveda de medio cañón, dispuesta sobre una gruesa imposta. El tránsito entre un ámbito y otro se realiza a través de un sencillo arco de medio punto de gran potencia.

Frente a este arco, por último, nos encontramos con una pila bautismal de trazas románicas, con el exterior de la cobra decorada con gallones y el borde con cintas ondulantes, formando círculos. Esto, evidentemente nos acredita el carácter de parroquia, que un día tuvo este templo.

\section{San Quirico y Santa Julita.}

Es la otra ermita que se conserva actualmente en este pueblo, la cual se corresponde con aquella dedicada a Nuestra Señora de Serracín, que decía P. Madoz. La utilización de este término, por parte de Madoz, quedaría explicada por el propio origen de esta ermita, la cual fue en su día, como bien indicaba en su obra, iglesia parroquial de un núcleo despoblado, conocido como Villaserracín, o simplemente Serracín. Esta localidad fue uno de los últimos núcleos de nuestra zona de estudio, que pasó a formar parte de la extensa lista de los despoblados, repartidos por nuestra comarca. Así, en el Becerro de las Behetrías, de mediados del siglo XIII todavía aparece registrado su nombre, como señorío dependiente del monasterio de San Pedro de Arlanza, si bien aquí se indica ya su carácter de despoblado ${ }^{961}$. Esta ermita de San Quirico y Santa Julita constituye, por lo tanto, el último resto visible de aquella población, en la cual cumplía las funciones de templo parroquial.

Se encuentra situada a unos 1.500 metros del pueblo de Barbadillo del Pez, en dirección noroeste, ocupando la cumbre de una suave loma, rodeada de un bello y tranquilo paraje, poblado por robles centenarios. El edificio mantiene prácticamente intactas sus trazas originales de sobrio estilo románico, mostrando una estructura de tipo caja, con una sola nave de planta rectangular, que se completa, en el extremo oriental, con una cabecera, compuesta por un corto presbiterio y un ábside de testero

961 G. MARTíNEZ DÍEZ: Libro Becerro de las Behetrías... ob. cit. (pp. 610 - 611). 


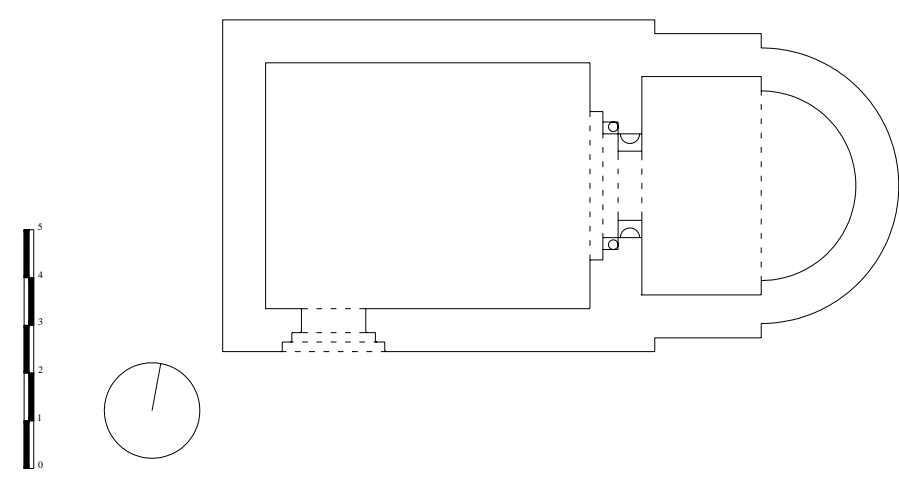

BARBADILLO DEL PEZ. Ermita de San Quirico y Santa Julita. Planta

semicircular. Toda su estructura se halla realizada en piedra, con sólidos muros de mampostería, reforzados en las esquinas con sillares de mejor labra, y rematados con una cornisa recorrida por una hilera de canecillos de labra bastante simple.

Con todo ello se consigue una imagen exterior sólida y compacta, en la que se manifiestan las diferentes partes, que hemos visto en planta. Dentro de esta imagen, el elemento más interesante lo constituye la portada, la cual se abre sobre la fachada meridional de la nave, mostrando una estructura abocinada, con tres niveles de arquivoltas de medio punto, de aristas redondeadas con moldura de cuarto de bocel, a las cuales enmarca una faja ajedrezada, dispuesta a modo de guardapolvo. Estas arquivoltas descansan, a través de una pequeña imposta, sobre columnas dispuestas en las jambas.

Otra pieza interesante, dentro de esta imagen exterior, lo constituye la ventana de traza rectangular y dintel plano, abierta en este mismo lado, a la altura del presbiterio. En ella destacan, además del sogueado que recorre todo su marco, la 


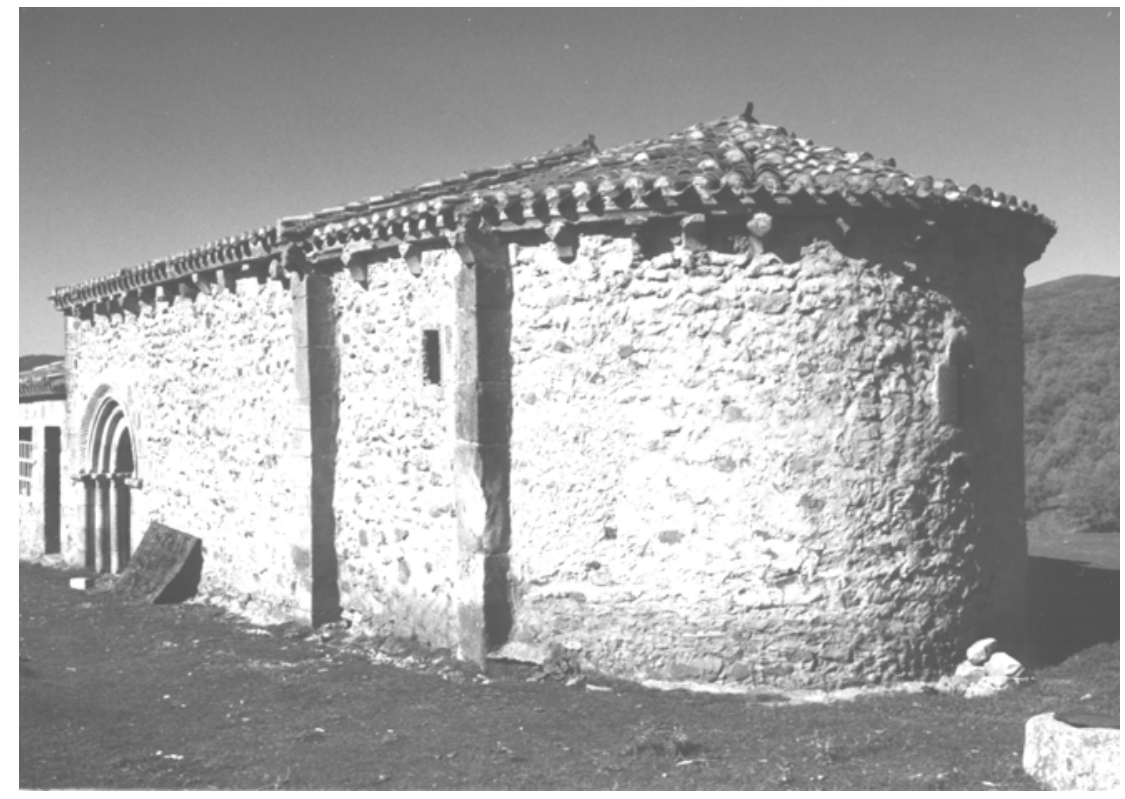

BARBADILLO DEL PEZ. Ermita de San Quirico y Santa Julita.

presencia, en todo el borde interior, de restos de lo que debió ser una celosía labrada en piedra. Junto a esta ventana debemos añadir también otra más, de tipo aspillera, con fuerte derrame hacia el interior, abierta sobre la parte central del muro del testero.

En el interior, nos encontramos con el desarrollo del característico concepto de espacio camino de este tipo de templos, dentro del cual se aprecia la clara separación entre el ámbito de la nave y la cabecera. La nave actualmente aparece cubierta por un sencillo cielo raso, mientras que la cabecera todavía mantiene el abovedamiento original, con una bóveda de medio cañón, para el presbiterio, y una de horno o cuarto de esfera para la capilla mayor. Aun así, la pieza más llamativa de esta imagen interior, la encontramos en el arco toral, que sirve de tránsito entre uno y otro ámbito, el cual aparece concebido como una auténtica portada monumental. Presente la típica estructura abocinada, con tres niveles de arquivoltas de medio punto. De ellas, las dos 
inferiores muestran aristas redondeadas con moldura de cuarto de bocel, descansando, a través de una gruesa imposta, sobre columnas dispuestas en el derrame de las jambas. El nivel superior, sin embargo, mantiene sus aristas vivas, proyectándose del mismo modo en las jambas. Una obra, por lo tanto, típicamente románica, dentro de la cual destacan, de modo especial, la serie de motivos escultóricos, recogidos en los capiteles de las jambas. Entre ellos, llama particularmente en enfrentamiento entre un ave y una serpiente, que debemos interpretar como una representación de la lucha entre el bien y el mal.

Estilísticamente, esta pieza al igual que el resto del templo, debemos encuadrarlos dentro de la llamada escuela románica de la sierra, correspondiente a las décadas centrales del siglo XII.

\section{Arquitectura civil.}

Barbadillo del Pez no es un pueblo que nos ofrezca buenos ejemplos de arquitectura denominada culta, en el ámbito de lo civil. Y no porque no se hayan conservado, sino más bien porque consideramos que nunca existieron. El hecho de tratarse de un núcleo cuya población se dedicó casi en exclusiva a la producción artesanal y manufacturera, durante buena parte de la Edad Moderna, y no al cuidado y cría de ganado lanar trashumante, como sucedía en los pueblos circundantes, hizo que aquí no existiera la figura del rico propietario de ganados merinos, que una vez adquirida su condición de hidalgo (o sin ella), decide plasmar su preeminencia en la edificación de una suntuosa vivienda.

La población de Barbadillo del Pez, a lo largo de la Edad Moderna, o al menos en su etapa final, la componían, según vimos con los datos del Catastro del Marqués de Ensenada, pequeños agricultores y ganaderos, que alternaban su trabajo en el campo con labores artesanales del sector textil. Esto hace que en el caserío del pueblo no aparezcan los ejemplos de casas blasonadas o solariegas, que sí encontramos en los núcleos vecinos. Aquí, por el contrario, nos topamos con construcciones de neto sabor popular, 
dentro de las cuales destacan especialmente las hileras de casas de fachada uniforme con soportal corrido en su planta inferior, dispuesto sobre postes de madera, con pies derechos y capitel de zapata. La presencia aquí de este tipo de arquitectura muy posiblemente debamos relacionarla con el tipo de actividad, que realizaban sus habitantes, y en concreto con la comercialización de los productos textiles, que ellos mismos elaboraban, pues en ningún otro pueblo de la zona volvemos a encontrar este tipo de edificio. Los ejemplos, que actualmente se conservan pie, se concentran principalmente en torno a la calle Mayor, siguiendo el eje viario, que comunica Salas de los Infantes con Barbadillo de Herreros. 
BEZARES.

La pequeña localidad de Bezares es hoy un pueblo deshabitado. Sus últimos vecinos abandonaron sus casas durante el éxodo rural de las décadas de 1960-70, los cuales, ni siquiera convirtieron su antiguo pueblo en un lugar de veraneo. Por ello, la destrucción está a punto de acabar con los últimos restos de lo que fuera su caserío.

Bezares se halla encuadrado dentro del Valle de Valdelaguna, constituyendo la localidad más septentrional de la citada junta de municipios. Apenas disponemos de datos sobre su historia, de tal modo, que la primera referencia escrita la encontramos en el Becerro de las Behetrías, donde aparece nombrada como Veçares, quedando incluida dentro del señorío de D. Pedro Fernández de Velasco ${ }^{962}$.

Aun así, los diferentes estudios realizados sobre este pueblo lo encuadran, primero en el pequeño alfoz de Barbadillo del Pez ${ }^{963}$, para pasar, más tarde, en el siglo XI, a formar parte del gran alfoz de Lara. A partir de este momento, y hasta el inicio de la Edad Moderna, queda incluido en la Merindad Menor de Santo Domingo de Silos ${ }^{964}$, como el resto de los pueblos del Valle de Valdelaguna.

962 G. MARTÍNEZ DÍEZ: Libro Becerro de las Behetrías. Estudio y texto crítico. León, Centro de Estudios e Investigación San Isidoro. Caja de Ahorros y Monte de Piedad. Archivo Histórico Diocesano. 1981. (pp.614).

963 G. MARTÍNEZ DÍEZ: Pueblos y alfoces burgaleses de la repoblación. Valladolid, Junta de Castilla y León. Consejería de Educación y Cultura. 1997. (pp. 196)

964 C. ESTEPA DÍEZ: "Estructura de poder en Castilla (siglos XII - XIII). El poder señorial en las merindades burgalesas. En III Jornadas burgalesas de Historia (3 1991). Burgos en la Plena Edad Media. Burgos, Asociación Provincial de Libreros de Burgos. 1994. (pp. 245 - 294). 
Durante la Edad Moderna, vemos como cambia su condición de señorío solariego, para convertirse en realengo, formando parte, como ya hemos indicado, del Real Valle y Villa de Valdelaguna. En el plano fiscal, sin embargo, queda enmarcada, como el resto del valle, dentro del partido de las Tierras del Condestable, que se incluye en la Provincia de Burgos ${ }^{965}$. Más tarde, ya en el siglo XVIII, pasa a formar parte, junto con las demás localidades del valle, del partido de Aranda ${ }^{966}$.

En cuanto a la administración eclesiástica, su parroquia dependió siempre de la Diócesis de Burgos, desde el momento en el que fue restituido este obispado ${ }^{967}$.

Su población siempre fue escasa, si bien, apenas contamos con datos concretos, que nos permitan trazar una línea evolutiva a lo largo de todo este período, pues al estar incluida dentro del Valle de Valdelaguna, los resultados de los distintos censos rara vez llegaban a aparecer individualizados. Aun así, a finales del siglo XVI, según el censo de los obispos, contaba con 14 vecinos $^{968}$. Esta cifra queda reducida a tan solo 10 vecinos en 1631, en el llamado censo de la sal ${ }^{969}$. Los siguientes datos pertenecen ya al siglo XVIII, momento en el que, según parece, esta localidad alcanza uno de sus épocas de esplendor, con 29 vecinos, contabilizados a mediados de la centuria por el Catastro del Marqués de Ensenada ${ }^{970}$, y 101 habitantes a finales de siglo, según el censo de Floridablanca $^{971}$. Según estos últimos censos, además, más de la mitad de estos habitantes ostentaban la condición de hidalgos.

\footnotetext{
965 G. MARTÍNEZ DÍEZ: Génesis histórica de la provincia de Burgos y sus divisiones administrativas. Burgos, Aldecoa. 1983.

966 Ibídem. ADPBU. CE. 297. RESPUESTAS GENERALES. Bezares, 5 - septiembre - 1753.

967 L. SERRANO El obispado de Burgos y Castilla primitiva. Desde el siglo V al XIII. Madrid. 1935.

968 T. GONZÁLEZ: Censo de población de las provincias y partidos de la Corona de Castilla en el siglo XVI... Ed. Facsímil. Madrid, Imprenta Real. 1829.

969 AGS. Dirección General del Tesoro, inventario 24. Leg. 1168 - 2.

970 Vecindario de Ensenada 1759. Vol. I. Madrid, Centro de Gestión Catastral y Cooperación Tributaria: Tabapress. D. L. 1991.

971 INE: Censo de 1787. "Floridablanca”. Madrid. INE. 1989.
} 
La mayor parte de estos vecinos se dedicaban a la ganadería trashumante, lo que hacía que durante una buena parte del año su población quedara diezmada, como bien se apunta en algunas reuniones del concejo ${ }^{972}$. Esta condición de la mayoría de sus vecinos permitía a Bezares formar parte de la Cuadrilla de San Pedro de la Vega, integrada, a su vez, en el Honrado Consejo de la Mesta.

El pueblo en sí, se encuentra asentado sobre las faldas de una suave y húmeda ladera, orientada sorprendentemente hacia el norte. Esto convierte a esta localidad, según palabras de P. Madoz, en un lugar frío donde baten todos los vientos, especialmente el norte ${ }^{973}$.

Su caserío, aunque prácticamente derruido en su totalidad, todavía conserva elementos, que nos permiten identificar las características propias de un núcleo típico de la Sierra de la Demanda, con su estructura compacta, de edificios muy juntos, construidos mayoritariamente en piedra, y dispuestos sin un orden preciso. Dentro de los escasos edificios que todavía se mantienen en pie, destaca de modo especial la iglesia parroquial.

Iglesia de Santa Lucía.

La iglesia de Bezares, dedicada a Santa Lucía, se ubica en la parte oriental del pueblo, a escasa distancia de las primeras casas del núcleo urbano, asentando su fábrica, como el resto de la localidad, sobre las faldas de una suave ladera. Su planta no presenta ningún tipo de complicación, mostrando una estructura de una sola nave, de trazado rectangular, con cabecera igualmente rectangular en el extremo oriental, sobre cuyo lado norte se añade la sacristía. Todo el conjunto queda incluido en un amplio

\footnotetext{
972 "Que son todos los vecinos que al presenta ay en él por estar como están los demás ausentes en la provincia de Extremadura" AHPBU. PN. Valle de Valdelaguna. Leg. 3257/2, fols. 164 - 164 vº Manuel Gil de la Cuesta. Bezares, 18 - marzo - 1748.

973 P. MADOZ: Diccionario geográfico - estadístico - histórico de España y sus posesiones de Ultramar. Valladolid, Ámbito D.L. 1984. (pp. 83).
} 
rectángulo, lo que provoca un manifiesto desplazamiento de la capilla mayor sobre el eje central, trazado por la nave.

Todo el edificio se encuentra realizado en piedra, predominando en sus muros el sillarejo de gran calibre, que se refuerza en las esquinas y marcos de los vanos, con sillares de mejor labra. Su imagen exterior está concebida mediante un amplio cuerpo prismático de escaso desarrollo en altura, de tal modo, que el único elemento que rompe mínimamente esta estricta sensación sobriedad lo encontramos en la espadaña, asentada sobre el muro de los pies. Esta espadaña está articulada en dos cuerpos, de anchura y altura decrecientes, separados por líneas de imposta planas y escoltados por pequeños aletones triangulares, que rematan en los extremos con pináculos de bola. Dos vanos con arco de medio punto se abren sobre el nivel inferior, por uno solo de menor tamaño, en el superior, el cual se remata con un frontón recto partido, en cuyo tímpano incorpora un pequeño neto, sobre el que debía existir una cruz.

La puerta de acceso al interior se abre sobre el muro meridional de la nave, y está formada por un sencillo arco de medio punto, sin ningún tipo de ornamentación. Junto a ella aparecen también dos ventanas, de trazado rectangular y dintel plano, ligeramente abocinadas a ambos lados, las cuales aparecen situadas sobre el muro de los pies, y en la parte meridional del presbiterio.

Esta misma sencillez se repite en la imagen interna, donde desarrolla un amplio espacio de ámbito único en la nave, a la cual se abre la capilla mayor, mediante un tosco arco escarzano de intradós cajeado, dispuesto sobre pilastras de fuste igualmente cajeado y remate formado por airosa cornisa. Dentro de esta nave, que se cubre con sencilla techumbre de madera dispuesta a dos aguas, sobre armadura de tipo parhilera, únicamente destaca el coro, ubicado en la zona de los pies, el cual está formado por una simple tarima de madera, delimitada por una barandilla, que se eleva levemente sobre el nivel del suelo. La capilla mayor, por su parte, cuenta con una bóveda de cañón muy rebajada, con amplios lunetos a los lados. Desde el interior de esta capilla se puede 


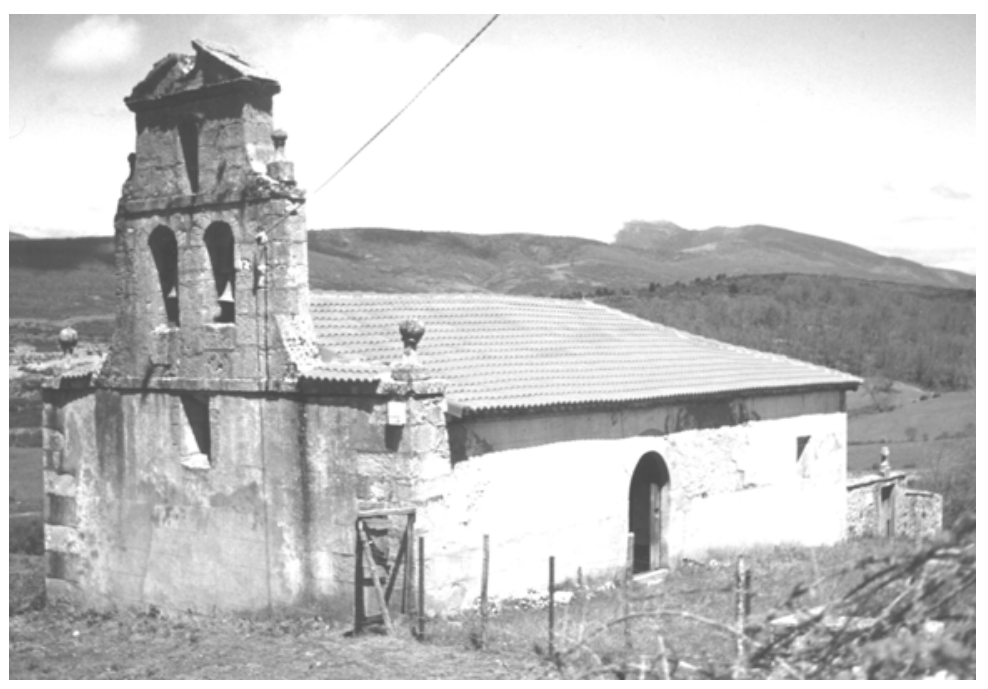

BEZARES. Iglesia de Santa Lucía.

acceder a la sacristía, a través de una pequeña puerta de dintel plano, practicada sobre el muro septentrional.

Un edificio, en definitiva, de proporciones sumamente modestas y escasas pretensiones artísticas, en el que destaca, por encima de todo, su marcado carácter funcional. Su fábrica actual, levantada con unos recursos económicos muy limitados, es el resultado de dos fases constructivas fundamentales, las cuales tienen lugar en los años finales del siglo XVII, y en el período central del XVIII. Durante el desarrollo de las mismas, se consuma la eliminación total del edificio anterior, desapareciendo, por lo tanto, todo vestigio de sus fases anteriores. Por ello, sólo la presencia de un bello ejemplo de pila bautismal de estilo románico ${ }^{974}$, es capaz de hablarnos de la más que probable existencia de un templo correspondiente a esta época.

974 G. BILBAO LÓPEZ: Iconografía de las pilas bautismales del románico castellano: Burgos y Palencia. Burgos, Editorial la Olmeda. 1996. 
La primera de estas dos importantes fases constructivas, que hemos determinado, se produce, como decimos, en los últimos años del siglo XVII. No tenemos datos precisos sobre la realización de esta obra, sin embargo, pensamos que durante este momento debió llevarse a cabo la construcción de la mayor parte de la estructura, que compone el edificio actual. Así, en este momento, no sólo se construiría la cabecera, sino también la parte correspondiente a la nave. Los pagos por este proyecto comenzaron a realizarse en 1695, si bien, la delicada situación económica en la que vivía esta parroquia, hizo que únicamente se comprometiera apagar 83.374 maravedís, los cuales, además, entregó, según dice, cuando tuviere el dinero necesario $^{975}$. Un esfuerzo, en cualquier caso, ciertamente importante para esta parroquia, a pesar de la modestia del proyecto. El resto correría a cargo de la feligresía.

La segunda fase tiene lugar en los años centrales del siglo XVIII, y durante ella se acomete principalmente trabajos encaminados a complementar y rematar el edificio heredado. Dentro de ello, la construcción de la espadaña y remodelación de toda la parte de los pies del templo, constituyó, sin duda, la parte más importante del proyecto. Esta obra fue encargada por el visitador del Arzobispado de Burgos de 1755, D. Juan de Tobías y Zuazo, el cual indica que:

"Y en lo demás se halla la iglesia sumamente indecente con peligro de ruina en mucha parte y sin espadaña para las campanas, lo que ha dado motivo a que se trate de su reparación a cuio efecto se manifestó a su merced la declaración y abanzo practicada por un maestro. Y verdaderamente es indispensable el reparar o hacer de nuevo el paredón que está a lo último de la iglesia y justo al qual se halla oi las campanas; el meter una viga en el medio en lugar de la que ahora atraviesa y ha hecho quiebra; el hacer una espadaña con hueco para las campanas; el componer y blanquear a lo menos el sitio de el tabernáculo de la capilla maior

\footnotetext{
975 AGDBU. LP. Bezares, parroquia de Santa Lucía. LF. (1685 - 1729). (fols. 20 - 21). Cuentas del año 1695. Bezares, 28 - diciembre - 1695.
} 
formando algún género de arco y poniendo alguna ventana o tronera que la da luz"976.

Para su realización, esta iglesia, no sólo tiene que emplear todos sus recursos disponibles (que no eran muchos), sino también debe elaborar un plan, que permita aumentar los ingresos y abaratar lo más posible los costes de la obra. Para lo primero, no duda en apelar a la generosidad de los fieles, y muy especialmente a la de los llevadores de diezmos, en concreto a la iglesia Metropolitana, y al Duque de Frías, a los cuales advierte de un posible secuestro de estos recursos, en caso de no cederlos voluntariamente $^{977}$. Para lo segundo, se pide la colaboración de los vecinos en la ejecución de determinados trabajos, al mismo tiempo que se disponen los materiales resultantes de la demolición de las ermitas de San Justo y San Pastor, y Santa Marina ${ }^{978}$.

Las obras se realizaron con absoluta inmediatez, nada más conocerse el mandato del visitador diocesano, desembolsando esta parroquia finalmente un total de 1.143 reales, repartidos en diferentes pagos. Durante el desarrollo de los trabajos, el Santísimo Sacramente tuvo que ser trasladado a la vecina localidad de Barbadillo de Herreros ${ }^{979}$.

La historia de este templo culmina, en cuanto a sus aspectos constructivos se refiere, con la incorporación del coro y del nuevo retablo para el altar mayor. La construcción del coro tiene lugar en 1775, pagando esta fábrica un total de 396 reales $^{980}$. El retablo, por su parte, se realiza cinco años más tarde, con un coste de 900 reales, de

\footnotetext{
976 Ibídem. LF. (1725 - 1771). (fols. 37 - 39vº). Visita realizada a la parroquia de Santa Lucía de Bezares en 1755, por D. Juan de Tobía y Zuazo, canónigo de la catedral. Canales a 1 de agosto de 1755. 977 Ibídem.

978 Se trata de dos ermitas ubicadas dentro del término municipal de este pueblo, cuyo mal estado de conservación aconsejaba su demolición. Finalmente, sin embargo, sólo fueron empleados los materiales de una de ellas, si bien, no se especifica cual, lo que nos lleva a sospechar que ambas corrieron la misma suerte. AGDBU. LP. Bezares, parroquia de Santa Lucía. LF. (1725 - 1771). (fols. 43 - 44). Visita realizada a la parroquia de Santa Lucía de Bezares en 1757, por D. Andrés Pérez Bracho, canónigo de la catedral de Burgos. Huerta de Arriba, 29 - julio - 1757.

979 Ibídem. (fols. 41 - 42 vº). Cuentas de los años 1755 - 56. Bezares, 30 - septiembre - 1756.
} 
los cuales la iglesia sólo tuvo que pagar 600 reales, pues los 300 restantes fueron aportados por los feligreses, en concepto de limosna ${ }^{981}$.

A partir de aquí, únicamente registramos trabajos relacionados con el mantenimiento del edificio, los cuales se centraron principalmente en las cubiertas ${ }^{982}$ y el suelo, este último muy castigado por las humedades ${ }^{983}$.

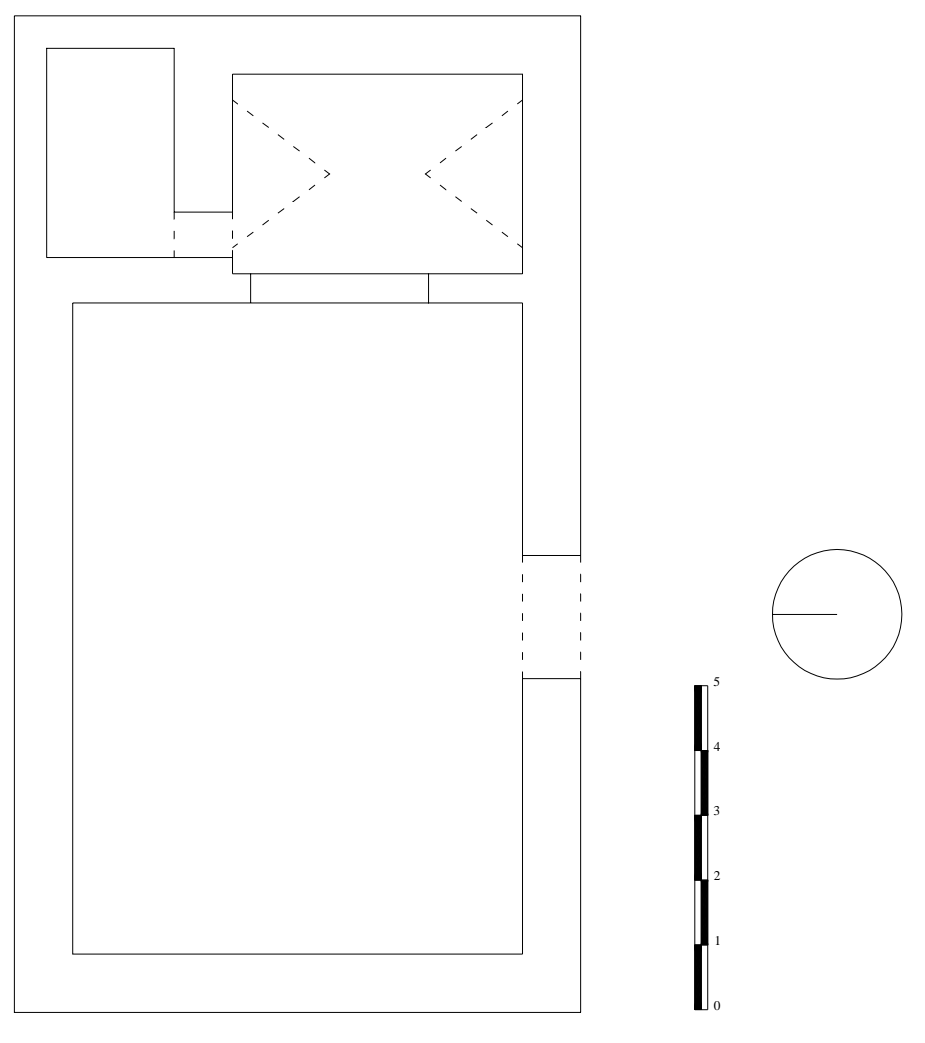

BEZARES. Iglesia de Santa I.uría Planta

980 Ibídem. LF. (1772 - 1832). (hojas 18 - 23). Cuentas del año 1775. Bezares, 26 - septiembre - 1776.

981 Ibídem. (hojas 37 - 40). Cuentas del año 1780. Bezares, 13 - septiembre - 1781.

982 Ibídem. (hojas 53 - 56). Cuentas del año 1785. Bezares, 12 - septiembre - 1786.

983 Ibídem. (hojas 89 - 93). Cuentas del año 1791. Bezares, 3 - septiembre - 1792; Ibídem. (hojas 133 142). Visita realizada a la parroquia de Santa Lucía en Bezares en 1803, por D. Manuel Cid Monroy, arzobispo de Burgos. Canales, 16 - septiembre - 1803; Ibídem. (hojas 146 - 148). Cuentas de 1803. Bezares, 29 - septiembre - 1804. 
Ermitas.

La escasa información de que disponemos para el conocimiento de la historia de este pueblo, apenas nos permite averiguar el número preciso de ermitas, que aquí existieron. Aun así, hemos conseguido recabar información de tres de ellas, a las cuales debemos sumar también las dedicadas a San Matías y a los Santos Mártires, cuya titularidad compartía el concejo de este pueblo con el de Barbadillo de Herreros ${ }^{984}$. Estas tres ermitas se encontraban dedicadas a San Justo y San Pastor, Santa Marina y San Miguel $^{985}$.

Sobre la primera de ellas se dice aver sido anteriormente parroquia ${ }^{986}$, lo cual nos obliga a vincular su origen con el despoblado de Villanueva de los Ferreros, desaparecido posiblemente a finales del siglo XIII o comienzos del XIV ${ }^{987}$. Se encontraba situada, por lo tanto, a escasos dos kilómetros del pueblo de Bezares, en dirección norte. De su estructura, sin embargo, nada se ha salvado (al menos en su lugar original), pues como ya tuvimos oportunidad de ver, sus restos, junto con los de la ermita de Santa Marina, fueron empleados en la construcción de la espadaña de la iglesia.

El origen y ubicación de esta segunda ermita resultan bastante más oscuros, pues apenas tenemos datos sobre ella. Debemos suponer, no obstante, que, al igual que la de San Justo y San Pastor, esta ermita se encontraba situada en un punto relativamente alejado del pueblo, pues en el momento de su demolición - para utilizar los materiales en la obra de la iglesia - uno de los principales problemas que se presenta es el traslado

\footnotetext{
984 Ver capítulo de Barbadillo de Herreros.

985 AGDBU. LP. Bezares, parroquia de Santa Lucía. LF. (1685 - 1729). (fols. 39 vo -41 vo). Visita realizada a la parroquia de Santa Lucía de Bezares en 1717, por D. Manuel Francisco Navarrete Ladrón de Guevara, Arzobispo de Burgos. Bezares, 28 - marzo - 1707.

${ }^{986}$ Ibídem. (fols. 54 - 56). Visita realizada a la parroquia de Santa Lucía de Bezares en 1715, por D. Alonso de Cossio Barreda. Barbadillo de Herreros, 5 - junio - 1715.

987 L. SERRANO: Cartulario de San Pedro de Arlanza. Madrid. Centro de Estudios Históricos. 1925. (pp. 276).
} 
de sus piedras hasta el pueblo. El final de sus días, por lo tanto, transcurrió de forma muy parecida a la anterior.

Sobre la tercera ermita, que hemos citado, dedicada a San Miguel, únicamente tenemos una serie de vagas referencias, las cuales, no sirven siquiera para precisar su emplazamiento exacto. La última mención que tenemos de ella nos la proporciona en 1718 el visitador del Arzobispado de Burgos, Fr. Ángel Benito ${ }^{988}$, tras la cual no volvemos a tener más noticias.

\section{Arquitectura civil.}

El núcleo urbano de Bezares, como hemos dicho, se encuentra prácticamente destruido en su totalidad, lo que hace que actualmente apenas podamos encontrar edificios dignos de interés. Aun así, a través de diferentes testimonios fotográficos, conservados de la época en la que todavía este pueblo se encontraba vivo, hemos podido constatar la existencia de algunos edificios, vinculados a la tipología de las casas solariegas, propias de los grandes propietarios de rebaños trashumantes. Dentro de ellas, destacaba especialmente la situada en la calle Mayor $n^{o}$ 22, la cual mostraba una magnífica portada con arco de medio punto de rosca casetonada, característico de los ejemplos de este tipo de casas, construidas en la zona durante el siglo XVIII. Un ejemplo más, lo encontramos en el $n^{o} 3$ de esta misma calle Mayor, cuya imagen ofrecía la característica estructura cúbica, de este tipo de edificios, con muros completamente planos, rematados por un volado alero, en el que las cabezas de las vigas aparecían decoradas con una bella talla. 


\section{CANICOSA DE LA SIERRA.}

La villa de Canicosa de la Sierra se halla ubicada en la vertiente meridional de la Sierra de Neila, dentro de la zona conocida como comarca de pinares. Su economía, por lo tanto, se encuentra directamente vinculada al aprovechamiento de los recursos forestales, que pueblan su término municipal, lo que hace de ella un importante productor de madera, un destacado representante de la Real Cabaña de Carreteros, y un centro ciertamente significativo de artesanía, ligado al mundo de la madera.

El origen de esta localidad, sin duda, se encuentra en los asentamientos realizados en la zona durante el período, que se extiende entre finales del siglo IX y el siglo X. No obstante, las primeras referencias documentales no aparecen hasta el siglo XI (1068) ${ }^{989}$. Durante este período esta localidad queda encuadrada dentro del alfoz de Lara $^{990}$, pasando más tarde a formar parte de la Merindad Menor de Santo Domingo de Silos $^{991}$.

988 AGDBU. LP. Bezares, parroquia de Santa Lucía. LF. (1685 - 1729). (fols.59 vo - 62 vo). Visita pastoral realizada a la parroquia de Santa Lucía de Bezares en 1718, por Fr. Ángel Benito, obispo auxiliar electo. Barbadillo de Herreros, 20 - septiembre - 1718.

989 L. SERRANO: El obispado de Burgos y Castilla primitiva. Desde el siglo V al XIII. Madrid. Centro de Estudios Históricos. 1935. Tomo I (pp. 24).

990 G. MARTÍNEZ DÍEZ: Pueblos y alfoces burgaleses de la repoblación. Valladolid, Junta de Castilla y León. Consejería de Educación y Cultura. 1997. (pp. 172).

991 Ibídem. Libro Becerro de las Behetrías. Estudio y texto crítico. León, Centro de Estudios e Investigación San Isidoro. Caja de Ahorros y Monte de Piedad. Archivo Histórico Diocesano. 1981. (pp. 621). C. ESTEPA DÍEZ: "Estructura de poder en Castilla (siglos XII - XIII). El poder señorial en las merindades burgalesas. En III Jornadas burgalesas de Historia (3 1991). Burgos en la Plena Edad Media. Burgos, Asociación Provincial de Libreros de Burgos. 1994. (pp. 245 - 294). 
Ya en la Edad Moderna, en el plano fiscal, encontramos a Canicosa incluida dentro del Partido de las Tierras del Condestable, de la provincia de Burgos ${ }^{992}$, si bien, no parece que llegara a pertenecer nunca al señorío de los Duques de Frías. Bien al contrario, inicia la Edad Moderna como señorío de abadengo, dependiente del monasterio de San Pedro de Arlanza, bajo cuya jurisdicción había quedado encuadrada desde el 23-VIII-1213, por permuta con el rey Alfonso VIII, que pretendía dotar al Hospital del Rey de Burgos con los terrenos que este monasterio tenía situados en las cercanías de esta ciudad ${ }^{993}$. Más adelante, sin embargo, logra recuperar su condición de realengo. Este cambio, aunque no contamos con datos concretos, que nos permitan situar el momento exacto en el que se produce, sospechamos que debió ocurrir en pleno siglo XVI, dentro de la política de enajenación de bienes eclesiásticos de los primeros Austrias $^{994}$. Al final de la Edad Moderna, con la reforma borbónica, Canicosa de la Sierra queda encuadrada dentro del partido de Aranda de Duero ${ }^{995}$.

Finalmente, en el ámbito eclesiástico, vemos cómo su única parroquia queda incluida, desde 1136, tras el Concilio de Burgos, dentro de la Diócesis de Osma ${ }^{996}$. Su incorporación a la Diócesis de Burgos, se produce ya a mediados del siglo $\mathrm{XX}^{997}$.

Aparentemente Canicosa contó siempre con un volumen de población por encima de la media general de los pueblos de la zona, lo que hace que debamos

992 G. MARTÍNEZ DÍEZ: Génesis histórica de la provincia de Burgos y sus divisiones administrativas. Burgos, Aldecoa. 1983.

993 L. SERRANO: Cartulario de San Pedro de Arlanza. Madrid, Centro de Estudios Históricos, 1925. (pp.252 - 254, 257 - 261).

994 Ver capítulo: Devenir histórico. A. DOMÍNGUEZ ORTIZ: Instituciones y sociedad en la España de los Austrias ... ob. cit. S. DE MOXÓ: La desamortización eclesiástica del Siglo XVI. En AHDE. N ${ }^{\circ}$ XXX. 1961. R. CARANDE: Carlos V y sus banqueros. Tomo II. Ob. cit. (pp. 412 y ss.). M. MODESTO: La Hacienda Real de Castilla en el reinado de Felipe II. Roma, 1963. N. LÓPEZ MARTÍNEZ: La desamortización de bienes eclesiásticos en 1574. En Hispania, nº 86.

995 G. MARTÍNEZ DÍEZ: Génesis histórica de la provincia de Burgos y sus divisiones administrativas. Burgos, Aldecoa. 1983. INE. Censo de 1787. “Floridablanca”. Madrid. INE. 1989.

996 L. SERRANO: El obispado de Burgos y Castilla primitiva. Desde el siglo V al XIII. Madrid. 1935. Tomo I (pp. 333 - 337, 374 - 378, 414 - 418). 
considerarlo uno de los núcleos más importantes. Los datos de que disponemos nos muestran, además, unos niveles bastante regulares, a lo largo de todo el período estudiado, experimentando, sorprendentemente un ligero descenso en la etapa final. Por el contrario, durante el siglo XVII, no parece que se produzcan descensos bruscos, como sí sucede en general, dentro de ámbito de la provincia de Burgos. Los primeros datos que poseemos, en este sentido, corresponden al censo de 1541, donde se da una cifra de tan solo 61 vecinos, que resulta sorprendentemente baja, lo que nos hace dudar de su fiabilidad. Más exactos parecen los datos que arrojan el censo de los obispos, de 158487, y el censo de 1591, en los cuales encontramos unos valores de 126 vecinos $^{998}$ y 146 respectivamente ${ }^{999}$. Estos valores se mantienen sin grandes cambios durante el primer tramo del siglo XVII, tal y como nos demuestra el llamado censo de la sal, de 1631, que nos arroja un resultado de 130 vecinos $^{1000}$. Finalmente, a mediados del siglo XVIII, el Catastro del Marqués de la Ensenada nos indica, que en este momento existían en Canicosa uno total de $111^{\prime} 5$ vecinos $^{1001}$, que se convierten en 424 habitantes en 1787 , en el censo de Floridablanca ${ }^{1002}$.

La economía de estos habitantes, a lo largo de toda la Edad Moderna, se encuentra vinculada, como hemos dicho, al aprovechamiento de los abundantes recursos forestales de su término municipal. En torno a ellos, se crea una estructura dedicada a la exportación de madera sin elaborar, y otros productos artesanales, como taburetes, bancos y gamellas, los cuales eran transportados y vendidos por ellos mismos en diferentes comarcas, mediante una nutrida flota de carretas. Dentro de ellas destacan especialmente las denominadas de puerto a puerto, dedicadas a viajes de larga distancia, en los que no sólo transportaban productos autóctonos, sino de todo tipo. A través de las

\footnotetext{
997 J. CIDAD PÉREZ: Historia de la Diócesis de Burgos. Burgos. Imprenta Monte Carmelo. 1985.

998 T. GONZÁLEZ: Censo de población de las provincias y partidos de la Corona de Castilla en el siglo XVI... Ed. Facsímil. Madrid, Imprenta Real. 1829.

999 Censo de Castilla de 1591. Vecindario. Madrid, Instituto Nacional de Estadística. 1984.

1000 AGS. Dirección General del Tesoro, inventario 24. Leg. 1168 - 2.

1001 Vecindario de Ensenada 1759. Vol. I. Madrid, Centro de Gestión Catastral y Cooperación Tributaria: Tabapress. D. L. 1991.

1002 INE. Censo de 1787. “Floridablanca”. Madrid. INE. 1989.
} 
Respuestas Generales del Catastro del Marqués de Ensenada, comprobamos cómo a mediados del siglo XVIII, prácticamente toda la población de esta localidad se hallaba vinculada, de un modo u otro, en estas actividades ${ }^{1003}$. La agricultura, por el contrario, prácticamente resulta inexistente ${ }^{1004}$.

Su núcleo urbano se halla bastante extendido, repartido en dos barrios claramente diferenciados, situados uno en la parte alta, y el otro en la parte más baja. Uno de los elementos que sirve de unión entre uno y otro, lo constituye la iglesia parroquial, la cual, al mismo tiempo se convierte en uno de los edificios más representativos del pueblo.

\section{Iglesia de San Esteban.}

La iglesia de Canicosa de la Sierra, dedicada a San Esteban Protomártir, se encuentra ubicada, como decimos, en la parte central del pueblo, sirviendo de nexo entre los dos barrios, que componen su caserío. Esto hace que deba asentarse sobre una superficie de marcada pendiente, lo cual no afecta al edificio en sí, que se levanta, en su mayor parte, sobre suelo rocoso, pero sí al atrio que lo circunda. Este atrio está formado por un potente muro de piedra, que actúa como auténtico elemento de contención, con el cual se crea el suelo adyacente al templo.

La fábrica actual de este edificio corresponde al segundo cuarto del siglo XVIII, tal y como ya vimos en su momento, cuando analizamos las formas propias de este período. No obstante, parece apropiado recordar algunos de sus aspectos más característicos. Vemos, por lo tanto, que se trata de uno de los edificios religiosos más grandes de la comarca, a lo cual debemos sumar también una extrema sencillez de formas, afianzada, en este caso, por una total desnudez, en su imagen interior y exterior.

\footnotetext{
1003 ADPBU. CE 396. RESPUESTAS GENERALES. Canicosa de la Sierra, 12 - julio - 1753.

1004 J. LOPÉRRAEZ CORVALÁN: Descripción histórica del Obispado de Osma con el catálogo de sus prelados. Madrid. Ed. Facsímil. Turnes. 1978. T. I. (pp. 3).
} 
Este edificio se alza sobre una planta extremadamente irregular, formada por una sola nave de trazado trapezoidal, cuyos muros laterales se abren a medida que avanzamos hacia la parte delantera, donde se incorpora la cabecera, compuesta por un amplio presbiterio, de planta cuadrangular, y una pequeña capilla mayor de testero poligonal. Fuera de este núcleo principal del templo quedan la sacristía y la torre, las cuales se alinean sobre el muro meridional del presbiterio.

Toda la fábrica está realizada en piedra, mostrando en sus muros un magnífico trabajo de cantería, con sillares bien labrados y ensamblados. Estos muros quedan rematado por una cornisa de codillo, y sólo en la parte de la cabecera, cuentan con estribos de refuerzo. Con todo ello se consigue una imagen exterior dominada por la presencia de los dos poderosos volúmenes, de muros completamente planos, que se corresponden con las partes de la nave y la cabecera. Dentro de ellos, este último muestra una mayor altura, la cual apenas consigue sobrepasar la torre, consiguiendo con ello un cierto aire de estructura macrocéfala.

La torre, adosada sobre el muro meridional del presbiterio, presenta una esbelta estructura prismática, sobre planta cuadrangular, dentro de la cual no encontramos ningún tipo de separación entre cuerpos. Si encontramos, sin embargo, restos de antiguas troneras, en su parte central, correspondientes a las distintas fases de crecimiento que fue viviendo. Actualmente, los únicos vanos abiertos se encuentran en su parte superior, mostrando un sencillo trazado rectangular con arco de medio punto, cuya distribución se realiza de forma irregular, con dos vanos en la cara de poniente y uno solo en cada uno de los tres lados restantes.

Esta imagen externa se completa con las dos portadas con las que cuenta este edificio, las cuales aparecen dispuestas a ambos lados de la nave, ocupando la parte central de estos muros. Su presencia nos habla, inevitablemente de las fases, que fue viviendo este templo a lo largo de su historia. 
La más antigua queda orientada hacia el mediodía, y está formada por un sencillo arco apuntado, enmarcado por una doble moldura, de trazas góticas, sobre cuyo vértice se incorpora la talla de un hombre, sumamente esquematizado, que sin duda corresponde a un edificio anterior.

La segunda puerta está orientada hacia el norte, y su construcción debemos relacionarla con el proceso de remodelación, que sufre este edificio, durante el segundo cuarto del siglo XVIII, del cual surge el templo actual. De hecho, en la cartela, que aparece sobre el dintel de esta puerta, encontramos una inscripción en la que leemos la fecha de 1739. En ella, sin embargo, nos encontramos unos rasgos, que nos recuerdan mucho las estructuras y formas propias del mundo del manierismo de finales del Quinientos. Consta de una amplio vano adintelado, escoltado por pilastras pareadas de orden toscano a los lados, sobre las que se dispone un entablamento interrumpido en el centro, que da paso a un amplio frontón recto partido, en cuyo centro se incorpora una hornacina avenerada, rematada, igualmente, por un pequeño frontón, de similares características, con cruces sobre cada uno de sus vértices. A cada lado de esta hornacina, por su parte, se alzan dos esbeltos pináculos de bola, rematados en punta, cuya disposición se corresponde con las pilastras inferiores. Sobre el dintel de la puerta, por último, aparece una pequeña cartela, enmarcada con decoración de cueros recortados y plumas, en la que se incluye la fecha que señalábamos.

En el interior nos encontramos con el desarrollo de un amplio espacio de ámbito único profundamente desornamentado, en el que únicamente destaca el retablo, que decora su altar mayor. Se trata de un retablo de estilo churrigueresco, realizado en 1746, poco después de culminar la remodelación del templo, con el patrocinio de Juan de Marcos Domingo ${ }^{1005}$. Dentro de este espacio destaca la marcada personalidad de la cabecera, a la cual se accede a través de un poderoso arco toral de medio punto e intradós cajeado, dispuesto sobre una línea de imposta plana de escaso resalte, que se

1005 R. J. PAYO HERNANZ: El retablo en Burgos y su comarca durante los siglos XVII y XVIII. Burgos, Excma. Diputación Provincial de Burgos. 1997. (T. II, pp. 469). 


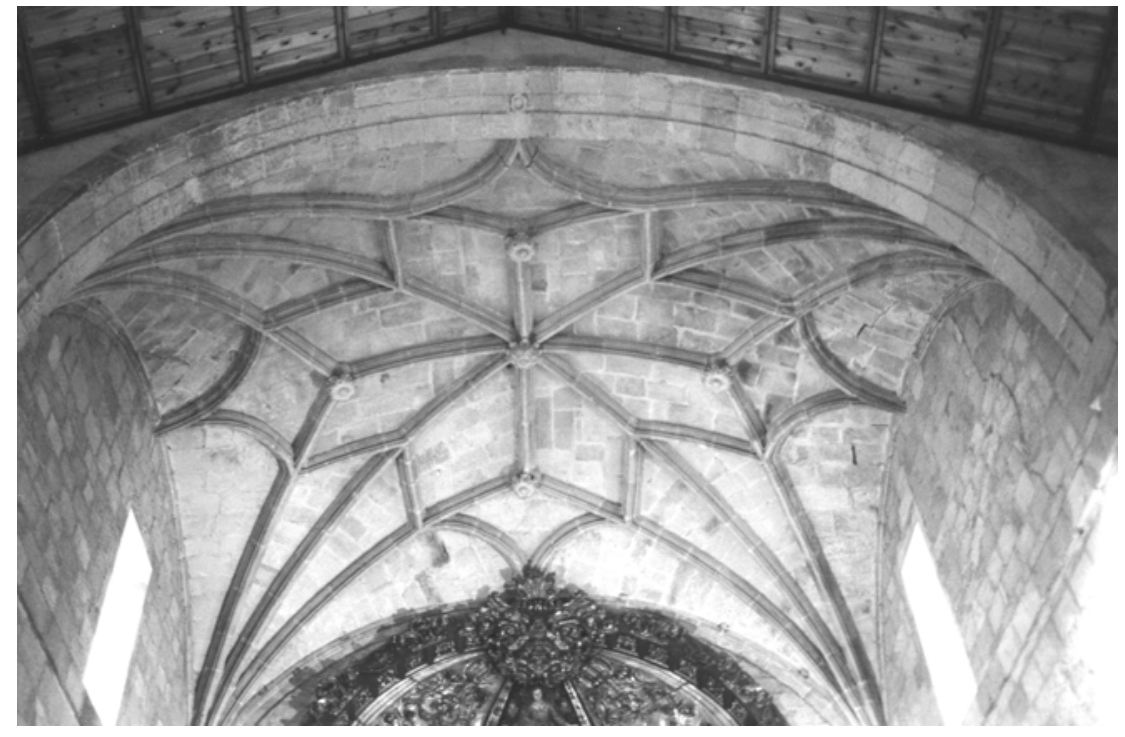

CANICOSA DE LA SIERR. Iglesia de San Esteban. Bóveda del presbiterio.

extiende a lo largo del muro, marcando el límite con el nivel de cubiertas. El suelo de esta cabecera se encuentra elevado sobre el nivel del resto del templo, sin embargo, el elemento más destacado lo encontramos en la cubierta, que cierra el amplio tramo del presbiterio, donde aparece una espectacular bóveda de crucería estrellada con terceletes y nervios secundarios rectos y curvos, con los que se dibuja una figura cruciforme, que nos recuerda mucho los diseños propios del gótico avanzado del siglo XVI. La nave, por su parte, se cierra con una sencilla techumbre a dos aguas, dispuesta, actualmente sobre una armadura metálica, que originalmente debió ser de madera.

La historia constructiva de este edificio resulta, como ya vimos, bastante difícil de reconstruir, pues nos son muchos los restos materiales, ni documentales, que nos informen con precisión sobre su pasado. Aun así, entre los restos materiales, conservados sobre la fachada meridional de la nave, encontramos elementos suficientes para saber, que la historia constructiva de este templo fue larga y complicada. Así, 
dentro de esta fachada encontramos restos de hasta tres niveles distintos de cornisa, los cuales nos hablan de otras tantas fases de crecimiento del edificio. Estas fases quedan igualmente reflejadas en los restos del antiguo pórtico, que cubría la entrada de la iglesia, y en la torre, con dos niveles de vanos diferentes. En el caso del pórtico, destacan especialmente los restos correspondientes a la fase más antigua, donde se conservan las ménsulas de los arcos diafragma, que soportaban este tejado. Una interpretación, por lo tanto, sumamente sencilla de una tipología, que perdió durante la Edad Moderna, el carácter monumental que había tenido durante los albores del románico, en la arquitectura de esta comarca.

Las fuentes documentales, sin embargo, no consiguen darnos la información necesaria, que nos permita precisar el momento exacto, en el que se producen cada una de estas fases constructivas. En este sentido, los únicos indicios que poseemos, sobre actuaciones de cierto porte, llevadas a cabo dentro de este edificio, los encontramos en una serie de anotaciones, fechadas en torno a los años finales de la década de 1620.

Entre ellas encontramos el pago de 53.506 maravedís, anotados en las cuentas de esta iglesia del año 1629, "por descargo de ayuda que da para facer la obra de la iglesia de esta dicha villa"1006. No obstante, bien debemos suponer que los maravedís pagados fueron mucho más, ya que en la visita del año siguiente, realizada por el canónigo de la catedral de Osma, Juan Sanz ${ }^{1007}$, se habla de la gran necesidad de dinero que tenía esta iglesia al quedar alcanzada, es decir, endeudada por la gran obra que se había realizado. Un mandato similar se repite en la visita realizada tres años más tarde, en el cual se apela a la generosidad de las ermitas de la localidad, pidiendo que: “aporten cantidades de dinero de sus cuentas quedándose con lo necesario para pagar el aceite y la cera, elaborando la escritura para que más tarde estas cantidades sean

\footnotetext{
1006 AGDBU. LP. Canicosa de la Sierra, parroquia de San Esteban. LF. Cuentas del año 1629. Canicosa de la Sierra, 2 - noviembre - 1629.

1007 Ibídem. Visita realizada por el Dr. Juan Sanz, canónigo magistral de la catedral de Osma, a la parroquia de San Esteban de Canicosa de la Sierra en el año de 1630. Canicosa de la Sierra, 29 - octubre $-1630$.
} 
devueltas»1008. Esta presunta fase constructiva debió terminar con los trabajos de enlosado, realizados en este año de $1633^{1009}$, y con la construcción de unas gradas para la capilla mayor ${ }^{1010}$.

El siglo XVII se cierra con un hecho, que tendrá mayores repercusiones espirituales que arquitectónicas, para esta iglesia. Nos referimos a la llegada de una reliquia de San Timoteo, que fue donada por D. Alfonso Pimentel, IX Duque de Benavente, "por la devoción que tiene a la iglesia de San Esteban de la villa de Canicosa de la Sierra de la Diócesis de Osma”. Esta reliquia se encontraba hasta el momento en el convento de Nuestra Señora del Carmen, en el Burgo de Osma, y su llegada a esta iglesia no propició la realización de obras de ningún tipo, pues de hecho, ni siquiera quedó dispuesta en el lugar que se había pensado para su custodia, como era el relicario del altar mayor, colocándola, por el contrario, en el retablo del altar de Nuestra Señora del Rosario ${ }^{1011}$.

Así, llegamos al siglo XVIII, momento en el que se consuma la renovación definitiva del templo, si bien, como ya indicábamos, apenas tenemos información sobre este proyecto, pese a ser una obra relativamente tardía. Los únicos datos concretos, que complementan la información arrojada por el análisis formal del edificio, los aporta la inscripción, que aparece sobre el dintel de la nueva portada, que ahora se construye, en la cual podemos leer lo siguiente: "O QVAM METVENDVS EST LOCVS ISTE VERENON HICALIVD NISI DOMVS DEI AETOR TACOLIA 1739”.

\footnotetext{
1008 Ibídem. Visita realizada a la parroquia de San Esteban de Canicosa de la Sierra en 1633.

1009 Ibídem. Cuentas de 1633: "42.177 maravedís que costó de losar la iglesia a el año pasado de 1633 que se hizo con licencia del tribunal como por ella consta”. Canicosa de la Sierra 1633.

1010 Ibídem. Visita realizada a la parroquia de San Esteban de Canicosa de la Sierra en 1636. Canicosa de la Sierra, 8 - abril - 1636 .

1011 AGDBU. LP. Canicosa de la Sierra, San Esteban. LF. (1677 - 1765). (fols. 37 v ${ }^{0}$ - 38). Acta de donación que se hace de la reliquia de San Timoteo correspondiente a un hueso de la nuca engastado en plata a la parroquia de San Esteban de Canicosa por parte del conde de Benavente. Canicosa de la Sierra, 28 - abril - 1682.
} 


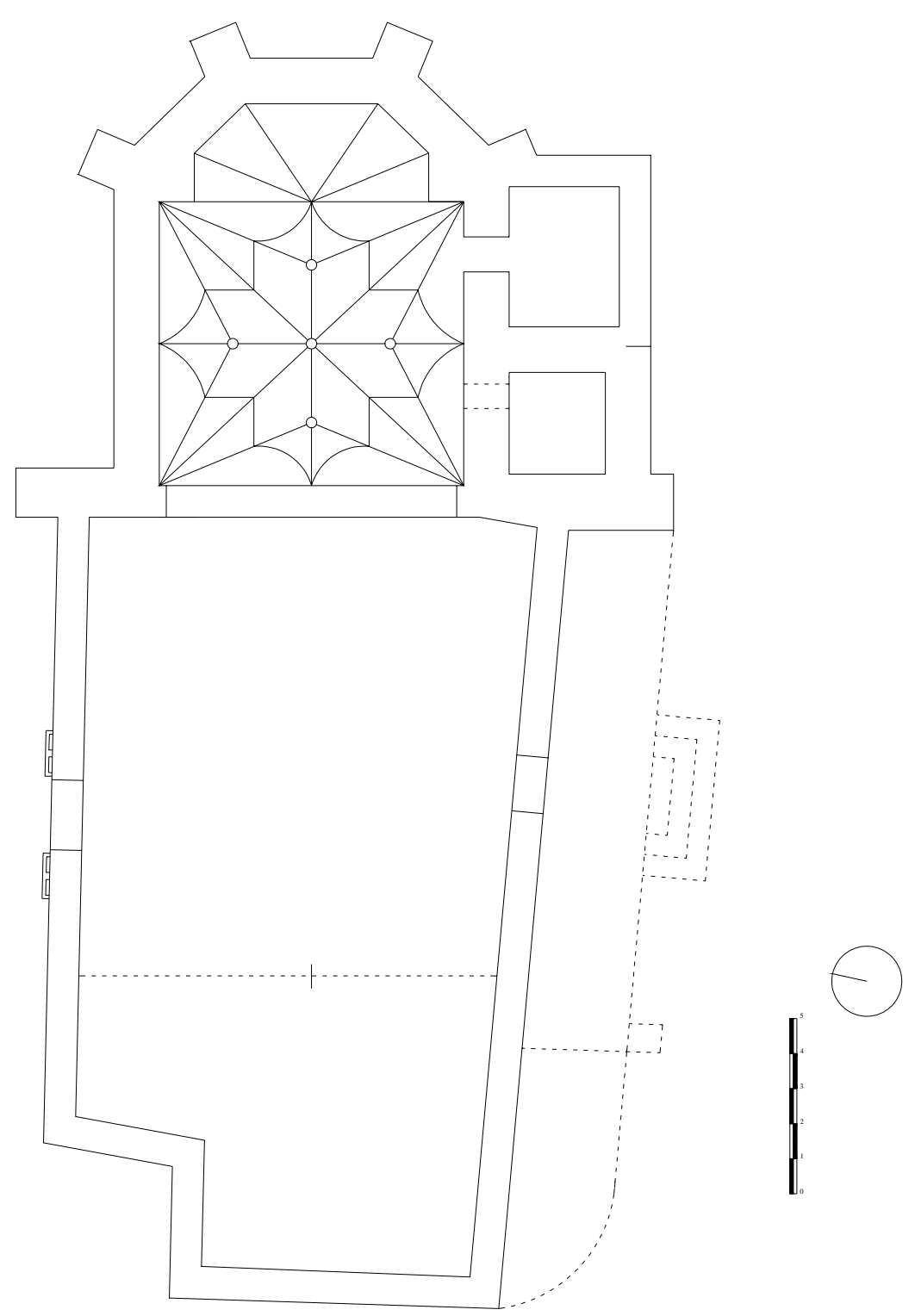

CANICOSA DE LA SIERRA.

Iglesia de San Esteban. Planta. 
Ermitas.

Canicosa de la Sierra contó tradicionalmente con cinco ermitas, dedicadas a Nuestra Señora del Carrascal, San Roque, la Vera Cruz, Santa Lucía y San Bartolomé. De ellas, las tres primeras han conseguido mantenerse en pie hasta nuestros días, conservando sus respectivos edificios en bastante buen estado.

\section{Nuestra Señora del Carrascal.}

Se encuentra ubicada en las proximidades del pueblo, a una distancia de dos tiros de bala, según el Diccionario de P. Madoz ${ }^{1012}$, en dirección oeste. Tradicionalmente fue la ermita más importante del pueblo, y uno de los centros devocionales más destacado de la comarca, convirtiendo su santuario en un destacado lugar de oración para los miembros de la Real Cabaña de Carreteros, y en receptor de continuas y cuantiosas donaciones. Esto permitió amasar un extenso patrimonio de dineros, tierras y ganados, que era necesario administrar con gran cuidado ${ }^{1013}$. Fiel testimonio de ello nos queda en sus Libros de Fábrica, cuyos registros se han conservado desde el año 1609 en adelante.

Su edificio se asiente sobre el lecho de una pequeña cárcava de suave ladera, orientada hacia naciente, y protegida por las colinas que rodean el pueblo. Presenta una estructura de nave única, de forma rectangular muy alargada, con cabecera de planta cuadrangular en su extremo oriental, sobre cuyo muro del testero se adosa una pequeña estancia, denominada capilla-camarín, que cumple también las funciones de sacristía.

Todo el edificio se encuentra realizado en piedra, con muros de sillería, alzados, en el caso de la cabecera, sobre un potente zócalo, que permite salvar la diferencia que marca el nivel del suelo sobre el que se asienta, y rematados por gruesa cornisa de papo

1012 P. MADOZ: Diccionario geográfico - estadístico - histórico de España y sus posesiones de Ultramar. Valladolid, Ámbito D.L. 1984. (pp.268).

${ }^{1013}$ AGDBU. LP. Canicosa de la Sierra, parroquia de San Esteban Protomártir. LF. Visita realizada a la parroquia de San Esteban de Canicosa de la Sierra en 1639, por el obispo de Osma D. Martín Carrillo Aloeche. Canicosa de la Sierra, 19 - septiembre - 1639. 


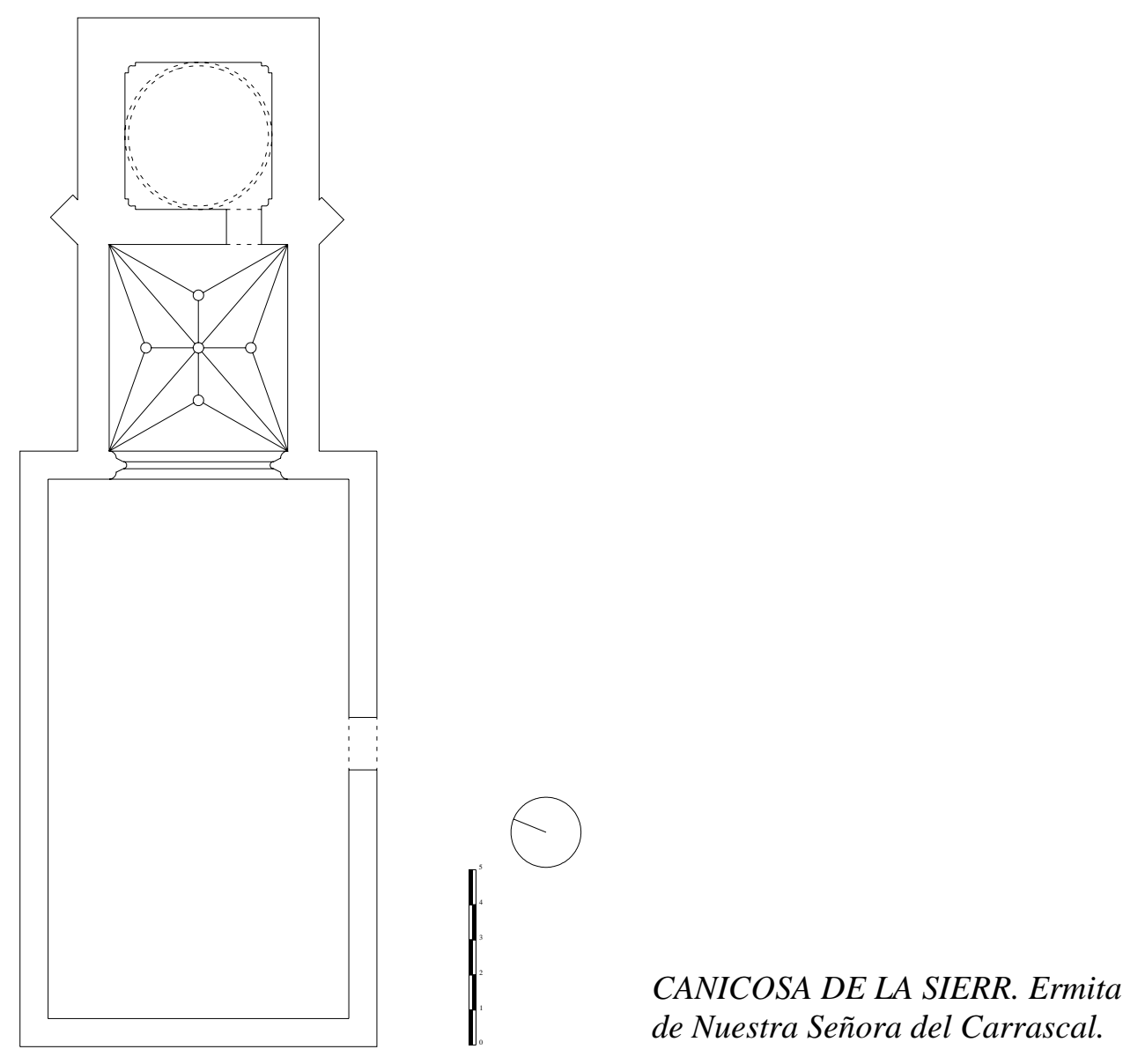

de paloma. Muestran, por lo tanto, una planitud prácticamente total, que solamente queda rota en la parte de la cabecera, con los restos de unos antiguos estribos, dispuestos en diagonal, sobre el muro del testero de la capilla mayor.

Cuenta con escaso vanos, los cuales se reparten por las diferentes fachadas del templo, exceptuando la cara norte, mostrando, al mismo tiempo, diferentes tipos de trazas, que nos hablan de su larga historia constructiva. Presenta así, ventanas de trazado rectangular enmarcadas con moldura plana con orejones, en la parte del camarín, un óculo con celosía de piedra, en el muro de la capilla mayor, y ventanas rectangulares con dintel plano y derrame hacia el exterior, en la zona de la nave. El acceso al interior 
se realiza a través de una sencilla puerta con arco de medio punto, dispuesta sobre la parte central del muro meridional de la nave.

En el interior, nos encontramos con una amplia nave, con coro alto de madera, dispuesto a los pies, y cubierta a dos aguas, sobre armadura de madera de tipo parhilera, en la que encontramos varios tirantes, sobre los que descansan pendolones. La cabecera, algo más estrecha que la nave, queda enmarcada entre dos pequeños retablos colaterales, accediendo a ella a través de un amplio arco apuntado de rosca poco moldurada, que se continúa a lo largo de las jambas, formando finos baquetones. Su interior se cierra con bóveda de crucería estrellada con terceletes. Finalmente, a través de una pequeña puerta, practicada sobre un lateral del muro del testero, llegamos al interior de la capilla-camarín, la cual nos presenta un pequeño espacio de muros encalados, cubierto con bóveda de media naranja, sobre anillo moldurado y pechinas. La principal particularidad de este espacio la encontramos en el pequeño vano que comunica con la capilla mayor, a través del cual se crea un efecto de transparente.

Este templo, como ya hemos dicho, constituye el resultado final de una larga secuencia constructiva, la cual se extiende prácticamente a lo largo de toda la Edad Moderna. Esta secuencia se inicia con una fase gótica, a la que pertenece la cabecera actual, destacando en ella los estribos, la cubierta abovedada del interior, y el arco toral, que enmarca su entrada. Todos estos elementos nos dan una cronología, que podemos situar aproximadamente entre los años finales del siglo $\mathrm{XV}$ y primeros momentos del XVI. La siguiente gran fase constructiva no se produce hasta los primeros momentos del siglo XVIII, momento en el que se realiza la completa renovación de la nave. Los encargados de su ejecución fueron el maestro de cantería Francisco de Maeda, el maestro de albañilería Antonio Mozal, y el maestro de carpintería Diego Tomé, los cuales percibieron por su trabajo un total de 6.700 reales. A esta cantidad debemos 
sumar además otros 400 reales más por los materiales empleados ${ }^{1014}$. Para afrontar estos gastos, y a pesar de la solvencia económica, sobradamente demostrada por parte de esta ermita, vemos como en este caso se produce una generosa ayuda por parte del concejo de la villa ${ }^{1015}$.

El último paso, dentro de esta secuencia, se produce pocos años más tarde, en 1728, con la construcción de la capilla-camarín. Se trata, como vimos, de una obra concebida con gran modestia, pero plenamente incluida dentro de la estética típicamente barroca, en la que el tratamiento de la luz se convierte en su principal propósito. Desconocemos, en este caso, los nombres de los artífices que participaron en su realización, a los cuales esta ermita entregó un total de 2.786 reales ${ }^{1016}$.

\section{Ermita de San Roque.}

Se ubica en la parte más elevada del pueblo, en la cumbre del cerro sobre cuya ladera se extiende el núcleo urbano de esta villa. El crecimiento del pueblo ha hecho, sin embargo, que hasta sus inmediaciones estén llegando algunas casas, lo que hace que se rompa el tradicional carácter aislado, que tuvo siempre este lugar.

El edificio que aquí nos encontramos presenta una estructura extremadamente sencilla, en la que se repite fielmente el modelo tradicional, que este tipo de templos nos suele ofrecer en la comarca. Es decir, planta de una sola nave de trazado rectangular, con cabecera plana y más estrecha en el extremo oriental. El edificio está realizado en piedra, con potentes muros de sillarejo y sillería, reforzados en las esquinas con piezas de mayor tamaño y mejor labra.

\footnotetext{
1014 AGDBU. LP. Canicosa de la Sierra, Nuestra Señora del Carrascal. L F. (1680 - 1743), (fols. 120 v 122). Cuentas del año 1716. Canicosa de la Sierra, 22 - enero - 1717; Ibídem. (fols. 123 - 128). Cuentas del año 1717. Canicosa de la Sierra, 1 - abril - 1718.

${ }^{1015}$ Ibídem.

1016 "Pagados a los maestros de cantería que fabricaron el camarín de Nuestra Señora del Carrascal". Ibídem. (fols. 147 v - 148). Cuentas del año 1728. Canicosa de la Sierra, 5 - marzo - 1729.
} 
CANICOSA DE LA SIERRA.

Ermita de San Roque.

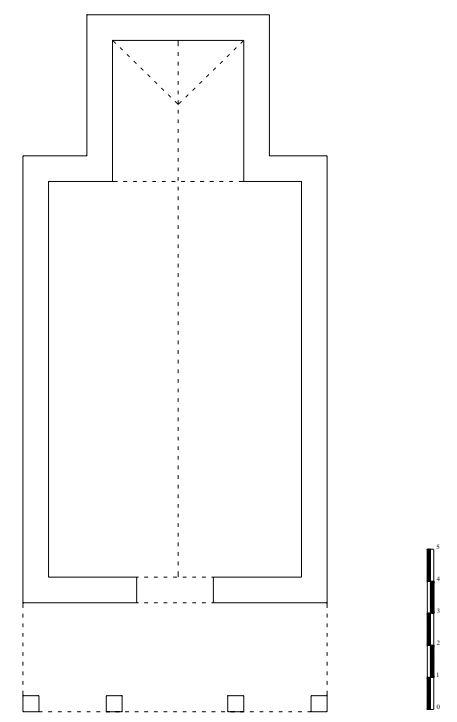

Al exterior, únicamente destaca el pequeño porche dispuesto a los pies, sobre la puerta de entrada, la cual está formada por un sencillo vano de dintel plano. En el interior, por su parte, su espacio de ámbito único, queda cubierto por una techumbre de madera dispuesta a cuatro aguas. Los únicos elementos, que podemos destacar, dentro de este espacio, son el retablo del altar mayor, y los dos colaterales, que lo acompañan. En el primero, encontramos las figuras del santo titular del templo, San Roque, escoltado por Santa Catalina y Santa Ana, y un Cristo crucificado en el remate. En el colateral del lado de la epístola, por su parte, aparecen las figuras de San Esteban, San Lorenzo y San Hipólito, mientras que en el del lado contrario están María Magdalena y una imagen del Santo Ángel de la Guarda.

Muy pocos datos, por lo demás, son los que podemos aportar sobre la historia de este templo, ya que carecemos de información sobre su origen o proceso constructivo. Su estructura arquitectónica, no obstante, tampoco presenta un especial interés artístico. 


\section{Ermita de la Vera Cruz.}

Esta ermita pertenecía a la antigua cofradía del mismo nombre, que existía en este pueblo. Como la mayor parte de las ermitas dedicadas a esta advocación, se encuentra situada dentro del propio casco urbano, en un emplazamiento ciertamente privilegiado, junto a la plaza Mayor, y a escasos metros de la iglesia parroquial.

El edificio en sí nos presenta una estructura simple, muy parecida a los dos ejemplos anteriores, con planta de una sola nave, de trazado rectangular, rematado en su extremo oriental con una capilla más estrecha de testero plano. Todo el edificio se encuentra realizado en piedra, con muros de sillería, elaborados mediante un cuidado trabajo de cantería, que rematan con una moldura de papo de paloma.

Al exterior, apenas encontramos elementos de interés, ofreciéndonos una estructura hermética de limpia volumetría, en la que apenas se abren vanos. Entre ellos encontramos la puerta de acceso al interior, abierta sobre el muro meridional de la nave, que remata con simple dintel plano.

Su interior se halla bastante alterado, ya que actualmente ha perdido su función de culto. Así, vemos cómo la mitad posterior de la nave se halla separada por un muro, creando aquí un salón, destinado a usos sociales. A pesar de todo, la parte delantera ha conseguido preservarse con más o menos fortuna, mostrándonos en la cubierta de la cabecera su elemento más interesante. Se trata de una cubierta en artesa invertida, en la que aparece una sencilla labor de artesonado de clara inspiración mudéjar. Una cubierta, por lo tanto, muy poco frecuente en la zona, que debemos relacionar con los otros ejemplos parecidos, que existen en las localidades de Terrazas y Vilviestre del Pinar. La nave, por su parte, cierra con una cubierta de madera a dos aguas, dispuesta sobre armadura de tipo parhilera.

También se conservan en el interior de esta ermita la estructura de los retablos que adornaban el altar mayor y los dos colaterales. Aunque actualmente han 


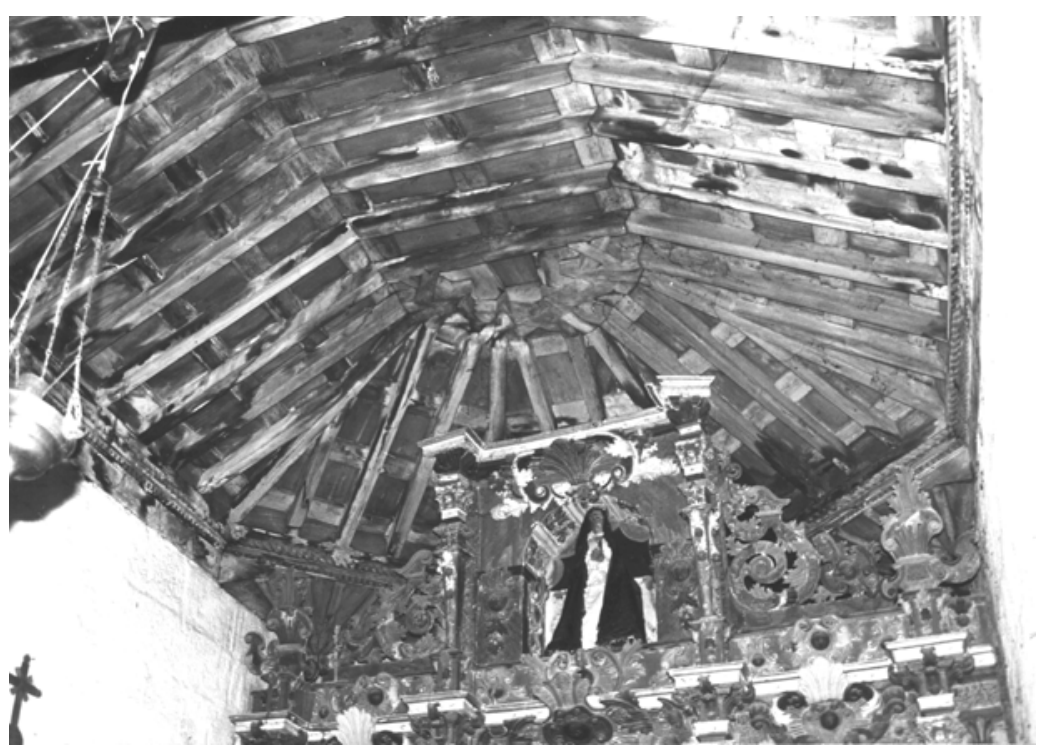

CANICOSA DE LA SIERR. Ermita de la Vera Cruz. Cubierta de la capilla mayor.

desaparecido las imágenes que portaban, sabemos que el altar mayor contaba con un Ecce Homo, un Cristo atado a la columna, y una imagen de Nuestra Señora de las Angustias. Los colaterales, por su parte, estaban dedicados a San Antonio y Santo Domingo, respectivamente.

Sobre la historia de este edificio, no es mucho más lo que podemos saber, sin embargo, los datos recabados a través de distintas fuentes, resultan suficientes para saber que el templo actual constituye el resultado final de dos fases constructivas diferentes, muy próximas entre sí, que tuvieron lugar durante el siglo XVII. La primera de ellas se produce en 1606, tal y como nos indica la inscripción conservada sobre el dintel de la puerta de entrada, y en ella debió realizarse una completa remodelación de la fábrica anterior. 
784 Arquitectura de la Edad Moderna en la sierra burgalesa.

La segunda se desarrolla en la década de 1640, y de ella nos dan cuenta los registros anotados en los libros de fábrica de esta cofradía. Tampoco conocemos mayores detalles sobre los trabajos ahora emprendidos, si bien, debemos suponer que de ellos surgió el edificio actual, pues después de esta fecha no volvemos a encontrar más noticias, que nos hablen de obras de este tipo. De este modo, el artesonado de la capilla mayor necesariamente tuvo que realizarse en este momento. El desembolso, que la ermita tuvo que realizar por esta obra, alcanzó los 2.622 reales $^{1017}$, los cuales fueron recaudados, en gran parte, a través del cobro de las deudas, que diferentes vecinos del pueblo habían contraído con ella ${ }^{1018}$.

Ermitas desaparecidas.

Como ya hemos indicado, contamos también con diferentes fuentes, que nos informan sobre la existencia de dos ermitas más, que no han llegado hasta nosotros, a las cuales podemos sumar incluso una tercer, de la que apenas tenemos datos.

Una de estas ermitas es la de San Bartolomé, la cual fue la última en desaparecer, sin embargo, esto no ha evitado que se haya perdido todo recuerdo de su existencia dentro de este pueblo. Así, ni la memoria de los más viejos del lugar, ni el estudio de la toponimia, nos han permitido despejar la duda de su ubicación. Por otra parte, contamos con datos suficientes, para suponer que su edificio no debía destacar, ni por sus proporciones, ni por su calidad artística. Contaba, eso sí, con un único retablo en su interior, presidido por la imagen titular del templo, a la cual acompañaban las figuras de San Blas, San Agustín y un Cristo crucificado en el remate.

\footnotetext{
${ }^{1017}$ AGDBU. LP. Cofradía de la Vera Cruz. (1595 - 1663). Cuentas tomadas a la cofradía de la Vera Cruz de Canicosa de la Sierra por el visitador del Obispado de Osma del año 1642, D. Mateo de Salas. Canicosa de la Sierra, 14 - junio - 1642.

1018 Uno de estos deudores fue Juan Chapero, conocido en el pueblo como el moreno, el cual, al parecer, venía adeudando a esta ermita la cantidad de 1.000 reales desde hacía más de 20 años. AGDBU. LP. Canicosa de la Sierra, Parroquia de San Esteban Protomártir. LF. Visita de 1638 realizada por el obispo de Osma D. Martín Carrillo de Aloeche. Canicosa de la Sierra, 19 - septiembre - 1639.
} 
Su desaparición debió producirse en un momento relativamente tardío, ya que dentro del inventario de ermitas, recogido en el Diccionario de P. Madoz, efectuado a mediados del siglo XIX, todavía aparece ${ }^{1019}$.

La segunda de estas ermitas es la dedicada a Santa Lucía, sobre la cual tenemos aun menos noticias, lo que nos impide precisar el lugar en el que se ubicaba. Tampoco tenemos datos sobre su aspecto, o los elementos que pudieron existir en su interior. La última referencia sobre ella se produce en el año 1742, dentro de la relación de ermitas, que realiza el visitador del obispado de Osma, D. Agustín de la Bodega ${ }^{1020}$. A partir de aquí, no volvemos a tener más noticias de ella.

La tercera y última es la dedicada a Nuestra Señora de la Cuesta, sobre la cual únicamente tenemos una vaga noticia, fechada en 1682. Se trata de un mandato, dado por el visitador del obispado de Osma en este año, D. Francisco Antonio Rodríguez de Minclaroz, en el cual ordena: "que se de nueva la ermita de Santa María de la Cuesta por estar muy arruinada e indecente״1021. Este mandato, sin embargo, parece que no llegó a cumplirse nunca, pues a partir de aquí no volvemos a encontrar más noticias sobre ella.

\section{Arquitectura civil.}

Canicosa de la Sierra es uno de los pueblos de la zona de pinares, que todavía ofrece buenos y bien conservados ejemplos de las características casas carreteras. Dentro de los edificios de este tipo conservados podemos encontrar incluso dos variantes de esta tipología, como son las denominadas casa solariega y la gran casona carretera. Ambas fueron estudiadas con detalle en los capítulos correspondientes a la

\footnotetext{
1019 P. MADOZ: Diccionario... ob. cit.

1020 AGDBU. LP. Canicosa de la Sierra, Parroquia de San Esteban Protomártir. LF. (1677 - 1765). (fols. $275 v^{0}$ - 288). Visita realizada a la parroquia de San Esteban Protomártir de Canicosa de la Sierra en 1742, por D. Agustín de la Bodega. Canicosa de la Sierra, 17 - abril - 1742.

1021 Ibídem. LF. (1677 - 1765). Visita realizada en el año 1682 a esta parroquia por D. Francisco Antonio Rodríguez Minclaroz. Canicosa de la Sierra a 15 de mayo de 1682.
} 
arquitectura civil durante el siglo XVIII, con lo cual no nos detendremos aquí sobre ellas. Simplemente recordaremos que los ejemplos más destacados de la primera variante se encuentran en la calle Nuestra Señora del Carrascal, $n^{\circ}$ 33, 36 y 54, calle del Obispo $n^{\circ} 12$, y calle Gregorio López $n^{\circ} 1$. La segunda, por su parte, ofrece un ejemplo muy alterado en la calle Pinachón $n^{\circ} 16$ - 18. 


\section{CASTRILLO DE LA REINA.}

La villa de Castrillo de la Reina está situada en la parte sur-oriental de nuestra comarca de estudio, dentro del borde mesozoico, que rodea el núcleo, que compone la Sierra de la Demanda. Ocupa la parte central de un reducido término municipal, que se complementa con su participación en la administración de amplios terrenos en varias de las ledanías circundantes.

Su origen se halla vinculado irremisiblemente a la creación de los primeros núcleos de población estables, aparecidos en la zona, en torno a los siglos IX y X, tal y como demuestran las sepulturas labradas en rocas, encontradas en el entorno de la ermita de Santa Ana, sobre el cerro de la Muela, que domina el pueblo ${ }^{1022}$. De forma casi inmediata debió comenzar un proceso de absorción de los pequeños núcleos cercanos, como San Justo (Santiuste), Saelices, las Viguillas o Ciruelos, situados en un radio de escasos kilómetros, hasta quedar finalmente despoblados. El testimonio más elocuente de este proceso lo encontramos en los restos de San Justo (o Santiuste), situados a las afueras del actual núcleo de Castrillo, donde aparecen vestigios de su iglesia y tumbas rupestres, los cuales nos dan una idea de la densidad y proximidad de estos primeros asentamientos. Sin embargo, las primeras referencias documentales

1022 J. ANDRIO GONZÁLEZ: “La Edad Media a través de los estudios arqueológicos”. En Historia de Burgos II. Edad Media (2). Burgos, Caja de Ahorros Municipal de Burgos. 1986. (pp. 203 y ss). F. REYES TÉLLEZ: “Arqueología y cultura material de la provincia de Burgos en la Alta Edad Media”. En II Jornadas burgalesas de historia (2 Burgos. 1990). Burgos en la Alta Edad Media. Burgos, Asociación Provincial de Burgos. 1991. (pp. 77 - 123). 
sobre estos pueblos no aparecen hasta los años finales del siglo $\mathrm{XI}^{1023}$ y primeros momentos del XII ${ }^{1024}$.

En este momento Castrillo formaba parte del gran alfoz de Lara ${ }^{1025}$, pasando más tarde, a partir del siglo XII, a quedar encuadrado en la Merindad Menor de Santo Domingo de Silos ${ }^{1026}$. En el terreno jurisdiccional, Castrillo de la Reina conservaba todavía, a mediados del siglo XIV, su condición de Behetría, si bien, esto no tarda en cambiar, pues en este momento ya aparece Pedro Fernández de Velasco como uno de los principales diviseros, con divisas adquiridas a través de sus enlaces familiares ${ }^{1027}$.

De este modo, vemos cómo en el inicio de la Edad Moderna, Castrillo aparece ya formando parte del señorío de los Duques de Frías, aspecto que no sufrirá cambios a lo largo de todo este período. Esto hace, que en el plano fiscal la villa de Castrillo quede incluida, desde el siglo XVI, en el partido de las Tierras del Condestable, dentro de la provincia de Burgos ${ }^{1028}$. Más tarde, durante la reforma borbónica del siglo XVIII, queda incluida en el partido de Can de Muñó ${ }^{1029}$. En el ámbito eclesiástico, por su parte,

1023 M. S. MARTÍN POSTIGO: San Frutos del Duratón: historia de un Priorato Benedictino. Segovia, Publicaciones de la Obra Cultural de la Caja de Ahorros y Monte de Piedad de Segovia. 1970. (pp. 207 y ss).

1024 L. SERRANO: Cartulario de Silos. (pp. 55).

1025 G. MARTÍNEZ DÍEZ: Pueblos y alfoces burgaleses de la repoblación. Valladolid, Junta de Castilla y León. Consejería de Educación y Cultura. 1997. (pp. 173).

1026 C. ESTEPA DÍEZ: "Estructura de poder en Castilla (siglos XII - XIII). El poder señorial en las merindades burgalesas. En III Jornadas burgalesas de Historia (3 1991). Burgos en la Plena Edad Media. Burgos, Asociación Provincial de Libreros de Burgos. 1994. (pp. 245 - 294).

1027 G. MARTíNEZ DÍEZ: Libro Becerro de las Behetrías. Estudio y texto crítico. León, Centro de Estudios e Investigación San Isidoro. Caja de Ahorros y Monte de Piedad. Archivo Histórico Diocesano. 1981. (pp.595 - 596).

1028 G. MARTÍNEZ DÍEZ: Génesis histórica de la provincia de Burgos y sus divisiones administrativas. Burgos, Aldecoa. 1983.

1029 Ibídem. 
vemos que su única parroquia forma parte, desde el concilio de Burgos de 1136, de la Diócesis de Osma ${ }^{1030}$.

Castrillo de la Reina contó tradicionalmente con un volumen de población relativamente alto, dentro de lo que es la media en los pueblos de la zona. Su evolución a lo largo de la Edad Moderna, sin embargo, muestra una línea más próxima a la vivida en el resto de la provincia de Burgos, que a los rasgos propios de los pueblos del interior de la comarca, donde las fluctuaciones son menos marcadas. Así vemos cómo el momento de máximo apogeo poblacional, que vivió esta localidad, se produce en el siglo XVI, con 135 vecinos pecheros, registrados en el censo de $1541^{1031}$, y 144 en el censo de los obispos de 1584-87 ${ }^{1032}$. A partir de aquí, se inicia un brusco descenso, que tiene sus primeras manifestaciones en el censo de 1591, con 126 vecinos contabilizados $^{1033}$, que alcanza sus cotas más bajas en la primera mitad del siglo siguiente, con 72 vecinos en el censo de la sal ${ }^{1034}$, de 1631, y sólo 40 en el de $1646^{1035}$. Después de esto, parece iniciarse una tímida recuperación, que se plasma, a mediados del Setecientos, en el Catastro del Marqués de Ensenada, con un total de 105'5 vecinos $^{1036}$. La culminación de esta línea se completa a finales de este siglo, con un registro de 596 habitantes en el censo de Floridablanca de $1787^{1037}$.

Los medios de vida de estos habitantes no parecen ofrecer un grado de especialización tan elevado, como ocurría en los pueblos del interior de la sierra. De este modo, encontramos una relativa diversificación de las actividades profesionales,

\footnotetext{
${ }^{1030}$ L. SERRANO: El obispado de Burgos y Castilla primitiva. Desde el siglo V al XIII. Madrid, Centro de Estudios Históricos. 1935. Tomo I (pp. 414 - 418).

1031 AGS. Contaduría General. Leg. 768. (fols. 61).

1032 T. GONZÁLEZ: Censo de población de las provincias y partidos de la Corona de Castilla en el siglo XVI... Ed. Facsímil. Madrid, Imprenta Real. 1829.

${ }^{1033}$ Censo de Castilla de 1591. Vecindario. Madrid, Instituto Nacional de Estadística. 1984.

1034 AGS. Dirección General del Tesoro, inventario 24. Leg. 1168 - 2.

1035 AGS. Cámara de Castilla - Diversos. Leg. 23, nº 4. (s/f).

${ }^{1036}$ Vecindario de Ensenada 1759. Vol. I. Madrid, Centro de Gestión Catastral y Cooperación Tributaria: Tabapress. D. L. 1991.
} 
alternando las labores agrícolas con la ganadería, el aprovechamiento forestal y el transporte. En todas estos trabajos los terrenos de las ledanías juegan un papel fundamental. En la agricultura prima la de secano, existiendo unas escasas huertas en la vega del río Saelices. La ganadería, por su parte, según los datos ofrecidos por el Catastro del Marqués de Ensenada, componía, a mediados del siglo XVIII, una nutrida cabaña de ganado estante, formada, entre otros, por más de 2.000 ovejas (suponemos que de raza churra), y casi 1.000 cabras. También encontramos aquí registrados un elevado número de burros y machos, próximo a las 2.000 cabezas $^{1038}$, las cuales eran utilizadas principalmente en el negocio de la trajinería, o transporte a corta distancia. Con estas caballerías los vecinos de Castrillo participaban en el comercio de intercambios de productos básicos con las comarcas próximas de la vega baja del Arlanza y la Ribera del Duero.

El núcleo de Castrillo de la Reina se expande a lo largo de una serie de pequeñas laderas de orientación variada y suelo eminentemente rocoso ${ }^{1039}$, que hace que la mayor parte de las casas se levanten sobre roca viva. Su caserío, por lo demás, aparece dispuesto sin ningún tipo de orden, guardando, en algunas de sus partes, una cierta distancia entre los edificios, lo que nos proporciona una imagen relativamente esponjosa. Dentro de esta estructura, como ocurre en la totalidad de estos pueblos, el edificio más relevante lo encontramos en la iglesia parroquial, la cual destaca, tanto por la calidad de sus paramentos, como por la altura que alcanza su fábrica. Esto hace que este edificio destaque de forma llamativa por encima de la línea de tejados del resto de las casas, de recio sabor popular.

Iglesia de San Esteban.

\footnotetext{
1037 INE. Censo de 1787. "Floridablanca”. Madrid. INE. 1989.

1038 ADBPU. CE. 463. RESPUESTAS GENERALES. Castrillo de la Reina, 7 - febrero - 1753.

1039 J. L. GARCÍA GRINDA: Arquitectura popular de Burgos. Crítica y teoría de la arquitectura popular: tipos y caracterización de la arquitectura rural autóctona castellano - leonesa: el caso burgalés. Burgos, Colegio Oficial de Arquitectos de Burgos. 1988. (pp. 111).
} 
La iglesia de Castrillo de la Reina se encuentra dedicada a San Esteban Protomártir, y constituye uno de los grandes templos levantados en la zona entre los años finales del siglo XV y primeros momentos del XVI ${ }^{1040}$. Aparece situado, como decimos, en la parte central del pueblo, en las faldas del cerro de la Muela, sobre una ladera de acentuada pendiente, orientada hacia el ángulo noroeste. Esto obligó, en su momento, a corregir este suelo, mediante la construcción del muro del atrio, que permitía crear una superficie firme y llana. Una buena parte del templo, por otro lado, se alza, al igual que varias de las casas del pueblo, sobre suelo rocoso, lo que concede una gran solidez a su estructura.

Su planta reproduce, como vimos en su momento, el característico modelo de iglesia hallenkirche, con cuerpo dividido en tres naves de dos tramos cada una, cabecera plana en el extremo oriental, con la sacristía adosada sobre su flanco meridional, y torre a los pies, en correspondencia con el ábside. Dentro de esta planta, sin embargo, encontramos una acentuada irregularidad en la parte septentrional del cuerpo, ya que su muro no es paralelo al del lado contrario, lo que hace que la nave del evangelio sea más estrecha que la de la epístola, y que los pilares torales no queden situados a la misma altura. Todo el edificio se halla levantado en piedra, con muros de sillería, alzados sobre un pequeño zócalo en la parte inferior, y rematados con cornisa de codillo y moldura de cuarto de bocel, que da paso al tejado. Estos muros están reforzados además con sólidos contrafuertes, dispuestos, en el caso de las esquinas, en diagonal, reflejando hacia el exterior la división interna de naves y tramos.

Con todo ello se consigue una imagen exterior sobria y elegantes, en la que se combinan, el carácter compacto y homogéneo de la parte correspondiente a las naves y cabecera, con el impulso ascensional aportado por la torre, situada a los pies. Esta torre queda formada por un sólido prisma de base cuadrada, articulado en dos cuerpos desiguales, que se corresponden con las fases, que se sucedieron en su construcción. El inferior, con un desarrollo mayor, se corresponde con la estructura de lo que fue la

1040 Ver capítulo Actividad constructiva. Evolución estilística: Siglo XVI. 
primera torre. Sus muros, completamente planos, todavía conservan en la parte superior las improntas dejadas por los dos vanos de las campanas, que existían en cada una de sus caras, formados por arcos de medio punto ligeramente rebajados y abocinados, con derrame hacia el exterior. El segundo cuerpo, corresponde ya a otra fase constructiva diferente, y presenta un desarrollo en altura mucho menor. Sus muros cuentan con una moldura, que marca un ligero decrecimiento en su grosor, mostrando un número de vanos igual al anterior, coronados, en este caso, con arco de medio punto sobre moldura plana de escaso resalte. Sobre ellos, y culminando esta estructura, se extiende un friso corrido completamente liso, acompañado por cornisa de papo de paloma, que da paso al tejado, en cuyas esquinas se alzan sencillos pináculos de bola, que sirven de remate. Esta torre se completa con un husillo adosado sobre su flanco septentrional, por cuyo interior asciende la escalera de caracol, que permite el acceso a su cuerpo de campanas.

El elemento más destacado, dentro de esta imagen exterior del templo, lo encontramos en su portada, abierta sobre el muro meridional de la nave, a la altura del segundo tramo. En ella se desarrolla, como tuvimos oportunidad de ver, un interesante ejemplo del llamado estilo Reyes Católicos, con un marcado carácter decorativo, que nos permite relacionarla con otros ejemplos representativos de este estilo, como la portada de la iglesia de Santa María de Aranda de Duero, y a su vez, y salvando las distancias, con la propia escuela de los Colonia ${ }^{1041}$.

Esta portada está acompañada por una serie de ventanas, dentro de las cuales se combinan distintos tipos de trazados, en los cuales se reflejan las diferentes fases constructivas del templo. La más antigua, aunque actualmente cegada, la encontramos en la cabecera, sobre el muro del testero. Es una ventana de estructura estilizada, rehundida dentro del muro a través de un doble abocinado, formado por dos molduras cóncavas, rematada con arco apuntado, e interior dividido por un esbelto mainel, que propicia un remate con doble arco trilobulado de marcado sabor flamígero. A ésta le siguen dos ventanas más, abiertas en la nave de la epístola, orientadas al mediodía y a

1041 Ibídem. 


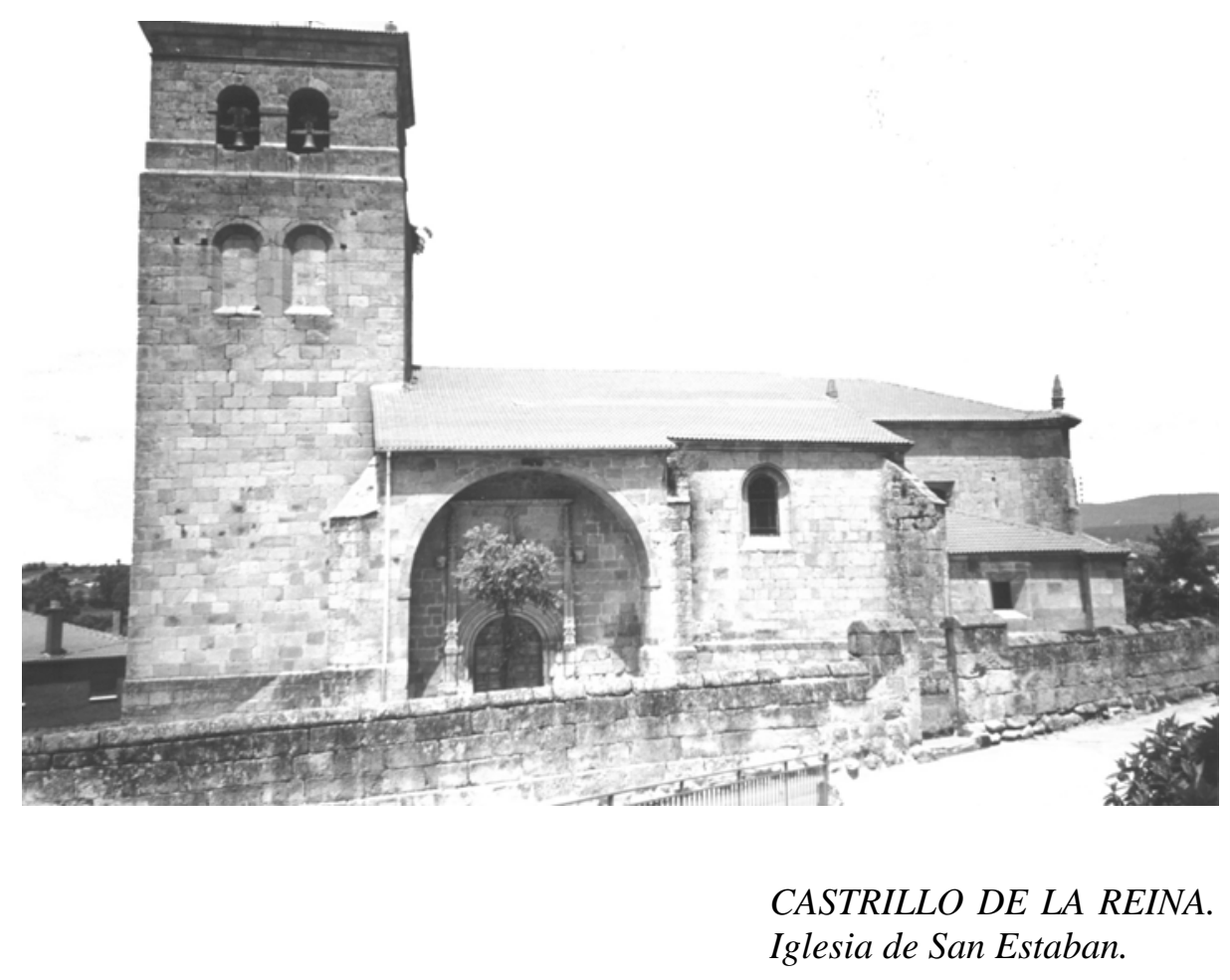

poniente. Presenta una estructura abocinada, con derrame exterior y arco de medio punto, enmarcado por un fino junquillo. Una ventana más aparece en la base de la torre, orientada hacia poniente con rasgada estructura rectangular de dintel plano y profundo abocinado, con derrame hacia el exterior muy moldurado. Finalmente, en el muro meridional del presbiterio, encontramos un simple vano rectangular con dintel plano y ligero abocinado al exterior, que en su día sustituyó a un óculo anterior, abierto sobre este mismo muro.

En el interior nos encontramos con el desarrollo del característico espacio de ámbito único, propio de este tipo de templos, al cual se incorporan, la capilla mayor, en la parte delantera, y el coro, dispuesto a los pies, en el interior de la base de la torre. La cubierta de todo este espacio interior se resuelve con una estructura abovedada, con bóvedas de crucería estrelladas con terceletes y cinco claves, dentro de las cuales, sin embargo, encontramos algunas excepciones. Este es el caso, por ejemplo, de los tramos 
de la nave del evangelio, cuya forma perlongada obliga a eliminar los terceletes en sus lados más cortos, junto con el nervio de ligadura transversal. El segundo tramo de la nave de la epístola, por su parte, incorpora, sobre el trazado básico, una serie de nervios combados, con los que se dibuja un círculo en torno a la clave central, con ligeros conopios en sus extremos longitudinales. Esta bóveda incorpora también una curiosa decoración de caireles góticos sobre algunas partes de su plementería, que se repite en el borde de las claves. La bóveda de la cabecera, por último, aunque no ofrece ningún tipo de variación en su trazado, resulta interesante por conservar restos de policromía en sus nervios y plementería, entre los que descubrimos la representación de distintas figuras humanas y de animales fantásticos, de formas claramente renacentistas.

Dentro de los arcos, encontramos distintos modelos, cuya utilización se queda determinada por las necesidades constructivas, impuestas por la estructura de bóvedas elevadas a una misma altura. Así, los tramos de la nave central (más ancha que las laterales), presentan arcos de medio punto, tanto en los fajones como en los formeros, con rosca muy moldurada en los primeros, y sección cuadrada con intradós plano, en los segundos. Las naves laterales, por su parte, recurren a arcos apuntados de rosca moldurada, más rebajados en la nave de la epístola (al ser más ancha), y más apuntados en la del evangelio, donde alcanzan un perfil prácticamente alancetado.

Estos arcos y bóvedas apean sobre dos sólidos pilares centrales, de núcleo rodeado por gruesas columnas en sus frentes y otras más delgadas en los ángulos o codillos. Estos pilares arrancan sobre un elevado pedestal, en el que se individualizan las basas de cada columna, terminando en capiteles también individualizados, formados por simples anillos lisos. En los muros laterales estos pilares se corresponden con medios pilares adosados de similares características. En las esquinas, sin embargo, encontramos ménsulas, en las cuales se combinan, representaciones de cabezas de niños aladas, propias del renacimiento, con los típicos relieves de bolas del estilo Reyes Católicos. 


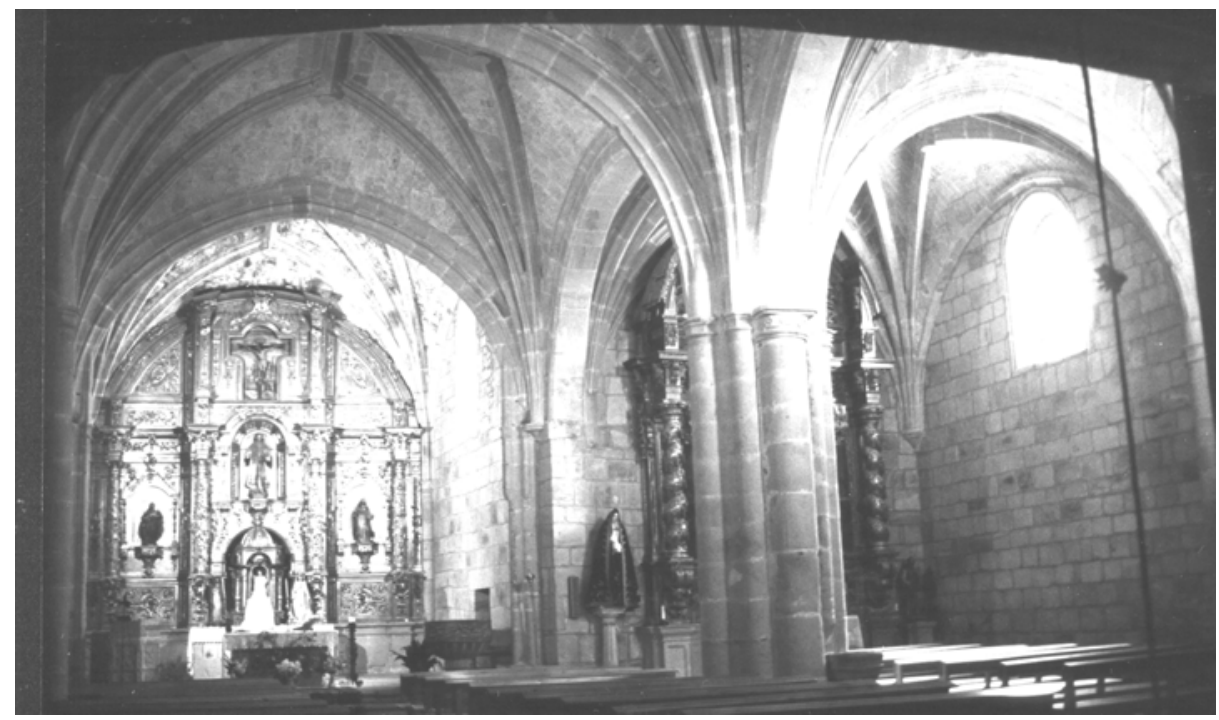

CASTRILLO DE LA REINA.

Iglesia de San Esteban. Interior.

Esta imagen se completa con un coro alto, elaborado en piedra, situado a los pies, en el espacio interior de la base de la torre, un sepulcro de trazas renacentistas sobre el muro del primer tramo de la nave del evangelio, y cuatro retablos. El de la capilla mayor y los dos colaterales, dispuestos junto a la entrada de este espacio delantero, son obras de estilo barroco, realizados entre los años finales del siglo XVII y primera mitad del siglo XVIII ${ }^{1042}$. Están presididos, el primero de ellos, por San Esteban, como titular del templo, el del lado de la epístola por la Virgen María con el Niño, y el lateral del evangelio por San Bartolomé. El cuarto retablo se encuentra situado en el muro del segundo tramo de la nave del evangelio, justo enfrente de la puerta de entrada, y es obra de carácter clasicista de 1644. Se trata del antiguo retablo del altar mayor, que fue trasladado aquí en 1754, tras la construcción del actual ${ }^{1043}$.

1042 R. J. PAYO HERNANZ: El retablo en Burgos y su comarca durante los siglos XVII y XVIII. Burgos, Excma. Diputación Provincial de Burgos. 1997. (T. II, pp.472 - 473). 
Este templo, a pesar de su aparente imagen de unidad estilística, constituye el resultado final de una larga e intensa historia constructiva. Dentro de ella, existe una fase especialmente importante, situada entre finales del siglo XV y principios del XVI, de la que surge la estructura principal del templo, a la cual siguen una serie de actuaciones menores, con las que se completa su imagen. Con el primero de estos procesos constructivos se produce también la eliminación prácticamente total del edificio anterior, eliminando de raíz cualquier vestigio, que nos permita reconstruir su estructura primitiva. El único elemento que se conserva de ella, lo constituye el muro septentrional del cuerpo, el cual provoca las irregularidades, que ya conocemos, en la parte de la nave del evangelio. Otro elemento conservado de las etapas anteriores es la pila bautismal, de estilo románico, con decoración gallonada en el exterior de la copa, y guirnalda vegetal en el borde exterior, muy similar, por lo tanto, a la que existe en la iglesia de Santa Eulalia, en Palacios de la Sierra ${ }^{1044}$.

El análisis formas del edificio, sin embargo, nos indica, que la construcción de este nuevo templo, en los albores de la Edad Moderna, no se realiza en una sola acometida. De esta forma, la evolución que muestran algunos de sus elementos nos permitan identificar, al menos, tres momentos distintos. Lamentablemente la falta de documentación no nos permite fijar una cronología precisa para cada uno de ellos. El primero, no obstante, debió producirse en las últimas décadas del siglo $\mathrm{XV}$, durante el cual se construye la cabecera, donde encontramos reflejados los rasgos propios del estilo flamígero. El segundo paso se desarrolla ya durante los primeros años del siglo XVI, y en él se acomete la construcción de toda la zona de las naves y la portada. Se trata, por lo tanto, de una obra encuadrada ya en la tradición gótica más avanzada, con un predominio de las formas propias del estilo Reyes Católicos, en la que se incluyen, al mismo tiempo, algunos elementos propios del nuevo estilo renacentista. El punto final a esta secuencia constructiva se pone con la edificación de la torre, la cual se inicia en los

1043 AGDBU. LP. Castrillo de la Reina, parroquia de San Esteban. LF. (1733 - 1788). Cuentas del año 1754. Castrillo de la Reina, 17 - diciembre - 1755. 
años finales del segundo tercio de este siglo XVI. El encargado de su ejecución fue el maestro de cantería trasmerano, Juan de la Fragua ${ }^{1045}$, que la terminó en $1572^{1046}$. Desconocemos, no obstante, los detalles que rodearon la ejecución de este proyecto, si bien, sabemos que los pagos efectuados por esta fábrica se dilataron tanto en el tiempo, que tuvo que ser la propia hija del maestro Juan de la Fragua, la que terminara de percibir las últimas cantidades. Sirva como ejemplo ilustrativo de esta circunstancia, el hecho de que en 1608 esta parroquia todavía adeudaba al citado maestro 1.165.721 maravedís $^{1047}$.

A partir de aquí, se inicia una nueva fase para esta iglesia, durante la cual se acometen distintos trabajos, relacionados con labores de reparación, mantenimiento, pero también con la incorporación de nuevos añadidos. El primero de ellos se produce nada más comenzar el siglo XVII, y consistió precisamente en incorporar un nuevo cuerpo de campanas sobre la torre recién levantada. La obra se completó en $1603^{1048}$, y el encargado de su ejecución fue el maestro de cantería, también trasmerano, Juan $\mathrm{Gil}^{1049}$.

Los añadidos más importantes, sin embargo, se producen ya en la segunda mitad de este siglo, durante las dos décadas que transcurren entre 1655-75. Este ciclo de obras se inicia con la construcción de la nueva sacristía, de la cual se encargó el maestro de

1044 G. BILBAO LÓPEZ: Iconografía de las pilas bautismales del románico castellano; Burgos y Palencia. Burgos, Editorial la Olmeda. 1996.

1045 M. C. GONZÁLEZ ECHEGARAY, M. A. ARAMBURU - ZABALA HIGUERA: Artistas cántabros de la Edad Moderna. Su aportación al arte hispánico. Salamanca, Servicio de Publicaciones de la Universidad de Cantabria, 1991. (pp. 220)

${ }^{1046}$ AGDBU. LP. Castrillo de la Reina, San Esteban. LF. (1572 - 1631). Carta cuenta de 1609 -1610. Burgos, 11 - mayo - 1610.

1047 Ibídem. Castrillo de la Reina, 11 - junio - 1609.

1048 AGDBU. LP. Castrillo de la Reina, San Esteban. LF. (1572 - 1631). Cuentas del año 1604. Castrillo de la Reina, 13 - junio - 1606.

1049 M. C. GONZÁLEZ ECHEGARÁY, M. A. ARAMBURU-ZABALA HIGUERA: Ob. cit. (pp. 243). SALTILLO, Marqués de: Artistas y artífices sorianos de los siglos XVI y XVII (1509 - 1699). Madrid. 1948. 
cantería Clemente de Hermosa, trasmerano natural de la localidad de Hermosa, en el valle de Cudeyo ${ }^{1050}$. En estos trabajos también participa el carpintero Juan Hierro ${ }^{1051}$. Con esta obra se pretendía sustituir la sacristía anterior por una nueva, pero sin eliminar aquella, lo que obliga a que esta nueva construcción deba acomodarse sobre el muro meridional de la nave, mientras que la otra permanecía en el lado contrario. En 1668, finalmente, se decide eliminar la vieja ${ }^{1052}$. Las obras de la nueva sacristía concluyeron, no sin ciertos problemas, en 1656, con un desembolso para la fábrica de esta iglesia de cerca de 60.000 maravedís, de los cuales 53.606 correspondieron al salario del citado maestro. Para poder hacer frente a estos gastos, la iglesia cuenta, en esta ocasión, con la inestimable colaboración de las ermitas de Santa Ana, San Roque y San Pelayo, situadas en este pueblo, las cuales adelantaron un dinero, que fue devuelto religiosamente años más tarde ${ }^{1053}$. El resultado final nos ofrece una obra encuadrada dentro de la línea de este tipo de construcciones, realizadas a lo largo de la centuria del Seiscientos, con estructura prismática sobre planta cuadrangular, reforzada con estribos en las esquinas, y espacio interior cubierto con bóveda de crucería estrellada con terceletes ${ }^{1054}$.

La siguiente obra, que tiene lugar, dentro de este ciclo, fue la construcción del gran arco, que protege la portada de la iglesia. Se trata de una obra sencilla, formada por un potente arco de medio punto, dispuesto entre los contrafuertes que delimitan este espacio, el cual descansa sobre impostas planas de escaso resalte. Su carácter recio y desornamentado nos permita encuadrarlo perfectamente dentro de la línea del más sobrio clasicismo, que impregna la actividad arquitectónica de la zona, desde las

1050 M. C. GONZÁLEZ ECHEGARAY, M. A. ARAMBURU-ZABALA HIGUERA: Ob. cit. (pp. 307). AGDBU. LP. Palacios de la Sierra, Nuestra Señora del Arroyal. (fols. 20 - 24); AGDBU. LP. Castrillo de la Reina, parroquia de San Esteban. LF. (1632 - 1673). Cuentas del año 1656. Castrillo de la Reina. 1657; Ibídem. Cuentas del año 1657. Castrillo de la Reina, 18 - mayo - 1659; Ibídem. Cuentas del año 1658 59. Castrillo de la Reina, 10 - septiembre - 1659.

${ }^{1051}$ AGDBU. LP. Castrillo de la Reina, San Esteban. LF. (1632 - 1673). Cuentas del año 1656: Castrillo de la Reina, 1657.

1052 Ibídem. Cuentas del ano 1668. Castrillo de la Reina, 11 - agosto - 1669.

1053 Ibídem. LF. (1673 - 1708). Cuentas del año 1689 - 1690. Castrillo de la Reina, 15 - octubre - 1690.

${ }^{1054}$ Ver capítulo: Actividad constructiva. Evolución estilística: Siglo XVII. 
primeras décadas del siglo XVII. Desconocemos, en este caso, el nombre del autor o autores, que participaron en esta obra, y los detalles que rodearon su construcción, si bien, sabemos que en 1662 los trabajos habían concluido, con un desembolso para esta fábrica de 42.568 maravedís ${ }^{1055}$.

A finales de esta misma década se procede también a renovar el coro, sustituyendo para ello el anterior, construido en los últimos años del siglo XVI, por el maestro Andrés de Nicolás ${ }^{1056}$. El encargo recae, en este caso, en el maestro de origen vasco Diego de Olano, el cual percibe de la fábrica de esta iglesia la suma de 102.000 maravedís ${ }^{1057}$. A esta cantidad debemos sumar también el gato de los materiales, la licencia de obra y otros pagos, alcanzando todo ello los 121.000 maravedís. Los trabajos finalizan en 1669, momento en el que es llamado el maestro de cantería y fraile lego del monasterio de Santo Domingo de Silos, Fr. Rodrigo de Hermosa, para tasar la obra ${ }^{1058}$. En este proyecto, a parte de construir el coro, con la correspondiente bóveda que cubre el sotocoro, se realiza también la bóveda que cierta este espacio interior de la torre, bajo el cual se halla el coro.

Cerramos este intenso ciclo de nuevas edificaciones y remodelaciones con la obra del cementerio, dentro de la cual se esconde un proyecto encaminado a renovar de forma íntegra todo el entorno de esta iglesia, reforzando, al mismo tiempo la estabilidad del edificio. Su construcción se desarrolla en dos fases, la primera de las cuales se pone en marcha a partir de la iniciativa del Visitador del Obispado de Osma de 1670, el cual manda edificar este muro para reforzar la seguridad del templo ${ }^{1059}$. Dos años más tarde, parece que los trabajos ya están en marcha, dándose por finalizados al año siguiente, en

1055 AGDBU. LP. Castrillo de la Reina, parroquia de San Esteban. LF. (1632 - 1673). Cuentas del año 1662. Castrillo de la Reina, 20 - noviembre - 1663.

1056 Ibídem. LF. (1587 - 1631). Cuentas del año 1599. Castrillo de la Reina. 1599; Ibídem. Cuentas del año 1600. Castrillo de la Reina, 2 - enero - 1604.

1057 Ibídem. LF. (1632 - 1673). Cuentas del año 1669. Castrillo de la Reina, 3 - julio - 1670.

1058 Ibídem.

1059 Ibídem. Visita pastoral realizada a la parroquia de San Esteban Protomártir de Castrillo de la Reina en 1670. Castrillo de la Reina, 31 - octubre - 1670. 
1673, con un coste para la fábrica de la iglesia de 71.026 maravedís en mano de obra y 31.433 maravedís en materiales ${ }^{1060}$. Este muro, que ahora se levanta, recorre los lados meridional y occidental del templo. Un año después se levanta el muro de los tramos restantes, hasta completar el cerco completo del templo ${ }^{1061}$. El coste de esta parte final de la obra ascendió a 56.032 maravedís, incluyendo también aquí los trabajos de rellenado de tierra, que fue necesario hacer en las partes más deprimidas del recinto ${ }^{1062}$.

En estos mismos años los visitadores del Obispado de Osma mandan también: "Que se haga un archivo en la Yglesia donde la pared de en alcance donde se metan todos lo s Papeles de la iglesia memorias y capellanias para que esten con mas

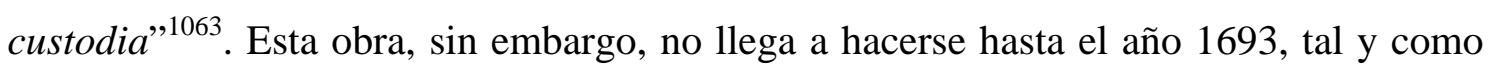
señala la inscripción que aparece en su frente ${ }^{1064}$, colaborando en su ejecución, además de la propia fábrica de la iglesia con 32.691 maravedís, el concejo de la villa, y la capellanía fundada por el licenciado Juan Izquierdo, pues ambas instituciones reservan aquí su sitio correspondiente para custodiar sus respectivos documentos ${ }^{1065}$. Este archivo se halla situado sobre el muro posterior de la nave del evangelio, y está formado por un muro completamente plano, sobre elevado zócalo y rematado con frontón recto, en cuyo frente se abren cuatro pequeñas portezuelas, sobre las cuales podemos leer; en la primera: "ESTE ARCHIVO ES D LA CAPELLANIA DE EL LIZdo JV”, IZQUIERDO”, en las dos siguientes: "ESTOS ARCHIVOS SON DLA IGLESIA”, y en la última: "ESTE ARCHIVO ES DEL CONCEJO”.

El resto de las obras, que podemos citar, dentro de la historia de esta iglesia, corresponden únicamente a trabajos de reparación y mantenimiento. Dentro de ello, sin embargo, encontramos también algunos proyectos con presupuestos ciertamente

\footnotetext{
1060 Ibídem. Cuentas del año 1672. Castrillo de la Reina, 22 - abril - 1673.

1061 Ibídem. LF. (1673 - 1708). Visita pastoral realizada a la parroquia de San Esteban de Castrillo de la Reina en 1674. Castrillo de la Reina, 7 - noviembre - 1674.

1062 Ibídem. Cuentas del año 1674. Castrillo de la Reina, 29 - diciembre - 1675.

1063 Ibídem. LF. (1632 - 1673). Visita pastoral de 1670. Castrillo de la Reina, 31 - octubre - 1670.

1064 AÑO D 1693 CVRA EL Br D. JV SIMON Y PEÑAS.
} 
elevados, cuya ejecución supuso un duro esfuerzo para la economía de esta parroquia. Este es el caso de las diferentes reparaciones realizadas sobre la estructura del tejado, entre la que podemos citar los trabajos que tuvieron lugar entre los años 1678-79. La cantidad que tuvo que pagar la fábrica de esta iglesia, en esta ocasión, superó los 6.200 reales ${ }^{1066}$. Casi un siglo después, en 1744 , sin embargo, fue necesario repetir parte de esta operación de reparo del tejado, alcanzando todo ello un coste de 3.326’5 reales ${ }^{1067}$. No obstante, y a pesar de los esfuerzos realizados, la seguridad de este tejado no parece que quedara garantizada, pues en 1781 nuevamente volvemos a ver cómo se hace necesaria una nueva intervención sobre la parte delantera del templo, donde se había desprendido parte de la cornisa del tejado, en la capilla mayor y de Nuestra Señora. El coste de estas obras superó ahora los 3.500 reales $^{1068}$.

No menos importante, en cuanto a las cantidades invertidas en ellos, fueron los trabajos realizados en el cuidado y renovación del suelo del templo. Así, podemos citar, por ejemplo, la renovación del enlosado efectuado en 1705 en la zona delantera de la nave de la epístola, frente al altar de Nuestra Señora, con un presupuesto de 636 reales ${ }^{1069}$. Una década más tarde estos trabajos se extienden al resto de las naves, encargándose de ello los maestros de cantería Lucas Crespo y Manuel Pedralos, por un precio de 1.200 reales $^{1070}$. Todo este enlosado, sin embargo, será remodelado por completo en 1768, incluyendo aquí las zonas de la capilla mayor y el sotocoro. El presupuesto, en esta ocasión, ascendió a 7.391 '5 reales ${ }^{1071}$.

\footnotetext{
1065 Ibídem. LF. (1673 - 1708). Cuentas del año 1692 - 93. Castrillo de la Reina, 11 - octubre - 1693.

1066 Ibídem. Cuentas de 1678. Castrillo de la Reina, 18 - enero - 1679; Ibídem. Cuentas del año 1679. Castrillo de la Reina, 15 - enero - 1680; Ibídem. Cuentas del año 1679. Castrillo de la Reina, 15 - enero $-1680$.

1067 Ibídem. LF. (1733 - 1788). Cuentas del año 1744. Castrillo de la Reina, 11 - octubre - 1745.

1068 Ibídem. Cuentas de 1781. Castrillo de la Reina, 12 - diciembre - 1782.

1069 Ibídem. LF. (1673 - 1708). Cuentas del año 1705. Castrillo de la Reina, 25 - julio - 1706.

1070 Ibídem. LF. (1709 - 1732). Cuentas del año 1715. Castrillo de la Reina, 25 - junio - 1716; Cuentas del año 1716. Castrillo de la Reina, 26 - junio - 1717.

1071 Ibídem. LF. (1733 - 1788). Cuentas del año 1768. Castrillo de la Reina, 30 - julio - 1769.
} 
Finalmente, fuera de estas obras de cantería, debemos mencionar también la construcción de los retablos, que decoran la imagen interior de este templo. En este sentido, el primer gran retablo construido para esta iglesia, durante la Edad Moderna, del cual tenemos constancia, es el realizado para el altar mayor, durante la década de $1640^{1072}$. A este retablo le sigue el dedicado a Nuestra Señora, construido poco después, en 1649. No obstante, y a juzgar por lo escaso del presupuesto invertido en su construcción, debemos pensar que se trataba de una pieza de pequeñas dimensiones ${ }^{1073}$. Es posible, que estas modestas proporciones motivaran su renovación, la cual se produjo a finales de esta centuria, levantando en su lugar el gran retablo que actualmente vemos, con un presupuesto para su construcción de 137.158 maravedís ${ }^{1074}$. El dorado del mismo se hizo en 1699, es decir, apenas cinco años después de ser montado, y se invirtieron en ello 173.349 maravedís $^{1075}$. Ya en el siglo XVIII esta imagen se completa con la construcción del retablo de San Bartolomé, situado en el lado contrario del templo, es decir, en la parte frontal de la nave del evangelio. Las obras comienzan en $1732^{1076}$, completándose al año siguiente el dorado del mismo ${ }^{1077}$. Por último, en la década de 1750, se decide renovar la imagen de la capilla mayor, para lo cual se construye un nuevo retablo ${ }^{1078}$. Esto hace, como ya vimos, que el anterior sea trasladado al muro del segundo tramo de la nave del evangelio, situado justo enfrente de la puerta de entrada. Desconocemos los nombres de sus creadores y el coste total de la obra, si bien, sabemos que solamente en el trabajo del dorado, que fue completado en

\footnotetext{
1072 Ibídem. LF. (1632 - 1673). Cuentas del año 1641. Castrillo de la Reina, 11 - junio - 1642; Ibídem. Cuentas del año 1642. Castrillo de la Reina, 3 - marzo - 1644; Ibídem. Cuentas del año 1643. Castrillo de la Reina, 3 - octubre - 1644; Ibídem. Cuentas del año 1644. Castrillo de la Reina, 24 - enero - 1646.

1073 Ibídem. Cuentas del año 1649. Castrillo del la Reina, 4 - octubre - 1651; Ibídem. Cuentas del año 1654. Castrillo de la Reina, 20 - septiembre - 1655.

1074 Ibídem. LF. (1673 - 1708). Cuentas del año 1694 - 95. Castrillo de la Reina, 29 - julio - 1695.

1075 Ibídem. Cuentas del año 1699 - 1700. Castrillo de la Reina, 24 - junio - 1700.

1076 Ibídem. LF. (1733 - 1788). Licencia para construcción del retablo de San Bartolomé. Burgo de Osma, 10 - junio - 1732; Ibídem. Cuentas del año 1732. Castrillo de la Reina, 28 - junio - 1733.

1077 Ibídem. Remate de la obra de dorado y estofado del retablo de San Bartolomé. Castrillo de la Reina, 20 - junio - 1733; Ibídem. Castrillo de la Reina, 13 - octubre - 1733; Ibídem. Cuentas del año 1733. Castrillo de la Reina, 3 - julio - 1734.

1078 Ibídem. Cuentas del año 1756. Castrillo de la Reina, 3 - julio - 1756.
} 
1760, esta iglesia tuvo que abonar la sobrecogedora cantidad de 10.000 reales $^{1079}$. Una cifra ciertamente importante para la economía de una parroquia como ésta.

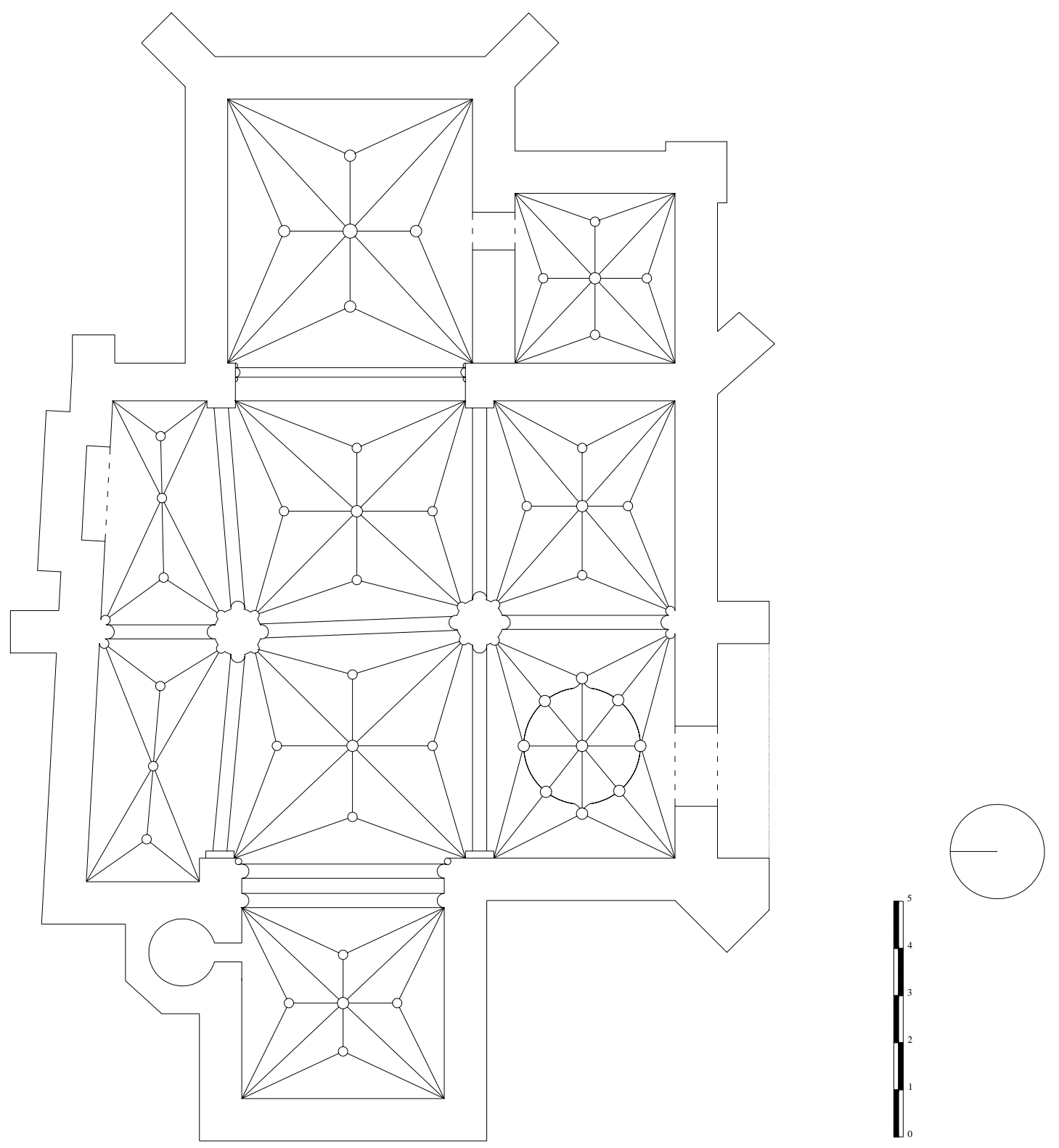

CASTRILLO DE LA REINA.

Iglesia de San Esteban. Planta.

1079 Ibídem. Cuentas del año 1760. Castrillo de la Reina, 28 - junio - 1761. 
Ermitas.

A través de las fuentes documentales hemos conseguido obtener noticias de la existencia de seis ermitas, dentro del término municipal de Castrillo de la Reina, las cuales estaban dedicadas a Santa Ana, San Roque, San Andrés, San Mateo, Santa Eugenia, y San Pelayo. De ellas, solamente la primera ha conseguido mantenerse en pie hasta nuestros días, si bien, con la estructura de su edificio brutalmente modificada.

Esta ermita se encuentra ubicada en la cima del cerro conocido como la Muela, que preside todo el pueblo, desde su flanco meridional. Su origen, posiblemente debamos buscarlo en la propia génesis de este pueblo, pues los restos de sepulcros labrados en piedra, que aparecen junto a ella, fechados entre los siglos IX-X, nos permiten contemplar la posibilidad de que nos encontremos ante la primer iglesia, que conoció el primitivo Castriello. Sin embargo, no es mucha la información que poseemos sobre ella. Su actual fábrica, por lo demás, es el resultado de una intensa labor de remodelación, que ha llevado incluso a variar la orientación original. De esta forma, su altar mayor mira actualmente hacia el oeste, mientras la puerta lo hace hacia el naciente. Nada queda, por lo tanto, del edificio primitivo, que no sean las tumbas ya señaladas, que aparecen junto a sus muros.

La ermita de San Pelayo consiguió sobrevivir, al menos, hasta mediados del siglo XIX, tal y como recoge el Diccionario de P. Madoz, el cual la situaba a un tiro de fusil de distancia del pueblo ${ }^{1080}$. Respecto a las tres siguientes, las de San Andrés, San Mateo y Santa Eugenia, muy poco es lo que podemos saber. La última información que tenemos sobre ellas corresponde al año 1747, momento en el que el obispo de Osma, D. Juan Antonio de Osuna Calderón de la Barca, en visita realizada a esta parroquia, da

1080 P. MADOZ: Diccionario geográfico - estadístico - histórico de España y sus posesiones de Ultramar. Valladolid, Ámbito D.L. 1984. (pp.285 - 286). 
cuenta de ellas, indicando que la de Santa Eugenia no estaba abierta al culto, por lo que anima a los vecinos a que emprendan su reparación ${ }^{1081}$.

Por último, la de San Pelayo, ni siquiera llegó a este momento de mediados del siglo XVIII. De este modo, la última referencia que encontramos de ella la tenemos en el episodio en el que colabora con la iglesia parroquial del pueblo, prestando dinero para la construcción de la nueva sacristía a mediados del siglo XVII. Este dinero, como sabemos, no fue devuelto hasta finales de esta centuria.

En cualquier caso, de ninguna de ellas han llegado restos materiales, que nos permitan apreciar las características que presentaban sus respectivos edificios.

\section{Arquitectura civil.}

La arquitectura civil de Castrillo de la Reina no nos proporciona ningún ejemplo de interés, dentro de lo que podemos denominar arquitectura culta. Bien al contrario, todo su caserío participa plenamente de los rasgos propios de la arquitectura popular serrana, en la que la cocina con chimenea cónica se convierte en su elemento más representativo $^{1082}$. En este sentido, debemos señalar que Castrillo es uno de los pueblos de la comarca que mejor ha sabido cuidad estas formas y tipos autóctonos, acaparando en sus tejados la mayor concentración de chimeneas de forma cónica, que existe en toda la comarca de la sierra burgalesa.

Igualmente, dentro de este caserío, creemos haber descubierto algunos ejemplos de casa carretera, aunque muy deteriorados por el paso del tiempo, en inmuebles como el situado en el Barrio Corralejo $n^{\circ}$ 98. Aparentemente se trata de un ejemplo de la variante de casa carretera, conocida como casa corralón, si bien, sus características son más fáciles de apreciar en las fotos tomadas hace algunos años, cuanto todavía mostraba

1081 AGDBU. LP. Castrillo de la Reina, parroquia de San Esteban. LF. (1733 - 1788). Visita realizada a la parroquia de San Esteban de Castrillo de la Reina en 1747, por el obispo de Osma D. Juan Antonio de Osuna Calderón de la Barca. Castrillo de la Reina, 9 - junio - 1747. 
su espléndido arco de medio punto de amplio dovelaje en su fachada principal, que en la actualidad.

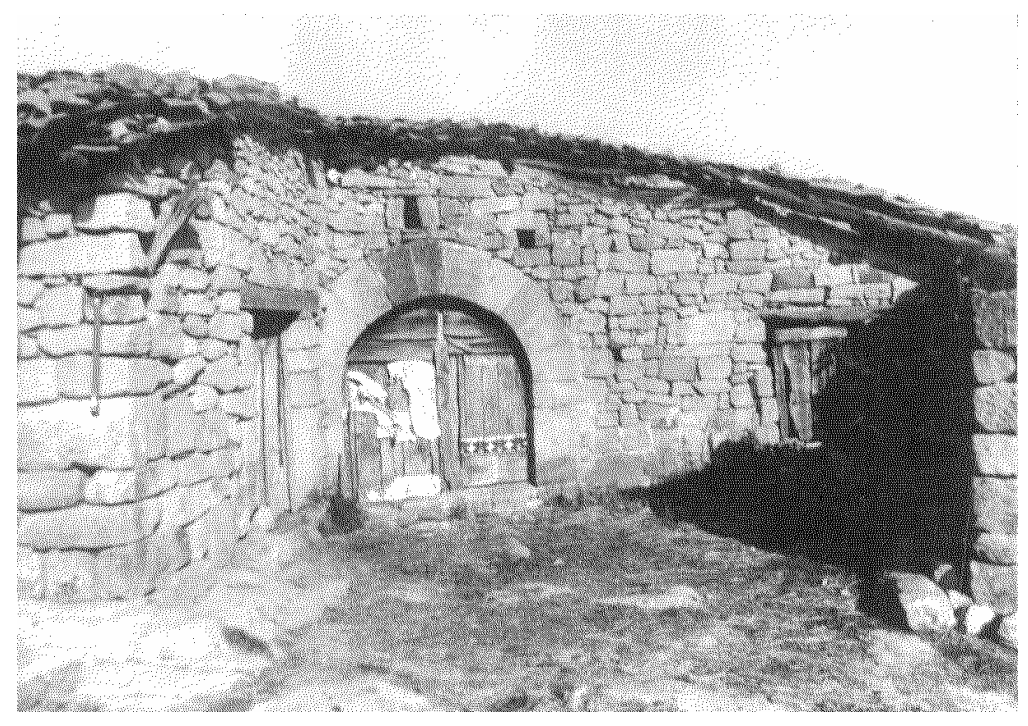

CASTRILLO DE LA REINA.

Barrio del Corralejo, $n^{\circ} 98$. 
CASTROVIDO.

La pequeña localidad de Castrovido se encuentra situada en la parte occidental de nuestra zona de estudio, muy cerca de Salas de los Infantes, sobre las últimas estribaciones de la Sierra de la Demanda, y con su rostro orientado hacia los bloques calizos, que forman los altos de Villanueva, Carazo y las Mamblas, y los consiguientes pasillos ortoclinales de la orla mesozoica. Se constituye, por lo tanto, en antesala de la sierra, y punto de paso obligado de la vía que cruza esta parte del Sistema Ibérico, adquiriendo por ello una renombrada importancia estratégica. Una vía, que ya utilizaron los primeros grupos celtíberos, y que reaprovecharon los romanos, creando la vía Clunia-Canales, por la que accedían a las riquezas minerales del interior de la Demanda. Destacados vestigios de ella son, el puente que cruza el río Arlanza a su paso por el pueblo, y la atalaya o torre de vigilancia, que cuida de este paso desde lo alto del cerro que domina el valle ${ }^{1083}$. La actual estructura de esta última, sin embargo, corresponde ya a una época muy posteriores ${ }^{1084}$.

Precisamente de esta pequeña torre de vigilancia, que P. Madoz atribuye a los árabes $^{1085}$, toma el nombre esta localidad, Castro de Vito, como derivación de los

1083 J. A. ABÁSOLO ÁLVAREZ: Comunicaciones de la época romana en la provincia de Burgos. Burgos. Excma. Diputación Provincial de Burgos. 1995. (pp. 203 - 206).

1084 L. A. CONTRERAS ABAD: Castrovido. Nuestros antepasados. Burgos, Asociación Amigos del Castillo de Castrovido. 2002. (pp. 24 - 27).

1085 P. MADOZ: Diccionario geográfico - estadístico - histórico de España y sus posesiones de Ultramar. Valladolid, Ámbito D.L. 1984. (pp. 293). 
topónimos que surgen de este tipo de términos. Las primeras referencias escritas sobre esta localidad no aparecen hasta el año 1094, donde es nombrado como Castravid $^{1086}$, apareciendo ya en el siglo XII la denominación actual de Castrovido ${ }^{1087}$.

Hasta este momento Castrovido había pertenecido al alfoz de Lara ${ }^{1088}$, pasando a partir de este siglo XII, como el resto de los pueblos de la jurisdicción de la casa de Salas, a la unidad administrativa, que forma la Merindad Menor de Santo Domingo de Silos ${ }^{1089}$.

Durante la Edad Moderna Castrovido queda encuadrado en el partido de las Tierras del Condestable, dentro de la provincia fiscal de Burgos ${ }^{1090}$. Y junto con el resto de estas localidades de Salas, pasa a formar parte del partido de Can de Muñó, a partir de la reforma borbónica del siglo XVIII ${ }^{1091}$. De igual modo, durante todo este período su jurisdicción depende de los Duques de Frías, formando parte, por ello, de este señorío secular. Anteriormente, durante la Baja Edad Media, su jurisdicción había pertenecido a Iohan Diaz Rotoful, y a donna Sancha, muger que fue de Diego López de Haro $^{1092}$.

En el ámbito eclesiástico, su parroquia sorprendentemente quedó encuadrada, durante toda la Edad Moderna, dentro de la Diócesis de Burgos, lo que la convierte en la

\footnotetext{
1086 L. SERRANO: Cartulario de San Millán. Madrid. Centro de Estudios Históricos. 1930. (pp. 82).

1087 Ibídem: Cartulario de San Pedro de Arlanza. Madrid. 1925. (pp. 182, 210).

1088 G. MARTÍNEZ DÍEZ: Pueblos y alfoces burgaleses de la repoblación. Valladolid, Junta de Castilla y León. Consejería de Educación y Cultura. 1997. (pp.173).

1089 C. ESTEPA DÍEZ: "Estructura de poder en Castilla (siglos XII - XIII). El poder señorial en las merindades burgalesas. En III Jornadas burgalesas de Historia (3 1991). Burgos en la Plena Edad Media. Burgos, Asociación Provincial de Libreros de Burgos. 1994. (pp. 245 - 294). G. MARTÍNEZ DÍEZ: Génesis histórica de la provincia de Burgos y sus divisiones administrativas. Burgos, Aldecoa. 1983.

1090 Ibídem.

1091 Ibídem.
} 
única localidad situada en la margen izquierda de esta cuenca alta del Arlanza, que no depende de la sede oxomense.

Su población siempre fue escasa, lo cual no evitó que sufriera drásticos descensos en los períodos de crisis. Los primeros datos, que poseemos para conocer su evolución demográfica durante la Edad Moderna, corresponden al censo de 1541, donde declara tener 24 vecinos pecheros ${ }^{1093}$. Esta cifra más o menos se mantiene a lo largo de toda la centuria, con un censo de 17 vecinos, según el censo de los obispos, de 1584$87^{1094}$, y 21 vecinos en el de $1591^{1095}$. Posteriormente, sin embargo, vemos que se produce un notable descenso durante el siglo XVII, de tal forma, que si hacemos caso de los valores arrojados por el censo de 1646, su población habría quedado reducida a tan sólo 8 vecinos ${ }^{1096}$. Una mayor fiabilidad debemos conceder a los datos del Catastro de Marqués de Ensenada, los cuales se corresponden, sin duda, con el período de esplendor de este lugar, durante la Edad Moderna, con 31'5 vecinos contabilizados y un clérigo $^{1097}$. Esta cifra se convierte, a finales de esta misma centuria del Setecientos, en 80 habitantes, según el censo de Floridablanca ${ }^{1098}$.

La economía de estos habitantes, estuvo basada siempre, durante este período de la Edad Moderna, en la agricultura y la ganadería. Una agricultura eminentemente de secano, basada en el cultivo de cereal y alguna legumbre. Y una ganadería estante, que a mediados del siglo XVIII, según los datos del Catastro de Ensenada, formaba una cabaña de 640 cabezas de ovejas y 690 de cabras, a las que debemos sumar casi 80

1092 G. MARTÍNEZ DÍEZ: Libro Becerro de las Behetrías. Estudio y texto crítico. León, Centro de Estudios e Investigación San Isidoro. Caja de Ahorros y Monte de Piedad. Archivo Histórico Diocesano. 1981.

1093 AGS. Contaduría General. Leg. 768. (fols. 61 vº).

1094 T. GONZÁLEZ: Censo de población de las provincias y partidos de la Corona de Castilla en el siglo XVI... Ed. Facsímil. Madrid, Imprenta Real. 1829.

1095 Censo de Castilla de 1591. Vecindario. Madrid, Instituto Nacional de Estadística. 1984.

1096 AGS. Cámara de Castilla - Diversos. Leg. 23, nº 4. (s/f).

1097 Vecindario de Ensenada 1759. Vol. I. Madrid, Centro de Gestión Catastral y Cooperación Tributaria: Tabapress. D. L. 1991. 
cabezas de ganado vacuno, entre bueyes para la labranza y vacas de huelgo ${ }^{1099}$. Una economía agropecuaria, que tenía su base fundamental en la participación, que la localidad de Castrovido tenía en las ledanías circundantes, pues su pequeño término municipal, no ofrecía suficientes tierras de labor y terreno de pasto, como para mantener los niveles mínimos de subsistencia de sus vecinos.

Su núcleo urbano se asienta a los pies de una escarpada ladera, orientada hacia el mediodía, sobre cuya cumbre se alzan majestuosos, los deteriorados restos del torreón de vigilancia, que domina este valle del Arlanza. Constituye, sin ninguna duda, una de las estampas más características de esta comarca. Dentro de su caserío apenas encontramos elementos dignos de destacar, pues todos sus edificios participan de los rasgos propios de una arquitectura popular, que ha ido evolucionando con el tiempo, para adaptarse a las necesidades de cada época. El único edificio que ha merecido un tratamiento algo mas cuidado es la iglesia parroquial, situada en el extremo oriental del pueblo.

Iglesia de San Martín.

La iglesia de Castrovido se encuentra dedicada a San Martín de Tours. Su templo nos muestra un edificio de dimensiones modestas, con unas características más próximas a la tradición de la arquitectura popular, que a la de algún estilo definido. En este sentido, solamente en la parte correspondiente a la cabecera encontramos algunos elementos, que podemos encuadrar dentro del estilo gótico. El resto corresponde fundamentalmente a renovaciones y añadidos posteriores, efectuados con un sentido puramente funcional.

Fruto de todo ello nos encontramos ante un templo sencillo, de una única nave de planta rectangular, con cabecera plana en el extremo oriental, de menor anchura que la nave, con la sacristía adosada sobre su flanco meridional, y la torre a los pies. Todo el

1098 INE. Censo de 1787. “Floridablanca”. Madrid. INE. 1989.

1099 ADPBU. CE. 491. RESPUESTAS GENERALES. Castrovido, 10 - enero - 1753. 


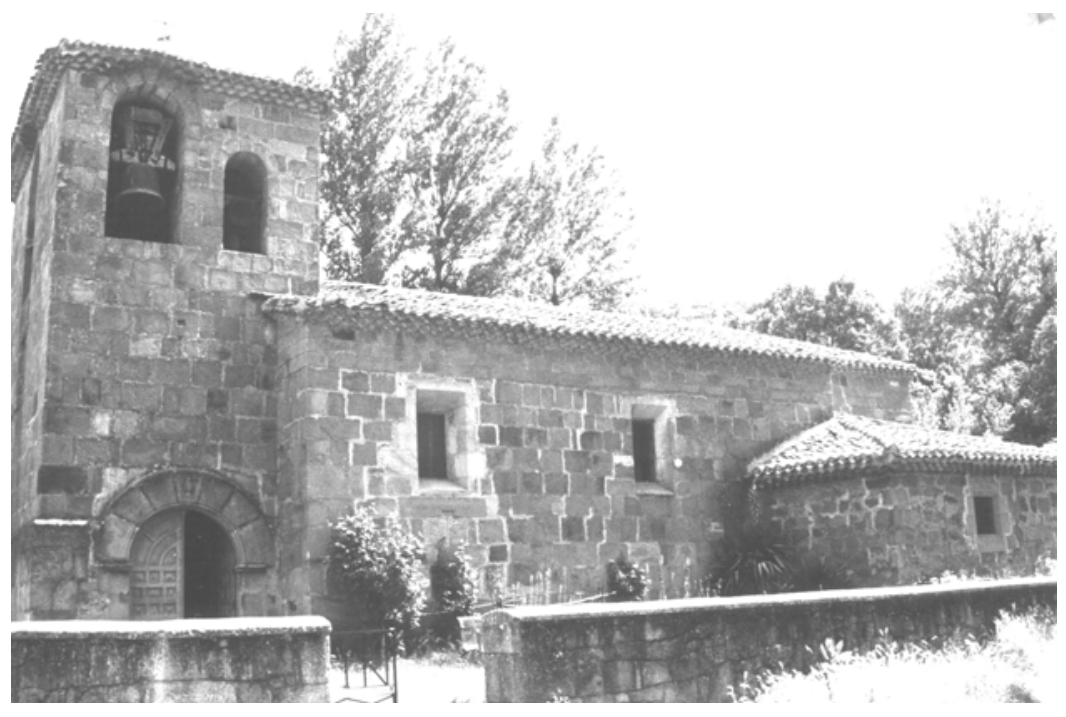

CASTROVIDO. Iglesia de San Martín de Tours.

edifico está realizado en piedra, con sillares de buena labra, con los cuales se forman muros completamente planos, reforzados únicamente en el caso del testero del ábside, con estribos dispuestos en diagonal.

En su imagen exterior, cada una de las partes señaladas en planta se manifiesta a través de limpios volúmenes de forma prismática, en los que la nave y la cabecera mantienen una misma altura, mientras que la sacristía queda por debajo. Solo la torre rompe este carácter achaparrado, que domina dentro de este conjunto, erigiéndose como auténtico contrapunto vertical. Una torre, por lo demás, de escasa altura, con un gran zócalo cuadrangular, sobre el que se levanta un cuerpo prismático sin divisiones. En su parte superior se abren los vanos, donde se alojan las campanas, los cuales aparecen coronados con arco de medio punto, presentando tamaños diferentes y una distribución irregular. Sobre el lado meridional de la base de esta torre, se abre, al mismo tiempo, la puerta de entrada, la cual corona con simple arco de medio punto de amplio dovelaje, sobre cuya clave aparecen representados una mitra y un báculo de obispo, como 
símbolos del santo titular del templo. Esta portada originalmente se encontraba situada sobre el muro meridional de la nave, si bien, en la década de 1970 fue trasladada al lugar que ocupa ahora. En su antiguo emplazamiento se colocó un gran sillar, reaprovechado de las obras, que en su día, se realizaron sobre la fábrica del templo, donde se recoge la siguiente inscripción: AD HONOR DEI ET S. MARTÍN ANO DNI. MDCCCLV.

En el interior, nos encontramos con el desarrollo de un sencillo concepto de ámbito único, dominado por el espacio de la nave, al cual se abre la cabecera, a través de un amplio arco apuntado de sección poligonal, apeado sobre columnas entregadas rematadas con capiteles poligonales, delimitados por gruesos anillos. Este espacio de la cabecera se cubre con una pesada bóveda de crucería octopartita de gruesos nervios, mientras que la nave presenta una sencilla cubierta de madera a dos aguas, sobre armadura de tipo parhilera. Fuera de este espacio queda el ámbito abierto en la base de la torre, el cual actualmente ha sido convertido en baptisterio y vestíbulo.

Los muros, en su cara interna, una vez eliminada la capa de enlucido original, muestran ahora un sobrio sillarejo, que alterna, en algunos puntos, con mampostería. La única ornamentación que existe, queda a cargo del retablo, situado en el altar mayor, y los dos colaterales, que aparecen escoltando la entrada al presbiterio. Todos ellos son de pequeño tamaño, y pertenecen a la etapa final del barroco. El del altar mayor es obra rococó, realizado entre las décadas de 1760-70, y cuenta con un solo cuerpo, articulado en tres calles, y remate. En la hornacina central aparece la imagen de San Martín, del siglo XV, acompañada por San Miguel y San Sebastián a los lados y la Virgen, en el remate. Los dos colaterales son obras gemelas de finales del siglo XVII, y está dedicados al Niño Jesús, el del lado de la epístola, y a Nuestra Señora del Rosario, el del evangelio $^{1100}$.

1100 R. J. PAYO HERNANZ: El retablo en Burgos y su comarca durante los siglos XVII y XVIII. Burgos. Excma. Diputación Provincial de Burgos. 1997. T. I. (pp. 373 - 374), T. II. (pp. 478). 
Resulta difícil reproducir la historia constructiva de este edificio, pues, como vemos, el análisis formal resulta poco revelador, y las fuentes documentales tampoco ayudan mucho. Aun así, sospechamos que este edificio pudo tener un pasado románico, del cual la pila bautismal, conservada en la entrada, sería su único testimonio. Se trata de una pieza sumamente original, de forma cúbica, alzada sobre cuatro patas, y decorada con arcos de herradura entrecruzados, que recorren todas sus caras. Este elemento ha sido interpretado como un símbolo apocalíptico de la Jerusalén celestial $^{1101}$.

Al margen de estas conjeturas, la fase más antigua, de la que tenemos absoluta constancia, se produce durante el período del gótico final, al cual pertenece la zona de la cabecera. Como ya hemos visto, la tosquedad de su estructura y la sencillez de los elementos que en ella aparecen, nos impiden precisar con seguridad una fecha concreta, si bien, y amparándonos en el arcaísmo que manifiestan muchas de estas construcciones, realizadas en estos pequeños pueblos de la comarca de la sierra, nos inclinamos a pensar en una cronología situada entre la segunda mitad del siglo XV o primeros años del XVI.

A partir de aquí, los únicos datos que tenemos sobre la historia de este edificio pertenecen ya a la segunda mitad del siglo XIX. Así, tal y como nos anunciaba la inscripción conservada sobre el sillar del muro meridional de la nave, en 1885 se realizan una serie de obras, que propician la renovación de la zona de la nave. Sin embargo, apenas tenemos datos, que nos informen sobre estas obras, pues aunque los libros de fábrica de la iglesia sí confirman la existencia de estos trabajos, éstos apenas nos dan detalles sobre su desarrollo y alcance ${ }^{1102}$.

\footnotetext{
1101 G. BILBAO LÓPEZ: Iconografía de las pilas bautismales del románico castellano: Burgos y Palencia. Burgos, Ed. La Olmeda, 1996. (pp. 57, 86).

1102 AGDBU. LP. Castrovido, parroquia de San Martín. LF. (1851 - 1893). (fol. 5). Cuentas del año 1855. Castrovido. 1855.
} 
A esta renovación de la nave le sigue, varias décadas después, la construcción de la sacristía, la cual se produce en 1893, tal y como nos indica la inscripción, que aparece sobre el dintel de la ventana, que mira hacia el lado meridional.

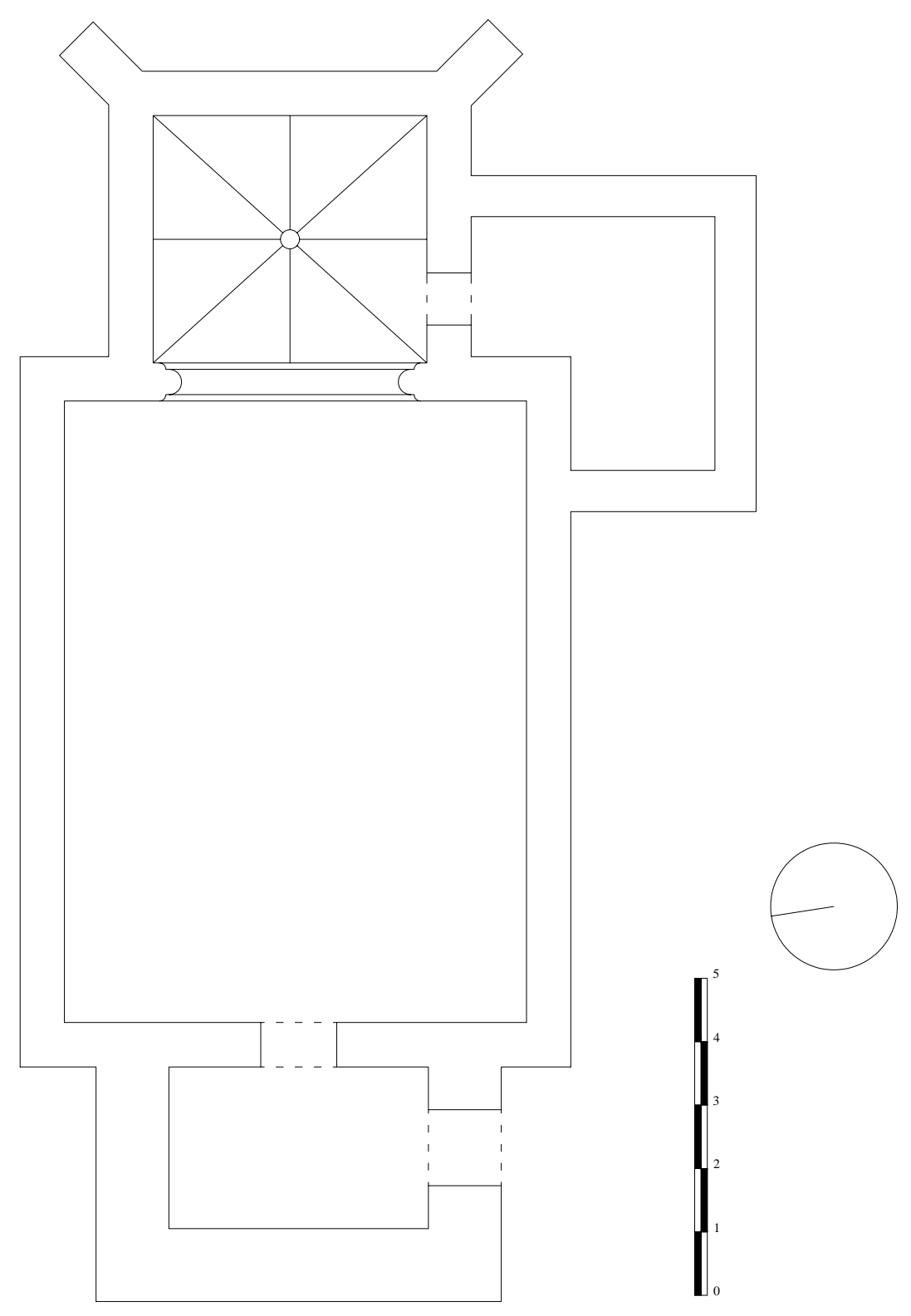




\section{Ermita de la Virgen del Carmen.}

Es la única ermita, que existe en el término municipal de Castrovido, y la única de la que tenemos constancia documental, pues los fondos conservados del antiguo archivo parroquial no dan testimonio de ninguna otra. Sí sabemos también, que ésta no fue su advocación original, pues anteriormente había estado dedicada a San Justo y San Pastor, titularidad que se mantuvo, al menos, hasta mediados del siglo $\mathrm{XIX}^{1103}$. En 1882, sin embargo, ya nos encontramos con la imagen de la Virgen del Carmen presidiendo su altar mayor ${ }^{1104}$.

Esta ermita se encuentra situada en la parte superior del pueblo, sobre la ladera que conduce al torreón, que domina el caserío. Cuenta con un sencillo edificio, resultado de una larga génesis constructiva, que ha deparado una estructura de tipo caja, sobre planta de una sola nave de trazado rectangular muy alargada, que se continúa en su extremo oriental con una cabecera plana de profundo presbiterio, sobre cuyo flanco meridional se añade la pequeña sacristía. Todo el edificio está realizado en piedra, con muros de sillería, tanto en el interior, como en el exterior, en los que apenas se muestran rasgos de las diferentes fases constructivas que ha ido conociendo.

Su imagen exterior está constituida por una sólida estructura prismática, de carácter achaparrado y cubierta a dos aguas, sobre cuyo lado meridional se incorpora el módulo, que forma la sacristía. La puerta de acceso queda orientada igualmente al mediodía, y está coronada con un sencillo arco escarzano. Sobre ella se alza una pequeña espadaña, de un solo vano coronado con arco de medio punto, que se remata con una cornisa, sobre la que aparecen, una cruz en el centro, escoltada por dos pináculos de bola de inspiración herreriana. A esta puerta le acompañan dos ventanas en este lado (una en la nave y otra en la cabecera) de trazado rectangular y dintel plano con pequeño abocinado hacia el exterior, y una más a los pies, bastante más ancha y sin abocinado. En la cornisa del lado septentrional de la cabecera, por último, se conservan

1103 P. MADOZ: Diccionario... ob. cit. (pp. 293). 
una serie de canecillos de época románica, en algunos de los cuales se aprecian los característicos modillones de rollo, de la llamada escuela románica de la sierra.

En el interior, su espacio único queda articulado en los dos ámbitos, que forman la cabecera y la nave, los cuales aparecen separados por un potente arco apuntado de aristas redondeadas con moldura de tres cuartos de bocel, que se continúa por las jambas, para formar pequeños baquetones. La mayor potencia de los muros de la cabecera, por otra parte, hace que este espacio sea más estrecho que la nave. La cubierta, en el caso de la nave, se resuelve con sencilla techumbre de madera a dos aguas sobre armadura de tipo parhilera, mientras que la cabecera muestra una pesada bóveda de medio cañón ligeramente apuntada, formada como resultado de la prolongación del arco toral, que enmarca su entrada. En el interior de esta cabecera, la separación entre el presbiterio y la capilla se realiza simplemente a través de la diferencia del nivel del suelo.

Este edificio, como decíamos, es el resultado de una larga historia constructiva, cuya secuencia comienza entre los siglos X-XI, según parecen indicar los restos de los sepulcros hallados en torno al ábside. Por otra parte, la propia estructura de la cabecera, pese a las modificaciones realizadas en ella, también nos recuerda la disposición y la traza de la arquitectura prerrománica de la zona, de época condal ${ }^{1105}$. También conserva, aunque de forma casi testimonial, como hemos visto, algunos elementos románicos, pertenecientes a las décadas iniciales del siglo XII, y que podemos atribuir al grupo de los primeros maestros de la escuela del románico de la sierra. Es por ello, que tal vez podamos considerar a este edificio como el templo parroquial de la primitiva población, que formó esta localidad de Castrovido, lo que llevaría a descartar la posibilidad de una fase románica en la fábrica de la iglesia parroquial.

1104 AGDBU. LP. Castrovido, parroquia de San Martín. LF. (1851 - 1893). (fol. 44 v ${ }^{0}$ - 45). Cuentas del año 1882. Castrovido, 31 - diciembre - 1882.

1105 L. A. CONTRERAS ABAD: Castrovido. Nuestros antepasados. Ob. cit. (pp 21 - 23). 


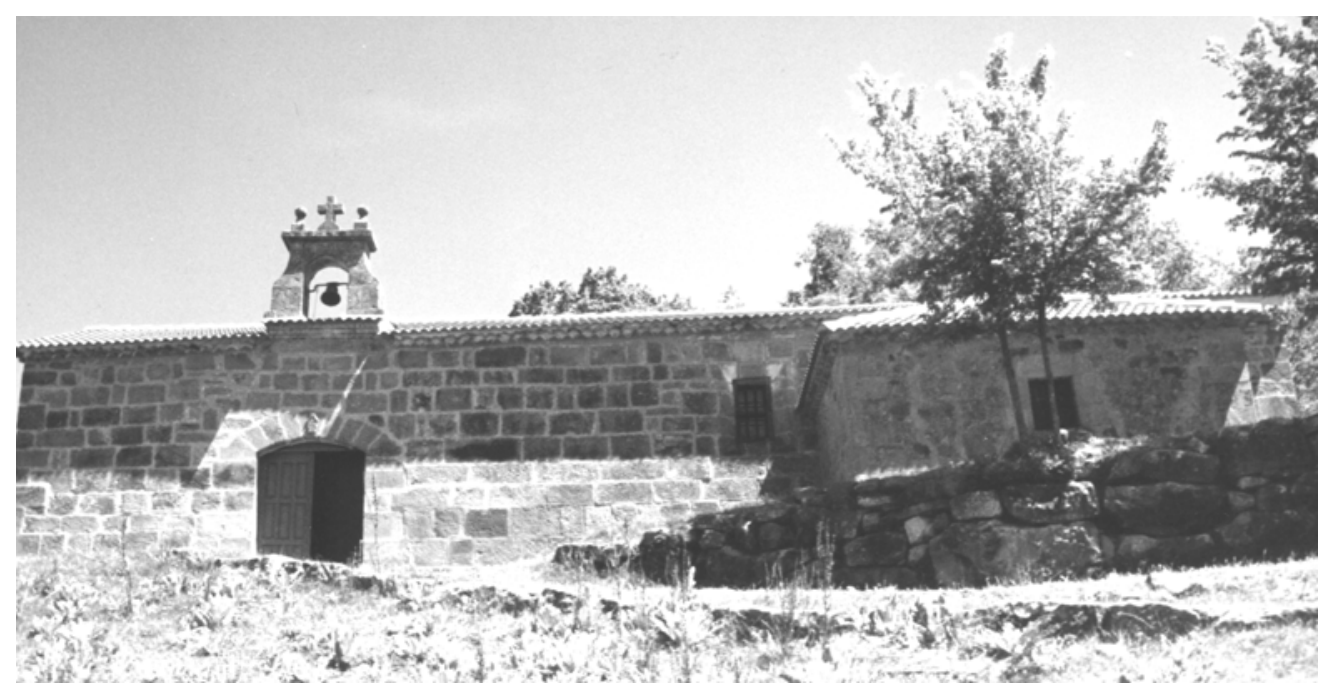

CASTROVIDO. Ermita de la Virgen del Carmen.

El edificio de esta ermita, sin embargo, fue completamente remodelado durante el período gótico, con un resultado que nos recuerda al ofrecido por otros templos de la zona, como por ejemplo, la actual ermita (antigua iglesia parroquial) de Santa María en Huerta de Arriba, y que podemos situar entre los siglos XIII y XIV. El resto del templo corresponde ya a una fase moderna, cuya ejecución podemos relacionar con las obras de construcción de la sacristía ${ }^{1106}$, edificada, según nos indica la inscripción conservada sobre el dintel de su ventana, en 1880. 
1106 Ibídem. 
HACINAS.

La villa de Hacinas se encuentra situada en el extremo sudoeste de nuestra comarca de estudio, hallándose ya dentro de la orla mesozoica, que rodea el núcleo de la Sierra de la Demanda. Su término municipal presenta por ello un terreno notablemente menos abrupto, con formas onduladas, salpicadas de suaves laderas, en las que aparecen diferentes afloramientos de calizas, areniscas y conglomerados. Hacinas, como el resto de las localidades próximas, complementa su término municipal con su participación en la administración y disfrute de las ledanías circundantes, aprovechando estos terrenos, tanto para uso agrícola como ganadero.

Las primeras referencias escritas, que tenemos sobre esta localidad, corresponden al siglo XII, en las cuales aparece nombrada como Facinas ${ }^{1107}$. Hasta este momento Hacinas había formado parte del alfoz de Lara ${ }^{1108}$, pasando a partir de aquí a quedar encuadrada dentro de la Merindad Menor de Santo Domingo de Silos ${ }^{1109}$.

1107 L. SERRANO: Cartulario de San Pedro de Arlanza. Madrid. Centro de Estudios Históricos. 1925. (pp. 182).

1108 G. MARTÍNEZ DÍEZ: Pueblos y alfoces burgaleses de la repoblación. Valladolid, Junta de Castilla y León. Consejería de Educación y Cultura. 1997. (pp.174).

1109 C. ESTEPA DÍEZ: "Estructura de poder en Castilla (siglos XII - XIII). El poder señorial en las merindades burgalesas. En III Jornadas burgalesas de Historia (3 1991). Burgos en la Plena Edad Media. Burgos, Asociación Provincial de Libreros de Burgos. 1994. (pp. 245 - 294). G. MARTÍNEZ DÍEZ: Génesis histórica de la provincia de Burgos y sus divisiones administrativas. Burgos, Aldecoa. 1983. 
Durante la Edad Moderna, en el plano fiscal, Hacinas forma parte del partido de Burgos, dentro de la provincia del mismo nombre ${ }^{1110}$, quedando encuadrada más adelante, tras la reforma borbónica del siglo XVIII, en el partido de Aranda ${ }^{1111}$. En lo que se refiere a su jurisdicción, Hacinas experimenta una interesante evolución, que parte de una condición de condominio, vivida durante la Baja Edad Media, pasando luego a ser señorío solariego, para terminar como villa de realengo. Así, a mediados del siglo XIV su jurisdicción se hallaba repartida entre dos señores laicos, como eran Juan Martínez y Avellaneda, y Juana, mujer de Juan Martínez de Leyva, y uno eclesiástico, como es el monasterio de Fuencaliente ${ }^{1112}$. En los primeros momentos de la Edad Moderna aparece ya solamente como señorío solariego, dependiente, en este caso, del conde D. Hernando de Andrade, cuya familia enlaza más tarde con la casa de los Zúñiga, lo que hace que se incluya esta localidad dentro del señorío de los condes de Monterrey $^{1113}$. Esta situación se mantiene a lo largo de la mayor parte de este período, hasta que a mediados del siglo XVIII, en el Catastro del Marqués de Ensenada, Hacinas es denominada como villa de realengo ${ }^{1114}$.

Su única parroquia quedó encuadrada, desde 1136, tras el concilio de Burgos, dentro de la Diócesis de Osma, tal y como ocurría con el resto de las localidades situadas en la margen izquierda de esta parte alta del curso del río Arlanza ${ }^{1115}$.

En los aspectos demográficos, Hacinas fue siempre una localidad de tipo medio, dentro de esta comarca, con unos niveles de población que apenas experimentaron

\footnotetext{
1110 G. MARTÍNEZ DÍEZ: Génesis histórica de la provincia de Burgos... ob. cit.

1111 Ibídem.

1112 G. MARTíNEZ DÍEZ: Libro Becerro de las Behetrías. Estudio y texto crítico. León, Centro de Estudios e Investigación San Isidoro. Caja de Ahorros y Monte de Piedad. Archivo Histórico Diocesano. 1981.(pp. 601).

1113 J. A. ÚZQUIZA: “Espigando en la Historia de Hacinas”. Amigos de Hacinas, nº 41, (1988). pp. 22 -24 .

1114 ADPBU. CE. 6. RESPUESTAS GENERALES. Hacinas, 7 - enero - 1753.

1115 L. SERRANO: El obispado de Burgos y Castilla primitiva. Desde el siglo V al XIII. Madrid. Centro de Estudios Históricos 1935. Tomo I (pp. 414 - 418).
} 
cambios drásticos durante todo este período. Los primeros datos que tenemos para este análisis pertenecen ya al último cuarto del siglo XVI, donde se sitúan el llamado censo de los obispos de 1584-87, con 77 vecinos $^{1116}$, y el censo de 1591, con 80 vecinos ${ }^{1117}$ contabilizados en cada uno de ellos respectivamente. Una cifra muy parecida arroja el censo de la sal, de 1631 , en el que se registran 82 vecinos $^{1118}$, lo que nos indica que, al menos en su primera etapa, esta localidad quedó al margen de los efectos de la crisis demográfica del Seiscientos, que sacudió la mayor parte de las comarcas burgalesas. El siglo XVIII presenta, por último, un moderado crecimiento, que se plasma en los datos del Catastro del Marqués de Ensenada, con 97’5 vecinos ${ }^{1119}$, y en los valores dados por el censo de Floridablanca de 1787, con 335 habitantes ${ }^{1120}$.

Su economía estuvo basada fundamentalmente en la agricultura, desarrollada fundamentalmente sobre tierras de secano, la cual se combinaba con algunos pequeños rebaños de ganado lanar y vacuno, para uso doméstico. Una economía, por lo tanto, más próxima a los modelos desarrollados en zonas de vega y páramos, que a los que podemos ver en el resto de los pueblos del interior de la sierra, con una gran especialización en determinadas actividades, como la ganadería extensiva o el transporte. Aun así, entre sus habitantes, también podemos encontrar algunos ejemplos de transportistas, que mediante mulas y carretas, trajinaban con mercancías dentro de un radio relativamente próximo al pueblo.

Su casco urbano se asienta sobre la falda de una suave ladera orientada hacia el mediodía, culminada por un poderoso afloramiento rocoso, en el que se conservan restos de una antigua fortaleza o torre de vigilancia. Estas ruinas hacen que este lugar sea conocido popularmente como el castillo. Junto a estos restos se alza la iglesia, que

1116 T. GONZÁLEZ: Censo de población de las provincias y partidos de la Corona de Castilla en el siglo XVI... Ed. Facsímil. Madrid, Imprenta Real. 1829.

1117 Censo de Castilla de 1591. Vecindario. Madrid, Instituto Nacional de Estadística. 1984.

1118 AGS. Dirección General del Tesoro, inventario 24. Leg. 1168 - 2.

1119 Vecindario de Ensenada 1759. Vol. I. Madrid, Centro de Gestión Catastral y Cooperación Tributaria: Tabapress. D. L. 1991. 
preside majestuosa todo el caserío, convirtiéndose al mismo tiempo, en el único edificio mínimamente relevante, que podemos señalar dentro del conjunto de esta localidad. El resto de los edificios, aparecen dispuestas sin ningún tipo de orden, formando un conjunto compacto, dentro del cual, según palabras de P. MADOZ, la mayoría de sus casas, son de inferior fábrica y no ofrecen comodidad alguna, excepto tres o cuatro de labradores, que tienen mejor construcción ${ }^{1121}$.

\section{Iglesia de San Pedro.}

La iglesia de Hacinas está dedicada a San Pedro, y se asienta, como decimos, sobre el afloramiento rocoso, que corona la ladera en la que se ubica el pueblo. El espacio que rodea este templo queda delimitado por un pequeño muro de piedra, que forma el atrio. Fuera de este recinto se levanta un espigado montículo rocoso, situado en su parte meridional, sobre cuyo vértice se eleva una airosa espadaña, formada por dos vanos con arco apuntado de estilo gótico. Actualmente esta espadaña está coronada por una escultura del Sagrado Corazón de Jesús, donada en 1928 por un vecino del pueblo, si bien, no fue colocada hasta el año $1941^{1122}$.

El templo propiamente dicho nos presenta un edificio de dimensiones modestas, bien proporcionado, y con un gran sentido de unidad en todo su conjunto, a pesar de los diferentes estilos que participan en su desarrollo. En su imagen domina principalmente la estética del barroco clasicista, desarrollado en la zona a partir de las primeras décadas del siglo XVII, si bien, también encontramos elementos pertenecientes a los estilos, románico, gótico final, y al barroco más movido. Presenta una planta de tres naves de dos tramos cada una, con una mayor anchura de la central. Sobre este cuerpo, en el extremo oriental, se añade la cabecera, de planta cuadrangular y testero plano con la

\footnotetext{
1120 INE. Censo de 1787. "Floridablanca”. Madrid. INE. 1989.

1121 P. MADOZ: Diccionario geográfico - estadístico - histórico de España y sus posesiones de Ultramar. Valladolid, Ámbito D.L. 1984. (pp.32).

1122 A. de JUAN GONZÁLEZ: “Dionisio González Lucas y el monumento al Sagrado Corazón de Jesús. Amigos de Hacinas” Burgos, nº 71 (1996), pp. 16-17.
} 
sacristía adosada sobre su flanco meridional, y en la parte de los pies la torre, también de planta cuadrangular, dispuesta en correspondencia con el ábside.

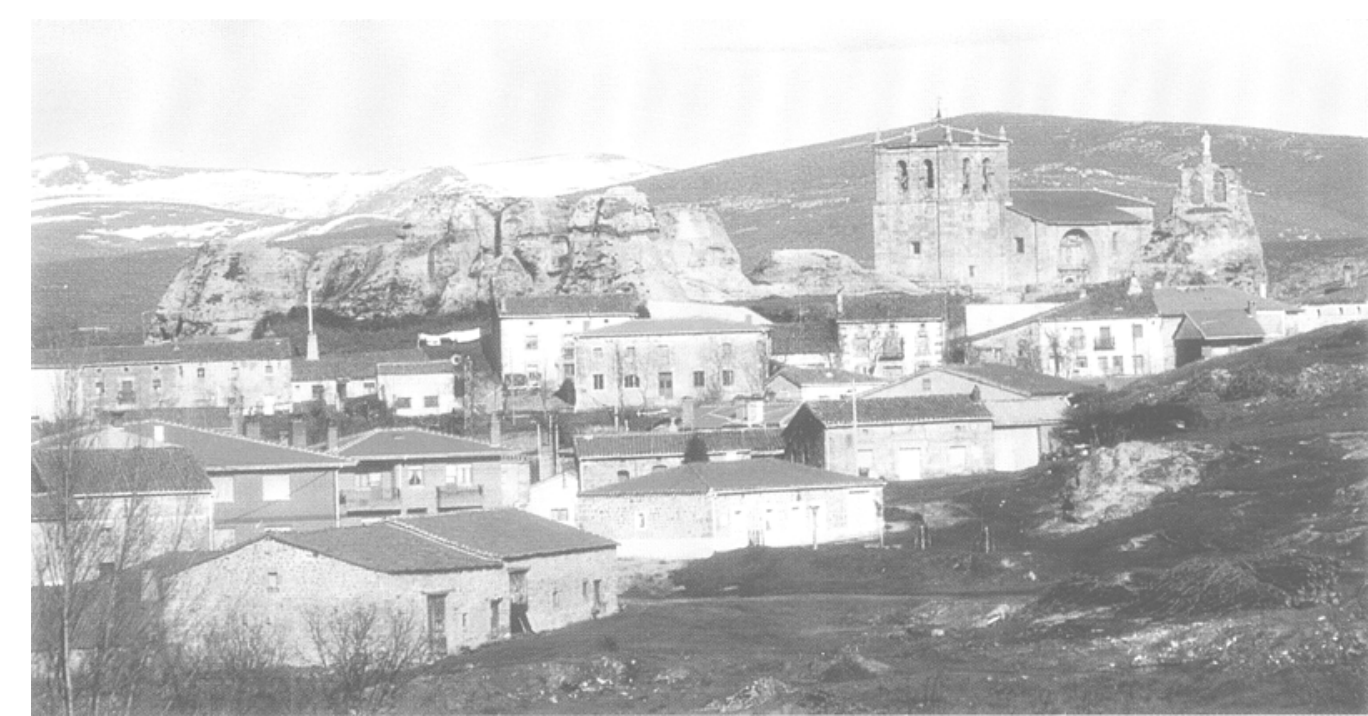

HACINAS.

Vista general del pueblo.

Todo el edificio se encuentra realizado en la característica piedra arenisca local de tonos dorados, extraída de canteras próximas, la cual aparece perfectamente labrada en sillares regulares. Sus muros se elevan sobre un pequeño zócalo, delimitado por una moldura, y están rematados por cornisa de cuarto de bocel y grueso listel. Estos muros se refuerzan exteriormente con sólidos estribos de formas prismáticas, dispuestos en diagonal, en el caso de las esquinas del muro del testero, y en ángulo recto con sus lados en paralelo al muro, en el resto. Con todo ello se consigue una imagen exterior concebida mediante limpios volúmenes de formas prismáticas, bien perfilados y proporcionados, dominados por la masa que conforma la zona del cuerpo. El único elemento que rompe esta idea de uniformidad lo encontramos en la torre, situada a los pies, la cual, a pesar de su carácter achaparrado, se convierte en el auténtico contrapunto vertical de este templo. Está formada por un sólido prisma de planta cuadrangular, reforzada en las esquinas con sólidos contrafuertes, y articulada en dos cuerpos 
desiguales, separados por una línea de imposta plana de escaso resalte. En el cuerpo inferior, únicamente destaca el vano cuadrado enmarcado por moldura plana con orejones, abierto en su muro de poniente, con el cual se ilumina el espacio interior del templo, desde la zona de los pies. En el cuerpo superior repite la misma estructura en cada una de sus caras, con dos vanos, para alojar las campanas, coronados con arco de medio punto, separados por anchas pilastras sobre las que se extiende un friso y una cornisa, que dan paso al tejado. Aquí, y en correspondencia con el eje de cada una de estas pilastras, se alzan pequeños pináculos piramidales, con los que se remata todo el conjunto. Un pequeño husillo, adosado sobre el flanco septentrional, con entrada desde el exterior del templo, completa esta pieza, permitiendo el acceso al cuerpo de campanas.

Las ventanas, que iluminan el interior del templo, quedan orientadas hacia el mediodía y poniente, y en ellas nos encontramos con una interesante variedad de trazados, con los cuales podemos hacer un recorrido por la historia constructiva del templo. Así, en la sacristía se conserva una ventana de tipo aspillera, con fuerte abocinado hacia el exterior, reaprovechada, con toda seguridad, de un templo románico anterior. En la cabecera aparece una ventana de arco de medio punto, y estructura abocinada con doble moldura cóncava hacia el exterior, de transición entre el gótico y el renacimiento. En la zona del cuerpo, por último, encontramos dos ventanas más de trazado rectangular y dintel plano, con ligero derrame hacia el exterior, y marco con orejones, que incluimos dentro de la estética del barroco clasicista.

La portada, por su parte, constituye el elemento más interesante de la imagen exterior de este templo. Esta portada, tal y como ya señalamos en el capítulo correspondiente a las formas propias del siglo XVII en la zona, nos ofrece un destacado ejemplo del barroco más avanzado, presentando un conjunto de gran dinamismo, con formas muy movidas, de fuerte resalte sobre el plano del muro, y nutrida combinación 
de tramos recto y curvos, que ciertamente constituyen una interesante novedad, dentro de la arquitectura desarrollada aquí en este período ${ }^{1123}$.

En el interior, nos encontramos con una imagen tendente al ámbito único, levemente interrumpida por la presencia de los pilares centrales, y marcada por un claro sentido longitudinal, siguiendo el eje trazado en torno a la nave central. Todo este espacio presenta cubiertas elevadas a una misma altura, lo cual favorece la sensación de amplitud, repitiendo en todas ellas la bóveda de crucería estrellada con terceletes de tradición gótica. Mayor variedad encontramos, sin embargo, en los arcos, que separan cada uno de estos tramos. Así, mientras los fajones de las naves central y laterales, el toral de la cabecera y el arco que conduce al espacio del coro en los pies, presentan un trazado apuntado, las líneas de los formeros utilizan amplios arcos de medio punto. Por otra parte, y junto a esto, vemos también cómo los arcos fajones de la central y el toral de cabecera presentan una rosca finamente moldurada, mientras que en el resto muestran sencilla sección cuadrada con intradós plano. Evidentemente se trata del resultado de una combinación de dos factores, por un lado, las necesidades constructivas, que propician las cubiertas elevadas a un mismo nivel, y por otro, el cambio de estilo, que se produce entre la construcción de la nave central y las laterales.

Esto tiene también sus consecuencias en los soportes sobre los que apean estos arcos y nervios de las bóvedas. Así, los pilares cuentan con un núcleo central de sección cuadrada con un haz de tres columnas sobre el frente que mira hacia el interior, rematadas con fajas corridas, decoradas con relieve de bolas. En los tres frentes restantes se incorporan pilastras de orden dórico, las cuales se corresponden en los muros con pilastras similares. El arco que conduce al interior de la cabecera, por su parte, descansa sobre sencillas columnas de fuste liso, rematadas con capiteles de estilo románico, reaprovechados de un edificio anterior. Son dos capiteles decorados, el uno, con sencillos motivos vegetales, y el otro, con una representación de un combate entre un caballero y un león, al cual atraviesa el cuello con su espada.

1123 Ver capítulo: Actividad constructiva. Evolución estilística. Siglo XVII. 
La imagen interior de este templo se completa con los retablos que adornan sus respectivos altares, en los cuales encontramos las formas propias del barroco más exaltado, que contrasta con la severidad desarrollada en la estructura del edificio. En total son cinco retablos, los cuales están dedicados a San Pedro, el del altar mayor, y a Nuestra Señora del Rosario, Santo Cristo, San Antonio y San Roque los colaterales ${ }^{1124}$. Junto a estos retablos debemos mencionar también los restos de un sepulcro, situado en el muro septentrional del presbiterio, el cual está formado por un amplio arco de medio punto de arista redondeada por moldura de tres cuartos de bocel, que se continúa por las jambas, mediante finos baquetones. Un escudo corona el conjunto con campo cuartelado en cruz, $1^{\circ}$ con un sol, $2^{\circ}$ una cruz decussata o de San Andrés, $3^{\circ}$ unas llaves de San Pedro cruzadas, y $4^{\circ}$ una flor de lis. Aunque se han dado diferentes interpretaciones sobre la propiedad de este escudo, no hemos encontrado ninguna prueba documental, que lo certifique. En la actualidad estas armas han sido adoptadas por el ayuntamiento de Hacinas como escudo de la localidad.

Tal y como decimos, este templo presenta una historia larga y compleja, la cual, en gran medida, podemos reconstruir, merced a los vestigios materiales conservados de épocas anteriores, y a los datos aportados por las fuentes documentales. Estos vestigios nos hablan de la existencia de una fase románica, la cual, a tenor de los elementos conservados, debemos considerar la más antigua. Dentro de estos restos destacan, los capiteles situados en la entrada de la cabecera, la pila bautismal, de copa semiesférica decorada con guirnaldas vegetales y diferentes filas de hojas imbricadas ${ }^{1125}$, y la pequeña ventana aspillera, colocada en la sacristía. Las formas desarrolladas en estas piezas, especialmente en el caso de los capiteles y la pila bautismal, nos permiten

1124 R. J. PAYO HERNANZ: : El retablo en Burgos y su comarca durante los siglos XVII y XVIII. Burgos. Excma. Diputación Provincial de Burgos. 1997. T. I. (pp.491).

1125 G. BILBAO LÓPEZ: Iconografía de las pilas bautismales del románico castellano; Burgos y Palencia. Burgos, Ediciones la Olmeda. 1996. (pp. 53, 107). 
encuadrarlas dentro de la estética relacionada con los talleres de Silos, que expandieron sus modelos por esta zona a lo largo de la segunda mitad del siglo XII ${ }^{1126}$.

La época gótica trae la renovación completa de este edificio, levantando en su lugar una fábrica totalmente nueva. Esta renovación se produce en la etapa final de este estilo, dentro del período conocido como Reyes Católicos. El templo que surge de aquí, como ya vimos en su momento, debía mostrar una sencilla estructura de tipo caja, con una sola nave articulada en diferentes tramos, de los cuales el delantero formaría la cabecera $^{1127}$. A pesar de las modificaciones posteriores, todavía resulta fácil identificar la estructura de este templo gótico en el edificio actual, convertido ahora en su nave central. Entre los elementos más característicos de este momento, que todavía podemos contemplar, debemos destacar los arcos apuntados de rosca finamente moldurada, los soportes rematados con capitel de faja, decorados con relieve de bolas, las cubiertas con sus claves enmarcadas con festones cairelados, la ventana del presbiterio, y la disposición de los estribos, que refuerzan las esquinas de los muros del ábside. Todo ello nos permite situar cronológicamente este edificio entre las décadas finales del siglo XV y primeros momentos del XVI.

Al mismo tiempo, dentro de este período gótico existen algunos indicios que nos permitan hablar de dos fases, o momentos constructivos, diferentes aunque consecutivos. Al menos esto es lo que se desprende al observar la línea de canecillos, que se conservan en la parte exterior del muro del testero de la capilla mayor, los cuales nos hablan de la existencia de una cubierta anterior, que se situaba por debajo de la actual bóveda.

El epílogo, aunque lejano, de esta renovación del templo se produce ya en el último tercio del siglo XVI, momento en el cual se construye la torre, que deja sin uso a la espadaña anterior. El encargado de realizar esta obra fue el maestro Pedro Ribero, el

1126 J.A. ÚZQUIZA: “Espigando en la Historia de Hacinas. VIII Templo y ermitas (1ª parte)”. Amigos de Hacinas. Burgos, no 45 (1989), pp. 30-32. 
cual terminó su trabajo en 1576, participando en la tasación final los maestros Juan de la Fragua $^{1128}$ y Germán Sanz del Prado. La suma de las cantidades entregadas por esta iglesia superó los 3.500 reales $^{1129}$. Una década después los visitadores del obispado de Osma ordenaron que se construyera la escalera de dicha torre ${ }^{1130}$. Nada sabemos, sin embargo, sobre el aspecto de esta primitiva torre, pues como veremos, apenas medio siglo después fue sustituida por otra nueva.

De esta forma, llegamos al siglo XVII, momento en el que se produce la última y definitiva fase constructiva, que vive este templo, fruto de la cual surge su imagen actual. Lo más interesante de estos trabajos, al margen de la completa renovación que se produce de la estructura de este templo, lo encontramos en el aspecto puramente formal, pues se introducen ahora las formas propias del clasicismo barroco, que desde principios de esta centuria del Seiscientos, empiezan a extenderse por esta comarca. Tras este proyecto de renovación y ampliación, el templo adquiere su imagen definitiva.

Esta última fase se inicia con la construcción de la nueva torre, la cual viene a sustituir a la que acaban de construir en 1576. Esta nueva obra se realiza a finales de la década de 1620, bajo la iniciativa del párroco de esta iglesia D. Pedro González Varaona ${ }^{1131}$. Participa en ella el prestigioso maestro de cantería Pedro Díaz de Palacios $^{1132}$, con la colaboración del maestro de carpintería, también trasmerano, Lucas de Arredondo, encargado de las partes realizadas en madera ${ }^{1133}$. Desconocemos el coste final que alcanzó la obra, pues la documentación conservada apenas nos aporta datos concretos sobre ello. No obstante, si sumamos los distintos pagos, registrados en las

\footnotetext{
1127 Ver capítulo: Actividad constructiva. Evolución estilística. Siglo XVI.

1128 El maestro Juan de la Fragua se encontraba, en estos mismos momentos realizando la construcción de la torre de la iglesia de San Esteban, en la vecina localidad de Castrillo de la Reina.

1129 AGDBU. LP. Hacinas, parroquia de San Pedro. LF. (1572 - 1702). Cuentas del año 1576. Hacinas, 7 - noviembre - 1576; Ibídem. Cuentas del año 1576. Hacinas, 1577.

1130 Ibídem. Visita realizada a la parroquia de San Pedro de Hacinas, en 1585. Hacinas, 1 - mayo - 1585.

1131 Ibídem. Hacinas 1628.

1132 Ibídem.

1133 Ibídem. Cuentas del año 1630. Hacinas 1631.
} 
cuentas que se han conservado, obtenemos una cifra próxima a los 12.000 reales, sólo para los trabajos de cantería. Para hacer frente a estos gastos, esta fábrica contó con la ayuda de vecinos y diferentes instituciones del pueblo, como es el caso de la ermita de Santa Lucía o la obra pía para casar doncellas, fundada por el antiguo párroco de esta iglesia, D. Juan Martínez Barranco ${ }^{1134}$.

El segundo paso, dentro de esta fase constructiva, consiste en la construcción de las dos naves laterales, con las cuales se logra prácticamente duplicar el espacio disponible en el interior del templo. Esta obra se realiza respetando complemente la estructura del cuerpo de la iglesia anterior, adaptando las nuevas naves a las proporciones marcadas por aquella, pero mostrando, eso sí, un lenguaje formal completamente nuevo. El vacío documental, que se extiende, dentro de los registros de cuentas de esta iglesia, desde la década de 1640 a la de 1670, nos impide conocer los nombres de los artífices y demás detalles del desarrollo de estas obras. Aun así, sabemos que uno de los principales impulsores del proyecto fue el párroco de este momento, D. Matías Moreno, el cual, con una aportación de algo más de 2.500 reales, consigue que los trabajos puedan ponerse en marcha ${ }^{1135}$. Retoma, de este modo, el testigo dejado por su antecesor, D. Pedro González de Varaona.

El broche final a esta fase constructiva lo pone la portada, levantada por el maestro de cantería Francisco de Hermosa (o Hermosilla), en 1684 sobre el muro meridional del cuerpo, recién levantado. Desconocemos también aquí los detalles que rodearon este proceso constructivo, así como el presupuesto final que alcanzó la obra, si bien, sumando los diferentes pagos entregados por la iglesia a este maestro obtenemos una cantidad de 192.834 maravedís $^{1136}$. Este maestro contó con la colaboración del maestro Bartolomé de la Torre, que le ayudó en la ejecución de parte de los trabajos ${ }^{1137}$.

\footnotetext{
1134 Ibídem. Visita realizada a la parroquia de San Pedro de Hacinas en 1634, por D. Pedro Sanz, abad de San Bartolomé. Hacinas, 6 - abril - 1634.

1135 Ibídem. Cuentas del año 1691. Hacinas, 5 - noviembre - 1691.

1136 Ibídem. Cuentas del año 1684. Hacinas 1685.

1137 Ibídem. Cuentas del año 1685. Hacinas, 18 - julio - 1686.
} 
Al siglo XVIII, por lo tanto, llegamos con un templo completamente renovado, el cual no vuelve a sufrir más cambios en su estructura a partir de ahora. Esto no evita, sin embargo, que se continúen desarrollando diferentes trabajos de conservación, mejora y mantenimiento del edificio heredado, los cuales, en algunos casos, alcanzan presupuestos ciertamente elevados. Este es el caso de la renovación del enlosado del interior del templo, efectuado en torno al año 1725, con un presupuesto superior a 3.400 reales $^{1138}$. Un coste más elevado aun alcanzaron los trabajos de retejo universal de la iglesia, sacristía y torre, llevados a cabo en 1783. En este caso, la cantidad invertida por esta iglesia llegó hasta los 4.727 reales $^{1139}$. En torno a estos mismos años finalizaron también las obras de adecuación del entorno del edificio, con la construcción del muro que delimita el atrio, y el rellenado del terreno, en aquellas partes donde fue necesario. Estos trabajos habían comenzado varios años antes, a principios de la década de 1730, con la demolición de parte del afloramiento rocoso, que emergía frente a la zona de la torre $^{1140}$. El final de estos trabajos se produce, como decimos, en 1781, con la construcción del muro que delimita el espacio del atrio, lo cual alcanzó un coste cercano a los 3.000 reales $^{1141}$.

Sin embargo, las actuaciones más destacadas, que conoce esta iglesia a lo largo de este siglo XVIII, son las relacionadas con la ornamentación de su espacio interior, donde encontramos la construcción de los diferentes retablos, que adornan sus altares. El primero que se construye es el del altar mayor, levantado en 1704 por el maestro Domingo Romero, el cual percibió de esta fábrica un total de 5.500 reales, repartidos en varias entregas $^{1142}$. El proceso de dorado del mismo, no obstante, tuvo que esperar hasta

\footnotetext{
1138 Ibídem. LF. (1703 - 1759). Cuentas del año 1725. Hacinas, 20 - diciembre - 1725.

1139 Ibídem. LF. (1778 - 1866). Cuentas del año 1783. Hacinas, 6 - febrero - 1784.

1140 Ibídem. LF. (1703 - 1759). Cuentas del año 1730. Hacinas, 11 - febrero - 1733.

1141 Ibídem. LF. (1778 - 1866). Cuentas del año 1781. Hacinas, 30 - septiembre - 1781.

1142 Ibídem. LF. (1703 - 1759). (fols. $44 v^{0}-47 v^{\circ}$ ). Cuentas del año 1704 . Hacinas, 4 - septiembre 1705.
} 
el año $1725^{1143}$, el cual se realizó en cumplimiento del mandato dejado por el visitador del obispado de Osma, D. José Iparín Ibáñez, unos años antes ${ }^{1144}$.

A este retablo le siguen los dedicados a Nuestra Señora del Rosario y al Santo Cristo, realizados a mediados de la década de 1740, con un intervalo de sólo dos años. El primero en construirse fue el de Nuestra Señora del Rosario, realizado en 1744, destinando esta fábrica para ello una cantidad aproximada de 3.000 reales $^{1145}$. El dorado del mismo, por su parte, no se realiza hasta los años 1752-53, con una aportación de la fábrica de 3.912 reales $^{1146}$. En 1761 se completa el retablo con la compra de una nueva imagen de su titular, con un coste de 706 reales ${ }^{1147}$. El retablo del Santo Cristo se realiza, por su parte, en 1746, con un coste para la iglesia de 3.000 reales, los cuales fueron abonados en una sola entrega ${ }^{1148}$. El dorado del mismo se produce, igual que en el caso anterior, ya en los primeros años de la década siguiente, ascendiendo su importe hasta los 3.865 reales, a los que sumamos otros 51 reales más, por las mejoras introducidas por el maestro ${ }^{1149}$.

En 1761 se construye el retablo dedicado a San Antonio, en cuya realización participa esta iglesia con 3.134 reales $^{1150}$, a los cuales debemos sumar otros 260 reales más, por la compra de la imagen del santo titular ${ }^{1151}$. El dorado de todo el retablo se completa a finales de esta misma década, invirtiendo en ello esta fábrica un total de 4.545 reales. Parte de esta cantidad, sin embargo, fue destinada a sufragar el cambio de

\footnotetext{
1143 Ibídem. Cuentas del año 1725. Hacinas, 20 - diciembre - 1725.

1144 Ibídem. (fols. $108 v^{0}$ - 112). Visita realizada a la parroquia de San Pedro en Hacinas en 1720, por D.

José Iparin Ibáñez, abad de Santa Cruz y canónigo. Hacinas, 24 - abril - 1720.

1145 Ibídem. Cuentas del año 1744. Hacinas, 29 - octubre - 1744.

1146 Ibídem. Cuentas del año 1752. Hacinas, 14 - julio - 1753.

1147 Ibídem. LF. (1758 - 1777). Cuentas del año 1761. Hacinas, 13 - septiembre - 1762.

1148 Ibídem. LF. (1703 - 1759). Cuentas del año 1744. Hacinas, 29 - octubre - 1744

1149 Ibídem. Cuentas del año 1750. Hacinas, 3 - marzo - 1751.

1150 Ibídem. LF. (1758 - 1777). Cuentas del año 1761. Hacinas, 13 - septiembre - 1762.

1151 Ibídem. Cuentas del año 1762. Hacinas, 22 - octubre - 1763.
} 
ubicación del retablo, colocándolo en su emplazamiento definitivo, sobre el muro lateral del primer tramo de la nave del evangelio ${ }^{1152}$.

El último de estos retablos en construirse es el dedicado a San Roque, realizado en 1782, con una participación de la iglesia de sólo 233 reales ${ }^{1153}$. Más generosa se mostró la parroquia, sin embargo, en las labores de dorado y estofado del mismo, realizadas una década más tarde, en las que aporta un total de 4.180 reales $^{1154}$.

La imagen interior de este templo se completa, finalmente con la construcción del cancel de la entrada, y el púlpito. El primero fue realizado por el maestro arandino Manuel Einazero en 1757, y la fábrica de la iglesia le entregó por su trabajo algo más de 4.000 reales, repartidos en diferentes pagos ${ }^{1155}$. El púlpito, por su parte, se realiza en 1769 con un presupuesto de 545 reales $^{1156}$. Se trata de una construcción de madera, que fue posteriormente estofada y dorada en 1794, por un precio de 600 reales $^{1157}$, aprovechando las labores de dorado realizadas en el último de los retablos construidos en esta iglesia. Actualmente este púlpito se conserva en la ermita de Santa Lucía de esta misma localidad $^{1158}$.

\footnotetext{
1152 Ibídem. Cuentas del año 1767. Hacinas, 10 - noviembre - 1767.

1153 Ibídem. LF. (1778 - 1866). Cuentas del año 1782. Hacinas, 16 - enero - 1783.

1154 Ibídem. Cuentas del año 1794. Hacinas, 12 - julio - 1794.

1155 Ibídem. LF. (1703 - 1759). Cuentas del año 1757. Hacinas, 24 - marzo - 1758; Ibídem. Cuentas del año 1758. Hacinas, 16 - abril - 1759; Ibídem. LF. (1758 - 1777). Cuentas del año 1759. Hacinas, 16 abril -1760 .

1156 Ibídem. Cuentas del año 1769. Hacinas, 18 - octubre - 1769.

1157 Ibídem. LF. (1778 - 1866). Cuentas del año 1794. Hacinas, 12 - julio - 1794.

1158 A de JUAN GONZÁLEZ: “La ermita de Santa Lucía”. Amigos de Hacinas, nº 72. (1996). pp. 43 45.
} 


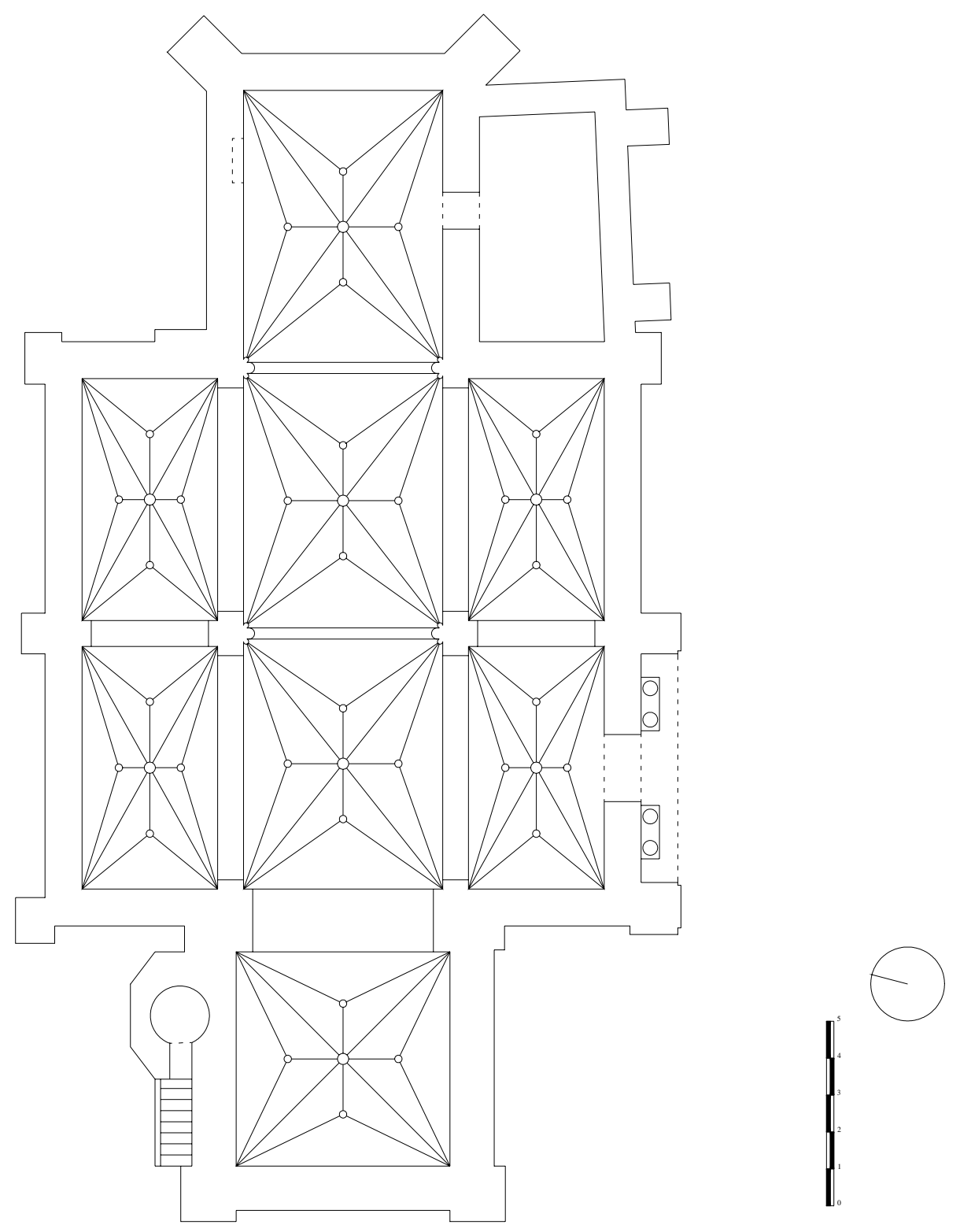

HACINAS. Iglesia de San Pedro. Planta. 
Ermitas.

Esta localidad de Hacinas contó con un total de seis ermitas, repartidas por su término municipal, las cuales estaban dedicadas a Santa Lucía, Santiago, San Cebrián, María Magdalena, la Vera Cruz, y Nuestra Señora de la Pinilla o Pinilloja ${ }^{1159}$. De ellas, sin embargo, solamente la primera ha llegado hasta nuestros días.

\section{Ermita de Santa Lucía.}

Como decimos, esta ermita es la única que ha conseguido mantenerse en pie hasta nuestros días, si bien, su edificio actual bien poco tiene que ver con el que debió existir durante la Edad Moderna. Esta ermita se halla situada a escasos quinientos metros del pueblo, en dirección oeste, ocupando el centro de una pequeña explanada, que se extiende junto a la carretera, que une Burgos y Soria. Nada queda actualmente, como decimos, de lo que fue su edificio original, el cual desapareció prácticamente por completo durante las obras de ampliación efectuadas en $1792^{1160}$. El templo actual, sin embargo, es el producto de una remodelación posterior, realizada a comienzos del siglo XX, por el cantero Juan Gonzalo, bajo el impulso, entre otros, del párroco de esta localidad en este momento, D. Remigio Peña ${ }^{1161}$.

Como resultado de ello surge un templo de planta basilical de tres naves, la central de mayor anchura que las laterales, articuladas en tres tramos, y rematadas por una cabecera plana, escoltada a los lados por dos pequeñas estancias, que forman la sacristía y un pequeño cuarto trastero. Todo el edificio queda inscrito, por lo tanto, dentro de un rectángulo perfecto, de unos 30 metros de largo por 16’6 metros de ancho.

Esta fábrica está realizada en piedra, con sólidos muros de sillería rematados con una cornisa de papo de paloma. La parte de los pies está reforzada por unos potentes y

\footnotetext{
1159 A. ANTÓN: “Ermitas”. Amigos de Hacinas, no 73. (1996). pp. 26 - 28.

1160 AGDBU. LP. Hacinas, cofradía de Santa Lucía. LF. (1730 - 1836). (fols. 63 vo - 64). Cuentas del año 1790. Hacinas, 24 - junio - 1791.
} 


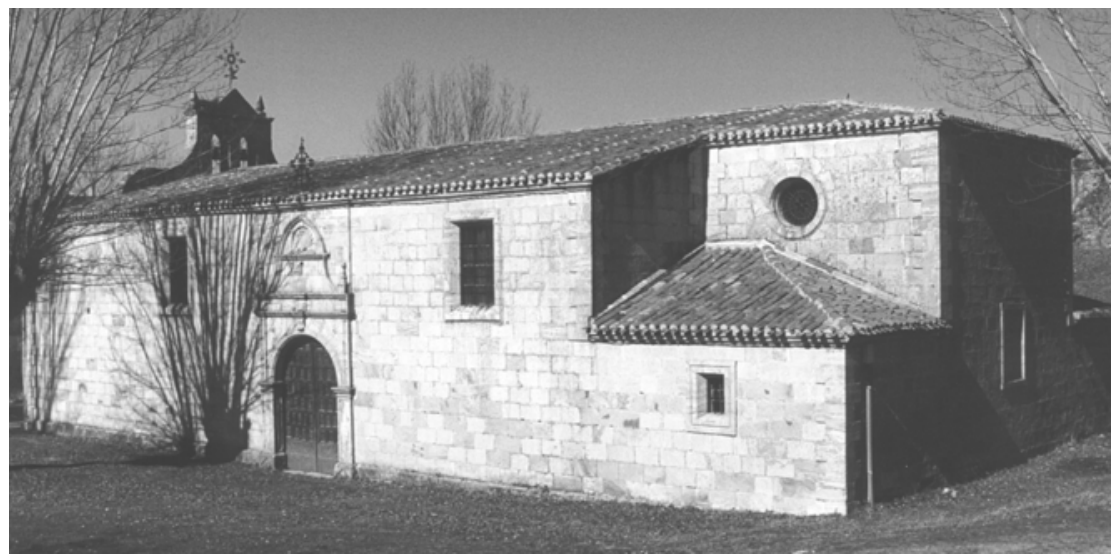

HACINAS. Ermita de Santa Lucía.

antiestéticos contrafuertes, que fue necesario colocar en 1933, ante la amenaza de ruina, que presentaba esta zona del templo ${ }^{1162}$. Sobre este mismo muro se alza también una sencilla espadaña, con dos vanos, escoltada por dos grandes aletas avolutadas, y rematada con un frontón recto, acompañado por pináculos piramidales. El acceso al interior se puede hacer a través de tres puertas, dos de ellas abiertas sobre el muro de los pies, con arco de medio punto, y la principal dispuesta hacia el mediodía. De ellas, sólo esta última cuenta con un tratamiento especial, mostrando una estructura de escaso resalte, de rasgos eclécticos, en la que se funden elementos tomados de distintos estilos artísticos. Consta de un amplio arco de medio punto, escoltado por dos niveles de pilastras cajeadas, entre las que se extiende un grueso friso, rematado con pináculos en los extremos, elevándose en el centro una especie de peineta, coronada con una venera, dispuesta bajo arco apuntado.

En el interior, nos encontramos con un amplio espacio de ámbito único, de muros encalados. Cada tramo de sus naves se encuentra cubierto con bóvedas de escayola, de superficie recorrida por finos nervios, que forman una traza octopartita,

${ }^{1161}$ A de JUAN GONZÁLEZ: “La ermita de Santa Lucía”. Ob. cit. 
separadas por arcos de medio punto de intradós plano, que apean sobre pilares de estructura prismática. Una obra, por lo tanto, que se inspira, salvando las distancias, en los modelos del clasicismo barroco, que calaron de forma tan profunda en la arquitectura de la zona, durante los siglos XVII y XVIII.

En el entorno de esta ermita se realiza una de las romerías más populares de la comarca, a la cual acuden devotos de todos los pueblos circundantes. Actualmente las fiestas patronales de esta localidad se celebran en honor de esta santa.

\section{Ermitas desaparecidas.}

Del resto de las ermitas, la dedicada a Santiago es, sin duda, la más desconocida. Sabemos, no obstante, que se encontraba situada en las inmediaciones del pueblo, sobre un cerro que lleva su nombre ${ }^{1163}$. Actualmente, todavía es posible apreciar parte de la planta de este edificio, a través de los restos dejados en el lugar donde se encontraba, los cuales nos indican que se trataba de una construcción de pequeñas dimensiones. Estos restos fueron mencionado en su momento por P. MADOZ en su Diccionario ${ }^{1164}$.

La ermita de San Cebrián (o San Cipriano), se hallaba situada en un altozano a las afueras del pueblo, conocido con un topónimo derivado del nombre de este templo, donde actualmente se encuentra el depósito de aguas ${ }^{1165}$. No ha llegado ni un solo resto de ella, con lo cual, desconocemos cual era su aspecto y dimensiones. Sí sabemos, sin embargo, que tuvo que ser reparada en diferentes ocasiones, durante la primera mitad del siglo XVII. Una de estas reparaciones tuvo lugar en el año 1600, durante la cual el concejo de la villa, como patrono de la misma, se comprometía a aportar toda la piedra necesaria ${ }^{1166}$. Más importantes, sin embargo, fueron las obras realizadas en 1627, en las

\footnotetext{
1162 Ibídem.

1163 A. ANTÓN: "Ermitas”. Ob. cit.

1164 P. MADOZ: Diccionario... ob. cit.

1165 A. ANTÓN: "Ermitas". Ob. cit.

1166 AGDBU. LP. Hacinas, parroquia de San Pedro. LF. (1572 - 1702). Visita realizada a la parroquia de San Pedro de Hacinas en 1600. Hacinas, 1600.
} 
cuales prácticamente se reconstruye por completo su edificio. El encargado de realizar estos trabajos fue el maestro Juan de Penagos, el cual remató la obra en 800 reales $^{1167}$. A mediados del siglo XVIII, sin embargo, ya no quedaba nada de ella.

La ermita de la Magdalena se encontraba situada en el lugar conocido como las Peñas de la Canal, junto a las eras de Santa María, a las afueras del pueblo ${ }^{1168}$. Como testimonio de su presencia todavía se observan en el terreno algunos restos de teja y piedras. Fue una de las primeras en desaparecer, lo que hace que apenas tengamos testimonios de ella.

La ermita de la Vera Cruz era la única que se encontraba dentro del pueblo, como suele ser costumbre entre las ermitas dedicadas a esta advocación. En ella se asentaba la cofradía del mismo nombre, a la cual pertenecía su patronato. Es la última de las ermitas de este pueblo en desaparecer, perdiendo su rastro entre los años 1816 y $1829^{1169}$. A partir de aquí, imaginamos que sus restos fueron languideciendo, hasta que en 1877 se decide levantar sobre este solar la nueva escuela ${ }^{1170}$. En esta nueva construcción, sin embargo, se reaprovechan parte de sus materiales, e incluso alguno de sus muros, lo cual nos permite apreciar sobre su fachada meridional, los restos del arco de medio punto, que enmarcaba su entrada, convertidos hoy en una ventana.

Por último, tenemos la ermita de Nuestra Señora de la Pinilla o Pinilloja, de la cual, sobre la cual tampoco contamos muchas noticias. De hecho, ni siquiera podemos concretar el lugar preciso en el que se ubicaba. Fue también de las últimas en desaparecer, si bien, ya desde mediados del siglo XVIII, comienza a dar signos evidentes de abandono, que terminan por convertirse en una lenta agonía. Así, en 1756, el visitador del obispado de Osma, D. Juan Fernández de Arcos, denuncia que este

\footnotetext{
1167 Ibídem. Cuentas del año 1627. Hacinas, 1627; Ibídem. Cuentas del año 1628. Hacinas, 1628.

1168 A. ANTÓN: "Ermitas”. Ob. cit.

1169 AGDBU. LP. Hacinas, parroquia de San Pedro. LF. (1778 - 1866). Visita realizada a la parroquia de San Pedro de Hacinas en 1816, por D. Juan de Caabro, obispo de Osma. Hacinas, 9 - agosto - 1816.

1170 A. ANTÓN: “Un poco de historia: la escuela”. Amigos de Hacinas, no 38. (1988). pp. 24 - 26.
} 
edificio ha sido profanado, pues algunos vecinos ha llegado a guardar ganado en su interior $^{1171}$. Este aviso, sin embargo, no parece mejorar el cuidado que se hace de este templo, pues una década más tarde, el propio obispo de Osma, en su visita a esta parroquia indica, que encuentra esta ermita "bastante maltratada e indezente por lo que mando su Ilma. al cura hiciese presente a la villa su estado para que la reparen en el término de 2 meses y no lo haciendo le dio comisión al dicho cura para que mande arruinarla bendiendo sus despojos al mejor remate y aplique su producto a la fábrica de la iglesia de dicha villa"1172. Pero a pesar de la contundencia de este mandato, no parece que se adopte ninguna medida, de tal modo, que varios años más tarde, en 1780, vemos cómo se repite el mismo aviso ${ }^{1173}$. Sin embargo, parece que ahora sí se decidió llevarlo a efecto, pues a partir de aquí no volveremos a tener más referencias sobre ella.

\section{Arquitectura civil.}

Los edificios pertenecientes al ámbito de lo civil, como ya mencionamos, quedan incluidos, todos ellos, dentro de la tradición de la arquitectura popular, sin mostrar en ningún caso el más mínimo interés artístico. No obstante, la participación de varios de estos vecinos en la actividad de la carretería y el transporte, hace que en algunos de estos edificios podamos reconocer vagamente algunos de los rasgos característicos de la casa típica carretera. Evidentemente se trata de inmuebles muy alterados por el paso del tiempo, en los cuales prácticamente lo único que podemos reconocer es la típica estructura de amplia fachada de perfil triangular, rematada con tejado dispuesto a dos aguas. Este es el caso de los inmuebles situados en la calle la Revilla $n^{\circ} 59$, calle San Juan $n^{\circ} 31$, calle Nuño Rasura $n^{\circ} 12$, calle Nueva $n^{\circ} 15$ y calle Mayor $n^{\circ}$ 6. Estas dos últimas, conservan sobre el dintel de su puerta de entrada un pequeño escudo con una cruz, la primera, y una flor de lis, la segunda. Actualmente la

\footnotetext{
1171 AGDBU. LP. Hacinas, parroquia de San Pedro. LF. (1703 - 1759). Visita realizada a la parroquia de San Pedro de Hacinas en 1756, por D. Juan Fernández de Arcos. Hacinas, 27 - agosto - 1756.

1172 Ibídem. LF. (1758 - 1777). Visita realizada a la parroquia de San Pedro de Hacinas en 1765, por D. Bernardo Antonio Calderón, obispo de Osma. Hacinas, 20 - octubre - 1765.

1173 Ibídem. LF. (1778 - 1866). Visita realizada a la parroquia de San Pedro de Hacinas en 1780, por D. Francisco Valer. Hacinas, 20 - mayo - 1780.
} 
mayor parte de ellas, por otra parte, se encuentran muy alteradas o completamente modificadas por reformas recientes, con lo cual su estudio únicamente ha sido posible gracias a fotografías tomadas con anterioridad a la década de 1970.

Junto a estos edificios podemos mencionar también la conocida como casa del curato, situada en la calle Laín Calvo $n^{\circ}$ 1, donde residían los párrocos del pueblo, la cual nos presenta una estructura de una planta de muros de sillería, de magnífica labra. 


\section{HOYUELOS DE LA SIERRA.}

La localidad de Hoyuelos de la Sierra se encuentra situada en el fondo de una amplia hondonada, de donde toma su nombre, situada en a los pies de la vertiente sur de la Sierra de la Demanda. Su término municipal presenta ya, de esta manera, una orografía notablemente más abrupta que los pueblos situados en las zonas más bajas. El determinante de la Sierra, que acompaña a su nombre, resulta, por lo tanto, obvio.

La primera mención documental sobre este pueblo está fechada el 1-I-1044, donde aparece nombrado como Foiolos ${ }^{1174}$, el cual queda convertido más adelante en Foyuelos $^{1175}$. Hoyuelos estuvo incluida hasta el siglo XII en el alfoz de Lara ${ }^{1176}$, para pasar más tarde, una vez extinguido el sistema de alfoces, a formar parte de la Merindad Menor de Santo Domingo de Silos ${ }^{1177}$.

1174 L. SERRANO: Cartulario de San Pedro de Arlanza. Madrid. Centro de Estudio Históricos. 1925. (pp. 86).

1175 G. MARTÍNEZ DÍEZ: Libro Becerro de las Behetrías. Estudio y texto crítico. León, Centro de Estudios e Investigación San Isidoro. Caja de Ahorros y Monte de Piedad. Archivo Histórico Diocesano. 1981.(pp. 612).

1176 G. MARTíNEZ DÍEZ: Libro Becerro de las Behetrías. Estudio y texto crítico. León, Centro de Estudios e Investigación San Isidoro. Caja de Ahorros y Monte de Piedad. Archivo Histórico Diocesano. 1981.(pp.174).

1177 ESTEPA DÍEZ: "Estructura de poder en Castilla (siglos XII - XIII). El poder señorial en las merindades burgalesas. En III Jornadas burgalesas de Historia (3 1991). Burgos en la Plena Edad Media. Burgos, Asociación Provincial de Libreros de Burgos. 1994. (pp. 245 - 294). G. MARTíNEZ DÍEZ: Génesis histórica de la provincia de Burgos y sus divisiones administrativas. Burgos, Aldecoa. 1983. 
Ya durante la Edad Moderna, en el plano fiscal, encontramos a este pueblo encuadrado dentro del partido de las Tierras del Condestable, de la provincia de Burgos $^{1178}$, pasando después al partido de Can de Muñó, tras la reforma borbónica del siglo XVIII ${ }^{1179}$. Su jurisdicción dependió durante este período de la Edad Moderna, de la casa de Salas, formando parte, por ello, del señorío de los Duques de Frías. Esta situación, sin embargo, no siempre fue así, pues hasta mediados del siglo XIV Hoyuelos todavía conservaba su condición de lugar de behetría, si bien, para entonces esto estaba a punto de cambias, pues sus dos diviseros habían tomado como señor a D. Pedro Fernández de Velasco ${ }^{1180}$. En el ámbito eclesiástico, su única parroquia dependió siempre de la diócesis de Burgos, desde la restauración de la misma, sin experimentar cambios en este sentido, a lo largo de todo el período estudiado ${ }^{1181}$.

La población de Hoyuelos siempre fue escasa, con unos niveles medios situados muy por debajo de la media en la zona. Tenemos, sin embargo, muy pocas fuentes para poder conocer su evolución a lo largo de la Edad Moderna, pues habitualmente - y de modo especial durante el siglo XVI - su población fue incluida siempre dentro del conjunto de los pueblos del Valle de Valdelaguna ${ }^{1182}$. Circunstancia ésta para la que no encontramos explicación aparente, pues Hoyuelos no estuvo nunca vinculado al citado valle. Esto hace que los únicos datos, que tenemos para establecer una línea evolutiva, son los proporcionados por el llamado censo de los obispos, de 1584-87, donde declara tener 16 vecinos $^{1183}$, el Vecindario del Catastro del Marqués de Ensenada, de mediados

\footnotetext{
1178 C. MARTÍNEZ DÍEZ: Génesis histórica de la provincia de Burgos... ob. cit. 1179 Ibídem.

1180 G. MARTÍNEZ DÍEZ: Libro Becerro de las Behetrías... ob. Cit. (pp. 612).

1181 L. SERRANO: El obispado de Burgos y Castilla primitiva. Desde el siglo V al XIII. Madrid, Centro de Estudios Históricos. 1935. Tomo I (pp. 414 - 418).

1182 AGS. Contaduría General. Leg. 768. (fols.62);. Censo de Castilla de 1591. Vecindario. Madrid, Instituto Nacional de Estadística. 1984.

1183 T. GONZÁLEZ: Censo de población de las provincias y partidos de la Corona de Castilla en el siglo XVI... Ed. Facsímil. Madrid, Imprenta Real. 1829
} 
del siglo XVIII, que nos da una cifra de 29 vecinos $^{1184}$, y el censo de Floridablanca, de 1787, que habla de 67 habitantes $^{1185}$. En cualquier caso, y a pesar de lo escaso de la información y la amplia separación entre cada uno de estos censos, podemos apreciar un significativo crecimiento demográfico entre el siglo XVI y el XVIII, lo cual debemos relacionar, en gran medida, con el auge vivido en estos momentos por la actividad de la ganadería trashumante, en la cual participaban varios de sus vecinos ${ }^{1186}$. Todos ellos pertenecían, sin embargo al estado llano ${ }^{1187}$.

La economía de estos habitantes dependía, en gran medida, como decimos, de la ganadería lanar trashumante, pero no de forma exclusiva. Así, aunque existían algunos propietarios de rebaños de ovejas merinas de tamaño medio, también encontramos una fuerte presencia de la agricultura, fundamentalmente de secano, combinada con la explotación de algunos hatos de ganado estante ${ }^{1188}$.

Su casco urbano se acomoda en el fondo de una suave hondonada, dominada en su flanco suroriental por el cerro conocido como Humarrero. Este núcleo está formado por un apretado conjunto de casas, repartidas en dos barrios, separados por la carretera, que conduce desde Salas de los Infantes, a los pueblos del interior de la Sierra de la Demanda. Cada uno de estos barrios está coronado con un hito referencia, que en el barrio de la vertiente orientada hacia el mediodía está representado por la iglesia parroquial, con su campanario, y en el de la vertiente septentrional, por un antiguo torreón defensivo, cuya construcción podemos fechar a inicios del siglo XV, muy alterado actualmente por las reparaciones y restauraciones, que en él se han acometido.

\footnotetext{
1184 Vecindario de Ensenada 1759. Vol. I. Madrid, Centro de Gestión Catastral y Cooperación Tributaria: Tabapress. D. L. 1991.

1185 INE. Censo de 1787. “Floridablanca”. Madrid. INE. 1989.

1186 ADPBU. CE - 887. RESPUESTAS GENERALES. Hoyuelos de la Sierra, 22 - septiembre - 1753.

1187 INE. Censo de 1787. “Floridablanca”. Madrid. INE. 1989. Ob. Cit.

1188 ADPBU. CE - 887. RESPUESTAS GENERALES. Hoyuelos de la Sierra, 22 - septiembre - 1753.
} 
Estos dos edificios, constituyen, por otra parte, los dos únicos elementos de este caso urbano, que despierta un cierto interés, pues el resto de las casas participan plenamente de las características propias de la arquitectura popular de la zona.

\section{Iglesia de San Esteban.}

Esta iglesia de Hoyuelos se encuentra dedicada a San Esteban y está ubicada, como hemos visto, en la parte superior de uno de sus barrios, sobre un terreno de marcada pendiente, orientada hacia el mediodía. Su fábrica, asentada, en parte, sobre un firme suelo rocoso, queda rodeada, en sus flancos meridional y de poniente, por un pequeño muro de piedra, que forma el atrio, al cual se accede a través de una amplia escalinata de piedra de un solo trazo.

Se trata de un edificio de formas sencillas y moderada calidad artística, más próximo a los modelos característicos de la arquitectura popular, que a algún estilo artístico definido. Esto se debe, fundamentalmente, a la tardía remodelación, que afectó a la mayor parte de su estructura, eliminando un buen número de los elementos más destacados del antiguo templo. Aun así, se han logrado conservar algunas piezas importantes, como la portada y parte de la zona de la nave, las cuales nos aportan una información ciertamente interesante sobre la historia de este edificio.

El templo actual se alza sobre una planta de cruz latina, de brazos bien marcado en planta, cabecera poco profunda de testero plano, y cuerpo formado por una sola nave, articulada en dos tramos, a los que se suma la base de la torre, incorporada a los pies. Todo el edificio está construido en piedra de sillería, con piezas de mediano tamaño, en cuyos muros encontramos numeroso sillares reaprovechados de períodos anteriores. Este hecho constituye, sin duda, uno de los aspectos más singulares del edificio, lo cual permite encontrar, en diferentes partes del exterior, sillares decorados con el característico ajedrezado románico, o en el interior, capiteles de este mismo estilo reconvertidos en ménsulas. 


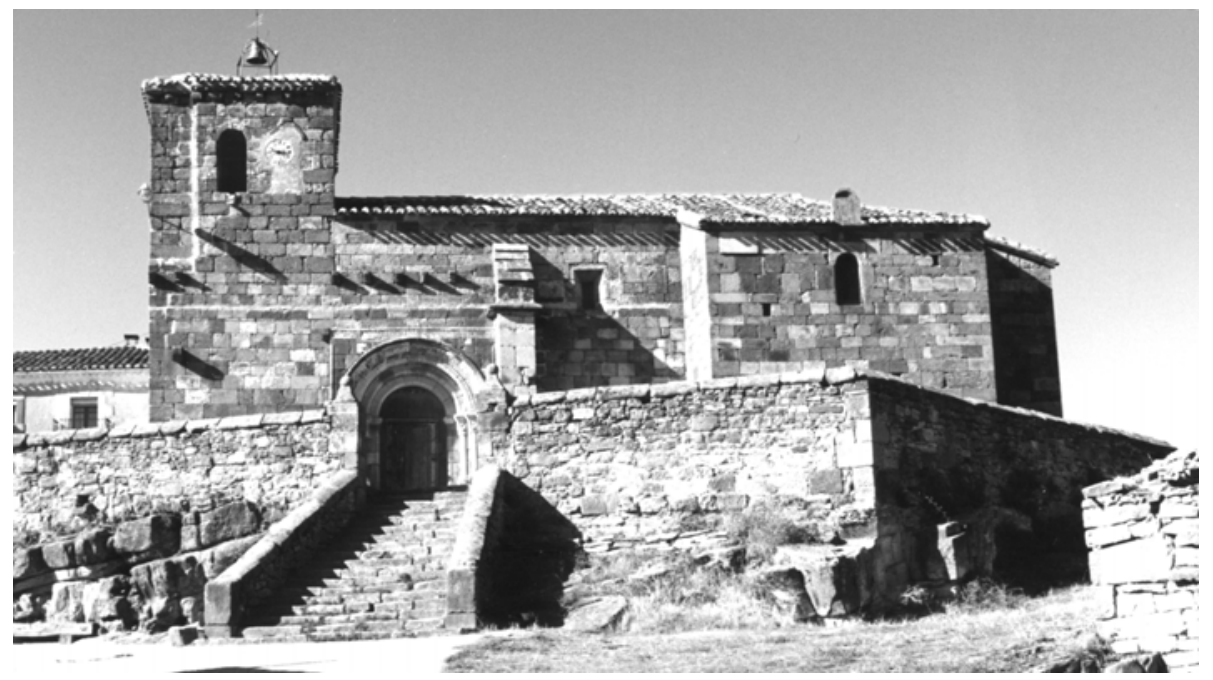

HOYUELOS DE LA SIERRA. Iglesia de San Esteban.

Su imagen exterior muestra una estructura de limpios volúmenes prismáticos, bien perfilados, de muros completamente planos, únicamente reforzados con contrafuertes en la parte central de la nave. En la parte de los pies se levanta la torre, la cual queda perfectamente integrada dentro del conjunto del templo, del que sobresale su cuerpo de campanas, compuesto por una sencilla estructura cúbica, con vanos de arco de medio punto, repartidos de forma irregular entre sus caras, de tal forma, que aparecen dos en la meridional ${ }^{1189} \mathrm{y}$ de poniente, $\mathrm{y}$ uno solo en el lado septentrional.

Los vanos que iluminan el interior del templo quedan distribuidos entre los extremos de los brazos del crucero, la fachada meridional de la nave y el presbiterio, y el muro de los pies.. Dentro de ellos predominan los de trazado rectangular con dintel plano y derrame hacia el exterior, si bien, en el brazo meridional del crucero, vemos cómo se reaprovecha el dintel de una antigua ventana románica, con arco de medio punto de rosca decorada con una cenefa de tallos entrelazados de fina talla. De igual 
846 Arquitectura de la Edad Moderna en la sierra burgalesa.

modo, en la ventana situada a los pies se reutilizan dos pequeñas columnas, también de estilo románico, rematadas con capiteles decorados con motivos vegetales.

La puerta de acceso, abierta sobre el segundo tramo del muro meridional de la nave, también conserva su estructura románica, con triple nivel de arquivoltas, con arcos de medio punto de aristas redondeadas con moldura de tres cuartos de bocel, enmarcados mediante una moldura con decoración vegetal, añadida más tarde. Estos arcos descansan, a través de una gruesa imposta, sobre columnas dispuestas en el derrame de las jambas, coronadas con capiteles decorados con figuras de animales fantásticos, en los que debemos destacar su alta calidad técnica. A través de estos motivos, deducimos que se trata de una obra del románico más avanzado de la zona, perteneciente a la segunda mitad del siglo XII, encuadrada ya, por lo tanto, dentro de la influencia de los maestros del claustro alto del monasterio de Santo Domingo de Silos, que acaban con las formas propias de la escuela del románico de la sierra ${ }^{1190}$.

En el interior se desarrolla el característico concepto de espacio comino, trazado en torno al eje longitudinal, que vertebra el templo, dentro del cual se suceden los espacios de la nave, el crucero y la capilla mayor. Este espacio incorpora, en la parte de los pies, un coro alto, realizado en madera, ubicado en el interior de la base de la torre, bajo el cual, se acomoda el baptisterio, cerrado por una sencilla balaustrada realizada también en madera. En las cubiertas de este templo descubrimos hasta tres tipos distintos de abovedamiento, lo cual constituye un signo evidente de su complicada historia constructiva. Aparecen así, bóvedas de crucería estrellada con terceletes en los dos tramos de la nave, cúpula semiesférica de media naranja sobre pechinas, en el crucero, y bóveda de crucería octopartita con pesados nervios cruzados en el centro, en el espacio de la cabecera y brazos del crucero. Los nervios de estas últimas descansan, en todos los casos, sobre capiteles románicos reconvertidos en ménsulas. El espacio del coro, por su parte, se cubre, al igual que la sacristía, con simple cielo raso.

\footnotetext{
1190 F. PALOMERO ARAGÓN, M. ILARDIA GÁLLEGO: El arte románico burgalés. Un lenguaje medieval actual. Madrid, Lancia. 1995
} 
Los arcos que separan cada uno de estos tramos de bóveda presentan igualmente una interesantes variedad de formas. Así, los tramos de la nave quedan separados por arco de medio punto de rosca moldurada, dispuesto sobre ménsulas, mientras que los arcos torales, que delimitan el espacio del crucero, y conducen hacia los brazos y la cabecera, utilizan arcos de medio punto de sección cuadrangular con intradós completamente plano, dispuestos sobre pilastras de fuste igualmente plano, coronadas con una potente imposta. En los pies, el arco que conduce al espacio del coro, repite estas mismas características, aunque con un trazado apuntado.

Si descendemos la mirada al suelo vemos que este templo mantiene todavía el enlosado original, formado por lápidas sepulcrales, perfectamente alineadas a lo largo de toda la nave y el espacio del crucero. Dentro de ellas, nos llama la particularmente atención, la situada en este espacio del crucero, frente a la capilla mayor, sobre la cual aparecen representadas dos grandes llaves cruzadas, una estrella de seis punta y un mar cargado con un ancla, y todo ello enmarcado por una inscripción, que recorre todo el marco de la losa, en la que podemos leer: AQUÍ YACE PERO FERNANDEZ DE BARRIO, CAPILLÁN DEL CONDESTABLE, CANONIGO E CURA BENEFICIADO EN SANTA MARÍA DE OSMA, MURIO A XXVII DE MAYO DE MIL QUINIENTOS Y CUATRO AÑOS.

Esta imagen interior se completa con los retablos, que decoran cada uno de sus diferentes altares. El de la capilla mayor es obra prechurrigueresca, de finales del siglo XVII, y consta de banco, un solo cuerpo de tres calles, y remate. En el banco encontramos dos lienzos, con imágenes de San Pedro y San Pablo. Sobre ellos, en el nicho central del cuerpo se alza una talla de San Esteban, acompañada por dos lienzos a los lados, con escenas de la vida de este santo, y una tabla en el remate, con la escena de la Crucifixión. A este retablo central le acompañan dos más, dispuestos en los brazos del crucero. El situado en el lado de la epístola está dedicado a San Juan Bautista, y es obra de trazas neoclasicistas, realizado ya a principios del siglo XIX. El del lado del 
evangelio, por su parte, está presidido por la Virgen, y fue realizado hacia el tercer cuarto del siglo XVIII, según el estilo rococó ${ }^{1191}$.

Este templo constituye el resultado final de una larga y compleja historia constructiva, con una secuencia, que parte del período románico, y se extiende hasta mediados del siglo XIX. Como hemos visto, son varios los restos que se conservan de su primera fase románica, si bien, la mayoría de ellos se hallan totalmente descontextualizados, lo que nos impide hacer una reconstrucción de la imagen que debía presentar. Entre estos elementos, como ya vimos, destacan, de manera especial, la portada, la ventana abierta sobre el extremo del brazo meridional del crucero, los capiteles, reconvertidos en ménsulas de la parte interior, y la pila bautismal. Esta última, constituye un ejemplo ciertamente interesante de este tipo de piezas, pues cuenta con una copa semiesférica, ornamentada con guirnaldas de hojas apuntadas, bolas con molduras circulares y pequeños arquillos, que se completan con un friso romboidal en el pie y otro en la base. Elementos, todos ellos, que nos permiten situarla dentro de los años centrales del siglo XII, y por lo tanto, algo anterior a la portada ${ }^{1192}$. Junto a estas piezas, como ya mencionamos en su momento, encontramos también numerosos sillares, decorados con el característico ajedrezado del románico, y con las marcas de los canteros, que realizaron el primitivo templo.

La siguiente fase constructiva importante, que conoció este templo, se produce durante las primeras décadas del siglo XVI. En ella, por lo tanto, se desarrollan las formas propias del gótico final, como nos indican los restos conservados. Tenemos, sin embargo, serias dudas sobre el alcance de estas obras, pues la única parte que se ha conservado, en la cual podemos apreciar los efectos de esta fase, es la nave. A tenor de lo que tenemos aquí, parece que en este caso simplemente se procedió a renovar las cubiertas del templo, incorporando las bóvedas de crucería estrelladas con terceletes,

1191 R. J. PAYO HERNANZ: El retablo en Burgos y su comarca durante los siglos XVII y XVIII. Burgos, Excma. Diputación Provincial de Burgos. 1997. (T. II, pp. 497). 
que ya vimos en la descripción, con las que se incrementaba, de forma notable, la altura del edificio. Esto obligaba, al mismo tiempo, a reforzar los muros, para lo cual se añaden los estribos laterales, dispuestos en correspondencia con el arco fajón del interior.

A partir de aquí, se abre un amplio paréntesis de más de tres siglos, durante los cuales no se vuelve a realizar ningún tipo de obra de renovación de gran alcance, manteniéndose así la estructura heredada de las fases anteriores. Las únicas intervenciones que tenemos registradas para todo este largo período, por lo tanto, consisten en los habituales trabajos de mantenimiento, cuidado y mejoras del edificio y su entorno.

Dentro de estas labores, una de las más destacadas fue la construcción del atrio, que rodea edificio en sus partes meridional y de poniente. Este proyecto se acomete a raíz del mandato dado por el visitador del Arzobispado de Burgos del año 1694, D. Juan de Caabro, el cual señala que:

"Y para su merced ha sido informado que dicha iglesia no tiene cementerio y que por estar en alto las aguas han menoscabado la tierra y se puede temer de su breda alguna ruina y que tiene dicha iglesia a su favor mediano alcance para obrar a los inconvenientes su merced daba y dio licencia e informa a los mayordomos eclesiástico y seglar de la fábrica de ella par que puedan dar a hacer el dicho cementerio a nuestro maestro y con más comodidad lo hiciere poniendo cédulas en la puerta de la iglesia y demás partes acostumbradas para que venga a continuación de todo señalado día de el remate, rematándolo al menor postor, atendiendo en todo al bien y utilidad de la dicha iglesia...”1193.

1192 G. BILBAO LÓPEZ: Iconografía de las pilas bautismales del románico castellano: Burgos y Palencia. Burgos. Editorial la Olmeda, 1996. (pp. 65, 95).

1193 AGDBU. LP. Hoyuelos de la Sierra, parroquia de San Esteban Protomártir. LF. (1682 - 1728). Visita realizada a la parroquia de San Esteban de Hoyuelos de la Sierra en 1694, por D. Juan de Caabro. Salas de los Infantes, 7 - septiembre - 1694. 
Descubrimos de este modo, la necesidad que existía de asegurar el suelo sobre el que se asienta este templo, adquiriendo este atrio, por lo tanto, no sólo una función funeraria, como cementerio, sino también constructiva, al reafirmar la solidez del terreno. Por otra parte, este visitador, al mismo tiempo que ordena la ejecución de esta obra, solicita: “...su merced a los alcaldes regidores concejo y vecinos del dicho lugar por ser en su utilidad y provecho el que la audiencia se conserve dijo la iglesia ayuden con sus limosnas a la fábrica del dicho cementerio, y a traer y acarrear la piedra y demás materiales que fueren necesarios, para que este medio tenga menor coste a la dicha iglesia"1194. Esta obra, sin embargo, no se termina de realizar hasta el año 1713, invirtiendo finalmente la fábrica un total de 1.400 reales $^{1195}$.

Otra obra de este tipo es la renovación de parte del enlosado del interior del templo, realizada en 1772. Esta renovación afectó a un total de once sepulturas y la sacristía, y el encargado de su ejecución fue el maestro de cantería Pedro de la Llana, por un precio de 700 reales $^{1196}$. Este mismo año se compra también una nueva cajonería para la sacristía ${ }^{1197}$.

Después de estas obras llegamos finalmente a la última y definitiva renovación, que sufre este templo, la cual tiene lugar, como ya indicamos, en los años centrales del siglo XIX, afectando a toda la parte delantera del edificio. Es una obra, como vimos, extremadamente sencilla, difícil de adscribir a un estilo concreto, aunque relacionada, en cierto modo, con la tradición de corte clasicista, que impregnó la arquitectura de esta zona durante los siglos XVII y XVIII. Su planta, sin embargo, no sabemos si es una creación nueva de este momento, o aprovecha simplemente el trazado ya existente. Por lo demás, en lo que se refiere al proceso de ejecución, los únicos detalles que poseemos

\footnotetext{
1194 Ibídem.

1195 Ibídem. Cuentas del año 1713. Hoyuelos de la Sierra, 27 - septiembre - 1714.

1196 Ibídem. LF. (1729 - 1778). (fols. 106 - 108). Cuentas del año 1772. Hoyuelos de la Sierra, 20 junio - 1773.

1197 Ibídem.
} 
son los transmitidos por una lápida colocada en la parte exterior, sobre el extremo del brazo meridional del crucero, en la que aparece la siguiente inscripción: SE PROPICIO Y HAZ BIEN SEÑOR, A TODOS AQUELLOS Y A LOS DESCENDIENTES DE LOS QUE POR LA PIEDAD GUIADOS EN HONOR TUYO PARA AMPLIFICAR ESTE TEMPLO SUS DONATIVOS ENTREGARON. AÑO DEL SEÑOR 1850.

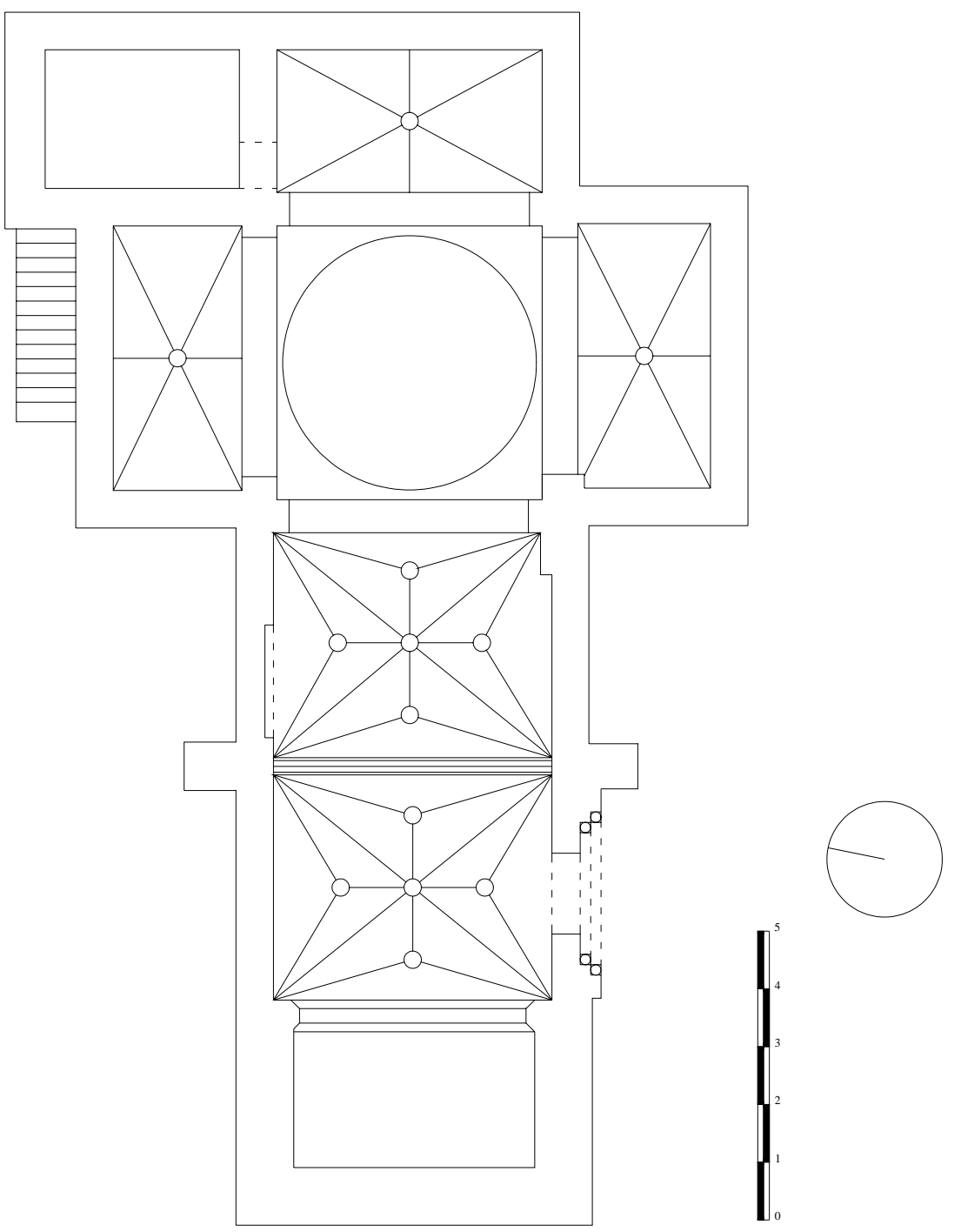

HOYUELOS DE LA SIERRA.

Iglesia de San Esteban. Planta. 


\section{Ermitas.}

Hoyuelos contó durante la Edad Moderna con cuatro ermitas, repartidas en su término municipal, las cuales estaban dedicadas a Nuestra Señora la Blanca, San Saturio, Santiago, y la Santa Cruz. De todas ellas, solamente la primera ha conseguido mantenerse en pie hasta nuestros días, si bien, en los últimos años de la década de 1980 ha iniciado su particular proceso de destrucción.

Esta ermita de la Blanca, por otra parte, representa el único ejemplo que poseemos en esta comarca, de templo privado con carácter funerario, ya que fue mandada construir por D. Pedro Fernández de Barrio, capellán de D. Pedro Fernández de Velasco, en los primeros años del siglo XVI para albergar sus restos, según indican diferentes inscripciones conservadas en el edificio. Actualmente se encuentra, como decimos, en un avanzado estado de ruina, con todo su tejado desprendido, y parte del muro septentrional de la nave venido a bajo. Aun con todo, los restos que todavía se conservan, unido al abundante material fotográfico proporcionado por los vecinos del pueblo $^{1198}$, hacen posible que podamos reconstruir con bastante fidelidad su imagen original.

La ermita se sitúa en un descampado, alejado del pueblo, unos quinientos metros en dirección sur, mostrándonos un edificio austero y bien proporcionado, encuadrado dentro del gótico final, como bien se encargan de mostrarnos varios de sus elementos. Presenta una sencilla estructura de tipo caja, con capilla mayor cuadrangular con testero plano, nave única rectangular algo más ancha que la cabecera, dentro de la cual se abre un pequeño espacio en la zona de los pies, incluido también dentro de este rectángulo. Todo el edificio está realizado en piedra, con muros de sillería de mediano tamaño la cabecera, y mampuesto en la nave, reforzado con sillares más grandes y de mejor labra en las esquinas y marcos de los vanos. Todos estos muros están rematados por una

\footnotetext{
1198 Debemos manifestar nuestro particular agradecimiento a D. Eduardo Moral Cabrejas, antiguo alcalde del pueblo, el cual nos ha facilitado gran parte de estas imágenes.
} 


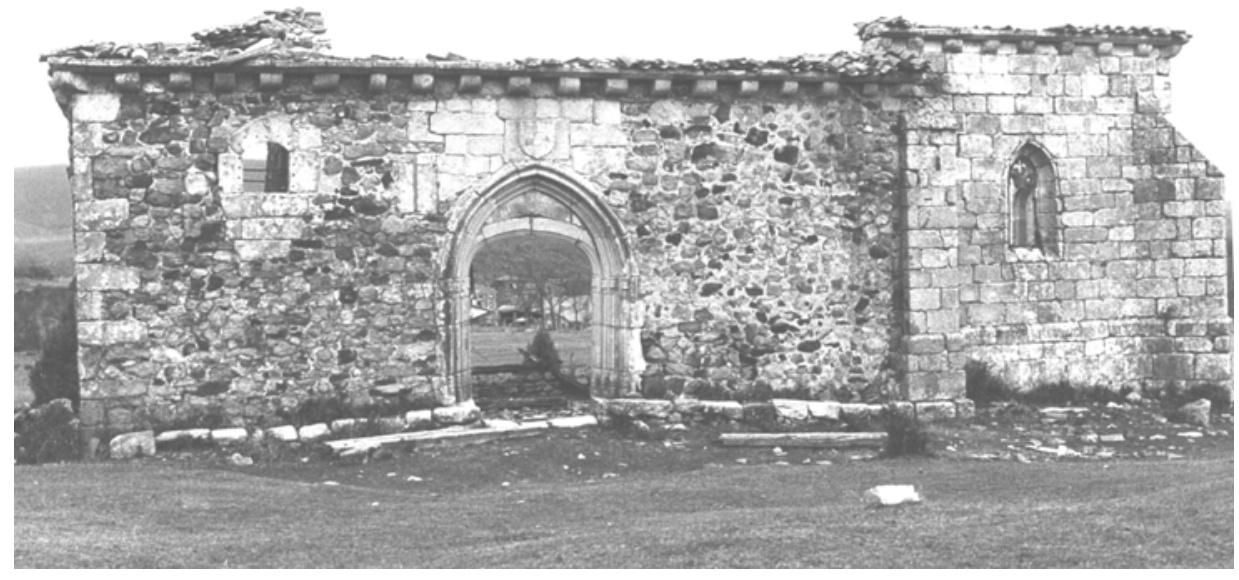

HOYUELOS DE LA SIERRA. Ermita de Nuestra Señora de la Blanca.

cornisa de piedra sostenida por canecillos sin ningún tipo de labra. La parte de cabecera, además, se refuerza con sólidos estribos, dispuestos en diagonal, en el caso del testero, y en perpendicular al muro, en el tránsito hacia la nave.

La cabecera cuenta con una esbelta ventana sobre su muro meridional, con arco apuntado de fuerte derrame hacia ambas partes, en cuyo interior conserva restos de dos pequeños arcos trilobulados de estilo flamígero. También orientada hacia el mediodía queda la puerta de entrada, que se abre sobre la parte central del muro de la nave. Nos presenta un magnífico ejemplo de estructura típica del gótico final, con arco escarzano en el centro, sobre el cual se superponen tres niveles de finas arquivoltas con estilizados arcos apuntados, que descansan sobre baquetones dispuestos en el derrame de las jambas. En el tímpano de esta puerta, sobre el arco escarzano, encontramos un pequeño escudo con las armas del patrocinador del templo, con campo ocupado por una estrella de ocho puntas y una cruz trebolada sobre el jefe, y un mar cargado con un ancla en la punta. A ambos lados de este escudo se extiende una inscripción en caracteres góticos, 
854 Arquitectura de la Edad Moderna en la sierra burgalesa.

en la que podemos leer: ES EL TINO AL PEREGRINO. A su vez, sobre la clave de la estructura de arquivoltas, aparece un escudo mayor, con campo cubierto por los jaqueles y veros característicos de los Velasco, y bordura con castillos y leones, acompañado de otro texto a los lados, también en caracteres góticos, en el que podemos leer: ESTA IGLESIA MANDO HACER PERO FERNÁNDEZ DE BARRIO, CANÓNIGO CAPELLÁN DE DON PERO FERNÁNDEZ DE VELASCO, CONDESTABLE DE CASTILLA, CONDE DE HARO ${ }^{1199}$.

Esta portada está acompañada por otras dos ventanas más, abiertas sobre esta fachada, una de tipo aspillera, y otra de trazado rectangular, coronada con arco escarzano. Este mismo trazado se repite en la ventana que se abre sobre el muro de los pies, dispuesta en el interior de una antigua portada, hoy cegada, que coronaba con arco de medio punto de amplio dovelaje.

En el interior, nos encontramos con dos espacios perfectamente diferenciados, en torno a los cuales se establece el característico concepto de espacio camino, tendente hacia el altar mayor. Fuera queda, por lo tanto, el espacio que existe en la parte de los pies de la nave, el cual doblaba en dos alturas mediante suelo de madera, accediendo al nivel superior desde el coro alto de madera, que existía en la nave, y al inferior desde el sotocoro, por una puerta de dintel plano. Todo el espacio de la nave se cubría con techumbre de madera a tres aguas sobre armadura de tipo parhilera. En el extremo opuesto, un amplio arco apuntado, dispuesto sobre columnas rematadas con un simple anillo, conducía al interior de la cabecera, la cual estaba cubierta con una bóveda de crucería estrellada con terceletes, de la que únicamente quedan los arranques de las jarjas. Los nervios de esta bóveda descansaban sobre ménsulas, que en el muro del testero estaban decoradas con los escudos del patrocinador de la obra, y el de su protector, D. Pedro Fernández de Velasco. Sobre este mismo muro del testero existe un

1199 Transcripción según: G. MIGUEL OJEDA: “Hoyuelos de la Sierra”. BIFG, nº 149. (1959). (pp. 799 $-805)$. 


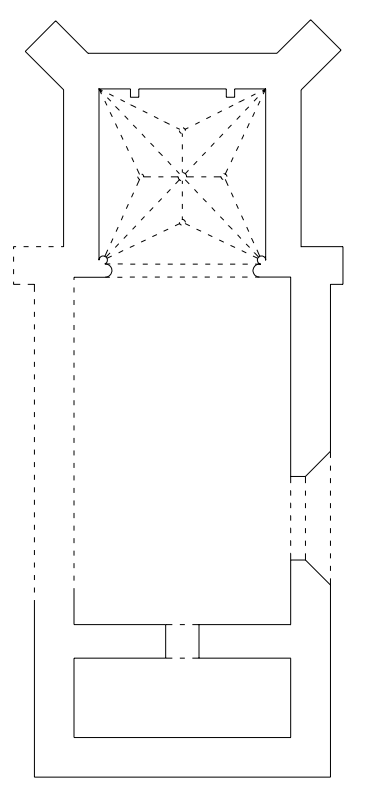

HOYUELOS DE LA SIERR. Ermita de Nuestra Señora de la Blanca. Planta.

arco conopial con moldura de tres cuartos de bocel, rematado por una pequeña penada, que servía de marco para el retablo que aquí existía.

Esta imagen interior se completa con una lápida sepulcral similar a la que existía en el crucero del templo parroquial, situada frente al espacio de la cabecera, en cuya inscripción añade el siguiente texto: EL CUAL HIZO ESTA IGLESIA. EL QUE MÁS HICIERE QUE YO PASE ADELANTE. Actualmente esta lápida se encuentra sepultada por un copioso manto de escombros, sin embargo, no deja de asaltarnos la duda sobre cuál es el lugar en el que está enterrado realmente este clérigo. Casi con toda seguridad podemos afirmar que es ésta la sepultura que posee sus restos y no la iglesia parroquial, la cual sería un simple monumento recordatorio.

La existencia de este templo transcurrió aparentemente sin dificultades hasta el siglo XVIII, momento en el cual comienzan a hacerse frecuentes los avisos sobre su mal estado de conservación y la falta de cuidados. Sabemos, gracias a los informes dejados 
por los visitadores del Arzobispado de Burgos, que su estado en 1711 no era del todo bueno $^{1200}$, lo cual hizo que una década más tarde aparecieran varias grietas en la zona de la cabecera ${ }^{1201}$. Estos daños, sin embargo, parece que no fueron atendidos con la diligencia necesaria, lo cual lleva a que el visitador, que llega aquí en 1728, D. Andrés Madrazo Escalera, indique textualmente que:

“visité la referida ermita de Nuestra Señora de la Blanca, la que se alló amenazando ruina toda la bóveda de la capilla, y aunque estaba apeada y an conducido a ella el resto de los materiales de la de Santiago y una porción de cal y tienen adbitrio sobre renta de diferentes heredades que an sembrado los vecinos de dicho lugar asta la cantidad de 300 reales para ayuda de su reedificación, como su merced lo hay reconocido y a sido informada, y que por sus cortos posibles no la an podido reparar por tanto mando a dichos vecinos y demás personas a cuyo cargo estuviere esta reparación de dicha ermita la compongan dentro de un año, pena de que serán castigados en la primera visita"1202.

parece que el tono empleado en esta ocasión sí surtió su efecto, con lo cual las obras de reparación se acometieron de forma inmediata.

Una situación similar, sin embargo, se vuelve a vivir a finales de este siglo XVIII, tal y como nos indican los informes de los visitadores de este momento, uno de los cuales, el de 1791, de D. Manuel María Izquierdo, llega a decir que:

“En el término de dicho pueblo existe la ermita de Nuestra Señora de la Blanca y que se halla con bastante necesidad de reparación, muy desflacada, ruinosa e indecente, en cuya visita se manda a la persona a

1200 AGDBU. LP. Hoyuelos de la Sierra, parroquia de San Esteban. LF. (1682 - 1728). Visita realizada a la parroquia de San Esteban en Hoyuelos de la Sierra en 1711, por D. Manuel Francisco Navarrete Ladrón de Guevara, arzobispo de Burgos. Salas de los Infantes, 22 - junio - 1711.

1201 Ibídem. Visita realizada a la parroquia de San Esteban en Hoyuelos de la Sierra en 1721, por Fr. Ángel Benito. Salas de los Infantes, 14 - julio - 1721 
cuyo cargo esté su cuidado y administración procuren componerla y adornarla de todo lo preciso hasta poner la enteramente lucida decente y en disposición de poderse celebrar, asegurando su puerta con cerradura y llave para evitar cualcuna irreverencia del lugar Sagrado; y en su defecto si pasan los seis meses del requerimiento que deverá hacerse el cura no lo hubiere cumplido, se da facultada este para que la demuela, y aplique sus materiales a favor a la fábrica” ${ }^{2203 .}$

Después de esto, los dos siglos siguientes transcurren sin mayores incidencias para este templo, hasta que a finales de la década de 1980, como ya hemos indicado, la despoblación prácticamente total, que sufre este pueblo, trae consigo una falta de cuidados para la ermita, que ha terminado con su ruina.

Las tres ermitas restantes, que existían en este pueblo, vivieron esta experiencia mucho antes, pues ninguna de ellas llega a conocer la segunda mitad del siglo XVIII. La primera en desaparecer fue la dedicada a San Saturio, cuya última referencia documental data del año $1717^{1204}$. Esta temprana desaparición ha hecho que se pierda incluso el recuerdo de su emplazamiento.

La pérdida de la ermita de Santiago se produce no mucho tiempo después, en 1728, según órdenes del visitador del Arzobispado, D. Andrés Fernández de Tejada, el cual, ante el mal estado en el que se encontraba manda: "al dicho concejo que con intervención del cura disponga de acabar de demoler y allanar el suelo de la referida

\footnotetext{
1202 Ibídem. Visita realizada a la parroquia de San Esteban en Hoyuelos de la Sierra en 1728, por D. Andrés Madrazo Escalera, canónigo de la catedral. Salas de los Infantes, 15 - julio - 1728.

1203 Ibídem. LF. (1781 - 1850). Visita realizada a la parroquia de San Esteban en Hoyuelos de la Sierra en 1791, por D. Manuel María Izquierdo. Barbadillo del Mercado, 4 - noviembre - 1791

1204 Ibídem. LF. (1682 - 1728). Visita realizada a la parroquia de San Esteban en Hoyuelos de la Sierra en 1711, por D. Manuel Francisco Navarrete Ladrón de Guevara, arzobispo de Burgos. Salas de los Infantes, 22 - junio - 1711.
} 
de Santiago en el término de dos meses de la publicación de esta visita"1205. Sus materiales fueron utilizados en las reparaciones efectuadas en torno a estos mismos años en la ermita de la Blanca ${ }^{1206}$. La completa eliminación de sus restos ha hecho igualmente que no se haya conservado el recuerdo de su existencia dentro del pueblo, ni tampoco su ubicación.

Por último, está la ermita de Santa Cruz, la cual se encontraba situada a unos trescientos metros del pueblo, en dirección noroeste, sobre un pequeño cerro, conocido como San Marcos. En él todavía es posible ver algunos restos de piedras y fragmentos de tejas, pertenecientes a este templo. Su desaparición se produce en torno a la década de 1730, si bien, ya desde comienzos de este siglo su edificio había mostrado graves deficiencias. Esto lleva a que en 1711 el propio arzobispo, en visita realizada a la parroquia, mande tapiar su puerta, y no celebrar los oficios en su interior, ante la indecencia que presentaba el edificio ${ }^{1207}$. Cuatro años más tarde vemos que sus imágenes habían sido trasladadas la iglesia parroquial, lo que suponía un claro anuncio de su pronta desaparición. No obstante, en 1721 vemos como se está trabajando en su reparación, ordenando el visitador, Fr. Ángel Benito, “blanquear de cal y yeso las paredes por dentro y retocar la tabla donde está pintada la Santa, que con motivo de ser antiguo quasi no se devisa y lo mismo nezesitan las pinturas de Santa Elena, San Roque y San Miguel”"1208.

Sin embargo, estas reparaciones no llegaron a realizarse en su totalidad, pues según le comunican al visitador, que llega aquí en 1723, D. Andrés Fernández de Tejada, el motivo de no averse echo a sido el que dicho lugar se alla pobre y no tiene

\footnotetext{
1205 Ibídem. Visita realizada a la parroquia de San Esteban en Hoyuelos de la Sierra en 1726, por D. Andrés Fernández de Tejada. Salas de los Infantes, 17 - septiembre - 1726.

1206 Ibídem. Salas de los Infantes, 15 - julio - 1728.

1207 Ibídem. Salas de los Infantes, 22 - junio - 1711.

1208 Ibídem. Salas de los Infantes, 14 - julio - 1721.
} 
medios para poderlo hacer como le a sido a su merced informado"1209. Esto lleva al visitador a tomar una decisión, según la cual el consejo debía elegir, entre derruir esta ermita o la de Santiago, destinando sus materiales a las reparaciones que se iban a efectuar en la ermita de la Blanca. La decisión tomada ya la conocemos, si bien, esto no sirvió para garantizar una larga vida para esta ermita de la Santa Cruz, pues después de 1728 no volvemos a tener más referencias de ella.

Arquitectura civil.

En el ámbito civil, como ya hemos dicho, el único edificio destacable lo encontramos en el torreón, que preside el segundo de los barrios, que forman este pueblo. Se trata de una pieza, correspondiente a la segunda mitad del siglo XV, de estructura prismática sobre planta cuadrangular, realizada en piedra, con muros de mampuesto de gran calibre, reforzados en las esquinas y marcos de los vanos con sólidos sillares. Los vanos se abren a diferentes alturas, y dentro de ellos encontramos varios ejemplos en los que el dintel aparece decorado con un sencillo angrelado, en forma de olas, y el alfeizar con un relieve de bolas. Muy posiblemente su construcción debemos relacionarla con la figura del capellán del Condestable de Castilla D. Pedro Fernández de Barrio, enterrado en la ermita de Nuestra Señora de la Blanca, constituyéndose, al mismo tiempo, en un símbolo de la influencia que la familia Velasco tenía en toda la comarca. Junto a este torreón se extendía, hasta hace no mucho, un edificio de dos plantas con varios vanos decorados con los mismos motivos. Durante la segunda mitad del siglo XX, sin embargo, fue derrumbándose progresivamente hasta que en la década de 1990 se eliminaron sus últimos restos. La imagen actual de este conjunto es el resultado de las profundas labores de restauración realizadas durante los mismos años de esta década de 1990.

Junto a este torreón, otro ejemplo interesante, que podemos señalar, dentro de la arquitectura civil, lo tenemos en la calle San Esteban $n^{\circ} 55$. Se trata de un bello ejemplo

1209 Ibídem. Visita realizada a la parroquia de San Esteban en Hoyuelos de la Sierra en 1723, por D. Antonio Íñigo de Angulo. Salas de los Infantes, 9 - noviembre - 1723. 


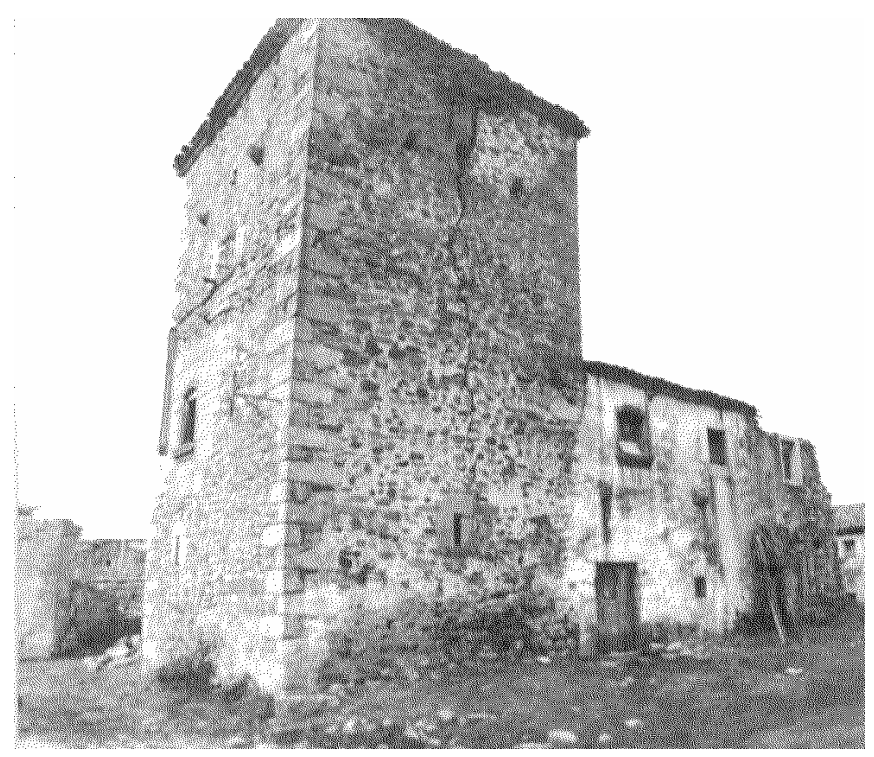

HOYUELOS DE LA SIERRA. C. del Torreón $n^{\circ}$ 8. (Imagen tomada en la década de 1970).

de casa solariega, hoy prácticamente arruinada, de la cual se conserva parte de su fachada principal. Entre los elementos, que todavía se mantienen en pie destaca su portada, coronada con arco de medio punto de rosca casetonada, característica del siglo XVIII. Sobre ella se abre, en la planta principal, una ventana de dintel plano, enmarcada con moldura plana con orejones, y entre ambas, una amplia inscripción, que nos informa sobre los promotores de la obra y el año de su construcción. Fue construida, según este texto, en 1717. 
HUERTA DE ABAJO.

La pequeña localidad de Huerta de Abajo se encuentra enclavada en el centro del valle, que se extiende entre las dos sierras de la Demanda y Neila, conocido como Valle de Valdelaguna. Este valle formaba durante la Edad Moderna una unidad administrativa denominada Real Valle y Villa de Valdelaguna, la cual agrupaba a un total de ocho localidades. En virtud de su posición geográfica destacada, Huerta de Abajo se convirtió desde siempre en el centro administrativo del valle, lo cual no se correspondía con el volumen de su población, que nunca fue muy elevado. Por todo ello, su historia, a lo largo de la Edad Moderna, estuvo siempre vinculada a las circunstancias, que se vivían en el valle.

Las primeras referencias documentales, que se han conservado sobre esta localidad, son ciertamente tempranas, pues aparece ya nombrada en un documento fechado en el 932, dentro del Cartulario del monasterio de San Pedro de Arlanza. Aquí aparece nombrado como Orto de Domno Belasco ${ }^{1210}$. Su origen, por lo tanto, debería remontarse a la época inmediatamente anterior, relacionado con los primeros asentamientos permanentes, que se iniciaron en esta comarca a partir de la segunda mitad del siglo IX, atraídos por la seguridad de estas montañas.

Hasta el siglo XII Huerta de Abajo presuntamente perteneció al pequeño y efímero alfoz de Barbadillo del Pez, si bien, con toda seguridad, en el inicio de esta centuria formaba ya parte del alfoz de Lara, como el resto de las localidades del valle de

1210 L. SERRANO: Cartulario de San Pedro de Arlanza. Madrid, Centro de Estudios Históricos. 1925. (pp. 37). 
Valdelaguna $^{1211}$. A partir de esta fecha, una vez eliminado el sistema de alfoces, esta localidad queda incluida dentro de la Merindad Menor de Santo Domingo de Silos ${ }^{1212}$.

Ya en la Edad Moderna, en lo que a la administración fiscal se refiere, Huerta de Abajo forma parte del partido de las Tierras del Condestable, dentro de la provincia de Burgos, pasando, a partir de la reforma borbónica del siglo XVIII, a depender del partido de Aranda ${ }^{1213}$. Su jurisdicción perteneció en un primer momento a la familia Velasco, formando parte del señorío solariego de esta casa, desde mediados del siglo $\mathrm{XIV}^{1214}$. No obstante, a partir del siglo XVII, en un momento que no podemos determinar, Huerta de Abajo, junto con el resto de las localidades que forman el valle de Valdelaguna, consigue adquirir su propia jurisdicción, convirtiéndose, con ellas, en localidades de realengo, formando el denominado Real Valle y Villa de Valdelaguna $^{1215}$. En el plano eclesiástico, la situación de su única parroquia no sufre cambios durante todo este período, dependiendo de la Diócesis burgalesa, desde la restitución de esta sede en plena Edad Media ${ }^{1216}$.

Su población, como ya hemos dicho, nunca fue muy abundante, aun así, apenas contamos con datos que nos permitan analizar mínimamente su evolución a lo largo de este período. Esto se debe, a que la mayor parte de los censos, realizados durante toda la

1211 G. MARTÍNEZ DÍEZ: Pueblos y alfoces burgaleses de la repoblación. Valladolid, Junta de Castilla y León. Consejería de Educación y Cultura. 1997. (pp.196).

1212 C. ESTEPA DÍEZ: "Estructura de poder en Castilla (siglos XII - XIII). El poder señorial en las merindades burgalesas. En III Jornadas burgalesas de Historia (3 1991). Burgos en la Plena Edad Media. Burgos, Asociación Provincial de Libreros de Burgos. 1994. (pp. 245 - 294). G. MARTíNEZ DÍEZ: Génesis histórica de la provincia de Burgos y sus divisiones administrativas. Burgos, Aldecoa. 1983.

1213 G. MARTÍNEZ DÍEZ: Génesis histórica de la provincia de Burgos... ob. cit.

1214 G. MARTíNEZ DÍEZ: Libro Becerro de las Behetrías. Estudio y texto crítico. León, Centro de Estudios e Investigación San Isidoro. Caja de Ahorros y Monte de Piedad. Archivo Histórico Diocesano. 1981.(pp. 615).

1215 P. MADOZ: Diccionario geográfico - estadístico - histórico de España y sus posesiones de Ultramar. Valladolid, Ámbito D.L. 1984. (pp. 344). 
Edad Moderna, contabilizan la población del valle en su conjunto y no en cada uno de los pueblos de forma individualizada. Por ello, los únicos datos precisos que tenemos son los proporcionados por el censo de los obispos, de 1584-87, realizado por parroquias y no por concejos, donde nos da una población de 30 vecinos $^{1217}$; el vecindario del Catastro del Marqués de Ensenada, de mediados del siglo XVIII, donde vemos que la población ha ascendido a 51 vecinos ${ }^{1218}$; y el censo de Floridablanca, de 1787, en el que nos encontramos con una población de 219 habitantes ${ }^{1219}$.

Estos datos, aunque escasos, sirven al menos para dejar claro que esta localidad vivió durante el siglo XVIII uno de sus momentos más dulces, el cual coincide con uno de los períodos de máximo auge de la ganadería trashumante. Otro dato de interés, que se desprende de estos censos, especialmente de la información aportada por el Catastro del Marqués de Ensenada, es que todos sus vecinos se declaran hidalgos ${ }^{1220}$, algo que fue relativamente común dentro de los pueblos de esta zona de la sierra, dedicados mayoritariamente a la ganadería trashumante ${ }^{1221}$.

El modo de vida de estos habitantes estuvo vinculado siempre, como hemos visto, al desarrollo de la ganadería ovina y la comercialización de su lana, circunstancia ésta que marcó el devenir de este pueblo durante toda la Edad Moderna y gran parte de la época Contemporánea ${ }^{1222}$. La propiedad de estos rebaños, según los datos proporcionados por el Catastro del Marqués de Ensenada, se encontraba aquí bastante repartida, pues cada propietario solía poseer una media de entre 150 y 300 cabezas de

1216 L. SERRANO: El obispado de Burgos y Castilla primitiva. Desde el siglo V al XIII. (Tomo I). Madrid, Centro de Estudios Históricos. 1935.

1217 T. GONZÁLEZ: Censo de población de las provincias y partidos de la Corona de Castilla en el siglo XVI... Ed. Facsímil. Madrid, Imprenta Real. 1829.

1218 Vecindario de Ensenada 1759. Vol. I. Madrid, Centro de Gestión Catastral y Cooperación Tributaria: Tabapress. D. L. 1991.

1219 INE. Censo de 1787. “Floridablanca”. Madrid. INE. 1989.

1220 Vecindario de Ensenada 1759. Ob. cit.

1221 Ver capítulo de Sociedad. 
ganado, mayoritariamente merino ${ }^{1223}$. No encontramos en este pueblo, por lo tanto, ningún propietario que sobrepasara el millar de cabezas, como sí ocurría en otros pueblos del valle. A parte de esta actividad ganadera, también se cultivaba algo de cereal, aunque de muy mala calidad, y algunas hortalizas ${ }^{1224}$. También posee, dentro de su término municipal, algunos yacimientos de mineral de hierro, que fueron explotados mínimamente durante los períodos celtibérico y romano ${ }^{1225}$, y que dieron lugar a un leve intento de industrialización del pueblo, entre los años finales del siglo XIX y principios del XX. Sin embargo, no parece que tuvieran ningún tipo de repercusión durante los siglos de la Edad Moderna. Como testigo mudo de todo ello, todavía se conservan, en la parte septentrional del pueblo, junto al arroyo que viene de Vega, los restos derruidos de un antiguo alto horno, puesto en funcionamiento durante los primeros años del siglo $\mathrm{XX}^{1226}$.

El núcleo urbano de Huerta de Abajo se extiende en la parte superior de un pequeño promontorio, orientado hacia el naciente, desde el cual se domina una gran parte de este valle, lo que hace de este lugar un punto de alto valor estratégico. Su caserío se esparce, por lo tanto, sobre una suave ladera, formando un apretado conjunto de casas, dispuestas sin ningún tipo de orden ni concierto. En varios de estos edificios se conservan todavía algunos elementos característicos de las típicas casas solariegas, vinculadas a los grandes y medianos propietarios de ganados merinos. No obstante, tal y como ha ocurrido en muchos de estos pueblos, bien poco es lo que queda hoy de aquel pasado esplendor, que se vivió especialmente durante el siglo XVIII. Por ello, el edificio más relevante lo constituye, como en todos los casos, su iglesia parroquial.

1222 Hasta hace pocas décadas todavía existían rebaños en el pueblo, que efectuaban este viaje hacia Extremadura durante los meses del invierno.

1223 ADPBU. CE. 900. RESPUESTAS GENERALES. Huerta de Abajo, 1 - mayo - 1753.

1224 Ibídem.

1225 Museo Arqueológico - Paleontológico de Salas de los Infantes. 


\section{Iglesia de Santa Cristina.}

La iglesia de Huerta de Abajo está dedicada a Santa Cristina, advocación poco frecuente dentro de la diócesis de Burgos, y más rara aun en nuestra comarca, donde no existen más templos que compartan esta titularidad ${ }^{1227}$. Está situado en la parte central del pueblo, junto a la plaza mayor y el ayuntamiento, acomodándose sobre una superficie inclinada, orientada hacia naciente, que obliga a levantar su cabecera sobre un potente zócalo, con el que se salva el desnivel del terreno. Presenta una planta de una sola nave, de trazado rectangular, articulada en dos tramos, con una cabecera planta en su extremo oriental, algo más estrecha que la nave, con la sacristía adosada sobre su flanco meridional, y la torre a los pies. Todo el edificio está realizado en piedra, alternando en sus muros el paramento de sillería con otros tramos de sillarejo o incluso mampuesto. Estos muros están reforzados por sólidos contrafuertes, dispuestos en sus esquinas y lados mayores, y se rematan con una gruesa cornisa de papo de paloma.

Su imagen exterior queda conformada por limpios volúmenes prismáticos, elevados, en el caso de la nave y la cabecera, a una misma altura, a través de lo cual se aprecia un marcado sentido de horizontalidad. La torre, dispuesta a los pies, por lo tanto, se convierte en el contrapunto vertical dentro de este conjunto, con una estructura prismática sobre base cuadrangular, articulada en dos cuerpos, separados por línea de imposta planta de escaso resalte. Cuatro troneras con arco de medio punto sobre imposta plana, se abren en el cuerpo superior, repartidas entre cada una de las caras, rematando sus muros con cornisa de papo de paloma, y pináculos de bola sobre las esquinas del tejado.

Tres vanos rectangulares con dintel plano y derrame hacia el exterior, iluminan el espacio interior. Todos ellos están orientados hacia el mediodía, repartidos entre cada uno de los tramos de la nave y la cabecera. Sobre esta misma fachada, a la altura del

1226 M. GONZÁLEZ BUENO: Ferrerías de la Demanda burgalesa. Burgos, Excma. Diputación Provincial de Burgos. 1997. 
segundo tramo de la nave, se abre también la puerta de entrada, la cual está formada por un arco de medio punto, escoltado por pilastras de fuste cajeado, sobre las que se extiende un entablamento ligeramente quebrado en los extremos, con el que se da paso al remate, formado por un frontón recto partido, con una pequeña cruz en el centro, y dos pináculos de bola en los extremos, en correspondencia con las pilastras. Una pieza, como ya señalamos en su momento, de gran corrección técnica y aspecto austero, que debemos incluir dentro de la línea más severo del barroco clasicista, desarrollado en la zona $^{1228}$.

Su imagen exterior se completa con la sacristía, adosada sobre el flanco meridional de la cabecera, cuyo tejado se continúa a lo largo de esta fachada, abarcando el primer tramo de la nave, con el que se forma un pequeño porche,

En el interior nos encontramos con un amplio espacio de ámbito único de claro sentido longitudinal, dentro del cual la parte de la cabecera queda perfectamente individualiza a través de un potente arco toral, de medio punto y sección cuadrada, con intradós cajeado, apeado sobre pilastras dóricas de fuste tableteado. Este original relieve se repite en las pilastras que soportan el arco fajón, dispuesto entre los tramos de las naves, también de medio punto, aunque ligeramente rebajado. A los pies de la nave se incorpora un pequeño coro alto, realizado en madera, desde el cual podemos acceder a una puerta con arco de medio punto, dispuesta sobre el muro de los pies, que permite el acceso al interior de la base de la torre. A este espacio también se puede acceder desde el exterior, a través de una puerta abierta sobre el muro de poniente.

Todo el espacio interior del templo se cubre con bóvedas de crucería estrelladas con terceletes, de rampante muy plana, y cinco claves, algunas de ellas decoradas con diferentes motivos de carácter litúrgico, y atributos de diferentes santos. En concreto, nos llama particularmente la atención una de las claves situadas en el tramo de la

\footnotetext{
1227 J. CIDAD PÉREZ: Historia de la Diócesis de Burgos. Burgos, Imprenta Monte Carmelo. 1985.

1228 Ver capítulo: Actividad constructiva. Evolución estilística. Siglo XVII.
} 


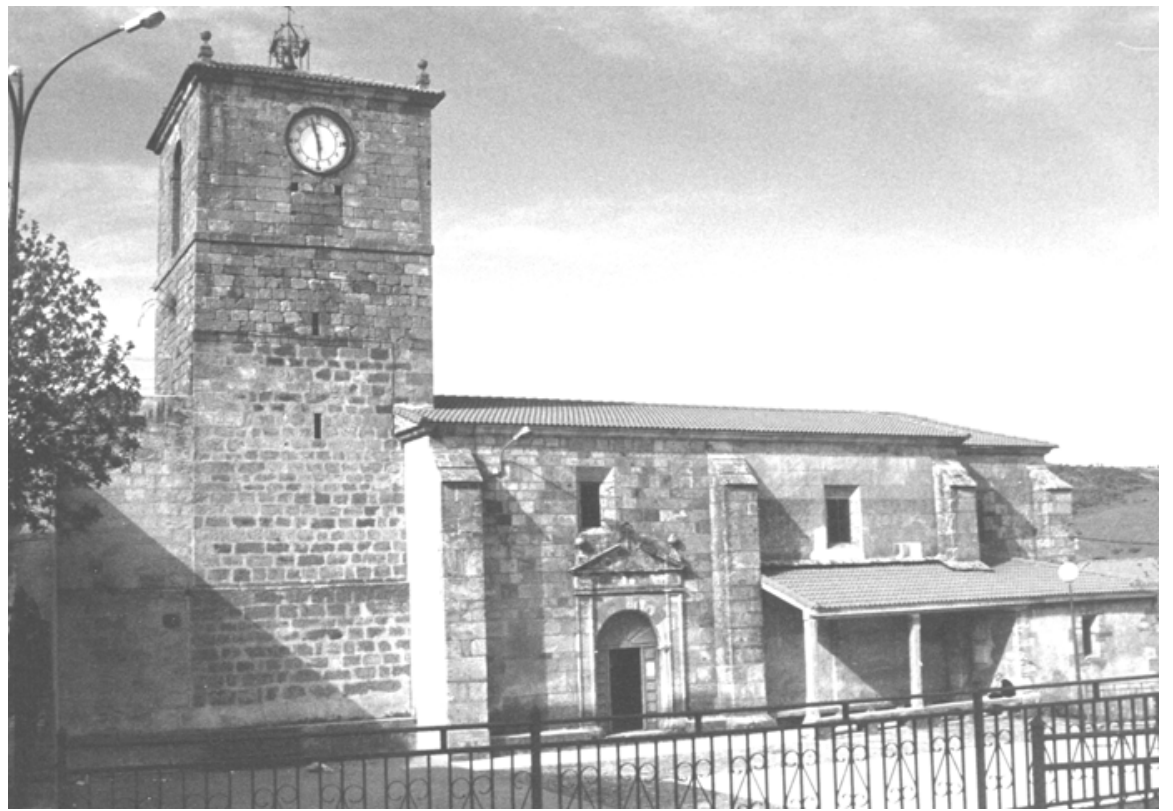

HUERTA DE ABAJO. Iglesia de Santa Cristina.

cabecera, en la que podemos ver representados una flecha y una palma, atributos característicos de la santa titular de este templo.

En las paredes, el enlucido que cubría los muros ha desaparecido, dejando ver unos paramentos de sillarejo y mampuesto, sobre los que destacan los elementos activos del templo, como pilastras y arcos, elaborados en sillería. Esta imagen interior se completa con la incorporación de los cinco retablos, que se reparten de forma simétrica entre sus muros, con el del altar mayor dedicado a Santa Cristina, los colaterales de la entrada del presbiterio a Nuestra Señora del Rosario y San Sebastián, y los dos del tramo delantero de la nave al Cristo crucificado y a las Benditas Ánimas. El del altar mayor es obra churrigueresca, realizado hacia $1767^{1229}$, y cuenta con la imagen de la

1229 AGDBU. LP. Huerta de Abajo, parroquia de Santa Cristina. LF. (1741 - 1797). (fols. 67 - 69). Cuentas del año 1767. Huerta de Abajo, 22 - septiembre - 1768. 
Santa titular, en el nicho central, escoltada por San Pedro y San Pablo en las calles laterales, y el Ángel de la Guarda, en el remate. Los dos retablos de la entrada de la capilla mayor son piezas gemelas de estilo rococó, realizados en la década de 1770, igual que los colaterales, del primer tramo de la nave, ejecutados hacia $1760^{1230}$.

Todo el conjunto de este templo nos muestra, como ya vimos en su momento, un buen ejemplo de la estética clasicista desarrollada en la zona a lo largo de los siglos XVII y XVIII. Sin embargo, la falta de fuentes documentales, como ya indicamos, nos impide establecer con precisión el momento exacto en el que fue construido. El análisis formal, por su parte, tampoco servía para concretar este aspecto, pues el tipo de estructura y las formas desarrolladas apenas conocen variaciones durante estas dos centurias. Es, por lo tanto, la presencia de algunos pequeños detalles lo que han hecho que nos inclinemos por los últimos momentos del siglo XVII. Entre ellos se encuentra, la sencillez de sus cubiertas, con un trazado muy simple, en el que no encontramos nervios combados, la disposición de los contrafuertes exteriores, que no llegan a alcanzar el nivel de la cornisa, y el propio concepto espacial del interior, que marca la perfecta diferenciación entre el ámbito de la nave y el de la cabecera.

La renovación, que se efectúa en este momento, acaba prácticamente con todo vestigio anterior, lo que hace que resulte prácticamente imposible rastrear su historia constructiva. Aun así, debemos suponer que existió una fase románica, de la cual todavía se conserva la pila bautismal, situada en el sotocoro, y dos pequeños canecillos, reaprovechados posteriormente en la construcción de la sacristía. Dentro de estas piezas destaca, de modo especial, la pila, pues en ella encontramos un elemento de extraordinario valor arqueológico, como es la inscripción que recorre todo el borde de

1230 R. J. PAYO HERNANZ: El retablo en Burgos y su comarca durante los siglos XVII y XVIII. Burgos, Excma. Diputación Provincial de Burgos. 1997. (T. II, pp. 498). 
su copa, en la cual todavía se puede leer el siguiente texto: : [...]IOR ME FECIT FACERE AD ONORE SCA: XPISNA V[IRGINIS] ${ }^{1231}$.

La única parte de la historia de este templo, que tenemos documentada, corresponde ya a los dos últimos tercios del siglo XVIII Dentro de esta etapa, sin embargo, se suceden también algunas obras interesantes de reparación y mantenimiento del edificio, entre las que destacan especialmente las relacionadas con el acondicionamiento del suelo. En este sentido, vemos cómo en 1744 el visitador del Arzobispado de Burgos, D. Diego Escalona, informa que el suelo "era de tierra movediza y por lo mismo se halla con bastante yndezencia. Ante ello ordena que con toda urgencia y valiéndose de maestro perito intelijente haya igualmente se entable el piso y pavimento de dicha iglesia (...) lo que executará inmediatamente, que la mencionada fábrica tenga caudales equibalentes para ello sacando dicha obra a remate y haciendo en el mexor postor sin admitir mexoras lo cumpla con apercivimiento $^{1232}$.

No sabemos hasta que punto fueron atendidos estos requerimientos, pero el caso es que una década más tarde un nuevo visitador, D. Andrés Pérez Bracho, repite en su informe un mandato muy parecido al anterior ${ }^{1233}$. Después de este segundo aviso, la parroquia se pone manos a la obra y renueva todo el entarimado del templo. El encargado de hacerlo fue el maestro de carpintería de origen vizcaino, José Durango, el

\footnotetext{
1231 G. BILBAO LÓPEZ: Iconografía de las pilas bautismales del románico castellano; Burgos y Palencia. Burgos, Ed. La Olmeda. 1996. (pp. 95, 107, 255).

1232 AGDBU. LP. Huerta de Abajo, Parroquia de Santa Cristina. LF. (1741 - 1797). (fols. 6 - 9vº ) Visita realizada a la parroquia de Santa Cristina de Huerta de Abajo en 1744, por el canónigo de la catedral de Burgos D. Diego Escalona. Barbadillo de Herreros, 26 - mayo - 1744.

${ }^{1233}$ Ibídem. (fols. $42-43 v^{\circ}$ ). Visita realizada a la parroquia de Santa Cristina de Huerta de Abajo en 1757, por D. Andrés Pérez Bracho, canónigo de la catedral de Burgos. Huerta de Arriba, 29 - julio 1757.
} 
cual percibió de esta fábrica 750 reales $^{1234}$. El coste de la madera, comprada para ello en la localidad de Monasterio de la Sierra, ascendió a 1.391 reales $^{1235}$.

Pero sin duda, dentro de las obras que ahora se acomete, las más destacadas son las relacionadas con la construcción de tres de los retablos que decoran su interior. Los construidos en este momento son, el del altar mayor, y los dos colaterales dedicados a Nuestra Señora del Rosario y San Sebastián. Los trabajos comienzan en 1767, con la confección de las trazas para el retablo mayor, completando su construcción dos años más tarde con la compra de las imágenes de San Pedro y San Pablo, que acompañan a la figura de Santa Cristina en este mismo retablo. En su ejecución participaron, además de la propia parroquia, diferentes instituciones y personas destacadas del pueblo, como el concejo, la cofradía de Nuestra Señora del Rosario, una vecina del pueblo llamada Citaria Hernaiz Barrio, D. Fernando Gil de la Cuesta, antiguo cura de esta parroquia, y varios familiares de este último ${ }^{1236}$. Dentro de esta operación debemos incluir también la venta del antiguo retablo de la capilla mayor de esta iglesia al concejo de Monasterio de la Sierra, por un precio de 460 reales, el cual lo destinó a la ermita de los Santo Mártires de esta localidad ${ }^{1237}$, donde hoy se conserva.

El punto final, dentro de la ejecución de estos retablos, se puso con los trabajos de dorado y estofado, los cuales se realizaron, en el caso del retablo del altar mayor, en 1782, con un coste para la parroquia de 4.600 reales $^{1238}$. Y en el caso de los colaterales, en 1790 , con un precio de 2.316 reales $^{1239}$. Estas labores estuvieron acompañadas, en el caso del retablo mayor, de la construcción de un nuevo tabernáculo y la restauración de la imagen de la santa titular del templo ${ }^{1240}$.

\footnotetext{
1234 Ibídem. (fols. $51-53 v^{\circ}$ ). Cuentas del año 1760. Huerta de Abajo, 28 - septiembre - 1761.

1235 Ibídem. (fols. 45 - 46v ${ }^{\circ}$ ). Cuentas del año 1757. Huerta de Abajo, 14 - octubre - 1758.

1236 Ibídem. (fols. 69 - 68). Cuentas del año 1768. Huerta de Abajo, 6 - septiembre - 1769.

1237 Ibídem.

1238 Ibídem. (fols. 100 - 102). Cuentas del año 1782. Huerta de Abajo, 16 - septiembre - 1783.

1239 Ibídem. (fols. $121 \mathrm{v}^{\mathrm{o}}-123 \mathrm{v}^{\circ}$ ). Cuentas del año 1790. Huerta de Arriba, 27 - septiembre - 1791.
} 
El punto final a las obras realizadas durante esta centuria lo pone la remodelación de la sacristía, efectuada en 1798 por un importe para la fábrica de 400 reales $^{1241}$

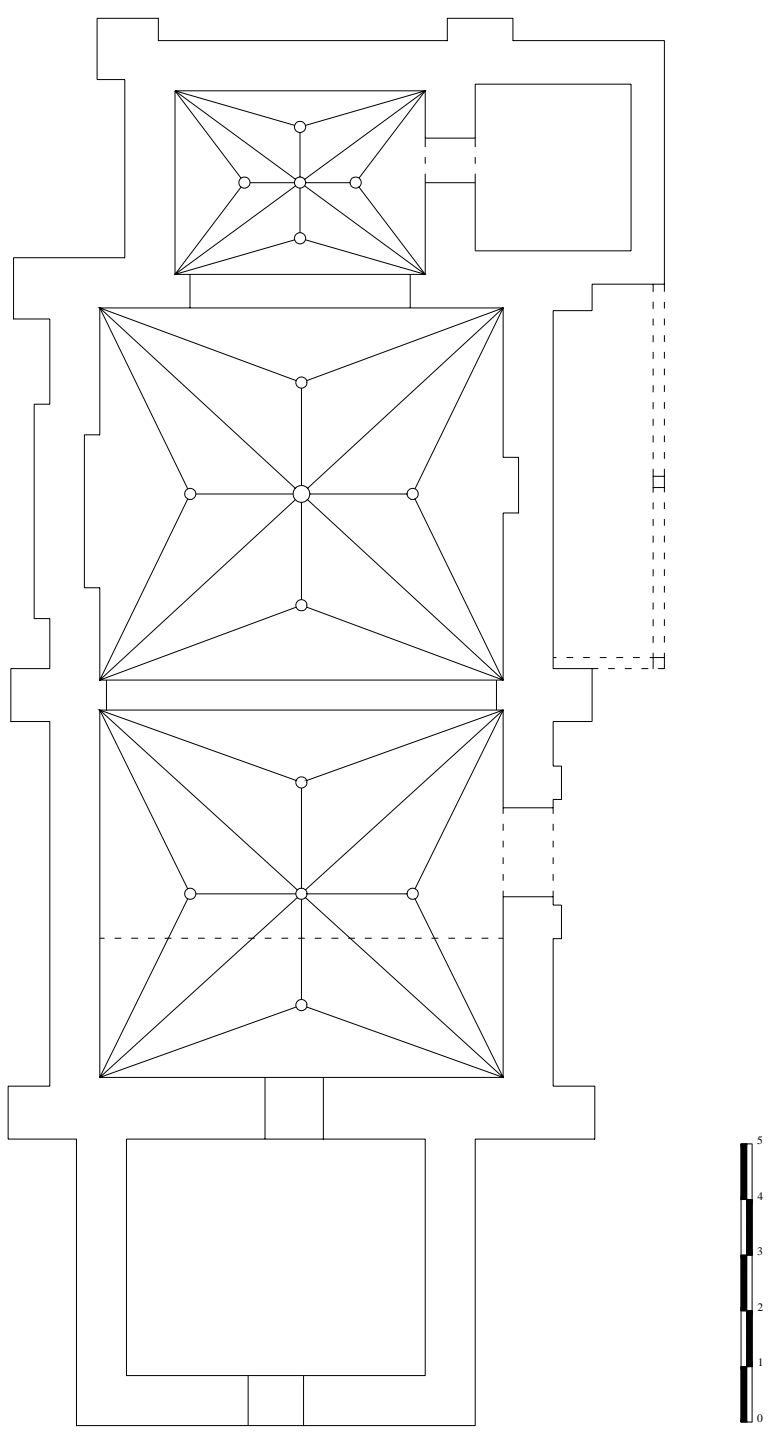

HUERTA DE ABAJO. Iglesia de Santa Cristina. Planta.

1240 Ibídem. (fols. 100 - 102). Cuentas del año 1782. Huerta de Abajo, 16 - septiembre - 1783.

1241 Ibídem. LF. (1798 - 1839). (fols. 3 - 4). Cuentas del año 1798. Huerta de Abajo, 9 - septiembre 1799. 
Ermitas.

Según las fuentes documentales conservadas, Huerta de Abajo solamente contó con dos ermitas, dentro de su término municipal, las cuales estaban dedicadas a San Millán y a Nuestra Señora de Barriús o Barriuso. Ninguna de ellas, sin embargo, ha llegado hasta nuestros días. La de San Millán es la primera en desaparecer, lo que hace que sea muy poco lo que podemos decir sobre ella. Las escasas noticias que tenemos proceden fundamentalmente de los informes dictados por los visitadores del Arzobispado de Burgos, en los cuales se va dando cuenta de su progresivo deterioro. Finalmente, en la visita realizada a esta parroquia por D. Andrés Pérez Bracho en 1761 se indica textualmente que la ermita de San Millán ya no existe ${ }^{1242}$. Su temprana desaparición ha hecho que se pierda todo recuerdo de su existencia, lo que nos impide, incluso, localizar su emplazamiento.

La ermita de Nuestra Señora de Barriús se encontraba situada a escasa distancia del pueblo, en dirección norte, junto a la carretera que une esta localidad con el santuario de Nuestra Señora de Vega. Su origen, por otra parte, parece estar vinculado a un antiguo despoblado, que existió muy cerca de Huerta de Abajo, conocido como Barriús $^{1243}$. De aquí, precisamente toma su nombre esta ermita. Su desaparición se produce, al parecer, en un momento relativamente tardío, pues según nos indica $\mathrm{P}$. MADOZ, en su Diccionario, todavía se conservaba en pie a mediados del siglo XIX. No obstante, en estos momentos su final debía estar próximo, pues los informes de los visitadores del Arzobispado, que llegaron hasta aquí en la primera mitad de este siglo XIX, advierten del mal estado en el que se encuentra. Aun así, en 1803, el propio Arzobispo de Burgos, D. Manuel Cid y Monroy, dice que se halla con la regular decencia para que se pueda celebrar el Santo Sacrificio de la misa y demás funciones

\footnotetext{
${ }^{1242}$ Ibídem. LF. (1741 - 1797), (fols. 50 - 51). Visita pastoral realizada a la parroquia de Santa Cristina de Huerta de Abajo en 1761, por D. Andrés Pérez Bracho, canónigo de la catedral. Huerta de Arriba, 26 mayo - 1761 .

1243 G. MARTÍNEZ DÍEZ: Pueblos y alfoces burgaleses de la repoblación. Ob. cit. (pp. 198).
} 
acostumbradas $^{1244}$. En la visita de 1831, sin embargo, se indica ya, que dicho templo se hallaba con mediana decencia, apremiando su reparación ${ }^{1245}$. Después de su desaparición no han quedado restos, que nos permitan apreciar mínimamente las dimensiones o características del edificio.

Arquitectura civil.

El casco urbano de Huerta de Abajo, como decíamos al inicio, todavía conserva edificios con algunos restos, que podemos incluir dentro de las características casas solariegas, vinculadas a los propietarios de rebaños trashumantes. En su mayor parte, sin embargo, se encuentras bastante deterioradas o muy alteradas por reformas posteriores, lo que hace que resulte muy difícil encontrar un conjunto completo en buen estado. Aun así, existen algunos inmuebles, que todavía conservan el característico arco de medio punto de rosca casetonada, en su fachada principal, que incorporan estas casas durante el siglo XVIII, como ocurre en la situada en la calle San Antonio $n^{\circ} 10$, o en la calle de la Iglesia $n^{\circ} 3$. El inmueble situado en la calle Real $n^{\circ} 7$ mantiene además un interesante alero volado, cuyas cabezas de vigas aparecen decoradas con diferentes motivos de carácter geométricos.

1244 AGDBU. LP. Huerta de Abajo, Santa Cristina. LF. (1798 - 1839). (fol. 8). Visita pastoral realizada a la parroquia de Santa Cristiana de Huerta de Abajo en 1803, por el arzobispo de Burgos D. Manuel Cid y Monroy. Canales, 22 - septiembre - 1803.

1245 Ibídem. (fols. 46 - 52). Visita pastoral realizada a la parroquia de Santa Cristina de Huerta de Abajo en 1831, por D. José López, vicario de la vicaría de Canales. Huerta de Arriba, 14 - octubre - 1831. 
HUERTA DE ARRIBA.

Huerta de Arriba se encuentra situada en el valle de Valdelaguna, el cual se extiende entre las sierras de la Demanda y Neila. Perteneció, por lo tanto, a la agrupación de localidades, que formaban el Real Villa y Valle de Valdelaguna, dentro de las cuales fue siempre la que contó con un mayor volumen de población. Tal vez por este hecho, en la década de 1950 decidió emanciparse, convirtiéndose en municipio independiente, con lo que ponía fin a una historia común de varios siglos.

Las primeras referencias escritas, que tenemos sobre esta localidad datan del siglo XI, y se encuentran en un documento del Cartulario de San Pedro de Arlanza, fechado el 10 de mayo de 1062, donde se la nombra como Orto de Suso ${ }^{1246}$, y otro del año 1083 del Cartulario de San Millán de la Cogolla, en el que se habla de la villa de Orta Superiora $^{1247}$. Para este momento, Huerta de Arriba había dejado ya de formar parte del pequeño y fugaz alfoz de Barbadillo de $\mathrm{Pez}^{1248}$, para integrarse en el gran alfoz de Lara ${ }^{1249}$. Con la extinción del sistema de alfoces, en el siglo XII, esta localidad queda

1246 L. SERRANO: Cartulario de San Pedro de Arlanza. Madrid, Centro de Estudios Históricos. 1925. (pp. 131).

1247 Ibídem. Cartulario de San Millán. Madrid, Centro de Estudios Históricos. 1930. (pp. 256).

1248 G. MARTÍNEZ DÍEZ: Pueblos y alfoces burgaleses de la repoblación. Valladolid, Junta de Castilla y León. Consejería de Educación y Cultura. 1997. (pp.196).

1249 I. ÁLVAREZ BORGE: Monarquía feudal y organización territorial: alfoces y merindades en Castilla (siglos X-XIV). Madrid, CSIC. 1993. (pp. 59). 
876 Arquitectura de la Edad Moderna en la sierra burgalesa.

encuadrada, durante el resto de la Edad Media, en la Merindad Menor de Santo Domingo de Silos ${ }^{1250}$.

Durante la Edad Moderna, su historia y situación transcurre de forma irremisiblemente unida al devenir del resto de las localidades, que forman el valle de Valdelaguna. De esta forma, en el plano fiscal, desde principios del siglo XVI Huerta de Arriba forma parte del partido de las Tierras del Condestable, en la provincia de Burgos $^{1251}$, pasando más tarde, con la reforma borbónica del siglo XVIII, a incorporarse al partido de Aranda ${ }^{1252}$. En lo que se refiere a su régimen jurisdiccional, inicia la Edad Moderna como localidad de señorío, dependiente de la casa de los Duques de Frías, abandonando más tarde esta condición para convertirse, junto con el resto del Valle de Valdelaguna, en localidad de realengo. Por último, en el plano eclesiástico, vemos que sus dos parroquias, con todas sus ermitas, quedaron encuadradas siempre dentro de la Diócesis de Burgos ${ }^{1253}$.

Su población siempre mostró unos valores relativamente altos, situándose significativamente por encima de los niveles medios de los pueblos de esta comarca de la sierra burgalesa, y, por su puesto, muy superiores también al resto de las localidades, que formaban el Real Valle y Villa de Valdelaguna. No obstante, como ocurre en todas las localidades de este valle, resulta prácticamente imposible establecer un análisis evolutivo detallado para todo este período de la Edad Moderna, pues los únicos datos de que disponemos corresponden a los años finales del siglo XVI y la segunda mitad del XVIII. La primera de estas fuentes es el censo de los obispos de 1584-87, donde declara

\footnotetext{
1250 C. ESTEPA DÍEZ: "Estructura de poder en Castilla (siglos XII - XIII). El poder señorial en las merindades burgalesas. En III Jornadas burgalesas de Historia (3 1991). Burgos en la Plena Edad Media. Burgos, Asociación Provincial de Libreros de Burgos. 1994. (pp. 245 - 294). G. MARTÍNEZ DÍEZ: Génesis histórica de la provincia de Burgos y sus divisiones administrativas. Burgos, Aldecoa. 1983.

${ }^{1251}$ G. MARTÍNEZ DÍEZ: Génesis histórica de la provincia de Burgos... ob. cit.

1252 Ibídem.

1253 L. SERRANO: El obispado de Burgos y Castilla primitiva. Desde el siglo V al XIII. (Tomo I). Madrid, Centro de Estudios Históricos. 1935.
} 
tener la cifra redonda de 100 vecinos $^{1254}$. El vecindario del Marqués de Ensenada, de mediados del siglo XVIII, nos refleja un fuerte crecimiento, arrojando una cifra de $183 ’ 5$ vecinos ${ }^{1255}$. Estos valores se mantienen más o menos estables durante la segunda mitad de esta centuria, pues según el censo de Floridablanca, en 1787 había 607 habitantes ${ }^{1256}$. A través de estos censos, y muy especialmente mediante el vecindario del Catastro del Marqués de Ensenada, descubrimos también, que la práctica totalidad de esta población declaran ser hidalgos, existiendo incluso cuatro pobres de solemnidad que pertenecen a este estamento ${ }^{1257}$. Esto, como ya vimos, resulta algo sumamente habitual dentro de estos pueblos del valle de Valdelaguna.

La economía de estos habitantes dependió, de forma casi exclusiva, de la ganadería trashumante, pues el terreno de su término municipal, como bien describe P. MADOZ, en su Diccionario, "es algo montuoso, pero tiene también buenas campiñas, más a propósito para los pastos del ganado en verano que para el cultivo y siembra de granos” ${ }^{258}$. La inmensa mayoría de sus habitantes, por lo tanto, vivían de la ganadería lanar trashumante, formando parte de la Cuadrilla de San Pedro de Vega, que aglutinaba a los pueblos de esta zona de Burgos, que marchaban anualmente con sus ganados merinos a tierras extremeñas para invernar. Formaba parte también, por ello, del Honrado Consejo de la Mesta.

En Huerta de Arriba encontramos ganaderos de todo tipo, predominando los propietarios de rebaños de tipo medio, compuestos por grupos de 200 a 400 cabezas de ganado, fundamentalmente de ovejas merinas. Sin embargo, también encontramos aquí algunos grandes propietarios, como es el caso de Manuel de la Braga, que declara tener,

1254 T. GONZÁLEZ: Censo de población de las provincias y partidos de la Corona de Castilla en el siglo XVI... Ed. Facsímil. Madrid, Imprenta Real. 1829.

1255 Vecindario de Ensenada 1759. Vol. I. Madrid, Centro de Gestión Catastral y Cooperación Tributaria: Tabapress. D. L. 1991.

1256 INE. Censo de 1787. "Floridablanca”. Madrid. INE. 1989.

1257 Vecindario de Ensenada 1759. Ob. cit.

1258 P. MADOZ: Diccionario geográfico - estadístico - histórico de España y sus posesiones de Ultramar. Valladolid, Ámbito D.L. 1984. (pp. 344). 
a mediados del siglo XVIII entre sus ganados más de 2.000 cabezas de ovejas merinas $^{1259}$. Y ello, a pesar de que en este mismo Catastro los vecinos de Huerta de Arriba declaran que: "si bien pueden afirmar que el número de ganado de esta especie no asciende ni con mucho al de los años pasados por la gran mortandad que se va experimentando este año a causa de la escasez de las yerbas, por la carestía de las aguas” ${ }^{260}$. Por todo ello, podemos considerar a Huerta de Arriba, junto con Neila y tal vez Barbadillo de Herreros, como los centros más importantes de la trashumancia en esta zona, y en general en toda la provincia de Burgos.

La imagen que nos ofrece su núcleo urbano, presenta un caserío apretado, asentado en el fondo de un pequeño valle, rodeado de suaves laderas. Esta imagen es el resultado final de una larga evolución, dentro de la cual se ha producido un proceso de compactación hasta llegar a formar el conjunto actual. Así, en su origen, Huerta de Arriba estaría formado por dos barrios perfectamente diferenciados, denominados San Martín y Santa María, localizados, el primero, en la parte más baja de esta hondonada, y el segundo, sobre la ladera de una suave loma, que se extiende en la parte noroeste de la anterior. Cada uno de estos barrios se hallaba presidido por sus respectivos templos parroquiales, de los cuales tomaban su nombre. Con el transcurso del tiempo, podemos comprobar cómo los habitantes del barrio de Santa María fueron desplazándose de modo progresivo hacia la zona más protegida del viento y demás inclemencias, que representaba el barrio de San Martín, hasta dejar totalmente aislada su iglesia en la cima de este cerro Como consecuencia de todo ello, el propio concejo del pueblo, apoyado por los responsables de cada una de estas parroquias, solicitaron a principios del siglo XVIII al Arzobispado de Burgos la supresión de la empobrecida parroquia de Santa María, y su anexión a la más rica y próspera de San Martín. Esta solicitud se realiza formalmente en 1717, y en ella los sacerdotes de las dos parroquias, junto con el concejo del pueblo, expresan que:

1259 ADPBU. CE - 906. LIBROS MAYORES DE LO RAÍZ Y PERSONALES DE AMBOS ESTADOS. Huerta de Arriba, 26 - julio - 1753.

1260 Ibídem. CE - 902. RESPUESTAS GENERALES. Huerta de Arriba, 26 - julio - 1753. 
"sienten el grave incombeniente de no poder mantener ni conserbar la referida iglesia de Santa María y menos el beneficiado de ella que lo es el dicho D. Juan Vicente, así por el riesgo y ruina que amenaza dicha iglesia como por hallarse ésta distante de dicho lugar y en un alto y eminencia en que se imposibilita el transito de imbierno en que aquella situación y los caminos están llenos de niebe con total imposibilidad, que sucede con frecuencia no poder subir a dicha iglesia por espacio de quince o veinte días el párroco ni los feligreses a celebrar y oír misa y frequentar los sacramentos y demás actos y funciones parroquiales con cuio motivo se an visto precisados muchos feligreses a mudar domicilio y pasarse a la iglesia de San Martín, que se halla en medio de la situación y población de dicho lugar por cuia causa y ser pocos y pobres los feligreses y parroquianos de la referida de Santa María no hay fuerzas ni caudales para rehedificarla y repararla de la ruina que amenaza ni rentas ni alimentos decentes para poderse mantener el beneficiado de ella"1261.

Una vez expuestos los motivos, la petición se realiza en los siguientes términos:

" $Y$ por estos motivos que son notorios de que ofrezco plenamente justificación consienten mis partes se haga unión y incorporación canonice et emperpetuam de la dicha iglesia de Santa María a la referida de San Martín y de su beneficio o beneficios eclesiásticos con extinción total de ella y sus beneficios para que así unida y incorporados con los de San Martín y su iglesia puedan todos los vecinos de dicho lugar como vecinos feligreses de ella ser asistidos del pasto spiritual y sus beneficiados tener la congrua competente y poder celebrar con más obsequio y aumento las funciones parroquiales"

1261 A.P. Salas de los Infantes. Documento sin clasificar. Unión de las parroquias de Huerta de Arriba de San Martín y Santa María. Huerta de Arriba, 22 - abril - 1717. 1262 Ibídem. 
A partir de aquí, y durante todo el año siguiente, se inician las consiguientes indagaciones por parte del Arzobispado, para verificar la necesidad de llevar a cabo la solicitada anexión. Las respuestas obtenidas de sus pesquisas no hacen sino confirmar lo ya expuesto en la petición inicial, ampliando datos, además, sobre la evolución que había experimentado la estructura urbana de este pueblo ${ }^{1263}$.

La sentencia definitiva se dicta en febrero de 1719, y en ella se determina realizar la unión, transvasando a la iglesia de San Martín todos los derechos de Santa María, y también todas sus obligaciones, como memorias, aniversarios, y demás cargas y obligaciones que estaban fundadas en ella ${ }^{1264}$. La comunicación de esta sentencia a la villa de Huerta de Arriba, sin embargo, no llegó hasta el 3 de agosto de este mismo año, ordenando en ella su inmediato cumplimiento. De este modo, tres días después, el 3 de agosto, tiene lugar la supresión definitiva de la iglesia de Santa María, la cual se produce en medio de una solemne ceremonia, desarrollada con toda la dignidad que el momento requería. La crónica de tan emotivo acto queda recogida en el acta levantada por el notario, D. Martín Fernández de la Cuesta, que certificó la ejecución de la sentencia. La emoción que emana de sus palabras, algo impropio de la frialdad que caracteriza siempre a los documentos notariales, nos obliga a cederle la palabra:

"Después de lo susodicho, dicho día (3 de agosto de 1719) su merced dicho Señor Juez de Comisión pasó a la dicha iglesia de Santa María y haviendo mandado tocar a misa de tercia en la forma acostumbrada la dijo y celebró y en ella consumió el Santísimo Sacramento que estaba en el Sagrario y acabada la misa que concurrió la maior parte del pueblo con su asistencia se sacó de la dicha iglesia la cruz parroquial y chrismeras y con la decencia devida se llevó a la de San Martín, en señal de quedar estinguida la dicha parroquia de Santa María. Todo lo cual se hizo

\footnotetext{
1263 Ibídem. Burgos, 27 - septiembre - 1718.

1264 Ibídem. Documento sin clasificar. Sentencia del Arzobispado de Burgos, dada a través de sus provisores, mediante la cual se declara la unión y anexión por parte de la iglesia de San Martín de Huerta de Arriba, de la de Santa María de esta misma villa. Burgos, 24 - febrero - 1719.
} 
y executó en mi presencia quieta y pacíficamente sin contradicción alguna"1265.

\section{Iglesia de San Martín.}

La iglesia de San Martín, por lo tanto, quedó desde 1719 como única parroquia de este pueblo. Se encuentra situada en la parte central del núcleo urbano, junto a la plaza mayor y el ayuntamiento. Su fábrica conserva diferentes elementos pertenecientes a su primitiva fase románica, si bien, la estructura actual constituye el resultado de las profundas labores de remodelación, que se hicieron después de la incorporación de la otra parroquia del pueblo, para dar cabida así a toda su feligresía. La intensidad de esta renovación fue tal, que en cierto modo podemos decir que se trata de un templo de nueva planta. Como resultado de ello, tenemos una fábrica de grandes dimensiones, en la que, a pesar de las fechas en las que se realiza, dominan las formas propias del barroco clasicista. A ello contribuyen diferentes factores, entre los que se encuentran, el profundo arraigo que alcanzaron estas formas en nuestra comarca, y el resurgir de las mismas, que se produce, dentro de esta diócesis, alentado por figuras tan destacadas dentro de este campo, como el maestro de cantería, Fr. Pedro Martín ${ }^{1266}$.

El templo, que tenemos en la actualidad, presenta una planta de nave única de grandes dimensiones, articulada en tres tramos desiguales, con cabecera plana y poco profunda en el extremo septentrional, la sacristía y una capilla cuadrangular, sobre el flanco oriental, que se corresponde con la antigua capilla mayor, y la torre sobre el flanco contrario, enfrentada con esta capilla. Esta capilla lateral y la torre, por lo tanto, constituyen los dos únicos restos que se conservan del templo anterior, los cuales manifiestan el cambio de orientación, que se produce en la estructura de este templo con la renovación de principios del siglo XVIII.

\footnotetext{
1265 Ibídem. Documento sin clasificar. Acta notarial redactada ante Martín Fernández de la Cuesta, escribano del Rey del ayuntamiento del Valle de Valdelaguna, en al cual se recoge el cumplimiento de la sentencia de la unión y anexión de la parroquia de Santa María de Huerta de Arriba por la de San Martín de la misma localidad. Burgos, 3 - agosto - 1717.

1266 Ver capítulo: Actividad constructiva. Evolución estilística. Siglo XVIII.
} 
El edificio presenta sólidos muros de piedra de sillería, alzados sobre un potente zócalo, también de sillería, y rematados por un friso, que recorre todo el contorno del templo, dando paso a una cornisa de cuarto de bocel y codillo. Estos muros están reforzados por sólidos estribos, de fuerte resalte sobre el plano del muro, los cuales aparecen dispuestos, en las esquinas, en ángulo recto con lados en paralelo a los del muro.

Con todo ello se consigue proyectar hacia el exterior una imagen de gran monumentalidad, dominada por el gran prisma, que constituye la zona del cuerpo, sobre el cual se añaden los diferentes módulos, que conforman los espacios añadidos, como son la capilla mayor, la capilla lateral, la sacristía y la torre. De todos ellos, la torre es el único elemento que rompe la uniformidad establecida en el nivel de cubiertas, constituyéndose como auténtico contrapunto vertical dentro de todo el conjunto. Esta torre está articulada en tres cuerpos desiguales, levantados sobre planta cuadrangular, con cada uno de los cuales se introduce un ligero decrecimiento en anchura. El inferior, de época románica, forma el basamento, sobre el que se alza el resto de la estructura. El central, de mayor desarrollo que el resto, está dividido, a su vez, en tres partes por líneas de imposta planas de escaso resalte. Por último, el superior, que forma el cuerpo de campanas, cuenta con cuatro vanos coronados con arcos de medio punto sobre impostas planas, repartidos entre cada una de sus caras, rematando sus muros, al igual que el resto del templo, con un friso corrido, que da paso a una cornisa de papo de paloma, con el que llegamos al tejado, donde aparecen pináculos de bola sobre cada una de las esquinas.

Los vanos, que iluminan el espacio interior, se reparten entre cada uno de los lados del templo, exceptuando la cara norte, donde está el testero de la capilla mayor. Todas estas ventanas comparten un mismo tipo de trazado rectangular con dintel plano, dentro del cual, las situadas en los muros laterales introducen un ligero derrame hacia el exterior. 


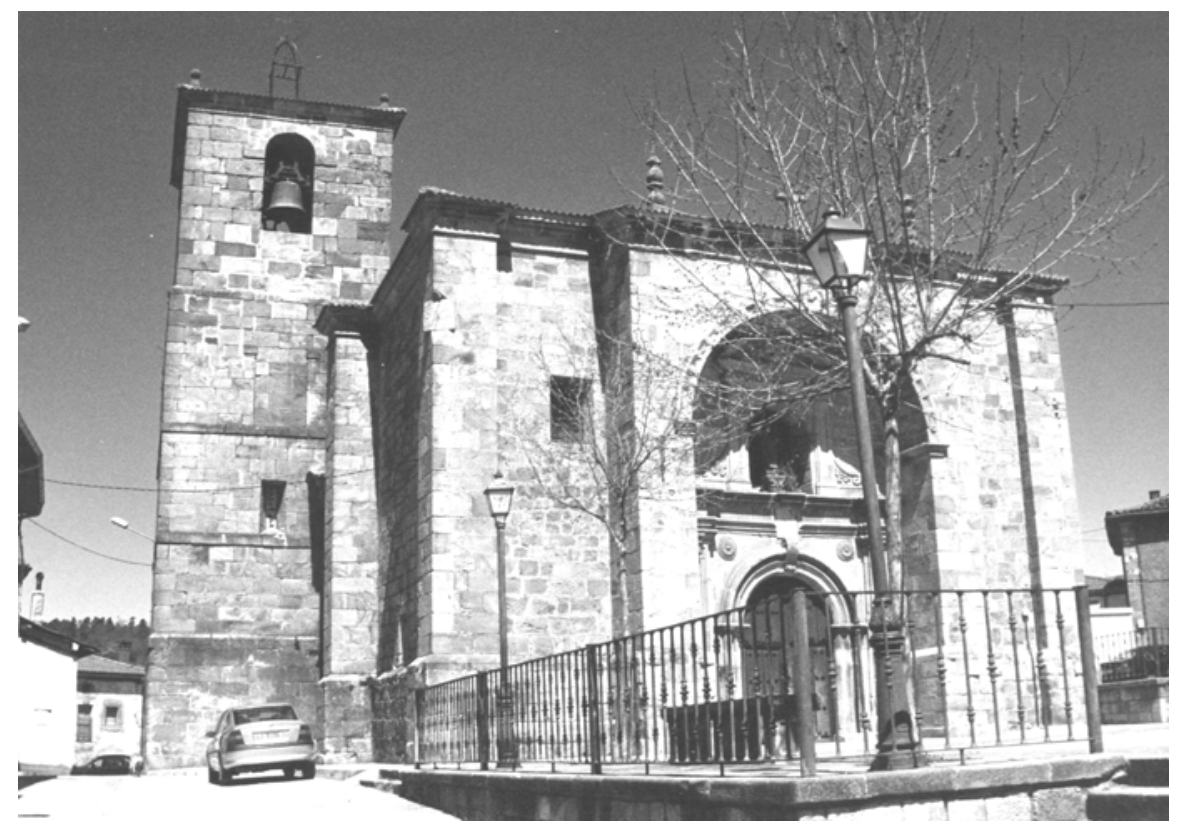

HUERTA DE ARRIBA.

Iglesia de San Martín.

La imagen exterior se completa con la puerta de acceso, abierta sobre el muro de los pies, donde aparece una estructura de marcado sabor clasicista, cobijada bajo un amplio arco de medio punto de rosca casetonada, dispuesto entre contrafuertes. Presenta, como vimos en su momento, una estructura articulada en dos cuerpos, con el inferior formado por una puerta coronada con arco de medio punto, enmarcado por una gruesa moldura de tres cuartos de bocel, que se continúan, a través de una fina imposta, para formar dos potentes baquetones en las jambas. A los lados aparecen pilastras cajeadas con penachos de frutas colgantes, decorando su tercio superior, sobre las que se extiende un entablamento de perfil quebrado y volada cornisa. El cuerpo superior, por su parte, está formado por una hornacina central, coronada con arco de medio punto de rosca casetonada, escoltada con pilastras cajeadas y frontón curvo partido, con un marcado retranqueado, en el remate. En el interior de la hornacina aparece la imagen de 
San Martín, colocada sobre un doble capitel de estilo románico, perteneciente, probablemente al templo primitivo. La unión de estos dos cuerpos se realiza mediante pequeños aletones de perfil avolutado, decorados con sencillos motivos vegetales, y rematados, en los extremos, con estilizado y movidos pináculos.

En el interior, nos encontramos con el desarrollo de un característico concepto de ámbito único, constituido por la gran nave, a la cual se abren la capilla mayor y la capilla lateral, dedicada a Nuestra Señora. Todo este espacio de la nave se cubre con bóvedas de crucería estrelladas con terceletes, sobre los cuales se incorporan, en el caso de los dos tramos delanteros, una serie de nervios combados, con los que se dibuja una estructura de ondas alrededor de la clave central, que alcanzan su mayor complicación en el tramo central. Estos tramos quedan separados por amplios arcos fajones de medio punto muy rebajados de intradós cajeado, que apean sobre sólidas pilastras de orden dórico y fuste igualmente cajeado, de fuerte resalte sobre el plano del muro. Tanto arcos como pilastras están realizados en piedra de sillería, mientras que los muros, una vez perdida su capa de enlucido, muestran un mampuesto de grueso calibre.

Un potente arco de medio punto e intradós cajeado, dispuesto sobre ménsulas avolutadas, marca el acceso al interior de la capilla mayor, abierta sobre el muro septentrional. Su espacio se cubre con una bóveda de medio cañón, formada como proyección de su arco de entrada. La capilla de Nuestra Señora, por su parte, se halla precedida de un arco apuntado dispuesto sobre gruesas impostas, decoradas con el característico relieve ajedrezado del estilo románico. Su interior se cubre con sólida cubierta de medio cañón, sin arcos fajones de refuerzo, en la cual se conservan algunos restos de la policromía, que en su día decoraba estos paramentos. Frente a esta capilla se conservan los restos del antiguo coro, alojado en el interior de la base de la torre, cuyo elemento más destacado lo constituyen los dos amplios vanos coronados con arco de medio punto, colocados sobre el mismo eje, que conducían al interior del coro y sotocoro respectivamente. 


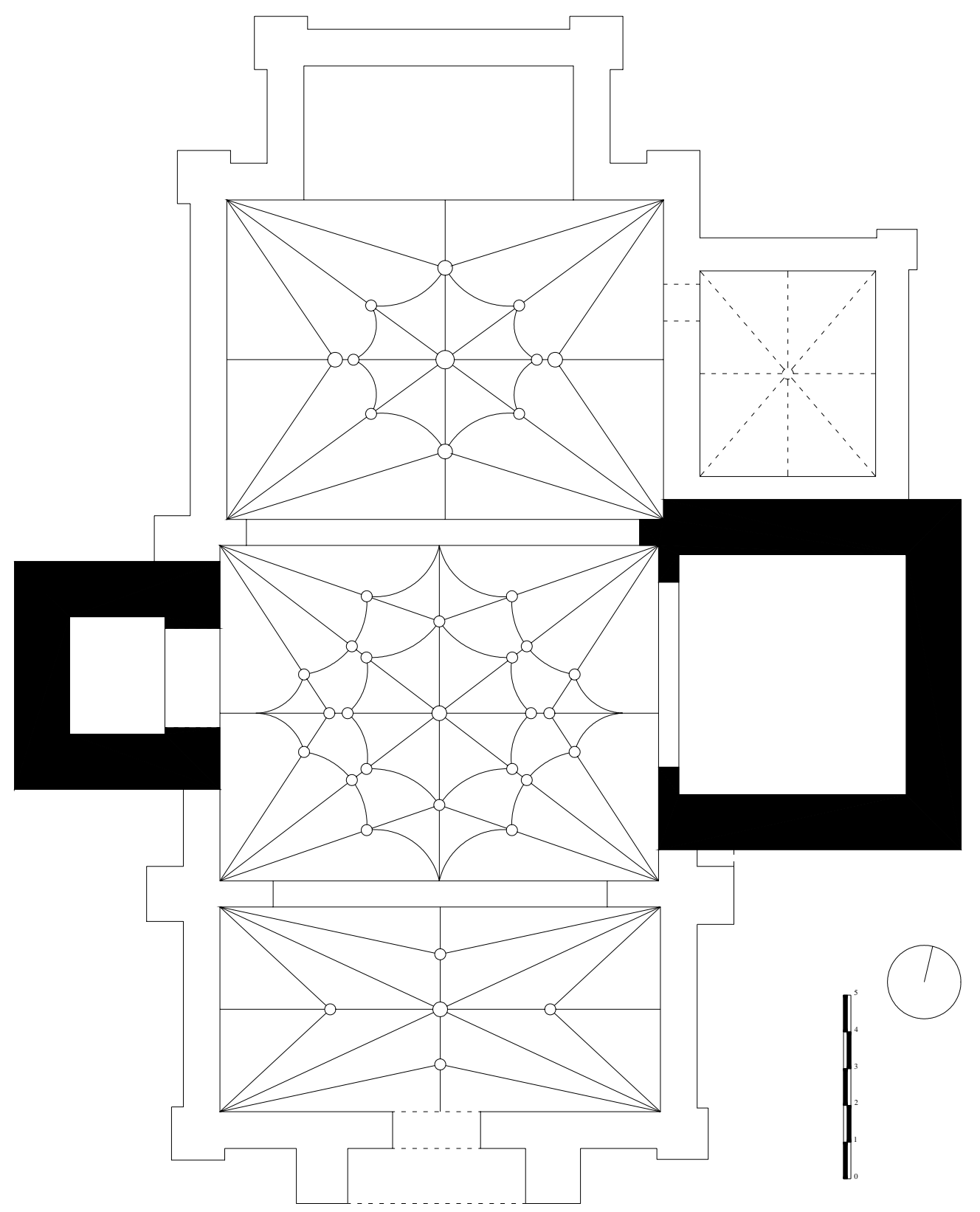

HUERTA DE ARRIBA. Iglesia

de San Martín. Planta. 
Por último, en la zona de los pies, encontramos el actual coro, el cual ocupa todo el espacio del tramo final de la nave. Se trata de un característico coro alto, de estructura mixta, formado por un amplio arco escarzano, dispuesto entre las pilastras que delimitan este tramo de los pies, sobre el cual se dispone en entarimado de madera, que constituye el suelo. Reproduce, por lo tanto, una de las variantes habituales de esta tipología, que venían desarrollándose en la zona desde el siglo XVI.

La imagen interior del templo se completa con los retablos, que decoran cada un de sus altares. Son cinco, y aparecen dispuestos de forma simétrica, con un gran retablo en el altar mayor, dos colaterales en la entrada de esta capilla, y dos más en los muros laterales del primer tramo de la nave. El retablo del altar mayor es obra churrigueresca, realizado en 1783, de complicada estructura, compuesta por un banco, un cuerpo articulado en tres calles y remate. Cuenta con una talla de San Martín en el gran nicho central, acompañado de San Juan Bautista, San José, Santiago Matamoros y San Mateo a los lados, y la Inmaculada Concepción en el remate. Los colaterales de la entrada de esta capilla mayor son dos retablos gemelos de estilo prechurrigueresco, realizados hacia 1670, presididos actualmente por una talla moderna de la Inmaculada, el del lado de la epístola, y por una Dolorosa de vestir, el del evangelio. Ninguna de estas imágenes, sin embargo, parece que fueron sus titulares en origen. Los situados en el primer tramo de la nave, por su parte, están dedicados a las Benditas Ánimas del Purgatorio y a Santa Teresa, y son obras de estilo churrigueresco, realizadas ambas en torno a la década de 1750. A estos retablos debemos sumar los situados en el interior de la antigua capilla mayor, hoy capilla lateral, dedicada a Santa María. En el muro frontal aparece un retablo de estilo churrigueresco, realizado hacia 1740, de un solo cuerpo con tres calles y remate, presidido por una talla de la Virgen con el Niño del siglo XVI, a la cual acompañan San Joaquín y Santa Ana a los lados, y un santo sin identificar, en el remate. A los lados de este retablo se alzan otras dos piezas más modestas, dedicadas a Jesús Nazareno y a San Vitores. El primero es de estilo churrigueresco, y fue realizado 
hacia mediados del siglo XVIII. El segundo es obra más temprana y modesta, de estilo prechurrigueresco, realizado hacia $1670^{1267}$.

A tenor de todo lo que hemos observado en el análisis de la estructura de este templo, podemos resumir su historia constructiva en dos fases o períodos perfectamente definidos, cada uno de los cuales nos depara un edificio completamente distinto. El modo en el que estas reformas se han llevado a cabo, por otra parte, ha permitido que se conserven elementos suficientes del templo primitivo, como para poder reconstruir su estructura. Estos elementos se complementan con la información de carácter documental, de fecha anterior a la gran renovación realizada durante el siglo XVIII.

El primer templo que conocemos, presentaba una estructura muy sencilla, con planta de una sola nave de trazado rectangular, con profunda cabecera plana en su extremo oriental, algo más estrecha que la nave, y torre dispuesta a los pies, levantada sobre planta cuadrangular. A tenor de las características de los muros que se han conservado, debemos pensar que todo el edificio se encontraba realizado en piedra de sillería, con piezas de mediano tamaño, bien labradas y ensambladas. Presentaba, con toda seguridad, un acceso en la parte de los pies, a través de la torre, si bien, opinamos que la entrada principal se hallaba en la parte meridional de la nave, frente a la cual se extendía una galería porticada. Así, al menos, parecen indicarlo diferentes testimonios documentales $^{1268}$, y también algunos restos de capiteles pareados, que se conservan en diferentes partes del templo ${ }^{1269}$. En el interior, el espacio de la nave estaría cubierto con una sencilla techumbre de madera dispuesta a dos aguas, tal y como nos indica la impronta dejada sobre el muro que se extiende por encima del arco de entrada a la antigua capilla mayor. La cabecera, por su parte, a pesar de las reparaciones efectuadas

1267 R. J. PAYO HERNANZ: El retablo en Burgos y su comarca durante los siglos XVII y XVIII. Vol. 2. Burgos, Excma. Diputación Provincial de Burgos. 1997. (T. I, pp. 34, 379, 413, 527, 551; T. II, pp. 498). 1268 AGDBU. LP. Huerta de Arriba, Parroquia de San Martín. LF. (1637 - 1674). Cuentas del año 1673. Huerta de Arriba, 4 - diciembre - 1673. 
en ella, no parece que haya sufrido alteraciones sustanciales en su estructura, con respecto a su imagen original. Conserva así, como vimos, el arco apuntado de la entrada y la bóveda de medio cañón, que forma su cubierta. Su imagen exterior, sin embargo, se encuentra totalmente alterada por las reparaciones sufridas durante el siglo XVIII, en el transcurso de las cuales se forraron por completo sus muros ${ }^{1270}$.

A través de las fuentes documentales, sabemos también, que frente a la entrada del presbiterio existía, a principios del siglo XVII, un sepulcro, formado simplemente por una losa ligeramente elevada sobre el nivel del suelo, en la que no aparecía ningún tipo de representación figurada o escrita. Esta pieza, lejos de constituir una obra, que aportara cierto porte al templo, llegó a convertirse en una auténtica molestia para la parroquia, no sólo desde el punto de vista estético y litúrgico, pues interrumpía el normal deambular de los feligreses, sino también en el plano económico. Así, según denuncia en 1635 el visitador del Arzobispado de Burgos, D. Antonio Sánchez Tristán, este sepulcro no contaba con ningún tipo de dotación por parte del difunto o difuntos allí enterrados, ni de sus familiares, lo cual contravenía claramente lo estipulado en las disposiciones, que sobre esta materia, macaban las Constituciones Sinodales de este Arzobispado $^{1271}$. Ante esto, directamente se decidió suprimir dicho sepulcro.

También sabemos que en el interior de esta nave se hallaban las trojes, donde se recogía el grano y demás productos recaudados por esta parroquia en los diezmos. Estas trojes debían situarse sobre uno de los muros laterales de la nave, junto al baptisterio, lo cual, evidentemente, afectaba a la dignidad de este lugar. Por ello, este mismo visitador, al hablar del baptisterio dice que: no se está en parte decente por estar junto a las trojes

1269 La imagen del santo titular del templo, que aparece en la hornacina de la portada, se encuentra dispuesta sobre uno de estos capiteles, que actúa como peana. Lo mismo sucede con las imágenes de los santos San Cosme y San Damián, que se encuentran en el interior de la capilla de Nuestra Señora.

1270 AGDBU. LP. Huerta de Arriba, parroquia de San Martín. LF. (1723 - 1778). Visita realizada a la parroquia de San Martín de Huerta de Arriba en 1744, por D. Diego Escalona, canónigo de la catedral de Burgos. Canales, 20 - mayo - 1744.

1271 Ibídem. LF. (1600 - 1637) (fols. 107 - 110). Visita realizada a la parroquia de San Martín de Huerta de Arriba el año 1635, por D. Antonio Sánchez Tristán. Huerta de Arriba, 7 - mayo - 1635. 
de la iglesia (...) comunicándose las inmundicias de retones y el polbo della ansi por esta razón como por no estar cercada ni guardada como combiene al paso de la puerta $^{1272}$. Para corregir esto ordena que la pila sea trasladada a otro lugar cercándolo con la reja de halavastro y la puerta donde se señaló, dejándolo con la capacidad y decente para poder administrar el Santo Sacramento del bautismo ${ }^{1273}$. Cuatro años más tarde, para poner fin a este problema, un nuevo visitador del Arzobispado de Burgos, D. Gabriel Muñoz, orden sacar las trojes fuera del espacio del templo ${ }^{1274}$, solución que ciertamente parecía más lógica.

Dentro de todos estos elementos, todavía se conserva la pila bautismal, la cual constituye, sin duda, una de las piezas más interesantes de cuantas guarda este templo. Es de estilo románico, y presenta en el exterior de su copa una serie de relieves de extraordinaria calidad artística e iconográfica, con representaciones de aves en posición rampante y diferentes círculos concéntricos ${ }^{1275}$. Sin embargo, y por desgracia, si no se pone remedio pronto, nuestra generación puede ser la última en disfrutar de esta maravilla, pues la extraordinaria fragilidad de la roca arenisca en que está hecha, unida a la humedad a la que se ve sometida en su emplazamiento actual, hace que su estado de conservación no sea el más idóneo.

Por lo demás, todo parece apuntar a que la estructura de este templo se mantuvo, sin grandes alteraciones, a lo largo de toda la Edad Moderna, hasta el siglo XVIII, cuando se realiza la gran remodelación, que cambia totalmente su fisonomía. Los únicos cambios que se introducen, se centran fundamentalmente en la parte de los pies, tal y como nos indican, el análisis formal y las fuentes documentales. Así, en un momento que debemos situar en torno al segundo cuarto del siglo XVII, se produce la renovación

\footnotetext{
1272 Ibídem.

1273 Ibídem.

1274 Ibídem. LF. (1637 - 1675). Visita realizada a la parroquia de San Martín de Huerta de Arriba el año 1639, por el licenciado Gabriel Muñoz. Huerta de Arriba, 25 - octubre - 1639.

1275 G. BILBAO LÓPEZ: Iconografía de las pilas bautismales del románico castellano; Burgos y Palencia. Burgos, Editorial Olmeda. 1996. (pp. 62 - 63, 117).
} 
del campanario, levantado la estructura correspondiente al cuerpo intermedio de la torre actual. Años más tarde, en 1666, se procede a construir en su interior el coro, posiblemente movidos por la imperiosa necesidad de ganar algo de espacio en el interior, ante el aumento de su feligresía. El encargado de realizar estos trabajos fue el maestro de cantería Juan de Solares, muy conocido en la zona por sus trabajos en el monasterio de Santo Domingo de Silos $^{1276}$ y la iglesia de Barbadillo del Mercado ${ }^{1277}$. Esta obra entrañaba una gran dificultad, pues había que romper el grueso muro de la torre, sin dañar su estructura, para abrir así los dos vanos superpuestos, que comunicaban con los espacios del coro y sotocoro, respectivamente. Los trabajos finalizaron con la colocación del suelo de madera, desembolsando la fábrica de esta iglesia por ello 18.105 maravedís $^{1278}$.

No mucho tiempo después, en 1671, se construye el nuevo retablo para el altar mayor, invirtiendo en esta ocasión la parroquia un total de 3.284 reales $^{1279}$. Con este retablo se completaba la ornamentación de esta capilla, para la cual en 1657 se había adquirido un frontal con un coste de 10.795 maravedís $^{1280}$.

El segundo templo del que debemos hablar es el que surge en los años finales de la década de 1720, después de la anexión de la parroquia de Santa María, y la incorporación de su feligresía a esta iglesia. Por lo que sabemos, las obras no se realizan de forma inmediata, pues aunque la licencia para su ejecución fue concedida en

\footnotetext{
1276 C. J. PALACIOS PALOMAR: Studia Silensia Series Mior IV. Patrimonio artístico y actividad arquitectónica del monasterio de Santo Domingo de Silos (1512 - 1835). Santo Domingo de Silos, Milenario del Nacimiento de Santo Domingo de Silos (1000 - 2000). Abadía de Silos. 2001. (pp. 32).

1277 A. C. IBÁÑEZ PÉREZ: “Arquitectura barroca burgalesa”. En Historia de Burgos. III Edad Moderna (3). Burgos, Caja Burgos. 1999. (pp. 313 - 359).

1278 AGDBU. LP. Huerta de Arriba, parroquia de San Martín. LF. (1637 - 1675). Cuentas del año 1666. Huerta de Arriba, 7 - diciembre - 1666.

1279 Ibídem. Cuentas del año 1671. Huerta de Arriba, 14 - diciembre - 1671.

1280 Ibídem. Cuentas del año 1657. Huerta de Arriba, 15 - noviembre - 1657.
} 
$1723^{1281}$, su puesta en marcha no se produce hasta el año 1726. Los motivos que impulsan esta renovación, en cualquier caso, parecen obvios, tal y como recogen los visitadores del Arzobispado de Burgos en sus informes, donde dicen que “dicha iglesia se está muy pequeña para poder entrar la jente que tiene dicho lugar de Huerta de Arriba, y estar con la comodidad y debozión que se requiere, mediante haverse unido a ella la de Santa María”1282. En todo el proceso de construcción observamos también una implicación ciertamente activa de las autoridades civiles y vecinos del pueblo, hasta el punto de que podemos hablar casi de un auténtico patrocinio del concejo de la villa, encargándose de dirigir, contratar, y en gran medida sufragar la mayor parte de los gastos.

Este ambicioso proyecto de remodelación se completa a lo largo de dos fases consecutivas, culminadas en 1727, la primera, y en 1729, la segunda. Durante la primera de ellas se acomete la construcción de toda la parte delantera del nuevo templo, levantando la nueva capilla mayor y el primer tramo de la nave, con sus respectivas cubiertas. Como recuerdo de ello se conserva una inscripción sobre una de las claves de la bóveda de esta nave, donde se indica que esta obra se hizo A COSTA DE ESTE CONCEXO I DEBOTOS AÑO DE 1727. El desarrollo de estos trabajos, por lo tanto, no obligó a mover ni una sola piedra de la antigua iglesia, en la cual se mantuvo en normal desarrollo del culto.

En la segunda fase se completa este proyecto renovador con la construcción de los dos tramos restantes de la nave, la sacristía, el coro en el interior, y la portada, que remata todo el conjunto. Esto obligó a demoler los muros laterales de la nave de la antigua iglesia, pero no así la cabecera y la torre, las cuales fueron incorporadas, como ya vimos, a la estructura del nuevo templo, sobre sus flancos laterales. La antigua capilla mayor quedó convertida, por lo tanto, en una sencilla capilla lateral, dedicada, a

1281 Ibídem. LF. (1723 - 1778). (fols. 1 - 3). Visita realizada a la parroquia de San Martín de Huerta de Arriba el año 1723, por D. Íñigo de Angulo. Canales, 29 - octubre - 1723. 
partir de este momento, a Nuestra Señora, seguramente como homenaje a la antigua parroquia desaparecida, y para que el traslado de su feligresía a esta nueva iglesia no supusiera un hecho traumático. La torre, por su parte, tuvo también que adaptarse a esta nueva fábrica, incrementando su altura, mediante la incorporación de un nuevo cuerpo de campanas, construido sobre la estructura ya existente. Pero esto, sin embargo, no se realizó de manera inmediata.

En cuanto a los detalles que rodearon la ejecución de este proyecto, sabemos que los encargados de dirigir los trabajos de cantería fueron los maestros Bernardo de la Torre y Melchor de la Ayuela, los cuales consiguieron hacerse con el contrato de la primera parte del proyecto. La segunda fase, sin embargo, fue rematada, en primera instancia, en el maestro Juan de la Vega, sin embargo, ante la imposibilidad de hacerse cargo de los trabajos, debido a los diferentes proyectos que tenía que atender, el concejo de esta localidad decidió designar de forma directa a los maestros anteriores, Bernardo de la torre y Melchor de la Ayuela, para su ejecución, dado el buen hacer, que habían demostrado en la primera parte de la obra. Desconocemos la cantidad en que fue ajustada la ejecución de la primera parte del proyecto, si bien sabemos que la cantidad aportada por la fábrica de la iglesia, en este caso, ascendió a 8.500 reales $^{1283}$. La segunda parte llegó hasta los 29.500 reales $^{1284}$. Las labores de carpintería, por su parte, fueron encargadas al maestro Tomás Juariste, el cual ajustó su trabajo en 5.800 reales $^{1285}$. Desconocemos, sin embargo, si este mismo maestro se encargó también de la obra de carpintería de la primera parte del proyecto.

\footnotetext{
1282 Ibídem. (fols. $8 \mathrm{v}^{\mathrm{0}}-13$ vo). Visita realizada a la parroquia de San Martín de Huerta de Arriba el año 1726, por D. Andrés Fernández de Tejada. Canales, 8 - agosto - 1726.

1283 Ibídem. (fols. $14-15 v^{\circ}$ ). Cuentas del año 1726. Huerta de Arriba, 2 - octubre - 1726; Ibídem. (fols. $17 v^{0}$ - 18). Cuentas del año 1727. Huerta de Arriba, 15 - septiembre - 1727.

1284 AHPBU. PN. Valle de Valdelaguna. Leg. 9802/1. (fols. 64 - 70 vo). Manuel Gil de la Cuesta. Huerta de Arriba, 5 - mayo - 1728.

1285 AHPBU. PN. Valle de Valdelaguna. Leg. 9802/1. (fols. 77 - 79 v ${ }^{\circ}$ ). Manuel Gil de la Cuesta. Huerta de Arriba, 31 - mayo - 1728.
} 
Tampoco conocemos el nombre del autor de las trazas, que se siguieron en esta obra, si bien, como ya señalamos en su momento, tanto por las fechas en que se realiza, como por las características de la misma, existe la firme posibilidad de que estuviera detrás el maestro Fr. Pedro Martín ${ }^{1286}$.

El resultado de estas obras, como vimos, nos presenta un templo de grandes proporciones, que prácticamente llega a triplicar el espacio del anterior, dentro del cual además se cambia su orientación. En este sentido, resulta difícil adivinar qué circunstancias motivaron esta variación. Pudo tratarse de un especial interés de los responsables de esta iglesia por mantener en pie su antigua cabecera y torre, o de una decisión obligada por la particular orografía del terreno sobre el que se asienta, si bien, lo más probable es que fueran aspectos de orden urbanístico los que motivaron este cambio de orientación, pues los edificios circundantes solo permitían un crecimiento en sentido transversal.

La conclusión de estas obras de renovación del templo, sin embargo, no constituyó el final de su historia constructiva, pues aun quedaban algunos trabajos por realizar, que se fueron completando a lo largo de esta centuria. No obstante, muchas de estas intervenciones no pasaron de ser meras labores de mantenimiento o reparación de elementos o partes deterioradas.

En el primero de los casos, el proyecto más interesante lo constituye la construcción del nuevo cuerpo de campanas, incorporado sobre la antigua torre, con el cual conseguía elevarse sobre el nivel de la cubierta del nuevo templo. La obra se realiza entre los años 1751-52 y supuso un desembolso para esta fábrica de 6.776 reales y 15 maravedís, aunque no descartamos que el coste final de la obra fuera algo

1286 Ver capítulo: Actividad constructiva. Evolución estilística. Siglo XVIII. 
mayor $^{1287}$. Tampoco conocemos el nombre o nombres de los artífices encartados de su ejecución.

En lo que se refiere a los trabajos de mantenimiento, encontramos algunos proyectos ciertamente importantes, como es el caso de los que se desarrollan en la antigua capilla mayor, ahora dedicada a Nuestra Señora. Los más destacados se producen en torno a la década de 1740, momento especialmente delicado para esta capilla, según nos informan los visitadores del Arzobispado de Burgos. En 1740, D. Francisco López de Angulo, llega a prohibir el desarrollo de los oficios en su interior, ante el grave peligro de ruina que presentaba ${ }^{1288}$. Cuatro años más tarde este peligro, lejos de cesar, había aumentado, y así D. Diego Escalona, en su visita de 1744, señala que:

“la capilla del lado de la epístola se halla amenazando notable ruina y por lo mismo tan desmantelada que causa suma yndecencia a dicha iglesia, también se manda a dichos curas y maiordomo que en el caso que no la reparen en la coformidad que se previno en la última visita, hagan se fabrique un tabique que llene el hueco del arco de dicha capilla para ympedir la correspondencia a ella y consiguientemente ocultar dicha indecencia procurando no sea de mucho coste y mirando solo a que quede dezente la nominada iglesia"1289.

Finalmente, aunque no tenemos prueba documental de ello, parece que las obras requeridas por los visitadores se llegaron a realizar, tal y como prueba la conservación de dicha capilla.

\footnotetext{
1287 AGDBU. LP. Huerta de Arriba, parroquia de San Martín. LF. (1723 - 1778). Cuentas del año 1751. Huerta de Arriba, 12 - octubre - 1752; Ibídem. Cuentas del año 1752. Huerta de Arriba, 18 - octubre 1753.

1288 Ibídem. Visita realizada a la parroquia de San Martín de Huerta de Arriba en 1744, por el licenciado Francisco López de Angulo. Barbadillo de Herreros, 20 - noviembre - 1740.

1289 Ibídem. Canales, 20 - mayo - 1744.
} 
Ligados a estos problemas de la capilla de Nuestra Señora, se halla también la situación vivida por la sacristía, adosada sobre su muro septentrional. En este caso, las reparaciones fueron tan frecuentes, que llegan a convertirse en una constante a lo largo de todo este siglo XVIII. El origen de todos estos males no es otro que la gran humedad que afecta a esta parte oriental del templo, a la cual se une también la proximidad con la inestable capilla de Nuestra Señora. En 1744, por ejemplo, el visitador del Arzobispado manda que "se repare un pedazo de la bóveda de la sachristía que cae encima de los caxones donde están los ornamentos, para que no se siga maior ruina"1290. Pocos años más tarde, en 1752, fue necesario hacer una reparación similar ${ }^{1291}$. Y en 1755 el visitador del Arzobispado de Burgos, D. Juan de Tovías y Zuazo, ordena que “sin dilación se componga y repare la parte de bóveda de la sachristía de dicha iglesia en que se halla abierta un vocarón"1292. Pero el momento más comprometido se vive entre los años 1761-62, cuando se decide atacar la verdadera raíz del problema de esta parte del templo. La iniciativa de estas obra parte del visitador del Arzobispado del año 1761, D. Andrés Pérez Bracho, el cual, al tiempo que advierte de la gravedad del problema que vive esta parte del templo, concede a los responsables de la parroquia la licencia oportuna para que "baliendose de maestro o maestros inteligentes y ajustándose por un tanto o a jornales como más bien paresciere a dichos curas, hagan la obra que fuere nezesaria asta conseguir la total exclusión de dichas humedades gastando lo nezesario de los haveres de la referida fábrica...”1293. Los trabajos se realizaron ese mismo año, destinando para ello esta iglesia un total de 4.000 reales, según se indica en las propias cuentas parroquiales, para "la obra que se hizo en la sachristía para la subsanación y corte de humedades de la sachristía, iglesia y capilla de Nuestra Señora y elevación de ésta”1294. Años después, y una vez subsanados estos problemas, por fin pudo comprarse

\footnotetext{
1290 Ibídem; Cuentas del año 1744. Huerta de Arriba, 12 - diciembre - 1744.

1291 Ibídem. Cuentas del año 1752. Huerta de Arriba, 18 - octubre - 1753.

1292 Ibídem. Visita realizada a esta parroquia de San Martín de Huerta de Arriba en el año 1755, por el canónigo de la catedral D. Juan de Tovías y Zuarzo. Canales, 4 - agosto - 1755.

1293 Ibídem. Visita realizada a la parroquia de San Martín de Huerta de Arriba el año 1761, por el canónigo de la catedral de Burgos, D. Andrés Pérez Bracho. Huerta de Arriba, 27 - mayo - 1761.

1294 Ibídem. Cuentas del año 1761. Huerta de Arriba, 2 - octubre - 1762.
} 
896 Arquitectura de la Edad Moderna en la sierra burgalesa.

la nueva cajonería para guardar las vestiduras y demás objetos litúrgicos en la sacristía $^{1295}$.

Cerramos este recorrido por la historia constructiva de este templo con la incorporación de los retablos, levantados durante esta centuria para decorar el altar mayor y los colaterales de la entrada del presbiterio. Su construcción, sin embargo, no se produce hasta las décadas finales de este siglo, efectuándose todos ellos en un breve plazo de apenas tres años. Este proceso comienza con la adquisición de una nueva imagen de San Martín, para el altar mayor, comprada en 1781 por un precio de 1.346 reales ${ }^{1296}$. Al año siguiente tiene lugar la construcción del retablo, para el cual iba destinada, invirtiendo la fábrica, en esta ocasión, un total de 11.000 reales ${ }^{1297}$. Y sólo un año después de esto, se levantan los dos colaterales, pagados, en esta ocasión por la propia parroquia, con la colaboración de la cofradía de San Sebastián y la generosa donación de un feligrés anónimo, que entregó 1.000 reales $^{1298}$.

Antigua iglesia de Santa María.

Constituye, como hemos visto, la segunda parroquia de Huerta de Arriba, hasta el año 1719. Se encuentra situada a las afueras del pueblo, sobre la cumbre de un pequeño cerro que se alza en la parte nororiental. Su edificio, aunque bastante desatendido, conserva en bastante buen estado la mayor parte de los elementos, que forman su estructura original. Presenta así, una estructura muy sencilla de iglesia de tipo caja, con una sola nave de trazado rectangular muy alargado, que se continúa en el extremo oriental con una cabecera plana de profundo presbiterio, algo más estrecha que la nave, por la mayor anchura de sus muros. Faltan actualmente la sacristía y la torre, los cuales, a través de la lectura de paramentos que podemos hacer, creemos que se encontraban adosados sobre el muro septentrional del presbiterio, la sacristía, y en el lado meridional, junto a la parte delantera de la nave, la torre.

\footnotetext{
1295 Ibídem. Cuentas del año 1783. Huerta de Arriba, 9 - agosto - 1784.

1296 Ibídem. LF. (1779 - 1852). Cuentas del año 1781. Huerta de Arriba, 9 - septiembre - 1782.

1297 Ibídem. Cuentas del año 1782. Huerta de Arriba, 14 - septiembre - 1783.
} 


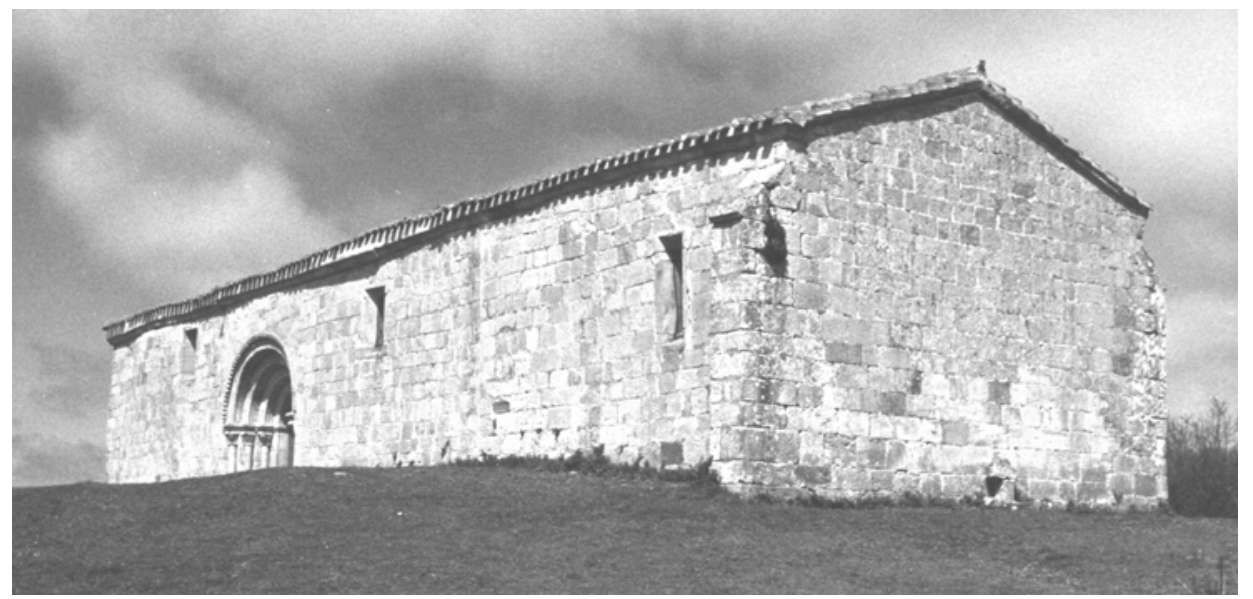

HUERTA DE ARRIBA. Ermita de Santa María. (antigua iglesia).

El edificio está realizado en piedra arenisca de tonos claros, trabajada en sillares de mediano tamaño y buena labra, con los cuales se forman muros completamente planos, rematados con gruesa cornisa. Dentro de ellos, a pesar de su aparente uniformidad, apreciamos, sin embargo, las marcas dejadas por las fases de crecimiento que se sucedieron dentro de la historia constructiva del templo. Unos pequeños estribos refuerzan lateralmente los muros de la cabecera, dentro de la cual, descubrimos además, sobre su muro septentrional, una serie de canecillos de estilo románico, que podemos incluir, merced a sus formas, dentro de la llamada escuela del románico de la sierra, pertenecientes al período central del siglo XII.

Con todo ello su imagen exterior queda constituida por un sencillo prisma de aspecto achaparrado, cubierto con techumbre uniforme dispuesta a dos aguas. Las ventanas que iluminan su interior, quedan orientadas hacia los lados meridional y de poniente, y presentan en todos los casos un sencillo trazado rectangular con dintel plano 


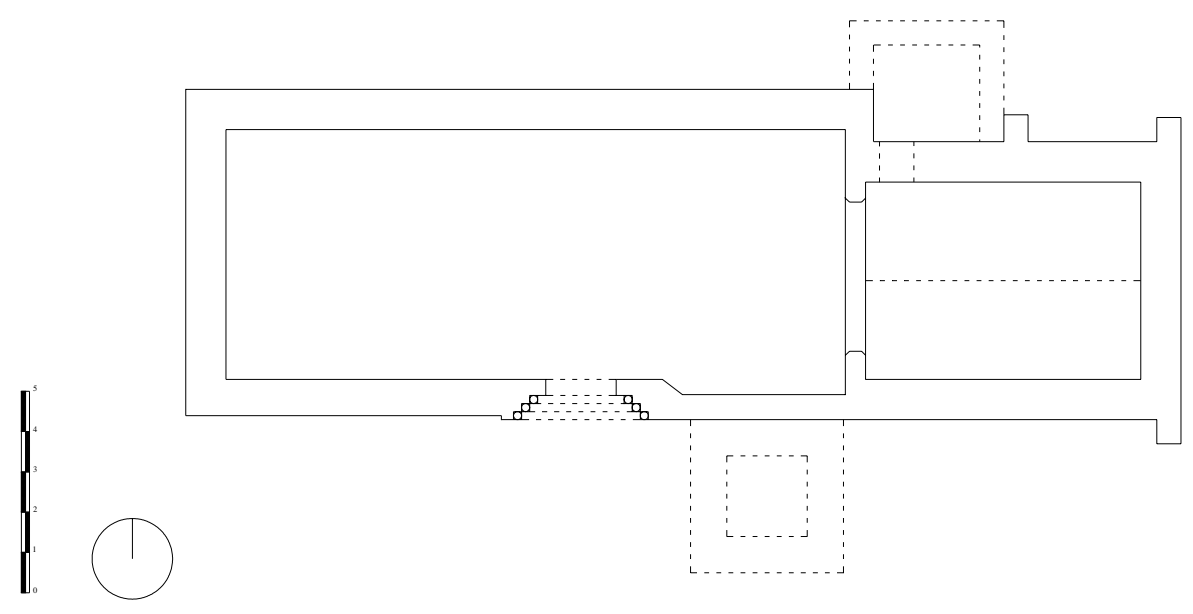

HUERTA DE ARRIBA. Iglesia de San Martín. Planta.

y ligero derrame hacia el exterior. Una calidad artística notablemente mayor presenta la puerta de acceso, que se abre sobre la parte central de este mismo muro meridional de la nave. Presenta una estructura típicamente románica, con cuatro niveles de arquivoltas, con arcos de medio punto de aristas redondeadas con gruesas moldura de tres cuartos de bocel, enmarcadas con una banda con relieve de puntas de diamante, que descansan, a través de gruesas impostas ajedrezadas, sobre columnas dispuestas en el derrame de las jambas, con capiteles decorados con motivos vegetales muy deteriorados. Una pieza, como decimos, de notable interés artístico, que debemos encuadrar, igual que los canecillos de la cabecera, dentro de la producción de los maestros de la escuela románica de la sierra burgalesa, si bien, corresponden ya a un momento algo más avanzado del siglo XII, en el que se manifiesta una sensibilidad escultórica distinta, próxima ya a la escuela de Silos. 
En el interior, este templo, nos muestra el característico concepto de espacio camino, propio de este estilo, con una clara separación entre los dos ámbitos, que componen la cabecera y el cuerpo. A la cabecera se accede a través de un potente arco apuntado de sección poligonal, dispuesto sobre gruesas impostas, el cual proyecta una bóveda de media cañón apuntada, con la que se cubre este espacio. Dentro de esta cabecera, la separación entre el ámbito de la capilla mayor y el presbiterio se efectúa mediante una sencilla balaustrada de madera, que da paso a una pequeña grada.

La nave por su parte, incorpora un sencillo coro alto en la parte de los pies, mientras que la cubierta se resuelve con una simple techumbre de madera dispuesta a dos aguas, sobre armadura de tipo parhilera.

La ornamentación que presentaba la imagen interior de este templo ha desaparecido en su mayor parte, de tal forma, que de los retablos que adornaban sus altares, hoy sólo queda el de la capilla mayor. El colateral, que actualmente vemos a la entrada del ábside, cuyas imágenes han desaparecido, pertenece a la antigua ermita de los Santos Mártires, que existía en esta localidad.

La historia de este templo durante la Edad Moderna, desde el punto de vista arquitectónico, apenas tiene trascendencia, pues su secuencia constructiva, en lo que se refiere a la estructura principal del templo, había concluido entre los siglos XII y XIII. De este modo, tenemos un edificio en el que se combinan los rasgos propios del románico, correspondientes a las etapas central y final del siglo XII, con algunos elementos que anuncian el protogótico, como ocurre en la cubierta de la cabecera.

El período de la Edad Moderna, y más en concreto sus dos últimos siglos, representa, por el contrario, la fase de crisis y decadencia de este templo, que termina con su desaparición como parroquia. En este momento, las obras más habituales son las relacionadas con el mantenimiento y conservación de la estructura heredada. Entre ellas, podemos mencionar la renovación del coro, efectuada en 1702, con un coste para la 
parroquia de 500 reales $^{1299}$, o la construcción de las gradas que elevan el nivel del suelo de la capilla mayor con respecto al presbiterio, efectuadas en 1713, poco antes de perder su condición de parroquia ${ }^{1300}$.

No obstante, dentro de este tipo de obras, sin duda alguna, las más interesantes fueron las relacionadas con el proceso de renovación de su antigua torre, pues en ellas queda perfectamente reflejado el proceso de decadencia al que había llegado esta parroquia. El deterioro de la estructura de la antigua torre había llegado a tales extremos a finales del siglo XVII, que en 1682 el visitador del Arzobispado de Burgos, D. Juan Saenz González Valatorre, indica en su informe que:

“aviendo visitado esta iglesia y después paseado alrededor y visto nuevamente la ruina tan grave que amenazava la torre de las campanas y que tenía precisa necesidad de reedificar antes que viniese al suelo a que estava muy próximo, que podía seguirse mayores daños si cayese de día cogiendo la gente devajo y de noche maltratando toda la capilla, por lo cual y reconociendo personalmente los daños y siendo esta iglesia corta de dinero en su renta dio su licencia en bastante forma al cura y mayordomo de esta iglesia y vecinos del barrio de Santa María para que puedan ajustarse con un maestro o maestros para que haciendo se pregone dicha obra y se remate en el que hiciere más conveniencia, a todo lo cual usando de autoridad interpone siendo necesario y les encargo la conciencia a unos y a otros poniendo gran cuidado así en lo perfecto de la obra como en excusar todos los gastos que se pudieren" ${ }^{1301}$.

\footnotetext{
1299 AGDBU. LP. Huerta de Arriba, parroquia de Santa María. LF. (1692 - 1721). Cuentas del año 1702. Huerta de Arriba, 6 - septiembre - 1703; Ibídem. Cuentas del año 1703. Huerta de Arriba, 24 septiembre -1704 .

${ }^{1300}$ Ibídem. Cuentas del año 1713. Huerta de Arriba, 18 - septiembre - 1714.

1301 Ibídem. (1640 - 1691). Visita realizada a la parroquia de Santa María de Huerta de Arriba en 1682, por D. Juan Saenz González de Valatorre, visitador del arzobispado. Huerta de Arriba, 25 - octubre 1682.
} 
Pero la obra no se llega a realizar, de tal modo, que poco tiempo después terminó por derrumbarse. Para solucionar esto en 1701 un nuevo visitador, D. Antonio Íñigo Angulo, manda que "se funde y fabrique la torre o espadaña de calidad, que devajo de ella se pueda poner la sacristía, o de la manera que fuese más conveniente para todo lo cual se da licencia al dicho cura"1302. La escasez de medios de esta iglesia hizo necesario contar con la ayuda, entre otros, de los propios Duques de Frías, beneficiarios de las tercias reales de los diezmos de esta parroquia, los cuales subvencionan parte de los trabajos. Este hecho nos permite conocer algún detalle más sobre el desarrollo de esta obra, y muy especialmente, sobre las circunstancias por las que atravesaba esta iglesia en los inicios del siglo XVIII.

"Digo que a causa de allarse dicha iglesia amenazando ruina en la virtud de licencia deste Tribunal se demolio la torre de ella y empezo a fabricar de nuevo y a causa de no haver sacado medios para proseguirla y acavarla se zeso en ella y al presente se alla de calidad que por ella entra cantidad de agua y nieve que cae sobre los altares de Nuestra Señora y San Sebastián (...)ocasionaran mayores daños que no se podrán remediar con muchas sumas de maravedís...”1303.

La obra resultante, sin embargo, tuvo una existencia efímera, pues en 1725 la parroquia de San Martín, ya única parroquia existente en el pueblo, encarga su demolición, para así aprovechar sus materiales en la renovación de su propia fábrica, que iba a comenzar en estos momentos ${ }^{1304}$.

Paradójicamente, mientras sucedía todo esto, en esta misma iglesia, durante segunda mitad del siglo XVII, se inicia una interesante renovación de los retablos, que

1302 Ibídem. Visita realizada a la parroquia de Santa María de Huerta de Arriba el año 1701, por el visitador del arzobispado de Burgos D. Antonio Íñigo de Angulo. Canales, 24 - octubre - 1701.

1303 AHN NOBLEZA, Osuna, Legajo 1354, n. 12. P. LEÓN TELLO: Archivo de los duques de Frías. Tomo I. Casa de Velasco. Madrid, Dirección general de Archivos y bibliotecas y casa de los duques de Frías. 1955. 
adornaban la imagen interior del templo. El primero de los retablos que se construye es uno de los colaterales, dedicado a San Pedro, realizado en 1654, con un coste para la parroquia de 21.054 maravedís ${ }^{1305}$. A éste le sigue el retablo del altar mayor, erigido en 1671 , con un coste de 2.867 reales $^{1306}$, a los que debemos sumar los 3.200 reales invertidos en el dorado y estofado del mismo, efectuado en 1688. Una buena parte de esta cantidad, sin embargo, fue aportada por D. Francisco García de Santa Coloma, comisario del Santo Oficio, y uno de los escasos feligreses adinerados, que se mantenían en esta parroquia ${ }^{1307}$. Terminamos, por último, con el dedicado a San Bartolomé, realizado en 1686, para cuya construcción esta iglesia solamente tuvo que aportar 51 reales $^{1308}$, lo que nos hace pensar, que el resto tuvo que ser sufragado por los feligreses.

\section{Ermitas.}

Además de esta antigua iglesia de Santa María, que tras la supresión de su parroquia quedó convertida en ermita, Huerta de Arriba contó con otras cuatro ermitas más, repartidas en el entorno del pueblo. Estas ermitas estaban dedicadas a San Vitores, San Roque, Santos Mártires, y la Vera Cruz. De todas ellas, solamente la de San Vitores ha conseguido sobrevivir hasta nuestros días, despojada, eso sí, de su función de culto, pues ha sido convertida en salón de usos sociales. Se encuentra situada a la entrada del pueblo, junto a la carretera que conduce al santuario de Nuestra Señora de Vega, y cuenta con un edificio de planta rectangular, de muros de sillería en su fachada principal, y mampuesto recubierto de revocadura en el resto. Forma con ello un limpio volumen de estructura prismática, cubierto con techumbre a doble vertiente. Su fachada principal, situada a los pies del edificio, presenta una sencilla puerta con arco de medio punto, acompañada por dos pequeñas ventanas de dintel plano a los lados, y una más

1304 AGDBU. LP. Huerta de Arriba, parroquia de San Martín. LF. (1723 - 1775). (fols. $\left.14-15 v^{\circ}\right)$. Cuentas del año 1725. Huerta de Arriba, 2 - octubre - 1726.

1305 AGDBU. LP. Huerta de Arriba, parroquia de Santa María. LF. (1640 - 1691). Cuentas del año 1654: Huerta de Arriba, 25 - octubre - 1655.

1306 Ibídem. Cuentas del año 1671. Huerta de Arriba, 16 - noviembre - 1672.

1307 Ibídem. Cuentas del año 1688. Huerta de Arriba, 17 - octubre - 1689. 
grande sobre su mismo eje. Remata todo ello con hastial triangular, sobre cuyo vértice se alza una pequeña cruz de piedra. La estructura interior se encuentra totalmente alterada.

El resto de las ermitas, como decimos, desaparecieron en un período relativamente tardío, pues a mediados del siglo XIX, según nos informa P. MADOZ en su Diccionario, todavía permanecían todas en pie. Este mismo autor añade también otra ermita más, dedicada a San Mamés ${ }^{1309}$, la cual debemos relacionar con un antiguo monasterio de época altomedieval, cuya existencia se encuentra fechada en torno al siglo $\mathrm{XI}^{1310}$.

Nada ha quedado, sin embargo, de ninguno de ellas, salvo el recuerdo de su ubicación. La ermita dedicada a San Roque se hallaba situada en la parte oriental del pueblo, sobre una de las laderas, que rodeaba este valle, a escasa distancia de las primeras casas. En sus inmediaciones se levantó posteriormente el actual cementerio parroquial.

No muy lejos de este lugar, pero ya junto a las primeras casas, al pie de la carretera que conduce hacia Canales, encontramos señalado en el suelo el espacio que ocupaba la ermita de la Vera Cruz.

La más alejada del pueblo era la de los Santos Mártires, situada a algo menos de un kilómetro, en dirección este, junto a la carretera que conduce hacia Neila. Algunos restos de piedras y tejas, en este caso, dan testimonio de su existencia.

\footnotetext{
1308 Ibídem. Cuentas del año 1686. Huerta de Arriba, 4 - diciembre - 1687.

1309 P. MADOZ: Diccionario... ob. cit. (pp. 344).
} 
904 Arquitectura de la Edad Moderna en la sierra burgalesa.

Arquitectura civil.

Huerta de Arriba conserva uno de los conjuntos de casas solariegas más interesantes de cuantos existen en esta comarca de la sierra burgalesa, dentro del cual encontramos ejemplos correspondientes a los siglos XVII y XVIII. Se trata de inmuebles pertenecientes, en su mayor parte, a los grandes y medianos propietarios de ganados trashumantes, que habían conseguido, en estos momentos, junto al aumento de su fortuna personal, un ascenso social, que se plasma en la obtención de su condición de hidalgo. Junto a ellos, encontramos otros ejemplos, como es el caso del comisario del Santo Oficio, D. Francisco García de Santa Coloma, que erige su vivienda con toda la pompa, en una de las zonas más destacadas del pueblo, como es el caso de la actual calle de las Moralas $n^{\circ} 25$ bis. La mayoría de estos ejemplos han sido analizados de forma detallada en los capítulos correspondientes a la arquitectura civil de los siglos XVII y XVIII, a los cuales remitimos. No obstante, recordamos aquí la ubicación de los casos más destacados. Para el siglo XVII tenemos los inmuebles situados en la calle Sebastianas $n^{\circ} 24-28$, 38, y 50, calle Mayor $n^{\circ}$ 5, calle Real $n^{\circ} 1$, 33, 39, calle San Juan $n^{\circ} 17$, y calle de las Huertas $n^{\circ} 5$. Y para el siglo XVIII los edificios situados en la calle de las Huertas $n^{\circ}$ 55, 25 bis, 29 y 127, calle Mayor 20-24, y calle Sebastianas $n^{o} 14$. Dentro de estos ejemplos los que mejor se han conservado, y nos presenta de una forma más clara las características propias de esta tipología son, evidentemente, estos últimos, pertenecientes al siglo XVIII, pues no sólo fueron edificados en un momento más próximo a nuestra época, sino que fueron realizados con una mayor disponibilidad de medios.

1310 L. SERRANO: Cartulario de San Millán. doc. 172, 180, 186, 212, 235, 238, 239, 253, 258, 282, 284. 
MONASTERIO DE LA SIERRA.

Monasterio de la Sierra se encuentra situado en las estribaciones de la Sierra de la Demanda, en medio de una serie de profundos valles que vierte al río Arlanza, desde su margen derecha. Su término municipal se halla totalmente rodeado por tierras de ledanías, originadas, con toda seguridad, a partir de los terrenos pertenecientes a diferentes despoblados, en cuya administración y explotación participa de forma directa.

En su territorio, montuoso y apartado, se han encontrado diferentes hallazgos arqueológicos, que nos hablan de la existencia de un núcleo de población durante la época celtíbera, que fue más tarde reutilizado por los romanos, desde principios del siglo IV hasta mediados del $\mathrm{V}^{1311}$. Sin embargo, sería un grave error intentar relacionar estos asentamientos con el origen de la actual población de Monasterio de la Sierra. Su origen debemos vincularlo, más bien, a la serie de poblados creados en la zona entre los siglos IX y X. De todos los núcleos que surgen en estos valles, Monasterio es el único que sobrevive a estos primeros siglos del período altomedieval, quedando en su entorno una serie de despoblados, entre los que se encuentran San Vicente, Butrón, Bustomediano, Nava, Pajares o Torneros ${ }^{1312}$.

1311 E. PASTOR DÍAZ DE GARAYO: Castilla en el tránsito de la Antigüedad al Feudalismo. Poblamiento, poder político y estructura social del Arlanza al Duero (siglos VII - XI). Valladolid, Junta de Castilla y León. Consejería de Educación y Cultura. 1996. (pp. 32 - 36).

1312 Ver mapa de despoblados. Capítulo. Aspectos urbanísticos: Núcleos de población. G. MARTínEZ DÍEZ: Pueblos y alfoces burgaleses de la repoblación. Valladolid, Junta de Castilla y León. Consejería de Educación y Cultura. 1997. (pp. 177 - 183). 
Su primera mención documental, sin embargo, no aparece hasta mediados del siglo XIV, en el Becerro de las Behetrías, donde es nombrado como Monasterio çerca de Salas ${ }^{1313}$. Este topónimo, sin duda, debemos relacionarlo con la proximidad del monasterio de Santa María de Alveinte, anteriormente conocido como de San Luis, o de Nuestra Señora de los Lirios, situado muy próximo al pueblo, aunque ya en terreno de ledanías.

Durante la Edad Media, Monasterio quedó encuadrado dentro del alfoz de Lara $^{1314}$, pasando más tarde, a partir del siglo XII, a formar parte de la Merindad Menor de Santo Domingo de Silos ${ }^{1315}$. Ya en la Edad Moderna, dentro de la administración fiscal, esta localidad queda incluida en el partido de las Tierras del Condestable, de la provincia de Burgos ${ }^{1316}$, para pasar más tarde, a partir de la reforma borbónica del siglo XVIII, al partido de Can de Muñó ${ }^{1317}$. Su jurisdicción pertenece durante este mismo período a la casa de Salas, lo que hace que forme parte del señorío jurisdiccional de los Duques de Frías. Esta situación se había originado en los últimos momentos del siglo XIV, pues aunque a mediados de este siglo, Monasterio todavía conservaba su condición de behetría, tenía ya entonces a Pedro Fernández de Velasco como señor y uno de sus principales diviseros ${ }^{1318}$. En el plano eclesiástico, su ubicación en la margen derecha de esta parte del río Arlanza, hace que su única parroquia dependiera siempre de la sede burgalesa ${ }^{1319}$.

1313 G. MARTíNEZ DÍEZ: Libro Becerro de las Behetrías. Estudio y texto crítico. León, Centro de Estudios e Investigación San Isidoro. Caja de Ahorros y Monte de Piedad. Archivo Histórico Diocesano. 1981. (pp.611).

1314 G. MARTÍNEZ DÍEZ: Pueblos y alfoces burgaleses de la repoblación... ob. cit. (pp. 175).

1315 C. ESTEPA DÍEZ: "Estructura de poder en Castilla (siglos XII - XIII). El poder señorial en las merindades burgalesas. En III Jornadas burgalesas de Historia (3 1991). Burgos en la Plena Edad Media. Burgos, Asociación Provincial de Libreros de Burgos. 1994. (pp. 245 - 294).

1316 G. MARTÍNEZ DÍEZ: Génesis histórica de la provincia de Burgos y sus divisiones administrativas. Burgos, Aldecoa. 1983.

1317 Ibídem.

1318 G. MARTÍNEZ DÍEZ: Libro Becerro de las Behetrías... ob. cit. (pp. 611).

1319 L. SERRANO: El obispado de Burgos y Castilla primitiva. Desde el siglo V al XIII. Madrid, Centros de Estudios Históricos. 1935. Tomo I (pp. 414 - 418). 
La población de Monasterio siempre fue escasa, manteniendo unos niveles muy por debajo de la media de la zona. Los datos que poseemos para estudiar la evolución demográfica durante la Edad Moderna presentan una amplia laguna para el siglo XVII, aun así, observamos un fuerte crecimiento para el siglo XVIII, donde prácticamente se llegan a doblar los niveles de la centuria del Quinientos. En el siglo XVI, según los datos del censo de 1541, existían en Monasterio un total de 23 vecinos $^{1320}$, que descienden a 20 vecinos, según el censo de los obispos de 1584-87 ${ }^{1321}$, recuperándose más tarde, para llegar hasta los 29 vecinos, en el censo de $1591^{1322}$. Estos valores, como decimos, prácticamente se duplican en el siglo XVIII, con 43 vecinos en el vecindario del Marqués de Ensenada, de mediados de siglo, y 76 habitantes en el censo de Floridablanca de finales de la centuria ${ }^{1323}$. Todos ellos pertenecían al estado llano.

La economía de estos vecinos estuvo vinculada siempre al aprovechamiento de los recursos que le brindaba el medio en el que se encontraba. Un medio de orografía sumamente abrupta, pero con un terreno generosamente regados por pequeños arroyos y manantiales, que permitían el cultivo de cereales y algunas hortalizas. No obstante, la base de su economía se encontraba fundamentalmente en las actividades de tipo silvopastoril, y de modo muy especial, en la explotación de sus recursos forestales, con la tala y venta de la madera de roble, extraída de sus tupidos bosques ${ }^{1324}$. De este modo, Monasterio, aunque estuvo muy lejos de convertirse en un gran exportador de madera, equiparable a los pueblos de la zona de pinares, como Canicosa, Quintanar de la Sierra, Palacios o Vilviestre del Pinar, fue uno de los más destacados proveedores de madera de roble de la zona, surtiendo a diferentes pueblos de la sierra de la Demanda, el Valle de

\footnotetext{
1320 AGS. Contaduría General. Leg. 768. (fols. 61 vº).

1321 T. GONZÁLEZ: Censo de población de las provincias y partidos de la Corona de Castilla en el siglo XVI... Ed. Facsímil. Madrid, Imprenta Real. 1829.

1322 Censo de Castilla de 1591. Vecindario. Madrid, Instituto Nacional de Estadística. 1984.

1323 INE. Censo de 1787. “Floridablanca”. Madrid. INE. 1989.

1324 ADPBU. CE. RESPUESTAS GENERALES. Monasterio de la Sierra, 26 - marzo - 1753.
} 
908 Arquitectura de la Edad Moderna en la sierra burgalesa.

Valdelaguna y la zona del entorno de Salas. Para todas estas actividades los vecinos de este pueblo se valen su de participación en los terrenos de ledanías.

Su núcleo urbano se asienta sobre las faldas de una suave ladera, orientada hacia el mediodía, en un pequeño claro, rodeado de prados y diminutas huertas, que quedan envueltas por un espeso manto de robledales. Esta bucólica estampa nos muestra un conjunto de casas, dispuestas de forma alargada sin ningún tipo de orden, entre las que predominan los tipos tradicionales de la arquitectura popular de la zona. Llama la atención, en este caso, los numerosos ejemplos de viviendas que presentan sobre el dintel de su puerta de entrada, o en una de sus ventanas, motivos o leyendas con un sentido protector. No obstante, el edificio más destacado del pueblo lo constituye, como siempre, su iglesia parroquial.

\section{Iglesia de San Pedro.}

Esta iglesia de Monasterio está dedicada a San Pedro, y se asienta sobre un espacio convenientemente allanado, rodeado por un pequeño muro de piedra, que forma el atrio. Se trata de un edificio de modestas proporciones y escasa calidad artística, más próximo a la tradición de la arquitectura popular, que a la de algún estilo artístico definido. Su fábrica actual, como ya vimos en su momento, al hablar de las formas durante el siglo XVIII, es el resultado de una intensa renovación, llevada a cabo durante los últimos años de este siglo y los primeros del siguiente ${ }^{1325}$. Esto hace que apenas se conserven restos de las fases previas, que forman su secuencia constructiva.

Fruto de esta intervención surge un edificio sencillo, de estructura tipo caja, con planta rectangular de una sola nave, articulada en tres tramos, de los cuales el situado en el extremo oriental forma la cabecera. A los pies de este núcleo central se incorpora la torre, levantada también sobre planta cuadrangular y algo más estrecha que la nave, mientras que sobre el costado meridional de la cabecera se adosa la sacristía. Todo el edificio está realizado en piedra, predominando los paramentos de mampuesto

1325 Ver capítulo: Actividad constructiva. Evolución estilística. Siglo XVIII. 


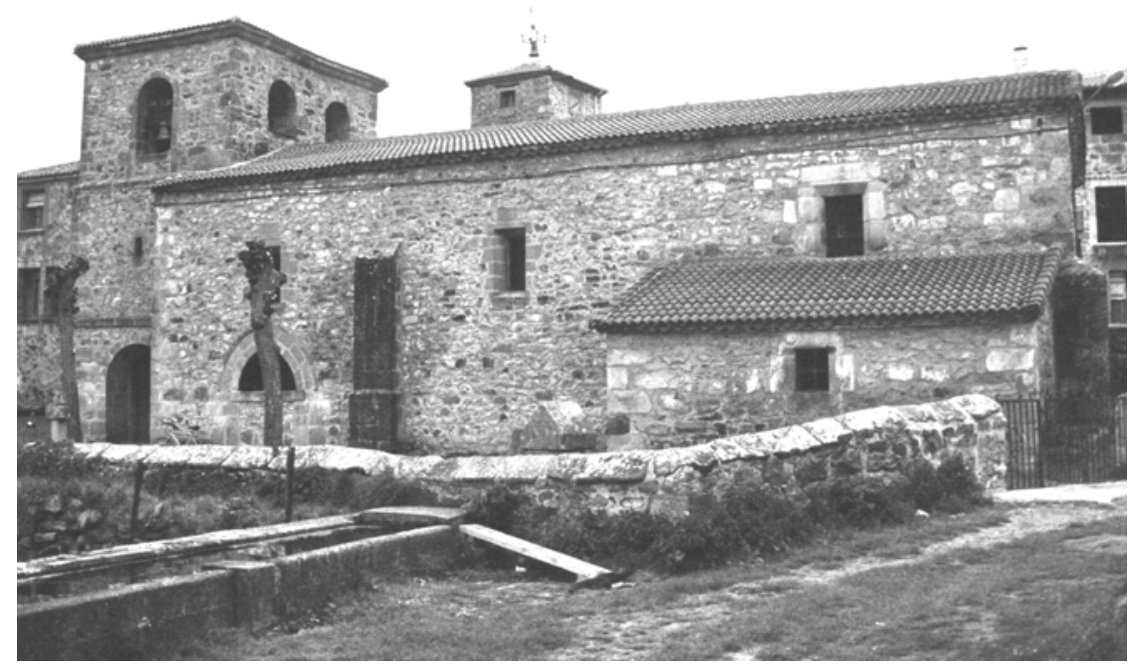

MONASTERIO DE LA SIERRA.

Iglesia de San Pedro.

reforzados en las esquinas y marcos de los vanos con sillares, si bien, en la parte de la cabecera encontramos también algunas partes de sillarejo. La planitud de estos muros solamente aparece interrumpida por dos pequeños contrafuertes, dispuestos a los lados de la nave, y otros dos, que refuerzan los extremos del muro del testero de la capilla mayor.

Su imagen exterior queda conformada, de este modo, por un gran prisma con cubierta a dos aguas, sobre el que se añaden los cuerpos, también prismáticos, de la sacristía y la torre. Esta torre se convierte, a pesar de su escaso desarrollo en altura, en el auténtico contrapunto vertical, dentro de un edificio de marcado carácter horizontal. Queda articulada en tres cuerpos, los dos primeros separados por línea de imposta plana, y el último por una moldura que marca un ligero adelagazamiento de sus muros. En el centro de cada uno de los tres lados exteriores del cuerpo inferior se abren amplios vanos, coronados con arco de medio punto, que convertían esta parte baja en un pequeño soportal. Por su parte, el nivel superior, que forma el cuerpo de campanas, 
910 Arquitectura de la Edad Moderna en la sierra burgalesa.

cuenta con vanos coronados con arco de medio punto, distribuidos entre cada una de sus cuatro caras, con dos en los frentes oriental y de poniente, y uno solo en el septentrional y del mediodía.

Las ventanas que iluminan el espacio interior, quedan orientadas, en todos los casos, hacia el mediodía, y están formadas por tres sencillos vanos, que se distribuyen entre cada uno de los tramos de la nave y la cabecera, repitiendo un sencillo trazado rectangular de dintel plano y ligero derrame hacia el exterior. El acceso al interior se realiza desde los pies, a través de uno de los arcos de la base de la torre. No obstante, en la fachada meridional de la nave, a la altura de su segundo tramo, se conservan los restos de una antigua puerta de estilo gótico, con un arco apuntado enmarcado por una doble moldura de bocel. Esta pieza constituye el único resto reconocible de lo que fuera la antigua estructura de este templo, previa a su remodelación de finales del Setecientos.

El interior desarrolla un sencillo concepto de ámbito único, articulado en tres tramos. El delantero, que forma la cabecera, aparece precedido por un potente arco de medio punto de sección cuadrada, dispuesto sobre pilastras rematadas con airosa cornisa. Su interior se cubre con bóveda de crucería octopartita de gruesos nervios. Los dos tramos correspondientes a la nave, por su parte, cierran con bóveda de medio cañón con lunetos, reforzados en su parte central por arco fajón de medio punto rebajadao, dispuesto sobre pilastras rematadas por una gruesa imposta. Sobre el muro de los pies, otro potente arco de medio punto daba paso al antiguo coro, el cual estaba ubicado en el interior del segundo cuerpo de la torre. Este espacio se iluminaba con una pequeña ventana de dintel plano, abierta sobre el muro de poniente.

Sobre el muro del altar mayor se levanta el único retablo, que adorna la imagen interior de este templo. Se trata de una pieza de estilo neoclásico, de un solo cuerpo, articulado en tres calles, y remate, con el nicho central ocupado por la imagen de San Pedro en cátedra, y las laterales por pequeñas tallas reaprovechadas de otros altares, entre las que están San Juan Bautista, San Sebastián, San Cristóbal, y un santo más sin 
identificar. En el remate aparece una imagen de San Miguel arcángel, y dos tallas más pequeñas de San Roque y San Antonio de Padua ${ }^{1326}$. A parte de este retablo, sobre el muro septentrional de la nave, a la altura de su primer tramo, encontramos también una amplia hornacina, coronada con arco de medio punto, dispuesto sobre impostas planas, en cuyo interior se alberga una talla de Cristo crucificado.

Resulta sumamente difícil reconstruir la historia constructiva de este templo, pues, como ya indicábamos, apenas quedan restos materiales del templo primitivo, y los testimonios documentales que existen, no consiguen dibujarnos una imagen nítida de su aspecto pasado. Esta documentación conservada únicamente sirve para ilustrarnos sobre la azarosa existencia que vivió el templo, especialmente a lo largo del siglo XVIII, la cual culmina con la renovación completa de su fábrica.

Antes de llegar esto, en 1674 se construye el muro que delimita el espacio del atrio. La iniciativa de esta obra parte del visitador del Arzobispado de Burgos de 1672, D. Diego Fernández de Humada, el cual se percató:

“Que por quanto pegante a la puerta y soportal de la dicha iglesia está el cimenterio. Frente y conjunto a unas casas de algunos vecinos quienes se salen a dicho ciminterio a travaxar sus carretas y hacer otras labores atando a ellos los bueyes pasando por dicho cimenterio el ganado llenándole de inmundicia, de que se causa gran indecencia, para cuyo remedio mandó su merced al cura de la dicha iglesia que lo mejor parado que tubiere y dejandolo lo preciso y necesario para los gastos precisos aga hacer un paredón que cerque el dicho cimenterio y no entre el ganado en él ni consienta que los dichos vecinos travaxen ni carreteen por la indecencia que causan. Antes bien los exorte ayuden para dicha obra con los

\footnotetext{
1326 R. J. PAYO HERNANZ: El retablo en Burgos y su comarca durante los siglos XVII y XVIII.
} Burgos, Excma. Diputación Provincial de Burgos. 1997. (T. II, pp. 510). 
materiales y demás que pudieren mediante ser obra precisa y necesaria adorno de su iglesia que para ello se le da comisión”"1327.

Las obras, como vemos, se acometieron de forma inmediata, con un desembolso para esta fábrica de más de 57.000 maravedís, de los cuales, 47.000 maravedís fueron destinados para la mano de obra y los 10.778 restantes para los materiales ${ }^{1328}$.

También durante este siglo XVII tiene lugar la construcción de la torre, la cual sustituye a una anterior, que tuvo que ser reparada en diferentes ocasiones a lo largo de esta centuria ${ }^{1329}$. Esta obra se culmina en 1693, con un presupuesto de 3.363 reales, de los cuales esta fábrica únicamente debió pagar 2.252 reales, ya que el resto fue sufragado por los propios feligreses con sus limosnas y prestaciones personales ${ }^{1330}$.

Durante el siglo XVIII, la historia de este templo está marcada por los problemas, que de modo constante, provocan las humedades. No se trata de algo nuevo, pues ya a mediados del siglo XVII encontramos algunos testimonios que dan cuenta de ello. Uno de los más elocuentes es el que nos deja el visitador del Arzobispado en 1656, D. Lucas Juez Sarmiento, el cual señala lo siguiente: “Otrosí halló su merced que esta iglesia estaba con mucha necesidad de que se enlose el soportal de esta iglesia por cuanto por debajo del sale una fuente y sucede llenarse de agua dicho soportal y por esa causa fue informado había sucedido sacar los huesos de los difuntos, que se entierran en dicho soportal, y para que se pueda enlosar su merced da licencia en

\footnotetext{
1327 AGDBU. LP. Monasterio de la Sierra, parroquia de San Pedro. LF. (1654 - 1701). (fols. 37 ${ }^{\circ}$ - 39). Visita realizada a la parroquia de San Pedro en Monasterio de la Sierra en 1672, por D. Diego Fernández de Humada. Monasterio de la Sierra, 18 - junio - 1672.

1328 Ibídem. (fols. 42vo - 45). Cuentas del año 1673. Arroyo de Salas, 9 - octubre - 1674.

1329 Ibídem. LF. (1614 - 1653). Cuentas del año 1624. Monasterio de la Sierra, 1 - agosto - 1624; Ibídem. LF. (1654 - 1701). Cuentas del año 1663. Terrazas, 5 - septiembre - 1663.

1330 Ibídem. (fols. $111-112 v^{0}$ ). Cuentas del año 1693. Monasterio de la Sierra, 24 - abril - 1695.
} 
forma a los mayordomos de esta iglesia que puedan hacer los enlosar dicho soportal”1331.

Estos problemas, lejos de desaparecer, se agravaron durante esta centuria del Setecientos. Su origen se encuentra en un manantial, situado en la parte septentrional del templo, cuyas aguas cruzaban literalmente el subsuelo del edificio. Tal y como señala D. Francisco López Angulo, visitador del Arzobispado en 1740, este problema no afectaba tanto a la seguridad del edificio, como al bienestar de sus arcas, pues al hacer imposible los enterramientos en su interior, tal y como era costumbre, la fábrica parroquial quedaba privada de los ingresos correspondientes a la apertura de nuevas tumbas. Sin embargo, tal vez sea mejor que nos lo cuente el propio visitador:

"Reconocidas la quentas de este libro no se encuentran cargadas a los maiordomos de fábrica de dicha iglesia daños algunos de rompimiento de sepulturas y aviendo inquirido su merced cual fuese el motivo que privar a dicha fábrica de tan junstificado daño se le informó que los vecinos y feligreses de dicha iglesia se sepultaban en una hermita inmediata a dicha iglesia con el título de San Torcuato - que reconoció su merced sin la decencia correspondiente, para que en esta se pueda celebrar el Santo Sacrificio de la Misa, cuio adorno y reparo es del cargo del conzejo y vecinos del dicho lugar - sin más motivo que el de suponerse húmeda dicha iglesia a causa de pasar por el centro de ella la fuente que nace al oriente, cuio pretexto no es suficiente para dejar de contribuir a la fábrica con los expresados dineros de rompimientos de sepulturas pues aquel inconveniente estaba susanado a muy poca costa encañando la referida fuente por la parte exterior de dicha iglesia siendo bien notable que los heredersos de los que fallecen tengan el arbitrio de hacer en ella elección del sitio para poner las luces y ofrendas; y atribuyéndose a maliciosa cautela de los vecinos de dicho lugar se les manda que de aquí en adelante

1331 Ibídem. LF. (1614 - 1653). Visita realizada a la parroquia de San Pedro en Monasterio de la Sierra en 1656, por D. Lucas Juez Sarmiento, canónigo de la catedral. Monasterio de la Sierra, 27 - marzo - 
914 Arquitectura de la Edad Moderna en la sierra burgalesa.

fallecido deudo pariente o persona por quien tengan interés no obstante, que se sepulte en dicha hermita de San Torquato paguen los derechos de rompimiento de sepultura a dicha fábrica conforme al estilo de las demás yglesias de la circunferencia y a ello les compelerá el cura de dicha iglesia por censuras y todo rigor para que se le da comisión"1332.

La solución propuesta para poner fin a este problema parecía fácil, llevándose a cabo poco después, tal y como había mandado el visitador.

Pero con el paso del tiempo, esta respuesta dada al problema de las humedades se torna insuficiente. Es por ello, que varias décadas después, en 1791, un nuevo visitador del Arzobispado, D. Manuel María Izquierdo, llama nuevamente la atención sobre este problema, señalando lo siguiente:

" $Y$ por quanto el tiempo que su merced visitó la referida iglesia reconoció que con las muchas humedades que ocasiona el encañado de aguas, que se conduce por debajo de su pabimento desde un pozo o fuente que sube para el surtido del pueblo se causa gravísimo perjuicio tanto en los cimientos y material del edificio quanto a las ropas, ornamentos y vasos sagrados mandaba y mando su merced que con la mayor brevedad disponga dicho cura si fuere posible condenar dicho conducto y dirigir las aguas por otra parte distante de la iglesia construyendo a este fin otro cañal que evita perjuicio de tercero, según hállase por más combeniente el maestro périto de quien se valga para la obra, procurando ajustarla con la mayor equidad y perfección, de modo que quede con seguridad, y esempta de dichas humedades y peligro de ruina, a cuio fin en caso necesario se le concede lizencia y para que supla todo su coste de los 4.336 R. que la fábrica tiene existentes del último alcance de quenta cumplientdo a los

1656.

1332 Ibídem. LF. (1701 - 1743). Visita realizada a la parroquia de San Pedro en Monasterio de la Sierra en 1740, por D. Francisco López de Angulo. Salas de los Infantes, 29 - noviembre - 1740. 
mayordomos o personas en cuio poder estubieren distribuidos a que los aprompten dentro de 15 días primeros”"1333.

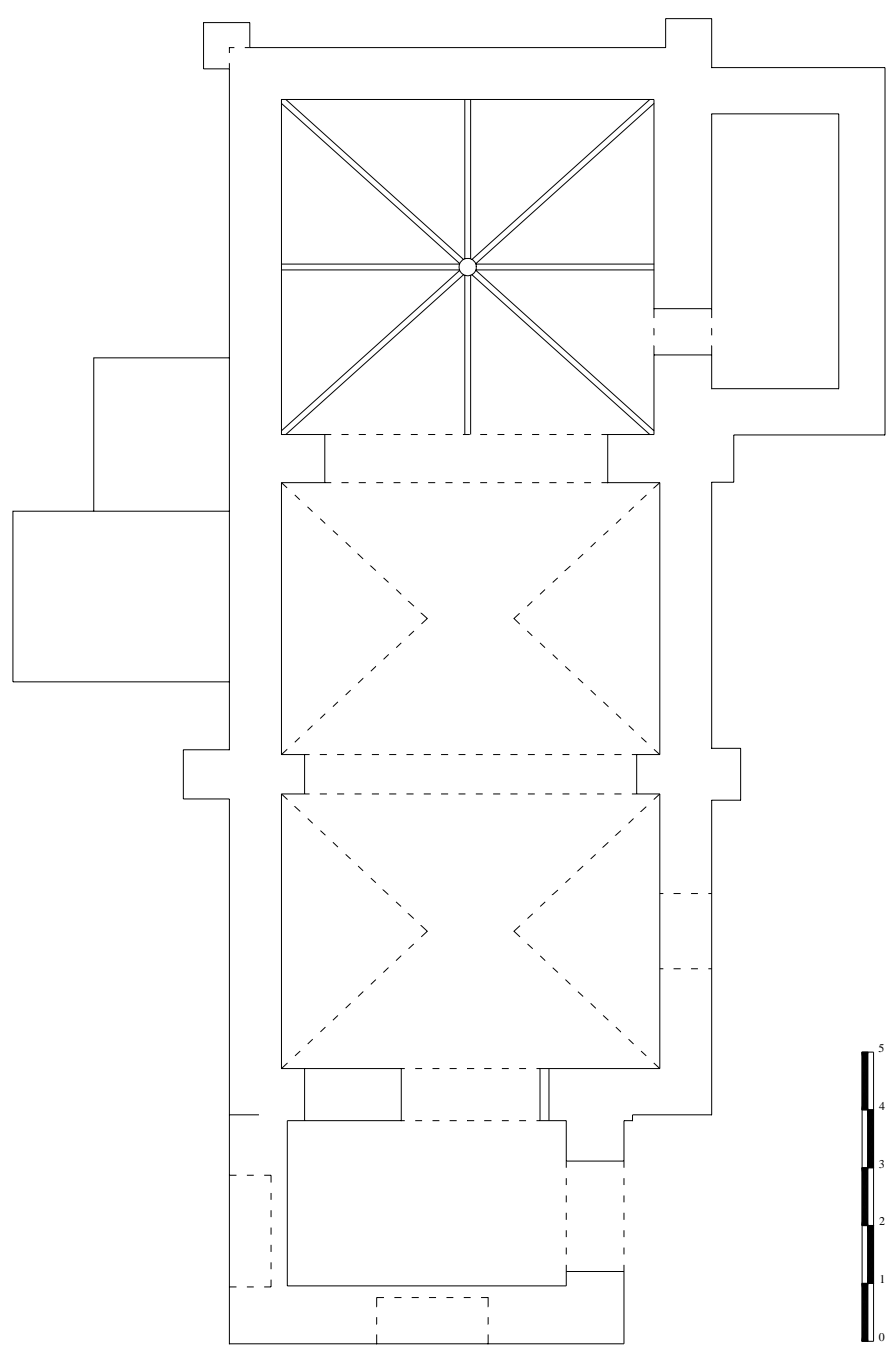

MONASTERIO DE LA SIERRA.

Iglesia de San Pedro. Planta.

1333 Ibídem. LF. (1776 - 1838). (fols. 35v - 38vº). Visita realizada a la parroquia de San Pedro en Monasterio de la Sierra en 1791, por D. Manuel María Izquierdo. Barbadillo del Mercado, 10 noviembre -1791 . 
916 Arquitectura de la Edad Moderna en la sierra burgalesa.

Este aviso, unido al carácter emprendedor del párroco de este momento, D. Felipe Gómez, llevan a tomar la decisión de renovar la práctica totalidad del templo. La obra se lleva a cabo en dos fases diferentes, que afectan en primer lugar a la cabecera y luego a la zona de la nave.

La renovación de la cabecera, que había sido intensamente reparada poco tiempo antes, en $1776^{1334}$, se realiza en 1794 , con un coste para esta iglesia de 9.481 reales. A ellos debemos sumar otros 1.300 reales más, gastados en el pleito mantenido con los maestros de cantería encargados de su fabricación ${ }^{1335}$. La parte de la nave no se completa hasta 1802, tal y como señala la inscripción colocada sobre el dintel de una de las ventanas ${ }^{1336}$, y supuso un desembolso para esta fábrica de 4.000 reales, a los que sumamos otros 200 reales más, gastados en acabar algunos detalles ${ }^{1337}$. A estas cantidades debemos sumar también la importante ayuda prestada por el propio cura de esta parroquia, la cual alcanzó los 5.888 reales $^{1338}$.

Estas obras se completan con la construcción de un nuevo retablo para el altar mayor, realizado en $1806^{1339}$, con el que se sustituye al anterior, ejecutado en 1640 por el maestro Juan de la Piedra y Arce ${ }^{1340}$. Al mismo tiempo, esta iglesia adquiere una

\footnotetext{
1334 Ibídem. (fols. 1 - 3vº ). Cuentas del año 1776. Monasterio de la Sierra, 9 - junio - 1777; Ibídem. (fols. $11 v^{0}-13 v^{0}$ ).Cuentas de año 1779. Monasterio de la Sierra, 16 - junio - 1779.

1335 Ibídem. (fols. 43 - 44vº). Cuentas del año 1793. Monasterio de la Sierra, 24 - julio - 1794; Ibídem. Cuentas del año 1794. Monasterio de la Sierra, 5 - septiembre - 1795.

1336 SE HIZO ESTA HOBRAS SIENDO CURA D. LÇFELIPE GOMEZ. AÑO 1802. - Y SIENDO MAYORDOMO JUAN ESTEBAN CORALO.

1337 Ibídem. (fols. 54v - 56). Cuentas del año 1801. Monasterio de la Sierra, 15 - septiembre - 1802; Ibídem. (fols. 56 - 57). Cuentas del año 1802. Monasterio de la Sierra, 4 - septiembre - 1803.

1338 Ibídem. Auto dictado por los Señores Provisores del Arzobispado de Burgos. Burgos, 12 - febrero 1824.

1339 Ibídem. (fols. $61 v^{0}-62 v^{0}$ ). Cuentas del año 1806. Monasterio de la Sierra, 21 - septiembre - 1807.

1340 Ibídem. LF. (1614 - 1653). Cuentas del año 1640. Monasterio de la Sierra, 15 - mayo - 1641; Ibídem. Cuentas del año 1641. Monasterio de la Sierra, 24 - septiembre - 1642.
} 
nueva imagen del santo titular del templo, para presidir el nuevo retablo ${ }^{1341}$. Poco tiempo después, en 1814 se construye el cancel para la puerta de entrada ${ }^{1342}$.

\section{Ermitas.}

Monasterio contó, además, con cuatro ermitas dentro de su término municipal, las cuales estaban dedicadas a los Santos Mártires, San Torcuato, San Cristóbal y San Sebastián. De ellas sólo la primera ha conseguido llegar hasta nuestros días en buen estado de conservación, pues el resto han desaparecido sin dejar rastro.

Esta ermita de los Santos Mártires era la más destacada de todas, celebrándose en honor de sus titulares, San Cosme y San Damián, las fiestas patronales del pueblo. Se encuentra situada a la entrada del pueblo, según P. MADOZ a una distancia de tiro de piedra $^{1343}$, junto a la carretera que llega desde Terrazas. El edificio actual es el resultado de la reconstrucción que se hace en los años finales de la década de 1670, según nos cuenta el visitador del Arzobispado que llegó hasta aquí en 1680, D. Hilario de Noriega. En dicho informe se indica lo siguiente:

“Otrosi alla su merced que la ermita antigua de San Cosme y San Damián, que ha corrido y corre por cuenta del concejo y vecinos de dicho lugar de Monesterio, por estar vieja y maltratada y de calidad que no se podía celebrar misa en ella, trataron dicho concejo y vecinos de demolerla, como la demolieron asta sus zimientos balbieron en el mismo sitio a hedificarla de nuevo y darla algún jenero de ensanche más del que antes tenía por ser pequeña. Con efecto la han vuelto a hazer toda de nuevo de calidad que esta decente menos que la faltan de asentar las dos puertas que tiene y dar un blanquio a las paredes por la parte de dentro y colocar los santos en la altar. Y cumpliendo dicho conzejo y vecinos con dar dicho

\footnotetext{
1341 Ibídem. LF. (1776 - 1838). (fols. 60 - 61). Cuentas del año 1805. Monasterio de la Sierra, 21 septiembre -1806.

1342 Ibídem. (fols. $71 v^{0}-72 v^{\circ}$ ). Cuentas del año 1814. Monasterio de la Sierra, 31 - agosto - 1815.

1343 P. MADOZ: Diccionario geográfico - estadístico - histórico de España y sus posesiones de Ultramar. Valladolid, Ámbito D.L. 1984. (pp. 385).
} 
blanqueo, colocar los santos y asentar las puertas con sus zerraduras. Desde luego dava licencia su merced al licenciado Esteban del Varrio, cura y beneficiado en el lugar de Oyuelos, para que la puede vendecir y estandolo se pueda decir misa en ella los días de los santos de su advocación, voto y letanías y de alguna rogatiba, todo ello sin perjuicio del derecho parroquial que para ello como ha dicho se da licencia en forma y por este su auto asi lo probe (...) y firmo en la villa de Salas de los Infantes día, mes y año dichos”1344.

Como resultado de ello surge un edificio de una sola nave, de planta rectangular, con cabecera plana en el extremo oriental, algo más estrecha que la nave, sobre cuyo costado meridional se añade la sacristía. Toda ella está realizada en piedra, con sencillos muros de mampuesto, reforzados con sillares en las esquinas y marcos de los vanos. La sacristía, en cambio, está realizada totalmente en sillería.

La puerta de acceso al interior se abre sobre el muro meridional de la nave, y está formada por un sencillo arco de medio punto dispuesto sobre impostas planas. Sobre este mismo muro se abre una pequeña ventana rectangular de dintel plano con derrame hacia el exterior, a la que acompañan dos más, dispuestas sobre el muro de los pies, y la cara septentrional de la cabecera.

En el interior, el espacio de la nave incorpora un sencillo coro alto a los pies, cubriéndose todo ello con techumbre de madera, dispuesta a tres aguas sobre armadura de tipo parhilera. En la parte delantera, un robusto arco de medio punto de sección cuadrada e intradós plano, conduce al interior de la capilla mayor, la cual se cubre con bóveda de crucería octopartita, ricamente decorada con pinturas, que representan diferentes motivos vegetales. El retablo, que decora el altar mayor, es una pieza

1344 AGDBU. LP. Monasterio de la Sierra, parroquia de San Pedro. LF. (1654 - 1701). (fols. 56vo - 60). Visita realizada a la parroquia de San Pedro de Monasterio de la Sierra en 1680, por el canónigo Hilario de Noriega. Salas de los Infantes, 3 - septiembre - 1680. 


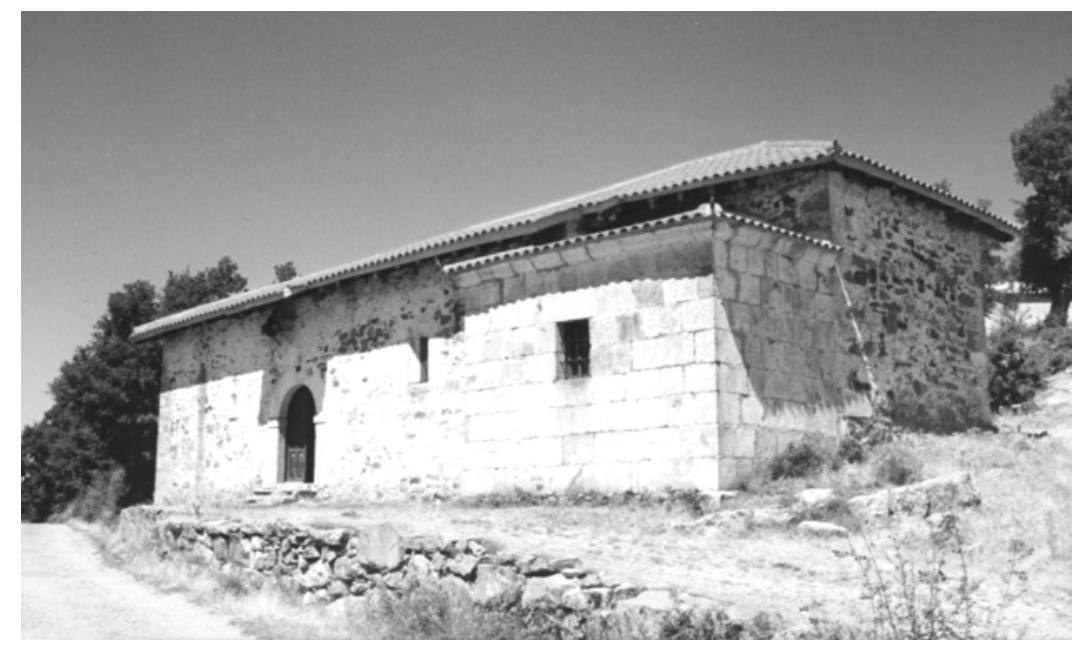

MONASTERIO DE LA SIERRA.

Ermita de los Santos Mártires.

adquirida por el concejo de este pueblo a la iglesia parroquial de Santa Cristina de Huerta de Abajo en 1768, por el cual pagó 460 reales $^{1345}$.

Del resto de las ermitas no es mucho lo que podemos contar, pues su desaparición borró cualquier huella o vestigio, que nos permita conocer algún detalle de las mismas. Tal vez, la más interesante sea la de San Torcuato o San Torcaz, la cual se encontraba, como hemos visto, en las inmediaciones del templo parroquial, efectuándose en su interior los enterramientos desde el siglo XVII. Su desaparición debió producirse en torno a la década de 1840, pues MADOZ ya no la recoge en su Diccionario. Su uso funerario, por otra parte, debió mantenerse hasta poco antes de su desaparición, pues según nos informa el visitador, que llegó hasta aquí en 1830, D. José

1345 AGDBU. LP. Huerta de Abajo, parroquia de Santa Cristina. LF. (1741 - 1797). (fols. 69 - 72). Cuentas del año 1678. Huerta de Abajo, 6 - septiembre - 1769. 
920 Arquitectura de la Edad Moderna en la sierra burgalesa.

del Hoyo Miguel, todavía en este momento se seguían haciendo enterramientos en su interior $^{1346}$.

Menos noticias aun tenemos aun de la ermita dedicada a San Cristóbal, pues ni siquiera hemos podido descubrir su ubicación. Sabemos, eso sí, que su último siglo de vida estuvo marcado por un agónico proceso de decadencia. Esta situación era ya evidente en 1740, cuando el visitador, D. Francisco López Angulo señala que "esta ermita se halla con suma indecencia y quasi arruinada"1347. Aun así, continuó manteniéndose en pie hasta las primeras décadas del siglo XIX. El informe del visitador de 1831, dice ya, sin embargo: “aver informado a su merced que la de San Cristóbal no existe, manda se ponga la cruz y mojones como está mandado" ${ }^{348}$.

Por último, la ermita dedicada a San Sebastián, es la que menos noticias nos ha dejado. Fue la primera en desaparecer, y las últimas noticias que tenemos de ella datan del año 1635. En ella se hace referencia, precisamente, al estado de ruina en el que se encontraba, y al deseo de los vecinos de reconstruirla en otro sitio más próximo al pueblo, para así poder atenderla con una mayor dedicación ${ }^{1349}$. Estos deseos, sin embargo, parece que no llegaron a cumplirse nunca, pues no volveremos a tener más noticias de ella. También aquí desconocemos el lugar en el que se encontraba.

\footnotetext{
1346 AGDBU. LP. Monasterio de la Sierra, parroquia de San Pedro. LF. (1776 - 1838). Visita realizada a la parroquia de San Pedro en Monasterio de la Sierra en 1831, por D. José del Hoyo Miguel, cura de Santa María de Lara. Monasterio de la Sierra, 15 - septiembre - 1831.

1347 Ibídem. (1701 - 1743). Visita realizada a la parroquia de San Pedro en Monasterio de la Sierra en 1740, por D. Francisco López de Angulo. Salas de los Infantes a 29 de noviembre de 1740.

1348 Ibídem. Monasterio de la Sierra a 15 de septiembre de 1831.

1349 Ibídem. LF. (1614 - 1653). Visita realizada a la parroquia de San Pedro en Monasterio de la Sierra en 1635, por D. Antonio Sánchez Tristán. Monasterio de la Sierra, 20 - mayo - 1635.
} 
MONCALVILLO.

La localidad de Moncalvillo se encuentra situada en la parte meridional de nuestra zona de estudio, dentro del terreno que forma la orla mesozoica, que rodea el núcleo central de la Sierra de la Demanda. Su término municipal presenta, por lo tanto, una orografía escarpada, salpicada por suaves cerros, poblados de monte bajo, poco atractivo para el desarrollo de la actividad agrícola. El nombre de este pueblo deriva del topónimo Montem Calvellum, que significa monte calvillo o pelado. Con esta denominación aparece citado por vez primera en un documento fechado el 5-XI-1172 del Cartulario de Arlanza ${ }^{1350}$.

Moncalvillo formó parte, hasta el siglo XII, del alfoz de Lara ${ }^{1351}$, quedando incluido, a partir de este momento, en la Merindad Menor de Santo Domingo de Silos $^{1352}$. Durante la Edad Moderna, dentro de la administración fiscal, Moncalvillo queda encuadrada dentro del partido de las Tierras del Condestable, de la provincia de Burgos, para pasar más tarde, en el siglo XVIII, tras la reforma borbónica, al partido de Aranda $^{1353}$. En el plano jurisdiccional, esta localidad estuvo en todo momento vinculada

1350 L. SERRANO: Cartulario de San Pedro de Arlanza. Madrid, Centro de Estudios Históricos. 1925. (pp. 219).

1351 G. MARTÍNEZ DÍEZ: Pueblos y alfoces burgaleses de la repoblación. Valladolid, Junta de Castilla y León. Consejería de Educación y Cultura. 1997. (pp.175).

1352 C. ESTEPA DÍEZ: "Estructura de poder en Castilla (siglos XII - XIII). El poder señorial en las merindades burgalesas. En III Jornadas burgalesas de Historia (3 1991). Burgos en la Plena Edad Media. Burgos, Asociación Provincial de Libreros de Burgos. 1994. (pp. 245 - 294).

1353 G. MARTÍNEZ DÍEZ: Génesis histórica de la provincia de Burgos y sus divisiones administrativas. Burgos, Aldecoa. 1983. 
al Monasterio de las Huelgas Reales de Burgos, formando parte de la dotación de este cenobio desde sus inicios. Moncalvillo mantuvo esta condición hasta la supresión del régimen señorial a comienzos del siglo XIX, constituyéndose, de este modo, en el único ejemplo de señorío eclesiástico, que sobrevive en esta comarca a lo largo de toda la Edad Moderna ${ }^{1354}$.

Su iglesia parroquial, a su vez, depende del obispado de Osma, en virtud de los límites fijados en el concilio de Burgos de 1136, entre las sedes oxomense y burgalesa $^{1355}$.

Moncalvillo fue siempre un núcleo de tipo medio, dentro de lo que son los niveles demográficos habituales en esta comarca de la sierra, con una evolución que apenas experimenta fluctuaciones bruscas, si exceptuamos los valores registrados para el primer tercio del siglo XVII. Los datos que poseemos para el siglo XVI muestra un ligero crecimiento, aunque con unos valores muy próximos entre sí, que nos obligan a hablar de una población prácticamente sin cambios. Así, el censo de 1541 da un valor de 69 vecinos $^{1356}$, que se mantiene prácticamente igual en el censo de los obispos, de 1584-87, con 70 vecinos $^{1357}$, y sube ligeramente en el de 1591 , con 74 vecinos $^{1358}$. Esta línea parece quebrarse en el siglo XVII, pues si damos crédito a los valores arrojados por el censo de la sal, de 1631, la población de Moncalvillo habría descendido hasta los 41 vecinos $^{1359}$. Este descenso queda compensado en el siglo XVIII, con una evidente recuperación, que lleva incluso a superar las mejores cifras de la centuria del

1354 G. MARTíNEZ DÍEZ: Libro Becerro de las Behetrías. Estudio y texto crítico. Vol. II. León. Centro de Estudios e Investigación San Isidoro. 1981. (pp. 624); INE. Censo de 1787. “Floridablanca”. Madrid. INE. 1989.

1355 L. SERRANO: El obispado de Burgos y Castilla primitiva. Desde el siglo V al XIII. Madrid, Centro de Estudios Históricos. 1935. Tomo I (pp. 414 - 418).

1356 AGS. Contaduría General. Leg. 768. (fols.62).

1357 T. GONZÁLEZ: Censo de población de las provincias y partidos de la Corona de Castilla en el siglo XVI... Ed. Facsímil. Madrid, Imprenta Real. 1829.

1358 Censo de Castilla de 1591. Vecindario. Madrid, Instituto Nacional de Estadística. 1984.

1359 AGS. Dirección General del Tesoro, inventario 24. Leg. 1168 - 2. 
Quinientos. De este modo, según los datos proporcionados por el Vecindario del Catastro del Marqués de Ensenada, a mediados de este siglo había en Moncalvillo 83’5 vecinos $^{1360}$, los cuales no dejan de crecer, para darnos en 1787 un total de 285 habitantes, según el censo de Floridablanca ${ }^{1361}$.

La economía de estos vecinos estuvo basada principalmente en la agricultura de secano y la ganadería estante, con la cría de ovejas de raza churra, que producían lana basta. Junto a ello, no obstante, también debemos citar su participación, como el resto de las localidades vecinas (por ejemplo, Castrillo de la Reina y Hacinas), en la actividad del transporte de corta distancia mediante mulas, como trajineros, en el intercambio de mercancías con las comarcas próximas.

Su núcleo urbano se asienta en el fondo de un abrigado valle, junto al tramo inicial del río Ciruelos, que nace a escasos metros. El conjunto de casas, que forma este núcleo, aparece dispuesto, de modo desordenado, en una apretada maraña surcada por estrechas y sinuosas calles. La mayor parte de estas casas se asienta sobre la vertiente izquierda de este valle, que mira hacia el sudeste, donde se extiende una pronunciada ladera, en cuya cumbre se asienta la iglesia parroquial. Este templo ha quedado en la actualidad totalmente aislado, debido al traslado de la población hacia el fondo del valle. Se trata, en cualquier caso, de un caserío compuesto únicamente por edificios, en los que se muestran las formas características de la arquitectura popular de la zona, con estructuras sumamente sencillas, de escasa altura, elaborados en sillarejo y mampostería, con sus tejados coronados por las habituales formas troncocónicas de las chimeneas de campana. Los únicos edificios que destacan mínimamente, por lo tanto, son los de carácter religioso, entre los que se encuentran la iglesia parroquial y la ermita de Santa Marina, situada dentro del pueblo.

\footnotetext{
1360 ADPBU. CE - 1114. RESPUESTAS GENERALES. Moncalvillo, 2 - mayo - 1753.

1361 INE. Censo de 1787. “Floridablanca”. Ob. cit.
} 
Iglesia de San Pedro.

La iglesia de Moncalvillo se encuentra dedicada a San Pedro, una de las advocaciones más frecuentes, dentro de la provincia de Burgos, y en las diócesis de Burgos y Osma. Se alza, como decimos, sobre la cumbre que preside el pueblo, asentándose en el interior de un espacio convenientemente allanado, que delimita un pequeño muro de piedra, que forma el atrio. Se trata de un edificio sencillo, de modestas proporciones, y gran heterogeneidad de formas, en el que se combinan los modelos propios de la estética del barroco clasicista, que arraigaron de un modo tan profundo en la arquitectura de la zona, con las formas populares, más austeras y funcionales. Todo ello constituye el reflejo de una secuencia constructiva, que se extiende a lo largo de algo menos de siglo y medio.

La planta de este edificio es bastante irregular, con un cuerpo dividido en dos naves rectangulares, de igual longitud pero desigual anchura, con un claro predominio de la situada en el lado del evangelio, que se convierte en la principal. Sobre el extremo oriental de esta nave se incorpora la cabecera, formada por una amplia estructura de planta cuadrangular y testero plano, de anchura similar a la nave, flanqueada por la sacristía en el lado septentrional y la torre en el meridional. Todo el edificio está realizado en piedra, con muros de sillería de tamaño medio, dentro de los cuales, sin embargo, descubrimos las huellas dejadas por las diferentes fases constructivas. Con estos muros se consigue una imagen exterior formada por limpios volúmenes prismáticos, que se corresponden con cada una de las partes señaladas en la planta. Dentro de ellos destacan especialmente la presencia de la cabecera y la torre. La cabecera se alza sobre un elevado zócalo de piedra, y remata sus muros con doble moldura de cuarto de bocel y codillo. El muro del testero queda reforzado en las esquinas por sólidos contrafuertes de formas prismáticas, dispuestos con sus lados en paralelo a los lados muro. Sobre su parte central se abre una ventana de dintel plano, enmarcada por una moldura de perfil quebrado, a la que se añaden algunas ramas de frutos colgantes de talla plana, dispuestos a los lados. Una segunda ventana se abre 


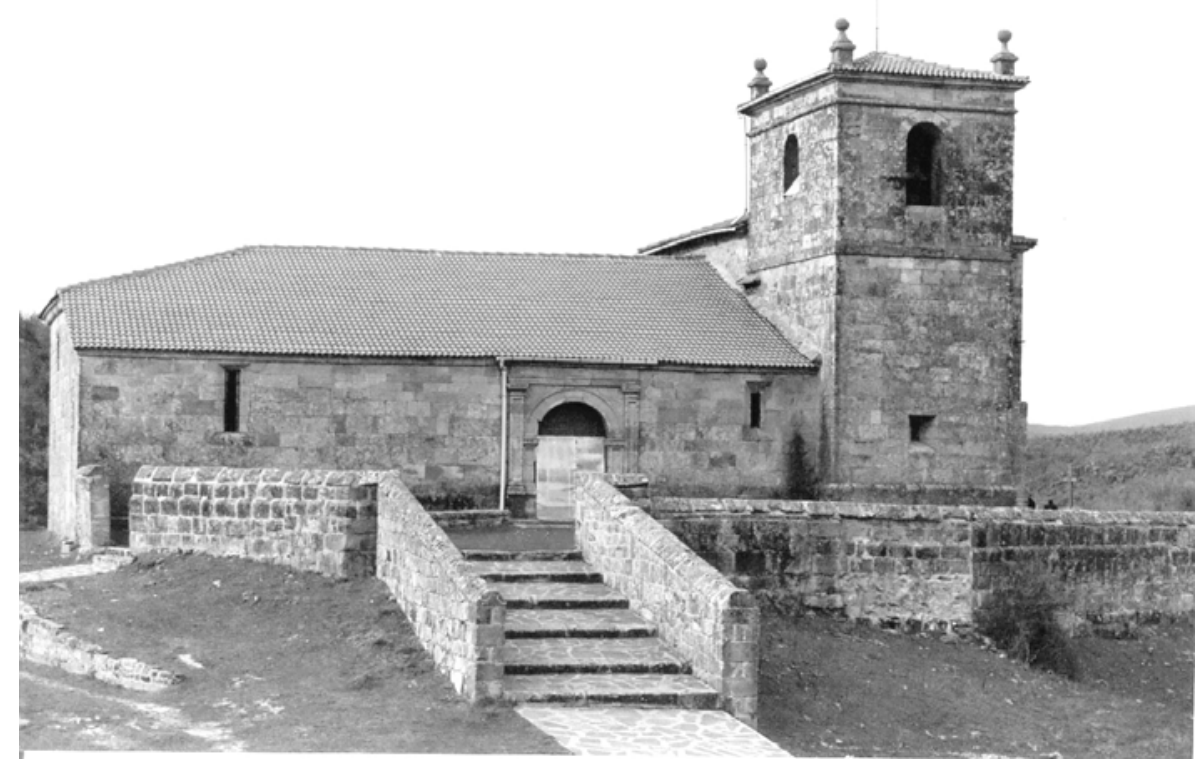

MONCALVILLO.

Iglesia de San Pedro.

sobre el lado meridional de esta cabecera, también de dintel plano, pero enmarcada por una moldura plana de escaso resaltes con orejones.

La torre, por su parte, está constituida por un prisma de sección cuadrangular, articulado en dos cuerpos, separados por moldura plana de escaso resalte. El superior, que forma el cuerpo de campanas, presenta dos vanos de arco de medio punto y antepecho, en su lado oriental, y uno solo de similares características, en cada uno de los tres lados restantes. Este cuerpo queda rematado por un friso corrido y una cornisa similar a la de la cabecera, con los que se da paso al tejado, en el que aparecen pináculos de bola, remarcando sus esquinas.

La zona del cuerpo cuenta con estilizadas ventanas de dintel plano y profundo derrame hacia el exterior, distribuidas entre sus caras meridional y de poniente. Sobre el muro del mediodía se abre la puerta de acceso, la cual está formada por un sencillo arco 
de medio punto, de rosca cajeada, escoltado por pilastras de orden toscano, entre las que se extiende un sencillo entablamento de friso completamente liso. Una estructura, como decimos, sencilla, de gran planitud y absolutamente desonamentada, que participa, pese a su simplificación, de los rasgos propios de la estética del estilo clasicista.

En el interior, las dos naves que forman la zona del cuerpo, aparecen separadas por una línea de dos amplios arcos formeros de medio punto de intradós cajeado, sobre los que descansa la armadura de madera, que soporta el tejado. En la parte de los pies incorpora un pequeño coro alto, elaborado en madera, que se extiende de un lado a otro, abarcando el espacio posterior de ambas naves. En el otro extremo de la nave principal, un potente arco de medio punto de intradós cajeado, conduce al interior de la cabecera, la cual queda cubierta con una bóveda de crucería estrellada con terceletes y nervios combados en el centro, dispuestos en forma de ondas. Las diferencias entre la parte de la cabecera y la zona de las naves, por lo tanto, queda perfectamente marcada, no sólo desde el punto de vista estructural, sino también estético, con una elaboración más cuidada y una mayor calidad artística en la primera.

La imagen interior de este templo se completa con los retablos, que adornan sus respectivos altares. Son cuatro en total, y están dedicados a San Pedro, el del altar mayor, y a San Isidro, Nuestra Señora, y a Cristo Resucitado, los restantes. El mayor es de estilo churrigueresco, de mediados del siglo XVIII, y está presidido por la imagen tallada de San Pedro en cátedra, cuya hornacina aparece transparentada, al hacerla coincidir con la ventana abierta sobre el muro del testero. El de San Isidro fue construido a comienzos del siglo XVIII, y originalmente estaba dedicado al Santo Cristo. El de Nuestra Señora es de la segunda mitad del siglo XVIII, y muestra una movida estructura propia de la estética rococó. Su hornacina central está presidida por una talla gótica de la Virgen. Finalmente el retablo de Cristo Resucitado nos muestra su imagen titular acompañada por las figuras de Cristo, la Virgen, San Juan Bautista y San Juan Evangelista, dispuestas en las calles laterales, mientras que en el remate aparece 
San Roque ${ }^{1362}$. A esta relación de retablos debemos añadir un altar en piedra, ubicado sobre el muro frontal de la nave de la epístola, de trazas clasicistas, con un nicho coronado con arco de medio punto, escoltado por columnas seudotoscanas de fuste estriado y fuerte éntasis, dispuestas sobre retropilastras, entre las que se extiende un entrablamento, que da paso a un frontón recto partido, con una cruz en el centro y pináculos de bola en los vértices laterales. Esta hornacina está ocupada actualmente por una talla de San Martín a caballo, partiendo su capa con el mendigo.

El proceso constructivo de la actual fábrica de este templo se inicia a comienzos del siglo XVII y se termina en las primeras décadas del siglo XVIII. Dentro de este proceso se producen, así mismo, diferentes fases, las cuales propician la construcción de cada una de las partes o piezas, que forman este conjunto. No conocemos, sin embargo, nada del templo anterior, el cual fue desapareciendo a medida que surgía el nuevo.

La primera parte que se renueva es la zona del cuerpo, a cuyas obras corresponden los arcos, que actualmente separan las dos naves. La fecha de 1601, inscrita sobre la dovela central del situado en la parte delantera, debe servirnos de referencia para establecer la cronología de estos trabajos. Resulta difícil reconstruir el aspecto de este primer templo, si bien debemos suponer que estos arcos, que hoy cumplen el papel de arcos formeros, debieron formar parte de un primitivo pórtico, abierto sobre este flanco meridional. Esto reducía considerablemente la anchura de la nave.

La siguiente emprendida es la construcción de la torre. Desconocemos, en este caso también, los detalles que rodearon su ejecución, e incluso la fecha en la que fue realizada, si bien, debemos suponer que se produce durante el primer tercio del siglo XVII. A ello nos conduce, no sólo las formas desarrolladas en su estructura, sino la información proporcionada por los libros de fábrica de esta iglesia, cuyos registros de

1362 R. J. PAYO HERNANZ: El retablo en Burgos y su comarca durante los siglos XVII y XVIII. Burgos, Excma. Diputación Provincial de Burgos. 1997. (T. II, pp. 510). 
cuentas, conservados desde el año 1644 en adelante, en todo momento nos hablan de esta torre como una obra ya terminada.

Durante el resto de la centuria del Setecientos simplemente se desarrollan trabajos de mantenimiento, reparaciones y acondicionamiento del edificio. Dentro de ellos, podemos citar, por ejemplo, la renovación del tejado, realizada en 1645 por el maestro de carpintería Lucas de Arredondo, con un coste para esta fábrica de 48.750 maravedís. A ellos debemos sumar el importe de los materiales, proporcionados, en su mayor parte, por los feligreses ${ }^{1363}$. Una década más tarde, se efectúan también otros trabajos de reparación en la zona de la cabecera, empleando la iglesia en esta ocasión 960 reales $^{1364}$. La centuria se cierra con la construcción del atrio, que rodea el entorno del edificio. Esta obra se realiza en 1693, y en ella participan activamente el concejo del pueblo y los vecinos, lo cual hizo que la iglesia únicamente tuviera que aportar 1.656 reales de sus arcas ${ }^{1365}$.

Con el siglo XVIII se inicia la última y decisiva fase constructiva, que conoce este templo. Ésta comienza con la ampliación del espacio del cuerpo, efectuada en 1704, en la cual se añade una nueva nave en la parte meridional. Esta nave absorbe el primitivo pórtico, cuyos arcos quedan incorporados en el interior, desempeñando la función de arcos formeros. Se trata, por lo tanto, de una obra sencilla, con la que se amplía de forma considerable el espacio interior, al mismo tiempo, que esta zona del templo alcanza su imagen definitiva. Su coste para esta fábrica apenas superó los 1.400 reales $^{1366}$.

La obra más importante de esta última fase, sin embargo, fue la construcción de la nueva cabecera, finalizada en 1732, tal y como señala la inscripción conservada sobre

\footnotetext{
1363 AGDBU. LP. Moncalvillo, parroquia de San Pedro. LF. (1644 - 1714). Cuentas del año 1645. Moncalvillo, 3 - abril - 1646.

1364 Ibídem. Cuentas del año 1656. Moncalvillo, 1657.

1365 Ibídem. Cuentas del año 1693. Moncalvillo, 1694.

1366 Ibídem. Cuentas del año 1704. Moncalvillo, 4 - marzo - 1705.
} 
la ventana del muro del testero, y corroboran las fuentes documentales. En su ejecución esta fábrica invirtió una cantidad próxima a los 10.000 reales, de los cuales 8.700 reales fueron destinados exclusivamente para sufragar la mano de obra ${ }^{1367}$. Para hacer frente a estos gastos, la parroquia no tuvo más remedio que endeudarse, adquiriendo un censo de 2.500 reales, cuyos réditos fueron pagados religiosamente en los años siguientes ${ }^{1368}$. El resultado de ello, como ya vimos, nos presenta una obra característica de este momento en la zona, con unas rasgos de marcado clasicismo, en los que la pureza de líneas y la moderación ornamental, se convierten en sus aspectos más representativos. Su precedente más cercano, sin duda, se encuentra en la cabecera construida solo unos años antes en la iglesia de Santa Eulalia, de la vecina localidad de Palacios de la Sierra.

Con esta obra, como decimos, se completa la secuencia constructiva de este templo, y de algún modo, su imagen definitiva, lo que hace que a partir de aquí únicamente nos encontremos con obras encaminadas a mejorar o completar esta estructura. Dentro de ellas, destaca de modo especial la construcción de retablos. El más importante es el del altar mayor, levantado en torno a 1745. Su construcción supuso un importante esfuerzo económico para esta fábrica, que tuvo que desembolsar una cantidad próxima a los 3.500 reales, a los que debemos sumar los 500 reales de la madera que se trajo de Quintanar ${ }^{1369}$. Con su incorporación se completa la imagen definitiva de la cabecera. Unos años antes, en 1701, se había construido el retablo del Santo Cristo, cuyo coste para esta fábrica rondó los 2.700 reales ${ }^{1370}$. En este mismo apartado podemos incluir también la compra de una nueva cajonería para la sacristía, efectuada en 1768, cuyo coste ascendió a 755 reales $^{1371}$.

\footnotetext{
1367 Ibídem. LF. (1715 - 1759). Cuentas del año 1732. Moncalvillo, 8 - marzo - 1733.

1368 Ibídem. Cuentas del año 1733. Moncalvillo, 15 - marzo - 1734; Ibídem. Cuentas del año 1734. Moncalvillo, 15 - abril - 1735.

1369 Ibídem. Cuentas del año 1745. Moncalvillo, 9 - febrero - 1746.

1370 Ibídem. LF. (1644 - 1714). Cuentas del año 1701. Moncalvillo, 1 - agosto - 1702.

1371 Ibídem. LF. (1760 - 1892). Cuentas del año 1768. Moncalvillo, 1 - febrero - 1769.
} 
La imagen interior de este templo, por su parte, se completa con la renovación del coro y la construcción del cancel para la puerta, efectuados ya a finales de este siglo XVIII. El coro fue ampliado en 1788, para abarcara toda la zona de los pies, extendiéndose hacia la nueva nave lateral, construida a principios de la centuria. Su ejecución alcanzó un coste de 959 reales $^{1372}$. El cancel, por su parte, se construye en

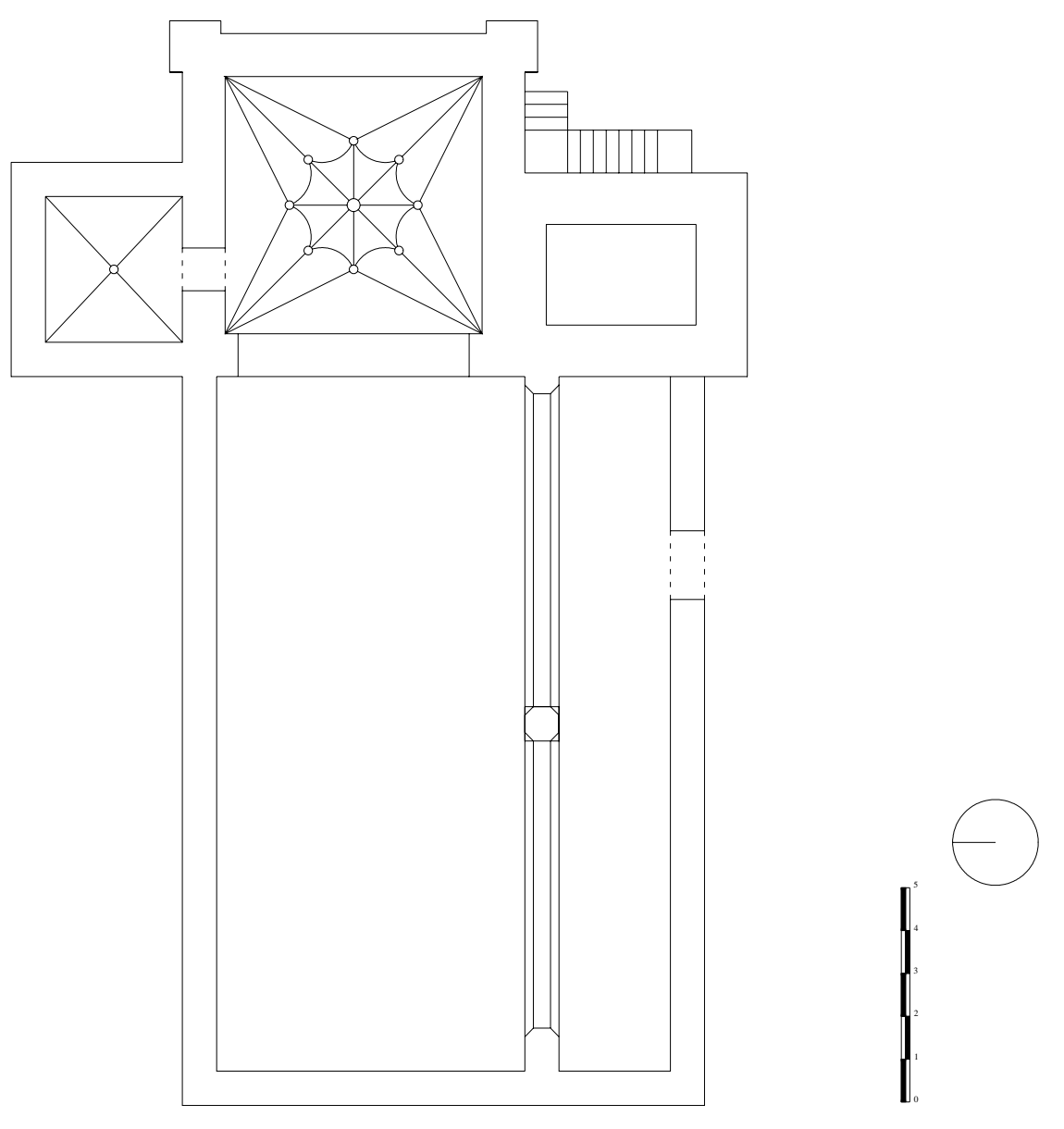

MONCALVILLO. Iglesia de San Pedro. Planta.

1372 Ibídem. Cuentas del año 1788. Moncalvillo, 16 - enero - 1789. 
1795, con un desembolso para esta iglesia de 1.568 reales, a los que sumamos 100 reales más, gastados en su transporte ${ }^{1373}$.

Ya en los primeros años del siglo XIX encontramos otra obra destacada por su elevado coste, como fue la renovación de toda la estructura del tejado, cuya ejecución superó los 7.600 reales $^{1374}$.

Ermitas.

En esta localidad de Moncalvillo existieron un total de seis ermitas, de las cuales sólo una ha permanecido en pie hasta nuestros días. Estas ermitas estaban dedicadas a Santa Marina, Nuestra Señora de la Paz, Nuestra Señora del Vallejo, San Roque, San Salvador y San Andrés. De ellas, estas tres últimas no han conseguido ni siquiera perdurar en la memoria de los habitantes del pueblo, lo que nos impide incluso fijar el lugar en el que se ubicaban. Sabemos, no obstante, que hasta los años centrales del siglo XVIII se mantenían en pie, mostrando un aceptable estado de conservación. Después de 1748, sin embargo, no volvemos a tener más noticias de ellas ${ }^{1375}$.

La ermita de Nuestra Señora de la Paz se encontraba situada en el límite entre los términos municipales de Moncalvillo y Palacios de la Sierra, y en virtud de ello, su patronato era desempeñado, de forma conjunta, por los concejos de estos dos pueblos. Al menos así nos lo indica el propio obispo de Osma, D. Juan de Cavía, en su visita realizada a los pueblos de esta zona en 1829, donde dice de esta ermita que está “...sita en la confinación de los términos de Palacios y Moncalvillo, y que por lo mismo corre al cuidado simultáneo de las dos villas, y está descuidada de una y otra; por lo que mando S.I que alternen las dos villas teniendo una sola las llaves cada año, y corran de

1373 Ibídem. Cuentas del año 1795. Moncalvillo, 13 - enero - 1796; Ibídem. Cuentas del año 1796. Moncalvillo, 24 - enero - 1797.

1374 Ibídem. Cuentas del año 1812 - 13. Moncalvillo, 1 - octubre - 1814.

1375 Ibídem. Visita realizada a la parroquia de San Pedro de Moncalvillo en 1748, por Lic. Joseph Hipólito de Urrutia. Castrillo de la Reina, 9 - julio - 1748. 
su cuenta las obras menores y las mayores se hagan a costa de las dos villas"1376. En el transcurso de esta misma visita, sin embargo, señala también que "no se visitó la que había de Nuestra Señora de la Paz por estar casi enteramente arruinada"1377. Después de esta visita no volvemos a tener más noticias de ella.

La dedicada a Nuestra Señora del Vallejo se encontraba situada dentro del pueblo, sin embargo, esta circunstancia, lejos de evitar su desaparición solamente sirvió para retrasar su final. Nada queda actualmente de su fábrica, cuya última mención aparece recogida en el Diccionario de P. MADOZ, a mediados del siglo XIX ${ }^{1378}$.

Por último, está la ermita de Santa Marina, la cual, como decimos, es la única que ha logrado sobrevivir hasta nuestros días. Se encuentra situada en la parte central del pueblo, confundida entre la maraña de casas que la rodean. Presenta un edificio de tipo caja, de estructura sumamente sencilla, con una forma prismática sobre planta rectangular, cubierta con tejado dispuesto a dos aguas. Toda ella está realizada en piedra, con sólidos muros de sillería, que la hacen destacar del resto de las construcciones circundantes. Sobre el muro de los pies, orientado hacia poniente, se levanta su fachada principal, la cual cuenta con una puerta con arco de medio punto escoltado por pilastras cajeadas, entre las que se extiende una airosa cornisa, con una pequeña cruz en el centro y dos pináculos de bola en los extremos. En la base de esta cruz podemos leer una pequeña inscripción, que dice: SANTA MARINA AÑO DE 1788. Esta fachada se completa con una ventana de dintel plano, dispuesta sobre el eje de la puerta, y una pequeña espadaña en el vértice superior del tejado, con un solo vano con arco de medio punto, rematado por dos pequeños pináculos piramidales.

1376 AGDBU. LP. Palacios de la Sierra, parroquia de Santa Eulalia y Santa María. LF. (1815 y ss). Visita realizada a la parroquia de Santa Eulalia el año 1829, por D. Juan de Cavía, obispo de Osma. Palacios de la Sierra, 22 - septiembre - 1829.

1377 AGDBU. LP. Moncalvillo, parroquia de San Pedro. LF. (1760 - 1892). Visita realizada a la parroquia de San Pedro de Moncalvillo el año 1829, por D. Juan de Cavía, obispo de Osma. Moncalvillo, 4 - septiembre - 1829 .

1378 P. MADOZ: Diccionario geográfico - estadístico - histórico de España y sus posesiones de Ultramar. Valladolid, Ámbito D.L. 1984. (pp. 385). 
$\mathrm{Su}$ interior se halla totalmente transformado, pues ha sido acondicionado para acoger el desarrollo de los oficios, durante los meses de invierno, ante la imposibilidad de muchos vecinos del pueblo de subir hasta el templo parroquial.

Este edificio fue construido, como hemos visto, en 1788, bajo la dirección del maestro de cantería Baltasar de la Torre. Sus obras fueron costeadas por la parroquia, que aportó 9.769 reales, y los vecinos del pueblo, cuyas limosnas y prestaciones personales sumaron un total de 6.188 reales $^{1379}$.

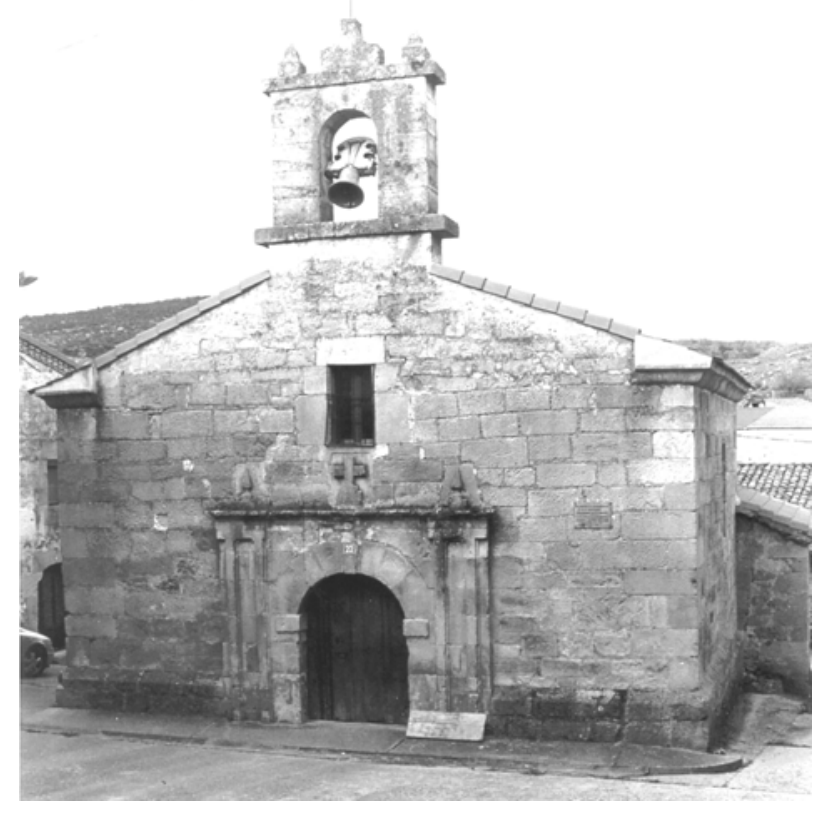

MONCALVILLO. Ermita de Santa Marina.

1379 AGDBU. LP. Moncalvillo, parroquia de San Pedro. LF. (1760 - 1892). Cuentas del año 1788. Moncalvillo, 16 - enero - 1789. 


\section{MONTERRUBIO DE LA DEMANDA.}

La localidad de Monterrubio se encuentra situada en plena Sierra de la Demanda, sobre cuyas laderas meridionales extiende su término municipal, mirando hacia la Sierra de Neila. Está situada, por lo tanto, junto a la entrada del valle de Valdelaguna, si bien su historia en ningún momento estuvo ligada a esta agrupación de pueblos. Monterrubio, por el contrario, buscó sus vínculos con las poblaciones situadas hacia su parte oriental, con los que conformó el coto conocido como las Cinco Villas y Valle de Canales. Estas cinco villas eran Montenegro, Brieva, Ventrosa, Viniegra de Abajo y Mansilla, mientras que el valle de Canales agrupaba a los pueblos de Canales, Villavelayo y Monterrubio de la Demanda.

El origen de este peculiar estado puede encontrarse en el carácter fronterizo, que estas tierras tuvieron entre los siglos X y XI, momento en el cual obtuvo una serie de privilegios, que algunos relacionan con la figura del mismísimo conde Fernán González $^{1380}$. Sea como fuere, el devenir histórico de Monterrubio permanece ligado al discurrir de esta agrupación, hasta el año 1833, en el que se hace el actual reparto de provincias, según el cual esta localidad pasa a formar parte de la provincia de Burgos, mientras que el resto del coto queda encuadrado en la provincia de Logroño.

Así, Monterrubio formó parte hasta el siglo XII del alfoz de Canales. Se trata de un pequeño alfoz, del cual apenas existen noticias, pues sólo dos documentos fechados

\footnotetext{
1380 D. ORTEGA GUTIÉRREZ, R. CAMARERO CAMARERO: La villa de Monterrubio de la Demanda. Una del Estado de las Cinco Villas y Valle de Canales. Burgos. 1999. (pp. 97 y ss.).
} 
936 Arquitectura de la Edad Moderna en la sierra burgalesa.

en los años 1062 y 1095, nos hablan de un territorim Valle de Canales $^{1381}$. Posteriormente, una vez extinguido este sistema de alfoces, Monterrubio, junto con el bloque que formaba esta agrupación, pasaron a formar parte de la Merindad Menor de Santo Domingo de Silos ${ }^{1382}$.

Ya en la Edad Moderna, dentro de la administración fiscal, vemos que la vinculación de esta localidad a la agrupación de las Cinco Villas y Valdecanales hace que quede encuadrada dentro de la provincia de Soria ${ }^{1383}$. Esto no sufre cambios, hasta que en 1833, como hemos dicho, se hace la última renovación del mapa provincial, repartiendo esta unidad entre las provincias de Burgos y Logroño. En el plano jurisdiccional, Monterrubio mantuvo su condición de realengo hasta mediados del siglo XIV. Sin embargo, desde 1366 pasa a formar parte del señorío de Cameros, dependiente de la familia Ramírez de Arellano, condes de Aguilar ${ }^{1384}$. Se convierte, de este modo, como el resto de los pueblos de esta agrupación, en villa de señorío, condición que se mantuvo sin cambios hasta la eliminación de este régimen. Por último, dentro de la organización eclesiástica del territorio, la iglesia parroquial de Monterrubio estuvo encuadrada en el marco de la diócesis de Burgos, si bien, en sus inicios, la vinculación

1381 I. ÁLVAREZ BORGE: Monarquía feudal y organización territorial: Alfoces y merindades en Castilla (Siglos $X-X I V$ ). Madrid, CSIC. 1993. (pp. 61). G. MARTíNEZ DÍEZ: Pueblos y alfoces burgaleses de la repoblación. Valladolid, Junta de Castilla y León. Consejería de Educación y Cultura. 1997. (pp. 1997) L. SERRANO: Cartulario de San Pedro de Arlanza. Madrid, Centro de Estudios Históricos. 1925. (pp. 124); Ibídem. Cartulario de San Millán de la Cogolla. Madrid. 1930. (pp. 288).

1382 D. ORTEGA GUTIÉRREZ, R. CAMARERO CAMARERO: La villa de Monterrubio de la Demanda... ob. cit. (pp.90 - 93). I. ÁLVAREZ BORGE: Monarquía feudal y organización territorial... ob. cit. (pp. 61). G. MARTíNEZ DÍEZ: Libro Becerro de las Behetrías. Estudio y texto crítico. Vol. II. León. Centro de Estudios e Investigación San Isidoro. 1981. (pp.618).

1383 M. DIAGO HERNANDO: Soria en la Baja Edad Media. Espacio rural y economía agraria. Madrid, Departamento de Historia Medieval. Editorial Complutense. 1993. M. C. PÉREZ DE GUINEA: Estudio sobre la sociedad soriana en el siglo XVIII. Los censos y la distribución de la población. Valladolid, Consejo General de Castilla y León. 1982.

1384 D. ORTEGA GUTIÉRREZ, R. CAMARERO CAMARERO: La villa de Monterrubio de la Demanda... ob. cit. (pp. 104 - 114). 
con el estado de las Cinco Villas y Valdecanales hizo que, por un breve espacio de tiempo, dependiera de la sede de Calahorra ${ }^{1385}$.

Monterrubio fue, a lo largo de la Edad Moderna, un núcleo de población escasa, el cual vivió su momento de esplendor en las décadas centrales del siglo XVIII. Durante el siglo XVI sus niveles demográficos apenas sufren variaciones notables, con 23 vecinos contados en el censo de $1541^{1386}$, 28 vecinos en el censo de los obispos de $1584-87^{1387}$, y 21 vecinos en el censo de $1591^{1388}$. El siglo XVII representa, sin embargo, un período de crisis, con una fuerte caída durante la primera mitad, reflejada en un censo de 1646 , que nos da una cifra de sólo 14 vecinos ${ }^{1389}$, a la que sigue una recuperación durante la segunda mitad de la centuria, plasmada en 1697 con un censo de 26 vecinos $^{1390}$. A partir de aquí se inicia un despegue, que alcanza su momento culminante en los años centrales del siglo XVIII, con los 59 vecinos, contabilizados en el Catastro del Marqués de Ensenada ${ }^{1391}$. Estas cifras se mantienen más o menos sin cambios durante la segunda mitad de siglo, como nos indica el censo de Floridablanca, con un total de 186 habitantes $^{1392}$.

La economía de Monterrubio, como la del resto de los pueblos del interior de la Sierra de la Demanda, estuvo basada principalmente en la ganadería trashumante, con la

1385 D. MANSILLA REOYO: “Obispado y monasterios”. En Hisotoria de Burgos II. Edad Media (1). Burgos, Caja de Ahorros Municipal de Burgos. 1986.

1386 AGS. Contaduría General. Leg. 768.

1387 T. GONZÁLEZ: Censo de población de las provincias y partidos de la Corona de Castilla en el siglo XVI... Ed. Facsímil. Madrid, Imprenta Real. 1829.

1388 Censo de Castilla de 1591. Vecindario. Madrid, Instituto Nacional de Estadística. 1984.

1389 AGS. Cámara de Castilla - Diversos. Leg. 23, nº 4. (s/f). Monterrubio de la Demanda, 11 diciembre - 1646 .

1390 D. ORTEGA GUTIÉRREZ, R. CAMARERO CAMARERO: La villa de Monterrubio de la Demanda... ob. cit. (pp. 119 - 124).

1391 ADPBU. CE - 1129. RESPUESTAS GENERALES. Monterrubio de la Demanda, 6 - agosto 1752.

1392 INE. Censo de 1787. “Floridablanca”. Madrid. INE. 1989. 
cría de ovejas merinas de lana fina ${ }^{1393}$. Su vinculación con el estado de las Cinco Villas y Valdecanales, sin embargo, hace que sus ganaderos no formen parte de la Cuadrilla de San Pedro de Vega, sino que se hallaban agrupados a los de la zona de Cameros. También fue importante en esta localidad la agricultura, para la que se aprovechaban las tierras ubicadas en la explanada, que se extiende a sus pies, cuya orientación meridional, al abrigo de las montañas de la Demanda, permitía moderar la severidad del clima. Junto a esto, debemos señalar también, la presencia de algunos yacimientos de mineral de hierro y cobre, que fueron explotados ya en época celtíbera y romana. Su aprovechamiento durante los siglos de la Edad Moderna, sin embargo, no parece que fuera muy destacado.

Su núcleo urbano se extiende sobre las faldas de una de estas laderas, que salpican su término municipal, orientada convenientemente hacia el mediodía. Su caserío presenta una estampa muy característica en la zona, con la iglesia ubicada en la parte superior, y el resto de las casas diseminadas a sus pies. Estas casas se agrupan, a su vez, en dos barrios, como son el situado en la parte alta, junto a la iglesia, y el de la parte baja, asentado sobre una zona más llana. Dentro de estas casas, encontramos algunos ejemplos interesantes de casas solariegas y blasonadas, vinculadas a los grandes propietarios de rebaños trashumantes. La mayoría, sin embargo, han sido profundamente alteradas por las reformas posteriores. Por ello, el edificio más representativo del pueblo lo constituye, como en todos los demás casos, la iglesia parroquial.

Iglesia de San Juan Bautista.

En esta iglesia, dedicada a San Juan Bautista, nos encontramos con un edificio de formas sencillas, producto de una larga secuencia constructiva, que se inicia en el período románico primitivo, y no termina hasta mediados del siglo XX. Por encima de todos estos avatares, el estilo dominante, dentro de esta fábrica, es el barroco de corte

\footnotetext{
1393 ADPBU. CE - 1129. RESPUESTAS GENERALES. Monterrubio de la Demanda, 6 - agosto 1752.
} 
clasicista, al cual corresponde la renovación más importante, realizada a mediados del siglo XVIII.

El edificio presenta una sencilla estructura de tipo caja, con una planta de una sola nave, de trazado rectangular, articulada en dos tramos, que se completa en el extremo oriental con una pequeña cabecera cuadrangular, de anchura considerablemente menor que la nave, sobre cuyo flanco meridional se añade la sacristía. Toda esta fábrica está realizada en piedra, predominando los muros de sillería, levantados sobre un pequeño zócalo también de piedra, y rematados con una gruesa cornisa de cuarto de bocel. Estos muros se refuerzan con sólidos estribos, más potentes en el lado meridional, por ser la parte más deprimida del terreno, y más ligeros en el septentrional. La sacristía, por su parte, presenta sencillos paramentos de sillarejo.

La imagen exterior de este edificio queda dominada por el gran volumen prismático, que conforma la parte del cuerpo, sobre el cual se añaden los módulos correspondientes a la cabecera y la sacristía. Sobre el muro de los pies de este cuerpo se levanta la que fuera su fachada principal, articulada en tres niveles, con la puerta en el inferior, un gran óculo en el centro y una espadaña como remate. De la puerta se conserva el contorno de su arco de medio punto y las pilastras cajeadas de los lados, coronadas con pináculos de bola, y unidas por una pequeña moldura plana. El óculo, dispuesto sobre ella, muestra un amplio derrame hacia el exterior. La espadaña, por su parte, se articula en dos cuerpos decrecientes en altura y anchura, unidos por pequeñas aletas triangulares, que se rematan en los extremos con pináculos de bola. Dos vanos, coronados con arco de medio punto, se abren en el cuerpo inferior, por uno solo en el superior, el cual remata con una pequeña cruz latina, escoltada con pináculos de bola. Esta espadaña es una obra reciente, de principios del siglo $\mathrm{XX}$, que sustituye a una torre anterior.

La actual entrada del templo se localiza en la fachada meridional de la nave, y cuenta con una sencilla puerta coronada con arco de medio punto. En esta fachada se 
abren también dos pequeños óculos, repartidos entre cada uno de los tramos de la nave, acompañados de una ventana de dintel plano, sobre el muro del tramo delantero.

La parte de la cabecera conserva más o menos íntegra la primitiva estructura del ábside románico, con sus muros recorridos, en su mitad inferior, por una galería de arcos ciegos (dos en los laterales y tres en el muro del testero), dispuestos sobre fajas rematadas con impostas ajedrezadas. En la parte central del muro del testero se abría una ventana, coronada con arco de medio punto, hoy cegada. En la parte septentrional de esta cabecera, por su parte, encontramos restos de la antigua sacristía, entre los que aparece el contorno de la puerta de acceso desde el interior de la capilla mayor, y el arranque de la bóveda de medio cañón, que formaba su cubierta.

En el interior de este templo encontramos un característico concepto de ámbito único, conformado por el espacio de la nave, con la capilla mayor abierta sobre el muro oriental, y coro alto a los pies. Los dos tramos, en los que se articula la nave, aparecen cubiertos con bóveda de crucería estrellada con terceletes de rampante muy plana. El tramo delantero además incorpora nervios combados, dispuestos en forma de onda en torno a la clave polar. La separación entre estos dos tramos se realiza mediante arco fajón de medio punto rebajado, de intradós cajeado, apeado sobre pilastras de orden dórico y fuste igualmente cajeado, de fuerte resalte sobre el plano del muro. El coro presenta una estructura mixta, con amplio arco escarzano de piedra, y superficie con entramado y suelo de madera.

En el extremo opuesto al coro, un arco de medio punto de intradós cajeados, sobre pilastras dóricas de fuste también cajeado, da paso al interior de la capilla mayor, cubierta con bóveda de crucería estrellada con terceletes de altura algo menor que las de la nave. La parte inferior de sus muros laterales repite la galería de arcos ciegos sobre fajas rematadas con imposta ajedrezada, que vimos en el exterior, mientras que en el muro del testero aparece, a media altura, un arco de medio punto, que se corresponde 


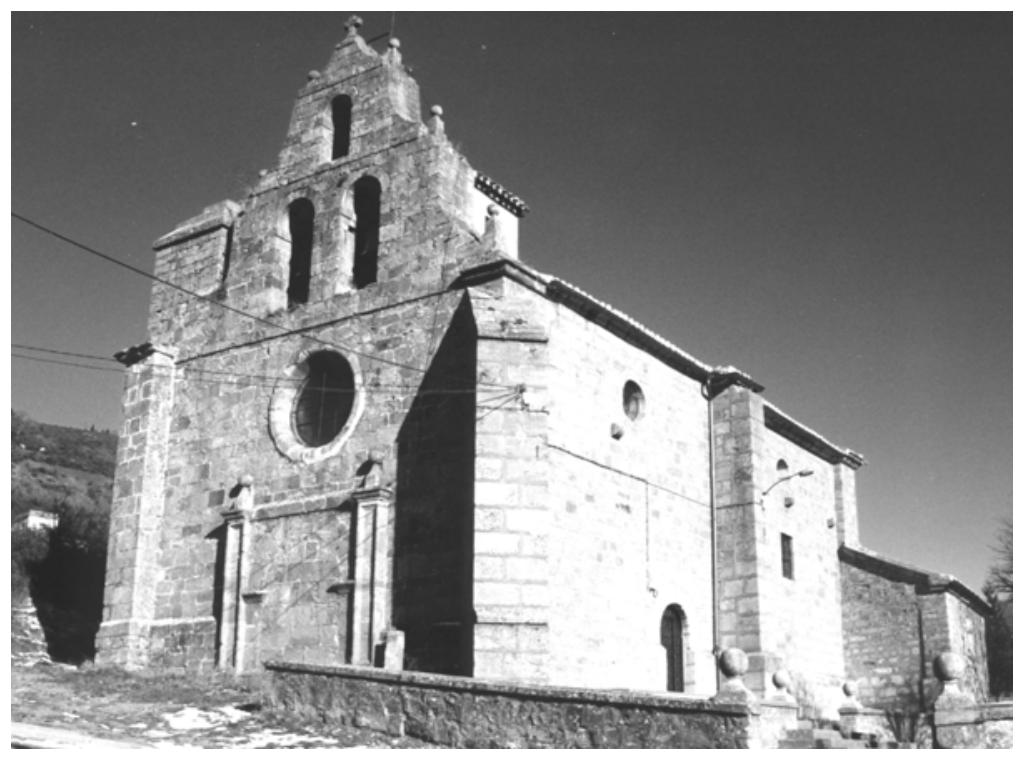

MONTERRUBIO DE LA DEMANDA.

Iglesia de San Juan Bautista.

con el arranque de la bóveda de medio cañón, que formaba la primitiva cubierta de este espacio.

Por lo demás, la imagen que actualmente ofrece el interior de este templo queda presidida por la más absoluta desnudez, pues las últimas labores de restauración, han eliminado, tanto los retablos, que decoraban sus altares, como el enlucido, que cubría sus muros.

La secuencia constructiva de este templo se inicia, como hemos dicho, en el período románico, al cual pertenece la parte inferior de los muros de la cabecera. A partir de ellos podemos apreciar, con total claridad, la imagen original de este primitivo ábside, dentro del cual nos llama la atención, además de su singular trazado de planta cuadrangular con testero plano, la decoración mediante arcos ciegos, que recorre sus muros. Todo ello nos permite encuadrar esta obra en la primera mitad del siglo XII, 
dentro de los primeros momentos de la expansión del estilo románico en la zona, manteniendo en su estructura ciertos rasgos propios de la arquitectura prerrománica ${ }^{1394}$.

A partir de aquí, no volvemos a tener más datos sobre la historia constructiva de este edificio hasta los primeros años del siglo XVIII, lo que nos impide conocer el aspecto que podía tener el templo durante los dos primeros siglos de la Edad Moderna. En este siglo XVIII tiene lugar la segunda gran fase constructiva, de la cual surge, en gran medida, la imagen definitiva de este templo. En este momento se procede a renovar de forma completa la zona de la nave, mientras que la cabecera sustituye su antigua cubierta de bóveda de cañón por la que hoy presente, incrementando con ellos su altura. Este proyecto de renovación se completa con la construcción de una torre, que se alzaba en la zona de los pies.

No conocemos muchos detalles de este proceso constructivo, ni tampoco los nombres de los artífices que participaron en él, si bien, parece claro que este proyecto renovador era una idea, que venían planteándose los responsables de esta fábrica, desde comienzos del siglo XVIII. Esta idea surge a raíz del mal estado en el que se encontraba, a principios de siglo, la fábrica anterior, lo que motiva incluso un abandono de las labores de mantenimiento por parte de sus responsables. De todo ello fue puntualmente informado el visitador del Arzobispado de Burgos en 1718, Fr. Ángel Benito, cuando observa esta falta de cuidados, indicando en su informe que: : “el motivo que havía avido para semejante omisión fue informado por el cura de dicho lugar haverlo suspendido a causa de estar para reedificarse de nuevo dicha iglesia...”1395.

Sin embargo, y a tenor de los datos que tenemos para los años siguientes, estas obras no se inician de forma inmediata, sino que tienen que esperar hasta finales de la

\footnotetext{
1394 F. PALOMERO ARAGÓN, M. ILARDIA GÁLLEGO: El arte románico burgalés. Un lenguaje medieval actual. Madrid, Lancia, 1995.

1395 AGDBU. LP. Monterrubio de la Demanda, parroquia de San Juan Bautista. LF. (1715 - 1781). Visita realizada a la parroquia de San Juan Bautista en Monterrubio de la Demanda en 1718, por Fr. Ángel Benito. Barbadillo de Herreros, 24 - septiembre - 1718.
} 
década de 1730 para ponerse en marcha ${ }^{1396}$. Su desarrollo, en cualquier caso, fue extremadamente lento, pues fueron muchos los problemas que surgieron en el transcurso de estos trabajos. De algunos de estos inconvenientes nos informa el visitador del Arzobispado de Burgos de 1740, D. Francisco López de Angulo, cuando dice:

“Al tiempo que hizo su merced la visita de dicha iglesia reconozió estar de por concluirse mucha parte de la fábrica material, siendo el motivo la quiebra que hizieron los maestros en quienes se remató, y respecto de hazer algunos años se alla pleito pendiente ante los Señores Provisores de este arzobispado sobre la conclusión de dicha obra e yntentada esta acción contra los fiadores de dichos maestros cuio litigio hace mucho tiempo está suspenso en perjuicio grande de dicha iglesia, por la omisión culpable del cura y mayordomo de fábrica suspendiendo por ahora providenciar en razón del adorno preciso de que carece dicha iglesia hasta la final determinación de dicho pleito: para que esta se consiga se manda a dicho cura y actual mayordomo de la fábrica, bajo excominión mayor, que en el término de quince días primeros (...) siguientes de la fecha de este auto otorgando poder a procurador del tribunal de dichos Señores Provisores sin levantar mano soliciten se fenezca y concluia dicho pleito dentro de quatro meses siguientes a los referidos quince días...”1397.

Estos problemas, lejos de solucionarse, se alargaron durante casi una década ${ }^{1398}$, hasta que al final, en 1749, se da la obra por concluida. Como muestra de ello tenemos la inscripción, que anuncia este hecho, sobre dos de las claves de la bóveda del tramo delantero de la nave. En ellas podemos leer lo siguiente: 1749, SIENDO CURA D. FERNANDO VELASCO. El estilo empleado en esta obra fue el barroco de corte

\footnotetext{
1396 Ibídem. Cuentas de 1736. Monterrubio de la Demanda, 14 - septiembre - 1737.

1397 Ibídem. Visita realizada a la parroquia de San Juan Bautista en Monterrubio de la Demanda en 1740, por D. Francisco López Angulo. Barbadillo de Herreros, 15 - noviembre - 1740.

1398 Ibídem. Visita realizada a la parroquia de San Juan Bautista de Monterrubio de la Demanda en 1744, por D. Diego Escalona. Barbadillo de Herreros, 26 - mayo - 1744.
} 
944 Arquitectura de la Edad Moderna en la sierra burgalesa.

clasicista, que revive con inusitado vigor en toda la archidiócesis burgalesa, y muy especialmente en esta comarca de la sierra, desde las primeras décadas de este siglo XVIII.

Esta renovación se completa con la construcción de un nuevo retablo para su remodelada capilla mayor, el cual fue realizado en 1771 por el escultor Manuel Garaña y el dorador Domingo Muñoz ${ }^{1399}$. Su dorado se realiza en $1777^{1400}$.

Durante el siglo XX se produce la última etapa constructiva, si bien para ser más rigurosos con el término, deberíamos hablar de etapa destructiva, pues son más los elementos eliminados, que los que se levantan. La primera de estas intervenciones se produce en 1916, y en ella se acomete la demolición de la torre, levantando en su lugar, sobre el muro de los pies, la actual espadaña. Muy posiblemente, durante estos trabajos se elimina también la portada de los pies, abriendo la actual, localizada en la fachada meridional. La intensidad de estos trabajos hace que el templo permanezca cerrado al culto durante un espacio de cinco años ${ }^{1401}$.

En 1958 tiene lugar otra actuación destacada, durante la cual se elimina el pórtico, que protegía la nueva puerta de entrada, el cual se extendía a lo largo de esta fachada meridional, descansando sobre amplios arcos de piedra, de medio punto. Las fotografías tomadas antes de esta obra nos permiten conocer su aspecto. Al mismo tiempo que se hacía esto en el exterior del templo, en el interior se procedía a eliminar tres retablos, como eran los dedicados a Nuestra Señora de los Dolores, la Inmaculada Concepción y San Roque ${ }^{1402}$. Finalmente, en 1984, se elimina el enlucido de sus muros y se renueva el entarimado del suelo.

\footnotetext{
1399 Ibídem. Cuentas del año 1771. Monterrubio de la Demanda, 25 - septiembre - 1772.

1400 Ibídem. Cuentas del año 1777. Monterrubio de la Demanda, 3 - septiembre - 1778.

1401 D. ORTEGA GUTIÉRREZ, R. CAMARERO CAMARERO: La villa de Monterrubio de la Demanda... ob. cit.

1402 Ibídem.
} 


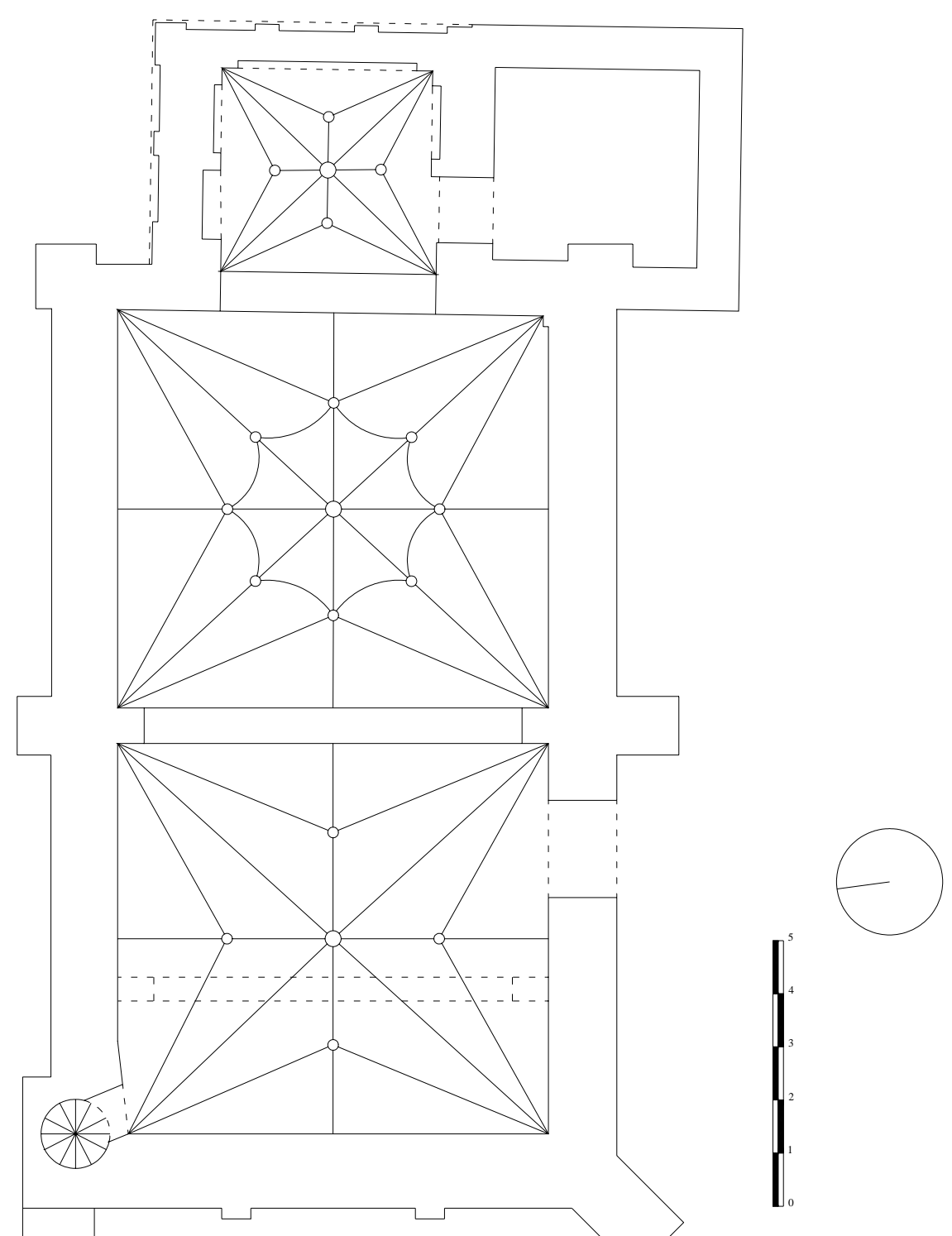

MONTERRUBIO DE LA DEMANDA.

Iglesia de San Juan Bautista. Planta. 


\section{Ermitas.}

La villa de Monterrubio contó con cuatro ermitas, las cuales estaban dedicadas a Nuestra Señora de la Caraba, Santiago, San Pedro y San Adrián. De todas ellas, solamente la de Nuestra Señora de la Caraba ha llegado hasta nuestros días. Se encuentra situada a las afueras del pueblo, en dirección oeste. Contó desde 1647 con una cofradía del mismo nombre asentada en su interior, si bien, su origen debió ser muy anterior, pues en las ordenanzas de la villa de 1622 ya se habla de ella ${ }^{1403}$. Su edificio actual, sin embargo, es el producto de la intensa actividad renovadora, llevada a cabo durante la década de 1980. Presenta un templo muy sencillo, de estructura de tipo caja, de planta rectangular con muros de sillería, y cubierta dispuesta a dos aguas. Su fachada principal se alza sobre el muro de los pies, y cuenta con una puerta con arco de medio punto, una pequeña ventana de dintel plano y un vano coronado con arco de medio punto, donde se aloja la campana, todo ello dispuesto sobre el eje central. Esta fachada se remate con un hastial, que incluye una cruz latina en el vértice superior y dos pináculos piramidales en los extremos. Se trata, por lo tanto, de una obra de recio sabor popular, y por lo tanto, difícil de adscribir a un estilo concreto.

Del resto de las ermitas no es mucho lo que podemos señalar, pues su temprana desaparición ha hecho que se pierda todo vestigio material de ellas. La dedicada a Santiago, se encontraba situada en la parte central del pueblo, entre los dos barrios en los que se reparte su caserío, ubicada en algún punto de la calle que lleva su nombre. No conocemos su origen, si bien, sabemos que ya existía en el siglo XVI. Respecto a su desaparición, debió producirse en torno a los últimos años del siglo XVIII, pues la última referencia que tenemos de ella corresponde al informe dejado por el visitador del

1403 F. GUTIÉRREZ: Nuestra Señora de la Caraba. Patrona de Monterrubio de la Demanda. Burgos, Excma Diputación Provincial de Burgos. 
Arzobispado de Burgos de 1791, D. Manuel María Izquierdo ${ }^{1404}$, mientras que en la visita de 1803 ya no aparece ${ }^{1405}$.

Una historia parecida vive la ermita de San Pedro, la cual se encontraba situada fuera del pueblo, en dirección norte, en un paraje conocido como Garganta de San Pedro, junto a un arroyuelo del mismo nombre. De ella, apenas quedan unos pocos restos en forma de piedras y tejas sueltas, dispersas por el suelo. Su desaparición debió producirse en tono a los mismos años que la de Santiago, pues la referencia de 1791 también es la última que se conoce. Sin embargo, en su caso, se trata de una muerta anunciada, pues son varios los avisos que tenemos, durante el siglo XVIII, en los que se da cuenta de su mal estado de conservación. Uno de los primeros lo da el visitador de 1715, D. Alonso Cossío Barrera ${ }^{1406}$, si bien, los más explícitos son los dejados por los visitadores de 1749 y 1755. El primero dice que "la dicha de San Pedro está muy indecente y que necesita componerse” ${ }^{\text {1407}}$, mientras que el segundo simplemente confirma “que no ha llegado el caso de reedificarla, según está mandado en la anterior visita” ${ }^{1408}$.

Por último, la ermita de San Adrián, conocida popularmente como Santricián, se encontraba situada en la parte sur del pueblo, junto al camino que conducía hacia

\footnotetext{
1404 AGDBU. LP. Monterrubio de la Demanda, parroquia de San Juan Bautista. LF. (1782 - 1851). (fols. $17 v^{0}-25 v^{0}$ ). Visita realizada a la parroquia de San Juan Bautista en Monterrubio de la Demanda en 1791, por D. Manuel María Izquierdo. Huerta de Arriba, 4 - septiembre - 1791.

1405 Ibídem. (fols. 57). Visita realizada a la parroquia de San Juan Bautista en Monterrubio de la Demanda en 1803, por el arzobispo de Burgos D. Manuel Cid Monroy. Canales, 17 - septiembre - 1803. 1406 Ibídem. LF. (1715 - 1781). Visita realizada a la parroquia de San Juan Bautista de Monterrubio de la Demanda en 1715, por D. Alonso de Cossío Barrera. Barbadillo de Herreros, 5 - mayo - 1715. 1407 Ibídem. Visita realizada a la parroquia de San Juan Bautista en Monterrubio de la Demanda en 1749, por D. Pedro de la Cuadra y Archiaga, arzobispo de Burgos. Canales, 29 - julio - 1749.

1408 Ibídem. Visita realizada a la parroquia de San Juan Bautista en Monterrubio de la Demanda en 1755, por D. Juan de Tobía y Zuazo, canónigo de la catedral de Burgos. Canales, 1 - agosto - 1755.
} 
Canales. Fue la primera en desaparecer, perdiéndose su rastro a finales del siglo XVII ${ }^{1409}$.

Arquitectura civil.

Monterrubio conserva todavía, como decíamos, un buen número de casas blasonadas, pertenecientes a los miembros más destacados de la ganadería trashumante. De ellas hablamos en los capítulos correspondientes a la arquitectura civil de los siglos XVII y XVIII. Comprobamos cómo la mayoría de los ejemplos se encuentran actualmente muy alterados por las reformas posteriores, lo que hace difícil adivinar su estructura original. Aun así, las casas situadas en la plaza San Roque $\mathrm{n}^{\circ} 21$, en la calle de las Escuelas $\mathrm{n}^{\circ} 2$, y en la calle de la Iglesia $\mathrm{n}^{\circ}$ 2, para el siglo XVII, y en la calle Santiago $\mathrm{n}^{\circ} 2$ y plaza Mayor $\mathrm{n}^{\circ} 10$, para el siglo XVIII, todavía nos permiten apreciar su estructura cúbica sobre amplia base cuadrangular, formando un sólido bloque articulado en dos plantas, con una disposición de vanos perfectamente ordenada, siguiente un esquema reticular. También debemos destacar los blasones, que se conservan en varias de ellas, entre los que debemos citar los de la calle Santiago $n^{\circ} 2$, calle de la Iglesia $n^{\circ} 2$, y calle Mayor $n^{0}$ 28. Son escudos con una compartimentación sencilla, de contorno cuadrilongo y sin adornos exteriores. Solamente los casos de la calle Santiago $\mathrm{n}^{\mathrm{o}} 2 \mathrm{y}$ Mayor $n^{\circ} 28$ rompen mínimamente esta norma. En lo que se refiere a sus armas, la repetición de varios muebles nos lleva a pensar en una intensa interrelación entre estas familias, vinculadas al mundo de la ganadería.

1409 D. ORTEGA GUTIÉRREZ, R. CAMARERO CAMARERO: La villa de Monterrubio de la Demanda... ob. cit. 
NEILA.

La villa de Neila se encuentra situada en el extremo oriental de esta comarca de la sierra. Su término municipal queda enclavado en medio de la serie de cumbres, que sirven de tránsito entre la sierra de la Demanda y los picos de Urbión en Soria, conocida como sierra de Neila ${ }^{1410}$. Esta peculiar posición hace que la mayor parte de sus aguas viertan a la cuenca del Ebro, entre cuyos afluentes se encuentra el río Neila, que nace precisamente en el propio casco urbano de esta localidad. Este río cambia de nombre al introducirse en la Comunidad de la Rioja, pasando a llamarse Najerilla.

Según parece, del nombre de este río procede el topónimo que da nombre a esta localidad, pues la primera referencia escrita que encontramos sobre ella, fechada el 1-I1044, aparece nombrada como Fonte de Naila ${ }^{1411}$, pasando poco después, en un documento de 10-V-1062, a utilizar el nombre de Nela ${ }^{1412}$. El origen de esta población, sin embargo, debemos buscarlo en una época algo anterior. Así, los enterramientos descubiertos en el cerro de San Mamés, situado junto al templo de San Miguel, estudiados por el profesor Alberto del Castillo, confirman la existencia de una población perfectamente asentada entre los siglos $\mathrm{X}-\mathrm{XI}^{1413}$. Esto permite, que a finales del siglo XI este núcleo se haya convertido en una población suficientemente consolidada como

\footnotetext{
1410 M. RINCÓN: Andar por las sierras de Urbión, Neila y Cebollera. Madrid, Acción Divulgativa. 1991.

1411 L. SERRANO: Cartulario de San Pedro de Arlanza. Madrid, Centro de Estudios Históricos. 1925. (pag. 86).

1412 Ibídem. (pag. 131).

1413 B. VALDIVIELSO AUSíN: Neila, una llamada al turismo. Burgos, Ayuntamiento de Neila. 1980. (pp. $188-190)$.
} 
950 Arquitectura de la Edad Moderna en la sierra burgalesa.

para levantar una iglesia de unas dimensiones tan destacadas como la que se hizo para su antigua parroquia de San Miguel.

Su proximidad con los núcleos del valle de Valdelaguna, y sobre todo, su coincidencia en el desarrollo de un mismo tipo de economía, como fue la de la ganadería trashumante, hizo que Neila mantuviera siempre una relación bastante estrecha con estos pueblos, aunque nunca formara parte de esta agrupación. De este modo, en un principio, Neila quedó encuadrada dentro del territorio del efímero alfoz de Barbadillo del Pez ${ }^{1414}$, pasando luego a formar parte del alfoz de Lara, una vez que aquel se había vaciado de contenido ${ }^{1415}$. A partir del siglo XII, cuando se extingue el sistema de alfoces, Neila, como casi toda esta comarca de la sierra, queda encuadrada en la Merindad Menor de Santo Domingo de Silos ${ }^{1416}$.

Ya en la Edad Moderna, dentro de la organización fiscal del territorio, esta localidad forma parte, desde el siglo XVI, del partido de las Tierras del Condestable, de la provincia de Burgos ${ }^{1417}$, para pasar más tarde, tras la reforma borbónica del el siglo XVIII, a quedar incluida dentro del partido de Aranda ${ }^{1418}$. Su régimen jurisdiccional también experimentó varios cambios desde la Edad Media. De este modo, a mediados del siglo XIV Neila todavía conservaba su condición de behetría, dependiendo de los señores de Lara y Vizcaya ${ }^{1419}$. El siglo XV lo inicia, sin embargo, como villa de

1414 G. MARTÍNEZ DÍEZ: Pueblos y alfoces burgaleses de la repoblación. Valladolid. Junta de Castillo y León. Consejería de Educación y Cultura. 1997. (pp.196).

1415 I. ÁLVAREZ BORGE: Monarquía feudal y organización territorial: alfoces y merindades en Castilla (siglos $X-X I V$ ). Madrid, CSIC. 1993. (pp. 59).

1416 C. ESTEPA DÍEZ: "Estructura de poder en Castilla (siglos XII - XIII). El poder señorial en las merindades burgalesas. En III Jornadas burgalesas de Historia (3 1991). Burgos en la Plena Edad Media. Burgos, Asociación Provincial de Libreros de Burgos. 1994. (pp. 245 - 294).G. MARTÍNEZ DÍEZ: Libro Becerro de las Behetrías. Estudio y texto crítico. León, Centro de Estudios e Investigación San Isidoro. Caja de Ahorros y Monte de Piedad. Archivo Histórico Diocesano. 1981. (pp. 620).

1417 G. MARTÍNEZ DÍEZ: Génesis histórica de la provincia de Burgos y sus divisiones administrativas. Burgos, Aldecoa. 1983.

1418 Ibídem.

1419 G. MARTÍNEZ DÍEZ: Libro Becerro de las Behetrías... ob. cit. (pp. 620). 
realengo, perdiendo esta condición en 1413, al donar el rey su jurisdicción a la casa de los Fernández de Velasco, futuros condestables de Castilla y Duques de Frías ${ }^{1420}$. En el siglo XVIII, finalmente, vemos que, al igual que había ocurrido con los pueblos de Valdelaguna, Neila logra recuperar su condición de realengo, como bien indica el Catastro del Marqués de Ensenada ${ }^{1421}$, y el censo de Floridablanca ${ }^{1422}$. En el plano eclesiástico, sus dos parroquias dependieron siempre de la diócesis de Burgos, a pesar de los diferentes intentos de la sede oxomense, tras su restauración, cuando los límites se hallaban poco claros, por incorporar estas iglesias a su diócesis ${ }^{1423}$.

Neila tuvo siempre un volumen de población situado por encima de los niveles medios de los pueblos de la zona. No obstante, los datos que poseemos son muy escasos, dejando entre ellos grandes lagunas, que hacen muy difícil establecer una línea evolutiva. En el siglo XVI, según el censo de 1541, existían en Neila un total de 103 vecinos $^{1424}$, cifra que se eleva hasta los 130 , en el censo de los obispos de los años 1584-87 ${ }^{1425}$. El censo de 1591, sin embargo, refleja un brusco descenso, que deja la población de este núcleo reducida a sólo 64 vecinos $^{1426}$, lo cual hace que nos planteemos serias dudas sobre su veracidad. No poseemos ningún dato para el siglo XVII, mientras que el siglo XVIII presenta unos valores muy parecidos a los que hemos visto en la centuria del Quinientos, si obviamos su último censo. Así, el Catastro del Marqués de Ensenada, de mediados de este siglo, nos da un total de 133 ’5 vecinos ${ }^{1427}$, que se convierten, a finales de la centuria, en 609 habitantes, según el censo de

\footnotetext{
${ }^{1420}$ B. VALDIVIELSO AUSÍN: Neila, una llamada al turismo... ob. cit. (pp. 198).

1421 ADPBU. CE - 1184. RESPUESTAS GENERALES. Neila, 12 - julio - 1753.

1422 INE. Censo de 1787. "Floridablanca”. Madrid. INE. 1989.

1423 L. SERRANO: El obispado de Burgos y Castilla primitiva. Desde el siglo V al XIII. Madrid, Centro de Estudios Históricos. 1935. T.I. (pp. 333 - 337; 374 - 378).

1424 AGS. Contaduría General. Leg. 768. (fols. 62).

1425 T. GONZÁLEZ: Censo de población de las provincias y partidos de la Corona de Castilla en el siglo XVI... Ed. Facsímil. Madrid, Imprenta Real. 1829.

1426 Censo de Castilla de 1591. Vecindario. Madrid, Instituto Nacional de Estadística. 1984.

1427 Vecindario de Ensenada 1759. Vol. I. Madrid, Centro de Gestión Catastral y Cooperación Tributaria: Tabapress. D. L. 1991.
} 
Floridablanca $^{1428}$. A través de estos mismos censos, además, descubrimos que un alto porcentaje de esta población disfrutaba de la condición de hidalgo. Así, según los datos del Catastro de Ensenada un 47’5 \% de su población eran hidalgos, porcentaje que desciende hasta el 27 \% según el censo de Floridablanca.

La economía de estos habitantes, como ya hemos referido más arriba, estuvo basada eminentemente en la ganadería trashumante, compuesta por grandes rebaños de ovejas merinas, con las que viajaban anualmente a tierras extremeñas. De este modo, no debe sorprendernos que al neilense se le defina fundamentalmente como pastor ${ }^{1429}$. En esta villa se asentaban algunos de los mayores propietarios de ganados trashumantes de la sierra burgalesa, con hatos de ovejas merinas que superaban, en algunos casos, las 4.000 cabezas, a las que debemos sumar también un buen número de cabras. Pero también existían en Neila otros propietarios más modestos, que poseían pequeños rebaños, con los que trashumaban en compañía de otros propietarios como ellos. Y por supuesto, junto a estos grupos, también aparece un buen número de pastores asalariados, que trabajaban al servicio de los grandes propietarios, a cambio de un jornal ${ }^{1430}$. Esto hacía que prácticamente toda la población de Neila estuviera vinculada, de un modo u otro, a este peculiar modo de vida. Todos estos ganaderos quedaban encuadrados en la Cuadrilla de San Pedro de Vega, junto con el resto de los pueblos del Valle de Valdelaguna y su entorno, formando parte, al mismo tiempo, del Honrado Concejo de la Mesta.

La otra gran riqueza, que atesora esta villa, es su patrimonio forestal, formado por los espesos bosques de pino, que pueblan su término municipal. Sin embargo, esta riqueza no fue explotada durante la Edad Moderna. Bien al contrario, parece que durante este período los pinos fueron vistos como algo molesto, que muchas veces resultaban incómodos para el pasto de los ganados en los meses de verano, cuando regresaban de su periplo extremeño. Neila no descubre las posibilidades que ofrece el

1428 INE. Censo de 1787. “Floridablanca”. Ob. cit.

1429 B. VALDIVIELSO AUSÍN: Neila, una llamada al turismo... ob. cit. (pp. 100). 
aprovechamiento de sus bosques hasta una época relativamente cercana, como es la segunda mitad del siglo XIX ${ }^{1431}$, justo cuando la Mesta había desaparecido, y la trashumancia se hacía cada vez más difícil, al ser abolidos los privilegios que protegían el tránsito de los ganados.

Junto a estas actividades, encontramos también otras fuentes de recursos menos importantes, aunque ciertamente singulares en la zona, como es la extracción de minerales. En concreto, hemos hallado una referencia para la segunda mitad del siglo XVI, en la que se habla de la explotación de un total de siete yacimientos de distintos tipos de minerales, abiertos dentro de este término municipal ${ }^{1432}$.

El núcleo de Neila se asienta en el fondo de un espacioso valle, rodeado por elevadas cumbres, algunas de ellas de más de 2.000 metros de altitud. Este pueblo nos presenta uno de los conjuntos más bellos e interesantes de cuantos podemos ver en toda la comarca de la sierra burgalesa, pues la presencia de los grandes propietarios de ganados se ha plasmado en la construcción de una amplia serie de casas solariegas, de fachadas decoradas con bellos escudos, que llegan a ensombrecer incluso a los propios edificios religiosos. Todas estas construcciones aparecen distribuidas en dos barrios, perfectamente diferenciados, cada uno de ellos presidido por su respectiva iglesia parroquial. De un lado, en la parte más oriental, tenemos el barrio de San Miguel, hoy muy deteriorado y casi deshabitado, pero que en su día fue el núcleo originario del pueblo y su barrio más populoso ${ }^{1433}$. Del otro el de Santa María, en la parte más occidental, el cual constituye en la actualidad el núcleo principal de este pueblo, donde reside la inmensa mayoría de su población. Durante la Edad Moderna, sin embargo, y a tenor de los datos que poseemos, esta diferencia entre sus dos barrios no debía ser tan importante, manteniéndose entre ellos un equilibrio, que solamente se rompe a finales

\footnotetext{
1430 ADPBU. CE - 1184. LIBRO MAYOR DE LO RAÍZ DE SEGLARES. Neila, 12 - julio - 1753.

1431 B. VALDIVIELSO AUSÍN: Neila, una llamada al turismo... ob. cit. (pp.57 - 65; 115 - 116).

1432 AGS. Cámara de Castilla - Diversos. Leg. 8. No 28. Aranda de Duero, 25 - marzo - 1568.

1433 B. VALDIVIELSO AUSÍN: Neila, una llamada al turismo... ob. cit. (pp.39 - 42).
} 
954 Arquitectura de la Edad Moderna en la sierra burgalesa.

del siglo XIX ${ }^{1434}$. Entre uno y otro barrio se extiende un pequeño espacio de huertas y prados, que contribuye a afianzar aun más esta separación. Cada uno de ellos, como decimos, aparece presidido por su respectiva iglesia parroquial, a la cual rodean una serie de viejas casas blasonadas, algunas de ellas bastante deterioradas por el paso del tiempo, o directamente derruidas.

\section{Iglesia de Santa María.}

Esta iglesia de Santa María es actualmente la única iglesia parroquial del pueblo. Se encuentra situada en la parte más baja de la suave ladera, en la que se asienta el barrio al que da nombre. Su fábrica, como la de todos los templos de la zona, es el resultado final de una extensa secuencia constructiva, que concluye en las primeras décadas del siglo XVI. De este modo, durante el resto de la Edad Moderna, este templo sólo conoce diferentes obras de reparación, mantenimiento, o construcción de pequeños añadidos, con los que se completa su estructura principal. El estilo artístico dominante es el gótico, dentro del cual detectamos diferentes fases, que van desde la transición del románico al gótico, hasta la fase final de este estilo, en los inicios del siglo XVI. Aun así, también encontramos algunos restos interesantes del período románico, correspondientes a su fábrica primitiva, y tímidos elementos renacentistas.

Su planta es bastante irregular, fruto de esta agitada historia constructiva. Cuenta con una estructura de tipo caja, de dos naves, articuladas en dos tramos cada una, que se completan en el extremo oriental con sus respectivas capillas, de planta cuadrangular y testero plano. Dentro de estas dos capillas, la del lado del evangelio es algo más profunda, cumpliendo la función de capilla mayor, mientras que la del lado de la epístola, es una capilla privada, mandada construir más tarde por la familia Márquez de Prado. Esta estructura se completa con la sacristía, adosada sobre el muro septentrional de la capilla mayor, la torre, dispuesta en este mismo lado, entre la capilla mayor y el

\footnotetext{
1434 Un buen medio para medir este equilibrio son los registros de diezmos, percibidos por cada una de estas parroquias, los cuales nos manifiestan esta igualdad.
} 
tramo delantero de la nave, y una pequeña capilla lateral, dedicada en la actualidad a Santa Ana, dispuesta a continuación de la torre, a la altura del primer tramo de la nave.

Todo el edificio, independientemente de la etapa constructiva a la que pertenece, se encuentra realizado en piedra de sillería, con bloques de tamaño medio, efectuados en roca arenisca de tonos rojizos, propios de esta zona. Sus muros, de aspecto sólido, están reforzados por fuertes estribos, de forma prismática, en la mayor parte de los casos, que se convierten en cilíndricos en la zona de los pies. Al mismo tiempo, dentro del remate de estos muros, podemos observar en varias zonas, numerosos ejemplos de canecillos de época románica, finamente tallados, que han sido reaprovechados del primitivo templo.

Su imagen exterior queda dominada por el gran prisma, que dibuja el bloque central del edificio, conformado por las naves y capillas de la cabecera, sobre el cual se incorporan, en su flanco septentrional, los módulos correspondientes a la sacristía, la torre y la capilla lateral, aquí adosados. Dentro de todos estos elementos destaca la torre, la cual muestra una esbelta estructura prismática de reducida base cuadrangular, coronada con un sencillo cuerpo de campanas, separado del resto por una cenefa ajedrezada. Sobre los muros de este cuerpo se abren cuatro vanos, orientados a cada uno de los puntos cardinales, coronados con arco de medio punto, que se unen entre sí a través de una moldura corrida de escaso resalte, dispuesta a la altura del salmer. En la parte superior, una cornisa de papo de paloma da paso al tejado, rematado por pináculos de bola en cada una de las esquinas. Se trata de una estructura románica, cuya parte superior fue remodelada posteriormente en el siglo XVIII. Representa, en cualquier caso, el contrapunto vertical dentro de una estructura general de marcado carácter horizontal.

Sobre el flanco meridional, en torno a una de las puertas de entrada, se incorpora un pequeño pórtico, formado por un tejadillo apeado sobre tres columnas de orden toscano, levantadas sobre elevado plinto. Se trata, por lo tanto, de una obra sencilla, en 
956 Arquitectura de la Edad Moderna en la sierra burgalesa.

la que se intenta reproducir la tradición de las galerías porticadas del período románico, bajo la estética, en este caso, del estilo renacentista. La puerta que se abre en su interior, por su parte, presenta una estructura de transición entre el románico y el gótico, formada por tres niveles de arquivoltas, con pesados arcos apuntados de aristas vivas, apeados, a través de una pequeña imposta, sobre columnas colocadas en el derrame de las jambas, coronadas con capiteles ornamentados con motivos vegetales de formas esquematizadas. Una segunda puerta se abre en el muro de los pies de la nave principal, coronada, en este caso, con arco de medio punto sobre gruesas impostas planas. Esta puerta queda enmarcada por un amplio arco de medio punto, marcado por un pequeño rebaje sobre la superficie del muro.

Las ventanas, que iluminan el interior, se reparten entre los muros meridional y de poniente, y presentan en todos los casos un sencillo trazado rectangular con dintel plano. La única excepción la encontramos en la ventana abierta sobre el muro lateral de la capilla privada de los Márquez de Prado. Esta ventana presenta una estructura abocinada de amplio derrame hacia el exterior, coronada con arco de medio punto, enmarcado por una moldura de bocel, mientras que el interior aparece partido por un grueso mainel, que corona con dos pequeños arco de medio punto. A estos vanos debemos unir la ventana abierta sobre el muro del testero de la capilla mayor, la cual sirve para crear, como veremos, un efecto de transparente sobre la imagen de este altar.

En el interior de este edificio nos encontramos con un espacio desdoblado en dos ámbitos claramente diferenciados, que conforman sus dos naves con sus respectivas capillas. La separación entre ambos espacios se establece por medio de una línea de potentes arcos formeros, con arcos apuntados de sección trapezoidal, que descansan sobre un grueso pilar cilíndrico, los de la parte delantera, y sobre un pilar irregular de sección cruciforme, los de la zona de la nave. Estas naves están cubiertas con bóvedas de crucería octopartitas, elevadas a diferente nivel, con una mayor altura para la nave del lado del evangelio, que cumple la función de nave principal. Los arcos fajones, que separan cada uno de estos tramos, en el caso de la nave meridional, están formados por 


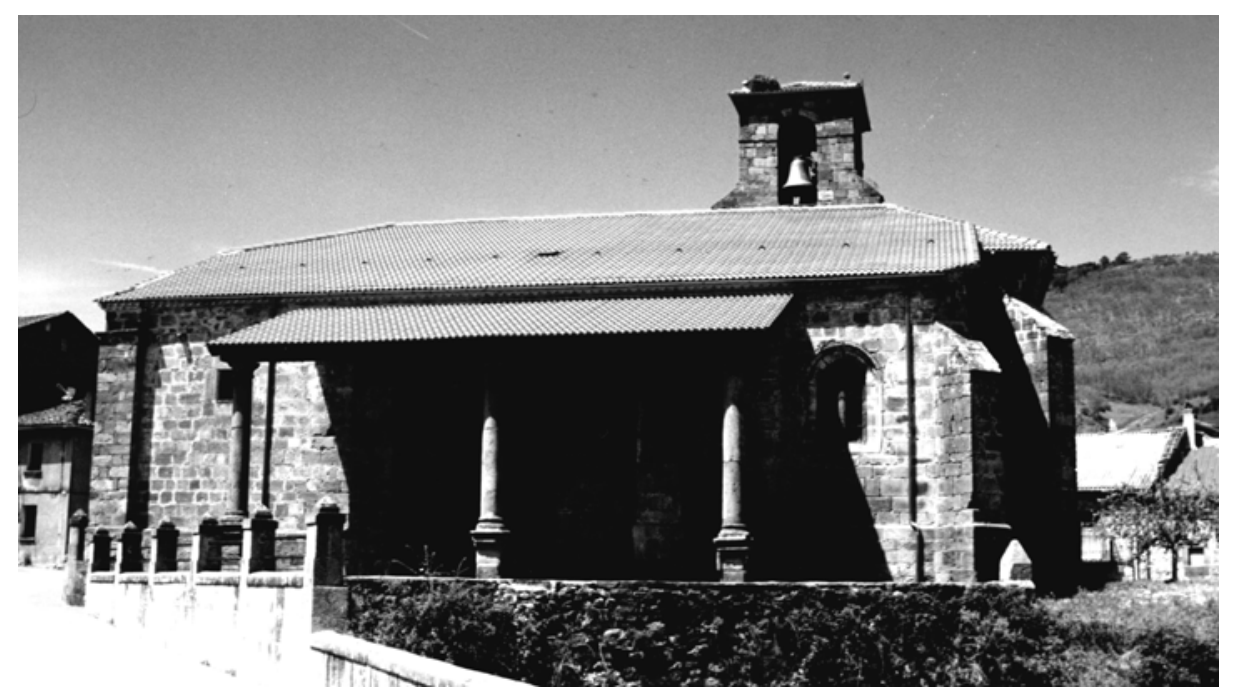

NEILA. Iglesia de Santa María.

pesados arcos apuntados doblados, que terminan desempeñando una auténtica función de arbotantes. Los de la nave principal, sin embargo, son arcos apuntados más finos, que apean sobre columnas entregadas.

En la zona de la cabecera, por su parte, vemos que la capilla mayor se cubre con bóveda de crucería estrellada con terceletes. A su interior se accede a través de un estilizado arco apuntado de rosca moldurada, dispuesto sobre ménsulas decoradas con las representaciones simbólicas de los evangelistas San Mateo y San Juan. La capilla lateral, situada junto a ella, que culmina la nave de la epístola, se cubre con cúpula de media naranja, sobre anillo moldurado y pechinas, con superficie interior decorada con pequeñas fajas planas. El arco apuntado, que comunica estas dos capillas, descansa sobre un sólido pilar cilíndrico, sin capitel ni faja de ningún tipo, que se corresponde, en el muro lateral de esta nave, con un haz de columnas de fuste liso, unidas por un capitel común en forma de faja.

La tercera capilla con la que cuenta este templo, dispuesta en la parte septentrional, a la altura del tramo delantero de la nave, se comunica con el espacio 
958 Arquitectura de la Edad Moderna en la sierra burgalesa.

principal a través de un amplio arco apuntado de sección trapezoidal, mientras que su interior se cubre con bóveda de crucería sexpartita de trazado perlongado, con nervios terceletes en sus lados más cortos. Junto a ella, sobre este mismo muro, aparece una pequeña puerta románica de estructura abocinada, con doble arquivolta de arcos de medio punto, el inferior de arista viva, y el superior de aristas redondeadas y rosca decorada con un relieve ajedrezado. Se trata de la puerta que permitía el acceso a la torre, la cual se encuentra actualmente cegada. A continuación de esta puerta, tenemos el acceso a la sacristía, también con arco de medio punto, e interior cubierto con bóveda de crucería estrellada con terceletes.

Esta imagen interior se completa con un coro alto de madera, dispuesto a los pies, el cual abarca toda la anchura del cuerpo, y los retablos, que decoran los diferentes altares. El de la capilla mayor es obra prechurrigueresca, de finales del siglo XVII, y está presidido por la imagen de la Inmaculada Concepción, acompañada por las tallas de San Pedro y San Pablo a los lados, y Cristo crucificado en el remate. El retablo de la capilla lateral de los Márquez de Prado es una obra rococó de la década de 1770, presidido actualmente por una imagen de la Virgen, y rematado por el escudo de armas de sus patronos ${ }^{1435}$. Por último, el altar de la pequeña capilla del lado del evangelio es una obra ya moderna, de estilo neogótico, con una sola hornacina, ocupada por la imagen de Santa Ana con la Virgen Niña.

La estructura de este templo, como decíamos, constituye el resultado final de una compleja historia constructiva, cuya secuencia queda prácticamente cerrada a comienzos del siglo XVI. Por ello, son muy pocos los elementos que podemos encontrar, correspondientes al período de la Edad Moderna. Los restos más antiguos pertenecen al período románico, entre los cuales destaca, de modo especial, el cuerpo inferior de la torre, y la nave del lado del evangelio, cuyos muros, sin duda, pertenecen a este primitivo templo. A ello debemos unir también, la serie de canecillos

1435 R. J. PAYO HERNANZ: El retablo en Burgos y su comarca durante los siglos XVII y XVIII. Burgos, Excma. Diputación Provincial de Burgos. 1997. (T. II, pp. 512). 


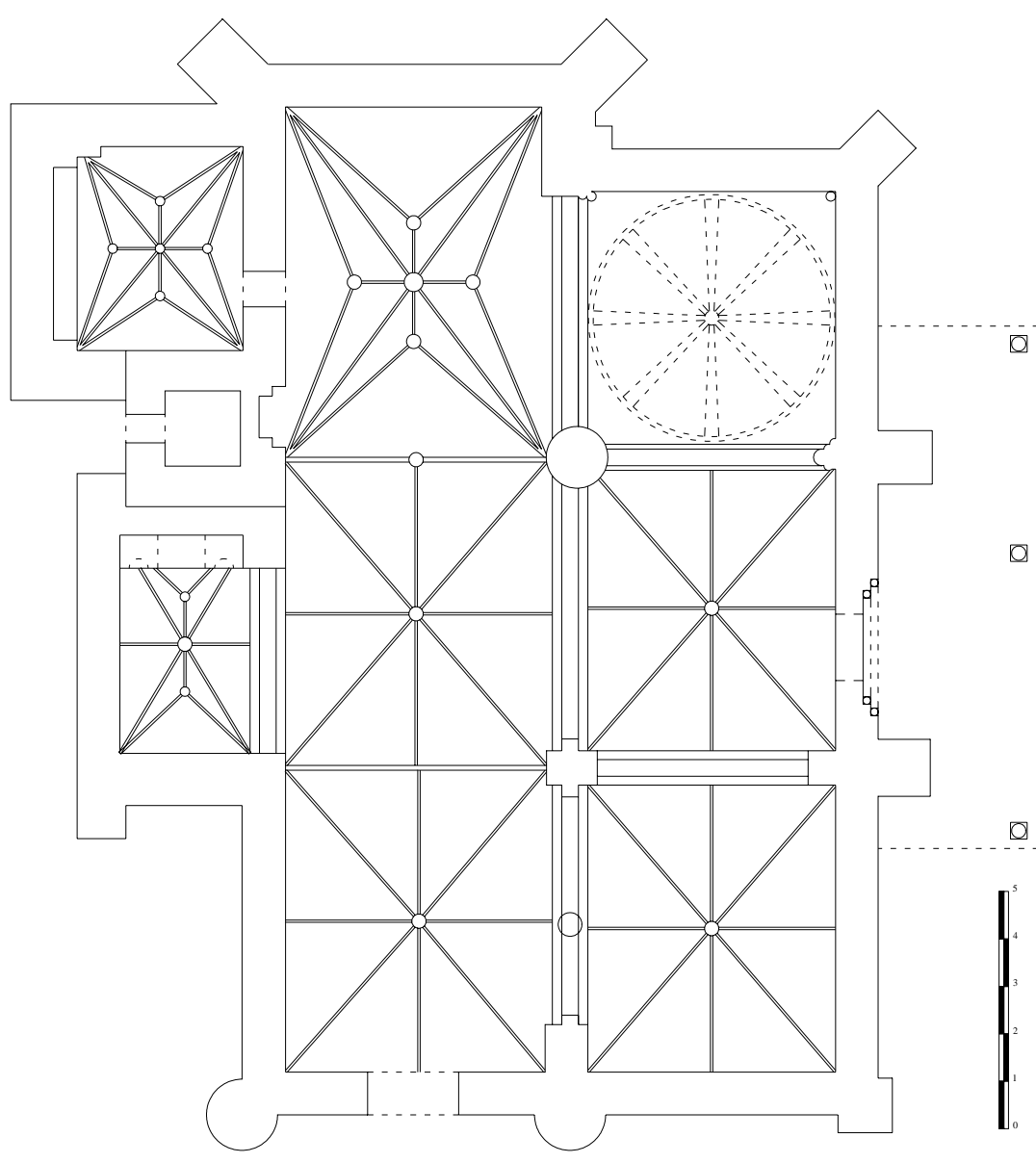

NEILA. Iglesia de Santa María. Planta.

reaprovechados en las remodelaciones posteriores, y la pila bautismal, de copa semiesférica, decorada en su parte exterior por un tupido manto de hojas dispuesta en forma de escamas, y borde recorrido por una cenefa con tallos entrelazados. Todo ello nos indica su pertenencia al período clásico de este estilo románico, situado a mediados del siglo XII.

Posteriormente, en el tránsito entre el siglo XII y XIII, se produce una segunda fase, en la que se amplía el edificio existente, construyendo la nave lateral del lado de la 
epístola. El elemento más destacado, en este caso, lo constituye la portada, levantada sobre su muro meridional, la cual muestra los rasgos propios de la transición entre el estilo románico y el gótico.

Estos trabajos de remodelación se continúan en el siglo XV. Para empezar, se renueva toda la estructura de la cubierta de las naves, donde se incorporan las actuales bóvedas de crucería, que obligan a reforzar los muros laterales con unos sólidos estribos en el exterior. En esta misma centuria pensamos que se construye la capilla lateral del lado del evangelio, si bien, la tosquedad de sus formas nos impide precisar el momento exacto en el que esta obra se lleva a cabo. A ella le sigue la renovación de la cabecera, ya en la transición entre el siglo XV y el XVI. De aquí surge la actual capilla mayor, de formas góticas con bóveda de crucería estrellada con terceletes.

En el siglo XVI se pone punto final a esta secuencia con la incorporación de los últimos añadidos. El más importante de todos ellos lo constituye la construcción de la capilla privada de los Márquez de Prado, dedicada a Santa Ana, en la parte delantera, sobre el flanco meridional de la capilla mayor. Se trata, como ya vimos, de una construcción modesta, realizada con un gran respeto hacia la estructura y proporciones del templo. Apenas tenemos datos, sin embargo, sobre su fundación. La única información precisa, que tenemos a este respecto, procede de una descripción que se realiza sobre ella en 1680, en la cual se habla, entre otras cosas, de su primitivo retablo, sobre cuyo banco aparecía el siguiente texto: ESTE RETABLO MANDARON FACER LA MUY NOBRE SEÑORA MARÍA DE PRADO Y SU HIJO BARTOLOMÉ MÁRQUEZ A HONOR Y REVERENCIA DE NUESTRA SEÑORA SANTA ANA: ACABOSE A 26 DÍAS DEL MES DE JULIO DEL NACIMIENTO DE NUESTRO SALVADOR JESUCRISTO DE MIL QUINIENTOS Y VEINTIDÓS AÑOS ${ }^{1436}$. Con esta información, y a tenor de los rasgos de la propia estructura arquitectónica de la capilla, debemos pensar que su construcción tuvo que realizarse no mucho tiempo antes.

1436 B. VALDIVIELSO AUSíN: Neila, una llamada al turismo... ob. cit. (pp.162 - 163). 
También en este siglo XVI debemos situar la construcción del pórtico, que se extiende sobre la fachada meridional. Se trata, como ya vimos, de una obra sencilla, en la que se manifiestan ya las formas y gustos propios de la arquitectura renacentista.

Las actuaciones, que se realizan a partir de este momento, se centran únicamente en el cuidado y mejora de la estructura heredada, sin intentar, en ningún caso, modificar su composición. La única incorporación de un nuevo elemento, que tenemos a partir de ahora, se produce en la sacristía. Se trata, en cualquier caso, de una obra sencilla, en la que se repite el modelo característico, elaborado en la zona para este tipo de estancias, a partir de mediados del siglo XVII. Presenta así, una estructura de cubo, con sólidos muros de sillería, reforzados en las esquinas con estribos prismáticos, cubriendo su espacio interior con bóveda de crucería estrellada con terceletes. Su construcción debió producirse en torno a los años centrales de la centuria del Seiscientos.

Otra intervención interesante, en este momento, se realiza en la torre, la cual había llegado a presentar, en los primeros años del siglo XVIII, un estado de conservación lamentable, hasta el punto de amenazar ruina. El primer aviso de ello lo da el visitador del Arzobispado de Burgos de 1701, D. Antonio Íñigo de Angulo, el cual declara, además, que el cuerpo de campanas con el que cuenta era insuficiente, para lo cual propone a los responsables de la fábrica su renovación, utilizando para ello los 600 ducados donados años atrás por un feligrés ${ }^{1437}$. Las trazas se encargan poco después ${ }^{1438}$, sin embargo, a pesar de ello el proyecto queda paralizado. Años más tarde, entre las décadas de 1730-40 esta idea se retoma de nuevo, ante el estado de ruina que presentaba toda la estructura de la torre, tal y como declaran los Provisores y Oidores del Arzobispado de Burgos y los maestros, que vinieron con ellos para examinar el templo ${ }^{1439}$. Poco antes, entre los años 1736 -37 la parroquia había puesto en marcha, por

\footnotetext{
1437 AGDBU. LP. Neila, parroquia de Santa María. LF. (1682 - 1747). (fols. 71 - 78 vo ). Visita realizada a la parroquia de Santa María de Neila en 1701, por el visitador del Arzobispado de Burgos, Dr. D. Antonio Íñigo de Angulo. Neila, 5 - octubre - 1701.

1438 Ibídem. Cuentas del año 1701. Neila, 5 - octubre - 1701.

1439 Ibídem. (fols. 202 vº - 205). Cuentas del año 1739. Neila, 7 - octubre - 1740.
} 
su parte, los mecanismos necesarios para iniciar el proyecto de renovación de la torre, comprando parte de los materiales y encargando unas nuevas trazas para la obra ${ }^{1440}$. Sin embargo, en el momento de iniciarse los trabajos, surge un fuerte desacuerdo entre los representantes del Arzobispado y los encargados del templo, pues mientras éstos pretenden construir una torre completamente nueva, aquéllos abogan por una simple, pero efectiva, reparación de la ya existente. Este enfrentamiento de pareceres lleva al consiguiente pleito, que retrasa de forma casi indefinida el inicio del proyecto. Finalmente en 1755 el visitador del Arzobispado, D. Juan de Tobías y Zuazo, indica que:

\begin{abstract}
"Sobre la cuestión de la torre hace notar que las campanas llevan mucho tiempo en el atrio sin poderse colocar por la ruina de la torre, y además una de ellas está rota. Así, manda de los diezmos se tome la cantidad que cubra los gastos de realizar una obra sencilla que sea suficiente para colocar las campanas. En caso de que los vecinos desearan una obra de mayor importancia, como una torre nueva, se realice de la contribución de los propios vecinos. La campana rota deberá ser fundida de nuevo, en lo cual perderá parte de su peso"1441.
\end{abstract}

Este mandato no tuvo, sin embargo, el efecto deseado, pues ni la obra se hizo con las condiciones del Arzobispado, ni los vecinos decidieron implicarse en el proyecto, con la entrega de generosas donaciones. De esta forma, tenemos que llegar hasta el año 1778 para ver cómo, finalmente, se pone en marcha la obra, en la cual se acomete la idea planteada por el Arzobispado, mucho más barata y fácil de realizar. En su construcción la fábrica de esta iglesia tuvo que aportar 5.000 reales $^{1442}$.

\footnotetext{
1440 Ibídem. (fols. 200 v -201 v )Cuentas del año 1736. Neila, 19 - septiembre - 1737; Ibídem. (fols. $202 \mathrm{v}^{\circ}$ ). Cuentas del año 1737. Neila, 10 - septiembre -1738.

1441 Ibídem. LF. (1748 - 1839). (fols. $30 \mathrm{v}^{0}$ - 35 vo). Visita realizada a la parroquia de Santa María de Neila en 1755, por el visitador del Arzobispado de Burgos, D. Juan de Tobía y Zuazo. Canales, 3 - agosto $-1755$.

1442 Ibídem. (fols. 121). Cuentas del año 1778. Neila, 30 - septiembre - 1779.
} 
El resto de las actuaciones, realizadas durante este siglo XVIII, son simples trabajos de mantenimiento, dentro de los cuales, sin embargo, encontramos algunos de cierto interés. Este es el caso de las labores de reparación, que fue necesario realizar, en la capilla privada de la familia Márquez de Prado. A través de ellos, sabemos que lo que había comenzado en el siglo XVI como una muestra de devoción y generosidad por parte de unos devotos feligreses, termina por convertirse en el siglo XVIII en una auténtica incomodidad para los responsables de la parroquia, pues la falta de cuidados había desembocado en un grave deterioro de su estructura, que empezaba a afectar al resto de la fábrica del templo. Desde la década de 1740 en adelante son continuos los mandatos de los visitadores, que reiteran el llamamiento a los patronos para que cumplan con sus obligaciones de cuidar su fundación. Uno de estos mandatos es el dado por D. Francisco López de Angulo en 1740, en el cual se advierte del mal estado de las sepulturas que formaban su enlosado ${ }^{1443}$. Más contundente se muestra D. Diego Escalera en 1744, cuando dice que:

"Y puesto al tiempo que su merced hizo su personal visita de dicha iglesia reconoció que en la capilla de Santa Ana, inclusa en ella, al lado de la epístola, que parece ser del patronato y que oy lego D. Juan José de San Pedro, vecino de la villa de Huercano, en el obispado de Calahorra (...) dicha capilla la que no se halla con la seguridad nezesaria, por no tener más que una rexa de muy poca o ninguna subisitencia, estando ésta por lo mismo expuesta a los peligros que se dexan considerar, ocurriendo al remedio también manda su merced a dicho cura que dentro de quince días siguientes a la publicación de esta visita haga saber a dicho patrono que sin la menor dilación asegure dicha ventana haciendo poner en ella una rexa de hierra fuerte y una vidriera con su red de alambre para la mayor dezencia de dicha capilla, y que la referida iglesia quede resguardada; Y si pasados un mes después de haverle hecho saber este capitulo de el qual le 
964 Arquitectura de la Edad Moderna en la sierra burgalesa.

remitirá copia no cumpliese el mencionado patrono con lo que ba prevenido, se da comisión y facultad a dicho cura para que pase a secuestrar y embargar las rentas y efectos que tuviere en esta dicha villa"1444.

En 1755 el visitador D. Juan de Tobías y Zuazo vuelve a indicar que: "la capilla de Santa Ana necesita una inmediata reparación ante el estado de ruina en el que se encuentra, producido por una gran grieta" ${ }^{\text {"1445 }}$. A ello se une el informe dictado por el Vicario General del Arzobispado de Burgos, D. Antonio de Liña Villarón en 1757, quién avisa a los patronos, que la parroquia de Santa María se apropiará de las rentas con que se dota la capellanía, que la familia Márquez de Prado tiene fundada aquí, dada su falta de interés hacia ella ${ }^{1446}$.

Parece que todos estos llamamientos surtieron su efecto, sin embargo, la situación nunca terminó de aplacarse, pues en 1791 el visitador D. Manuel María debe pedir de nuevo a los responsables de esta parroquia, que se pongan en contacto con $\mathrm{D}$. José Juan de Pablo, para que se haga cargo de las nuevas reparaciones ${ }^{1447}$. Como consecuencia de todos estos mandatos, durante la segunda mitad de este siglo XVIII, se remodela gran parte de la imagen interna de esta capilla, cambiando su cubierta original, de bóveda de crucería estrellada con terceletes, por la actual cúpula de media naranja, e incorporando un nuevo retablo.

\footnotetext{
1443 Ibídem. LF. (1682 - 1747). (fols. 206 v - 217). Visita realizada a la parroquia de Santa María en el año 1740, por el visitador del Arzobispado de Burgos, D. Francisco López Angulo. Canales, 6 noviembre -1740 .

1444 Ibídem. (fols. 223 - 227). Visita realizada a la parroquia de Santa María de Neila en 1744, por el visitador del Arzobispado de Burgos, D. Diego Escalena. Neila, 8 - mayo - 1744.

1445 Ibídem. LF. (1747 - 1839). (fols. $30 \mathrm{v}^{\mathrm{o}}-35$ vo). Visita realizada a la parroquia de Santa María de Neila en el año 1755, por el visitador del Arzobispado de Burgos, D. Juan de Tobías y Zuarzo. Canales, 3 - agosto - 1755.

1446 Ibídem. (fols. 44 - 46). Burgos, 11 - enero - 1757.

1447 Ibídem. (fols. 151 - 161). Visita realizada a la parroquia de Santa María de Neila en 1791, por el visitador del Arzobispado de Burgos, D. Manuel María. Huerta de Arriba, 11 - septiembre - 1791.
} 
Una última obra, que debemos mencionar, dentro de las labores realizadas en esta etapa final de la Edad Moderna, es la construcción del llamado transparente, realizado para la capilla mayor. Se trata de una obra sencilla, que consisten en abrir una simple ventana sobre el muro del testero, a la altura de la hornacina central del retablo del altar mayor, dejando pasar la luz, para crear un efecto de ingravidez sobre la imagen titular del templo. Esta obra fue posible, merced a la donación realizada por D. Francisco Benito y su esposa Dña. Teresa Benito, y se ejecutó hacia el año $1755^{1448}$.

Iglesia de San Miguel Arcángel.

Es la iglesia del segundo de los barrios de Neila, al cual da nombre, cuyo declive llevó finalmente a que perdiera su condición de parroquia. En la actualidad ha sido convertida en ermita. Fue, sin embargo, el primer gran templo con el que contó esta localidad, fundado el año 1087, tal y como explica una inscripción conservada en el interior. Aquella primitiva iglesia fue pronto sustituida por un nuevo templo de trazas románicas, del cual todavía se conserva la parte del ábside y la torre. El resto, sin embargo, corresponde ya a las remodelaciones emprendidas durante el siglo XVII.

Nos encontramos, por lo tanto, ante un templo que combina, de modo armónico, dos épocas y estilos tan lejanos y diversos, como son el románico de principios del siglo XII, y el barroco de corte clasicista, de la segunda mitad del siglo XVII. El resultado de ello nos depara un edificio de una sola nave, de planta rectangular, articulada en dos tramos, que se continúa en su extremo oriental con una cabecera de profundo presbiterio y capilla con testero semicircular, escoltada a los lados, por la torre y la sacristía. Todo el edificio, independientemente de su etapa constructiva, está realizado en piedra, con muros de sillería de mediano tamaño, bien labrados y ensamblados. Solamente la sacristía nos ofrece algunas partes de sillarejo y mampuesto en sus muros, fruto de reparaciones posteriores.

1448 Ibídem. (fols. $30 \mathrm{v}^{\mathrm{o}}-35 \mathrm{v}^{\mathrm{o}}$ ). Visita realizada a la parroquia de Santa María de Neila en el año 1755, por el visitador del Arzobispado de Burgos, D. Juan de Tobías y Zuarzo. Canales, 3 - agosto - 1755. 
En su imagen exterior este templo se presenta con sus dos partes, correspondientes a la nave y la cabecera, perfectamente definidas, al mismo tiempo que se integran dentro de un conjunto compacto y bien proporcionado. Dentro de esta estructura destaca la torre, que presenta una sólida estructura prismática, sobre planta cuadrangular, con recios muros dispuestos en ligero talud, rematados en un perfil almenado, con el que se da paso al tejado. En su parte superior, sobre cada una de sus caras, se abre un vano, rematado con sencillo arco de medio punto, donde se alojan las campanas.

La cabecera, junto a la que se adosa, presenta el característico ábside románico con testero semicircular, dividido en tres paños por columnas entregadas, rematadas por capiteles de tosca escultura, que se unen a la fila de canecillos, que recorre toda la cornisa. En el centro de cada uno de estos paños se abre una pequeña ventana de tipo aspillera, enmarcada por grueso arcos de medio punto, dispuestos sobre columnas rematadas con capiteles, decorados con el mismo tipo de labra que los canecillos de la cornisa. Sobre el flanco meridional de esta cabecera se añade la sacristía, la cual muestra la característica forma cúbica, de los modelos del siglo XVII, reforzada con estribos prismáticos en las esquinas.

La zona del cuerpo, como ya vimos al hablar de la arquitectura religiosa durante el siglo XVII ${ }^{1449}$, presenta una sólida estructura prismática, sobre base rectangular, con cubierta a dos aguas, y muros reforzados por potentes estribos laterales, también con forma de prisma. En la zona de los pies se alza su fachada principal, enmarcada por los potentes estribos laterales, entre los cuales se extiende un frontón triangular con pináculos piramidales con bola en sus vértices, y tímpano decorado con un óculo contorneado. Debajo, sobre el eje central de esta fachada, quedan dispuestas la puerta de entrada y un amplio ventanal. La puerta presenta un arco de medio punto con pilastras a los lados, sobre las que se extiende una airosa cornisa con dos pequeños pináculos

1449 Ver capítulo: Actividad constructiva. Evolución estilística. Siglo XVII. 


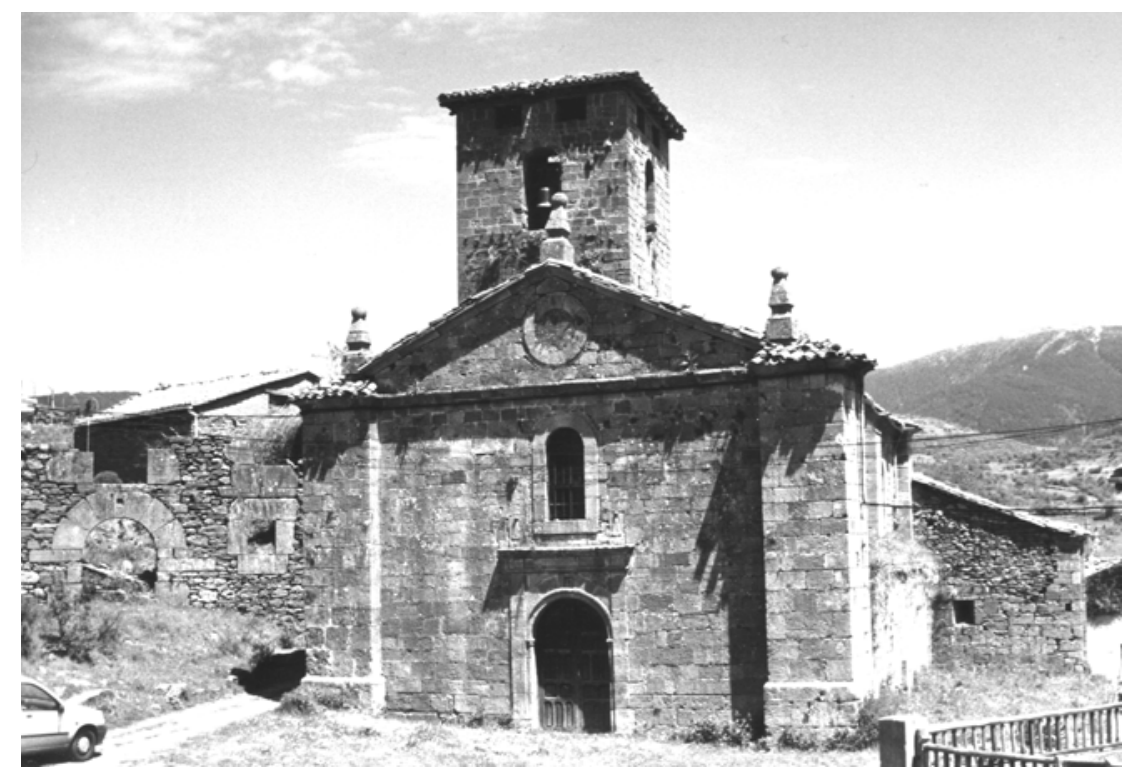

NEILA. Antigua

iglesia de San Miguel.

piramidales con bola en los extremos, dispuestos en correspondencia con las pilastras inferiores. Sobre esta puerta se abre la ventana, la cual está coronada con arco de medio punto y enmarcada por una gruesa moldura plana de escaso resalte. Una fachada, como ya señalamos en su momento, poco habitual en la zona, que debemos relacionar con la influencia del foco lermeño y su arquitectura de corte clasicista.

En el interior nos encontramos con dos espacios claramente diferenciados, como son la nave y la cabecera. La nave, como ya vimos, desarrolla un concepto de ámbito único, articulado en dos tramos, que se cubren con bóveda de crucería cuatripartita, separados por potente arco fajón de medio punto de sección cuadrada, dispuesto sobre sobrias pilastras de fuerte resalte sobre el plano del muro. A los pies incorpora un pequeño coro alto de madera. 
968 Arquitectura de la Edad Moderna en la sierra burgalesa.

En el extremo oriental de esta nave, un arco doblado de medio punto con aristas vivas, apeado sobre columnas entregadas con capitel vegetal muy esquematizado, conduce al interior de la cabecera, compuesta por un presbiterio, cubierto con bóveda de medio cañón, y la capilla mayor, con bóveda de horno o cuarto de esfera. Desde este presbiterio se puede acceder al interior de la torre, a través de una pequeña puerta, compuesta por doble arco de medio punto de aristas vivas. Justo enfrente se abre la puerta, que da entrada a la sacristía, rematada, en este caso, con dintel plano. La capilla mayor se adorna con un retablo de tipo cascarón, de estilo prechurrigueresco, que se adapta a la redondez de la superficie de sus muros, sin imágenes en sus hornacinas.

La historia constructiva de este templo, por lo tanto, queda resumida en las dos etapas, que ya hemos mencionado. Como paso previo, tenemos la ceremonia de la consagración del templo, que se efectúa en 1087, tal y como nos indica la inscripción conservada en un sillar reaprovechado de la primitiva fábrica, que podemos ver sobre uno de los estribos de la nave. En esta inscripción se dice que el promotor de la obra fue el abad Nuño, y el encargado de su ejecución Nuño Sancho ${ }^{1450}$.

Sin embargo, relacionar el actual ábside y la torre de esta iglesia, con este primitivo templo, constituye un grave error ${ }^{1451}$, ya que el análisis formal de su estructura arquitectónica, y muy especialmente de sus elementos escultóricos, nos lleva a una fecha, que difícilmente puede superar una antigüedad anterior a la primera mitad del siglo XII. Así, los elementos escultóricos de este ábside y de la torre, nos hablan de la

1450 “PRIMVM IN NAILA ... FVN/DABIT ECCLESIA(M) ET LABOR A PETRACALE / ABBAS NVNNVEST CVM PROXIMIS SVIS / CVI TITVLVM FECIT MVNIO SANCIO MA/GISTER ISTOS OPERANTES REQVIES / CANT IN PACE D(OMI)NI S(AN)C(T)I MICAELIS / DMV ERA TMCSSV HEC EST DOM(VS) / TE IN NOMORE IN ISTA LABOREM BONVM “. ("Fundó primeramente en Neila (esta) iglesia y construcción de piedra y cal el abad Núñez con los suyos, para el cual hizo la iglesia propia el maestro Nuño Sancho. Estos operarios descansen en la paz del señor San Miguel. En (esta) casa, en la era 1125. Esta casa fue construida por amor a Dios y es buena en su construcción”). B. VALDIVIELSO AUSÍN: Neila, una llamada al turismo... ob. cit. (pp.164). 


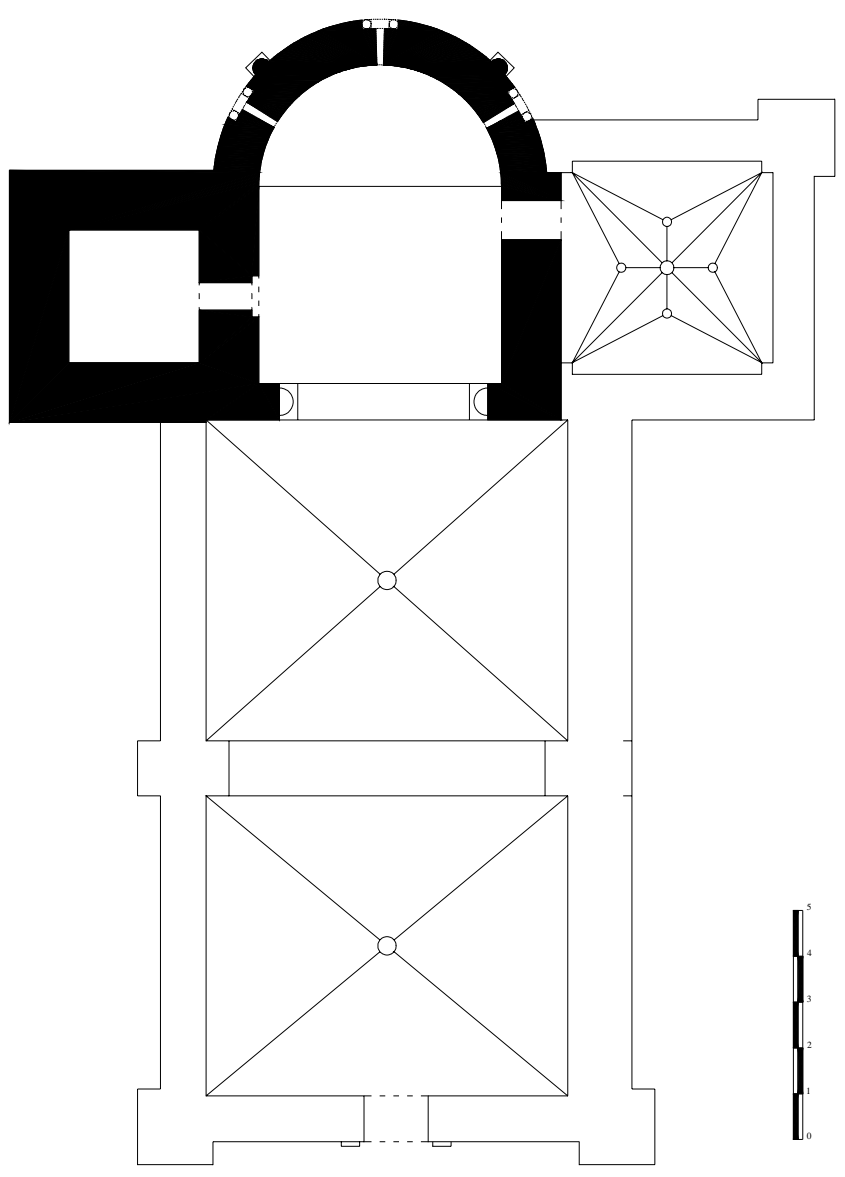

NEILA. Antigua iglesia de San Miguel. Planta.

primera generación de maestros de la escuela del románico de la sierra, donde todavía se muestran evidentes carencias en la definición del espacio plástico, con una composición poco afortunada, disarmónica y un gran respeto por las formas simétricas,

1451 J. RIVERO RADA (coord.), S. ANDRÉS ORDAX: Catálogo Monumental de Castilla y León. Bienes inmuebles declarados. Salamanca, Junta de Castilla y León. Consejería de Cultura y Turísmo. 1995. 
a lo que sumamos una labra dura y angulosa ${ }^{1452}$. Su cronología, como decimos, debe situarse en torno a la primera mitad del siglo XII, lo que hace que el templo construidos por Nuño Sancho tuviera una corta existencia.

La siguiente fase constructiva, que reconocemos dentro la historia de este templo, se produce casi seis siglos después, entre los últimos años del siglo XVII y principios del XVIII. La falta de fuentes documentales, sin embargo, nos impide concretar con mayor precisión esta fecha. Esta fase afectó, como vimos, a toda la zona del cuerpo, eliminando la anterior estructura, para dar lugar a la nave actual. Las formas desarrolladas en ella, como señalamos, son las propias del clasicismo barroco, con una clara influencia del foco lermeño. Es precisamente este hecho el que dota de cierta singularidad a esta obra, pues como sabemos, la influencia de este foco no fue especialmente importante, dentro del territorio burgalés. Por otra parte, estas formas, junto con la simplificación con la que aparecen desarrolladas, son las que nos inclinan a situar su construcción dentro del siglo XVII. Durante esta misma centuria, y no necesariamente dentro del mismo proyecto constructivo, se construye también la sacristía.

\section{Ermitas.}

La villa de Neila fue una de las localidades de esta comarca de la sierra, que contó con un mayor número de ermitas dentro de su término municipal, lo cual constituye uno de los mejores índices indicadores de la intensidad de la religiosidad popular. Si descartamos la antigua iglesia de San Miguel, hoy convertida, como decimos, en ermita, encontramos en este pueblo durante la Edad Moderna no menos de diez ermitas. Esta abundancia, sin embargo, no se vio acompañada de un adecuado cuidado de las mismas, lo que hace, que, a partir de los primeros años del siglo XVIII, se inicie un proceso de destrucción, que acaba con todas ellas en un plazo de poco menos de dos siglos. Ante esto, y dada la falta de restos en la casi totalidad de los casos,

1452 F. PALOMERO ARAGÓN, M. ILARDIA GÁLLEGO: El arte románico burgalés. Un lenguaje medieval actual. Madrid, Lancia. 1995 (pp. 64 - 71); J. SÁINZ SÁIZ: El románico en Burgos. Madrid, 
nuestro trabajo ha consistido fundamentalmente en buscar la localización exacta de cada una de ellas.

Estas diez ermitas estaban dedicadas a Santa Catalina, Santos Mártires (San Cosme y San Damián), Santa Elena y Santa Centola, San Mamés, Santo Cristo, San Andrés, San Lorenzo, San Roque, San Millán y San Narciso. De ellas, tres se hallaban fuera del pueblo, mientras que las siete restantes se repartían, de modo desigual, entre el barrio de Santa María, con dos, y el de San Miguel, con cinco.

En el primer grupo destaca la de Santa Catalina, situada a unos cuatro kilómetros del pueblo, en dirección oeste, sobre un claro del bosque, abierto junto a la carretera que une esta localidad con Huerta de Arriba. De ella, sin embargo, apenas quedan unos escasos restos de piedras y tejas esparcidos por el suelo. Sabemos, no obstante, que en su interior existía una capellanía, fundada en el siglo XVII, por D. Pedro Pérez Ulloa, vecino del pueblo, la cual destinaba anualmente una parte importante de sus recursos en invitar a pan y vino a todos aquellos devotos, que se acercaran hasta aquí el día de su fiesta ${ }^{1453}$. Suponemos que esto debió ser un importante incentivo, pero no el único, para que los vecinos de Neila se animaran a visitar de forma masiva este santuario. Sin embargo, su lejanía del pueblo, y el entorno montuoso que lo rodeaba, como indican los propios visitadores del Arzobispado ${ }^{1454}$, hacían que el resto del año permaneciera prácticamente abandonado. Por ello, desde este mismo siglo XVII, los llamamientos de los visitadores del Arzobispado, para que se atendiera el mantenimiento de esta ermita, comienzan a ser constantes. Uno de los más contundentes fue el dado en 1682 por el visitador D. Juan Saez González, el cual dice que "para remediar semejante indecencia ayo que podrá castigara la justicia y Reximiento desta

Ediciones Lancia. 2001.

1453 AGDBU. LP. Neila, iglesia de Santa María. LF. (1682 - 1747). (fols. 97 vo - 102 vº). Visita realizada a la parroquia de Santa María de Neila en 107, por D. Miguel Francisco Navarrete Ladrón de Guevara, arzobispo de Burgos. Neila, 15 - abril - 1707.

1454 Ibídem. (fols. $8 \mathrm{v}^{\mathrm{o}}$ ). Visita realizada a la parroquia de Santa María de Neila en 1682, por D. Juan Saez González de Valatorre. Neila, 15 - noviembre - 1682. 
villa por cuya cuenta han corrido y corren los reparos de dicha hermita usando de su hacienda y reparandola”1455. A pesar de ello, su deterioro siguió avanzando, hasta que finalmente en 1728 se dice que la ermita está totalmente arruinada, invitando al concejo de Neila y demás personas responsables de su cuidado, a que la reparen, pues según se dice, los materiales de su fábrica todavía permanecían en el lugar ${ }^{1456}$. Pero su reconstrucción no llegó nunca, de tal modo, que esta referencia se convierte en la última noticia que tenemos de ella.

Menos datos tenemos sobre las otras dos ermitas situadas fuera del pueblo, dedicadas a San Millán y San Nicasio. De hecho, los únicos testimonios que poseemos son los proporcionados por los propios vecinos de Neila, los cuales nos han ayudado a situar su emplazamiento exacto. La de San Nicasio se hallaba aproximadamente a un kilómetro del pueblo en dirección sudoeste, mientras que la de San Millán se encontraba en dirección contraria, a una distancia de unos tres kilómetros. Ninguna de ellas, sin embargo, ha dejado restos materiales.

Dentro de las situadas en el propio casco urbano, las que más restos han dejado son las ubicadas en el barrio de Santa María, dedicadas al Santo Cristo y a San Andrés. Ambas se hallaban en el extremo noroeste de dicho barrio, junto a las últimas casas del pueblo. La primera, la del Santo Cristo, ha sido convertida en una vivienda, conservado del primitivo edificio el arco de medio punto de su entrada y parte de su espadaña, coronada por un solo vano. Fue de las últimas en desaparecer, pues todavía aparece citada en el Diccionario de P. MADOZ, de mediados del siglo XIX ${ }^{1457}$. Su presencia, además, ha servido para dar nombre a la plaza que se extiende frente a ella, justo detrás del actual frontón, y a una de las calles más importantes del pueblo. La de San Andrés se hallaba situada a escasos metros de ésta, aunque algo más alejada de las primeras

\footnotetext{
1455 Ibídem.

1456 Ibídem. (fols. 186 - 187). Visita realizada a la parroquia de Santa María de Neila en 1728, por D. Andrés Madrazo Escalera. Canales, 16 - junio - 1728.

1457 P. MADOZ: Diccionario geográfico - estadístico - histórico de España y sus posesiones de Ultramar. Valladolid, Ámbito D.L. 1984. (pp. 391).
} 
NEILA. Ermita de San Andrés. (Restos hacia 1970)

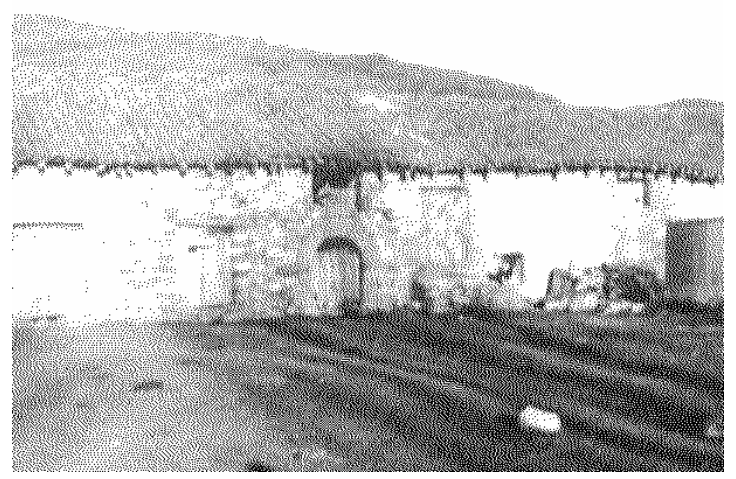

casas. Su desaparición debió producirse en un momento relativamente temprano, pues las últimas referencias, que tenemos, son del año 1726. Esto no evita, sin embargo, que hasta hace pocos años todavía se conservara parte del arco de medio punto de amplio dovelaje, que enmarcaba su puerta de entrada, y algunos tramos de sus muros. A ello pudo contribuir, quizás, una posible reutilización de este templo, con una advocación diferente, pues varias personas del pueblo la conocían como ermita de San Esteban.

Las ermitas situadas en el barrio de San Miguel han corrido peor suerte, pues ninguna de ellas ha dejado restos evidentes de su existencia. Entre ella se encuentra la de San Mamés, ubicada en lo alto del cerro del mismo nombre, que preside todo el barrio. Podría tratarse del primer lugar de culto, que existió en esta villa, antes de que surgieran las dos iglesias parroquiales, pues así parecen indicarlo los enterramientos, fechados entre los siglos X y XI, hallados en su entorno ${ }^{1458}$. La última referencia que tenemos de ella se produce en 1726, lo que nos indica que debió desaparecer poco tiempo después $^{1459}$.

1458 B. VALDIVIELSO AUSÍN: Neila, una llamada al turismo... ob. cit. (pp.188 - 190). 
974 Arquitectura de la Edad Moderna en la sierra burgalesa.

También próxima a la iglesia de San Miguel se encontraba la ermita de Santa Elena y Santa Centola, si bien, en este caso tampoco ha quedado ningún resto de ella. Sus referencias documentales son escasas y siempre confusas, dada esta doble advocación, las cuales prácticamente sólo sirven para dar testimonio de su desaparición. Ésta debió producirse poco después del año 1715, momento en el que se habla ya de su mal estado de conservación ${ }^{1460}$.

No lejos de aquí estaba también la ermita de San Roque, la cual se mantuvo en pie, al menos, hasta mediados del siglo XIX ${ }^{1461}$. Esto no evitó, sin embargo, que tras su desaparición, sus restos fueran eliminados, sin dejar rastro. Por último, debemos citar las ermitas de los Santos Mártires y de San Lorenzo, las cuales nos ha sido imposible localizar su ubicación exacta. La primera desapareció a finales del siglo XVIII, si bien, a lo largo de toda esta centuria fueron constantes los avisos sobre su mal estado de conservación $^{1462}$. La de San Lorenzo desaparece mucho antes, pues su última referencia se produce en 1726.

\section{Arquitectura civil.}

Como ya indicábamos al inicio, la villa de Neila atesora entre sus calles una interesante relación de casas solariegas, que recuerdan su pasado esplendor, como importante centro ganadero, donde se afincaban algunos de los más destacados propietarios de ovejas merinas. Algunas de ellas han sido muy alteradas por las modificaciones posteriores, y otras ha sido víctima del deterioro provocado por el abandono y el inexorable paso del tiempo, si bien, en la mayoría de los casos

\footnotetext{
1459 AGDBU. LP. Neila, parroquia de Santa María. LF. (1682 - 1747). (fols. 175 vo - 180 vo). Visita realizada a la parroquia de Santa María de Neila en 1726, por D. Andrés Fernández de Tejada. Canales, 26 - agosto - 1726 .

${ }^{1460}$ Ibídem. (fols. $130 \mathrm{v}^{0}$ - 135). Visita realizada a la parroquia de Santa María de Neila en 1715, por D. Alonso de Cossio y Becerra. Canales, 22 - junio - 1715.

1461 P. MADOZ: Diccionario... ob. cit. (pp. 391).

1462 AGDBU. LP. Neila, parroquia de Santa María. LF. (1682 - 1747). (fols. 130vº - 135). Visita realizada a la parroquia de Santa María de Neila en 1715, por D. Alonso de Cossio y Becerra. Canales, 22 - junio - 1715; Ibídem. (fols. $175 \mathrm{v}^{0}$ - 180 vo ). Canales, 26 - agosto - 1726.
} 
conservados, permanecen todavía evidentes los rasgos y signos propios de esta tipología de casas, que en su momento relacionamos con la arquitectura culta. Este tipo de construcciones comenzaron a realizarse en Neila durante el siglo XVII, si bien, los ejemplos más notables pertenecen ya al siglo XVIII, coincidiendo con uno de los momentos de máximo auge de esta economía ganadera. Todas ellas, no obstante, responden, en mayor o menor medida, a las características de edificios sólidos de forma prismática, sobre amplia base cuadrangular, articulado en dos pisos, con una distribución regular de los vanos, siguiendo un esquema reticulado. Dentro de su estructura destaca de modo muy especial la fachada principal, donde se abre la puerta de acceso, coronada, regularmente, por un amplio arco de medio punto, al que acompaña, en la mayoría de los casos, el escudo, como signo parlante, que refleja hacia el exterior la prosapia de sus dueños.

Entre los ejemplos que citamos en su momento, para el siglo XVII mencionamos los edificios situado en la calle Real $n^{\circ}$ 30, 66 y 72. Son tres casas en las que su fachada de trazado rectangular, coronada con volado alero, y potente arco de medio punto, de amplio dovelaje, en el centro, se convierten en sus elementos más representativos. A estas casas tenemos que añadir también algunos inmuebles del barrio de San Miguel, si bien, los ejemplos más destacados de esta parte del pueblo se encuentran convertidos ya en una pura ruina.

El siglo XVIII, sin embargo, nos ofrece, como decimos, los ejemplos más destacados y mejor conservados de esta tipología, a través de los cuales, además, podemos hacer un completo recorrido por las familias más poderosas y representativas del vecindario de esta villa. La primera de estas casas es la perteneciente a la prestigiosa familia de los Márquez de Prado, situada en la calle Real entre los $n^{\circ} 34-38$ C. Es un edificio muy alterado por el paso del tiempo y las divisiones introducidas sobre su estructura, sin embargo, todavía podemos apreciar parte de su empaque en su fachada lateral, orientada hacia poniente, y en su fachada principal, dispuesta hacia el mediodía, en la cual se incluye su flamante escudo. 
Otra casa interesante es la de los Márquez, situada en la calle del Cristo $n^{\circ}$ 4-6. De ella destaca, de modo especial, su fachada principal, orientada hacia naciente, la cual, a pesar de las divisiones efectuadas sobre la estructura del edificio, ha conseguido mantener prácticamente intacto su esquema original. Se trata de una fachada, como vimos en su momento, articulada en dos pisos, separados por imposta plana, con la puerta de entrada, coronada con arco de medio punto de rosca casetonada, y un balcón, dispuestos sobre el eje central, y dos sencillas ventanas de dintel plano, a los lados, enmarcadas con moldura plana con orejones. A ambos lados del balcón del piso superior se incorporan los escudos de la familia, ricamente ornamentados, con abundantes elementos exteriores, como suele ser frecuente en muchos casos durante este siglo XVIII en la zona ${ }^{1463}$.

Por último, tenemos que citar también la casa de los Fernández de la Cuesta, situada en el Barrio de San Miguel, en la calle San Roque $n^{\circ}$ 57. Constituye un ejemplo ciertamente impresionante, dadas sus proporciones, en la cual se dibuja una amplia estructura prismática, de planta cuadrangular de más de treinta metros de lado, articulada en dos pisos y cubierta con tejado a cuatro aguas, del cual sobresale un amplio alero. Su elemento más destacado, como ya vimos en su momento, lo constituye su fachada principal, orientada hacia naciente, frente a la cual se abre una pequeña plaza, delimitada por otros edificios pertenecientes al mismo conjunto. En ella sobresale la puerta principal, decorada con un arco de medio punto de rosca casetonada, dispuesto entre pilastras cajeadas, sobre las que se extiende un frontón recto partido, en cuyo tímpano se incorpora el escudo de la familia ${ }^{1464}$.

\footnotetext{
1463 Ver capítulo: Actividad constructiva. Evolución estilística. Siglo XVIII. Arquitectura civil. 1464 Ibídem.
} 


\section{PALACIOS DE LA SIERRA.}

Palacios de la Sierra se encuentra situada en la parte meridional de nuestra zona de estudio, en el inicio de la comarca de pinares, dentro de los terrenos que componen la orla mesozoica, que rodea las sierras de la Demanda y Neila. Su extenso término municipal presenta, por lo tanto, una orografía ciertamente accidentada, con escarpadas laderas, que ascienden prácticamente hasta la cima del cerro de la Campiña, que marca el techo de la Sierra de Neila. Gran parte de este terreno se encuentra poblado por extensos bosques de pinos, donde sus pobladores encuentran una de sus principales fuentes de recursos.

Dentro de este territorio han aparecido restos de algunos despoblados altomedievales, como los de Bañuelos y San Miguel $^{1465}$, y algunas necrópolis pertenecientes a la misma época. Entre estas últimas destaca, de modo especial, la situada en el llamado cerro del Castillo, situado junto al pueblo, sobre una plataforma elevada sobre el cauce del río Arlanza, desde donde se domina una amplia extensión de terreno. En realidad, se trata de la reutilización de un lugar, que ya había sido ocupado en época celtíbera y romana ${ }^{1466}$. Se trata, a juicio de diferentes investigadores del tema, de una de las necrópolis más importantes de este período, excavadas en la península

\footnotetext{
1465 G. MARTínEZ DÍEZ: Pueblos y alfoces burgaleses de la repoblación. Valladolid. Junta de Castillo y León. Consejería de Educación y Cultura. 1997. (pp.177, 189).

1466 E. PASTOR DÍAZ DE GARAYO: Castilla en el tránsito de la Antigüedad al Feudalismo. Poblamiento, poder político y estructura social del Arlanza al Duero. (siglos VII - XI). Valladolid, Junta de Castilla y León. Consejería de Educación y Cultura. 1996. (pp. 33 - 36).
} 
978 Arquitectura de la Edad Moderna en la sierra burgalesa.

Ibérica $^{1467}$. Consta de una iglesia de trazas románicas, de la cual únicamente se conserva la planta, a la que acompañan un grupo de varios cientos de tumbas (434 se hallan excavadas), entre las que predominan, de forma mayoritaria, las de tipo de lajas, con forma rectangular o trapezoidal, cubiertas con losas. Todo este conjunto ha sido fechado entre los siglos XI y XII, si bien, junto a estas tumbas, también aparecen numerosos ejemplos de estelas funerarias, entre las cuales encontramos algunas de época romana y aun anteriores, que han sido reaprovechadas en este momento del que estamos hablando ${ }^{1468}$

El origen de esta localidad de Palacios, por lo tanto, tenemos que buscarlo en la población que originó esta necrópolis, cuyos primeros vestigios podrían remontarse hasta el siglo IX ${ }^{1469}$. Se trataba de una población, que se repartía entre esta zona del cerro del Castillo, y la zona más baja, próxima al río Arlanza, formando dos barrios claramente diferenciados, con sus respectivas iglesias parroquiales. Estos barrios fueron evolucionando, primero con el descenso al llano de los habitantes de la zona alta, lo que debió suceder en torno al siglo XII, para, más tarde, fundirse en un solo núcleo, con un caserío más o menos compacto. Este proceso, que se completa en plena Edad Moderna, culmina con la fusión de las dos parroquias en una sola.

El término Palacios surge, según el P. ARGAIZ, “...por haber en él tres palacios de tres señores antiguamente ${ }^{, 470}$. Ya desde el siglo XIV aparece nombrado como Palaçios de la Sierra ${ }^{1471}$, si bien, en algunas ocasiones podemos encontrar

1467 J. ANDRIO GONZALO: “La Edad Media a través de los estudios arqueológicos”. En Historia de Burgos II. Edad Media (2). Burgos, Caja de Ahorros de Burgos. 1986. (pp. 211 - 212).

1468 Ibídem; A. del CASTILLO: Excavaciones altomedievales en las provincias de Soria, Logroño y Burgos. Madrid, Comisaría General de Excavaciones Arqueológicas. 1972.

1469 Ibídem.

1470 G. ARGAIZ (OBS): La soledad laureada por San Benito y sus hijos en las Iglesias de España y teatro monástico de la provincia... Madrid, Francisco Nieto: a costa de Gabriel de León. 1669.

1471 G. MARTÍNEZ DÍEZ: Libro Becerro de las Behetrías. Estudio y texto crítico. León, Centro de Estudios e Investigación San Isidoro. Caja de Ahorros y Monte de Piedad. Archivo Histórico Diocesano. 1981. (pp. $625-626)$. 
también la denominación Palacios de Santa Olalla, dado que a esta santa estaba dedicada una de sus parroquias ${ }^{1472}$.

Palacios, como la mayor parte de los pueblos de esta comarca de pinares de la provincia de Burgos, formó parte, hasta el siglo XII, del alfoz de Lara ${ }^{1473}$, quedando incluido, más tarde, una vez extinguido el sistema de alfoces, en la Merindad Menor de Santo Domingo de Silos ${ }^{1474}$. Ya durante la Edad Moderna, en el plano fiscal, esta localidad aparece encuadrada dentro del partido de las Tierras del Condestable, de la provincia de Burgos ${ }^{1475}$, para pasar más tarde, en el siglo XVIII, tras la reforma borbónica, a formar parte del partido de Aranda ${ }^{1476}$. En el aspecto jurisdiccional, Palacios dependió, en un primer momento, de Doña Mayor, mujer de Ferrant Sánchez de Velasco ${ }^{1477}$, quedando, a partir del siglo XV, incluido dentro del señorío solariego de los Duques de Frías y Condestables de Castilla ${ }^{1478}$. Al final de la Edad Moderna, sin embargo, Palacios disfruta de la condición de villa de realengo ${ }^{1479}$. En lo que se refiere a cuestiones de orden eclesiástico, las parroquias de Palacios dependieron, desde el Concilio de Burgos de 1136, de la Diócesis de Osma ${ }^{1480}$, lo cual no sufre cambios hasta mediados del siglo XX, cuando se integra dentro de la Archidiócesis de Burgos.

En el aspecto demográfico, Palacios, como ocurre en general en estas localidades de la zona de pinares, contó siempre con unos niveles de población situados

\footnotetext{
1472 G. ARGAIZ (OBS): La soledad laureada por San Benito y sus hijos... ob. cit.

1473 G. MARTÍNEZ DÍEZ: Pueblos y alfoces burgaleses... ob. cit. (pp. 175).

${ }^{1474}$ C. ESTEPA DÍEZ: "Estructura de poder en Castilla (siglos XII - XIII). El poder señorial en las merindades burgalesas. En III Jornadas burgalesas de Historia (3 1991). Burgos en la Plena Edad Media. Burgos, Asociación Provincial de Libreros de Burgos. 1994. (pp. 245 - 294).G. MARTínEZ DÍEZ: Libro Becerro de las Behetrías... ob. cit. (pp. 625 - 626).

1475 G. MARTÍNEZ DÍEZ: Génesis histórica de la provincia de Burgos y sus divisiones administrativas. Burgos, Aldecoa. 1983.

1476 Ibídem.

1477 G. MARTÍNEZ DÍEZ: Libro Becerro de las Behetrías... ob. cit. (pp. 625 - 626).

1478 G. MARTÍNEZ DÍEZ: Génesis histórica de la provincia de Burgos... ob. cit.

${ }^{1479}$ ADPBU. CE - 1278. RESPUESTAS GENERALES. Palacios de la Sierra, 21 - mayo - 1753.
} 
significativamente por encima de los valores medios de los pueblos de esta comarca de la sierra burgalesa. Unos niveles de población, que muestran un crecimiento no muy elevado, pero constante, a lo largo del siglo XVI, el cual se ve truncado a finales de la centuria, dando paso a una ligera crisis, que se mantiene hasta mediados del siglo siguiente. Este descenso se ve compensado durante la primera mitad del siglo XVIII por un fuerte crecimiento, que permite superar, de forma holgada, los valores anteriores del siglo XVI. El dato más antiguo, que tenemos, en este sentido, es el que nos proporciona el censo de 1541, que nos da una población de 138 vecinos $^{1481}$, la cual asciende hasta los 182 vecinos, durante la segunda mitad del siglo, según el censo de los obispos de 1584-87 ${ }^{1482}$. El censo de 1591, sin embargo, rebaja ligeramente esta cantidad hasta los 176 vecinos $^{1483}$, iniciándose así una caída, que se manifiesta en el censo de la sal, de 1631, con 171 vecinos $^{1484}$, y el censo de 1646 , que nos da una cifra de 150 vecinos $^{1485}$. La recuperación de esta crisis se confirma a mediados del siglo XVIII en el vecindario del Catastro del Marqués de Ensenada, donde tenemos un total de 234'5 vecinos ${ }^{1486}$, que se convierten, a finales de siglo, en 691 habitantes, según el censo de Floridablanca $^{1487}$.

La economía de estos habitantes, como la del resto de los pueblos de la zona de pinares, estuvo basada fundamentalmente en el aprovechamiento de sus recursos forestales, y de modo especial, en la carretería. En este sentido, el Catastro del Marqués de Ensenada nos muestra una perfecta imagen del desarrollo de este tipo de actividad en esta localidad, al informarnos de los tipos de carretas que existían, de sus propietarios, y

1480 L. SERRANO: El obispado de Burgos y Castilla primitiva. Desde el siglo V al XIII. Madrid. 1935. T.I. (pp. 333 - 337; $374-378$ ).

1481 AGS. Contaduría General. Leg. 768. (fols.62).

1482 T. GONZÁLEZ: Censo de población de las provincias y partidos de la Corona de Castilla en el siglo XVI... Ed. Facsímil. Madrid, Imprenta Real. 1829.

1483 Censo de Castilla de 1591. Vecindario. Madrid, Instituto Nacional de Estadística. 1984.

1484 AGS. Dirección General del Tesoro, inventario 24. Leg. 1168 - 2.

1485 AGS. Cámara de Castilla - Diversos. Leg. 23, nº 4. (s/f).

1486 Vecindario de Ensenada 1759. Vol. I. Madrid, Centro de Gestión Catastral y Cooperación Tributaria: Tabapress. D. L. 1991. 
de los salarios que se manejaban en cada tipo de trabajo. En Palacios predominaban, como vemos, los llamados carreteros de puerto a puerto, que eran los que realizaban los transportes a larga distancia, agrupando las carretas en conjuntos, denominados cuadrillas $^{1488}$. En cuanto a los propietarios, vemos que existían, desde los grandes propietarios, que poseían varias decenas de carretas, hasta los más humildes, con una o dos carretas, que trabajaban, en la mayoría de los casos, como asalariados de aquellos, incluyendo sus carretas en las cuadrillas del patrón.

El absoluto predominio de esta actividad hace que la agricultura y la ganadería, siempre que no estuvieran vinculados al mundo del transporte, es decir, que no cultivaran pastos, y no criaran bueyes para el tiro de las carretas, fueran poco menos que testimoniales. Sólo existían algunas huertas de hortalizas, en las vegas del río Arlanza, y unos pequeños hatos de ganado lanar y porcino, que complementaban los recursos adquiridos con el dinero obtenido de la carretería.

El núcleo urbano de Palacios forma un conjunto compacto, en el cual resulta muy difícil advertir la separación entre sus dos barrios tradicionales, pues su caserío se extiende entre ambos, sin solución de continuidad. Este caserío se asienta sobre las suaves laderas que conducen hacia el río Arlanza, llegando a ocupar parte de la llanura aluvial inmediata al propio río. En la actualidad, la expansión de este núcleo ha hecho que parte de los nuevos barrios rebasen el propio cauce del río, ocupando la margen derecha, lo que hace que hoy podamos hablar de un pueblo articulado en dos partes claramente diferenciadas, que no se corresponden con los barrios antiguos. Dentro de este núcleo todavía se conservan algunos ejemplos de las tradicionales casas carreteras, pertenecientes, en su mayoría, al siglo XVIII, si bien, los cambios experimentados en esta población, a lo largo de la segunda mitad del siglo XX, han hecho que los edificios modernos acaben con la mayor parte de esos ejemplos de arquitectura tradicional.

\footnotetext{
1487 INE. Censo de 1787. "Floridablanca”. Madrid. INE. 1989.

${ }^{1488}$ Ver capítulo de: Economía.
} 
La historia vivida por esta población, como ya hemos apuntado más arriba, pasa por una primera fase en la que tenemos dos núcleos perfectamente diferenciados, uno en la parte alta del cerro del Castillo, y otro sobre una pequeña colina junto al cauce del río. Con el paso del tiempo, este primer núcleo comienza a despoblarse, al descender sus habitantes hacia el llano, propiciando un acercamiento entre ambos, que terminan por fusionarse durante el siglo XVI. Aun así, hasta las décadas finales de este siglo cada uno de estos núcleos contaba con su propia parroquia, las cuales estaban dedicadas a Santa Eulalia, la del barrio de abajo, y a Santa María, la del barrio del Castillo, que posteriormente es trasladada también al llano. La fusión de ambas parroquias en una sola, efectuada en 1591 por el obispo de Osma, D. Sebastián Pérez ${ }^{1489}$, de algún modo supone la consumación definitiva de este proceso de unión de los dos núcleos.

Esta fusión entre las dos parroquias, sin embargo, no estuvo exenta de complicaciones, pues, al mismo tiempo que la iglesia de Santa Eulalia queda convertida en la sede de la única parroquia, se produce un cambio de advocación, tomando como titular a Santa María, mientras que la santa emeritense pasa a presidir el altar del templo que perdía su condición parroquial. La explicación a esto, tal vez la podamos encontrar en la especial devoción profesada hacia la imagen de Santa María, mientras el templo de Santa Eulalia era el que presentaba unas condiciones más adecuadas para la ubicación de la nueva parroquia unificada. Solamente en el siglo XIX, cuando la antigua iglesia de Santa María (ahora convertida en ermita de Santa Eulalia), desaparece y la imagen de esta santa es trasladada de nuevo a su antiguo templo, esta iglesia de Palacios recobra su antigua denominación. Aun así, la imagen que preside su altar mayor sigue siendo la de Santa María. Nosotros, para evitar confusiones, emplearemos la denominación tradicional, es decir, iglesia de Santa Eulalia, para hablar del templo parroquial, y ermita de Santa Eulalia (antigua parroquia de Santa María), para la iglesia suprimida.

1489 A. M. Palacios de la Sierra. Clasific. 040107. Sig. 4849. Palacios de la Sierra, 9 - diciembre - 1591. 


\section{Iglesia de Santa Eulalia.}

Como hemos visto, desde 1591, queda convertida en la única iglesia parroquial de Palacios, constituyendo, al mismo tiempo, su edificio más representativo. Se encuentra situada en la parte occidental del pueblo, dispuesta sobre un ligero altozano, que se eleva sobre el cauce del río Arlanza. Este montículo queda rodeado, en tres de sus partes, por un sólido muro, el cual, al mismo tiempo que delimita el espacio del atrio, sirve de elemento de contención para garantizar la firmeza del suelo sobre el que se asienta el edificio. Este templo presenta una fábrica realmente compleja, fruto de las numerosas fases constructivas, que han ido marcando su crecimiento. A través de ellas, también se han ido plasmando los rasgos propios de cada uno de los estilos dominantes en cada período. Un edificio, en definitiva, que sintetiza gran parte de la evolución experimentada por la arquitectura de esta comarca de la sierra burgalesa, durante todo el período de la Edad Moderna.

Todo el edificio queda inscrito en un alargado rectángulo, del cual únicamente sobresale la cabecera, dispuesta sobre el extremo oriental, con planta cuadrangular y testero plano. En este cuerpo rectangular, por lo tanto, quedan incluidas, la torre, la sacristía, el baptisterio, y las tres naves que forman el cuerpo, entre las cuales encontramos notables diferencias. La central, más ancha, está articulada en cuatro tramos iguales, con el último de ellos ocupado por el coro. La del lado de la epístola, de menor anchura, cuenta con tres tramos solamente, que se corresponden con los tres tramos delanteros de la central, incorporando a los pies el baptisterio. La del lado del evangelio, por su parte, es mucho más corta, y cuenta sólo con un tramo y medio, pues su desarrollo longitudinal queda interrumpido por la presencia de la torre. Este eje septentrional se prolonga hacia el extremo oriental con la sacristía, dispuesta junto al tramo delantero de la nave central, mientras que en la zona de los pies se completa con una capilla rectangular, dedicada a Nuestra Señora del Rosario.

Los muros, que componen este edificio, son todos de sillería, con piezas de mediano tamaño, dentro de los cuales, sin embargo, encontramos algunas diferencias en 


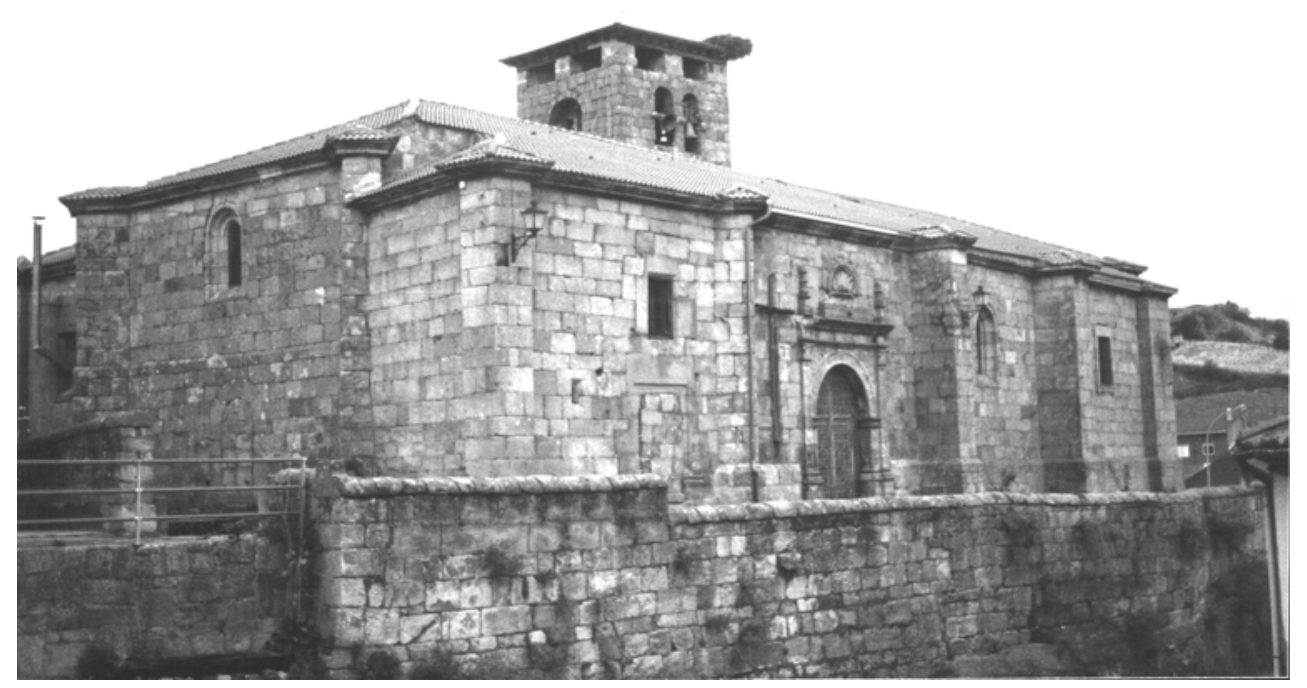

PALACIOS DE LA SIERRA. Iglesia de Santa Eulalia.

el tipo de paramento, que son consecuencia de las diferentes etapas constrictivas. Estas diferencias se manifiestan igualmente en las cornisas, que rematan estos muros, y en los estribos, que sirven de refuerzo. En las cornisas vemos que, mientras la cabecera combina una moldura de cuarto de bocel con un grueso filete, en el resto se emplea este mismo filete acompañado por una moldura de tipo papo de paloma. La zona del baptisterio, por su parte, repite el modelo de la cabecera, al cual añade otro pequeño cuarto de bocel. Los estribos, por su parte, combinan los modelos característicos del gótico y del clasicismo barroco. Los primeros muestran una sección rectangular, con fuerte resalte sobre el plano del muro, adoptando, en el caso de las esquinas, una disposición en diagonal. Los segundos presentan una forma prismática de sección cuadrada y un menor resalte sobre el plano del muro, con una disposición, en el caso de las esquinas, de lados en paralelos a los lados del muro. 
Otro elemento, que muestra las diferencias entre las distintas etapas constructivas, son las ventanas, las cuales se abren a los lados, meridional, de poniente, y sobre el muro del testero. Encontramos aquí tres tipos de ventanas, como son, las de estructura abocinada con arco de medio punto, que vemos en el segundo tramo de la nave $\mathrm{y}$ en el centro del muro de los pies, correspondientes al siglo XVI, las rectangulares con dintel plano y derrame hacia el exterior, que aparecen en el lado del evangelio, del muro de los pies, del siglo XVII, y las rectangulares enmarcadas con moldura plana con orejones, dispuestas en la cabecera y primer tramo de la nave de la epístola, pertenecientes ya al siglo XVIII. Estos vanos se complementan con la puerta de entrada, orientada hacia el mediodía, a la altura del tercer tramo del cuerpo. Se trata de una obra encuadrada dentro del período plateresco, muy ornamentada, con una decoración vegetal muy plana, que cubre la mayor parte de sus elementos. Cuenta con un amplio arco de medio punto, escoltado por pilastras cajeadas, con decoración de flores sobre el fuste y rosca del arco, y jarrones con roleos en las enjutas. Sobre estas pilastras se extiende un entablamento, coronado con una venera en el centro y dos pináculos abalaustrados en los extremos, dispuestos en correspondencia con el eje de las pilastras inferiores. Sus formas, como ya señalamos en su momento, nos permiten relacionarla con las características del primer renacimiento soriano ${ }^{1490}$. A parte de esta puerta, dentro del perímetro del templo encontramos restos de otros dos accesos, actualmente cegados. El primero se localiza sobre el tramo final de esta misma fachada meridional, a la altura del baptisterio, y se trataba de una puerta de dintel plano, enmarcada por una doble moldura de perfil quebrado. La segunda se hallaba en la parte central del muro de los pies, y presentaba un pequeño arco de medio punto de grandes dovelas.

La imagen exterior de este edificio queda dominada por el fuerte carácter horizontal, que impone su escasa altura y la línea uniforme de las cubiertas del gran prisma, que forma su núcleo central. El único elemento que rompe este perfil es la torre, ubicada en la parte septentrional, constituyendo, al mismo tiempo, el único vestigio del

${ }^{1490}$ Ver capítulo: Actividad constructiva. Evolución estilística. Siglo XVI. 
986 Arquitectura de la Edad Moderna en la sierra burgalesa.

primitivo templo románico. Consta de un único cuerpo de muros ligeramente inclinados en forma de talud, rematados con un perfil almenado, sobre cuya parte superior se abren los vanos para las campanas, coronados todos ellos con arco de medio punto, y distribuidos de forma irregular, con dos en la cara meridional, y uno solo en cada una de las tres caras restantes.

En el interior encontramos un evidente dominio del ámbito constituido por la nave central y la capilla mayor, abierta frente a ella, a través de las cuales se establece un claro concepto de espacio camino. A este espacio central se incorporan los diferentes ámbitos, que constituyen las naves laterales y las capillas abiertas a sus pies. En el tramo de los pies de la nave central, por su parte, se levanta el coro, formado por una sencilla construcción de madera, que abarca todo este tramo final.

Todo este espacio interior se halla cubierto con bóvedas de crucería estrelladas con terceletes, con los tramos de la nave central y capilla mayor elevados ligeramente sobre el resto. Este tipo de trama se complica ligeramente en el tramo final de la nave central, que cubre el espacio del coro, donde incorpora una serie de nervios combados, formando una estructura trebolada con conopios en los extremos longitudinales. El espacio del baptisterio, por su parte, utiliza una cúpula ovalada, dispuesta sobre anillo moldurado y pechinas, con decoración de carácter geométrico en su interior.

Esta uniformidad de las cubiertas no se repite en los arcos y soportes, en los cuales se refleja el paso de las diferentes fases constructivas. En los arcos predominan los apuntados de rosca moldurada, característicos de la fase más avanzada del gótico, como vemos en la mayor parte de la nave central. Sin embargo, en varios puntos de las naves laterales, los arcos apuntados muestran un tipo de sección diferente, con intradós cajeado. El otro tipo de arco, que encontramos, es el de medio punto de sección cuadrada e intradós cajeado, que podemos ver en la entrada de la capilla mayor, y en los formeros del tramo delantero de la nave de la epístola, y segundo tramo del lado del evangelio. La utilización de un tipo de arco u otro, en definitiva, se encuentra 
determinado, no sólo por el período en el que se realiza, sino también por las puras necesidades constructivas, al tener que adaptarse a la altura y proporciones de los elementos anteriores.

Mayor variedad encontramos en los soportes, los cuales reflejan de forma más clara los distintos períodos constructivos. La irregular organización de esta planta hace que existan sólo tres pilares exentos, cada uno con sus propias características. El delantero del lado de la epístola presenta una sección cuadrada, con gruesas pilastras de orden toscano y fuste cajeado, adosadas en sus frentes oriental y meridional, un pilar semicircular sin capitel ni basa, en el frente de poniente, y un fino baquetón escoltado por columnas formadas por la prolongación del arco, en la cara interna. El segundo pilar de este lado de la epístola está formado por una sólida estructura cilíndrica sin capitel ni basa, del cual surgen los arcos y nervios directamente. En el lado contrario, a la misma altura que éste, se halla el tercer y último pilar, que queda compuesto por un núcleo de sección cuadrada, con un pilar semicircular en el frente que mira hacia el interior, y pilastras cajeadas en los tres frentes restantes, formadas como mera prolongación de los arcos. Cada uno de estos soportes, a su vez, se corresponde con otros similares en los muros, situados frente a ellos.

Esta imagen interior se completa con los retablos que adornan sus respectivos altares. El retablo del altar mayor es obra de mediados del siglo XVII, y presenta un cuerpo articulado en tres calles, con las imágenes de Santa María en el centro, y Santa Catalina y Santa Eulalia a los lados, un pequeño banco, con pinturas alusivas a la vida de esta última santa, y el remate, con tres nichos ocupados por Cristo crucificado, San Bartolomé y San Pedro. El retablo del Santo Cristo, situado en el muro septentrional de la nave central, es obra clasicista de 1642, y está presidido por una talla de Cristo Crucificado, con la Virgen y San Juan Evangelista detrás sobre lienzo. Fue mandado construir por Juan de Santa Olalla y su mujer, tal y como indica la inscripción recogida sobre uno de los netos. El retablo de Nuestra Señora del Rosario fue realizado en 1644, por donación de Juan de Mancio, familiar del Santo Oficio, y está presidido por la 


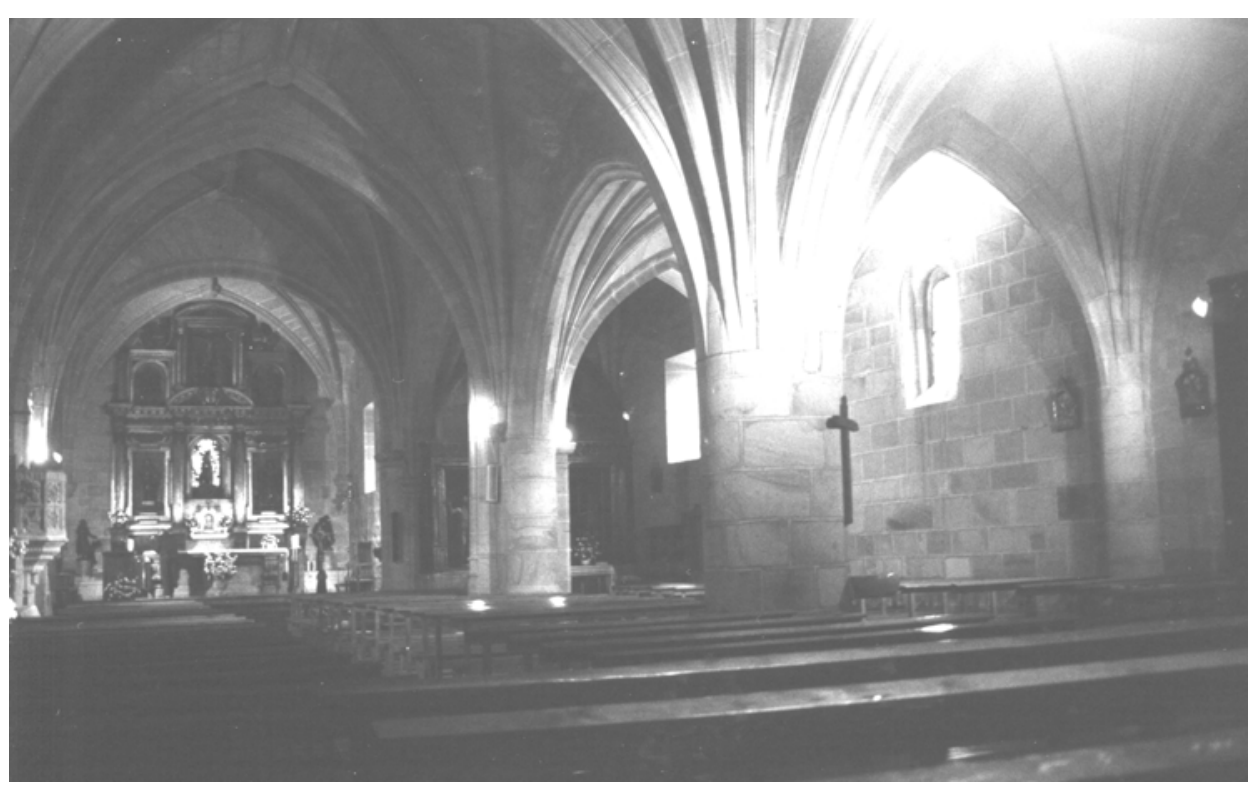

PALACIOS DE LA SIERRA. Iglesia de Santa Eulalia. Vista interior.

imagen de la Virgen del Rosario y San José, con el Niño Jesús en el remate. El retablo de Santa Ana, situado en la nave de la epístola, es obra también clasicista de mediados del siglo XVII, y está presidido por la imagen de Santa Ana con la Virgen Niña, acompañada de la Flagelación y la Resurrección de Cristo a los lados, y la Piedad en el remate. En la nave del evangelio está el retablo de San Bartolomé, obra prechurrigueresca de la década de 1670, que cuenta, en su nicho central, con la imagen de San Bartolomé, acompañado a los lados por San Pedro y San Pablo, y el Salvado en el remate. Por último, en esta misma nave, está el retablo de San Antonio, obra rococó de la década de 1770, presidida por la imagen de San Antonio de Padua en el centro, Santo Domingo y San Ramón No Nato, a los lados, y San Miguel Arcángel en el remate $^{1491}$.

1491 R. J. PAYO HERNANZ: El retablo en Burgos y su comarca durante los siglos XVII y XVIII. Burgos, Excma. Diputación Provincial de Burgos. 1997. (T. II, pp. 512). 
Este templo, como ya señalamos al inicio, constituye el resultado final de una larga secuencia constructiva, la cual, a partir del siglo XVI, se resume en una continua incorporación de nuevos elementos y estancias, que han deparado su imagen definitiva. Este crecimiento se produce siempre en sentido horizontal, y sin destruir los elementos anteriores, lo que permite que podamos reconstruir, con relativa facilidad, el aspecto que presentaba esta fábrica en cada una de las fases, que se producen a partir de esta centuria del Quinientos. Para los períodos anteriores, el único vestigio que tenemos es la torre, la cual, a pesar de las diferentes reparaciones y reconstrucciones sufridas, todavía conserva su aire primitivo, que nos permite situar su construcción entre los años finales del siglo XI y principios del XII. Su estructura muestra un inconfundible aire militar, que la relaciona, salvando las distancias, con algunos ejemplos anteriores de este tipo de arquitectura, como es el caso de la torre de Doña Urraca de Covarrubias, fechada en el siglo $\mathrm{X}$.

Al margen de esto, la estructura del templo actual comenzó a gestarse a finales del siglo XV, momento en el cual se inicia la renovación de la anterior fábrica. Esta renovación se realiza en dos fases consecutivas, separadas por un corto espacio de tiempo, el cual, sin embargo, resultó suficiente para manifestar un cambio formal en la última parte de estos trabajos. El proyecto renovador comienza con la construcción de una nueva cabecera, la cual se asentaba sobre lo que hoy es el tramo delantero de la nave central. De ella sólo se conserva el muro septentrional, el arco toral de entrada, y uno de los contrafuertes del muro del testero, empotrado en los muros de la cabecera que se construye más tarde. Son restos suficientes para saber que esta cabecera presentaba una estructura de planta cuadrangular con testero plano, cubierta con bóveda de crucería, similar a otras piezas de este tipo, levantadas en diferentes templos de la zona, durante este mismo período. Las características del arco de entrada y los soportes sobre los que descansa, nos permiten precisar su fecha de construcción en torno a los últimos años de este siglo XV. 
La segunda parte, con la que se culmina esta renovación, se produce ya durante la década de 1520, y de ella surge, como vimos en su momento, un cuerpo articulado en dos naves, de tres tramos, la situada en el lado septentrional, que arranca como prolongación de la cabecera, y dos tramos la dispuesta sobre su flanco meridional. Es una obra ya del gótico más avanzado, en la cual encontramos todos y cada uno de los rasgos propios de la arquitectura de la zona en este momento. La portada, que remata este proyecto, sin embargo, es obra ya renacentista, del período plateresco.

La actividad constructiva no se reanuda hasta la segunda mitad del siglo XVII, con una nueva fase, que conoce también dos etapas diferentes. Esta nueva fase aporta, como novedad, las formas propias del clasicismo barroco, las cuales, sin embargo, consiguen adaptarse a la estructura existente sin demasiadas dificultades. El objetivo primordial, durante esta fase, es aumentar el espacio disponible en el interior del templo, pues el deterioro del otro templo del pueblo, en el cual, a pesar de haber perdido su condición de parroquia, todavía se continuaban desarrollando los oficios normales, hacía que la práctica totalidad de los habitantes de Palacios acudieran ya de forma habitual a esta iglesia. Para ello, en un primer momento, se decide ampliar el espacio del cuerpo, creando una nueva nave en el lado septentrional. Se trata de la nave del evangelio, la cual se completa en la parte de los pies con un nuevo tramo, que constituye la capilla de Nuestra Señora del Rosario. Esta obra se realiza entre los años 1669-70, y participan en ella los maestros de cantería Martín Garray y Pedro de Arteche ${ }^{1492}$, y los maestros de carpintería Juan y Pedro Jarro ${ }^{1493}$, estos últimos vecinos de esta localidad. Resulta imposible, sin embargo, precisar el precio definitivo que alcanza este proyecto. El desarrollo de esta obra, sin embargo causó serios daños en el resto del templo, pues al desmontar el muro septentrional del cuerpo, para incorporar la nueva nave, gran parte de la estructura del edificio se resintió. Entre las partes más afectadas se encuentra la torre, la capilla mayor y todo el entramado de bóvedas del resto del edificio. Estos

1492 AGDBU. LP. Palacios de la Sierra, parroquia de Santa Eulalia y Santa María. (1653 - 1674). (fols. $188 v^{\circ}$ ). Palacios de la Sierra, 7 - diciembre - 1670.

1493 Ibídem. (fols. 39 - 41). Cuentas del año 1657. Palacios de la Sierra, 20 - marzo - 1658. 
daños fueron subsanados de forma inmediata por los mismos maestros, que habían participado en la construcción de la nueva nave ${ }^{1494}$.

Esta fase constructiva se completa, en los primeros años del siglo XVIII, con la renovación de toda la parte delantera del templo, donde se construye una nueva cabecera, al mismo tiempo, que se amplía el espacio existente. De esta forma, el ámbito que ocupaba la antigua capilla mayor, ahora se convierte en el tramo delantero de la nave central. Este crecimiento afecta también a la nave de la epístola, la cual añade un nuevo tramo en su parte delantera, que pasa a denominarse capilla de San Juan Bautista. La obra se acomete entre los años 1703-1704, con trazas del maestro Baltasar de Pontones ${ }^{1495}$, el cual participa también en las labores de extracción de la piedra empleada en su construcción ${ }^{1496}$. No obstante, los encargados de dirigir estos trabajos fueron los maestros de cantería Francisco de la Torre y Francisco de Pontones ${ }^{1497}$, los cuales concertaron la obra por un precio de 112.786 ’ 5 reales ${ }^{1498}$. Para hacer frente a este elevado presupuesto el visitador del Obispado de Osma de 1706, D. Blas de Tobalina, propuso buscar una fuente de ingresos alternativa a los cauces normales, con la venta de las sepulturas resultantes en las nuevas capillas recién construidas, estableciendo para ello unas tasas de ocho ducados, para las situadas en la capilla mayor, y 6 ducados en los espacios más alejados de este altar ${ }^{1499}$. Esta medida, sin embargo, pronto se vio que resultaba contraproducente, tal y como nos indica el nuevo visitador del año 1710, D. Tomás Manuel García de Aguilar:

\footnotetext{
1494 Ibídem. (fols. 188 vº). Palacios de la Sierra, 7 - diciembre - 1670.

1495 Ibídem. LF. (1673 - 1726) (fols. 184 v - 188). Pagos realizados en 1703: “600 reales son a quenta que se le dieron a Baltasar de Pontones, maestro de cantería, por hacer las condiciones y trazas de planta que han de llevar las dos capillas que se han de hacer en esta iglesia como está mandado por comisión del Tribunal deste Obispado”. Palacios de la Sierra, 7 - abril - 1704.

1496 Ibídem.

1497 Ibídem; (fols. 193). Pagos realizados en 1704. Palacios de la Sierra, 23 - agosto - 1705.

1498 AHPBU. PN. Palacios de la Sierra. Leg. 3232/8, (fols. 1). Antonio Martín Sanz. Palacios de la Sierra, 20 - enero - 1705.

1499 AGDBU. LP. Palacios de la Sierra, Santa Eulalia y Santa María. LF. (1673 - 1726). (fols. 201 205). Visita realizada a la parroquia de Santa María y Santa Eulalia de Palacios de la Sierra en 1706, por D. Blas de Tobalina, canónigo de la catedral de Osma: Palacios de la Sierra, 12 - abril - 1706.
} 
“Que respecto aberse mandado por el doctor D. Blas de Tobalina en la visita del año 1706 con el motivo de aberse fabricado de nuevo la capilla mayor que se pagasen las gradas de las sepulturas el primero a ocho ducados y el segundo a seis, abiendo reconocido su merced su mucha cantidad, que por este medio pierde mucha más la fábrica atendiendo a lo prebenido y ordenado por la Constituzión Sinodal de este obispado en que manda que en bajo de las dotes que se dan a las fábricas de las iglesias por las sepulturas se guarde la costumbre de los pueblos mando su merced que en dicha iglesia se pongan los números y gradas de letra buena y crecida, anotando en la capilla mayor gradas de sacerdotes y de ella abajo cada grada donde correspondiese su número y se pague por el sacerdote que se enterrase en dicha capilla mayor que no fuese cura de dicha iglesia por razón de sepultura ocho ducados” ${ }^{, 1500}$.

El resultado de esta obra nos depara una estructura perfectamente integrada dentro del resto del conjunto del templo, en la que se manifiestan, eso sí, las formas propias del clasicismo barroco, que en estos años iniciales del siglo XVIII, continuaban en pleno vigor dentro de esta comarca. El elemento más interesantes de esta nueva cabecera, sin duda, lo encontramos en la imagen exterior, que proyecta el muro del testero, el cual queda enmarcado por un gran frontón partido, compuesto por los remates de los dos módulos laterales, que forman la capilla de San Juan Bautista y la sacristía. Para que se complete esta imagen, sin embargo, todavía tenemos que esperar unos años, hasta que se produce la renovación de la sacristía. De igual forma, sobre este muro del testero se abre un amplio ventanal, que se hace coincidir con el nicho central del retablo del altar mayor, creando así un efecto de transparente sobre la imagen titular del templo.

El colofón a esta intensa labor constructiva lo ponen la incorporación del baptisterio y la renovación de la sacristía, efectuadas a lo largo de las décadas

\footnotetext{
1500 Ibídem. (s/f). Visita realizada a la parroquia de Santa María y Santa Eulalia de Palacios de la Sierra, en 1710, por D. Tomás Manuel García de Aguilar. Palacios de la Sierra, 27 - mayo - 1710.
} 
siguientes. Sobre la primera de estas obras apenas tenemos datos, pues ni siguiera podemos precisar con exactitud el año en el que se construye. Sabemos, no obstante, que debió edificarse entre 1710-15, participando en su ejecución con toda seguridad el maestro de cantería Francisco de Maeda ${ }^{1501}$. Esta estancia, como vimos, se incorpora a la zona de los pies, como prolongación de la nave de la epístola, cerrando con ella el rectángulo de la planta del cuerpo principal del templo, en esta parte trasera.

La nueva sacristía no se levanta hasta la década de 1730, y su construcción responde a los continuos requerimientos efectuados por los visitadores del obispado de Osma. El primero de estos llamamientos lo realiza en 1728 D. Gaspar de Lamas Montenegro, el cual advierte de las humedades e insalubridad, que presenta la sacristía vieja, aconsejando mudar su emplazamiento ${ }^{1502}$. Más contundente se muestra, dos años más tarde, D. Luis de Alaro, quien dice “““...haver visto su merced la sacristía ser muy corta y humeda y que por este motivo tienen peligro los ornamentos de echarse a perder mando su merced se alargue o aga a nuevo en la parte que más conbenga sea más proporzión por ser como es útil a dicha iglesia y para executarla dio su merced comisión al vicario y cura desta villa" ${ }^{\text {1503 }}$. En estos mismo términos, se expresa en 1732 el nuevo visitador, D. Ventura Gaitero ${ }^{1504}$, hasta que finalmente en 1734 los responsables de esta parroquia deciden acometer la obra. El encargado de su ejecución fue el maestro de cantería, Manuel de la Torre, el cual ajusta la obra en 5.895 reales y 22 maravedís $^{1505}$. La obra resultante es una pieza sencilla, similar a las estancias de este tipo, realizadas en la zona desde la segunda mitad del siglo XVII, con una estructura

1501 Ibídem. Cuentas del año 1715. Palacios de la Sierra, 1716. Cuentas del año 1716. Palacios de la Sierra, 1716.

1502 Ibídem. LF. (1728 - 1770). Visita de 1728 realizada a la parroquia de Santa María y Santa Eulalia de Palacios de la Sierra en 1728, por D. Gaspar Lamas y Montenegro. Palacios de la Sierra, 18 - junio 1728.

1503 Ibídem. Visita realizada a la parroquia de Santa María y Santa Eulalia de Palacios de la Sierra en 1730, por D. Luis de Alaro. Palacios de la Sierra, 1 - junio - 1730.

1504 Ibídem. Visita realizada a la parroquia de Santa María y Santa Eulalia de Palacios de la Sierra en 1732, por Don Ventura Gaitero. Palacios de la Sierra, 21 - octubre - 1732.

1505 Ibídem. Cuentas del año 1734. Palacios de la Sierra, 11 - enero - 1735. 
cúbica, de esquinas reforzadas por estribos prismáticos, y espacio interior cubierto con bóveda de crucería estrellada con terceletes. Con su incorporación, no sólo se cierra, en esta parte delantera, el rectángulo que dibuja el núcleo principal del templo, sino que se completa el frontón partido, que enmarca el testero de la capilla mayor. Dos años después, esta parroquia compra una cajonería para la nueva sacristía ${ }^{1506}$.

Una última obra, que podemos señalar, dentro de la historia de este templo, es la construcción del atrio. Con este proyecto se pretende cubrir la demanda de espacio, destinado a sepultar a los difuntos, pero al mismo tiempo se aprovecha para reforzar la seguridad del suelo sobre el que se asienta el edificio. Las obras se llevan a cabo en dos fases distintas, la primera tiene lugar en 1736, y fue realizada por el maestro de cantería Francisco de Arche ${ }^{1507}$, y la segunda en 1745, bajo la dirección del maestro Manuel de la Torre ${ }^{1508}$.

1506 Ibídem. Cuentas del año 1736. Palacios de la Sierra, 7 - marzo - 1737.

1507 Ibídem. 

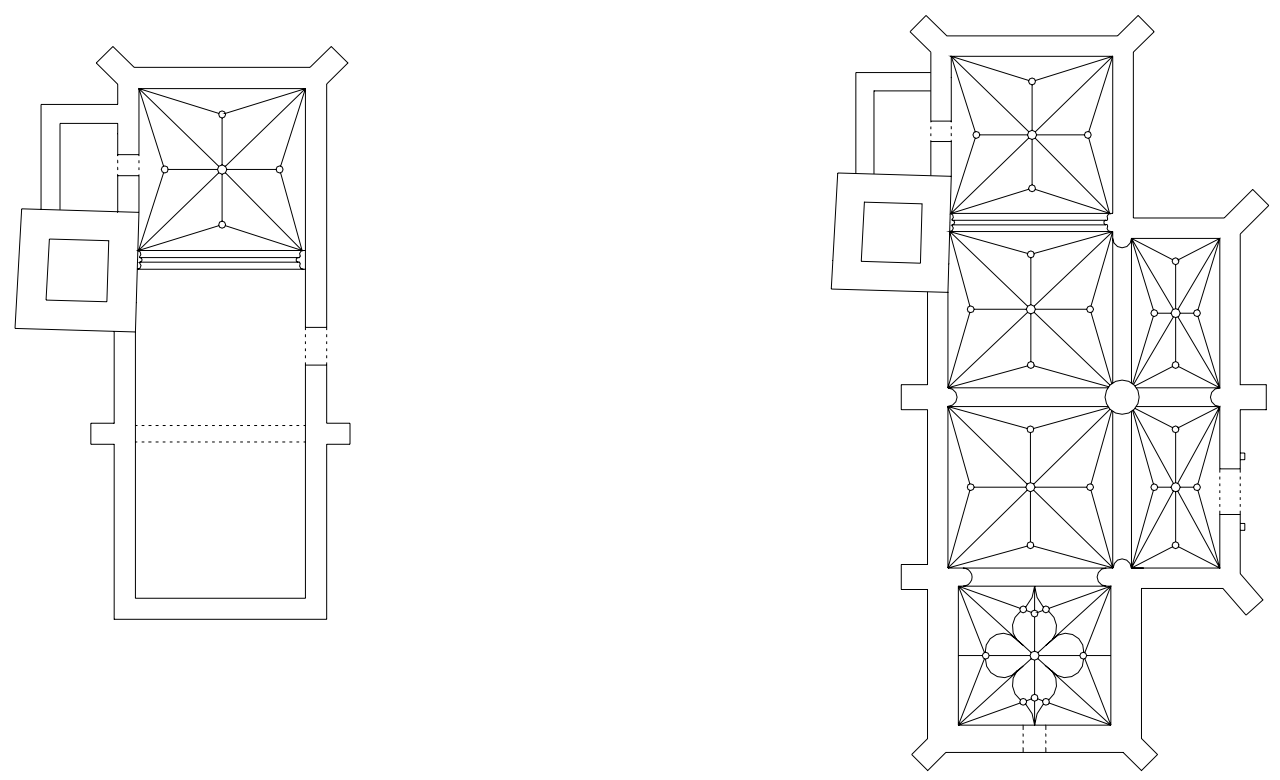

a)

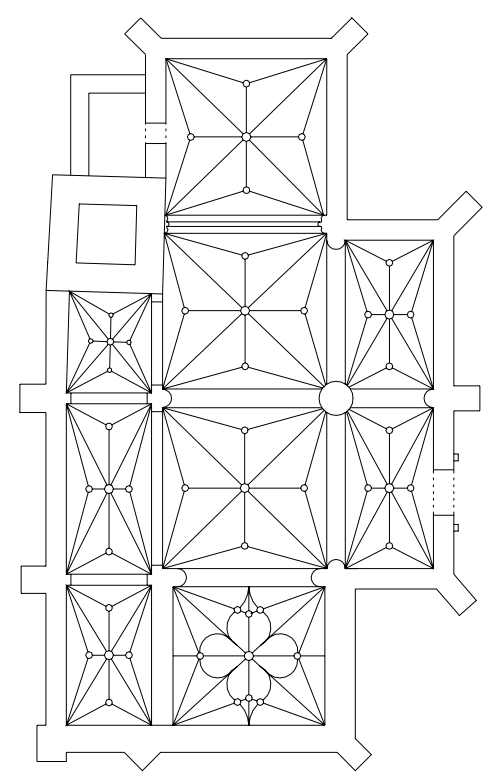

c) b)

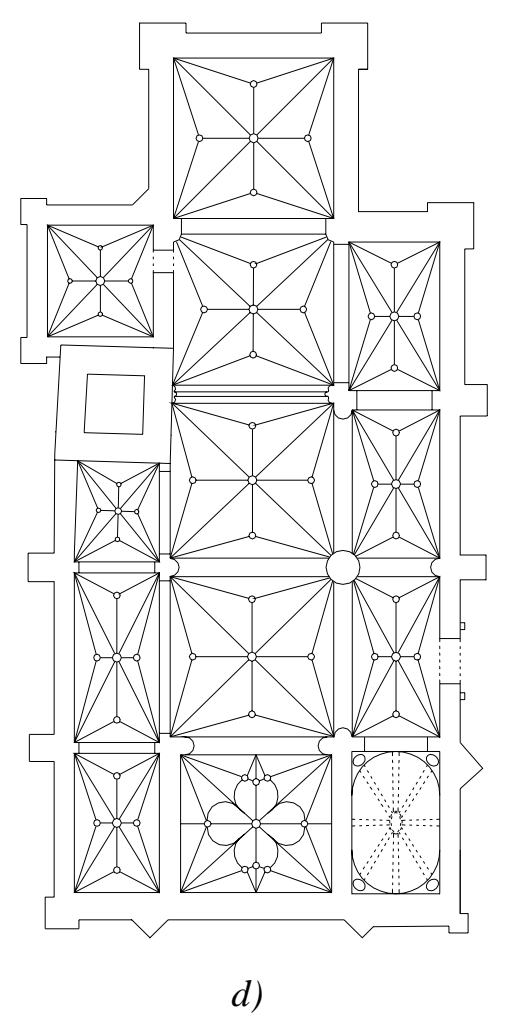

Iglesia de Santa Eulalia: a) y b).Fase constructiva entre siglos XV-XVI; c) Planta a finales del siglo XVII; d) Planta definitiva a mediados del siglo XVIII.

1508 Ibídem. Cuentas del año 1745. Palacios de la Sierra, 27 - febrero - 1746. 
996 Arquitectura de la Edad Moderna en la sierra burgalesa.

Ermita de Santa Eulalia (antigua iglesia de Santa María).

Fue, como hemos dicho, la iglesia de la otra parroquia del pueblo. Se encontraba situada en la parte central del actual casco urbano de Palacios, junto a la plaza mayor, en el espacio que ocupa hoy el edificio del ayuntamiento. Su origen, sin duda, se encuentra vinculado a la antigua parroquia, que existía en el cerro del Castillo, la cual, ante el traslado masivo de sus feligreses a la zona del valle, se vio obligada a construir un nuevo templo, mientras que el anterior quedaba abandonado. En el año 1591, como hemos visto, pierde su condición de parroquia, quedando convertida en simple ermita o vicariato dependiente de la única iglesia parroquial, como indica la propia documentación parroquial, al mismo tiempo que cambiaba su titular.

A partir de aquí, se inicia un proceso de decadencia, que marca su historia durante el resto de la Edad Moderna. Un signo evidente de este declive lo tenemos en 1659, cuando el visitador del Obispado de Osma manda que: “desagan la torre de la iglesia vieja de Santa María (actual ermita de Santa Eulalia) asta igualarla con el tejado de dicha iglesia y en esta forma se le ponga tejado de manera que se coxan las aguas como se coxen los de la dicha iglesia, y la piedra que resultare de ella se venda a los que más dieren por ella y con lo que resultare se adereze la dicha iglesia y lo que sobrere sea para los gastos y conservación della lo qual agan los curas todo con quenta y razón para que en todo tiempo conste el recibo y gasto y (...) de quenta a los señores obispo o sus bisitadores de la visita"1509.

Medio siglo más tarde, esta situación de desamparo había conducido a un estado de deterioro del edificio, que afectaba a la mayor parte de su estructura. Así lo indica en 1710 el visitador del Obispado de Osma, D. Tomás Manuel García de Aguilar en su informe, donde dice lo siguiente: “Que por quanto la iglesia de Santa Olalla, que fue parroquia primitiva desta dicha villa, está arruinándose en atenzión a que en ella hay muchos cuerpos de difuntos y que los frutos y rentas que la pertenezían están

\footnotetext{
1509 Ibídem. LF. (1653 - 1674). Visita realizada a la parroquia de Santa María y Santa Eulalia de Palacios de la Sierra en 1659. Palacios de la Sierra, 14 - mayo - 1659.
} 
yncorporados en esta dicha iglesia (se refiere a la actual iglesia parroquial), mando su merced que por quenta de las rentas de ella se repare dicha iglesia de Santa Olalla, poniendo dichos curas en la consideración de dichos bezinos concurran con algunas limosnas en atenzión a estar sepultados en ellas sus ascendientes”"1510.

Resulta imposible cuantificar la ayuda prestada por los vecinos y antiguos feligreses de esta parroquia, si bien, sabemos que las cantidades aportadas por la iglesia parroquial del pueblo alcanzaron los 2.000 reales $^{1511}$. Las labores que ahora se emprenden debieron centrarse en reparar aquellas partes más dañadas, o que amenazaban de forma directa la estabilidad del edificio. Sin embargo, estos trabajos constituyeron un simple bálsamo, con el que enjugar las heridas más profundas, y prolongar así la vida del templo, pues la sentencia de muerta, a juicio de este último visitador, se había dictado el mismo día que perdió su condición de templo parroquial, y con ella sus recursos ${ }^{1512}$.

Aun así, consiguió prolongar su vida durante todo el resto del siglo XVIII. En cualquier caso, en la visita efectuada en 1816 por el propio obispo de Osma, D. Juan de Cavía, se indica que "no se pudo visitar la ermita de Santa Olalla por estar arruinada”1513. Trece años después, ya no hay ningún tipo de mención sobre ella ${ }^{1514}$.

La construcción, a mediados del siglo XX, del actual edificio del ayuntamiento en el mismo solar en el que se encontraba este templo, acabó con los últimos restos que

\footnotetext{
${ }^{1510}$ Ibídem. LF. (1674 - 1726). Visita realizada a la parroquia de Santa María y Santa Eulalia de Palacios de la Sierra en 1710, por D. Tomás Manuel García de Aguilar. Palacios de la Sierra, 27 - mayo - 1710.

1511 Ibídem. Pagos registrados en 1711. Palacios de la Sierra 1711; Ibídem. Pagos registrados entre los años 1713 - 1713. Palacios de la Sierra, 1713.

1512 Ibídem. Palacios de la Sierra, 27 - mayo - 1710.

1513 Ibídem. LF. (1783 - 1815). Visita realizada a la parroquia de Santa María y Santa Eulalia de Palacios de la Sierra en 1816, por D. Juan de Cavía, obispo del Burgo de Osma. Palacios de la Sierra, 3 - mayo 1816.
} 
quedaban, los cuales, en opinión de los más viejos del lugar, que fueron testigos presenciales de su desaparición, tampoco eran muy importantes. En cualquier caso, debemos pensar que se trataba de un edificio de modestas proporciones, lo cual hizo que, a finales del siglo XVI, fuera descartado como sede de la parroquia reunificada de este pueblo.

\section{Ermitas.}

Además de esta antigua iglesia de Santa María, Palacios de la Sierra contó con otras ocho ermitas más, repartidas por su término municipal, a las que podemos sumar la de Nuestra Señora de la Paz, cuyo patronato compartía el concejo de esta localidad con la vecina de Moncalvillo ${ }^{1515}$. Estas ermitas estaban dedicadas a Nuestra Señora del Arroyal, San Andrés, San Felipe, San Justo y San Pastor, San Miguel, San Sebastián, Santa Ana y Santo Cristo de Zalamea. De ellas, sólo las dos primeras han conseguido sobrevivir hasta nuestros días.

La de Nuestra Señora del Arroyal fue la más importante de todas, y uno de los más destacados santuarios marianos de esta comarca de pinares, hasta el punto de ser considerada una de las tradicionales Cuatro capitanas de la Cabaña Real de Carreteros, junto con las ermitas de Nuestra Señora del Carrascal, en Canicosa, Nuestra Señora de la Guía, en Quintanar de la Sierra, y Nuestra Señora del Torrejón, en Vilviestre del Pinar. Fruto de esta devoción, la ermita y la cofradía del mismo nombre aquí fundada, consiguieron acumular un importante patrimonio, en el que no faltaban fincas, prados y algunos hatos de ganado ${ }^{1516}$. Todo ello procedente de las generosas donaciones hechas por los fieles, tal y como nos indican sus libros de fábrica.

\footnotetext{
1514 Ibídem. LF. (1815 - ). Visita realizada a la parroquia de Santa María y Santa Eulalia de Palacios de la Sierra en 1829, por D. Juan de Cavía, obispo del Burgo de Osma. Palacios de la Sierra, 22 - septiembre 1829.

1515 Ver capítulo: Moncalvillo.

1516 AGDBU. LP. Palacios de la Sierra, Ermita de Nuestra Señora del Arroyal. LF. (1657 - 1781). (fols. 34 - 38). Palacios de la Sierra, 12 - marzo - 1674.
} 
La ermita se encuentra situada en medio del monte, a varios kilómetros del pueblo, en dirección sudoeste. Su origen, según los testimonios del P. ARGAIZ, podría estar vinculado a la presencia en la zona de una primitiva comunidad de monjes benedictinos $^{1517}$, si bien, no existen pruebas documentales de ello. El edificio actual, sin embargo, es una obra relativamente reciente, pues la mayor parte de su estructura fue realizada durante el tercer cuarto del siglo XVII. Como resultado de ello tenemos una ermita de una sola nave, de planta rectangular muy alargada, que se completa en el extremo oriental con una cabecera algo más estrecha, formada por una capilla mayor cuadrangular de testero plano, y una estancia de similares características, dispuesta a continuación de ella, sobre el muro del testero. Este conjunto se completa con la llamada “casa del ermitaño”, donde residía el encargado de cuidar de los bienes del santuario, la cual estaba formada por una sencilla casa de planta rectangular, adosada sobre el flanco meridional del templo, a la altura de la nave, formando con ella un pequeño compás.

El edificio de la ermita se levanta sobre un elevado zócalo de piedra de sillería, con muros de sillería en la cabecera y mampuesto y sillarejo en el resto, que rematan con moldura de papo de paloma, que forma la cornisa. En su imagen exterior, como ya vimos en su momento, el elemento más destacado lo encontramos en la puerta de entrada $^{1518}$, abierta sobre el muro meridional de la nave. Consta de un amplio vano adintelado, escoltado por pilastras cajeadas, entre las que se extiende un entablamento perfectamente formado, que da paso a un frontón recto partido, con una cruz en su vértice superior, y pináculos piramidales en los laterales, situados en correspondencia con el eje de las pilastras. En el tímpano de este frontón se abre una pequeña hornacina avenerada, que acoge la imagen de la titular del templo. Sobre ella, en la base de la cruz que remata este conjunto, aparece una pequeña inscripción con las siglas de JESÚS y MARÍA, y el año 1665, correspondiente a la construcción de esta portada, con la que se remataron las obras de remodelación del templo.

1517 G. ARGAIZ (OBS): La soledad laureada por San Benito y sus hijos... ob. cit.; J. MANRIQUE: Palacios de la Sierra. Burgos. 1996. (pp. 106 - 107). 


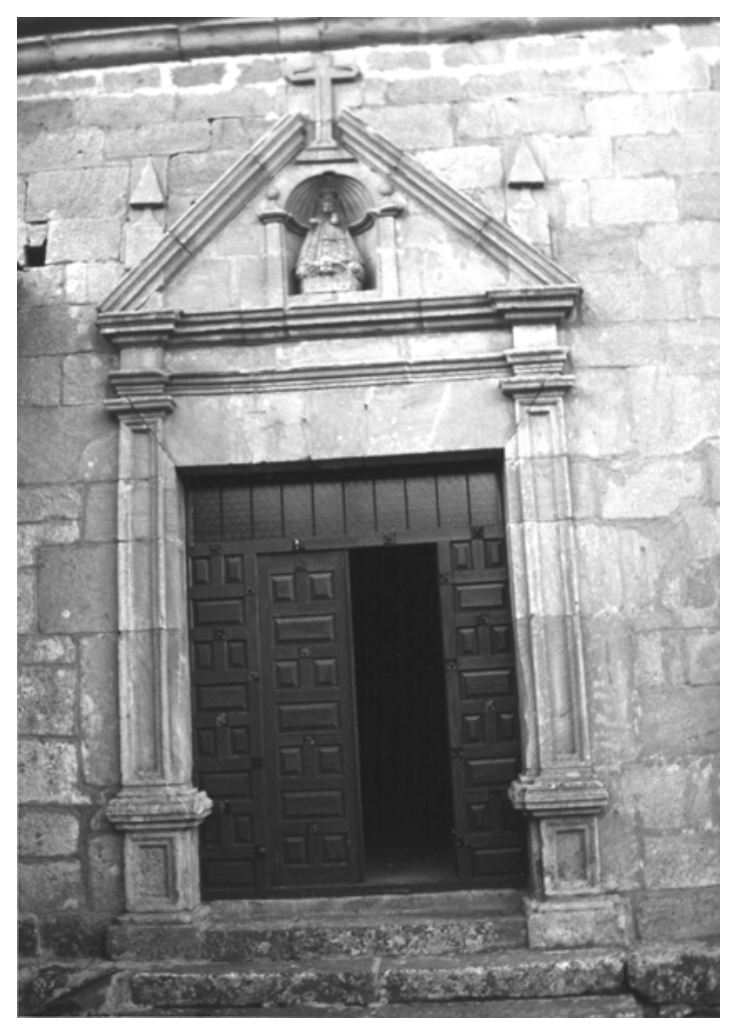

PALACIOS DE LA SIERRA. Ermita de Nuestra Señora del Arroyal. Portada.

En el interior, nos encontramos con un concepto de espacio camino, trazado en torno al eje de su única nave. Esta nave cuenta con un pequeño coro alto a los pies, elaborada en madera, y cubre su espacio con techumbre a cuatro aguas, dispuesta sobre armadura de tipo parhilera. En su extremo oriental, un amplio arco de medio punto de intradós cajeado, dispuesto sobre pilastras también cajeadas, de orden seudotoscano, conduce al interior de la capilla mayor. Este ámbito se cubre con bóveda de crucería estrellada con terceletes, que arrancan de pequeñas ménsulas dispuestas en las esquinas. Desde esta capilla mayor, a través de una pequeña puerta practicada en uno de los laterales del muro del testero, se accede al llamado camarín, el cual está formado por una pequeña estancia, bien iluminada con amplio ventanal abierto sobre el testero, que

1518 Ver capítulo: Actividad constructiva. Evolución estilística. Siglo XVII. 
se cubre con bóveda de crucería cuatripartita. Se trata de un pequeño cuarto que desempeña las funciones de sacristía, cuya principal particularidad se encuentra en el vano que comunica con el nicho central del retablo del altar mayor, a través del cual penetra la luz, para crear un efecto de transparente sobre la imagen titular del templo.

La estructura principal de este edificio corresponde, como hemos dicho, a la segunda mitad del siglo XVII, si bien, su construcción se realiza en diferentes fases. La primera tiene lugar en1657, coincidiendo con el período en el que Francisco Gil ejerce como mayordomo de la ermita, y en ella se lleva a cabo la construcción de la capilla mayor. El encargado de su ejecución fue el maestro de cantería Clemente de Hermosa, el cual ajusta la obra en 170.000 maravedís, que fueron religiosamente pagados por este mayordomo ${ }^{1519}$. La tasación, que daba por bueno este trabajo, fue realizada en este mismo momento por el maestro de cantería, también trasmerano, Juan de Caabra ${ }^{1520}$.

En la segunda parte de esta renovación se acomete la construcción de la actual nave, la cual culmina con la construcción de su portada, realizada, como hemos visto, en 1665. La iniciativa de esta obra parte, en esta ocasión, del visitador del obispado de Osma en 1664, D. Francisco Berdeces y Tamayo, el cual ordena al nuevo mayordomo, Pedro Llorente, que con la mayor premura busque los artífices necesarios que finalicen el proyecto de renovación del templo ${ }^{1521}$. La obra fue encargada al maestro de cantería Juan de Villael Riego, vecino de Pameses en la montaña de la Junta de Cudeyo, el cual ajustó su trabajo en 330 ducados $^{1522}$. De la parte de carpintería se encargaron los maestros locales Juan y Pedro Jarro, por un precio de 1.450 reales $^{1523}$. Los pagos a uno

\footnotetext{
1519 AGDBU. LP. Palacios de la Sierra, Ermita de Nuestra Señora del Arroyal. LF. (1657 - 1781). (fols 20 - 24). Palacios de la Sierra, 28 - septiembre - 1664.

1520 Ibídem.

1521 Ibídem. Visita realizada a la ermita de Nuestra Señora del Arroyal de Palacios de la Sierra en 1664, por D. Francisco Beideces y Tamayo. Palacios de la Sierra, 10 - octubre - 1664.

1522 Ibídem. Palacios de la Sierra, 31 - diciembre - 1664.

1523 Ibídem. (fols. 30 vo - 31). Palacios de la Sierra, 26 - septiembre - 1666.
} 
y otro se realizaron en los años sucesivos, añadiendo a las cantidades fijadas, en el caso de la obra de cantería, otros 200 reales más en concepto de mejora ${ }^{1524}$.

Esta obra del templo se completa, poco tiempo después, con la construcción de un nuevo retablo para el altar mayor, del cual se encarga den 1674 el maestro Juan de la Piedra y Arce. El coste de la obra ascendió a 2.200 reales, de los cuales 1.545 reales fueron pagados por la ermita, y los 655 reales restantes, aportados por el concejo de la villa de Palacios ${ }^{1525}$. El dorado del mismo fue realizado en 1686, por el maestro José Martínez Sepúlveda, vecino de Soria, el cual ajustó su trabajo en 6.800 reales ${ }^{1526}$.

A esta renovación de la ermita le sigue la reforma efectuada en la casa del ermitaño, realiza en torno al año 1695, con un coste de 25.032 maravedís, en la parte correspondiente a la cantería, y 16.150 maravedís para la carpintería ${ }^{1527}$.

La imagen definitiva del templo se completa, ya en el siglo XVIII, con la construcción del llamado camarín, realizado en 1728. El encargado de esta obra fue el maestro de cantería Manuel de la Torre, el cual percibió de la ermita por su trabajo un total de 1.270 reales. Esta estancia se completa con un pequeño retablo, colocado en torno al vano que forma el transparente, en cuya construcción la ermita desembolsó 1.200 reales $^{1528}$.

A partir de aquí los únicos trabajos, que se acometen en esta ermita son los relacionados con las labores de mantenimiento y adorno de su estructura. Entre ellos podemos citar, la ejecución de las pinturas que decoran la bóveda de la capilla mayor, realizadas en torno al año 1730. Esta labor fue comenzada por el maestro Antonio

\footnotetext{
1524 Ibídem. (fols. 30 v o - 31). Palacios de la Sierra, 26 - septiembre - 1666.

1525 Ibídem. (fols. 34 - 38). Cuentas tomadas en 1674 tomadas a Pedro Llorente. Palacios de la Sierra, 12 - marzo - 1674 .

1526 Ibídem. (fols. 48 - 49 v o). Pagos realizados el año 1686. Palacios de la Sierra, 1 - abril - 1686.

1527 Ibídem. (fols 51 - 53). Pagos realizados el año 1695. Palacios de la Sierra, 27 - febrero - 1695.

1528 Ibídem. Cuentas tomadas el año 1728. Palacios de la Sierra, 14 - junio - 1728.
} 
Ayuso, el cual ajustó su trabajo en 600 reales, si bien, esta cantidad resultó insuficiente, quedando la obra inacabada. Ante ello, el visitador del Obispado de Osma, D. Jesús de Haro Argüero, exhortó a este pintor a que completara la obra por el dinero concertado, perdonando a la ermita la cantidad que excediera, la cual sería considerada como una limosna de este maestro a la imagen de Nuestra Señora del Arroyal. La negativa del maestro a aceptar esta solución obligó a los responsables de la ermita a buscar un nuevo artífice, que se encargara de completar la obra. El elegido fue el maestro Moliros, pintor vecino de la ciudad de Soria, que vino a acabar la pintura de la capilla de Nuestra Señora, por un precio de 250 reales $^{1529}$.

Poco tiempo después de esto, en 1737, fue necesario reconstruir gran parte de la estructura de la ermita, la cual, por motivos que desconocemos, se había venido abajo. La parte más afectada, en cualquier caso, parece que fue la estructura del tejado, la cual es reconstruida de forma inmediata, con un coste para la ermita próximo a los 1.200 reales. En estas labores participó el maestro de cantería Francisco de Arche ${ }^{1530}$. Por último, en 1780 se lleva a cabo la construcción del coro, con un coste de 944 reales y 24 maravedís, donde quedan incluidos, tanto la mano de obra como los materiales empleados $^{1531}$.

La segunda ermita, que se ha conservado en pie, es la de San Sebastián, situada en las inmediaciones del pueblo, en dirección sur, prácticamente rodeada ya por los nuevos barrios, que están surgiendo en esta zona. A mediados del siglo XIX, sin embargo, P. MADOZ todavía la sitúa fuera del caserío que forma el pueblo ${ }^{1532}$. Se trata de un edificio sencillo y de aspecto tosco, compuesto por una sola nave, de trazado rectangular muy alargada, en cuyo extremo oriental se añade la cabecera, más estrecha que la nave, levantada sobre planta cuadrangular con testero plano. Todo el edificio se

\footnotetext{
1529 Ibídem. Cuentas tomadas el año 1733. Palacios de la Sierra, 5 - junio - 1733.

1530 Ibídem. Cuentas tomadas el año 1737. Palacios de la Sierra, 1 - septiembre - 1737.

1531 Ibídem. Cuentas tomadas el año 1780. Palacios de la Sierra, 14 - abril - 1780.

1532 P. MADOZ: Diccionario geográfico - estadístico - histórico de España y sus posesiones de Ultramar. (tomo II). Valladolid, Ediciones Ámbito, 1984. (pag. 401).
} 
encuentra realizado en piedra, con muros de sillería, en cuyo paramento podemos observar las huellas dejadas por las diferentes reparaciones efectuadas a lo largo del tiempo. Con estos elementos, su imagen exterior deviene en un sencillo prisma de aspecto achaparrado, cubierto con techumbre a cuatro aguas, y con escasos vanos, para iluminar su interior. La puerta de acceso se abre sobre el muro meridional de la nave, y consta de un sencillo arco de medio punto, sin decoración de ningún tipo. En el interior, el prolongado espacio, que constituye la nave, queda cubierto con una armadura de madera, de tipo parhilera, cuyas vigas de ligaduras descansan sobre postes, adosados a los muros laterales. En el extremo oriental de esta nave, un pesado arco de medio punto, dispuesto sobre gruesas impostas, conduce al interior de la capilla mayor, la cual cubre con bóveda de crucería cuatripartita de gruesos nervios. Se trata, en definitiva, de un edificio más próximo a las características propias de la arquitectura popular, que a las de un estilo artístico concreto. Resulta difícil establecer, por lo tanto, una cronología precisa, no obstante, la parte de la cabecera podría corresponder a las primeras décadas del siglo XVI.

De las seis ermitas restantes, las únicas que han dejado restos son las de Santa Ana y el Santo Cristo de Zalamea. La de Santa Ana, estaba situada en la parte central del pueblo, en una de las bocacalles que desemboca en la calle Mayor. Tras su desaparición, en la segunda mitad del siglo XIX, parte de su estructura fue convertida en una vivienda, conservando algunos de sus muros, en los que observamos un cuidado paramento de sillería, con piezas de mediano tamaño, bien labradas y ensambladas. También se conservan restos de lo que fue su fachada principal, donde apreciamos el contorno de un arco de medio punto, escoltado por pilastras cajeadas, sobre las que se extiende una gruesa moldura plana de escaso resalte. Todo ello nos permite situar su construcción entre los años finales del siglo XVII y primeras décadas del siglo XVIII. Sin embargo, resulta imposible reconstruir la estructura original, que podía presentar este edificio. 
La ermita del Santo Cristo de Zalamea se encontraba situada fuera del pueblo, a una distancia de unos trescientos metros, en dirección este, en un paraje próximo al río Arlanza. El único resto que se conserva de ella es el arco, que enmarcaba su puerta de entrada, el cual actualmente se halla en una de las casas construidas en la década de 1990, en las inmediaciones de la ermita de San Sebastián. Se trata de un arco de medio punto, de aristas redondeadas con moldura de tres cuartos de bocel, y rosca decorada mediante sencillos motivos vegetales. Resulta, sin embargo, difícil establecer una cronología precisa para esta pieza.

Del resto de las ermitas, la última en desaparecer fue la de San Andrés, de la cual tenemos noticias hasta el año 1816. Esta última referencia simplemente sirve para dar cuenta del estado de ruina en el que se encontraba, previo a su destrucción ${ }^{1533}$.

Respecto a las de San Felipe, San Junto y San Pastor, y San Miguel, sabemos que su desaparición se produce a finales de la década de 1760. De este modo, en la visita realizada en 1770 por el propio obispo de Osma, D. Bernardo Antonio Calderón, se indica que las tres "se encontraron ruinosas" $" 1534$. El paso siguiente, tal y como era preceptivo, fue proceder a su demolición, aplicando sus materiales a la fábrica de la iglesia, y poner una cruz en su emplazamiento, para recordar el carácter de suelo sagrado, que tenían estos lugares. Su deterioro, sin embargo, parece que se había iniciado bastantes años antes, pues ya en la visita de 1730, el visitador del Obispado, D. Luis de Alaro, indica a los responsables de la parroquia del pueblo, que : "compelan y apremien a la Justicia y Reximiento desta villa a que compongan las hermitas de San Felipe y San Justo y San Pastor, que se an bisitado, antes de que acaven de devorar y

\footnotetext{
1533 AGDBU. LP. Palacios de la Sierra, Santa Eulalia y Santa María. LF. (1783 - 1815). Visita realizada a la parroquia de Santa María y Santa Eulalia de Palacios de la Sierra en 1816, por D. Juan de Cavía, obispo del Burgo de Osma. Palacios de la Sierra, 3 - mayo - 1816.

${ }^{1534}$ Ibídem. LF. (1728 - 1770). Visita realizada a la parroquia de Santa María y Santa Eulalia de Palacios de la Sierra en 1770, por D. Bernardo Antonio Calderón, obispo de Osma. Palacios de la Sierra, 19 septiembre -1770 .
} 


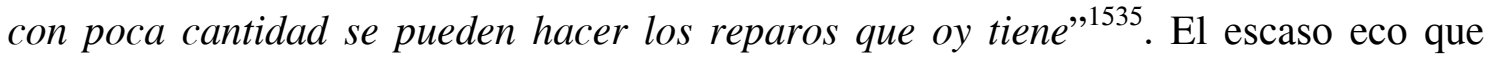
tuvieron estas palabras queda evidenciado en la suerte posterior, que siguieron las ermitas.

Arquitectura civil.

Como ya señalamos en el inicio de este apartado, dedicado a Palacios de la Sierra, esta localidad conserva muy pocos restos de los que fueron sus edificios más representativos, en el ámbito de la arquitectura civil. Aun así, todavía existen algunos ejemplos de la tipología más característica desarrollada en esta zona de pinares, como fue la casa carretera. Dentro de estos edificios, encontramos ejemplos pertenecientes a dos de sus variantes más comunes, como fueron, la casa portalón, y la llamada gran casona carretera ${ }^{1536}$.

En el primer caso tenemos la casa situada en la calle de la Peña $n^{\circ} 17$, cuya construcción podríamos retrasar, incluso, hasta las décadas finales del siglo XVII. Presenta la característica estructura de esta variante de casa carretera, en la cual destaca su fachada principal, donde se abre el amplio portalón que le da nombre, delimitado a los lados por los dos módulos, que sobresalen. En la parte central del portalón se abre la puerta de entrada al zaguán interior, coronada por un gran arco de medio punto de amplio dovelaje, mientras que en los módulos laterales se abren ventanas de dintel plano enmarcadas con moldura plana con orejones. Los muros exteriores de todo el edificio están realizados en piedra de sillería, mostrando un magnífico trabajo de cantería, mientras que la estructura de madera del tejado, aparece formada por sólidas vigas de pino.

En la segunda variante tenemos las casas situadas en la Travesía del Rosario $n^{\circ}$ 4, y $\mathrm{n}^{\mathrm{o}} 7-9$, y la ubicada en la calle Mayor $\mathrm{n}^{\mathrm{o}}$ 87. La primera de ellas es la más destacada, pues todavía conserva su magnífica fachada principal, orientada hacia el

1535 Ibídem. Visita realizada a la parroquia de Santa María y Santa Eulalia de Palacios de la Sierra en 1730, por D. Luis de Alaro. Palacios de la Sierra, 1 - junio - 1730. 


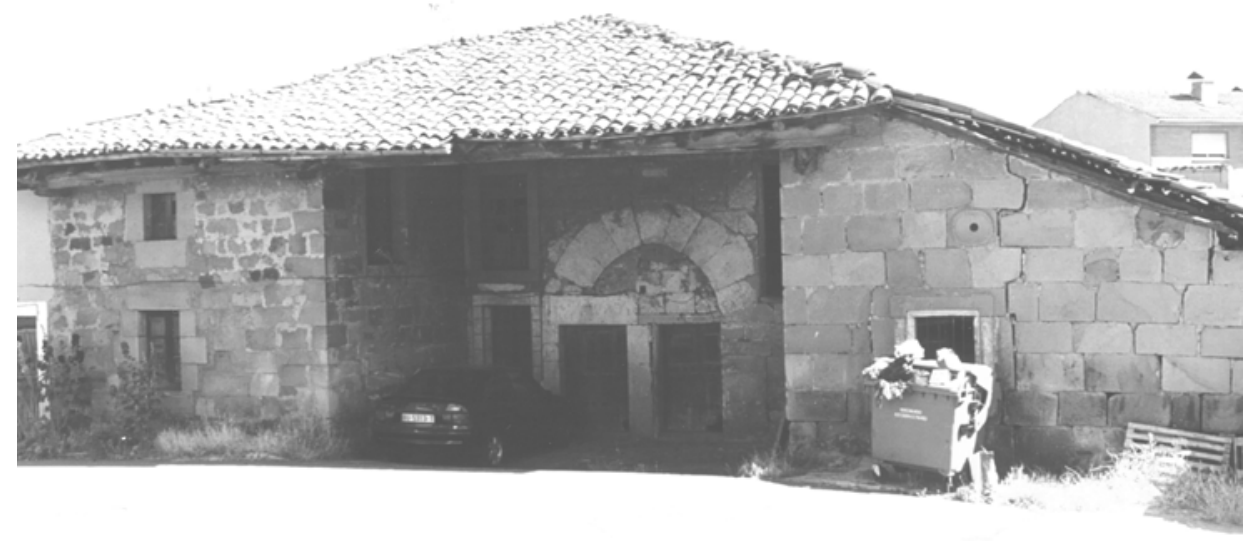

PALACIOS DE LA SIERRA.

C. de la Peña $n^{\circ} 17$

mediodía, con su característica estructura articulada en planta baja y entrecubierta, que remata con techumbre a dos aguas, achaflanada en su parte central. En el centro de la primera planta se abre la puerta de entrada, con simple estructura adintelada, y sobre ella un balcón con puerta de dintel plano, enmarcado con doble moldura quebrada, con orejones. La situada en la calle Mayor $n^{\circ} 87$ ha perdido gran parte de los elementos característicos de su fachada principal, aun así, todavía conserva el magnifico arco de medio punto, de su puerta principal, cuya rosca está decorada con diferentes motivos de carácter vegetal.

${ }^{1536}$ Ver capítulo: Actividad constructiva. Evolución estilística. Siglo XVIII. Arquitectura civil. 


\section{QUINTANAR DE LA SIERRA.}

El pueblo de Quintanar de la Sierra se encuentra situado en la parte oriental de nuestra zona de estudio, entre la sierras de Neila y Urbión, dentro de la llamada comarca de pinares. De hecho, tal vez sea el pueblo burgalés más representativo de esta tierra de pinares, dentro de la cual ha tenido tradicionalmente un papel relevante. Su amplio término municipal se extiende por las laderas de la vertiente meridional de la Sierra de Neila, presidido por el cerro de la Campiña. La mayor parte de este territorio (un $92 \%$ ), se encuentra cubierto por una inmensa masa de pinos, que se complementa con algunas manchas de hayedos y robledales ${ }^{1537}$. Es en estos bosques donde Quintanar, como todo el resto de los pueblos de la comarca de pinares, encuentra su principal fuente de recursos.

Dentro de este término municipal existen también numerosos vestigios de poblamientos altomedievales, que constituyen el precedente más inmediato del actual núcleo de Quintanar de la Sierra. Entre estos vestigios, sin duda, el más destacado es la necrópolis de Cuyacabras, situada a unos cuatro kilómetros del pueblo, en dirección noreste. Se trata de un amplio conjunto ceremonial, dentro del cual la parte más destacada lo constituye un afloramiento rocoso, sobre cuya superficie están labradas la mayor parte de las más de 170 tumbas localizadas. Este afloramiento está presidido, en su parte más elevada, por los restos de una pequeña iglesia, de la cual se conserva parte

1537 P. GIL ABAD: Quintanar de la Sierra, un pueblo burgalés de la comarca de pinares. Burgos, Excma. Diputación de Burgos. 1986. (pp. 65 - 70). 
1010 Arquitectura de la Edad Moderna en la sierra burgalesa.

de su planta y las escaleras de acceso. Todo el conjunto ha sido fechado entre el siglo X y primeros momentos del $\mathrm{XI}^{1538}$.

No menos importante es el eremitorio de Cueva Andrés, situado también en el término de Quintanar, en un lugar apartado y de difícil acceso. Este conjunto está formado por la cueva, que servía de habitación del eremitorio, la alacena, la sepultura y un curioso altar con arco de herradura esciso, con una cruz patada en su interior, acompañada por una inscripción prácticamente ilegible ${ }^{1539}$. Todos estos rasgos han permitido situar su construcción en pleno siglo $\mathrm{X}^{1540}$.

Junto a estos asentamientos, podemos citar también los despoblados, documentados en torno a estas mismas fechas ${ }^{1541}$, de Peñalbas ${ }^{1542}$, Río Cabrones ${ }^{1543}$ y San Martín ${ }^{1544}$, todos ellos situados dentro del término municipal de Quintanar de la Sierra.

1538 J. ANDRIO GONZALO: "La Edad Media a través de los estudios arqueológicos”. En Historia de Burgos II. Edad Media (2). Burgos, Caja de Ahorros Municipal de Burgos. 1986. (pp. 210); P. GIL ABAD: Quintanar de la Sierra... ob. cit. (pp. 95 - 96).

1539 J. ANDRIO GONZALO: "La Edad Media a través de los estudios arqueológicos” ob. cit. (pp. 212); J. L. MONREAL JIMENO: "Eremitorios rupestres en territorio burgalés durante la Alta Edad Media". En II Jornadas burgalesas de historia (2 ${ }^{a}$ Burgos. 1990). Burgos en la Alta Edad Media. Burgos, Asociación Provincial de Libreros de Burgos. 1991; P. GIL ABAD: Quintanar de la Sierra... ob. cit. (pp.96 - 98).

1540 A. del CASTILLO: Excavaciones altomedievales en las provincias de Soria, Logroño y Burgos. Madrid, Comisaría General de Excavaciones Arqueológicas. 1972. (pp. 8 - 16); E. RUBIO MARCOS: Monjes y eremitas. Santuarios de roca del sureste de Burgos. Burgos, Excma. Diputación de Burgos. 1986; M. A. BIELSA: Avances sobre el eremitorio de Cueva Andrés en Quintanar de la Sierra. Burgos, Actas del Congreso de Jaén. 1971.

1541 G. MARTÍNEZ DÍEZ: Pueblos y alfoces burgaleses de la repoblación. Valladolid. Junta de Castillo y León. Consejería de Educación y Cultura. 1997. (pp. 183, 186 y 188).

1542 L. SERRANO: Cartulario de San Pedro de Arlanza. Madrid, Centro de Estudios Históricos. 1925. (pp. 112, 121 y 191); P. GIL ABAD: Quintanar de la Sierra... ob. cit. (pp. 112).

1543 L. SERRANO: El obispado de Burgos y Castilla primitiva. Desde el siglo V al XIII. Madrid, Centro de Estudios Históricos. 1935. T.I. (pp 31).

1544 G. MARTÍNEZ DÍEZ: Pueblos y alfoces burgaleses... ob. cit. (pp. 188). 
Sin duda, el origen de la actual localidad de Quintanar debemos situarlo también en torno a esta época, entre el siglo $\mathrm{X}$ y principios de $\mathrm{XI}$, si bien sus primeras referencias documentales se producen el 18-III-1068, y el 14-XII-1096 ${ }^{1545}$. Antes de estas fechas también existen documentos que hablan de un Quintanar en esta zona, el cual, sin embargo, debemos identificar con un despoblado, situado en la ledanía que rodea el término de Monasterio de la Sierra, que aparece ligado a otro despoblado, conocido como Bustomediano ${ }^{1546}$.

Dentro de la organización del territorio, Quintanar quedó encuadrada, hasta principios del siglo XII, como la mayor parte de las localidades de esta zona de pinares de la provincia de Burgos, en el alfoz de Lara $^{1547}$, pasando más tarde, una vez extinguido este sistema, a formar parte de la Merindad Menor de Santo Domingo de Silos ${ }^{1548}$. Ya durante la Edad Moderna, en el plano fiscal, Quintanar aparece entre los pueblos del partido de las Tierras del Condestable, de la provincia de Burgos ${ }^{1549}$, para pasar más tarde, ya en el siglo XVIII, tras la reforma borbónica, a quedar englobado en el partido de Aranda ${ }^{1550}$.

En el plano jurisdiccional, esta localidad se mantuvo como núcleo de realengo hasta el 23-VIII-1213, en que pasa a depender del abad del monasterio de San Pedro de Arlanza, por permuta con el rey Alfonso VIII. A cambio, este cenobio había cedido una

1545 L. SERRANO: El obispado de Burgos y Castilla primitiva... ob. cit. T. III. (pp. 31). Cfr. P. GIL ABAD: Quintanar de la Sierra... ob. cit. (pp. 112).

1546 L. SERRANO: Cartulario de San Pedro de Arlanza... ob. cit. (pp. 86); G. MARTíNEZ DÍEZ: Pueblos y alfoces burgaleses... ob. cit. (pp. 177, 183).

1547 G. MARTÍNEZ DÍEZ: Pueblos y alfoces burgaleses... ob. cit. (pp.175).

1548 C. ESTEPA DÍEZ: "Estructura de poder en Castilla (siglos XII - XIII). El poder señorial en las merindades burgalesas. En III Jornadas burgalesas de Historia (3 1991). Burgos en la Plena Edad Media. Burgos, Asociación Provincial de Libreros de Burgos. 1994. (pp. 245 - 294).G. MARTíNEZ DÍEZ: Libro Becerro de las Behetrías. Estudio y texto crítico. León, Centro de Estudios e Investigación San Isidoro. Caja de Ahorros y Monte de Piedad. Archivo Histórico Diocesano. 1981. (pp. 621 - 622).

1549 G. MARTÍNEZ DÍEZ: Génesis histórica de la provincia de Burgos y sus divisiones administrativas. Burgos, Aldecoa. 1983.

1550 Ibídem; INE. Censo de 1787. “Floridablanca”. Madrid. INE. 1989. 
serie de terrenos, situados en las proximidades de Burgos, con los cuales el monarca pretendía dotar su fundación del Hospital del Rey ${ }^{1551}$. Queda convertida así en señorío abadengo $^{1552}$, hasta que en 1556, D. Juan Asenjo de Millán, compra su jurisdicción por un precio de 1.285 .774 maravedís ${ }^{1553}$. Esta operación queda encuadrada dentro del proceso de venta de bienes de diferentes órdenes religiosas, realizada a mediados de este siglo XVI, por Felipe II, en virtud de la Bula concedida a su padre Carlos I por el papa Julio III ${ }^{1554}$. Esta nueva condición de señorío solariego no sufrirá ningún cambio hasta el final de este régimen, a principios del siglo $\mathrm{XIX}^{1555}$.

En lo que se refiere al apartado eclesiástico, la ubicación del pueblo en la margen derecha del río Arlanza, hizo que, tras el Concilio de Burgos de 1136, quedara incluida definitivamente dentro del territorio de la Diócesis de Burgos ${ }^{1556}$.

Quintanar fue una localidad relativamente grande, dentro de los que es habitual en la zona, con una población situada siempre por encima de los niveles medios, que presentan los pueblos de esta comarca de la sierra burgalesa. Esta población mostró siempre un comportamiento bastante regular, a lo largo de toda la Edad Moderna, tal y como nos muestra el detallado estudio demográfico, realizado por el investigador local P. GIL ABAD ${ }^{1557}$. Según el gráfico resultante, durante los siglos XVI y XVII la población de Quintanar mostró una línea más o menos ascendente, que se corresponde

\footnotetext{
1551 L. SERRANO: Cartulario de San Pedro de Arlanza... ob. cit. (pp. 45); P. GIL ABAD: Quintanar de la Sierra... ob. cit. (pp. 117 - 121).

1552 G. MARTÍNEZ DÍEZ: Libro Becerro de las Behetrías... ob. cit. (pp. 621 - 622).

1553 AGS. DGS. Env. 24. Leg. 281. (fols. 200); Cfr. P. GIL ABAD: Quintanar de la Sierra... ob. cit. (pp.121 - 123).

1554 Ver capítulo: Devenir histórico. A. DOMÍNGUEZ ORTIZ: Instituciones y sociedad en la España de los Austrias ... ob. cit. S. DE MOXÓ: La desamortización eclesiástica del Siglo XVI. En AHDE. N ${ }^{\circ}$ XXX. 1961. R. CARANDE: Carlos V y sus banqueros. Tomo II. Ob. cit. (pp. 412 y ss.). M. MODESTO: La Hacienda Real de Castilla en el reinado de Felipe II. Roma, 1963. N. LÓPEZ MARTÍNEZ: La desamortización de bienes eclesiásticos en 1574. En Hispania, no 86.

1555 P. GIL ABAD: Quintanar de la Sierra... ob. cit. (pp. 116 - 117).

1556 L. SERRANO: El obispado de Burgos y Castilla primitiva... ob. cit. T.I. (pp. 333 - 337; 374 - 378).

1557 P. GIL ABAD: Quintanar de la Sierra... ob. cit. (pp. 219 - 275).
} 
con el momento de máximo esplendor de la localidad. Los valores más representativos para estos años son los que nos arrojan el censo de 1541 , con 79 vecinos ${ }^{1558}$, el censo de los obispos, de 1584-87, con 170 vecinos $^{1559}$, y el censo de 1591 , con 159 vecinos $^{1560}$. Durante el último cuarto del siglo XVII observamos, sin embargo, una fuerte caída, que alcanza su cenit en la parte central de la década de 1680, donde se registra un pronunciado ascenso de la mortalidad, acompañado de un fuerte descenso del número de nacimientos ${ }^{1561}$. A partir de las primeras décadas del siglo XVIII se inicia, sin embargo, una tendencia contraria, que permite recuperar los niveles anteriores, los cuales se mantienen a lo largo de toda la centuria, con diferentes altibajos. El Catastro del Marqués de la Ensenada nos da una cifra de 155 vecinos $^{1562}$, que se convierten en 586 habitantes a finales de la centuria, en el censo de Floridablanca ${ }^{1563}$. Se mantienen, por lo tanto, unos niveles muy parecidos.

El modo de vida de estos habitantes, como la del resto de los pueblos de la zona de pinares, estuvo basada, desde la Baja Edad Media, en el aprovechamiento de sus recursos forestales. Esta localidad, de algún modo, llegó a ser una de las cabezas más visibles de esta industria exportadora de madera de pino, hasta el punto de convertir su nombre en sinónimo de calidad y buen precio, dentro de mundo de la construcción. La venta de madera dio lugar, al mismo tiempo, al desarrollo de una importante actividad relacionada con el transporte, convirtiéndose por ello en uno de los más destacados centros de la carretería burgalesa y castellana en general ${ }^{1564}$. Esta dependencia de las actividades relacionadas con el aprovechamiento forestal, unido a las condiciones

\footnotetext{
1558 AGS. Contaduría General. Leg. 768. (fols.62 vº).

1559 T. GONZÁLEZ: Censo de población de las provincias y partidos de la Corona de Castilla en el siglo XVI... Ed. Facsímil. Madrid, Imprenta Real. 1829.

1560 Censo de Castilla de 1591. Vecindario. Madrid, Instituto Nacional de Estadística. 1984.

1561 P. GIL ABAD: Quintanar de la Sierra... ob. cit. (pp. 227 - 231).
}

1562 ADPBU. CE. 1497. RESPUESTAS GENERALES. Quintanar de la Sierra. 1753. Cfr. P. GIL ABAD: Quintanar de la Sierra. Según las Respuestas Generales del Catastro de Ensenada. Burgos, Centro de Gestión Catastral y Cooperación Tributaria. Ministerio de Economía y Hacienda. 1982.

1563 INE. Censo de 1787. “Floridablanca”. Madrid. INE. 1989. 
adversas que imponía la orografía, el clima y los tipos de suelo, hizo que la agricultura apenas fuera explotada. Como muestra de ello, vemos que el suelo cultivado dentro de su territorio, apenas supera al $5 \%{ }^{1565}$.

Algo mejor suerte tuvo la ganadería, la cual debemos entenderla como parte fundamental de la actividad carreteril, pues la mayor parte de los ganados que se crían son de tipo vacuno, destinados al tiro de las carretas. Junto a la cría de estos bueyes de raza serrana, encontramos también algunos rebaños de ovejas, fundamentalmente de raza churra, y cabras, que en conjunto apenas llegaban a alcanzar las 1.500 cabezas de media $^{1566}$.

El núcleo urbano de Quintanar se encuentra situado en la parte más baja de todo el término municipal, extendiendo su caserío sobre la cumbre y ladera meridional de un altozano, conocido como “el Cerro”. La particular forma alargada de esta colina es la que marca la estructura extendida, que dibuja el caserío. Dentro de este núcleo, sin embargo, vemos cómo el brusco e incontrolado crecimiento experimentado por esta localidad, durante la segunda mitad del siglo XX, ha hecho que apenas encontremos ejemplos de su arquitectura tradicional, dentro de la cual debían existir interesantes ejemplos de casas carreteras. De este modo, su edificio más representativo, como ocurre en la mayoría de los pueblos de la zona, lo constituye su iglesia parroquial.

\section{Iglesia de San Cristóbal.}

La iglesia de Quintanar se encuentra dedicada a San Cristóbal, si bien parece que en algún momento pudo estar bajo la advocación de San Sebastián ${ }^{1567}$. Está situada en la parte central del pueblo, pero no en una posición dominante, sino confundida entre el apretado caserío, que se extiende sobre la ladera del “Cerro”. Su edificio queda rodeado,

\footnotetext{
1564 P. GIL ABAD: Quintanar de la Sierra... ob. cit. (pp.277 - 310); Ibídem. Junta y Hermandad de la Cabaña Real de Carreteros Burgos - Soria. Burgos, Aldecoa. 1983.

1565 Ver capítulo: Economía.

1566 ADPBU. CE. 1497. RESPUESTAS GENERALES.

1567 P. GIL ABAD: Quintanar de la Sierra... ob. cit. (pp. 111).
} 
en tres de sus partes, por un potente muro, el cual, al mismo tiempo que delimita el espacio del atrio, funciona como elemento de contención, con el que se crea una superficie llana. Este templo se levanta, por lo tanto, sobre un suelo totalmente artificial.

Respecto a su estructura, como ya vimos en el apartado dedicado a la arquitectura religiosa durante el siglo $\mathrm{XVII}^{1568}$, es una obra de comienzos de esta centuria, cuyos trabajos de construcción finalizan en 1622. El epílogo a esta obra se puso ocho años más tarde, con la incorporación de su portada principal. Todo este conjunto, por lo tanto, desarrolla las formas propias de la arquitectura clasicista de tradición herreriana, incorporadas a las diferentes comarcas burgalesas a partir de las primeras décadas de este siglo XVII. El hecho de ser una obra realizada prácticamente en una sola fase constructiva, además, nos proporciona un caso insólito de unidad estilística, pues como sabemos, las fábricas religiosas de esta comarca suelen reflejar la sucesión de diferentes etapas y estilos. El autor de la obra, al menos en lo que se refiere a sus trazas, pudo ser, como ya vimos, Juan de Naveda, maestro de cantería, formado en las obras del conjunto monumental de Lerma, que ocupó el puesto de Veedor de obras del Arzobispado de Burgos desde el año 1615 en adelante. Tanto las fechas como las formas desarrolladas en el templo, corroboran esta atribución.

El templo se levanta sobre una amplia planta de salón de tres naves, articuladas en cuatro tramos, todo ello inscrito en un gran rectángulo, del cual sobresalen, la capilla mayor y la sacristía, en el extremo oriental, la torre, a los pies, y una pequeña capilla lateral, adosada sobre el flanco septentrional, a la altura del tercer tramo de la nave. Tanto esta capilla, como la que forma la cabecera, presentan planta rectangular, poco profunda con testero plano, mientras que la sacristía y la torre se alzan sobre base cuadrangular.

Todo el edificio se halla realizado en piedra, con sólidos muros de sillería, levantados sobre un elevado zócalo, rematados en su parte superior por una doble

1568 Ver capítulo: Actividad constructiva. Evolución estilística. Siglo XVII. 
moldura de codillo y papo de paloma, y reforzados por fuertes estribos, de estructura prismática, de escaso resalte sobre el muro, que, en el caso de las esquinas, adoptan una posición de lados en paralelo a los lados del muro.

Con todo ello se consigue una imagen exterior dominada por la gran masa prismática, que forma el cuerpo, sobre la cual se añaden los diferentes módulos, correspondientes a cada una de las estancias anexas. El contrapunto vertical a esta estructura, de marcado carácter horizontal, lo pone la torre, incorporada a los pues, la cual desarrolla un esbelto prisma de base cuadrangular, articulado en tres cuerpos desiguales, separados por ligeras líneas de imposta. El nivel superior, que forma el cuerpo de campanas, es el único que recibe un tratamiento especial. Cuenta con un estilizado vano coronado con arco de medio punto, en cada una de sus caras, rematando los muros con un friso y una airosa cornisa, con los que se pasa al tejado, donde se alzan esbeltos pináculos piramidales, dispuestos sobre netos que se unen con balaustrada de piedra. Los dos cuerpos inferiores apenas cuentan con elementos destacables, salvo el central, donde encontramos restos de unos antiguos vanos, que nos hablan de su anterior función como cuerpo de campanas.

Este templo cuenta con dos puertas, orientadas al mediodía y al norte. La principal se abre sobre el flanco meridional, a la altura del tercer tramo de la nave. Es obra también clasicista, como el resto del templo, y se dispone bajo un potente arco de medio punto, cuya rosca aparece recorrida por una inscripción en la que podemos leer: ESTA PORTADA SE ACABÓ DE HACER AÑO 1630, SIENDO CURA EL LICENCIADO BLANCO MARCOS. La portada en sí presenta una estructura de escaso resalte sobre el plano del muro, formada por un vano coronado con arco de medio punto de rosca moldurada, decorado con pequeños tondos floreado en las enjutas, y un cáliz con una sagrada forma sobre la clave, acompañada de una inscripción, que dice: ALAVADO SEA EL SANTÍSIMO SACRAMENTO Y LA CONCEPCIÓN PURÍSIMA DE NUESTRA SEÑORA. Este vano está escoltado por pilastras y retropilastras de orden dórico y fuste cajeado, entre las que se extiende un entablamento, 


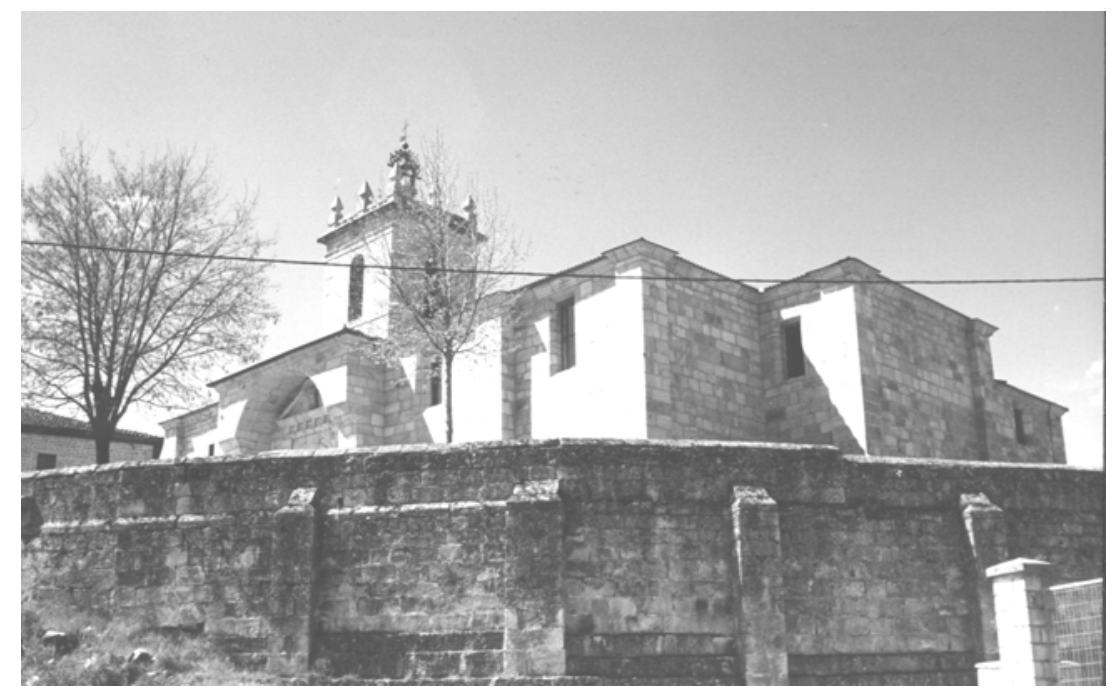

QUINTANAR DE LA SIERRA.

iglesia de San Cristóba.

con las metopas del friso decoradas mediante tondos floreados, y airosa cornisa, que da paso a un frontón recto, con una pequeña hornacina en el tímpano, en cuyo interior se aloja una talla en piedra de San Cristóbal, con su tipo iconográfico tradicional.

La segunda puerta se abre a la altura del tramo final del muro septentrional, y presenta un vano adintelado, enmarcado por moldura plana con orejones y cornisa de escaso vuelo, sobre la que se coloca una pequeña cruz en el centro y dos pináculos de bola a los lados. Se trata, por lo tanto, de una obra sencilla, en la que se manifiesta también un acusado sabor clasicista.

Por último, las ventanas, que iluminan el interior, quedan repartidas a ambos lados del templo, entre cada uno de los tramos, y en ellas se repite un trazado rectangular de dintel plano con ligero derrame hacia el exterior. Dos de ellas, sin embargo, incorporan un remate con arco de medio punto, al mismo tiempo que acentúan su abocinado exterior. Se trata de las ventanas abiertas, sobre el muro meridional, a la 
altura del segundo tramo de la nave, y sobre el muro del testero de la capilla lateral del lado del evangelio.

La estructura interna del edificio, a pesar de alzarse sobre una planta de salón, dista bastante de conseguir la imagen de diafanidad y amplitud espacial, que perseguían los modelos hallenkirche del siglo XVI. A ello contribuye, tanto la escasa altura de sus cubiertas, como la gran potencia de los soportes, que llegan a interrumpir la visión del altar mayor desde las naves laterales. Tiene mayor peso, por lo tanto, el sentido longitudinal, que introducen los respectivos ejes direccionales, trazados en torno a cada una de las naves.

Todo el espacio interior del templo queda cubierto con bóvedas de crucería estrelladas con terceletes de trama muy sencilla, dentro de los cuales, la única variación aparece en el segundo tramo de la nave de la epístola, que incorpora una serie de nervios combados, con los que se dibuja una estructura trebolada en el centro. Los arcos, que separan cada uno de estos tramos, son de medio punto con intradós cajeado, los cuales descansan, como vimos en su momento, sobre sólidos pilares de sección cuadrada, frenteados por pilastras de fuste liso, y cuarto de columna en los codillos, todo ello rematado por una gruesa moldura plana de escaso resalte. Las únicas variantes sobre este tipo de soporte vuelven a aparecer en el segundo tramo de la nave de la epístola, donde encontramos haces de columnas, dispuestas sobre elevado basamento y desprovistas de capitel.

A este espacio principal del templo se incorporan, la capilla mayor, en el extremo oriental, y la capilla lateral, dedicada actualmente a la Inmaculada Concepción, en el lado del evangelio, mientras que en la zona de los pies se añade un coro alto, elaborado en madera, que abarca todo el tramo final de las tres naves. La capilla mayor forma un espacio poco profundo, de suelo ligeramente elevado mediante gradas, $\mathrm{y}$ cubierta con bóveda de crucería estrellada con terceletes, similar a las empleadas en los tramos de la nave. La capilla lateral, por su parte, presenta un espacio mucho más 
reducido, al cual se accede a través de un amplio arco de medio punto, dispuesto sobre impostas planas, que proyecta la bóveda de medio cañón, que forma su cubierta.

Esta imagen interior se completa con los retablos, que decoran sus respectivos altares. El del altar mayor es obra prechurrigueresca, de la década de $1670^{1569}$, y cuenta con un cuerpo de tres calles, sobre banco decorado con pinturas de los Padres de la Iglesia, y escenas de la Pasión de Cristo y de San Juan. El nicho principal del cuerpo está ocupado por la talla de San Cristóbal, al cual acompañan a los lados San Pedro y San Pablo, con relieves de los Evangelistas San Mateo y San Juan, mientras que en el remate aparece una talla de la Trinidad, en la que se desarrolla el tipo iconográfico conocido como Trono de Gracia. El retablo situado en el muro frontal de la nave de la epístola está dedicado a Nuestra Señora del Rosario, y es obra rococó, de la década de 1770. Está presidido por la imagen de vestir de la Virgen del Rosario, acompañada, a los lados, por tallas de San Sebastián y San Antón, y en el remate por una talla de San Jerónimo. Todas las imágenes de este retablo, salvo la titular, son obras del siglo $\mathrm{XVI}^{1570}$. En el lado contrario, sobre el muro frontal de la nave del evangelio, se levanta un retablo similar al anterior, dedicado a San Pedro Regalado. Cuenta con las imágenes de San Pedro Regalado en el nicho central, acompañado por San Ildefonso y San Blas a los lados, y el Santo Ángel de la Guarda en el remate. Estas últimas tallas, como en el caso anterior, son obras de finales del siglo $\mathrm{XVI}^{1571}$. Por último, el retablo de la capilla lateral, es obra prechurrigueresco, de la década de 1670, como el del altar mayor. Cuenta con tres calles, ocupadas en la actualidad por una talla de la Inmaculada Concepción del siglo XVI, en el centro, y dos imágenes más, de la Virgen con el Niño y San Roque a los lados. Sobre el remate se han colocado dos figuras modernas de Cristo Resucitado y San José con el Niño.

\footnotetext{
1569 R. J. PAYO HERNANZ: El retablo en Burgos y su comarca durante los siglos XVII y XVIII. Burgos, Excma. Diputación Provincial de Burgos. 1997. (T. II, pp. 525).

1570 Ibídem.

1571 Ibídem.
} 
La historia constructiva de este templo, en función de la información que poseemos, queda reducida, prácticamente, a una sola fase constructiva, la cual finaliza en 1622. La intensidad de esta renovación ha hecho que sean muy pocos los restos conservados del templo anterior, los cuales se concentran, como hemos visto, en el segundo tramo de la nave de la epístola. Estos vestigios nos hablan de la existencia de una fase constructiva durante el período del gótico final, cuya realización podemos situar en torno a la década de 1520. En cualquier caso, resultan insuficientes para poder hacer una reconstrucción de la estructura del templo al que pertenecieron ${ }^{1572}$.

En lo que se refiere a la historia de este templo, que se abre a partir de su renovación en las primeras décadas del siglo XVII, las actuaciones emprendidas quedan reducidas a labores de remate y mantenimiento de la estructura heredada. Entre ellas podemos citar la construcción del coro, realizado en torno a $1650^{1573}$, con un coste para la parroquia de sólo 12.872 maravedís ${ }^{1574}$, o la reparación del muro del atrio, efectuada entre los años 1667-68 por el maestro de cantería, Tomás Barquinero, cuyos gastos fueron cubiertos, en su mayor parte, por el concejo de la villa ${ }^{1575}$. Poco tiempo después, en 1676 , se remodela el enlosado del interior del templo ${ }^{1576}$, con la participación del maestro Luis Crespo ${ }^{1577}$, creando un suelo, que posteriormente, a mediados del siglo XVIII, se cubre mediante un entarimado de madera de pino ${ }^{1578}$. Sin embargo, la obra más importante que se acomete en este templo, tras su conclusión, tiene lugar en la torre, con la incorporación de un nuevo cuerpo de campanas. La obra se realiza en torno a 1772, bajo la dirección del maestro Bernardo Ordoricas ${ }^{1579}$, y consiste, simplemente,

\footnotetext{
1572 Ver capiítulo: Actividad constructiva. Evolución estilística. Siglo XVI.

1573 AGDBU. LP. Quintanar de la Sierra, parroquia de San Cristóbal. LF. Visita realizada a la parroquia de San Cristóbal de Quintanar de la Sierra en 1650, por Martín Gallego. Quintanar de la Sierra 1650.

1574 Ibídem. Cuentas del año 1652. Quintanar de la Sierra, 16 - enero - 1653.

1575 Ibídem. Cuentas del año 1667. Quintanar de la Sierra, 29 - agosto - 1668; Cuentas del año 1668. Quintanar de la Sierra, 2- agosto - 1669.

1576 Ibídem. Visita realizada en 1676. Quintanar de la Sierra, 18 - octubre - 1676.

1577 Ibídem. Cuentas del año 1685. Quintanar de la Sierra, 10 - junio - 1686.

1578 Ibídem. Cuentas del año 1746. Quintanar de la Sierra, 11 - abril - 1747.

1579 Ibídem. Zayos de la Torre, 5 - agosto - 1772.
} 
en añadir un nuevo cuerpo sobre la estructura ya existente. Con este añadido la imagen de la torre, no sólo ganaba esbeltez, sino que se convierte definitivamente en el principal punto de referencia visual, dentro de la estampa del pueblo.

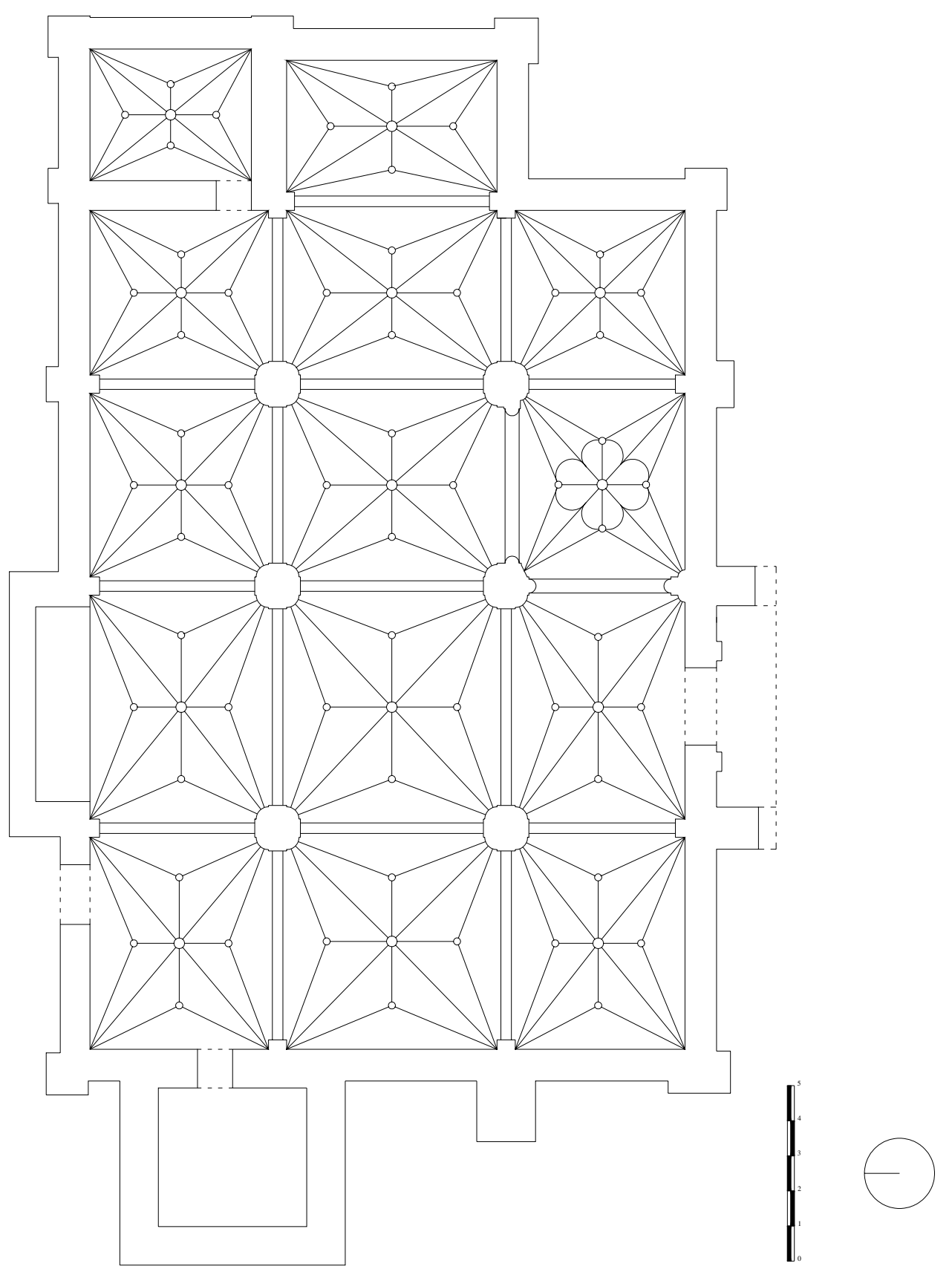




\section{Ermita de Nuestra Señora de la Guía.}

Es la única ermita, de las nueve que existieron en Quintanar de la Sierra, que se ha conservado hasta nuestros días. Fue, al mismo tiempo, la más importante del pueblo, y junto con las ermitas del Carrascal, en Canicosa, del Arroyal, en Palacios de la Sierra, y del Torrejón en Vilviestre del Pinar, uno de los santuarios marianos más destacados de esta zona burgalesa de la comarca de pinares. Se encuentra situada a escasos quinientos metros del pueblo, en dirección sur, en el centro de la extensa pradera que se extiende a los pies de este caserío. Su fábrica actual, como vimos en su momento, corresponde en su totalidad al siglo XVII, si bien, dentro de ella se puede apreciar, con claridad, la existencia de tres fases constructivas diferentes ${ }^{1580}$.

El edificio presenta planta de una sola nave, con crucero, solo marcado en altura, y cabecera cuadrangular con testero plano, de anchura algo menor que el crucero. Cuenta con sólidos muros de piedra, con paramento de sillería en las zonas correspondientes a la nave y la cabecera, y mampostería sobre basamento de sillería, en el caso del crucero. Todos estos muros, en cualquier caso, rematan con cornisa, formada por doble moldura de codillo y papo de paloma. El muro del testero de la cabecera, además, queda reforzado por dos estribos prismáticos, dispuestos con sus lados en paralelo a los ejes del muro.

La imagen exterior de este templo queda formada por tres prismas, que se corresponden con cada una de las partes descritas en planta, dentro de las cuales destaca, por su mayor altura, el cuerpo central, que representa el crucero, mientras que la parte de la nave y la cabecera mantienen una misma altura. Esta imagen se complementa con la espadaña, que se levanta sobre el muro de los pies, la cual está formada por dos cuerpos decrecientes en altura y anchura, unidos por pequeños aletones triangulares con pináculos de bola en los extremos, y un solo vano en el cuerpo superior, rematado con arco de medio punto. La puerta de acceso al interior se abre sobre el muro meridional de la nave, y presenta un sencillo vano con dintel plano 


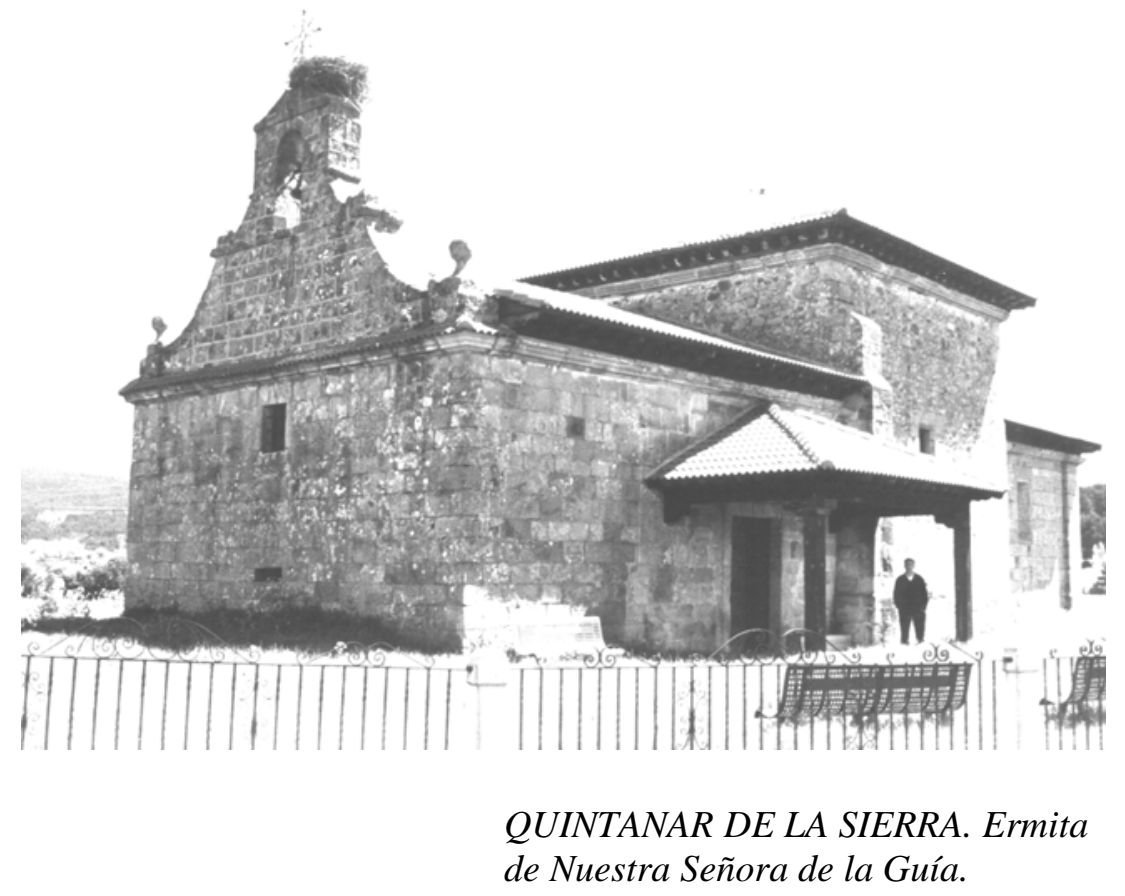

enmarcado por moldura plana con orejones. Esta puerta queda protegida por un pequeño tejadillo, que descansa sobre dos postes de madera.

En el interior nos encontramos con tres ámbitos claramente diferenciados, como son la nave, el crucero y la cabecera. El primero cuenta con un coro alto a los pies, elaborado en madera, y cubre todo su espacio con techumbre a dos aguas, dispuesta sobre armadura de tipo parhilera. El espacio del crucero se encuentra delimitado, en sus cuatro lados, por amplios arcos de medio punto, que nos indican la existencia, de una antigua cubierta abovedada. Actualmente, sin embargo, este espacio se cubre con una techumbre de madera dispuesta a cuatro aguas, con una claraboya en el centro. Por último tenemos la capilla mayor, a la cual se accede a través de un potente arco de medio punto de intradós cajeado, dispuesto sobre pilastras seudotoscanas. Este espacio se cubre con bóveda de crucería estrellada con terceletes de rampante muy plana. Su 
altar se decora con un retablo de estilo prechurrigueresco, obra del maestro Lucas de Hermosa, que lo realizó en 1683 por un precio de 2.596 reales $^{1581}$. Consta de tres calles separadas por columnas salomónicas, en cuya hornacina central encontramos la imagen de la titular del templo, acompañada a los lados por las escenas de la Anunciación y la Coronación de la Virgen, y un pequeño Calvario en el remate.

La falta de fuentes documentales, para la mayor parte de este siglo XVII, nos impide fijar el momento exacto en el que se llevan a cabo cada una de las fases constructivas. No obstante, todo apunta a que esta zona de la cabecera fue la última en construirse, perteneciendo ya al tercer cuarto de esta centuria del Seiscientos. Por el contrario, la parte de los pies es la zona más antigua, dentro del edificio actual, cuya fecha de construcción debemos retrasar hasta las primeras décadas de este siglo. La obra, que completa la imagen definitiva de este templo, por su parte, se realiza en torno al año 1689. Se trata del transparente construido para la capilla mayor. Es una obra sencilla, que consiste simplemente en abrir un vano sobre el muro del testero, en correspondencia con el nicho central del retablo del altar mayor. De este modo, con la luz que se proyecta desde aquí se consigue crear el efecto nimbado, que persiguen este tipo de creaciones. El encargado de realizar estos trabajos fue el maestro de cantería Francisco de la Torre ${ }^{1582}$. En torno a estos mismos años el maestro Alonso de Andía procede a dorar el retablo mayor, por un precio de 5.542 reales ${ }^{1583}$.

\section{Ermitas desaparecidas.}

A parte de este santuario de Nuestra Señora de la Guía, en los libros parroquiales de esta localidad hemos encontrado referencias de otras ocho ermitas, que se hallaban repartidas por el propio pueblo y sus inmediaciones. Estas ermitas estaban dedicadas a la Vera Cruz, San Andrés, San Juan, San Martín, San Salvador, Santa Catalina, La

\footnotetext{
1581 AGDBU. LP. Quintanar de la Sierra, parroquia de San Cristóbal. Libros de la Cofradía de Nuestra Señora de la Guía. (1665 - 1695). (fols. 269 - 271). Cuentas del año 1683. Quintanar de la Sierra, 5 abril - 1684 .

1582 Ibídem. (fols. 216 - 217 vo). Cuentas del año 1689. Quintanar de la Sierra, 26 - abril - 1690.

1583 Ibídem.
} 
Soledad, y el conocido como el Humilladero. Ninguna de ellas, sin embargo, ha dejado restos materiales, que nos permitan conocer su aspecto. La última en desaparecer fue la de la Vera Cruz, cuyos restos fueron demolidos entre los años 1933-35, para levantar sobre este solar el colegio que lleva su nombre ${ }^{1584}$. La casualidad, no obstante, ha querido que podamos conocer vagamente el aspecto, que presentaba su fachada principal, merced a una antigua fotografía, tomada en la década de 1920, con motivo de la inauguración del actual edificio del ayuntamiento, junto al cual se encontraba. A través de esta imagen se aprecia una construcción de gran altura, de estilo barroco, articulada en tres cuerpos de anchura decreciente, separados por líneas de imposta, y rematados en los extremos por pináculos piramidales. El cuerpo inferior acogía la puerta, escoltada por pilastras cajeadas y coronada por amplio arco de medio punto de rosca casetonada, como solían ser frecuente en las construcciones de este tipo en la zona, durante siglo XVIII. El cuerpo central mostraba un pequeño óculo en el centro, mientras que el superior se remataba con un frontón triangular, levantado sobre un ancho neto. Una obra, por lo tanto, de aspecto sencillo, con un claro sentido ascensional, en la que se muestra la austeridad y simplificación con la que era entendido el estilo barroco en esta zona.

Sobre las siete ermitas restantes, como decimos, apenas contamos con noticias, que nos permitan, incluso, preciar su ubicación. Todas ellas, sin embargo, salvo el Humilladero, lograron sobrevivir sin aparente dificultades hasta los primeros años del siglo XIX. En el caso del Humilladero la pista se pierde en los primeros momentos del siglo XVIII, con una última referencia fechada en el año $1707^{1585}$. Para las demás ermitas, es decir, las dedicadas a San Andrés, Santa Catalina, San Juan, San Martín, San Salvador y la Soledad, su final llegó en la década de 1820. La última referencia, que encontramos de ellas, es la que deja el visitador del Arzobispado de Burgos de 1819, D.

\footnotetext{
1584 P. GIL ABAD: Quintanar de la Sierra... ob. cit. (pp. 319).

1585 AGDBU. LP. Quintanar de la Sierra, parroquia de San Cristóbal. LF. Visita realizada a la parroquia de San Cristóbal de Quintanar de la Sierra en 1707, por Manuel Francisco Navarrete Ladrón de Guevara. Quintanar de la Sierra, 18 - abril - 1707.
} 
Fermín López Taido ${ }^{1586}$. Doce años más tarde, sin embargo, el visitador D. José del Hoyo Miguel solamente nos habla ya de las ermitas de Nuestra Señora de la Guía y de la Vera Cruz, mientras que el resto indica que, "se hallan arruinadas e inservibles y se manda que se vendan los materiales y su valor se agregará a el caudal de la iglesia, haciendo en los sitios de las citadas ermitas lo que se manda en el Libro de Constituciones Sinodales"1587.

1586 Ibídem. (fols. 225 vº). Visita realizada a la parroquia de San Cristóbal de Quintanar de la Sierra en 1819, por Fermín López Taido. Quintanar de la Sierra. 1819.

1587 Ibídem. (fols. 244 v $^{0}$ - 249). Visita realizada a la parroquia de San Cristóbal de Quintanar de la Sierra por D. José del Hoyo Miguel, presbítero cura beneficiario de Lara. Quintanar de la Sierra, 18 diciembre -1831 . 
QUINTANILLA DE URRILLA.

La pequeña localidad de Quintanilla de Urrilla se encuentra situada dentro del llamado valle de Valdelaguna, que se extiende entre las sierras de la Demanda y Neila. Es, de hecho, el pueblo más occidental del citado valle, y por lo tanto el primero que nos encontramos, al adentrarnos en esta zona de las tierras altas del Sistema Ibérico desde su vertiente occidental. Su destino, por ello, ha estado desde siempre vinculado a esta agrupación de pueblos, que forman el Real Valle y Villa de Valdelaguna.

El origen de esta localidad está relacionado, con total seguridad, con los primeros poblamientos estables, que se producen en esta zona durante la alta Edad Media, entre los siglos IX-X. No obstante, las primeras referencias escritas no las encontramos hasta mediados del siglo XII. En ellas aparece nombrado, en un primer momento, simplemente como Quintanella, y más adelante como Quintaniella Xemena $^{1588}$, tomando ya a mediados del siglo XIV la denominación de Quintaniella de Hurriella ${ }^{1589}$, de donde procede le nombre completo actual.

Como hemos dicho, Quintanilla de Urrilla formó parte en todo momento de la agrupación de pueblos, que constituyen el Valle de Valdelaguna, lo que hace que su devenir histórico haya estado unido de forma irremediable al destino de estas

1588 L. SERRANO: Cartulario de San Pedro de Arlanza. Madrid, Centro de Estudios Históricos. 1925. (pp. 191).

1589 G. MARTÍNEZ DÍEZ: Libro Becerro de las Behetrías. Estudio y texto crítico. León, Centro de Estudios e Investigación San Isidoro. Caja de Ahorros y Monte de Piedad. Archivo Histórico Diocesano. 1981. (pp. 616 - 617). 
poblaciones. De esta forma, Quintanilla formó parte, en un primer momento, del pequeño y efímero alfoz de Barbadillo del Pez ${ }^{1590}$, hasta que en el siglo XI pierde su contenido, y pasan sus pueblos a depender del alfoz de Lara ${ }^{1591}$. Desde principios del siglo XII, una vez extinguido el sistema de alfoces, esta localidad, como el resto de los pueblos del Valdelaguna, queda incluida en la Merindad Menor de Santo Domingo de Silos $^{1592}$.

Ya en la Edad Moderna, dentro de la organización fiscal del reino de Castilla, este pueblo queda encuadrado en el partido de las Tierras del Condestable ${ }^{1593}$, dentro de la provincia de Burgos, para pasar luego, tras la reforma borbónica del siglo XVIII, a formar parte del partido de Aranda ${ }^{1594}$. Durante este mismo período su régimen jurisdiccional experimenta la misma evolución que el resto de las localidades de Valdelaguna. Vemos, por lo tanto, que fue uno de los primeros núcleos de la zona que pasó a depender de la cada de los Velasco, pues a mediados del siglo XIV ya aparece D. Pedro Fernández de Velasco como señor del lugar ${ }^{1595}$. Más adelante, en un momento que no podemos determinar, todo el valle consigue adquirir su propia jurisdicción, alcanzando con ello la condición de realengo. Aun así, la presencia de sus antiguos señores, los Duques de Frías, continúa en vigor, pues siguen percibiendo, hasta el final del Antiguo Régimen, las alcabalas y las tercias reales de los diezmos parroquiales ${ }^{1596}$. En el plano eclesiástico, su parroquia perteneció siempre a la Diócesis de Burgos.

\footnotetext{
1590 G. MARTÍNEZ DÍEZ: Pueblos y alfoces burgaleses... ob. cit. (pp.191).

1591 I. ÁLVAREZ BORGE: Monarquía feudal y organización territorial: alfoces y merindades en Castilla (siglos $X-X I V$ ). Madrid, CSIC. 1993. (pp. 59).

1592 C. ESTEPA DÍEZ: "Estructura de poder en Castilla (siglos XII - XIII). El poder señorial en las merindades burgalesas. En III Jornadas burgalesas de Historia (3 1991). Burgos en la Plena Edad Media. Burgos, Asociación Provincial de Libreros de Burgos. 1994. (pp. 245 - 294).G. MARTÍNEZ DÍEZ: Libro Becerro de las Behetrías... ob. cit. (pp. 616 - 617).

1593 G. MARTÍNEZ DÍEZ: Génesis histórica de la provincia de Burgos y sus divisiones administrativas. Burgos, Aldecoa. 1983.

1594 Ibídem. INE. Censo de 1787. “Floridablanca”. Madrid. INE. 1989.

1595 G. MARTÍNEZ DÍEZ: Libro Becerro de las Behetrías... ob. cit. (pp. 616 - 617).

1596 AGDBU. CE - 1582. RESPUESTAS GENERALES. Quintanilla de Urrilla, 6 - mayo - 1753.
} 
Quintanilla, en cualquier caso, fue siempre una localidad pequeña, con una población escasa. Sin embargo, tal y como ocurre en estos pueblos del Valle de Valdelaguna, apenas contamos con datos concretos, que nos permitan ver su evolución a lo largo de la Edad Moderna. Sabemos, no obstante, que a finales del siglo XVI, según el censo de los obispos, de 1584-87, existían en este pueblo 14 vecinos ${ }^{1597}$. No tenemos más datos hasta mediados del siglo XVIII, con el Catastro del Marqués de Ensenada, que da una cifra de 22’5 vecinos ${ }^{1598}$. Esta cantidad se transforma, a finales de esta misma centuria, según el censo de Floridablanca, de 1787, en 106 habitantes $^{1599}$, lo cual, si aplicamos el coeficiente medio de la zona, que situamos en 3’5 aproximadamente ${ }^{1600}$, observamos que se produce un significativo crecimiento.

Los medios de vida de estos habitantes estuvieron basados fundamentalmente en la ganadería lanar trashumante, como ocurre en el resto de los pueblos de Valdelaguna, formando parte, junto con ellos, de la Cuadrilla de San Pedro de Vega, que aglutinaba a los más importantes ganaderos trashumantes de esta zona de la sierra burgalesa. Esta economía se completaba con una agricultura de secano, que recogía principalmente trigo camuña, centeno, cebada y algo de avena, y una ganadería estante, centrada en la cría de bueyes, vacas, ovejas de raza churra, cabras y algún cerdo.

El propio pueblo de Quintanilla se encuentra situado en el fondo de una suave hondonada, surcada por el pequeño río que lleva su nombre, con su apretado caserío dispuesto en la ladera que mira hacia el mediodía. Se trata, en todos los casos, de edificios sencillos, de una o dos plantas, levantados en piedra, con muros de sillarejo o mampuesto de grueso calibre, propios de la arquitectura popular de la zona. Dentro de

\footnotetext{
1597 T. GONZÁLEZ: Censo de población de las provincias y partidos de la Corona de Castilla en el siglo XVI... Ed. Facsímil. Madrid, Imprenta Real. 1829.

1598 Vecindario de Ensenada 1759. Vol. I. Madrid, Centro de Gestión Catastral y Cooperación Tributaria: Tabapress. D. L. 1991.

1599 INE. Censo de 1787. “Floridablanca”. Madrid. INE. 1989.

1600 Ver capítulo de: Población.
} 
esta tradición podemos incluir también la iglesia parroquial y la ermita de San Bartolomé, que preside el pueblo.

\section{Iglesia de San Martín de Tours.}

La iglesia de Quintanilla, dedicada a San Martín, se encuentra situada en la parte meridional del pueblo, en el punto más bajo de todo el conjunto del caserío. Es un edificio sencillo, cuya fábrica actual constituye el resultado final de una serie de remodelaciones recientes, que han acabado con la mayor parte de los elementos antiguos. Resulta, por lo tanto, prácticamente imposible encuadrarlo dentro de un estilo concreto.

Su planta dibuja un amplio rectángulo, orientado hacia naciente, al cual se adosan una recogida sacristía, sobre el muro del testero, y la torre, en el lado septentrional, a la altura de los pies. Su imagen exterior, por lo tanto, muestra una sencilla estructura de tipo caja, con muros de mampostería, reforzados en las esquinas con sillares de mayor tamaño. Parte de su fachada principal, levantada sobre el muro de los pies, sin embargo, presenta también paramentos de sillería y sillarejo, que pierden calidad a medida que ascendemos por ella. En la parte central de esta fachada se abre la puerta de entrada, la cual está formada por un sencillo arco de medio punto de amplio dovelaje, sin ningún tipo de ornamentación. El muro que se extiende sobre ella queda rematado por un perfil triangular, bajo el cual se aprecian restos de dos vanos coronados con arco de medio punto, hoy cegados, correspondientes a una antigua espadaña. Junto a esta fachada principal, en su parte septentrional, se incorpora la torre, la cual está formada por un potente prisma de base cuadrangular, articulado en cuatro pisos, ligeramente separados por pequeñas líneas de imposta. Todos ellos presentan muros de mampostería con refuerzo de sillares en las esquinas, salvo el piso superior, que forma el cuerpo de campanas, el cual muestra paramentos de sillería. En este cuerpo se abre dos vanos coronados con arco de medio punto, en el lado septentrional, que mira al pueblo, y uno solo en cada uno de los tres restantes. 


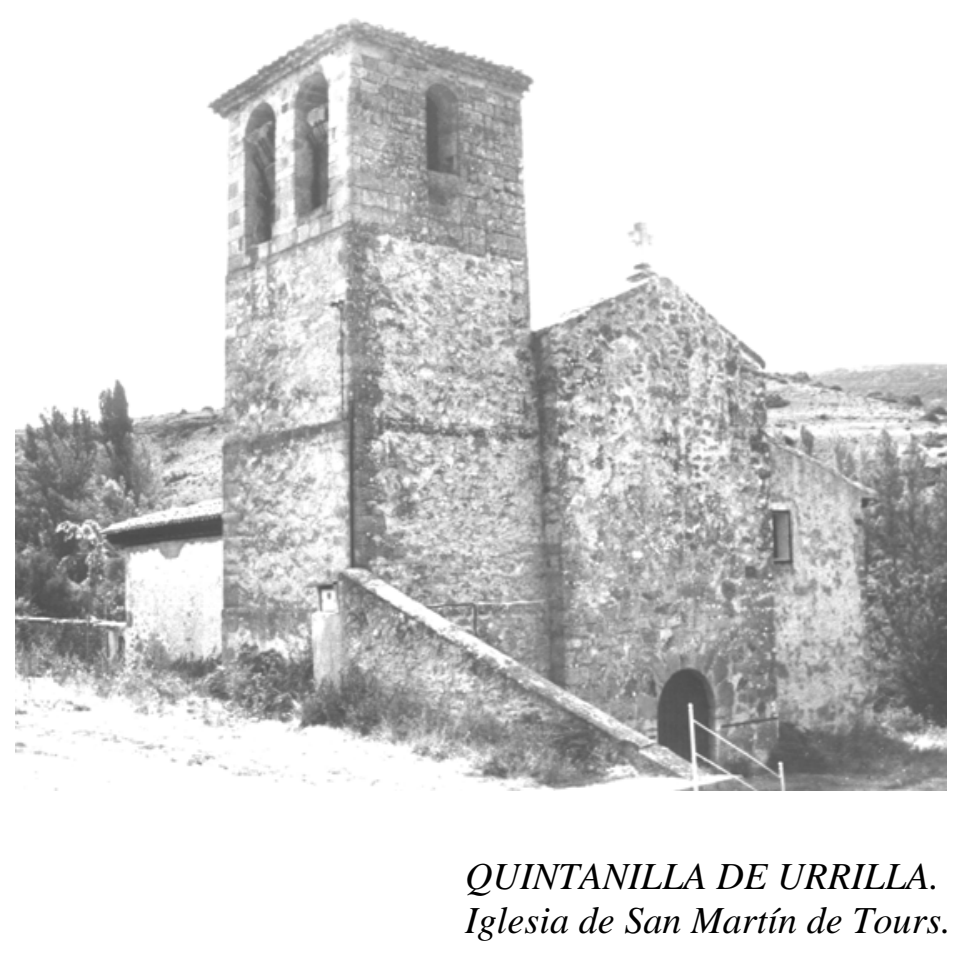

El interior ofrece un espacio de claro ámbito único, con coro alto de madera dispuesto a los pies, y cabecera delimitada simplemente por una sencilla grada y una balaustrada, también de madera. Todo este espacio se cubre con techumbre dispuesta a dos aguas sobre armadura de tipo parhilera, reforzada por gruesas vigas pareadas, colocadas a modo de tirantes. La desnudez de sus muros, solamente queda rota por la presencia de diferentes imágenes, rescatadas de su primitivo retablo. Entre ellas identificamos un gran Cristo Crucificado, que preside el altar mayor, flanqueado por una talla de San Martín y otra de la Virgen del Rosario, dispuestas sobre pequeñas peanas. En los muros laterales, también sobre peanas, encontramos dos tallas más de San Miguel Arcángel y San Antonio, todas ellas pertenecientes a los siglos XVII y XVIII. 
Resulta prácticamente imposible hacer un seguimiento de la historia constructiva de este edificio, pues, a la eliminación prácticamente total de los restos más antiguos del templo, se une la escasez de fuentes documentales, que nos informen puntualmente sobre su pasado. Las fuentes documentales conservadas, entre las que destacan los libros de fábrica, apenas consiguen informarnos sobre el devenir del templo durante el siglo XVIII. Durante esta centuria prácticamente las únicas obras que se realizan son las que tienen que ver con el mantenimiento del edificio. Estas actuaciones se hicieron, en algunos momentos, ciertamente necesarias, ante el estado de ruina al que se había llegado, por la falta de cuidados y las limitaciones económicas en las que vivía la parroquia.

En este sentido, un momento especialmente delicado fue el que se vivió en torno a los años centrales de este siglo XVIII. Así, en 1750 el visitador del Arzobispado de Burgos, D. José Cacho, se ve obligado a solicitar la colaboración de los vecinos y del concejo del pueblo, para reparar la ermita de San Bartolomé, situada en sus inmediaciones, “...por si acaso sucediese algún caso fortuito que no se pueda celebrar en la iglesia parroquial”1601. Cinco años más tarde, un nuevo visitador, D. Juan Tobías y Zuazo, vuelve a apelar a la generosidad de los feligreses para reparar la iglesia, pues de no hacerlo, el edificio corría serio riesgo de ruina, y si esto sucede, “...se mandará resumir el Santo Sacramento, y concederá licencia a el cura para que lo administre desde el lugar de Vallejimeno, que se halla cercano"1602. Todo ello, en definitiva, no hace sino reflejar las limitaciones de una parroquia sumamente pobre, que apenas podía afrontar los gastos esenciales del culto ordinario. Así lo indica, al menos, en 1803 el propio arzobispo de Burgos, D. Manuel Cid Monroy, en su visita a este pueblo, cuando dice: "Al tiempo que se executó la visita de esta referida iglesia se advirtió la suma

\footnotetext{
1601 AGDBU. LP. Quintanilla de Urrilla, parroquia de San Martín. LF. (1704 - 1762). (fols. 100 $106 v^{\circ}$ ). Visita realizada a la parroquia de San Martín de Quintanilla de Urrilla en 1750, por D. José Cacho, canónigo de la catedral de Burgos. Huerta de Arriba, 10 - noviembre - 1750.

1602 Ibídem. (fols. $116 v^{0}-119 v^{\circ}$ ). Visita realizada a la parroquia de San Martín de Quintanilla de Urrilla en 1755, por el visitador D. Juan de Tobías y Zuazo, canónigo de la catedral de Burgos. Canales, 31 julio -1755 .
} 
pobreza en que se halla por la cortedad de rentas de su fábrica, careciendo por lo mismo de algunas ropas que la faltan para la celebración de los divinos oficios”" ${ }^{1603}$.

Ermita de San Bartolomé.

Es la única ermita que existió en este pueblo, según hemos podido saber. Se encontraba situada, como hemos visto, en las inmediaciones del pueblo, en su parte septentrional, marcando el punto más alto de este casco urbano. Presenta una estructura sencilla, propia de la arquitectura popular, sin inquietudes artísticas de ningún tipo, formada por un sencillo volumen prismático sobre planta rectangular, orientada hacia naciente, con muros de mampuesto de grueso calibre, reforzados en las esquinas con sillares de mayor tamaño, y cubierta dispuesta a cuatro aguas. El acceso al interior se realiza a través de una única puerta, abierta sobre el muro meridional, que corona con sencillo arco de medio punto. A esta puerta se unen dos diminutas ventanas de dintel plano, distribuidas entre el muro meridional y de poniente.

El interior presenta un único espacio cubierto con techumbre de madera, dispuesta sobre armadura de tipo parhilera. Cuenta con un pequeño coro a los pies,

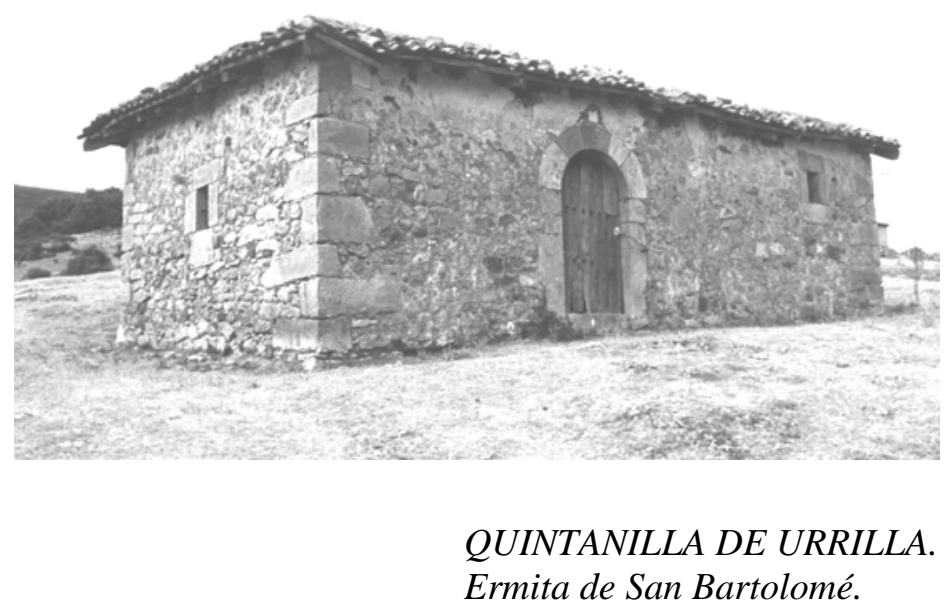

1603 Ibídem. LF. (1763 - 1836). Visita realizada a la parroquia de San Martín de Quintanilla de Urrilla en el año 1803, por D. Manuel Cid Monroy, arzobispo de Burgos. Canales, 18 - septiembre - 1803. 
1034 Arquitectura de la Edad Moderna en la sierra burgalesa.

formado por una sencilla tarima de madera, ligeramente elevada sobre el nivel del suelo. Esta estructura se corresponde con otra similar, situada en el extremo contrario, con la cual se señala el espacio de la capilla mayor.

Desconocemos el origen de esta ermita y la fecha de construcción de su edificio actual. Sin embargo, sabemos que su existencia no estuvo exenta de complicaciones, al menos durante la centuria del Setecientos, momento particularmente delicado para la suerte de buen número de templos de este tipo, dentro de nuestra comarca de estudio. A finales de la década de 1720, por ejemplo, su estado de conservación no debía ser del todo bueno, pues aunque en 1726 el visitador del Arzobispado de Burgos, D. Andrés Fernández de Tejada, había indicado que "tiene nezesidad de repararse y especialmente por la parte del tejado que se alla muy maltratado"1604, la visita siguiente de 1728, indica que estas labores no se habían hecho y la ermita "se alló amenazando ruina”"1605.

No obstante, el momento más difícil se produce en torno a la década de 1750, igual que había sucedido con la iglesia parroquial del pueblo. En este momento vemos como, mientras por un lado, en la visita de 1755, se ordena la reparación de la ermita para acoger el culto normal de la parroquia, ante el estado de ruina que amenazaba la iglesia, por otro, en la visita de 1755, se ponen a disposición de la fábrica de la iglesia los materiales resultantes de la posible demolición de esta ermita ${ }^{1606}$. Afortunadamente, no parece que esta última opción llegara a producirse nunca.

En la actualidad, sin embargo, esta ermita se encuentra en pie, aunque totalmente abandonada. En cualquier caso, de no emprenderse de forma inmediata las actuaciones

\footnotetext{
1604 Ibídem. LF. (1704 - 1762). (fols.51 vº - 54). Visita realizada a la parroquia de San Martín de Quintanilla de Urrilla en 1726, por D. Andrés Fernández de Tejada. Barbadillo de Herreros, 12 septiembre -1726 .

1605 Ibídem. (fols. $57-58 v^{\circ}$ ). Visita realizada a la parroquia de San Martín de Quintanilla de Urrilla en 1728, por D. Andrés Madrazo Escalera, canónigo de la catedral de Burgos: Barbadillo de Herreros, 10 julio -1728.

1606 Ibídem. (fols. $116 v^{\circ}-119 v^{\circ}$ ). Canales, 31 - julio - 1755.
} 
necesarias, todo apunta a que su enésima destrucción pudiera estar cerca. Esperemos, que en caso de producirse no sea la última. 


\section{REBOLLAR.}

La ermita de Nuestra Señora de Rebollar se encuentra situada en las estribaciones de la Sierra de la Demanda, junto al Valle de Valdelaguna, dentro de un término comunal, conocido como Trasomo, que es administrado por una junta, formada por representantes de los municipios de Barbadillo del Pez, Hoyuelos de la Sierra, Quintanilla de Urrilla y Vallejimeno. Esta junta se constituyó en 1190, tras la venta que realizó el rey Alfonso VIII, según indica un documento fechado el 12 de febrero de este año, por el cual el mencionado monarca otorgaba, con carácter perpetuo, a estos pueblos la administración del antiguo despoblado de Santa María de Rebollar. Dicho documento comienza así:

In nomine Patris et Filii et Spiritus. Amen. Praesentiantibus notum facio literas, quod ego Alde fonsus Dey gratum rez Castellar et Toleti, una cum uxore mea Alonor Regina et cum filio meo Ferrando vendo vobis concilliis de Barbadello Piseis et Vilasemeno et Qintanella de Hurriela et de Fojolos praesentibus et futuris harum villarun conciliis duos villares haeremos quorum unum villare nogscitur Sancta María de Rebollar et alterum dicitur Mosqueron pro duobus millibus arietum, quos jam a vobis recepi. Concedo ego vobis et filiis praesentibus et futuris et omni sucesioni ure praedictor duos viilares heremos jure hereditario habendos et dorebocabiliter possidendos cum terminis paseuis aquis nemonibus fontibus et cum omnibus diretis et pertenentiis suis. Si quis hanc cartam voluerit infringere ut diminuere iram Omnipontentis Dei plenarie ineurrat maravedises $M$ sinibios mea auctoritati pactabit et dannum, quod vobis intulerit 
1038 Arquitectura de la Edad Moderna en la sierra burgalesa.

duplicabitur. Facta carta apud alberqueriam Martín Quendul Era
MCСХХVIII-II idus februari... ${ }^{1607}$.

El origen de esta ermita, por lo tanto, se encuentra vinculado al primitivo centro de culto, que existió en este antiguo despoblado, de igual modo que el comunal de Trasomo representa el término municipal que lo rodeaba. La ermita actual, sin embargo, es obra relativamente reciente, pues fue remodelada en su totalidad en 1739.

Se halla emplazada en medio de un amplio paraje de suaves laderas, cubiertas por verdes pastos, que tradicionalmente fueron aprovechados por los ganados trashumantes de estos pueblos como agostaderos. El edificio presenta una sencilla estructura de tipo caja, con una sola nave de planta rectangular, y cabecera cuadrangular con testero plano en el extremo oriental, sobre cuyo flanco meridional se adosa la sacristía. Cuenta todo el conjunto con sólidos muros de mampostería, reforzados con sillares en las esquinas, y pequeños estribo, que no llegan a culminar el muro, en las esquinas del muro del testero de la cabecera, con forma prismática, dispuestos con lados en paralelo a los lados del muro. La puerta de acceso se abre sobre el muro meridional de la nave, y está formada por un sencillo arco de medio punto, dispuesto sobre impostas planas de escaso resalte. Sobre este mismo lado se abren las dos ventanas, que iluminan la nave y la capilla mayor, las cuales presentan un trazado rectangular con dintel plano y ligero derrame hacia el exterior. Una tercera ventana se abre sobre el

\footnotetext{
1607 En el nombre del Padre, del Hijo y del Espíritu. Amen. A todos los que estas letras vieren les hago saber que yo Alfonso, por la gracia de Dios rey de Castilla y Toledo, junto con mi esposa Leonor, la reina y mi hijo Fernando, os vendo a vosotros los concejos de Barbadillo del Pez, Vallejimeno, Quintanilla de Urrilla, y de Hoyuelos, a los concejos presente y futuros de estas villas, dos villorrios despoblados de los cuales uno se llama Santa María de Rebollar y el otro Mosqurón, por los dos mil carneros, que de vosotros ya he recibido. Yo os concedo a vosotros a vuestros hijos presente y futuros y a toda vuestra sucesión gozar de estos dos villorrios despoblados que han de ser transmitidos por derecho hereditario y poseidos irrebocablemente con sus términos, pastos, aguas, laderas, fuentes y con todos sus derechos y pertenencias. Si alguien osare violar esta carta o disminurila caiga sobre él la ira plena de Dios Omnipresente, pagará al contado a mi autoridad mil maravedies y a vosotros el doble del daño que
} 


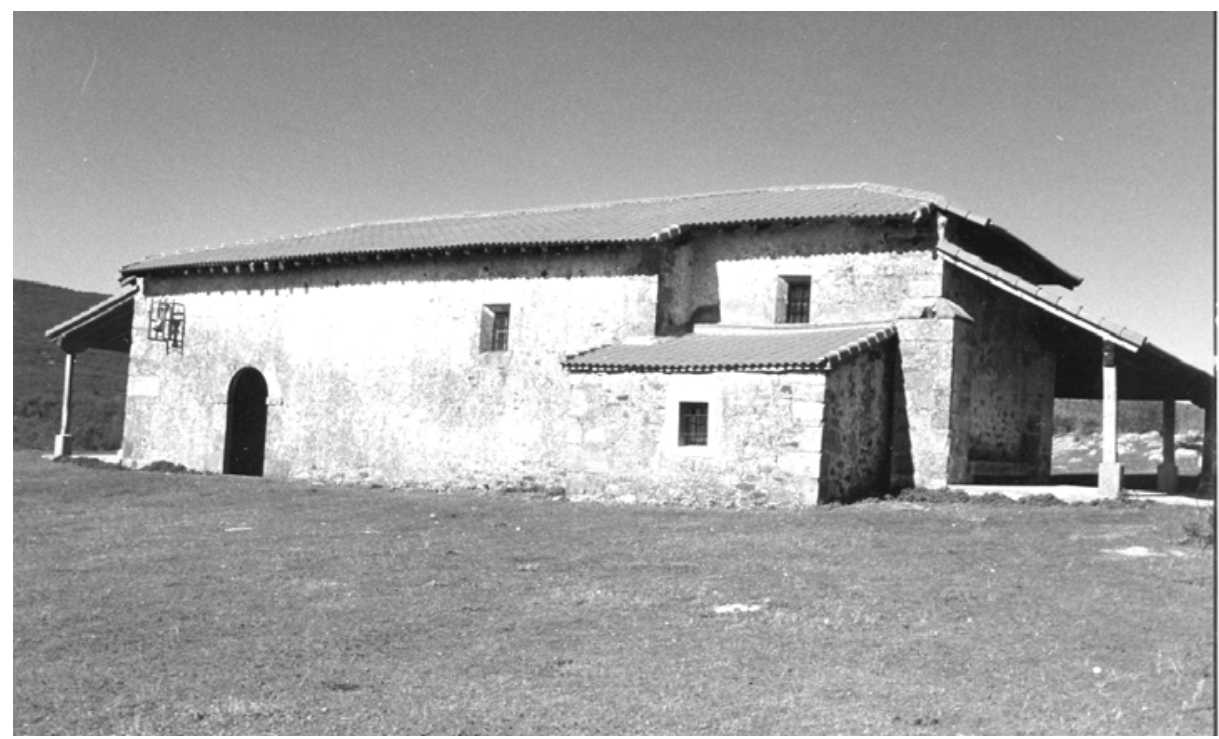

TRASOMO. Ermita de

Santa María de Rebollar.

muro de los pies, la cual permite contemplar el altar mayor desde el exterior. Sin embargo, el elemento más característico, que presenta la imagen exterior de este templo, lo constituye el amplio pórtico, que se extiende por sus fachadas oriental, septentrional y de poniente. Está formado por una acentuada prolongación del alero del tejado, que descansa sobre pies derechos de madera, alzados sobre piedras poyales y coronados con zapatas. Bajo esta cubierta se protegen los feligreses, que acuden hasta aquí en romería, los cuales se reparten este espacio, en función del pueblo del que proceden ${ }^{1608}$.

En el interior, el espacio correspondiente a la nave cuenta con un pequeño coro alto de madera en la zona de los pies, cubriendo todo este espacio con sencilla

os haya hecho. Dada esta carta en la alberguería de Martín Duendul. Era de mil doscientos veinticinco el doce de febrero...(transcripción de D. SALAS GARCÍA).

1608 Los llegados desde Vallejimeno se sitúan en el lado este, los de Barbadillo del Pez y Quintanilla de Urrilla se reparten el flanco septentrional, mientras que el lado de poniente es para los feligreses de Hoyuelos de la Sierra. Esta tradición se sigue conservando en la actualidad, donde la fiesta en honor de Nuestra Señora de Rebollar es una de las más respetadas por los descendientes de estos pueblos, y de las más populosas de la zona. 
techumbre dispuesta a tres aguas sobre armadura de madera de tipo parhilera. Sobre el extremo oriental se abre la cabecera, a la cual se accede a través de un arco de medio punto de intradós cajeado, apeado sobre pilastras toscanas de fuste también cajeado. Este ámbito se cubre con bóveda de crucería estrellada con terceletes, marcando así su carácter preponderante. El retablo que decora este altar mayor es una obra churrigueresca sin policromar, realizado hacia mediados el siglo XVIII, y cuenta con la imagen de Nuestra Señora de Rebollar en el nicho central y San Martín en el remate.

Esta ermita, como vimos en su momento ${ }^{1609}$, fue realizada en 1739 por los maestros Juan de Maurtúa y Juan de Arrieta, los cuales ajustaron su trabajo en 4.166 reales y 24 maravedís ${ }^{1610}$. Esta postura representaba exactamente una rebaja de una sexta parte sobre los 5.000 reales, que el anterior adjudicatario de la obra, el maestro de cantería, Bartolomé González, había presentado tan solo unos meses antes ${ }^{1611}$. El resultado es una obra sencilla, de marcado carácter popular, en la cual encontramos diferentes elementos propios de la estética clasicista, que impera en esta zona durante toda la primera mitad del siglo XVIII.

\footnotetext{
1609 Ver capítulo: Actividad constructiva. Evolución estilística. Siglo XVIII.

1610 AHPBU. PN. Valle de Valdelaguna. Leg. 9803/1, fols. 15 - 16. Manuel Gil de la Cuesta. Vallejimeno, 9 - mayo - 1739.

1611 AHPBU. PN. Valle de Valdelaguna. Leg. 9803/1. fols. 1 - 4v $\mathrm{v}^{\circ}$. Manuel Gil de la Cuesta. Barbadillo de Herreros, 12, enero, 1739.
} 
REGUMIEL DE LA SIERRA.

Esta localidad se encuentra situada en el extremo oriental de nuestra zona de estudio, sobre las estribaciones de la sierra de los Picos de Urbión, en plena comarca de pinares. Su término municipal, por lo tanto, se halla poblado por un tupido bosque de pinos, salpicado por algunas manchas de robledales y hayas, estas últimas, en los lugares más húmedos y umbríos. De este modo, la economía de sus habitantes estuvo vinculada al aprovechamiento de los recursos forestales de estos montes.

El origen del término Regumiel, aunque no está del todo claro, parece proceder de la unión de Río y Gomiel, este último tomado de la derivación de Zumiel, nombre del río que cruza su actual casco urbano de este pueblo ${ }^{1612}$. Esta denominación la encontramos ya en sus referencias más antiguas, de los siglos XIII ${ }^{1613}$ y XIV ${ }^{1614}$.

En la parte alta del núcleo urbano, junto a la iglesia, existen varios restos de enterramientos labrados en piedra, de época altomedieval, fechados entre los años finales del siglo IX y el siglo $\mathrm{X}^{1615}$, con lo cual debemos situar en este momento la

1612 Fr. V. de la CRUZ: “Notas para la historia de Regumiel de la Sierra (Burgos)”. BIFG, $n^{\circ}$ 175, (1958). pp. $309-320$.

1613 G. MARTÍNEZ DÍEZ: Pueblos y alfoces burgaleses de la repoblación. Valladolid. Junta de Castillo y León. Consejería de Educación y Cultura. 1997. (pp 176).

1614 G. MARTÍNEZ DÍEZ: Libro Becerro de las Behetrías. Estudio y texto crítico. León, Centro de Estudios e Investigación San Isidoro. Caja de Ahorros y Monte de Piedad. Archivo Histórico Diocesano. 1981. (pp.621).

1615 A. del CASTILLO: Excavaciones altomedievales en las provincias de Soria, Logroño y Burgos. Madrid, Comisaría General de Excavaciones Arqueológicas. 1972. 
aparición de esta población. Sin embargo, las primeras referencias escritas no se producen hasta el año 1213, con motivo de su incorporación al señorío del monasterio de San Pedro de Arlanza ${ }^{1616}$. Estos desfases, aunque no tan acentuados, vemos que suelen ser frecuentes dentro de esta comarca ${ }^{1617}$.

El recorrido histórico de este pueblo, en cierto modo, es bastante parecido al resto de los pueblos burgaleses de esta zona de pinares. De este modo, hasta los inicios del siglo XII lo encontramos encuadrado dentro del gran alfoz de Lara ${ }^{1618}$. A partir de este momento, una vez extinguido este sistema administrativo, Regumiel queda incluida en la Merindad Menor de Santo Domingo de Silos ${ }^{1619}$, como la mayor parte de los pueblos de su entorno.

En la Edad Moderna, dentro de la estructura fiscal, esta localidad forma parte, desde el siglo XVI, del partido de las Tierras del Condestable, de la provincia de Burgos $^{1620}$, para pasar más tarde, ya en el siglo XVIII, tras la reforma borbónica, a quedar vinculado al partido de Aranda ${ }^{1621}$. En el plano jurisdiccional, como hemos visto, Regumiel depende, desde el año 1213 del señorío de abadengo del monasterio de San Pedro de Arlanza, por permuta con el rey Alfonso VIII, que a cambio obtenía diferentes localidades próximas a Burgos, dependientes de este cenobio, con las cuales

\footnotetext{
1616 L. SERRANO: Cartulario de San Pedro de Arlanza. Madrid, Centro de Estudios Históricos, 1925. (pp.252 - 254, 257 - 261).

1617 E. PASTOR DÍAZ DE GARAYO: Castilla en el tránsito de la Antigüedad al Feudalismo. Poblamiento, poder político y estructura social del Arlanza al Duero. (siglos VII - XI). Valladolid, Junta de Castilla y León. Consejería de Educación y Cultura. 1966. (pp. 50).

1618 G. MARTÍNEZ DÍEZ: Pueblos y alfoces burgaleses... ob. cit. (pp 176).

1619 C. ESTEPA DÍEZ: "Estructura de poder en Castilla (siglos XII - XIII). El poder señorial en las merindades burgalesas. En III Jornadas burgalesas de Historia (3 1991). Burgos en la Plena Edad Media. Burgos, Asociación Provincial de Libreros de Burgos. 1994. (pp. 245 - 294).G. MARTÍNEZ DÍEZ: Libro Becerro de las Behetrías... ob. cit. (pp. 621).

1620 G. MARTÍNEZ DÍEZ: Génesis histórica de la provincia de Burgos y sus divisiones administrativas. Burgos, Aldecoa. 1983.

1621 Ibídem. INE. Censo de 1787. “Floridablanca”. Madrid. INE. 1989.
} 


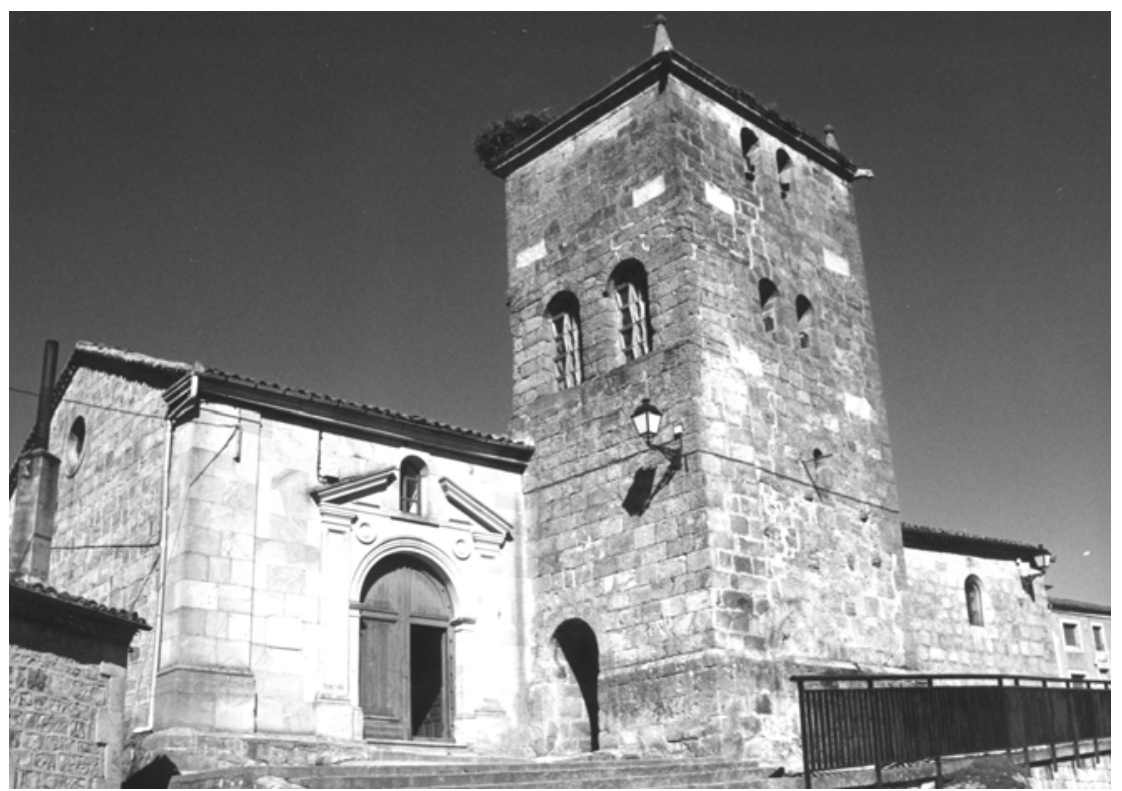

REGUMIEL DE LA SIERRA.

Iglesia de San Adrián.

pretendía dotar su nueva fundación del Hospital del Rey ${ }^{1622}$. Más adelante, en un momento que no podemos determinar, aunque suponemos que debió producirse a mediados del siglo XVI, Regumiel corre la misma suerte que la vecina localidad de Quintanar de la Sierra, y pasa a convertirse en señorío solariego, dependiente, en este caso, de los Duques de Veraguas ${ }^{1623}$. Esta nueva condición continúa invariable hasta la extinción de los regímenes señoriales. En el plano eclesiástico, vemos cómo su única parroquia queda incluida, desde el Concilio de Burgos de 1136, dentro de la Diócesis de Osma ${ }^{1624}$. Dentro de esta circunscripción permanece hasta mediados del siglo XX.

Regumiel fue siempre una población pequeña, de escasos habitantes, cuyo número, aunque experimenta un notable progreso durante el siglo XVI, no deja de

\footnotetext{
1622 Fr. V. de la CRUZ: “Notas para la historia de Regumiel de la Sierra...”. ob. cit.

1623 ADPBU. CE - 1633. RESPUESTAS GENERALES. Regumiel de la Sierra, 24 - mayo - 1753.

1624 L. SERRANO: El obispado de Burgos y Castilla primitiva. Desde el siglo V al XIII. Madrid, Centro de Estudios Históricos. 1935. Tomo I (pp. 333 - 337, 374 - 378, 414 - 418).
} 
descender en los dos siglos siguientes. Los escasos datos de que disponemos, en este apartado, así parecen confirmarlo. De este modo, vemos que el siglo XVI se corresponde con el momento de máximo esplendor y prosperidad del pueblo, pues los 34 vecinos, que arroja el censo de $1541^{1625}$, se transforman en 52 vecinos entres los años 1584-87, según el censo de los obispos ${ }^{1626}$, y poco después en 57 vecinos, según el censo de $1591^{1627}$. El único dato que tenemos para la centuria siguiente es el censo de la sal de 1631, según el cual la población había quedado reducida a menos de la mitad, con sólo 25 vecinos contabilizados ${ }^{1628}$. Este descenso se prolonga durante el siglo XVIII, pues el Catastro del Marqués de Ensenada, de mediados de esta centuria, nos muestra una población de sólo 14 vecinos $^{1629}$, los cuales quedan convertidos en 48 habitantes, en el censo de Floridablanca de $1787^{1630}$.

La economía de estos habitantes, como la del resto de los pueblos de la zona de pinares, estuvo basada, tal y como hemos indicado, en el aprovechamiento de sus recursos forestales, y en la carretería y el transporte de mercancías. Así lo indica, al menos, la información proporcionada por el Catastro del Marqués de Ensenada, el cual nos dice, que de los 14 vecinos que había en este momento en el pueblo, 4 eran carreteros, mientras que el resto se empleaban como ayudantes de aquellos, o como arrieros vinculados a este oficio ${ }^{1631}$. También encuentran especial desarrollo aquí otras actividades vinculadas a este trabajo, como es la cría de ganado boyal y asnal, este último para el tráfico arriero. ${ }^{1632}$ La agricultura, sin embargo, prácticamente brilla por

\footnotetext{
1625 AGS. Contaduría General. Leg. 768. (fols.62).

1626 T. GONZÁLEZ: Censo de población de las provincias y partidos de la Corona de Castilla en el siglo XVI... Ed. Facsímil. Madrid, Imprenta Real. 1829.

1627 Censo de Castilla de 1591. Vecindario. Madrid, Instituto Nacional de Estadística. 1984.

1628 AGS. Dirección General del Tesoro, inventario 24. Leg. 1168 - 2.

1629 Vecindario de Ensenada 1759. Vol. I. Madrid, Centro de Gestión Catastral y Cooperación Tributaria: Tabapress. D. L. 1991.

1630 INE. Censo de 1787. "Floridablanca”. Madrid. INE. 1989.

1631 ADPBU. CE - 1633. RESPUESTAS GENERALES. Regumiel de la Sierra, 24 - mayo - 1753.

1632 Ibídem.
} 
su ausencia, si exceptuamos algunas pequeñas huertas, que, de modo testimonial, se cultivan en las inmediaciones del pueblo.

El núcleo urbano de Regumiel se asienta en una de las partes más bajas de su término municipal, ocupando una suave ladera orientada hacia el sudoeste. Las nuevas construcciones, que forman el barrio más reciente, sin embargo, se extienden ya en la parte más llana, que forma la pradera abierta a los pies de esta ladera. El apretado caserío, que forma el barrio de la parte alta, está formado también, en su mayoría, por construcciones relativamente recientes, pues fueron levantadas a partir de los primeros años del siglo XIX, debido a la destrucción del núcleo anterior por un devastador incendio, provocado por las tropas francesas durante la guerra de la Independencia. Al parecer, este hecho pretendía servir de escarmiento a todos aquellos grupos hostiles a la presencia francesa, que anidaban en estas sierras ${ }^{1633}$. Es por ello, que apenas existen edificios de interés, pertenecientes a la Edad Moderna. La única construcción, que albergan algún resto de una fábrica anterior a esta fecha es su iglesia parroquial.

\section{Iglesia de San Adrián.}

Se encuentra situada en la parte alta del pueblo, asentada, en su mayor parte, sobre un sólido afloramiento rocoso, en el que encontramos labradas diferentes tumbas, fechadas entre finales del siglo IX y X. El centro de culto vinculado a esta necrópolis, sin duda, debió constituir el origen del templo actual.

Este templo, en gran medida, es una obra relativamente reciente, en la cual se conservan muy pocos restos de sus fases más antiguas. La mayor parte de su estructura es fruto de la reconstrucción efectuada a partir del incendio de 1816, a la cual, debemos unir también la importante renovación efectuada en 1966, después de que el día 8 de noviembre de ese año, una buena parte del edificio se viniera abajo ${ }^{1634}$. De este modo, lo que se conserva del templo anterior apenas alcanza a algunas partes de sus muros, entre

\footnotetext{
1633 Fr. V. de la CRUZ: “Notas para la historia de Regumiel de la Sierra...”. ob. cit. 1634 Ibídem.
} 
los que se incluye la zona donde se halla la portada, y la estructura de la torre, con sus añadidos posteriores.

Este templo actual se levanta sobre una estructura de una sola nave de trazado rectangular. Fuera de este rectángulo quedan la cabecera y la sacristía, añadidas sobre el extremo oriental, la torre, que se incorpora sobre el flanco del mediodía, y una pequeña capilla, dedicada a la Virgen de Fátima, en el lado septentrional. Su imagen exterior queda dominada por el gran prisma, que dibuja su única nave, constituida por muros de sillería de escaso desarrollo en altura y cubierta a dos aguas. Entre los elementos anexos destaca la torre, dispuesta, como hemos visito, sobre el flanco meridional. Está formada por un gran prisma de base cuadrangular, de un solo cuerpo, con muros de sillería rematados por una gruesa cornisa, que da paso al tejado, donde se elevan cuatro pináculos piramidales con bola. En la parte superior de estos muros se abren los vanos, donde se alojan las campanas, los cuales aparecen dispuestos en dos niveles, que debemos interpretar como el resultado de dos fases constructivas diferentes. Todos ellos enmarcados con arcos de medio punto. En la parte inferior, por su parte, un pequeño pasadizo, cubierto con bóveda de medio cañón, atraviesa de lado a lado su base.

Sobre este muro meridional de la nave se abre también la puerta de acceso, dispuesta en su tramo final. Es una obra de estilo clasicista, correspondiente, seguramente, a la segunda mitad del siglo XVIII, con estructura de escaso resalte sobre el plano del muro y absoluta contención ornamental. Presenta un vano con arco de medio punto de rosca moldurada con tondos en las enjutas. A los lados se incorporan pilastras dóricas de fuste cajeado, sobre las que se extiende un frontón recto partido, con una pequeña ventana con arco de medio punto, abierta sobre el tímpano. Constituye, sin duda, la pieza más destacada de la imagen exterior del templo, pues en el resto no encontramos más elementos de interés. Sobre estos muros se abren también las ventanas, que iluminan el espacio interior, formadas por vanos coronados con arco de medio punto y fuerte derrame hacia el interior. A ella se unen dos tondos, dispuestos sobre el muro del testero de la capilla mayor, y el de los pies, respectivamente. 


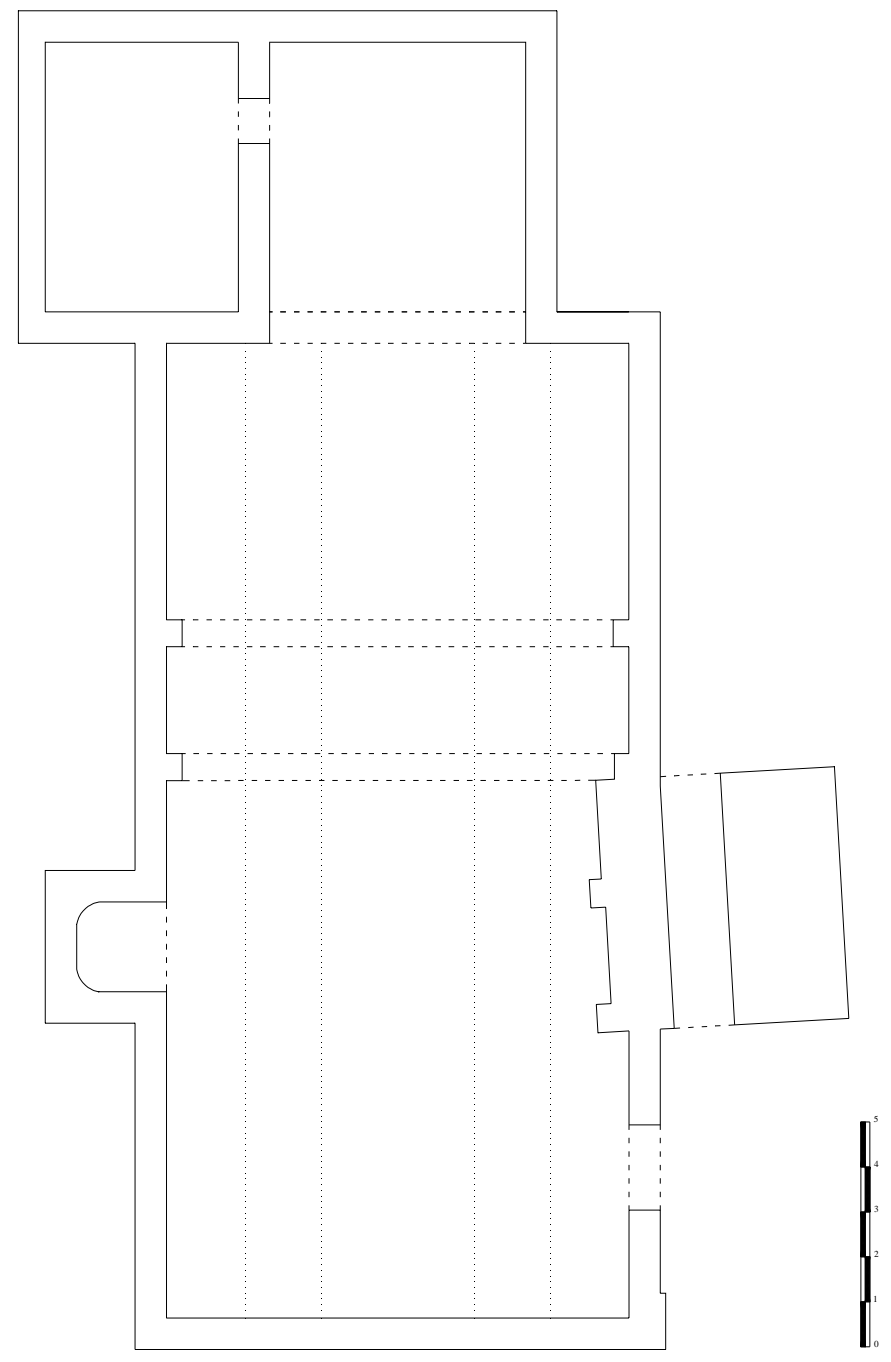

REGUMIEL DE LA SIERRA.

Iglesia de San Adrián. Planta.

En el interior nos encontramos con un espacio de ámbito único, con coro alto a los pies, cubierto todo ello con un moderno artesonado de madera, en forma de artesa 
invertida. La capilla mayor, abierta sobre el extremo oriental, queda precedida por un amplio arco de medio punto, y cubre su espacio con bóveda de medio cañón dispuesta sobre una gruesa cornisa, que marca el remate del muro. Sobre el lado del evangelio, en la parte final de la nave, se abre también la pequeña capilla dedicada a la Virgen de Fátima, formada por un espacio muy recogido de frente semicircular y testero plano al exterior, al cual se accede a través de un arco de medio punto ligeramente rebajado, de rosca recorrida por triple moldura de tres cuartos de bocel.

Esta imagen interior se completa con la decoración de los diferentes altares. En el altar de la capilla mayor encontramos una pequeña imagen gótica de la Virgen con el Niño, depositada en el interior de una hornacina, a la que acompañan, una talla de San Adrián, colocada sobre ella, y dos figuras a los lados, de la Virgen y el Sagrado Corazón de Jesús, sobre peanas. Junto a la entrada a la capilla mayor, se incorporan dos retablos colaterales de estilo neogótico, dedicados a Cristo Crucificado con la Virgen y San Juan, el del lado del evangelio, y a la Virgen con el Niño, el de la epístola. La mayoría de estas imágenes son obras modernas, igual que la propia estructura arquitectónica del edificio.

Las intensas remodelaciones, que ha sufrido este templo en época moderan, hacen que resulte prácticamente imposible determinar el aspecto que pudo presentar su fábrica durante la Edad Moderna, y las fases constructivas que aquí existieron. En este sentido, tal vez, la única obra que, con seguridad, podemos situar dentro de este período es la portada, la cual ha conservado su estructura primitiva, no sin ciertos retoques. El resto, como decimos, debemos considerarlo como fruto de las reconstrucciones y remodelaciones efectuadas durante los siglos XIX y XX. 


\section{REVENGA.}

El término de Revenga, se encuentra situado entre las sierras de Neila y Picos de Urbión, en plena comarca de pinares. Se trata de un territorio comunal, que administran de forma conjunta, desde finales del siglo XV, los concejos de Canicosa, Quintanar y Regumiel de la Sierra ${ }^{1635}$, por donación del monasterio de San Pedro de Arlanza ${ }^{1636}$. Este territorio se corresponde, en definitiva, con el término de un antiguo despoblado, conocido como Revenga, que estuvo habitado aproximadamente hasta el siglo XII.

Los restos materiales de este despoblado forman un interesante conjunto, constituido por una iglesia rupestre de planta de una sola nave de trazado rectangular y cabecera plana, una amplia necrópolis, con tumbas labradas en roca, de las que se han excavado 132, y un hábitat, en el que aparecen varias casas de planta rectangular apoyadas sobre roca ${ }^{1637}$. Todos estos restos sugieren, para el profesor A. del CASTILLO, una cronología situada entre finales del siglo IX y el siglo $\mathrm{X}^{1638}$. M. RIU,

1635 G. MARTíNEZ DÍEZ: Pueblos y alfoces burgaleses de la repoblación. Valladolid. Junta de Castillo y León. Consejería de Educación y Cultura. 1997. (pp. 186).

1636 P. GIL ABAD: Quintanar de la Sierra, un pueblo burgalés de la comarca de pinares. Burgos, Excma. Diputación de Burgos. 1986. (pp.130).

1637 J. ANDRIO GONZALO: “La Edad Media a través de los estudios arqueológicos”. En Historia de Burgos II. Edad Media (2). Burgos, Caja de Ahorros Municipal de Burgos. 1986. (pp.208 - 209).

1638 A. del CASTILLO: Excavaciones altomedievales en las provincias de Soria, Logroño y Burgos. Madrid, Comisaría General de Excavaciones Arqueológicas. 1972. (pp. 8 - 16). 
1050 Arquitectura de la Edad Moderna en la sierra burgalesa.

sin embargo, encontró restos cerámicos y de tejas, fechables entre los siglos X y XII, los cuales permiten extender notablemente el período de ocupación de este núcleo ${ }^{1639}$.

Dentro de este mismo término encontramos también el eremitorio de la Cerca, muy maltratado por las intervenciones posteriores, el cual debía tratarse de un asentamiento de importancia equiparable al de Cueva Andrés, de Quintanar de la Sierra $^{1640}$.

Las fuentes documentales, por su parte, nos hablan también de la existencia, en este lugar, de un monasterio dedicado a San Millán, el cual, en el año 1008, debía encontrarse deshabitado, pues el hablar de él se utiliza el término desertum ${ }^{1641}$. Más tarde, durante la segunda mitad de este siglo XI, encontramos nuevas referencias de este monasterio, en las cuales se indica que la familia de los Lara, a través de uno de sus miembros, D. Gonzalo Núñez de Lara, poseía el control del cenobio, el cual ya no aparece como despoblado $^{1642}$. Esta familia lo dona en 1089 al monasterio de San Millán de la Cogolla, del cual depende a partir de este momento ${ }^{1643}$. Después de esta fecha, sin embargo, no volvemos a encontrar más referencias, que nos hablen sobre él.

1639 M. RIU: “Apuntes comentados en un viaje arqueológico por tierras de la Castilla medieval”. En la España Medieval. Estudios dedicados al profesor D. Julio González. Madrid, Universidad Complutense. 1980. (pp. 480).

1640 G. MARTÍNEZ DÍEZ: Pueblos y alfoces burgaleses... ob. cit. (pp.178); A. MONREAL JIMENO: “Eremitorios rupestres en territorio burgalés durante la Alta Edad Media”. En II Jornadas burgalesas de historia (2 ${ }^{a}$ Burgos. 1990). Burgos en la Alta Edad Media. Burgos, Asociación Provincial de Libreros de Burgos. 1991; P. GIL ABAD: Quintanar de la Sierra, un pueblo burgalés de la comarca de pinares. Burgos, Excma. Diputación de Burgos. 1986. (pp.98 - 99).

1641 G. MARTÍNEZ DÍEZ: Pueblos y alfoces burgaleses... ob. cit. (pp. 186); I. ÁLVAREZ BORGE: Poder y relaciones sociales en Castilla en la Edad Media. Los territorios entre el Arlanzón y el Duero en los siglos $X-X I V$. Salamanca, Consejería de Educación y Cultura. Junta de Castilla y León. 1996. (pp. 60); E. PASTOR DÍAZ DE GARAYO: Castilla en el tránsito de la Antigüedad al Feudalismo. Poblamiento, poder político y estructura social del Arlanza al Duero (siglos VII - IX). Valladolid, Consejería de Educación y Cultura, Junta de Castillo y León. 1996. (pp. 44).

1642 I. ÁLVAREZ BORGE: Poder y relaciones sociales en Castilla en la Edad Media... ob. cit. (pp. 60).

1643 L. SERRANO: Cartulario de San Millán de la Cogolla. Madrid, Centro de Estudios Históricos. 1930. (PP. 86, 320). 


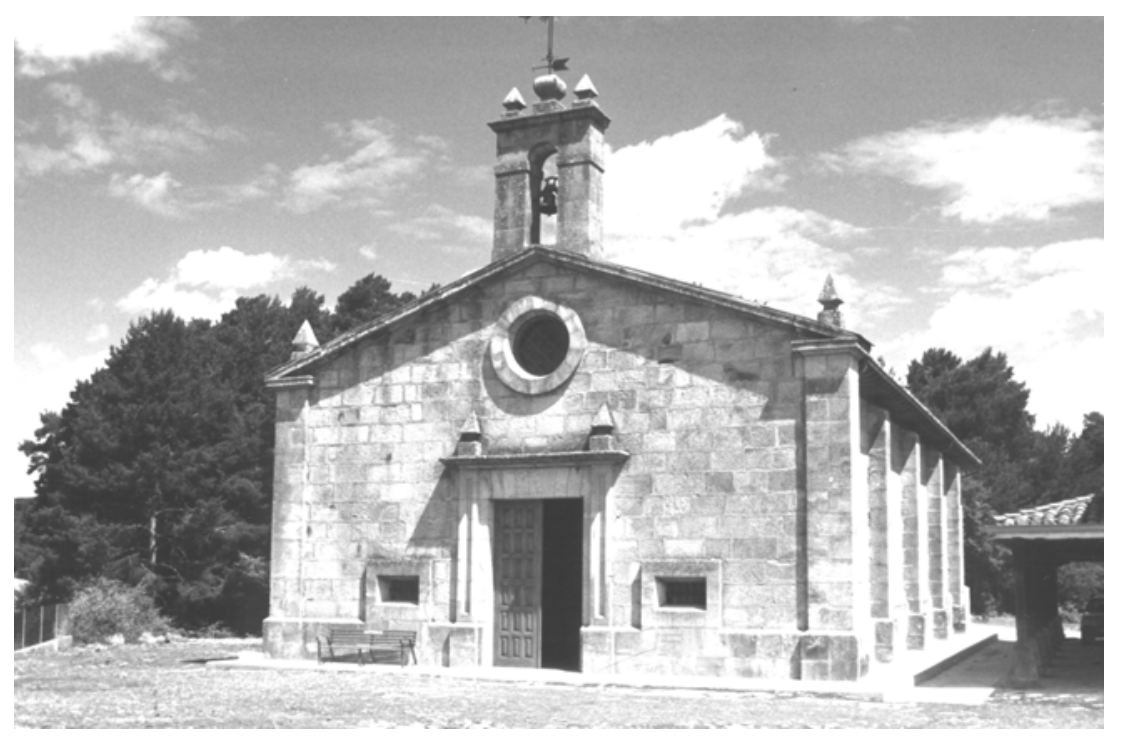

REVENGA. Ermita de Nuestra Señora de Revenga.

En lo que se refiere al propio núcleo de Revenga, sabemos que quedó convertido en señorío de abadengo a partir del 23-VIII-1213, dependiente del monasterio de San Pedro de Arlanza, por permuta con el rey Alfonso VIII, el cual obtenía a cambio el control de diferentes localidades situadas en las inmediaciones de Burgos, con las que pretendía dotar su fundación del Hospital del Rey ${ }^{1644}$. Poco más de dos siglos más tarde, una vez despoblado este núcleo, como hemos dicho, su término pasa a depender de las localidades de Canicosa, Quintanar y Regumiel, situadas a su alrededor, las cuales han seguido administrándolo hasta hoy.

Las únicas edificaciones, que existen en la actualidad en este término de Revenga, son las que forman el conjunto de la ermita, donde se venera la imagen de

1644 Ibídem. Cartulario de San Pedro de Arlanza. Antiguo monasterio Benedictino. Madrid, Centro de Estudios Históricos. 1925. (pp. 252 - 254; 257 - 261). 
Nuestra Señora de Revenga, y la casa de juntas, en la que se reúnen los representantes de estos tres municipios, que participan en su administración. Estos dos edificios se hallan situados en medios de una amplia campa, abierta en un claro del espeso bosque de pinos, que puebla todo este terreno. Las dos son construcciones recientes, surgidas de la intensa labor renovadora desarrollada en la década de 1920.

La ermita muestra una sencilla estructura de tipo caja, sobre planta rectangular orientada hacia el norte, sobre cuyo muro del testero se añade la sacristía. Toda la estructura está realizada en piedra, con muros de sillería al exterior, y sillarejo en su cara interna, reforzados mediante sólidos estribos, dispuestos en sus lados mayores. La cubierta está formada por una simple techumbre de teja sobre estructura de madera, dispuesta a dos aguas. En su imagen exterior su elemento más destacado lo constituye su fachada principal, levantada sobre el muro de los pues, que mira al mediodía. Consta de una amplia puerta de dintel plano, con pilastras cajeadas a los lados y pequeña cornisa, rematada con pináculos piramidales en los extremos. Sobre esta puerta se abre un amplio óculo, enmarcado por gruesa moldura plana de escaso resalte, la cual se repite en las dos ventanas más pequeñas, que se abren a los lados de la puerta. El remate de esta fachada lo forma una esbelta espadaña de un solo vano, dispuesta sobre el vértice superior del tejado, a la cual acompañan dos pináculos piramidales, colocados en los vértices laterales. Una obra, en cualquier caso, moderna, en la que se intentan evocar ciertos rasgos característicos de la arquitectura clasicista, que tanto arraigo tuvo en toda la comarca.

En el interior, dentro del amplio espacio de ámbito único que se dibuja, únicamente podemos destacar la presencia de un coro alto de madera situado a los pies. El espacio de la capilla mayor apenas aparece señalado por una ligera elevación del suelo, mediante un escalón.

La casa de juntas, situada junto al lado oriental de la ermita, se levanta sobre amplia planta cuadrangular, con un alzado articulado en dos plantas, que se cubre con 


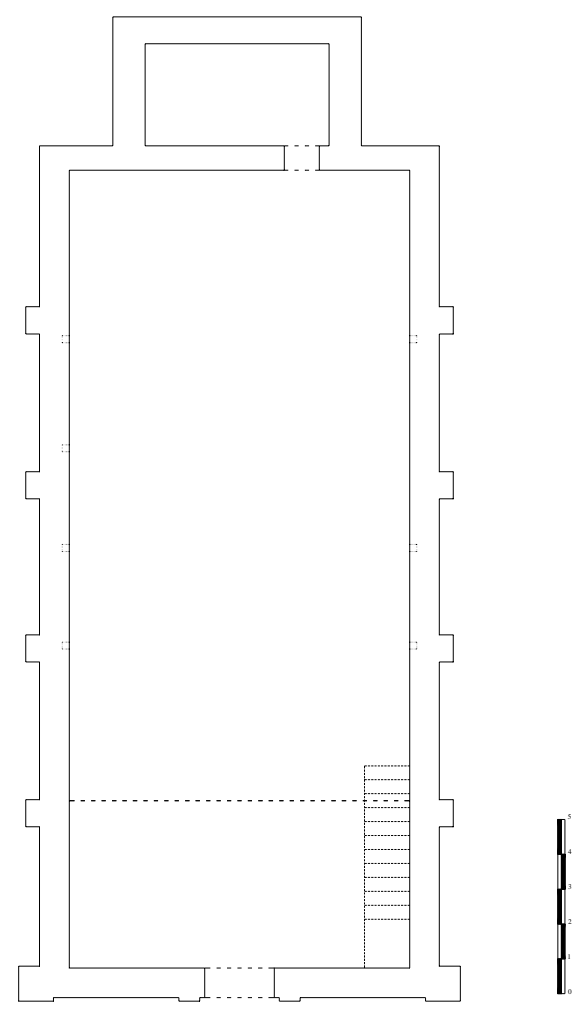

REVENGA. Ermita de Nuestra Señora de Revenga. Planta.

techumbre dispuesta a cuatro aguas. En su fachada principal, orientada hacia el mediodía, igual que la ermita, se abren tres amplios arcos de medio punto, que conducen a un espacioso soportal, que ocupa prácticamente la mitad de esta planta baja. Estos arcos se corresponden, en el piso superior, con sencillos balcones de dintel ligeramente arqueado. En las tres fachadas restantes se incorpora un pórtico corrido, formado por un tejadillo dispuesto sobre pies derechos, que alcanza sólo la altura del primer piso. Su función es la de servir de refugio a los fieles de cada uno de los tres pueblos, que participan de la administración de este lugar, cuando acuden en romería el día de la fiesta. 
RIOCAVADO DE LA SIERRA.

Riocavado de la Sierra se encuentra enclavado en plena Sierra de la Demanda, con la mayor parte de su extenso término municipal ocupado por un suelo pizarroso del Cámbrico y Precámbrico, que constituyen los materiales más antiguos de todo el territorio de la provincia de Burgos ${ }^{1645}$. Se encuentra, también muy próximo al Valle de Valdelaguna, lo cual ha hecho que comparta varios aspectos de carácter económico y social con estos pueblos, si bien en ningún momento parece que llegara a formar parte de esta agrupación de municipios.

El origen de esta localidad, con toda seguridad, debemos buscarlo en la serie de poblaciones, que se asientan en la zona entre los siglos IX y X. No obstante, las primeras referencias escritas no se producen hasta el siglo XI, con un documento fechado el 6-XII-1028 ${ }^{1646}$, en el que se da cuenta de la donación, por parte del rey Sancho de Navarra, de un tercio de los derechos de este pueblo al monasterio de San Millán de la Cogolla ${ }^{1647}$.

Riocavado formó parte, en un primer momento, del alfoz de Barbadillo del Pez, hasta que en el año $1062^{1648}$, una vez vaciado de contenido este alfoz, queda

\footnotetext{
1645 Ver capítulo: Medio físico.

1646 L. SERRANO: Cartulario de San Millán de la Cogolla. Madrid, Centro de Estudios Históricos.
} 1930. (pp. 109).

1647 I. ÁLVAREZ BORGE: Monarquía feudal y organización territorial: alfoces y merindades en Castilla (siglos X - XIV). Madrid, CISC, 1993.

1648 L. SERRANO: Cartulario de San Pedro de Arlanza. Madrid, Centro de Estudios Históricos, 1925. (pp. 131); G. MARTÍNEZ DÍEZ: Pueblos y alfoces burgaleses de la repoblación. Valladolid. Junta de Castillo y León. Consejería de Educación y Cultura. 1997. (pp 198). 
1056 Arquitectura de la Edad Moderna en la sierra burgalesa.

incorporada al alfoz de Lara ${ }^{1649}$. Desde principios del siglo XII, una vez extinguido este sistema de alfoces, pasa a formar parte de la Merindad Menor de Santo Domingo de Silos ${ }^{1650}$.

En la Edad Moderna, dentro de la organización territorial, que impone el sistema fiscal, vemos cómo Riocavado resulta una de las pocas localidades de esta zona que no pertenece al partido de las Tierras del Condestable, formando parte, por el contrario, del partido de Burgos, dentro de esta misma provincia ${ }^{1651}$. En el siglo XVIII, tras la reforma borbónica, pasa a depender del partido de Aranda, junto con los pueblos que formaban el Valle de Valdelaguna y los de la zona de pinares. En el plano jurisdiccional, hemos visto cómo en 1028 un tercio de su jurisdicción había pasado a depender del monasterio de San Millán de la Cogolla. A finales de este siglo XI, sin embargo, todo el pueblo dependía de D. Pedro Fernández, miembro del linaje de Diego Álvarez ${ }^{1652}$, señor de Carazo, el cual dona sus derechos el año 1083 al monasterio de San Pedro de Cardeña ${ }^{1653}$. A mediados del siglo XIV, según el Becerro de las Behetrías, encontramos a Riocavado nuevamente como señorío solariego, dependiendo, en esta ocasión, de D. Pedro Fernández de Velasco, de su hermana María, de Juan Sánchez de Velasco, de los hijos de Gómez Carriello, y de los hijos de Juan Martínez Leiva ${ }^{1654}$. Esta situación se mantuvo hasta mediados del siglo XV, momento en el cual D. Pedro Sánchez de Velasco y Rojas parece poseer en solitario la jurisdicción de este pueblo, transmitiéndola a sus sucesores, con el título de vizconde de Riocavado. A principios del siglo XVII, encontramos al frente de este pequeño señorío a D. Pedro Velasco y

\footnotetext{
1649 I. ÁLVAREZ BORGE: Monarquía feudal y organización territorial...ob. cit. (pp. 59).

1650 C. ESTEPA DÍEZ: "Estructura de poder en Castilla (siglos XII - XIII). El poder señorial en las merindades burgalesas. En III Jornadas burgalesas de Historia (3 1991). Burgos en la Plena Edad Media. Burgos, Asociación Provincial de Libreros de Burgos. 1994. (pp. 245 - 294).G. MARTÍNEZ DÍEZ: Libro Becerro de las Behetrías. Estudio y texto crítico. León, Centro de Estudios e Investigación San Isidoro. Caja de Ahorros y Monte de Piedad. Archivo Histórico Diocesano. 1981. (pp. 616).

1651 G. MARTÍNEZ DÍEZ: Génesis histórica de la provincia de Burgos y sus divisiones administrativas. Burgos, Aldecoa. 1983.

1652 I. ÁLVAREZ BORGE: Monarquía feudal y organización territorial...ob. cit. (pp. 83 - 88).

1653 L. SERRANO: Cartulario de San Pedro de Cardeña. (pp. 339).
} 
Albarado, biznieto del anterior, el cual había incorporado a su título el de señor de Santa Cruz del Valle y su tierra. A mediados del siglo XVIII, el Catastro del Marqué de Ensenada nos informa, que este puesto era ostentado por D. José Hechán (o Hecharoz), de Velasco, el cual presentaba los títulos de vizconde de Riocavado, Santa Cruz, Soto y Gargancho ${ }^{1655}$. En el plano eclesiástico, por último, su parroquia dependió en todo momento de la sede burgalesa.

Riocavado fue siempre una población de tipo medio, dentro del contexto de esta comarca, con un vecindario que experimentó, sin embargo, un fuerte crecimiento, durante toda la Edad Moderna. No obstante, apenas tenemos datos, que permitan ilustrar esta tendencia con todo detalle. El dato más antiguo que poseemos nos lo proporciona el censo de los obispos, de 1584-87, con una cifra de sólo 22 vecinos ${ }^{1656}$. El censo de la sal de 1631, sin embargo, muestra ya un considerable aumento, con un total de 55 vecinos $^{1657}$. Este crecimiento se continúa hasta mediados del siglo XVIII, donde el vecindario del Catastro del Marqués de Ensenada, arroja un número de 81’5 vecinos. ${ }^{1658}$ El censo de Floridablanca, de 1787, ofrece una cifra de 226 habitantes $^{1659}$. A partir de la información proporcionada por estos dos últimos censos, sabemos también, que, dentro de los 81'5 vecinos contabilizados en el vecindario del Catastro del Marqués de Ensenada, un total de 71’5 (un 87’7\%) aparecen inscritos en el registro de hidalgos, mientras que en el censo de Floridablanca, son todos los habitantes del pueblo, sin excepción, los que declaran poseer esta condición.

La economía de todos estos habitantes estuvo basada fundamentalmente en la ganadería trashumante, formando parte de la Cuadrilla de San Pedro de Vega, que se

\footnotetext{
1654 G. MARTÍNEZ DÍEZ: Libro Becerro de las Behetrías... ob. cit. (pp. 616).

1655 ADPBU. CE - 1674. RESPUESTAS GENERALES. Riocavado de la Sierra, 12 - junio - 1753.

1656 T. GONZÁLEZ: Censo de población de las provincias y partidos de la Corona de Castilla en el siglo XVI... Ed. Facsímil. Madrid, Imprenta Real. 1829.

1657 AGS. Dirección General del Tesoro, inventario 24. Leg. 1168 - 2.

1658 Vecindario de Ensenada 1759. Vol. I. Madrid, Centro de Gestión Catastral y Cooperación Tributaria: Tabapress. D. L. 1991.

1659 INE. Censo de 1787. "Floridablanca”. Madrid. INE. 1989.
} 
inscribía, a su vez, dentro del Consejo de la Mesta. Como complemento de esta economía encontramos también algunos cultivos de cereal, hortalizas y pastos, junto con algunos hatos de ganado estante, formados por ovejas de raza churra, y ganado vacuno $^{1660}$.

El caserío, que forma este pueblo, se extiende sobre una pronunciada ladera, orientada hacia el mediodía, descendiendo sus edificios hasta la orilla del río Valdorcas, que surca el fondo de este valle. En la parte superior, y presidiendo todo el pueblo, se alza su iglesia parroquial, la cual constituye, sin duda, el edificio más representativo del pueblo. Aun así, también podemos destacar aquí algunos ejemplos ciertamente interesantes de casas solariegas, cuya presencia debemos relacionar, de forma clara, con los grandes propietarios de rebaños de ovejas merinas, que aquí existieron.

\section{Iglesia de Santa Coloma.}

La iglesia de Riocavado de encuentra dedicada a Santa Coloma, santa de origen cordobés, del monasterio de Tábaro, que fue martirizada en el año 853 por los musulmanes ${ }^{1661}$. Está situada, como decimos, en la parte superior del pueblo, ligeramente separada del resto del caserío, que ha ido buscando la protección del fondo del valle. Su edificio aúna estilos tan diferentes como el románico, que vemos en la parte de la cabecera y en la torre, y el clasicismo de época tardía, en el que se encuadra la zona de la nave.

Su planta está compuesta por una sola nave de trazado rectangular, articulada en dos tramos, que se complementa, en la parte oriental, con una cabecera, formada por un presbiterio de planta cuadrangular, y una capilla mayor de testero en semicírculo. Sobre el flanco septentrional de la nave se añade una estancia alargada, que originalmente cumplía las funciones de baptisterio y granero, y a continuación aparece la torre. En el

\footnotetext{
1660 ADPBU. CE - 1674. RESPUESTAS GENERALES. Riocavado de la Sierra, 12 - junio - 1753.

1661 J. FERRANDO ROIG: Iconografía de los santos. Barcelona, Ediciones Omega. 1950. (pag. 78).
} 
lado contrario, a la altura de presbiterio, se conservan los restos de la planta de la sacristía.

Todo el edificio, a pesar de las diferentes épocas y estilos, se encuentra realizado en piedra, con muros de sillería de buena calidad, para los que se utiliza la roca arenisca local. En la parte exterior de la cabecera, el semicírculo, que forma el testero de la capilla mayor, está recorrido por una galería de amplios arcos ciegos, ligeramente apuntados, separados por columnas entregadas. En la parte central de este testero y a los lados del presbiterio, se abren ventanas de tipo aspillera, enmarcadas por estructura típicamente románica, de potente arco de medio punto soportado por pequeñas columnas con capiteles ricamente decorados.

La zona de la nave, por su parte, forma una sencilla estructura de tipo caja, de muros rematados por cornisa de papo de paloma, y reforzados por estribos de escaso resalte, que en el caso de las esquinas adoptan una posición de lados en paralelo a los lados del muro. Sobre el segundo tramo de la fachada meridional de este cuerpo se abre la puerta, formada, como vimos en su momento, por una sencilla estructura de aire clasicista, de escaso resalte sobre el plano del muro ${ }^{1662}$. Consta de un vano central con arco de medio punto de rosca ligeramente moldurada, escoltado por pilastras arquitrabadas de fuste cajeado, sobre las que se alza un frontón recto partido, con una pequeña cruz sobre el tímpano, y pináculos de bola en los vértices laterales, dispuestos en correspondencia con el eje de las pilastras. Sobre el muro de los pies encontramos restos de otras dos puertas, hoy cegadas. La una se encuentra en la parte central de la zona correspondiente a la nave, y consta de un sencillo arco de medio punto de amplio dovelaje. Se trata de los restos de la antigua puerta del templo románico, que fueron trasladados aquí durante las obras de renovación, realizadas a mediados del siglo XVIII. La segunda puerta, con dintel plano, se halla ligeramente desplazada hacia el lado septentrional, y permitía el acceso desde el exterior a las trojes, adosadas a este flanco del templo. Las ventanas de esta zona de la nave, por su parte, están formadas por vanos

1662 Ver capítulo: Actividad constructiva. Evolución estilística. Siglo XVIII. 
de dintel plano con ligero derrame hacia el exterior, y se distribuyen entre la fachada meridional y el muro de los pies.

La imagen exterior de este templo se completa con la torre, que aparece dispuesta, como hemos visto, junto al flanco septentrional de la nave, en su parte delantera. Presenta una estilizada estructura prismática, sobre estrecha base cuadrangular, con el cuerpo de campanas delimitando en su parte superior, por una estrecha cenefa, decorada con relieve ajedrezado. Los vanos destinados a alojar las campanas se distribuyen entre cada una de las caras de este cuerpo, los cuales quedan enmarcado por amplio arco de medio punto. Esta pieza se convierte en el auténtico contrapunto vertical dentro de este templo, en el cual, por otra parte, domina claramente un marcado carácter horizontal.

La imagen interior del edificio nos muestra un espacio articulado en dos ámbitos claramente diferenciados, como son la cabecera románica y la nave, construida en el siglo XVIII. A la cabecera se accede a través de un pesado arco de medio punto de aristas vivas. En el interior su espacio queda organizado en dos partes, con un presbiterio cubierto con bóveda de medio cañón, y la capilla mayor, que cierra con bóveda de horno o cuarto de esfera. La parte inferior de los muros de toda esta estancia está recorrida por una galería de arcos ciegos de aristas redondeadas con molduras de tres cuartos de bocel, que descansan sobre columnas decoradas con capiteles, en los que encontramos representados diferentes escenas y motivos animales y vegetales. Estilísticamente se encuadran dentro de la llamada escuela del románico de la sierra $^{1663}$.

1663 B. VALDIVIELSO AUSíN: Rutas del románico en la provincia de Burgos. Valladolid, Castilla Ediciones. 1999. (160 - 161); F. PALOMERO ARAGÓN, M. ILARDIA GÁLLEGO: El arte románico burgalés. Un lenguaje medieval actual. Madrid, Lancia. 1995. (pp. 114 - 115); F. PALOMERO ARAGÓN: Rutas para descubrir el arte de la Sierra de la Demanda. Valladolid, Ámbito Ediciones. 2000. (pp. $109-110)$. 


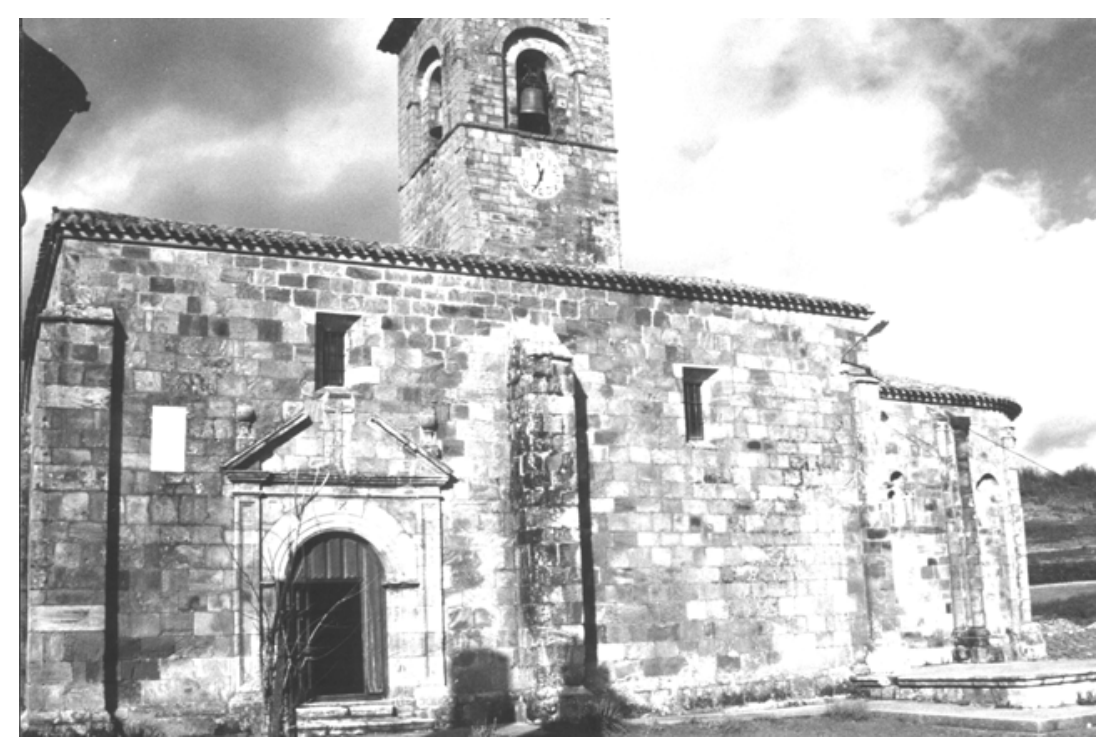

RIOCAVADO DE LA SIERRA.

Iglesia de Santa Coloma.

La nave, por su parte, muestra un amplio espacio de ámbito único, articulado en dos tramos, con coro alto a los pies, elaborado en madera. La cubierta de todo este espacio se resuelve con bóvedas de crucería estrelladas con terceletes, las cuales aparecen separadas por un amplio arco toral de medio punto, dispuesto sobre pilastras toscanas de fuste cajeado, igual que el intradós del arco. Sobre el muro septentrional, a la altura del segundo tramo, prácticamente frente de la puerta de entrada, se abre una puerta, coronada con arco de medio punto sobre impostas planas, que conduce al interior del antiguo baptisterio. Hoy este baptisterio se halla unido a las antiguas trojes o graneros de la parroquia, formando con ellas una única estancia. En su interior se conservan los restos de un antiguo sepulcro de trazas góticas, de mediados del siglo XV. Esta pieza cuenta con la figura del yacente, bastante deteriorada, tendido sobre una cama moderna. Sobre esta figura se extiende un panel adosado al muro, en el que se representa un amplio arco conopial, dispuesto sobre ménsulas decoradas con cardinas, y macollas en el extradós, que corona con una serie de cresterías características de este 
estilo. Una amplia cartela, escrita en el siglo XVII, nos informa sobre los datos de este difunto:

AQUÍ YACE EL VALEROSO CABALLERO DON PEDRO SÁNCHEZ DE VELASCO Y ROJAS, QUE FLORECIÓ EN TIEMPOS DEL REY DON JUAN EL SEGUNDO A QUIEN HIZO NOTABLES SERVICIOS Y EN PARTICULAR EN LA TABLA DE LA VEGA DE GRANADA DEL AÑO 1431 Y FUE LLAMADO COMÚNMENTE EL GRAN CABALLERO DE RIOCAVADO. FUE CASADO CON DOÑA URRACA DE GAONA, HIJA DE LOS SEÑORES DE ARRAYA. MURIÓ AÑO 1447. MANDO RENOVAR ESTA MEMORIA Y ARMAS DON PEDRO VELACO Y ALBARADO CAPITAN DE INFANTERÍA ESPAÑOLA SU BISNIETO, SUCESOR EN LA CASA Y MAYORAZGO Y SEÑOR DE ESTA VILLA Y DE LA DE SANTA CRUZ DEL VALLE Y SU TIERRA. HIJO DEL MAESTRO DEL CAMPO, DON FRANCISCO DE ALBARADO Y VELASCO Y DE DOÑA CATALINA DE ROJAS. AÑO 1606.

Por lo demás, la imagen interior de este templo se encuentra presidida por una total desnudez, pues todos sus retablos han sido eliminados durante las últimas labores de restauración. Entre estos retablos se encontraban el del altar mayor y el dedicado a Nuestra Señora del Rosario, construidos, el primero en la década de $1670^{1664}$, y el segundo en los años finales de este mismo siglo XVII ${ }^{1665}$.

La historia constructiva de este edificio, como decíamos, se resume en dos fases perfectamente definidas, como son la desarrollada durante el siglo XII, y la renovación emprendida en el segundo cuarto del siglo XVIII. En lo que respecta a los elementos románicos (que componen la cabecera y la torre), se conserva en el interior del templo

\footnotetext{
1664 AGDBU. LP. Riocavado de la Sierra, parroquia de Santa Coloma. LF. (1660 - 1704). Cuentas del año 1665. Riocavado de la Sierra, 25, octubre - 1665.

1665 Ibídem. Cuentas del año 1697. Riocavado de la Sierra, 8 - octubre - 1697.
} 


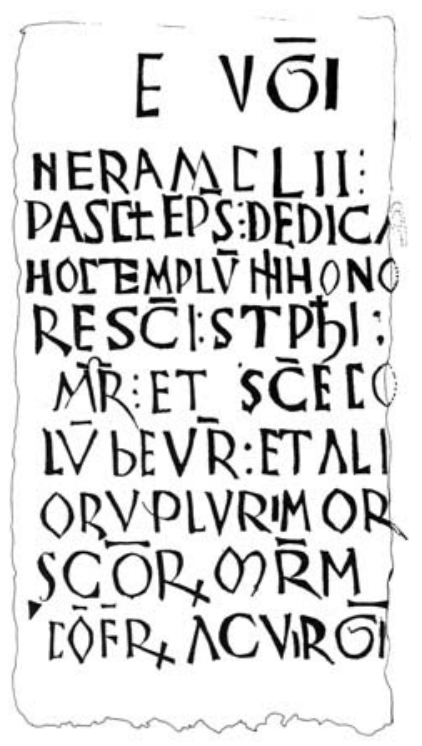

RIOCAVADO DE LA SIERRA. Iglesia de Santa Coloma. Inscripción dedicatoria del

una inscripción, en la que se indica la fecha de 1114, como el momento de su construcción. Es posible, sin embargo, que esta fecha simplemente haga referencia al momento de consagración del templo, pues los rasgos formales, que presenta esta estructura no permiten dar una cronología tan temprana. Aun con todo, las esculturas, que aparecen en los capiteles del interior y exterior del edificio, se encuentra relacionada con el estilo de los primeros maestros de la escuela de la sierra, del románico burgalés. Es una escultura de labra excesivamente dura, en la que no se aprecia una definición correcta del espacio plástico, por lo que su composición resulta poco armónica, ya que las figuras no terminan de adaptarse plenamente al marco ${ }^{1666}$. La estructura de esta cabecera, por lo demás, conserva perfectamente su trazado original románico, tanto en alzado como en planta.

No sucedió lo mismo con la zona del cuerpo, que tuvo que ser remodelada de forma completa en el segundo cuarto del siglo XVIII. Las deficiencias de esta parte del

\footnotetext{
1666 F. PALOMERO ARAGÓN, M. ILARDIA GÁLLEGO: El arte románico burgalés. Un lenguaje medieval actual. Madrid, Lancia. 1995. (pp. 64 - 71).
} 
templo, que terminaron con su renovación, comenzaron a evidenciarse en los primeros años de esta centuria. Así, en 1712 ya hubo que reemplazar parte de la cubierta y reparar algunos tramos de sus muros ${ }^{1667}$. Sin embargo, según expresa el informe del visitador del Arzobispado de Burgos de 1726, D. Andrés Fernández de Tejada, parece que los verdaderos problemas, que presentaba este templo, procedían de las condiciones del suelo.

“Alló su merced que el suelo della (de la iglesia) por haber poca tierra y estar inmediata piedra biba no se pueden cubrir los cadáveres quedando algunos tan superficiales que llegan a manifestarse, como su merced conoció y fue informado, de que se puede seguir corrupción de alguno y della grandísimos inconvenientes de epidemias”" ${ }^{\text {} 1668}$.

A ello se añade que:

"Y respecto allarse su fábrica tan pobre que aun no tiene para sus gastos precisos y ordinarios, atendiendo su merced ser necesario la obra de componer dicho suelo para los cualos vecinos de dicho lugar ofrecen concurrir con cuanto le sea posible teniendo la corta de la madera necesaria para entarimarla que es el mejor y más fácil remedio que se puede dar el cual no podrá llegar al devido y pronto que se requiere por la pobreza de dicha fábrica y vecinos mando se embarguen y secuestren los diezmos en que fuesen interesados sus llevadores hasta la concurrente cantidad"1669.

Pero a pesar de estas reparaciones, la iglesia llegó a la década de 1740 en un estado deplorable, con parte de su estructura amenazando ruina. Así, en 1740 el visitador del Arzobispado, D. Francisco López de Angulo, al mismo tiempo que alababa

\footnotetext{
1667 AGDBU. LP. Riocavado de la Sierra, parroquia de Santa Coloma. LF. (1705 - 1734). Cuentas del año 1712. Riocavado de la Sierra, 3 - diciembre - 1712.

1668 Ibídem. (fols. 36 - 39v ) Visita realizada a la parroquia de Santa Coloma de Riocavado de la Sierra en 1726, por D. Andrés Fernández de Tejada. Barbadillo de Herreros, 12 - septiembre - 1726. 1669 Ibídem.
} 


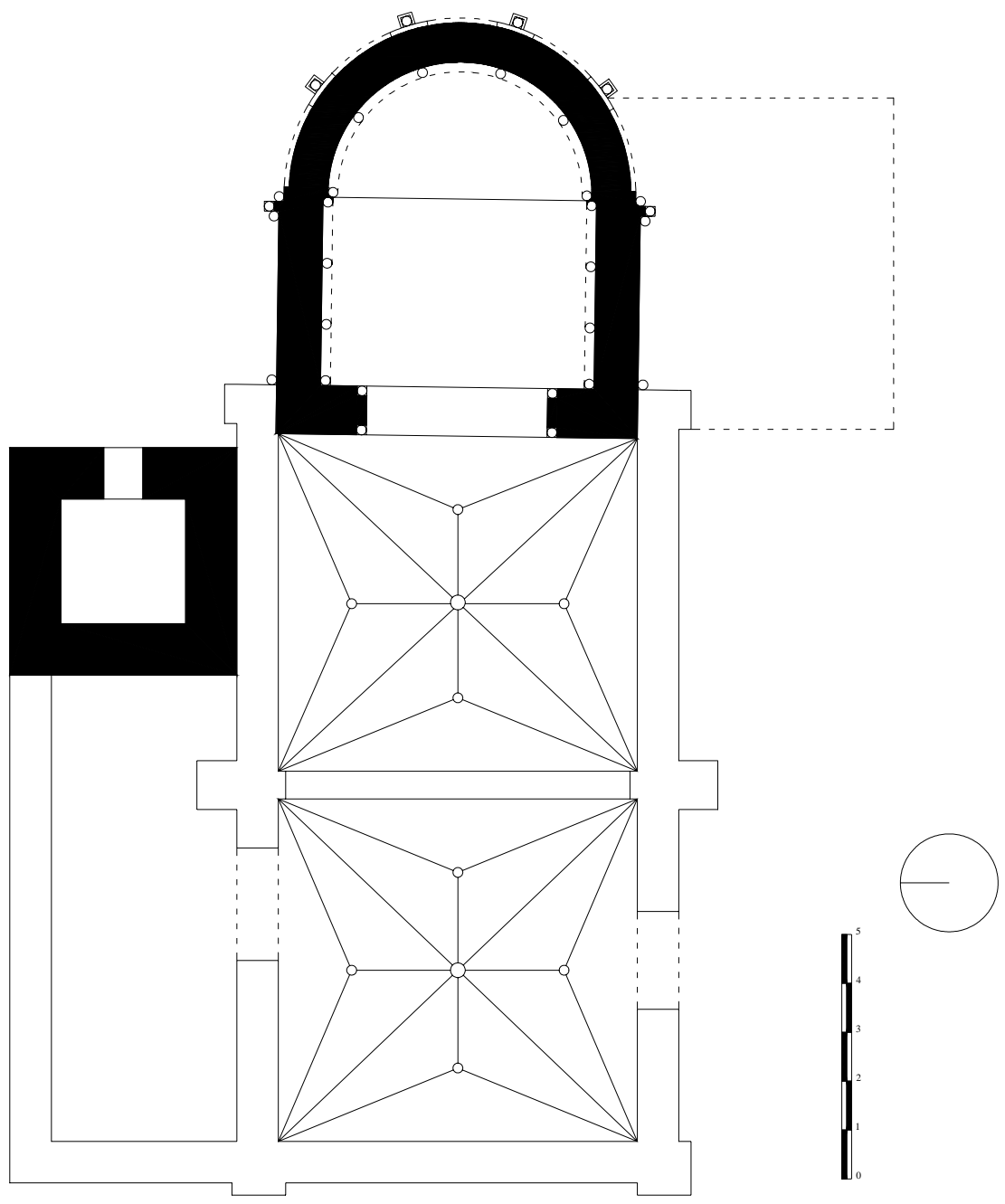

RIOCAVADO DE LA SIERRA.

Iglesia de Santa Coloma. Planta.

el celo de los responsables de esta iglesia en el cuidado y mantenimiento de los ornamentos y altares, exigía que se mantuviera la misma atención con la conservación 
de la fábrica parroquial ${ }^{1670}$. Pero esta advertencia no fue atendida, de tal modo, que en 1744 el propio arzobispo de Burgos obliga a los feligreses y responsables de la parroquia a abandonar el edificio y trasladar el Santísimo Sacramento a la ermita de Santiago, situada en el propio pueblo, para que los oficios se pudieran realizar mientras se reparaba esta iglesia.

Una vez llegados a este punto, las obras de construcción de la nueva nave se pusieron en marca de forma inmediata. De este modo, en el mes de septiembre de este mismo año se contrata la obra, cuya conclusión se fija para el primer día de septiembre del año siguiente. Las trazas y condiciones del proyecto se encargaron al maestro de cantería Juan de Maurtúa, el cual, al mismo tiempo, se hizo con el remate de la obra con una postura de 9.500 reales $^{1671}$. La parte de carpintería se contrató con el maestro Juan de Arrieta, residente en esta localidad de Riocavado, y colaborador habitual de este maestro de cantería. El presupuesto de este último alcanzó los 6.660 reales ${ }^{1672}$. Durante estos trabajos se aprovechó también para realizar diferentes labores de reparación en el resto del templo, las cuales se centraron principalmente, en el cuerpo de campanas de la torre, y en la cornisa y cubiertas de la cabecera y la sacristía. El resultado de estos trabajos, como hemos visto, depara un edificio sencillo y funcional, en el cual se manifiestan con claridad los rasgos propios de la estética clasicista, imperantes dentro de esta comarca durante todo el siglo XVIII.

Con esta obra, por otra parte, podemos dar prácticamente por concluida la historia constructiva de este templo, pues las intervenciones, que se acometen a partir de aquí consisten simplemente en labores de reparación y mantenimiento del edificio heredado. Este es el caso del entarimado del suelo de la nave, que se realizó entre los

1670 Ibídem. (1735 - 1835). (fols. 16 - 21). Visita realizada a la parroquia de Santa Coloma de Riocavado en el año 1740, por el visitador D. Francisco López de Angulo. Barbadillo de Herreros, 15 - septiembre 1740.

1671 AHPBU. PN. Valle de Valdelaguna. Leg. 9803/2, fols. 73 - 77 vo. Manuel Gil de la Cuesta. Riocavado de la Sierra, 3 - septiembre -1744. 
años 1749-50, con un coste para la fábrica de 489 reales y 17 maravedís $^{1673}$. Sin embargo, la actuación más importante de este tipo fue la reparación de las bóvedas, que cubrían la nave, efectuada en 1780. Estos trabajos alcanzaron un presupuesto de 6.370 reales, de los cuales 1.100 reales fueron aportados por el concejo del pueblo, y el resto por la fábrica de la iglesia ${ }^{1674}$. En este mismo año se realiza también, por un precio de 440 reales, el cancel para el interior de la puerta de entrada ${ }^{1675}$.

Ermitas.

Esa localidad tuvo cuatro ermitas repartidas entre el pueblo y sus alrededores, si bien, ninguna de ellas ha conseguido sobrevivir hasta nuestros días. Se encontraban dedicadas a Santiago, Santa Inés, Santa María de la Peña y San Benito.

La más destacada, y última en desaparecer, fue la de Santiago, santo en cuyo honor se celebran las fiestas patronales del pueblo. Se encontraba situada dentro del pueblo, en la parte oriental del casco urbano, y sus últimos restos fueron demolidos al construirse en su lugar el edificio de las actuales escuelas. No conocemos, por lo tanto, nada de su estructura, aunque suponemos que se trataba de un edificio muy sencillo, con una arquitectura de claro carácter popular. Respecto a su historia, como hemos visto, uno de sus episodios más destacados lo vivió a mediados de la década de 1740, cuando se convirtió, de forma provisional, en sede de la parroquia del pueblo, mientras se realizaban las obras de renovación de la iglesia. En este momento, el arzobispo de Burgos ordenó que “...se trasladase a ella el Santísimo Sacramento hasta que se repare y pusiese decente y asegurada dicha iglesia..."1676. Unos años antes, sin embargo, esta ermita no parecía presentar un aspecto tan acogedor, pues en 1715 el visitador del

1672 AHPBU. PN. Valle de Valdelaguna. Leg. 9803/2, fols. 61 - 64 vo . Manuel Gil de la Cuesta. Riocavado de la Sierra, 24 - agosto - 1744.

1673 AGDBU. LP. Riocavado de la Sierra, parroquia de Santa Coloma. LF. (1735 - 1835). (fols. 50v ${ }^{\circ}-$ 52) Cuentas del año 1749. Riocavado de la Sierra, 26 - septiembre - 1749; Ibídem. (fols. 55 $\left.56 v^{\circ}\right)$.Cuentas del año 1750. Riocavado de la Sierra, 1 - octubre - 1751.

1674 Ibídem. (fols. 119 - 121) Cuentas del año 1781. Riocavado de la Sierra, 13 - septiembre - 1781.

1675 Ibídem.

1676 Ibídem. Riocavado de la Sierra, 24 - agosto - 1744. 
Arzobispado, D. Manuel Cosío Barreda, mandó tapiar su puerta “...por allarse arruinada"1677. A mediados del siglo XIX, según nos informa P. MADOZ, el edificio todavía se mantenía en pie y abierto al culto $^{1678}$, con lo cual, suponemos que su desaparición debió producirse ya en pleno siglo XX.

En lo que se refiere a las tres ermitas restantes, la primera en desaparecer fue la de San Benito, cuya última referencia escrita data del año 1757. En ella se habla de su mal estado de conservación y de la imperiosa necesidad de ser reparada ${ }^{1679}$. Desconocemos, no obstante, el lugar de su emplazamiento. Esto mismo sucede con la de Santa María de la Peña, cuya última referencia documental corresponde al año $1803^{1680}$. La de Santa Inés, sin embargo, sabemos que se hallaba situada en el límite con el término municipal de Barbadillo de Herreros, en un paraje conocido como "el collado”, junto al camino que une estos dos pueblos. Sus últimas referencias escritas se producen también, como en el caso anterior, en $1803^{1681}$.

\section{Arquitectura civil.}

En el apartado de la arquitectura civil, como ya señalamos anteriormente, y analizamos en su capítulo correspondiente, Riocavado cuenta con un interesante legado de casas solariegas, pertenecientes, en su mayoría, a los grandes propietarios de rebaños de ovejas merinas ${ }^{1682}$. Varias de ellas se encuentran profundamente alteradas, debido a

\footnotetext{
1677 Ibídem. LF. (1705 - 1734). (fols. 25 - 29 vo). Visita realizada a la parroquia de Santa Coloma de Riocavado de la Sierra en 1715, por D. Manuel de Cosío Barreda. Barbadillo de Herreros, 4 - junio 1715.

1678 P. MADOZ: Diccionario geográfico - estadístico - histórico de España y sus posesiones de Ultramar. Valladolid, Ámbito D.L. 1984. (pp. 437).

1679 AGDBU. LP. Riocavado de la Sierra, parroquia de Santa Coloma. LF. (1735 - 1835). (fols. 68 - 69 $\mathrm{v}^{0}$ ). Visita realizada a la parroquia de Santa Coloma de Riocavado de la Sierra en 1757, por D. Andrés Pérez Blanco, canónigo de la catedral de Burgos. Huerta de Arriba, 30 - julio - 1757.

1680 Ibídem. (fols. 171 v $^{0}$ - 176). Visita realizada a la parroquia de Santa Coloma de Riocavado de la Sierra en 1803, por D. Manuel Cid Monroy, arzobispo de Burgos. Barbadillo de Herreros, 7 - septiembre $-1803$.

1681 Ibídem.

1682 Ver capítulo: Actividad constructiva. Evolución estilística. Siglo XVIII. Arquitectura civil.
} 
las reparaciones y reformas posteriores, por lo que sólo podemos conocerlas a través de fotografía tomadas antes de que esto sucediera. En el resto, sin embargo, todavía podemos contemplar con bastante claridad en sus fachadas los rasgos propios de esta tipología.

Son edificios pertenecientes al siglo XVIII, y en todos ellos se repite el mismo tipo de estructura, en la que se dibuja una limpia forma prismática, levantada sobre amplia planta cuadrangular, con muros de mampostería, reforzados en las esquinas y marcos de los vanos con grandes sillares, y cubierta dispuesta a cuatro aguas, con alero muy saliente, para proteger las fachadas. En su fachada principal se repite igualmente la misma estructura, con la puerta de acceso al interior dispuesta en el centro, coronada con arco de medio punto con rosca casetonada, como suele ser habitual en estos pueblos durante el siglo XVIII. Sobre ella, en la planta principal, se abre un balcón de escaso vuelo, o una pequeña ventana, sobre cuyo dintel es frecuente encontrar una leyenda, en la que se alude a los promotores de la obra y su año de construcción. Esta parte central se hace acompañar, en ambas plantas, por pequeñas ventanas de dintel plano dispuestas a los lados.

Entre los ejemplos mejor conservados, se encuentra el inmueble situado en la calle Real $n^{\circ} 17$, realizada, según reza la inscripción dispuesta sobre el arco de entrada, en 1744. Prácticamente contemporánea a ésta es la casa que fabricaron en 1742 D. Manuel García Sainz y su mujer María Aparicio en la actual calle San Juan $n^{\circ} 11$. En ella se repiten las mismas características anteriores de forma prácticamente mimética. Lo mismo sucede en la situada en la calle de las Eras $n^{\circ} 1$, construida el año 1788 por D. Pedro Crespo y su mujer. Por último, tenemos que citar la casa situada en la calle de la Olma $n^{\circ} 17$, construida, según reza la inscripción de su fachada principal, en 1733. La principal particularidad que presenta este inmueble, es que se trata de uno de los pocos casos que tenemos en esta zona, en los que el promotor fue un miembro del clero, ya que fue mandada construir por el cura del pueblo, D. Juan de la Braga y Sedano. 


\section{SALAS DE LOS INFANTES.}

Salas es la población más destacada de la comarca, pues a sus funciones de cabeza de partido judicial, une también la condición de núcleo de servicios, dentro de un área de poblamiento disperso, que se agrupa en pequeños núcleos. Se encuentra situada en el extremo occidental de nuestra zona de estudio, dentro de los terrenos mesozoicos, inmediatos a los relieves invertidos de las peñas de Carazo y Villanueva, y fuera, por lo tanto, del núcleo más montañoso de las sierras de la Demanda y Neila. A pesar de ello, Salas es conocida en general, dentro de la provincia de Burgos, como la capital de la sierra. Para los naturales de la zona, sin embargo, Salas ya no es sierra.

No está muy claro cual es el origen de este topónimo, el cual se ha querido relacionar con el vocablo godo Sal, que quiere decir edificio, casa o quinta ${ }^{1683}$, o también edificio que consta de un gran espacio de recepción ${ }^{1684}$. Algo más fantasiosas fueron las conclusiones dadas por Méndez Silva en 1679, quién establece que "el señor de Salas fabricó suntuoso palacio en siete quartos repartidos, o salas, para cada uno la suya"1685. P. MADOZ, más tarde, a mediados del siglo XIX, se hace eco de esta curiosa

\footnotetext{
1683 J. PÉREZ CARMONA: “La historiografía y la geografía burgalesa reflejadas en su toponímia”. En BIFG, n¹63.(1964). (pp. 238 - 271); J. M. PIEL: “Toponimia germánica” En ELN (Enciclopedia Lingüística Hispánica) Tomo I. Madrid (1960). (pp. 538).

1684 A. BENGOECHEA: Historia de Salas I. Paisaje, clima, economía, etnología, apellidos, dinosaurios, primeros pobladores, antigüedad, Edad Media, los 7 infantes de Lara. Burgos. Museo de Salas. 2003. (pp. 9).

1685 Ibídem.
} 
teoría, si bien, no la otorga gran credibilidad ${ }^{1686}$. A estas interpretaciones podemos unir también una reciente teoría, no menos original, que vincula el nombre de Salas con el término de origen sabaeno - idioma hablado en la zona sur de Yemen - Sayl, que quiere decir torrente de cruces. La presencia de este tipo de términos en la península Ibérica tendría su explicación en los importantes contingentes de naturales de estas tierras arábicas, que vinieron a España con la invasión musulmana ${ }^{1687}$. Lo más inquietante de esta teoría es que podría albergar cierto poso de verdad, pues Salas se asienta en un punto próximo a la confluencia de dos ríos, como son el Arlanza y el Ciruelos.

Por su parte, el determinante de los Infantes, tiene un origen obvio, en la leyenda tejida en torno a los siete hijos de Gonzalo Gustios, el repoblador de estas tierras, que en la Edad Media fue convertida en cantar de gesta. Esta leyenda parece estar ambientada en la época del conde García Fernández, dentro del clima de guerra constante, que se vivía a finales del siglo $\mathrm{X}$, frente al enemigo, que representaba el califato de Córdoba. Según este relato, los infantes habrían perecido en uno de estos encuentros de armas, alcanzando, merced al relato recogido en el cantar de gesta, la vitola de héroes de legendarios. Las acciones narradas en este relato debemos entenderlas como hechos totalmente ficticios, no obstante, es muy posible que se encuentren inspirados en ciertos episodios reales. Estos episodios, con el paso del tiempo, y la pasión de los juglares, en su primera fase de transmisión oral, debieron enriquecerse de tal modo, que quedaron convertidos finalmente en un relato de carácter totalmente novelesco. Aun así, o tal vez por ello mismo, esta leyenda ha calado de forma tan profunda en la zona, y en esta localidad en particular, que terminó por incluirlos en su nombre. Esta incorporación, según parece, se produce en la segunda mitad del siglo XVI, con motivo del hallazgo, en uno de los muros de la iglesia de Santa María de Salas, de los restos de las cabezas de estos infantes y su ayo, Nuño Salido. Los cuerpos, sin embargo, se encuentran en el monasterio de San Millán de la Cogolla. El documento notarial, fechado el 12-XII-

\footnotetext{
1686 P. MADOZ: Diccionario geográfico - estadístico - histórico de España y sus posesiones de Ultramar. Valladolid, Ámbito D.L. 1984. (pp. 447).
} 
1579, ha sido reproducido por A. BENGOECHEA ${ }^{1688}$. Posteriormente este arca se ha abierto en otras tres ocasiones, para hacer las pertinentes comprobaciones, en 1846, en 1924, y por última vez en $1974^{1689}$.

La historia de esta localidad, al parecer, arranca en el año 974, con la elaboración del llamado "Fuero de Salas”, que concede el conde García Fernández al señor de la villa, Gonzalo Gustios. Este fuero se ha conservado a través de una copia, que se incluye en una carta de confirmación, expedida el 20-XI-1351, por la corte del rey Pedro I. Esta confirmación, presuntamente, reproduce una copia anterior, del siglo XII, que a su vez había sido extraída del original del siglo X. Según este documento, el conde García Fernández concedía fueros y heredades a Gonzalo Gustios para poblar Salas, formando, al mismo tiempo, una agrupación con las localidades próximas ${ }^{1690}$. Se trata, en definitiva, de una acción muy habitual en estos momentos, que se encuadra dentro del clima bélico en el que se vivía, donde era importante incentivar los asentamientos de población estable en áreas de frontera con un alto valor estratégico, como era este caso. Al mismo tiempo, era un intento de reorganizar un territorio, poniéndolo bajo el control de un señor de confianza próximo al conde.

Sin embargo, este documento no ha logrado pasar ni uno solo de los controles de autenticidad a los que se ha visto sometido por los analistas contemporáneos, mostrando todos ellos su falsedad. Al parecer, el documento conservado no sería más que una mera falsificación, realizada, eso sí, a mediados del siglo XIV, con la clara intención de dar mayor antigüedad y legitimidad a un dominio, como era el del señor de Salas, que en estos momentos estaba siendo incorporado a la casa de los Velasco. No obstante, esto

1687 M. AGUIRRE: “Benidorm, noria... vienen de Yemen”. En “Crónica” del Diario el Mundo, n 435 (Domingo 15 de febrero de 2004). pp. 12 - 13.

1688 A. BENGOECHEA: Historia de Salas I... ob. cit. (pp. 98 - 99).

1689 E. GONZÁLEZ BARRIUSO: Salas de los Infantes en la Sierra Burgalesa. Burgos, Grupo Editorial 7. 1999. (pp.30).

1690 Esto ha permitido hablar, al mismo tiempo, de la existencia de un pequeño alfoz, independiente del alfoz de Lara. I. ÁLVAREZ BORGE: Monarquía feudal y organización territorial: alfoces y merindades en Castilla (siglos $X-X I V$ ). Madrid, CISC, 1993. (pp. 89). 
no excluye la posibilidad de que realmente existiera, en su momento, un documento auténtico de estas características, pues las circunstancias que presentaba Salas y su comarca en estos momentos, hacen perfectamente viable la presencia de una concesión como aquella. Los nombres citados en el documento apócrifo, además, son personajes históricos, cuya existencia se encuentra sobradamente contrastada. Así, Gonzalo Gustios, señor a favor del cual se redacta este presunto fuero, es un destacado miembro de uno de los más importantes linajes de diviseros y magnates, que existen en la zona en estos momentos $^{1691}$. Un linaje que llega a estar emparentado con la casa de los Lara, e incluso con el propio linaje condal. Este Gonzalo Gustios es además el padre de los infantes de Lara. Estos fueros, en cualquier caso, simplemente trataban de organizar y poner bajo una determinada autoridad política a una población, como era el caso de Salas, que ya existía con anterioridad. De esta forma, aun dando validez y carácter de autenticidad al citado fuero, no podemos tomar la fecha de 974, como punto de origen de esta población, sino simplemente como el de su nacimiento para la historia escrita. Como testimonio de la presencia de poblamientos estables en este lugar, tenemos los restos del eremitorio de Peña Rota, situados a las afueras del pueblo, sobre un afloramiento rocoso, junto a la carretera que parte hacia Nájera. Se trata de una serie de cuevas, encuadradas dentro de las típicas concentraciones de eremitorios, que se suceden en la zona, durante la Alta Edad Media, cuyo objetivo fundamental era cristianizar a los pobladores del entorno ${ }^{1692}$. En la actualidad quedan restos de diez cuevas, cuya actividad parece que cesó en torno al siglo $\mathrm{X}^{1693}$.

Eliminado este fuero, las primeras referencias escritas sobre esta localidad no se producen hasta el año 1062, en un documento del monasterio de San Pedro de Arlanza, por el cual un miembro de la familia Fortuniz cedía a este cenobio unos terrenos

1691 I. ÁLVAREZ BORGE: Poder y relaciones sociales en Castilla en la Edad Media. Los territorios entre el Arlanzón y el Duero en los siglos X - XIV. Salamanca, Consejería de Educación y Cultura. Junta de Castilla y León. 1996.

1692 J. L. MONREAL JIMENO: "Eremitorios rupestres en territorio burgalés durante la Alta Edad Media”. En II Jornadas burgalesas de historia (2a Burgos. 1990). Burgos en la Alta Edad Media. Burgos, Asociación Provincial de Libreros de Burgos. 1991. (pp. 553 - 554). 
situados en Salas ${ }^{1694}$. Poco más tarde, lo encontramos citado en otro documento de San Millán de la Cogolla, fechado el 28-II-1094, con motivo de la donación a este monasterio de algunos derechos sobre la villa ${ }^{1695}$.

A partir de aquí, esta localidad inicia su recorrido histórico, primero encuadrada dentro del gran alfoz de Lara ${ }^{1696}$, y más tarde, una vez extinguido este sistema de alfoces, en la Merindad Menor de Santo Domingo de Silos ${ }^{1697}$. Como paso previo, es posible que se constituyese, durante un corto espacio de tiempo, en el último cuarto del siglo $\mathrm{X}$, un pequeño alfoz propio, que incluía las poblaciones de Castrovido, Terrazas, Torneros, Hacinas, Castrillo de la Reina, Pinilla de Cedrón, Honillos, Palacios de la Sierra, Nava y Arroyo de Salas. El problema es que ningún otro documento, aparte del apócrifo alfoz de Salas, corrobora la existencia de dicha circunscripción ${ }^{1698}$.

Ya durante la Edad Moderna, en el plano fiscal, Salas queda incluida, como el resto de las localidades que componen su jurisdicción, dentro del partido de las Tierras del Condestable, de la provincia de Burgos ${ }^{1699}$. Más adelante, ya en el siglo XVIII, después de la reforma borbónica, Salas y su jurisdicción forman parte del partido de Candemuñó, también dentro de la provincia de Burgos ${ }^{1700}$.

\footnotetext{
1693 A. BENGOECHEA: Historia de Salas I... ob. cit. (pp. 78).

1694 L. SERRANO: Cartulario de San Pedro de Arlanza. Madrid, Centro de Estudios Históricos, 1925. (pp. 128 - 132).

1695 L. SERRANO: Cartulario de San Millán de la Cogolla. Madrid, Centro de Estudios Históricos. 1930. (pp. 284).

1696 G. MARTÍNEZ DÍEZ: Pueblos y alfoces burgaleses de la repoblación. Valladolid. Junta de Castillo y León. Consejería de Educación y Cultura. 1997. (pp. 176).

1697 C. ESTEPA DÍEZ: "Estructura de poder en Castilla (siglos XII - XIII). El poder señorial en las merindades burgalesas. En III Jornadas burgalesas de Historia (3 1991). Burgos en la Plena Edad Media. Burgos, Asociación Provincial de Libreros de Burgos. 1994. (pp. 245 - 294).G. MARTÍNEZ DÍEZ: Libro Becerro de las Behetrías. Estudio y texto crítico. León, Centro de Estudios e Investigación San Isidoro. Caja de Ahorros y Monte de Piedad. Archivo Histórico Diocesano. 1981. (pp. 598). 1698 Ver nota 7.

1699 G. MARTÍNEZ DÍEZ: Génesis histórica de la provincia de Burgos y sus divisiones administrativas. Burgos, Aldecoa. 1983.

1700 INE. Censo de 1787. "Floridablanca”. Madrid. INE. 1989.
} 
En el aspecto jurisdiccional, Salas mantuvo hasta mediados del siglo XV su condición de villa de Behetría ${ }^{1701}$. Sin embargo, desde mediados de la centuria anterior, esta condición se ajustaba bien poco a la realidad, pues ya en 1350 Pedro Fernández de Velasco se hace con el dominio de la casa-palacio de los señores de Salas, incorporándola a su recién fundado mayorazgo ${ }^{1702}$. Esta casa le sirve de trampolín para extender su dominio en la zona, e incorporar diferentes pueblos a su señorío. Finalmente, desde 1456 Salas se declara villa solariega, lo que permite a los Condestables y futuros Duques de Frías, controlar directamente la justicia y el concejo $^{1703}$. La fiscalidad, en cambio, hacía ya tiempo que estaba bajo su control ${ }^{1704}$. Esta condición no la abandona hasta prácticamente el final del Antiguo Régimen, con la guerra de la Independencia, cuando se produce la huida del último señor de la cada de los Velasco ${ }^{1705}$.

En el plano de la organización eclesiástica, Salas llega a vivir una situación ciertamente curiosa. En un primer momento, tras la restitución de las diócesis de Burgos y Osma, el Concilio de Husillos, en el que se hace el primer reparto del territorio, determina que Salas quede encuadrada dentro de la Diócesis de Burgos. Más tarde, sin embargo, tras el nuevo reparto, efectuado en el Concilio de Burgos de 1136, se establece como línea divisoria entre ambas sedes el cauce alto del río Arlanza, hasta su paso por Salas, de este modo, esta localidad ve como sus dos parroquias quedan repartidas entre ambas diócesis. La de Santa Cecilia, situada en la margen derecha, se mantiene en Burgos, mientras que la de Santa María, situada en la margen contraria, pasa a depender de Osma ${ }^{1706}$. Esta situación se mantuvo sin cambios hasta el siglo XVI,

1701 G. MARTÍNEZ DÍEZ: Libro Becerro de las Behetrías... ob. cit. (pp. 598).

1702 A. BENGOECHEA: Historia de Salas I... ob. cit. (pp. 104).

1703 Ibídem. (pp. 106 - 107).

1704 G. MARTÍNEZ DÍEZ: Libro Becerro de las Behetrías... ob. cit. (pp. 598).

1705 R. HILARIO RODRÍGUEZ: Los Velasco. Vida, obra y patrimonio de una dinastía. Burgos, Excmo. Aymto. de Medina de Pomar - Caja de Ahorros del Círculo Católico de Burgos. 2002. (pp. 181 y ss.).

1706 L. SERRANO: El obispado de Burgos y Castilla primitiva. Desde el siglo V al XIII. Madrid. 1935. Tomo I (pp. 333 - 337, 374 - 378, 414 - 418). 
en el que se decide, entre ambas sedes, establecer una serie de pequeños cambios, que ayudaran a mejorar la administración de sus respectivos territorios. De este modo, las dos parroquias de Salas pasan a depender de la Diócesis burgalesa ${ }^{1707}$.

Salas comienza a vivir el gran apogeo, que hace que desempeñe un papel preeminente en la zona, a finales del siglo XV, una vez convertida en villa solariega. A ello contribuye, de manera evidente, el respaldo de la familia Velasco, convertidos ya en Condestables de Castilla. Esta familia fija en Salas el centro administrativo de los territorios que componen su señorío jurisdiccional en esta zona de la sierra, lo que hace que, al mismo tiempo que llegan funcionarios y administradores del propio Condestable, se asienten también familias pudientes, algunas de ellas nobles, que contribuyen a dinamizar, de forma notable, la actividad económica de la villa y su entorno $^{1708}$. El reflejo más claro de este ambiente de progreso lo tenemos en las dos iglesias parroquiales, las cuales acometen la remodelación de sus respectivas fábricas en el período que se extiende entre la segunda mitad del siglo XV y los primeros años del siglo XVI. De ello surge un templo como el de Santa María, que excedían de forma notable las posibles necesidades de culto que podía presentar este barrio.

En el aspecto demográfico, no sabemos hasta que punto estos acontecimientos pudieron afectar a esta localidad durante el siglo XV. A partir del siglo XVI, sin embargo, el nivel de población nos ofrece una línea más o menos estable, que se mantiene sin grandes cambios a lo largo de toda la Edad Moderna, si exceptuamos el período central del siglo XVII. El dato más antiguos que poseemos, en este caso, nos lo proporciona el censo de 1541 , que nos da una cifra de 136 vecinos ${ }^{1709}$. Este valor crece ligeramente en la segunda mitad de este siglo, hasta alcanzar los 140 vecinos ${ }^{1710}$, en el

\footnotetext{
1707 E. GONZÁLEZ BARRIUSO: Salas de los Infantes en la Sierra Burgalesa. Ob. cit. (pp. 70).

1708 A. BENGOECHEA: Historia de Salas I... ob. cit. (pp. 110).

1709 AGS. Contaduría General. Leg. 768. (fols. 61).

1710 T. GONZÁLEZ: Censo de población de las provincias y partidos de la Corona de Castilla en el siglo XVI... Ed. Facsímil. Madrid, Imprenta Real. 1829.
} 
censo de los obispos de 1584-87, y los 143 vecinos $^{1711}$ en el censo de 1591. Este aumento se mantiene hasta bien avanzado el siglo XVII, si hacemos caso al censo de la sal de 1631, pues tenemos aquí una cifra de 167 vecinos ${ }^{1712}$. Poco después, sin embargo, en el censo de 1646, esta población queda reducida prácticamente a la mitad, con sólo 90 vecinos censados ${ }^{1713}$. Frente a esto, la llegada del siglo XVIII logra restablecer los valores de la centuria del Quinientos, y así, en el vecindario del Catastro del Marqués de Ensenada, de mediados de este siglo, vemos que se ha llegado hasta los $143 ’ 5$ vecinos ${ }^{1714}$, los cuales en el censo de Floridablanca de 1787, quedan convertidos, con un ligero crecimiento, en 568 habitantes ${ }^{1715}$. Dentro de esta población encontramos, ya desde el siglo XVI, algunos representantes del estado noble, si bien su número siempre fue muy reducido, alcanzando sólo a dos o tres familias ${ }^{1716}$.

La economía de Salas, durante la Edad Moderna, representa, en cierto modo, una síntesis de las actividades más características, que se realizan en los pueblos de su entorno a lo largo de este período. Al mismo tiempo, la presencia del delegado del Duque de Frías, para vigilar los intereses de sus dominios en la comarca, convirtió a este núcleo en un destacado centro administrativo. Pero no debemos equivocarnos, pues Salas, a pesar de la presencia de estos administradores y de las actividades de ciertas familias de hidalgos, nunca logró alcanzar un carácter urbano. Bien al contrario, el ambiente y la vida de esta villa fue siempre el de un núcleo rural, con unos habitantes dedicados, de forma prácticamente plena, a la explotación del campo, con el desarrollo de las actividades más habituales en la comarca. Así, al estar emplazada en una zona de orografía menos abrupta y de clima más suave, que en las partes más elevadas de la sierra, la agricultura pudo constituirse en la base principal de su economía. Se trata,

1711 Censo de Castilla de 1591. Vecindario. Madrid, Instituto Nacional de Estadística. 1984.

1712 AGS. Dirección General del Tesoro, inventario 24. Leg. 1168 - 2.

1713 AGS. Cámara de Castilla - Diversos. Leg. 23, nº 4. (s/f).

1714 Vecindario de Ensenada 1759. Vol. I. Madrid, Centro de Gestión Catastral y Cooperación Tributaria: Tabapress. D. L. 1991.

1715 INE. Censo de 1787. “Floridablanca”. Madrid. INE. 1989.

1716 A. DÍAZ MEDINA: “Economía y Hacienda (siglos XVI - XVII). En Historia de Burgos. III Edad Moderna (2). Burgos, Caja de Ahorros Municipal de Burgos. 1992. (pp. 231 - 266). 
evidentemente, de una agricultura de secano, centrada en la producción de cereales, como el trigo camuña, centeno, cebada y algo de avena. También se cultivan algunas hortalizas, hierva para el forraje del ganado, y algo de lino, destinado a la artesanía textil. El sistema de cultivo empleado en todos estos casos es el de año y vez.

Junto a esta actividad, como no podía ser de otra forma, encontramos también un importante desarrollo de la ganadería, en la que destaca, por una parte, la ganadería estante, pues era en la que participaban un mayor número de vecinos. Dentro de ella, predomina, sobre todo, la cría de ganado ovino de raza churra y caprino, cuyo número pudo llegar en algunos momentos a rondar las 3.000 cabezas. Esta cabaña se completa con algunos hatos de vacuno y porcino ${ }^{1717}$. Por otro lado, no menos importante fue el desarrollo de la ganadería trashumante, cuyo número de cabezas, aunque nunca existieron cifras precisas, no debió bajar nunca de las 2.000 unidades. Estos ganados, sin embargo, se hallaban concentrados en unas pocas manos, de tal modo, que a mediados del siglo XVIII, según los memoriales del Catastro del Marqués de Ensenada, sólo tres familias participaban en esta actividad. Se trata de tres de las familias más poderosas de Salas en este momento, las cuales mantenían a sus ganados durante nueve meses en tierras de Alcántara, en Extremadura, para luego hacer el agostadero en los extensos terrenos de las ledanías, que rodean el término municipal de Salas ${ }^{1718}$. Esta villa, por otra parte, fue tradicionalmente un punto importante dentro del comercio de la lana, pues por aquí, no sólo pasaban los rebaños de esta comarca de la sierra en sus viajes anuales ${ }^{1719}$, sino que existía también un lavadero de lana ${ }^{1720}$, convirtiéndose además en punto de encuentro de los compradores de este producto, enviados por los grandes mercaderes burgaleses.

\footnotetext{
1717 ADPBU. CE - 1740. RESPUESTAS GENERALES. Salas de los Infantes, 10 - febrero - 1753.

1718 ADPBU. CE - 1741. MEMORIALES PARTICULARES. (fols. 520; $593 \mathrm{v}^{0}-594 \mathrm{v}^{0}$ ). Salas de los Infantes, 10 - febrero - 1753.

1719 El Duque de Frías tenía el derecho de cobrar un pequeño peaje a los ganados que pasaban por el puente de Salas. ADPBU. CE - 1740. RESPUESTAS GENERALES. Salas de los Infantes, 10 - febrero 1753.

1720 E. LAGUNA SANZ: Historia del merino. Madrid. Ministerio de Agricultura, Pesca y Alimentación. 1986. (pp. 148).
} 
En esta localidad, por otra parte, a pesar de no existir extensas masas de pinares en su término municipal ni en las ledanías que lo rodean, también encontramos vecinos dedicados al transporte, formando, junto con los de Castrillo de la Reina y Hacinas, la denominada derrama de abajo, constituida por los carreteros y arrieros de esta zona baja de la sierra.

A parte de estas tres actividades predominantes, Salas, como buen núcleo de servicios, contó con una serie de profesionales, que alternaban su trabajo en el campo, como agricultores o propietarios de ganados, con determinadas labores artesanales, como tejedor, sastre, herrero, boyero o alfarero. Junto a ellos encontramos también otros profesionales, como médico, cirujano, boticario, escribano, maestro de primeras letras, y por supuesto, el administrador del Duque de Frías.

Con todo ello, la imagen, que presentaba esta localidad durante la Edad Moderna, distaba mucho de ofrecernos un ambiente urbano. Su caserío, desprovista de murallas, quedaba articulada en dos barrios perfectamente diferenciados, separados por la vega del río Arlanza. En la margen derecha, sobre una ladera orientada hacia el sudoeste, se encuentra el barrio de Costana, presidido por su iglesia parroquial de Santa Cecilia. En la margen contraria, a una mayor distancia de este cauce, y sobre un pequeño altozano, se asienta el barrio de Santa María, con su iglesia del mismo nombre, en su parte más alta. En esta misma margen izquierda, en un punto equidistante de ambas parroquias, se levantaba la casa fuerte o casa-palacio de los señores de Salas, que desde mediados del siglo XIV pasó a simbolizar la presencia y el poder del señorío de la familia de los Velasco en la zona. En la actualidad apenas quedan unos escasos restos de sus muros, en los que se abren algunas saeteras y dos puertas con arco ojival, pertenecientes a este siglo XIV. En el siglo XVIII todavía mantenía en pie la mayor parte de su estructura, como bien describen sus contemporáneos en un documento, que ha sido recogido por A. BENGOECHEA ${ }^{1721}$. Un buen número de estos restos se

1721 A. BENGOECHEA: Historia de Salas I... ob. cit. (pp. 99 - 101). 
conservaron hasta principios del siglo XX, entre los que se hallaba una buena parte de sus muros y algunas torres, que a juicio de los testigos, "alcanzaban una altura poco menor que la torre de la iglesia de Santa María, ...era almenada, más sin ninguna ventana y aspillera en sus muros...”1722.

Esta estructura del núcleo urbano de Salas se mantuvo sin grandes cambios a lo largo de toda la Edad Moderna. Las únicas variaciones que se producen, vienen como consecuencia de la sustitución de las pequeñas y pobres casas de los pobladores más humildes, de una sola planta y tejado de paja, por edificios más sólidos, elaborados en piedra, con diferentes plantas y tejado de teja curva. Su conversión en cabeza de partido judicial en 1834, y la concesión del título de ciudad por Alfonso XIII en 1925, a petición del cardenal Juan Benlloch, sin embargo, ha propiciado un cambio radical en la fisonomía de Salas. Este cambio ha sido particularmente intenso a partir de la década de 1960-70, con la instalación de algunas industrias, ligadas al tratamiento de la madera, que han atraído un importante volumen de población nueva. Esto ha provocado la aparición de un caserío moderno, formado por grandes bloques de viviendas de varias plantas, elaborados con unos materiales, unas técnicas y unas estructuras, que no tienen nada que ver con la arquitectura tradicional. Estos nuevos edificios se han extendidos, fundamentalmente, a lo largo de la margen izquierda de río, en el entorno del solar de la antigua casa-palacio, hasta unir los dos barrios tradicionales en un solo conjunto, en el que no se aprecia interrupción alguna. Solamente el río Arlanza consigue dividir mínimamente la ciudad en dos partes, y mantener con ello el recuerdo de sus antiguos barrios.

La arquitectura tradicional, sin embargo, no ha llegado a desaparecer totalmente. Así, en el barrio de Costana aun podemos contemplar numerosos ejemplos de arquitectura popular, en la que se repiten los modelos tradicionales, aunque perfeccionados, de las casas de los ganaderos y agricultores de los siglos de la Edad Moderna. En el barrio de Santa María, por su parte, todavía se conservan, en las

1722 Ibídem. 
inmediaciones de la iglesia parroquial, algunos inmuebles, en los que se reflejan las características de las casas solariegas, con sus amplias fachadas, presididas por el arco de medio punto de su entrada y los blasones. Aun así, los dos edificios más representativos de este núcleo siguen siendo sus dos iglesias parroquiales, dedicadas, como hemos visto, a Santa María y Santa Cecilia, cuyas parroquias se unieron en una sola en $1939^{1723}$.

\section{Iglesia de Santa María.}

Se encuentra situada, como decimos, sobre la cima de un pequeño altozano, elevado sobre la margen izquierda del río Arlanza, presidiendo el barrio, que lleva su nombre. El caserío de este barrio se organiza en torno a ella, formando un apretado y tortuoso callejero, dentro del cual se abren algunas plazas. El entorno inmediato del templo queda rodeado por un potente muro, que delimita un amplio atrio, al cual se accede a través de dos escaleras, dispuestas en los lados meridional y de poniente, o por dos pasos a piso llano, abiertos en el flanco septentrional.

Se trata, como vimos en su capítulo correspondiente ${ }^{1724}$, de un templo de estilo gótico, elaborado entre la segunda mitad del siglo XV y primeros momentos del siglo XVI. Sobre su estructura principal se añaden, más tarde, diferentes elementos, que no consiguen, sin embargo, alterar su imagen original. Constituye uno de los primeros ejemplos, que encontramos en la arquitectura castellana, de templo de tipo hallenkirche, con planta de salón articulada en tres naves de tres tramos cada una, con claro predominio en anchura de la central sobre las laterales. Sobre este cuerpo se añaden, en el extremo oriental, la cabecera, formada por una amplia capilla mayor cuadrangular con testero plano, acompañada por la sacristía en su flanco meridional. Y en el extremo opuesto, en la zona de los pies, la torre, dispuesta sobre el mismo eje que la capilla mayor, y también con base cuadrangular, formando una especie de contraábside, donde se aloja el coro. Sobre el flanco meridional de esta torre se adosa el baptisterio.

\footnotetext{
1723 E. GONZÁLEZ BARRIUSO: Salas de los Infantes en la Sierra Burgalesa. Ob. cit. (pp. 70).

1724 Ver capítulo: Actividad constructiva. Evolución estilística: Siglo XVI.
} 


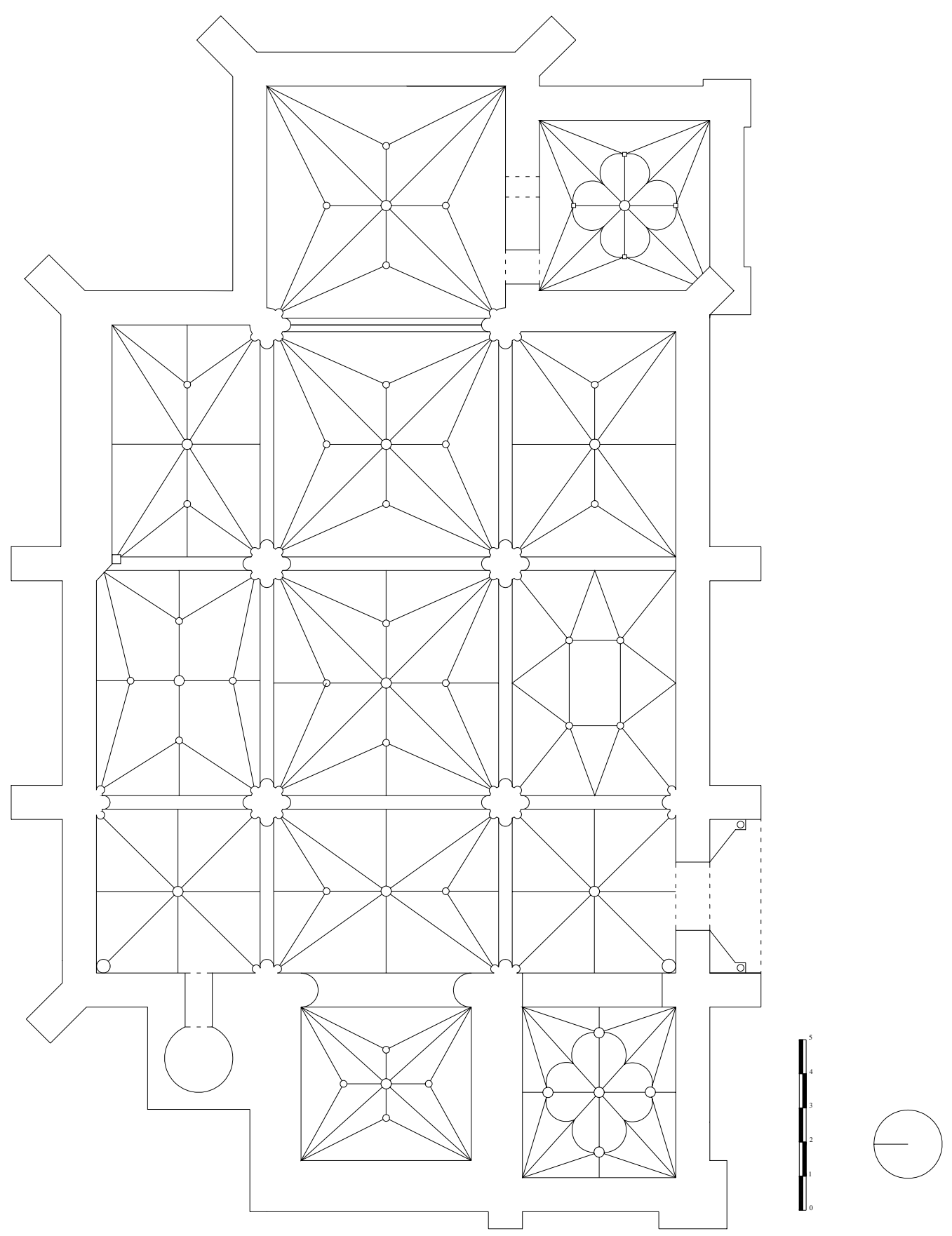

SALAS DE LOS INFANTES.

Iglesia de Santa María. Planta. 
Sus muros están realizados en piedra de sillería, con roca arenisca local, rematados con cornisa de codillo y papo de paloma, y reforzados por sólidos estribos de fuerte resalte sobre el plano de muro, que en las esquinas adoptan una posición en diagonal. Esta última norma sólo se rompe en la zona del baptisterio y en la sacristía, cuyos contrafuertes, de forma prismática, presentan sus lados en paralelo a los lados del muro.

Con ello se consigue una imagen exterior compacta y de gran sobriedad, dominada por el gran volumen, que forma el núcleo central del templo, cuya uniformidad en altura solamente queda rota en la parte de los pies, con la incorporación de la torre. Esta torre, no sólo destaca dentro de la estructura general del templo, sino también dentro del propio caserío que lo rodea, donde aparece dominando la estampa general del pueblo. Consta de un esbelto prisma de base cuadrangular, cuyo tramo superior aparece delimitado por una pequeña cornisa, con la que se da paso al cuerpo de campanas. Este cuerpo se presenta como un claro añadido posterior, y ofrece, en cada una de sus caras, dos vanos con antepecho y arco de medio punto, sobre los que se abren grandes óculos de clara inspiración herreriana. El remate está formado por un friso y una pequeña cornisa, que dan paso al tejado, en el que se alzan cuatro pináculos de bolas repartidos entre sus esquinas. En la base de la torre, orientada hacia poniente, encontramos un interesante ventanal de transición entre el gótico y el renacimiento, formado por arco de medio punto, con fuerte derrame hacia el exterior, de superficie muy moldurada. En el interior aparece una estructura geminada con mainel en el centro, sobre el que se superpone un fino baquetón en el que descansan dos pequeños arcos con angrelados en el intradós. Esta torre se completa con el husillo, adosado sobre el flanco septentrional, de base cuadrangular, por cuyo interior asciende la escalera de caracol, que permite el acceso al cuerpo superior.

Si volvemos al cuerpo principal del templo, encontramos, como elemento más destacado, la portada, abierta sobre el tercer tramo de la fachada meridional. Se trata de una obra plateresca, realizada en 1549, según reza la inscripción, que aparece sobre la cartela del dintel de la puerta. Su estructura está cobijada bajo amplio arco de medio 
punto, con intradós decorado mediante casetones floreados, y dragones rampantes con cestos de frutas en las enjutas. Por debajo de este arco, encontramos la portada en sí, formada por una estructura abocinda con arco de medio punto con profundos casetones en su rosca, dispuestos a modo de arquivoltas. Bajo este arco se abre una amplia puerta de dintel plano, escoltada en las jambas por nichos avenerados con las imágenes en piedra de San Pedro y San Pablo, acompañados por recuadros decorados con relieves planos, donde se representan de nuevo figuras de dragones rampantes y copas de frutas. En los extremos aparecen columnas de orden compuesto con fuste liso en su tercio inferior y estriado en el resto, sobre los cuales se dispone un entablamento adaptado al perfil quebrado de la estructura de la puerta. Bajo este friso, en la parte central, en correspondencia con el dintel de la puerta, aparece una pequeña cartela con la fecha de 1549, y una cinta colocada a modo de guirnaldas colgantes, entre la cual se inscriben diferentes textos con sentencias de carácter moralizante ${ }^{1725}$. Finalmente, sobre el tímpano del arco central encontramos una talla en piedra, también de estilo renacentista, de la Asunción de la Virgen, a la cual está dedicada este templo. Todo el conjunto constituye una obra de estilo plenamente renacentista, en la que se ha producido ya una profunda simplificación de sus elementos decorativos, para mostrar así un mayor protagonismo de las líneas, que forman su estructura arquitectónica. Supone, por ello, uno de los mejores intentos por introducir las formas propias del renacimiento dentro del panorama arquitectónico de la zona. Tal y como indicamos en su momento ${ }^{1726}$, su autor parece ser Diego Guillén, maestro vinculado a los círculos de Diego de Siloe, en su etapa burgalesa, y Juan de Vallejo, algunos de cuyos rasgos adivinamos en esta obra.

A parte de la portada, debemos destacar también la presencia de las ventanas, que iluminan el espacio interior, las cuales aparecen orientadas principalmente hacia el mediodía. Las abiertas en los tramos de la nave muestran arco apuntado muy rebajado,

\footnotetext{
1725 LA MALDICIÓN DE LA MADRE ABRASA Y DESTRUYE DE RAÍZ HIJOS Y CASA. EN LA CADA DEL QUE JURA NO FALTARÁ DESVENTURA. DE TODA PALABRA OCIOSA DARÁN LOS HOMBRES CUENTA RIGUROSA. OH, QUE MUCHO LO DE ALLÁ, Y QUÉ POCO LO DE ACÁ. O GLORIA PARA SIEMPRE, O PENA, PENA PARA SIEMPRE.

1726 Ver capítulo: Actividad constructiva. Evolución estilística: Siglo XVI.
} 
próximo al medio punto, con fuerte derrame hacia el exterior. Una ventana similar aparece en el muro meridional del presbiterio, si bien en este caso, encontramos ya un arco de medio punto enmarcado por una gruesa moldura de tres cuartos de bocel. Corresponde, por lo tanto, a un período posterior, cuya apertura debemos relacionar con la construcción del retablo del altar mayor, a mediados del siglo XVI, que obligó a cegar las dos ventanas del muro del testero. Estos dos ventanales, que han sido recuperados recientemente, muestran una estructura mucho más arcaica que cualquier de las anteriores, lo que nos permite deducir, que nos encontramos ante la parte más antigua del templo actual. Presentan arco apuntado, muy estilizado, con fuerte derrame hacia el exterior, mientras que su luz queda partida por un grueso mainel con tracerías flamígeras en la parte superior. Estos vanos se completan con los abiertos en la sacristía y el baptisterio, los cuales presentan una sencilla estructura de dintel plano y fuerte derrame hacia el exterior, como es frecuente en las construcciones de los siglos XVII y XVIII.

En el interior encontramos la característica estructura de los templos de tipo hallenkirche, con amplio espacio tendente al ámbito único, cubierto con bóvedas elevadas a una misma altura, y soportes que tienden a aligerarse, para así conseguir acentuar la sensación de desahogo. Sus bóvedas son todas de crucería, con predominio de las estrelladas con terceletes, no obstante, las necesidades constructivas y la pericia de los canteros encargados de su ejecución, han hecho que apenas encontremos dos tramos iguales, variando constantemente el tipo de trama. Así, en los tramos perlongados de las naves laterales y del último tramo de la nave central, suelen desaparecer los terceletes en sus lados más largos, alargando, por el contrario, el nervio de ligadura hasta la clave de los arcos formaletes. Un caso ciertamente singular lo encontramos en el segundo tramo de la nave de la epístola, donde sus nervios forman un rectángulo central, que hace desaparecer la clave polar. El resto de las variaciones se producen ya con la incorporación de nervios combados, lo cual sucede únicamente en aquellas piezas, que fueron añadidas con posterioridad, como es el caso del coro, la sacristía y el baptisterio. 


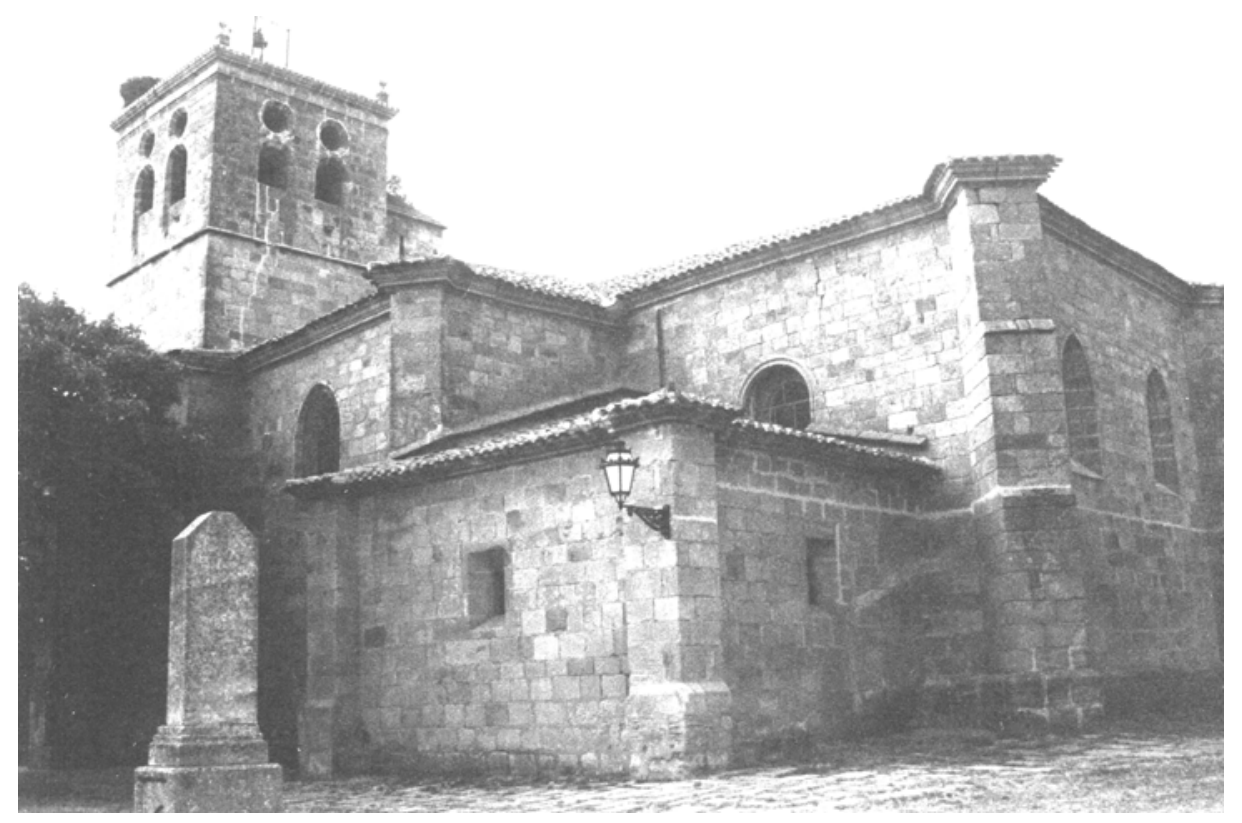

SALAS DE LOS INFANTES. Iglesia de Santa María.

La separación de los tramos de bóveda, en la zona del cuerpo, se realiza, en todos los casos, con arcos apuntados de sección trapezoidal, cuyo nivel de apuntamiento se acentúa de forma notable en los fajones de las naves laterales, dada la necesidad de igualar su altura con la nave central. Las únicas variantes sobre este tipo de arco, nuevamente, proceden de aquellas partes, que se incorporan más tarde. Este es el caso del espacio abierto en el interior de la base de la torre, donde se aloja el coro, al cual se accede a través de un potente arco apuntado de rosca fuertemente moldurada. Este arco descansa sobre pilares semicirculares sin capitel. El acceso al baptisterio, por su parte, se realiza a través de un grueso arco escarzano de intradós casetonado.

Los soportes, en la zona de la nave, están formados por dos parejas de pilares de núcleo circular, rodeados por columnas, de mayor potencia, las situadas en los frentes, y 
más estrechas las dispuestas en los ángulos, alzadas sobre elevado basamento y rematadas por anillo de sección poligonal. Estos pilares se corresponden con haces de columnas de similares características en los muros, si bien, en algunos casos son sustituidos por sencillas ménsulas. En la zona de los pies, algunas columnas incorporan ya relieves de bolas en el anillo que forman el capitel, elemento característico del estilo Reyes Católicos.

Entre los elementos más destacados de esta estructura interior encontramos el coro, situado, como hemos dicho, en el espacio abierto en el interior de la base de la torre. Es obra plateresca de mediados del siglo XVI, realizado en piedra caliza de Hontoria, y está formado por un arco escarzado de rosca profusamente moldurada y decorada por relieves de dentellones, ovas y flechas, que se repiten en el friso superior, que da paso a la balaustrada. El sotocoro se cubre con bóveda de crucería estrellada con terceletes de rampante prácticamente planta, en cuya trama incluye diferentes nervios combados.

En el aspecto ornamental debemos destacar, sin ningún género de dudas, el retablo del altar mayor, obra plateresca de mediados del siglo XVI, atribuido, al igual que la portada, al maestro Diego Guillén. Consta de una estructura levantada sobre amplio banco, de tres cuerpos y remate, articulados en tres calles, separadas por pequeñas entrecalles con ligero resalte sobre el plano de la obra. En los paneles que decoran el banco aparecen representadas, en relieves policromados, diferentes escenas de la Pasión de Cristo, como la entrada de Jesús en Jerusalén, la Oración en el huerto, el Juicio ante Caifás, y el camino del Calvario. En las entrecalles del banco, dentro de grandes tondos, vemos también los relieves de los cuatro evangelistas, representados con sus característicos atributos de escribientes, y acompañados por su animal simbólico respectivo. En el primer cuerpo, su nicho central está presidido por la talla de la Virgen en su trono con el Niño en su regazo. A los lados, dentro de este mismo nicho, encontramos dos relieves, con las escenas de la Asunción y el Nacimiento de Jesús, y sobre todo el recuadro un amplio arco abocinado de medio punto con casetones en su 


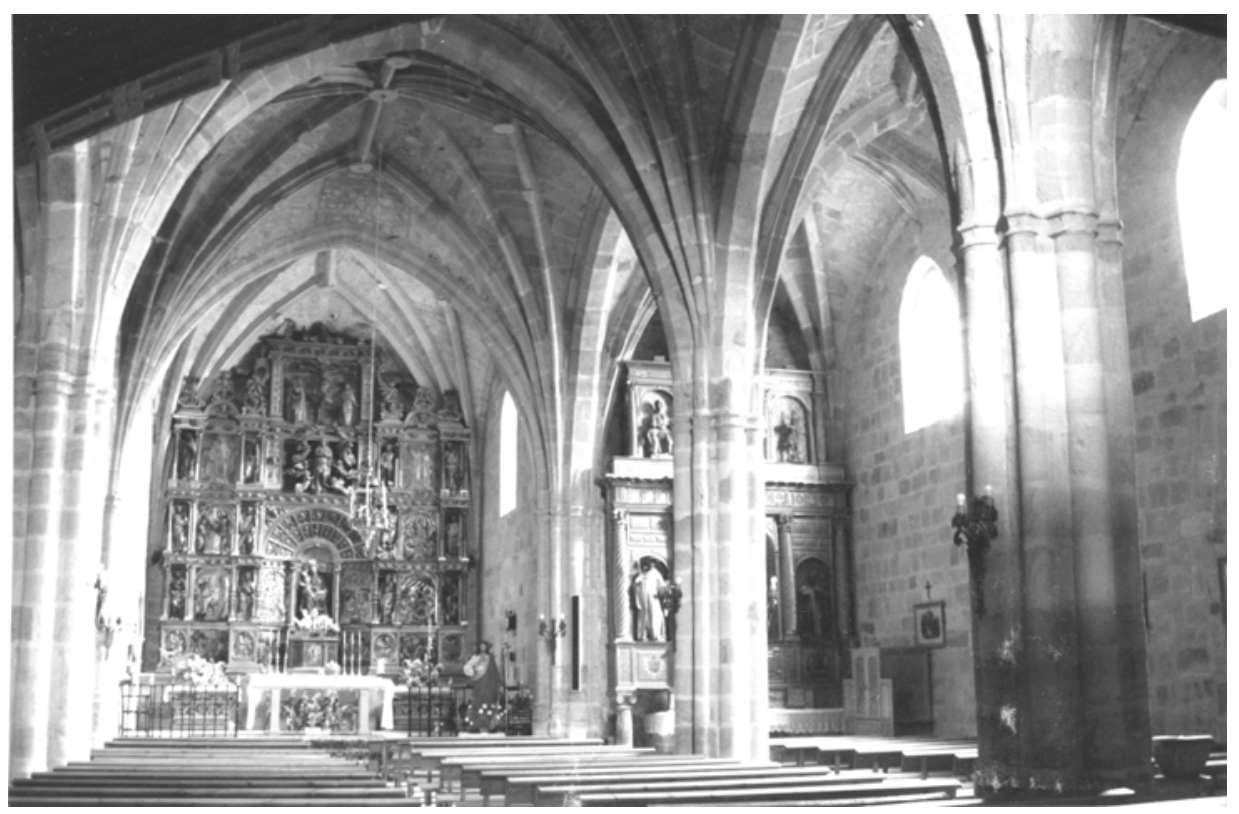

SALAS DE LOS INFANTES.

Iglesia de Santa María. Interior.

rosca, similares a los de la puerta de entrada, pero decorados, en esta ocasión, con relieves de putti entre grutescos. En las calles laterales de este mismo cuerpo encontramos las escenas de la Presentación de la Virgen en el Templo, y la Adoración de los Reyes Mayos, y en las entrecalles las tallas de San Pedro y San Pablo, en el centro, y Santo Tomás y Santiago el Menor, en los extremos. En el segundo cuerpo su nicho central queda ocupado por el gran arco de la hornacina inferior, ya mencionado, mientras que en los laterales encontramos las escenas de la Presentación del Jesús en el templo, y el Niño Jesús entre los doctores. En las entrecalles aparecen las tallas de San Andrés y San Miguel, en el centro (esta última colocada con posterioridad), y San Felipe y San Juan Bautista, en los extremos. El tercer cuerpo cuenta con una talla de la Asunción rodeada por un coro de ocho ángeles, en el nicho central, y dos relieves muy planos en las calles laterales, con las imágenes de los Santos Padres, San Ambrosio y San Agustín, cada uno con sus atributos característicos. En las entrecalles se sitúan San Felipe y San Judas Tadeo, en el centro, y Santiago el Mayor y San Bartolomé, en los 
extremos. Por último, el remate queda formado por la representación del Calvario, con la figura de Cristo Crucificado, la Virgen y San Juan en bulto redondo, dispuestos sobre una pintura en tabla, que representa la ciudad de Jerusalén al fondo. Por encima del recuadro, que enmarca esta escena, sobresale el busto de Dios Padre en actitud de bendecir.

Una obra, en definitiva, de proporciones monumentales y gran complejidad compositiva, en la que se desarrolla un completo programa iconográfico, centrado en las figuras de Jesús y la Virgen. Todas las escenas están concebidas de acuerdo a los gustos y formas propios de la escultura plenamente renacentista, si bien, la estructura arquitectónica continúa todavía poblada de una gran masa ornamental, formada, principalmente por cabezas de ángeles y grutescos.

Sobre el muro frontal de la nave de la epístola encontramos el retablo dedicado a San Benito, obra ya barroca de corte clasicista, realizado en 1654 por mandato de Miguel Morcate Moreno y su esposa, Fabiana Martínez Zabala, tal y como indica la inscripción que aparece en el centro del banco ${ }^{1727}$. Presenta una estructura articulada en dos cuerpos decrecientes de tres calles y remate, levantada sobre un pequeño banco. Sus nichos están ocupados por tallas en madera policromadas, con las imágenes de San Benito, en el centro del primer cuerpo, acompañado por San Bernardo y San Antón, a los lados, y la Inmaculada en el central del segundo cuerpo, escoltada por San José con el Niño y San Miguel Arcángel, ésta última incorporada más tarde. En el remate aparece un Cristo Crucificado, dispuesto sobre tabla pintada con motivos muy toscos.

En el lado contrario, sobre el muro frontal de la nave del evangelio, se alza un altar ocupado por una talla de Cristo Crucificado del siglo XIV. Se trata de un altar realizado en piedra, de estilo clasicista, efectuado, posiblemente, durante la primera mitad del siglo XVII, en el que se muestra una clara influencia de la arquitectura 
escurialense. Consta de un amplio nicho, coronado con arco de medio punto, escoltado por dos niveles de pilastras de orden dórico y fuste cajeado, sobre las que se extiende un grueso entablamento, que da paso al remate, formado por frontón recto partido con cruz en el vértice central, y pináculos piramidales en los extremos. En el tímpano encontramos un escudo de contorno ovalado, con campo ocupado por siete coronas, y dos pequeños relieves a los lados, donde se representan dos llaves cruzadas y un cáliz con una Sagrada Forma.

La gran homogeneidad estilística, que presenta la imagen de este templo, hace que su historia constructiva quede reducida únicamente a una gran fase, que se desarrolla entre la segunda mitad del siglo XV y principios del XVI, a lo largo de la cual se consigue componer el núcleo principal del edificio. Estas obras comenzaron por la parte de la cabecera, continuaron con los diferentes tramos, que componen las naves, y se completaron finalmente con la incorporación de la torre. De esta forma, entre la primera parte y la última, encontramos un pequeño desfase, que se manifiesta en los tipos de arcos y soportes empleados en uno y otro caso, y también en el tipo de ventana. En la zona de las naves, encontramos también pequeños cambios, que propician la incorporación de relieves de bolas en los tramos finales, que no vemos en la parte delantera. En cualquier caso, se trata siempre de pequeñas concesiones formales, incorporadas dentro de un proyecto, que sigue con todo rigor las pautas marcadas por la idea original.

Una vez finalizada la estructura principal del templo, se inicia el proceso de incorporación de nuevos añadidos. Así, a mediados del siglo XVI, como vemos, se construye la nueva puerta de entrada, lo que propicia el cierre de la anterior, cuya impronta a quedado grabada sobre el muro del segundo tramo de esta misma fachada meridional, en forma de un sencillo arco apuntado de amplio dovelaje. Prácticamente en estos mismos años se levanta el retablo mayor, que obliga, como hemos indicado, a

1727 ESTA OBRA IÇO DON MICAEL DE MORCATE MONTERO FAMILIAR DEL SANTO OFICIO DE LA INQUISICIÓN Y SU MUGER DOÑA MARÍA MARTÍNEZ ZABALA SU MUGER LOS 
cegar los ventanales del muro del testero de la cabecera, y a abrir una nueva ventana en el muro meridional del presbiterio. Esta primera secuencia de añadidos termina con la construcción del coro.

Más tarde, ya en las primeras décadas del siglo XVII, se renueva la torre, a la que se añade un nuevo cuerpo de campanas, con el cual se incrementa su altura. Este nuevo cuerpo se incluye ya plenamente dentro del estilo herreriano. A mediados de este mismo siglo se construyen también las dos últimas piezas, que se añaden al templo, como son la sacristía y el baptisterio. La primera se levanta en 1659, tal y como indica la inscripción que existe en su bóveda, y en ella se desarrolla la estructura, que había sido habitual para este tipo de piezas, desde mediados del siglo XVII hasta bien entrada la centuria siguiente. Presenta una sencilla estructura cúbica, con estribos prismáticos en las esquinas, y dos pequeñas ventanas rectangulares con ligero derrame hacia el exterior, orientadas al mediodía y naciente. En el interior su espacio se cubre con bóveda de crucería estrellada con terceletes de rampante muy planta, sobre cuya trama se añaden una serie de nervios combados, para formar una figura trebolada. Más o menos contemporánea a esta pieza es el baptisterio. Se trata de una pieza articulada en dos alturas, que permite igualar el nivel de cubiertas de las naves, y mantener con ellas la misma proporción. Al exterior, por lo tanto, queda perfectamente integrado dentro del bloque general del templo, repitiendo, sin embargo, los mismo tipos de estribos y ventanas que vimos en la sacristía. Estas coincidencias se mantienen en el interior, donde su planta baja, que forma el baptisterio propiamente dicho, se cubre también con una bóveda de crecería estrellada con terceletes y nervios combados en el centro, formando una estructura trebolada. En la parte superior, a la cual se accede a través de una pequeña puerta situada en el coro, encontramos una estancia que originalmente debió desempeñar las funciones de almacén. En la actualidad ha sido acondicionado como museo parroquial. 


\section{Iglesia de Santa Cecilia.}

Es la iglesia del barrio de Costana, cuya parroquia se funde, como hemos visto, con la de Santa María en 1939. Se encuentra ubicada en el extremo oriental del barrio, sobre las suaves laderas de las márgenes del río Arlanza. El suelo sobre el que se asienta ha sido convenientemente allanado y delimitado por un potente muro, que forma el atrio, el cual, en los lados de mediodía y naciente, funciona como elemento de contención. Este muro incorpora en su entrada de poniente una portada románica, que fue trasladada en 1980 desde el pueblo abandonado de Mazariegos, formada por dos niveles de arquivoltas ${ }^{1728}$.

Este templo constituye el resultado final de una larga secuencia constructiva, compuesta por diferentes fases, que arrancan en pleno siglo XVI, y no terminan hasta principios del siglo XVIII. En todas estas incorporaciones, sin embargo, se mantiene un gran respeto por las proporciones de la estructura de la fábrica anterior, lo que hace que el conjunto del edificio presente un claro sentido de unidad. Aun con todo, resulta relativamente fácil reconocer los rasgos estilísticos de cada una de estas fases, y hacer un recorrido por cada una de ellas.

Este templo presenta unas dimensiones considerablemente más reducidas que el de Santa María, con una estructura próxima al modelo de planta salón, con cuerpo de tres naves de dos tramos cada una, más un pequeño añadido en la parte de los pies, donde se incorpora el coro y el baptisterio. Dentro de estas naves se aprecia un marcado predominio de la central sobre las laterales, a las que llega a doblar en anchura. En el extremo oriental se incorpora la cabecera, formada por una capilla de planta cuadrangular con testero plano, sobre cuyo flaco septentrional se añade la sacristía.

El edificio se encuentra realizado en piedra, utilizando para ello la roca arenisca local, con al que se forman sólidos muros de sillería, en los que apenas se observan cambios en el tipo de paramento, que indiquen las distintas fases constructivas, que se

1728 E. GONZÁLEZ BARRIUSO: Salas de los Infantes en la Sierra Burgalesa. Ob. cit. (pp.98). 
1094 Arquitectura de la Edad Moderna en la sierra burgalesa.

producen. Estos cambios son más fáciles de apreciar en los diferentes estribos, que sirven de refuerzo, y en las ventanas. En el caso de los estribos, los situados en la parte delantera, en el muro meridional, y el primer tramo del muro septentrional, que se corresponden con las fases góticas, muestran un fuerte resalte sobre el plano del muro, adoptando una posición en diagonal, en las esquinas. Los estribos situados en el ángulo noroeste, sin embargo, atenúan su resalte y adoptan, en el caso de las esquinas, una posición de lados en paralelo a los lados del muro.

En las ventanas encontramos hasta cuatro tipos de trazado diferentes. Las más antiguas se encuentran en la cabecera, sobre el muro del testero de la capilla mayor, y sobre el lado meridional del presbiterio, y presentan arco apuntado con fuerte derrame hacia el exterior y restos de tracerías góticas en el interior. Su construcción debe situarse en a la segunda mitad del siglo XV. En la fachada meridional, sobre el primer tramo de la nave, aparece una ventana de arco apuntado muy rebajado, próximo al medio punto, y ligero derrame hacia el exterior, correspondiente ya a los primeros momentos del siglo XVI. La abierta en el tramo siguiente de esta misma fachada, sobre la puerta de entrada, presenta un trazado rectangular con dintel plano y derrame hacia el exterior, que nos permite relacionarla con las construidas en la zona durante los siglos XVII y XVIII. Una ventana similar a ésta, salvo que coronada con arco de medio punto, encontramos en el extremo septentrional del muro de los pies, mientras que en el centro se abre un simple vano de dintel plano.

La puerta de acceso al interior, abierta, como hemos visto, sobre el segundo tramo de la fachada meridional, muestra unas trazas góticas ya muy evolucionadas. Consta de amplio vano coronado con arco escarzano de aristas redondeadas con moldura de cuarto de bocel, sobre la cual se extienden tres niveles de arquivoltas, con arcos apuntados muy rebajados, que se continúan, junto con el anterior, por las jambas, para formar cuatro finos baquetones a cada lado. Una portada, por lo tanto, que podemos relacionar con las realizadas en la iglesia de San Martín, en Vilviestre del Pinar, y en la ermita de Nuestra Señora de la Blanca, en Hoyuelos de la Sierra, 


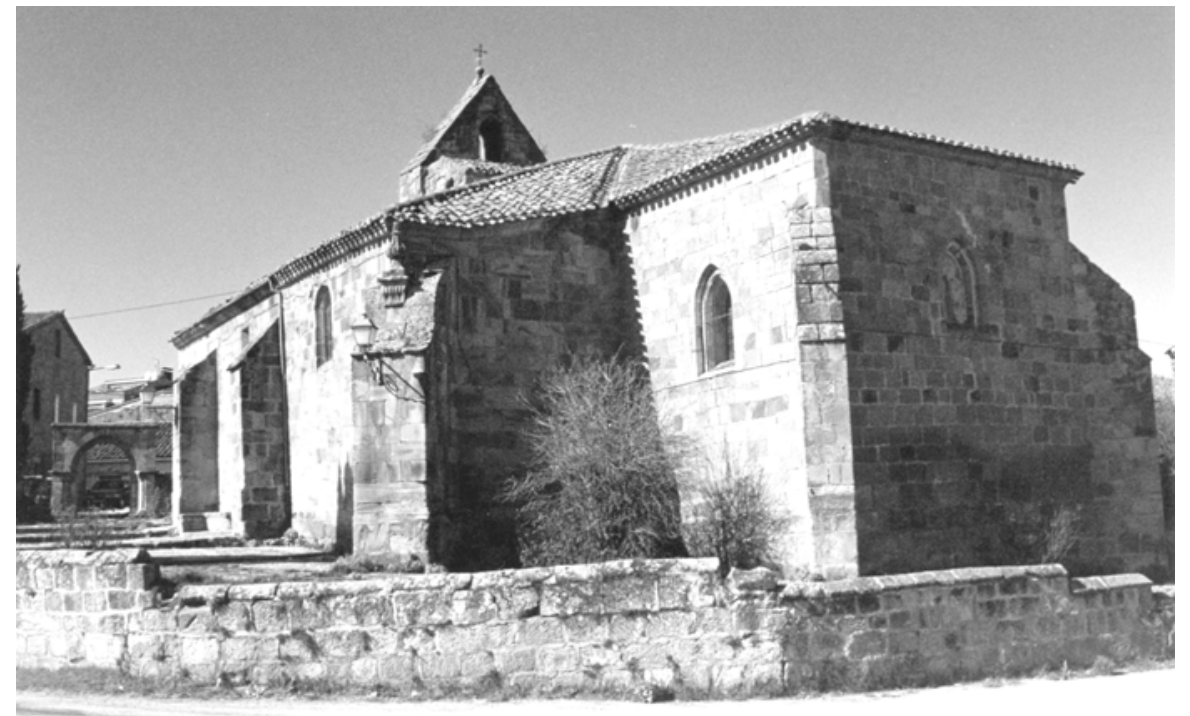

SALAS DE LOS INFANTES. Iglesia de Santa Cecilia.

ejecutadas ya en los primeros años del siglo XVI. La imagen exterior se completa con la espadaña, que se alza sobre el muro de los pies, formada por dos sencillos vanos, coronados con arco de medio punto.

En el interior del templo se intenta dibujar un espacio de ámbito único, con cubiertas elevadas prácticamente a la misma altura (algo más altas las de la nave central), al que se incorporan, en la zona de los pies, un coro alto, y el baptisterio, en la parte correspondiente a la nave del evangelio. Esta sensación de espacialidad, sin embargo, queda truncada, en gran medida, por los gruesos pilares centrales.

Las cubiertas presentan bóvedas de crucería, con trazado sexpartito, en la capilla mayor y tramos delanteros de las naves laterales, y estrellado con terceletes, en los tramos restantes. En los arcos de separación de estos tramos se produce un predominio de los arcos apuntados con rosca moldurada, sin embargo, en la entrada de la capilla mayor se reduce esta molduración, hasta tomar la apariencia de un arco doblado. Por su 
parte, en el tramo final de la nave del evangelio y en el baptisterio, el tipo de arco empleado es de medio punto ligeramente peraltado, con intradós cajeado, propio de los siglos XVII y XVIII.

Estos arcos y los nervios de las bóvedas apenan sobre dos potentes pilares centrales de núcleo circular frenteados por columnas similares a los vistos en la iglesia de Santa María. En el pilar del lado del evangelio, sin embargo, los frentes septentrional y de poniente sustituyen estos haces de columnas por pilastras de orden toscano y fuste cajeado. Este mismo tipo de soporte se repite en toda esta zona del ángulo noroeste, incluyendo el baptisterio. En la parte de los pies, por último, se añade un tercer pilar exento de estructura cilíndrica, sin capitel ni basa, que nos permite fechar esta parte del templo en torno a las décadas iniciales del siglo XVI. A media altura de este pilar se insertan unos pequeños arcos escarzanos de rosca moldurada, sobre los cuales descansa la estructura del coro.

La imagen interior de este templo se completa con los retablos, que adornan sus respectivos altares. El del altar mayor es obra clasicista, de la década de 1640, y consta de una sencilla estructura, levantada sobre estrecho banco, con dos cuerpos articulados en tres calles, más un remate. En el nicho central del primer cuerpo aparece una talla de Santa Cecilia, acompañada a los lados por lienzos con escenas de su vida. En el segundo cuerpo vemos en el centro una talla de la Virgen sedente con el Niño, con otros dos lienzos a los lados, con la escena del martirio de Santa Cecilia y una imagen de San Pío V, mientras que en el remate aparece una talla de Cristo Crucificado.

El retablo situado en el muro frontal de la nave del evangelio está dedicado a la Inmaculada, y es también obra clasicista, contemporánea de la anterior. Fue costeado por Andrés Cámara y su esposa en 1640, según reza la inscripción del banco ${ }^{1729}$, y cuenta con la imagen de la Inmaculada en el nicho central y una talla de San Andrés en el remate. Este retablo se encuentra flanqueado por dos pequeños retablos de tipo

1729 A COSTA DE ANDRÉS CÁMARA Y MUGER AÑO DE 1640. 
marco, que custodian lienzos del Ecce Homo y de la Dolorosa, ambos fechados también en torno a esta década de 1640.

En el lado contrario, sobre el muro frontal de la nave de la epístola, se encuentra el retablo dedicado a Cristo Crucificado, conocido como el Cristo de la Trinidad, obra también clasicista de la misma cronología que los anteriores. En el centro aparece una talla de Cristo en la Cruz, acompañado a los lados por lienzos de la Virgen y San Juan, mientras que en el remate aparece una representación de Dios Padre con el Espíritu Santo. Por último, sobre el muro del segundo tramo de la nave del evangelio, aparece el retablo dedicado al Niño Jesús, obra ya churrigueresca de la década de 1730. Cuenta con un solo cuerpo de tres calles, con la talla del Niño en el nicho central, escoltada por San José y San Antonio de Padua a los lados, y San Miguel Arcángel en el remate ${ }^{1730}$.

La historia constructiva de este templo, como venimos diciendo, conoce distintas fases. Suponemos que debió existir un edificio anterior, posiblemente románico, si bien, los elementos más antiguos del templo actual son ya de época gótica, pertenecientes a la segunda mitad del siglo XV. El edifico, que surge en este momento, presenta una original planta próxima a la cruz griega, y se levanta en dos períodos diferentes. Esto hace que podamos encontrar algunas diferencias entre la cabecera y el resto del cuerpo, especialmente visibles en el arco y los soportes de entrada a la capilla mayor, y en las ventanas.

La siguiente fase constructiva se produce ya en los primeros años del siglo XVI, y en ella se mantiene el estilo gótico, aunque con unas formas bastante más moderna. En este momento se incorpora una nueva nave en la parte meridional, aprovechando para ello el tramo que forma el brazo de este lado del crucero. Se construye también ahora el coro, situado en la zona de los pies, la portada y posiblemente también la

1730 R. J. PAYO HERNANZ: El retablo en Burgos y su comarca durante los siglos XVII y XVIII. Burgos, Excma. Diputación Provincial de Burgos. 1997. (T. II, pp. 535 - 536). 
espadaña. En todos estos elementos encontramos ya unos rasgos que permiten situar esta obra entre las décadas de 1510-20.

El siglo XVII no aporta ninguna obra de carácter arquitectónico a este templo, pues tampoco parece que exista una necesidad de incrementar el espacio existente, ni de remodelar la fábrica heredada. Sí fue importante esta centuria, sin embargo, en las obras de carácter mueble, de tal forma, que la mayor parte de los retablos que decoran su espacio interior se levantan ahora.

La última fase constructiva se produce ya en el siglo XVIII, en torno a las décadas de 1710-20, y en ella se incorpora una nueva nave en el lado septentrional, tal y como se había hecho antes en la parte del mediodía. Se añade también ahora, a esta nave, un pequeño espacio en la parte de los pies, donde se aloja el baptisterio. En esta obra se respetan con todo rigor las proporciones, que marca la fábrica anterior, si embargo, en el aspecto formal, vemos cómo se abandona el estilo gótico, incorporando en su lugar elementos propios de la estética clasicista. También podemos situar en este momento la construcción de la sacristía, adosada sobre el muro septentrional de la capilla mayor. Presenta un pequeño espacio de planta rectangular, cubierto con bóveda de medio cañón, si bien, el elemento más interesante lo encontramos en su puerta de acceso, que se abre sobre el muro lateral del presbiterio, formada por un sencillo vano de dintel plano, enmarcado por doble moldura quebrada con orejones.

Durante el resto del siglo XVIII, como es habitual, los únicos trabajos que se realizan son ya labores de mantenimiento y reparaciones de los elementos dañados. Dentro de este tipo de intervenciones destacan, de manera especial, las llevadas a cabo sobre la parte delantera de la nave de la epístola, conocida como capilla del Santo Cristo de la Trinidad. Los primeros trabajos, que aquí se realizan, tiene lugar en torno al año 1750, y se ponen en marcha tras el aviso del visitador del Arzobispado de Burgos, D. Manuel José Ortiz Torancos, el cual señala que: 


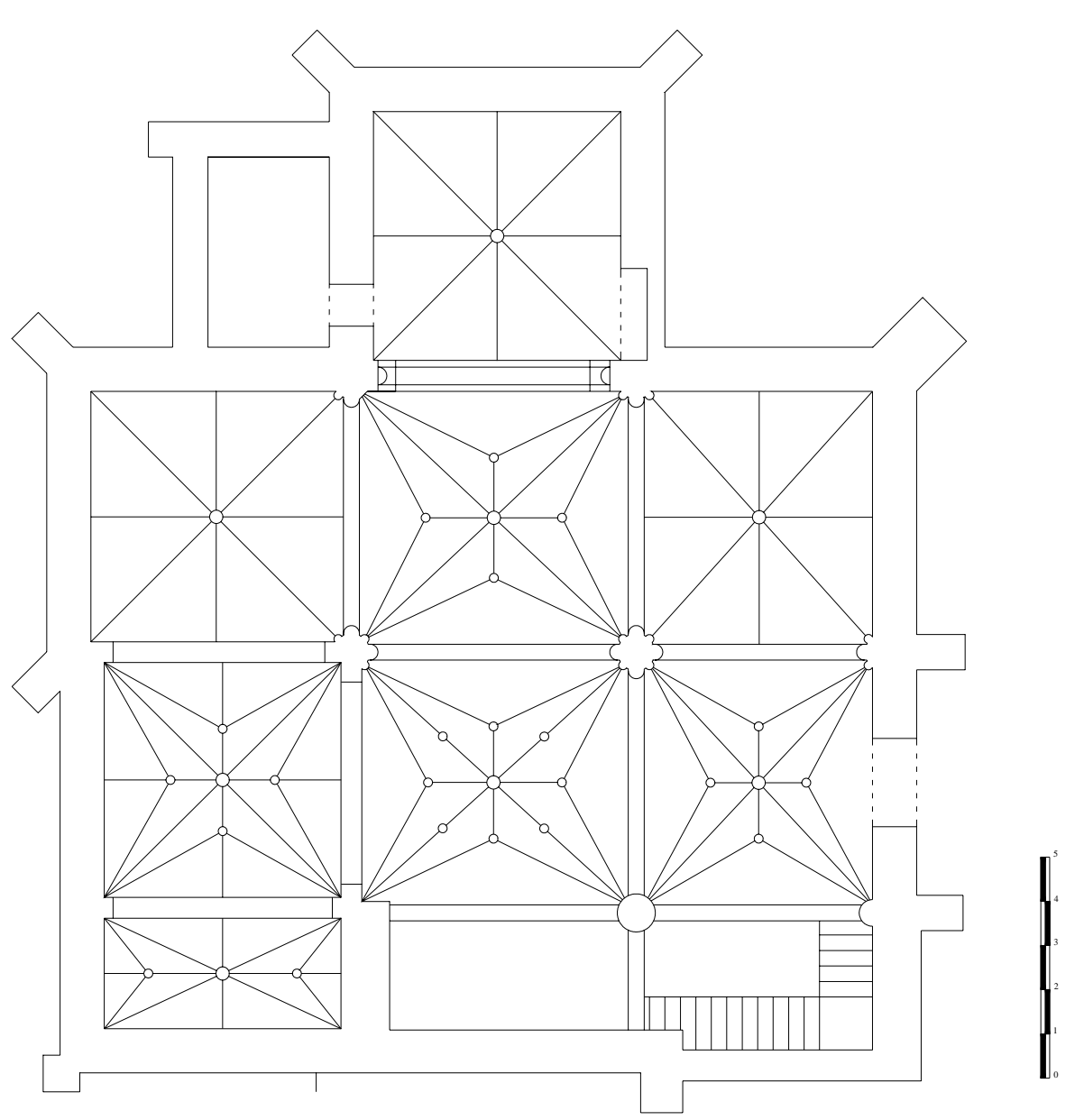

SALAS DE LOS INFANTES.

Iglesia de Santa Cecilia. Planta.

"por cuanto en la visita que se hizo de dicha iglesia reconoció su merced que la bóveda de la capilla mayor y la del Santísimo Cristo de la Trinidad se hallan con unas aberturas que parecen amenazar ruina debía de mandar a los mayordomos ecleiástico y secular de fábrica sin dilación se valgan de maestro périto que reconozca dichas bóvedas y si hallase por 
causa de las dichas aberturas se puede seguir dicha ruina se asegurará y reparará antes que vaya en aumento en primer lugar por cuenta de los efectos y caudales que tiene existentes la expresada fábrica. $Y$ segundo si estos no alcanzasen también se manda al dicho cura que declarando el mencionado maestro con individualidad la suma de dichos reparos, remítanos tanto deste capítulo junto con dicha declaración y relación certificada de los mencionados caudales a los llevadores de diezmos de dicha iglesia para que contribuyan sueldo o libra por lo que faltare hasta dejarla asegurada y en estado decente, ${ }^{, 1731}$.

En esta reparación la parroquia llegó a invertir una cantidad próxima a los 3.500 reales ${ }^{1732}$. Años después, sin embargo, esta parte del templo, posiblemente por estar en la zona más deprimida, volvió a resentirse, lo que obliga, en esta ocasión, a reedificar todo el muro frontal de la nave de la epístola. Estas obras se realizan en 1783, y de ellas surge, como pieza más destacada, un potente estribo en la esquina de este muro, con el cual se pretendían evitar futuros problemas. Este estribo queda rematado por un movido perfil avolutado, del que surge un pináculo en forma de jarrón, con la fecha de la obra inscrita en su base. El coste, que todo esto supuso para la parroquia, fue de 3.408 reales $^{1733}$.

Entre los trabajos de mantenimiento los más destacados, tal vez por su elevado presupuesto, son la renovación del enlosado del suelo de la zona de las naves, efectuado en 1740, por mandato del visitador del Arzobispado ${ }^{1734}$. En ello la parroquia llegó a

\footnotetext{
1731 A P. Salas de los Infantes. LP. Parroquia de Santa Cecilia. LF. (1721 - 1809). Visita realizada a la parroquia de Santa Cecilia de Salas de los Infantes en 1756, por D. Manuel José Ortiz Torancos. Salas de los Infantes, 2 - septiembre - 1756.

1732 Ibídem. Cuentas del año 1756. Salas de los Infantes, 6 - septiembre - 1756.

1733 Ibídem. Cuentas tomadas en 1783. Salas de los Infantes, 2 - octubre - 1783.

1734 Ibídem. Visita realizada a la parroquia de Santa Cecilia de Salas de los Infantes en 1740, por Francisco López de Angulo. Salas de los Infantes, 29 - noviembre - 1740.
} 
gastar un total de 5.123 reales, a los que debemos sumar las aportaciones realizadas por los vecinos ${ }^{1735}$.

\section{Ermitas.}

Entre las mencionadas en la documentación parroquial y las construidas posteriormente, esta localidad contó con un total de once ermitas, repartidas por su término municipal. De ellas, en la actualidad sólo tres se conservan en pie, como son las dedicadas a San Roque, San Isidro y la de las Benditas Ánimas. Las desaparecidas, por su parte, se encontraban dedicadas a Nuestra Señora de la Soledad, San Andrés y San Esteban, las del barrio de Santa María, y San Miguel, San Cristóbal, San Martín, San Bartolomé y San Pelayo, en el barrio de Costana.

Dentro de las que se han conservado hasta hoy, la más destacada es la de San Roque, abogado contra la peste y patrón de esta localidad, junto con la Asunción de la Virgen. Se encuentra situada en la parte oriental del pueblo, sobre la margen derecha del río Arlanza, en un paraje, originalmente apartado y tranquilo, pero que hoy día se ha visto rodeado ya por las edificaciones de los nuevos barrios de la ciudad. Su actual edificio pertenece al siglo XVIII, y presenta una estructura muy sencilla, propia de la arquitectura popular, en la que encontramos ciertos rasgos de sabor clasicista, concentrados principalmente en su fachada principal.

Consta de una estructura de tipo caja, de nave única sobre planta rectangular, con cabecera plana en el extremo oriental, algo más estrecha que la nave, y sacristía adosada sobre su flanco septentrional. El edificio se encuentra realizado en piedra, con sólidos muros de sillería, bien trabajados, para los que se ha utilizado la roca arenisca local. En su imagen exterior destaca especialmente su fachada principal, dispuesta sobre el muro de los pies. En centro de ella se abre la puerta de entrada, coronada con arco de medio punto de rosca casetonada, propia del siglo XVIII, y sobre ella, en el remate, una pequeña espadaña, con uno solo vano con arco de medio punto, también con su rosca

1735 Ibídem. Cuentas tomadas el año 1740. Salas de los Infantes, 20 - julio - 1741. 
SALAS DE LOS INFANTES. Ermita de San Roque.

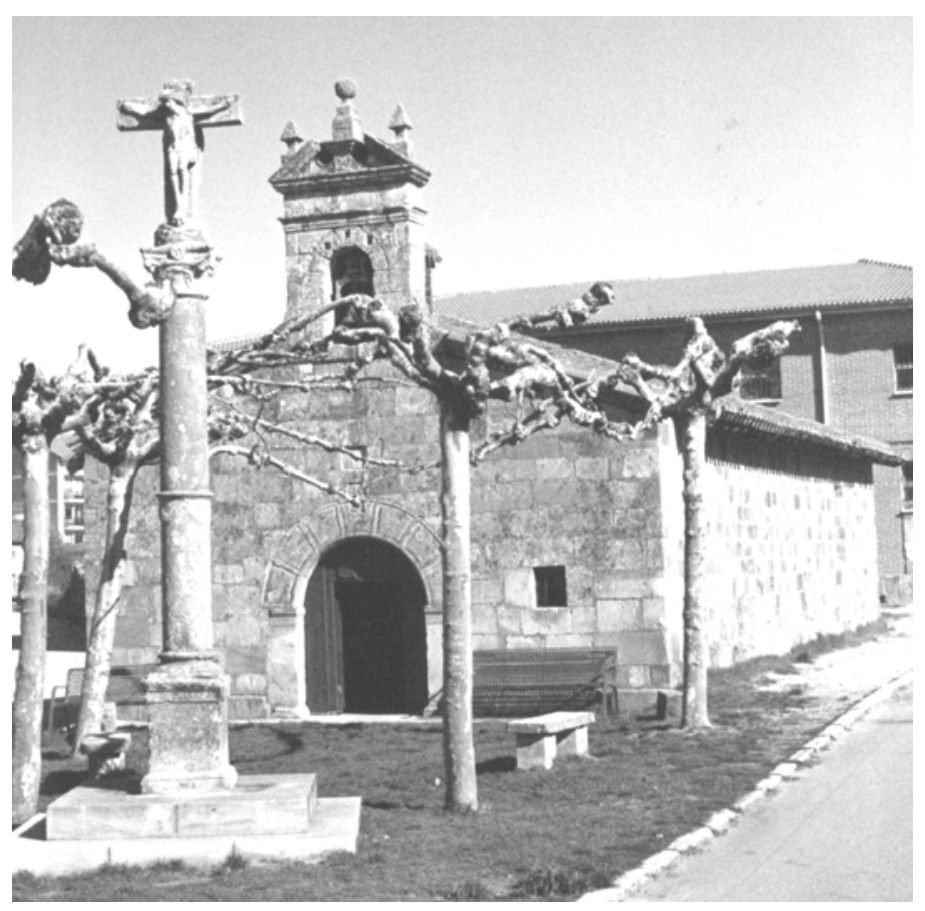

casetonada, que remata con grueso entablamento y frontón recto partido, con un pináculo de bola en el centro, sobre elevado neto, y dos pináculos piramidales en los vértices laterales. Un conjunto sencillo, como decimos, en el que se muestran, de forma tenue, algunos rasgos propios del lenguaje clasicista.

Frente a esta fachada se levanta un crucero, elevado sobre columna de orden compuesto, de fuste anillado en su parte central, y coronado con una cruz tallada por ambas caras, con la representación de Cristo Crucificado en una, y la Virgen con el Niño en la otra. Se trata de una obra renacentista, perteneciente posiblemente a las décadas centrales del siglo XVI, en la cual podemos admirar, junto a la pureza de su talla, la soberbia majestuosidad con la que son concebidas ambas imágenes.

Ya en el interior, encontramos el amplio espacio de la nave, sobre cuya zona de los pies se incorpora un pequeño coro alto de madera. La techumbre de este espacio, dispuesta a dos aguas, descansa sobre armadura de tipo par y nudillo. En el extremo 
oriental se abre la capilla mayor, a la cual se accede a través de amplio arco de medio punto rebajado, que apea sobre pilastras de fuste cajeado, que no podemos incluir en ningún orden concreto. Este espacio se cubre con bóveda de crucería estrellada con terceletes. El retablo, que decora el altar mayor, es obra churrigueresca de la segunda mitad del siglo XVIII, y cuenta con la imagen del santo titular en el centro, flanqueada por movidos estípites, a la que se suma una pequeña talla de la Virgen con el Niño en el remate.

La ermita de San Isidro, se encuentra situada en el extremo oriental de la localidad, sobre uno de los cerros, que domina el caserío. Aun no han llegado hasta aquí las modernas edificaciones de los nuevos barrios, con lo cual, todavía mantiene su carácter de lugar tranquilo, al que los vecinos acuden en los días soleados. Esta ermita fue construida a finales del siglo XVIII, si bien, su aspecto actual es fruto de las renovaciones y ampliaciones efectuadas entre los últimos años del siglo XIX y principios del $\mathrm{XX}^{1736}$.

Repite el mismo tipo de estructura que la ermita anterior, aunque con unas dimensiones algo mayores y una menor calidad artística. Sus muros están realizados en mampostería, y se levantan sobre un zócalo de tres hileras de sillares. De su imagen exterior destaca el muro de los pies, donde se abría su primitiva puerta de entrada, la cual se encontraba rematada por arco de medio punto. Sobre ella se abre un pequeño óculo, y remata el conjunto una sencilla espadaña de un solo vano. La puerta actual está orientada al mediodía, a la cual acompañan tres ventanales, distribuidos entre la nave y el presbiterio, de trazas neogóticas, con arco ojival muy apuntado y fuerte derrame hacia el exterior. En el interior, como en el caso de la ermita de San Roque, el amplio espacio de la nave cuenta con un pequeño coro alto de madera a los pies, mientras que su espacio se cubre con techumbre a dos aguas sobre armadura de tipo par y nudillo. A la capilla mayor, dispuesta sobre el extremo oriental, se accede a través de un amplio arco de medio punto dispuesto sobre pequeñas impostas de cuarto de bocel. Esta capilla se

1736 E. GONZÁLEZ BARRIUSO: Salas de los Infantes en la Sierra Burgalesa. Ob. cit. (pp. 106 - 107). 
cubre con un sencillo cielo raso, mientras que el muro frontal se decora con un pequeño retablo de estilo clasicista, de un solo cuerpo y remate, de mediados del siglo XVII. En sus nichos encontramos las imágenes del santo titular de la ermita en el centro, San Sebastián y San Cristóbal, a los lados, y una tabla con la imagen de la Dolorosa en el remate.

La ermita de las Benditas Ánimas se encuentra situada a unos quinientos metros de la localidad, en dirección este, junto a la carretera, que parte desde Salas en dirección a Quintanar de la Sierra y el resto de la zona de pinares. En realidad se trata de un simple oratorio, que consta de una pequeña construcción levantada sobre planta cuadrangular, con muros en los que se alterna la sillería y el sillarejo, y cubierta dispuesta a cuatro aguas. El acceso al interior se realiza a través de una pequeña puerta coronada con arco de medio punto rebajado, orientada hacia el mediodía. Es una obra propia de la arquitectura popular, sin ningún tipo de valor artístico. Aun así, su estructura resulta particularmente interesante, pues nos muestra el modelo, que debieron repetir muchas de las ermitas de esta comarca, que desaparecieron entre los siglos XVIII y XIX.

En lo que se refiere a las ermitas desaparecidas, la única que despierta un cierto interés es la de San Pelayo, cuyo origen parece estar vinculado a un antiguo priorato, dependiente del monasterio de Santo Domingo de Silos, que existió en las inmediaciones de Salas, entre los siglos XII al XIV. El documento más antiguo, que nos habla de este pequeño cenobio, está fechado en $1187^{1737}$. Posteriormente, en el siglo XVI, aparece citado ya como ermita, dependiente de la parroquia de Santa Cecilia, del barrio de Costana, perdiéndose su rastro en el siglo XVIII ${ }^{1738}$. La falta de restos nos ha impedido localizar el lugar exacto en el que se encontraba situado.

Arquitectura civil.

1737 M. FEROTIN: Recueil des chartres de l'abbaye de Silos. París. 1987. Cfr. A. BENGOECHEA: Historia de Salas I... ob. cit. (pp.104). 
SALAS DE LOS INFANTES.

Ermita de las Benditas Ánimas.

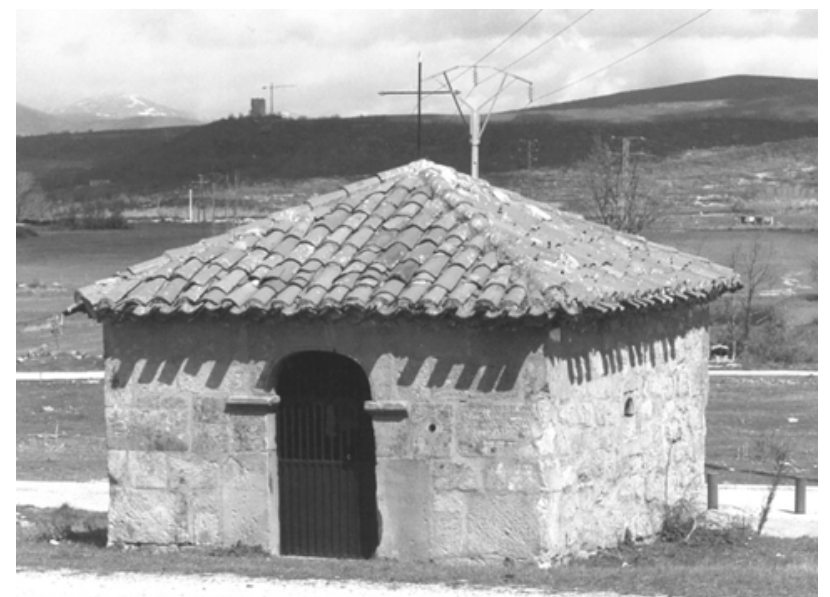

La arquitectura civil de la Edad Moderna en Salas ha corrido peor suerte que la religiosa, como ya señalamos al principio, fruto del crecimiento incontrolado que ha sufrido este núcleo. De la casa-palacio o casa fuerte de los señores de Salas, como hemos visto, actualmente no queda más que su recuerdo y unos escasos restos de su muralla. Mientras, en el barrio de Costana, los inmuebles que conforman su caserío, simplemente nos aportan ejemplos de una arquitectura popular muy evolucionada y adaptada a los nuevos tiempos.

Los únicos ejemplos de construcciones de cierta calidad, dentro del ámbito civil, pertenecientes a los siglos de la Edad Moderna, por lo tanto, los vamos a encontrar en el barrio de Santa María. Destacan aquí las edificaciones agrupadas en torno a su iglesia parroquial, las cuales forman una pequeña plaza, junto a la zona de los pies del templo, de fachadas regulares, con las que se delimita un espacio perfectamente ordenado. Dentro de esta plaza, que lleva el nombre de Santa María, destaca especialmente el inmueble situado en el $\mathrm{n}^{0} 1$, el cual presenta una magnífica fachada de muros de sillería, con puerta coronada con amplio arco de medio punto de rosca casetonada y escudo

1738 E. GONZÁLEZ BARRIUSO: Salas de los Infantes en la Sierra Burgalesa. Ob. cit. (pp. 109). 
sobre su clave central. Son rasgos característicos, que los modelos de este tipo de casa desarrollaron en la zona fundamentalmente durante el siglo XVIII, a los cuales se unen, en esta ocasión, ciertas preocupaciones por el ordenamiento urbano.

Otro ejemplo interesante de este tipo de casa, aunque muy alterado por el paso del tiempo y las modificaciones posteriores, es el que encontramos en la plaza Condestables $n^{\circ} 1$, en un lugar bastante alejado ya de la iglesia de Santa María.

En el campo de la arquitectura popular, entre las construcciones que rodean ambas iglesias, donde se halla el núcleo más castizo de Salas, todavía encontramos varios ejemplos de casas con tejados, coronados con la majestuosa estampa de las chimeneas de estructura cónica, típicas de las cocinas serranas. Las del barrio de Santa María son casas de una sola planta o dos a lo sumo, cuya estructura nos recuerda, en muchos casos, el perfil de las típicas casas carreteras, que abundaban en la vecina zona de pinares. 
TERRAZAS.

Terrazas es un pequeño pueblos situado en las inmediaciones de Salas de los Infantes, en cuyo ayuntamiento se encuentra incluido actualmente, como un barrio más. Está situado en las estribaciones de la Sierra de la Demanda, en un terreno árido de orografía ondulada, que anuncia ya el perfil netamente montañoso de las zonas más altas. El pequeño término, que rodea este pueblo, se encuentra situado en el centro de una amplia extensión de terrenos de ledanías, en cuya explotación participaron también los vecinos de esta localidad.

El origen de este pueblo debemos relacionarlo con el proceso poblador, que se vive en la zona en torno a los siglos IX y X, del cual quedan abundantes testimonios en su entorno, en forma de despoblados, como Torneros, Casto, Castejón, o San Andrés $^{1739}$. Aparece citado en el fuero apócrifo de Salas del 974, si bien, la primera referencia documental cierta no se produce hasta principios del siglo XII, en un documento del monasterio de San Pedro de Arlanza ${ }^{1740}$. Hasta este momento Terrazas había formado parte del gran alfoz de Lara ${ }^{1741}$, quedando incluido, a partir de estas fechas en la Merindad Menor de Santo Domingo de Silos ${ }^{1742}$.

1739 G. MARTÍNEZ DÍEZ: Pueblos y alfoces burgaleses de la repoblación. Valladolid. Junta de Castillo y León. Consejería de Educación y Cultura. 1997. (pp. 178, 187, 190).

1740 L. SERRANO: Cartulario de San Pedro de Arlanza. Madrid, Centro de Estudios Históricos, 1925. (pp. 182).

1741 G. MARTÍNEZ DÍEZ: Pueblos y alfoces burgaleses... ob. cit. (pp. 176).

1742 C. ESTEPA DÍEZ: "Estructura de poder en Castilla (siglos XII - XIII). El poder señorial en las merindades burgalesas. En III Jornadas burgalesas de Historia (3 1991). Burgos en la Plena Edad Media. Burgos, Asociación Provincial de Libreros de Burgos. 1994. (pp. 245 - 294).G. MARTínEZ 
Ya en la Edad Moderna, en el plano fiscal, Terrazas aparece dentro de los pueblos del partido de las Tierras del Condestable, de la provincia de Burgos ${ }^{1743}$, para pasar más tarde, tras la reforma borbónica del siglo XVIII, a formar parte del partido de Candemuñó, dentro de esta misma provincia ${ }^{1744}$. En el aspecto jurisdiccional, a mediados del siglo XIV este pueblo figura como señorío solariego, dependiente de Iohan Díaz Rocoful (o Roca Fuy) e Donna Sancha, muger que fue de Diego López de Haro $^{1745}$. A comienzos de la Edad Moderna, sin embargo, forma parte ya del señorío dependiente de la cada de los Velasco, Condestables de Castilla y Duques de Frías, condición que no perderá prácticamente hasta el final de este período. Por último, en el orden eclesiástico, su única parroquia, dedicada a Santa Eugenia, depende, desde el Concilio de Burgos de 1136, de la sede burgalesa, pues se encuentra situada sobre la margen derecha del río Arlanza, que marca el límite con la Diócesis de Osma ${ }^{1746}$.

Terrazas, como venimos diciendo, fue siempre un pueblo pequeño, con unos niveles de población muy bajos, que apenas experimentan cambios bruscos a lo largo de todo este período de la Edad Moderna. El dato más antiguo que tenemos nos lo proporciona el censo de 1541, con una cifra de 24 vecinos $^{1747}$. Esta cantidad se mantiene, aunque con un ligero descenso, durante la segunda mitad de este siglo, con 16 vecinos ${ }^{1748}$ contabilizados en el censo de los obispos de 1584-87, y 17 vecinos $^{1749}$ en el censo de 1591. Los siguientes datos que poseemos corresponden ya al siglo XVIII, y en

DÍEZ: Libro Becerro de las Behetrías. Estudio y texto crítico. León, Centro de Estudios e Investigación San Isidoro. Caja de Ahorros y Monte de Piedad. Archivo Histórico Diocesano. 1981. (pp. 612 - 613).

1743 G. MARTÍNEZ DÍEZ: Génesis histórica de la provincia de Burgos y sus divisiones administrativas. Burgos, Aldecoa. 1983.

1744 ADPBU. CE - 2031. RESPUESTAS GENERALES. Terrazas, 18 - abril - 1753.

1745 G. MARTÍNEZ DÍEZ: Libro Becerro de las Behetrías... ob. cit. (pp. 612 - 613).

1746 L. SERRANO: El obispado de Burgos y Castilla primitiva. Desde el siglo V al XIII. Madrid. 1935. Tomo I (pp. 333 - 337, 374 - 378, 414 - 418).

1747 AGS. Contaduría General. Leg. 768. (fols. 61).

1748 T. GONZÁLEZ: Censo de población de las provincias y partidos de la Corona de Castilla en el siglo XVI... Ed. Facsímil. Madrid, Imprenta Real. 1829.

1749 Censo de Castilla de 1591. Vecindario. Madrid, Instituto Nacional de Estadística. 1984. 
ellos se reflejan unos valores muy parecidos. Así, el vecindario del Catastro del Marqués de Ensenada, de mediados de este siglo, contabiliza 16 vecinos ${ }^{1750}$, mientras que el censo de Floridablanca, de 1787, convierte esta cifra en 59 habitantes ${ }^{1751}$, con lo cual, si aplicamos en coeficientes de 3'5, que hemos considerado como el más ajustado para la realidad de esta comarca, tenemos unos valores prácticamente idénticos a los anteriores.

La economía de estos habitantes estuvo basada, fundamentalmente, en la agricultura y en la ganadería. En la primera predominan, ante todo, los cultivos de secano, como trigo, cebada o avena, a los que se suman algunas hortalizas, extraídas de las huertas situadas en la vega del río Arlanza, junto al pueblo. La ganadería que aquí se desarrolla es únicamente de tipo estante, con unas cuantas cabezas de ganado lanar y caprino, y algunas vacas y cerdos $^{1752}$. No participaron en ningún momento, por lo que parece, de la ganadería trashumante.

El pueblo de Terrazas se encuentra situado junto a la margen derecha del río Arlanza, con su pequeño caserío dispuesto, de forma escalonada, sobre una pronunciada pendiente, orientada hacia el mediodía, que desciende hacia este cauce. Se trata de un caserío formado por construcciones sencillas, sin alardes de ningún tipo, que se incluyen dentro de la tradicional arquitectura serrana. Esto hace que la iglesia parroquial sea el único edificio que consigue destacar mínimamente.

Iglesia de Santa Eugenia.

La iglesia de Terrazas está dedicada a Santa Eugenia, advocación muy poco frecuente dentro del territorio de la Diócesis de Burgos ${ }^{1753}$. Este templo está situado en

\footnotetext{
1750 Vecindario de Ensenada 1759. Vol. I. Madrid, Centro de Gestión Catastral y Cooperación Tributaria: Tabapress. D. L. 1991.

1751 INE. Censo de 1787. “Floridablanca”. Madrid. INE. 1989.

1752 ADPBU. CE - 2031. RESPUESTAS GENERALES. Terrazas, 18 - abril - 1753.

1753 J. CIDAD PÉREZ: Historia de la Diócesis de Burgos. (Ensayo). Burgos, Imprenta Monte Carmelo. 1985.
} 
la parte más alta del pueblo, sobre pequeño espacio, que ha sido convenientemente allanado, y delimitado por un muro en su parte meridional. Nos presenta un edificio sencillo, de aspecto más bien tosco, compuesto por elementos y piezas pertenecientes a los más variados estilos y épocas, que arrancan en el siglo XII, y no terminan hasta el siglo XVIII.

Como resultado de ello surge un edificio de estructura de tipo caja, levantado sobre planta de nave única de trazado rectangular, acompañada por la cabecera, en el extremo oriental, formada por una capilla mayor cuadrangular de testero plano, y una sacristía adosada sobre su flanco meridional. Todo ello se completa con la torre, dispuesta a los pies. Dentro de sus muros predomina el paramento de mampostería, elaborado con piedras de mediano tamaño, que se refuerzan en las esquinas y marcos de los vanos con sillares de mayor tamaño. La torre, sin embargo, está compuesta totalmente por muros de sillería, con los cuales se forma un sólido prisma de base cuadrangular, con el tramo superior, que forma el cuerpo de campanas, delimitado por una moldura plana de escaso resalte. Cuenta este cuerpo superior con cuatro vanos de arco de medio punto repartidos entre cada una de sus caras, para alojar las campanas, mientras que el remate está formado por moldura de tipo papo de paloma. Es una pieza perteneciente al siglo XVII, en la que se desarrolla un modelo muy repetido en varias de las iglesias de la zona durante este período.

Otro elemento interesante de esta imagen exterior es la portada, abierta sobre el tramo final del muro meridional de la nave. Actualmente se encuentra muy alterada, aunque conserva gran parte de su estructura original románica. Presenta una estructura abocinada con dos niveles de arquivoltas, con arcos de medio punto de aristas redondeadas, y el segundo de ellos con rosca decorada con relieve de bolas, sobre el cual se superpone, a su vez, un relieve ajedrezado, que enmarca todo el conjunto. Estos arcos, que descansan sobre finas líneas de imposta, se corresponden en las jambas con columnas decoradas con capiteles, en los que aparecen figuras de hombres y animales enfrentados. Estos elementos escultóricos, y otros más que aparecen repartidos por esta 


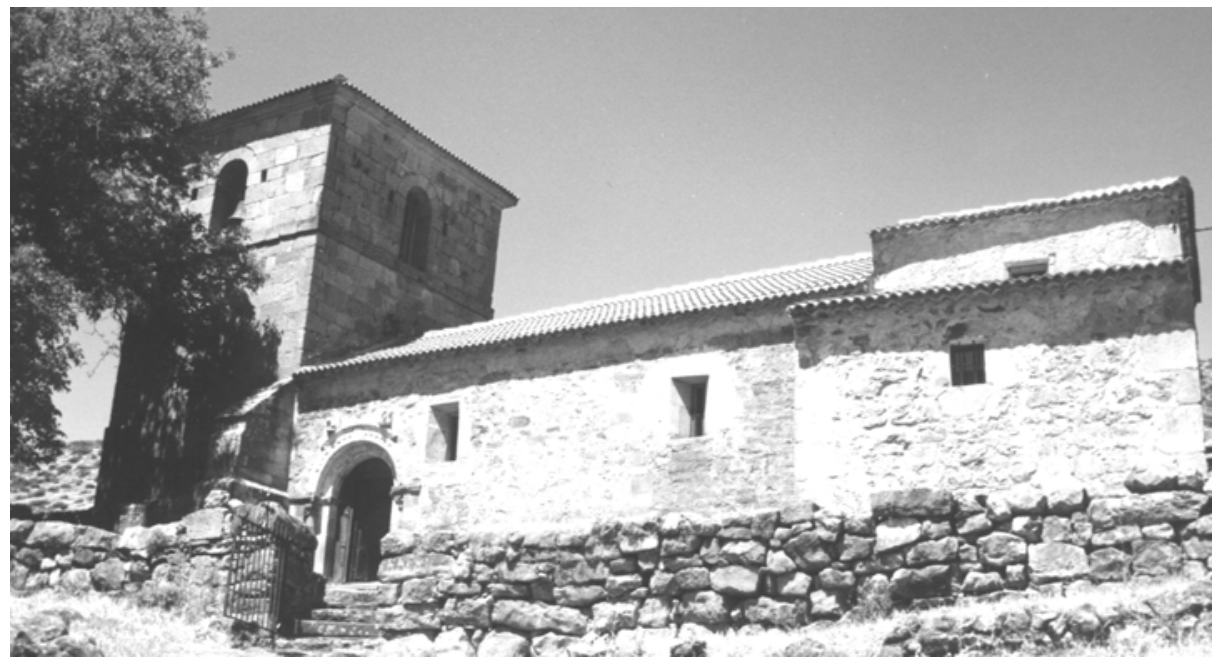

TERRAZAS. Iglesia de Santa Eugenia.

fachada, y que fueron extraídos de esta portada, nos permiten relacionar esta construcción con el taller de los llamados primeros maestros de la escuela del románico de la sierra, fechados en torno a la primera mitad del siglo XII ${ }^{1754}$. Sobre esta misma fachada encontramos también las ventanas, que iluminan el espacio interior, formadas, en todos los casos, por sencillos vanos rectangulares de dintel plano. Dentro de ellas, las dos correspondientes al tramo de la nave, presentan además un ligero abocinado hacia el exterior.

El espacio interior se encuentra en la actualidad totalmente alterado, después de las últimas labores de restauración, realizadas en las últimas décadas del siglo XX. Así, encontramos, por un lado, la zona reservada al culto, en la que se incluye la cabecera y la mayor parte de la antigua nave. Fuera de esta zona quedan el tramo final de la nave y el espacio interior de la base de la torre, donde se asienta el antiguo coro, elaborado en

1754 F. PALOMERO ARAGÓN, M. ILARDIA GÁLLEGO: El arte románico burgalés. Un lenguaje medieval actual. Madrid, Lancia. 1995. (pp. 114 - 115); F. PALOMERO ARAGÓN: Rutas para descubrir el arte de la Sierra de la Demanda. Valladolid, Ámbito Ediciones. 2000. (pp. 82). 
madera. Esta parte de los pies ha sido convertida, por lo tanto, en una especie de recibidor, donde se ha ubicado también la pila bautismal.

En la zona destinada al culto, la parte más interesante es la capilla mayor, de estilo gótico, perteneciente a los siglos XIII o XIV. A este espacio se accede a través de un potente arco apuntado de aristas redondeadas, y su interior está cubierto por un bello artesonado de madera, dispuesto en forma de artesa invertida, que podemos relacionar con otros ejemplos similares, realizados en la zona en torno a las décadas centrales del siglo XVII, como son los de la iglesia parroquial de Vilviestre del Pinar y la ermita de la Vera Cruz, en Canicosa de la Sierra ${ }^{1755}$. El muro del altar mayor queda cubierto por un bello retablo de estilo churriguresco, realizado hacia la década de 1760 . Consta de un pequeño banco, decorado con dos pinturas sobre tabla del siglo XVI, donde se representan las imágenes de los Evangelistas. En el cuerpo, el nicho central está ocupado por una talla de la imagen de la santa titular del templo, perteneciente al siglo XVII, a la cual acompañan, en las calles laterales, otras dos tablas, similares a las anteriores, con las imágenes de San Fabián y San Roque, mientras que en el remate se ha colocado una talla de San Sebastián de la segunda mitad del siglo XVI ${ }^{1756}$. El espacio de la nave, que se cubre con techumbre dispuesta a dos aguas sobre armadura de madera de tipo par y nudillo, apenas cuenta con elementos de interés, pues toda su estructura es producto de las modernas obras de restauración.

En la zona de los pies del templo, que forma el recibidor, destaca, además del antiguo coro de madera, ubicado en el interior de la base de la torre, la antiguo pila bautismal románica. Se trata de una pieza de gran belleza, perteneciente a la primera mitad del siglo XII, y está formada por una gran copa semiesférica, con decoración de

\footnotetext{
1755 En Canicosa de la Sierra, la ermita de la Vera Cruz conservan en su capilla mayor restos de un artesonado prácticamente idéntico a éste, que fue realizado en las obras de renovación del edificio, efectuadas hacia 1640. En Vilviestre del Pinar, dentro de su iglesia parroquial, existía una cubierta parecida, en la zona de las naves, levantada también en la década de 1640.

1756 R. J. PAYO HERNANZ: El retablo en Burgos y su comarca durante los siglos XVII y XVIII.
} Burgos, Excma. Diputación Provincial de Burgos. 1997. (T. II, pp. 549). 


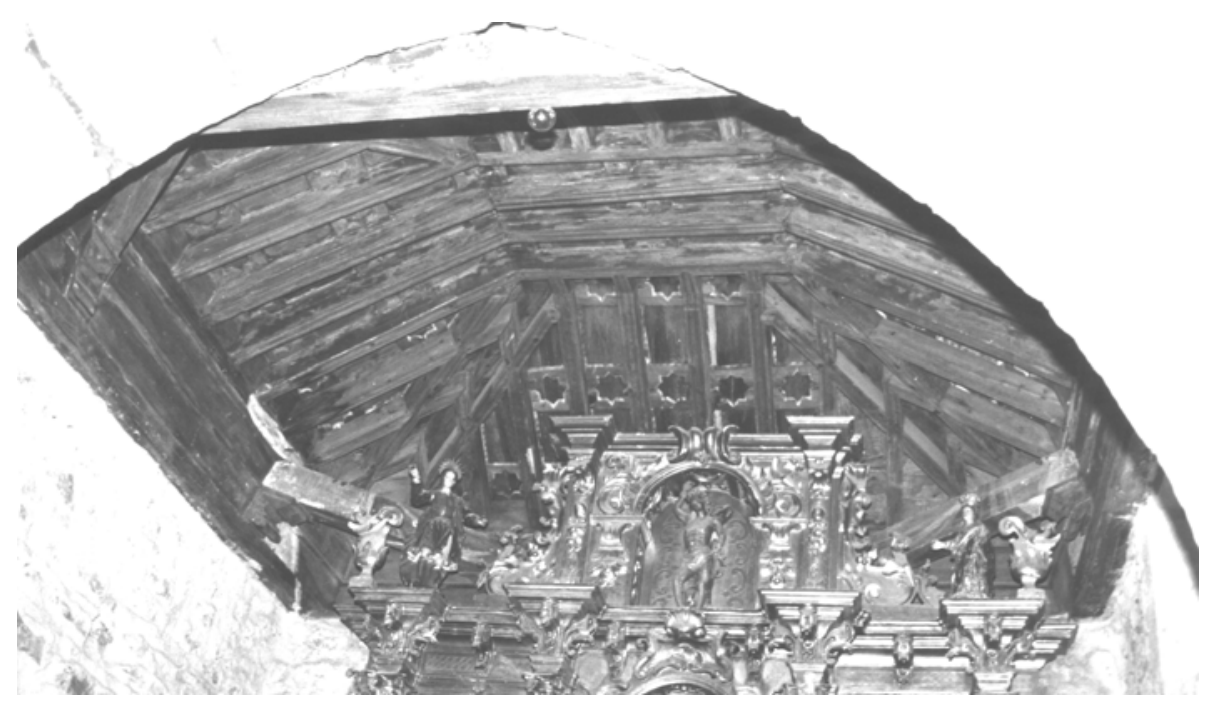

TERRAZAS. Iglesia de Santa Eugenia. Artesonado capilla mayor.

gallones en el exterior y una gruesa faja con tallos entrelazados que recorre su borde, mientras que en el pie encontramos un sólido prisma, con arcos ciegos de medio punto sobre columnas pareadas, recorriendo todo su contorno ${ }^{1757}$. Se trata, sin duda, de la pieza más interesante que alberga este templo, y una de los ejemplos más brillantes de esta tipología, que podemos encontrar en las iglesias de la zona.

La historia constructiva de este templo, por lo tanto, comienza con un primer edificio románico, que podemos fechar en torno a las décadas iniciales del siglo XII, tal y como nos indican los restos de su portada, y corrobora su pila bautismal. A este primer templo le sigue una segunda fase, fechada entre los siglos XIII y XIV, a la cual corresponde el arco de entrada de la capilla mayor. Resulta imposible, en cualquier caso, reconstruir la imagen, que podía presentar el templo en estos momentos.

1757 G. BILBAO LÓPEZ: Iconografía de las pilas bautismales del románico castellano; Burgos y Palencia. Burgos, Editorial la Olmeda. 1996. 
La imagen del templo actual es el resultado, en gran medida, de las intervenciones desarrolladas entre los siglos XVII y XVIII. A la primera de estas centurias corresponde, con toda seguridad, la construcción de la torre, cuya estructura reproduce, como hemos dicho, los modelos habituales, desarrollados durante este siglo en la arquitectura religiosa de la comarca. También podemos incluir aquí, como vimos, la construcción de la cubierta de la capilla mayor, la cual, sin duda, supuso la culminación de una obra más profunda de renovación de la cabecera. Por último, en 1742, se renueva la estructura de la nave, tal y como nos indica la inscripción situada sobre el dintel de una de sus ventanas. Dentro de estos trabajos se decide conservar parte de la portada del primitivo templo románico, mientras que algunos de sus capiteles se incrustan entre los sillares de sus muros.

\section{Ermitas.}

Terrazas ha conservado restos de dos ermitas, dependientes de su parroquia, las cuales estaban dedicadas a San Francisco y a San Pantaleón y Santa Cristeta. De ella, la más destacada es la de San Francisco, situada a las afueras del pueblo, junto a la carretera, que conduce hacia Monasterio de la Sierra. En época reciente se ha producido el derrumbe de su tejado, lo cual no impide apreciar el aspecto que debió presentar este templo en su estado original. Se trataba de un edificio sencillo, de aspecto tosco, perteneciente al siglo XVIII, tal y como nos indica el arco de su puerta de entrada y la espadaña que se alza sobre ella. Consta de una estructura de tipo caja, levantada sobre planta rectangular orientada hacia oriente, con muros de sillarejo, reforzados en las esquinas y marcos de los vanos por sillares de mayor tamaño. De su imagen exterior, destaca su fachada principal, levantada sobre el muro de los pies. Aquí se abre la puerta de entrada, formada por potente arco de medio punto de amplio dovelaje, dispuesto sobre impostas planas de escaso resalte. Sobre ella se abre una pequeña ventana de dintel plano, y rematando todo el conjunto encontramos una espadaña con un solo vano de arco de medio punto, y sobre él una cruz escoltada por pináculos piramidales. 


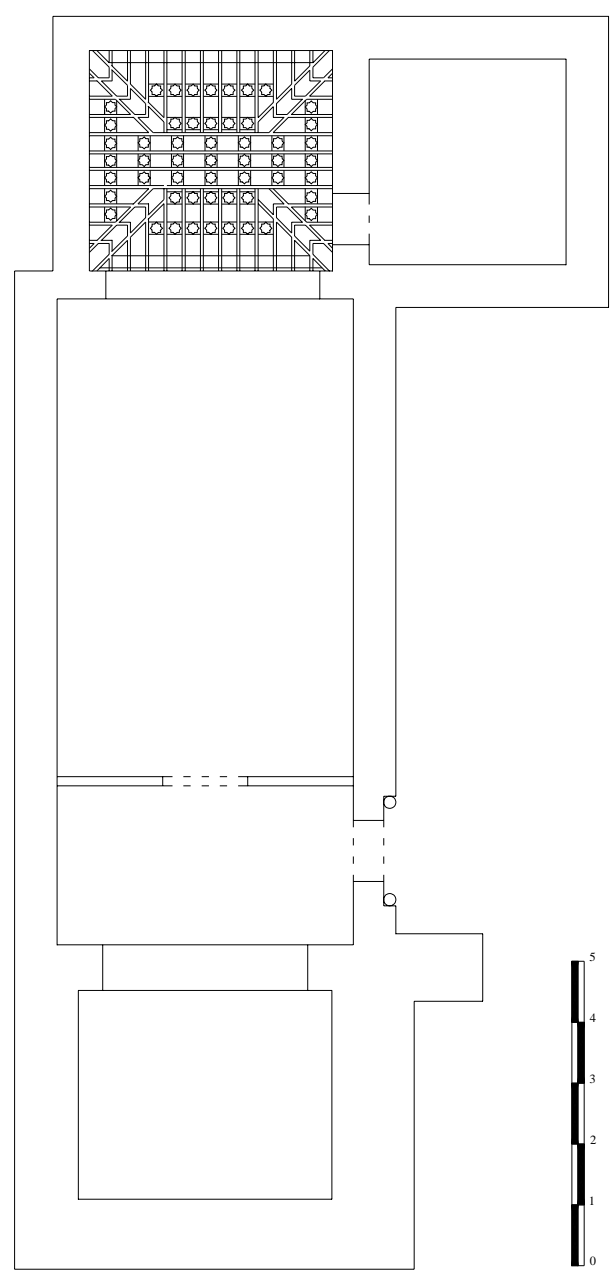

TERRAZAS. Iglesia de Santa Eugenia. Planta.

La ermita de San Pantaleón y Santa Cristeta está algo más alejada del pueblo, en dirección este, aproximadamente en un punto intermedio entre las localidades de Terrazas y Monasterio de la Sierra. Su aspecto tosco y desarreglado hacen que se confunda con alguna de las tenadas, donde se guardaba el ganado, que tanto abundan en esta zona. Se levanta sobre una planta rectangular orientada hacia naciente, con muros de mampuesto de gran calibre, reforzados en las esquinas con sillares de mayor tamaño, y cubierta con techumbre formada por teja curva, dispuesta a cuatro aguas. A su interior se accede a través de una pequeña puerta de dintel plano, abierta sobre el muro 
meridional. No existen en la parte exterior, por lo tanto, elementos que nos indiquen su condición de edificio religioso. Al igual que el caso anterior, desconocemos el origen de este templo. 
TOLBAÑOS DE ABAJO.

Tolbaños de Abajo es una pequeña localidad situada en el valle de Valdelaguna, sobre la vertiente norte de las cumbres, que componen la Sierra de Neila. Su escasa población y lo reducido de su caserío han hecho que este pueblo sea conocido de forma cariñosa, entre las poblaciones vecinas, como Tolbañitos, diferenciándolo así de Tolbaños de Arriba, al que se le conoce simplemente como Tolbaños.

El origen de esta localidad, como el resto de los pueblos de la zona, se encuentra relacionado con la ola de poblamientos, que se produce en estas sierras entre los siglos IX y X, si bien, las primeras referencias escritas no se producen hasta mediados del siglo XI (1-I-1044) ${ }^{1758}$. Su destino estuvo ligado, desde estos primeros momentos, a la agrupación de pueblos que componen el valle de Valdelaguna, con los cuales aparece formando, durante la Edad Moderna el Real Valle y Villa de Valdelaguna.

Tolbaños de Abajo forma parte, hasta el año 1062, del efímero alfoz de Barbadillo del Pez ${ }^{1759}$, pasando luego a depender del gran alfoz de Lara ${ }^{1760}$, como el resto de los pueblos del valle. Más tarde, una vez extinguido el sistema de alfoces, este

\footnotetext{
1758 L. SERRANO: Cartulario de San Pedro de Arlanza. Madrid, Centro de Estudios Históricos, 1925. (pp. 86).

1759 G. MARTÍNEZ DÍEZ: Pueblos y alfoces burgaleses de la repoblación. Valladolid. Junta de Castillo y León. Consejería de Educación y Cultura. 1997. (pp. 198).

1760 I. ÁLVAREZ BORGE: Monarquía feudal y organización territorial: alfoces y merindades en Castilla (siglos $X-X I V)$. Madrid, CSIC. 1993. (pp. 59).
} 
pueblo, junto con el resto localidades de Valdelaguna, queda incluido en la Merindad Menor de Santo Domingo de Silos ${ }^{1761}$.

Ya en la Edad Moderna, dentro de la organización fiscal del territorio, esta localidad aparece incluida dentro del partido de las Tierras del Condestable de la provincia de Burgos ${ }^{1762}$, para luego más tarde, tras la reforma borbónica del siglo XVIII, pasar a formar parte del partido de Aranda ${ }^{1763}$. En el plano jurisdiccional, a mediados del siglo XIV, esta localidad poseía la condición de señorío solariego, dependiente de Pedro Fernández de Velasco, María, su hermana, Iohan Sánchez de Velasco, de filios de Gómez Carriello, de filios de Iohan Martínez Leyva ${ }^{1764}$. En el orden eclesiástico, su única parroquia dependió siempre de la Diócesis de Burgos.

Tolbaños de Abajo fue siempre un núcleo de población escasa, si bien, no podemos considerarla como la localidad más pequeña del valle. Por ello, la elección del diminutivo, empleado en su denominación más popular, debemos entenderlo no por su condición de núcleo más pequeño del conjunto del valle, sino por su menor población con respecto al otro Tolbaños, el de Arriba. Apenas tenemos datos que nos permitan conocer la evolución, que experimentó esta población a lo largo de la Edad Moderna, pues como ocurre habitualmente en los recuentos realizados durante todo este período en la zona, los habitantes de esta agrupación, que forman los pueblos de Valdelaguna, se realizó de forma conjunta la mayoría de las veces. Por ello, los únicos datos que poseemos, propios de este pueblo, pertenecen ya a la segunda mitad del siglo XVIII. Según el vecindario del Catastro del Marqués de Ensenada, a mediados de esta centuria

\footnotetext{
1761 C. ESTEPA DÍEZ: “Estructura de poder en Castilla (siglos XII - XIII). El poder señorial en las merindades burgalesas. En III Jornadas burgalesas de Historia (3 1991). Burgos en la Plena Edad Media. Burgos, Asociación Provincial de Libreros de Burgos. 1994. (pp. 245 - 294).G. MARTÍNEZ DÍEZ: Libro Becerro de las Behetrías. Estudio y texto crítico. León, Centro de Estudios e Investigación San Isidoro. Caja de Ahorros y Monte de Piedad. Archivo Histórico Diocesano. 1981. (pp. 615).

1762 G. MARTÍNEZ DÍEZ: Génesis histórica de la provincia de Burgos y sus divisiones administrativas. Burgos, Aldecoa. 1983.

1763 ADPBU. CE - 2046. RESPUESTAS GENERALES. Tolbaños de Abajo, 25 - septiembre - 1753.

1764 G. MARTÍNEZ DÍEZ: Libro Becerro de las Behetrías... ob. cit. (pp. 615).
} 
existían en Tolbaños de Abajo un total de 45 vecinos $^{1765}$. Esta población se convierte, a finales de siglo, según el censo de Floridablanca de 1787, en 158 habitantes $^{1766}$. A través de estos censo, sabemos también que todos sus habitantes disfrutaban en este momento de la condición de hidalgos ${ }^{1767}$.

La economía de esta población durante la Edad Moderna estuvo centrada de forma casi exclusiva en la ganadería lanar trashumante, al igual que el resto de los pueblos del Valle de Valdelaguna. En esta actividad participan la práctica totalidad de la población, bien guiando rebaños propios, que podían ser de tamaño variable, o bien como asalariados de otros ganaderos más importantes de los pueblos vecinos, donde desempeñaban los distintos puestos, dentro de la cuadrilla de pastores. Los propietarios de rebaños merinos de Tolbaños de Abajo formaban parte de la Cuadrilla de San Pedro de Vega, en la que se agrupaban todos los ganaderos trashumantes de la zona de la sierra burgalesa. Esta economía se completaba con algunos pequeños cultivos de cereales y hortalizas, y la cría de algunos ganados estantes ${ }^{1768}$.

El pueblo de Tolbaños de Abajo se asienta sobre las laderas de un pequeño valle, mirando hacia del mediodía, formándose aquí un pequeño grupo de casas, dispuestas sin ningún orden, entre las que predominan los tipos tradicionales de la arquitectura popular de la zona. Durante el período final de la Edad Moderna, debió contar con varios ejemplos de casas solariegas, pertenecientes a los más ricos propietarios de ganados merinos, sin embargo, el paso del tiempo, y las numerosas remodelaciones efectuadas posteriormente, han llevado a la desaparición prácticamente total de todas ellas. De este modo, lo único que se conserva son algunos restos de portadas con arco de medio punto, y diversos blasones empotrados en sus fachadas, como testimonio del pasado esplendor. El edificio más representativo, por lo tanto, vuelve a ser su iglesia parroquial.

1765 Vecindario de Ensenada 1759. Vol. I. Madrid, Centro de Gestión Catastral y Cooperación Tributaria: Tabapress. D. L. 1991.

1766 INE. Censo de 1787. “Floridablanca”. Madrid. INE. 1989.

1767 Ibídem.

1768 ADPBU. CE - 2046. RESPUESTAS GENERALES. Tolbaños de Abajo, 25 - septiembre - 1753. 
Iglesia de San Quirico y Santa Julita.

La iglesia de Tolbaños de Abajo se encuentra dedicada a una advocación muy poco frecuente, dentro de la Diócesis de Burgos, como son San Quirico y Santa Julita, hijo y madre, que fueron martirizados en época del emperador romano Diocleciano ${ }^{1769}$.

Esta iglesia está situada fuera del pueblo, a unos cien metros de las primeras casas, en dirección este, ocupando un espacio, que ha sido convenientemente allanado, al que flanquean dos muros, que forman el atrio. Es un edificio singular, elaborado en dos etapas constructivas perfectamente diferenciadas, en las que se manifiestan las formas propias de los estilos prerrománico y románico. Con ellas prácticamente se cierra la secuencia constructiva de este templo.

El doble proceso constructivo a dado lugar a una planta en la que podemos distinguir con claridad dos templos perfectamente diferenciados, ambos de nave única, dispuestos en paralelo. El más antiguo, y de mayores dimensiones, es el situado en el lado septentrional, y cuenta con una amplia nave de trazado rectangular sobre cuyo extremo oriental se añade la cabecera, formada por un espacio cuadrangular de testero plano algo más estrecho que la nave. Sobre el flanco meridional de esta nave se adosa la segunda parte del templo, que consta también de una planta de nave única de trazado rectangular, que se prolonga en su extremo oriental, con un pequeño tramo, para formar una segunda capilla, también rematada con testero plano. Las dimensiones de esta parte del templo son significativamente más reducidas, que las de la parte anterior, tanto en longitud como en anchura. Separada de este núcleo principal del templo, queda la torre, la cual aparece de forma exenta, en la zona septentrional. Todo el edificio se encuentra realizado en piedra, con muros de mampostería, que se refuerzan en las esquinas con sillares de mayor tamaño y mejor labra.

1769 S. DE LA VORÁGINE: La Leyenda Dorada. Madrid, Alianza Editorial. 1996. (pp. 330 - 331); J. FERRANDO ROIG: Iconografía de los Santo. Barcelona, Ediciones Omega. 1950. (pp. 233). 


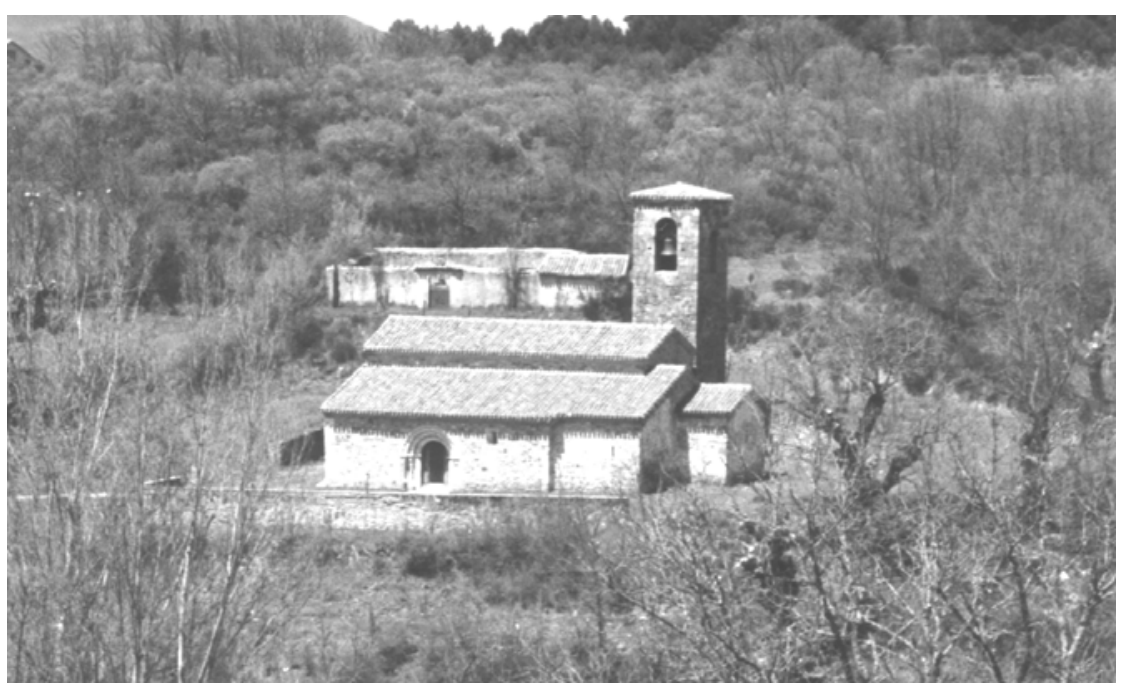

TOLBAÑOS DE ABAJO. Iglesia de San Quirico y Santa Julita.

$\mathrm{Al}$ exterior este edificio se manifiesta como un interesante juego de volúmenes, en el que se combinan los diferentes prismas, que forman, por un lado, la nave de la zona más antigua y su cabecera, y por otra, la parte más reciente, que constituye la estructura del flaco meridional. Los dos primeros aparecen cubiertos con techumbres dispuestas a dos aguas, mientras que el último lo está a una sola vertiente. Totalmente exenta, como decimos, aparece sobre el flanco septentrional la torre, la cual ofrece una esbelta estructura prismática sobre base cuadrangular, formada por muros dispuestos en ligero talud, que resulta prácticamente inapreciable. Son muros de mampostería reforzados con sillares en las esquinas, igual que el cuerpo del templo, si bien, el tramo superior, que forma el cuerpo de campanas, presenta un paramento más cuidado de sillería, que remata con cornisa de tipo papo de paloma. Evidentemente esta parte superior es fruto de una renovación posterior, realizada posiblemente en el siglo XVIII, en la que aparecen amplios vanos con arco de medio punto, para alojar las campanas, repartidos por cada una de sus caras, salvo en el lado occidental, en el que encontramos una ventana rasgada de dintel plano y fuerte derrame hacia el exterior. 
En lo que respecta al núcleo principal del templo, su elemento más destacado es la portada, obra románica de finales del siglo XII, que podemos incluir ya dentro de la influencia de la escuela silense ${ }^{1770}$. Consta de un potente arco de medio punto de aristas redondeadas, al que se superponen dos niveles de arquivoltas, con arcos de similares características, enmarcados por una moldura decorada con relieve de bolas. Estos arcos de las arquivoltas descansan sobre gruesas impostas, decoradas con pequeños arcos entrecruzados, y se corresponden en las jambas con columnas rematadas por capiteles, en los que a duras penas podemos adivinar estas formas silenses, que mencionábamos, dada la fuerte erosión de sus sillares.

En el interior aparecen los dos espacios que ya anunciábamos en planta, correspondientes a cada una de las fases constructivas, los cuales se comunican a través de una galería de potentes arcos de medio punto, apeados sobre gruesos pilares de sección cuadrangular. Estos arcos, sin embargo, más que unir, afianzan aun más la personalidad de cada uno de estos espacios. Dentro de ellos se aprecia una clara preponderancia de la parte septentrional, que se corresponde con la zona más antigua, la cual aparece afianzada por una mayor altura de su cubierta. Esta cubierta está formada por una simple estructura de madera sobre armadura de tipo parhilera de construcción moderna. A la cabecera de esta parte del templo se accede a través de un potente arco de medio punto con ligero peralte con aristas redondeadas, y su interior se cubre con bóveda de medio cañón, también ligeramente peraltada.

La otra parte de este templo, situada en el lado meridional, reproduce con pequeñas diferencias este mismo esquema, aunque representado a una escala más reducida. Su nave, por lo tanto, se cubre a una menor altura, con una techumbre de madera dispuesta a una sola vertiente. La capilla abierta en su extremo oriental está precedida por un potente arco apuntado, mientras que su interior se cubre con bóveda de

1770 F. PALOMERO ARAGÓN: Rutas para descubrir el arte de la Sierra de la Demanda. Burgos, Ámbito Ediciones. 2000. (pp.114 - 116). 
TOLBAÑOS DE ABAJO. Iglesia de San Quirico y Santa Julita. Cabecera.

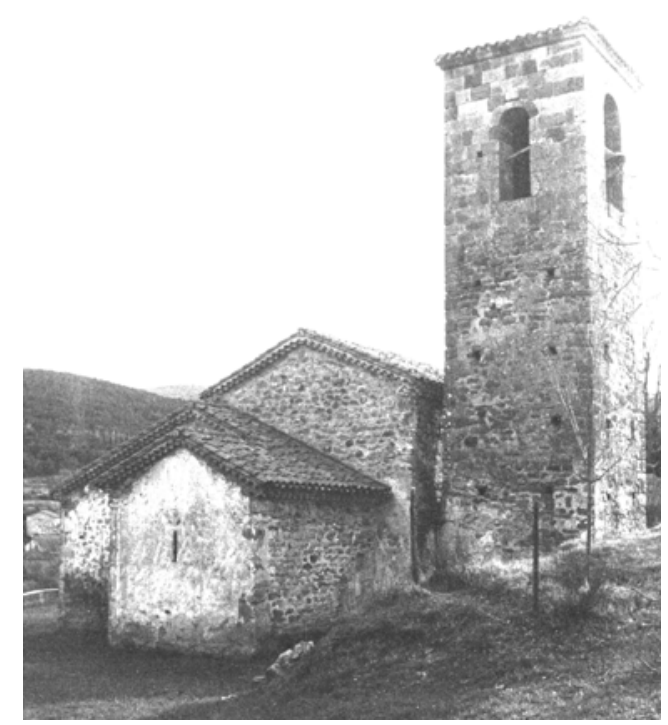

medio cañón, también ligeramente apuntada, que anuncia ya la transición del románico al gótico.

De este modo, historia constructiva de este templo queda reducida a dos fases perfectamente diferenciadas. La primera se encuadra dentro del estilo prerrománico de la época condal del siglo X, y en ella se desarrollan las formas más toscas de este estilo, con una construcción de limpios volúmenes perfectamente individualizados y perfilados, en los que su rasgo más singular lo representa su torre exenta. La segunda fase se produce ya a finales del siglo XII o incluso principios del XII, y en ella observamos ya la presencia de un estilo románico muy avanzado, tanto en la concepción de sus elementos estructurales, como en la confección de la escultura, que compone su decoración. A esta etapa corresponden, como hemos visto, toda la parte meridional del templo actual, así como la arquería, que sirve para unir las dos naves.

Con esta segunda fase se completa prácticamente la secuencia constructiva de este edificio, pues a partir de aquí las únicas obras que registramos son las relacionadas 
con el mantenimiento y el cuidado de esta fábrica. Un buen ejemplo de ello son las obras llevadas a cabo en 1729, consistentes en retirar la parte de tierra, que descansaba sobre el flanco septentrional del templo, con el fin de eliminar las humedades, que procedían de la ladera en la que se asentaba. La obra se realizó por orden de los Provisores del Arzobispado, encargándose de estos trabajos el maestro Tomás Juariste, por un precio de 1.950 reales. Y en ellas se siguieron las condiciones redactadas por dos colegas suyos, como eran Melchor de la Ayuela y Diego Barquiero, con los que colaboraba habitualmente ${ }^{1771}$. Evidentemente la importancia de esta obra, no radica tanto en la aportación de nuevos elementos, como es el muro que se levanta en esta parte del entorno del templo, como en la conservación del edificio heredado, que con ello se pretendía conseguir.

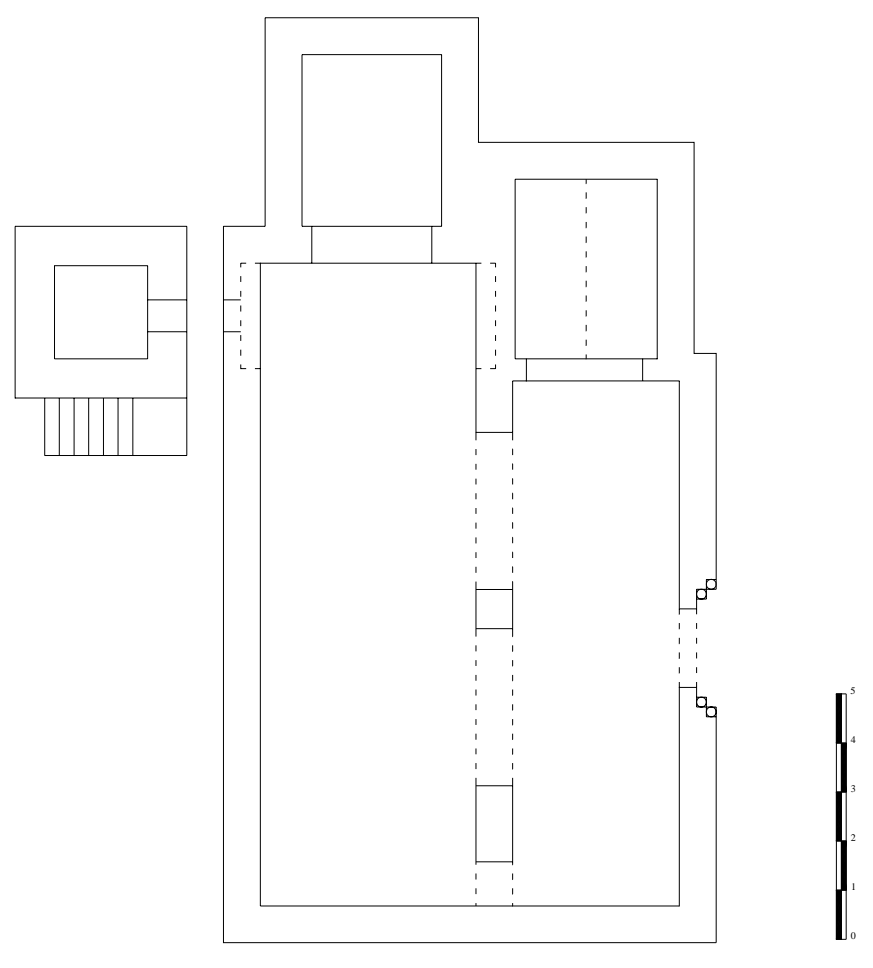

TOLBAÑOS DE ABAJO. Iglesia de San Quirico y Santa Julita. Planta.

\footnotetext{
1771 AHPBU. PN. Valle de Valdelaguna. Leg. 9802/1, fols. 3 - 4 v . Manuel Gil de la Cuesta. Tolbaños de Abajo, 16 - marzo - 1729.
} 
Ermitas.

Solamente hemos encontrado referencias de una ermita, dentro de Tolbaños de Abajo, la cual estaba dedicada a San Millán ${ }^{1772}$. Se encontraba situada dentro del propio casco urbano, y parte de sus restos todavía se pueden contemplar en el inmueble ubicado en la calle de Abajo $n^{\circ} 35$. Entre ellos se reconoce lo que fue su fachada principal, donde aparece su puerta de acceso, coronada con potente arco de medio punto de amplio dovelaje, sobre el que se abre una pequeña ventana de dintel plano con una amplia cruz de piedra encima de ella. Desconocemos el origen de esta ermita, si bien, sabemos que su desaparición como edificio de culto debió producirse en algún momento de la segunda mitad del siglo XIX. P. MADOZ todavía la menciona en su Diccionario, aunque no especifica su advocación ${ }^{1773}$.

\section{Arquitectura civil.}

En arquitectura civil los mejores restos de casas blasonadas los encontramos en los inmuebles situados en la calle de Abajo $n^{\circ} 10$, y en la calle de las Escuelas $n^{\circ} 15$. En las primera todavía podemos admirar el amplio arco de medio punto, que corona la entrada principal, y los dos escudos dispuestos sobre esta misma fachada, en su piso principal. En el segundo caso, simplemente quedan restos del arco de su puerta de entrada. A estos dos ejemplos podemos sumar también la casa situada en la calle Mayor $n^{\circ} 42$, si bien este edificio ha sido completamente remodelado en época reciente, lo que hace que su aspecto original, en el que destacaba su fachada principal con potente arco de medio punto de amplio dovelaje, solamente podamos observarlo en fotografías tomadas antes de su reforma.

1772 AGDBU. LP. Tolbaños de Abajo, parroquia de San Quirico y Santa Julita. LF. (1852 - 1878). (fols. 3 - 7). Visita realizada a la parroquia de San Quirico y Santa Julita en 1853, por D. Manuel del Río Ballesteros. Tolbaños de Abajo, 10 - noviembre - 1853.

1773 P. MADOZ: Diccionario geográfico - estadístico - histórico de España y sus posesiones de Ultramar. Valladolid, Ámbito D.L. 1984. (pp. 466). 


\section{TOLBAÑOS DE ARRIBA.}

La localidad de Tolbaños de Arriba se encuentra situada junto a su homónima de Abajo, dentro del Valle de Valdelaguna. Sus características e historia, por lo tanto, son muy parecidas. La primera referencia escrita, igual que en el caso anterior, se produce en un documento fechado el 1-I-1044 ${ }^{1774}$, si bien, debemos suponer que su creación debió producirse bastante tiempo antes. En estos momentos todavía formaba parte del alfoz de Barbadillo del Pez ${ }^{1775}$, pasando luego a depender del gran alfoz de Lara ${ }^{1776}$. En el siglo XII aparece ya incluido dentro de la Merindad Menor de Santo Domingo de Silos ${ }^{1777}$.

Durante la Edad Moderna esta localidad forma parte del partido de las Tierras del Condestable, dentro de la provincia de Burgos ${ }^{1778}$, pasando más tarde, tras la reforma borbónica del siglo XVIII, a quedar encuadrada en el partido de Aranda, como

1774 L. SERRANO: Cartulario de San Pedro de Arlanza. Madrid, Centro de Estudios Históricos, 1925. (pp. 86).

1775 G. MARTÍNEZ DÍEZ: Pueblos y alfoces burgaleses de la repoblación. Valladolid. Junta de Castillo y León. Consejería de Educación y Cultura. 1997. (pp. 198).

1776 I. ÁLVAREZ BORGE: Monarquía feudal y organización territorial: alfoces y merindades en Castilla (siglos X-XIV). Madrid, CSIC. 1993. (pp. 59).

1777 C. ESTEPA DÍEZ: "Estructura de poder en Castilla (siglos XII - XIII). El poder señorial en las merindades burgalesas. En III Jornadas burgalesas de Historia (3 1991). Burgos en la Plena Edad Media. Burgos, Asociación Provincial de Libreros de Burgos. 1994. (pp. 245 - 294).G. MARTÍNEZ DÍEZ: Libro Becerro de las Behetrías. Estudio y texto crítico. León, Centro de Estudios e Investigación San Isidoro. Caja de Ahorros y Monte de Piedad. Archivo Histórico Diocesano. 1981. (pp. 614).

1778 G. MARTÍNEZ DÍEZ: Génesis histórica de la provincia de Burgos y sus divisiones administrativas. Burgos, Aldecoa. 1983. 
el resto del Valle de Valdelaguna ${ }^{1779}$. En el aspecto jurisdiccional, según el Becerro de las Behetrías, a mediados del siglo XIV Tolbaños de Arriba era localidad de señorío, dependiente de Pedro Fernández de Velasco, de donna María, su hermana, muger de Diego Pérez Sarmiento, e de Iohan Sánchez de Velasco e fiios de Iohan Martínez Leyva $^{1780}$. Más adelante consigue su propia jurisdicción, para formar, junto con los demás pueblos de la zona, la agrupación denominada Real Valle y Villa de Valdelaguna. En el orden eclesiástico, su única parroquia dependió siempre de la Diócesis de Burgos.

Tolbaños de Arriba fue una población de tipo medio, si bien, apenas tenemos información que nos permitan conocer su evolución a lo largo de la Edad Moderna, pues sus datos, la mayor parte de las veces, aparecen incluidos, dentro del recuento general del Valle de Valdelaguna. Aun así, a través del censo de los obispos de 1584-87 sabemos que contaba con una población de 22 vecinos $^{1781}$. Esta cifra experimenta un crecimiento espectacular en los siguientes recuentos, pertenecientes ya al siglo XVIII, hecho que debemos relacionar con la revitalización, que vive un sector tan importante para la zona, como es la ganadería lanar. De este modo, según el vecindario del Catastro del Marqués de Ensenada, a mediados de este siglo XVIII, esta localidad había alcanzado los 72’5 vecinos ${ }^{1782}$. Esta cifra, con un ligero incremento, se convierte, según el censo de Floridablanca de 1787 , en 310 habitantes ${ }^{1783}$. A través de estos dos últimos censos vemos también que una buena parte de sus habitantes ostentaba la condición de hidalgo. En el caso del vecindario del Catastro del Marqués de Ensenada, de los 72’5 vecinos contabilizados, un 90’3\%, es decir, 65’5 se declaran hidalgos, mientras que en el censo de Floridablanca esta proporción baja hasta los 148 habitantes, lo que hace un $47^{\prime} 7 \%$.

\footnotetext{
1779 ADPBU. CE - 2046. RESPUESTAS GENERALES. Tolbaños de Abajo, 25 - septiembre - 1753.

1780 G. MARTÍNEZ DÍEZ: Libro Becerro de las Behetrías... ob. cit. (pp. 614).

1781 T. GONZÁLEZ: Censo de población de las provincias y partidos de la Corona de Castilla en el siglo XVI... Ed. Facsímil. Madrid, Imprenta Real. 1829.

1782 Vecindario de Ensenada 1759. Vol. I. Madrid, Centro de Gestión Catastral y Cooperación Tributaria: Tabapress. D. L. 1991.
} 
La economía de esta población, como ocurría en el caso de Tolbaños de Abajo, y en el resto de los pueblos del Valle de Valdelaguna, estuvo basada fundamentalmente en la ganadería trashumante, lo que hace que gran parte de sus habitantes pasen la mayor parte del año en Extremadura. Formaba parte, por ello, de la Cuadrilla de San Pedro de Vega, que agrupaba a los ganaderos trashumantes de la comarca. El tipo de propietario que predomina aquí es el de tipo medio, con rebaños que difícilmente superaban las 500 cabezas. Junto a ellos, también aparece un nutrido grupo de pastores, que trabajan como asalariados de los ganaderos más importantes de los pueblos vecinos, especialmente de Huerta de Arriba y Neila. Esta economía se complementaba con algo de agricultura, en la que se cultivaban cereales, como el trigo camuña - aquí conocido como morcajo cebada y algo de avena ${ }^{1784}$.

Este pueblo se asienta en el fondo de un cerrado valle, situado frente a la cara norte del cerro de la Campiña, que corona la Sierra de Neila. Su caserío se reparte entre dos barrios, separados por la carretera, los cuales se asientan en cada una de las vertientes del valle. Este caserío, como es habitual en la zona, aparece dispuesto sin ningún tipo de orden ni concierto, formando un apretado callejero de trama irregular, en el que quedan muy pocos espacios abiertos. Dentro de este conjunto todavía es posible contemplar varios inmuebles, en los que se conservan restos vinculados a la característica tipología de las casas solariegas. No obstante, la ausencia de grandes propietarios de rebaños merinos hace que nos encontremos ante versiones simplificadas de este tipo de casas, en las cuales se produce un intento de imitar los grandes ejemplos, que aparecen en localidades como Barbadillo de Herreros, Huerta de Arriba o Neila. Por ello, el edificio más destacado del pueblo queda representado, una vez más, por la iglesia parroquial.

\footnotetext{
1783 INE. Censo de 1787. "Floridablanca”. Madrid. INE. 1989.

1784 ADPBU. CE - 2046. RESPUESTAS GENERALES. Tolbaños de Abajo, 25 - septiembre - 1753.
} 
Iglesia de San Juan Bautista.

Se encuentra situada dentro del propio casco urbano, dispuesta sobre una pronunciada ladera, en la vertiente del valle que mira hacia el mediodía. El edificio que contemplamos en la actualidad fue construido, en su mayor parte, en 1724, según indica la inscripción conservada en una de sus bóvedas, y en él nos encontramos una versión muy simplificada de la arquitectura de corte clasicista, que se desarrolla en la comarca durante este período ${ }^{1785}$. Desarrolla una sencilla estructura de tipo caja, con planta rectangular orientada hacia naciente, articulada en tres tramos desiguales, dentro de los cuales, el delantero, de mayor tamaño que los restantes, forma la cabecera. A este cuerpo principal se añaden la torre, la sacristía y un pequeño pórtico cerrado, todos ellos perfectamente alineados sobre el flanco meridional.

En su imagen exterior este templo se muestra, por lo tanto, como un sólido volumen prismático, formado por muros de mampostería de grueso calibre, rematados por cornisa de tipo papo de paloma, y reforzado en las esquinas y lados mayores por sólidos estribos de sillería. Estos estribos, en el caso de las esquinas, adoptan una posición de lados en paralelo a los del muro. Sobre el flanco meridional de este cuerpo se adosan la sacristía y el pórtico cerrado, los cuales guardan la proporción con el núcleo principal del templo. En el pórtico nos encontramos con una primera puerta, enmarcada por un potente arco de medio punto sobre pilastras seudotoscanas de fuste cajeado, igual que el intradós del arco, y decorado con una pequeña ménsula avolutada en su clave central. En el interior de este espacio se abre la puerta de entrada al templo, coronada con pesado arco de medio punto de amplio dovelaje, sobre cuya clave encontramos un pequeño escudo con campo ocupado por una gran cruz de Malta, acompañada por una estrella de ocho puntas en el jefe, y tres más similares a ella en la punta.

1785 Ver capítulo: Actividad constructiva. Evolución estilística: Siglo XVIII. 


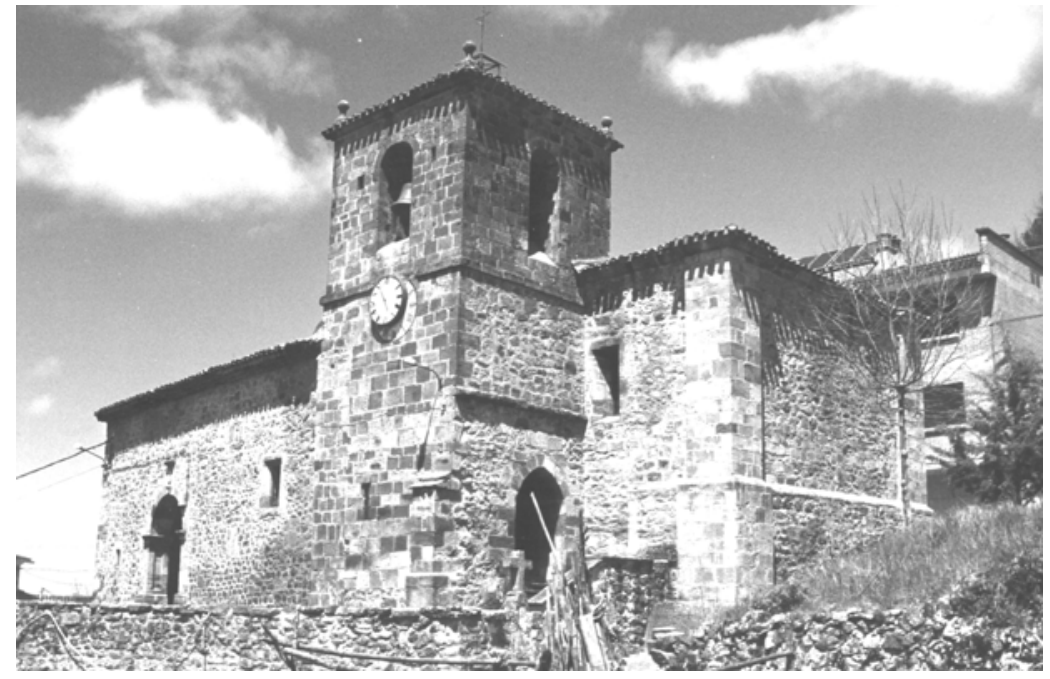

TOLBAÑOS DE ARRIBA.

Iglesia de San Juan Bautista.

Sobre este flaco meridional se incorpora también la torre, la cual consigue romper ligeramente el marcado carácter horizontal que presenta este conjunto. Esta pieza es anterior al resto del templo, tal y como nos muestran su estructura y el tipo de paramento empleados en sus muros - de sillería frente a la mampostería del resto del templo - la cual debemos encuadrar dentro del modelo que se desarrolla para este tipo de piezas durante el siglo XVII. Consta de una sobria estructura prismática de base cuadrangular, articulada en dos cuerpos separados por imposta plana de escaso resalte. El acceso a su interior se hace desde la calle a través de una pequeña puerta, practicada en el muro oriental de la base, mientras que en el cuerpo superior se abren cuatro sencillos vanos con arco de medio punto repartidos entre cada una de sus caras. Una sencilla cornisa de papo de paloma remata estos muros, con la cual se pasa al tejado, sobre cuyas esquinas se alzan pináculos de bola, que reflejan la tradición herreriana.

El interior de este templo desarrolla un concepto de ámbito único de marcado carácter longitudinal, con coro alto de madera a los pies. Todo el espacio está cubierto 
con bóveda de crucería estrellada con terceletes de rampante muy planta, dentro de las cuales la delantera, que cubre el espacio de la capilla mayor, ha sido remodelada en época actual, sustituyendo su plementería de piedra por una de ladrillo. La separación entre cada uno de los tramos se realiza mediante arcos fajones de medio punto apeados sobre pilastras de orden toscano y fuste ligeramente cajeado, igual que el intradós de los arcos, elaborado todo ello en piedra de sillería, remarcando, de este modo, su papel de elemento activo dentro del edificio. Los muros, una vez eliminado el enlucido, muestran una tosca labor de mampostería.

La imagen interior se completa con el retablo del altar mayor y los dos pequeños colaterales de los lados. Todos ellos son obras de estilo rococó pertenecientes a las décadas de 1760-70, mientras que las imágenes que los pueblan, en su mayoría son piezas reaprovechadas de altares anteriores, pertenecientes a los siglos XVI y XVII. El central, de un solo cuerpo de estructura tetrástila, cuenta con una talla de San Juan Bautista en el nicho central, escoltada por San Roque y San Pedro a los lados, y una imagen, posiblemente de San Nicolás en el remate. Los pequeños retablos colaterales, por su parte, son estructuras gemelas del mismo estilo que el anterior, y están dedicados a la Virgen del Rosario, el del lado del evangelio, y a la Inmaculada Concepción, el de la epístola.

La historia de este templo, como vemos, queda reducida prácticamente a una sola fase constructiva, como es la desarrollada en las décadas iniciales del siglo XVIII. La intensidad de esta renovación hace que se eliminen prácticamente todos los restos de los templos anteriores que pudieron existir, salvándose únicamente la torre. 


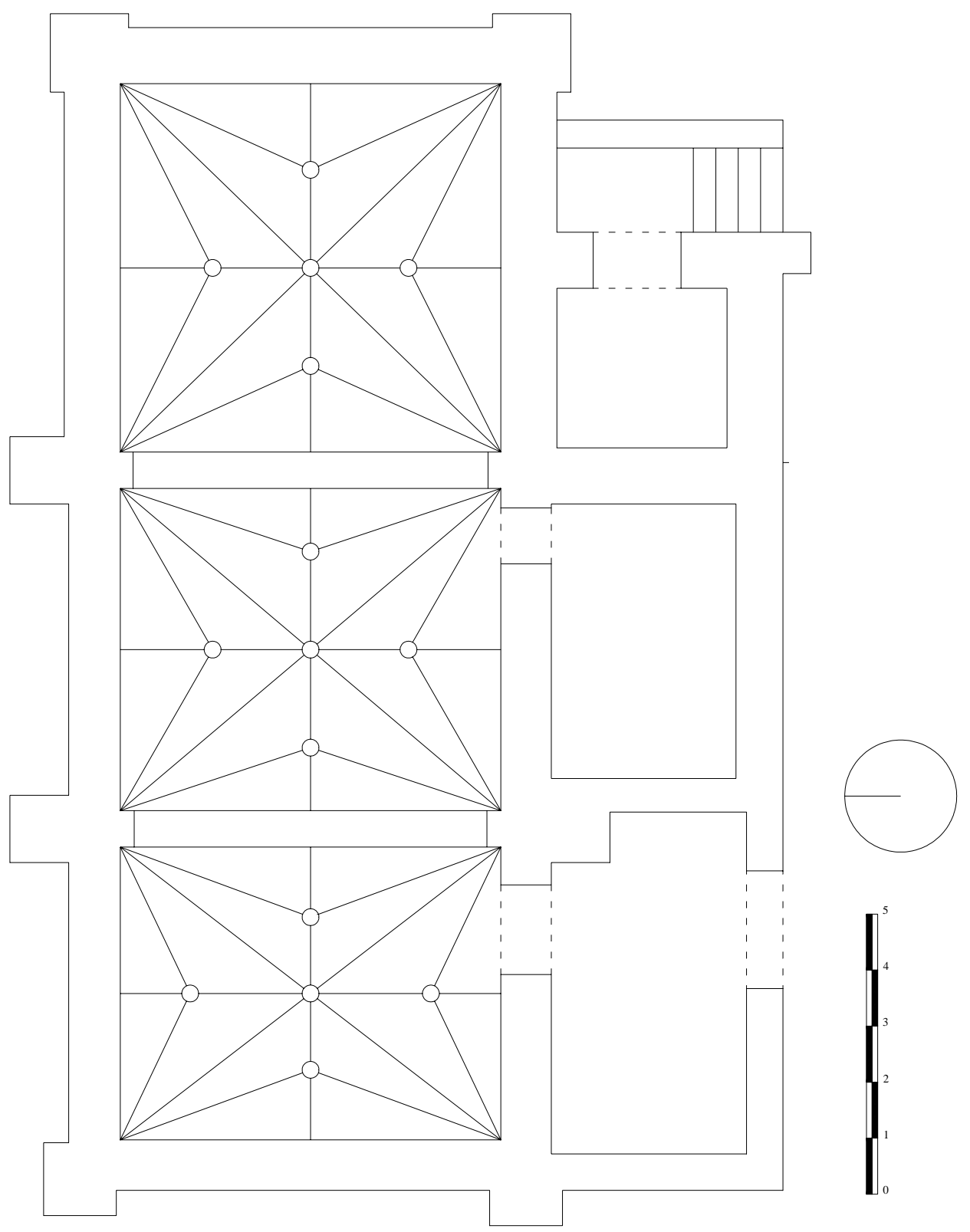

TOLBAÑOS DE ARRIBA. Iglesia de San Juan Bautista. Planta. 
Ermitas.

Tolbaños de Arriba llegó a poseer hasta cinco ermitas, repartidas por su término municipal, las cuales estaban dedicadas a Nuestra Señora del Salterio, la Vera Cruz, Santa Águeda, Santa María y San Sebastián. De ellas, solamente la primera ha conseguido sobrevivir hasta nuestros días.

La de Nuestra Señora del Salterio se encuentra situada aproximadamente a un kilómetro del pueblo, en dirección sudeste. Su edificio, profundamente reformado en 1994, presenta una estructura muy sencilla, propia de la arquitectura popular de la zona, dentro de la cual, sin embargo, descubrimos algunos rasgos vinculados al estilo clasicista de principios del siglo XVIII. Consta de una estructura de tipo caja, en la que se repite el modelo habitual para este tipo de edificios, con planta de una sola nave de trazado rectangular y cabecera plana en el extremo oriental, algo más estrecha que la nave. Toda su estructura está elaborada en piedra, con muros de mampostería, que se refuerzan con sillares de mayor tamaño en las esquinas. Este refuerzo se realiza, en el caso del muro del testero de la cabecera, con sólidos estribos de estructura prismática, dispuestos con sus lados en paralelo a los del muro. La puerta de acceso se abre sobre el muro de los pies, y consta de un simple arco de medio punto de amplio dovelaje. Sobre este arco se abre un pequeño óculo, que junto con otras dos ventanas, orientadas hacia el mediodía, de trazado rectangular y dintel plano con ligero derrame hacia el exterior, completan la iluminación del templo.

En el interior, el amplio espacio de la nave se cubre con sencilla techumbre a tres aguas, sobre moderna armadura de tipo par y nudillo. La capilla mayor, por su parte, marca su carácter preponderante con bóveda de crucería estrellada con terceletes de rampante muy plana.

Esta ermita fue un importante lugar de culto, dentro de esta zona del valle de Valdelaguna, y gozó siempre por ello de una envidiable buena situación económica. De este modo, a través de la generosidad que tradicionalmente mostraron los fieles a esta 


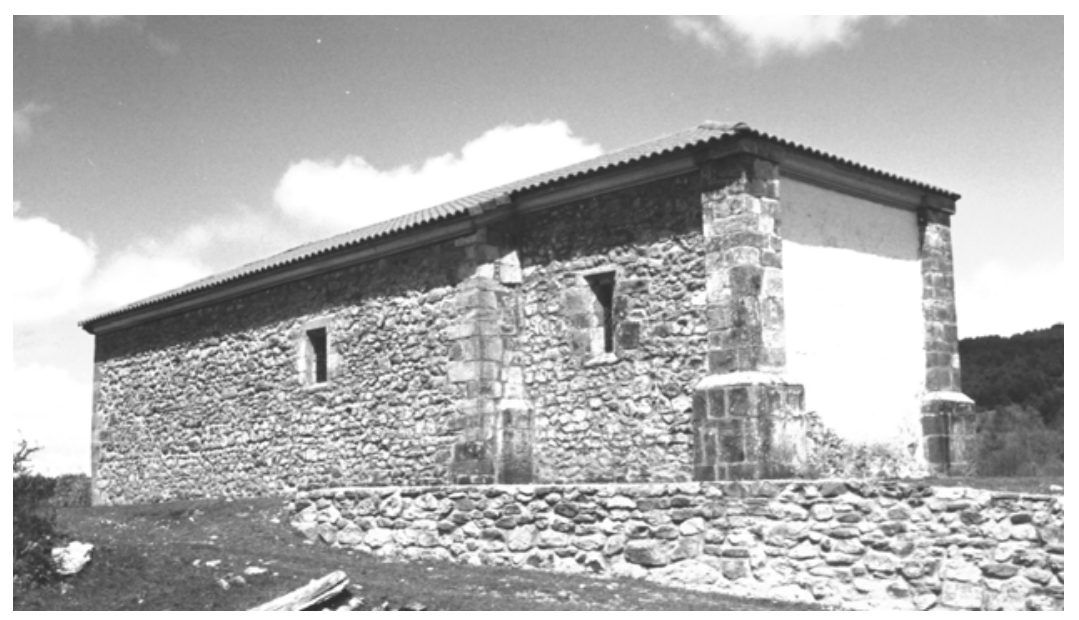

TOLBAÑOS DE ARRIBA. Ermita de Nuestra Señora del Salterio.

imagen, la ermita consiguió acaparar un rico patrimonio, en el que figuraban importantes cantidades de dinero, rentas, propiedades repartidas en distintos pueblos, $\mathrm{y}$ un nutrido rebaño de ovejas merinas ${ }^{1786}$.

Del resto de las ermitas, la de la Vera Cruz es la única que ha dejado algún resto de interés. Se hallaba situada a las afueras del pueblo, en dirección este, y junto a ella encontramos el actual cementerio. De su estructura original se conservan aun tres de sus muros, los cuales están realizados en mampostería con refuerzo de sillares en las esquinas. Sobre el muro que mira hacia el mediodía, aparece la puerta de entrada, coronada por un potente arco de medio punto de amplio dovelaje, dispuesto sobre impostas planas de escaso resalte, perteneciente, posiblemente a las primeras décadas del siglo XVIII. La parte de la cabecera se ha perdido en su totalidad, si bien sabemos que contaba con una pequeña sacristía, construida en 1784 por un precio de 760

1786 AGDBU. LP. Tolbaños de Arriba, iglesia parroquial de San Juan Bautista. LF. (1775 - 1850). (fols. 33 - 41). Visita realizada a la parroquia de San Juan Bautista de Tolbaños de Arriba en 1791, por D. Manuel María Izquierdo, canónigo de la catedral. Huerta de Arriba, 6 - septiembre - 1791. 
reales $^{1787}$. En estas fechas finales del siglo XVIII, sin embargo, este edificio comenzaba a mostrar ya algunos signos evidentes de decadencia, tal y como nos indica el visitador del Arzobispado de Burgos en 1791, D. Manuel María Izquierdo, cuando dice:

“...en la actualidad necesita dicha hermita una puerta segura y de toda firmeza, con cerradura, componer su tejado y parte de una pared demolida, mandaba y mando su merced que inmediatamente se ejecutan estas obras, reparándola de todo lo necesario hasta ponerla decente para celebrar el Santo Sacrificio de la misa, adorno de la imagen, su altar y pabimento interior, por quenta de los caudales existentes" ${ }^{1788}$.

A pesar de los inconvenientes, la ermita no llega a extinguirse en estos momentos, y de este modo, vemos cómo unos años más tarde, entre 1806-08 manda construir un nuevo retablo para su altar mayor ${ }^{1789}$. Su vida se prolonga prácticamente hasta finales del siglo XIX, iniciándose su destrucción ya en los primeros momentos del siglo $\mathrm{XX}$.

Poco antes de estas fechas debió desaparecer también la ermita de Santa Águeda, pues el Diccionario de P. MADOZ, todavía la menciona entre los lugares de culto, que se mantenían en pie a mediados del siglo $\mathrm{XIX}^{1790}$. Se encontraba situada algo más lejos del pueblo, en un paraje perdido dentro del monte, en dirección sudoeste, próxima ya al límite con el término municipal de Neila. De su edificio, sin embargo, apenas quedan unos escasos restos de piedras y tejas esparcidos por el suelo, a través de los cuales resulta imposible deducir el aspecto que pudo presentar.

\footnotetext{
1787 Ibídem. Libros de la Cofradía de la Vera Cruz. (1774 - 1884). (fols. 63vº - 64). Cuentas de los años 1784 - 85. Tolbaños de Arriba, 28 - mayo - 1785.

1788 Ibídem. (fols. 9 - 11). Visita realizada a los la ermita y cofradía de la Vera Cruz de Tolbaños de Arriba en 1791, por D. Manuel María Izquierdo, canónigo de la catedral. Canales a 25 de octubre de 1791.

1789 Ibídem. (fols. 20 - 20vº ). Cuentas de la Cofradía de la Vera Cruz correspondientes a los años 1807 1808. Tolbaños de Arriba, 5 - agosto - 1810.

1790 P. MADOZ: Diccionario geográfico - estadístico - histórico de España y sus posesiones de Ultramar. Valladolid, Ámbito D.L. 1984. (pp. 466).
} 
Más cercana al pueblo estaba la ermita de Santa María, la cual se hallaba situada en la parte superior de una de las laderas que bordea este caserío, en el solar que ocupa el actual depósito de aguas. Las últimas referencias documentales que tenemos de ella pertenecen al año 1791, lo que nos hace suponer que su desaparición debió producirse poco tiempo después ${ }^{1791}$. Los restos que quedaban de su edificio desaparecieron con la construcción de este depósito.

Por último, tenemos la ermita de San Sebastián, de la que se ha perdido incluso el recuerdo de su existencia, lo que nos ha impedido localizar su ubicación. Su desaparición debió ocurrir en torno a los mismos años que la ermita anterior, pues la última referencia que tenemos de ella corresponde también al año $1791^{1792}$.

Arquitectura civil.

Dentro de la arquitectura civil podemos destacar algunos ejemplos de las tradicionales casas solariegas, vinculadas a los ganaderos trashumantes. Sin embargo, la ausencia de grandes propietarios afincados en este pueblo, hace que nos encontremos ante versiones ciertamente simplificadas de las grandes casonas blasonadas, que aparecen en otras localidades vecinas. Son casas, las que aquí aparecen, de dimensiones notablemente más reducidas, en las que se mantiene, eso sí, la estructura prismática, articulada en dos pisos, con cubierta dispuesta a cuatro aguas y fachadas rematadas por un pronunciado alero. En la fachada principal destaca, de igual modo, el gran arco de medio punto, que enmarca la puerta de acceso, si bien, en este caso, la menor anchura del frente de esta fachada, hace que aparezca desplazada hacia uno de los laterales, situada así en correspondencia con una de las dos ventanas, que suelen aparecer en el piso principal.

1791 AGDBU. LP. Tolbaños de Arriba, iglesia parroquial de San Juan Bautista. LF. (1775 - 1850). (fols. 33 - 41). Visita realizada a la parroquia de San Juan Bautista de Tolbaños de Arriba en 1791, por D. Manuel María Izquierdo, canónigo de la catedral. Huerta de Arriba, 6 - septiembre - 1791. 
La mayor parte de los ejemplos conservados se encuentran profundamente alterados por el paso del tiempo, pero especialmente por las renovaciones efectuadas en épocas recientes. Aun así, la imagen que proyecta su fachada principal se mantiene en varias de ellas. No ocurre lo mismo, sin embargo, con su estructura interna, pues aquí las remodelaciones introducidas en todos estos inmuebles, han terminado por eliminar su compartimentación original.

Dentro de los ejemplos que se mantienen en pie merece especial atención la casa situada en la calla Mayor $n^{\circ}$ 49, mandada construir en 1691 por Lorenzo Martínez Temiño. Conserva todavía el potente arco de medio punto de su entrada principal, y una de sus ventanas del piso superior, con el característico marco de moldura plana de escaso resalte con orejones. Desarrollan una tipología similar los inmuebles situados en la calle Mayor $n^{\circ} 35$, calle Mayor $n^{\circ} 59$, calle del Pinar $n^{\circ}$ 9, calle del Norte $n^{\circ} 1$, calle Mayor s/n, esta última construida en 1729. Muy alteradas se encuentran las casas situadas en la calle del Molino $n^{o} 3$, y la calle Mayor $n^{\circ} 39$, cuyo aspecto primitivo hemos podido conocer solamente a través de fotografías tomadas en la década de 1970. Todas ellas, en cualquier caso, son obras pertenecientes ya al siglo XVIII. También en este período podemos situar la casa ubicada en la calle de los Pajares 19, de cuya fachada principal únicamente se ha salvado su escudo ${ }^{1793}$.

\footnotetext{
1792 Ibídem.

1793 Ver capítulo: Actividad constructiva. Evolución estilística: Siglo XVIII. Arquitectura civil.
} 


\section{VALLEJIMENO.}

La localidad de Vallejimeno se encuentra situada entre las sierras de la Demanda y Neila, dentro del valle de Valdelaguna. La primera referencia escrita, que existe sobre este pueblo, está fechada el 18-III-932, y en ella se habla de Villa de Munio Scemeno $^{1794}$. En este documenta se hace referencia a un pequeño monasterio, dedicado a San Cristóbal, que existía en las inmediaciones del pueblo, el cual tenía como patronos en estos momentos a Velasco González y a Fernando Gustios ${ }^{1795}$. Este monasterio se encontraba situado a escasa distancia del pueblo, en dirección este, en un paraje conocido precisamente como San Cristóbal. En este lugar, apenas quedan unos escasos restos de diferentes sepulturas ${ }^{1796}$. En la centuria siguiente volvemos a tener nuevas noticias sobre este cenobio, donde se habla de la cesión de parte de sus derechos al monasterio de San Pedro de Arlanza ${ }^{1797}$. En este documento, fechado el 1-I-1044, se mantiene la misma denominación de Villa de Munnio Scemeno ${ }^{1798}$, que vimos anteriormente, pasando poco más tarde, el 10-V-1071, a ser nombrado ya como Villa Exemeno $^{1799}$, de donde procede el nombre actual.

1794 L. SERRANO: Cartulario de San Pedro de Arlanza. Madrid, Centro de Estudios Históricos, 1925. (pp. 37).

1795 I. ÁLVAREZ BORGE: Poder y relaciones sociales en Castilla en la Edad Media. Los territorios entre el Arlanzón y el Duero en los siglos $X-X I V$. Salamanca, Consejería de Educación y Cultura. Junta de Castilla y León. 1996. (pp. 58 - 59; 77 - 80).

1796 G. MARTÍNEZ DÍEZ: Pueblos y alfoces burgaleses de la repoblación. Valladolid. Junta de Castillo y León. Consejería de Educación y Cultura. 1997. (pp. 198 - 199).

1797 I. ÁLVAREZ BORGE: Poder y relaciones sociales en Castilla en la Edad Media... ob. cit.

1798 L. SERRANO: Cartulario de San Pedro de Arlanza... ob. cit. (pp. 85).

1799 Ibídem. (pp. 152). 
La historia de este pueblo permanece ligada en todo momento al devenir del conjunto de pueblos, que conforman la agrupación del valle de Valdelaguna. De este modo, en un primer momento aparece formando parte del pequeño alfoz de Barbadillo del Pez ${ }^{1800}$, para pasar luego, tras su desaparición, a depender del alfoz de Lara ${ }^{1801}$. Una vez extinguido el sistema de alfoces, Vallejimeno queda incluido, como la mayor parte de los pueblos de la zona, en la Merindad Menor de Santo Domingo de Silos ${ }^{1802}$.

Ya en la Edad Moderna, en el plano fiscal, encontramos a Vallejimeno formando parte del partido de las Tierras del Condestable, de la provincia de Burgos ${ }^{1803}$, para luego más tarde, tras la reforma borbónica del siglo XVIII, quedar incluida en el partido de Aranda ${ }^{1804}$. En el plano jurisdiccional, vemos cómo en el siglo X esta localidad formaba parte de los dominios de Fernando Gustios ${ }^{1805}$, patrono también del monasterio de San Cristóbal. A mediados del siglo XIV, según el Becerro de las Behetrías, Vallejimeno era lugar de señorío, y tenía por señor a Pedro Fernández de Velasco y a Diego Pérez Sarmiento ${ }^{1806}$. Esta condición cambió durante la Edad Moderna, cuando esta localidad, junto con el resto de pueblos del valle, adquiere la condición de realengo, constituyendo el Real Valle y Villa de Valdelaguna. Por último, en el aspecto eclesiástico, su parroquia dependió siempre de la Diócesis de Burgos, desde el momento en el que fue restituida esta sede.

\footnotetext{
1800 G. MARTÍNEZ DÍEZ: Pueblos y alfoces burgaleses... ob. cit. (pp. 198).

1801 I. ÁLVAREZ BORGE: Monarquía feudal y organización territorial: alfoces y merindades en Castilla (siglos $X-X I V$ ). Madrid, CSIC. 1993. (pp. 59).

1802 C. ESTEPA DÍEZ: "Estructura de poder en Castilla (siglos XII - XIII). El poder señorial en las merindades burgalesas. En III Jornadas burgalesas de Historia (3 1991). Burgos en la Plena Edad Media. Burgos, Asociación Provincial de Libreros de Burgos. 1994. (pp. 245 - 294).G. MARTÍNEZ DÍEZ: Libro Becerro de las Behetrías. Estudio y texto crítico. León, Centro de Estudios e Investigación San Isidoro. Caja de Ahorros y Monte de Piedad. Archivo Histórico Diocesano. 1981. (pp. 613).

${ }^{1803}$ G. MARTÍNEZ DÍEZ: Génesis histórica de la provincia de Burgos y sus divisiones administrativas. Burgos, Aldecoa. 1983.

1804 ADPBU. CE - 2179. RESPUESTAS GENERALES. Vallejimeno, 19 - mayo - 1753.

1805 I. ÁLVAREZ BORGE: Poder y relaciones sociales en Castilla en la Edad Media... ob. cit. (pp. 77 $-80)$.
} 
Vallejimeno fue una localidad de tipo medio con una población, que experimentó un importante crecimiento durante el siglo XVIII. No obstante, carecemos de los datos precisos, que nos permitan seguir con todo detalle su evolución a lo largo de todo este período de la Edad Moderna. Sabemos, en cualquier caso, merced al censo de los obispos de 1584-87, que en aquel momento contaba con un total de 40 vecinos $^{1807}$. Esta cifra crece de forma considerable, hasta alcanzar los 76 vecinos, a mediados del siglo XVIII, según el vecindario del Catastro del Marqués de Ensenada $^{1808}$. Estos vecinos se convierten en 197 habitantes $^{1809}$, según el censo de Floridablanca de 1787. A través de estos dos últimos censo sebemos también, que un alto porcentaje de esta población disfrutaba de la condición de hidalgo. Así, en el vecindario del Catastro del Marqués de Ensenada, 69 vecinos eran hidalgos, es decir, un 90’7 \%, mientras que en el censo de Floridablanca este porcentaje desciende hasta el 47’1\%, con 140 habitantes de esta condición.

Su economía estuvo basada principalmente en la ganadería trashumante, como ocurre en el resto de los pueblos del valle de Valdelaguna y otras localidades próximas. En general, el tipo de ganadero que aquí encontramos es un propietario de tipo medio, con rebaños que difícilmente llegaban a las 500 cabezas, la mayoría de ellas ovejas de raza merina. Esto no evita que podamos encontrar algunos ejemplos de grandes propietarios, como es el caso de Juan Blanco de la Torre, el cual, según el Catastro del Marqués de Ensenada, poseía a mediados del siglo XVIII un rebaño de más de 2.000 cabezas de ovejas merinas, a las que se suman otras 1.000 cabezas más, entre carneros, borras y cabras. El rebaño de Antonio Gómez, otro vecino de Vallejimeno, superaba en

\footnotetext{
1806 G. MARTÍNEZ DÍEZ: Libro Becerro de las Behetrías... ob. cit.(pp. 613).

1807 T. GONZÁLEZ: Censo de población de las provincias y partidos de la Corona de Castilla en el siglo XVI... Ed. Facsímil. Madrid, Imprenta Real. 1829.

1808 Vecindario de Ensenada 1759. Vol. I. Madrid, Centro de Gestión Catastral y Cooperación Tributaria: Tabapress. D. L. 1991.

1809 INE. Censo de 1787. "Floridablanca”. Madrid. INE. 1989.
} 
aquellos momentos con holgura las 500 cabezas $^{1810}$. Todos estos ganaderos pertenecían a la Cuadrilla de San Pedro de Vega.

Esta ganadería trashumante, en la que participa la gran mayoría de la población, se completa con algunos hatos de ganadería estante, compuestos por ovejas de raza churra, bueyes, vacas y algún cerdo. También encontramos aquí algo de agricultura, con cultivos de cereales, como el trigo camuña, centeno, cebada y algo de avena. El desarrollo de esta actividad, sin embargo, estuvo fuertemente condicionado por el dominio de la economía ganadera, ya que Vallejimeno era el lugar de paso obligado de las cerca de 60.000 cabezas de ganado, que en algunos momentos llegaron a juntar los rebaños de los pueblos de Valdelaguna. Esto hace que su tierra “... no puede servir para simiaza (...) a causa de haber en esta jurisdicción dos pasos o cañadas de ganado merino que los dificultan al tiempo de tránsito...”1811.

El pueblo de Vallejimeno está formado por un apretado conjunto de casas, organizadas sobre una suave ladera, orientada hacia el mediodía, que se extiende junto a la margen derecha del río Tejero (o Quintanilla ${ }^{1812}$ ). En la otra margen del río se apilan un pequeño grupo de casas, a las cuales se accede a través de un esbelto puente medieval de un solo ojo, formado por un amplio arco de medio punto. Este puente, sin duda, constituye el elemento más representativo de la imagen del pueblo.

Dentro del caserío, advertimos la presencia de numerosos restos de edificios, en los que intuimos las características propias de las tradicionales casas solariegas de los pueblos de economía ganadera. La mayoría, sin embargo, han sufrido importantes modificaciones posteriores, que han alterado su estructura original.. El otro edificio destacado es su iglesia parroquial.

1810 ADPBU. CE - 2179. RESPUESTAS GENERALES. Vallejimeno, 19 - mayo - 1753.

1811 Ibídem. 


\section{Iglesia de San Martín.}

La iglesia de Vallejimeno se encuentra dedicada a San Martín de Tours, y está situada en el extremo oriental del pueblo, prácticamente fuera ya del propio caserío. Es un edificio sencillo, que surge como consecuencia de diferentes actuaciones, efectuadas especialmente durante el segundo cuarto del siglo XVIII. Nos muestra, por lo tanto, unos marcados rasgos clasicistas, que resultan especialmente evidentes en el interior, mientras que en el exterior se acusa una marcada sobriedad, más vinculada a la arquitectura de carácter popular.

Desarrolla una estructura de tipo caja, con planta de trazado rectangular de una sola nave, orientada hacia naciente, que se articula en tres tramos, de los cuales el delantero conforma la capilla mayor. Sobre el flanco meridional de esta cabecera se añade la sacristía, organizada en dos pequeños tramos, que se continúan con una pequeña capilla, dedicada al Santo Cristo, de planta cuadrangular, situada ya a la altura del tramo delantero de la nave. Fuera de este núcleo principal queda también la torre, adosada sobre muro de los pies.

La imagen que proyecta al exterior queda dominada por el sólido prisma, que forma el núcleo principal del templo, formado por recios muros de mampostería, reforzados con sillares en las esquinas del muro de los pies, y estribos prismáticos, también de sillería, en el extremo contrario, correspondiente al testero de la capilla mayor. Estos muros quedan rematados por cornisa de codillo entre doble moldura de papo de paloma. Sobre su flanco meridional se añade el pequeño cuerpo que conforman la sacristía y la capilla del Cristo, cuya cubierta se prolonga hasta la zona de los pies, para formar un pequeño pórtico. Bajo esta cubierta se abre la puerta de entrada, en la que se desarrolla un modelo muy tosco de arquitectura clasicista. Está formada por amplio arco de medio punto, escoltado por dos niveles de pilastras de fuste estriado, sobre las cuales discurre una cornisa, rematada con un pequeño frontón recto partido en el centro, y pináculos de bola en los extremos, en correspondencia con los ejes de las 
pilastras. Sobre esta misma fachada meridional se abren las ventanas, que iluminan el interior, repartidas entre cada uno de los tramos de la nave y cabecera. Las dos correspondientes a la nave presentan arco escarzano y fuerte derrame hacia el exterior, mientras que la abierta en el tramo de la cabecera ofrece una original estructura geminada, con dos pequeños arcos de medio punto sobre fino mainel. Evidentemente se trata de una pieza reaprovechada de una construcción anterior.

La imagen exterior se completa con la torre dispuesta a los pies, la cual se levanta sobre un pequeño afloramiento rocoso, que le da un aspecto de gran rotundidad. Se convierte en el auténtico contrapunto vertical, dentro de una estructura de marcado carácter horizontal. Presenta forma de prisma sobre base cuadrangular, articulado en cuatro cuerpos, separados por pequeñas líneas de imposta. En el nivel superior, que forma el cuerpo de campanas, se abren los vanos para acoger las campanas, de sencillo trazado rectangular con arco de medio punto. Dos de ellos se abren en la cara meridional y uno solo en cada uno de los lados restantes.

En el interior se desarrolla un concepto espacial de ámbito único de marcado sentido longitudinal, característico de esta arquitectura del Setecientos. Dentro de este espacio, sin embargo, apreciamos la marcada personalidad de la zona de la cabecera, a la cual se accede a través de un amplio arco de medio punto, apeado sobre pilastras de orden seudotoscano y fuste cajeado, igual que el intradós del arco. Este espacio se cubre con bóveda de crucería estrellada de rampante planta con terceletes y nervios combados dispuestos en torno a la clave polar, en forma de ondas. Reproduce, por lo tanto, un tipo muy habitual en la arquitectura de la zona a partir de la década de 1720. El espacio correspondiente a la nave cuenta con coro alto de madera en la zona de los pies, bajo el cual se dispone el baptisterio, dentro de un espacio delimitado con una balaustrada de madera. Todo el espacio de la nave se cubre con dos tramos de bóvedas de aristas, separados por arco fajón de medio punto, apeado sobre una pequeña ménsula con decoración de placas, que nos recuerda algunos motivos muy utilizados en el barroco riojano. En el lado de la epístola del tramo delantero de esta nave se abre la pequeña 


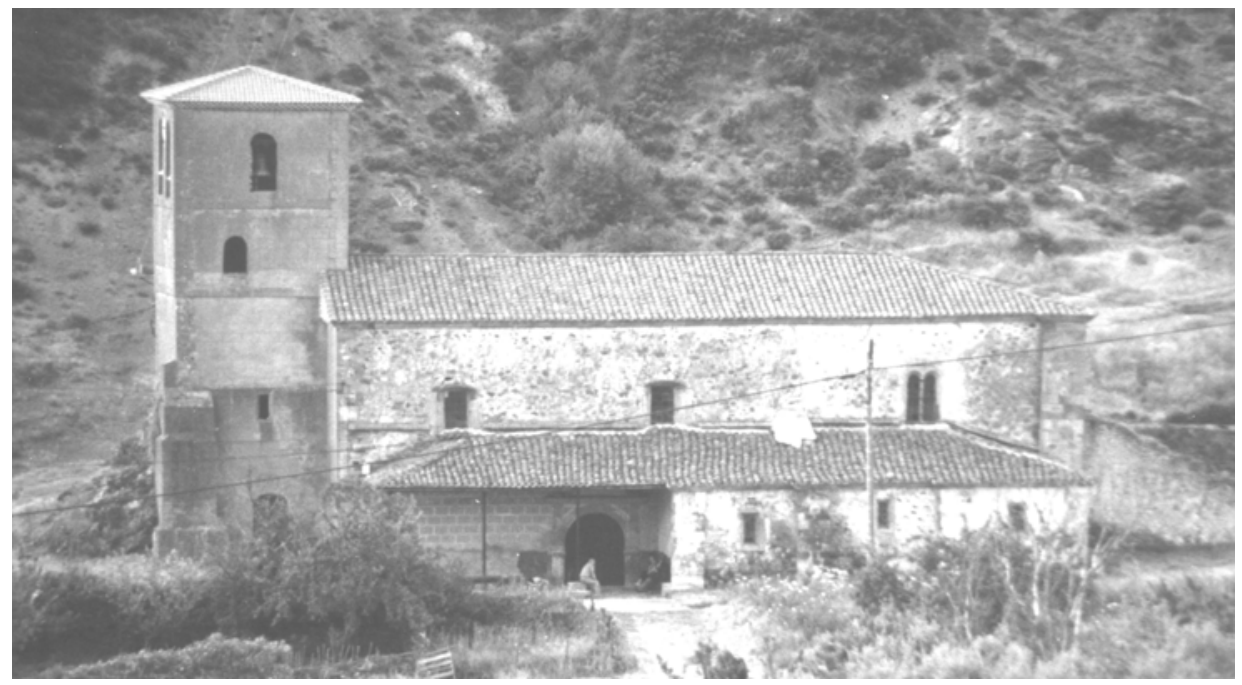

VALLEJIMENO. Iglesia de San Martín de Tours.

capilla del Cristo, precedida por arco de medio punto de intradós cajeado, al igual que las pilastras sobre las que descansa, y cubierta formada por bóveda de crucería.

La imagen interior de este templo se completa con una amplia relación de retablos de estilo barroco, entre los que destaca, muy especialmente el del altar mayor, realizado en torno a los años centrales de la década de $1720^{1813}$. Su dorado, sin embargo, tuvo que esperar hasta el año 1757, labores que alcanzaron un coste de 6.600 reales, de los cuales la parroquia sólo tuvo que pagar 1.605'5 reales, pues el resto fue sufragado por el concejo del pueblo y sus vecinos ${ }^{1814}$. Este retablo está presidido por la imagen de San Martín, al que acompañan a los lados San Pedro y San Pablo, y en el remate una

1813 AGDBU. LP. Vallejimeno, parroquia de San Martín. LF. (1704 - 1751). (fols. 68v - 71) Visita realizada a la parroquia de San Martín de Vallejimeno el año 1723, por D. Antonio Íñigo de Angulo. Canales, 29 - octubre - 1723; Ibídem. Cuentas del año 1724. Vallejimeno, 9 - octubre - 1725; Ibídem. Cuentas del año 1726. Vallejimeno, 17 - septiembre - 1727; Ibídem. Cuentas del año 1727. Vallejimeno, 16 - septiembre - 1728.

1814 Ibídem. LF. (1751 - 1851). Cuentas del año 1757. Vallejimeno, 12 - octubre - 1758. 
pequeña talla gótica de la Virgen y dos santas más a los lados, sin identificar. Este retablo del altar mayor está flanqueado por dos pequeños retablos de tipo marco, realizados hacia 1770, presididos, el del lado del evangelio, por San Roque, y el del lado de la epístola, por un Cristo Nazareno.

Sin salir del espacio de la cabecera, sobre el muro del evangelio, se levanta el retablo dedicado a Nuestra Señora del Rosario, obra de estilo churrigueresco de mediados del siglo XVIII. Está presidido por una imagen renacentista de Nuestra Señora del Rosario, a la que acompaña, en el remate, una pequeña talla de San Miguel. Frente a él, sobre el muro meridional de la capilla mayor, se levanta otro retablo, también de estilo churrigueresco, de principios del siglo XVIII, dedicado a San Juan Bautista. Cuenta con una talla de este santo en el nicho principal, y una pintura sobre lienzo en el remate, donde se representa la escena de San Martín a caballo partiendo su manto con el mendigo.

Sobre el muro septentrional de la nave encontramos el retablo de las Ánimas, formado por una estructura de tipo marco de estilo rococó, realizado hacia 1770. Por último, en la capilla del Cristo, se levanta un pequeño retablo de estilo clasicista, realizado en torno a 1630, con una talla gótica de Cristo Crucificado ${ }^{1815}$.

La historia de la actual fábrica del templo se resume en dos fases constructivas fundamentales. La primera de ellas se realiza hacia 1720, y en ella se construye la parte correspondiente a la capilla mayor. El tipo de bóveda empleado nos permite establecer esta cronología, si bien, desconocemos los nombres de los artífices encargados de su construcción. La segunda fase se lleva a cabo en 1736, y en ella se acomete la renovación de la nave. Esta obra fue realizada por los maestros de cantería trasmeranos

1815 R. J. PAYO HERNANZ: El retablo en Burgos y su comarca durante los siglos XVII y XVIII. Burgos, Excma. Diputación Provincial de Burgos. 1997. (T. II, pp. 555). 
Martín Delgado y Manuel de la Torre, por un precio de 3.715 reales ${ }^{1816}$, mientras que la parte de carpintería fue adjudicada al maestro de origen vizcaíno, Juan de Arrieta, por un importe de 2.800 reales $^{1817}$. Los materiales empleados en esta obra se trajeron de la localidad próxima de Monterrubio de la Demanda, participando en su extracción y traslado hasta la iglesia los vecinos del pueblo ${ }^{1818}$. Como epílogo a estos trabamos debemos mencionar también la renovación de la torre, que se hace hacia 1740. En estas labores participa también el maestro Juan de Arrieta ${ }^{1819}$.

Una vez completada la estructura principal del templo, las intervenciones que se realizan a partir de aquí están orientadas únicamente a la consolidación y mantenimiento de la fábrica heredada. Este es el caso de las obras efectuadas hacia la década de 1750, con un presupuesto superior a los 5.000 reales. En esta intervención se acondiciona todo el entorno del templo, al mismo tiempo que se reparan los estribos de refuerzo de la zona de la cabecera ${ }^{1820}$. No menos interesante es “...el ensanche de la sacristía antigua con su bóveda de piedra, sirviendo al mismo tiempo esta obra de cimientos y empuje para sobstener la fábrica principal de la iglesia y reparar de modo posible la quiebra que cimentaba la capilla mayor, con el cimiento que por la parte de atrás se ha hecho para ello"1821. Esta obra se realiza en 1774 , y con ella, como vemos, se pretendía conseguir un doble objetivo, como era el de dar un carácter más digno a este espacio de la sacristía, al mismo tiempo que se reforzaba la estructura del templo. Como resultado surge una sacristía de planta rectangular, articulada en dos tramos, cubiertos con bóveda de crucería, y separados por un potente arco de medio punto de rosca cajeada, que pasa

\footnotetext{
1816 AHPBU. PN. Valle de Valdelaguna. Leg. 9803/1, fols. 14 - 17 vº. Manuel Gil de la Cuesta. Vallejimeno, 13 - mayo - 1736.

1817 AHPBU. PN. Valle de Valdelaguna. Leg. 9803/1, fols. 18 - 21. Manuel Gil de la Cuesta. Barbadillo de Herreros, 20 - mayo - 1736.

1818 AGDBU. LP. Vallejimeno, parroquia de San Martín. LF. (1704 - 1751). Cuentas del año 1733. Vallejimeno, 6 - septiembre - 1734 .

1819 Ibídem. Cuentas del año1741. Vallejimeno, 20 - diciembre - 1741.

1820 Ibídem. LF. (1751 - 1851). Cuentas del año 1752. Vallejimeno, 16 - septiembre - 1753.

1821 Ibídem. Cuentas del año 1774. Vallejimeno, 23 - septiembre - 1775.
} 
a desempeñar una auténtica labor de arbotante, trasladando hacia el estribo exterior los empujes de la capilla mayor.

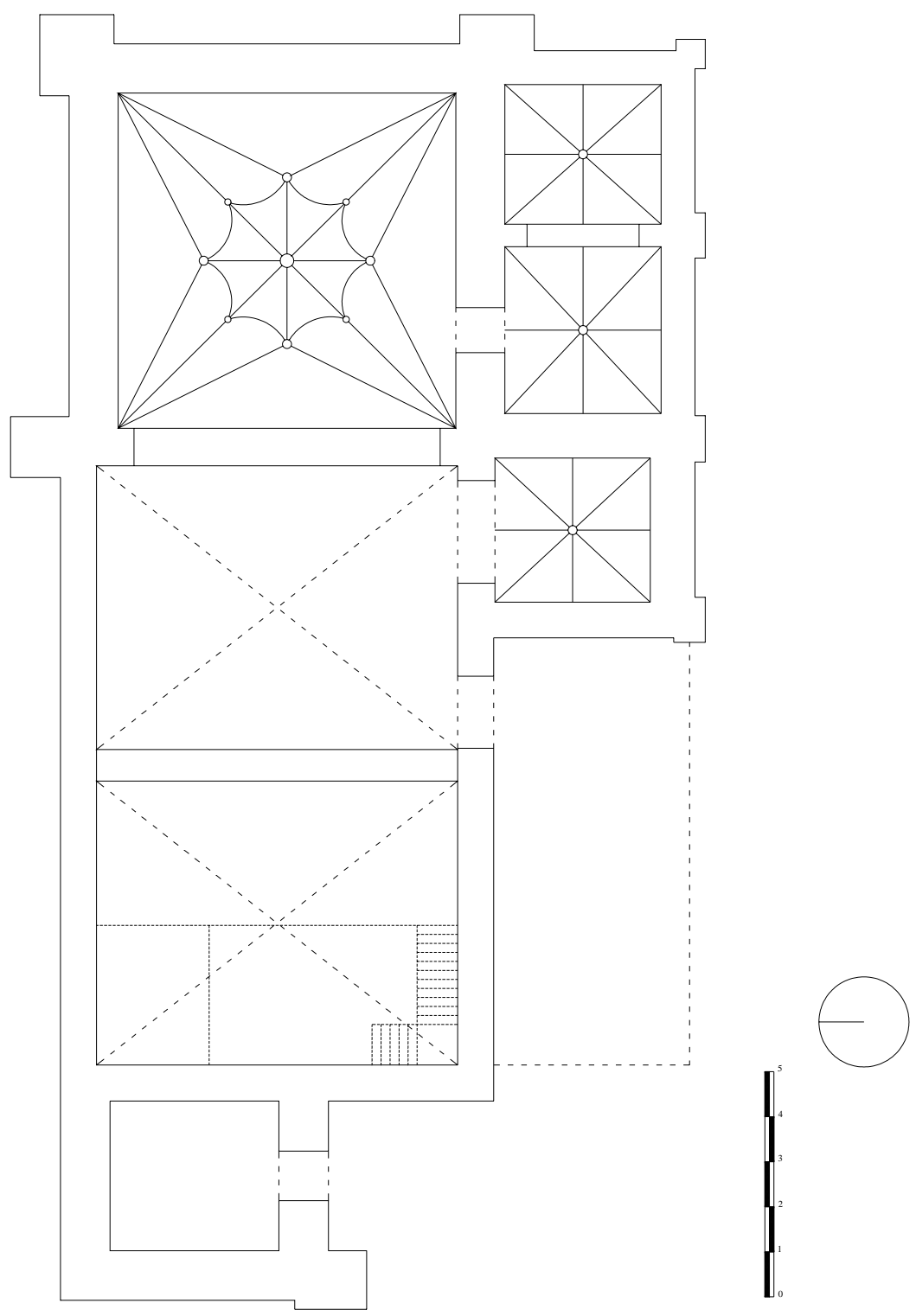

VALLEJIMENO. Iglesia de

San Martín de Tours. Planta. 
Ya a finales del siglo XVIII se decide renovar la techumbre de madera, que hasta el momento existía en la zona de la nave, levantando, en su lugar, las actuales bóvedas de aristas. El proyecto se ejecuta en 1794, con un coste para la parroquia de 6.572 reales ${ }^{1822}$. Su construcción, sin embargo, no debió ser muy sólida, pues apenas un cuarto de siglo después, la fábrica debe invertir otros 5.521 reales en su reparación ${ }^{1823}$. También en estos primeros años del siglo XIX se completa la imagen interior del templo con la construcción del cancel de la puerta y la renovación del coro. La primera de estas intervenciones se realiza en 1801, y supuso un desembolso de 1.300 reales $^{1824}$. La segunda se ejecuta ya en 1825 , y alcanza un presupuesto de 1.130 reales $^{1825}$.

Ermitas.

Además del templo parroquial y del antiguo monasterio de San Cristóbal, Vallejimeno contó con cuatro ermitas, repartidas por su término municipal. Estas ermitas se encontraban dedicadas a Nuestra Señora del Campo, Santo Cristo, Santa Eugenia y San Andrés.

De ellas, solo la de Nuestra Señora del Campo ha conseguido sobrevivir hasta nuestros días, aunque con distinto nombre, pues hoy es conocida simplemente como ermita de Santa María. Se halla situada a escasos 500 metros del pueblo en dirección sur, y su edificio nos presenta una sencilla construcción de neto sabor popular, sin ningún tipo de valor artístico. Consta de una estructura de tipo caja, sobre planta rectangular orientada hacia naciente, con muros de mampostería, reforzados en las esquinas con sillares de mejor labra, y cubierta dispuesta a dos aguas, sobre armadura de tipo parhilera. Dos pequeñas ventanas de dintel plano y derrame hacia el interior se abre en el muro meridional, mientras que la puerta de acceso, también de dintel plano,

\footnotetext{
1822 Ibídem. Cuentas del año 1794. Vallejimeno, 4 - octubre - 1795.

1823 Ibídem. Cuentas del año 1819. Vallejimeno, 1820

1824 Ibídem. Cuentas del año 1801. Vallejimeno, 9 - octubre - 1802.
} 
aparece en el lado contrario, mirando hacia el pueblo. Su interior se adorna con un pequeño retablo de estilo clasicista, de mediados del siglo XVII, con su única hornacina, ocupada por una talla de la Virgen.

De las ermitas restantes, sabemos que la dedicada al Santo Cristo se encontraba situada en el centro del pueblo, en algún punto de la calle Mayor ${ }^{1826}$. En realidad debía tratarse de una construcción muy modesta, pues algunos documentos se refieren a ella como un simple humilladero ${ }^{1827}$. Su última referencia documental se halla en el informe del Visitador del Arzobispado de Burgos en $1831^{1828}$, lo que nos hace suponer que su desaparición debió producirse poco tiempo más tarde, pues el Diccionario de P. MADOZ ya no la menciona ${ }^{1829}$.

Bastante más temprana fue la desaparición de las dos ermitas restantes, las de Santa Eugenia y San Andrés, cuya última referencia se encuentra en la visita efectuada en 1728 por el canónigo de la catedral de Burgos, D. Andrés Madrazo Escalera. En este informe ya se indica, que la ermita de San Andrés “... se alló indecente y mal reparada” ${ }^{1830}$. En términos similares se había expresado sólo dos años antes el Visitador D. Andrés Fernández de Tejada, sobre la ermita de Santa Eugenia ${ }^{1831}$. Esta desaparición

\footnotetext{
1825 Ibídem. Cuentas del año 1825. Vallejimeno, 12, noviembre, 1826.

1826 Ibídem. Visita realizada a la parroquia de San Martín de Vallejimeno el año 1803, por D. Manuel Cid Monroy, arzobispo de Burgos. Canales, 9 - septiembre - 1803.

1827 Ibídem. LF. (1704 - 1751). (fols. 43 - 46). Visita realizada a la parroquia de San Martín de Vallejimeno el año 1718, por D. Ángel Benito, electo obispo auxiliar de Burgos. Barbadillo de Herreros, 21 - septiembre -1718.

1828 Ibídem. LF. (1751 - 1851). Visita realizada a la parroquia de San Martín de Vallejimeno el año 1831, por D. José López, cura de Huerta de Arriba y vicario del partido de Canales. Huerta de Arriba, 13 - octubre - 1831 .

1829 P. MADOZ: Diccionario geográfico - estadístico - histórico de España y sus posesiones de Ultramar. Valladolid, Ámbito D.L. 1984. (pp. 478).

1830 AGDBU. LP. Vallejimeno, parroquia de San Martín. LF. (1704 - 1751). Visita realizada a la parroquia de San Martín de Vallejimeno en el año 1728, por D. Andrés Madrazo Escalera, canónigo de la catedral de Burgos. Barbadillo de Herreros, 10 - julio - 1728.

1831 Ibídem. Visita realizada a la parroquia de San Martín de Vallejimeno en el año 1726, por D. Andrés Fernández de Tejada. Barbadillo de Herreros, 7 - septiembre - 1726.
} 
tan temprana, en ambos casos, ha hecho que se pierda incluso el recuerdo de su emplazamiento

Arquitectura civil.

Dentro de la arquitectura civil encontramos numerosos inmuebles en los que todavía se aprecian restos propios de las llamadas casas solariegas, que tanto abundan en esta comarca ganadera. Son edificios muy alterados por el paso del tiempo y las numerosas modificaciones introducidas en su estructura. Aun así, la gran mayoría de ellas todavía conserva en su fachada principal la característica estructura de vanos dispuestos según estricto esquema reticular, con la puerta de entrada en el centro, coronada con potente arco de medio punto, con un pequeño balcón o ventana sobre ella, y dos ventanas más a los lados, en ambas plantas. Varias de estas ventanas mantienen también el típico marco con orejones, muy habitual en esta arquitectura durante el siglo XVIII, igual que el casetonado de la rosca del arco de entrada.

Ejemplos destacados de este tipo de casa los tenemos en la calle Mayor $n^{\circ}$ 8-9 (construida en el año 1794), calle Mayor $n^{\circ} 24$, calle Mayor $n^{\circ} 26$, Paraje de las Eras $n^{o}$ 6, calle Principal $n^{\circ} 28$, y calle Principal $n^{\circ}$ 30. Estos dos últimos inmuebles, se encuentran agrupados en una sola manzana, fundiendo sus fachadas en un solo paño de estructura uniforme. Una variante simplificada de este esquema nos ofrece la casa situada en la calle de San Cristóbal $n^{\circ}$ 16, construida en 1772 por D. José Gómez de la Fuente y su mujer ${ }^{1832}$. Esta casa nos presenta una fachada bastante más estrecha, con dos ventanas sobre el piso superior y la puerta de entrada y otra ventana en la planta baja, dispuestas en correspondencia con el eje trazado por aquellas. 
1832 Sobre el dintel de una de las dos ventanas del piso superior encontramos esta inscripción: AÑO DE 1772 / SE IZO ESTA OBRA A COSTA DE D. JOSEPH Y DÑA. / JOSEPHA SV MVGER AMBOS 
VEGA.

El despoblado de Vega se encuentra situado dentro del término municipal de Huerta de Abajo, entre las sierras de la Demanda y Neila, ocupando el centro geográfico del valle de Valdelaguna. En sus inmediaciones se han encontrado abundantes restos de época romana, datados entre mediados del siglo I d. C. y último tercio del siglo II, pertenecientes a un grupo estable de población, dedicado a la explotación de los yacimientos mineros de la zona ${ }^{1833}$.

Las referencias documentales, que existen sobre este poblamiento, ya en época medieval, son escasas y muy confusas, lo que ha llevado a hablar de la existencia de dos núcleos diferentes, conocidos como San Pedro de Vega y Santa María de Vega ${ }^{1834}$. La primera de estas denominaciones aparece en un documento del monasterio de San Pedro de Arlanza del 1-I-1044 ${ }^{1835}$, mientras que la segunda se encuentra en otro texto de este mismo cenobio, fechado un siglo más tarde, el 30-III-1144 ${ }^{1836}$. Su desaparición, como ocurre en la mayor parte de los despoblados de esta zona de la sierra burgalesa, se produce poco después de estas fechas, lo que hace que a mediados del siglo XIV, cuando se redacta el Becerro de las Behetrías, ya no aparezca ninguna referencia.

GOMEZ DE LA FUENTE.

1833 E. PASTOR DÍAZ DE GARAYO: Castilla en el tránsito de la Antigüedad al Feudalismo. Poblamiento, poder político y estructura social del Arlanza al Duero (siglos VII - IX). Valladolid, Consejería de Educación y Cultura, Junta de Castillo y León. 1996. (pp. 33 - 34).

1834 G. MARTÍNEZ DÍEZ: Pueblos y alfoces burgaleses de la repoblación. Valladolid. Junta de Castillo y León. Consejería de Educación y Cultura. 1997. (pp. 199).

1835 L. SERRANO: Cartulario de San Pedro de Arlanza. Madrid, Centro de Estudios Históricos, 1925. (pp. 86).

1836 Ibídem. (pp. 191). 
El único vestigio que ha quedado es su templo convertido, tras su desaparición, en ermita dedicada a San Pedro. El territorio dependiente de este pueblo, sin embargo, no se mantuvo unido, como había ocurrido en los casos similares de Rebollar y Revenga, situados a pocos kilómetros, sino que fue repartido entre los pueblos más próximos, como eran Huerta de Abajo, Huerta de Arriba, Tolbaños de Abajo y Tolbaños de Arriba. Estos pueblos continúan aun hoy celebrando su fiesta, congregándose sus vecinos en romería en torno a este lugar. Pero esta ermita, no sólo simboliza los vínculos ancestrales mantenidos entre estos cuatro pueblos, sino que representa también el principal punto de referencia de toda la comunidad, que conforma el valle de Valdelaguna. No debemos olvidar tampoco, que las inmediaciones de esta ermita sirvieron de punto de encuentro para los rebaños trashumantes de la sierra burgalesa, en su partida hacia tierras extremeñas. Por ello, la cuadrilla que agrupaba a estos ganaderos recibió el nombre de San Pedro de Vega, en honro al patrón que presidía el templo. Esta cuadrilla efectuaba también aquí sus reuniones periódicas al final de cada campaña, en las que se trataban todas aquellas cuestiones que afectaban a esta actividad, desde el tránsito de los ganados, hasta los precios pagados por los pastos en los agostaderos. Estas reuniones tenían lugar entre los últimos días del mes de junio y todo el mes de julio.

Las dos únicas construcciones que encontramos actualmente en este lugar son, la ermita, ya señalada, y la llamada casa de juntas. La ermita actual está dedicada a la Virgen, conocida como Nuestra Señora de Vega, si bien, sabemos que es una advocación reciente. Desconocemos, en cualquier caso, las razones que llevaron a este cambio. La ermita nos muestra una fábrica sencilla, de marcado sabor clasicista, construida a lo largo de diferentes etapas durante el siglo XVIII ${ }^{1837}$. No obstante, la única fecha concreta que poseemos es la que hace referencia a la construcción de la zona de la cabecera, levantada, según reza la inscripción de su arco de entrada, en 1772.

1837 Ver capítulo: Actividad constructiva. Evolución estilística. Siglo XVIII. 


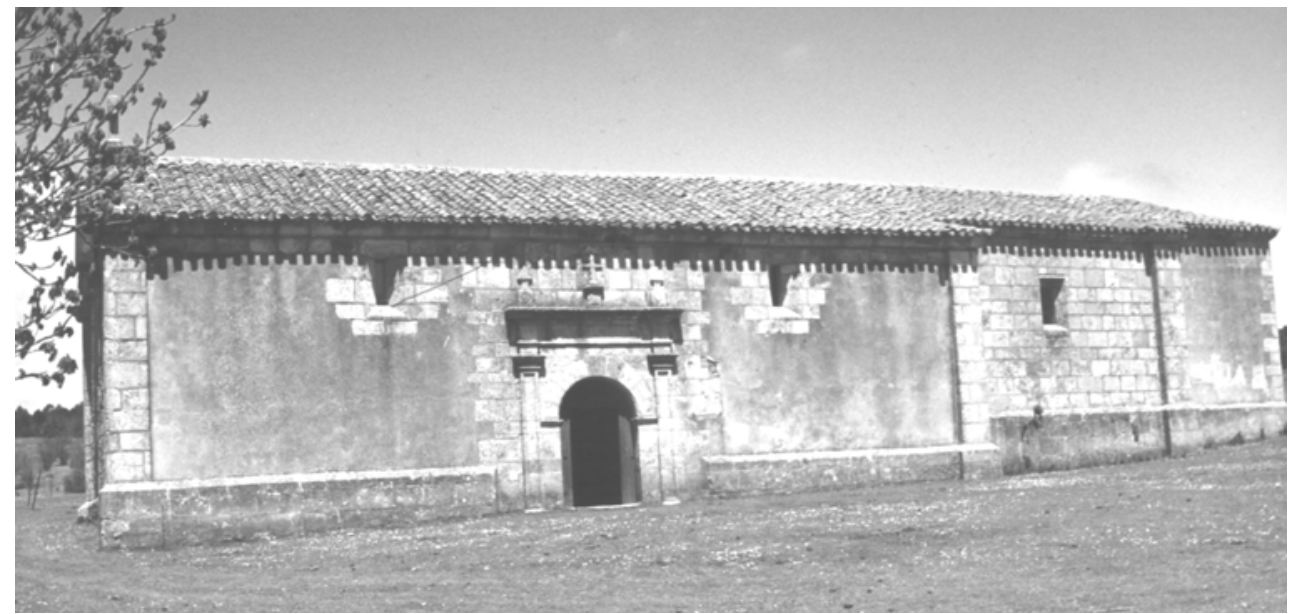

VEGA. Ermita de Nuestra Señora de Vega. (antigua ermita de San Pedro de Vega).

Este edificio desarrolla una estructura de tipo caja, con una sola nave de trazado rectangular, sobre cuyo extremo oriental se añade la cabecera, formada por una capilla mayor cuadrangular, algo más estrecha que nave, y un cuarto-camarín, que cumple la función de sacristía, adosada al muro del testero. Al exterior, por lo tanto, se muestra como una sucesión de volúmenes prismáticos, dispuestos sobre un mismo eje, entre los que se guarda una misma proporción en altura. Sus muros se levantan sobre un sólido zócalo de sillería, y presentan paramentos de mampuesto, en la nave y camarín, y sillería en la capilla mayor, rematados con cornisas, en las que varía el tipo de moldura, lo que refleja la presencia de distintas fases dentro de su proceso constructivo. Las ventanas, que iluminan el interior, se reparten entre las fachadas oriental, meridional y de poniente, y en todas ellas encontramos un sencillo trazado rectangular con dintel plano. Las del lado meridional, además, introducen un marcado derrame hacia el exterior. Sobre esta misma fachada se abre la puerta de entrada, en la que encontramos una sencilla estructura de estilo clasicista, formada por arco de medio punto entre 
pilastras de orden toscano, sobre las que se dispone un ancho friso y una volada cornisa, en la que descansa una cruz en el centro y dos pináculos piramidales en los extremos.

En el interior, su única nave dibuja un amplio espacio longitudinal, con coro alto a los pies, y cubierta a dos aguas sobre una moderna armadura metálica. En el extremo oriental se incorpora la capilla mayor, abierta a través de potente arco de medio punto, dispuesto sobre pilastras de orden toscano y fuste cajeado, como el intradós del arco. Este espacio se cubre con bóveda de crucería estrellada con terceletes y nervios combados, dispuestos en el centro a modo de ondas. Desde esta capilla, a través de una pequeña puerta de dintel plano, podemos acceder al camarín, formado por una pequeña estancia bien iluminada, cubierta con un sencillo cielo raso. Originalmente un pequeño vano, practicado sobre el muro del testero de la capilla mayor, en el lugar ocupado por la hornacina, en la que se coloca la imagen del titular del templo, comunicaba ambos espacios, creándose un efecto de transparente. En la actualidad, sin embargo, este vano ha sido cegado.

Junto a esta ermita, como decimos, se halla la casa de juntas, en la cual se reúnen los representantes de los cuatro pueblos, que comparten el patronato de esta ermita. De igual modo, esta casa sirvió de lugar de encuentro para los ganaderos, que componían la cuadrilla de San Pedro de Vega, reuniéndose aquí para tratar los asuntos concernientes a su actividad.

El edificio que vemos actualmente es una obra reciente, realizada ya en el siglo XX. Cuenta con una estructura en forma de prisma, con un solo cuerpo, levantado sobre planta cuadrangular, y cubierto con techumbre dispuesta a cuatro aguas. En sus lados oriental y meridional el alero de esta cubierta se extiende para formar un pequeño porche, que sirve de abrigo al visitante. Su interior presenta una distribución muy sencilla, con una cocina, un almacén y una amplia sala, en la que se podían celebrar las reuniones. 


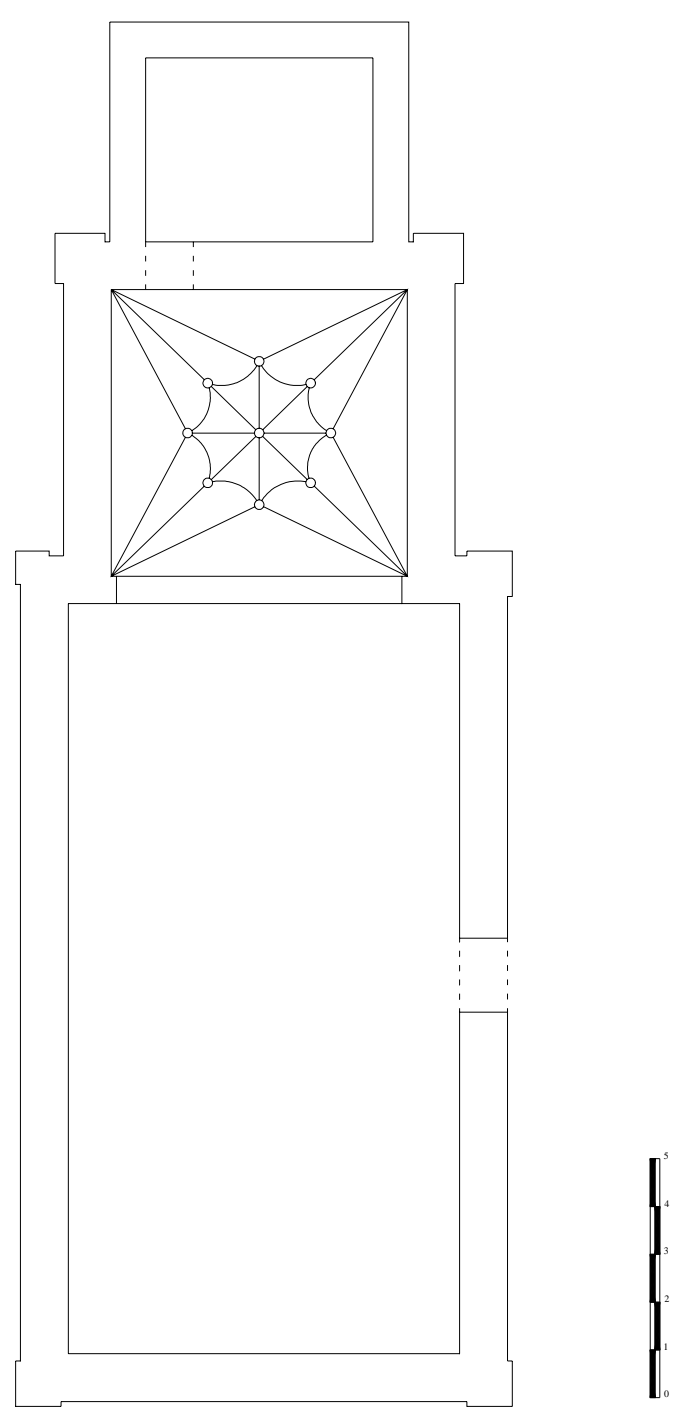

VEGA. Ermita de Nuestra

Señora de Vega. Planta. 
VILVIESTRE DEL PINAR.

La localidad de Vilviestre del Pinar se asienta sobre las laderas de la vertiente meridional de la Sierra de Neila, dentro de la orla mesozoica, que rodea el núcleo más montañoso de esta comarca. Se halla incluida también dentro de la llamada zona de pinares, mostrando, de este modo, un término municipal densamente poblado de pinos, que constituyen la base fundamental de su economía, hasta el punto de convertirlo en el determinante de su nombre.

Las primeras referencias escritas, que encontramos sobre este pueblo, las tenemos en tres documentos fechados el 5-VIII-1052, el 12-VI-1092 y el 30-V-1144 ${ }^{1838}$. Vilviestre del Pinar estuvo encuadrada hasta principios del siglo XII en el gran alfoz de Lara $^{1839}$, pasando a depender después, una vez extinguido aquel sistema, de la Merindad Menor de Santo Domingo de Silos ${ }^{1840}$.

1838 L. SERRANO: Cartulario de San Pedro de Arlanza. Madrid, Centro de Estudios Históricos, 1925. (pp. 163, 191); E. PASTOR DÍAZ DE GARAYO: Castilla en el tránsito de la Antigüedad al Feudalismo. Poblamiento, poder político y estructura social del Arlanza al Duero (siglos VII - IX). Valladolid, Consejería de Educación y Cultura, Junta de Castillo y León. 1996. (pp. 33 - 34).

1839 G. MARTÍNEZ DÍEZ: Pueblos y alfoces burgaleses de la repoblación. Valladolid. Junta de Castillo y León. Consejería de Educación y Cultura. 1997. (pp. 176).

1840 C. ESTEPA DÍEZ: "Estructura de poder en Castilla (siglos XII - XIII). El poder señorial en las merindades burgalesas. En III Jornadas burgalesas de Historia (3 1991). Burgos en la Plena Edad Media. Burgos, Asociación Provincial de Libreros de Burgos. 1994. (pp. 245 - 294).G. MARTÍNEZ 
Ya en la Edad Moderna, dentro de la organización fiscal, encontramos a Vilviestre formando parte del partido de las Tierras del Condestable, de la provincia de Burgos $^{1841}$, pasando luego, tras la reforma borbónica del siglo XVIII, a quedar incluido en el partido de Aranda ${ }^{1842}$. En el plano jurisdiccional, Vilviestre aparece a mediados del siglo XIV, según los datos aportados por el Becerro de las Behetrías, como señorío solariego, dependiente de Doña Sancha, mujer que fue de Diego López de Haro, y de Juan Díaz de Roca Fuy ${ }^{1843}$. Poco después, sin embargo, esta localidad queda incluida dentro del mayorazgo fundado por Doña Mayor de Castañeda para su hijo Don Pedro Fernández de Velasco, formando parte así del señorío de la casa de los Velasco, futuros Condestables de Castilla y Duques de Frías ${ }^{1844}$. Esto no cambiará durante el resto de la Edad Moderna. En el orden eclesiástico, vemos cómo la ubicación de este pueblo sobre la margen izquierda del curso alto del río Arlanza hizo que su parroquia quedara incluida, desde el concilio de Burgos de 1136, dentro de la Diócesis de Osma ${ }^{1845}$. Esta dependencia de la sede oxomense se mantuvo sin cambios hasta 1956, que se incorpora a la Archidiócesis de Burgos.

Vilviestre contó habitualmente con un volumen de población superior a la media de los pueblos de esta zona de la sierra, el cual no fue ajeno a las fluctuaciones vividas durante la Edad Moderna. En este sentido, el siglo XVI nos muestra un importante crecimiento, que debemos relacionar con el auge de la actividad carretera. Así, de los 72 vecinos $^{1846}$ contabilizados en el censo de 1541 , pasamos a los $114^{1847}$, que nos ofrece a

DÍEZ: Libro Becerro de las Behetrías. Estudio y texto crítico. León, Centro de Estudios e Investigación San Isidoro. Caja de Ahorros y Monte de Piedad. Archivo Histórico Diocesano. 1981. (pp. 626).

1841 G. MARTÍNEZ DÍEZ: Génesis histórica de la provincia de Burgos y sus divisiones administrativas. Burgos, Aldecoa. 1983.

1842 ADPBU. CE - 2224. RESPUESTAS GENERALES. Vilviestre del Pinar, 2 - septiembre - 1753.

1843 G. MARTÍNEZ DÍEZ: Libro Becerro de las Behetrías. Ob. cit. (pp. 626).

1844 E. de. DOMINGO ANGULO: Vilviestre del Pinar, pasado, presente y futuro. Burgos, Aymto. de Vilviestre del Pinar. 1995. (pp. 24 - 25).

1845 L. SERRANO: El obispado de Burgos y Castilla primitiva. Desde el siglo V al XIII. Madrid. 1935. Tomo I (pp. 333 - 337, 374 - 378, 414 - 418).

1846 AGS. Contaduría General. Leg. 768. (fols. 61).

1847 Censo de Castilla de 1591. Vecindario. Madrid, Instituto Nacional de Estadística. 1984. 
finales de la centuria el censo de 1591. A este progreso le sigue un período de crisis, que se deja sentir especialmente en el primer tercio de la centuria de Seiscientos, donde, según el censo de la sal de 1631, se llega hasta los 73 vecinos ${ }^{1848}$. Inmediatamente después de esta fecha, sin embargo, debió iniciarse un importante proceso de recuperación, que no podemos cuantificar en cifras concretas, pero que queda perfectamente reflejado en la necesidad, que surge en aquel momento, de ampliar el templo parroquial, ante la imposibilidad de acoger a todos los fieles ${ }^{1849}$. La tendencia ascendente, con las fluctuaciones lógicas de la sociedad del Antiguo Régimen, se mantiene a lo largo de esta centuria y el resto de la centuria siguiente. Esto permite que durante la segunda mitad del siglo XVIII se alcance el techo en el nivel de población de esta localidad con 146’5 vecinos ${ }^{1850}$, contabilizados a mediados de siglo, según el vecindario del Catastro del Marqués de Ensenada, que continúan creciendo al final del siglo, para convertirse en 574 habitantes $^{1851}$, según el censo de Floridablanca de 1787.

La economía de estos habitantes, como la del resto de los pueblos de su entorno, estuvo basada fundamentalmente en el aprovechamiento de sus amplios recursos forestales, y de modo muy especial, en la carretería. Esto hace que la mayoría de sus vecinos se encuentren vinculados a esta actividad, bien como propietarios de grandes o medianos grupos de carretas, o bien como pequeños propietarios, que trabajan al servicio de aquellos. Junto a esto, encontramos también un importante desarrollo de la actividad ganadera, ligada de modo especial al tráfico de carretas, con la cría de bueyes destinados para el tiro. Según estudios realizados sobre el tema, Vilviestre del Pinar

\footnotetext{
1848 AGS. Dirección General del Tesoro, inventario 24. Leg. 1168 - 2.

1849 A.P. Vilviestre del Pinar. LP. Vilviestre del Pinar, parroquia de San Martín de Tours. LF. (1635 1673), (fols. $61-66$ v $^{\circ}$ ). Visita realizada a la parroquia de San Martín de Vilviestre del Pinar en 1648, por D. Mateo Salas. Vilviestre del Pinar, 28 - febrero - 1648.

1850 Vecindario de Ensenada 1759. Vol. I. Madrid, Centro de Gestión Catastral y Cooperación Tributaria: Tabapress. D. L. 1991.

1851 INE. Censo de 1787. “Floridablanca”. Madrid. INE. 1989.
} 
mantuvo habitualmente una cabaña de bueyes por encima de las 1.000 cabezas $^{1852}$. La actividad agrícola, como en el resto de pueblos vinculados a la carretería, queda reducida al cuidado de algunos prados, donde se cultivan pastos para el ganado, y a la siembra de unas pocas hortalizas en las huertas próximas al pueblo ${ }^{1853}$. A diferencia de otros pueblos vecinos, sin embargo, no encontramos aquí un desarrollo de actividades artesanales, como las realizadas en Canicosa de la Sierra o Quintanar de la Sierra, relacionadas con la elaboración de gamellas y taburetes.

El pueblo de Vilviestre se asienta sobre una pronunciada ladera, convenientemente orientada hacia el mediodía, coronada por un prominente afloramiento rocoso en forma de cresta, donde se asienta su iglesia. El crecimiento que ha experimentado esta localidad, especialmente durante los dos primeros tercios del siglo XX ha hecho que el caserío del pueblo se haya expandido hacia las laderas próximas, orientadas al norte. Este crecimiento ha terminado por afectar también al núcleo primitivo del pueblo, conocido como barrio de San Martín, en el cual, a pesar de todo, se han conseguido conservar un buen número de sus edificios más representativos de los siglos XVII y XVIII. De esta forma, Vilviestre nos ofrece tal vez el mejor ejemplo de casas carreteras de toda esta zona de pinares, en cuanto a cantidad y calidad. Dentro de ellas, además, encontramos representadas distintas variantes tipológicas, lo que contribuye a incrementar su riqueza. Aun con todo, el edificio más representativo del pueblo continúa siendo la iglesia parroquial, que preside todo este caserío.

Iglesia de San Martín de Tours.

La iglesia de Vilviestre del Pinar está dedicada a San Martín de Tours, y se halla situada, como decimos, en la parte superior de la ladera, sobre la que se extiende la parte más antigua del núcleo. La cumbre de este cerro presenta una forma alargada, con orientación oeste-este, a la cual se adapta el templo.

1852 P. GIL ABAD: Quintanar de la Sierra, un pueblo burgalés de la comarca de pinares. Burgos, Excma. Diputación de Burgos. 1986. (pp. 303); Ibídem. Junta y Hermandad de la Cabaña Real de Carreteros Burgos - Soria. Burgos, Aldecoa. 1983. 
Es un edificio complejo, constituido a lo largo de diferentes fases constructivas, lo que propicia una singular suma de estilos, que no siempre consiguen complementarse de forma satisfactoria. Esta complejidad se manifiesta ya en su planta, donde se establece una diferencia perfectamente marcada entre la zona de la cabecera y la parte del cuerpo. La zona delantera, que mira hacia naciente, está compuesta por un amplio crucero de brazos poco salientes, a la que se une una capilla mayor de testero poligonal, precedida de un corto presbiterio. Esta zona se completa con la sacristía, adosada sobre el flanco meridional de la capilla mayor, formada por una pequeña estancia rectangular, articulada en dos tramos. La zona del cuerpo, por su parte, presenta una estructura de tres naves, con la central más ancha que las laterales, las cuales presentan además un trazado irregular, con sus muros laterales convergentes hacia la parte de los pies, formando una figura trapezoidal.

Esta diferencia queda perfectamente marcada en su imagen externa, donde la estructura volumétrica de una parte y otra muestran características totalmente diferentes, tanto en su disposición como en proporciones. La parte delantera se ajusta a los modelos propios del estilo barroco, aunque con un gran respeto por la ortodoxia clasicista, y muestra, por tanto, una suma de volúmenes de altura decreciente, que desciende de forma escalonada desde la parte del cimborrio, que envuelve la cúpula central, hasta la pieza correspondiente a la sacristía. Los vanos que se abren en esta parte quedan orientados hacia el mediodía, y en ellos se alternan óculos con ventanas de dintel plano. Dentro de estas últimas, llama particularmente la atención la abierta sobre el extremo del brazo del crucero, enmarcada mediante una tupida decoración de placas, en la que se incluyen también otros elementos propios de un barroco más movido ${ }^{1854}$. Los muros, que conforman estos volúmenes, están realizados todos ellos en piedra de sillería, y rematan con un friso y una cornisa de tipo papo de paloma.

1853 ADPBU. CE - 2224. RESPUESTAS GENERALES. Vilviestre del Pinar, 2 - septiembre - 1753.

1854 Ver capítulo: Actividad constructiva. Evolución estilística: Siglo XVIII. 
La parte correspondiente al cuerpo muestra una estructura de menor desarrollo en altura, con un aspecto mucho más tosco. Sus muros, sin embargo, mantienen un cuidado trabajo de cantería, con paramentos de elegante sillería. Estos muros, en la fachada de los pies, están reforzados por sólidos estribos de forma prismática, dispuestos con lados en paralelo a los ejes del muro. Entre ellos se colocan las ventanas, las cuales se extiende por el muro meridional, repitiendo siempre un mismo tipo de trazado rectangular de dintel plano con forma estilizada y fuerte derrame hacia el exterior. Solamente la del centro del muro de los pies presenta una mayor anchura, a la cual acompaña un característico marco con orejones. La puerta de entrada se abre en la parte delantera del muro meridional, mostrándonos una sencilla estructura de estilo gótico muy avanzado, similar a la que existe en la iglesia de Santa Cecilia en Salas de los Infantes, o en la ermita de la Virgen Blanca en Hoyuelos de la Sierra, cuya construcción podemos situar hacia la primera década del siglo XVI. Consta de una puerta coronada con arco escarzano de aristas redondeadas en forma de moldura de tres cuartos de bocel, al que se superponen tres niveles de arquivoltas, con arcos apuntados, en los que se repite el mismo tipo de aristas. Estos arcos se corresponden, en el derrame de las jambas, con finos baquetones. Sobre el tímpano de la puerta encontramos también una pequeña cruz, perteneciente a la orden de Calatrava, cuya incorporación tal vez podamos relacionar con la presencia en esta localidad de una importante familia apellidada así.

Como elemento de tránsito, o de unión si se prefiere, entre ambas partes del templo, tenemos la torre, alojada en esta parte meridional, junto a la puerta. Está compuesta por un recio prisma de base cuadrangular, en el que se integra el husillo por el que asciende la escalera de caracol, que lleva a los pisos superiores. Sobre este prisma se levanta el cuerpo de campanas, de anchura algo menor que la base, y separado por una pequeña imposta. Este cuerpo presenta dos vanos con arco de medio punto en el lado meridional y uno solo en cada uno de los tres lados restantes, y su remate está formado por gruesa cornisa de codillo, interrumpida en su lado meridional por gárgolas 


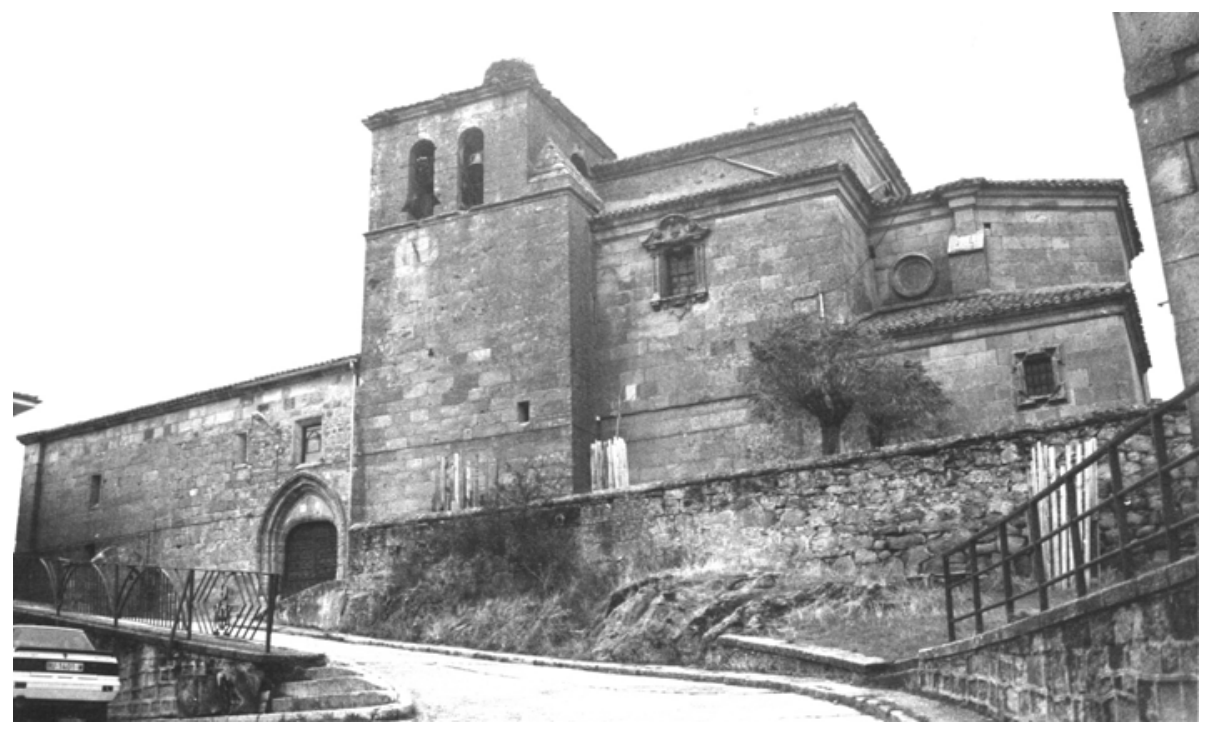

VILVIESTRE DEL PINAR.

Iglesia de San Martín de Tours.

en forma de cañón. Todo ello, aunque con ciertas reservas, nos permita situar su construcción en pleno siglo XVI.

Ya en el interior, nos encontramos con un espacio dividido en dos ámbitos claramente diferenciados, en cada uno de los cuales se muestra un concepto espacial radicalmente distinto. La zona del cuerpo, con sus tres naves, desarrolla un tipo de espacio-camino de estructura longitudinal, con un claro predominio del ámbito correspondiente a la nave central. Estas naves se encuentras separadas por dos hileras de poderosos arcos formeros, con amplios arcos de medio punto de rosca moldurada en los dos tramos delanteros de la nave del evangelio, y sección cuadrada con intradós cajeado en los restantes. La pieza más interesante de esta parte, sin embargo, lo constituye su cubierta, formada por un espectacular artesonado en forma de artesa invertida, el cual, a pesar de ser una obra reciente (realizada a principios de la década de 1990), reproduce la estructura y dibujos de su trama original. 
La zona de la cabecera, por su parte, muestra un concepto de ámbito único de carácter centralizado, dominado por el gran espacio del crucero, en el que se integran los ámbitos, que componen los brazos, el presbiterio y la capilla mayor. Esta zona, al mismo tiempo, incorpora un fuerte componente ascensional, propiciado por la gran cúpula semiesférica, que cubre este espacio central del crucero, la cual descansa sobre anillo moldurado y pechinas decoradas con medallones, en los que se colocan imágenes de distintos santos. La superficie de la cúpula queda dividida en ocho paños separados por pilastras, que se decoran con diferentes motivos de temática natural poco abultada. Los espacios adyacentes de los brazos del crucero y el presbiterio se cubren con bóvedas de medio cañón con lunetos, decorados con motivos geométricos de formas mixtilíneas. Los arcos torales, que delimitan el espacio central, son de medio punto con intradós cajeado, y descansan sobre pilares achaflanados, frenteados con pilastras de fuste también cajeado, que rematan con volada cornisa. Esta cornisa se extiende por los muros, marcando la separación con el nivel de las cubiertas. Arcos y pilastras, así como la cornisa del remate, están elaborados en piedra de sillería, mientras que los muros, una vez eliminado en enlucido original, muestran un tosco paramento de sillarejo y mampostería. Se reafirma así su papel de elementos activos dentro del edificio.

Esta imagen interior se completa con los retablos que decoran cada uno de sus altares. El del altar mayor es obra rococó, realizada en la década de 1770, poco después de la propia cabecera. Consta de un solo cuerpo de tres calles, adaptado al perfil poligonal del testero, y en su nicho central aparece la imagen de San Martín a caballo partiendo su manto, mientras que a los lados nos encontramos con las tallas de la Inmaculada Concepción y San José. El remate, formado por un cascarón, cuenta con un óvalo en el centro, donde se creaba un efecto de transparente, a través de una ventana abierta en la parte superior del paño central del testero. 
En el extremo del brazo meridional del crucero se encuentra el retablo de la Piedad, obra de estilo clasicista, realizada hacia mediados del siglo XVII. Está presidido por una imagen de vestir de la Piedad, acompaña de un Cristo Crucificado en el remate. Justo enfrente, en el brazo septentrional, se levante el antiguo retablo del altar mayor, obra plateresca realizada hacia 1540. Consta de banco, dos cuerpos articulados en cinco calles, y remate. El banco cuenta con el tabernáculo en el centro y parejas de santos en cada una de sus calles. En el primer cuerpo encontramos el nicho central ocupado actualmente por una imagen de la Virgen, mientras que a los lados aparecen representaciones en relieve de diferentes escenas de la vida de San Martín. El segundo cuerpo presenta la imagen de la Asunción en el nicho central, y en los laterales relieves con las escenas de la Adoración de los Magos, el Nacimiento de Jesús, la Visitación y la Anunciación. En el remate se representa un sencillo calvario. En este mismo brazo del crucero tenemos el retablo de Nuestra Señora del Torrejón, actualmente ocupado por la imagen de San Antonio. Es obra churrigueresca de principios del siglo XVIII, que consta de un cuerpo con un solo nicho escoltado por columnas salomónicas, presidido por San Antonio, al cual acompañan en el remate las figuras de San Cosme y San Damián.

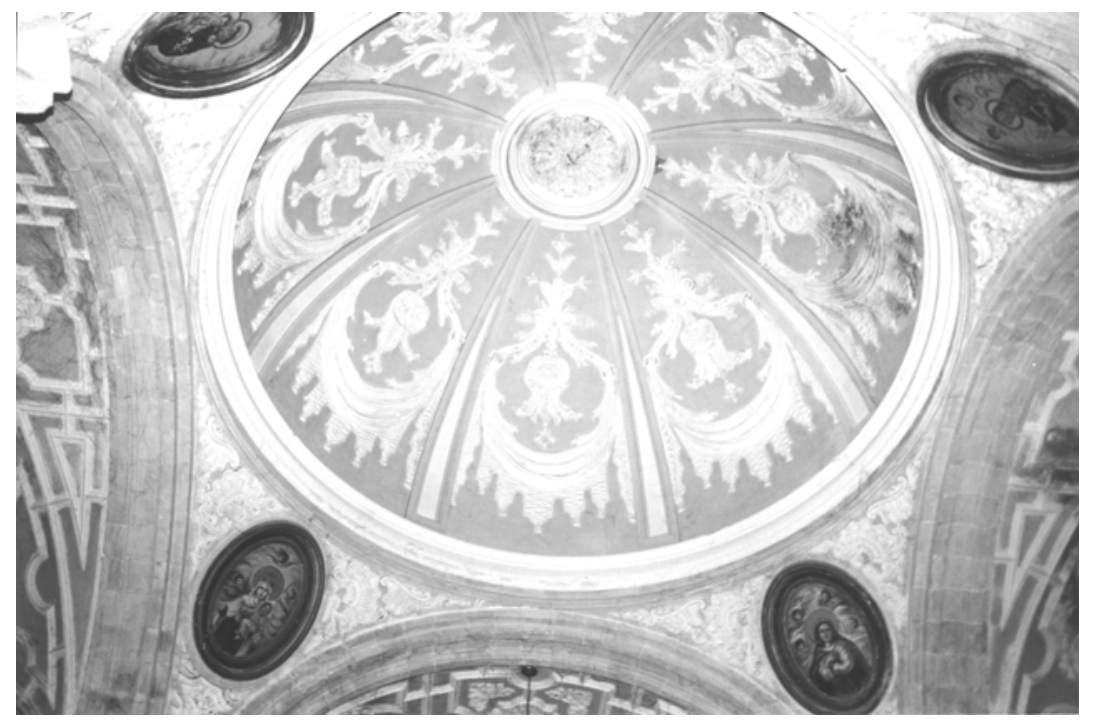

VILVIESTRE DEL PINAR. Iglesia de San Martín de Tours. Cúpula del crucero. 
En la zona del cuerpo, sobre el muro frontal de las naves laterales se alzan dos pequeños retablos gemelos de estilo rococó, realizados hacia 1770. El del lado del evangelio está presidido por la Virgen con el Niño, a la cual acompañan dos santos más a los lados y un tercero en el remate, sin identificar. El de la epístola está dedicado a Cristo Crucificado, cuya imagen se encuentra acompañada por San Julián y otro obispo a los lados, y San Joaquín en el remate. Un último retablo, dedicado al Santo Cristo, aparece en la nave del evangelio. Es un retablo de tipo marco de estilo churrigueresco, realizado a principios del siglo XVIII ${ }^{1855}$.

Este templo, como ya indicábamos, constituye el resultado final de una larga secuencia constructiva, cuyas principales fases se producen entre los siglos XVI, XVII y XVIII. Los únicos restos que se conservan del templo o templos precedentes, que aquí existieron, quedan reducidos, por lo tanto, a una serie de sepulcros labrados en roca, hallados en la zona de los pies del actual edificio ${ }^{1856}$. Son tumbas de carácter antropomorfo, cuyos rasgos han permitido fecharlas entre los siglos XII y XIII ${ }^{1857}$.

Dentro del edificio actual la fase más antigua que podemos identificar se produce en torno a las décadas iniciales del siglo XVI, a la cual corresponden los dos tramos delanteros del cuerpo, donde se incluye la puerta de entrada. En esta obra se desarrolla un estilo típicamente gótico, aunque ya muy evolucionado, como podemos ver en los arcos formeros del interior y en los soportes sobre los que descansan. Los arcos del lado de la epístola, sin embargo, fueron sustituidos posteriormente por unos de sección cuadrada con intradós cajeado. Se incluye también dentro de esta misma fase la portada.

Este cuerpo de planta de salón de tres naves de dos tramos cada una con cubierta de madera, se completaba, con toda seguridad, con una cabecera de trazado

1855 R. J. PAYO HERNANZ: El retablo en Burgos y su comarca durante los siglos XVII y XVIII. Burgos, Excma. Diputación Provincial de Burgos. 1997. (T. II, pp. 556).

1856 E. de. DOMINGO ANGULO: Vilviestre del Pinar, pasado, presente y futuro. Ob. cit. 
cuadrangular con testero plano, similar a los modelos habituales en la comarca durante este período. A esta cabecera se adaptaría perfectamente el primitivo retablo del altar mayor. La fase constructiva, desarrollada durante el siglo XVI, se completa con la incorporación de la torre, obra realizada posiblemente hacia mediados de aquella centuria, tal y como nos indica el tipo de gárgolas, incorporadas en el remate.

La siguiente gran fase constructiva se produce a mediados del siglo XVII, la cual consiste en una ampliación del cuerpo del templo en sentido longitudinal, alargando las naves con un nuevo tramo. La iniciativa de esta obra parte del visitador del Obispado de Osma en 1648, D. Mateo Salas, el cual se hace eco de la necesidad que tenía esta iglesia de aumentar su espacio "por no ser capaz para la gente que ay"1858. Esta necesidad hace que las obras se completen de forma inmediata, dándose por concluidas al año siguiente, tal y como indica la inscripción recogida en la cornisa exterior del muro meridional, que dice: HIZOSE ESTA OBRA AÑO 1649 SIENDO CURA EL LICENCIADO CRISTÓBAL DÍEZ. JUAN CHICOTE DEL CUBILLO MAYORDOMO. Así lo confirma también el informe dejado por el mismo D. Mateo de Salas en su vista realizada en 1650: “Otrossi por quanto la iglesia se alargado y está muy capaz y decente para ansi los ombres como las mujeres estén con mucha comodidad en ella, mandava y mando que el cura señale reya y no pasen de ella las mujeres durante se celebren los dichos divinos oficios ansi misas como bisperas ni pongan dilante de los ombres ni entre ellos en virtud de lo dispuesto y mandado por las Constituciones Signodales"1859.

El incremento de las naves propicia la incorporación de dos nuevos arcos en la zona de los pies, los cuales continúan las líneas de formeros ya existentes, aunque con unas formas muy diferentes, pues en ellos se muestran ya los rasgos propios de la

\footnotetext{
1857 Ibídem.

1858 A.P. Vilviestre del Pinar. LP. Vilviestre del Pinar, parroquia de San Martín de Tours. LF. (1635 1673), (fols. $61-66 \mathrm{v}^{\mathrm{o}}$ ). Vilviestre del Pinar, 28 - febrero - 1648.

1859 Ibídem. (fols. $70-75 \mathrm{v}^{\circ}$ ). Visita realizada a la parroquia de San Martín de Vilviestre del Pinar en 1650, por D. Mateo de Salas. Vilviestre del Pinar, 24 - enero - 1650.
} 
estética clasicista. Al mismo tiempo vemos también cómo la intensidad de los trabajos desarrollados obliga a remodelar toda la parte de la nave de la epístola, cuyos arcos formeros y muro exterior tuvieron que ser reconstruidos completamente, exceptuando el tramo delantero, donde se halla la puerta de entrada. Esto hace que no se conserve ninguna ventana perteneciente a la fase anterior. Desconocemos los nombres de los artífices encargados de su ejecución y el presupuesto total invertido en la obra, no obstante, sabemos que existió una fuerte implicación de los vecinos, los cuales participaron con una aportación de 200 ducados, y la prestación de su trabajo personal $^{1860}$.

Durante esta misma centuria se producen también otras obras de carácter menor, centradas fundamentalmente en el mantenimiento, cuidado y mejora del edificio. Entre ellas podemos citar las reparaciones efectuadas hacia 1639 en la zona de la cabecera, consistentes principalmente en la renovación del embaldosado, la construcción de una grada para el altar mayor, y algunas otras reparaciones. El encargado de su ejecución fue un cantero vizcaíno, cuyo nombre no se cita, el cual percibió de esta fábrica una cantidad superior a los 12.000 maravedís $^{1861}$. Obras de naturaleza similar se llevaron a cabo en la torre, en distintos momentos de esta centuria. En las realizadas en 1639 participa el maestro trasmerano Domino de Pontones ${ }^{1862}$, mientras que las efectuadas en 1653 fueron encargadas al maestro de Palacios de la Sierra, Juan Jarro ${ }^{1863}$. No obstante, el escaso presupuesto empleado en cada una de ellas, nos indica que debió tratarse de obras de poca importancia.

Dentro de este apartado de obras de mantenimiento podemos citar también las intervenciones efectuadas en ámbitos muy concretos del templo, como es el caso de alguna de las capillas secundarias. Entre ellas destacan las realizadas en la capilla

\footnotetext{
1860 Ibídem. (fols. 61 - 66 v ). Vilviestre del Pinar, 28 - febrero - 1648.

1861 Ibídem. (fols. 35 v $^{0}$ ). Cuentas del año 1639. Vilviestre del Pinar, 13 - junio - 1642; Ibídem. (fols. $36 \mathrm{v}^{\mathrm{o}}$ - 37). Cuentas del año 1640. Vilviestre del Pinar, 13 - junio - 1642.

1862 Ibídem. (fols. $21-22$ v ). Cuentas del año 1638. Vilviestre del Pinar, 4 - septiembre - 1639.

1863 Ibídem. (fols. 91 v - 92). Cuentas de 1653. Vilviestre del Pinar, 1653.
} 
dedicada a Santiago, fundada por Bartolomé Blanco, posiblemente a finales del siglo XVI. En este caso, el abandono de las más elementales labores de mantenimiento por parte de los patronos había conducido a una situación ciertamente delicada, que nos describe el visitador del Obispado de Osma en 1644, D. Antonio del Valdés:

”...oy está casi hundido el techo de dicha capilla y el retablo está con peligro de caerse y este daño está causado desde el tiempo que fue capellán el comisario Juan Blanco y vuestra obligación es repararlo de la renta de la capilla; mando que los herederos de dicho comisario reparen y aderecen dicha capilla y retablo..." 1864.

Informes similares a éste se repiten en las visitas siguientes de 1646 y 1648, realizadas por D. Mateo de Salas, lo que nos indica el escaso efecto de los llamamientos ${ }^{1865}$. Mejor suerte parecen vivir las capillas dedicadas a Nuestra Señora y San Andrés, situadas en la parte delantera de las naves, junto a la entrada de la capilla mayor $^{1866}$. Estas capillas, al mismo tiempo que acometen distintos trabajos de mantenimiento, deciden renovar sus respectivos retablos, obra que se realiza en 1640, con la participación del maestro Juan de la Piedra, para la hechura de ambos retablos $^{1867}$, y del pintor soriano Martín Mazorro para el dorado ${ }^{1868}$.

1864 Ibídem. (fols. 50). Visita realizada a la parroquia de San Martín de Vilviestre del Pinar en 1644, por D. Antonio del Valdés. Vilviestre del Pinar, 28 - abril - 1644.

1865 Ibídem (fols. 51 - 55). Visita realizada a la parroquia de San Martín de Vilviestre del Pinar en 1646, por D. Mateo de Salas. Vilviestre del Pinar, 19 - mayo - 1646; Ibídem. (fols. 61 - 66 vo). Vilviestre del Pinar, 28 - febrero - 1648.

1866 Ibídem. (fols. 255 y ss.).“Fuera de la capilla al lado izquierdo un retablo de Nuestra Señora con la imagen de Santa María y la de la Magdalena, y al lado derecho otro retablillo donde están las imágenes de Sres. S. Andrés, San Antonio y Santa Polonia”. Vilviestre del Pinar, 15 - septiembre - 1639.

1867 Ibídem. (fols. 36 v v - 37) .Cuentas del año 1640. Vilviestre del Pinar, 13 - junio - 1642.

1868 Ibídem. (fols. 55 - 56 vo).Cuentas del año 1644. Vilviestre del Pinar, 12 - mayo - 1647. 
Pequeños trabajos de mantenimiento se realizaron también en la llamada capilla del Santo Cristo en 1650, la cual debía constar simplemente de un altar colocado sobre uno de los muros laterales de la nave ${ }^{1869}$.

Este tipo de trabajos se continúan desarrollando durante el siglo XVIII, con nuevas reparaciones en la capilla de Santiago y el resto de la zona de la cabecera del templo. En la capilla de Santiago, nuevamente por mandato de los visitadores diocesanos, se reparó parte de su tejado y sus muros en $1722^{1870}$, mientras que en 1756 se ordena "que la capilla de Santiago se adorne a costo del Patrono haciendo frontal, retablo, verjas, se blanqueen y retejen...”1871. En 1709 es la sacristía la que compone su tejado y renueva su imagen interna con una nueva cajonería, que tuvo un coste próximo a los 600 reales $^{1872}$. A ello le sigue, entre los años 1720-22, diversos trabajos en la capilla mayor, efectuados por los maestros José Gil ${ }^{1873}$ y Bartolomé de Camporredondo ${ }^{1874}$.

De este modo, llegamos hasta los años centrales de este siglo XVIII, momento en el que se produce la última gran fase constructiva, que conoce el templo, durante la cual se levanta toda la parte delantera. La obra se concluye, como indica la inscripción que aparece sobre el muro exterior del brazo meridional del crucero, en $1761^{1875}$, si bien, parece que el proyecto comenzó a gestarse unos años antes. Así, en 1756 el visitador del Obispado de Osma, D. Juan Fernández de Arcos, había instado a los

\footnotetext{
1869 Ibídem. (fols. 77 - 78 v ${ }^{\circ}$ ). Cuentas del año 1650. Vilviestre del Pinar, 12 - octubre - 1651.

1870 Ibídem. LF. (1716 - 1737). (fols. 15 v ${ }^{0}-26$ vo). Visita realizada a la parroquia de San Martín de Vilviestre del Pinar en 1722, por D. Joseph Martín Ibáñez, abad de Santa Cruz. Vilviestre del Pinar, 17 abril - 1722 .

1871 Ibídem. LF. (1756 y ss), (fols. 10vº-20vº). Visita realizada a la parroquia de San Martín de Vilviestre del Pinar en 1756, por D. Juan Fernández de Arcos. Vilviestre del Pinar, 20 - agosto - 1756.

1872 Ibídem. (1685 - 1716). Cuentas del año 1709. Vilviestre del Pinar, 15 - febrero - 1710.

1873 Ibídem. LF. (1716 - 1737), (fols. 61 v - 64)). Cuentas del año 1720. Vilviestre del Pinar, 27 febrero - 1721 .

1874 Ibídem. (fols. $68 \mathrm{v}^{0}-71$ vo). Cuentas del año 1722. Vilviestre del Pinar, 17 - febrero - 1723.

1875 ESTA OBRA SE HIZO A COSTA DE ESTA VILLA SIENDO CURA D. PEDRO CAMPOS CUESTA 1761.
} 
responsables de la parroquia, "que dentro de un breve término reintegre a su iglesia todos los caudales que se le están deviendo y que con la maior brevedad se execute la capilla maior y crucero”"1876. La suma recaudada a través de esta operación superó los 12.000 reales $^{1877}$, a lo que debemos sumar las generosas contribuciones efectuadas por los vecinos del pueblo. Estas contribuciones debieron constituir la parte más importante del presupuesto final del proyecto. El encargado de dirigir los trabajos, o al menos de elaborar sus trazas, parece que fue el maestro de cantería Domingo de Ondátegui, el cual imprime a la obra resultante su sello personal ${ }^{1878}$. Constituye, como vimos, una obra perfectamente identificada con la interpretación del estilo barroco, que ofrece este artista, en la que apreciamos un profundo respeto por la limpieza de líneas y la proporción de cuerpos, en el exterior, mientras que en la parte interna se observa una inclinación más clara hacia la línea ornamental. Este proyecto se completa con la construcción del retablo para el altar mayor, realizado en la década de $1770^{1879}$, al que sigue la apertura de un trasparente en la parte superior del muro del testero, que se corresponde con el óvalo situado en el remate del retablo ${ }^{1880}$.

Con esta obra, como decimos, se cierra definitivamente la secuencia constructiva del templo, pues las intervenciones realizadas a partir de ahora en ningún caso consiguen modificar su imagen. Aun así, podemos mencionar las importantes obras de restauración realizadas a comienzos de la década de 1990, en las que se reconstruye de nuevo el artesonado, que cubre la zona del cuerpo, y se añade un nuevo coro en la zona de los pies.

\footnotetext{
1876 A.P. Vilviestre del Pinar. LP. Vilviestre del Pinar, parroquia de San Martín de Tours. LF. (1756 y ss) (fols. $10 \mathrm{v}^{0}-20 \mathrm{v}^{0}$ ). Visita realizada a la parroquia de San Martín de Vilviestre del Pinar en 1756, realizada por D. Juan Fernández de Arcos. Vilviestre del Pinar, 20 - agosto - 1756.

1877 Ibídem. (fols. 31v $\mathrm{v}^{\circ}$ 33). Cuentas de año 1757. Vilviestre del Pinar, 14 - febrero - 1758.

1878 Ibídem. (fols. 23 - 26vº). Cuentas del año 1756. Vilviestre del Pinar, 8 - febrero - 1757.

1879 R. J. PAYO HERNANZ: El retablo en Burgos y su comarca durante los siglos XVII y XVIII. Ob. cit. (T. II, pp. 556).

1880 A.P. Vilviestre del Pinar. LP. Vilviestre del Pinar, parroquia de San Martín de Tours. LF. (1756 y ss) (fols. 148 - 150). Cuentas del año 1781. Vilviestre del Pinar, 12 - abril - 1782.
} 


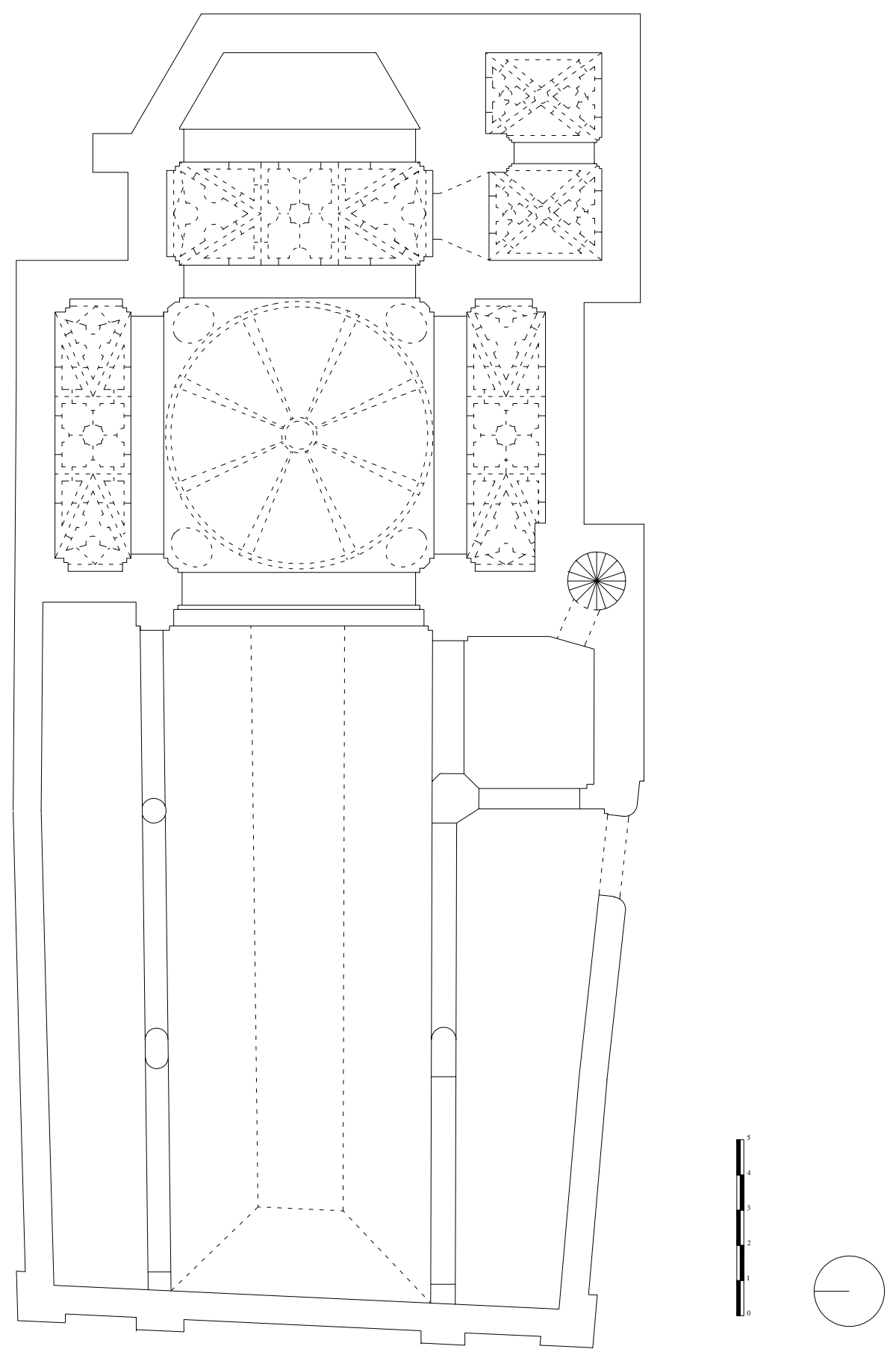

VILVIESTRE DEL PINAR. Iglesia de San Martín de Tours. Planta. 
Ermitas.

Existían en Vilviestre, durante la Edad Moderna, un total de ocho ermitas, las cuales estaban dedicadas a Nuestra Señora del Torrejón, San Antonio y Santa Catalina, la Vera Cruz, San Bartolomé, San Jorge, San Juan, San Roque y Nuestra Señora de la Soledad.

De ellas, solamente la de San Antonio y Santa Catalina se ha conservado entera. Este templo tiene una historia peculiar, pues en 1732 el visitador del Obispado de Osma, D. Ventura Gaitero, manda trasladar su edificio desde el emplazamiento original, en la margen derecha del río Arlanza, a las inmediaciones del pueblo ${ }^{1881}$. Este mandato se volvió a repetir en los mismos términos tres años más tarde ${ }^{1882}$, hasta que finalmente entre los años 1736-37 los vecinos la levantan en su ubicación actual, a escasos quinientos metros del pueblo en dirección norte ${ }^{1883}$. Esta ermita desarrolla una sencilla estructura de tipo caja de una sola nave de planta rectangular, que se complementa, en el extremo oriental, con una cabecera cuadrangular algo más estrecha. Al exterior se muestra como una estructura de volúmenes bien perfilados, conformados por muros de mampostería y sillarejo, y cubiertos con techumbre a dos aguas, la nave, y a cuatro la cabecera. Las dos únicas ventanas con que cuenta están orientadas hacia el mediodía, y presentan sencillo trazado rectangular de dintel plano con derrame hacia el exterior, mientras que la puerta, dispuesta en este mismo flanco, se corona con arco de medio punto de amplio dovelaje.

En el interior encontramos dos ámbitos perfectamente diferenciados. La nave, por un lado, presenta un amplio espacio de estructura longitudinal cubierto con armadura de madera de tipo par y nudillo. Por su parte, la cabecera a la cual se accede a través de potente arco de medio punto de intradós casetonado sobre pilastras de orden

1881 Ibídem. LF. (1716 - 1737). (fols. 136 - 136 vº). Visita realizada a la parroquia de San Martín de Vilviestre del Pinar en 1732, por D. Ventura Gaitero. Vilviestre del Pinar, 20 - octubre - 1732.

1882 Ibídem. LF. (1735 - 1755). (fols. 2 - $10 \mathrm{v}^{\mathrm{o}}$ ). Visita realizada a la parroquia de San Martín de Vilviestre del Pinar en 1732, por Esteban Ruiz. Vilviestre del Pinar, 8 - octubre - 1735.

1883 E. de. DOMINGO ANGULO: Vilviestre del Pinar, pasado, presente y futuro. Ob. cit. (pp. 42 - 43). 
toscano, se cubre con una amplia cúpula de media naranja, dispuesta sobre anillo moldurado y pechinas. La superficie de esta cúpula se divide en ocho paños, cubiertos con decoración geométrica de perfil mixtilíneo, que se extienden por las pechinas. Se muestra aquí, por lo tanto, un barroco más marcado, que en otros edificios contemporáneos de la zona, donde se continuaba imponiendo la bóveda de crucería estrellada con terceletes, como único modelo de cubierta. Esta imagen interior se completa, en el altar mayor, con un retablo de estilo churrigueresco de formas muy movidas, organizado en un solo cuerpo de tres calles, y remate, cuajado todo ello de una apretada decoración vegetal. A ambos lados de la entrada de esta capilla encontramos dos pequeños retablos colaterales gemelos, también de estilo churrigueresco, aunque de composición más severa, que constan de una única hornacina y remate.

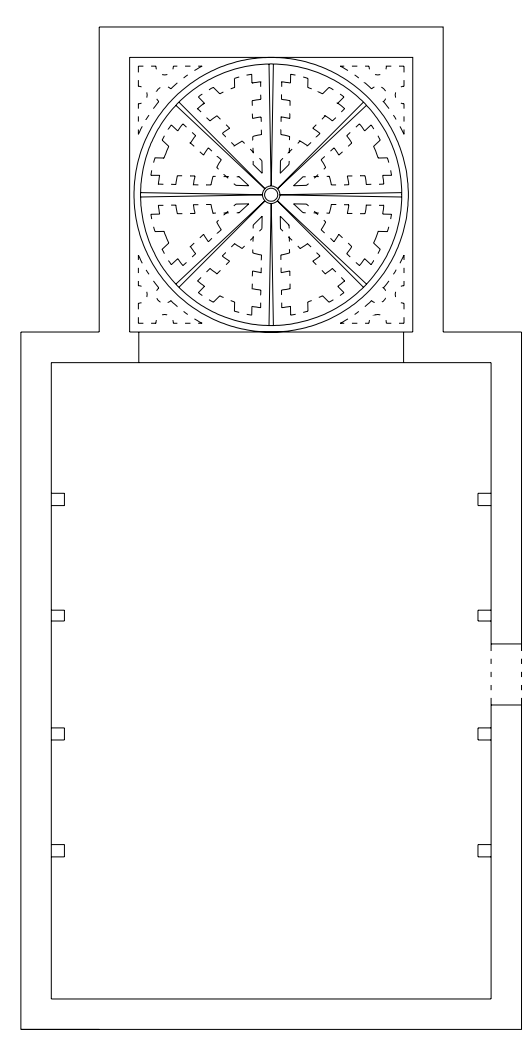


La otra ermita, que nos ha dejado restos, es la de Nuestra Señora del Torrejón, la cual fue, sin duda, el centro de culto más importante que existió en Vilviestre. Se encuentra situada a unos doscientos metros del pueblo en dirección norte, y aunque han desaparecido toda la estructura del tejado de la zona de la nave, todavía conserva intacta la parte de la cabecera y los muros del cuerpo. Repite el mismo tipo de estructura que la ermita anterior, con nave única de trazado rectangular, que se complementa con cabecera cuadrangular de testero plano. Todo el edificio está realizado en piedra, con sólidos muros de sillería, que en la cabecera se refuerzan con estribos prismáticos en las esquinas, y rematan con un friso y una cornisa moldurada. El acceso al interior se realizaba a través de una puerta con arco de medio punto, dispuesta a los pies, que completa con una pequeña ventana abierta sobre ella. No obstante, en el muro meridional se conserva la impronta de una antigua puerta, también de arco de medio punto.

De la estructura interna sólo se conserva la cabecera, a la cual se accede a través de un potente arco de medio punto, apeado sobre pilastras de orden toscano y fuste cajeado, igual que el intradós del arco. Su interior se cubre con bóveda de crucería estrellada con terceletes y nervios combados, que dibujan un círculo central. Es una obra, que a pesar de su tosquedad y el avanzado estado de deterioro que muestra, podemos encuadrar dentro de la arquitectura de sabor clasicista, realizada en la zona hacia la primera mitad del siglo XVIII. Presenta además claros vínculos con otros ejemplos de cabeceras, realizados en estas mismas fechas, como las de las iglesias de Palacios de la Sierra y Moncalvillo.

Este edificio se mantuvo abierto al culto hasta principios de la década de 1820, momento en el que se cierran sus libros de fábrica. Sin embargo, a principios de la segunda mitad de este siglo XIX se reconstruye con las aportaciones de D. Martín Barriuso, abriéndola al culto bajo la advocación de Nuestra Señora del Carmen. Así se 


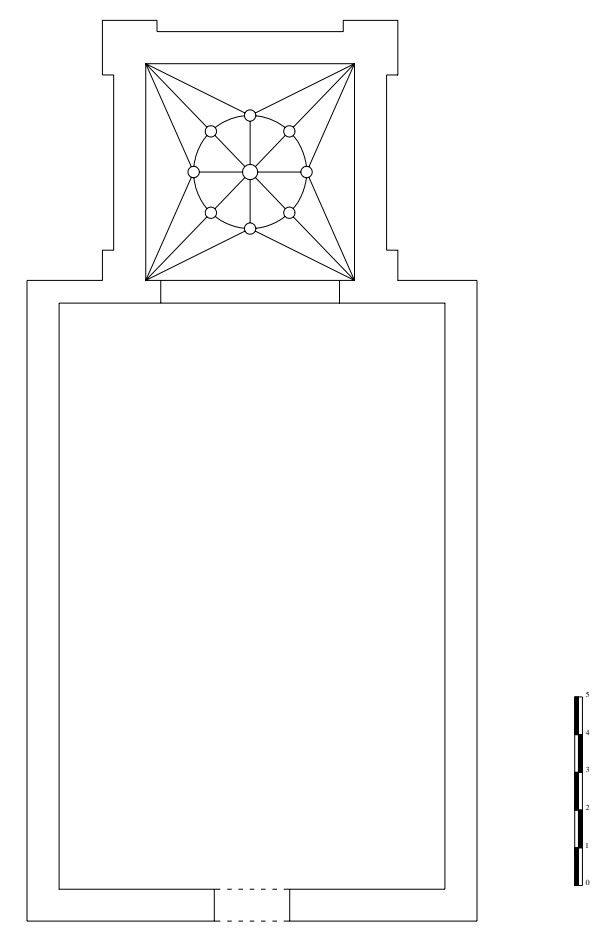

VILVIESTRE DEL PINAR.

Ermita de Nuestra Señora del Torreión. Planta.

mantuvo hasta que en los primeros años del siglo XX se abandona completamente, iniciándose poco después el desplome del edificio ${ }^{1884}$.

Por aquellas mismas fechas desaparecieron los últimos restos que quedaban de la ermita de la Vera Cruz, la cual se encontraba situada en el centro del pueblo, junto a la plaza mayor. Del resto de las ermitas apenas contamos con datos, que nos confirmen su existencia. Las de San Juan y San Roque, por ejemplo, fueron las últimas en desaparecer, las cuales se mantuvieron en pie hasta bien entrado el siglo XIX. La de San Roque, de hecho, todavía existía a mediados de esta centuria, y por ello aparece mencionada en el Diccionario de P. MADOZ ${ }^{1885}$.

1884 Ibídem. (pp. 39 - 41). 


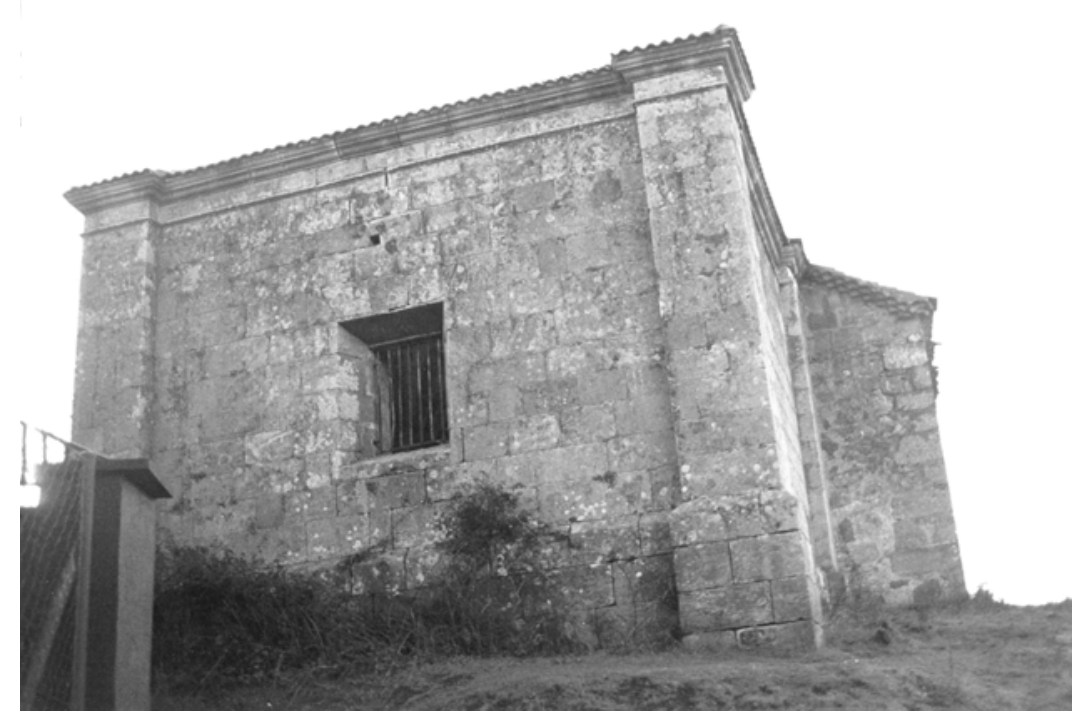

VILVIESTRE DEL PINAR. Ermita de Nuestra Señora del Torrejón.

Las tres restantes, esto es, las de San Bartolomé, San Jorge y Nuestra Señora de la Soledad, debieron desaparecer durante el tercer cuarto del siglo XVIII, pues en la relación de ermitas, que se hace en el informe dictado por el visitador del Obispado de Osma en 1780, D. Francisco Felipe Vález, ya no se mencionan ${ }^{1886}$. Las de San Bartolomé y San Jorge llevaban ya varios años con la amenaza de ruina presente, según nos indican los informes de los visitadores anteriores, lo que había hecho que la de San Bartolomé fuera desmontada en $1747^{1887}$. Aun así, fue reconstruida poco después para

1885 P. MADOZ: Diccionario geográfico - estadístico - histórico de España y sus posesiones de Ultramar. Valladolid, Ámbito D.L. 1984.

1886 A.P. Vilviestre del Pinar. LP. Vilviestre del Pinar, parroquia de San Martín de Tours. LF. (1756 y ss) (fols. 136 - 145). Visita realizada a la parroquia de San Martín de Vilviestre del Pinar en 1780, por D. Francisco Felipe Vález. Vilviestre del Pinar, 14 - mayo - 1780.

1887 Ibídem. LF. (1735 - 1755), (fols. 79 - 137 vo). Visita realizada a la parroquia de San Martín de Vilviestre del Pinar en 1747, por D. Juan Antonio de Osuna Calderón de la Barca. Vilviestre del Pinar, 7 - junio -1747. 
prolongar su existencia unos años más. El rastro de la ermita de Nuestra Señora de la Soledad, por su parte, desaparece en 1758. Sus últimos restos fueron demolidos el año $1834^{1888}$.

\section{Arquitectura civil.}

Vilviestre del Pinar, como ya señalamos, conserva una interesante relación de casas carreteras, concentradas principalmente en el llamado Barrio de San Martín, que se extiende a los pies de la iglesia, y que constituye el núcleo originario del pueblo. Dentro de estas casas, además, encontramos representados de forma amplia dos variantes de la casa carretera, como son la casa solariega y la casa portalón.

Entre las primeras encontramos un ejemplo fechado en los últimos años del siglo XVII, como es la casa situada en el $n^{o} 13$ de este barrio de San Martín, localizada en la parte más elevada del pueblo, en las inmediaciones de la iglesia. Es un edificio muy alterado por las diversas divisiones introducidas en su estructura, si bien conserva todavía la característica morfología exterior, conformada por un prisma sobre base rectangular articulada en dos pisos, separados por líneas de imposta. En su fachada principal, orientada hacia poniente, destaca su puerta de entrada, coronada con potente arco de medio punto de rosca casetonada, lo que es ya una característica propia de estos edificios durante el siglo XVIII.

Dentro ya de la centuria del Setecientos el ejemplo mejor conservado de este tipo de casa lo tenemos en el $n^{o} 85$ del Barrio de San Martín, conocido como la casa de los Calatravas, por el escudo que preside su fachada principal. Esta fachada, realizada toda ella en sillería, cuenta con la puerta en el centro, formada por amplio arco de medio punto de rosca casetonada, escoltada por ventanas de dintel plano a los lados, que se corresponden con otras más pequeñas en el piso principal. Sobre la puerta, como decimos, aparece un escudo con la cruz de Calatrava representada en el centro. 
Frente a esta casa, en el $\mathrm{n}^{\circ} 88$, aparece otro inmueble que conserva diferentes rasgos propios de esta tipología. Entre ellos vuelve a destacar la puerta de entrada, coronada con arco de medio punto de rosca casetonada, y diferentes ventanas enmarcadas con moldura plana de escaso resalte con orejones. La casa situada en el $n^{o}$ 176 mantiene la misma estructura, que hemos visto en la cada de los Calatravas, con amplia fachada principal articulada en dos plantas, donde aparece la puerta de entrada con arco de medio punto de rosca casetonada en el centro del piso inferior y dos ventanas a los lados, y ventanas similares dispuestas en correspondencia con aquellas, en piso superior. Otros edificios en los que se conservan restos de primitivas casas, encuadradas dentro de esta tipología, son las situadas en los números 161 y 164, ambas pertenecientes al siglo XVIII ${ }^{1889}$.

Por último, un ejemplo ciertamente interesante de la variante de la casa carretera, conocida como casa portalón, lo tenemos en el $n^{\circ} 82$ B del Barrio de San Martín. Como ya vimos en su capítulo correspondiente, se trata de una obra del siglo XVIII, en la que se muestran los característicos rasgos de esta variante, como es el amplio portalón abierto en el centro de su fachada principal, escoltado por los dos módulos laterales, que se proyectan hacia delante. Toda esta fachada, además, presenta un cuidado trabajo de cantería, con magnífico paramento de sillería en todos sus muros $^{1890}$.

\footnotetext{
1889 Ver capítulo: Actividad constructiva. Evolución estilística: Siglo XVIII. 1890 Ibídem.
} 
- A. ABAD IZQUIERDO, L. M. GONZÁLEZ: Estudio de la iglesia de Castrillo de la Reina y otros Documentos Históricos. Castrillo de la Reina, Edición Propia. 1985.

- J. A. ABÁSOLO ÁLVAREZ: Epigrafía romana de la región de Lara de los Infantes. Burgos, Excma. Diputación Provincial de Burgos. 1974.

- Comunicaciones de la época romana en la provincia de Burgos. Burgos, Excma. Diputación Provincial de Burgos. 1995.

- Carta arqueológica de la provincia de Burgos: Partido Judicial de Salas de los Infantes. Burgos, Excma. Diputación Provincial de Burgos. 1990.

- M. AGUIRRE: “Benidorm, noria... viene de Yemen”. En Crónica de Diario el Mundo. Domingo, 15 de febrero de 2004. Madrid, Diario el Mundo. 2004, pp. 12 13.

- R. AITKEN: "Rutas de trashumancia en la meseta castellana". En Estudios Geográficos, (febrero 1947), pp. 185 - 199.

- F. ALDEA CHACOBO: Aleros en la Arquitectura popular de la provincia de Valladolid. Valladolid, Universidad de Valladolid. 1984.

- M. ALMAGRO: “Tres nuevos hallazgos del Bronce final en España”. En Ampurias, $n^{\circ} 5.1943$, pp. $270-277$.

- $\quad$ R. ALONSO OLALlA: "Hoyuelos de la Sierra”. En Amigos de Hacinas, $n^{\circ} 75$. Burgos, 1997, pp. 22 - 24.

- Hacinas. Estella, Gráficas Lizarra. 1995. 
- J. L. ALONSO PONGA: Arquitectura popular leonesa. León, Caja España. 1990.

- J. ALONSO ROMERO: La arquitectura barroca en el Burgo de Osma, Soria, Centro de Estudios Sorianos. 1986.

- B. ALONSO RUIZ: El arte de la cantería. Los maestros trasmeranos de la Junta de Voto. Santander, Universidad de Cantabria. Asamblea Regional de Cantabria. 1991.

- A. ALVAR EZQUERRA: Demografía y sociedad en la España de los Austrias. Mdrid, Arco. 1996.

- I. ÁLVAREZ BORGE: Monarquía feudal y organización territorial: Alfoces y merindades en Castilla. (Siglos X - XIV. Madrid, CSIC. 1993.

- Poder y relaciones sociales en Castilla en la Edad Media. Los territorios entre el Arlanzón y el Duero en los siglos $X-X I V$. Salamanca, Consejería de Educación y Cultura. Junta de Castilla y León. 1996.

- “Merindades y merinos menores de Silos, Muñó y Castrojeriz. (1200 - 1350)”. En Jornadas Burgalesas de Historia (3 1991. Burgos). Burgos en Plena Edad Media. Burgos, Asociación Provincial de Libreros de Burgos. 1994.

- "Estructura social y organización territorial en Castilla la Vieja meridional: los territorios entre el Arlanzón y el Duero. Siglos X al XIV”. En I Jornadas Burgalesas de Historia (1º 1989. Burgos). Introducción a la Historia de Burgos en la Edad Media. Burgos, Asociación Provincial de Libreros. 1990.

- Monarquía feudal y organización territorial: alfoces y merindades en Castilla (siglos X-XIV). Madrid, CSIC. 1993.

- El feudalismo castellano y el libro Becerro de las Behetrías: la merindad de Burgos. León, Universidad Servicio de Publicaciones. 1987.

- G. J. ALLANEGUI BURRIEL: Arquitectura popular de Aragón. Zaragoza, Librería General. 1979.

- J. P. AMALRIC: “En la España del siglo XVIII. ¿una agricultura agarrotada?. En Orígenes de atraso económico español (Dir. B. BENNASSAR). Barcelona, 1985.

- A. L. AMPLIATO BRIONES: “Algunos aspectos sobre teoría y práctica arquitectónica en la Andalucía del siglo XVI a través del manuscrito de arquitectura 
de Hernán Ruiz II”. Actas del IV Congreso Internacional de Expresión Gráfica Arquitecónica. Valladolid, 1992, pp. 117 - 177.

- $\quad$ L. ANCESCHI: La idea del barroco. Estudio sobre un problema estético. Madrid. 1991.

- S. ANDRÉS ORDAX: “Arte románico”. En Historia de Burgos. Vol. 2 - 2. Burgos, Caja de Ahorros Municipal de Burgos. 1987, pp. 27 - 82.

- "La iglesia de Santa María la Real y Antigua de Gamonal. Consideraciones sobre su iconografía arquitectónica”. BSAA, nº 54. Madrid. 1988, pp. 339 - 345.

- “Arte gótico”. En Historia de Burgos. Vol. 2 - 2. Burgos, Caja de Ahorros Municipal de Burgos. 1987, pp. 83 - 170.

- “Arte hispanovisigodo”. En Historia de Burgos. Vol. 1. Burgos, Caja de Ahorros Municipal de Burgos. 1987, pp. 447 - 470.

- “Arte Paleocristiano”. En Historia de Burgos. Vol. 1. Burgos, Caja de Ahorros Municipal de Burgos. 1985, pp, 429 - 446.

- “Arte época condal”. En Historia de Burgos. Vol. 2 - 2. Burgos, Caja de Ahorros Municipal de Burgos. 1987, pp. 9 - 26.

- $\quad$ La provincia de Burgos. León, Lancia DL. 1991.

- Las tierras de Burgos. Burgos, Excma. Diputación Provincial de Burgos. 1994.

- Catálogo Monumental de Castilla y León. Bienes inmuebles declarados. Salamanca, Junta de Castilla y León. Consejería de Cultura y Turismo. 1995.

- La ermita de Santa María. Quintanilla de las Viñas. Burgos, Caja de Ahorros Municipal de Burgos. 1980.

- “El foco artístico burgalés”. Congreso de historia de Burgos (1984, Burgos). La ciudad de Burgos. Valladolid. Consejería de Educación y Cultura, 1985, pp. 845 859.

- “Arte burgalés en la Alta Edad Media”. En Jornadas burgalesas de Historia (2 Burgos, 1990). Burgos en la Alta Edad Media. Burgos, Asociación Provincial de Libreros de Burgos, 1991, pp. 125 - 140.

- Inventario artístico de Cáceres y su provincia. Madrid, Ministerio de Cultura. 1990. 
- Fr. A. ANDRÉS (OSB): "Belorado - convento de San Francisco". BIFG, $n^{\circ}$ 128, Burgos, 1954, pp. 255 - 260.

- J. ANDRIO GONZALO: “La Edad Media a través de los estudios arqueológicos”. En Historia de Burgos II. Edad Media (2). Burgos, Caja de Ahorros Municipal de Burgos. 1986.

- G. ANES: “El siglo de las luces”. En Historia de España. (dir. M. Artola). T. IV. Madrid, Alianza Editorial. 1990.

- $\quad$ La crisis agraria en la Edad Moderna. Madrid. 1970.

- A. ANTÓN: “Un poco de Historia: la escuela”. Amigos de Hacinas, no 38. Burgos, 1988, pp. $24-26$.

- “Ermitas”. Amigos de Hacinas, $n^{\circ}$ 73. Burgos, 1996, pp. 26 - 28.

- M. A. ARAMBURU - ZABALA (dir.), J. GÓMEZ MARTÍNEZ (coord.): “Juan de Herrera y su influencia”. Actas del Simposio - Camargo, 14 / 17 julio 1992. Santander, Fundación Obra Pía Juan de Herrera: Universidad e Cantabria. 1993.

- M. A. ARAMBURU - ZABALA HIGUERA: La arquitectura de puentes en Castilla y León (1575 - 1650). Valladolid, Junta de Castilla y León. Consejería de Cultura y Turismo. 1992.

- “Arquitectura en Cantabria en la época del Renacimiento. I Los Arquitectos”. Altamira, $n^{\circ}$ 44. Santander, 1983 - 1984, pp. 211 - 226.

- “La arquitectura barroca en Cantabria”. Altamira, n 48. Santander, 1989 - 1984, pp. $118-142$.

- “Juan de Herrera y su influencia”. Actas del Simposio - Camargo, 14 / 17 julio 1992. Santander, Fundación Obra Pía Juan de Herrera: Universidad e Cantabria. 1993.

- "Los maestros canteros de Cantabria en Madrid: Iglesia parroquial de Cobeña (siglos XVI - XVII)”. Altamira, $n^{\circ}$ 43. Santander, 1982, pp. 141 - 146.

- “Arquitectura herreriana”. Altamira, no 56. Santander, 1996, pp. 79 - 124.

- M. A. ARAMBURU - ZABALA HIGUERA, J. POLO SÁNCHEZ, Ma C. GONZÁLEZ ECHEGARAY: El valle de Soba. Santander, Ed. Tres. 1995. 
- M. A. ARAMBURU - ZABALA HIGUERA, B. ALONSO RUIZ: "La arquitectura después de Juan de Herrera”. En Juan de Herrera. Arquitecto Real. Madrid, 1997.

- J. J. ARANDA LÓPEZ: “La actividad de veedor de obras de cantería en los arciprestazgos vascongados de la diócesis de Pamplona. (Siglos XVII y XVIII)”. Ondare. Cuadernos de artes plásticas y monumentales, $n^{\circ}$ 19. 2000, pp. 277 - 291.

- P. ARIES: El hombre ante la muerte. Madrid, 1983.

- F. de. ARFE VILLAFAÑE: De varia commensuración para la escultura y architectura. (Ed. Facsímil), Valencia. 1979.

- G. ARGAIZ (OBS): La soledad laureada por San Benito y sus hijos en las Iglesias de España y teatro monástico de la provincia... Madrid, Francisco Nieto: a costa de Gabriel de León. 1669.

- G. C. ARGÁN: El concepto del espacio arquitectónico desde el Barroco a nuestros días. Buenos Aires. 1973.

- V. M. ARMENDÁRIZ, J. BARANIGARRAMENTERÍA, Ma. C. GONZÁLEZ (J. M. GONZÁLEZ dir.): Las casonas carreteras. Burgos, Escuela Universitaria de Arquitectura Técnica. UBU. 1998.

- E. ARNÁIZ PAZ: El hogar solariego montañés. Evoluciones. Madrid, Centro de Estudios Montañeses. 1935.

- J. ARNÁIZ BADILLO: Jerarquía urbana y áreas funcionales en la Rioja. Logroño, Instituto de Estudios Riojanos. 1985.

- J. ARRANZ ARRANZ: El renacimiento sacro en la Diócesis de Osma - Soria. Burgo de Osma, 1979.

- $\quad$ Ma A. ARRÁZOLA ECHEVARRÍA: El renacimiento en Guipúzcoa. Arquitectura, escultura, pintura y artes menores. San Sebastián, Diputación de Guipúzcoa. 1967.

- M. ARTOlA: La España del Antiguo Régimen. En Castilla la Vieja. T. III. Salamanca, 1967.

- M. I. ASTIAZARÍN ACHABAL: Arquitectos guipuzcoanos del siglo XVIII. San Sebastián. 1988.

- J. ATIENZA: Nociones de Heráldica. Madrid, Aguilar. 1989. 
- J. AYALA CARCEDO (dir.): Atlas del medio físico de la ciudad de Burgos y su marco provincial. Madrid, Instituto Tecnológico geominero de España. 1988.

- J. M. AZCÁRATE RISTORI: "Iglesias toledanas de tres naves cubiertas con bóvedas de crucería”. AEA, $n^{\circ}$ 31, 1958, pp. 213 - 216.

- “Castilla en el tránsito al Renacimiento” En España en las crisis del arte europeo (Coloquios celebrados en conmemoración de los XXV de fundación de CSIC). Madrid, CSIC, 1969, pp. 201 - 223.

- “La presencia del Gótico en el Renacimiento Español”. Arte Gótico Postmedieval (Simposio Nacional del C. E. H. A.). Segovia, 1987, pp. 27 - 31.

- Inventario artístico de Guadalajara y su provincia. Madrid, Ministerio de Cultura. 1983.

- F. AZCONEGUI MORÁN: El trabajo de la Piedra. León, Escuela Talle de Restauración “Centro Histórico de León. 1993.

- A. BAESCHLIN: La arquitectura del caserío vasco. Bilbao. 1980.

- J. M. BÁEZ MEZQUITA: Arquitectura popular de Castilla y León. Bases para su estudio. Valladolid, Instituto de Ciencias de la Educación, Universidad de Valladolid. 1992.

- B. BAILS: Diccionario de arquitectura civil. Oviedo, Colegio Oficial de Aparejadores y Arquitectos de Asturias. 1973.

- J. BALLART: El patrimonio histórico y arqueológico: valor y uso. Barcelona, 1997.

- F. BALlESTEROS CABALlERO: La Sociedad Económica de Amigos del País de Burgos. Avance histórico. Burgos, 1983.

- T. BALLESTEROS IZQUIERDO: Actividad artística en Vitoria durante el primer tercio del siglo XVII: Arquitectura. Vitoria. 1980.

- M. BARASCH: Teoría del arte. De Platón a Winckelmann. Madrid, 1991.

- J. BARCELÓ: Descripción de las Cañadas Reales. Madrid, Ediciones del Museo Universal. 1984.

- M. BARCELÓ: “Los límites de la información documental escrita”. En Arqueología Medieval. En las afueras del “medievalismo”. Barcelona, Crítica. 1988. 
- P. BARDOU, V. ARZOUMANIAN, M. TUSQUETS TRÍAS DE BES: Arquitectura de Adobe. México, G. Gili. 1986.

- M. BARRIO GOZALO: "Rentas de un privilegiado del Antiguo Régimen. Los arzobispos de Burgos 1550 - 1835”. En La ciudad de Burgos. Valladolid, Junta de Castilla y León, 1985, pp. 411 - 423.

- J. A. BARRIO LOZA: Inventario de arquitectura rural alavesa. Vitoria, Diputación Foral de Álava. Dirección de Arquitectura. 1985.

- "Los canteros vizcaínos: fenómeno migratorio coyuntural en los siglos XVI y XVII”. Letras de Deusto, $n^{\circ} 8$ (16), Bilbao, 1978, pp. 165 - 174.

- J. A. BARRIO LOZA, J. G. MOYA VALGAÑÓN: “El modo vasco de producción arquitectónica en los siglos XVI - XVII”. Kobie, $n^{\circ}$ 10. Bilbao, Grupo Espeliológico Vicaíno. Diputación Foral de Vizcaya., 1980, pp. 283 - 369.

- J. L. BARRIO MOYA: Arquitectura barroca en Cuenca. Madrid, Editorial de la Universidad Complutense. 1991.

- R. BARROSO CABRERA, J. MORÍN DE PABLOS: La iglesia de Santa María de Quintanilla de las Viñas. Madrid, Ediciones BMM\&P. 2001.

- El árbol de la vida, un estudio de iconografía visigoda: San Pedro de la Nave y Quintanilla de las Viñas. Madrid, Ediciones BMM\&P. 1993.

- M. BASAS: “Mercaderes burgaleses en el S. XVI”. BIFG. Burgos, 1954, pp. 55 67, $156-169$.

- $\quad$ El consulado de Burgos en el siglo XVI. Madrid. 1963.

- $\quad$ "Burgos en el comercio lanero del S. XVI. Moneda y Crédito, 1961, pp. 37 - 69.

- E. BATTISTI: Renacimiento y Barroco. Madrid, Cátedra. 1990.

- G. BAZÍN: Barroco y Rococó. Toledo. 1992.

- C. BEDAT: La Real Academia de Bellas Artes de San Fernando (1744 - 1808). Madrid. 1989.

- A. DE BEGOÑA AZCARRAGA: Arquitectura doméstica y urbanismo. Vitoria. 1977.

- Arquitectura doméstica en la Llanada de Álava. Siglos XVI, XVII, y XVIII. Vitoria, 1986. 
- A. BENGOECHEA: Historia de Salas I. Paisaje, clima, economía, etnología, apellidos, dinosaurios, primeros pobladores, antigüedad, Edad Media, los 7 infantes de Lara. Burgos, Museo de Salas. 2003.

- J. A. BENITO: "Hacinas en publicaciones”. Amigos de Hacinas, $n^{\circ}$ 71, Burgos, 1996, pp. $14-15$.

- F. BENITO: Arquitectura tradicional de Castilla y León. T. I. Salamanca, 1998.

- B. BENNASSAR: Orígenes del atraso económico español. Barcelona, 1985.

- Los españoles, actitudes y mentalidad desde el siglo XVI al XIX. San Lorenzo del Escorial, Swan. 1985.

- $\quad$ R. BENTMANN, M MÜLLER: La villa como arquitectura del poder. Barcelona, Ed. Barral. 1975.

- J. BÉRCHEZ, F. JARQUE: Arquitectura barroca valenciana. Valencia, Bancaixa. 1993.

- A. BERMEJO BARASOAIN: "Sobre arquitectura navarra: Miguel de Armequeta, maestro de cantería”. Notas y estudios de ciencias sociales, $n^{\circ} 1$. 1988, pp. 1 - 10 .

- M. A. BIELSA: Avance sobre el eremitorio de cueva Andrés en Quintanar de la Sierra. Burgos, Actas del Congreso de Jaén. 1971.

- L. BILBAO BILBAO: "Explotación y comercialización de lanas en Castilla durante el siglo XVII”. En El Pasado Histórico de Castilla y León. Vol II. Edad Moderna. Burgos, Junta de Castilla de León. 1993, pp. 225 - 243.

- G. BILBAO LÓPEZ: Iconografía de las pilas bautismales del románico castellano; Burgos y Palencia. Burgos, Editorial la Olmeda. 1996.

- J. A. BONACHÍA HERNANDO: "El campo: Crisis y recuperación (siglos XIV XV)”. En. Historia de Burgos, desde sus orígenes hasta nuestros días. Tomo 2. Desde el año 1000 a los Tiempos Modernos. Burgos, Diario 16 de Burgos, 1993, pp. $447-458$.

- "El desarrollo de una artesanía local (siglos XIV - XV)”. En. Historia de Burgos, desde sus orígenes hasta nuestros días. Tomo 2. Desde el año 1000 a los Tiempos Modernos. Burgos, Diario 16 de Burgos, 1993, pp. 459 - 470.

- $\quad$ El señorío de Burgos durante la Baja Edad Media (1255 - 1508). Valladolid. 1988. 
- A. BONET CORREA: Iglesias madrileñas del siglo XVII. Aportaciones al barroco español. Madrid, Instituto Diego Velázquez. 1961.

- Fiesta, poder y arquitectura. Madrid, Akal. 1990.

- Andalucía barroca. Arquitectura y urbanismo. Barcelona, Poligrafía. 1978.

- “Las ciudades españolas del Renacimiento al Barroco”. En Vivienda y urbanismo en España. Barcelona, 1982, pp. 107 - 135.

- $\quad$ La arquitectura en Galicia durante el siglo XVII. Madrid, 1984.

- Iglesias madrileñas del siglo XVII. Madrid, 1984.

- “Los tratados de cortes de piedra españoles en los siglos XVII y XVIII”. Academia $n^{\circ}$ 69, 1989, pp. $29-62$.

- Figuras, modelos e imágenes en los tratadistas españoles. Madrid, 1993.

- G. M. BORRÁS GUALÍS: Teoría del Arte I. Las obras de arte. Madrid, Historia 16. 1996.

- J. L. BOUZA ÁLVAREZ: Religiosidad contrarreformista y cultura simbólica del Barroco. Madrid, CSIC. 1990.

- F. BRUMONT: "Economía, actividades industriales y artesanales, agricultura y ganadería”. En Historia de Burgos III. Edad Moderna (2). Burgos, Caja de Ahorros Municipal de Burgos, 1992, pp. 93 - 146.

- J. R. BUENDÍA: “El Barroco y su ámbito”. Boletín Museo e Instituto “Camón Aznar”. T. XXVI, 1986, pp. 5-12.

- A. BUSTAMANTE GARCÍA: La arquitectura clasicista en el foco vallisoletano: 1561 - 1640. Valladolid, Instituto de Simancas. 1983.

- Introducción al arte español del siglo XVII. Clasicismo y barroco. Madrid, Silex. 1993.

- “Apuntes arquitectónicos madrileños de hacia 1660”. AEA, no 58 (229). Madrid, 1985, pp. $34-43$.

- “En torno al clasicismo: Paladio en Valladolid”. AEA, no 52 (205), Madrid, 1979, pp. $34-54$.

- " “En torno a Juan de Herrera y la arquitectura”. BSAA, n 42, 1976, pp. 227 - 250. 
- “Imágenes de la Sabiduría. La decoración de la biblioteca Escurialense”. Cuadernos de Arte e Iconografía, $n^{\circ} 6$ (11). Madrid, 1993, pp. 334 - 346.

- El siglo XVII. Clasicismo y Barroco. Madrid. 1994.

- T. BUSTILlO VICARIO: Viaje a tierra de pinares. Valladolid, Consejería de Medio Ambiente y Ordenación del Territorio, Ayuntamiento de Quintanar de la Sierra. 1933.

- T. BUSTILLO VICARIO (coord.): Apellidos y apodos serranos. Burgos, Amábar. 1992.

- $\quad$ L. CABEZAS GELABERT: Del "arte de la cantería" al "oficio de la cantería". En Juan de Herrera y su influencia: actas del Simposio: Camargo 14 / 17 Julio 1992. Santander, Fundación Obra Pía de Juan de Herrara: Universidad de Cantabria, 1993,

- $\quad 137-142$.

- A. CABO ALONSO: “Medio natural y trashumancia en la España peninsular”. En Mesta, trashumancia y vida pastoril.: exposición organizada por la Sociedad V Centenario del Tratado de Tordesillas. Soria, Sede de la Fundación Duques de Soria. 19 de septiembre a 30 de noviembre 1994. Madrid, I + P Investigación y Progreso.1994.

- A. CABO ALONSO, M. VIGIL: “Condicionamientos geográficos. Edad Antigua”. En Historia de España (dir. M. ARTOLA). Madrid, Alianza Editorial. 1990.

- I. CADIÑANOS BARDECI: Rollos, picotas y cruceros en la provincia de Burgos. Burgos, 1993.

- E. CALATAYUD FERNÁNDEZ: Arquitectura religiosa en la Rioja Baja: Calahorra y su entorno (1500 - 1650). Madrid, Universidad Complutense. 1987.

- J. CALATRABA: Arquitectura y cultura en el siglo de las luces. Granada, Universidad de Granada. 1999.

- M. CALÍ: De Miguel Ángel a El Escorial. Monumentos del debate religioso en el arte del siglo XVI. Torrejón de Ardoz, Akal. 1994.

- $\quad$ W. J. CALLAHAN: Iglesia, poder y sociedad. Madrid. 1989.

- R. CAMACHO MARTÍNEZ: “El espacio del milagro: el camarín en el barroco español”. En I Congreso internacional do barroco. Porto, 1991, pp. 185 - 212. 
- Málaga barroca. Málaga. 1981.

- A. CÁMARA ANTÓN: “ La cofradía de la Vera Cruz”. Amigos de Hacinas, $n^{\circ} 74$. Burgos, 1997, pp. 8 - 9.

- “La población de Hacinas”. Amigos de Hacinas, $n^{\circ}$ 71. Burgos, 1996, pp. 28 - 31.

- C. CÁMARA FERNÁNDEZ: “Arquitectura clasicista en Castilla. En torno a la figura del trasmerano Pedro de la Torre Bueras y su obra de carácter religioso”. En Juan de Herrera y su influencia: actas del Simposio: Camargo 14 / 17 Julio 1992. Santander, Fundación Obra Pía Juan de Herrera: Universidad de Cantabria, 1993, pp. $251-259$.

- “Aportación al estudio de los maestros de obra trasmeranos que trabajan en Palencia en el siglo XVII”. Actas del II Congreso de Historia de Palencia. T. V. Palencia, 1990, pp. $173-179$.

- “Artistas de Trasmiera en el Burgos barroco: Bernabé de Hazas y Francisco del Pontón Setién”. Actas del I Congreso Internacional do Barroco. T. I. Porto, 1991, pp. $229-240$.

- “Campanas y campaneros en Burgos durante la primera mitad del siglo XVII”. En Las campanas Cultura de un sonido milenario. Actas del I Congreso Nacional. Santander, 1997, pp. $227-240$.

- C. CÁMARA FERNÁNDEZ, L. S. IGLESIAS ROUCO, Mª J. ZAPARAÍN YÁÑEZ: “Juan de Naveda. En torno a su actividad en Burgos (1607 - 1631) y el ejercicio de la profesión”. BIFG, 1998/1, pp. 43 - 42.

- C. CÁMARA FERNÁNDEZ, Ma . J. ZAPARAÍN YÁÑEZ: “Artistas de norte de Burgos (siglo XVII y XVIII). Las relaciones familiares y el papel de la mujer”. Actas VIII Congreso C. E. H. A. Badajoz, 1992, pp. 807 - 810.

- A. CÁMARA MUÑOZ: Arquitectura y sociedad en el Siglo de Oro. Madrid, Ediciones el Arquero. 1990.

- C. CAMARERO BULLÓN: “La provincia de Burgos en el Siglo de las Luces”. En Historia de Burgos III. Edad Moderna (1). Burgos, Caja de Ahorros Municipal de Burgos, 1991, pp. $153-270$.

- J. CAMÓN AZNAR: “El estilo trentino”. RIE, $n^{\circ}$ 12, Madrid, 1945, pp. 429 y ss. 
- La arquitectura y la orfebrería españolas del siglo XVI. En Summa Artis. T. XVII. ,(dir. José Piján). Madrid, Espasa Calpe. 1982.

- $\quad$ Al arquitectura plateresca. Madrid, CSIC. 1945.

- J. CAMÓN AZNAR, J. L. MORALES Y MARTÍN, E. VALDIVIELSO GONZÁLEZ: Arte español del siglo XVIII. En Summa Artis, T. XXVI,(dir. José Piján). Madrid, Espasa Calpe. 1984.

- C. CAÑEDO ARGÜELLES: Arte y teoría: La contrarreforma en España. Oviedo, 1982.

- $\quad$ R. CARANDE: Carlos V y sus banqueros. Barcelona, Editorial Crítica. 1987.

- G. CARERI: “El artista”. En El hombre barroco. Madrid, 1992, pp. 349 - 373.

- J. CARO BAROJA: La ciudad y el campo. Madrid, 1966.

- “Los núcleos urbanos de la España cristiana medieval”. En Vivienda y urbanismo en España. Barcelona. 1982.

- E. CARRERO SANTAMARÍA, V. GONZÁLEZ DE CASTRO: “Arquitectura clasicista en Burgos: noticias documentales de la obra de Pedro Díaz de Palacios en San Pedro de Arlanza (1629-1659)”. Anuario del Dep. Historia y Teoría del Arte. (UAM), $n^{\circ}$ 5, Madrid, 1993, pp. $111-119$.

- C. CARRICAJO CARBAJO: Arquitectura popular, construcciones secundarias. Valladolid, Centro Etnográfico de Documentación. Diputación de Valladolid. 1990.

- A. CASASECA CASASECA: Rodrigo Gil de Hontañón. (Rascafría 1500 - Segovia 1577). Salamanca, 1988.

- “Arquitectura y Urbanismo del siglo XVII”. En Historia del Arte en Castilla y León. T. VI. Arte Barroco. Valladolid, 1994, 9 - 116.

- J. CASTÁN: “La polémica entre el gótico y el renacimiento en el siglo XVI. La iglesia de los Santos Juanes en Nava del Rey (Valladolid)”. BSAA, $n^{\circ}$ 56, 1990, pp. $384-403$.

- R. CASTEJÓN Y MARTÍNEZ DE ARIZOLA: El merino andaluz. Tipología artística. Córdoba, 1979. 
- A. CASTILlO DE LA LASTRA: Molinos de la zona de Piedrahíta y el Barco de Ávila. Consideraciones sobre arquitectura popular. Ávila, Instituto Gran Duque de Alba. 1992.

- A. CASTILLO: Excavaciones altomedievales en las provincias de Soria, Logroño y Burgos. Madrid, Comisaría General de Excavaciones Arqueológicas. 1972.

- F. M․ CASTRILLEJO IBÁÑEZ: La desamortización de Madoz en la provincia de Burgos (1855 - 1869). Valladolid. 1987.

- A. CASTRO SANTAMARÍA: “Canteros vascos en el primer renacimiento salmantino". Ondare. Cuadernos de artes plásticas y monumentales, $n^{\circ} 17.1998$, pp. $231-247$.

- C. CASTRO: El pan de Madrid: El abasto de las ciudades españolas del Antiguo Régimen. Madrid, Alianza Editorial, 1987.

- A. CASTRO VILLALBA: Historia de la construcción arquitectónica. Barcelona, 1995.

- L. CERVERA VERA: El conjunto palacial de la villa de Lerma. Valencia, Ed. Castalia. 1969.

- $\quad$ El convento de Santo Domingo, de la villa de Lerma. Valencia, Ed. Castalia. 1969.

- El monasterio de San Blas, de la villa de Lerma. Valencia, Ed. Castalia. 1969.

- El monasterio de la Madre de Dios en la villa de Lerma. Valencia, Ed. Castalia. 1969.

- La iglesia colegial de San Pedro en Lerma. Burgos, Caja de Ahorros Municipal de Burgos. 1981.

- El monasterio de la Ascensión en la villa de Lerma. Lerma, Monasterio de la Ascensión. 1985.

- Lerma. Síntesis histórico - monumental. Lerma. 1982.

- J. CIDAD PÉREZ: Historia de la Diócesis de Burgos. (Ensayo). Burgos, Imprenta Monte Carmelo. 1985.

- B. CLAVERO: Mayorazgo: propiedad feudal en Castilla. 1369 - 1836. Madrid, Siglo XXI, 1974. 
- I. COFIÑO FERNÁNDEZ: “Arquitectura religiosa del Valle de Mena durante la primera mitad del siglo XVIII”. BIFG, $n^{\circ}$ 222. Burgos, 2000/2001, pp. 87 - 108.

- M. COLCHEN: Geologie de la Sierra de la Demanda: Burgos - Logrono (Espagne). 2 tomos. Madrid, Ministerio de Industria, Servicios de Publicaciones. 1974.

- Congreso Nacional de Historia del Arte (10 ${ }^{\circ}$ 1994. Madrid). UNED. Departamento de Historia de Historia del Arte. Los clásicismos en el arte español. Madrid, UNED, Departamento de Historia del Arte. 1994.

- L. A. CONTRERAS ABAD: Castrovido. Nuestros antepasados. Burgos, Asociación Amigos del castillo de Castrovido. 2002.

- Fr. V. CRUZ: “Notas para la historia de Regumiel de la Sierra (Burgos)”. BIFG, $n^{\circ}$ 175. Burgos, 1958, pp. 309 - 320.

- "Notas para la Historia de Palacios de la Sierra”. BIFG, $n^{o}$ 171. Burgos, 1968, pp. $305-311$.

- Primer milenario de la ciudad de Salas de los Infantes 974-1974. Burgos, Junta Oficial de Milenario. 1974.

- Burgos: mansiones señoriales. Burgos, Caja de Ahorros Municipal de Burgos. 1982.

- Burgos: remanso de la Historia y del Arte. Burgos, Caja de Ahorros Municipal de Burgos. 1987.

- “Autobiografía del río Arlanza, Jornada II”. BIFG, n 167, Burgos, 1966, pp. 396 408.

- “Autobiografía del río Arlanza, Jornada I”. BIFG, nº 168, Burgos, 1968, pp. 567 580.

- C. L. CUENCA: "Problemas de la producción de lanar en los países mediterráneos”. Simposium del Comité Nacional Español de la FEZ. 1970

- F. CHECA CREMADES, J. M. MORÁN TURINA: El Barroco. Madrid, Ediciones Istmo. 1982.

- $\quad$ El arte y los sistemas visuales. El Barroco. Madrid, 1986. 
- W. A. CHRISTIAN: Religiosidad local en la España de Felipe II. Madrid, Nereda. 1991.

- F. CHUECA GOITIA: Historia de la arquitectura occidental. Tomo VII. Barroco en España. Madrid, Editorial Dossar. 1985.

- Historia de la arquitectura occidental. Tomo IX. Neoclasicismo. Madrid, Editorial Dossar. 1985.

- Historia de la arquitectura. Edad Media cristiana en España. Madrid, Investigaciones Editoriales Dossar. 2000.

- “La arquitectura religiosa en el siglo XVIII y las obras de Osma”.AEA. 1949, pp. $209-241$.

- Invariantes castizos de la arquitectura española. Madrid, Dossart. 1979.

- $\quad$ La arquitectura del siglo XVI. En Ars Hispaniae. T. XI Madrid, Plus Ultra. 1953.

- J. CLARET RUBIRA: Detalles de arquitectura popular española. Barcelona, 1976.

- G. DELIBES DE CASTRO, A. ESPARZA ARROYO: "Neolítico y Edad del Bronce”. En Historia de Burgos I. Edad Antigua. Burgos, Caja de Ahorros Municipal de Burgos, 1985, pp. 115 - 178.

- M. DIAGO HERNANDO: La industria y el comercio de productos textiles en Europa, siglos XI al XV. Madrid, Arcos Libros D. C. 1997.

- M. DIAGO HERNANDO: "Soria y su tierra en el Obispado de Osma durante los siglos XV - XVI. Organización eclesiástica y práctica religiosa”. En XIV Centenario Diócesis de Osma - Soria. Premios de investigación. Soria, Excma. Diptuación Provincial de Soria, 2000, pp. 425 - 573.

- Soria en la Baja Edad Media: Espacio rural y economía agraria. Madrid, Departamento de Historia Medieval. Editorial Complutense. 1993.

- L. DÍAZ MARTÍN: “Estructura social”. En Historia de Burgos II. Edad Media (1). Burgos, Caja de Ahorros Municipal de Burgos, 1986, pp. 246 - 293.

- A. DÍAZ MEDINA: “Economía y Hacienda (siglos XVI - XVII)”. En Historia de Burgos. III. Edad Moderna (2). Burgos, Caja de Ahorros Municipal de Burgos, 1992, pp. $231-266$. 
- F. DÍEZ VÁZQUEZ, I. PÉREZ TAULER: Rutas para descubrir la Sierra de al Demanda. Valladolid, Ámbito Ediciones. 2000.

- E. DOMINGO ANGULO: Vilviestre del Pinar, pasado, presente y futuro. Burgos, Ayuntamiento de Vilviestre. 1995.

- A. DOMÍnguEZ ORTIZ: El Antiguo Régimen: Los Reyes Católicos y los Austrias. En Historia de España. T. III. (dir. Miguel Artola). Madrid, Alianza Editorial. 1990.

- Regalismo y relación Iglesia - Estado en el siglo XVII. En Historia de la Iglesia en España. T. IV. Madrid. BAC, 1979, pp. $73-124$.

- Instituciones y sociedad en la España de los Austrias. Barcelona, Editorial Ariel. 1985.

- Aspectos sociales de la vida eclesiástica en los siglos XVII y XVIII. En Historia de la Iglesia en España. T. IV. Madrid. BAC, 1979, pp. 5 - 72.

- $\quad$ Las clases privilegiadas en el Antiguo Régimen. Madrid, Ediciones Istmo. 1985.

- La sociedad española en el siglo XVII. Tomo I - II. Granada, CSIC. Universidad de Granada. 1992.

- Vecindario de Ensenada 1759. Vol. 1. Madrid, Centro de Gestión Castastral y Cooperación Tributaria Tabapress. 1991.

- M. DURÁN SALGADO: El arte de la cantería. Madrid, Escuela de Artes y Oficios Artísticos. 1945.

- U. ECO: Arte y belleza en la estética medieval. Barcelona, Lumen. 1997.

- J. H. ELLIOTT: Poder y sociedad en la España de los Austrias. Barcelona, Editorial Crítica. 1982.

- J. ENCINA: El estilo barroco. México, Universidad Nacional Autónoma de México. 1980.

- E. ENCISO VIANAJ. CANTERA ORIBE: Catálogo Monumental Diócesis de Vitoria. T. I. Rioja Alavesa. Arciprestazgo de Laguardia. Labastida y salinillas de Buradón. Vitoria. 1967.

- J. ESCALONA MONGE: “Algunos problemas relativos a la génesis de las estructuras territoriales de la Castilla Altomedieval”. En II Jornadas burgalesas de 
Historia. (2 1990 Burgos). Burgos en la Alta Edad Media. Burgos, Asociación Provincial de Libreros de Burgos, 1991, pp. 489 - 506.

- J. F. ESTEBAN LORENTE, G. M. BORRÁS GUALIS, M. I. ALVARO ZAMORA: Introducción general al Arte. Arquitectura, Escultura, Pintura, Artes Decorativas. Madrid, Istmo. 1984.

- J. F. ESTEBAN LORENTE: Arquitectura. En Introducción general al Arte. Arquitectura, Escultura, Pintura, Artes Decorativas. Madrid, Istmo, 1984, pp. 15 135.

- C. ESTEPA DÍEZ: “Estructura de poder en Castilla (siglos XII - XIII). El poder señorial en las merindades burgalesas”. En III Jornadas burgalesas de Historia. ( $3^{a}$ 1991 Burgos). Burgos en la Plena Edad Media. Burgos, Asociación Provincial de Libreros de Burgos, 1994, pp. 245 - 294.

- M. EXPÓSITO SEBASTIÁN: “El gremio de canteros de Zaragoza (1760-1812)”. Artgrama, $n^{\circ} 1.1984$, pp. $269-286$.

- T. FALCÓN MÁRQUEZ: Arquitectura barroca en Jerez. Jerez, Centro de Estudios Históricos Jerezanos. 1993.

- L. M. FEDUCHE: Arquitectura popular española. Cataluña, Aragón, Levante y Baleares. Barcelona, Ed. Blume. 1976.

- L. FERNÁNDEZ MARTÍN (SJ.): “La construcción de la iglesia de la Magdalena. Sus diversas etapas”. BSAA, $N^{\circ} 55.1989$, pp. 323 y ss.

- J. E. FERNÁNDEZ MARTÍN: "La arquitectura rural segoviana en el siglo XVII”. Goya, $n^{\circ} 157,1990$, pp. 28 - 33.

- J. E. FERNÁNDEZ REDONDO: La arquitectura del Renacimiento en la provincia de Segovia (1550 - 1650). Madrid, Universidad Complutense. 1990.

- J. FERRANDO ROIG: Iconografía de los Santos. Barcelona, Ediciones Omega, 1996.

- F. FLORES DEL MANZANO: Andar por las cañadas reales. Madrid, Acción Divulgativa. 1993.

- C. FLORES: Arquitectura popular española. Madrid, Ed. Aguilar. 1976. 
- La España popular. Raíces de una arquitectura vernácula. Madrid, Ed. Aguilar. 1979.

- $\quad$ E. FLÓREZ: España Sagrada. Madrid, 1754 - 1789.

- M. C. FOLGAR DE LA CALLE: Arquitectura gallega del siglo XVIII. Santiago de Compostela, Universidad de Santiago de Compostela. 1985.

- E. FORSSMAN: Dórico, jónico, corintio en la arquitectura del Renacimiento. Bilbao, 1983.

- D. FREEDBERG: El poder de las imágenes. Estudios sobre la historia y la teoría de la respuesta. Madrid. 1992.

- A. FRUTIGER: Signos, símbolos, marcas, señales. Barcelona. 1981.

- M. B. GANZO PÉREZ, L. F. IBEAS MIGUEL: "La fecundidad en un área burgalesa: Neila (1690 - 1800)”. En El pasado histórico de Castilla y León. Actas del primer Congreso de historia de Castilla y León. Vol II. Burgos, Junta de Castilla y León, 1984, pp. 337 - 354.

- J. GÁllEGO: Visión y símbolo de la pintura del Siglo de Oro. Madrid, Ed. Cátedra. 1992.

- R. GARCÍA CÁRCEL: Las estructuras sociales en los siglos XVI - XVII. En Historia de España, vol. 6. Edad Moderna II. Madrid, Espasa Calpe. 1997.

- $\quad$ Las culturas del Siglo de Oro. Madrid, Historia 16. 1998.

- “La iglesia triunfante. Reforma católica y Contrarreforma”. En Arte y saber. La cultura en tiempos de Felipe III y Felipe IV. Madrid, 1999, pp. 77 - 87.

- J. GARCÍA CORTÁZAR: La sociedad rural en la España medieval. Madrid. 1988.

- El dominio del Monasterio de San Millán de la Cogolla (siglos X - XIII). Introducción a la historia rural de la Castilla altomedieval. Salamanca, 1969.

- Del Cantábrico al Duero. En Organización social del espacio en la España medieval. La Corona de Castilla en los siglos VIII - XV. Barcelona, Ariel. 1985.

- E. GARCÍA CHICO: Documentos para el estudio del Arte en Castilla. Arquitectos. Valladolid. 1940.

- Catálogo monumental de la provincia de Valladolid. T. I. Medina de Rioseco. Valladolid, Diputación Provincial. 1959. 
- Catálogo monumental de la provincia de Valladolid. T. II. Partido judicial de Medina de Rioseco. Valladolid Diputación Provincial, 1961.

- Catálogo monumental de la provincia de Valladolid. T. III. Medina del Campo. Valladolid, Diputación Provincial, 1961.

- E. GARCÍA CHICO, A. BUSTAMANTE GARCÍA: Catálogo monumental de la provincia de Valladolid. T. V. Partido judicial de Nava del Rey. Valladolid, Diputación Provincial, 1972.

- B. GARCÍA DE LA TORRE, A. ZAVALA: Los merineros. Oyarzum, Biblioteca de Narrativa Popular. 1999.

- J. I. GARCÍA DE LOS RÍOS COBO, J. M. BAEZ MEZQUITA: La piedra en Castilla y León. Valladolid, Junta de Castilla y León. Consejería de Industria, Comercio y Turismo. 2001.

- E. GARCÍA ESPAÑA, A. MOLINIÉ - BERTRAND: Censo de Castilla de 1591. Madrid, Instituto Nacional de Estadística. 1986.

- J. L. GARCÍA FERNÁNDEZ, E. GARCÍA FERNÁNDEZ, C. FERNÁNDEZ BERNALDO DE QUIRÓS: El camino real del Puerto la Mesa. León, Colegio Oficial de Arquitectos de León y Asturias. 1976.

- J. L. GARCÍA GRINDA: Arquitectura popular de Burgos. Crítica y teoría de la arquitectura popular: tipos y caracterización de la arquitectura rural autóctona castellano - leonesa: el caso burgalés. Burgos, Colegio Oficial de Arquitectos de Burgos. 1988.

- "La aplicación y el concepto del tipo en la arquitectura popular: evolución versus permanencia en el territorio castellano - burgalés”. En Arquitectura popular en España. Madrid, 1990, pp. 431 - 463.

- P. GARCÍA MARTÍN: La Mesta. Madrid, Historia 16, 1990.

- P. GARCÍA MARTÍN (coord.): Cañadas, cordeles y veredas. Valladolid, Junta de Castilla y León. Consejería de Agricultura y Ganadería. 2000.

- F. GARCÍA MERCADAL: Arquitecturas regionales españolas. Madrid, Comunidad de Madrid. Dirección General de Cultura. 1984. 
- $\quad$ Ma. V. GARCÍA MORALES: La figura del arquitecto en el siglo XVII. Madrid, 1990.

- J. GARCÍA ORO, Ma . J. PORTELA SILVA: "Felipe II y las iglesias de Castilla a la hora de la Reforma Tridentina. Preguntas y respuestas sobre la vida religiosa castellana”. Cuadernos de Historia Moderna, $n^{\circ}$ 20, Madrid, 1998, pp. 9 - 32.

- I. GARCÍA RÁMILA: La zona de Salas de los Infantes en su aspecto histórico, legendario y artístico. Burgos, Aldecoa. 1960.

- "Fiestas y romerías tradicionales y famosas en tierras burgalesas". BIFG, $n^{\circ} 115$, Burgos, 1951, pp. $461-476$.

- "Del Burgos de Antaño: Posturas y remate de la obra del retablo mayor de la igleisa parroquial de San Esteban de la ciudad de Burgos (1666-1668)”. BIFG, $n^{\circ} 100$, Burgos, 1947, pp. $623-631$.

- M. GARCÍA RAMOS: El mundo de los canteros y el léxico del marmol en Macael y el Valle del Almanzora. Almería, Arráez, Aymto. de Macael, 1996.

- A. GARCÍA SANZ: "El siglo XVIII: entre la prosperidad de la trashumancia y la crítica antimesteña de la Ilustración. (1700 - 1808)”. En Mesta, trashumancia y vida pastoril.: exposición organizada por la Sociedad V Centenario del Tratado de Tordesillas. Soria, Sede de la Fundación Duques de Soria. 19 de septiembre a 30 de noviembre 1994. Madrid, I + P Investigación y Progreso, 1994, pp. 137 - 158.

- A. GARCÍA SANZ: Desarrollo y crisis del Antiguo Régimen en Castilla la Vieja. Madrid, Akal. 1977.

- N. GARCÍA TAPIA: Técnica y poder en Castilla durante los siglos XVI - XVII. Valladolid, Junta de Castilla y León, Consejería de Cultura y Bienestar. 1989.

- Ingeniería y arquitectura en el Renacimiento español. Valladolid, 1990.

- P. GIL ABAD: Quintanar de la Sierra, un pueblo burgalés de la comarca de pinares. Burgos, Excma. Diputación de Burgos. 1986.

- Quintanar de la Sierra. Según las Respuestas Generales del Catastro de Ensenada. Burgos, Centro de Gestión Catastral y Cooperación Tributaria. Ministro de Economía y Hacienda. 1992. 
- Junta y Hermandad de la Cabaña Real de Carreteros Burgos - Soria. Burgos, Aldecoa, 1983.

- A. GIL CRESPO: "La Mesta de Carreteros del Reino”. Anales de la Asociación para el Progreso de las Ciencias, $n^{\circ} 22,1957$.

- O. GIORDANO: Religiosidad popular en la Alta Edad Media. Madrid, Gredos. 1995.

- J. GIRONÉS DESCARREGA: L'art de la pedra en sec a les comarques de Tarragona. Tarragona, Diputació de Tarragona. 1999.

- J. GÓMEZ MARTÍNEZ: “Canteros trasmeranos en Valladolid en torno a un pleito del Archivo de la Real Chancillería”. BSAA, n 57. 1991, pp. 301 - 310.

- El gótico español en la Edad Moderna. Bóveda de crucería. Valladolid, Secretariado de Publicaciones e intercambio científico. Universidad de Valladolid. 1998.

- "La parroquia de Nuestra Señora de las Lindes en Suances: Proceso de construcción y ornamentación del edificio parroquial. Cofradías y tradicionales”. Altamira, $n^{\circ} 48$, Santander, 1989, pp. 143 y ss.

- “La casa montañesa con solana y estragal. Orígenes y configuración de una tipología arquitectónica. Actas VIII Congreso C. E. H. A. Badajoz, 1992, pp. 235 238.

- J. GÓMEZ MARTÍNEZ, M. A. ARAMBURU - ZABALA HIGUERA: La bóveda de crucería en la arquitectura de la Edad Moderna. Valladolid, Secretariado de Publicaciones e intercambio científico. Universidad de Valladolid. 1995.

- M. GÓMEZ MORENO: “Juan de Herrera y Francisco de Mora en Santa María de la Alhambra”. AEA, $n^{\circ}$ 14, 1940 / 1941, pp. 5.

- J. M. GÓMEZ - MORENO CALDERA: La arquitectura religiosa granadina en la crisis del Renacimiento (1560 - 1650). Granada, Universidad, 1989.

- M. GÓMEZ - MORENO MARTÍNEZ: Catálogo monumental de la provincia de Ávila. Madrid, M. C. 1983.

- Las águilas del Renacimiento español. Madrid, Instituto Diego Velázquez, 1941.

- $\quad$ El libro español de arquitectura. Madrid, Instituto Diego Velázquez, 1949. 
- $\quad$ F. J. GÓMEZ OÑA: Covarrubias, cuna de Castilla. Vitoria. 1979.

- C. GÓMEZ URDAÑEZ: Arquitectura civil en Zaragoza en el siglo XVI. Zaragoza Ayuntamiento. 1988.

- B. GONZÁLEZ ALONSO: El corregidor castellano (1348 - 1808). Madrid, 1970.

- E. GONZÁLEZ BARRIUSO: Salas de los Infantes en la Sierra Burgalesa. Burgos, Grupo Editorial 7. 1999.

- M. GONZÁLEZ BUENO: Ferrerías de la Demanda burgalesa. Burgos, Excma. Diputación de Burgos. 1997.

- E. GONZÁLEZ DÍEZ: Estructura jurídico administrativa. En Historia de Burgos II Edad Media (1). Burgos, Caja de Ahorros Municipal de Burgos, 1986, pp. 145 246.

- F. GONZÁlEZ DORIA: Diccionario Heráldico y nobiliario de los reinos de España. Madrid, Editorial Bitácora. 1987.

- $\quad M^{a}$ C. GONZÁLEZ ECHEGARY, M. A. ARAMBURU - ZABALA HIGUERA: Artistas cántabros de la Edad Moderna. Su aportación al arte hispánico. (Diccionario biográfico - artístico). Salamanca, Servicio de Publicaciones de la Universidad de Cantabria.

- M. A. GONZÁLEZ GARCÍA: "La diócesis como centro periférico de influencia artística: El caso de Astorga en los Siglos XVI y XVII. (Las periferias de la periferia)”. VIII Congreso Nacional de Historia del Arte, 1992, pp. 243 - 247.

- T. GONZÁlEZ: Censo de Población de las provincias y partidos de la Corona de Castilla en el siglo XVI. con varios apéndices para completar la del resto de la península en el mismo siglo, y formar juicio comparativo con la del anterior y siguiente, según resulta de los libros y registros que se custodian en el Real Archivo de Simancas. (Ed. Facsímil). Madrid, Imprenta Real. 1829.

- J. L. GONZÁLEZ MORENO - NAVARRO: Legado oculto de Vitruvio. Madrid, 1993.

- A. GRACIANI: La técnica de la arquitectura medieval. Sevilla, Universidad de Sevilla, Secretariado de Publicaciones. 2001. 
- Y. GUERRERO NAVARRETE: “La economía de Burgos en la Edad Media”. En Historia de Burgos. II. Edad Media (1). Burgos, Caja de Ahorros Municipal de Burgos, pp. 1986, pp. 425 - 488.

- $\quad$ A. GUITART: La arquitectura gótica en Aragón. Zaragoza, Librería General. 1979.

- A. GUTIÉRREZ ALONSO: "La economía y la sociedad burgalesa durante la época Moderna”. En. Historia de Burgos, desde sus orígenes hasta nuestros días. Tomo 2. Desde el año 1000 a los Tiempos Modernos. Burgos, Diario 16 Burgos, 1993, pp. $627-638$.

- “Burgos en el siglo XVI”. En Historia de Burgos III. Edad Moderna (1). Burgos, Caja de Ahorros Municipal de Burgos, 1991, pp. 21 - 92.

- “Gobiernos municipales y haciendas locales durante la Época Moderna”. En. Historia de Burgos, desde sus orígenes hasta nuestros días. Tomo 2. Desde el año 1000 a los Tiempos Modernos. Burgos, Diario 16 Burgos, 1993.

- “La población burgalesa durante la Edad Moderna”. En. Historia de Burgos, desde sus orígenes hasta nuestros días. Tomo 2. Desde el año 1000 a los Tiempos Modernos. Burgos, Diario 16 Burgos, 1993, pp. 567 - 578.

- “Burgos en el siglo XVII”. En Historia de Burgos III. Edad Moderna (1). Burgos, Caja de Ahorros Municipal de Burgos, 1991, pp. 93 - 152.

- I. GUTIÉRREZ PASTOR, J. M. RAMÍREZ MARTÍNEZ: “Noticias sobre algunos canteros montañeses del siglo XVII en la Rioja”. Berceo, $n^{\circ}$ 104, 1983. Pp. 7 - 48.

- F. GUTIÉRREZ, R. CAMARERO CAMARERO: Nuestra Señora de la Caraba. Patrona de Monterrubio de la Demanda. Burgos, Excma. Diputación Provincial de Burgos, 1998.

- J. HALE: La civilización del renacimiento en Europa. 1450 - 1620. Barcelona, Crítica. 1996.

- J. HALL: Diccionario de temas y símbolos artísticos. Madrid, Alianza Editorial. 1996.

- F. HASKELL: La historia y sus imágenes. El arte y la interpretación del pasado. Madrid, 1994. 
- I. HENARES CUÉLLAR: La teoría artística en España en la segunda mitad del siglo XVIII. Madrid, 1977.

- F. HERAS GARCÍA: La arquitectura religiosa del siglo XVI en la primitiva Diócesis de Valladolid. Valladolid, Diputación Provincial. 1975.

- J. HERGUEDAS: “Talleres de cantería”. Restauración y Rehabilitación, $n^{\circ}$ 2, Madrid, 1995, pp. 70 - 73.

- J. HERNÁNDO DÍAZ, J. J. MARTÍN GONZÁLEZ, J. M. PITA ANDRADA: La escultura y la arquitectura española del siglo XVII. En Summa Artis. T. XXVI, (dir. J PIJÁN). Madrid, Espasa Calpe. 1985.

- J. HERNANDO: Arquitectura en España. 1770 - 1900. Madrid, 1989.

- R. HILARIO RODRÍGUEZ: Los Velasco. Vida, obra y patrimonio de una dinastía. Burgos, Excmo. Aymto. de Medina de Pomar - Caja de Ahorros del Círculo Católico. 2002.

- J. D. HOAG: Rodrigo Gil de Hontañón. Gótico y Renacimiento en la arquitectura española del siglo XVI. Madrid, 1985.

- L. HUIDOBRO SERNA: "Excursión arqueológica a la Sierra de la Demanda: San Vicente del Valle”. BCPM, $n^{\circ}$ 39, Burgos, 1932, pp. 315 - 317.

- “Señoríos y prelados burgaleses. Fortalezas y palacios a ellos anejos - iglesias”. BIFG, $n^{\circ} 130$, Burgos, 1955, pp. 395 - 409.

- A. C. IBÁÑEZ PÉREZ: Burgos y los burgaleses en el siglo XVI. Burgos, Excmo. Aymto. de Burgos. 1990.

- Arquitectura civil del siglo XVI en Burgos. Burgos, Caja de Ahorros Municipal de Burgos. 1977.

- "El maestro de cantería Juan de la Puente. Obras burgalesas”. BSAA, n 55, 1989, pp. $307-322$.

- “Arquitectura barroca burgalesa”. En Historia de Burgos. III Edad Moderna (3). Burgos, Caja Burgos, 1999, pp. 313 - 359.

- “Arquitectura, escultura, pintura y artes menores del siglo XVI”. En Historia de Burgos. III Edad Moderna (3). Burgos, Caja Burgos, 1999, pp. 7 - 196. 
- "La introducción del Neoclasicismo en Burgos. Retablos y escultura”. Academia, $n^{o}$ 69, 1989, pp. $63-89$.

- Aspectos sociólogo del arte burgalés. Burgos. 1978.

- "La crisis en la actividad artística del siglo XVIII en Burgos”. Actas IX C. E. H. A. El arte español en épocas de transición. Madrid, 1994, pp. 79 - 84.

- " "Rodrigo Gil de Hontañón y la iglesia colegial de Peñaranda de Duero (Burgos)”. BSSA, T. LV, 1989, pp. $398-401$.

- M. IGLESIAS COSTA: Arte Religioso del Alto Aragón Oriental. Vol. 2/1. En Arquitectura sacra. Desde el periodo gótico (siglo XIII) hasta la actualidad. Zaragoza, Gobierno de Aragón. Departamento de Educación y Cultura. 1998.

- "El arquitecto Juan de Sagarvínaga. Obras ejecutadas en Burgos, Palencia y Soria entre 1735 - 1753”. BSAA, T. LVIII, Valladolid. 1992.

- L. S. IGLESIAS ROUCO: "En torno a la actividad profesional en la arquitectura religiosa burgalesa”. Actas del simposio Juan de Herrera y su influencia. Santander, 1993, pp. $217-226$.

- Arquitectura y urbanismo en Burgos bajo el Reformismo Ilustrado (1747 - 1813). Burgos, 1978.

- Arquitectura y urbanismo en el siglo XIX en Burgos. Valladolid, Universidad de Valladolid. 1978.

- "En torno a la arquitectura burgalesa de la segunda mitad del siglo XVIII y su problemática profesional”. Actas IX Congreso C. E. H. A. El Arte español en épocas de transición. Madrid, 1994, T. II, pp. 43 - 51.

- L. S. IGLESIAS ROUCO, Ma J. ZAPARAÍN YÁÑEZ: "En torno a la actividad profesional en la arquitectura religiosa burgalesa, 1600 - 1650”. En Juan de Herrera y su influencia: actas del Simposio: Camargo 14 / 17 Julio 1992. Santander, Fundación Obra Pía Juan de Herrera. Universidad de Cantabria, 1993, pp. $217-225$.

- “Los núcleos medievales burgaleses y sus transformaciones. 1750 - 1800”. En La ciudad medieval. Actas del IV Congreso de Medievalismo y Neomedievalismo en la arquitectura española. Ávila. 1990. 
- “Problemática del cementerio contemporáneo en Burgos”. Congreso de Medievalismo y Neomedievalismo en la Arquitectura española: La Arquitectura y la muerte. Ávila, 1991.

- “Los órdenes en los retablos burgaleses de la segunda mitad del siglo XVIII”. Actas X Congreso C. E. H. A. Los clasicismo en el arte español. Madrid, 1994, pp. 233 237.

- “El proceso de construcción en Burgos 1700 - 1765. Aportaciones a su estudio”. Actas del Primer Congreso de Historia de la Construcción. Madrid, 1996, pp. 283 289.

- "El Monasterio de San Pedro de Cardeña, centro dinamizador del desarrollo artístico burgalés en los primeros decenios del siglo XVIII”. BIFG, $n^{\circ}$ 220, 2001/2001, pp. $107-140$.

- Burgos y sus villas. Arquitectura y paisaje. 1750 - 1800. Burgos, Caja Círculo de Burgos. 2002

- INSTITUTO GEOLÓGICO Y MINERO DE ESPAÑA (IGME): Mapa Geológico de España E. 1:50.000. Salas de los Infantes. Segunda serie- Primera edición. Madrid, Servicio de Publicaciones Ministerio de Industria. 1978.

- Mapa Geológico de España E. 1:50.000. Quintanar de la Sierra. Segunda seriePrimera edición. Madrid, Servicio de Publicaciones Ministerio de Industria. 1986.

- INSTITUTO NACIONAL DE ESTADÍSTICA (INE): Censo de Población de la Corona de Castilla. "Marqués de la Ensenada", 1752: mandado formar por el conde de Valparaiso mediante las Reales Órdenes de 31-7-1756 y 9-7-1759, basándose en los datos recopilados entre 1750 y 1754 para el catastro del Marqués de Ensenada. Madrid, INE. 1993.

- Censo de 1787. "Floridablanca". Madrid, INE. 1989.

- Censo de Castilla de 1591.Vecindario. Del INE. 1984. (ISBN 84 - 260 - 1241 - 8). Madrid, INE. 1984.

- F. ÍÑIGUEZ ALMECH: Geografía de la arquitectura española. Madrid, Ed. Patrimonio Artístico Nacional. 1957. 
- I. JIMÉNEZ CABALLERO: La arquitectura neoclásica en el Burgo de Osma. Soria. 1996.

- “El Neoclásico en el Burgo de Osma”. Revista de Soria, $n^{\circ}$ 16, 1997.

- A. JUAN GONZÁLEZ: "Dionisio González Lucas y el monumento al Sagrado Corazón de Jesús”. Amigos de Hacinas, nº 71, Burgos, 1996, pp. 16 - 17.

- “La ermita de Santa Lucía”. Amigos de Hacinas, n 72, Burgos, 1996, pp. 43 - 45.

- “Ermitas”. Amigos de Hacinas, nº 73, Burgos, 1996, pp. 26 - 28.

- "Hacinas en Osma: Ochocientos años de vida en común”. Amigos de Hacinas, $n^{\circ}$ 74, Burgos, 1997, pp. 14 - 16.

- “Los retablos de la iglesia de Hacinas”. Amigos de Hacinas, $n^{\circ}$ 73, Burgos, 1996, pp. $16-17$.

- H. KAMEN: La inquisición española. Barcelona, 1992.

- J. KLEIN: La Mesta. Estudio de la historia económica española. 1273 - 1836. Madrid, Alianza Editorial. 1994.

- J. M. G. KLEINPENNING: La región pinariega. Estudio geográfico del Noroeste de Soria y Sudeste de Burgos (España). Groningen, Druk V. R. B. Kleine. 1962.

- L. C. KOFMAN, Ma I. CARZOLIO: “Acerca de la demografía astur - leonesa y castellana en la Alta Edad Media”. Cuadernos de Historia de España, $n^{\circ} 47$ - 48, 1968, pp. $136-170$.

- H. W. KRUFT: Historia de la teoría de la arquitectura. T. I. Desde la antigüedad hasta el siglo XVIII. Madrid, 1990.

- G. KUBLER: La obra del Escorial. Madrid. 1987.

- Arquitectura de los siglos XVII y XVIII. En Ars Hispaniae, T. XIV. Madrid, Ed. Plus Ultra. 1957.

- C. R. LAFORA: Por los caminos del románico porticado. Una fórmula arquitectónica para albergar el derecho a la libertad. Madrid, Ediciones Encuentro. 1988.

- E. LAGUNA SANZ: Historia del merino. Madrid, Ministerio de Agricultura y alimentación. 1986. 
- V. LAMPÉREZ Y ROMEA: Historia de la arquitectura cristiana en la Edad Media. Barcelona, 1906.

- $\quad$ Arquitectura civil española de los siglos I al XVIII. Madrid, 1922.

- H. LAPEYRE: Las monarquías europeas del siglo XVII. Las relaciones internacionales. Barcelona, Editorial Labor. 1979.

- A. LASTRA VILLA: Dibujos y comentarios sobre arquitectura montañesa popular. Santander, Rosa Castro Carral. 1992.

- J. P. LE FLEM, J. PÉREZ, J. M. PELORSON, J. M. LÓPEZ PINERO, J. FAYARD: La frustración de un imperio (1476 - 1714). En Historia de España (dir. M. TUÑÓN DE LARA). Tomo V. Barcelona, Editorial Labor. 1984.

- M. L. LEDESMA RUBIO: Cartulario de San Millán de la Cogolla (1076 - 1200). Zaragoza, 1989.

- P. LEÓN TELLO: Archivo de los duques de Frías: inventario. Tomo I Casa de Velasco. Madrid, Dirección general de Archivos y bibliotecas y casa de los duques de Frías. 1955.

- E. LIAÑO MARTÍNEZ: Inventario artístico de Tarragona y su provincia. Madrid, M C. 1983.

- J. M. LIZOAÍN GARRIDO: “Del Cantábrico al Duero, siglos VIII - X: Propuestas historiográficas”. En II Jornadas burgalesas de Historia. (2 1990 Burgos). Burgos en la Alta Edad Media. Burgos, Asociación Provincial de Libreros de Burgos, 1991, pp. $653-714$.

- J. LOPÉRRAEZ CORVALÁN: Descripción Histórica del Obispado de Osma con el catálogo de sus prelados. (Ed. Facsímil). Madrid, Turner. 1978.

- M. T. LÓPEZ FERNÁNDEZ: Arquitectura civil del siglo XVI. Ávila, Caja de Ahorros y Préstamos de Ávila. 1984.

- A. LÓPEZ GÓMEZ: "Valdelaguna: colectivismo agrario en las montañas burgalesas”. Estudios Geográficos, $n^{\circ}$ 57. Madrid, 1954, pp. 551 - 567.

- "Evolución de los bosques en las Montañas Ibéricas: observaciones en las Sierra de Neila”. Estudios Geográficos, nº 58. Madrid, 1955, pp. 167 - 170. 
- “La trashumancia en Valdelaguna (Burgos)”. Estudios Geográficos, $n^{\circ}$ 58. Madrid, 1955, pp. $163-166$.

- N. LÓPEZ MARTÍNEZ: “La iglesia en Burgos durante la Época Moderna”. En. Historia de Burgos, desde sus orígenes hasta nuestros días. Tomo 2. Desde el año 1000 a los Tiempos Modernos. Burgos, Diario 16 Burgos, 1993, pp. 675 - 686.

- "Religión, religiosidad y heterodoxias en Burgos. (Siglo XVI - XVIII)”. En. Historia de Burgos, desde sus orígenes hasta nuestros días. Tomo 2. Desde el año 1000 a los Tiempos Modernos. Burgos, Diario 16 Burgos, 1993, pp. 687 - 698.

- “Aspectos de la vida eclesiástica en el Burgos moderno (siglos XVI - XVIII)”. En Historia de Burgos III. Edad Moderna (1). Burgos, Caja de Ahorros Municipal de Burgos, 1992, pp. $351-420$.

- T. LÓPEZ MATA: "Hachas de Bronce de Sotoscueva”. BIFG, $n^{\circ}$ 112, Burgos, 1950, pp. $218-219$.

- R. S. LÓPEZ: The origin of the merino sheep. Barcelona, Estudios de Historia Moderna. 1954.

- $\quad M^{a}$. C. LOSADA VAREA: "El retorno de los maestros canteros de la Junta del Voto”. Altamira, $n^{\circ}$ 52. Santander, 1996, pp. $263-284$.

- J. A. LUCIO: “Los trasmeranos de Flandes”. Altamira, n 44. Santander, 1983 1984, pp. $165-176$.

- C. LOZANO GUIRAO: “Arquitectura barroca en Murcia”. AEA, $n^{\circ}$ 104, 1953, pp. $11-30$.

- J. M. LUENGO: Esquemas de la arquitectura civil en el Bierzo. León, 1967.

- J. de LUIS MONTEVERDE: "Hallazgos burgaleses de la Edad del Hierro". AEArq., $n^{\circ}$ 44, Madrid, 1941, pp. 442.

- P. MADOZ: Diccionario geográfico - estadístico - histórico de España y sus posesiones de Ultramar”. Valladolid, Ámbito DL. 1984.

- P. G. MAGRO: Merindades y señoríos de Castilla en 1353. Madrid, Espasa Calpe. 1976.

- J. R. MALDONADO: “Arquitectura popular manchega”. Cuadernos de Estudios Manchegos, $n^{\circ} 13$, (Diciembre, 1982), pp. $71-82$. 
- J. MANRIQUE: Palacios de la Sierra. Burgos, 1996.

- G. MARIQUE: La casa popular del Alto Duero. Madrid, 1950.

- D. MANSILLA REOYO: “Obispado y monasterio”. En Historia de Burgos II. Edad Media (1). Burgos, Caja de Ahorros Municipal de Burgos, 1986.

- J. A. MARAVALL: La cultura del Barroco. Barcelona, Ed. Ariel. 1975.

- Poder, honor y élites en el siglo XVII. Madrid, 1979.

- Antiguos y Modernos. Madrid, Alianza Editorial, 1986.

- A. MARCOS MARTÍN: “La población de Castilla la Vieja y León en el siglo XVIII a la luz del Censo de Floridablanca”. En Congreso Histórico Nacional. II Centenario del Censo de Floridablanca. (Murcia 1987). Madrid, INE, 1992, pp. 119 -140 .

- "Los estudios de demografía histórica en Castilla la Vieja y León (siglos XIV XIX). Problemas y resultados”. En Demografía histórica en España. (Eds.PÉREZ MOREDA, Vicente. REHER, David - Seven.). Madrid, Ediciones el Arquero, 1988, pp. $247-268$.

- $\quad$ S. MARCHÁN FIZ: El universo del Arte. Barcelona, Salvat. 1983.

- Del arte objeto al arte concepto: 1960 - 74). Torrejón, Akal. 1994.

- F. MARÍAS: En torno al problema del barroco en la arquitectura española. Roma, Multigrafía Editrice, 1984.

- "La dicotomía entre arte culto y arte popular (coloquio internacional de Zacatecas)”. AEA, $n^{\circ} 53$ (209), Madrid, 1980, pp. 132 - 133.

- $\quad$ El siglo XVI: gótico y renacimiento. Madrid, Silex, 1992.

- El manierismo: Precedente de a propósito del manierismo y el arte español del siglo XVI. Madrid, Xarait, 1984.

- La arquitectura del Renacimiento en Toledo (1541 - 1631). Madrid, Instituto Provincial de Investigaciones y Estudios Toledanos. 1983.

- "El renacimiento "a la castellana" en el País Vasco: concesiones locales y resistencia a lo antiguo”. Ondare, $n^{\circ} 17,1998$, pp. $17-31$.

- Introducción al arte español: El siglo XVI: Gótico y renacimiento. Madrid, Silex. 1992. 
- $\quad$ Teoría del Arte II. Madrid, Historia 16. 1996.

- El largo siglo XVI. los usos artísticos del renacimiento español. Madrid, Taurus, 1989.

- “Orden y Modo en la Arquitectura Española”. En Dórico, jónico, corintio en la Arquitectura del Renacimiento. (E. FORSSMAN). Bilbao, 1983.

- F. MARTÍN BARRIGUETE: “Trashumancia y Mesta en los siglos XVI y XVII”. En Mesta, trashumancia y vida pastoril.: exposición organizada por la Sociedad V Centenario del Tratado de Tordesillas. Soria, Sede de la Fundación Duques de Soria. 19 de septiembre a 30 de noviembre 1994. Madrid, I + P Investigación y Progreso, 1994, pp. $93-133$.

- M. MARTÍN GALÁN: “Fuentes y método para el estudio de la demografía histórica castellana durante la Edad Moderna”. Hispaniae, T. XLI, $n^{\circ}$ 148, 1981, pp. 231 325.

- J. J. MARTÍN GONZÁLEZ: El artista en la sociedad española del siglo XVII. Madrid, Cátedra. 1994.

- Escultura barroca castellana. T. II. Madrid, 1971.

- “La arquitectura barroca en Valladolid”. Goya, $n^{\circ}$ 107, 1972, pp. 210 - 215.

- “Centros artísticos de la provincia de Palencia”. Actas del I Congreso de historia de Palencia. T. I. Palencia, pp. 83 - 85.

- “La catedral como núcleo promotor del barroco español”. Actas I Congreso Internacional do Barroco. T. II. Oporto, 1991, pp. 11 - 23.

- $\quad$ El retablo barroco en España. Madrid, 1993.

- “La vida de los artistas en Castilla la Vieja y León durante el siglo de Oro”. Revistas de Archivos, Bibliotecas y Museos. 1959.

- J. J. MARTÍN GONZÁLEZ, J. URREA FERNÁNDEZ: Catálogo monumental de la provincia de Valladolid, XIV, I. Monumentos religiosos de la ciudad de Valladolid. Valladolid, Instituto Cultural Simancas. 1985.

- J. J. MARTÍN GONZÁLEZ, F. J. DE LA PLAZA SANTIAGO: Catálogo monumental de la provincia de Valladolid, XIV, II. Monumentos religiosos de la ciudad de Valladolid. Valladolid, Instituto Cultural Simancas. 1987. 
- M. S. MARTÍN POSTIGO: San Frutos del Duratón: Historia de un Priorato Benedictino. Segovia, Publicaciones de la Obra Cultural de la Caja de Ahorros y Monte de Piedad de Segovia. 1970.

- J. J. MARTÍN GONZÁLEZ, L. S. IGLESIAS ROUCO: "La escultura barroca en Burgos, siglos XVII y XVIII”. En Historia de Burgos III. Edad Moderna (3). Burgos, Caja de Ahorros Municipal de Burgos, 1991, pp. 197 - 265.

- $\quad$ M. J. MARTÍN HERNÁNDEZ: La invención de la arquitectura. Madrid. 1997.

- J. L. MARTÍN, J. VALDEÓN, A. GARCÍA SANZ: “La Mesta”. En Cuadernos de Historia 16, $n^{\circ}$ 7, Madrid, Historia 16. 1985.

- M. MARTÍNEZ AÑÍBARRO Y RIVES: Intento de Diccionario biográfico y bibliográfico de autores de la provincia de Burgos. Madrid, 1889.

- P. MARTÍNEZ - BURGOS: "Las constituciones sinodales y la imagen procesional. Normas para la fiesta del siglo XVI”. Espacio, Tiempo y Forma, $n^{\circ}$ 2, 1989, pp. 81 92.

- Ídolos e imágenes. La controversia del arte religioso en el siglo XVI español. Valladolid. 1990.

- G. MARTÍNEZ DÍEZ: “Administración, gobierno y justicia”. En. Historia de Burgos III. Edad Moderna (1). Burgos, Caja de Ahorros Municipal de Burgos, 1991, pp. $327-350$.

- Fueros locales en el territorio de la provincia de Burgos. Burgos, Caja de Ahorros Municipal de Burgos. 1991.

- “Alfoces burgaleses: división administrativa de los siglos X - XI”. BIFG, No 194, Burgos, (1ºmestre 1980), pp. 172 - 192.

- Génesis histórica de la provincia de Burgos y sus divisiones administrativas. Burgos, Aldecoa, 1983.

- “Supresión de conventos de religiosos en la provincia de Burgos (1820 - 1836)”. BIFG, $n^{\circ}$ 213, Burgos, (2ºmestre 1996), pp. $641-689$.

- “La época condal”. En Historia de Burgos II Edad Media. (1). Burgos, Caja de Ahorros Municipal de Burgos, 1986, pp. 41 - 98. 
- “Época visigoda”. En Historia de Burgos I. Edad Antigua. Burgos, Caja de Ahorros Municipal de Burgos, 1985, pp. 471 - 485.

- Libro Becerro de las Behetrías. Estudio y texto crítico. León, Centro de Estudios e Investigación San Isidoro. Caja de Ahorros y Monte de Piedad. Archivo Histórico Diocesano. 1981.

- Las comunidades de villa y tierra de la extremadura castellana. Madrid, Editora Nacional. 1983.

- Pueblos y alfoces burgaleses de la repoblación. Valladolid, Junta de Castilla y León, Consejería de Educación y Cultura. 1997.

- “Administración, gobierno y justicia”. En Historia de Burgos. III. Edad Moderna. (1). Burgos, Caja de Ahorros Municipal de Burgos, 1991, pp. 327 - 349.

- J. M. MARTÍNEZ FRÍAS: El Gótico en Soria. Arquitectura y escultura monumental. Salamanca, Universidad. 1980.

- L. MARTÍNEZ GARCÍA: "Solariegos y señores. La sociedad rural burgalesa en la Plena Edad Media. (siglos XI - XIII)”. En III Jornadas burgalesas de Historia. ( $3^{a}$ 1991 Burgos). Burgos en la Plena Edad Media. Burgos, Asociación Provincial de Libreros de Burgos, 1994, pp. 355 - 410.

- "Los sectores deprimidos de la sociedad feudal burgalesa (siglos XIV - XV)”. En. Historia de Burgos, desde sus orígenes hasta nuestros días. Tomo 2. Desde el año 1000 a los Tiempos Modernos. Burgos, Diario 16 Burgos, 1993, pp. 495 - 506.

- "El desarrollo institucional burgalés en la Baja Edad Media. (siglos XIV - XV)”. En. Historia de Burgos, desde sus orígenes hasta nuestros días. Tomo 2. Desde el año 1000 a los Tiempos Modernos. Burgos, Diario 16 Burgos, 1993, pp. 519 - 530.

- "El sector dominante de la sociedad feudal burgalesa (siglos XIV - XV)”. En. Historia de Burgos, desde sus orígenes hasta nuestros días. Tomo 2. Desde el año 1000 a los Tiempos Modernos. Burgos, Diario 16 Burgos, 1993, pp.483 - 494.

- “La depresión del siglo XIV y la recuperación del siglo XV: la perspectiva demográfica”. En. Historia de Burgos, desde sus orígenes hasta nuestros días. Tomo 2. Desde el año 1000 a los Tiempos Modernos. Burgos, Diario 16 Burgos, 1993, pp. 435 - 446. 
- $\quad$ E. MARTÍNEZ GLERA: La arquitectura religiosa barroca en el Valle del Iregua. Logroño, Instituto de Estudios Riojanos, 1982.

- $\quad$ A. MARTÍNEZ IBÁÑEZ: El valle de Salas. Burgos, Edición propia. 2000.

- F. J. MARTÍNEZ LLORENTE: Régimen jurídico de la Extremadura Castellana Medieval: las comunidades de villa y tierra. (siglos X - XIV). Valladolid, Universidad de Valladolid. 1990.

- Poder político y repoblación en la Castilla del Duero: alfoces y tendencias (siglo X - XIII). En Santo Domingo de Caleruega. Jornadas de Estudios Medievales. Salamanca, 1994, pp. 81 - 104.

- J. MARTÍNEZ MILLÁN: “Inquisición y contrarreforma” En Los inquisidores. Vitoria, 1993, pp. $103-155$.

- J. MARTÍNEZ SANTA OLALLA: “Escondrijo de la Edad del Bronce Atlántico en Huerta de Arriba (Burgos)”. Atlántis, $n^{\circ}$ 17, 1942, pp. 127 - 164.

- M. MARTÍNEZ Y SANZ: Historia del templo catedral de Burgos: escrita con arreglo a los documentos de su archivo. Burgos, Imprenta de D. Ansemo Revilla. 1866.

- O. MAZARRASA MOWINCKEL, F. FERNÁNDEZ HERRERO: Mazarras, maestros cantero y arquitectos de Trasmiera. Santander, Colegio Oficial de Arquitectos de Cantabria. 1988.

- T. MEDRAZO LÁZARO: A mi desgraciado pueblo. Burgos, Hijos de Santiago Rodríguez. 1913.

- Lo que fue y es Quintanar y para Quintanar de la Sierra. Burgos, Hijos de Santiago Rodríguez. 1950.

- El patrimonio de Quintanar de la Sierra. Burgos, Hijos de Santiago Rodríguez. 1955.

- A. MELORI: “El mapa prefectual de España (1810)”. Estudios Geográficos, $n^{\circ}$ 46, 1952, pp. $10-12$.

- G. MENÉNDEZ PIDAL: Los caminos en la Historia de España. Madrid, 1956.

- J. B. MERINO URRUTIA: Los artífices vascos en la Rioja. Ensayos históricos de una gran emigración. Bilbao, 1976. 
- $\quad$ L. F. MESSÍA DE LA CERDA Y PITA: Heráldica española. El diseño heráldico. Madrid, Ediciones Aldaba. 1990.

- A. MESTRE SANCHÍS: "Religiosidad y cultura en el siglo XVIII”. En Historia de la Iglesia en España. (Tomo IV. La Iglesia en la España de los siglos XVII - XVIII). Madrid, BAC, 1979, pp. 596 - 598.

- M. A. MIGUEL LÓPEZ: Guía del macizo de Ayllón. Madrid. 1982.

- T. de MIGUEL DE MIGUEL: Historia de la iglesia de San Leonardo. San Leonardo de Yagüe, Parroquia de San Leonardo Abad. 2000.

- G. MIGUEL OJEDA: “Hoyuelos de la Sierra”. BIFG, $n^{\circ}$ 149, Burgos, 1959, pp. 799 -805 .

- “Torres y castillos burgaleses”. BIFG, $n^{\circ}$ 157, Burgos, 1961, pp. 717 - 727.

- "El atractivo turístico de Burgos y los lazos de relación”. BIFG, $n^{\circ}$ 138, Burgos, 1957, pp. $447-452$.

- J. MONJÓ CARRIÓN: De los sistemas y detalles constructivos a la edificación popular castellana. Madrid, 1983.

- P. MOLAS RIBALTA: “Edad Moderna (1474 - 1808)”. En Manual de Historia de España. III. Madrid, Espasa Calpe, 1988, pp. 582.

- A. L. MOLINA MOLINA: La vida cotidiana en la Palencia medieval. Palencia, Diputación Provincial de Palencia. 1998.

- L. A. MONREAL JIMENO: "Eremitorios rupestres en territorio burgalés durante la Alta Edad Media”. En II Jornadas burgalesas de historia (2 $2^{a}$ Burgos. 1990). Burgos en la Alta Edad Media. Burgos, Asociación Provincial de Libreros, 1991, pp. 539 556.

- A. MONTENEGRO DUQUE, J. M. BÁZQUEZ MARTÍNEZ, J. M. SOLANA SÁINZ: “España romana”. En Historia de España. Tomo 3. Madrid, Editorial Gredos, 1986.

- A. MONTENEGRO DUQUE: "Pueblos y tribus del Burgos prerromano”. En Historia de Burgos I. Edad Antigua. Burgos, Caja de Ahorros Municipal de Burgos, 1985, pp. $221-284$. 
- O. MORAL GARACHANA: "La arquitectura de Silos en su entorno durante el periodo barroco”. En Silos. Un milenio. Actas del Congreso Internacional sobre la Abadía del Santo Domingo de Silos, octubre de 2001. Burgos, Universidad de Burgos - Abadía de Silos, 2003, pp. 615 - 621.

- A. J. MORALES MARTÍNEZ: “El Ayuntamiento de Sevilla: Maestros canteros, entalladores e imagineros”. Laboratorio de Arte, $n^{\circ}$ 4, 1991, pp. 61 - 81.

- M. MORENO ALCALDE: La Tierra de Segovia: arquitectura religiosa y escultura monumental en el periodo gótico. Madrid, Universidad Complutense, 1982.

- J. L. MORENO PEÑA: “Burgos. La configuración física del espacio provincial”. En Historia de Burgos, desde sus orígenes hasta nuestros días. Tomo 1. Desde los orígenes al año 1000. Burgos, Diario 16 Burgos, 1993, pp. 5 - 14.

- “Burgos. Elementos del complejo ecológico provincial”. En. Historia de Burgos, desde sus orígenes hasta nuestros días. Tomo 1. Desde los orígenes al año 1000. Burgos, Diario 16 Burgos, 1993, pp. 15 - 26.

- “Burgos. Evolución histórica del espacio administrativo”. En. Historia de Burgos, desde sus orígenes hasta nuestros días. Tomo 1. Desde los orígenes al año 1000. Burgos, Diario 16 Burgos, 1993, pp. 27 - 38.

- " “Burgos en su espacio geográfico”. En Historia de Burgos I. Edad Antigua. Burgos, Caja de Ahorros Municipal de Burgos, 1985, pp. 39 - 82.

- C. MORTE GARCÍA: "Notas sobre arquitectura civil en Zaragoza durante el siglo XVII”. Boletín del Museo e Instituto Camón Zanar, Zaragoza, 1985.

- J. MOURE ROMANILLO: “El Paleolítico y el arte rupestre en Burgos”. En Historia de Burgos I. Edad Antigua. Burgos, Caja de Ahorros Municipal de Burgos, 1985, pp. $83-114$.

- "Clasificación de los niveles musterienses de la cueva de la Ermita (Hortigüela, Burgos)”. BSAA, $n^{\circ}$ 37, 1971, pp. 385 - 395.

- “El yacimiento musteriense de la cueva de la Ermita (Hortigüela, Burgos)”. NA HISP. Prehistoria, $n^{\circ}$ 1, 1972, pp. 9 - 44.

- M. MOUTINHO: Arquitectura popular portuguesa. Lisboa, Estampa. 1995. 
- J. G. MOYA VALGAÑÓN: "Historia del Arte Riojano: Estado de la cuestión, fuentes y bibliografía”. Cuadernos de Investigación Histórica, $n^{\circ} 10$ (2), 1984, pp. 7 $-43$.

- $\quad$ El arte de la Rioja. Logroño, Diputación de la Rioja, Unidad de Cultura. 1982.

- Arquitectura religiosa del siglo XVI en la Rioja Alta. Logroño, Diputación de la Rioja, Unidad de Cultura. 1980.

- Inventario artístico de Logroño y su provincia. Madrid, Ministerio de Cultura. 1985.

- J. M. MUÑOZ JIMÉNEZ: Fr. Alberto de la Madre de Dios, arquitecto (1575 1635). Santander, 1990.

- "El eco de Juan de Herrera en la arquitectura religiosa: las iglesias parroquiales y colegiatas”. En Juan de Herrera y su influencia: actas del Simposio: Camargo 14 / 17 Julio 1992. Santander, Fundación Obra Pía Juan de Herrera: Universidad de Cantabria, 1993, pp. $205-216$.

- La arquitectura del manierismo en Guadalajara. Guadalajara, Instituto de Cultura “Marqués de Santillana”. 1987.

- “La aportación de los maestros canteros de Trasmiera a la arquitectura española”. Cuadernos de Trasmiera, $n^{\circ}$ 2. Santander, 1990, pp. $57-100$.

- “Juan de Naveda y la arquitectura del manierismo clasicista en la villa de Santander”. Altamira, T. XLVI, Santander, 1986 - 1987, pp. 189 - 208.

- Fray Alberto de la Madre de Dios y la arquitectura cortesana, urbanismo en la villa de Lerma”. Goya, no 211 - 212, 1989, pp. 52 -59.

- Arquitectura carmelitana (1562 - 1800). Ávila. 1990.

- “Consideraciones sobre el Gótico arcaizante en la arquitectura de la provincia de Guadalajara”. En Arte Gótico postmedieval (Actas del VIII C. E. H. A.). Segovia Caja de Ahorros, 1987, pp. 125 - 132.

- J. MUÑOZ JIMÉNEZ: Catálogo de árboles notables de la provincia de Soria. Madrid, Consejería de Medio Ambiente y Ordenación Territorial. Junta de Castilla y León. 1991.

- P. MURRAY: Arquitectura del renacimiento. Madrid, 1979.

- $\quad$ Las montañas. Madrid, Alianza Editorial, 1995. 
- J. NADAL: La población española (siglos XVI a XX). Barcelona, Ariel. 1976.

- A. NAVAL MAS: Arquitectura doméstica del somontano en el Alto Aragón. Madrid, 1988.

- Inventario artístico de Huesca y su provincia. Madrid, Ministerio de Cultura. 1980.

- A. NAVAREÑO MATEOS, F. M. SÁNCHEZ LOMBA: “Terminología técnico artística en los maestros del renacimiento extremeño”. En Juan de Herrera y su influencia: actas del Simposio: Camargo 14 / 17 Julio 1992. Santander, Fundación Obra Pía Juan de Herrera: Universidad e Cantabria. 1993.

- J. NAVARRO TALEGÓN: Catálogo monumental de Toro y su alfoz. Valladolid, Caja de Ahorros Provincial de Zamora. 1980.

- P. NAVASCUÉS PALACIOS: “La arquitectura”. En Del Neoclasicismo al Modernismo. Historia del Arte Hispánico V. Madrid, 1978.

- $\quad$ G. NIETO GALLO: “Los monumentos de Lerma”. BIFG, $n^{\circ}$ 146, 1959, 549 - 554.

- J. R. NIETO GONZÁLEZ, Ma . T. PALIZA MONDUATE: La arquitectura en las dehesas de Castilla y León. Albacete, Junta de Castilla y León, Consejería de Agricultura y Ganadería. 1998.

- V. NIETO, A. J. MORALES, F. CHECA: Arquitectura del Renacimiento en España (1488 - 1599). Madrid, Cátedra. 1997.

- NOEL SALOMÓN: La vida rural castellana en tiempos de Felipe II. Barcelona, 1983.

- CH. NORBERG SCHULZ: Arquitectura Barroca. Madrid, 1989.

- Arquitectura barroca tardía y Rococó. Madrid, 1989.

- R. OJEDA SAN MIGUEL: “Crecimiento y subsistencia de un centro textil rural burgalés (siglos XVI - XVII): Pradoluengo”. En El Pasado Histórico de Castilla y León. Vol II. Edad Moderna. Burgos, Junta de Castilla y León, 1993, pp. 473 - 492.

- M. OLLERO OJEDA: Demanda y Urbión: sierras occidentales de la Rioja. Bilbao, Sua. 1995.

- D. ORTIZ JUAREZ y otros: Catálogo artístico y monumental de la provincia de Córdoba. Córdoba, Diputación Provincial. 1981.

- E. OROZCO DÍAZ: Manierismo y Barroco. Madrid, Cátedra, 1988. 
- D. ORTEGA GUTIÉRREZ, R. CAMARERO CAMARERO: La villa de Monterrubio de la Demanda. Una del Estado de las Cinco Villas y Valle de Canales. Burgos, 1999.

- $\quad$ M$^{\mathrm{a}}$. T. ORTEGA VILLAZÁN: El clima del sector norte de la Cordillera Ibérica: estudio geográfico de la Sierra de la Demanda a la del Moncayo. Valladolid, Secretariado de Publicaciones, Universidad. 1993.

- M. ORTEGA: Conflicto y continuidad en la sociedad rural española del siglo XVIII. Madrid, Síntesis. 1993.

- B. OSABA Y RUIZ DE ERENCHUN: "Poblados, monasterios y castillos desaparecidos en la provincia de Burgos”. BIFG, T. XVII, Burgos, 1966 - 1967.

- F. PACHECO DE TOLEDO: Constituciones synodales del Arçobispado copiladas, hechas y ordenadas, agora nuevamente, conforme al Santo Concilio de Trento por... Don...Burgos, Phelippe de Junta, 1577.

- A. PACHO POLVORINOS: “Exclaustración en Burgos (1835 - 1837)”. Burgense, $n^{\circ}$ 37/1, Burgos, 1996, pp. 329 - 358.

- C. J. PALACIOS PALOMAR: Patrimonio artístico y actividad arquitectónica del monasterio de Santo Domingo de Silos (1512 - 1835). En Studia Silensia Series Mior IV. Santo Domingo de Silos, Milenario del Nacimiento de Santo Domingo de Silos (1000 - 2000). Abadía de Silos. 2001.

- J. I. PALACIOS SANZ: Órganos y organeros en la provincia de Soria. Soria. 1994.

- Fr. B. PALACIOS (O de M.): Historia de la ciudad de Burgos, de sus familias y de su Iglesia. (1729). En Boletín de la Estadística Municipal. Burgos, Aymto. de Burgos.

- J. C. PALACIOS: Trazas y cortes de cantería en el Renacimiento español. Madrid, Instituto de la Conservación y Restauración de Bienes Culturales. 1990.

- $\quad$ A. PALLADIO: Los cuatro libros de arquitectura. Madrid, 1988.

- F. PALOMERO ARAGÓN: Rutas para descubrir el arte de la Sierra de la Demanda. Valladolid, Ed. Ámbito. 2000.

- F. PALOMERO ARAGÓN, M. ILARDIA GÁLLIGO: El arte románico burgalés. Un lenguaje medieval actual. Madrid, Lancia. 1995. 
- “Hacinas ejemplo de arquitectura popular”. Amigos de Hacinas, $n^{\circ}$ 78, Burgos, 1998, pp. $30-34$.

- J. L. PANO GARCÍA: “Introducción al estudio de las hallenkirchen en Aragón”. Artigrama, $n^{\circ} 1$, Zaragoza, 1984, pp. $113-145$.

- E. PASTOR DÍAZ DE GARAYO: Castilla en el tránsito de la Antigüedad al Feudalismo. Poblamiento, poder político y estructura social del Arlanza al Duero. (siglos VII - XI). Valladolid, Junta de Castilla y León, Consejería de Educación y Cultura. 1996.

- “Del Arlanza al Duero: la configuración de un espacio rural (siglos X - XIII)”. En Jornadas burgalesas de Historia (1 $1^{a}$ 1989. Burgos). Introducción a la Historia de Burgos en la Edad Media. Burgos, Asociación Provincial de Libreros de Burgos, 1990, pp. $719-727$.

- “Estructura del poblamiento en la Castilla Condal: consideraciones generales”. En II Jornadas burgalesas de Historia (2 ${ }^{a}$ 1990. Burgos). Burgos en la Alta Edad Media. Burgos, Asociación Provincial de Libreros de Burgos, 1990, pp. 633 - 651.

- N. PAVÓN: Signos lapidarios de los canteros en la catedral de Burgos. Burgos, Excma. Diputación Provincial de Burgos. 1998.

- $\quad$ R. J. PAYO HERNANZ: El retablo en Burgos y su comarca durante los siglos XVII y XVIII. Burgos, Excma. Diputación Provincial de Burgos. 1997.

- “Aproximación al estudio de la arquitectura clasicista y protobarroca en Burgos y su comarca en el siglo XVII”. En Juan de Herrera y su influencia: actas del Simposio: Camargo 14 / 17 Julio 1992. Santander, Fundación Obra Pía Juan de Herrera: Universidad de Cantabria, 1993, pp. 227 - 242.

- El arte de la madera en Burgos durante los siglos XVII - XVIII. Burgos, 1997.

- "El retablo en Burgos en la segunda mitad del siglo XVIII: Entre la tradición barroca y la Neoclásica”. Actas IX C. E. H. A. El arte español en épocas de transición. Madrid, 1994, pp. 179 - 191.

- J. M. PELORSON: “Aspectos ideológicos”. En Historia de España. T. 4. La frustración de un Imperio. (1476 - 1714). Barcelona, Labor, 1989, pp. 263 - 356. 
- F. J. PEÑA PÉREZ: “La ganadería en tierras de Burgos en los siglos centrales de la Edad Media: del corral familiar a la ganadería trashumante”. En. Historia de Burgos, desde sus orígenes hasta nuestros días. Tomo 2. Desde el año 1000 a los Tiempos Modernos. Burgos, Diario 16 Burgos, 1993, pp. 363 - 374.

- "Progreso espiritual en la Plena Edad Media burgalesa: monjes, obispos, curas, cruzados, peregrinos, frailes, cofrades y fieles en general”. En. Historia de Burgos, desde sus orígenes hasta nuestros días. Tomo 2. Desde el año 1000 a los Tiempos Modernos. Burgos, Diario 16 Burgos, 1993, pp. 411 - 422.

- “La sociedad burgalesa plenomedieval”. En. Historia de Burgos, desde sus orígenes hasta nuestros días. Tomo 2. Desde el año 1000 a los Tiempos Modernos. Burgos, Diario 16 Burgos, 1993, pp. 387 - 398.

- "El triunfo de la aldea en una sociedad en crecimiento: El "territorio burgalés" en los siglos plenomedievales”. En. Historia de Burgos, desde sus orígenes hasta nuestros días. Tomo 2. Desde el año 1000 a los Tiempos Modernos. Burgos, Diario 16 Burgos, 1993, pp.339 - 350.

- A. PÉREZ ALONSO: Historia de la Real Abadía de Nuestra Señora de Valvanera en la Rioja. Gijón. 1971.

- J. PÉREZ CARMONA: Arquitectura y escultura románicas en la provincia de Burgos. Madrid, Espasa Calpe. 1974.

- "Historia y Arte del partido judicial de Salas de los Infantes (Burgos)”. Burgense Collectanea Scientífica, nº 3, Burgos, 1962, pp. 349 - 376.

- “La historia y la geografía burgalesas reflejadas en su toponimia”. BIFG, $n^{\circ} 163$, Burgos, 1964, pp. $238-271$.

- “Conmemoraciones franciscanas”. BIFG, $n^{\circ}$ 161, Burgos, 1963, pp. 762 - 764.

- M. C. PÉREZ DE GUINEA: Estudio sobre la sociedad soriana en el siglo XVIII. Los censos y la distribución de la población. Valladolid, Consejo General de Castilla y León. 1982.

- V. PÉREZ MOREDA: Las crisis de mortalidad en la España interior. Siglos XVI XIX. Madrid, Siglo Veintiuno de España Editores. 1980. 
- V. PÉREZ MOREDA, D. S. REHER: Demografía histórica en España. Madrid, Ediciones el Arquero. 1988.

- E. PÉREZ ROMERO: Patrimonios comunales, ganadería trashumante y sociedad en la Tierra de Soria. Salamanca, Junta de Castilla y León. Consejería de Educación y Cultura. 1995.

- A. E. PÉREZ SÁNCHEZ: "Villaveta: noticias sobre obras de arte en un pueblo burgalés”. Regañón, $n^{\circ}$ 24, 1997, pp. 14 - 18.

- J. PÉREZ: “España moderna (1474 - 1700): Aspectos políticos y sociales”. En Historia de España. T. 4. La frustración de un Imperio. (1476 - 1714). Barcelona, Labor. 1989.

- $\quad$ N. PEUSNER: Historia de las tipologías arquitectónicas. Barcelona. 1979

- J. M. PIEL: “Toponimia germánica”. ELH (Enciclopedia Lingüística Hispánica), $n^{\circ}$ 1, Madrid, 1960.

- S. PIQUERO, R. OJEDA, E. FERNÁNDEZ DE PINEDO: “El vecindario de 1631: presentación y primeros resultados”. En Evolución demográfica bajo los Austrias. (Actas del II Congreso de la Asociación Demográfica histórica. Alicante, abril de 1990. Vol. III). Alicante, Instituto de Cultura Juan Gil Albert, Diputación de Alicante, Seminari d'Estudis sobre la Població del Pais Valenciá, 1991, pp. 77 - 89.

- E. PIRIZ PÉREZ: Arquitectura gótica en la diócesis de Ciudad Rodrigo. Salamanca, Centro de Estudios Salmantinos. 1974.

- J. M. PITA ANDRADE: La arquitectura española del siglo XVII. En Summa Artis. T. XXVI. Madrid, Espasa Calpe. 1992.

- J. J. PIZARRO GÓMEZ: Arquitectura popular y urbanismo en el valle del Jerte. Badajoz. 1983.

- C. POLANCO MELERO: Muerte y sociedad en Burgos en el siglo XVI. Burgos, Excma. Diputación Provincial de Burgos. 2001.

- J. J. POLO SÁNCHEZ: "La edificación de la iglesia de la Revilla de Soba: un ejemplo de mecenazgo laico en Cantabria”. BSAA, $n^{\circ}$ 57, 1991, pp. 403 - 418.

- Arte Barroco en Cantabria. Retablos e imaginería. Santander, Universidad de Cantabria. 1991. 
- "Patronos artísticos en el Barroco de Cantabria: una propuesta para su clasificación”. Actas VII Congreso X. E. H. A. Patronos, Promotores, Mecenas y Clientes. Murcia, 1992, pp. 333 - 335.

- "Iglesias columnarias en la zona oriental de Cantabria”. En Arte Gótico postmedieval (Actas del VIII C. E. H. A.). Segovia, Caja de Ahorros, 1987, pp. 91 103.

- A. PORTABALES PICHEL: Los verdaderos artífices de El Escorial y el estilo indebidamente llamado herreriano. Madrid, 1945.

- A. QUINTANA MARTÍNEZ: La arquitectura y los arquitectos en l a Real Academia de Bellas Artes de San Fernando (1744 - 1774). Madrid, Xarait Ediciones. 1983.

- C. RÁBANOS FACI: Arquitectura popular. Fuentes para su estudio y metodología de trabajo. Zaragoza, Instituto de Ciencias de la Educación, Universidad de Zaragoza. 1993.

- E. RABASA DÍAZ: “Técnicas góticas y renacentistas en el trazado y la talla de las bóvedas de crucería españolas del siglo XVI”. En Actas del Primer Congreso Nacional de Historia de la Construcción. Madrid, C.E.H.O.P.U. Instituto Juan de Herrera, 1996, pp. $423-434$.

- G. RAMALLO ASENSIO: “Documentación y estudio de la obra realizada por Fray Pedro Martínez de Cardeña en el monasterio de San Pelayo de Oviedo”. Boletín del Instituto de Estudios Asturianos, vº 87, 1976, pp. 183 - 204.

- La arquitectura civil asturiana (Edad Moderna). Gijón, 1978.

- J. A. RAMÍREZ: Cómo escribir sobre arte y arquitectura. Libro de estilo e introducción a los géneros de la crítica y de la historia del arte. Barcelona, Ediciones Serbal. 1996.

- J. M. RAMÍREZ MARTÍNEZ: Retablos mayores de la Rioja. Agoncillo (La Rioja), 1993.

- G. RAMOS DE CASTRO: "Los hermanos Juan y García de la Vega, maestros de Cantería”. BSAA, $n^{\circ}$ 46, 1980, pp. 285 - 292.

- $\quad$ L. REAU: Iconografía del arte cristiano. Barcelona, Serbal. 1996. 
- $\quad$ Ma J. REDONDO CANTERA: "La política bonapartista sobre los bienes artísticos desamortizados del clero regular y su repercusión en un medio provincial. Valladolid 1803 - 1813”. Academia, nº 73, 1991, pp. 253 - 290.

- "El patrimonio arquitectónico y urbanístico de Valladolid durante la Guerra de la Independencia”. Anales de Arquitectura, $n^{\circ} 4$, 1992, pp. 50 - 65.

- $\quad M^{\mathrm{a}}$. J. REDONDO CANTERA, M. A. ARAMBURU ZABALA: "La construcción de puentes en el siglo XVIII: innovación y tradición”. Actas del I Congreso Internacional de Historia de la Construcción. Madrid, 1996, pp. 435 - 443.

- D. S. REHER, A. VALERO LOBO: Fuentes de información demográfica en España. Madrid, Centro de Investigaciones Sociológicas. 1995.

- J. L. REOYO: "Explotaciones mineras en la provincia de Burgos durante la centuria 1850 - 1950”. BIFG, Burgos.

- A. REPRESA: "Las comunidades de villa y tierra castellanas: Soria”. Celtiberia, $n^{o}$ 57, Soria, Centro de Estudios Sorianos, 1979, pp. 7 - 17.

- F. REYES TÉLLEZ: “Arqueología y cultura material de la provincia de Burgos en la Alta Edad Media”. En II Jornadas burgalesas de historia (2 ${ }^{a}$ Burgos. 1990). Burgos en la Alta Edad Media. Burgos, Asociación Provincial de Libreros de Burgos, 1991, pp. $77-123$.

- A. RIEGL: El culto moderno a los monumentos. Madrid, 1987.

- M. RINCÓN: Andar por las sierras de Urbión, Neila y Cebollera. Madrid, Acción Divulgativa. 1991.

- Andar por la Sierra de la Demanda. Madrid, Penthalon. 1990.

- D. R. RINGROSE: El transporte y el estancamiento económico de España. Madrid, Ed. Tecnos. 1972.

- $\quad$ W. RINCÓN GARCÍA: Ayuntamientos de España. Madrid, 1988.

- M. RIU: Apuntes comentados de un viaje arqueológico por tierras de la Castilla medieval. En La España Medieval. Estudios dedicados al profesor D. Julio González. Madrid, Universidad Complutense de Madrid. 1980.

- J. RIVAS CARMONA: “Camarines y sagrarios”. En El Barroco en Andalucía. T. I. Córdoba. 1983. 
- J. RIVERA BLANCO: “Tradición y modernidad en la arquitectura palentina de los comienzos de la Edad Moderna”. En Jornadas sobre el renacimiento en la provincia de Palencia. Palencia, 1987, pp. 21 - 38.

- Arquitectura de la segunda mitad del siglo XVI en León. León, Instituto Fray Bernardino de Sahagún. 1982.

- J. RIVERA: Juan Bautista de Toledo y Felipe II. La implantación del clasicismo en España. Valladolid, 1984.

- $\quad$ E. RIVERO: Sierra de la Demanda. Burgos, Patronato de Turismo. 1998.

- El sur de la Sierra de la Demanda. En Rincones singulares de Burgos. T. VI. Burgos, Caja Burgos. 2002.

- C. RODICIO: “Fray Pedro Martínez y la fachada de San Pedro de Eslorza”. Tierras de León, $n^{\circ} 34$ - 35, 1979.

- S. RODRÍGUEZ BECERRA: "Formas de religiosidad popular. El Exvoto: su valor histórico y etnográfico”. En La religiosidad popular III. Barcelona, 1989.

- J. C. RODRÍGUEZ, ESTÉVEZ: Los canteros de la Catedral de Sevilla. Del gótico al Renacimiento. Sevilla, Diputación Provincial de Sevilla. 1998.

- A. RODRÍGUEZ G. CEBALLOS: Arquitectura barroca en Castilla y León. Siglos XVII y XVIII. Salamanca, Ediciones Colegio de España. 1996.

- "La arquitectura religiosa de Juan de Herrera y la Contrarreforma”. En Juan de Herrera y su influencia: actas del Simposio: Camargo 14 / 17 Julio 1992. Santander, Fundación Obra Pía Juan de Herrera: Universidad de Cantabria, 1993, pp. $197-203$.

- "Liturgia y configuración del espacio en la arquitectura española y portuguesa a raíz del Concilio de Trento”. Anuario del Departamento de Historia y Teoría del Arte. Universidad Autónoma de Madrid, nº 3, Madrid, 1991, pp. 43 - 52.

- Introducción al arte español del siglo XVIII. Entre la tradición y la academia. Madrid, Silex. 1992.

- $\quad$ El siglo XVIII. Entre tradición y Academia. Madrid, 1993.

- "La reforma de la arquitectura religiosa en el reinado de Carlos III. El neoclasicismo español y las ideas jansenistas”. Fragmentos, $n^{\circ} 12$ - 14, 1988, pp. 115 - 127. 
- J. RODRÍGUEZ GARCÍA, J. CASTILLA SOTO: Diccionario de términos de Historia de España. Edad Moderna. Barcelona, Ariel. 1998.

- P. RODRÍGUEZ ROBLEDO: Pedro de Tolosa. Primer aparejador de cantería de El Escorial. Madrid, Colegio de Aparejadores y Arquitectos Técnicos de Madrid. 1994.

- A. RODRÍGUEZ SÁNCHEZ: “Burgos en el siglo XVI”. En. Historia de Burgos, desde sus orígenes hasta nuestros días. Tomo 2. Desde el año 1000 a los Tiempos Modernos. Burgos, Diario 16 Burgos, 1993, pp. 591 - 602.

- “Espacio, población y sociedad. Siglos XVI - XVIII”. En Historia de Burgos. III. Edad Moderna (2). Burgos, Caja de Ahorros Municipal de Burgos, 1992, pp. 9 - 42.

- M. L. ROKISKI LÁZARO: Arquitectura del siglo XVI en Cuenca. Arquitectos, canteros y carpinteros. Cuenca, Diputación Provincial de Cuenca. 1989.

- F. P. ROLDÁN MORALES: Arquitectura popular de la provincia de Valladolid. Valladolid, Diputación Provincial de Valladolid. 1996.

- $\quad$ R. ROSENBLUM: Transformaciones en el arte del siglo XVIII. Madrid, 1986.

- E. RUBIO MARCOS: Monjes y eremitorios. Santuarios de roca del sureste de Burgos. Burgos, Excma. Diputación Provincial de Burgos. 1986.

- J. C. RUBIO MASA: Arquitectura popular de Extremadura. Mérida, Editora Regional de Extremadura. Dirección General de Acción Cultural. 1985.

- C. RUBIO VELASCO: Barbadillo de Herreros. Burgos, Imprenta Santos. 2001.

- M. RUIZ CALVENTE: "Los canteros Andrés de Salamanca y Juan de Rica, artífices de la torre de campanas de la parroquia de San Mateo”. Boletín del Instituto de Estudios Giennense, $n^{\circ} 40$ (154), 1994, pp. 119 - 136.

- J. A. RUIZ DE LA ROSA: Trazas y Simetría de la Arquitectura. En la Antigüedad y Medievo. Sevilla, 1987.

- F. RUIZ GÓMEZ: Las aldeas castellanas en la Edad Media: Oña en los siglos XIV - XV. Madrid. 1990.

- J. RUZ PEÑA: “Nuevas memorias de Mambruno”. BIFG, $n^{\circ}$ 153, Burgos, 1960, pp. $314-348$.

- J. RUPERT MARTÍN: Barroco. Bilbao. 1986. 
- J. RYKWERT: Los primeros modernos. Los arquitectos del siglo XVIII. Barcelona. 1982.

- J. D. SACRISTÁN DE LAMA, I. RUIZ VÉLEZ: “La Edad del Hierro”. En Historia de Burgos I. Edad Antigua. Burgos, Caja de Ahorros Municipal de Burgos, 1985, pp. $179-220$.

- D. DE SAGREDO: Medidas del Romano. (Ed. Facsímil). Murcia, 1986.

- J. L. SÁINZ CASADO, F. J. SANZ DE LA HIGUERA: “Evolución demográfica del partido de Candemuñó (1700 - 1850)”. En El Pasado Histórico de Castilla y León. Vol II. Edad Moderna. Burgos, Junta de Castilla y León, 1993, pp. 355 - 379.

- J. L. SÁINZ GUERRA: La génesis de la plaza en Castilla durante la Edad Moderna. Valladolid. 1990.

- J. SÁINZ SÁIZ: El románico rural en Castilla y León. Madrid, Ediciones Lancia. 1991.

- El románico en Burgos. Madrid, Ediciones Lancia. 2001.

- M. del SALTILLO: Artistas y artífices sorianos de los siglos XVI y XVII (1509 1699). Soria. 1948.

- C. SAMBRICIO: La arquitectura española de la Ilustración. Madrid, 1986.

- P. SAMPEDRO VALIÑAS, y otros: Inventario artístico de Lugo y su provincia. Madrid, Ministerio de Cultura. 1976.

- L. SAN VALENTÍN BLANCO: De la trashumancia del ganado merino. Desde nuestros puertos de la Sierra de la Demanda hasta las dehesas de Extremadura y Andalucía. Burgos, Excma Diputación Provincial de Burgos. 1984.

- A. SAN VICENTE: Canteros y obras de cantería del Bajo Renacimiento en Zaragoza. Zaragoza, Real Sociedad Económica Aragonesa de Amigos del País. 1994.

- C. SÁNCHEZ ALBORNOZ: "Itinerario de la conquista de España por los musulmanes”. Cuadernos de Historia de España, n 10, Buenos Aires, 1948, pp. 45 $-46$. 
- A. SÁNCHEZ BELDA, Ma . C. SÁNCHEZ TRUJILLANO: Razas ovinas españolas. Madrid, Publicaciones de Extensión Agraria. Ministerio de Agricultura. 1979.

- J. M. SÁNCHEZ DIANA: "Burgos en el siglo XVII". BIFG, n 18, 1970 - 1971, pp. $97-114$.

- “La Castilla germánica”. BIFG, n 180, Burgos, 1973, pp. 584 - 604.

- J. SÁNCHEZ GÓMEZ: Minería y metalurgia en la Edad Moderna. Madrid, Akal. 1997.

- F. M. SÁNCHEZ LOMBA: "Arquitectura del Renacimiento en Extremadura". Norba, nº 8. Cáceres, 1988, pp. 69 - 96.

- "Gótico y Renacimiento a mediados del siglo XVI: Pedro de Ybarra, en Extremadura”. En Arte Gótico postmedieval (Actas del VIII C. E. H. A.). Segovia, Caja de Ahorros, 1987, pp. 149 - 153.

- F. M. SÁNCHEZ LOMBA, A. NAVAREÑO MATEOS: "Vizcaínos, trasmeranos y otros artistas norteños en la Extremadura del siglo XVI" Norba-Arte, $n^{\circ}$ 9, 1989, pp. $7-13$.

- A. SANCHO CORBACHO: Dibujos arquitectónicos del siglo XVII. Sevilla, Ayuntamiento de Sevilla. Servicio de Publicaciones. 1983.

- C. SARAVIA: "Repercusión en España del Decreto del Concilio de Trento sobre las imágenes”. BSAA, $n^{\circ}$ 26, 1960, pp. 129 - 143.

- S. SARDUY: Barroco. Buenos Aires, 1974.

- E. SATUÉ: El diseño gráfico: desde los orígenes hasta nuestros días. Madrid, Alianza Editorial. 1988.

- R. SCHIMITT: "El clima de Castilla la Vieja y Aragón”. Estudios Geográficos, noviembre 1945, pp. 727 - 812.

- J. V. SCHOLOSSER: Las cámaras artísticas y maravillosas del renacimiento tardío. Ávila, 1988.

- W. SCHRIEL: La Sierra de la Demanda y los Montes Obarenses. Madrid, CSIC. 1945. 
- O. SCHUBERT: Historia del Barroco en España. Madrid, Editorial Saturnino. 1924.

- S. SEBASTIÁN LÓPEZ: Contrarrefoma y barroco. Madrid, Alianza Editorial. 1981.

- Espacio y Símbolo. Córdoba, 1976.

- J. J. SEDRAS SALAS, J. NAVARRO CASAS: "La iglesia como lugar de la música”. Actas del Primer Congreso Nacional de la Historia de la Construcción. 1996, pp. $381-387$.

- La evolución de las condiciones acústicas en las iglesias del paleocristiano al barroco. Sevilla, Instituto Universitario de Ciencias de la Construcción. Escuela Técnica Superior de Arquitectura. Universidad de Sevilla. 1997.

- J. A. SEGURA JIMÉNEZ: Diego Camporredondo y el arte barroco y rococó en Calahorra y comarca. Logroño, Gobierno de la Rioja; Instituto de Estudios Riojanos. 1994.

- F. SESMERO PÉREZ: El arte del Renacimiento en Vizcaya (El arte en Vizcaya desde finales del siglo XV hasta la época barroca). Bilbao. 1954.

- L. SERRANO: Fuentes para la historia de Castilla, I, Colección diplomática de San Salvador de El Moral. Madrid. 1906.

- Cartulario de San Millán. Madrid, Centro de Estudios Históricos. 1930.

- Cartulario del Infantado de Covarrubias. Madrid, Centro de Estudios Históricos. 1906.

- El obispado de Burgos y Castilla primitiva. Desde el siglo V al XIII. Madrid, Centro de Estudios Históricos. 1935.

- Cartulario de San Pedro de Arlanza. Antiguo monasterio Benedictino. Madrid, Centro de Estudios Históricos. 1925.

- F. SOJO LOMBA: Los maestros canteros de Trasmiera. Madrid. 1935.

- V. SORIA: “Canteros vascos en Mérida y Oropesa en el siglo XVII”. Boletín de la Real Sociedad Bascongada de Amigos del País, n 43, 1987, pp. 364 - 368.

- $\quad$ R. STRONG: Arte y poder. Fiestas del renacimiento 1450 - 1650. Madrid, 1988. 
- D. SUÁREZ QUEVEDO: Arquitectura barroca en Toledo. Siglo XVII. Madrid, Universidad Complutense de Madrid. Facultad de Geografía e Historia. Departamento de Are II. 1988.

- La arquitectura barroca en Toledo. Toledo, Caja de Ahorros de Toledo. 1990.

- J. SUREDA (dir.): Los siglos del Barroco. Madrid, Akal. 1997.

- J. SUREDA, A. E. PÉREZ SÁNCHEZ: El siglo de Oro. El sentimiento de lo barroco. En La historia del Arte Español. T. VII. Barcelona, Ed. Planeta. 1996.

- J. SUREDA, E. LIAÑO: El despertar de Europa. La pintura románica, primer lenguaje común europeo. Siglos XI - XIII. Madrid, Ediciones Encuentro. 1998.

- W. SZAMBIEN: Simetría, gusto carácter: Teoría y terminología de la arquitectura en la época clásica (1550-1800). Torrejón de Ardoz, Akal. 1993.

- M. TAÍN GUZMÁN: Los arquitectos y la contratación de obra arquitectónica en la Galicia barroca (1650-1700). La Coruña, Ediciones do Castro. 1997.

- A. TAMAYO: Las iglesias barrocas madrileñas. Madrid, Talleres Suc. de J. Sánchez. 1946.

- V. L. TAPIÉ: Barroco y clasicismo. Madrid, Cátedra. 1978.

- J. S. TAYLOR: Arquitectura anónima. Una visión cultural de los principios prácticos del diseño. Barcelona, Ed. Stylos. 1984.

- J. TERES LANDETA: “La cañada segoviana”. En Cañadas, cordeles y veredas. (Pedro García Martín. Coord.) Valladolid, Junta de Castilla y León. Consejería de Agricultura y Ganadería, 2000, pp. 125 - 143.

- A. S. TESSARI: “Antonio Possevino e l'architettura”. AHSI. Archivum Historicum Societatis Iesus, LII, 104, 1983.

- $\quad$ L. TORRES BALBÁS: Arquitectura gótica. En Ars Hispaniae T. VII. Madrid, Plus Ultra. 1952.

- V. TOVAR, J. J. MARTÍN GONZÁLEZ: El arte del Barroco I. Arquitectura y escultura. Madrid, Taurus. 1990.

- V. TOVAR MARTÍN: Arquitectura madrileña del siglo XVII (Datos para su estudio). Madrid, CSIC. 1983.

- $\quad$ El siglo XVIII español. En Historia del Arte 16. Vol 34. Madrid, Historia 16. 1989. 
- “El arquitecto Juan Gómez de Mora iniciador del Barroco en España. Proyecto del templo de San Antonio de los Portugueses”. Goya, n 174, 1983, pp. 338 - 344.

- “La arquitectura doméstica madrileña en la segunda mitad del siglo XVIII”. Instituto de Estudios Madrileños. T. XXII, Madrid, 1985, pp. 117 - 127.

- J. R. TRAIDO: Las claves del arte Barroco. Barcelona, Editorial Planeta. 1991.

- M. UllOA: La Hacienda Real de Castilla en el reinado de Felipe II. Madrid, Fundación Universidad Española, Seminario Cisneros. 1977.

- J. I. URIOL SALCEDO: Historia de los caminos T. I. Madrid. 1990.

- J. A. ÚZQUIZA: “Espigando en la Historia de Hacinas”. Amigos de Hacinas, $n^{\circ} 41$, Burgos, 1988, pp. $22-24$.

- “Espigando en la Historia de Hacinas”. Amigos de Hacinas, $n^{\circ}$ 43, Burgos, 1989, pp.30 - 32 .

- “Mirar una pila bautismal”. Amigos de Hacinas, nº 17, Burgos, 1983, pp.18 - 20.

- J. VALDEÓN BARUQUE: “La Mesta y el pastoreo en Castilla en la Baja Edad Media (1273 - 1474)”. En Mesta, trashumancia y vida pastoril.: exposición organizada por la Sociedad V Centenario del Tratado de Tordesillas. Soria, Sede de la Fundación Duques de Soria. 19 de septiembre a 30 de noviembre 1994. Madrid, I + P Investigación y Progreso. 1994.

- B. VALDIVIELSO AUSíN: Neila, una llamada al turismo. Burgos, Ayuntamiento de Neila. 1980.

- Rutas del románico en la provincia de Burgos. Valladolid, Castilla Ediciones. 1999.

- Burgos en el camino de Santiago. Burgos, Aldecoa. 1992.

- Aranda de Duero y la Ribera. Burgos, 1995.

- E. VALDIVIELSO GONZÁLEZ: La arquitectura española del siglo XVIII. En Summa Artis. T. XXVII. Madrid, Espasa Calpe. 1984.

- E. VALDIVIELSO GONZÁLEZ, R. OTERO, J. URRETA: El barroco y el Rococó. En Historia del Arte Hispánico IV, Madrid, 1978.

- M. VALENZUELA RUBIO: “La cantería en la Sierra de Guadarrama. Una actividad extractiva de influencia urbana”. Estudios Geográficos, $n^{\circ}$ 36, 1975, pp. $1077-1112$. 
- J. VALLEJO BOZAL, Ma D. TEIJEIRA PABLOS: "Fuentes para el estudio de la iglesia del Monasterio de San Pedro de Arlanza. En los inicios del románico pleno en España”. Boletín del Museo Arqueológico Nacional, $n^{o} 1$ - 2, Madrid, 1995, pp. $55-70$.

- $\quad$ L. VASALLO TORANZO: Arquitectura en Toro (1500 - 1650). Salamanca. 1994.

- D. E. VASSBERG: Tierra y sociedad en Castilla. Señores, poderosos y campesinos en la España del siglo XVI. Barcelona, Editorial Crítica. 1986.

- J. J. VÉLEZ CHAURRI: El retablo barroco en los límites de las provincias de Álava, Burgos y la Rioja (1600 - 1770). Vitoria, 1990.

- L. VICENTE ELÍAS: “La Mesta y la cultura pastoril”. En Mesta, trashumancia y vida pastoril.: exposición organizada por la Sociedad V Centenario del Tratado de Tordesillas. Soria, Sede de la Fundación Duques de Soria. 19 de septiembre a 30 de noviembre 1994. Madrid, I + P Investigación y Progreso, 1994, pp. 207 - 237.

- L. VICENTE ELÍAS, R. MONCOSI DE BORDÓN: Arquitectura popular en la Rioja. Madrid, Ministerio de Obras Públicas. 1978.

- J. VIDAURRE JOFRE: Ciudad y arquitectura medievales, morfologías imaginarias en Castilla y León, 1050 - 1450. Madrid, 1990.

- M. DE VIGURI, J. L. SÁNCHEZ: Arquitectura en la Tierra de Campos y el Cerrato. Dibujos y documentos ss. XVI - XVIII. Madrid, 1993.

- $\quad$ Ma . D. VILA JATO: "Promotores, clientes y talleres en la Galicia barroca”. Actas I Congreso Internaciona do Barroco. T. II. Oporto, 1991, 559 - 569.

- D. VILLAPLANA: “Arquitectura Barroca catellonense y de las comarcas limítrofes”. Estudios Castellonenses, nº 7, Castellón, 1996 - 1997, pp. 15 - 40.

- O. VILlUGA: Repertorio de todos los caminos de España. Median del Campo, 1546.

- $\quad$ M. VITRUVIO: Los diez Libros de Arquitectura. (Ed. Facsímil). Madrid, 1983.

- M. C. VIVANCOS (O.S.B), C. J. PALACIOS: La iglesia de San Pedro de Santo Domingo de Silos. Santo Domingo de Silos, Centro de Iniciativa Turística de Silos y sus Aldeas. 2003.

- J. C. VIZUETE: La iglesia en la Edad Moderna. Madrid, Síntesis. 2000. 
- $\quad$ S. de la VORÁGINE: La Leyenda Dorada. Madrid, Alianza Editorial. 1997.

- VV.AA.: Nobleza y sociedad en la España moderna. Oviedo, Ediciones Nobel. 1996.

- VV.AA.: Análisis del medio físico de Burgos. Delimitación de unidades y estructura territorial. Valladolid, Junta de Castilla y León. Consejería de Fomento. 1988.

- VV. AA.: “Arte Sacro: un proyecto actual”. Actas del Curso celebrado en Madrid . Octubre 1999. Fundación Félix Granado. Madrid, Cofás, 2000, pp. 327.

- VV. AA.: Inventario de la arquitectura rural alavesa. Vitoria, Diputación Foral de Álava. Dirección de Arquitectura. 1981.

- VV. AA.: Renacimiento y Clasicismo. En Historia del Arte de Castilla y León. T. V. Valladolid, Ámbito. 1994.

- VV. AA.: Arte Gótico. En Historia del Arte de Castilla y León. T. III. Valladolid, Ámbito. 1994.

- VV. AA.: Diccionario de Historia Eclesiástica de España. Madrid, CSIC. 1972.

- VV. AA. : La iglesia en la España de los siglos XVII y XVIII. En Historia de la Iglesia en España. T. IV. (R. GARCÍA - VILLOSLADA dir.). Madrid, BAC. 1979.

- VV. AA. : El hombre barroco. Madrid. 1992.

- W. WEISBACH: El Barroco, arte de la Contrarreforma. Madrid, Espasa Calpe. 1942.

- $\quad$ R. M. WITTKOWER: Nacidos bajo el signo de Saturno. Genio y temperamento de los artistas desde la Antigüedad hasta la Revolución Francesa. Madrid, Cátedra. 1988.

- H. WÖLFFLIN: Renacimiento y Barroco. Madrid, Alberto Coraón. 1977.

- B. YUN CASALILlA: La crisis del siglo XVII en Castilla: Indicaciones, cronologías y factores en la Tierra de Campos (1580 - 1640). En Historia de España. vol 4. La frustración de un Imperio. (1476 - 1714). Barcelona, Labor. 1989.

- M. A. ZALAMA RODRÍGUEZ: La arquitectura del siglo XVI en la provincia de Palencia. Palencia, Diputación Provincial, 1990.

- "Palencia en el Renacimiento. El desarrollo arquitectónico de un centro artístico secundario”. En El problema del arte en las zonas periféricas (Actas del VIII 
Congreso C. E. H. A.). Mérida, Editorial Regional de Extremadura, 1992, pp. 357 360.

- “Tradición y modernidad en la arquitectura española del último cuarto del siglo XVI: la capilla funeraria del Arzobispo de Santiago en Capillas (Palencia)”. En Juan de Herrera y su influencia: actas del Simposio: Camargo 14 / 17 Julio 1992. Santander, Fundación Obra Pía Juan de Herrera: Universidad de Cantabria, 1993, pp. $371-377 .^{\circ}$

- Ma . J. ZAPARAÍN YÁÑEZ: “La aportación de los maestros vascos a la arquitectura barroca castellana. Nuevos datos sobre la obra de Domingo de Ondátegui”. Ondare Cuadernos de artes plásticas y monumentales, $n^{\circ}$ 19, 2000, pp. 425 - 433.

- Desarrollo artístico de la comarca arandina. Siglos XVII y XVIII. Burgos, Excma. Diputación Provincial de Burgos. Ilustre Ayto. de Aranda de Duero. 2001.

- “Desarrollo artístico del antiguo Partido de Aranda de Duero, 1600 - 1799”. I Jornadas Burgalesas de Historia. Burgos, 1990, pp. 603 - 617.

- "El patronato de D. Juan Antonio Serrano en Sotillo de la Ribera (Burgos). Un ejemplo de sensibilidad y comportamiento en el Barroco tardío”. Actas I Congreso Internacional do Barroco. Oporto, 1991, T. II, pp. 571 - 592.

- "La arquitectura de la segunda mitad del siglo XVIII en el Obispado oxomense. En torno a la obra de Ángel Vicente Ubón” Actas IX Congreso C.E.H.A. El arte español en épocas de transición. León, septiembre-octubre, 1992, T.II, pp. 139 147.

- Belorado en los siglos XVII y XVIII. Su desarrollo urbanístico-arquitectónico. Madrid. 1993.

- El monasterio de Santa María de la Vid. Arte y Cultura. Del medioevo a las transformaciones arquitectónicas de los siglos XVII y XVIII. Palencia, 1994.

- "La villa de Guzmán durante los siglos XVII y XVIII. Desarrollo urbanístico y arquitectónico”. Biblioteca, nº 9, Aranda de Duero, 1994, pp. 39 - 71.

- “La comarca de Roa durante los siglos XVII y XVIII. Su arquitectura religiosa”. Biblioteca, $n^{\circ}$ 10, Aranda de Duero, 1995, pp. 69 - 127. 
- "Maestros palentinos en la comarca occidental burgalesa. Su actividad arquitectónica durante el siglo XVIII”. Actas del III Congreso de Historia de Palencia. T. IV. Palencia, 1995, pp. 691 - 704.

- Fuentelcesped. La villa y su patrimonio. Siglos XVII y XVIII. San Sebastián. 1998.

- Fuentespina. La villa y su arte. Siglos XVII y XVIII. San Sebastián. 1995.

- B. ZEVI: Saber mirar la arquitectura. Barcelona, Ed. Poseidón. 1991. 